Universidad deValladolid

PROGRAMA DE DOCTORADO EN ESPAÑOL:

LITERATURA, LINGÜÍSTICA Y COMUNICACIÓN

TESIS DOCTORAL:

\title{
El humor como construcción discursiva de identidades sociales y conflicto ideológico. Un estudio desde la Retórica Constructivista y el análisis del discurso social
}

\author{
Presentada por Pablo Romero Velasco para \\ optar al grado de \\ Doctor/a por la Universidad de Valladolid
}

Dirigida por:

Dr. José David Pujante Sánchez

Dra. Sara Molpeceres Arnáiz 


\section{ÍNDICE}

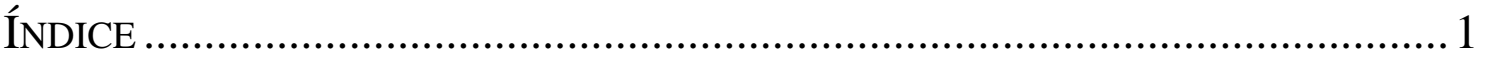

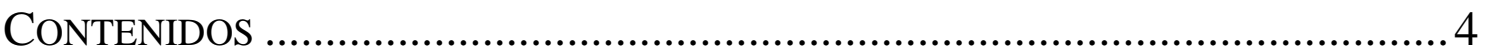

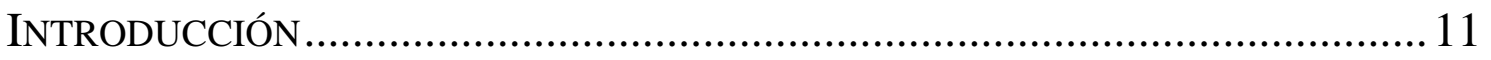

0.1. OBJETIVOS, MARCO TEÓRICO Y PERSPECTIVA METODOLÓGICA ……………..... 11

0.2. ESTRUCTURA DEL TRABAJO................................................................... 15

0.3. ESTADO DE LA CUESTIÓN Y OTRA BIBLIOGRAFÍA RELEVANTE .......................... 19

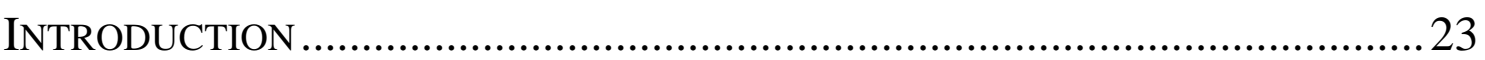

0.1. GOALS, THEORETICAL FRAMEWORK AND METHODOLOGICAL APPROACH ..... 23

0.2. STRUCTURE OF THIS THESIS................................................................. 27

0.3. STATE OF THE ART AND RELEVANT BIBLIOGRAPHY ....................................... 30

I. HISTORIA DEL PENSAMIENTO HUMORÍSTICO EN OCCIDENTE .....................33

1. EL IMPERIO DE LA RISA ................................................................................ 34

1.1. La risa en la Antigüedad .......................................................................... 34

1.2. La risa en la Edad Media y el Renacimiento.................................................. 75

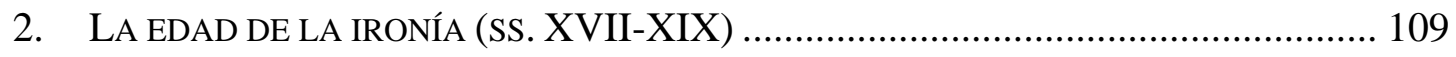

2.1. La desaparición del carnaval ...................................................................... 111

2.2. La pervivencia de lo carnavalesco en la caricatura ...................................... 114

2.3. Intelectualización del humor y lo cómico en los siglos XVII y XVIII ....... 119

2.4. El humor y lo cómico en el Romanticismo y el siglo XIX .......................... 136

2.5. Conclusiones parciales al estudio histórico.................................................. 165

II. MARCO RETÓRICO-HERMENÉUTICO PARA EL ANÁLISIS DE LOS DISCURSOS

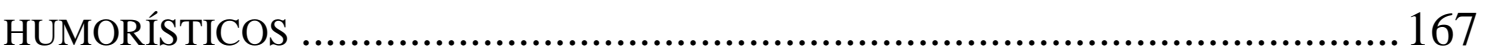

3. LAS CIENCIAS DEL HUMOR EN EL SIGLO XX Y EL XXI.......................................... 168

3.1. Humor y psicoanálisis .............................................................................. 168

3.2. La comedia, la parodia y la ironía en la teoría literaria................................ 213 
3.3. Humor y ciencias sociales: lingüística, psicología, sociología 276

3.4. Apocalípticos e integrados frente a la sociedad humorística 289

4. LA RETÓRICA CONSTRUCTIVISTA COMO MARCO EPISTEMOLÓGICO Y TEÓRICO .. 305

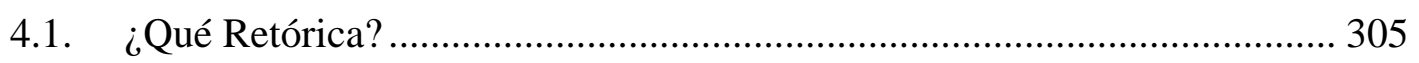

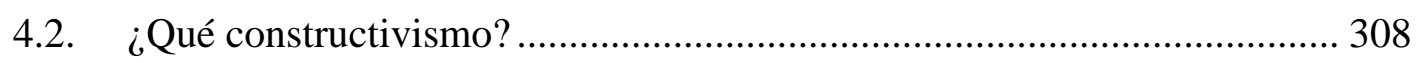

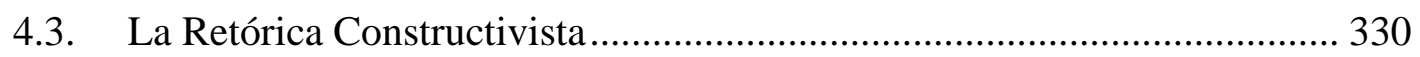

5. UNA PROPUESTA DE ANÁLISIS DE LOS DISCURSOS HUMORÍSTICOS ...................... 340

5.1. Propedéutica: la estructura de la ironía ................................................. 340

5.2. Lo cómico como fiesta, como juego, como ficción .................................. 344

5.3. Lo cómico como incongruencia, como ruptura de expectativas, como polifonía 351

5.4. Caracterización del personaje cómico.................................................... 362

5.5. La recepción y el pathos de lo cómico: identificación, distanciamiento, frivolización 366

5.6. Conclusiones: usos de lo cómico 370

III. EL ORDEN HUMORÍSTICO DEL DISCURSO 374

6. LA ESPECTACULAR VERDAD DEL CUERPO: CAMP, PARODIA E IDENTIDAD TRANSEXUAL EN DOS NOVELAS DE EDUARDO MENDICUTTI.. 375

6.1. Camp: de una sensibilidad "gay" a la teoría queer. Conflictos de interpretación en torno a la identidad transexual 383

6.2. Metáforas travestis y cuerpos transexuales: análisis de Una mala noche la tiene cualquiera......

6.3. La mística del cuerpo en Yo no tengo la culpa de haber nacido tan sexy . 451 7. ANÁLISIS IDEOLÓGICO DE UN DISCURSO HUMORÍstiCO DE MASAS. LA MASCULINIDAD EN FRIENDS. 474

7.1. Psicopolítica del género cómico. El significado social de la comedia de situación 478

7.2. El concepto de masculinidad. Parámetros del análisis. 500 
7.3. Análisis de la masculinidad en Friends .................................................. 515

7.4. Conclusiones hermenéuticas: lecturas ideológicas de la Comedia ............ 557

IV. EL ORDEN DEL DISCURSO HUMORÍSTICO......................................... 560

8. EL DEBATE SOBRE LOS LÍMITES DEL HUMOR EN ESPAÑA .................................... 561

8.1. Dos estudios de caso acerca de la posición actual del humor .................... 564

8.2. El orden del discurso en la aldea global ................................................ 575

8.3. El debate sobre los límites del humor en España en su contexto político.. 593

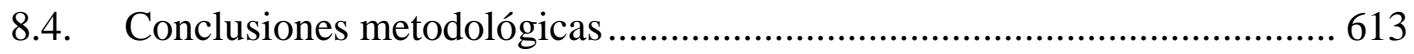

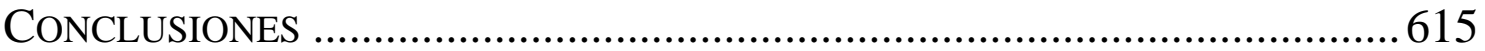

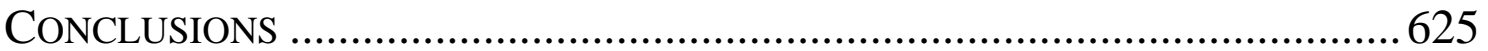

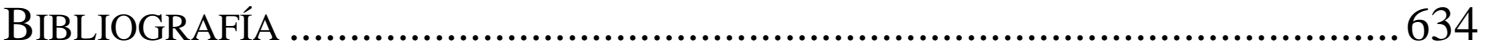




\section{CONTENIDOS}

ÍNDICE

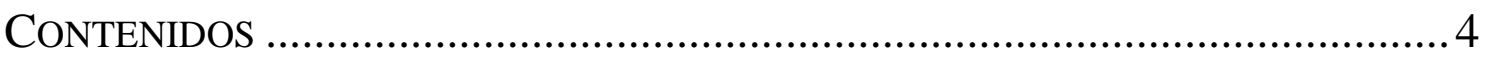

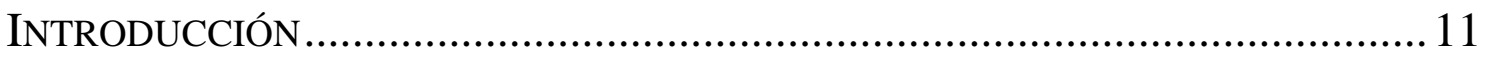

0.1. OBJETIVOS, MARCO TEÓRICO Y PERSPECTIVA METODOLÓGICA ……………..... 11

0.2. ESTRUCTURA DEL TRABAJO.................................................................... 15

0.3. ESTADO DE LA CUESTIÓN Y OTRA BIBLIOGRAFÍA RELEVANTE .......................... 19

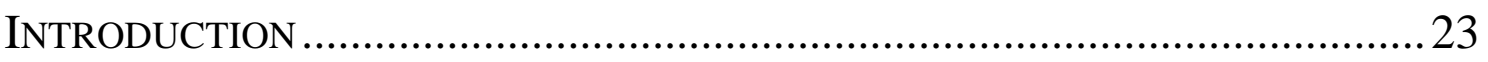

0.1. GOALS, THEORETICAL FRAMEWORK AND METHODOLOGICAL APPROACH ..... 23

0.2. STRUCTURE OF THIS THESIS...................................................................... 27

0.3. STATE OF THE ART AND RELEVANT BIBLIOGRAPHY ....................................... 30

I. HISTORIA DEL PENSAMIENTO HUMORÍSTICO EN OCCIDENTE ......................33

1. EL IMPERIO DE LA RISA ............................................................................... 34

1.1. La risa en la Antigüedad ........................................................................... 34

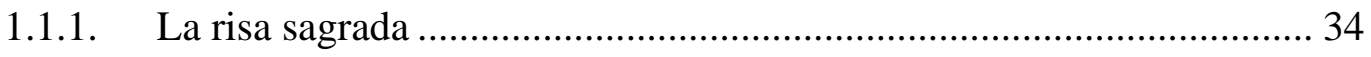

1.1.1.1. En la mitología y la obra homérica ................................................. 34

1.1.1.2. La risa ritual ................................................................................ 37

1.1.2. Origen, significado y desarrollo de la comedia latina y romana y otros

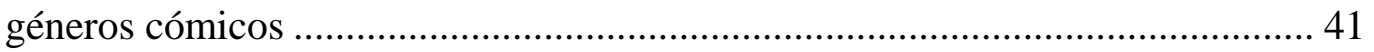

1.1.2.1. Origen ritual de la Comedia............................................................ 41

1.1.2.2. La Comedia Antigua. Aristófanes........................................................ 43

1.1.2.3. La Comedia Nueva........................................................................ 47

1.1.2.4. La comedia latina ............................................................................ 50

1.1.2.5. La sátira romana y la menipea ........................................................ 52

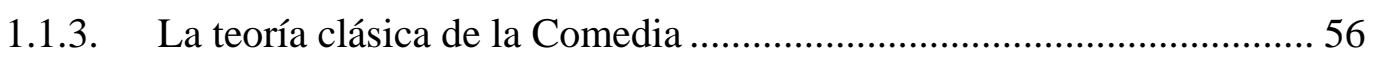

1.1.3.1. Lo cómico en la Poética de Aristóteles .............................................. 56

1.1.3.2. El Tractatus Coislinianus ................................................................ 58

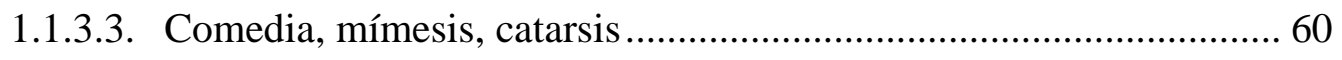

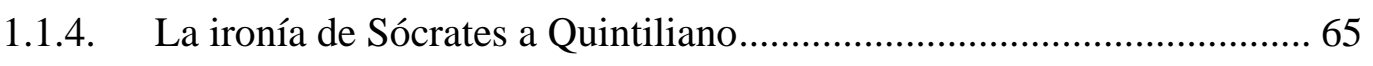

1.1.5. El pensamiento griego sobre la risa ..................................................... 68 
1.1.5.1. La risa de Demócrito. Medicina y filosofía 68

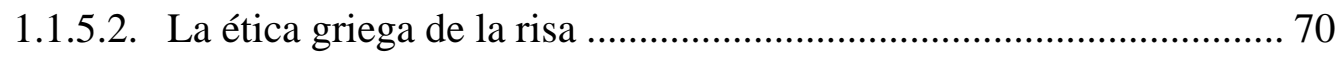

1.2. La risa en la Edad Media y el Renacimiento.............................................. 75

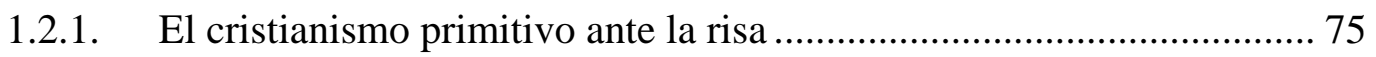

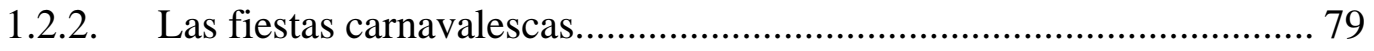

1.2.2.1. La risa en la Iglesia y los monasterios ........................................... 79

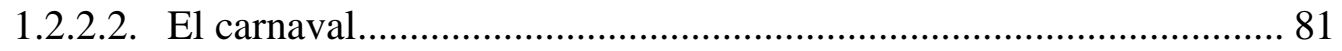

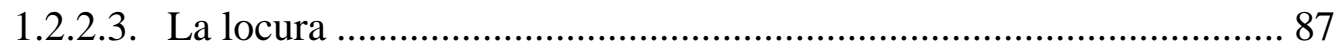

1.2.3. La tradición artística y cultural de lo grotesco...................................... 90

1.2.3.1. El juego con la imagen: los gruttesche ............................................ 90

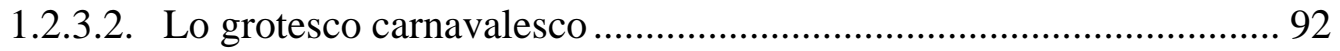

1.2.3.3. Lo carnavalesco en la tradición pictórica flamenca .......................... 94

1.2.4. La risa y lo cómico en el pensamiento renacentista............................ 97

1.2.4.1. La risa y lo carnavalesco en la literatura del Renacimiento.............. 97

1.2.4.2. Teoría renacentista de la risa...................................................... 101

1.2.4.3. Teoría renacentista de la Comedia ................................................. 103

1.2.4.4. La comedia renacentista y barroca ................................................. 105

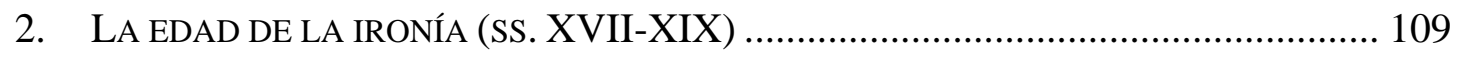

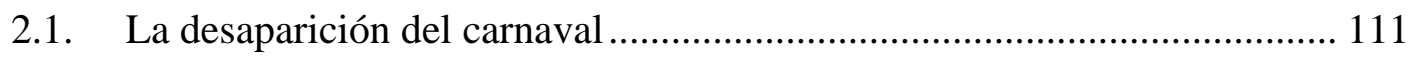

2.2. La pervivencia de lo carnavalesco en la caricatura ................................... 114

2.3. Intelectualización del humor y lo cómico en los siglos XVII y XVIII ....... 119

2.3.1. Contexto filosófico y epistemológico ............................................... 119

2.3.2. La teoría de la incongruencia .......................................................... 124

2.3.3. La conversación ingeniosa: Addison, Shaftesbury ........................... 126

2.4. El humor y lo cómico en el Romanticismo y el siglo XIX ........................ 136

2.4.1. La ironía romántica de Friedrich Schlegel........................................ 136

2.4.2. La poesía humorística de Jean Paul ................................................. 150

2.4.3. Lo grotesco romántico: Victor Hugo. Lo cómico y lo siniestro ......... 155

2.4.4. La esencia de la risa según Baudelaire ............................................. 159

2.4.5. Reflexión general sobre lo grotesco y lo cómico................................ 163

2.5. Conclusiones parciales al estudio histórico................................................. 165

II. MARCO RETÓRICO-HERMENÉUTICO PARA EL ANÁLISIS DE LOS DISCURSOS

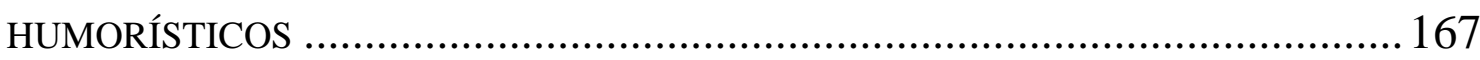




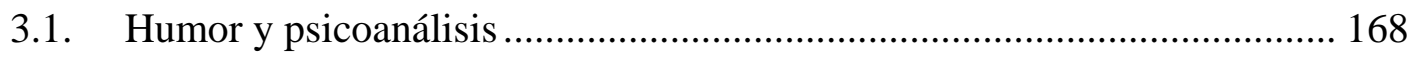

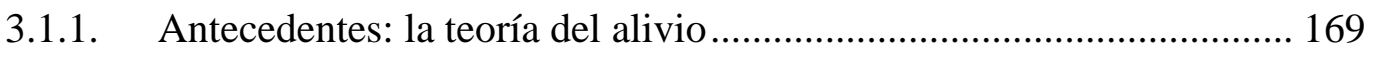

3.1.2. Bergson: La risa. Ensayo sobre la significación de lo cómico............ 170

3.1.2.1. Consideraciones preliminares sobre la risa ................................... 170

3.1.2.2. El mecanismo de lo cómico ........................................................ 172

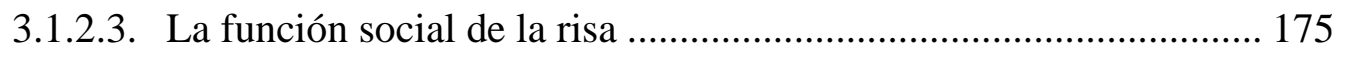

3.1.2.4. La risa entre el arte y la vida ..................................................... 176

3.1.2.5. Lo cómico y la lógica del sueño y el juego................................... 178

3.1.2.6. El personaje cómico. Preludio al inconsciente............................... 179

3.1.3. Freud: El chiste y su relación con lo inconsciente ............................... 182

3.1.3.1. La técnica (verbal) del chiste: condensación y desplazamiento...... 183

3.1.3.2. Las dos tendencias del chiste y sus mecanismos de placer............. 184

3.1.3.3. El chiste, el sueño y el juego ....................................................... 186

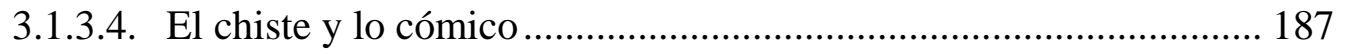

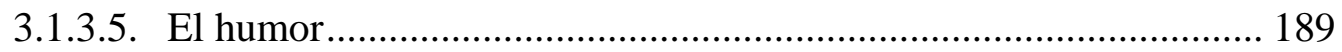

3.1.3.6. Posibles aplicaciones de la explicación freudiana de la fantasía y el arte al fenómeno cómico ............................................................................. 192

3.1.4. Ernst Kris: Psicoanálisis de lo cómico .............................................. 199

3.1.5. Charles Mauron: Psicocrítica del género cómico................................ 201

3.1.5.1. Risa y juego infantil .................................................................. 202

3.1.5.2. El arte cómico como juego......................................................... 202

3.1.5.3. La fantasía cómica de triunfo ....................................................... 203

3.1.5.4. Figuras grotescas y fantasías edípicas........................................... 204

3.1.5.5. La fantasía de triunfo como proyección histórica .......................... 205

3.1.6. La escuela hegeliano-lacaniana: The odd one in, de Alenka Zupancic .206

3.1.6.1. La incongruencia como cortocircuito y el materialismo cómico .... 206

3.1.6.2. Psicoanálisis de algunas figuras cómicas...................................... 210

3.1.6.3. Estructuras temporales de lo cómico .......................................... 212

3.2. La comedia, la parodia y la ironía en la teoría literaria............................. 213

3.2.1. Visiones contemporáneas de la comedia .......................................... 213

3.2.1.1. Comedia y vitalismo .................................................................. 213

3.2.1.2. Comedia: ¿¿control o subversión? ................................................ 216

3.2.1.3. La identificación cómica y el problema de la catarsis.................... 217 
3.2.2. Bajtín y la literatura carnavalesca .................................................... 228

3.2.3. Tropología: la visión irónica ............................................................. 230

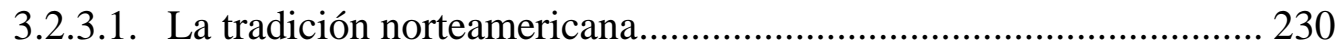

3.2.3.1.1. I. A. Richards y el New Criticism .......................................... 230

3.2.3.1.2. Kenneth Burke ....................................................................... 232

3.2.3.1.3. El «modo irónico» de Northrop Frye ....................................... 236

3.2.3.1.4. La tropología de Hayden White............................................... 240

3.2.3.2. La disputa por el sentido. Ironía e interpretación............................ 245

3.2.3.2.1. La Retórica de la ironía de Wayne Booth................................ 245

3.2.3.2.2. La ironía postestructuralista de Paul De Man.......................... 249

3.2.3.2.3. Ironía y postestructuralismo: la frivolidad como categoría del

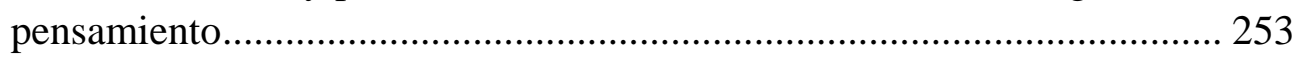

3.2.3.2.4. Una propuesta pragmatista: los usos de la ironía ..................... 260

3.2.3.3. Linda Hutcheon: ironía, parodia y posmodernidad........................ 266

3.3. Humor y ciencias sociales: lingüística, psicología, sociología .................. 276

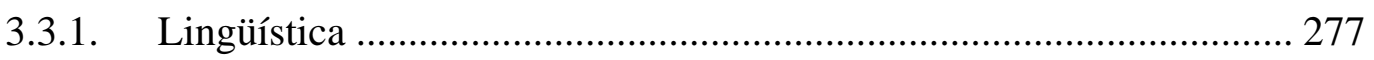

3.3.1.1. Los modelos formales: de las isotopías a la script theory............... 277

3.3.1.2. Teoría de la relevancia .................................................................. 282

3.3.1.3. Pragmática y análisis de la conversación ....................................... 282

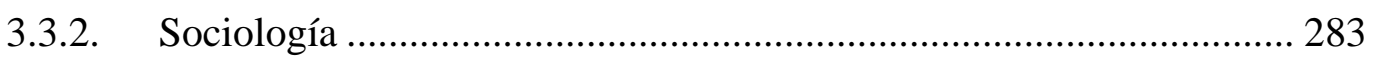

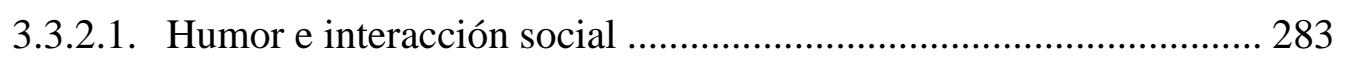

3.3.2.2. El sentido del humor y las jerarquías sociales del gusto ................. 285

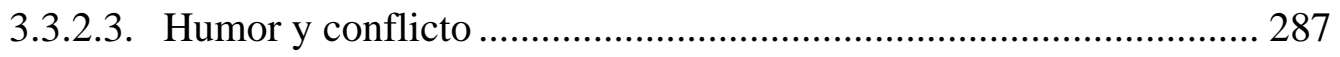

3.4. Apocalípticos e integrados frente a la sociedad humorística .................... 289

3.4.1. Los mitos humorísticos en el pensamiento actual.............................. 289

3.4.2. La «ideología positiva» en las ciencias del humor ............................ 292

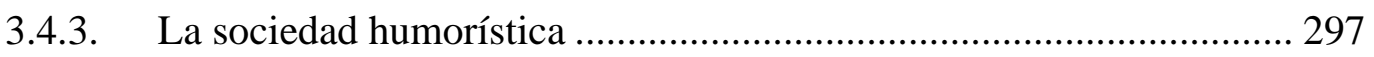

4. LA RETÓRICA CONSTRUCTIVISTA COMO MARCO EPISTEMOLÓGICO Y TEÓRICO .. 305

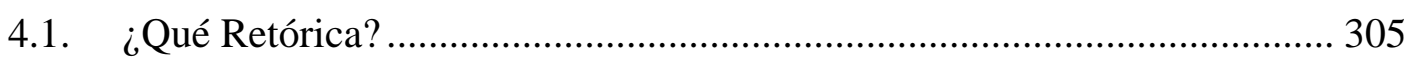

4.1.1. Los orígenes de la Retórica en la antigua sofística........................... 305

4.1.2. Decadencia y reconsideración de la Retórica .................................... 307

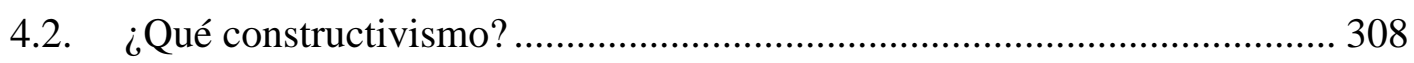

4.2.1. Una aproximación retórico-pragmatista al lenguaje: como uso, como

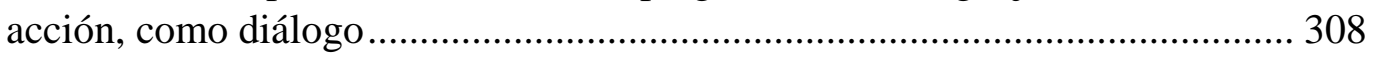


4.2.2. Constructivismo en las ciencias biológicas y cognitivas

4.2.3. El Análisis Crítico del Discurso y el concepto de ideología................ 320

4.3. La Retórica Constructivista................................................................... 330

4.3.1. Retórica y construcción de significado. La recuperación de la elocutio como operación fundamental del discurso.

4.3.2. Retórica y Hermenéutica. La dispositio como operación interpretativa.

4.3.3. Retórica y emociones. Persuadir para convencer. .............................. 336

5. UNA PROPUESTA DE ANÁLISIS DE LOS DISCURSOS HUMORÍSTICOS ....................... 340

5.1. Propedéutica: la estructura de la ironía ................................................ 340

5.2. Lo cómico como fiesta, como juego, como ficción ................................... 344

5.3. Lo cómico como incongruencia, como ruptura de expectativas, como polifonía 351

5.4. Caracterización del personaje cómico 362

5.5. La recepción y el pathos de lo cómico: identificación, distanciamiento, frivolización 366

5.6. Conclusiones: usos de lo cómico 370

III. EL ORDEN HUMORÍSTICO DEL DISCURSO

6. LA ESPECTACULAR VERDAD DEL CUERPO: CAMP, PARODIA E IDENTIDAD TRANSEXUAL EN DOS NOVELAS DE EDUARDO MENDICUTTI. 375

6.1. Camp: de una sensibilidad "gay" a la teoría queer. Conflictos de interpretación en torno a la identidad transexual 383

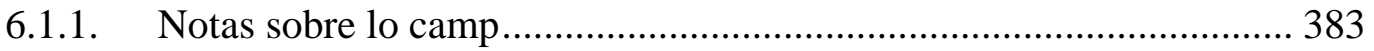

6.1.2. El camp como discurso humorístico ................................................. 389

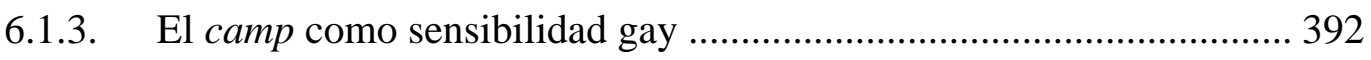

6.1.4. La reapropiación queer del camp.................................................... 396

6.1.5. Camp y drag. La teoría de la identidad performativa de Judith Butler .399

6.1.6. Crítica de Jay Prosser a la lectura butleriana de la transexualidad ..... 405

6.1.7. Conclusiones parciales: el camp como discurso cómico y como problema hermenéutico 412 
6.2. Metáforas travestis y cuerpos transexuales: análisis de Una mala noche la tiene cualquiera

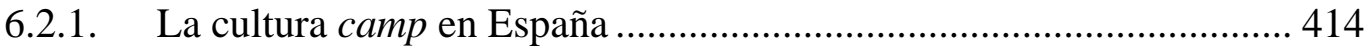

6.2.2. Una mala noche la tiene cualquiera como novela camp.................... 419

6.2.3. Lecturas maricas e histéricas de la Transición................................... 424

6.2.4. El conflicto de interpretaciones ....................................................... 436

6.2.5. La retórica de la lectura y sus metáforas........................................... 447

6.3. La mística del cuerpo en Yo no tengo la culpa de haber nacido tan sexy . 451

6.3.1. Santa Rebecca de Windsor, o un Quijote transexual a lo divino ........ 451

6.3.2. La narrativa autobiográfica del cuerpo transexual según Jay Prosser 457

6.3.3. El camp como mística del cuerpo ...................................................... 464

7. ANÁLISIS IDEOLÓGICO DE UN DISCURSO HUMORÍSTICO DE MASAS. LA MASCULINIDAD EN FRIENDS.

7.1. Psicopolítica del género cómico. El significado social de la comedia de situación 478

7.1.1. Estructura y función de la comedia de situación en su contexto socio-

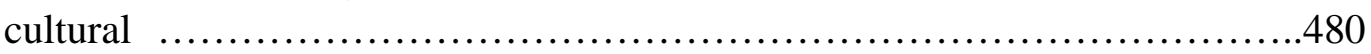

7.1.2. Breve historia de la comedia de situación........................................... 485

7.1.3. La revolución televisiva de Friends: su significado psico-social ....... 492

7.2. El concepto de masculinidad. Parámetros del análisis............................. 500

7.2.1. El estudio de la masculinidad ........................................................ 502

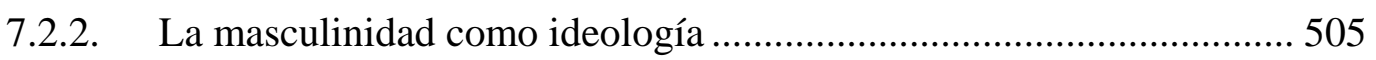

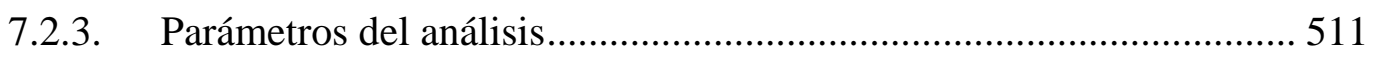

7.3. Análisis de la masculinidad en Friends ................................................... 515

7.3.1. Joey o el latin lover. Hombres, apetitos y sexualidad........................ 521

7.3.2. Ross o el perdedor romántico. Sobre-actuaciones de masculinidad. Hombres, mujeres y relaciones de poder.......................................................... 529

7.3.3. Chandler o el sujeto neurótico. Afeminamiento, ansiedad homosexual y

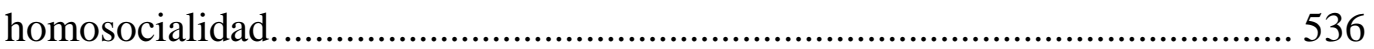

7.3.4. La masculinidad son los otros. La masculinidad como performance. Fantasmas y fantasías de la masculinidad. .................................................... 548

7.4. Conclusiones hermenéuticas: lecturas ideológicas de la Comedia ............ 557

IV. EL ORDEN DEL DISCURSO HUMORÍSTICO......................................... 560 
8. EL DEBATE SOBRE LOS LÍMITES DEL HUMOR EN ESPAÑA

8.1. Dos estudios de caso acerca de la posición actual del humor 564

8.1.1. Una concepción popular del humor: entrevista a Jorge Cremades ..... 564

8.1.2. El humor como provocación: un artículo de Arturo Pérez Reverte.... 571

8.2. El orden del discurso en la aldea global ................................................. 575

8.2.1. Las caricaturas danesas de Mahoma y la tragedia de Charlie Hebdo. 575

8.2.2. Corrección política y guerras culturales ............................................ 581

8.2.3. Identidad social, comunicación en internet y polarización política.... 588

8.3. El debate sobre los límites del humor en España en su contexto político.. 593

8.3.1. Ofendiditos y guerras culturales en el contexto español..................... 593

8.3.2. Algunos discursos de defensa de humoristas ...................................... 598

8.3.3. El conflicto del humor desde el punto de vista del orden del discurso605

8.4. Conclusiones metodológicas

CONCLUSIONES 615

CONCLUSIONS 625

BIBLIOGRAFÍA 634 


\section{INTRODUCCIÓN}

\subsection{OBJETIVOS, MARCO TEÓRICO Y PERSPECTIVA METODOLÓGICA}

El título de este trabajo es El humor como construcción discursiva de identidades sociales y conflicto ideológico. Un estudio desde la Retórica Constructivista y el Análisis del Discurso Social. Su objeto es, por tanto, el humor en su dimensión discursiva; no el uso del humor en discursos de diversa índole (en la conversación, el discurso político o institucional, etc.), sino el «discurso humorístico», aquel que se presenta y circula explícitamente como tal. Muy provisionalmente, definimos el discurso humorístico como aquel tipo de discurso (oral o escrito; lingüístico o audiovisual; mediático, literario o cotidiano, etc.) cuyo propósito manifiesto es resultar divertido o hacer reír, aunque pueda tener otros usos secundarios, como presentar una opinión crítica. Uno de los objetivos de este trabajo es dilucidar qué puede significar que el discurso humorístico «resulte divertido» o «presente una opinión crítica».

Concretamente, los discursos humorísticos se estudiarán desde el punto de vista de su relación con la ideología o lo ideológico. Uno de los lugares comunes más frecuentes al hablar de las relaciones entre el humor y la ideología es el de la capacidad crítica y subversiva del humor, de sus virtudes como antídoto contra el dogmatismo, etc.: a través de la importante tradición de la literatura y el periodismo satíricos o la caricatura, que nace en el siglo XVIII, de comedias cinematográficas como El gran dictador de Charles Chaplin o cómicos como Lenny Bruce... el humor se ha idealizado como uno de los puntales del pensamiento crítico y democrático. Este trabajo no se centra en la tradición del humor satírico, por otra parte abundantemente estudiado; de hecho, en ocasiones toma una postura crítica ante esta idealización. Nuestro interés se centra más bien en la forma en que el discurso humorístico, como todo discurso, es ideológico en un sentido amplio, es decir, que, inmerso en un cierto contexto social y cultural, refleja o refracta el sentido común, los valores, los prejuicios y las visiones del mundo de una comunidad. En este sentido, la postura opuesta a la idealización del humor es la condena del mismo como vehículo y perpetuador de estereotipos, actitudes y prejuicios negativos (sexistas, racistas, etc.). Este trabajo se quiere posicionar en un lugar intermedio: reconoce que existen discursos humorísticos críticos y otros conservadores, pero se interesa más por los que son ambivalentes, los que pueden dar lugar a interpretaciones, valoraciones y 
reacciones opuestas, así como por los rasgos formales y los factores contextuales que favorecen esta ambigüedad. Es más: nuestra postura principal es que es improductivo establecer generalizaciones acerca del carácter ideológico del humor, que es necesario analizar cada caso en su contexto concreto, y que, en última instancia, la cualidad de un discurso humorístico depende por entero de la actitud y la posición del intérprete en su contexto.

Los dos fenómenos ideológicos que se estudian en este trabajo son, como su título indica, la «identidad social» y el «conflicto». La «identidad social» se trata en este trabajo como un fenómeno ideológico en dos sentidos: en primer lugar, cada grupo social se define en parte por compartir una ideología en el sentido de visión de mundo o conjunto de creencias, valores, representaciones, etc. (Van Dijk, 2003a); en segundo lugar, cada ideología crea y representa identidades sociales de determinada manera (por ejemplo, una ideología sexista conceptualiza de un modo muy concreto las identidades de hombres, mujeres y personas homosexuales). Sus relaciones con el humor son evidentes: por una parte, es un lugar común que cada cultura, cada nación, cada grupo social, tiene su particular sentido del humor, difícilmente trasladable a otros grupos. No solo nos referimos al estilo: cada grupo social se ríe o no de las mismas cosas porque comparte ciertas creencias, valoras, representaciones sociales, etc. Por otra, el propio discurso humorístico, como argumentaremos, se construye en referencia a ciertos estereotipos y lugares comunes que contribuyen a la constitución de diferentes identidades sociales: de este modo, a través de ciertos géneros y tradiciones humorísticas se perfilan las figuras del «político corrupto» o el «homosexual afeminado» - o bien se cuestionan y critican estos mismos estereotipos.

El segundo aspecto en el que se centra el análisis es el del «conflicto ideológico» al que puede dar lugar el humor. Es notorio cómo diferentes discursos humorísticos son frecuentemente motivo de polémicas públicas y políticas, en ocasiones con trágicas consecuencias, como es el caso del atentado contra la revista satírica Charlie Hebdo acaecido en 2015. A lo largo de este trabajo estudiaremos los aspectos del discurso humorístico que parecen explicar su especial proclividad a causar polémicas y controversias, pero sobre todo nos centraremos en los discursos sobre el humor, analizando las estrategias retóricas y los presupuestos ideológicos que les subyacen.

La perspectiva adoptada en este trabajo se apoya en el marco teórico de la Retórica Constructivista (Pujante Sánchez y Morales López, 2013; Pujante Sánchez, 2016, 2017, 
2018), que considera que la percepción individual y social de la realidad se da exclusivamente en forma de discursos que son construcciones interpretativas determinadas por el contexto histórico, social y cultural. Desde esta perspectiva constructivista se considera, por una parte, que el discurso humorístico, como todo discurso, es una interpretación particular de la realidad social basada en presupuestos ideológicos concretos; y, por otra, que las distintas concepciones que se puedan tener del humor, que guían tanto la producción como la recepción de los discursos humorísticos, son ellas mismas construcciones discursivas, ideológicas y variables. No existe una “esencia” del humor, una descripción del discurso humorístico que pueda aplicarse a cualquier caso en cualquier contexto, tanto a una comedia de Aristófanes como a un chiste visual difundido en internet, sino que es preciso atender al contexto particular en que se da cada uno, y particularmente a la concepción y significación social que dicho contexto otorga al humor. Esta premisa se aplica tanto a la recepción cotidiana como a la artística o la académica, y uno de los objetivos de este trabajo es mostrar cómo ciertas consideraciones ideológicas determinan la visión que teóricos, críticos y estudiosos del humor en general dan de este fenómeno.

La Retórica Constructivista se apoya, en parte, en la tradición del Análisis Crítico del Discurso (Morales López, 2013), pero, sobre todo, en la milenaria tradición de la Retórica, recuperando su dimensión originaria de ciencia global de discurso en su contexto (García Berrio, 1984; Albaladejo, 1993; Pujante Sánchez, 2003a). Este inmenso bagaje teórico y analítico le permite, como a casi ninguna disciplina, analizar el discurso desde una perspectiva integral, siendo capaz de analizar los mecanismos formales y su dimensión lingüística y argumentativa (su «microestructura») en toda su concreción, como estrategias de construcción del significado discursivo (la «macroestructura») y sobre todo en relación no solo con su contexto en su sentido más o menos amplio de los factores que determinan dicho significado, sino también con su intención retórica persuasiva, su uso (la «situación retórica»). El análisis retórico, en resumen, nos permite salvar la ilusoria distancia entre la forma y el contenido; y entender los diferentes mecanismos lingüísticos como orientados a la construcción de un significado particular que tiene ciertos objetivos sociales persuasivos.

Más concretamente, la perspectiva de este trabajo es fundamentalmente hermenéutica, ya que coloca la interpretación en el centro, en varios sentidos. En primer lugar, el objetivo de este trabajo no es presentar una hipótesis teórica en su sentido fuerte 
de realizar una descripción más o menos abstracta del discurso humorístico y sus rasgos formales, así como de la relación que estos rasgos formales establecen con su contenido ideológico, para luego probar sistemáticamente su validez en un corpus determinado. Al contrario, esta tesis toma la forma de una serie de estudios de caso, de análisis de discursos de distinta índole (literario, audiovisual, mediático), en distintos contextos, y que pertenecen a tradiciones y géneros humorísticos diferentes. De este modo, se propone mostrar la notable complejidad y variedad de los discursos humorísticos y de las relaciones que establece con diferentes contextos históricos, sociales y culturales, y con otros discursos artísticos, ideológicos, políticos y sociales; así como de los diversos aspectos y modos de acercamiento que se ponen en juego al hablar del humor. Así, este trabajo no busca dar una respuesta simple a la cuestión de la relación entre el humor y la ideología, o de las implicaciones ideológicas del discurso humorístico, sino explorar las diferentes formas en las que se puede responder a las preguntas «¿qué se puede decir de un discurso humorístico?», «¿cómo se puede leer el humor?».

La perspectiva de este trabajo es hermenéutica también en el sentido de que, como hemos dicho, considera que el humor es, como todo discurso, una construcción interpretativa, una interpretación de la realidad desde determinados presupuestos ideológicos. Pero, al mismo tiempo, sostiene que el humor es un modo discursivo concreto, cercano o asimilable al artístico, que hace que tanto esta interpretación de la realidad como su relación con sus presupuestos ideológicos sea compleja y particularmente ambigua. De este modo, el humor es un discurso que puede dar lugar a interpretaciones muy diferentes - y, en este sentido, cuando hablamos de «conflicto ideológico» hacemos referencia también a un conflicto de interpretaciones. Estas interpretaciones son, a su vez, construcciones discursivas, sujetas ellas mismas a unos presupuestos interpretativos e ideológicos determinados. Por esta razón, los análisis de este trabajo se enfocan en el modo en que los diferentes discursos humorísticos pueden ser interpretados: desde qué concepciones del humor y con qué implicaciones ideológicas.

Hablamos de diferentes concepciones del humor porque, como decimos, no existe de una esencia fija del discurso humorístico. Por ello, más que las clasificaciones que se han intentado desde diversas disciplinas de los distintos tipos de humor o de los mecanismos y técnicas humorísticas, verbales y no verbales, que puedan emplear, nos interesan las distintas tradiciones y géneros cómicos (concibiendo los «géneros» no como esencias sino como convenciones históricas): la comedia, la sátira, la farsa, la caricatura, 
el vodevil... Estas tradiciones y géneros no solo determinan la forma o el contenido de los discursos humorísticos, sino también la manera en que estos discursos se reciben, los usos que se les da y los efectos que se les atribuye. Así, existen tradiciones de pensamiento que entienden el humor como una forma de pensamiento crítico, y que dan lugar a que determinados discursos pertenecientes a dicha tradición, asociados a ciertos géneros como los satíricos, se reciban y se interpreten como instancias críticas de otros discursos. En esta línea, hablaremos de dos «mitos humorísticos» generales y muy presentes en nuestra sociedad: uno "popular" que concibe el humor como un discurso de entretenimiento, que no tiene más objetivo que divertir y que por tanto es inocuo; y otro “intelectual” que lo entiende, como decimos, como forma de pensamiento crítico y racional, lo que garantiza su objetividad y su valor de verdad. Frente a estas dos tradiciones, se sitúan algunas posiciones críticas, ciertamente minoritarias en la actualidad, que hacen hincapié en la violencia o frivolidad que entraña el humor. Cuando estas distintas concepciones del humor se encuentran, se produce el conflicto.

\subsection{ESTRUCTURA DEL TRABAJO}

Parte de la tarea de este trabajo es, por tanto, estudiar las concepciones del humor que subyacen a las interpretaciones analizadas y trazar su genealogía. La perspectiva hermenéutica nos lleva, en suma, a adoptar un enfoque historicista si queremos analizar con rigor el fenómeno humorístico. Como apunta Gadamer, «el que no quiera dejarse llevar por el lengujae sino que pretenda una autocomprensión histórica se ve obligado a moverse incesantemente entre cuestionas de historia de las palabras y los conceptos» (Gadamer, 2012: 38). Del mismo modo, Michael Billig afirma que si se quiere adoptar una mirada crítica ante cualquier fenómeno ideológico es necesario estudiar la historia de dichos fenómenos, descubrir las formas y significados que han ido adoptando con el fin de dilucidar sus transformaciones y sus implicaciones para el presente (Billig, 2005: 67). En definitiva, aunque no podamos describir de manera total y universal un fenómeno como el humor, estudiar las diferentes formas históricas que ha tomado y las diferentes visiones que sobre el mismo se han ofrecido, nos permiten acercarnos a una naturaleza compleja, multifacética, fundamentalmente ambigua.

Un estudio histórico general de la risa, los géneros cómicos y los fenómenos humorísticos en general, y sobre todo del pensamiento sobre estos mismos fenómenos, 
ocupará la primera parte del trabajo. En el primer capítulo estudiaremos los periodos históricos antiguo y medieval: la presencia de la risa y lo cómico en la religión, los rituales, el arte, el teatro, la literatura, la filosofía y el pensamiento griegos; así como en la teología y en la sociedad medieval. Este largo período está caracterizado por una visión de la risa fundamentalmente distinta a nuestra concepción contemporánea del humor, determinada por su dimensión fisiológica, corporal, que la liga a otros aspectos como la sexualidad, la locura, y justifica su presencia en ciertas creencias y rituales religiosos y populares. Esto ofrece al estudioso una cierta dimensión «antropológica» de lo cómico, pero sobre todo demuestra, por oposición, cuán diferente es nuestro propio modo de entender la categoría y el fenómeno de lo cómico. Los diferentes acercamientos a lo cómico y la risa en la Antigüedad y la Edad Media también son prueba de hasta qué punto los diferentes intereses y contextos sociales y culturales de cada momento determinan la visión de estos períodos: así, las interpretaciones de la significación social de la comedia aristofánica o de las fiestas medievales carnavalescas están determinadas por ciertas preconcepciones de la importancia universal de la risa, así como a su vez sirven de pretexto para diferentes idealizaciones, como la de la esencial vitalidad subversiva de la comedia o los géneros carnavalescos. Por otra parte, Grecia, Roma y la Europa medieval nos legan importantísimas tradiciones literarias (como la Comedia Nueva o la sátira), artísticas e iconográficas (como la tradición de lo grotesco o la imaginería de la commedia dell'arte) y reflexiones éticas y filosóficas (la ironía socrática, la eutrapelia o buen humor aristotélico, el vitalismo de la risa festiva, etc.).

El segundo capítulo se centra en los siglos XVIII y XIX, período que va a determinar nuestra visión contemporánea del humor. A la desaparición de la fiesta carnavalesca en su significado original le sigue su formalización en la tradición de la caricatura, la literatura satírica o burlesca, o la comedia de caracteres de Molière; más aún, la emergencia del racionalismo da lugar a que la risa desaparezca del pensamiento sobre lo cómico y el humor pase a ser visto como un fenómeno puramente lingüístico y cognitivo. Esta transformación culminará con las importantes teorizaciones románticas y decimonónicas, algunas de las cuales, como las reflexiones de Friedrich Schlegel sobre la ironía, serán muy influyentes en el pensamiento del siglo XX.

El tercer capítulo sirve de transición entre el estudio histórico y el teórico. Expone los diferentes acercamientos al fenómeno humorístico que durante el siglo XX se han realizado desde diferentes perspectivas científicas: el psicoanálisis, tendencia inaugurada 
por el fundamental estudio de Freud sobre el chiste (2012); la teoría y la crítica literarias y su atención a la comedia y la ironía; y las ciencias sociales (lingüística, psicología y sociología), que se han centrado en el papel que el humor tiene en las interacciones sociales cotidianas. El capítulo se cierra con las reflexiones que algunos sociólogos y críticos marxistas como Debord, Baudrillard, Lipovetsky o Fredric Jameson han realizado acerca del importante papel que el humor, asociado a lo lúdico y lo frívolo, tiene en la constitución ideológica de la actual cultura de masas.

El cuarto capítulo expone los presupuestos teóricos de la Retórica Constructivista y cómo estos determinan nuestro enfoque analítico. El quinto realiza una sumaria recapitulación de algunos de los rasgos del discurso humorísticos que hemos encontrado pertinentes para los análisis realizados en los capítulos siguientes. Este capítulo no presenta, como decimos, una teoría del humor ni se presenta como una descripción exhaustiva y definitiva de los discursos humorísticos, sino que describe algunos elementos que, desde nuestra propia perspectiva interpretativa, pondremos en juego. En este sentido, a pesar de la obligada presentación lineal de este trabajo, cabe señalar que estas consideraciones no constituyen tanto un marco interpretativo a priori, sino que más bien son inducciones y reflexiones a partir de los aspectos y dificultades que hemos encontrado en el curso de los análisis concretos que se presentan en los últimos capítulos.

Los capítulos sexto, séptimo y octavo, como decimos, constituyen la parte analítica del trabajo. En el primero de ellos se estudian dos novelas del escritor español Eduardo Mendicutti, Una mala noche la tiene cualquiera (1982) y Yo no tengo la culpa de haber nacido tan sexy (1997), y su relación con la llamada estética o sensibilidad camp, muy ligada a la cultura homosexual norteamericana y española del siglo XX - hasta el punto de que hablaremos de lo camp como uno de los elementos principales de la identidad social y cultural de la comunidad gay. Estas novelas, además, tienen como sendas protagonistas a dos mujeres transexuales pertenecientes a dos épocas muy diferentes de la situación social del colectivo transexual español (la Transición y los años noventa), lo que nos permitirá estudiar la plasmación de la identidad transexual en el discurso camp. El segundo capítulo analítico estudia la representación de la identidad masculina en la popular comedia estadounidense ${ }^{1}$ Friends (1994-2004). De este modo,

\footnotetext{
${ }^{1}$ Podría cuestionarse la pertinencia de incluir una ficción angloamericana en un corpus a primera vista español. Se pueden aducir varias explicaciones de este hecho: en primer lugar, sencillamente no se ha considerado el criterio geográfico como significativo para los objetivos de este trabajo; en segundo lugar, se podría alegar que Friends, al ser una serie televisiva enormemente popular, también está muy presente
} 
se incluye en el trabajo el análisis ideológico de un discurso humorístico popular, inclusión necesaria por varios motivos: en primer lugar, si uno de los aspectos que investiga este trabajo es cómo el discurso humorístico puede transmitir y perpetuar discursos ideológicos, es necesario estudiar uno de estos discursos por su amplia difusión y aceptación; en segundo lugar, y sobre todo, el humor es, antes que nada, un fenómeno popular, masivamente presente en la cultura popular de todos los tiempos y especialmente en la contemporánea. En suma, un trabajo como el que se presenta no estaría completo sin incluir en su corpus un discurso humorístico popular.

El octavo capítulo se centrará en la dimensión polémica del humor. En España, concretamente, viene dándose en los últimos años un debate en la opinión pública, a través de medios de comunicación y en ocasiones a raíz de demandas judiciales contra determinados humoristas o medios cómicos como El Mundo Today o las revistas Mongolia y El Jueves, acerca de los límites del humor. En este debate se plantea si es legítimo permitir la circulación de discursos humorísticos que pueden ser considerados perniciosos por su cualidad sexista, racista, etc., o que frivoliza sobre temas sociales espinosos como el sentimiento religioso, la enfermedad... Por otra parte, se discute si este planteamiento no puede dar lugar a una actitud censora que, al prohibir la circulación de ciertos tipos de humor, coarta la libertad de expresión. En esta ocasión, se desplaza el foco del análisis de los discursos propiamente humorísticos a los discursos sobre el humor, a favor o en contra de ciertos discursos u humoristas concretos, con el objetivo de analizar qué argumentos se utilizan, qué concepciones del humor les subyacen, qué relaciones establecen con otros temas como la libertad de expresión, y qué implicaciones ideológicas tienen estos discursos. El corpus de este capítulo está conformado principalmente por artículos de opinión publicados en diferentes periódicos y revistas generalistas, así como comunicados oficiales de los humoristas implicados en alguna polémica, aparecidos en sus redes sociales.

A pesar de que parece que los dos primeros capítulos analíticos se centran en lo que concierne a la «identidad social», y el tercero, al «conflicto ideológico», todos los capítulos de este trabajo, incluidos los históricos y teóricos, están atravesados por ambos factores. En cierto sentido, las identidades sociales y los conflictos están mutuamente

en el contexto cultural español. Por otra parte, lo cierto es que en los otros dos capítulos analíticos, tanto en el dedicado a la obra de Mendicutti como el posterior centrado en el debate español sobre los límites del humor, hacen referencia a elementos contextuales, de índole social y cultural, provenientes de Estados Unidos. 
implicados: se produce un conflicto ideológico cuando un determinado discurso choca con las premisas ideológicas propias de un colectivo; en otro, como veremos, algunos discursos humorísticos se utilizan conscientemente como arma polémica contra un cierto colectivo: no solo un discurso satírico puede criticar cierto grupo (cierto partido político, cierta institución); también la crítica de un tipo de humor puede constituir una crítica a un grupo social con el que se identifico, o la acusación de falta de sentido del humor puede servir como estrategia polémica en una discusión ideológica.

Además, desde una perspectiva más general, argumentaremos que el discurso humorístico es un discurso particularmente ambiguo que se presta a interpretaciones diversas e incluso contradictorias. Veremos cómo la cultura camp se ha visto como una práctica que perpetúa algunos estereotipos negativos acerca de la homosexualidad, o, por el contrario, como un discurso particularmente crítico con dichos estereotipos y la sociedad en general; también estudiaremos cómo Una mala noche la tiene cualquiera, ambientada en la Transición española y el intento de golpe de Estado del 23-F, ha sido leída de formas diametralmente opuestas según las premisas ideológicas del intérprete: o bien ha sido entendida como una celebración apologética del proceso democratizador, o bien como una ácida crítica al período que abarca desde la muerte de Franco a la consolidación de la democracia. Por otra parte, veremos cómo la serie Friends ha atraído desde su estreno a la par críticas y alabanzas, acusada de retrógrada o celebrada como progresista; también intentaremos demostrar en el curso de nuestro análisis cómo, efectivamente, y por su propia naturaleza de discurso cómico, puede ser interpretada de manera ambivalente.

\subsection{ESTADO DE LA CUESTIÓN Y OTRA BIBLIOGRAFÍA RELEVANTE}

Si el estudio del humor es potencialmente infinito, la bibliografía sobre él lo es más. Lo cómico ha atraído las reflexiones de filósofos y literatos ilustres desde Platón hasta Kant, Schopenhauer o Baudelaire (Ballart, 1994; Billig, 2005; Morreall, 1983), y ya en el pasado siglo contamos con profundas indagaciones como las de Bergson (2016), Freud (2012) o Escarpit (1967). Si el siglo XX parece haber dado lugar a un estudio cada vez más sistemático del humor, es en los últimos años cuando podemos decir que se ha consolidado como disciplina, con la fundación de diversas asociaciones y centros de investigación, como la francesa CORHUM o la International Society for Humor Studies; 
así como sendas revistas científicas asociadas, Humoresques y Humor. International Journnal of Humor Research, respectivamente. Mouton de Gruyer tiene desde 2001 una línea editorial dedicada exclusivamente a estudios sobre el humor. En España contamos con el grupo de investigación GRIALE (Grupo de Investigación sobre Ironía y Humor en Español), que ha dado un gran impulso a la investigación lingüística del humor en español, así como GRICOHUSA, el Grupo de Investigación de la Comunicación, el Humor y la Sátira, que se ha centrado en el estudio de la tradición satírica.

El campo de investigación del humor, por tanto, es genuinamente multidisciplinar. Por un lado, la historiografía francesa inspirada por la Escuela de los Annales, y particularmente su interés por la historia de las mentalidades, ha abierto un fecundo campo de estudio en la historia de la risa y del humor, capitaneado por Jacques Le Goff (1977, 1999), que ha dado grandes estudios como la Histoire du rire et de la dérision, de George Minois (2000), una de las principales obras de referencia en este trabajo, y varios monográficos como los de Bertrand (1995) o Ménager (1995); la obra del helenista Stephen Halliwell (2008) sobre la risa en la mentalidad griega (2008) es igualmente indispensable para el estudio de dicho período, así como una lección de erudición y rigor interpretativo. Por supuesto, la legendaria obra de Bajtín, La cultura popular en la Edad Media y el Renacimiento. El contexto de la obra de Rabelais (1998), así como sus diversos estudios de la literatura carnavalesca $(1989,2012)$ son puntos de partida inexcusables para cualquier reflexión sobre lo cómico. Así mismo, el libro de Pere Ballart Eironeia (1994) constituye una importante introducción a la historia del pensamiento filosófico y literario sobre la ironía.

Por otra parte, la lingüística ha contribuido formidablemente a la adopción de una visión teórica sistemática para el estudio lingüístico formal del humor. Con sus ventajas y limitaciones, las propuestas de Victor Raskin (1985) y Salvatore Attardo (1994, 2001; Attardo y Raskin, 1991) han determinado gran parte de la investigación humorística en ese campo. Tampoco hay que desdeñar las aportaciones realizadas desde la sociología o la psicología.

Entre toda la bibliografía disponible para el investigador, algunos libros y autores han sido especialmente relevantes. La Histoire du rire de Minois, como decimos, ha sido una obra de referencia en el aspecto histórico de este trabajo, en su calidad de recopilación y sistematización de la vasta bibliografía existente en dicho ámbito, además de haber sido complementado con los ya mencionados monográficos de Halliwell, Ménager, Bertrand, 
y otros. En esta línea, también ha sido una referencia muy sugestiva el libro de la historiadora del arte Frances S. Conelly (2015) sobre la tradición cultural y pictórica de lo grotesco, que ha servido para complementar nuestra formación principalmente literaria y filosófica con una perspectiva artística más amplia, y nos ha motivado a establecer importantes relaciones de parentesco de algunas tradiciones cómicas con otros fenómenos como el del manierismo en el arte o lo siniestro.

En nuestro entendimiento general del humor, la mayor inspiración la hemos encontrado en el libro del filósofo francés Henri Bergson, Ensayo sobre la significación de lo cómico. Otra gran influencia en la perspectiva crítica tomada en este trabajo ha sido el singular trabajo de Michael Billig, Laughter and ridicule (2005). En esta obra, el profesor de Loughborough polemiza con la visión imperante del humor como algo esencialmente beneficioso, analizando las raíces ideológicas de dicha visión y destacando los aspectos negativos que pueden estar en la base del fenómeno humorístico, inspirando tanto la necesidad de un amplio sentido histórico como una visión crítica en la lectura y asimilación de las distintas teorías actuales sobre el humor.

La Retórica Constructivista es un marco teórico fundamentalmente transdisciplinar: se nutre del pensamiento sofístico antiguo, el nietzscheano, la hermenéutica, la deconstrucción, el constructivismo socio-cognitivo e incluso las aportaciones de neurobiólogos como Humberto Maturana o Antonio Damasio. En nuestro acercamiento a los diferentes discursos humorísticos y los aspectos relacionados también nos hemos apoyado en otras disciplinas además de las principales fuentes, primarias y secundarias, sobre lo humorístico: hemos acudido a la obra de antropólogos como Victor Turner (1982) y Mary Douglas (2007) para la correcta dilucidación del significado de lo cómico en los sistemas de creencias de las sociedades preindustriales, y, en relación con sus aportaciones hemos adoptado en nuestros análisis y reflexiones generales algunas de las perspectivas abiertas por Freud y el psicoanálisis. Muchas otras corrientes de pensamiento subyacen a nuestros análisis y premisas teóricas: la hermenéutica de Gadamer (2012) y Paul Ricoeur (1980, 2001); la filosofía del lenguaje de Bajtín y su círculo (Bajtín, 1989, 2011; Voloshinov, 2009); las posiciones pragmatistas de Richard Rorty (1996, 2001, 2013) y Stanley Fish (1980, 1992); la polifacética obra de Michel Foucault (2005, 2009b, 2009a, 2015, 2017); el materialismo cultural de Raymond Williams (1982) o el tratamiento de Umberto Eco de la cultura de masas (2013); las teorías sobre la ideología de autores marxistas como Althusser (2003) o Žižek (2018)... 
Como hemos mencionado, en los capítulos sexto y séptimo hemos tomado como hilo temático conductor del análisis la identidad sexual y de género en su dimensión ideológica, por lo que para nuestro cometido han sido fundamentales las aportaciones de Judith Butler (2007) y de distintas teorías queer (Bernini, 2018), así como otros acercamientos de corte sociológico a la masculinidad como los de Raewyn Connell (2005) y Óscar Guasch (2006). 


\section{INTRODUCTION}

\subsection{GOALS, THEORETICAL FRAMEWORK AND METHODOLOGICAL APPROACH}

The title of this work is «Humour as a discursive construction of social identities and ideological conflict. A study from Constructivist Rhetorics and Social Discourse Analysis». Its subject matter is, hence, humour in its discursive dimension; not the use of humour within discourses of various kinds (in everyday conversation, political or institutional discourse, and so on), but humourousdiscourse, that which is presented and explicitly circulates as such. Provisionally we will define humouristic discourse as that type of discourse (written or spoken; verbal or audiovisual; media, artistic or everyday discourse...) which overt purpose is to produce amusement or to make people laugh, although it can be used to secondary aims, such as presenting a critical opinion. One of this work's aims is to clarify what it means for humourousdiscourse to «be amusing» or «present a critical opinion».

Specifically, humourousdiscourses will be studied from the point of view of their links to ideology. One of the most frequent commonplaces when speaking of humor in its relationship with ideology is its ability to be critical and subversive, its power/potential as an antidote against dogmatism and such: through the important literary and journalistic tradition of satire or caricature, born in the 18th century, famous comedies such as The Great Dictator by Charles Chaplin or comedians of the likes of Lenny Bruce, humor has been highly idealised as a one of the most useful means of critical and democratic thinking. This work does not focus on the much-studied satiric tradition - indeed, it sometimes takes a critical stance against this idealisation. It is more interested in the way in which humourousdiscourse, like every kind of discourse, is ideological in a broad sense, that is, humourousdiscourse, engaged in a certain social and cultural context, reflects and refracts the values, commonsense biases and world-visions of a community. In this respect, the opposed view to the idealised one consists of the disapproval of humour as a vehicle and perpetuator of negative prejudices and attitudes - linked to sexism, racism, and so on. This work aims to set itself in the middle: it aknowledges that there are both "critical” and "conservative" humourousdiscourses, but it pays more attention to those which are ambivalent, those which can be interpreted and evaluated in different or opposed ways, as well as the formal and contextual features which foster this 
ambiguity. Furthermore, its main stance is that it is not useful to try to make general assumptions about humour, but that it is necessary to analyse each discourse in its specific context, and that the traits of each humourousdiscourse ultimately depends on the attitude of the reader.

Two ideological aspects will be analyzed: «social identity» and «conflict». In this work, social identity is seen as an ideological phenomenon in two ways: first, each social group is defined by a shared ideology or world view in the shape of a set of certain beliefs, values, representations, etc. (Van Dijk, 2003a); secondly, each ideology produces and represents social identities in specific ways (e.g. a sexist ideology will conceive the identities of men, women, homosexuals and others in a particular way ). The link between social identities and humour is clear: on one hand, it is broadly accepted that each culture, each country, each social group, has its own sense of humor, hardly easily translated to other groups. We are not just referring to style: each social group laughs at the same things (or does not) because they share certain beliefs, values orsocial representations. On the other hand, humourousdiscourse itself, as we will argue, is produced alluding to certain stereotypes and commonplaces which contribute to the conception of social identities: for example, humourousthe characters of the «corrupt politician» or the «sissy» can either be built or maybe criticized through some humourousgenres and traditions.

The second notion this work is focused on is «ideological conflict» which may be caused by humour. It is remarkable how often some humourousdiscourses are a point of public and political contention, sometimes resulting in tragic events like the attack against the satirical magazine Charlie Hebdo in 2015. Over the course of this pages we will cover some aspects of humourousdiscourse which may explain its special proclivity to triggering controversies -but mainly we will focus on discourses about humour analysing their rhetorical strategies and the ideological assumptions implied in them.

The approach undertaken in this investigation is that of Constructivist Rhetoric (Pujante Sánchez and Morales López, 2013; Pujante Sánchez, 2016, 2017, 2018). This theoretical framework considers individual and social perception of reality as discursively constructed as a result of an interpretation which depends on its historical, cultural and social background. From this constructivist point of view, humourousdiscourse is regarded as a specific interpretation of social reality based on an ideological basis. Moreover, it is considered that every different idea about humour is in itself ideological and a variable discursive construction. There is no such thing as an essence of humour, $a$ 
description of humourousdiscourse that can be applied to every specific case under any circumstance, be it a comedy by Aristophanes or some visual joke on the internet. It is necessary to pay attention to the particular context in which each discourse appears, especially to the notion and social meaning given to humour. This assumption is applied to academic or artistic discourse as much as everyday conversation. Indeed, one of the goals of this work is to analyse how certain ideological premises determine the views which theoriticians, critics and scholars in general hold about humour.

Constructivist Rhetoric relies partly on Critical Discourse Analysis (Morales López, 2013), but it is mostly based on the millenary rhetorical tradicion, restoring its original thrust as a global science of discourse (García Berrio, 1984; Albaladejo, 1993; Pujante Sánchez, 2003a). This immensely rich theoretical and analytical background allows for discourse analysis from a comprehensive point of view, being able of analysing its formal mechanisms in its verbal and argumentative dimension in detail as strategies for the construction of meaning, especially as far as its context and above all its persuasive intentions, its use, are concerned. Briefly, rhetorical analysis allows us to avoid the fictitious distance between form and content, and to understand the different verbal mechanisms directed to the construction of a particular meaning aiming to particular social purposes.

More specifically, the approach undertaken in this work is mostly hermeneutical for it focuses on interpretation in various senses. First, offering some theoretical hypothesis, i.e. a more or less abstract description of humourousdiscourse, its formal features and its relations with ideological contents in order to test them in a systematically produced corpus is not the goal. On the contrary, this thesis is shaped as a collection of case studies thoroughly analysing different discourses (literary, audiovisual, media discourses), set in different backgrounds and belonging to different humourousgenres and traditions. This way, it aims to show the notorious variety and complexity of humourousdiscourse, the relationships it can establish with different social, cultural and historical contexts, other artistic, ideological, political and social discourses and the different approaches that can be taken when discussing humour. This work does not intend to provide a simple answer to the relationship between humour and ideology, or to the ideological implications of humourousdiscourse, but to explore the different ways questions such as «What can be said about humourousdiscourse?» or «How can humour be interpreted?» can be answered. 
The approach undertaken in this work is also hermeneutic in the sense that, as it has been said, it regards humour as an interpretive construction, an interpretation of reality from certain ideological points of view. However at the same time it asserts that humour is a special discursive mode, close to artistic discourse, meaning that this interpretation of reality and its relation to its ideological assumptions is complex and ambiguous. An analysis of the sitcom Friends will allow us to study how a comic discourse reportedly simple can complicate the functioning of ideology. Humour is a kind of discourse that can result in very different readings, so when we talk about ideological conflict we are also speaking of conflicting interpretations. These interpretations are themselves discursive constructions and vary depending on the interpreter's own ideological assumptions. This is the reason why analysis in this work focus on the manners in which different humourousdiscourses can be read, namely from which views and with which ideological implications. In the analysis of the novels by Eduardo Mendicutti we will see how a particular view of humourousdiscourse which is frivolous and shallow can indirectly determine the way in which trans identity is conceptualized.

We speak of different conceptions of humour because, as mentioned, there is no fixed essence of humourousdiscourse. More than in the various clasifications of types of humour attempted by different disciplines or the lists of mechanisms and comic techniques, we are interested in the different comic traditions and genres (conceiving genres as historical conventions and not abstract rules of formation) such as comedy, satire, farce, cartoon... These genres and traditions not only determine the style or the content of humourousdiscourses, but also how they are received and read, how they are used and the effect they are said to have. Thus, there are traditions which conceive humour as a form of critical thinking, and in this way humourousdiscourses belonging to these traditions are received and read as critical. In this respect, we will refer to two general «humourousmyths» existing in our contemporary society: one is a "popular" view which conceives humour as a form of enterteainment with no other goal than to amuse others; humour in this view is therefore seen as inocuous. The other myth is an "intellectual" one and envisages humour as a manner of rational and critical thinking, which guarantees its objectivity and truth value. Opposite to these traditions, there are some minority critical opinions which emphasise the trivialisation or even violence which humour entails. When these different conceptions of humour collide, conflict is served. 


\subsection{STRUCTURE OF THIS THESIS}

Part of the task assumed by this work is, thus, to study the conceptions of humour underlying the analysed interpretations and to outline its genealogy. The hermeneutic perspective leads us to embrace a historicist approach if we want to analyse rigorously the humourous phenomenon. As Gadamer points out, «el que no quiera dejarse llevar por el lenguaje sino que pretenda una autocomprensión histórica se ve obligado a moverse incesantemente entre cuestionas de historia de las palabras y los conceptos» (Gadamer, 2012: 38) [«the one who does not be carried away by language but who intends a historical self-comprehension is required to move relentlessly within the history of words and concepts»]. In a similar way, Michael Billig claims that if it is aimed to adopt a critical look before any ideological phenomenon, as in this work, it is required to study the history of said phenomenons, to trace the forms and meanings adopted over time in order to uncover its implications in the present (Billig, 2005: 6-7). To sum up, although we can not describe entirely humourous phenomenon, to study the different forms it has assumed and different views offered on it will allow us to approach to its most complex, polifacetic and ambiguous nature.

This historical approach is present in each one of the chapters that encompass the analytical part of this work: the history of camp, the history of the conceptions of transsexuality or masculinity, the history of sitcom as a genre, the genealogy of concepts such as "political correctness», etc. will prove essential to the understanding of the discourses analysed in these chapters. In addition, a general study on the history of laughter, comical artistic and literary genres, humourous phenomena and their conception will make up the first part of this work. In the first chapter we will study the ancient and medieval ages: the prominent role of laughing and comedy in Greek religion, theatre, literature, philosophy and ethics, as well as in medieval theology and society. This long period is characterised by a view on humour and laughter substantively different from our own, determined by a physiological conception which links it to phenomena like sexuality or madness and accounts for its pressence in rituals and religious and popular beliefs. This conception offers a certain «anthropological» dimension to comedy, but moreover it proves how different it is from our way views on it. Different approaches to laughter and comedy during Greek and Medieval times are also evidence of to what extent different interests and social and cultural contexts determine our view of these periods: thus, the different accounts of Aristophanic comedy or carnivalesque festivals are determined by 
certain preconceptions of the general importance of laughter, while they serve as pretence for different idealisations such as the intrinsic vitalism shown by comedy or carnivalesque literature. All things considered, Greece, Rome and Medieval Europe has left us such significant literary (Old Comedy or satire), artistic and iconographic (like grotesque or the commedia dell'arte) traditions and ethical and philosophical considerations like socratic irony, the Aristotelian eutrapelia or «good mood» or the subversive vitalism of comedy and festive laughter.

The second chapter deals with the time period betweenthe $17^{\text {th }}$ and $19^{\text {th }}$ centuries, when our contemporary view on humor will emerge. After the disappearance of medieval festivals and its original meaning, formalization of these festivals in the tradition of caricature, satiric literature, or Molière's Comedy of Character will follow. Moreover, the birth of rationalism will result in a displacement of focus from bodily laughter to humour and the comic as a purely mental and cognitive phenomenon. This change will culminate in the reflections on humour by romantic authors, some of which, like Friedrich Schlegel's considerations on irony, will be enormously influential in the $20^{\text {th }}$ century.

The third chapter works as a transition between historical and theoretical analyses. It explains some of the many approaches to humour during the 20th century from different scientific perspectives: psychoanalysis, in a trend begun by Freud's famous book on jokes, literary criticism and theory and its attention on comedy and irony and social sciencies such as linguistics, sociology or psychology. This chapter ends with the thoughts provided by some marxist critics and sociologists such as Debord, Baudrillard, Lipovetsky or Fredric Jameson on the relevant role played by humour, seen as frivolous in the contemporary mass culture and ideological climate.

The fourth chapter lays out the theoretical premises of Constructivist Rhetorics and how they shape our analytical approach. The fifth chapter carries out, in a much abbreviated fashion, some of the traits of humourous discourse found relevant for the next chapters. This chapter will not present, as mentioned, a humour theory nor will it exhaustively describe the components of humourous discourse, but it lists some elements displayed by our own interpretative point of view. In this sense, despite the mandatory linear presentation of the contents of this work, it is to be noted that these considerations do not build an a priori frame of thinking but come from features and difficulties found during the analysis presented in the last chapters. 
Chapters six, seven and eigth constitute the analytical part of this work. In the first one, we will study two novels by the spanish writer Eduardo Mendicutti, Una mala noche la tiene cualquiera (1982) [«Anybody can have a hard night»] and Yo no tengo la culpa de haber nacido tan sexy (1992) [«It’s not my fault if I was born this hot»], and the relations they establish with camp culture, closely linked to Spanish and American gay culture, to the point that we can speak of camp sensibility as the main feature of gay social and cultural identity in the 20th century. These novels, furthermore, portray two transsexual women from two different periods for the trans community in Spain (the Spanish transition to democracy after Franco's death and the democratic normalization in the nineties) as the main characters. This will enable us to analyse the representation of trans identity within camp aesthetics.

The second chapter studies the representation of masculinity in the popular American sitcom Friends (1994-2004). This way a required ideological analysis of a popular humourous discourse is included. If one of the main subjects of this research is to explain how humourous discourse can display and convey ideological discourses, it is necessary to study one of these popular discourses. On the other hand, we must acknowledge that humour is mainly a popular phenomenon, overwhelmingly present in every culture throughout history, including ours. Thus, this work would not be complete if a popular humourous discourse were not included.

The eighth chapter will focus on the controversies caused by humour. In Spain there is an ongoing public discussion portrayed in the media about the limits of humour, sometimes on account of lawsuits against comedians or humourous media such as $E l$ Mundo Today or satirical magazines Mongolia or El Jueves. This debate is centered around the legitimacy of the spread of humourous discourses in the media that might be considered harmful because of sexist, racist and other features it might contain or because it trivializes serious subjects such as religious beliefs, illnesses, social tragedies, etc. On the other side, it is discussed if this approach against humour can result in the restriction of basic democratic rights such as freedom of speech. This debate will be the subject of the last chapter. This time, the focus is shifted from humourous discourses to discourses about humour, for or against humour or certain comedians. The aim is to analyse which arguments are used, what ideas about humour are displayed, what relationships are established with other issues as freedom of expression, and what ideological assumptions and implications are implied. The body of discourses analysed in this chapter mainly 
consists of opinion pieces published in different journals and magazines and official statements by comedians involved in this kind of controversies.

Although it would appear that the two first analytical chapters focus on social identity while the last one focuses on conflict, all chapters, including the historical and theoretical ones actually revolve around both factors. Social identities and conflict are mutually implied: an ideological conflict is developed when certain discourse collides with ideological premises of certain communities. Furthermore, as we will see, some humourous discourses are explicitly used as a controversial weapon against some social groups: a satirical discourse can criticise a political party, an individual or an institution, but also the critiques towards certain types of humour can constitute an attack against a social group. More frequently, the accussation of lacking a sense of humor can serve as an strategy in a social or ideological discussion.

Besides, from a more general point of view, we will argue that humourous discourse is particularly ambiguous in a way that lends itself to be apprehended in different and even conflicting readings. We shall see how camp culture has been judged as perpetuating some homophobic and mysoginistic prejudices, or, on the contrary, as critical and subversive regarding these same stereotypes and a sexually-normative society. We will also study how Una mala noche la tiene cualquiera, set during thedemocratic transition in Spain and the failed coup d'état of 23 February 1981, is simultaneously interpreted as an apologetic celebration of the social and political democracy process and as a harsh critique of the period between Franco's death and the consolidation of the democratic system. Additionally, we will see how Friends has since its broadcasting received both praise and criticism on account of its allegedly conservatism or progressivism; we will aim to demonstrate how in fact it can be interpreted ambivalently due to its humorous nature.

\subsection{STATE OF THE ART AND RELEVANT BIBLIOGRAPHY}

Given that the field of study of humour is potentially infinite, the bibliography is immense. Humour and comedy have appealed to important philosophers and thinkers from Plato to Kant, Schopenhauer or Baudelaire, and we count on the works of Bergson or Freud from past centuries. The 20th century seems to have witnessed an increasingly systematic study of humour, which has consolidated as a multidisciplinar field with the 
creation of several associations and research centres such as CORHUM or the International Society for Humor Studies, and scientific journals like Humoresques and Humor. International Journal of Humor Research. Mouton de Gruyer has developed an editorial line exclusively devoted to humour studies. In Spain there are several research groups like GRIALE (Research Group on Humor and Irony in Spanish), which has fostered linguistic research in Spanish verbal humour, or GRICOHUSA, the Research Group on Communication, Humour and Satire, focused on the study of the satiric tradition.

Humour studies are, thus, truly multidisciplinary. On the one hand, French historiography inspired by the Annales School, and particularly by its interest in the history of mentalities, has opened a fertile field for the history of laughter and humour led by Jacques Le Goff (Le Goff, 1977, 1999). This field has paved the way for significant studies like Histoire du rire et de la dérision by George Minois or the monographs by Bertrand (1995) or Ménager (1995); work by scholar Stephen Halliwell, expert in Hellenistic studies, on the Greek cultural psychology on laughter (2008) is equally crucial to the research in this period. Of course, Bakhtin's Popular culture in Middle Ages and the Rennaissance (1998) and his several studies on carnivalesque literature (Bajtín, 1989, 2012) are essential starting points for any reflection on laughter and comedy. Pere Ballart's Eironeia (1994) is also a useful introduction to the history of philosophical and literary though on irony.

On the other hand, linguistic research has contributed to the implementaton of a systematic point of view for formal research in verbal humor. With its pros and cons to be explored further, the proposals by Victor Raskin (1985) and Salvatore Attardo (1994, 2001; Attardo and Raskin, 1991) have been key to most linguistic research in this field. Sociological and psychological research (Holmes and Marra, 2002; Kothoff, 2006; Kuipers, 2006a) can not be disdained either.

Among the vast bibliography available, some authors and books have been clearly more influential. Histoire du rire by Minois has been a work of reference for the historical aspects of our research as an excellent compilation and systematization of the inmense bibliography on this field, in addition to the mentioned monographs by Ménager, Bertrand or Halliwell. In this respect, Art History scholar Frances S. Connelly's book on the cultural and artistic tradition of grotesque has also been highly suggestive and has served to supplement our mostly literary and philosophical training with a wider point of view, 
and it has led us to establish significant relationships between certain humorous traditions and phenomena of the likes of manierism or the uncanny.

In our general understanding of humour, the often-forgotten French philosopher Henri Bergson's book, Essay on the meaning of laughter, has been the most influential. Another crucial influence in the critical approach undertaken in this work has been Michael Billig's Laughter and ridicule (2005). In this book, the English professor argues the common view of humour as intrinsically positive and analyses the ideological roots of these assumptions while highlighting some of the negative features that underlie humour. The book inspires the neeed for a historical sense and the adoption of a critical view on the several existing contermporary theories and research on humour.

Constructivist Rhetorics is an essentially multidisciplinary theoretical framework: it relies on ancient sophistry, Nietzsche's thought, Hermeneutics, deconstruction, sociocognitivist constructivism and even the insights offered by neurobiologists like Humberto Maturana or Antonio Damasio. In our own approach to the different humourousdiscourses and its related aspects, we have looked for the theoretical and analytical support of several disciplines other than primary and secondary sources on humour: we have relied on the work of anthropologists Victor Turner or Mary Douglas for the correct understanding of the meaning of laughter and comedy in preindustrial societies. Many others trends of thought underlie our analytical and theoretical premises: Ricoeur (1980, 2001) and Gadamer's (2012) hermeneutics; Bakhtin and his circle’s (Bajtín, 1989, 2001; Voloshinov, 2009) philosophy of language; the pragmatic stances set by Richard Rorty (1996, 2001, 2013) and Stanley Fish (1980. 2012); the polifacetic works by Michel Foucault (2005, 2009b, 2009a , 2015, 2017); cultural materialism by Raymond Williams (1982) or Umberto Eco’s approach to mass culture (2013); theories of ideology by marxist authors like Althusser (2003) or Zizek (2018), and so on. As mentioned befoe, gender identity is the guiding thread both in chapters six and seven. In this respect, we have resorted to Judith Butler (2007) and several others' queer theories (Bernini, 2018) and sociological approaches to masculinity and gender identity such as Connell’s (2005) and Óscar Guasch (2006). 
I. HISTORIA DEL PENSAMIENTO HUMORÍSTICO EN OCCIDENTE 


\section{EL IMPERIO DE LA RISA}

\subsection{La risa en la Antigüedad}

Gran parte de las reflexiones modernas y contemporáneas sobre la risa deben mucho a los significados que los griegos le atribuyeron desde los muy distintos ámbitos del culto religioso, la literatura, la medicina, la ética, el derecho, etc. Pero, al mismo tiempo, la risa en la cultura griega presenta unos aspectos y un estatuto difícilmente asimilables a nuestra mentalidad moderna. Probablemente la presencia de la risa en tantos ámbitos de la vida y el pensamiento griegos se deba precisamente a su posición liminal y extremadamente ambigua en su cosmovisión general. La conocida afirmación de Aristóteles de que la risa es lo propio del hombre es de hecho una opinión relativamente inusual en la cultura de su época, donde la risa pertenece fundamentalmente al ámbito de la naturaleza y lo divino. Fuertemente anclada en el cuerpo, la risa es lo de que sobrehumano hay en el ser humano, síntoma de vitalidad excesiva y de locura. Vinculada especialmente a los mitos y cultos de Deméter y Dioniso, que ya de por sí ocupan un lugar especial en el sistema religioso griego, la risa es dadora de vida, íntimamente ligada a la sexualidad y la fertilidad, pero también lleva al éxtasis orgiástico de Dioniso y da la muerte a muchos de los que se ven poseídos por ella. Tanto en el escenario de la comedia como en la plaza pública, la Asamblea o los tribunales, la risa es vista como una agresión, un arma muy peligrosa en una cultura donde la afrenta al honor es casi peor que la muerte física. En suma, debemos ser muy cautos antes de afirmar que la cultura griega tenía una actitud totalmente positiva hacia la risa, pues esta también representaba el lado violento, peligroso, de la naturaleza, los dioses y los hombres. Es por eso que, en realidad, la risa solo era permitida en contextos muy específicos y regulados: el de ciertas fiestas religiosas, el de los banquetes o simposios, o el de la comedia; y por eso, también, Platón, Aristóteles y otros filósofos dedicaron muchos esfuerzos a intentar desterrarla de la polis o establecer firmemente los límites en que su uso era adecuado y no entrañaba ningún peligro.

\subsubsection{La risa sagrada}

\subsubsection{En la mitología y la obra homérica}

Como no podía ser de otra manera, la mitología va a reflejar el estatus fundamentalmente ambiguo, entre lo propiamente humano y lo sagrado natural, entre el nacimiento y la muerte, que la risa tiene en la cosmovisión griega. Si bien las cosmogonías de origen 
oriental que atribuyen la creación del universo a un estallido de risa a la divinidad primigenia (Minois, 2000: 15-16) aparecen en el contexto del gnosticismo y el neoplatonismo y por tanto son de incorporación relativamente tardía (Halliwell, 2008: 15), lo cierto es que la asociación de la risa con la alegría y la fuerza creadora y violenta de la naturaleza está presente desde el período arcaico. La misma etimología del térmnio griego para la risa apunta a ello: la voz gelân se relaciona con el verbo gelaîn, «brillar», «florecer», aplicado a la vegetación y las flores pero también al resplandor de las corazas (López Eire, 2004: 164). En Homero encontramos frecuentes alusiones metafóricas a la risa de las olas marinas, donde el brillo de la espuma señala esa alegría de las fuerzas naturales. Pero la metáfora también apunta a su fuerza destructora: «the earliest passages in which the trope occurs bring into play both a sense of more-than-human fecundity and, sometimes, simultaneously, a perception of the dangerously charged energies of (divine controlled) nature» (Halliwell, 2008: 16).

Si atendemos a la aparición de la risa en la obra de Homero, encontramos una caracterización similar. La risa tierna y amable de Héctor con su hijo (Halliwell, 2008: 53-55) es una excepción: en muchos otros pasajes de la Ilíada y la Odisea la risa está vinculada a la sed de sangre, como la demente de Áyax en el campo de batalla o la de la esclava Euriclea durante la matanza de los pretendientes (Halliwell, 2008: 56-57). Es sintomático que el adjetivo «asbastos», «irrefrenable» o «inextinguible», que Homero aplica a la risa de los dioses, se use también para caracterizar el furor de la batalla, y que los únicos mortales que rían con una risa «irrefrenable» sean los pretendientes de Penélope hechizados por Atenea, cuyo destino próximo es la muerte (Halliwell, 2008: 62). La risa es una fuerza divina que sobrepasa a los frágiles mortales, como atestiguan los muchos mitos en los que un ser humano muere por un ataque demente de risa provocado por un dios (Minois, 2000: 19-20). En el caso de los pretendientes de Penélope en la Odisea, su risa está asociada a la ebriedad, la lujuria y la locura, al exceso, y en última instancia, como decimos, a su muerte violenta (Halliwell, 2008: 88). En el pasaje en que Atenea provoca su risa, en unos versos que anuncian su próxima matanza a manos de Odiseo, Homero describe a los pretendientes como riéndose con mandíbulas que no son las suyas: «the suitors very faces, as well as their minds, are possessed from outside and alienated from themselves (...) The suitors become, as it were, psychologically convulsed marionettes under Athena’s control» (Halliwell, 2008: 95). 
La risa como expresión de gozo es, por tanto, una prerrogativa divina. A pesar de los rasgos antropomórficos y los matices psicológicos de la risa de los dioses homéricos, esta no deja de tener un poso de inescrutabilidad: «part of the point of Zeus' laughter, as of his smiles, is the elusiveness of meaning which plays around it. But it is legitimate to see one face of Zeus's laughter (...) as an externalisation of divine pleasure in its own of strength and domination» (Halliwell, 2008: 69). Sobre todo, es una risa que tiene que ver con la violencia, la obscenidad y la amoralidad (Minois, 2000: 17), como comprobamos en dos de los pasajes de la obra de Homero en que se dice que los dioses ríen con esa risa irrefrenable: en el primero de ellos, al ver a Hefesto servir la ambrosía, en imitación paródica y deforme de los bellos efebos usualmente encargados de tal cometido (Halliwell, 2008: 61); en el segundo, el mismo dios inventa un artefacto que atrapa a su esposa Afrodita en flagrante adulterio con Ares para que lo vean los demás dioses y se burlen de ellos. Es significativo que Hefesto sea el protagonista de ambos pasajes: tanto por su deformidad física como por su ingenio parece un personaje particularmente apto para estas historias cómicas (Halliwell, 2008: 85). Al mismo tiempo, en el segundo de estos pasajes vemos que la risa divina está muy relacionada, como decimos, con la amoralidad y la sexualidad desatada y, sobre todo marca una distancia entre las esferas de lo divino y lo humano: en el contexto de la Odisea, la actitud de los dioses hacia el adulterio contrasta con las terribles consecuencias que tiene en el ámbito humano en los casos de Helena, Clitemnestra y Penélope (Halliwell, 2008: 84).

En ámbitos distintos al de los dioses olímpicos, la risa está ligada al nacimiento de la vida y su regeneración, sin perder sus asociaciones con la destrucción y la muerte: hablamos de su vínculo con los dioses Deméter y Dioniso. Según el mito, durante la búsqueda de su hija Perséfone, raptada por Pluto, Deméter, que no puede ni comer debido a la tristeza, se encuentra con la humana Bobo, quien consigue hacerle reír levantándose el vestido y mostrándole lo que hay debajo de él. Los intérpretes no saben exactamente qué es lo que Bobo enseña, pero sí que tiene que ver con su vulva y la figura de Yaco, otro de los nombres de Dioniso. En todo caso, este mito relaciona la risa con la sexualidad, la fertilidad y la vuelta a la vida a la alegría, y de hecho encontramos mitos parecidos en Creta y Egipto relacionados con Isis (Minois, 2000: 17-18). En otra versión del mito, es Yambo quien hace reír a la diosa, de donde vendría la relación de la poesía yámbica con la superación de la tristeza mediante la risa (Minois, 2008: 18). 
Asimismo, varios seres divinos relacionados con la risa forman parte del cortejo de Dioniso. El dios de la risa es Momo, representado portando una marota, símbolo de la locura, y una máscara: este dios es expulsado del Olimpo porque los dioses se hartan de sus bromas, y se refugia con el dios de las transformaciones (Minois, 2000: 22). Por otra parte, los sátiros, comandados por Sileno, son los protagonistas del drama satírico, obra de carácter cómico y paródico que se representaba después de las tragedias durante las Grandes Dionisias: «être hybrides, ils exhibent leur animalité: dotés d’un sexe en érection et d'une queue de cheval, ils mettent en scène un univers parodique et burlesque» (Minois, 2000: 29).

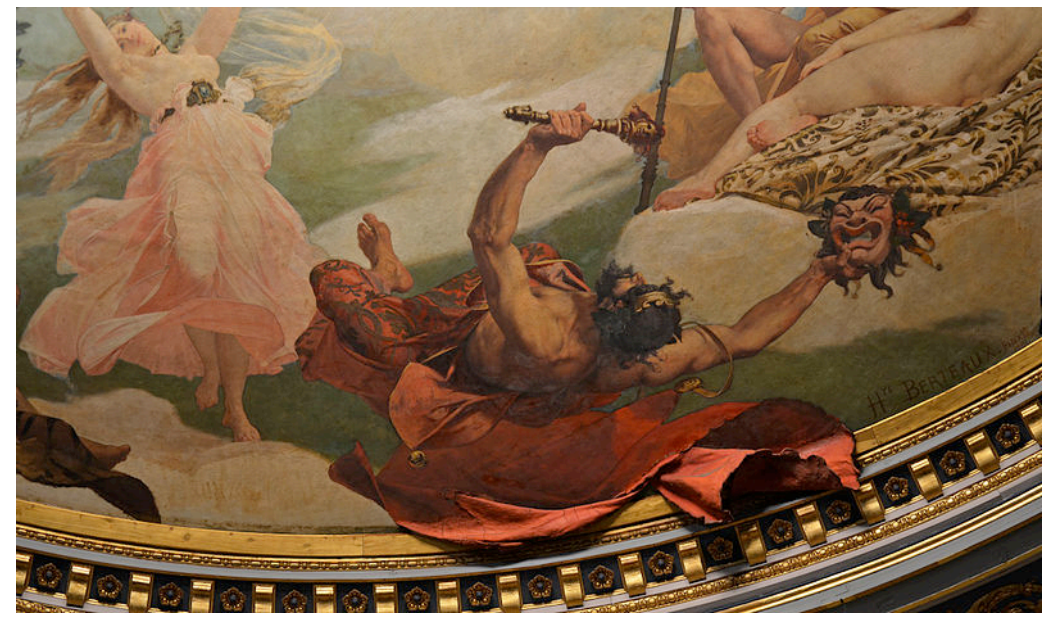

Fig 1. El dios Momo. Detalle de la pintura de Hyppolite Berteaux que decora el techo del Teatro Graslin, en Nantes.

\subsubsection{La risa ritual}

Estos mitos, por supuesto, encuentran su recreación en diversos rituales en que la risa, efectivamente, tiene un papel protagónico. Como ha probado Apte, el uso ritual de la risa está presente en gran cantidad de ritos relacionados con la fertilidad y los ciclos de destrucción/restauración (López Eire, 2004: 160). En la Grecia antigua, las Dionisias rurales y las Grandes dionisíacas, las Leneas, las Tesmoforias y las Panateneas, así como las Cronias, a las que podríamos sumar las saturnales y las bacanales romanas, se podrían llamar fiestas «cómicas» en tanto que la risa es omnipresente (Minois, 2000: 23). Todas están, como decimos, relacionadas con Deméter o Dionisos (Halliwell, 2008: 191). Las interpretaciones de estas fiestas y rituales, en conjunto y de cada uno de sus elementos ${ }^{2}$,

\footnotetext{
2 Todas estas fiestas tienen cuatro elementos en común: reactualización de mitos relacionados con Dionisos o Deméter, mascaradas más o menos codificadas, una etapa de inversión social, exceso y transgresión en la que las orgías y la ebriedad son protagonistas, y la elección de un esclavo o prisionero como "rey" festivo que luego será sacrificado. (Minois, 2000: 23). Como veremos en su momento, muchos estos elementos
} 
y de la risa ritual en particular, difieren: en algunos casos, son garantes del orden y la cohesión social al representar un regreso al caos primordial para una posterior restauración de la ley (Minois, 2000: 23-24); para Konrad Lorenz la representación festiva de la agresividad supone su canalización y su disipación para salvaguardar la sociedad (Minois, 2000: 27). Según otras interpretaciones, estos rituales suponen una reintegración con las fuerzas sagradas de la naturaleza y un regreso al caos primigenio que re-genera el mundo (Minois, 2008: 24-25) o tienen una función mágica que pretende asegurar la fertilidad de las cosechas (Halliwell, 2008: 196). El uso de máscaras supone una experiencia de la alteridad presente en muchos ritos de paso a la vida adulta como los de Atenas y Esparta (Minois, 2000: 25). Sea cual sea la función concreta que tiene la risa en estos rituales (ver Halliwell, 2008: 160-191), lo que parece innegable es que las festividades en que aparece están concernidas por los contrastes de la vida y la muerte, de la pérdida y la regeneración, de la sexualidad y la fertilidad, en los casos de los cultos a Deméter, y de la desinhibición orgiástica y la afirmación de los valores comunales en los destinados a Dionisos (Halliwell, 2008: 203-204):

(...) a correlation between ritual laughter and a desire/hope for fertility forms a culturally well-embedded pattern (...) Demeter and Dionysus gave and give human crops which are the basis of civilisation, i.e. life in agriculturally and socially settled communities: the relevant rituals on their account constitute 'commemorative symbols'. If that is right, the element of laughter per se in such rituals might be best understood (...) as life-affirming exuberance, a vivacious accompaniment to festive celebration (or anticipation) of the fecundity of humans, animals and earth (Halliwell, 2008: 198-199)

La asociación de la risa con los mitos y rituales de Dioniso es una prueba más de la ambigüedad fundamental que el pensamiento griego le asigna, pues este es el dios de la contradicción, la metamorfosis y la transgresión (Daraki, 2005: 34). Al fin y al cabo, el culto de Dioniso es, según argumenta Maria Daraki, el resultado de la asimilación de los cultos arcaicos a las divinidades femeninas en la religión de la Grecia clásica, por lo que ocupa una posición paradójica en el panteón olímpico (Daraki, 2005: 250).

Hermes, otra divinidad muy vinculada con la risa como dios del engaño y las transformaciones, y de hecho personaje frecuente en la comedia, se asocia en el correspondiente himno homérico a otra práctica social muy presente en la cultura griega,

son análogos a los que encontraremos en los carnavales y otras fiestas medievales, aunque su filiación histórica es muy debatida. 
que, a pesar de no ser de carácter explícitamente religioso, está muy vinculada a estos ritos: la del banquete o simposio (Halliwell, 2008: 101-102). Asociado generalmente a la juventud ciudadana como expresión de su ímpetu vital, el banquete ofrecía un marco festivo en el que la embriaguez, las bromas y los insultos estaban permitidos. En este sentido, ofrecía un contexto análogo al de los festivales religiosos en los que estas actividades estaban exentas de las restricciones de la vida ordinaria (Halliwell, 2008: 102103). Hay más analogías con las fiestas dionisíacas: como se ve en el mismo himno a Hermes, el simposio está relacionado con los komos de las fiestas dionisíacas, ya que muchas veces los banquetes acababan en procesiones improvisadas de jóvenes ebrios; en general, la risa estaba relacionada en ambos contextos con el consumo de vino, la música, una inclinación al erotismo y el entusiasmo, etc. (Halliwell, 2008: 105-106). Y, sobre todo, encontramos el implícito deseo de abandonar temporalmente los esfuerzos de la vida cotidiana, y acercarse, por analogía, a los dioses homéricos y sus propios banquetes:

The thematic place of laughter in human feasts [en paralelo al festín de los dioses que encontramos en el primer canto de la Ilíada] is connected at least subliminally to a simulation of immortality: a simulation that, for the duration of the symposium, tacitly renders the participants god-like, suspended in the hoped-for-perfection of the moment and able to float temporarily free of the downward drag of pessimism (Halliwell, 2008: 104)

En los simposios encontramos, como vemos, una especie de cultos dionisíacos relativamente civilizados, donde la risa ritual, la embriaguez y el erotismo evocan un deseo de inmortalidad y comunión. No es de extrañar, por tanto, que el más ejemplar de los banquetes, el del diálogo platónico, tenga en su centro la reflexión de Diotima sobre la aspiración humana a la trascendencia y la inmortalidad (Halliwell, 2008: 105). En este texto, Eros, la divinidad protagonista, presenta unos rasgos eminentemente dionisíacos, del mismo modo en que el Sócrates retratado por Alcibíades tiene rasgos satíricos:

En realidad, hay una transición constante entre el mundo de Dioniso y el mundo de Eros. El Sócrates que nos describe Alcibíades, con su ambigüedad entre lo festivo y lo serio, con búsqueda apasionada de la sabiduría, con su figura entre fea y hermosa es, se ha reconocido muchas veces, una contrafigura de Eros. Pero también podría pensarse en Dioniso, dios de la alegría y de la muerte, que provoca la burla y da la liberación, perseguido y triunfante, afeminado y viril. Los temas de la felicidad, de la alegría, de la curación, de la liberación, del éxtasis, de la inmortalidad incluso, que aparecen una y otra vez como propios de Eros, son también propios de Dioniso (...) Eros (...) solo conserva 
los aspectos primarios: no ligado al culto, es más moldeable y ha permitido a Platón crear un símbolo de toda la búsqueda de la liberación que es la vida del hombre (...) Lo importante en él es esa fuerza con que arrastra al hombre fuera de su normalidad, esa locura que la libera y la lleva a la felicidad reconquistando su pasado o alejando el miedo y el riesgo (...) A escala humana es Sócrates el que simboliza esa búsqueda; y en el retrato que de él traza Alcibíades se ven bien claros, a un tiempo, los rasgos satirescos y entusiásticos y aquellos en que en realidad es un duplicado de Eros (Rodríguez Adrados, 1969: 94-95)

Como vemos tanto en el caso del banquete como de la fiesta dionisíaca propiamente dicha, otro rasgo de esta risa ritual es la libertad supuestamente total de la que gozaba, ajena a cualquier limitación moral o, más importante aún, legal. Estas fiestas eran la oportunidad para el lenguaje obsceno y el insulto agresivo hacia grupos o personalidades concretas perfectamente reconocibles (Halliwell, 2008: 158):

Existe, pues, un «humor ritual», un humor grueso, realista y grotesco que se manifiesta y patentiza mediante una ausencia total de control social, por una conducta ajena a las normas culturales establecidas, o a través de elementos sexuales y escatológicos, o de burlas de otros rituales en teoría más serios, o mediante la invectiva o el escarnio de personajes socialmente bien conocidos, o a base de la sátira político-social de una comunidad, o bien dando la impresión del desorden total y del caos primigenio o anterior al orden (López Eire, 2004: 161)

Ahora bien, es necesario matizar esta libertad, literalmente sagrada, de la risa y el insulto que encontramos en los festivales griegos y tener siempre presente que, efectivamente, hablamos de una risa ritual, y por tanto confinada a los límites espaciales y temporales firmemente establecidos de la fiesta y extremadamente ritualizada, es decir, codificada (Halliwell, 2008: 203). En muchos casos, la risa ritual está propiamente teatralizada e implica un grupo específico de personas actuando una cierta coreografía en un espacio definido e incluso portando máscaras (Halliwell, 2008: 195-196). Un caso muy significativo de esta codificación de la risa es el hecho de que aunque los ritos mistéricos incluyen la risa ritual, la parodia de estos mismos rituales en reuniones civiles fuera del contexto de la fiesta religiosa eran considerados escándalos blasfemos que incluso podían ser juzgados (Halliwell, 2008: 158).

El problema, por tanto, es determinar la relación de esta risa ritual y el significado del humor y del sentimiento de lo cómico en un sentido más amplio para la cultura griega, 
sobre todo en relación a la manera en que las interpretaciones modernas alimentan nuestra propia concepción de estos fenómenos. El hecho de que efectivamente la obscenidad, la risa y concretamente el escarnio de instituciones y personajes públicos gocen de una libertad total pero solo en ciertos contextos muy concretos y definidos oficialmente determinan la recepción e interpretación de estas prácticas y, de modo más relevante, del género dramático que nace de estas fiestas, la Comedia Antigua, y su representante más importante, Aristófanes.

1.1.2. Origen, significado y desarrollo de la comedia latina y romana y otros géneros cómicos

\subsubsection{Origen ritual de la Comedia.}

Poco hay de seguro en las especulaciones acerca del origen del teatro griego y de la comedia en particular. Como se sabe, Aristóteles afirmaba en la Poética que su origen estaba en los himnos fálicos (Rodríguez Adrados, 1972: 21), aunque parezca ser más una extrapolación teórica paralela a la hipótesis del origen ditirámbico de la tragedia que una afirmación basada en alguna evidencia histórica (Storey y Allan, 2014: 174). También la etimología del término es discutida desde la Antigüedad, y las diferentes propuestas dependen de su origen hipotético: así, como también atestigua Aristóteles, el griego komoidia se hacía derivar de kome + ode («canción de la villa») por los partidarios de la procedencia dórica del género; la derivación de komos + ode («canción festiva») parece apoyar la teoría de que la comedia habría evolucionado de los komos, procesiones festivas que tenían lugar durante las celebraciones dionisíacas en que un grupo de actores insultaban y se burlaban de los ciudadanos o de algunos individuos públicos concretos (Rodríguez Adrados, 1972: 40, 80-81).

Esto último se relaciona con las hipótesis de algunos estudiosos que buscan el origen de la comedia y el teatro en general en ciertos rituales de fecundidad y regeneración muy concretos. Cornford, por ejemplo, vio en la estructura de la Comedia Antigua los trasuntos de elementos rituales como la lucha entre lo viejo y lo nuevo, la boda sagrada y la expulsión del pharmakos o chivo expiatorio (Rodríguez Adrados, 1972: 76), si bien este esquema se rechaza en la actualidad por su excesiva rigidez (López Eire, 2000b: 78). También Rodríguez Adrados propone un origen relativamente común a los tres géneros dramáticos griegos (tragedia, comedia y drama satírico) en el contexto antropológico de 
ciertos rituales de regeneración y fecundidad (1972: 74-77), lo que explicaría ciertos rasgos estructurales y temáticos que tienen en común, como la presencia del coro, el conflicto del héroe, el chivo expiatorio, la salvación de la ciudad, etc. (Rodríguez Adrados, 1972: 80-94).

En suma, muy probablemente la comedia griega tenga su origen en los coros animalescos, las danzas de sátiros, los komos y otros elementos que formaban parte de las fiestas religiosas en que aparece por primera vez (Storey y Allan, 2014: 177). Otro problema, sin embargo, es cuánto de la significación religiosa de estos elementos permanece en la comedia propiamente dicha tal y como la conocemos en la obra de Aristófanes. Sea cual sea el origen concreto del género, lo que es evidente es la explícita vinculación de la comedia con las festividades de las que hablábamos en el apartado anterior, empezando porque, al igual que la tragedia, se representaba durante las Leneas y las Grandes Dionisias (Storey y Allan, 2014: 13), concretamente desde el año 486 a.C. Además, el lenguaje y los temas obscenos y los insultos contra personalidades públicas eran comunes tanto a las fiestas dionisíacas como a las primeras comedias, y el propio Aristófanes incorpora y dramatiza algunos de los elementos rituales de estas festividades en sus obras, principalmente en Acarnienses, Avispas y Ranas (Halliwell, 2008: 207-214).

Esta estricta vinculación de la comedia, sobre todo la aristofánica, con las festividades dionisíacas va a determinar de manera problemática las interpretaciones acerca de la función social de aquella, sobre todo la cuestión de hasta qué punto este origen ritual pudiera afectar a los contenidos y significados de una forma dramática que, como veremos, se secularizó en un período relativamente corto de tiempo. El hecho de que las únicas obras que conservemos íntegramente sean las de Aristófanes, quien ejerció sesenta años después de la instauración oficial de la comedia, es una dificultad añadida. En primera instancia, las representaciones teatrales tanto trágicas como cómicas compartirían con el resto de prácticas rituales de estos festivales el papel de regeneración y restauración de la convivencia, «reintroduciendo el orden a partir del desorden a base de exponerlo a las risotadas de los espectadores» (López Eire, 2000b: 81). De ahí las claras similitudes que para Rodríguez Adrados tienen la comedia, la tragedia y el drama satírico en cuanto que el tema central es la salvación de la polis (1972: 92): el teatro griego buscaría la conciliación de los ciudadanos al exponerlos al sufrimiento y la rotura del sistema y su crítica y a través de la descarga de tensiones (Rodríguez Adrados, 1972: 96) - la catarsis aristotélica, de la que nos ocuparemos más adelante. Concretamente, la risa 
provocada por la comedia daría lugar a dicha descarga al permitir conductas y palabras socialmente proscritas de la vida cotidiana (López Eire, 2000b: 83) y ofrecer una especie de reacción compensatoria a un complejo de inferioridad mediante la proyección, como veremos, de utopías sociales alternativas al problemático estado de cosas real de la polis (Gil Fernández, 1996: 18). Tendría también un componente de agresión ritualizada (Minois, 2000: 31) mediante la que se criticarían y expulsarían ritualmente los elementos nocivos para la sociedad.

\subsubsection{La Comedia Antigua. Aristófanes}

Por tanto, el teatro griego tendría un carácter fundamentalmente ritual y político, en el sentido propiamente griego de lo concerniente a la polis (López Eire, 2000b: 72). Esta agresión ritualizada de la comedia tomaba la forma de una crítica política directa de instituciones y personalidades públicas. La comedia, a pesar de la técnica aparentemente más 'realista' o verosímil de la tragedia frente a las libérrimas fantasías de la Comedia Antigua, estaba más apegada que esta a la realidad social al centrarse en el presente de la ciudad, respecto al cual adopta una actitud crítica cuando no agresivamente nihilista (Gil Fernández, 1996: 14; Minois, 2000: 30-32): frente a los grandes temas trágicos, «la intención del poeta cómico es la más modesta de hacer una crítica de la actualidad», y al centrarse en los asuntos humanos y sociales antes que en los divinos, «señalan aspectos susceptibles de ser corregidos» (Gil Fernández, 1996: 17).

La Comedia Antigua tiene una relación obvia con las instituciones oficiales, porque la polis siempre se preocupó por hacer posible la representación de comedias mediante un sistema de mecenazgo (Storey y Alan, 2014: 18; Riu, 1999: 21). La misma instauración oficial de la comedia en los festivales de la ciudad podría haber tenido mucho de estrategia política, pues coincidió con la instauración de otras medidas que buscaban limitar el poder de la aristocracia: el apoyo a la comedia buscaba probablemente una crítica a personajes aristocráticos como modo de legitimación del nuevo sistema político (Sommerstein, 2014: 292). Y sin embargo, este interés de la polis por la comedia es paradójico, puesto que, a pesar de que el auge de las obras más explícitamente políticas coincidiera con el período ateniense de la democracia radical, estas no parecen estar muy al servicio de la misma, ya que la mayoría de los ataques se dirigían contra los líderes democráticos y parecían defender las posiciones propias de la oligarquía (Riu, 1999: 22).

¿Podría servir la Comedia Antigua, en este sentido, de “válvula de escape” de todo ese 
resentimiento ciudadano hacia el Estado, salvaguardando la democracia al evitar una revuelta directa? En un sentido más general, para muchos estudiosos esta parece haber sido la función de la comedia en el mundo antiguo, también en la cultura romana.

En todo caso, se debe ser extremadamente cauto a la hora de valorar el sentido de los rasgos más explícitamente políticos de la Comedia Antigua, puesto que no hay consenso entre los propios helenistas respecto a su función, significado e implicaciones. La mayor dificultad la presenta el hecho de que, como hemos apuntado, conozcamos el género casi exclusivamente a través de Aristófanes, de quien se conservan solo once obras, aparentemente un tercio de su producción total (Steen, 2007: 108), lo que plantea la pregunta de si esta muestra es realmente representativa de la Comedia Antigua. Por otra parte, nos encontramos el problema aún más fundamental de hasta qué punto hay que tomarse en serio el contenido y las afirmaciones de la obra: el hecho de que sean, precisamente, representaciones dramáticas en un contexto festivo, ¿implica que la comedia no tiene contenido político alguno? Y si lo tienen, ¿̇son de igual o diferente naturaleza los insultos e invectivas que encontramos en la comedia aristofánica de los de las procesiones y el resto de actos rituales? Si el lenguaje obsceno y los insultos personales estaban permitidos en el contexto de las festividades, ¿tenían o no algún efecto “real” en la vida pública cotidiana? (Riu, 1999: 13-14). Si un elemento clave de las lecturas ideológicas de las comedias de Aristófanes ha sido la parábasis, momento de la pieza donde el coro se quita la máscara y se dirige explícitamente a la audiencia como portavoz del pensamiento "serio" del autor, no hay que olvidar el contexto cómico y "literario” en que estos discursos se pronuncian, y que estas parábasis bien podrían formar parte del mismo como una broma más, con total independencia de un supuesto contenido moralizante o político (Steen, 2014: 109). Sin embargo, el propio Aristófanes reivindica en sus comedias la dignidad de su oficio como maestro y guía de los ciudadanos atenienses: «La comedia conoce y defiende lo justo, repite varias veces, aunque sea difícil de decir y duro de escuchar». El poeta cómico, en este sentido, sería «un educador político del pueblo que (...) aspira, como un médico, a curar las dolencias de la ciudad» (Gil Fernández, 1996: 81). Aunque también estas afirmaciones podrían ser un comentario irónico en un contexto cómico, sin ninguna intencionalidad real.

Como podemos ver, el debate acerca del sentido político de la Comedia Antigua se centra casi exclusivamente en el caso concreto de la ideología de Aristófanes, pero, aun si obviáramos los problemas de recepción de lo cómico planteados en el párrafo 
anterior y diéramos por válido el contenido político de sus obras, averiguar desde qué horizonte de pensamiento se da este no está exento de problemas, y las interpretaciones de los estudiosos llegan a ser diametralmente opuestas, desde quienes como Koch proponen la idea de un Aristófanes conservador y defensor de los intereses de la nobleza, hasta quienes lo presentan como el portavoz del pueblo llano frente a la opresión a la que le somete el Estado y las clases dominantes (Gil Fernández, 1996: 82-83). El mayor problema quizá sea evitar proyectar los posicionamientos políticos modernos en términos de "derecha” e “izquierda” sobre la sociedad ateniense de la época, obliterando de este modo sus propias particularidades: por ejemplo, la población rural de Atenas a la que el autor apela en numerosas ocasiones podría ser vista como portadora de los valores más tradicionales y al mismo tiempo más a favor de un sistema democrático que no privilegie la oligarquía urbana (Steen, 2014: 108). Por otra parte, podría darse el caso de que las ideas políticas expuestas por Aristófanes en sus obras no sean las suyas necesariamente, sino un modo de ganarse el favor del público en el contexto competitivo de los festivales (Gil Fernández, 1996: 84):

If, as in the late fifth century BC, the far 'left' has become the political establishment, then our playwright could be subversive for positioning himself to the right in politics (...) Acting as a detractor is simply the better pose for the job. Political criticism can then substitute for more hazardous political self-positioning; it encourages the 'older-is-better' advocate to single out novelties and weaknesses - and the persons embodying these - for effective public ridicule. Again, we see emerge an Aristophanes capitalizing on the support from the underdog in Greek society in meeting his essential needs of the stage (Steen, 2014: 111)

En este sentido, Alan Sommerstein argumenta que el público de las comedias podría haber sido más selecto de lo que se cree, y por tanto Aristófanes habría buscado contentar a una audiencia en general más conservadora (2014: 296). También habría que plantearse, en todo caso, la influencia real de estas críticas políticas, ya que ninguna de sus "víctimas" se vio realmente perjudicada en su carrera política a causa de los ataques de Aristófanes (Sommerstein, 2014: 295). Esto explicaría también por qué las Comedias constituían una excepción de las leyes atenienses que prohibían difamar a personajes públicos (Riu, 1999: 17) - aunque, según Henderson, esta libertad de expresión no sería exclusiva de la comedia, sino que respondía a los principios democráticos de isogoria y parrhesía (ver Henderson, 2004). Sea como fuere, la Comedia Antigua solo vivió dos brevísimos períodos en que se promulgaron leyes que limitaban su libertad de expresión, y los pocos 
poetas cómicos que fueron denunciados por aquellos a quienes criticaban, como en el caso de Aristófanes, nunca llegaron a ser condenados (Riu, 1999: 16). Planteamos estas cuestiones acerca de las diferentes perspectivas en torno a las lecturas políticas e ideológicas de la obra aristofánica para señalar hasta qué punto es difícil una interpretación de este tipo, debido no solo a la distancia histórica: también a la especial naturaleza del discurso cómico e, incluso, a la dificultad de dilucidar el sentido que este discurso podía tener en la sociedad griega y hasta qué punto difiere de nuestro sentido moderno.

En todo caso, los insultos y críticas directas no era el único sentido en que la Comedia Antigua era política: también hay que tener atender al aspecto «utópico» de sus argumentos. Casi todas las obras de Aristófanes funcionan según el esquema planteado por Koch de la articulación de una «idea crítica» y un «tema cómico»: al principio de la obra se presenta una situación de descontento de uno o más personajes que da lugar a una idea que potencialmente pueda salvarles, y el resto del argumento consiste en el desarrollo y consecuencias de este plan. Por tanto, el poeta cómico parte de una observación crítica de la situación social frente a la que se propone una utopía (Gil Fernández, 1996: 19) que permite explorar, aunque sea cómicamente, alternativas políticas como la redistribución de la riqueza, el pacifismo o la igualdad entre sexos (Ruffell, 2014: 211). De este modo, «the comedies of Aristophanes were clearly one of the primary means by which political and in particular speculative thinking became a wide part of public discourse in Athens» (Ruffell, 2014: 212-213).

Esta idea cómica era puesta en práctica por la figura que Cedric Whitman llamó «héroe cómico», que sería, según este crítico, el verdadero motor de la Comedia Antigua en lugar del comentario político o social directo (Rosen, 2014: 224). Sin embargo, se trata de un heroísmo paradójico: lo que le hace heroico a este personaje, que los antropólogos han relacionado con el arquetipo mitológico del Trickster $^{3}$ (Riu, 1999: 3, 244), es su individualismo, su tendencia al exceso y los extremos, y el ingenio de sus planes y su capacidad de persuasión; pero al mismo tiempo, su naturaleza cómica hace que viole sistemáticamente las leyes y normas sociales para su propio beneficio - si bien se trataría

\footnotetext{
${ }^{3}$ En antropología se conoce como trickster a un dios o ser mitológico bromista o embaucador, presente en muchas mitologías, como el Hermes griego, el Loki germánico, Anansi en el África occidental, o el Coyote de algunas tribus de nativos americanos. Obviamente, la figura tiene mucha relación con lo que durante la Edad Media sería el pícaro o el bufón.
} 
de una transgresión justificada por la situación de opresión en que vive, lo que hace de él un héroe popular (Rosen, 2014: 225).

Para algunos autores, la comedia aristofánica y su sentido político puede ser mejor entendida a partir del concepto de polifonía ${ }^{4}$, sobre todo en el uso paródico de la tragedia y otros discursos públicos (Platter, 1993: 210-211, 213). En efecto, en una sociedad en la que tanta importancia tenía la performance entendida en un sentido amplio, desde los contextos rituales hasta los discursos ofrecidos en la Asamblea y los juzgados (ver Martin, 2007), la Comedia Antigua no solo bebía de las prácticas festivas como las procesiones, que, como hemos dicho, Aristófanes reflejó ocasionalmente en sus comedias, ni tenía vínculos más o menos explícitos con la tragedia; estaba también muy relacionado con los géneros de la Oratoria: de hecho, las propias ideas utópicas eran presentadas de manera polémica, oratoria, sobre todo en el agón, el momento de la comedia en que el protagonista tenía que persuadir al coro de la idoneidad de su plan. En este sentido, las comedias de Aristófanes bebían de ideas y discursos que circulaban en la sociedad ateniense:

Clearly, the genre fed on and was in dialogue with other genres and modes of discourse (...) It is likely that Aristophanes is taking a set of ideas from a variety of sources and running with them - comic approaches to wealth, including sympotic elements; novel societies (...) political calls for redistribution going back to the time of Solon; and, perhaps, philosophical speculation (Ruffell, 2014: 212)

\subsubsection{La Comedia Nueva}

Como hemos visto, si bien el carácter político, entendido como concerniente a la polis, de la Comedia Antigua es evidente, es extremadamente difícil establecer el sentido y la dirección en que lo es. Más allá de los problemas filológicos e históricos de averiguar el pensamiento político y la ideología del único autor de quien conservamos obras enteras, Aristófanes, y el grado en que estas son representativas de todo el género, nos encontramos el problema teórico y hermenéutico de preguntarnos cómo afecta el carácter ritual y evidentemente extra-ordinario de las representaciones cómicas a su recepción e interpretación.

\footnotetext{
${ }^{4}$ En el capítulo correspondiente [5.2] utilizaremos el concepto de polifonía para desarrollar nuestra propuesta hermenéutica de análisis de discursos humorísticos.
} 
Fuera como fuere exactamente este carácter político de la Comedia Antigua y la influencia real que tuvo sobre la sociedad ateniense de la época, lo cierto es que el género perdió este carácter con el paso de los años: las dos últimas obras conservadas de Aristófanes no lo presentan apenas y se consideran pertenecientes a la época de transición de la Comedia Media; y la pérdida de la independencia política de Atenas en el año 322 a. C. acabó con la posibilidad del comentario político y social explícito. Es en esta época cuando comienza su carrera Menandro, representante de lo que se conoce como Comedia Nueva (Sommerstein, 2014: 296).

Aunque haya más continuidad de la que normalmente se reconoce entre la Comedia Antigua de Aristófanes y la Nueva de Menandro en cuanto a personajes, temas y técnicas cómicas (Hunter, 1985: 8-9), lo cierto es que existen diferencias fundamentales entre ambas. Las más evidentes son la desaparición del coro como personaje y la pérdida de los aspectos que conectaban más explícitamente la comedia al ritual: el escenario se eleva sobre el suelo, y desaparecen del vestuario los falos y otros complementos grotescos (Hunter, 1985: 9-11). En general, los argumentos dejan de lado la utopía fantástica y el ámbito de acción se reduce a espacios urbanos ocupados por la clase media (Gil Fernández, 2010: 187; Hunter, 1985: 10). Esta aparente apuesta por un mayor realismo, sin embargo, no era tal: las situaciones siguen siendo fantasías escapistas y poco apegadas a la realidad cotidiana, si bien ahora entran dentro de los límites de lo posible, y los personajes están fuertemente estereotipados y homogeneizados (Hunter, 1985: 11; Gil Fernández, 2010: 188). Sobre todo, desaparecen el lenguaje grosero y las alusiones explícitas a personajes públicos reales (Hunter, 1985: 12).

La sustitución del protagonismo colectivo de la polis por el individuo "burgués” respondería a un cambio en el público de la comedia, que pasaría a reflejar su nueva moral y sus intereses:

There is certainly little social damage advocated in these plays, and the common expression of sentiment about the duties of the rich to the poor and the equality of men regardless of social situation at birth, need be no more than the conventional pieties with which successful social class often satisfies its conscience (Hunter, 1985: 10-11).

El mundo de la Comedia Nueva es, por tanto, falsamente realista, estereotipado y, sobre todo, inmutable: «new comedy offers no grand vision of a new world; the plays offer 
rather the comforting spectacle of the restoration of the status quo after disturbance caused by folly or ignorance» (Hunter, 1985: 12). Frente a la obra de Aristófanes,

Menander offers a very different approach to utopianism, both drawing on earlier comic traditions and fundamentally rejecting them (...) It is in the very fixedness of the comic world that we can see the utopian dimension to New Comedy. Utopian ideas can be expressed by characters (...) In the permanence of the comic world, we see the rejection of such ideals. Characters who idealize worlds beyond the comic norm are definitively excluded and marginalized (...) In Menander's presentation of worlds where social differences are minimized, where moderation is rewarded and happy endings result in family unity and social solidarity, he is far more utopian and idealizing but far less challenging than the worlds presented in Old Comedy. This is the comedy of utopian consolidation, not utopian critique. (Ruffle, 2014: 214)

Por tanto, con la decadencia de la democracia el interés por las cuestiones colectivas de la polis se ve desplazado por un teatro “psicológico" en el que no importa tanto la posición social o ideológica de los personajes, sino el retrato de caracteres que se salen de lo convencional $^{5}$ (Gil Fernández, 2010: 199) y la crítica política y social se ve sustituida por una misión moralizante y universal. De este supuesto carácter moralizante de la Comedia Nueva da cuenta el hecho de que antes del descubrimiento en el siglo XX de unos papiros que contenían textos de Menandro, la mayoría de las fuentes que se tenían sobre este género provenían de citas que se usaban como ejemplos en tratados morales (Hunter, 1985: 139). Lo paradójico es que, al ser usadas fuera de contexto, se perdía el sentido cómico original de tales citas, por el que estas “enseñanzas morales” eran vistas originalmente de manera paródica, como convenciones sociales y teatrales sin propósito serio real (Hunter, 1985: 140). De hecho, Menandro parecía ver la comedia como un arte fundamentalmente dedicado al entretenimiento, una especie de "arte por el arte”: «la intención propia de la comedia no es reproducir la vida tal como es, sino, como muy finamente ha expresado Claire Préaux, la de vengarnos de la vida, porque no es tal como quisiéramos que fuese, o la de abrir un portillo a la evasión» (Fernández Gil, 2010: 213). Ya Platón lamentaba que el drama hubiera perdido su objetivo educacional y estuviera dictado por los gustos del público y no por exigencias morales (Gil Fernández, 2010:190).

\footnotetext{
${ }^{5}$ En este sentido, debemos tener en cuenta la enorme influencia que el libro de los Caracteres de Teofrasto tendría sobre la cultura griega (Fernández Gil, 2010: 199)
} 
La Comedia Nueva, por tanto, pierde cualquier conexión con el ritual y su función social y política, y pasa a servir al entretenimiento de un público más selecto y “burgués”, cuyo mundo pasa a reflejarse en el escenario - de manera idealizada, por supuesto. Esto no significa que las obras de Menandro estuvieran ausentes de cualquier resonancia política (Hunter, 1985: 12-13), ni que no reflejaran ciertas angustias sociales propias de su clase: «No theme is more persistent in these plays than the mutability of fortune and the external limits which are placed upon human action» (Hunter, 1985: 11). Para muchos autores (Grote, 1983; Sutton, 1993a; Mauron, 1998), el tema central de la Comedia Nueva sería el conflicto generacional en el sentido de que las obras tratarían de la rebeldía de las generaciones más jóvenes intentando librarse de la tiranía de sus mayores, siendo un reflejo de las tensiones de una sociedad fuertemente jerárquica, y a la vez una válvula de escape a esas mismas tensiones que salvaguardaran dicha sociedad ${ }^{6}$.

La Comedia Nueva, en resumen, supuso un cambio drástico en la concepción del género respecto a la Antigua: a la crítica social y política le sustituiría un propósito didáctico y moralizante de crítica de vicios individuales, si bien solo superficialmente, puesto que la misión principal del cómico sería la de entretener; pero esta doctrina del “arte por el arte” no impediría que, si bien no explícitamente, reflejara ciertas tensiones sociales.

\subsubsection{La comedia latina}

En todo caso, si conocemos la Comedia Nueva griega, aparte de los fragmentos precariamente conservados, citas en tratados morales y el recientemente descubierto Dyskolos de Menandro, es a través de las numerosas adaptaciones que los comediógrafos romanos realizaron de sus obras; sobre todo las veintiuna obras conservadas de Plauto y las ocho de Terencio (Hunter, 1985: 1-8). De hecho, la primera comedia escrita en latín, en el año 240 a. C., y cuyo autor fue el dramaturgo de origen griego Livio Andronico, era una estricta continuación de esta tradición de la comedia griega (López y Pociña, 2007: 17, 28). De los cuatro subgéneros de la comedia romana (pallatia, togata, atellana y el mimo) los dos primeros son claramente imitaciones del modelo griego, y la atellana, si bien es la continuación literaria de una tradición autóctona de carácter más popular, recibió desde muy pronto influencias griegas (López y Pociña, 2007: 23).

\footnotetext{
${ }^{6}$ En el punto 3.2.1. analizaremos las distintas teorías que en el siglo XX se han ofrecido sobre el significado social de la comedia.
} 
Como decimos, los comediógrafos latinos tuvieron una clara y absoluta preferencia por la Comedia Nueva, representada casi en su totalidad por Menandro, en detrimento de la obra aristofánica. Las razones de este hecho son evidentes: las comedias de Aristófanes y sus contemporáneos, tan ancladas en el contexto social inmediato, suponían una dificultad mayor a la hora de ser adaptadas a un público romano, amén de la presencia de invectivas políticas personales que no tenían cabida en el orden legal romano $^{7} ; \mathrm{y}$, sobre todo, la obra de Menandro era mucho más cercana en el tiempo a los primeros autores latinos (López y Pociña, 2007: 38). Además de las convenciones tipificadas en época griega, como la condición social de los personajes cómicos, la ambientación urbana o el tipo de lenguaje utilizado, los comediógrafos latinos heredaron, o al menos así lo afirmaban, su naturaleza edificante y ejemplar:

La comedia parece haberse concebido en Roma, ya desde su nacimiento, como un tipo de obra que tenía que servir para la transmisión de modelos positivos de comportamiento, o bien para la condena de los negativos, debido sin duda a ese carácter de personas reales que repetidamente le confería Aristóteles en su Poética (López y Pociña, 2007: 19)

Sin embargo, de nuevo sería necesario tomar con cierta precaución esta supuesta intención moralizante, muchas veces puesta en boca de los personajes de Plauto, puesto que bien podía ser expresada, en el contexto de la comedia, de manera irónica, o como defensa contra posibles críticas de inmoralidad. De hecho, Plauto fue un autor mucho más apegado al gusto popular: latinizó de manera muy intensa sus modelos griegos y sus obras estaban mucho más claramente orientadas a divertir al público que a educarlo. Terencio, en contraste, fue un autor mucho más aristocrático, fiel al original menandreo, y su obra es de carácter más reflexivo y “serio” - y de hecho de mucho menor éxito entre el público (López y Pociña, 2007: 47-48).

Como en el caso de su ascendiente griego, las comedias romanas solo se celebraban en ocasiones festivas, ya fueran privadas (funerales o triunfos) o estatales (como los ludi Romani; si bien estas fiestas no tenían el carácter dionisíaco de las Leneas o las Dionisias), y por tanto implicaban, sobre todo en la obra de Plauto, una suspensión, más que subversión, de las normas sociales - es bastante significativo el hecho de que las comedias más populares, las palliata, estuvieran ambientadas en Atenas y otras ciudades

\footnotetext{
${ }^{7}$ Aunque la comedia romana se desarrolló durante la República y la vida política era suficientemente apasionada como para dar lugar a jugosos comentarios cómicos, la ley prohibía ridiculizar a los ciudadanos ilustres por su nombre. De hecho, Nevio, cómico de la generación anterior a la de Plauto, fue a prisión por transgredir esta norma en una de sus comedias (Graf, 1999: 33)
} 
griegas, a cuya extranjería se achacaban las excentricidades y licencias de los personajes de las comedias (Graf, 1999: 35-36). En general, la comedia romana refuerza la identidad de grupo: bien mediante el humor "étnico”, por el que la exageración de las diferencias entre los romanos y los extranjeros sirve para reforzar la identidad de aquellos; bien mediante la censura de los vicios privados y grupales y la exclusión por la risa de aquellos que se apartaran de las normas y expectativas de la sociedad. Y en la obra de Plauto, como decimos, encontramos por encima de todo el humor puramente teatral y vivaz cuyo único objetivo es divertir (Graf, 1999: 34-36). Y, como en el caso de la comedia griega, la presentación cómica de ciertas tensiones sociales servía como válvula de escape para las tensiones de una sociedad fuertemente jerarquizada:

Ce que ne change d'ailleurs rien au rôle de la comédie dans le monde latin: provoquer une rire de défoulement au sein d'une société extrêmement légaliste, structurée par son cadre juridique méticuleux et pesant. Pratiquer la dérision, sous une forme déguisée, c’est assourir à bon compte les pulsions meurtrières qui devaient parfois assaillir les Romans contre les tutelles des vieux, des usuriers, des souteneurs, des magistrats et autres piliers de la société. Le comédie fonctionnée comme soupape de sécurité de la société civile, comme évasion vers un monde à l'envers (...) Conduites d'évasion hors du monde réel qui ont pour but de consolider ce même monde, de lui éviter la subversion et la révolution par la dérision codifiée, circonscrite dans le temps et dans l'espace (Minois, 2000: 90)

\subsubsection{La sátira romana y la menipea}

El conocimiento del teatro griego se fue produciendo progresivamente a partir del siglo III a.C., primero por el contacto con el pueblo etrusco, con influencias helenas, y después directamente con las poblaciones griegas de la Italia meridional (López y Pociña, 2007: 28). Tanto Tito Livio como Horacio planteaban en sus relatos sobre la historia de la comedia romana las interferencias de dos vertientes dramáticas: una extranjera, más formalizada, profesional y literaria, y una autóctona de naturaleza más improvisada y gestual (López y Pociña, 2007: 29-30). A las tradiciones autóctonas de los versos Fescennini y las atellanas, de origen rural y campesino, se les sumó a partir del siglo III a.C., como decimos, la influencia del teatro griego, primero por vía de actores etruscos y posteriormente con el conocimiento de las comedias de Menandro y otros autores de la Comedia Nueva (López y Pociña, 2007: 30).

Además de un sustrato cómico pre-teatral, esta predisposición que hizo que la comedia griega tuviera un éxito tan masivo y temprano estaría dada también por la propia 
idiosincrasia de los latinos: la mayor propensión de los pueblos mediterráneos a las representaciones de tipo teatral, el origen campesino de la población romana, en que son habituales manifestaciones populares de tipo festivo-religioso para celebrar momentos señalados del ciclo agrícola, y el carácter marcadamente teatral tanto de sus manifestaciones religiosas como de las artísticas (escultura y pintura) (López y Pociña, 2007: 31-32). En un sentido más general, los propios romanos se sentían especialmente orgullosos de su sentido del humor (Graf, 1999: 29), nacido de un supuesto carácter cáustico autóctono que reivindicaron autores como Horacio y Virgilio y que en latín era conocido como la dicacitas, basada en el sarcasmo, el juego de palabras, etc. (Minois, 2000: 71).

Este supuesto carácter cáustico propio de los romanos casa bien con la atrevida afirmación del rétor Quintiliano de que la sátira es el único género literario genuinamente latino (Freudenburg, 2005: 1). Sin embargo, en sus propias sátiras Horacio señala a los autores griegos de la Comedia Antigua, con Aristófanes a la cabeza, como inspiradores principales de Lucilio, el autor que consolidó el género en su forma clásica latina, y lo cierto es que en las obras de Lucilio, Horacio, Persio y Juvenal encontramos trazas de otros géneros griegos como la invectiva, la epístola o la diatriba filosófica (Hooley, 2007: 15-16).

La ambivalencia respecto al origen autóctono o importado de la sátira romana la encontramos en la misma etimología del término: desde la Antigüedad se ha discutido si proviene de «sátiro», lo que explicaría el carácter cómico y crítico que hemos llegado a conocer, precisamente, como "satírico”, o del latín «satura», «lleno», que señala el carácter de mezcla genérica propia de la forma satírica (Hooley, 2007: 13). Es este carácter de mixtura de géneros al que parece estar el nombre de saturae que Ennio (239 a.C - 169 a.C.) da a algunos de sus poemas, de los que solo nos han llegado algunos fragmentos. La literatura de este poeta latino, mejor conocido por sus Annales, dependía mucho de modelos helenos, y de hecho sus sátiras tenían más que ver con las misceláneas poéticas griegas que con la sátira posterior (Freudenburg, 2005: 3). Algunos de estos poemas, de hechos, estaban escritos en metro yámbico, haciéndose eco de la comedia y de la invectiva poética de Arquíloco (Freudenburg, 2005: 16). Claro que la poesía griega escrita en verso yámbico excede estos dos géneros, pero siempre está relacionada con lo cómico y lo cotidiano, y Ennio comparte con esta poesía el uso de un lenguaje coloquial, conversacional e incluso obsceno, una ubicación urbana y cierta afinidad con los 
personajes de la comedia palliata (es decir, la Comedia Nueva latinizada), aunque sería con Lucilio que la sátira adoptaría su característico tono crítico (Muecke, 2005: 37). En suma,

In the satires, with his use of iambic meters (among others), variety of subject matter, personal expression, “autobiography”, incorporation of elements of popular poetry such as fables in a more sophisticated environemnt, Ennius wrote in the spirit of that Hellenistic poetry which had begun to unravel the tradicional generic links between meter, tone, and subject matter (Muecke, 2005: 36)

De este modo, desde su origen, la sátira ha sido un género fuertemente experimental y, más aún, autoconsciente respecto de su propio estatuto genérico (Hooley, 2007: 5-6). Más allá de sus probables influencias griegas, es más relevante el significado social y cultural que la sátira tuvo para autores posteriores como Lucilio y Horacio así como el propio Ennio. Tanto él como Lucilio escribieron durante un periodo en el que la expansión romana había derivado en una “crisis de identidad” provocada por la "globalización” y la helenización de su cultura. En este contexto, la experimentación de estos dos autores buscaban una expresión adecuada de lo que significaba ser auténticamente romano (Hooley, 2007: 6):

Ennius writes his Saturae in pivotal and parlous times, when Greek cultural bearing and the realities of Roman political and military power were sweeping whole peoples into their train (...) Ennius' experiments with Romanized Greek genres, virtually inventing a literature for Rome, initially define, as well as help shape, Romans' sense of self in a wider world (Freudenburg, 2005: 18)

En este sentido, la insistencia en el carácter propiamente latino de la sátira que se da sobre todo a partir de la obra de Lucilio fue «an aggresive overstatement of what it means to be a genuine Roman in second-century Rome» (Freudenburg, 2005: 4). Tanto Ennio como Lucilio y sus sucesores Horacio, Persio y Juvenal, por tanto, dan una imagen del satirista como intelectual comprometido con la realidad social de la Roma de sus respectivos tiempos (Freudenburg, 2005: 19).

Este carácter identitario, forjado sobre todo frente a la “invasión cultural” griega, da a la sátira latina una forma principalmente conservadora. Mediante el retrato de personajes caricaturescos, ignorantes, viciosos, corruptos, hipócritas, etc., los satiristas se definen a sí mismos y a la comunidad a la que apelan como romanos auténticos (Freudenburg, 2005: 9). Según David Mankin, tanto la sátira como los géneros yámbicos 
de los que bebe tienen como fundamento la idea de philotes o amicitia: «the iambus was meant to remind the audience of what might be a threat to the very shared customs, morals, and so on wich brought them together and united them as an audiencie» (Mankin, cit. en Hooley, 2007: 17). En este sentido, según Fritz Graf, la sátira es la formalización literaria de otras costumbres rituales autóctonas romanas basadas en la burla y la invectiva como las maldiciones, la difamación pública,, o los versos Fescennini antes mencionados:

[La sátira] shared with the more ritualized forms the occasion of public display, and it shared with it the main purpose, to confront a member of the Roman elite with the value system that Roman society adopted (...) The information we have scanned depicts a society in which public and ritualized blame was an instrument of social control and enforcement of social values (...) Roman satire is embedded in a culture in which public shaming had a long tradition as an instrument of social control. This is what we would expect in a society where honor was a central value, at least for its ruling elite, but presumably well beyond that. In this respect, Roman satire appears as the literarization of fundamental social concerns and ways of behavior (Graf, 2005: 203-205)

Para los críticos de orientación bajtiniana, la conexión con estos rituales vincularía la sátira romana con la literatura carnavalesca [ver 3.2.2.]. Sin embargo, como veremos [2.1; 2.2] Bajtín opinaría que, aunque estos rituales de la risa sí pertenezcan a la órbita de lo carnavalesco, la sátira en su forma latina es una degradación individualista en la que el autor se sitúa por encima de la comunidad, y no como parte de ella (Graf, 2005: 204). Para otros críticos, de hecho, la sátira ha sido uno de los primeros géneros literarios en los que se ha forjado una idea de subjetividad, un yo poético con ideas propias: «satire came to be where the poet could manipulate his textual image as a self-consciously foregrounded carácter or caricature in his own work» (Hooley, 2007: 9)

Claro que lo satírico es algo más que las obras de Horacio, Persio, y Juvenal, hasta el punto de que algunos consideran la existencia de un “impulso antropológico” satírico presente, por ejemplo, en el arquetipo mitológico del trickster antes mencionado (Hooley, 2007: 141). En todo caso, existe toda una tradición de obras, quizá demasiado heterogéneas para ser consideradas como pertenecientes a un mismo género, pero que han venido a denominarse como «sátiras menipeas», siguiendo el título que Terencio Varro puso a sus obras en honor de las de Menipo de Gadara (Hooley, 2007: 142). Otros autores vinculados a esta tradición son Séneca, Petronio, Luciano de Samostata, Boecio... La sátira menipea comparte ciertas características con la sátira latina, como el ánimo crítico 
y moralizante, las alusiones sexuales, la ubicación de bajos fondos urbanos, el uso de un lenguaje coloquial y vulgar, etc., pero sus límites son mucho más difusos, hasta el punto de que el Satiricón de Petronio parece estar más cerca de la novela griega que de la obra de Varro (Hooley, 2007: 143). Más adelante [3.3] expondremos la importancia que Mijaíl Bajtín concede a la sátira menipea dentro de lo que llama «literatura carnavalesca».

\subsubsection{La teoría clásica de la comedia}

\subsubsection{Lo cómico en la Poética de Aristóteles}

Es ya un lugar común comenzar cualquier discusión sobre las ideas aristotélicas sobre la comedia por el relato imaginado por Umberto Eco en el que el segundo libro de la Poética es destruido por un monje fanático que no quiere que el potencial disruptivo de la risa sea legitimado - en otro momento [3.4.1] mencionaremos las implicaciones ideológicas de esta interpretación plenamente moderna. Pero lo cierto es que, como veremos, Aristóteles no parece tener en mucha estima la comedia frente a la tragedia, e incluso muchos estudiosos han llegado a dudar de que Aristóteles llegara a dedicarle, ya no un libro entero, ni siquiera un fragmento añadido al primero de la Poética (Llanos López, 2007: 152). En todo caso, sí que contamos con algunas opiniones aristotélicas sobre la risa y la comedia, diseminadas por textos como la Ética, la Retórica o la Política, y por supuesto también en la Poética misma.

En este texto hay de hecho una serie de argumentos que contradicen la supuestamente tajante distinción aristotélica entre los géneros de la comedia y la tragedia, sobre todo en lo que se refiere a su origen común en la obra de Homero, que escribió tanto la Ilíada y la Odisea como el Margites (Rodríguez Adrados, 1968: 17-18). En efecto, el esbozo histórico del origen y desarrollo de la comedia va mano a mano con su concepción de lo cómico y lo risible. Como es sabido Aristóteles distingue la tragedia y la comedia según se imite a hombres esforzados o de baja calidad (2018: 1448a) ${ }^{8}$ : ambos tienen su origen en los géneros primitivos de los himnos y encomios para el caso de la tragedia, y las invectivas para la comedia. Un momento decisivo en este desarrollo es, según el estagirita, la aparición de Homero:

\footnotetext{
${ }^{8}$ Citamos el texto aristotélico por la edición trilingüe de Valentín García Yebra.
} 
Y así como, en el género noble, Homero fue el poeta máximo (pues él solo compuso obras que, además de ser hermosas, constituyen imitaciones dramáticas), así también fue el primero que esbozó las formas de la comedia, presentando en acción no una invectiva, sino lo risible. El Margites, en efecto, tiene analogía con las comedias como la Ilíada y la Odisea con las tragedias (...) Una vez aparecidas la tragedia y la comedia, los que tendían a una u otra poesía según su propia naturaleza, unos, en vez de yambos, pasaron a hacer comedias, y los otros, de poetas épicos se convirtieron en autores de tragedias, por ser estas formas de más fuste y más apreciadas que aquéllas (Aristóteles, 1449a 1-34)

Como decimos, que Homero escribiera tanto la Ilíada como el Margites parece entrar en contradicción con su afirmación que los poetas imitan hombres mejores o peores según su propia naturaleza. Pero precisamente la innovación de Homero a ojos de Aristóteles es que en el Margites no se dramatizan invectivas, sino solamente lo risible, que el filósofo definirá como «un defecto y una fealdad que no causa dolor ni ruina» (1449a 31-35): al contrario que el «lance patético» de la tragedia, que es una acción destructora o dolorosa, la acción cómica no causa daño (García Yebra, 2018: 261).

La condición que establece Aristóteles de que lo cómico no cause dolor ni ruina plantea la cuestión, nada baladí, de a quién se supone que no debe causar daño, si al personaje cómico o al espectador. Más que un respeto por el personaje cómico objeto de la risa, la condición de Aristóteles parece referirse a la gravedad de sus vicios y delitos: de hecho, como veremos, en la teoría retórica coetánea, el uso del ridículo contra el adversario estaba indicado para aquellos vicios que no supusieran un peligro real para la sociedad - uno podía criticar mediante el ridículo a un lujurioso, pero no a un asesino. Por tanto, más que un respeto por el personaje cómico, Aristóteles podría estar refiriéndose a que el vicio cómico no sea tan grave como para causar malestar al espectador (Llanos López, 2007: 62).

La asociación que realiza Aristóteles de la risa con el ridículo y la denigración es algo comúnmente aceptado en Grecia: «it ties comedy to the observable function of derision in a culture which possessed a strongly developed sensitivity to public reproach and dishonour» (Halliwell, 1987: 85). Pero que Aristóteles establezca los límites de lo ridículo en aquello que no es grave ni cause dolor excluye los textos de Arquíloco y Aristófanes, donde sí encontramos hechos graves y dolorosos, lo que parece apuntar a que el objetivo de Aristóteles era limitar las prácticas teatrales existentes (Halliwell, 1987: 85). En todo caso, expresa su preferencia por las nuevas formas de la comedia de su 
tiempo que en el siglo siguiente culminaría con Menandro, centradas «on the relatively innocuous failings of somewhat standardised comic 'types' (...) Comedy restrained within inoffensive bounds, and shirking subjects of a potentially disturbing kind, is the broad ideal which Ar. apparently sanctions» (Halliwell, 1987: 86).

Pero más que por un rechazo de los insultos y el lenguaje grosero de las obras de Aristófanes, parece que las preferencias de Aristóteles por la Comedia Media seguían otros criterios más estéticos que morales. Por un lado, las fantasías utópicas de Aristófanes casan mal con el criterio de verosimilitud que Aristóteles impone a la mímesis dramática (Gil Fernández, 1996: 15). Por otro, y, sobre todo a la luz de la alusión al Margites homérico, el pensamiento de Aristóteles en este punto depende de una distinción entre la invectiva personal de la poesía yámbica y lo que considera propiamente cómico, de carácter ficticio y general: «the development of the comic branch of the poetic tradition is taken to have moved gradually away from coarse, personalised invective, towards a style of humour whose characters and actions represent fictional universals» (Halliwell, 1987: 85-86). Esta distinción tiene sentido si tenemos en cuenta la afirmación aristotélica de que lo distingue la poesía de la historia es que esta trata lo particular y aquella lo general: las comedias aristofánicas, tan dependientes del contexto político y el ataque a individuos concretos, no cumplirían este criterio de ficción universalista. La referencia de Aristóteles a la máscara cómica apunta en el mismo sentido: «the example of a mask also serves to illuminate Ar.'s contrast between comedy proper and the 'iambic' mode. The mask is almost certainly meant to imply a fictional identity, and so to provide a focus for laughter directed against human features whose significance is universal, not particular» (Halliwell, 1987: 87). La preferencia de Aristóteles por la Comedia Media parece, por tanto, provenir de una mayor apreciación por el alcance universalista de la ficción cómica.

\subsubsection{El Tractatus Coislinianus}

Otra posible fuente con la que contamos para conocer las ideas de Aristóteles sobre la comedia es el conocido como Tractatus Coislinianus, una serie de notas muy esquemáticas sobre la tragedia y la comedia y editado por primera vez en 1839 por J.A. Cramer, quien lo atribuyó a un comentarista de la Poética que debió de tener acceso a un texto más completo que el conservado modernamente. Se ha debatido intensamente acerca de la pertenencia de estas notas a una tradición peripatética, incluso pertenecientes a Teofrasto, el sucesor de Aristóteles en el Liceo, la posibilidad de que se trate de un 
resumen del perdido libro segundo de la Poética o incluso que sea directamente de autoría aristotélica (Llanos López, 2007: 146-147)9.

Entre todos los estudios de este texto, encontramos el intento de Richard Janko de reconstruir este libro sobre la Comedia, lo que realiza completando las esquemáticas notas del Tractatus con otros pasajes del primer libro de la Poética, la Ética y la Retórica. Así, según esta hipotética reconstrucción la Comedia se definiría de este modo:

A Comedy is a representation of an absurd, complete action, one that lacks magnitude, with embellished language, the several kinds of embellishment being found separately in the several parts of the play: directly represented by the persons acting, and not by means of narration: through the pleasure and laughter achieving the purgation of the like emotions. It has laughter, so to speak, for its mother (Janko, 1984; las negritas, del autor, indican los fragmentos extraídos del Tractatus)

También desarrolla la distinción entre lo cómico y la invectiva basada en la oposición entre lo general y particular de que hablábamos anteriormente:

Comedy differs here from abuse, since abuse rehearses without concealment the bad actions and qualities attaching to people, but comedy requires the so-called innuendo, or fantasy through which reality is transformed and distorted. Although comedy evolved from abusive performances, in its essential nature to which it has attained it aims at a representation of how people might behave, rather than of how actual people like Alcibiades do behave. So comic poets use invented names for the characters in their plots, such as present an appearance of reality, and do not submit individuals to abusive attack like the writers of scurrilous verses

Es interesante también que el Tractatus relacione lo risible y lo ridículo en la comedia con una función moralizante y educativa: «Even so, there is a place for some mockery in comedy, since a reproach becomes acceptable if it is sweetened with wit. The joker aims to expose faults of mind and body in his victims, and this is amusing, provided that the

\footnotetext{
${ }^{9}$ De este debate destacan dos intentos por demostrar la filiación aristotélica del Tractatus Coislinianus. El primero es el de Lane Cooper, quien en 1922 publicó An aristotelian theory of Comedy, que incluía una traducción del Tractatus. Pero esta se incluía como apéndice, y la teoría anunciada en el título del trabajo eran más bien una adaptación a la comedia realizada por el mismo Cooper de las ideas aristotélicas sobre la tragedia. De hecho, Cooper no llega a hacer una apuesta segura por la filiación peripatética del texto, aunque le otorgue suma importancia para conocer el pensamiento griego sobre la Comedia (Llanos López, 2007: 148-149). Más atrevida fue la propuesta de Richard Janko, que cotejando los materiales del manuscrito con otras fuentes postula la necesidad de un origen común a todos que sería el del segundo libro de la Poética, y defiende la autoría aristotélica de las ideas vertidas en el Tractatus a partir de una comparación de estas, principalmente sobre el análisis de los modos de suscitar la risa, con otros escritos aristotélicos (Llanos López, 2007: 156-159).
} 
fault is painless and embarrassing rather than destructive». Esto tiene que ver con la definición de los caracteres de la comedia, que en su reconstrucción Janko pone en relación con la Ética:

Comic characters are those who are in error in some way: typical characters of comedy are the buffoonish, the ironical and the boasters. As is stated in the Ethics, those who in character diverge from the mean deserve not praise but reproach (...) Not every kind of bad character is suitable, however, but only those that are not painful or destructive.

La última frase del fragmento citada apoya la tesis de que el límite que Aristóteles impone a lo cómico es el de la gravedad del vicio del personaje cómico, y no del daño causado a este. Por otra parte, estos fragmentos ayudan a analizar el papel central que la poética aristotélica parece darle al personaje cómico: así, la comedia sería la representación de acciones de personajes bajos (tengamos en cuenta que en el pensamiento aristotélico el análisis del carácter, ethos, cae en el terreno de la ética y no de la psicología) cuyos vicios y errores son susceptibles de ser castigados mediante el ridículo.

Pero esta supuesta centralidad del personaje ridículo entra en contradicción con lo que Janko denomina «the quantitative elements of comedy». En efecto, parte del Tractatus Coislinianus trata de los modos de suscitar la risa, que, según el mismo texto es la madre de la comedia como el miedo lo es de la tragedia. La risa, nos dice el Tractatus, puede ser provocada por la dicción o por las acciones - distinción que Cicerón establece también en el De Oratore, como veremos. En el primer caso, la risa es causada por la homonimia, la sinonimia, la repetición, los parónimos, los diminutivos, la parodia y la transferencia categorial; en el caso de las acciones, el engaño, el disimulo o disfraz, lo imposible, lo ilógico, lo irracional o lo inesperado.

\subsubsection{Comedia, mímesis, catarsis}

Pero, más que centrarse en hipotéticas definiciones concretas, quizá sea más productivo acudir a las nociones generales acerca de la poesía y la tragedia de la Poética de Aristóteles en lo que sus reflexiones puedan aplicarse a la comedia. En este sentido son particularmente interesantes los conceptos aristotélicos de mimesis y catarsis. Por supuesto, la bibliografía acerca del sentido y las implicaciones de estas dos nociones fundamentales en la historia del pensamiento estético de Occidente es inabarcable, y su discusión en este punto nos llevaría muy lejos de nuestros objetivos e intereses. Por tanto, aunque volvamos a ellos en la posterior discusión teórica [3.1, 3.2], nos limitaremos aquí 
a dar algunas notas sobre sus orígenes y posibles sentidos que estos términos pudieron tener en la época de Aristóteles.

Como se sabe, la teoría del arte como mímesis ya había sido formulada por Platón en varios de sus escritos para justificar la expulsión de los poetas de la ciudad, y de hecho es una opinión comúnmente aceptada que Aristóteles formuló su Poética para contestar las ideas de su maestro, ofreciendo una valoración positiva de la mímesis que salvara un elemento tan importante de la cultura griega (Halliwell, 1987: 1). Pero el término es de hecho anterior a los escritos platónicos: según Koller, los términos «mimos», «mimesis», etc., tendrían su origen en las danzas y representaciones rituales, concretamente en el ditirambo dionisíaco (Rodríguez Adrados, 1968: 20). Aunque Halliwell rechace este origen cultual, sí que afirma que en el siglo IV a.C. una amplia variedad de prácticas artísticas como la poesía, la pintura, la escultura, la danza, la actuación y la música eran consideradas miméticas (Halliwell, 2002: 7, 15). Antes de su uso por parte de Platón, la palabra «mímesis» parece ocupar los siguientes campos semánticos: semejanza visual, imitación en el comportamiento, fingir ser otra persona («impersonation»), producción musical o vocal de sonidos significativos y expresivos, conformidad metafísica, como en la creencia pitagórica de que el mundo material es mimesis del ámbito de las matemáticas (Halliwell, 2002: 15).

En todo caso, parece que el origen de la teoría mimética del arte está en la música y la danza. La teoría musical de los pitagóricos establecía que la música y la danza son mímesis del ethos y el pathos del ejecutante - lo que daría lugar al influjo que estas ejercen sobre las almas, de ahí su función en la educación («paideia») y la catarsis (Rodríguez Adrados, 1968: 21). Platón, en el octavo libro de las Leyes (817e y ss.) establecía una analogía entre las danzas “serias” con la tragedia (Rodríguez Adrados, 1968: 21-22), y, muy reveladoramente, las danzas que imitan los cuerpos feos y chabacanos con la comedia, donde se imitan «cuerpos feos y pensamientos vergonzosos (...) que provocan risas con lo que dicen, cantan y bailan» (Platón, 1999). En resumen,

El Teatro como mímesis es un desarrollo, probablemente anterior a Platón, de la concepción de la danza y música como mímesis; el arranque está en las danzas dramáticas de origen religioso, que eran calificadas en griego de mímesis. Pero la mímesis suponía una enajenación o posesión (manía, enthusiasmós); los ejecutantes, en este tipo de danzas, revisten una nueva personalidad, dejan de ser ellos mismos, se sienten transportados a un mundo de fuerzas divinas (Rodríguez Adrados, 1968: 25) 
También Demócrito y Gorgias hablaban del entusiasmo como origen de la poesía, que Aristóteles dejaría de lado en su propia formulación (Rodríguez Adrados, 1968: 23, 25), lo que da cuenta del carácter cognitivo que el estagirita le da al proceso mimético, como él mismo establece en este conocido pasaje de la Poética:

Parecen haber dado origen a la poética fundamentalmente dos causas, y ambas naturales. el imitar, en efecto, es connatural al hombre desde la niñez, y se diferencia de los demás animales en que es muy inclinado a la imitación y por la imitación adquiere sus primeros conocimientos, y también el que todos disfruten con las obras de imitación. Y es prueba de esto lo que sucede en la práctica; pues hay seres cuyo aspecto real nos molesta, pero nos gusta ver su imagen ejecutada con la mayor fidelidad posible, por ejemplo, figuras de los animales más repugnantes y de cadáveres. Y también es causa de esto que aprender agrada muchísimo no sólo a los filósofos, sino igualmente a los demás (1448b 4-19)

El concepto de mímesis, que Halliwell aboga por que se traduzca como «representación» mejor que como «imitación», se ha interpretado de dos modos en la cultura occidental:

The first of these places central emphasis on the "outward-looking” relationship between the artistic work or performance and reality (...) whereas the other gives priority to the internal organization and fictive properties of the mimetic object or act itself (...) On the first of these interpretations, mimesis incorporates a response to a reality (whether particular or general) that is believed to exist outside and independently of art. It engages with this reality, or at the very least with other experience and perceptions of it, and has the capacity to promote and enlighten the understanding of it. On the second interpretation, mimesis is the production of a "heterocosm" (Baumgarten's term again), an imaginary world-in-itself, which may resemble or remind us of the real world in certain respects (and may thus in some cases be partly a matter of "worldlike" consistency or plausibility), but is not to be judged primarily or directly by comparison with it (Halliwell, 2002: 23)

Es decir, el debate se mueve entre la mímesis como imitación fidedigna de la naturaleza tal cual es, como se interpretó durante el neoclasicismo dieciochesco, o una noción de la mímesis como ficción, de creación de un mundo que no cumpla los requisitos de veracidad sino de verosimilitud. Un índice importante de la propia concepción aristotélica de la mímesis es su comparación entre Homero como poeta y Empédocles como filósofo de la naturaleza: «by so doing, he opens up the possibility that poetry may offer material which, if not describable in terms of truth, can at any rate be argued to make some contribution to the understanding of human realities» (Halliwell, 1987: 71-73). 
Pero Aristóteles niega la opinión común en la cultura griega, expuesta por Platón en el Ión, de que el poeta pase por ser experto en todas las materias de las que habla, sino que solo le concierne la representación de la acción humana; acción que, en el marco teórico aristótelico, es acción con un fin («purposive»), es decir, orientada al cumplimiento de unas intenciones: «so (...) [Aristóteles] implies that poetry is capable of treating, if only in fictional form, the fundamental patterns of life» (Halliwell, 1987: 7475). Ahora bien, cabría dudar de que Aristóteles, quien, como hemos mencionado, parece tener en menor estima la comedia que la tragedia (Llanos López, 2007: 63), considerara que aquella tuviera la misma capacidad cognitiva o educativa que esta. En la misma Poética, sin ir más lejos, asegura que «los poetas [cómicos], al componer, se pliegan al deseo de los espectadores»: es decir, que lejos de guiarse por los criterios de necesidad interna de la fábula y su posible carácter educativo, su único objetivo es satisfacer los gustos del público.

Como veremos en capítulos posteriores [5.2.], el carácter cognitivo de la mímesis como aprendizaje, así como «imitación de acciones», será fundamental para nuestra caracterización de lo cómico. Esta cuestión también afecta a la noción, estrechamente asociada, de la catarsis como telos de la mímesis trágica. El concepto, de nuevo, no es original de Aristóteles:

Because hypothesized realities are imagined possibilities of experience, the Greek tradition, both before and after Plato, is greatly interested in the effects of mimetic artworks on their viewers or hearers, and repeatedly attempts to characterize the kinds of recognition, understanding, emotional response, and evaluation that such artworks can or should elicit in their audiences (Halliwell, 2002: 25)

Es casi unánimemente aceptado que el término «katharsis» es propio del lenguaje de la medicina, equivalente a «purgación», y del religioso, entendido como «purgación» o «expiación»; también figuradamente entendido en sentido psíquico como purgación de las pasiones del alma, que sería el sentido utilizado por Aristóteles en su Poética (García Yebra, 2018: 381-382). En las Leyes, Platón habla de la curación de enfermos mentales gracias a la danza de las coribantes, danzas que precisamente en el Ión y el Fedro se comparaban con la manía poética y la atracción dionisíaca ejercida por Sócrates (Rodríguez Adrados, 1968: 19-20). Por tanto, la catarsis aristotélica estaría vinculada a estos dos textos platónicos por los fenómenos religioso de tipo orgiásticos que son, en la teoría platónica, tanto el origen como el fin de la poesía. En este sentido, también Gorgias 
hacía hincapié en el efecto mágico y curativo del logos (Rodríguez Adrados, 1968: 25) de hecho, recordemos que era común en la sofística la comparación de la Retórica con la Medicina (López Eire, 2000a: 20).

Ahora bien, lo conflictivo es determinar el alcance de la metáfora médica en el lenguaje aristotélico: la purgación, ¿̇se refiere a una extirpación o erradicación de las pasiones o simplemente una moderación? Según el estudioso Guarini, es claro que, si en la purgación quirúrgica de los humores no se elimina de todo el humor, sino solo el exceso que provoca la patología, Aristóteles hablar de catarsis como moderación de las emociones (García Yebra, 2018: 382-383). Pero Jonathan Lear (1988) rechaza las lecturas de purgación médica o expiación religiosa, y para Halliwell, teniendo en cuenta la psicología filosófica de Aristóteles, parece improbable que concibiera la catarsis como una simple descarga de emociones, menos aún de emociones consideradas patológicas; es más probable que la catarsis sea un elemento de un sistema más complejo según el que Aristóteles concibe que las emociones tienen un papel natural y fundamental en la experiencia de la realidad. Por tanto, la catarsis podría interpretarse como una intensa experiencia emocional «which conduce to their rightful functioning as part of our understanding of, and response to, events in the human world» (Halliwell, 1987: 90).

Pero la verdadera cuestión que nos atañe es si Aristóteles consideraba que también la mímesis cómica daba lugar a la catarsis, o qué tipo de emociones despertaría un espectáculo que, como hemos citado más arriba, se pliega a los gustos del público. Como hemos visto, en el Tractatus Coislinianus leemos esta caracterización de la catarsis cómica: «through the pleasure and laughter achieving the purgations of the like emotions» igual que la tragedia conseguiría la purgación del miedo. Pero, ¿qué significa que la comedia purgue "la risa”? Para algunos autores, esta expresión se podría referir a la agresividad de la que esta risa es manifestación, lo que concordaría con la idea, expuesta en el apartado anterior, de que la comedia serviría de válvula de escape para las tensiones sociales. Ciertamente, Platón, en el Filebo, expone que en la risa se dan a la vez dos sentimientos contradictorios, el placer y el dolor. Como este es un debate en el que tienen más peso las interpretaciones modernas que los propios testimonios griegos, trataremos la cuestión en capítulos posteriores [3.1; 3.3.2; 5.5]. 


\subsubsection{La ironía de Sócrates a Quintiliano}

Sin duda, la herencia más importante respecto de lo cómico y el humor recibida de Grecia es la de la ironía como figura y posición filosófica. Como veremos a lo largo de este trabajo [2.4.1; 3.2.3; 3.4.1], la ironía aparecerá a lo largo de la historia de la cultura y el pensamiento occidental como centro de muchas discusiones fundamentales acerca de la literatura y su interpretación, el lenguaje y el conocimiento filosófico.

El término griego eironeia tiene su origen en el teatro: el eiron era el personaje que, frente al alazon o «fanfarrón», disimulaba sus habilidades y conocimientos para tenderle una trampa y revelar al público su impostura. Pero, por supuesto, la eironeia ha llegado hasta nosotros a través de su practicante más ejemplar, Sócrates (Ballart, 1994: 39-41), de ahí que se haya asociado, especialmente a partir del Romanticismo, con la filosofía, sobre todo por su relación con el conocido como «método socrático»: el uso de la ironía por parte de Sócrates, entendida como disimulo y falsa alabanza, no solo servía para rebatir a los sofistas y desnudar su ignorancia, sino que, mediante un juego de preguntas y respuestas que pone a prueba todo conocimiento hasta alcanzar una verdad más alta. De ahí que la ironía socrática se haya hecho equivaler al pensamiento filosófico como pensamiento crítico, por una parte, y, por otra, como actitud objetiva y racional que permite un conocimiento elevado.

Claro que no existe un solo Sócrates, y cada filósofo ha construido una figura irónica a la medida de su respectivo pensamiento. A esto contribuye, sin duda, el que ha acabado por conocerse como «problema socrático»: hasta qué punto los testimonios de su postura y doctrina recogidos y recreados por Platón, Jenofonte y otros es realmente el que sostuvo el Sócrates histórico. Gregory Vlastos, por ejemplo, sostiene que en los mismos diálogos platónicos encontramos dos Sócrates completamente opuestos: el de los primeros diálogos, supuestamente más cercanos y fieles al personaje real, es un filósofo exclusivamente moral, que no busca construir un conocimiento doctrinal y estable, sino poner a prueba el ya existente a partir de un escepticismo absoluto, mientras que el segundo, que expone las propias teorías de Platón, es un pensador metafísico, esencialista y absolutamente racionalista (Vlastos, 1991: 48-49). Esta dualidad, como comprobaremos a lo largo de este trabajo, dará lugar a dos concepciones enfrentadas de la ironía como posición filosófica [2.4.1; 3.2.3]. 
Sobre todo, como vemos, Sócrates, sobre todo en los primeros diálogos platónicos, deja abierta la interpretación de su actitud irónica:

When speaking ironically, does he simply mean the opposit of what his words literarlly say - so that, if he is ironically disavowing knowledge of humann excellence and virtue he is really claiming to possess it? Or is irony a more mysterious and potentially allembracing aspect of one's character, making the ironist esentially opaque? Further, is Socratic irony an occasional and incidental phenomenon or does it permeate his very being and function as essencial to his philosophy? (Lane, 2011: 239)

La esencial inescrutabilidad de Sócrates quedó inmortalizada en el retrato que de él hace Alcibíades en el Banquete de Platón, donde lo compara con las estatuillas de silenos que, siendo de fea apariencia, esconden tesoros en su interior: del mismo modo, aunque feo en apariencia, Sócrates guarda en su interior un espíritu bellísimo; más aún, a pesar de la ignorancia de la que tanta gala hace, guarda un conocimiento precioso que es el que Alcibíades intentaba alcanzar. Siglos más tarde, Erasmo utilizaría esta metáfora para hablar del texto alegórico: igual que la figura del Sócrates-sileno guarda un tesoro en su interior, el significado literal de un texto encierra un significado figurado más profundo. Y, muy significativamente, Rabelais, tomaría como referencia a Erasmo en el prólogo a su Gargantúa y Pantagruel para defender la riqueza de su obra a pesar de su aparente frivolidad (Dane, 2011: 23-24).

A pesar de todo, la ironía socrática no estaba del todo bien vista en la Grecia antigua. Demóstenes considera que el ironista se escabulle de sus responsabilidades públicas, mientras que Teofrasto directamente caracteriza al ironista como un mentiroso (Ballart, 1994: 44). Aristóteles, en la Ética a Nicómaco considera al alazon y el eiron como dos extremos respecto a la relación de la persona con la veracidad: la fanfarronería es un vicio porque dice poseer más verdad de la que realmente conoce, mientras que la actitud ironía disimula que sabe más de lo que dice - si bien reconoce que es preferible el vicio de la eironeia que el de la alazoneia (Ballart, 1994: 45).

En todo caso, en el análisis aristotélico, la ironía tiene un sentido restringido de disimulo y fingida humildad, y en su Retórica relacionaría la figura con la de la antífrasis, consistente en decir lo contrario de lo que realmente se piensa o se pretende que se entienda, y este sentido es el que pasaría al latín de la mano de Cicerón ${ }^{10}$ (Lane, 2011:

${ }^{10}$ Cicerón dedica un extenso pasaje de su tratado de retórica De Oratore (Cicerón, 2002) a lo risible, es decir, a las posibles ventajes e inconvenientes de recurrir a la risa en la Asamblea y los tribunales para 
240). De este modo, la ironía se verá progresivamente reducida en la doctrina retórica como un tropo que afecta a una sola palabra y que consiste únicamente en decir lo contrario de lo que dice, despojando a la figura, de este modo, de la aureola filosófica que Sócrates le había concedido. Sin embargo, esta reducción no se completaría hasta los tratados dieciochescos de Du Marsais o Fontanier, cuyas definiciones serían las heredadas por la lingüística del siglo XX (Kerbrat-Orecchioni, 1980: 108-109). Sin embargo, la consideración de la ironía en la Retórica clásica es bastante más rica de lo que se cree. Quintiliano, por ejemplo, considera que la ironía puede considerarse tanto como tropo como figura, es decir, puede actuar tanto localizada en una palabra como en una oración - más aún, incluso cuando funciona como tropo necesita de todo el contexto oracional para ser comprendida (Pujante Sánchez, 1999: 208); más aún, según Quintiliano, la ironía puede afectar a una frase, a un discurso e incluso a una vida entera, poniendo a Sócrates como ejemplo de vida irónica.

Para comprobar la verdadera concepción que la Retórica clásica tiene de la ironía podemos acudir a la magna obra de Heinrich Lausberg, que recopiló para el siglo XX la vasta teoría retórica clásica. En su Manual de Retórica literaria, Laurberg mantiene la doble definición de la ironía como tropo y como figura. En el primer caso, la define como «expresión de una cosa palabra que significa lo contrario de ésta. La ironía es un arma de la parcialidad (...) en una reducida sermocinatio utiliza la escala léxica de valores de su adversario, haciendo ver su falsedad mediante el contexto (lingüístico y situacional) (...) ayuda al triunfo de la verdad (expresada por su contrario)» (Lausberg, 1994: §582; el destacado es nuestro). Y, como figura, la ironía es

un fingimiento de una opinión propia que coincide con la opinión de la parte contraria (...) susceptible de realizarse tanto en una sola palabra como en el pensamiento [entero] (...) [La ironía] se dirige al público para desenmascarar al adversario (...) mostrando la evidente falta de sentido que demuestra (...) en la terminología con que valora las cosas (...) Ni la misma dissimulatio socrática, en cuanto apunta no sólo a la victoria dialéctica sobre el adversario ante el público está exenta de miras retóricas (...) La ironía de

\footnotetext{
ganarse el favor del público. Este pasaje, lleno de clasificaciones y ejemplos, servirá, como veremos, de fuente a los manuales de cortesía y retórica renacentistas y posteriores que se ocupaban del uso del humor y el ingenio en la conversación cortesana. Cicerón define lo risible como «designar lo desagradable de modo no desagradable», en una caracterización similar a la aristotélica; también distingue entre la dicacitas, un dicho breve, agudo y mordaz, y la cavillatio, que se refiere más bien a un tono distendido del discurso en general; y diferencia lo risible en la palabra de lo risible de la situación, según lo cómico se produzca mediante un juego de palabras o por la situación descrita.
} 
pensamiento es una sermocinatio tomada del ideario del adversario para caracterizarlo (1994: §902.2-.3; el destacado es nuestro)

Aparentemente, la definición de Lausberg nos sigue ofreciendo una concepción de la ironía como antífrasis reducida a la palabra. Pero no hay que pasar por alto el cometido dialéctico y el contenido de verdad que acompaña esta definición: la ironía hace ver la falsedad del discurso del contrario, reduciendo sus argumentos al absurdo, y por tanto ayuda al triunfo de la verdad. Significativamente, el ironista hace esto imitando el léxico y el modo de expresión de su contrincante. En este sentido, es interesante que Lausberg identifique la ironía como un tipo de sermocinatio, un recurso también llamado «etopeya» que consiste «en fingir para caracterizar personas naturales (históricas o inventadas), dichos, conversaciones, monólogos o reflexiones inexpresadas de las personas correspondientes» (Lausberg, 1984: §820). La ironía, por tanto, consiste en una imitación, de tipo teatral, que sirve para caracterizar al adversario y sus palabras como ridículas. Como podemos comprobar, por tanto, la definición clásica de la ironía en su contexto retórico es bastante más compleja y sugerente de lo que su posterior reducción a la antífrasis da a entender. Sobre todo, introduce un componente de imitación y de fingimiento que conecta la ironía con su origen dramático y sugiere una naturaleza teatral que, como veremos, estará muy presente en muchas caracterizaciones de lo cómico, y que será central en nuestra propia propuesta de acercamiento hermenéutico al discurso humorístico [5.2]. Más adelante [5.1] retomaremos esta caracterización para compararla con las teorías lingüísticas contemporáneas de la ironía, y la tomaremos como modelo propedéutico del que extrapolar una definición más general del fenómeno cómico.

\subsubsection{El pensamiento griego sobre la risa}

\subsubsection{La risa de Demócrito. Medicina y filosofía}

En las tardías Epístolas de Pseudo-Hipócrates se narra la leyenda de la visita del insigne doctor a Abdera, alertado por los ciudadanos de que el filósofo Demócrito parece haberse vuelto loco, ya que no deja de reírse de todas las cosas y personas. Sin embargo, Demócrito consigue convencer a Hipócrates de que no es locura, sino sabiduría, lo que le lleva a reírse de las locuras de los seres humanos y de la insignificancia de su vida (Halliwell, 2007: 360-364). Como se sabe, a partir de esta leyenda, la risa de Demócrito 
ha sido tomada como emblema de una actitud vital y filosófica hacia lo absurdo de la existencia, frente a las lágrimas de Heráclito.

Pero la anécdota también dice mucho de la concepción fisiológica que los griegos tenían de la risa, y sobre todo de su relación con la locura. Como hemos visto, en la misma mitología griega y en su literatura había una estrecha relación entre ambas, como en el caso de los pretendientes enajenados por Atenea, en el del Áyax de Sófocles o el del furor del Heracles euripideo (Halliwell, 2008: 18). En el corpus hipocrático, la risa es presentada como terapéutica (recordemos el mito de Deméter “curada” por la risa que Baubo consigue provocarle), pero también como síntoma o causa de enfermedades y desarreglos psíquicos (Gil Fernández, 2010: 14). Cuando Aristóteles trata la risa en sus tratados de biología y fisiología, la explica como el resultado de un calentamiento del diafragma, lo que explicaba el efecto de las cosquillas; pero también estaba provocada por la percepción de una incongruencia o sorpresa. Sin embargo, para el estagirita la risa es un fenómeno que tiene que ver con la percepción sensorial y la inteligencia, pero no con la voluntad, por lo que viene a ser como «un ataque de locura pasajero y un engaño» (Gil Fernández, 2010: 15).

Lo evidente es que los griegos situaban la risa en el ámbito de lo fisiológico y lo corporal - como, por otra parte, atestiguan la relación de la risa ritual con los cultos orgiásticos y de fertilidad, o la preferencia de esta y la Comedia Antigua por el lenguaje y las bromas obscenas y escatológicas. En la alusión a los simposios en el himno homérico a Hermes que mencionábamos unas páginas más arriba, sin ir más lejos, vemos cómo los insultos intercambiados ritualmente entre los participantes relacionan los placeres del ingenio verbal con los del cuerpo (Halliwell, 2008: 102). Sobre todo, se relaciona con una característica muy específica del cuerpo: la fealdad y la deformidad - recordemos la definición aristotélica de lo cómico como lo contrahecho; la fealdad era a la vez motivo de burla y signo exterior de una fealdad o vicio moral:

Ugliness carries an intrinsic complexity vis-à-vis laughter. It may be viewed as an apt target of derision in its own right; it may somehow legitimise (by marking as socially licensed) the performers whose business it is to generate laughter; but it also may be regarded, by moralists at least, as a signal that laughter is an ugly, 'shameful' thing which disfigures those who yield it (Halliwell, 2008: 72)

En este sentido, es muy elocuente el pasaje de la Ilíada en que Tersites interrumpe la disputa entre Aquiles y Agamenón, parodiando el ataque de aquel contra el jefe del 
ejército griego. La broma no es bien recibida entre los líderes reunidos, y Odiseo le propina una paliza, lo que sí provoca la risa del ejército y la relajación de la tensión creada por la pelea entre Aquiles y Agamenón, convirtiendo a Tersites en una especie de víctima sacrificial. El personaje de Tersites coincide con muchos de los rasgos del bufón o «bomolochos» ${ }^{11}$ o el «parasitos» 0 «gelotopoios» (bufones profesionales que amenizaban los simposios); Odiseo le describe como un agudo orador pero falto de juicio, $\mathrm{y}$, sobre todo, parece ser extremadamente feo y contrahecho (Halliwell, 2008: 70-76). El episodio revela la importante función social que la risa tenía en la cultura griega, y cómo por esa misma razón estaba sometida a la regulación de las convenciones para ser bien recibida - la broma de Tersites provoca la ira de sus compañeros por su falta de oportunidad, de «kairos». En efecto, si parece que los pensadores griegos dedicaron mucha más atención al fenómeno de la risa que los filósofos modernos, al contrario de estos no se preocuparon tanto por los motivos y mecanismos psicológicos que la provocaban si no por delimitar en qué momentos y de qué manera era lícito reír («gelan») y concretamente reírse de alguien («katagelan») - una distinción que, como veremos, no era nada tajante.

\subsubsection{La ética griega de la risa}

En este sentido, la corporalidad y materialidad de la risa y su relación con la deformidad y el descontrol, corporal y moral, si bien no supondría un problema en sí mismo hasta época más tardía y sobre todo, como veremos, por parte de los primeros autores cristianos con una agenda claramente antigelástica, sí exigía de cierta atención por el énfasis de la ética griega en el control del cuerpo y los emociones - ética en el sentido de sophrosyne o dominio de sí tal y como lo entiende Foucault en su segundo tomo de la Historia de la sexualidad (Foucault, 2009b). En suma, «the physicality of laughter is never in itself the whole story and can only be judged when laughter is placed within contexts of social meaning» (Halliwell, 2008: 10).

Ante todo, la risa estaba relacionada con el ámbito de la «paidia», tanto en lo que tiene que ver con la educación como con el jugar («paizein»). Si el término deriva de «país», «niño», la risa es percibida como rasgo de la infancia, y de hecho «paidia» aplicado al ámbito de los adultos implica «fingir conscientemente» ${ }^{12}$ que se es niño, y

\footnotetext{
11 Bomolokhía deriva del adjetivo bomolokhos, «el emboscado junsto al altar», que hace reír a los participantes en los sacrificios (López Eire, 2004: 160)

${ }^{12}$ La palabra usada por Halliwell para traducir paidia es play, es decir, «representar» además de «jugar». Recordemos también la importancia en la Comedia Antigua de la imitación de rituales y otros casos de
} 
este sentido está fuertemente asociado con actividades como la música, la danza, la festividad, etc. (Halliwell, 2008: 19-20). La relación de la risa con la paidia adulta implica una consciente fuga de la normatividad cotidiana, del "tomarse las cosas en serio" - de ahí, también, su relación con la práctica de la bebida y en general del banquete (Halliwell, 2008: 21) - y Aristóteles, en la Política (VIII, 3, 1227b33-1338a) así como en la Retórica (I, 11, 1371b33-35 y II 3 1386b3), la define precisamente como una medicina para contrarrestar los esfuerzos del trabajo, y, en general, centra su análisis de la adecuación de la risa a los períodos de «anapausis» o relajación entre amigos (Halliwell, 2008: 309310).

Pero, si la risa es algo necesario y deseable como cura y alivio ante los esfuerzos de la vida cotidiana, también es entendido por Aristóteles como algo a lo que las personas son demasiado propensas, y desaprueba a aquellos más interesados en el ocio que en los asuntos serios (Halliwell, 2008: 309, 313). La risa para Aristóteles es una capacidad fisiológica exclusiva del hombre (aunque no, como muchas veces se piensa, definitoria), y por tanto algo natural que hay que someter; la risa no es una expresión voluntaria del individuo sino algo corporal que irrumpe: «laughter is not just manifested in the face; it breaks out of the body, forcing its way, often compellingly, from inside to outside» (Halliwell, 2008: 314). En general, los griegos ven la risa como demasiado anclada en el cuerpo y que entraña el riesgo de enajenar al individuo, y que por tanto necesita de un férreo control racional: para Platón, los guardianes de su Estado ideal no deberían reír demasiado, y Aristóteles define el personaje del bomolochos como alguien fuera de control y que no puede evitar reír e intentar hacer reír (Halliwell, 2008: 285, 314). De hecho, la risa está explícitamente relacionada con los extranjeros: Platón concede en las Leyes la representación de comedias, siempre y cuando de esta se encarguen esclavos y extranjeros.

En resumen, la risa es un obstáculo para la sophrosyne, el autodominio sobre todo de los adolescentes y hombres jóvenes y plantea problemas para su educación: por un lado, la risa forma parte esencial de la infancia, pero, por otro, conlleva el riesgo de caer en una actitud irrespetuosa (Halliwell, 2008: 23). Porque en el pensamiento griego la risa siempre conlleva un elemento de agresión: en la práctica no se puede distinguir entre «gelan» y «katagelan», reír y reírse de alguien. Otros términos relacionados expresan imbricación entre el representar y el juego y su interés para la concepción de lo cómico. 
también esta ambigüedad: «skóptein» significa tanto broma inocente como burla hostil, y también fingimiento; el término «charis», «gracia», está relacionado con el ingenio verbal pero también tiene usos peyorativos (Halliwell, 2008: 18-19); como vimos, «komodein» significa «componer una comedia» pero también, significativamente, «burlarse de alguien» (Gil Fernández, 2010: 15).

Saber discernir la oportunidad o kairos de la risa y distinguir entre los límites de una broma inocente y una burla agresiva es fundamental en una cultura «where the dynamics of maintaining or losing status (or impugning the status of others), of suffering or avoiding shame (or wielding its public power against others), were so fundamental» (Halliwell, 2008: 25). En el contexto cotidiano, el ciudadano griego tenía miedo de ser objeto de burla en el espacio público, y los individuos indiferentes a las burlas y agresiones verbales de sus enemigos eran vistos con más suspicacia que admiración (Halliwell, 2008:31-32). Lo que se colige de la literatura y los mitos griegos y los tratados de ética es un uso social y cohesivo de una risa siempre agresiva mediante la exclusión de lo extraño. Tan importante era este uso agresivo y combativo que, según Plutarco, formaba parte de la instrucción militar de los niños espartanos (Minois, 2000: 35-37).

En este sentido, la opinión hacia la risa de Platón, a quien muchos consideran uno de los primeros y más importantes antigelastas, tal y como se refleja en sus diálogos es mucho más matizada de lo que normalmente se cree. Parece que distingue entre todos tipos de burla: la primera, la de aquellos que se burlan de Sócrates, tiene que ver con la ignorancia basada en arraigadas creencias y normas culturales, pero la segunda, la implicada en la ironía socrática, tiene que ver con la búsqueda de la verdad (Halliwell, 2008: 284-287). En la República concederá un uso moderado de la risa para castigar los vicios y ridiculizar a aquellos que están en el error. Es decir, en todo caso hay un uso agresivo y ridiculizante de la risa y orientada a las mismas consideraciones éticas y sociales de corrección de los individuos que se salen de lo deseable para la sociedad.

En suma, aunque la paidia a la que pertenece la risa es, por definición, no seria, no toda la risa lo es, y la distinción en el ámbito de las relaciones sociales entre una risa inocente y la agresión o hubris es fundamental. En este sentido es sumamente interesante el análisis que Aristóteles lleva a cabo en la Ética a Nicómaco y otros lugares sobre la adecuación de la risa. Este análisis se centra en el contexto de la convivencia entre amigos y en la necesidad de establecer los límites de la educación en la interacción social (Halliwell, 2008: 308). En la Retórica (II, 4, 138133-8) califica como deseable estar 
dispuesto a participar con los amigos en un sano bromear $^{13}$ (Halliwell, 2008: 308) y repite una opinión común en la Grecia Clásica al considerar como extremos indeseables tanto el bufón (bomolochos) como el «agroikos» o rústico que es incapaz de bromear y relajarse - hasta el Sócrates platónico se ve obligado a defenderse en muchas ocasiones de esta descalificación (Halliwell, 2008: 311).

La noción central de esta discusión es la de «eutrapelia», que en el período clásico designa a alguien de carácter fácil («easy-going») y también gracioso, ingenioso («witty»); término relacionado con la charis o gracia, que también tiene que ver con la belleza física y la gracia en el movimiento - Aristóteles también lo utiliza en el sentido de armonioso, adaptable a cada situación y coordinado con los compañeros (Halliwell, 2008: 310-313). Vemos retornar, por tanto, la asociación de la risa con la música y la danza, pero también con la belleza en contraposición con la deformidad física y moral de la que hablábamos anteriormente. Esta distinción, que como veremos se mantendrá a lo largo de toda la historia cultural de Occidente (será retomada, por ejemplo, en la Edad Media para calificar la actitud vital de San Francisco de Asís), entre una risa burda, corporal, agresiva, baja, etc., y una risa contenida, amigable, espiritual y deseable, sin embargo, no llega a implicar la diferencia fundamental entre ambos tipos de risa que más tarde se desarrollará. Como hemos visto, la actitud "bromista” entre amigos sigue siendo la de la burla, si bien sin ánimo real de ofender, y de hecho Aristóteles define la eutrapelia como una «educated hubris» (Halliwell, 2008: 25); por otra parte, para los griegos hasta la burla más baja y escatológica contenía una parte importante de ingenio verbal (Minois, 2000: 36), como se puede colegir de cualquier análisis sobre los mecanismos humorísticos usados por Aristófanes (Gil Fernández, 1996). Por tanto, las llamadas de Aristóteles a controlar la risa o limitar el lenguaje obsceno tiene más que ver con consideraciones de estatus social (como se deduce del hecho de que asocie la bufonería con la esclavitud) que de fundamentalismo moral. Cuando en la Ética distingue los dos vicios opuestos de bomolochia y eironeia, aunque los sigue considerando defectos, prefiere el segundo por ser más propio de ciudadanos libres.

Es particularmente significativo el hecho de que un rasgo básico de este «teasing» entre amigos para que no caiga en la hubris directa sea un cierto grado de fingimiento ${ }^{14}$.

\footnotetext{
${ }^{13}$ Halliwell habla de «teasing», es decir, una burla amigable.

${ }^{14}$ Como veremos [3.3; 8.3], uno de los argumentos más frecuentes ante los conflictos producidos por el humor es el de apelar a este carácter fingido asegurando que "es solo una broma”
} 
En cierto modo, Aristóteles concibe la burla segura como un ataque fingido (como hemos mencionado, «skoptein» también puede significar «fingir»): es mejor que el objeto de la risa sea ficcionado, como los personajes de una comedia (Halliwell, 2008: 327). En general, y como hemos venido comprobando a lo largo de estas páginas, la comedia ofrecía un contexto especial que permitía la risa más agresiva, como se ve en las Leyes, donde Platón, al proscribir el insulto público, distingue, en el escenario de la comedia, entre las bromas inofensivas y las que suponen un riesgo social real; o Aristóteles en la Política, al tratar de la regulación del lenguaje indecente, concede dos excepciones: los contextos religiosos, incluyendo la poesía yámbica y la comedia, y los simposios (Halliwell, 2008: 24-25, 319).

Como vemos, este carácter ficcional será fundamental no solo en las definiciones de lo cómico y la comedia, sino también, como comprobaremos, en las discusiones acerca de los límites de la risa y el humor. Si bien prácticas culturales como las fiestas dionisíacas, la Comedia Antigua o los simposios nos podrían hacer imaginar una excepcional libertad en la cultura griega frente a la risa, nos hablan más bien, junto a las discusiones médicas, éticas y hasta filosóficas hasta aquí tratadas, del intenso y estricto control social a la que estaban sometidas estas ocasiones para la risa - hasta tal punto que podríamos decir que la risa no era permitida sino más bien obligatoria. 


\subsection{La risa en la Edad Media y el Renacimiento}

\subsubsection{El cristianismo primitivo ante la risa}

Ya durante la época clásica, Grecia conoció a algunos individuos excepcionalmente hostiles a la risa en cualquiera de sus manifestaciones. Uno de los primeros filósofos antigelastas conocidos es Pitágoras, o al menos es conocida la aversión a la risa asociada al pitagorismo. Tanto Diogénes Laercio como Porfirio dicen de este filósofo que nunca cometió excesos en la comida, la bebida, la ira, la risa... (Halliwell, 2008: 272), es decir, que rechazaba cualquier impulso del cuerpo, entre los que incluía la risa. Pero esta tendencia antigelasta conocerá un nivel muy superior de generalidad e intensidad con la llegada del cristianismo:

The pagan culture of the Greek world had long been familiar with the idea of exceptionally agelastic, even antigelastic, individuals, and Greek philosophy had sometimes found reasons to cultivate deep wariness of the impulses that might feed laughter. But such reasons related to laughter's symptomatic connections with purely, worldly forms of folly (even, at the extreme, madness), lack of self-control, and social antagonism. Paganism as a whole, which ascribed a capacity of 'unquenchable laughter' to the gods themselves and which regarded human laughter as (among much else) finding an exemplary, life-enhancing setting in the festive worship of those gods, could never have grounded a systematic repudiation of laughter. Yet that was at any rate a path that was to be opened up for Christianity (Halliwell, 2007: 482)

En este sentido, podríamos comparar esta censura de la risa por parte de los primeros Padres de la Iglesia con el giro en la concepción de la sexualidad según lo concibe Foucault en su Historia de la Sexualidad (Foucault, 2009b): si, como hemos visto, los griegos conciben la risa como algo natural anclado en el cuerpo, y por tanto deseable e incluso saludable siempre y cuando se mantenga dentro de unos límites razonables, y su control o rechazo se plantea exclusivamente como muestra de un dominio de sí mismo y por tanto de una excepcional nobleza de espíritu, el cristianismo condenará tout court la risa como pecado, a veces incluso mortal, haciendo extensible a este fenómeno su condena del cuerpo y lo terrenal - y, paralelamente, la asociación griega de la risa con lo dionisíaco y las potencias de la naturaleza será mutado en la cultura cristiana en un vínculo directo con el diablo. Los Padres de la Iglesia, de hecho, siguiendo a San Pablo, asociarán estrechamente la risa con la sexualidad: si la risa excesiva supone una pérdida 
de control sobre el cuerpo, esto puede ser un síntoma e incluso una causa de lascivia por eso, Clemente de Alejandría advertirá que es necesario atender y controlar especialmente la risa de las mujeres y los adolescentes (Halliwell, 2008: 493-494). En opinión de San Juan Crisóstomo, que el instinto sexual y el instinto de reír sean naturales no es excusa para no reprimirlos (Halliwell, 2008: 510).

Hay que tener en cuenta que los primeros Padres estaban formados en la cultura helénica, por lo que sus reflexiones sobre a la risa entroncan en muchos puntos con algunas de las preocupaciones de los griegos (Halliwell, 2008: 481). Así, Clemente de Alejandría trata de la risa en el Pedagogo, una disertación acerca del modo de vida apropiada para el cristiano, en la línea de muchos tratados éticos helénicos. Concretamente se ocupa de la risa en el libro segundo, junto a las costumbres sobre la dieta, la bebida, el lujo, la convivencia, etc.: es decir, elementos propios de la esfera del simposio pagano, de la socialidad (Halliwell, 2008: 484-485). Allí, reconociendo que reír es parte de la naturaleza humana, permite una risa controlada (Minois, 2000: 110), distinguiendo dos maneras de reír: la carcajada abierta y sonora es fea, deforma el rostro y es propia de prostitutas y paganos, mientras que la sonrisa contenida es signo de armonía y autocontrol (Halliwell, 2008: 489; Minois, 2000: 111). Como vemos, Clemente de Alejandría entronca con la ética platónica y la noción aristotélica de la risa como una capacidad natural del hombre, que, si bien no es necesario erradicar del todo, hay que someter a autocontrol (Halliwell, 2008: 489). Pero, como decimos, en el primer cristianismo la condena a la risa fue más bien sistemática y total. Esta ya tenía un papel negativo en la misma narrativa de la Pasión, concretamente en la burla de los romanos a Cristo, a quien honran sarcásticamente como rey de los judíos; por lo que es lógico que el cristianismo primitivo rechazara la risa de pleno (Halliwell, 2008: 471-475).

Las Escrituras sentaban una base general para este rechazo, si bien el Antiguo Testamento y el judaísmo no presentaba tanta aversión a la burla como el Nuevo (Halliwell, 2008: 478-479) ${ }^{15}$. En los libros sapienciales se distinguen, en una línea muy

\footnotetext{
${ }^{15}$ La interpretación de ciertos pasajes del Antiguo Testamento, y la cuestión más general de qué cabida tienen lo cómico y la risa en el texto bíblico, ha ocupado a los teólogos a lo largo de toda la historia del cristianismo. Estos discuten, por ejemplo, si Adán y Eva sonreían en el Edén: la respuesta dependía de si la sonrisa se entiende como algo completamente distinto de la risa o solo una cuestión de grado (Minois, 2000: 96). Mayor dificultad ofrece la risa de Sarah ante el anuncio divino de que tendrán un hijo a su avanzada edad: los exégetas se las veían para interpretar su sentido como expresión de alegría, de incredulidad o de mofa a Dios (Minois, 96-97). En general, estas interpretaciones hablan más de la mentalidad de los exégetas y su tiempo que del propio texto bíblico. En el siglo XX, con el cambio de actitud hacia la risa y el humor
} 
cercana al concepto aristotélico de eutrapelia, entre la risa burlona de los pecadores, y la sonrisa interna de los buenos creyentes (Minois, 2000: 101). Las discusiones teológicas siguieron durante mucho tiempo la dirección establecida en el Antiguo Testamento, que distinguía dos tipos de risa: la risa feliz («sâkhaq») y la risa burlona («lêag»). Esta distinción se hizo coincidir con la diferencia en griego entre «gelan» y «katagelan»y en latín entre «subrisus» (que alrededor del siglo XII derivó en la sonrisa) y «risus»; se intentó establecer una risa buena, interior, propia del cristiano que se regocija en el amor de Dios, y la risa mala, desabrida, soberbia y agresiva, propia de paganos (Le Goff, 1999: 49; Minois, 2000: 207). Santo Tomás de Aquino recuperaría la noción aristotélica de eutrapelia (Minois, 2000: 209) y San Francisco de Asís, de quien se decir que siempre sonreía, se convertirá en el símbolo de esta espiritualidad amable y jovial (Le Goff, 1999: 52).

Pero en general el Nuevo Testamento es bastante más hostil a la risa, siempre en boca de pecadores y enemigos de Cristo (Minois, 2000: 103). Uno de los pasajes fundamentales en este sentido es el de la bienaventuranza que encontramos en el Evangelio de Lucas, «Bienaventurados los que lloráis ahora, porque reiréis», que encuentra su paralelo en las maldiciones: «Ay de los que reiréis ahora, porque tendréis aflicción y llanto»: «Laughter, as a metonym for the soul’s elation, is here displaced from the current life of the body onto the spiritualized joy of an eternal afterlife» (Halliwell, 2008: 476). La condena por parte de los primeros Padres, como venimos diciendo, era casi unánime: el peso que el cristianismo le da a la blasfemia y el sacrilegio impide en general cualquier insinuación de una faceta cómica de lo divino o de Cristo (Minois, 2000: 106). Tertuliano arremete contra las comedias, San Ambrosio señala que reír va en contra de las enseñanzas de Cristo, y Basilio de Cesárea directamente prohíbe toda risa. El sabio cristiano, según San Agustín, deplora la risa frenética del loco y el imbécil, y su risa es la sonrisa interior de la alegría divina; y de manera parecida San Jerónimo distingue entre la risa idiota propia de judíos, bárbaros y adolescentes, y la risa moderada y beatífica de los cristianos. (Minois, 2000: 108-110). Aunque esta opinión no le impidió, como a muchos otros, escribir invectivas satíricas contra los paganos; hay, de hecho, una importante nómina de satiristas cristianos: San Jerónimo y San Ireneo escribieron contra

de la sociedad, los teólogos comenzaron a "descubrir" abundantes pasajes cómicos de la Biblia, o a asegurar que Cristo sí que reía, en contra de la opinión largamente sostenida (Minois, 2000: 99-102). 
los herejes y los paganos; Tertuliano se burlaba de las debilidades humanas, etc. (Minois, 2000: 114).

La condena de la risa de los primeros cristianos tiene que ver con la asociación de esta con el diablo en un clima apocalíptico en el que constantemente se anuncia el Fin del Mundo (Minois, 2000: 107). Para este cristianismo la risa aparece con el Pecado Original, es por tanto de raigambre diabólica y ligada a la imperfección y la corrupción (Minois, 2000: 96). En las Cuestiones de Bartolomeo, es el mismo Satán quien afirma que la risa es una de sus armas más eficaces para ganar las almas de los mortales, y en otros textos de la época esta aparece como un claro signo de posesión demoníaca (Minois, 2000: 107108).

Quien más lejos llevó este rechazo de la risa por considerarla diabólica fue San Juan Crisóstomo, escribiendo dos siglos después de Clemente de Alejandría. La risa, afirma Crisóstomo, aunque parezca un fenómeno nimio, es una de las estratagemas del diablo para que nos entretengamos en las cosas insignificantes y que nos alejan del camino de Dios. En general, la risa, como signo de una actitud frívola hacia la vida, es obra del diablo, patrón de la enfermiza cultura pagana de los teatros, los circos, los bufones, etc. (Halliwell, 2008: 498-499, 505). Para Crisóstomo, esta frivolidad es impropia del cristiano serio, repitiendo un motivo de estirpe paulina del cristiano como soldado de Dios en guerra contra el diablo - «and soldiers demonstrate on their very faces the concentrated readiness for the battles ahead» (Halliwell, 2008: 497). En sus homilías acerca del evangelio de Mateo centra su atención en la paradójica felicidad cristiana en el valle de lágrimas que es la vida terrenal, basada en la bienaventuranza antes mencionada: la alegría espiritual del cristiano solo se consigue mediante el sufrimiento y la expiación de la culpa, porque así es que como se imita a Cristo, que lloró en muchas ocasiones, pero jamás rio (Halliwell, 2008: 503). La risa, de este modo, solo es síntoma de ignorancia y ceguera respecto de Dios y del sufrimiento terrenal, pues la promesa de Cristo es la de ofrecer una vida de alegría en el Más Allá (Halliwell, 2008: 504). En resumen,

John Chrysostom's attitude to laughter grows out of an uncompromising ethical code of both corporal and psychological self-surveillance. Holding a standard Cristian 'twoworld' model which constructs the present life as a kingdom of grief-ridden exile, John defers the experience of true rejoicing to the 'kingdom' to come. Laughter in the present becomes an indicator of sinful and perverted values: a contradiction of Christ's own example as well as the message of the beatitudes, a refusal of repentance, a shameless 
celebration of the fallen state itself (specially as symbolised in human nakedness), a yielding to the impulsive gratification of the present - in these and other respects, the work of the devil (Halliwell, 2008: 510-511)

Esta actitud será, a grandes rasgos, la predominante en el Cristianismo, y pronto será implantada en las reglas monacales, tanto en Oriente de la mano de San Basilio como en Occidente, por San Benito de Ariano (Minois, 2000: 103). Aunque, como veremos, la relación de la iglesia medieval con la risa y la festividad pagana será cambiante y muchas veces contradictoria.

\subsubsection{Las fiestas carnavalescas}

\subsubsection{La risa en la Iglesia medieval y los monasterios}

Como vemos, los Padres de la Iglesia y el cristianismo en general condenaron sin apenas reservas a la risa, considerándola pecado (muy literalmente) carnal. Las opiniones al respecto de San Juan Crisóstomo pronto pasaron a las reglas monacales, que se centraron en su relación con la fisiología. La Regla Magistri del siglo VI después de Cristo, por ejemplo, modelo de la Regla de San Benito que serviría como regulación general a partir del siglo IX, presta especial atención a la fisiología del cuerpo cristiano: si los ojos, los oídos y la boca permiten que el alma se comunique con el exterior, dejando pasar al bien, por consiguiente también deben impedir que el mal entre en el cuerpo: en este sentido, la risa, signo de soberbia y lascivia, es el peor de los pecados que pueden afectar a la boca (Le Goff, 1999: 46-47).

Por supuesto, la larga Edad Media no fue una época uniforme, y la percepción de la risa tuvo variaciones a lo largo de los siglos. En líneas generales, en esta época se enfrentan dos concepciones opuestas y fundamentales que parten respectivamente de dos cuestiones diferentes: la de si Jesucristo llegó a reír en su vida terrenal, y la afirmación aristotélica de que el hombre es el único animal que ríe (Le Goff, 1999: 44). Como hemos visto, teólogos como Santo Tomás de Aquino realizaron una adaptación de la noción aristotélica de eutrapelia y San Francisco de Asís, de quien se dice que siempre sonreía, se convertirá en el símbolo de esta espiritualidad amable y jovial (Le Goff, 1999: 52). Pero esta actitud, como decíamos, era en todo caso muy diferente a la risa desenfrenada, que se seguía viendo como una grave falta de humildad y de control de uno mismo. Aun así, encontramos en muchos monasterios la tradición del risus monasticus y se llegaron a 
hacer recopilaciones de joca monacarum (Le Goff, 1999: 51). Otra tradición fue la del risus paschalis, la risa alegre y franca que acompañaba los sermones de la Pascua florida para celebrar el fin de las restricciones de la Cuaresma (Burucúa, 2001: 138). Más relevante aún era la Fiesta de los Locos, celebrada el Día de los Inocentes o a lo largo de las Navidades en muchos puntos de Europa Occidental. En estos días los clérigos se disfrazaban de mujeres, bufones o demonios y realizaban danzas burlescas o celebraban festines en el interior mismo de las Iglesias. También se elegía a uno de los niños del coro para que ocupara como "obispo de los pobres” la cima de una jerarquía eclesiástica y pronunciara una misa grotesca (Bercé, 1976: 26-27).

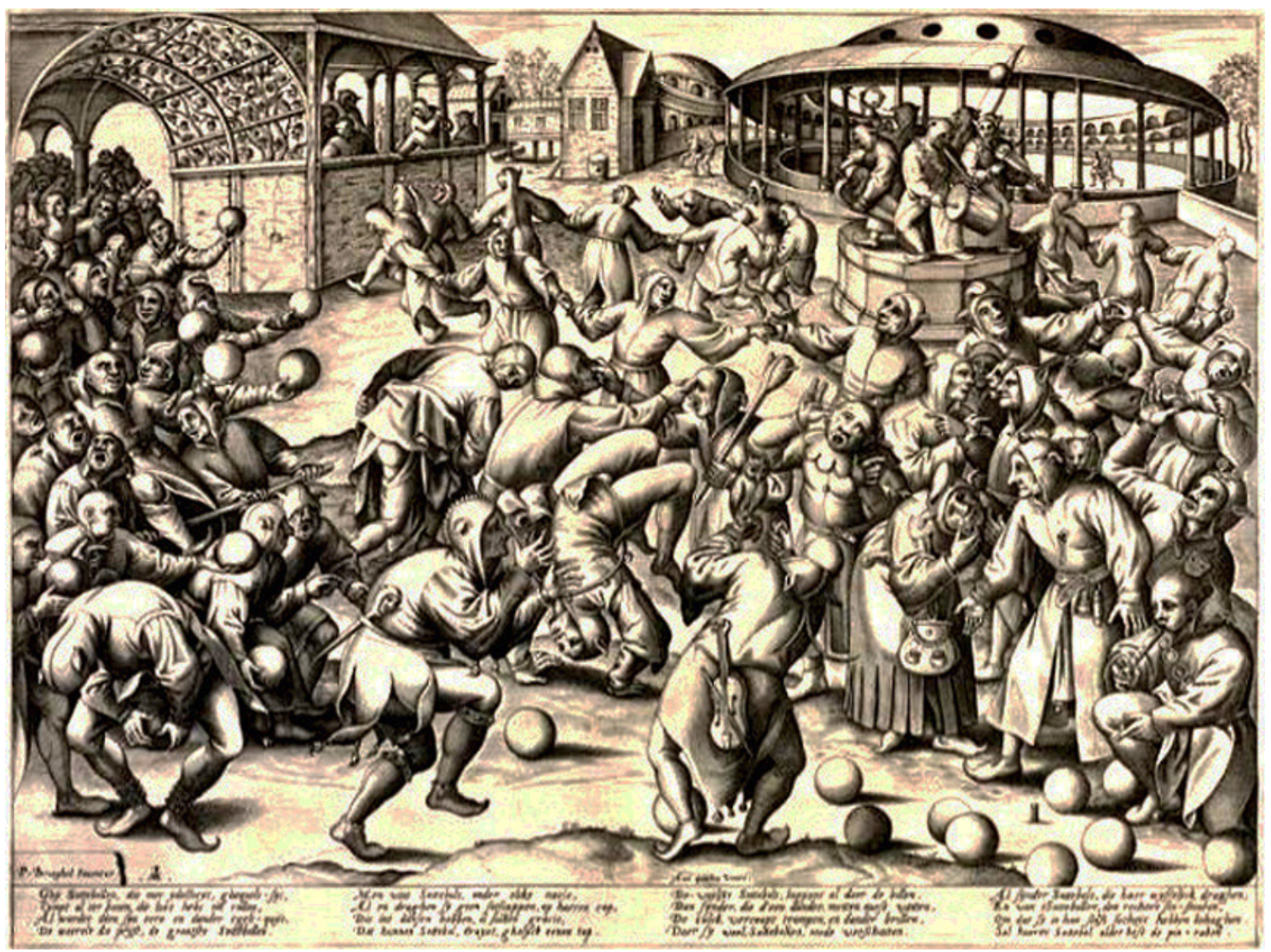

Fig. 2. Fiesta de los locos (1559). Grabado de Van der Heyden según dibujo de Peter Brueghel el Viejo

Como señala Jacques Heers, que estas fiestas se celebren durante el período de la natividad de Jesús hace que tengan relación con la infancia y, por analogía, que se concibieran como celebraciones de los individuos más débiles y de posición social más baja de la sociedad medieval (pobres, locos, enfermos, etc.): de ahí la importancia de la inversión jerárquica, que sigue la afirmación del Magnificat: «Deposuit potentes de sede et exaltavit humildes» (Burke, 1996: 275). La existencia de este tipo de fiestas en el seno de la Iglesia, tan extrañas a nuestra percepción contemporánea, se debe sin duda a los 
rasgos propios de una religiosidad popular más sensorial y espectacular y un bajo clero que establece un contacto íntimo con los parroquianos: de ahí una mayor familiaridad entre lo sacro y lo profano (Bercé, 1976: 138; Heers, 1983: 74).

\subsubsection{El carnaval}

Las fiestas de los locos están obviamente relacionadas con el Carnaval ${ }^{16}$, típico de las zonas mediterráneas y celebrado antes del inicio de la Cuaresma, así como con otras fiestas que, por analogía, se suelen llamar «carnavalescas»: el martes de Pascua, las fiestas de mayo, el Corpus Christi, la noche de San Juan... (Burke, 1996: 274-275); estos festejos también tienen que ver con otro tipo de festividades y celebraciones civiles como victorias de batallas, ejecuciones públicas, entrada solemne de personajes importantes, coronaciones, etc., muchas veces acompañadas de procesiones y cabalgatas análogas a las de las Fiestas de los Locos o los carnavales (Burke, 1996: 281).

El Carnaval se puede concebir como una gigantesca y larguísima representación teatral que hace de toda la ciudad un escenario en el que no están claras las distinciones entre actores y espectadores. Son elementos típicos de estas fiestas la abundancia de comida y bebida, el travestismo y el uso de máscaras y disfraces que representan diablos, bufones, clérigos, animales salvajes, etc.; cantos y bailes populares; agresiones ritualizadas como lanzamiento de comida y desechos o maltrato de animales; cabalgatas y procesiones organizadas por clubes de jóvenes liderados por reyes o abades farsescos; celebraciones de parodias de actos oficiales como juicios, misas, nombramientos... También se representaban obras de teatro: de hecho «era muy difícil trazar una línea divisoria entre lo que sería una obra de teatro formal y los «juegos» informales» (Burke, 1996: 263-268). Los temas de estas prácticas eran la abundancia de comida, el sexo (muchos elementos de las procesiones y juegos tenían sentidos fálicos o sexuales: las máscaras de larga nariz, la siembra, los hombres salvajes, los osos...) y la violencia (Burke, 1996: 267-269). El evento central de la fiesta era el combate entre Carnaval, representado por un hombre gordo, y Cuaresma, una mujer vieja y enjuta, es decir, las encarnaciones respectivas de la vitalidad y la abundancia de la fiesta popular y la

\footnotetext{
${ }^{16}$ De hecho, muchos historiadores consideran que los carnavales, si no son una herencia directa de las Fiestas de los Locos, desaparecidas en el siglo XIV, sí que toman muchos de sus elementos (Bercé, 1976: 26-27; Heers, 1983: 223)
} 
abstinencia propia de la cultura eclesiástica tal y como queda inmortalizado en el celebérrimo cuadro de Peter Brueghel el Viejo [Fig. 3].

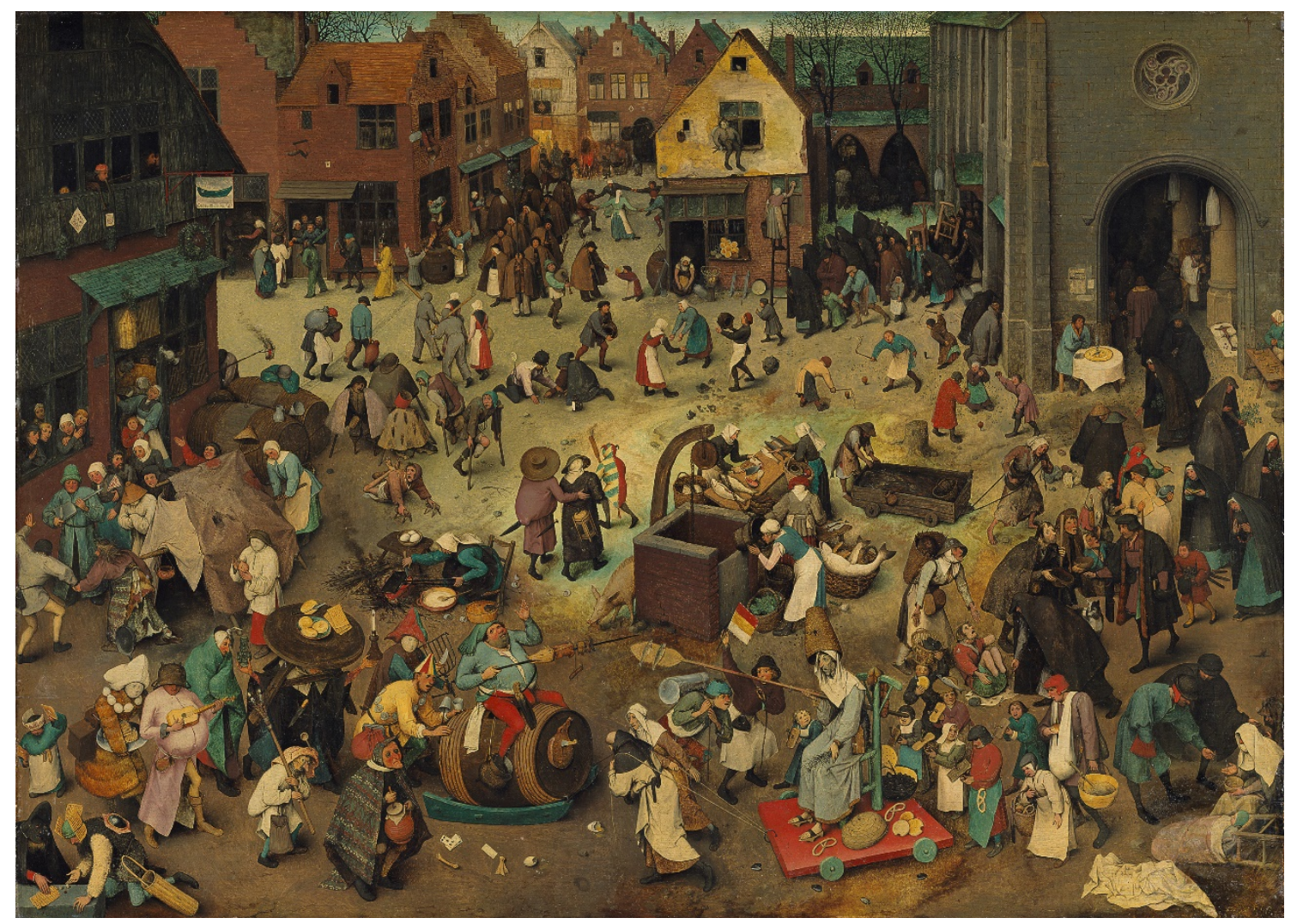

Fig. 3. Peter Brueghel el Viejo, Combate de don Carnal y Doña Cuaresma, 1559

Como es de sobra conocido, fue la fascinación del teórico de la literatura Mijaíl Bajtín por la presencia de lo carnavalesco en la cultura renacentista, y más particularmente en la obra de Rabelais, la que atrajo la atención contemporánea hacia estas celebraciones medievales. En su seminal La cultura popular en la Edad y el Renacimiento. El contexto de Rabelais, el crítico ruso planteaba la oposición entre la cultura popular, donde reinan la risa y la jovialidad, y la seria y religiosa cultura oficial.

Según Bajtín, los ritos y espectáculos cómicos que se llevan a cabo durante el Carnaval se oponen a las ceremonias oficiales de la Iglesia y ofrecen una visión del mundo totalmente opuesta a la del cristianismo oficial y el Estado feudal (Bajtín, 1998: 11). La fiesta, en un sentido antropológico, siempre es algo más que el descanso de los días de trabajo, conllevan una ideología o visión particular del mundo; el sentido carnavalesco de la cultura popular medieval se basa en la idea de la renovación universal y la huida provisional de la vida ordinaria (Bajtín, 1998: 13-14). El carnaval es algo más que una representación o espectáculo artístico: es ante todo una forma de vida efectivamente 
experimentada por todo el pueblo que en ella participa, una segunda vida festiva que representa la utopía de la universalidad, la libertad, la igualdad y la abundancia; de ahí que se oponga a la seriedad y la abstinencia de la Cuaresma, a la que precede (Bajtín, 1998: 13-15). Si la fiesta popular carnavalesca supone, por tanto, una liberación transitoria, el establecimiento de un tiempo utópico, la fiesta religiosa oficial, en cambio, solo sirve para reforzar el régimen existente, no se vincula con la renovación sino con un pasado inmóvil que legitima el orden social, presentado como inmutable; en oposición a la rígida jerarquización de la sociedad feudal, el carnaval propugna un contacto libre y familiar entre los individuos, sin ninguna consideración de clase: el hombre se relaciona humanamente con el hombre (Bajtín, 1998: 15).

Por tanto, esta segunda vida del pueblo supone una parodia de la vida cotidiana, pero una parodia muy distinta de su sentido moderno, puramente negativo. La risa carnavalesca es popular, universal y ambivalente; supone la destrucción de lo viejo, pero al mismo tiempo anuncia la renovación del cuerpo colectivo del pueblo. La risa festiva está esencialmente vinculada con la sucesión circular de las estaciones y los ciclos agrícolas, haciendo énfasis en lo nuevo, en lo que está a punto de llegar, expresando «la esperanza popular en un porvenir mejor, en un régimen social y económico más justo, en una nueva situación» (Bajtín, 1998: 78). Por eso tiene un papel central el elemento del disfraz, que supone la renovación de la personalidad social y la inversión de la jerarquía: el bufón se proclama rey, se nombra un obispo de la fiesta y se representan misas paródicas. Lo relativo y lo evolutivo se oponen a las pretensiones de inmutabilidad e intemporalidad del orden medieval oficial; se insiste en la transición, en la sucesión, en la dualidad y la plurivocidad de la autoridad y las verdades (Bajtín, 1998: 78). La risa se opone a la seriedad temerosa e intimidante: lo temible se vuelve ridículo, las figuras amenazantes se vuelven espantajos que solo mueven a la risa (Bajtín, 1998: 86).

La risa festiva, por tanto, no es una expresión individual sino colectiva, es la reunión del pueblo en un solo sentir: «de ahí que la comicidad popular contenga un elemento de victoria no solo sobre el miedo que inspiran los horrores del más allá, las cosas sagradas y la muerte, sino también sobre el miedo que infunden el poder, los monarcas terrenales, la aristocracia y las fuerzas opresoras y limitadoras» (Bajtín, 1998: 87); la risa popular medieval se opone a la mentira, la adulación y la hipocresía de las verdades y autoridades oficiales a través de la boca del bufón (Bajtín, 1998: 87). 
Es difícil sobredimensionar la importancia que el libro de Bajtín ha tenido sobre los estudios de la Edad Media y el Renacimiento, la etnografía y la antropología, la literatura humorística, la teoría de la literatura, etc. Su trabajo fue tan sugestivo y provocador que abrió un nuevo campo intelectual en las ciencias sociales, pero lo cierto es que, como todo trabajo innovador, pecaba de unilateralidad en la interpretación de fuentes por otra parte bastante escasas, que precisamente su libro motivó a completar. De ahí que posteriormente se hayan criticado y matizado muchas de las afirmaciones del estudioso ruso.

En el plano historiográfico, muchos han descartado la hipótesis bajtiniana de la continuidad entre los carnavales y las fiestas paganas de la Antigüedad como las saturnales romanas, de las que habrían heredado muchas prácticas y el sentido de la experiencia al retorno a la Edad de Oro o la regeneración de la naturaleza (Bajtín, 1998: 13). Esta creencia en el origen pagano de las fiestas medievales ya había sido enunciado por los propios clérigos en el siglo XII, y sería repetida por los censores de los siglos XVI y XVII como argumento para eliminar estas fiestas; posteriormente, en el siglo XIX, el interés de los etnógrafos en un origen común y ancestral de las costumbres folklóricas aceptarían esta creencia, aunque por motivos contrarios (Minois, 2000: 140-141). Sin embargo, muchos historiadores y antropólogos contemporáneos critican esta simplificación cronológicamente inexacta. Para Jacques Heers, el parecido superficial de algunas prácticas no implica que tenga la misma significación, y Caro Baroja (2006) niega categóricamente que existan pruebas de continuidad alguna entre las festividades antiguas y medievales (Minois, 2000: 141). Como argumenta Gurevich, el carnaval solo surge a finales de la Edad Media: las primeras referencias fiables a la fiesta datan de finales del siglo XIII y principios del XIV (Gurevich, 1999: 57).

Relacionar los carnavales y otras fiestas populares con los ritos paganos de fertilidad supone sobre todo omitir lo íntimamente ligado que el carnaval está a la cultura específicamente cristiana. Que Bajtín obvie la evidente relación que la cultura popular tiene con la religión es uno de los errores más relevantes en opinión de Gurevich (1999: 55). De hecho, la etimología más probable para el término «Carnaval» lo haría derivar de la expresión «carne vale», es decir, «eliminar la carne», en referencia a la Cuaresma a la que precede (Heers, 1983: 224) - y no de «currus navales», procesión de carrozas que desfilaban en las fiestas de Isis en marzo (Minois, 2000: 141). Aquella etimología destaca en efecto la relación que el carnaval y en general las fiestas populares tenían con el 
calendario litúrgico: los Santos Inocentes, la noche de Epifanía, el día del Corpus Christi, etc. Y, sobre todo, como acabamos de ver, los clérigos participaban activamente y hasta organizaban algunas de estas fiestas, como la Fiesta de los Locos. Por tanto, aunque los Padres de la Iglesia sí habían condenado las fiestas paganas, las autoridades civiles y eclesiásticas fueron conscientes de que la solución más fácil era crear fiestas propiamente cristianas que las sustituyeran y las resignificaran (Minois, 2000: 161). Por ejemplo, el mismo Bajtín cita una apología de la Fiesta de los Locos escrita en el siglo XV, a la que defiende aduciendo su carácter no serio, de divertimento indispensable para aliviar los instintos de burla naturales en el hombre (1998: 72-73). En general, muchos estudiosos critican la rígida oposición que Bajtín propone entre la cultura oficial clerical y la popular (Minois, 2000: 143; Gurevich, 1999: 60).

Esto nos lleva a la crítica al aspecto más relevante de la teoría bajtiniana de lo carnavalesco: su supuesto sentido de subversión social. Como hemos visto, para Bajtín el carnaval supone la unión del pueblo en la inversión de las jerarquías feudales, la liberación de las prohibiciones y los tabúes y la promesa de un futuro utópico, más justo e igualitario. Pero esta es una interpretación que hoy en día es rechazada casi unánimemente. En opinión de Gurevich, la visión del estudioso ruso no es sino la traslación a la Edad Media y el Renacimiento de la sociedad estalinista en la que él mismo vivía y que sí conocía una distancia insalvable entre la cultura oficial y la del pueblo (Gurevich, 1999: 59). Pero en la realidad histórica, el carnaval y otras fiestas semejantes más bien suponían un alivio de las tensiones sociales gracias al cual se reforzaba el orden social: «Es como si estas [las clases dirigentes] fueran conscientes de que una sociedad como la suya - con profundas desigualdades en la riqueza, el poder y el estatus - no podría sobrevivir sin una válvula de seguridad, a través de la cual las clases subordinadas purgasen sus sentimientos y viesen compensadas sus frustraciones» (Burke, 1996: 287).

La presencia e incluso participación de las autoridades eclesiásticas y civiles en estas fiestas, las cuales llegaban a organizar las propias clases poderosas 0 económicamente pudientes de la ciudad (Bercé, 1976: 63; Heers, 1983: 261-266), dice mucho del carácter difícilmente subversivo de estas celebraciones (Minois, 2000: 144). Como explica Yves-Marie Bercé, estas fiestas, sí, están marcadas « comme un temps hors du temps, un moment privilégié qui échappe aux règles de l’habitude (...) La durée de la fête est un règne ; la communauté en liesse est un royaume et à sa tête est un roi» pero «le règne, le royaume et le roi sont de farce et ne sont institués que pour rire » (Bercé, 1976 : 
32). Si las fiestas carnavalescas suponen una explosión de la libertad y lo irracional, debemos tener en cuenta que este desorden también tiene sus normas:

Les fêtes (...) autorisaient des comportements voulus absurdes et grotesques, non une liberté absolue. Le maire de Noël était un maire ridicule et non un maire subversif. Le roi de folie donnait des prescriptions dont l'ineptie était calqué sur le réel, que le renversait sans innover, sans modifier rien dans son ordonnance (Bercé, 1976: 35-36).

En esta inversión paródica de la jerarquía no hay subversión ni mucho menos la postulación de un orden social alternativo, como quería Bajtín, solo divertimento. A pesar de la apariencia de libertad absoluta del tiempo carnavalesco, es un tiempo perfectamente reglado por las autoridades (Burke, 1996: 284-286). Como expresa Rover Bastide, «la fête est de la culture, non la revanche de la nature contre la culture, et la culture est un ensemble des normes» (cit. en Minois, 2000 : 147) ; el carnaval, «dérision ritualisée, (...) est (...) l'envers burlesque qui ne fait que confirmer la nécessité des valeurs et hiérarchies établies» (Minois, 2000 : 147). En este sentido, la quema del rey del carnaval o cualquier chivo expiatorio al final de las fiestas es muy indicativo de esta vuelta al orden (Minois, 2000: 147; Burke, 1996: 188).

El ejemplo más claro de la función fundamentalmente conservadora de la risa carnavalesca es el de la tradición los charivari de algunas zonas de Francia (chiavramarito en Italia; skimmington en Inglaterra; Katzenmusik en Alemania y «cencerrada» en España, como nos informa Caro Baroja(2006)), procesiones ruidosas de jóvenes que acosaban a los vecinos que se habían apartado de las buenas costumbres de la villa: mujeres adúlteras, hombres cornudos o agredidos por sus esposas, viejos casados con jóvenes... (Minois, 2000: 148-149). Otras prácticas análogas consistían, por ejemplo, en hacer que estos individuos cabalgaran un asno al revés (Burke, 1996: 285). De este modo, los charivari establecían una justicia alternativa y festiva con la que condenaban los vicios morales y contra las costumbres (Bercé, 1976: 52). Bajtín, sin embargo, había negado al carnaval cualquier rasgo de violencia y agresión:

Es obvio que la comicidad no fue nunca un agente de la violencia, ni erigía hogueras. La hipocresía y el engaño no podían reír. La risa no prescribía dogmas; no podía ser autoritaria ni amedrentar a nadie. Era una expresión de fuerza, de amor, de procreación, de renovación y fecundidad: estaba vinculada a la abundancia, la comida, la bebida, la inmortalidad terrenal del pueblo, el porvenir, la novedad que abría nuevos caminos (Bajtín, 1998: 90) 
Pero los charivari son la prueba evidente no solo de que la ebriedad y la exaltación emocional podían resultar en estallidos violencia, como de hecho ocurría con cierta frecuencia (Heers, 1983: 241; Gurevich, 1999: 57), sino también de la existencia de una risa sancionadora de desviaciones sociales y morales que, lejos de ser subversiva, refuerza el sentimiento de comunidad al agredir y expulsar los elementos extraños (Burke, 1996: 285; Bercé, 1996: 53):

\begin{abstract}
Nous sommes à mille lieues du rire désarmant le fanatisme. Il s’agit ici d'un rire guerrier, substitut des armes, rire de déficit, d'agression et d'exclusion. Ce rire de group, anti individualiste, bien loin de favoriser la tolérance, est au contraire un instrument d'oppression, qui ne tolère pas la différence (...) Au Moyen Age, le rire collectif joue un rôle conservateur et régulateur. Par la parodie bouffonne et la raillerie agressive, il conforte l'ordre établi en jouant son opposé grotesque ; il exclut l'étrange, l'étranger, l'anormal et la néfaste en raillant le bouc émissaire et en humiliant le déviant. Le rire est à cette époque une arme oppressive au service du groupe, une arme d'autodiscipline (Minois, $2000:$ 151, 152)
\end{abstract}

\title{
1.2.2.3. La locura
}

Todas estas fiestas están presididas por la figura del Loco: locos son Carnaval y los reyes y abades farsescos; el ambiente general de la fiesta es el de la locura y el descontrol. La locura es un tema ambiguo en la época medieval: el loco representa al mismo tiempo la inocencia de los elegidos de Dios - de ahí que sea la figura central de las fiestas de los inocentes y las navidades, que como dijimos están consagradas a los débiles - y la amenaza del caos, el pecado y la muerte (Minois, 2000: 146).

Por un lado, en la Edad Media el loco es el portador de una marca sagrada, ha sido elegido por Dios como chivo expiatorio para asumir la culpa del hombre; por ello se le supone la capacidad de alcanzar verdades vedadas para el común de los mortales: «le dément voit ce que d'autres ne peuvent voir ; il sait dire l'avenir et connaît par avance le destin des hommes» (Heers, 1983 : 142). El loco es más sabio e inocente que el resto: está libre de excesos, de ambiciones y de todas las locuras humanas que llevan al pecado (Heers, 1983: 143). Ocupan el centro de las farsas «como poseedores de la verdad (...). Si la locura arrastra a los hombres a una ceguera que los pierde, el loco, al contrario, recuerda a cada uno su verdad (...) Dice, con su lenguaje de necio, sin aire de razón, las palabras razonables que dan un desenlace cómico a la obra» (Foucault, 2015: 30). También en la literatura erudita y sapiencial la locura actúa pareja a la razón, es objeto de 
discursos e incluso ella misma los pronuncia: «cuando se la denuncia, se defiende, y reivindica una posición más cercana a la felicidad y a la verdad que la razón, más cercana a la razón que la misma razón» (Foucault, 2015: 31).

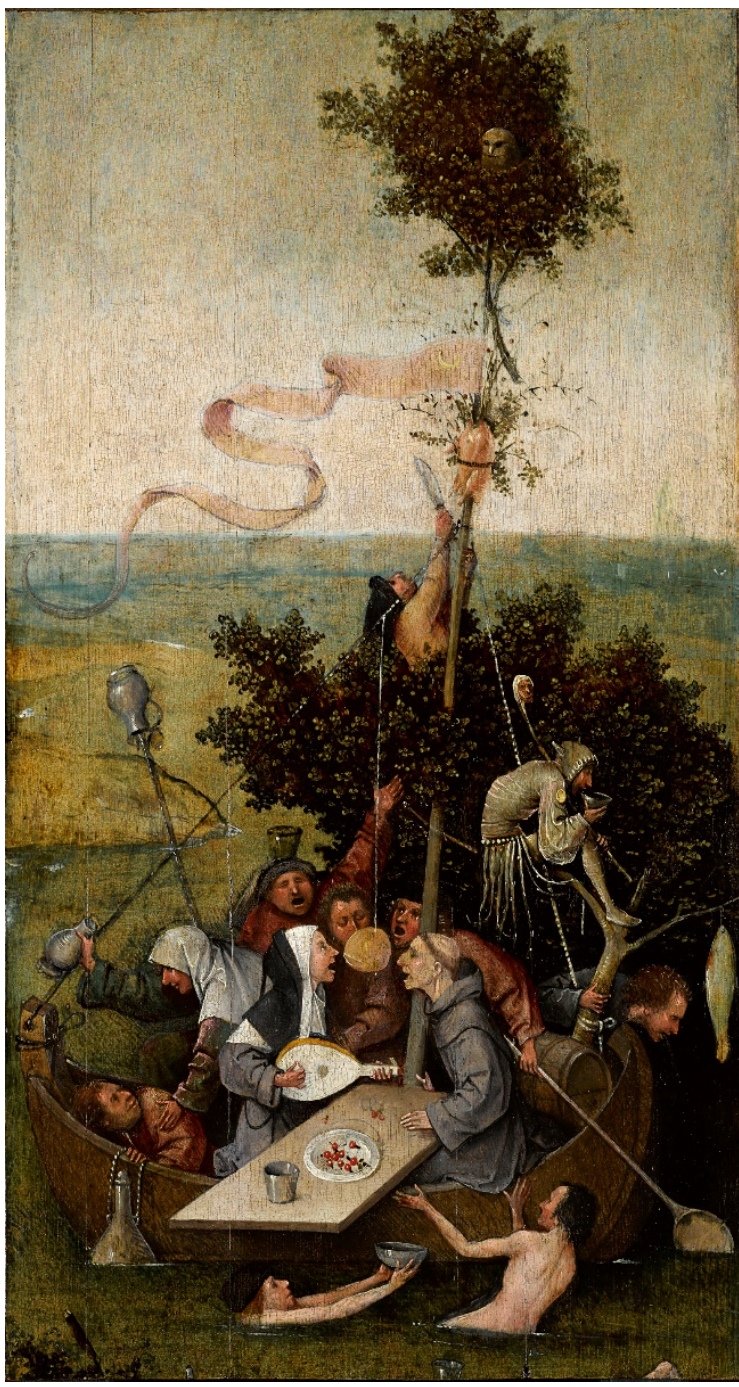

Fig. 4. Hyeronimus Bosch «El bosco», La Nave de los Locos (1503-1504)

De ahí el motivo o tema literario e iconográfico de la Nave de los Locos [Fig. 4], que surge entre los siglos XIV y XV, aunque no se sepa a ciencia cierta si tenía una base histórica en una práctica real (Foucault, 2015: 21-25; Heers, 1983: 149). Esta iconografía se extiende por toda Europa occidental como alegoría moral similar a las Danzas de la Muerte: los que van en la nave no son locos per se, sino hombres supuestamente cuerdos pero llenos de vicios y manías ridículas: «décrire la Nef de fous, dénombrer ses passagers et dire le pourquoi de leur présence à bord conduit à une satire, burlesque ou franchement irrévérencieuse, voir acerbe ou violente, de la société du temps et de ses différents corps» (Heers, 1983: 149).

No es de extrañar, por tanto, que la figura más representativa de la cultura medieval y renacentista de la risa sea la del bufón de la corte (Minois, 2000). Para Bajtín, los bufones son los representantes de la visión carnavalesca del mundo en la vida cotidiana; no actores que representan locos en un escenario, sino bufones en todo momento y en todos los aspectos de su vida; estos «encarnaban una forma especial de la vida, a la vez real e ideal. Se situaban en la frontera en la vida y el arte, ni personajes excéntricos o estúpidos ni actores cómicos» (1998: 13):

La existencia misma de tales figuras no tiene sentido propio, sino figurado: su mismo aspecto exterior, todo lo que hacen y dicen no tiene sentido directo, sino figurado, a veces contrario; no pueden ser entendidas literalmente, no son lo que parecen. (...) Su existencia 
es reflejo de alguna otra existencia; es, además, un reflejo indirecto. Son los comediantes de la vida, su existencia coincide con su papel, y no existen fuera de ese papel. Tienen la peculiar particularidad, y el derecho, de ser ajenos a ese mundo; no se solidarizan con ninguna de las situaciones de la vida de este mundo, no les conviene ninguna, porque ven el reverso de cada situación y su falsedad ${ }^{17}$. Tan sólo pueden, por ello, utilizar toda situación en la vida como una máscara (...). El bufón y el tonto «no son de este mundo» y tienen, por ello, derechos y privilegios especiales. Esas figuras se ríen de los demás y también los demás se ríen de ellas. Su risa tiene el carácter de risa popular, de plaza pública. Restablecen el carácter público de la figura humana, ya que la existencia de dichas figuras como tales, se manifiesta, por entero y hasta el final, hacia el exterior; lo exponen todo, por decirlo así en la plaza; toda su función se reduce a esa exteriorización (aunque no de su propia existencia, sino de una existencia ajena, reflejada; pero tampoco tienen otra). Con esto se crea una modalidad especial de exteriorización del hombre por medio de la risa paródica (Bajtín, 1989: 311)

El loco, por tanto, es totalmente ajeno al hombre y a la vez su reflejo distorsionado; un ser en cierta medida sagrado, de ahí «cette forte angoisse des hommes sains devant les malades de folie, devant ceux qui se trouvent en quelque sorte hors de leur monde, parfois au-delà : angoisse de ne pouvoir y accéder ; crainte aussi, peur manifeste» (Heers, 1983 : 142). El loco es mirado con recelo, y por ello usado como chivo expiatorio durante los carnavales y el resto de fiestas (Minois, 2000: 146).

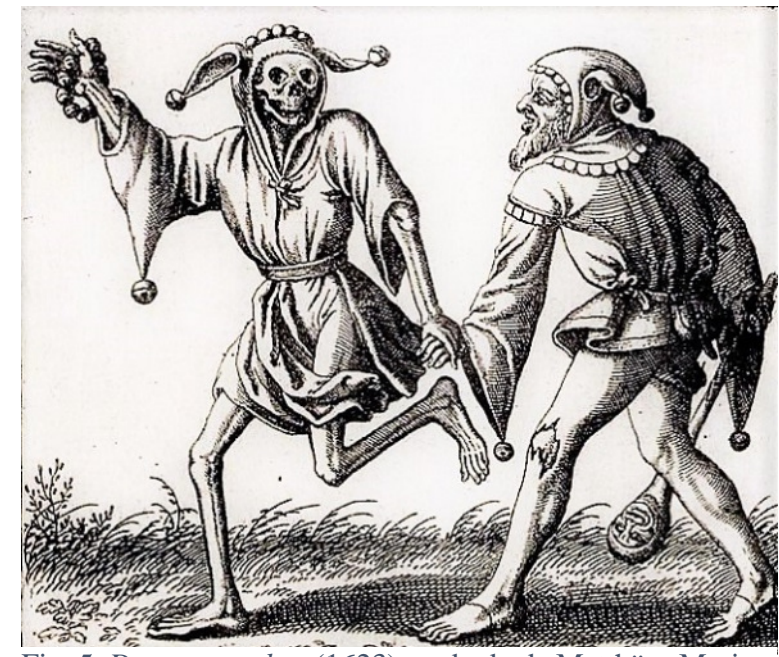

Fig. 5. Danza macabra (1623), grabado de Matthäus Merian. Como vemos, tanto la muerte como el hombre al que se lleva están caracterizados con los símbolos de la locura y del bufón.
La locura medieval es sobre todo un símbolo del caos y de lo absurdo en general de la existencia. En la tradición literaria popular encontramos una serie de cuentos sobre la locura que, aunque critican vicios y efectos, más que responsabilizar al individuo achacan la presencia del pecado a una sinrazón general del mundo (Foucault, 2015: 29). La locura también está relacionada con la muerte, como demuestra Gaignebert (1972) en su análisis del cuadro de

\footnotetext{
${ }^{17}$ Esta caracterización, como veremos [2.4.1], tiene mucho parecido con el retrato que se hará durante el siglo XIX de Friedrich Schlegel como ironista.
} 
Brueghel arriba mostrado. De este modo, la Nave de los Locos va a sustituir a la Danza Macabra [Fig. 5]: del descubrimiento de la insignificancia de la vida frente a una muerte segura se pasa a la burla de esa misma insignificancia:

El horror delante de los límites absolutos de la muerte se interioriza en una ironía continua: se la vuelve risible, dándole una forma cotidiana y domesticada (...) diseminándola en los vicios, en los defectos y en los aspectos ridículos de cada uno (...) El aniquilamiento de la muerte no es nada, puesto que ya era todo, puesto que la vida misma no es más que fatuidad, vanas palabras, ruido de cascabeles. Ya está vacía la cabeza que se volverá calavera. En la locura se encuentra ya la muerte (Foucault, 2015: 32-33)

La nada, lo absurdo de la existencia, es la inquietud que yace bajo ambos motivos, el de la locura y la muerte, pero la locura ya no es considerada como límite externo y final a la vida, sino como su constitución misma. Si antes se señalaba la locura de quien olvida la proximidad de la muerte, ahora se denuncia la locura por doquier, la enseñanza de que los hombres ya son muertos en vida (Foucault, 2015: 34).

La locura y lo carnavalesco tendrán su reflejo temático y estético en el arte y literatura de finales de la Edad media y sobre todo en el Renacimiento. Por un lado, la fantasía y la libertad de la locura encontrarán su contraparte en la estética de lo grotesco del arte ornamental y el manierismo, desafiando las convenciones de la representación ilusionista; por otro, los motivos y significaciones de la fiesta carnavalesca inspirarán a artistas como Brueghel y escritores como Rabelais, dando lugar a lo que Bajtín denominará «realismo grotesco».

\subsubsection{La tradición artística y cultural de lo grotesco}

\subsubsection{El juego con la imagen: los gruttesche}

A finales del siglo XV son desenterradas en Roma las ruinas del palacio de Nerón, y en él se descubren decoraciones murales con dibujos caprichosos de animales, figuras vegetales, criaturas míticas, etc., que se transforman unas en otras, borrando las fronteras entre lo animal, lo vegetal y lo mineral. Al estar estas decoraciones por debajo del nivel del suelo, como en una gruta, se les llamó «gruttesche» (Bajtín, 1998: 35; Connelly, 2015: 26). Lo grotesco como modo estético, como sistema de construcción de imágenes, había 
tenido su origen, antes de recibir su nombre, en el arte arcaico, y había convivido con el arte clásico griego como dominio marginal en las máscaras cómicas, las estatuillas de demonios de la fecundidad o silenos, o figuras como el Tersites homérico (Bajtín, 1998: 34). El grotesco antiguo había vivido un período de eclosión, alimentado por la influencia del arte oriental, a finales del período imperial, como reflejo de una cosmovisión pesimista frente a la desintegración del orden hasta entonces imperante:

La prise de conscience du ridicule, du monstrueux et de l'absurde au coeur de l'être engendre un hoquet chaotique et glacé, qui n’a plus que les caractéristiques physiques du rire: «instrument d'art, vision déstructurée du monde, mais construction aussi d'un univers voulu total, le grotesque constitue l'instrument efficace d'une analyse lucide, parfois risible, mais cruelle, de l'homme absurde de tous les temps». C'est bien pourquoi le comique n'apparaît qu'à un stade tardif de l'évolution des mentalités et de la culture dans une Civilization donnée (...) Le rire grotesque porte sur l'essence même du réel, qui perd sa consistance. Véritable revanche du diable dans le sens où il pulvérise l'ontologie, il désintégre la création divine, réduite à l'état d’illusion (Minois, 1999: 82)

La primera reflexión sobre este tipo de fantasía artística la había realizado, si bien de manera indirecta, Horacio: en el famoso comienzo de su Ars Poetica rechaza forzar los límites del arte y la licencia del artista; su condena, en tanto que poeta e intelectual preocupado por la función didáctica de la literatura, se centra en el riesgo de que este exceso de invención de formas fantásticas pueda amenazar el significado (Connelly. 2015: 66-68). También en la Retórica clásica podemos encontrar discusiones sobre la función del ornamento, el sermo ornatus: Quintiliano opina que la figura se ha de utilizar con moderación pues puede acabar por ahogar la lógica de la argumentación. Lo relevante es que tanto el ornamento pictórico como el retórico están relacionados con la sensualidad, con lo corporal, en oposición al pensamiento conceptual (Connelly, 2015: $68)$.

Sin embargo, el arte ornamental del Renacimiento italiano, las imitaciones de estas figuras grotescas, fueron consideradas sobre todo emblemas de libertad creativa e imaginación artística (Connelly, 2015: 27). En este período también se usaba para este estilo términos como «bizarrie», «fantasía», «capricho», «scherzi», «concetti», «invenzioni», etc., designando con estos conceptos obras y motivos de extrema fantasía e invención (Connelly, 2015: 89). El grotesco se llegó a comprender como «juego y artificio inspirado y sofisticado» (Connelly, 2015: 66), sobre todo a partir de 
comentaristas de la obra de Miguel Ángel como Vasari. Lo grotesco pasó a ser debatido como principio artístico dentro del contexto del manierismo, movimiento que hacía del estilo y del virtuosismo el centro de la expresión artística (Connelly, 2015: 88). Con su acento en el estilo, el objetivo del arte manierista era una reflexión sobre las convenciones de la representación precisamente en la época en la que la pintura se concibe como imitación naturalista, explotando el componente de juego, «ludere», que encontramos en la noción de «illusio» (Connelly, 2015: 93-97).

Este énfasis en la imaginación, la invención asombrosa y el ingenio tiene que ver con la epistemología renacentista que se interesa por los «monstruos naturales», las propias invenciones de la naturaleza: es la época en que proliferan las colecciones de maravillas y anomalías naturales como fósiles, piedras raras, animales y plantas exóticos, etc., y se muestra un interés particular por la alquimia, ciencia que consiste precisamente en la mezcla de materiales particulares y conocimientos esotéricos que revelan las conexiones ocultas del universo (Connelly, 2015: 110). Esta vinculación entre la fantasía grotesca pictórica y las maravillas de la ciencia natural se condensa en la expresión «natura pictrix», la naturaleza pintora: la naturaleza misma tiene un sentido lúdico de la creación (Findlen, 1990: 297-298), dando lugar a las caprichosas formas de conchas marinas, flores de mil formas y colores, seres vivos como el coral a caballo entre lo mineral y lo vegetal, etc. - en este sentido, las Metamorfosis de Ovidio, por su énfasis en la transformación, fue un texto capital tanto para la literatura y el arte como para la filosofía natural (Findlen, 1990: 310). En resumen, el juego, la invención y la fantasía eran potencias de conocimiento en la ideología renacentista.

\subsubsection{Lo grotesco carnavalesco}

En los artistas del norte, alemanes, holandeses y flamencos, el impulso grotesco se vino a fusionar con la tradición medieval de las drolerie (del francés «drôle»y el alemán «drol», «duende») [Fig. 6], también nombradas como «fabula», «curiositate», «babuini», etc.: pequeños dibujos cómicos y extravagantes en los márgenes de los manuscritos

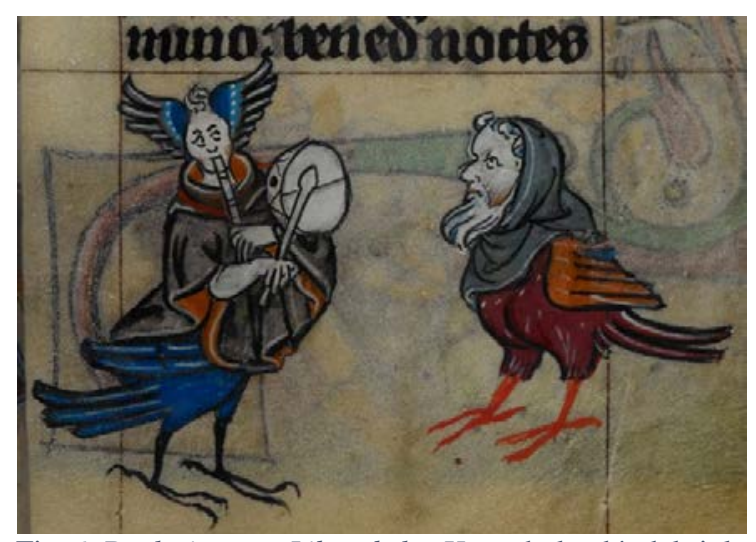

Fig. 6. Drolerie en un Libro de las Horas holandés del siglo XIV 
medievales (Connelly, 2015: 82). Artistas como el Bosco asimilarían este estilo, entroncándolo con la tradición carnavalesca y la de las grylle (Connelly, 2015: 83). A diferencia del grotesco ornamental, refinado y sutil ejercicio de fantasía, el grotesco carnavalesco provoca la carcajada, subvierte la convención social e invierte las jerarquías, centrándose más en aspectos éticos y sociales que en las reflexiones estéticas. El grotesco carnavalesco tiene como centro el cuerpo, sirve de consuelo frente a una ética cristiana del control de la carne (Connelly, 2015: 169).

El cuerpo carnavalesco es material y carnal: en este caso, lo grotesco trabaja con la experiencia del cuerpo en vez de jugar con la forma puramente estética: «la imaginería carnavalesca presenta cuerpos con bocas muy abiertas y vientres abultados, cuerpos lascivos, exagerados o en posiciones ridículas, cuerpos de los que salen cosas» (Connelly, 2015: 173). Es a este sistema de imágenes al que Bajtín da el nombre de «realismo grotesco», gobernado, como decimos, por el principio de lo material y lo corporal y la libertad utópica y universal de la fiesta: «lo cósmico, lo social y lo corporal están ligados indisolublemente en una totalidad viviente e indivisible. Es un conjunto alegre y bienhechor» (Bajtín, 1998: 23). Por otra parte, este principio de lo material da lugar a la degradación escatológica propia de la risa carnavalesca, la transferencia al plano bajo y corporal de todo lo elevado, lo espiritual, lo ideal y lo abstracto (Bajtín, 1998: 25). Según Bajtín, el Renacimiento, y particularmente Rabelais, va a apropiarse de este realismo grotesco y sus significaciones para incorporarlo a la nueva concepción histórica y optimista del humanismo, que plantea la muerte de un tiempo y la regeneración y la evolución de otro: de ahí que encontremos imágenes que mezclan indistintamente la fecundación, la gestación, el parto, la vejez y la muerte: ancianas embarazadas, por ejemplo, que unen en una sola representación la vida y la muerte (Bajtín, 1998: 29).

La expresión grotesca es hiperbólica porque el portador de este principio no es el individuo sino el pueblo; el cuerpo carnavalesco, que hace énfasis en la comida, la bebida, la sexualidad y la fertilidad es el símbolo del crecimiento y la abundancia (Bajtín, 1998: 24). Este cuerpo no es individual, sino que está en conexión con los demás cuerpos, la naturaleza y el cosmos:

El cuerpo grotesco no está separado del resto del mundo, no está aislado o acabado ni es perfecto, sino que sale fuera de sí, franquea sus propios límites. El énfasis está puesto en las partes del cuerpo en que éste se abre al mundo exterior o penetra en él a través de orificios, protuberancias, ramificaciones y excrecencias tales como la boca abierta, los 
órganos genitales, los senos, los falos, las barrigas y la nariz. En actos tales como el coito, el embarazo, el alumbramiento, la agonía, la comida, la bebida y la satisfacción de las necesidades naturales, el cuerpo revela su esencia como principio en crecimiento que traspasa sus propios límites. Es un cuerpo eternamente completo, eternamente creado y creador, un eslabón en la cadena de la evolución de la especie, o, más exactamente, dos eslabones observados en su punto de unión, done el uno entra en el otro (Bajtín, 1998: 30)

Por contraposición, el cuerpo del canon clásico y oficial es acabado, individualizado, rigurosamente delimitado, cerrado, visto desde el exterior (Bajtín, 1998: 288). Se elimina todo lo que emerge del cuerpo y lo pone en contacto con otros cuerpos; el cuerpo se cierra, se hace énfasis en todo lo que caracteriza e individualiza: el rostro y particularmente, los ojos, los labios (Bajtín, 1998: 289). Por el contrario, el grotesco destaca del rostro la boca como contacto del mundo (la boca abierta es un elemento básico en la construcción de máscaras cómicas y demoníacas) y la nariz como sustituto del falo; los ojos, que en el canon clásico expresan la personalidad individual, solo interesan en el plano grotesco cuando se salen de las órbitas, «pues lo grotesco se interesa por todo lo que sale, hace brotar, desborda el cuerpo» (Bajtín, 1998: 285; destacado del autor). El cuerpo grotesco, en fin, es cósmico y universal, está relacionado con los elementos de la naturaleza, el sol, los astros, los signos del zodíaco, etc. (Bajtín, 1998: 286-287), lo que se relaciona con la ideología renacentista del microcosmos y el macrocosmos, en la que el cuerpo humano se corresponde con el universo (Foucault, 2017: 40) ${ }^{18}$.

\subsubsection{Lo carnavalesco en la tradición pictórica flamenca}

Como hemos apuntado, el Bosco y Brueghel el Viejo introdujeron en las bellas artes estos elementos de la cultura popular carnavalesca (Burucúa, 2007: 175). Realmente, la representación de la risa no había preocupado a los artesanos medievales, y los artistas del Renacimiento no contaban con modelos clásicos ni en la pintura ni en la escultura a los que recurrir - lo que dio lugar a que, paradójica y significativamente, se echara mano de la iconografía del escarnio de Cristo (Burucúa, 2007: 25). La representación de hombres y mujeres riendo, que no simplemente sonríen, sino que enseñan los dientes «y hacen gestos que inducen en nosotros la sensación de un movimiento corporal intenso,

\footnotetext{
${ }^{18}$ En el capítulo dedicado al análisis de la obra de Eduardo Mendicutti [6.2], veremos que esta definición del cuerpo grotesco es perfectamente aplicable al personaje principal de Una mala noche la tiene cualquiera y a su relación con el contexto sociopolítico de la Transición española.
} 
invadido e incontrolable», la podemos encontrar sobre todo en los motivos de la fiesta campesina, la representación de los cinco sentidos y el tema del Heráclito que llora y el Demócrito que ríe (Burucúa, 2007: 25-27).

Brueghel el Viejo representa en la fiesta campesina la risa asociada al juego y al baile, al movimiento frenético que destruye la armonía anatómica, «de modo que risa, movimiento y danza forman una mezcla regida por el sentimiento del desborde, sin ningún control de las expresiones corporales» (Burucúa, 2007: 28). Significativamente, en las representaciones iconográficas de los cinco sentidos, son el gusto y el olfato, es decir, los motivos de la glotonería y los placeres sensuales, los que se asocian con la expresión risueña (Burucúa, 2007: 29). En la obra, más tardía, de Jacob Jordaens hallamos una combinación de los motivos de la fiesta campesina y los sentidos, como en el cuadro sobre el tema carnavalesco del Rey del Haba ${ }^{19}$ [Fig. 7], donde encontramos las alusiones a la fiesta, la bebida, y el exceso.

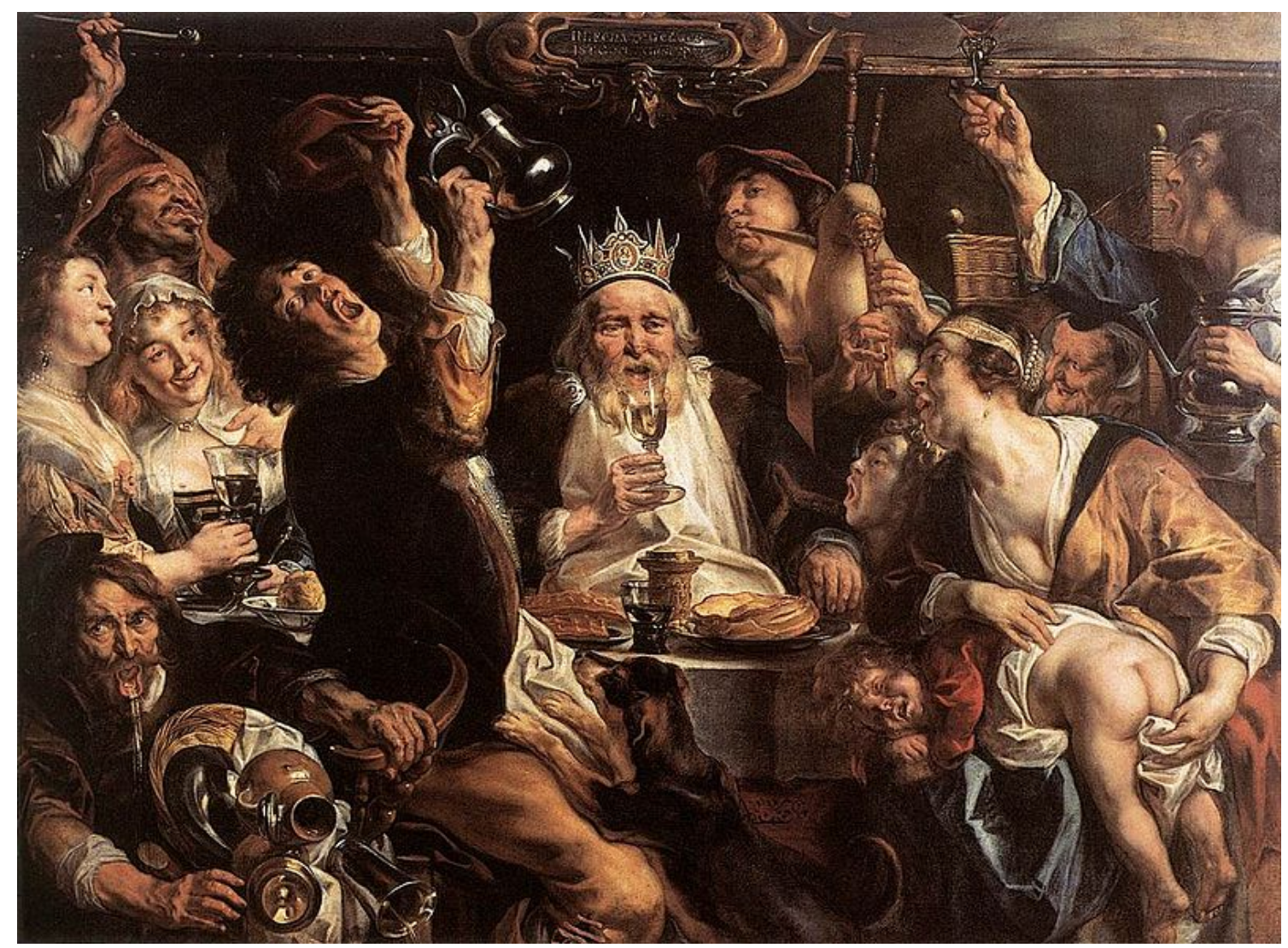

Fig. 7. Jacob Jordaens, El rey bebe o El rey del haba (1623)

\footnotetext{
${ }^{19}$ Referencia a la tradición que aún pervive en la Noche de Reyes española.
} 
En resumen, vemos en la representación renacentista y barroca de la risa una forma expresiva grotesca

sobre la base de dos procedimientos de diseño de los cuerpos que operan por antítesis, esto es, por un lado, las violaciones totales o parciales de las proporciones canónicas (...); y, por otro, la línea quebrada y nunca fluida en la definición de los perfiles de las caras o de la totalidad de las figuras. (...) La emoción característica del ser grotesco [es contradictoria] desde el principio de nuestro contacto con ella: las figuras grotescas suscitan un sentimiento de desasosiego, de rechazo y hasta de terror, pero al mismo tiempo no estimulan la huida ni el apartamiento de la mirada, al contrario, la rareza, lo inesperado, la variabilidad de sus elementos captura la atención de los ojos y engendran un rápido efecto de goce (Burucúa, 2007: 33-34)

Otro tema muy presente en la representación pictórica de lo carnavalesco era, por supuesto, la locura. La iconografía tratará la locura de manera diferente a como lo hace la literatura: la locura del Bosco no es la misma que la de Erasmo o Sebastian Brant. En las artes visuales la locura se representa como el exceso de imaginería gótica privada de su significado, como si la locura fuera la de la propia sobreabundancia de significaciones, «de una multiplicidad del sentido (...) que crece entra las oscuras relaciones tan numerosas, tan entretejidas, tan ricas, que no pueden ya ser descifradas más que en el esoterismo», donde la distancia entre las figuras de la locura y este saber esotérico crea

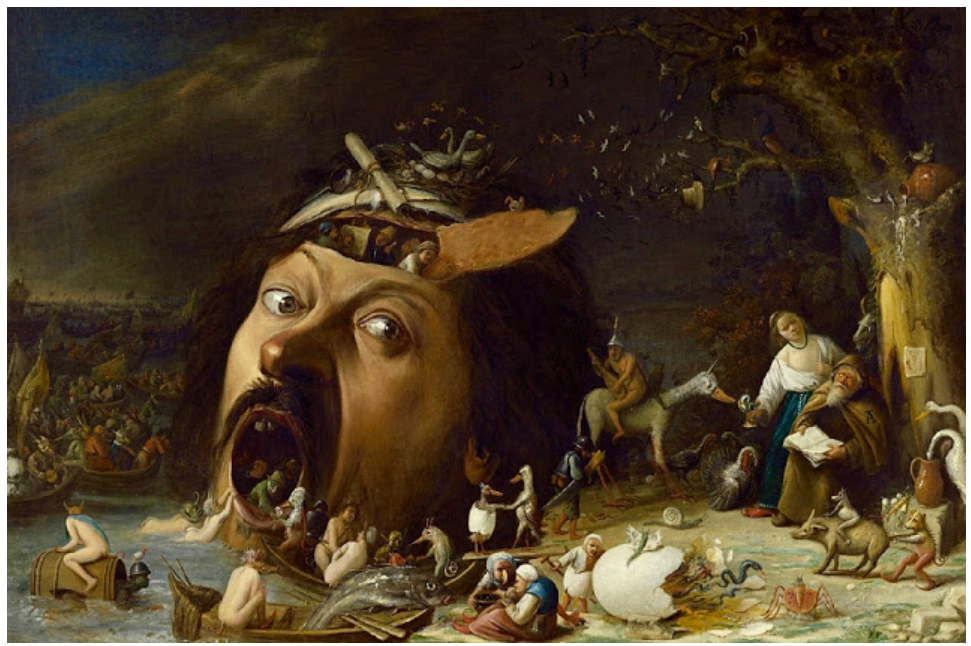

Fig. 8. Tentaciones de San Antonio Abad (1650), de Joos Van Craesbeeck un espacio libre donde «el sueño, lo insensato, lo irrazonable pueden deslizarse a este exceso de sentido» (Foucault, 2015: 35-37). Las figuras fantásticas de los grylles toman el protagonismo del tema de las Tentaciones de San Antonio [Fig. 8]:

Todo lo que hay de imposibilidad, de fantástico, de inhumano (...) todo eso, precisamente le da su extraño poder. La libertad de sus sueños - que en ocasiones es horrible - los fantasmas de su locura tienen para el hombre del siglo XV mayor poder de atracción que la deseable realidad de la carne (Foucault, 2015: 39) 
La animalidad fantástica, imposible, revela al hombre su verdadera naturaleza, la locura que le es propia; en el polo opuesto, estas figuras representan un saber místico, esotérico: son la tentación no de la carne sino la de la sabiduría divina, vedada al hombre (Foucault, 2015: 39-40).

\subsubsection{La risa y lo cómico en el pensamiento renacentista}

\subsubsection{La risa y lo carnavalesco en la literatura del Renacimiento}

En Noche de Reyes, una de las comedias más logradas de William Shakespeare, reina la locura. Toda la trama secundaria consiste en la broma de la criada Maria y Sir Toby y Sir Andrew de hacer pasar por loco a Malvolio, pero ciertamente él no es el único loco: Olivia teme estar «as mad as he [Malvolio]/ if sad and merry madness equal be» (Acto III, escena 4, versos 15-16) ${ }^{20}$; Sebastian, al ser confundido por Olivia con su hermana gemela Viola, que se hace pasar por el siervo Cesario, y recibir los favores de la condesa, se pregunta si él, u Olivia, estarán locos (IV, 3, 1-21) y al ser atacado por Andrew y Toby, exclama: «Are all the people mad?» (IV, 1, 25). También Malvolio, cuando riñe a los díscolos sires por su juerga nocturna, les espeta: «My masters, are you mad?» (I, 3, 82). Los personajes más propiamente cómicos de la obra, Maria y los dos caballeros, están estrechamente asociados a la comida y bebida en exceso, como Malvolio les reprocha, y este apetito desmedido y alienante es la contrapartida de los excesivos (y locos) enamoramientos del duque Orsino y la condesa Olivia, engañados ambos por el disfraz de hombre de Viola, la protagonista.

No es de extrañar que, concebida para ser representada en la noche de Epifanía, la comedia del bardo esté impregnada por este ambiente festivo carnavalesco en el que las normas y jerarquías sociales son puestas patas arriba (ver Coddon, 1993 y Jenkins Logan, 1982). En este sentido es particularmente interesante la figura del bufón Feste, cuyo nombre y profesión apuntan, por supuesto, a la tradición del Feast of Fools. Feste es en varias ocasiones retratado, efectivamente, como un bufón profesional que finge ser estúpido, como Viola dice de él: «This fellow is wise enough to play the fool;/ and to do that well craves a kind of wit. (...) For folly that he wisely shows is fit;/ but wise men, folly-fallen, quite taint their wit» (III, 1, 59-67). En sus palabras oímos de nuevo el tema

\footnotetext{
${ }^{20}$ Citamos por la edición bilingüe preparada por el Instituto Shakespeare para Cátedra (2006).
} 
medieval de la locura que desenmascara a los falsos sabios: «Wit, an’t be thy will, put me into good fooling. Those wits that think they have thee do very oft prove fools; and I that am sure I lack thee may pass for a wise man. For what says Quinapalus? 'Better a witty fool tan a foolish wit’» (I, 5, 30-35). Pero muy significativamente, Feste se declara no el bufón de Olivia, sino «her corrupter of words» (III, 1, 36), capaz de darle la vuelta a las palabras: «A sentence is but a cheveril glove to a good wit; how quickly the wrong side may be turned outward!» (III, 1, 11-13). Los otros personajes ingeniosos («witty») de la obra son Viola y Maria, y ambas están caracterizadas también por su capacidad para el engaño y la falsificación, que dará lugar a las dos tramas de la comedia: la criada falsificando la letra de su señora para hacer creer a Malvolio que Olivia está enamorada de él; y Viola disfrazándose de hombre para entrar a servir al duque de Orsino, del que se enamora - y disfraz que hace que Olivia se enamore de ella.

En suma, vemos que el ambiente festivo-carnavalesco de Twelfth Night tiene un trasfondo de locura y de excesos pasionales que, motivados por los engaños de Viola y Maria, hacen que la jerarquía social se tambalee - al fin y al cabo, no solo es escandaloso que Olivia se enamore de Viola, u Orsino de su personaje travestido Cesario, sino que además lo hacen de un criado. Vemos también repetirse los motivos de la tradición carnavalesca medieval y renacentista: la locura, los excesos en la comida y la bebida, la lascivia disfrazada de amor, la inversión de las jerarquías, el engaño y el disfraz, etc.; elementos mezclados con el emergente «wit», «ingenio», que tan importante va a ser en el pensamiento occidental sobre lo cómico a partir de este momento. Noche de Reyes, en fin, es un claro ejemplo de la apropiación humanista de la cultura popular carnavalesca, representada por esas tres cumbres de la literatura europea que son Shakespeare, Cervantes y Rabelais.

Para Bajtín, la obra y la época de estos tres escritores representan un punto de inflexión en la historia de la risa, marcando una frontera entre el siglo XVI y los siguientes (1998: 64). Como hemos apuntado ya, el Renacimiento viene a apropiarse de la cultura cómica medieval como vehículo de expresión de una nueva ideología y una nueva concepción histórica: la risa de la fiesta medieval, con su acento puesto en el cambio y el porvenir, con la inversión desanquilosadora de las rígidas jerarquías sociales, viene a prefigurar la autoconciencia humanista de estar viviendo una época totalmente nueva, dejando atrás el oscurantismo de la Edad Media (Bajtín, 1998: 93): los humanistas usan esta risa popular para romper con la rigidez escolástica de la sociedad y el pensamiento 
medievales para introducir una visión del mundo más dinámica, optimista y materialista (Minois, 2000: 245) ${ }^{21}$.

Pero esta cercanía de Rabelais a la risa popular no era ni mucho menos extraordinaria. Como hemos visto, tanto el clero como las clases altas participaban activamente en las fiestas medievales, y de hecho a un observador actual podría sorprenderle la permisividad hacia la risa de tipo popular que encontramos en la Italia renacentista (Burke, 1999: 64; ver también Burckhardt, 2004: 159-167). Los géneros literarios cómicos comprendían desde la comedia culta a la commedia dell'arte, que como veremos tanto habría de influir en el teatro y la imaginación de otros países y de los siglos venideros; las novella (como el Decamerón) o las facezie recogidas en libros (como el Liber facetorum del eminente humanista Poggio Bracciolini [Burucúa, 2001: 143]); también existían otros géneros aún menores como los borchiellygare o versos absurdos, y hasta los sermones religiosos mezclaban lo serio con lo cómico (Burke, 1999: 65).

Paralelamente, la locura ocupa un papel protagónico en la literatura moral, como ya hemos visto parcialmente. Das Narrenschiff («La nave de los necios») de Sebastian Brant, publicada en 1494, inaugura este tema satírico en que, como dijimos, la locura sirve para criticar los vicios y defectos de la sociedad. La locura, tanto aquí como en el Elogio de la locura de Erasmo, está por tanto estrechamente vinculada al saber, «pero no porque lo contenga, sino más bien es el castigo de la ciencia errada»; la locura en la literatura moral no es la sinrazón cósmica de la tradición iconográfica, sino la locura del hombre, de sus saberes, vicios e ilusiones vanas; es el castigo de los orgullosos, de los soberbios, de los falsos sabios; es, en suma, un fenómeno moral y no ontológico que toma la forma de la sátira (Foucault, 2015: 45-47). No obstante, Erasmo también habla de una locura santa y cristiana, que aboga por la simplicidad y la inocencia según el modelo de Jesucristo:

Hacia el final del Elogio, el autor incita a manifestarse a una variedad santa y alta de la locura. Después de violentar las palabras del Eclesiastés que señalan el dominio de la tristeza sobre el corazón de los sabios y el de la alegría sobre el corazón de los necios, nuestro humanista salta rápidamente a la afirmación de San Pablo en la segunda Epístola

\footnotetext{
${ }^{21}$ En contra de la interpretación unilateralmente optimista que Bajtín da a su obra, para otros estudiosos como Géralde Naïma bajo esta bufonería se esconde lo absurdo de la existencia: la risa rabelaisiana refleja la angustia ante la muerte de la época y su apetito característico se revela más bien como una bulimia desesperada (Minois, 2000: 248-250). Según esta interpretación, Rabelais inauguraría la risa moderna, aquella que encuentra un extraño placer en la certeza de que no hay ninguna certeza (Minois, 2000: 247).
} 
a los Corintios: "Hablo como loco, porque lo soy más que nadie”; y se explaya luego acerca de esa forma superior de la insania, salvadora y de impronta divina, que es la locura de la cruz, ensalzada por el mismo apóstol en su primera carta a los corintios. Cristo nos dice Erasmo - no dejó de comportarse como los simples de mente, en contra de los escribas y de los sabios fariseos, ni perdió ocasión de exaltarlos, simbolizando hasta en los animales que eligió por compañeros reales o metafóricos a lo largo de la vida su preferencia por los tontos: el burro que fue su cabalgadura en Jerusalem o las "ovejas” que serían sus fieles (Burucúa, 2001: 73)

Como vemos, la asociación de la risa con la verdad era un lugar común en la ideología renacentista, hasta el punto de que incluso Galileo Galilei, en su Diálogo sobre los sistemas del mundo, intercambia sarcasmos e ironías con sus colegas de profesión, pero con un fondo más que simplemente polémico: «el uso de la risa era, mucho más que un recurso retórico, un componente íntimo del modo de la argumentación que compartían nuestro sabio y sus adversarios» (Burucúa, 2001: 121). Así pues, aun escribiendo a principios del siglo XVII, Galileo es todavía

un heredero consciente de las ideas y de las costumbres, bien burguesas ellas, realizadas en el ambiente urbano florentino desde los tiempos de Boccaccio, según las cuales el polemizar y el competir (il giostrar) riendo, casi en los antípodas de la violencia señorial (...) podían ser vistos como una forma de máxima disponibilidad para el ascenso del espíritu por el camino de los saber más altos (Burucúa, 2001:125)

En resumen, Burucúa distingue tres vertientes en el uso de la risa en este período:

i. la crítica de tipo satírico de vicios y costumbres inaugurada por Boccaccio y continuada en las facetie y novelle del siglo XV y XVI, de signo particularmente anticlerical;

ii. un remedo culto de la risa campesina y plebeya, convivial, «risa sagrada de las comidas celeste y mundana, de la comunión con el creador y entre los hombres», $\mathrm{y}$

iii. una risa humanista, fundamentada en los textos de la Antigüedad recién rescatados, «risa impregnada de la religiosidad (...) antigua y precristiana»; una risa escéptica como la del Momus de León Batista Alberti, de espíritu claramente lucianesco, «risa corrosiva de las creencias que solo se detiene en los umbrales de la misericordia» (Burucúa, 2001: 225-227) 


\subsubsection{Teoría renacentista de la risa}

En general, la actitud del Renacimiento hacia la locura y la risa como signos de sabiduría puede verse en la preferencia por el Demócrito que ríe frente al Heráclito que se lamenta ante la vanidad de la vida humana: el médico Laurent Joubert, en su importantísimo Tratado de la risa, había incluido la carta del pseudo Hipócrates de la que hablamos en el capítulo anterior, y que se convirtió en un tópico extendidísimo en la cultura europea (Pujante Sánchez, 2018: 30): los humanistas se identifican con la decisión de Demócrito de reír ante la estulticia humana, como comprobamos en las obras de Erasmo, Rabelais o Montaigne (Pujante Sánchez, 2018: 37).

Esta reivindicación de la risa casa perfectamente con el nuevo espíritu humanista del que hablábamos antes. La afirmación aristotélica de que la risa es propia del hombre sirve de justificación para considerar que la risa es un fenómeno fisiológico natural, lo que lleva a los humanistas a estudiarla, dignificarla y cultivarla (Ménager, 1995: 13-15; Pueo, 2001: 11). La risa es considerada una relajación necesaria después del duro estudio y el trabajo; privilegio del ser humano y señal optimista de su posición especial en el universo (Ménager, 1995: 16-17).

El saber médico se interesa especialmente por la risa como manifestación emocional y como movimiento corporal, interés del que el mencionado Tratado de Joubert es el caso más importante, si bien médicos anteriores como Fracastore o Valleriola ya habían tratado el tema (Ménager, 1995: 15). La descripción fisiológica de la risa divergía entre aquellos para quienes, como Joubert, su origen está en el corazón, sede de los afectos y sensaciones al que la teoría concede también una función cognitiva, y aquellos para quienes la risa es una capacidad de la potencia imaginativa del cerebro (Ménager, 1995: 21-23).

En todo caso, para la medicina humanista la risa es propia de un cuerpo sano, pero a la vez un fenómeno fascinante, «un mystère ou plutôt, pour reprendre le langage de Joubert, une «merveille». Entendons par là, avec la Renaissance, une réalité naturelle mais qui intrigue» (Ménager, 1995 : 26). En líneas generales, la concepción médica griega de la risa sigue vigente, y muchos siguen viéndola como un fenómeno fisiológico ambiguo y necesitado de vigilancia: Celso Mancini la asemeja al deseo sexual como algo que se escapa al control de la voluntad, y Policiano la considera, como el sexo, un gasto energético inútil que fatiga al individuo y puede llevar incluso a la muerte (Ménager, 
1995: 27). Se debate, asimismo, si la risa es signo de alegría o goce, «laetitia» o «gaudium», y Joubert afirma que la risa proporciona a la vez placer y dolor, alegría y tristeza (Ménager, 1995: 33-35): «L’une de ses grandes contributions à la théorie du rire se trouve ici : dans la découverte qu'il est autre chose que la simple expression de la joie ou du plaisir ; qu'en lui se mêlent des sentiments complexes, miroir de l'homme et de ses contradictions» (Ménager, 1995: 35).

Esta recomendación de un uso moderado de la risa se encuentra también en el otro ámbito principal de discusión sobre el tema, el de los manuales de cortesía y modales apropiados para los nuevos hombres renacentistas. El Cortesano de Castiglione, por ejemplo, dedicará una sección a este asunto, pero es Pontano quien establece un puente entre la teoría retórica clásica y el pensamiento renacentista al aplicar la teoría de la risa a la conversación cotidiana entre gentilhombres, justificando que, dado que la risa es algo natural, es digna de ser cultivada como el mejor uso de la facultad humana del ingenio (Pueo, 2001: 99):

No resulta demasiado extraño, entonces, el hecho de que, teniendo la risa una justificación como un aspecto no pecaminoso, sino completamente natural y beneficioso dentro de la existencia humana, se le diese un papel importante dentro de la educación del hombre ideal del Renacimiento, razón por la que comenzaron a surgir numerosas reflexiones sobre la risa y su papel dentro de las actividades del hombre (Pueo, 2001: 171)

Esta inclusión de la risa en las altas esferas no era nada nuevo, sino más bien una moderación de costumbres previas. Las «beffa» o bromas pesadas, normalmente de carácter escatológico, eran relativamente frecuentes en Italia, tanto en las clases bajas como las altas, y sus límites no estaban nada claros; de hecho, se le reconocía un cierto placer estético y se llegaban a considerar "bellas". La beffa era una herramienta útil de humillación en una sociedad altamente competitiva donde la vergüenza y el honor eran valores cardinales (Burke, 1999: 66-69). Ahora bien, a partir del siglo XVI se inicia un proceso de disolución de lo festivo que, como veremos, encontrará su momento álgido en los siglos XVII y XVIII. El ámbito de lo permitido en las beffa se irá reduciendo: se condenará el carácter escatológico y la crueldad de antaño, y los cortesanos las irán sustituyendo por la mera chanza y conversación ligera como muestra de ingenio verbal (Burke, 1999: 72). Para Della Casa, ya en el siglo XVI, la burla jocosa era una variante aminorada del escarnio, la agresión y el engaño, una práctica que resultaba imprescindible 
como solaz de la vida fatigosa del trabajo, «claro que los chistes habrán de decirse con una elegancia particular, alejada de los ademanes del juglar y las bufonadas» (Burucúa, 2001: 232). En general, los manuales de cortesía y los tratados que se ocupaban de la risa distinguían entre la risa propia de campesinos y la adecuada para la clase alta (Pueo, 2001: 184-185). Había que tener cuidado también con hacer bromas hacia determinados colectivos: ni los miserables, a quienes hay que tener compasión; ni los demasiado malvados, que merecían castigo; y mucho menos a los poderosos, a quienes se debía respeto (Pueo, 2001: 194).

Todos estos tratados seguían, como vemos, la discusión que Cicerón había ofrecido sobre los usos de la risa en la oratoria en su De oratore (Pueo, 2001: 107), que partía de una definición de lo ridículo que, con la Poética de Aristóteles aún por descubrir, también se aplicaría a ciertas definiciones de la comedia.

\subsubsection{Teoría renacentista de la Comedia}

Como decimos, dado que la Poética de Aristóteles no se conoció hasta su edición en 1536, el modelo teórico medieval y del primer Renacimiento se había basado en la tradición retórica que partía de Cicerón, teniendo en cuenta adicionalmente algunas alusiones laterales al género cómico por parte de Platón y Horacio (Pueo, 2001: 35).

En la Rhetorica ad Herennium ya se relacionaba la comedia con el estilo «gracioso» y con el relato de ficción, y se establecía el sistema tripartito de estilos elocutivos alto, medio y bajo, que en la Edad Media se pondría en relación con la posición social del personaje y con un determinado género; idea que se reforzaría con la noción horaciana de decoro por la cual a cada género le corresponde un estilo determinado y un tipo concreto de verso (Llanos López, 2007: 169-172, 199). Pero, como sabemos, había sido Cicerón el que había ofrecido la discusión teórica más completa sobre la risa y lo que la provoca en el segundo libro del De Oratore, y muy significativamente en el contexto de la discusión acerca de las distintas pasiones que el orador puede despertar sobre el auditorio (Llanos López, 2007: 173). Allí, Cicerón define, en un sentido muy próximo al de Aristóteles, lo risible como lo deforme o torpe que no causaba dolor (Llanos López, 2007: 177) - definición a la cual los humanistas añadirían la condición de que debía causar asombro gracias al ingenio con que se decía; de hecho algunas versiones de la definición ciceroniana entendían lo risible como lo feo dicho "no feamente”. Quintiliano también trata la risa después de una discusión sobre los efectos, y si bien sigue 
de cerca a Cicerón, distingue entre dos tipos: el ethos, los afectos mitigados y continuos, y el pathos, las pasiones intensas y violentas; según el orador de Calahorra, un ejemplo de pathos era el efecto de la Tragedia, y del ethos, la Comedia. (Llanos López, 2007: 193194).

Pero las máximas autoridades durante la Edad Media y el Renacimiento para la teoría de la comedia fueron, de lejos, Evancio con su tratado De Fabula y los comentarios a las obras de Terencio de Donato - ambas obras se consideraban en ese período de autoría exclusivamente donatiana (Pueo, 2001: 39). Estos textos ofrecían dos definiciones de comedia. Según Donato, esta es «imitación de la vida, espejo de la costumbre e imagen de la verdad» (Llanos López, 2007: 231-232): el mundo cómico es una especie de microcosmos que debe servir de espejo de las costumbres morales, y por lo tanto se rige por criterios más morales que estéticos, es decir, según su utilidad didáctica (Llanos López, 2007: 233-234) - equilibrio entre el prodesse y el delectare que ya había introducido Horacio (Llanos López, 2007: 204). Evancio por su parte extrae su idea de comedia a partir de su comparación con la definición aristotélica de la tragedia. La comedia, así, es imitación de hombres ordinarios, de una acción inventada que comienza en un estado turbulento, ofrece varios peligros en su desarrollo, pero ha de acabar bien; la comedia terenciana es una imitación que nos debe mostrar qué es útil y bueno y qué no (Llanos López, 236-238).

Por tanto, la definición donatiana de la comedia hace hincapié en el carácter privado de las acciones representadas y su realismo moralista, y Evancio añadía el carácter ficticio o inventado de la comedia, frente a las historias "reales" (en tanto que conocidas por todos) que representa la tragedia (Pueo, 2001: 41). Pero, ante todo, el comentario de Donato a las obras de Terencio es el de un gramático, y a partir de él se hace del comediógrafo latino un modelo de excelencia retórica al que imitar. Los comentaristas posteriores se centraron, por tanto, en los ejemplos de narraciones, alusiones al público, argumentaciones entre personajes, etc., que podían encontrar en las comedias, y hacían coincidir su estructura con las partes del discurso retórico, es decir, exordium, narratio, divisio, confirmatio, confutatio y conclusio (Pueo, 2001: 42). Los ejemplos que se encuentran en Terencio se adaptan a los tres géneros retórico, deliberativo, forense y epidíctico; y estando en general la comedia, como decimos, orientada a la corrección de vicios, se la incluía en la retórica demostrativa (Pueo, 2001: 43-44). 
Como hemos apuntado, la Poética de Aristóteles no se publicó hasta 1536, y en 1548 le dedicó un exhaustivo comentario Robortello (Pueo, 2001: 35). Los humanistas italianos se tuvieron que enfrentar al reto de adaptar las ideas del Estagirita a géneros contemporáneos como la novella o la lírica petrarquista, pero sin duda una de las mayores dificultades con las que se encontraron fue la tarea de completar la laguna dejada por la pérdida del análisis aristotélico de la comedia (Pueo, 2001: 36). En este proceso, muchos autores, influidos por la vía retórica latina, entendieron por ejemplo que Aristóteles, al hablar de personajes inferiores, lo hacía en un sentido social, así como la necesidad de un final feliz opuesto al final triste de las tragedias (Pueo, 2001: 37-38) - opinión que, como acabamos de ver, ya estaba prefigurada en los comentarios donatianos.

Al mismo tiempo, el sentido didáctico de la comedia llevó a considerar que no era la risa el motor de esta, sino la imitación de personajes (social y moralmente) inferiores (Pueo, 2001: 38). Robortello, por ejemplo, se hacía eco de la reflexión aristotélica de la risa como propia del género cómico, pero la subordinaba a la construcción de la trama y los caracteres y, en este mismo sentido, diferenciaba la risa que encontramos en la comedia de la invectiva personal propia de la sátira (Pueo, 2001: 54, 60). En la línea que predicaba la “amabilidad” de la comedia (Llanos López, 2007: 194), para Trissino el espectador ha de salir "pacificado" de la comedia, y, por tanto, la trama debe conducir al placer y la tranquilidad (Pueo, 2001: 67). Vincenzo Maggi fue uno de los pocos que consideró que la definición de la comedia como imitación de acciones de hombres inferiores quedaba incompleta si no se aludía a que estas acciones habían de ser risibles (Pueo, 2001: 71), pero también para él la risa tenía que estar al servicio de la moralidad y el castigo de los defectos morales (Pueo, 2001: 82). Y, por supuesto, este didactismo de lo cómico es posible bajo el amparo de la teoría de lo ridículo, inspirado en las definiciones aristotélica y ciceroniana de lo risible: así, por ejemplo, para Castelvetro, la comedia consiste en la imitación de personajes ridículos, siendo lo ridículo una especie de lo feo, de la deformidad, del cuerpo o del alma, que no causa dolor (Blanco Valdés, 2003: 447).

\subsubsection{La comedia renacentista y barroca: la commedia dell'arte y Moliére}

Por supuesto, debemos tener en cuenta la distancia entre esta teorización humanista de la comedia y la práctica teatral real de la época. En este sentido, existe una relativa distancia 
entre la comedia culta humanista y el teatro popular, que encuentra su expresión más acabada y relevante en la commedia dell'arte.

Para hacernos una idea del ámbito en que se movió el teatro humanista, tengamos en cuenta, por ejemplo, que el descubrimiento de doce de las comedias de Plauto fue celebrado como un acontecimiento importante para el estudio de la Retórica, y no del teatro (Berthold, 1974: 7-8). Poco después se empezaron a dramatizar estos textos y a escribir comedias originales a imitación de las latinas, pero, aunque podemos encontrar obras importantes como La Celestina o la Mandrágora de Maquiavelo, lo cierto es que se representaban en universidades y palacios, a cargo de nobles, académicos y estudiantes y aficionados ante un público reducido y culto (Berthold, 1974: 8). Es decir, la comedia humanista no tenía ni de lejos la resonancia ni la relevancia social que el teatro había ocupado en el mundo grecolatino.

Esta posición de relevancia la ocupaba, al contrario, la commedia dell'arte, surgida en Italia a finales del siglo XV y principios del siglo XVI. También conocida como commedia all'improviso, popolare o Maaschare, es una forma dramática surgida del pueblo bajo, embebida de los festejos carnavalescos y las tradiciones bufonescas (Salvat, 1996: 32; Berthold, 1974: 99):

Commedia dell'arte, es decir, arte mímico basado en la inspiración del momento, improvisación pronta a la réplica, la forma burlesca y obscena más primitiva del teatro como ya la habían ofrecido las antiguas atalantas en sus escenarios ambulantes: tipos grotescos según los esquemas fundamentales de los conflictos humanos, demasiado humanos; (...) pero también significa: dominio artístico de los medios de expresión corporales, reserva siempre lista de modelos de escenas y situaciones, riqueza disponible de combinaciones, acuerdo espontáneo con el ingenio del momento (Berthold, 1974: 98)

La commedia dell'arte, por tanto, está muy cerca del teatro grecorromano más popular y del mimo: en el centro de la representación está la gestualidad y expresividad del cuerpo del actor, que improvisa sobre el esbozo de un guion basado en tipos fijos que recuerdan, efectivamente, a las máscaras de la atelana latina, de la que algunos estudiosos creen que deriva (Salvat, 1996: 33, 39). En este sentido, es muy significativo que para muchos estudiosos la commedia sea la especie más representativa y esencial del arte cómico (Salvat, 1996: 33). 
Surgida en la cultura campesina, fue gracias a la labor de Angelo Beolco el Ruzzante que la nobleza se empieza a interesar por esta forma dramática popular en la primera mitad del siglo XVI (Salvat, 1996: 35). La commedia, de este modo, es una perfecta mezcla entre el espíritu popular y los gustos de la nobleza. De hecho, no hay tanta distancia entre la commedia dell'arte y el teatro literario: el Ruzzante conocía a Plauto, y muchos de sus temas y argumentos están inspirados en obras de Aristófanes, Plauto y Terencio; además, las piezas se estructuran según una doble trama y se sitúan en los típicos espacios urbanos de la Comedia Nueva (Salvat, 1996: 36-37). Los mismos tipos del repositorio de la commedia dell'arte recuerdan enormemente a los de la comedia plautina: así, Pantalón es una versión del senex, el Dottore se asemeja al pedante, es evidente la filiación del Capitán con el miles gloriosus... (Salvat, 1996: 41). Pero sin duda los personajes más cómicos y relevantes, y los que pasarán a formar parte del imaginario occidental en los siglos siguientes son los zanni, los criados, como Polichinela, Arlequín (cuyo nombre deriva del jefe de diablos de los misterios medievales) o Pierrot, que se convertirá en un símbolo de la melancolía a partir del Romanticismo francés (Salvat, 1996: 42-43).

Sin duda, una de las más relevantes de estas influencias de la commedia dell'arte fue la que ejerció sobre Moliére, quien a partir de sus tipos y máscaras y su sentido de la comicidad creó una comedia de caracteres (Berthold, 1974: 95). El comediógrafo francés basó sus obras en la crítica de costumbres, declarando la guerra «a los hipócritas, santurrones y envidiosos, y a todo el que se sintiera aludido» (Berthold, 1974: 95). En este sentido, el teatro de Molière es la expresión más acabada del sentido didáctico y moral de la comedia humanista, basado en una teoría del ridículo: con la censura mediante la risa, Molière pretendía extirpar los vicios y males que, en su opinión, atenazaban a la sociedad cortesana de su tiempo: «Molière une la grandeza de la Commedia dell'arte con la voluntad desmitificadora de un Maquiavelo o un Plauto» (Salvat, 1996: 127).

La labor dramática de Molière coincide prácticamente con la formulación del dramaturgo inglés Ben Jonson de su teoría de los caracteres cómicos, basada en la teoría medieval de los humores. Situándose en la tradición del teatro alegórico medieval, y motivado por la reciente traducción de los Caracteres de Teofrasto, Jonson define los personajes cómicos según un temperamento concreto, provocado, según la doctrina médica de la época, por un desequilibrio entre los humores y el predominio patológico de algunos frente a otros en el cuerpo de un individuo. Frente al teatro psicológico e 
individualizador de Shakespeare, Ben Jonson predica una comedia de caracteres cuya comicidad reside en la extravagancia de sus personajes, que no están definidos por una psicología sino por el sometimiento unilateral a un temperamento extravagante. En este sentido, el teatro de Molière, aunque no conocía la obra de Jonson, es la mejor ilustración de su teoría (Escarpit, 1967: 13-14) ${ }^{22}$.

La teoría de Jonson también es importante, desde el punto de vista histórico, porque constituye el primer momento en que el término humour, antes restringido al ámbito de la medicina, se vincula a lo cómico, dando un comienzo a un desarrollo semántico y filosófico que terminará en el sentido contemporáneo de humor. Pero antes, el término y la concepción misma de aquello que designa habrán de pasar por una serie de profundas transformaciones que estudiaremos en el capítulo siguiente.

\footnotetext{
${ }^{22} \mathrm{El}$ teatro de Molière será objeto de sugestivas reflexiones, como veremos, por parte de Henri Bergson y Charles Mauron. Es también interesante, para la propuesta hermenéutica del personaje cómico que desarrollaremos en su momento, que en la teoría de Jonson los personajes no solo sean "viciosos" en un sentido moral, sino que sean enfermos. Se establece, así, una relación entre el personaje cómico y la enfermedad (mental) que tiene que ver con la asociación secular entre risa y locura que venimos tratando y que irá reapareciendo en los siglos siguientes.
} 


\section{LA EDAD DE LA IRONÍA (SS. XVII-XIX)}

La época que comprende los siglos XVII y XVIII, lo que en la historiografía francesa se conoce como «época clásica», supone un período fundamental en nuestro estudio. Como ocurre con muchos otros fenómenos de la cultura occidental, la visión de la risa y lo cómico va a sufrir una transformación que da lugar a nuestra concepción contemporánea del humor; de hecho, podríamos sintetizar dicha evolución como la desaparición de la risa y el nacimiento del humor. Hablamos de desaparición de la risa en el sentido de que, a diferencia de lo que hemos visto en el capítulo anterior, la risa en tanto que fenómeno fisiológico y corporal dejará de ser una preocupación central de filósofos, médicos o religiosos. Con la decadencia de las fiestas carnavalescas, el progresivo refinamiento de las clases altas, la conversión de la locura en un problema estrictamente médicocientífico, etc., la risa desaparecerá tal y como se la concibió durante los siglos: ya no será una manifestación divina ni demoníaca, ni restaurará ningún vínculo perdido con los ciclos naturales; ya no curará enfermedades ni provocará la muerte ni será vista como un exceso irracional y animal. Lo cómico quedará relegado al ámbito de la literatura satírica, la imagen caricaturesca y la conversación cortesana distendida, y esta nueva consideración de lo humorístico en el plano del discurso traerá dinámicas relativamente nuevas, la más importante de las cuales quizá sea su desafío a la racionalidad cartesiana, transformación que alcanza su punto culminante en la reflexión de Friedrich Schlegel sobre la ironía.

Por supuesto, esta ruptura no es ni repentina ni total, ni las transformaciones son evidentes a simple vista. Tampoco significa que simplemente desaparezca la discusión sobre la risa: al contrario, en opinión de Dominique Bertrand, el siglo XVII vive una eclosión extraordinaria de reflexiones acerca de este fenómeno desde los ámbitos de la medicina, la ética, la cortesía, la filosofía, la teología, etc. (1995: 8). Pero el subtítulo del libro de Bertrand, «Représenter pour mieux controler», es suficientemente significativo: este aumento de los discursos sobre la risa responde a un proyecto de «mise en ordre» que es parte de un dispositivo más amplio de control del cuerpo y las afectividades en la época clásica (Bertrand, 1995: 11) ${ }^{1}$.

\footnotetext{
${ }^{1}$ Si en la sección correspondiente [1.2.1] aventurábamos una correspondencia del cambio de actitud hacia la risa en el paso de la cultura griega al cristianismo con el cambio de la experiencia de la sexualidad esbozado por Foucault, Bertrand asimila, para el período clásico, esta puesta en orden de la risa al
} 
Muchos de los motivos, ideas y discusiones acerca del problema de la risa y lo cómico que se mantienen en los siglos XVII, XVIII, XIX e incluso el XX son una continuación de la tradición griega, medieval o renacentista: se seguirán teniendo en cuenta los argumentos a favor o en contra de la risa, la función didáctica o inmoral de lo cómico y la comedia, su potencial subversivo o renovador del orden social, o las reflexiones de Cicerón y sus continuaciones humanistas acerca de la oportunidad de recurrir a la risa en la conversación. También las tradiciones cómicas artísticas y literarias continuarán: como veremos, el grotesco ornamental del manierismo se combinará con la tradición arabesca en el siglo XVIII, lo carnavalesco pervivirá en la caricatura y lo grotesco romántico, las figuras de la commedia dell'arte y los personajes de Molière, considerado como cima de la comedia en su sentido clasicista, pervivirán en la imaginación de los caricaturistas y las reflexiones de Friedrich Schlegel, Baudelaire, Henri Bergson...

Pero, aunque en un nivel superficial parezcan mantener una relativa continuidad, estos motivos ofrecen una significación totalmente nueva porque el contexto en que se formulan es completamente diferente. En el período que tratamos se sucederán una serie de cambios sociales y culturales que contribuirán a esta evolución: la creación de los Estados absolutistas y centralistas, el auge de la burguesía y el surgimiento, con la progresiva industrialización, del proletariado; el alejamiento de las clases altas respecto de la cultura popular y la lenta pero imparable alfabetización de las clases bajas, así como la aparición y proliferación de la prensa como nuevo medio de comunicación, etc. Pero más importantes aún son los cambios epistemológicos y en la propia concepción del ser humano (el cambio de «episteme», por recurrir a la terminología foucaultiana): la desaparición del cuerpo, la imposición del racionalismo y una nueva centralidad del lenguaje como vehículo u obstáculo del conocimiento.

Desprovista la risa de su importancia fisiológica, reprimida como expresión corporal, expulsada de los salones de la nobleza y la burguesía en su forma más obscena, escatológica, desabrida y violenta, lo cómico se aloja, aparentemente domesticado, en el wit y el sprit, el dicho ingenioso e inocente. Así es como nacerá el humor como fenómeno eminentemente discursivo, tal y como lo entendemos contemporáneamente. Como decimos, hasta el Renacimiento lo que ocupaba las reflexiones intelectuales era la risa: su de la sociedad disciplinaria (ver Foucault, 2009b) (Bertrand, 1995: 151). 
fisiología, sus efectos sobre la salud, su carácter moral; como mucho, los tratados de retórica y cortesía atendían los modos de provocarla, pero no ofrecían una reflexión acerca de lo propiamente cómico del discurso retórico. Al final del período que estudiaremos a continuación, lo importante no será la risa sino el humor como rasgo del discurso, como modo de lenguaje, sus implicaciones cognitivas y filosóficas y sus

posibles usos (satíricos, didácticos, etc.). El humor seguirá siendo visto como algo potencialmente benéfico o peligroso, pero los ámbitos en los que aparecerán estas consideraciones serán totalmente distintos. De todas estas transformaciones, la más temprana y visible es la de las mutaciones en la cultura popular que conllevará a la desaparición de la fiesta carnavalesca en su significación medieval y renacentista.

\subsection{La desaparición del carnaval}

Entre los siglos XVI y XVIII encontramos la lenta pero inexorable desaparición de las fiestas medievales de tipo carnavalesco (Bercé, 1976: 8); desaparición provocada por diversos factores políticos, culturales, económicos y sociales, de los cuales las condenas y prohibiciones por parte de la Iglesia católica y, más tarde, los movimientos protestantes, fueron de hecho el factor menos relevante. En general, las condenas eclesiásticas e intentos de prohibición se venían dando de manera periódica desde el siglo XIII, e incluso desde los orígenes del Cristianismo (Bercé, 1976: 141; Burke, 1996: 308-309): los censores consideraban estas fiestas restos paganos y manifestaciones que inducían al pecado, además de blasfemas e irreverentes para con la jerarquía eclesiástica (Burke, 1996: 227-228, 299). Pero no es hasta mediados del siglo XVI, con los movimientos de Reforma y Contrarreforma cuando estos intentos de prohibir las fiestas populares se constituyeron en una ofensiva general, radical y, sobre todo, coordinada con los poderes civiles (Minois, 2000: 294; Burke, 1996: 309). A partir de la segunda mitad del siglo XVII y a lo largo del XVIII se produjo una segunda oleada de reforma debido al impulso del jansenismo y los pietistas y a la que se añadieron argumentos laicos relacionados con la educación moral y el buen gusto; periodo en el que las prohibiciones se extendieron finalmente a las zonas católicas y las protestantes menos urbanizadas (Burke, 1996: 331338). 
Con la Reforma protestante, los carnavales del norte de Europa habían sido aprovechados para la difusión de propaganda anticatólica, lo que dio lugar a que los poderes eclesiásticos tradicionales empezaran a sospechar de las fiestas populares como catalizadores de subversión (Bercé, 1976: 66-67). Pero, a pesar de este primer uso político, fueron las ciudades reformistas las primeras en prohibirlas: el famoso Schembart de Nuremberg, por ejemplo, fue celebrado por última vez en la temprana fecha de 1539 (Bercé, 1976: 68). Esto se pudo deber, en parte, a las características de la nueva ética ascética protestante:

Peut-être l'esprit de réforme, de censure des modes, n’a-t-il eu gain de cause que dans les villes où une élite lettrée assez nombreuse et puissant pouvait imposer ou montrer l'exemple d'une rupture avec les modes ancestrales (...) Le refus de la pompe, la crainte des tentatives mondaines, l'ascèse de goût et des modus construisaient de nouvelles manières de faire, donc l'austérité fini par constituer une tradition emblématique, caractéristique de la communauté réformée (Bercé, 1976: 69)

Los carnavales, por tanto, fueron un elemento más en la guerra política y religiosa entre Reforma y Contrarreforma. Pero si el catolicismo en un primer momento reivindicó, frente a la austeridad protestante, los fastos de la Pasión y las espectaculares expresiones de piedad (Bercé, 1976: 69), en el siglo XVII, como decimos, también arremetió contra las manifestaciones festivas populares. En general, en ambas ramas del cristianismo se produjo durante este período una progresiva interiorización del sentimiento religioso: si la religión medieval era una religión familiar, omnipresente, que no conocía límites entre lo sacro y lo profano, a partir del siglo XVI surgió y se desarrolló una ruptura entre esta religiosidad popular y otra intelectualizada, purista, que denuncia estas manifestaciones populares como inmorales y paganas (Bercé, 1976: 138). Es en esta época cuando se empieza a formar al clero en universidades y seminarios y, sobre todo, se exige que sean más serios y menos familiares en la relación con sus feligreses (Burke, 1996: 377).

Pero, como decimos, la historia de la animadversión de la Iglesia hacia los carnavales contaba ya con varios siglos de intentos infructuosos de erradicación, y solo pudo triunfar cuando los poderes civiles apoyaron esta ofensiva. Como ya hemos apuntado, las autoridades de los países católicos empezaron a mirar con recelo estas fiestas cuando se convirtieron en vehículo de propaganda reformista. En general, en el período entre las guerras religiosas y la instauración definitiva de los centralizados Estados modernos, las fiestas populares y las revueltas fueron a menudo de la mano, y las imágenes del carnaval empezaron a ser utilizados como símbolos de rebelión del pueblo 
(Connelly, 2015: 194; Bercé, 1976: 73-74; Bertrand, 1993: 130), por lo que la necesidad de reprimirlo se hizo cada vez más evidente.

Sobre todo, estas fiestas, surgidas en el contexto de la sociedad feudal, no tenían cabida en los Estados modernos, centralizadores y absolutistas (Minois, 2000: 296). Con la progresiva pérdida de autonomía de las ciudades, cuyas autoridades civiles eran las que habían permitido, incentivado e incluso organizado los carnavales y otras fiestas análogas, estas estaban condenadas a la desaparecer junto a esta forma de organización social. El sentido de comunidad vinculado a esta relativa autonomía también se perdía:

Au début, il y avait la ville, la communauté d’habitat, enserrée dans ses remparts, communauté de destin dans les siècles d’insécurité. Les fêtes citadines et tout leur apparat de chars et d'associations constituaient le langage visuel par lequel on célébrait cette unité, la gloire et le bonheur de la cité-mère. Lorsque la ville perdit son autonomie guerrière (...), financière (...), politique (...) les sentiments d'appartenance, le patriotisme et le militantisme quittèrent cet ancrage pour des entités plus lointaines. Les fêtes citadines étaient alors condamnées par la naissance des États nationaux (Bercé, $1976: 125)$

A pesar de todas las prohibiciones, por supuesto, las clases populares se resistieron a abandonar sus festejos: estos pervivieron a lo largo de los siglos XVII y XVIII, y aún en el siglo XIX aún se podían encontrar algunas fiestas en zonas campesinas resistentes a la modernización, si bien es cierto que habían perdido casi por entero el significado que tenían en su origen medieval (Burke, 1996: 331).

Por tanto, más que los intentos eclesiásticos y estatales de reforma fueron los cambios demográficos, económicos y sociales los que hicieron mutar por entero la cultura popular: el crecimiento de la población urbana, la expansión comercial proto-capitalista, la evolución de los medios de transporte y de comunicación... (Burke, 1996: 344). El crecimiento urbano dio lugar a una progresiva comercialización del ocio, que era vendido a las clases bajas más que producido por ellas; esta comercialización afectó incluso a las fiestas populares: los carnavales de Roma y Venecia se convirtieron en auténticos destinos turísticos (Burke, 1996: 348-349). Por tanto, las formas de ocio de las clases populares cambiaron completamente: el tiempo de la fiesta, como espacio ucrónico delimitado a unos días concretos del año, apartado por entero de las normas de la vida ordinaria, desapareció; en su lugar, el ocio se introdujo en el día a día cotidiano como descanso de la jornada de trabajo en las incipientes fábricas, y quedó relegado a la vida privada y doméstica, individual (Bajtín, 1998: 36-37; Connelly, 2015: 194). 
En suma, asistimos a lo largo del siglo XVIII al nacimiento de la moderna cultura de masas (Burke, 1996: 356-357), lo que, como veremos, afecta por entero al lugar, atributos y funciones de lo cómico en la sociedad. Además, la progresiva extensión de la alfabetización de la población, la toma de conciencia política por parte de las clases populares durante los movimientos de Reforma o la Revolución Inglesa (Burke, 1996: 362-363), junto con el nacimiento coetáneo del periódico (Burke, 1996: 365), fueron el caldo cultivo de perfecto para la espectacular eclosión de la prensa satírica y la caricatura durante el siglo XIX.

\subsection{La pervivencia de lo carnavalesco en la caricatura}

Paralelamente a esta desaparición de lo carnavalesco, una mutación análoga se produce en la literatura humorística, de la que da cuenta la distancia que hay entre Rabelais y Scarron: la risa es aún una forma de ver el mundo, pero en lugar de liberadora y optimista, es amarga y cínica respecto de la naturaleza humana (Minois, 2000: 331). Esta risa burlesca surge como reacción ante el nuevo autoritarismo absolutista, apoyada en la constatación de lo absurdo y vano de las convenciones sociales:

Comique des limites, le burlesque a partie liée avec un rire philosophique dans la lignée des cyniques grecs et Démocrite. Le burlesque transgresse tous les tabous, revendiquant le droit à rire de tout, y compris de la mort et du sacré (...) Derrière le rire, c'est la libération de la pensée qui est en cause (Ménager, cit. en Minois, 2000: 357)

El burlesco es, ante todo, una expresión del pesimismo imperante en el siglo XVII: «c'est l'humanisme déçu, l'expression de l'amertume qui accompagne l'effondrement d'un grand rêve» (Minois, 2000: 360). A pesar de esta eclosión de la literatura burlesca y satírica, estas manifestaciones quedaron cada vez más relegadas a los márgenes de la cultura oficial y la gran literatura debido al auge de las doctrinas neoclasicistas (Bertrand, 1995: 91). Lo cómico sobrevivía en géneros considerados inferiores: el teatro popular, las fábulas y sobre todo en los nuevos géneros literarios, especialmente la novela.

Como venimos diciendo, el aliento cómico barroco es muy diferente al del período renacentista: lo cómico es degradado, según la visión de Bajtín, convertido en algo puramente decorativo y frívolo; las novelas de Scarron o Sorel solo ven en el Quijote una mera parodia de las novelas de caballerías, y las obras de poetas libertinos como Saint 
Amant recogen las imágenes rabelaisianas pero para darles un carácter individualista y hedonista (Bajtín, 1998: 95-99). En general, durante los siglos XVII y XVIII la tradición iconográfica, temática y literaria carnavalesca sufrió un proceso de formalización por el cual sus formas se tradujeron en procedimientos literarios al servicio de fines concretos, como en las sátiras de Voltaire: «La risa (...) se reduce al mínimo, y sólo queda la ironía desnuda (...) Toda su fuerza y su profundidad residen en la agudeza y el radicalismo de la negación, mientras el aspecto renovador y regenerador está casi totalmente ausente» (Bajtín, 1998:109). En otros ámbitos, particularmente en la de las controversias religiosas entre Reforma y Contrarreforma, la risa grotesca empezó a servir como arma retóricoideológica (Minois, 2000: 332). Bien es cierto que, como dijimos, desde los orígenes del cristianismo la risa agresiva había sido usada como arma polémica contra paganos y herejes, pero ahora se legitima intelectual y moralmente: Pascal, por ejemplo, defenderá el uso del sarcasmo en una de sus cartas (Minois, 2000: 358).

Es este nuevo uso polémico y unilateral de la risa el que Bajtín lamentará como una degradación del “auténtico” espíritu del grotesco carnavalesco (Bajtín, 1998: 36): la nueva literatura grotesca, la que encontramos en las comedias de Molière o las novelas cómicas de Voltaire, Diderot o Swift, pierde sus vínculos con su origen popular y festivo; recurren a unas imágenes carnavalescas formalizadas que sirven para burlarse de las convenciones oficiales (Bajtín, 1998: 37), pero es una risa puramente negativa, sin el fundamental significado de comunión y regeneración que estaba en el origen de lo carnavalesco medieval y renacentista. Posteriormente, como veremos [2.4.3], con el Romanticismo nacerá lo que Bajtín denomina «grotesco subjetivo» en las obras de Sterne, Tieck o Hoffmann, surgido como reacción contra el clasicismo y el racionalismo del siglo XVIII. Pero este grotesco ya no presenta la dimensión universal y colectiva de la cultura popular medieval (Bajtín, 1998: 39): es un «grotesco de cámara», carnaval representado individualmente y que solo agudiza el aislamiento del artista y su lector (Bajtín, 1998: 40).

En efecto, la asimilación dada a partir del Renacimiento de lo grotesco por parte de la literatura culta y las bellas artes supuso que esta experiencia colectiva y directamente vivida se traspusiera a espacios y dispositivos virtuales e individualizados: a través de las obras artísticas y literarias, el lector/espectador podía contemplar lo grotesco de manera indirecta, frente a lo carnavalesco como experiencia vivida (Connelly, 2015: 50). La difusión en grabados de las imágenes grotescas, destinadas a engrosar las colecciones 
privadas de nobles y burgueses, por ejemplo, da cuenta de esta individualización de la experiencia carnavalesca (Burucúa, 2007: 101-102).

Pero, como hemos apuntado, las revueltas populares de la Edad Moderna eligieron lo grotesco y lo carnavalesco como símbolos de protesta social, dando lugar, en los siglos XVIII y XIX, a la aparición de la caricatura como forma de sátira y protesta social (Connelly, 2015: 51). La caricatura, como forma artística, había aparecido en la Italia del siglo XVI del mismo ímpetu creativo del que habían nacido el grotesco pictórico y ornamental y el capriccio, es decir, como modos de virtuosismo manierista que se alejaban de las convenciones realistas y miméticas - «caricare» significaba en aquella época «sobrecargar» (Connelly, 2015: 188). Fue en el siglo XVII cuando la caricatura se fusionó con la tradición carnavalesca en los grabados de Jacques Callot [Fig. 9], que combinó la tradición caricaturesca con la imaginería del norte de Europa, centrándose en la representación de elementos marginales de la sociedad, como personas deformes o trabajadores pobres, y personajes de la commedia dell'arte (Connelly, 2015: 188).

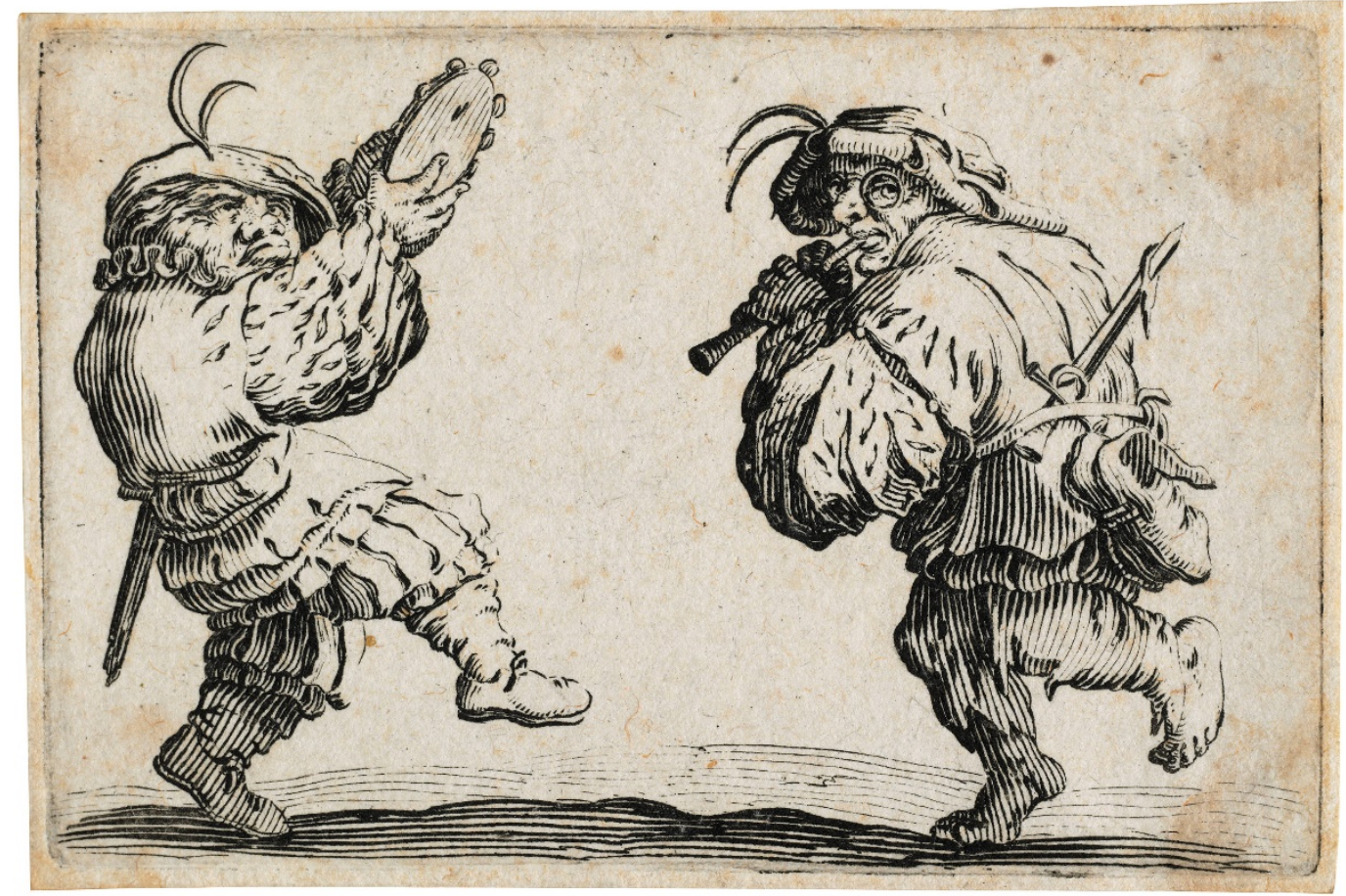

Fig. 9. Músicos callejeros, de la serie de grabados Varie figuri Gobbi (1606). Los gobbi era una compañía teatral callejera italiana

De este modo, lo carnavalesco reapareció en el siglo XVIII en la caricatura difundida por los nacientes medios de comunicación de masas (Connelly, 2015: 194): 
Por las mismas razones que el carnaval y el teatro callejero desaparecieron de la cultura europea durante el siglo XVIII, la caricatura se instauró rápidamente. En muchos sentidos, la caricatura suplantaba las subversiones ritualizadas del carnaval en el ámbito público. A comienzos del siglo XIX, la caricatura fue el vehículo fundamental de la sátira social para el público en general y un modo increíblemente efectivo de protesta en las sociedades emergentes (Connelly, 2015: 200)

Así, en el siglo XVIII el término «caricatura» ya designaba la sátira popular. Los representantes más significativos de este naciente género fueron Tiépolo, con sus grabados basados en la commedia dell'arte, las caricaturas de William Hogarth y la serie de los Caprichos de Goya (Connelly, 2015: 195). Hogarth combinó la posición canónica marginal de las revistas populares con las técnicas y sobre todo las aspiraciones de las bellas artes en su trabajo, que él identificaba como «historias cómicas» donde primaba la intención moralizante en la línea de la novela cómica burguesa de Henry Fielding (Connelly, 2015: 206) ${ }^{2}$. Sintomáticamente, Goethe criticó la obra de Hogarth y sus imitadores por sus dibujos «informes», refiriéndose a los peligros morales y sociales que la caricatura comportaba: «la constatación de Goethe revela aún más que, tras este miedo a lo informe se trasluce un miedo aún mayor por la pérdida del orden y el desmantelamiento de las jerarquías sociales establecidas» (Connelly, 2015: 209).

Por su parte, los Caprichos de Goya [Fig. 10] se sitúan en la línea que acerca lo carnavalesco a lo grotesco terrorífico del Romanticismo que estudiaremos más adelante: los dibujos goyescos van desde la sátira social y moral hasta la fantasía más perturbadora, abriendo «lo carnavalesco a una

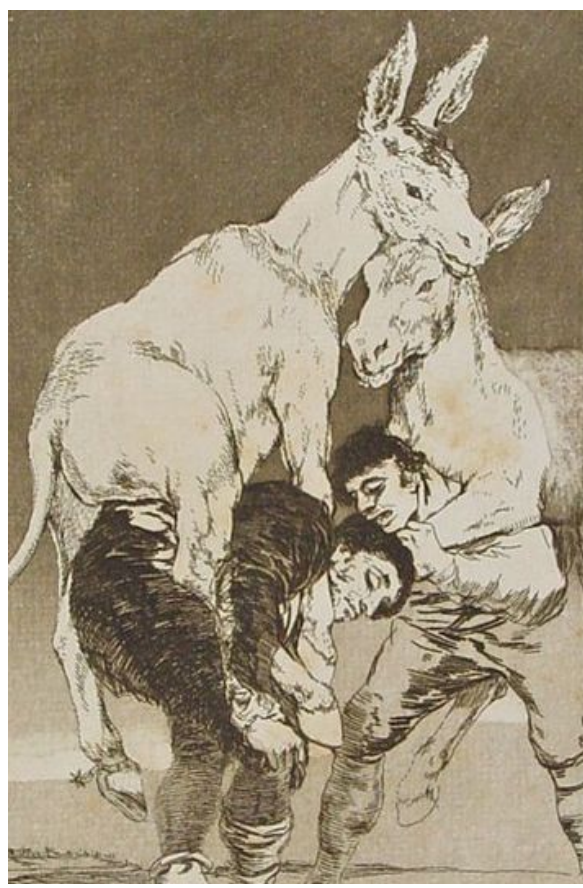

Fig 11. Capricho no 42 de Francisco de Goya (1799) nueva frontera de risa amarga y aterradora, transformándolo irrevocablemente (...) El poder de los Caprichos no reside solamente en

\footnotetext{
${ }^{2}$ De hecho, a Hogarth no le gustaba que su obra se etiquetara como caricatura, ya que entendía sus dibujos como retratos psicológicos de personajes: la exageración de sus rasgos faciales, sus posturas corporales y sus gestos tenían el objetivo de representar su verdadera naturaleza, según la tradición de estudios fisiognómicos (Connelly, 2015: 202-203). Como vemos, de nuevo encontramos un vínculo entre exageración y deformación cómicas, personalidad y desviaciones psicológicas, como en la teoría humorística de Jonson.
} 
la fusión innovadora de fantasía y sátira de Goya, sino en su exploración de todos los aspectos de lo irracional» (Connelly, 2015: 211).

Si bien Goya influyó enormemente en el Romanticismo francés, la faceta más siniestra de sus Caprichos no encontró una verdadera continuación hasta finales del siglo XIX con la obra de James Ensor, quien retomó el tema de la máscara del carnaval para darle un significado inquietante [Fig. 11] (Connelly, 2015: 216). A partir de mediados del siglo XIX, la estética grotesca de la caricatura se empezó a relacionar con el primitivismo, lo que encontrará su realización artística en el Impresionismo y sobre todo las vanguardias del siglo XX, como en el caso de la obra de Picasso (Connelly, 2015: 223) ${ }^{3}$.

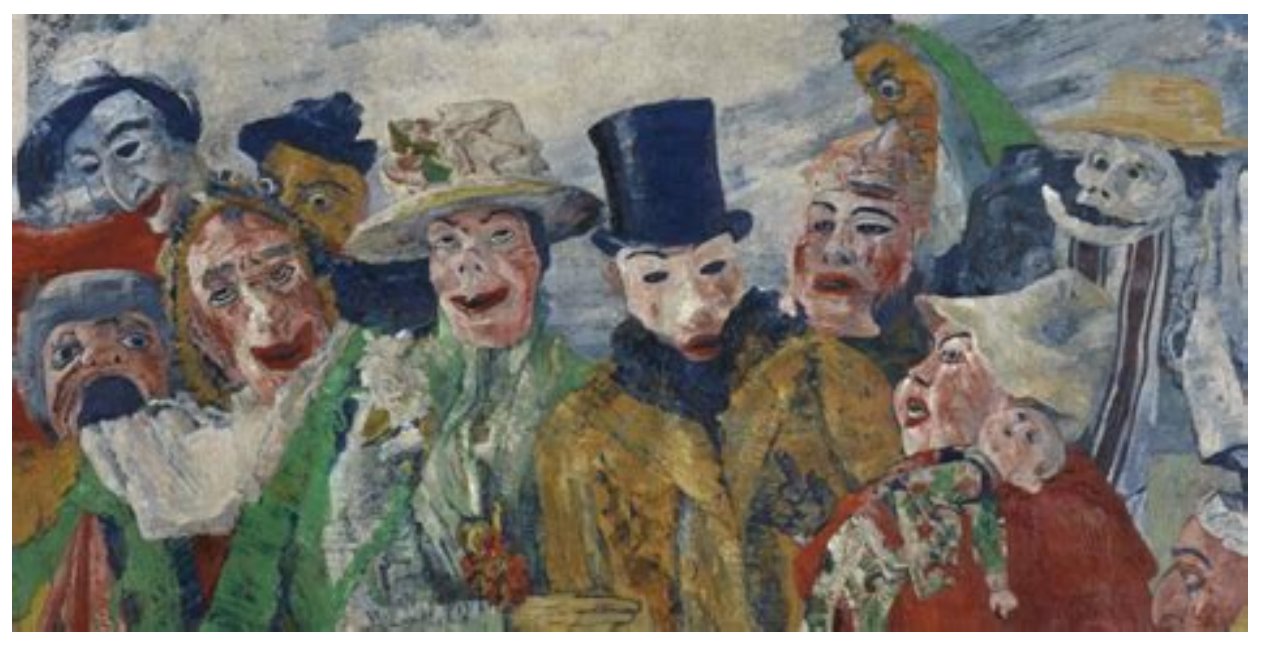

Fig 11. Intriga (1890), de James Ensor

En resumen, a través de la caricatura, pervivió en el siglo XIX la tradición carnavalesca, en su sentido de subversión social, de inversión de las jerarquías - y también en sus asociaciones con lo inquietante, lo demoníaco y lo irracional, sobre todo en las manifestaciones del grotesco siniestro de Hoffmann o Víctor Hugo, como veremos. Pero, ante todo, como venimos diciendo, el significado de estas asociaciones es muy diferente del que tiene en el mundo del carnaval medieval, sobre todo en las reflexiones filosóficas de Tieck, Schlegel o Baudelaire. Por ello, debemos dar cuenta del proceso social, filosófico y epistemológico que dio lugar a la intelectualización del humor y su concepción contemporánea.

\footnotetext{
${ }^{3}$ Existe, por tanto, una clara filiación, a través de lo grotesco carnavalesco y su reformulación, entre lo cómico y el arte moderno, por su desafío a las convenciones representacionales miméticas del clasicismo; filiación que recuperaremos más adelante para su desarrollo teórico.
} 


\subsection{Intelectualización del humor y lo cómico en los siglos XVII y XVIII}

\subsubsection{Contexto filosófico y epistemológico}

La conversión de la risa renacentista, colectiva y regeneradora, en la risa amarga y satírica de la literatura burlesca y la caricatura es asimismo un reflejo del profundo cambio de costumbres que también afecta a las clases altas. Paralelamente a esta adaptación de lo carnavalesco como vehículo de crítica social, se produce una apropiación burguesa y cortesana de la obra de Rabelais: sus personajes se convierten en protagonistas de fiestas, mascaradas y balés celebrados en la Corte (Bajtín, 1998: 95-96): en general, el carnaval es adaptado y desnaturalizado en estos bailes de la clase alta:

Le bal, les spectacles, le jeu réglé, des voyages brillants, la galanterie et le commerce des dames, des repas somptueux, un luxe élégant et délicat écartèrent ces sombres plaisirs, le triste amusement de rechercher des ressources contre l'ennui dans les plaisanteries d'un malheureux, privé de l’usage de la raison (Bercé, 1976 : 72)

Estas apropiaciones, como decimos, son consecuencia del progresivo refinamiento en las costumbres de la clase alta, lo que Norbert Elias (1988) ha denominado el «proceso de civilización», consistente en un absoluto silenciamiento del cuerpo y sus funciones, y en un uso calculado de los gestos (Burke, 1996: 377):

La satisfacción de las necesidades humanas pasa poco a poco a realizarse entre los bastidores de la vida social y se carga de sentimientos de vergüenza y (...) la regulación del conjunto de la vida impulsiva y afectiva va haciéndose más y más universal, igual y estable a través de una autodominación continua (Elias, 1988: 449)

Parte de este proceso de refinamiento tiene que ver con un alejamiento, desde el siglo XVI, de las clases altas (tanto la nobleza como la creciente burguesía) respecto de la cultura popular campesina y urbana (Burke, 1996: 376): debido a la pérdida de la función militar de la nobleza, esta tuvo que buscar nuevos modos de diferenciarse socialmente y justificar sus privilegios; actitud imitada por los burgueses, mercaderes y funcionarios que también buscaban distinguirse del simple campesinado y los trabajadores urbanos (Burke, 1996: 378).

Este apartamiento tuvo que ver con una nueva visión del mundo dada por la invención de la imprenta y la revolución científica, por lo que las clases altas rechazaban 
lo relativo a las supersticiones del pueblo, y del pensamiento mágico en general (Burke, 1996: 379-380), pero también suponía un rechazo de sus formas de entretenimiento, es decir, de las fiestas carnavalescas y sus comportamientos excesivos y aparentemente irracionales: «Cette scission socio-esthétique entre le goût des honnêtes gens et celui du peuple est vécue par l'élite sur le mode du progrès historique : un rire moderne et plus civilisé est censé supplanter des formes d'amusement archaïques et bâtardes» (Bertrand, 1995: 89). La nobleza y la burguesía sustituyeron la costumbre de las beffa, bromas pesadas y escatológicas, por el humor verbal y el ingenio, en una suerte de sublimación de la expansión cómica carnavalesca: «la afición barroca por los juegos de palabras vino a ser una suerte de compensación psicológica (...) por el estrechamiento del ámbito de lo cómico» (Burke, 1999: 73). Asimismo, la desaparición del bufón de la corte, quien ahora es visto como algo monstruoso (Bertrand, 1995: 79) da paso a divertimentos más refinados a cargo de comediógrafos como Molière (Bertrand, 1995: 130).

Hay, por tanto, una distinción de clase en lo referente a la risa: si esta es un fenómeno corporal, excesivo, que da cuenta de una falta de control del propio cuerpo, el hombre que ríe se identifica con el campesino (Bertrand, 1995: 72). Este cambio también se refleja en las reflexiones sobre la risa desde distintos ámbitos, que podríamos incluir en una desaparición general del cuerpo en la epistemología del período. La desaparición de la risa, tal y como se había concebido hasta el Renacimiento, se debe a esta desaparición o más bien silenciamiento del cuerpo. Así lo comprobamos, por ejemplo, en la visión médica sobre la fisiología de la risa. Descartes, en su Tratado de las pasiones, propondrá un modelo mecanicista y autómata del cuerpo, que opone categóricamente al alma; por ello encontramos un notable cambio de punto de vista en su descripción del mecanismo que produce la risa respecto de la de Joubert: si en el caso del médico renacentista, la descripción es «grotesca» en un sentido bajtiniano («les métaphores sousjacentes de l'accouchement et de la mort maintiennent une dynamique fusionnelle entre l'intérieur et l'extérieur, l’homme et le cosmos»), la definición de Descartes, absolutamente mecánica, da lugar a un silenciamiento del aspecto carnal de la risa: se omiten las descripciones del torso que se tuerce, los miembros que tiemblan, los dientes que se asoman, etc., que tan centrales eran en las descripciones renacentistas: «Le corps s'efface dans sa matérialité et dans sa substance, en raison de l'abstraction mécaniste mais aussi de la discrétion requise par les nouvelles règles de civilité de l'âge classique » (Bertrand, 1995: 35-37). De este modo, y como ya había señalado Bajtín, al cuerpo abierto de la visión renacentista se le opone la clausura del cuerpo clásico (Bertrand, 1995: 35). 
Esta descarnalización de la risa también da lugar a que se desestimen las propiedades terapéuticas que el período anterior le concedía a la risa: como mucho, sirve a la cura de temperamentos melancólicos, es decir, a los aspectos psíquicos del individuo, pero no a los más puramente fisiológicos (Bertrand, 1995: 42). También se negará definitivamente cualquier voluntariedad a los estallidos de risa, que son vistos inequívocamente como síntomas de locura, mientras que Joubert distinguía una risa sana y normal de la patológica (Bertrand, 1995: 103).

Esta desaparición del cuerpo, como decimos, es un fenómeno general del período que estudiamos. Lo encontramos no solo, como hemos visto, en el refinamiento de los modales de las clases altas, sino también en las prácticas punitivas (Foucault, 2009b: 17), la epistemología médica (Foucault, 2007: 144) y en la epistemología de las ciencias en general: «el Tacto y la Vista están marcados por una asimetría epistemológica radical: el Tacto es ciego, mientras que la Vista toca con la mirada sin ser contaminada ni por lo particular, ni por la materia, es decir, la Vista supone un modo superior de la experiencia que no necesita ni de la mano ni de la piel» (Preciado, 2018: 89). Este proceso, por supuesto, es uno de los rasgos que señalan la emergencia del racionalismo en el siglo XVII (Valverde, 2000: 114-115), un racionalismo que depende de una absoluta independencia de la razón respecto de la circunstancia corporal: la filosofía cartesiana dividió definitivamente el cuerpo y el alma, la materia y el espíritu racional (Valverde, 2000: 121; Sánchez Meca, 2013: 110-111)4.

Este nuevo racionalismo es entendido por Foucault como consecuencia de un cambio de episteme: la analogía, forma de pensamiento imperante del saber durante el Renacimiento, se sustituye a principios del siglo XVII por el principio del análisis (Foucault, 2017: 67-71). En la ciencia, por ejemplo, la importancia de las semejanzas y los «juegos» de la naturaleza, que tanto peso tenían en la época anterior, como hemos visto al hablar del grotesco, queda reducido, bajo la influencia de Newton o Descartes, al mero juego superficial sin ningún tipo de contenido cognitivo ni potencial de descubrimiento (Findlen, 1990: 325-328). Esta reducción de la semejanza y la analogía a

\footnotetext{
${ }^{4}$ El nacimiento del racionalismo en el siglo XVII se ha atribuido comúnmente a la importancia creciente del comercio y los procesos de abstracción que conlleva el cálculo mercantil (ver por ejemplo Zizek, 2018: 42-45). Significativamente, como veremos, algunos de los proyectos de creación de una lengua perfecta y universal nacen en Inglaterra como necesidad surgida de la expansión comercial y colonial (Eco, 1994: 176). Norbert Elias también lo atribuye a la psicologización y racionalización de las relaciones sociales a causa de la desaparición de la violencia física como manera de conseguir unos objetivos (1998: 492).
} 
mero juego de lenguaje, que tanta importancia, como veremos, tendrá en la teoría contemporánea de lo cómico, es un fenómeno generalizado:

La época de lo semejante (...) no deja, detrás de sí, más que juegos. Juegos cuyos poderes de encantamiento surgen de este nuevo parentesco entre la semejanza y la ilusión; por todas partes se dibujan las quimeras de la similitud, pero se sabe que son quimeras; es el tiempo privilegiado del trompe-l'oeil, de la ilusión cómica, del teatro que se desdobla y representa un teatro (...) Es el tiempo en el que las metáforas, las comparaciones y las alegorías definen el espacio poético del lenguaje (Foucault, 2017: 68)

Por contraposición, el mecanismo y la matemática son los nuevos ideales de conocimiento (Foucault, 2017: 73; Valverde, 2000: 122), aunque, para Foucault, lo que se da es más exactamente una vinculación, en la época clásica, del saber con la mathesis en tanto que ciencia del orden (2017: 73-74).

En este nuevo orden epistemológico, el lenguaje va a ocupar un lugar central, pero invisible (Foucault, 2017: 95). El lenguaje, como representación del pensamiento, es pensamiento en sí mismo, y por ello su análisis permite el análisis del pensamiento: ya no es un conjunto de símbolos esotéricos que interpretar, como en el Renacimiento, sino un sistema que analizar; su función principal no es la de la comunicación sino la del conocimiento: «no es tanto un instrumento de comunicación de los hombres entre sí como el camino por el cual la representación se comunica necesariamente con la reflexión» (Foucault, 2017:100) ${ }^{5}$.

De este modo, es natural que surja en el siglo XVII la búsqueda de un lenguaje perfecto, ideal, que elimine los equívocos y errores que oscurecen el conocimiento e impiden el progreso científico (Eco, 1994: 177). Dalgarno, por ejemplo, plantea «la necesidad de una lengua que reduzca las redundancias, las irregularidades, los equívocos y las ambigüedades, y precisa que esto favorecerá la comunicación entre las gentes y curará a la filosofía de las enfermedades de los sofismas y las logomaquias» (Eco, 1994: 178). Este lenguaje «filosófico a priori» es un lenguaje perfecto, que transparenta sin posibilidad de error el proceso del pensamiento:

En la época clásica, lo que recibe el nombre de lengua universal no es el idioma primitivo inmaculado y puro, que podría restablecer (...) la armonía anterior a Babel. Se trata de una lengua que sería susceptible de dar a cada representación y a cada elemento de cada

\footnotetext{
${ }^{5}$ Como veremos en varias ocasiones [3.2.3; 3.4.1; 4.1] la ironía y lo cómico juegan un papel especial en la discusión entre dos concepciones enfrentadas del lenguaje como comunicación o como modo de conocimiento racional.
} 
representación el signo que pudiera marcarlos de una manera inequívoca; sería también capaz de indicar de qué manera se componen los elementos en una representación y cómo se ligan unos a otros (Foucault, 2017: 101)

Este lenguaje perfecto sería la imagen del mundo en tanto que mecanismo racional: «debe haber un lenguaje, posible cuando menos, que recoja la totalidad del mundo en sus palabras y, a la inversa, el mundo, como totalidad de lo representable, debe poder convertirse, en su conjunto, en una enciclopedia» (Foucault, 2017: 103). Se da, en suma, una vinculación muy estrecha entre lenguaje y pensamiento: «Saber es hablar como se debe y como lo prescribe la marcha cierta del espíritu; hablar es saber como se puede y según el modelo que imponen quienes comparten el nacimiento. Las ciencias son idiomas bien hechos, en la medida misma en que los idiomas son ciencias sin cultivo» (Foucault, 2017: 104). De ahí que se imponga, en esta época, la tarea de someter el lenguaje, en tanto que pensamiento en bruto, a un tratamiento que lo purgue de los equívocos, errores y ambigüedades propios de las lenguas naturales: «todo idioma está por rehacer: es decir, por explicar y juzgar a partir de este orden analítico que ninguno de ellos sigue con exactitud, y por reajustar eventualmente a fin de que la cadena de los conocimientos pueda aparecer con toda claridad, sin sombras ni lagunas» (Foucault, 2017: 104).

Francis Bacon fue de los primeros en plantear la necesidad de "limpiar” la lengua de sus malos usos y de los errores que el vulgo y su ignorancia han ido depositando en ella: es necesaria, pues, una «terapia del lenguaje» (Eco, 1994: 178-179). También Hobbes habla de los «abusos» del lenguaje, relacionados principalmente con sus usos retóricos: «cuando los hombres registran erróneamente sus pensamientos a través de la mutabilidad de los significados de las palabras, cuando utilizan las palabras metafóricamente, es decir, en un sentido distinto a su sentido ordinario, cuando con las palabras declaran que quieren hacer lo que no quieren» (Hobbes, cit. en Eco, 1994: 179).Y para Locke, el lenguaje no sirve como instrumento de comunicación, puesto que «una palabra cualquiera no suscita en el oyente la misma idea que significa en la mente del hablante» (Eco, 1994: 179).

Pero el problema de construir un lenguaje perfecto y universal, que designe unos conceptos de manera inequívoca de modo que cualquier individuo comprenda exactamente a qué se refiere cada palabra, es, según advierte Descartes, que la tarea no solo consiste en asignar y aprender estos nombres «primitivos», sino que previamente ha de existir un sistema filosófico de ideas y claras y distintas (Eco, 1994: 183-184). Por eso, 
la construcción de este lenguaje perfecto es más un trabajo filosófico que propiamente lingüístico. En este sentido, el lenguaje matemático es el modelo ideal de este lenguaje filosófico (Eco, 1994: 185). Leibniz propondrá un proyecto de lengua, pero no destinado a la comunicación, sino a ser usado como instrumento para el descubrimiento de la verdad: lo importante no es la exactitud de los nombres en la designación de los conceptos, sino las reglas combinatorias que permiten el paso de las proposiciones conocidas a las desconocidas, de la misma manera en la que opera el álgebra (Eco, 1994: 238). Durante la Ilustración, sin embargo, se descartará la posibilidad de construir esta gramática filosófica a priori, y los esfuerzos se volverán a centrar en la «terapia del lenguaje» propuesta por Locke (Eco, 1994: 244).

\subsubsection{La teoría de la incongruencia}

La aparición de esta nueva episteme, con su énfasis en la racionalidad, la desaparición del cuerpo y, sobre todo, la centralidad que le otorga al lenguaje, tendrá enormes consecuencias para la concepción del humor y lo cómico que iremos desgranando en las páginas siguientes. Por lo pronto, supone un viraje en el punto de interés a la hora de definir lo risible, concretamente en la dirección de una intelectualización que deja fuera consideraciones fisiológicas y morales.

Durante siglos, las especulaciones acerca de la causa de la risa (más allá de la enfermedad, la locura o el rapto divino) se reducían a lo que se ha dado en llamar «teoría de la superioridad» (Morreall, 1983: 4). Como hemos visto, las teorías clásicas y renacentistas de la comedia se basan en el concepto de lo «ridículo» o risible: los personajes de la comedia son risibles porque son o actúan de algún modo anormal o “inferior”. Esta teoría se basa en una consideración más básica sobre la risa, que podemos remontar a Platón (Morreall, 1989): a saber, que la risa es expresión de un sentimiento de superioridad respecto al objeto de la risa. La formulación más conocida de esta teoría es la que ofrece de pasada Thomas Hobbes en su tratado Sobre la naturaleza humana (1650), donde afirma que la gente ríe «at the infirmities of others wherewith their own abilities are set off and illustrated», por lo que la risa es «a sudden glory arising from sudden conception of some eminency in ourselves, by comparison with the infirmities of others, or with our own formerly» (cit. en Billig, 2005: 52).

La teoría de la superioridad, como vemos, no solo arroja una percepción negativa de la risa, sino que la conceptualiza como una pasión, como un sentimiento irracional («a 
sudden glory»). Los teóricos de la risa ingleses del siglo XVII y XVIII criticarían la definición de Hobbes, centrándose en el carácter cognitivo de la risa y dando lugar a lo que se conoce como la «teoría de la incongruencia». El primero en operar este cambio de paradigma fue John Locke en su Ensayo sobre el entendimiento humano (1688). En su análisis del juicio como la facultad de discernir claramente, Locke definió el ingenio («wit») como «the assemblage of ideas, and putting those together with quickness and variety, wherein can be found any resemblance or congruity, thereby to make up pleasant pictures and agreeable visions in the fancy» (cit. en Billig, 2005: 63). El cambio más importante en este proceso es precisamente el uso del término «wit», que conllevaba el desplazamiento del acento de la risa como expresión de un sentimiento o pasión, a la operación puramente cognitiva y abstracta del juego con ideas, que podía o no dar lugar a la risa. De este modo, lo cómico y el humor pasaban a ser un fenómeno puramente mental, alejados de cualquier determinante emocional o fisiológico.

La teoría de la incongruencia se ha manifestado en las definiciones de otros pensadores tan ilustres como Kant o Schopenhauer. Kant, por ejemplo, asociaba la risa con la percepción de un absurdo: «In everything that is to excite a lively convulsive laughthere must be something absurd (in which the Understanding, therefore, can find no satisfaction). Laughter is an affection arising from the sudden transformation of a strained expectation into nothing» (Kant, cit. en Morreall, 1983: 16). Como vemos, Kant entiende la risa como un afecto, adelantándose de alguna manera a lo que luego sería la «teoría del alivio» [ver 3.1.1], pero sigue vinculando ese afecto al entendimiento. Por su parte, Schopenhauer define lo cómico como la «inclusión paradójica y por tanto inesperada de una cosa en un concepto que no le corresponde, y la risa indica que de repente se advierte la incongruencia entre dicho concepto y la cosa pensadas, es decir, entre la abstracción y la intuición» (cit. en Ballart, 1994: 89). Como vemos, tanto Kant como Schopenhauer introducen en la teoría de la incongruencia un matiz importante: esta incongruencia debe ser, en cierto sentido, descendente: para Kant, la risa proviene de la percepción de una expectativa que queda en nada; para Schopenhauer, lo cómico reside en la inadecuación de un concepto (una expectativa) a una cosa percibida (una realidad). La incongruencia cómica, por tanto, consiste principalmente en la ruptura de una expectativa, y en el capítulo corresondiente exploraremos las consecuencias que esta formulación puede tener para la relación del humor con los presupuestos ideológicos [5.3]. 


\subsubsection{La conversación ingeniosa: Addison, Shaftesbury}

Como vemos, estos dos fenómenos correlativos y codependientes (la desaparición del cuerpo tanto en los modales y costumbres de la clase cortesana como en la epistemología racionalista y la consiguiente emergencia del lenguaje como centro del saber) son los que dan lugar a un cambio en la concepción de lo cómico hasta nuestros días. Desterrada la risa como expresión corporal, se refugia en la conversación y el intelecto: lo cómico pasa a ser, a la larga, una cuestión de lenguaje, un discurso humorístico. La reflexión sobre la risa, como hemos visto, deja de preocuparse por su fisiología y se centra en los mecanismos psíquico-cognitivos que la provocan; paralelamente se intensifica una reflexión retórica sobre el arte de la agudeza, del uso ingenioso y humorístico del lenguaje heredado de los manuales de cortesía renacentistas. Y esta reflexión, consecuencia de un intento de domesticación de la risa por parte de la razón, se volverá contra la razón misma al culminar en la ironía romántica predicada por Friedrich Schlegel, como veremos.

En esta transformación, insistimos, tienen mucho que ver las nuevas costumbres cortesanas. Es imprescindible para entender las nuevas reflexiones sobre lo humorístico conocer los contextos sociales en los que este se daba, más allá de la literatura satírica y burlesca. Como venimos diciendo, el progresivo alejamiento de las clases altas de la cultura campesina deja cada vez más espacio al honesto divertimento del ingenio, de la ocurrencia verbal (Burke, 1999: 72). En las nuevas relaciones sociales cortesanas, tal y como se refleja en los manuales de cortesía, cada vez se le concede mayor importancia a una disposición de ánimo amable y dispuesta a la conversación lúdica, y es, además, una oportunidad para demostrar la capacidad intelectual y la distinción respecto de las clases bajas (Bertrand, 1995: 135): «le rire cultivé implique une capacité individuelle à juger, faisant primer le plaisir intellectuel de l'analyse sur l'emportement de la contagion» (Bertrand, 1995: 99). La amable raillerie se convierte en un arte sutil, requiere destreza e imaginación y goza de un carácter casi estético (Bertrand, 1995: 135). Y no solo en la corte: a partir del siglo XVII, nacen los salones parisinos y, en Inglaterra, donde se producirá, en el siglo siguiente, una abundante producción reflexiva sobre el lugar del humor en la conversación, es la época de los nuevos cafés, «places in which gentlemen could meet to take the new beverages and to discuss agreeably the latest art, commerce and politics» (Billig, 2005: 59).

Pero la aparición del humor no solo se reduce a la ocurrencia verbal inocente: cada vez tiene más importancia la burla irónica utilizada como arma contra el rival. Contenida 
la violencia física, el control social y la competitividad toman formas más sutiles (Elias, 1998: 457): el temor ya no es a sufrir un castigo físico, sino la pérdida del prestigio social (Elias, 1998: 469); en este sentido, el ridículo y la risa satírica cobran gran relevancia, dada la importancia de la conversación como combate verbal:

\begin{abstract}
Aunque la espada ya no tiene la importancia que tuvo antaño en la solución de los conflictos, aparecen ahora en su lugar las intrigas, las luchas que se libran con palabras y en las que se deciden asuntos de carrera y de éxito social. Estas exigen y fomentan propiedades distintas de las de los combates que se libraban con las armas en la mano (Elias, 1998: 483)
\end{abstract}

Los individuos ahora han de alcanzar sus objetivos, en lugar de por la fuerza bruta, mediante el arte de la conversación (Elias, 1998: 492). En este contexto, la risa y su amenaza de ridículo es una nueva arma disciplinaria de normalización social: «Épée de Damoclès, le rire garantit une intériorisation par les individus des impératifs de la société. Il convoque la honte et la crainte du blâme public» (Bertrand, 1995 : 150). De este modo, la risa colectiva aparece como análoga a la utopía penal del panóptico de Bertham descrita por Foucault (Bertrand, 1995: 151).

En consecuencia, las reflexiones sobre el humor se sitúan en el contexto de la conversación privada entre caballeros, y tiene que ver con el gusto y el rango social: en este sentido, las preocupaciones son muy cercanas a las que Aristóteles trataba, como vimos, en la Ética a Nicómaco (Billig, 2005: 59-60). Paralelamente, durante los siglos XVII y XVIII se ha producido en Inglaterra un deslizamiento semántico del término «humor», que desembocará en su acepción contemporánea como categoría estética (Lavie, 2014: 627, 630). Como vimos, a partir de la publicación del tratado de Ben Jonson sobre los humores de los caracteres cómicos, el término pasó de pertenecer exclusivamente a la teoría médica de los humores a designar un carácter extravagante y ridículo, y llevado, irracionalmente, por sus pasiones, quedando ligado al campo de la comedia y lo cómico. En el siglo XVII, el campo semántico del «humour» se ampliará para designar los efectos cómicos de un discurso o una acción, así como la facultad de percibir dicho efecto; y en el siglo XVIII ya habrá pasado a designar la capacidad de producir deliberadamente un discurso o acción cómica (Lavie, 2014: 628). En esta época, por tanto, el humor ya no es algo involuntario, una manera de ser de alguien, sino una acción voluntaria, un fingimiento consciente de una extravagancia: «l’humour efficace est une construction volontaire, une «composition», proposée au public par un artiste 
conscient, et non une façon de sentir, de voir les choses, subie par l'humoriste» (Escarpit, 1967: 33-35).

Con este desplazamiento, el término «humour» se asociará cada vez más con el «wit»o «ingenio», si bien ambos aún se mantendrán diferenciados largo tiempo (Lavie, 2014: 637): el ingenio es una ocurrencia puramente verbal, un juego de palabras, mientras que el humor es una extravagancia del carácter, real o fingida, que se puede manifestar en el discurso del humorista o personaje humorístico. Así se ve, por ejemplo, en los ensayos que Joseph Addison le dedicará, en 1711, al wit y al humour. Publicados en su periódico The Spectator, estos ensayos están dirigidos precisamente a los asistentes a los cafés para caballeros de que hablábamos antes: con ellos, pretende denunciar los falsos ingenios que pueblan estos lugares y colaborar a mejorar el gusto literario de la sociedad cultivada de Inglaterra (Addison, 1970: 1).

Al hablar concretamente del wit, cita la definición de Locke que vimos en el apartado anterior, y le añade la condición de que este acercamiento de ideas aparentemente lejanas tiene que conllevar sorpresa y deleite al lector u oyente (Addison, 1970: 16). Según Addison, la definición de Locke comprende todas las especies de ingenio: agudezas, metáforas, alegorías, enigmas parábolas, visiones, escritos burlescos, etc. (1970: 16). Además, distingue entre un falso wit y uno genuino: el primero consiste, simplemente, en la semblanza en los sonidos de las palabras, mientras que el segundo conlleva un auténtico acercamiento de ideas (Addison, 1970: 17). Al hacer esta distinción entre un wit falso y otro verdadero, Addison concede al fenómeno una dignidad mayor que el filósofo empirista le otorgaba, al reconocerle cierto contenido cognitivo: «le wit (faux ou vrai) est la forme anglaise de cet esprit de recherche intelectuelle ou formelle qui se manifeste dans toute l'Europe au lendemain de la Renaissance, entre le milieu du XVIe et le milieu du XVIIe siècle, et dont relève en Angleterre le pseudo-humor verbal» (Escarpit, 1967: 39).

También inaugura una tendencia que se repetirá en todos los pensadores que dedican sus reflexiones al humor o la ironía, sobre todo a partir de las cruciales aportaciones de Friedrich Schlegel: la de distinguir entre un tipo de humor falso o limitado, y uno genuino y de mayor calado intelectual o filosófico. A lo largo de nuestro recorrido histórico, por supuesto, hemos observado unas distinciones similares entre tipos de risa de mayor o menor calidad o dignidad. Pero la diferencia es crucial: hasta ahora, esta distinción era de tipo moral y/o de clase: existía una risa mala, escatológica, excesiva, 
propia de esclavos, para los griegos, o pagana, agresiva e irreverente, para los cristianos; y una risa buena, educada, controlada, signo de una alegre paz espiritual. Pero, como vemos, para Addison la diferencia entre un wit falso o verdadero es de carácter intelectual. Por supuesto, en esta distinción sigue habiendo un componente de clase: así, al comentar la teoría de la superioridad de Hobbes, dirá que esta es acertada, en todo caso, para las clases más incultas, para quienes la risa efectivamente es la expresión de una emoción tan innoble, mientras que las clases intelectuales prefieren objetos de risa más sofisticados que son mejor explicados por la definición de Locke (Addison, 1970: 31; Billig, 2005: 68). Pero, insistimos, aunque subyazca una diferencia social, el criterio usado para determinar la distinción es intelectual ${ }^{6}$.

Addison realiza una separación parecida al tratar el humour: critica un tipo de humor que considera falso, estúpido y monstruoso, basado simplemente en el absurdo («nonsense»), porque considera que el humor «should always lie under the check of reason, and (...) it requires the direction of the nicest judgment» (Addison, 1970: 26), utilizando, por tanto, de nuevo, un criterio intelectual para valorar los discursos humorísticos. En este sentido, Addison relaciona explícitamente el humor con el ingenio: concretamente, dice que el humor es hijo del ingenio y la risa («mirth»), mientras que el humor falso desciende del absurdo («nonsense»), la falsedad («falsehood») y la locura («folly») (Addison, 1970: 27). También hace una distinción entre el buen y el falso humorista paralela a la de Aristóteles entre el bufón y el ironista: «for as True Humour generally looks serious, whilst eberybody laughs about him; False Humour is always laughing, whilst eberybody about him looks serious» (Addison, 1970: 27).

A pesar de esta filiación tan estrecha, Addison, como podemos ver, sigue distinguiendo el wit del humour, considerando aquel puramente intelectual, sin la coloración afectiva del segundo. En general, las teorías dieciochescas inglesas de lo cómico y el ingenio oscilarán entre un sentido jonsoniano de lo humorístico como carácter extravagante o ridículo (aunque sea este carácter una ficción voluntaria) o como rasgo o disposición de ánimo de una conversación. Así, aunque la mayoría de estas discusiones

\footnotetext{
${ }^{6}$ En las siguientes reflexiones sobre lo cómico o la ironía que tratemos, encontraremos clasificaciones análogas según criterios de mayor o menor mérito intelectual o filosófico; a grandes rasgos podemos decir que, aún hoy en día, bajo la preferencia por un humor "inteligente” (o, como veremos, humor "blanco" o “negro", "ofensivo" o "inocente”, comprometido o no, políticamente correcto o incorrecto) subyace un criterio de clase social. Lo relevante es destacar que, en el fondo, las distinciones estéticas entre tipos de humor de mayor o menor cualidad siempre se basan en criterios de clase, morales o ideológicos que determinan su recepción, más que en una inexistente cualidad intrínseca del discurso humorístico.
} 
comiencen por criticar la teoría hobbesiana de la superioridad, todavía implican una teoría de lo ridículo (Billig, 2005: 70-71). Para Campbell, lo humorístico reside en las deficiencias del carácter. Hutcheson, aunque se mofe de Hobbes, indica que la incongruencia que provoca la risa ha de implicar cierta oposición entre dignidad e indignidad. Beattie recoge una idea similar: la risa aparece cuando las cosas que parecen importantes o elevadas aparecen como frívolas y vulgares (Billig, 2005: 72). Como vemos, aunque estas teorías sigan la hipótesis de Locke de la incongruencia, la oposición en la que esta reside implica siempre una degradación: «the yuxtaposition finds the superior person, or rather the person with pretensions of superiority, getting their comeuppance. And this is what is found to be funny» (Billig, 2005: 72). En resumen, la incongruencia no es una mera operación intelectual: para ser cómica, ha de implicar un contenido afectivo degradante o frívolo. El caricaturista Hogarth, en sus reflexiones sobre la belleza, expresa algo parecido: la risa se da cuando se encuentran dos excesos impropios o incompatibles que son presentadas con formas «inelegantes»; si esta incongruencia se dibujara con líneas elegantes (como los amorcillos pictóricos, que unen alas de pájaro a un bebé) no resultaría cómica (Billig, 2005: 73).

De todos estos escritos sobre el humor, el más relevante es, sin duda, el del tercer conde de Shaftesbury, titulado Sensus communis. An essay on the freedom of wit and humour y publicado en su compilación de escritos de 1711 Characteristics of Men, Manners, Opinions, Times. Como Addison, el contexto para el ingenio y el humor del que habla Shaftesbury es el de las conversaciones en los cafés (Klein, 2012: xiii). Además, hay que tener en cuenta el cometido general que Shaftesbury se propone con sus escritos: el conde preconiza una filosofía práctica y mundana, que ayude a los ciudadanos a ser unos eficaces participantes del Estado: para él, «philosophy was neither an intelectual discipline for specialists nor a profession (...) but a wisdom that had to touch each thoughtful individual» (Klein, 2012: viii). De ahí que critique el tono de gravedad y tediosa seriedad impostada de los sermones teológicos y los tratados filosóficos. Por eso defiende la liberalidad en la conversación y el uso del humor, aunque esta verse sobre asuntos serios y profundos: «Llegaremos a razonar mejor si razonamos agradablemente y a nuestras anchas» (Shaftesbury, 1995: 147). Además, el conde cree firmemente en la natural sociabilidad del hombre, y la filosofía también debe contribuir a un correcto fluir de esta. De ahí que Shaftesbury, en sus escritos, no examine, como su maestro Locke, el proceso cognitivo abstracto del conocimiento, sino cómo «the community might best 
order itself and what beliefs were appropriate to the well-ordered community» (Billig, 2005: 75).

Es en este punto en el que el uso del ridículo sirve como herramienta intelectual: exponer cualquier verdad al ridículo es la mejor manera de comprobar su validez, pues solo las cosas verdaderas superarán esta prueba. Por eso, Shaftesbury arguye que el verdadero sabio es el que deja que sus opiniones sean sometidas al ridículo:

Lo que sólo puede mostrarse a una cierta luz, es cuestionable. Hay que suponer que la verdad puede soportar todas las luces; y una de esas principales luces o medios naturales a cuya luz hay que ver las cosas para verificar un reconocimiento completo, es el ridículo, o sea, ese modo de prueba mediante el cual discernimos cuanto en un asunto está expuesto a una justa chanza (Shaftesbury, 1995: 133)

La postura de Shaftesbury deriva de su concepción estético-moral, según la cual verdad, bondad y belleza van unidas (Shaftesbury, 1995: 202). Según el conde, la mente humana está diseñada para encontrar placer en la armonía de las formas y las acciones, y disgusto en las incongruencias: el sentido del ridículo es la expresión de este rechazo por las disarmonías, vinculadas así a los errores y las faltas morales, y es por tanto un camino seguro hacia el conocimiento: «the faculty will only ridicule that which is actually ridiculous» (Billig, 2005: 77).

El humor, que es la forma que tiene el ingenio para señalar lo ridículo y con ello eliminar los errores de juicio, es por tanto un método eficaz para la filosofía. El modelo de Shaftesbury es, por supuesto, el de Sócrates, que discutía con humor e ingenio sobre asuntos filosóficos en la plaza pública (Klein, 2012: xxv). En este sentido, su teoría del humor está cercana a cierto escepticismo, pero no el «escepticismo hipócrita que, sin creer en la religión, sabe utilizarla muy bien para sus propios intereses, ni la del escepticismo taimado de quienes no creen en la naturaleza humana (...) [y dejan] luego a los hombres entregados a una suerte de nihilismo» (Andreu, 1995: 109). El del conde de Shaftesbury es un escepticismo optimista; no es un desprecio de la ignorancia de los demás, sino «al contrario, una forma de aprecio: la sensación que interpreta una limitación determinada como equivocación, como transitoria, como graciosa casi, como anuncio de segura superación» (Shaftesbury, 1995: 105).

El uso del humor y el ridículo según Shaftesbury, por tanto, no lleva, como llevará a Friedrich Schlegel, a una desconfianza total en la capacidad de la razón para alcanzar verdades absolutas. El conde es consciente de que con este tipo de conversación, dedicada a ridiculizar cualquier opinión, corre el riesgo de llegar a un escepticismo sin fin, pero 
para él también es ridículo creer que toda opinión es errónea, como si un visitante extranjero acudiera a Venecia durante el carnaval y creyera que sus habitantes llevan máscaras a diario:

Si sucediera que, en ese acceso de ridículo, no viendo todavía más que máscaras y desconociendo enteramente la complexión corriente y el modo común de vestir de los europeos; si sucediera que, ante el aspecto de un rostro y un vestido naturales, se riera tan cordialmente como antes, ¿̇acaso no haría el ridículo él mismo llevando demasiado lejos la broma, por haber tomado, con candorosa presunción, la naturaleza por mero artificio, y haber confundido tal vez a un hombre sobrio y sensato con una de esas ridículas máscaras? (Shaftesbury, 1995: 152-153)

Shaftesbury ya había tratado la importancia del humor y el ridículo en su Carta sobre el entusiasmo, publicada en ocasión de la aparición de un grupo de fanáticos religiosos en Londres (Andreu, 1995: 69). El término «entusiasmo» se utilizaba para caracterizar, en la Inglaterra de la época, precisamente a este tipo de fanáticos, y el cometido principal del conde con este texto era desviar su significado hacia un sentido positivo, como combinación de la imaginación y la pasión naturales en el ser humano (Klein, 2012: xxx). Pero antes de esto, Shaftesbury propone el ridículo y el humor como arma contra el tipo de entusiasmo fanático que lo que hace es coartar la libertad de voluntad y de pensamiento (Billig, 2005: 75). Como afirmará posteriormente en Sensus Communis, corremos el peligro de que, al encontrarnos con opiniones que nos disgustan, nos enfrentemos a ellas con horror, y el anti-fanatismo se vuelva tan fanático como aquel que busca eliminar: «para la razón el único veneno es la pasión» (Shaftesbury, 1995: 159-160). La mejor manera de evitar los males de un entusiasmo excesivo e irracional no es prohibirlo, sino suavizarlo mediante el buen humor y exponerlo al ridículo, como muestra el ejemplo de la cultura griega:

Los antiguos (...) no sólo toleraban a los visionarios de toda índole, sino que, además, la filosofía tenía vía libre otro tanto, y se la permitía como elemento de equilibrio frente a la superstición. Y como algunas sectas, tales las de los pitágóricos y los platónicos, abrazaron la superstición y el entusiasmo de su tiempo, hubo que permitir a los epicúreos, a los académicos y a otros, echar mano de la fuerza de la chanza y del humor frente a ellos. Y así se equilibraban < felizmente> las cosas, tenía juego la razón y florecían la cultura y la ciencia (Shaftesbury, 1997: 106)

Por tanto, el mejor antídoto contra el fanatismo y la impostura es el ingenio que los expone al ridículo. Únicamente el pensamiento verdaderamente sabio no teme al ridículo, puesto 
que sabe que este no puede afectarle; al contrario, la impostura sabe que solo la jocosidad puede amenazar su fachada de gravedad aparente (Shafestbury, 1997: 100, 108). El humor es, de este modo, un garante de la libertad, puesto que en una nación verdaderamente libre todas las ideas e instituciones han de estar sujetas a crítica (Shaftesbury, 1997: 98):

Tengo la seguridad de que el único modo de salvar el entendimiento de los hombres o de preservar el ingenio en el mundo, es absolutamente darle libertad al ingenio. Ahora bien, no puede tener su libertad el ingenio donde se haya suprimido la libertad de chanza. Porque no hay otro remedio sino éste, frente a las serias extravagancias y al humor bilioso (Shaftesbury, 1997: 107)

En Sensus Communis Shaftesbury volverá sobre esta necesidad de una libertad total para ejercer el ingenio y el ridículo. De hecho, frente a quienes temen que esta libertad del humor para campar a sus anchas amenace con destruir los asuntos serios, el conde arguye que el ingenio, dejado a su libre albedrío, se limitará a sí mismo y regulará el buen funcionamiento de la sociabilidad que es necesaria para el buen entendimiento de los hombres, puesto que esta libertad para bromear y cuestionar las opiniones de otros y de uno mismo les enseñará a razonar:

Se enmendará el ingenio en nuestras manos y se refinará el humor, si procuramos no entrometernos en él y no violentarlo mediante un uso acerbo del mismo y mediante prescripciones rigurosas. Toda forma de cortesía es debida a la libertad. Nos afinamos los unos a los otros, limamos nuestros ángulos y lados ásperos, mediante una suerte de colisión amigable. Restringirla es inevitablemente como oxidar la inteligencia humana. Es destruir la civilidad, la buena crianza y la caridad misma, bajo el pretexto de conservarla (Shaftesbury, 1995: 136)

Ahora bien, no estamos, aunque pueda parecerlo, ante una modernísima reivindicación de una total libertad de expresión respecto del humor. Shaftesbury distingue claramente los contextos en los que se puede bromear liberalmente: las conversaciones privadas de los clubs, entre amigos que se conocen perfectamente. Hablar de este modo sobre asuntos serios en público, sin embargo, sí puede ser una falta de respeto: «Semejantes materias, o no se las debe tratar en público en absoluto, o bien hay que hacerlo de manera que no den pie a escándalo o perturbación. Por ningún motivo hay que reírse del público en su cara, o reprenderlo por sus desatinos hasta el punto de que piense que se le desprecia» (Shaftesbury, 1995: 145-146). 
Del mismo modo, tampoco valora las diferentes manifestaciones del humor por igual. Critica a quienes usan la chanza para confundir «arteramente» a los demás, bien para obtener alguna ventaja o por simple entretenimiento: «Es la clase grosera de chanza que resulta ofensiva en sociedad. Y, efectivamente, entre una y otra clase hay tanto diferencia como entre la sinceridad y la hipocresía o como entre el más gentil ingenio y la más insolente bufonería» (Shaftesbury, 1995: 135) ${ }^{7}$. Shaftesbury afirma que el ingenio es algo que hay que aprender a usar correctamente, en los momentos oportunos y en la cantidad justa. El criterio general es el de ridiculizar solo lo que es susceptible de serlo, y no usar el humor como pretexto para arremeter contra lo que es verdaderamente bueno u honesto:

En realidad, se requiere un ejercicio para aprender a atemperar y regular este humor que nos concedió la Naturaleza cual más suave remedio contra el vicio y como peculiar específico contra la superstición y la desilusión melancólica. Hay una gran diferencia entre ver cómo provocar la risa sobre cualquier cosa y ver qué hay justamente de ridículo en todas las cosas. Pues nada hay de ridículo sino lo deforme, ni hay nada a salvo de chanza sino lo que es hermoso y ajustado (...) Verdaderamente, tiene que ser ridículo quien se ponga, con todo el ingenio imaginable, a ridiculizar a la sabiduría, o a reírse de la honestidad o de las buenas maneras (Shaftesbury, 1995: 191)

Bajo estos criterios de regulación del ingenio subyacen, por supuesto, criterios de clase y género: el conde se esfuerza por distinguir entre un ridículo vulgar, propio del pueblo no educado, y el ridículo razonable de los verdaderos gentlemen (Billig, 2005: 75). De hecho, explica el humor chocarrero y popular como resultado precisamente de la limitación externa sobre el impulso natural al humor: los hombres buscan librarse de esta coacción y así surge el humor burlesco y la bufonada grosera contra aquellos que intentan coartarles (Shaftesbury, 1995: 141-142).

En resumen, Shaftesbury propone una concepción del humor que es garante del entendimiento porque está bajo el cuidado de la razón. Pero lo importante es que esta razón no es ya la lógica puramente deductiva que promueve el cartesianismo, sino la razón dialógica de la conversación, basada en un criterio más estético y moral que de cálculo matemático. En este sentido, Shaftesbury forma parte de una reducida nómina de pensadores de la época que preconizan una ampliación de la racionalidad cartesiana más

\footnotetext{
${ }^{7}$ En este sentido, esta distinción es análoga a la crítica de Aristóteles a la ironía, a la que, como vimos, consideraba un defecto moral por falta de sinceridad.
} 
allá de la lógica deductiva y el cálculo hacia el ingenio y la invención (Arnau, 1995: 86): Shaftesbury, en suma, está defendiendo una concepción retórica y dialógica de la razón (Billig, 2005: 75), y reivindicando y continuando la tradición humanista que promocionó, en el Renacimiento, la Retórica contra la tradición escolástica (Gadamer, 2012: 47).

De este modo, Shaftesbury se acerca al pensador italiano del siglo XVII Giambattista Vico, que se remitía al ideal humanístico de la elocuencia como un «hablar bien» en el doble sentido de hablar bellamente y decir lo verdadero (Gadamer, 2012: 49). Con esta reivindicación, Vico señalaba los límites de la ciencia cartesiana moderna, a la que oponía la vieja tópica y el poder la fantasía y las imágenes (Gadamer, 2012: 51). Tanto él como Shaftesbury se remiten a un sensus communis que

no significa en este caso evidentemente solo cierta capacidad general sita en todos los hombres, sino al mismo tiempo el sentido que funda la comunidad. Lo que orienta la voluntad humana no es, en opinión de Vico, la generalidad abstracta de la razón, sino la generalidad concreta que representa la comunidad de un grupo, de un pueblo, de una nación o del género humano en su conjunto (Gadamer, 2012: 50)

En resumen, Shaftesbury, quien influirá decisivamente en el primer romanticismo alemán, forma parte de una corriente marginal de pensamiento que, a lo largo de la historia de la filosofía occidental, promueve un tipo de razón retórica que, frente al racionalismo absoluto representado por Descartes, reivindica la conversación como contraste de opiniones y visiones del mundo como modo de construir conocimiento, y el lenguaje figurado como un proceso cognitivo complementario al de la pura lógica ${ }^{8}$. En este contexto, el humor y el ingenio, tal y como los entiende Shaftesbury, aun estando aparentemente bajo el control de la razón, acaban por constituirse como una alternativa a esta, y ello en el seno de un lenguaje dialógico y conversacional que se opone diametralmente al sueño de un lenguaje perfecto tal y como vimos que proponían filósofos como Bacon o Leibniz. Este escepticismo frente a la capacidad de la razón y el lenguaje científicos llegará a su punto culminante, como venimos anunciado, con la reflexión de Friedrich Schlegel sobre la ironía.

${ }^{8}$ Más adelante [4.1] retomaremos esta tradición como una influencia fundamental en la Retórica Constructivista que nos sirve de marco teórico de este trabajo. 


\subsection{EI humor y lo cómico en el Romanticismo y el siglo XIX}

\subsubsection{La ironía romántica de Friedrich Schlegel}

Como venimos argumentando, el uso del ingenio y del humor en la conversación es consecuencia de la domesticación de la risa llevada a cabo en la Edad Moderna como parte de un proceso general de desaparición del cuerpo, que lleva a limitar lo risible al ámbito de la conversación honesta; pero al encerrar lo cómico en el plano del lenguaje se transforma en una vía alternativa de conocimiento que amenazará el imperio mismo de la razón cartesiana, recuperando la tradición retórico-humanista. Esta relación de lo humorístico con cierto escepticismo frente a la razón alcanzará una nueva dimensión en las reflexiones de los románticos alemanes, y particularmente de Friedrich Schlegel.

La ironía, como figura socrática, hacía tiempo que solo era considerada desde una perspectiva teórica en los manuales de retórica, reducida a un tropo semántico equivalente a la antífrasis (una palabra que quiere decir lo contrario de su significado literal); aunque en la práctica no hubiera desaparecido del todo, ni en los discursos polémicos (pensemos en las burlas entre paganos y cristianos en el comienzo de nuestra era, o, ya en la época moderna, entre católicos y protestantes, como bien ejemplifica Pascal) ni en la literatura satírica de Voltaire o Jonathan Swift; el humor y la ironía, como hemos visto, tampoco faltaban en las conversaciones corteses de ingleses y franceses. Tampoco eran nuevos los procedimientos que a partir de las reflexiones y prácticas de Tieck o Jean Paul se adscribirán al marco de la ironía romántica, como la ruptura dramática de la cuarta pared o de la ilusión de realidad narrativa, o procedimientos de dilación como los que presenta el Tristam Shamdy de Sterne. Lo que sí son nuevos es la amplitud y el alcance del giro teórico que Friedrich Schlegel, apoyándose en el idealismo de Fichte y de acuerdo con las inquietudes literarias, filosóficas y religiosas del Círculo de Jena, imprime en a la reflexión teórica sobre la ironía y sus posibilidades epistemológicas e incluso morales. Es precisamente a partir de su intervención en la teoría de la ironía que esta se convertirá, para el siglo XX, en un término clave de la teoría literaria y una parte considerable de la filosofía; e, indirectamente, como tendremos ocasión de comprobar [3.4], a una especie de sacralización de la ironía y el humor en general como principio supremo de inteligencia y objetividad. Es por ello que estas reflexiones suponen, en cierto modo, un lugar especial en nuestra investigación histórica, como punto culminante de este recorrido por la 
transformación de lo cómico en el pensamiento occidental, y que al tiempo abre nuevas vías de consideración ${ }^{9}$.

En cierto sentido, es la formación neohumanista de Friedrich Schlegel la que parece llevarle, en su Historia de la poesía de griegos y romanos, al elogio de la ironía socrática como mezcla de seriedad y frivolidad, oponiendo la ironía a la inspiración poética en el sentido de delirio y posesión que aparece en los diálogos platónicos, sobre todo en el Ión (Ayrault, 1970: 164). En esta fase temprana del desarrollo de su pensamiento, Schlegel distingue, siguiendo al Sócrates platónico, una poesía reflexiva y otra inspirada, órfica, que parece valorar más (Ayrault, 1970: 165). Es más adelante, en los fragmentos publicados en la revista Lyceum, cuando afirmará la necesidad de subordinar la inspiración a un momento reflexivo (Ayrault, 1970: 166).

Porque, efectivamente, el nuevo desarrollo del concepto de ironía tendrá su mayor influencia en el ámbito de la práctica y reflexión estética, y sobre todo en la literatura (Ballart, 1994: 67), como instrumento esencial en la teoría romántica de la obra de arte. Según esta, en tanto que la obra artística ya no es una representación mimética de la naturaleza sino la expresión autosuficiente de la subjetividad del Yo creador, la ironía es necesaria como un momento reflexivo y autoconsciente de la propia obra como tal creación subjetiva y por tanto limitada (Lourdes A. Ferraz, cit. en Ballart, 1994: 67; Sánchez Meca, 2007: 11), cumpliendo así la condición schlegeliana de que la poesía sea poesía sobre la poesía, una poesía que se tome a sí misma como objeto (Sánchez Meca, 1999: 88 ${ }^{10}$. Puesto que el arte tiene, en el romanticismo, el designio de superar la escisión entre naturaleza y conciencia, entre objeto y sujeto, que afecta a la época moderna, y a la

\footnotetext{
${ }^{9} \mathrm{El}$ estudio fundamental para el desarrollo intelectual de Friedrich Schlegel y sus conceptos teóricos más importantes siguen siendo las páginas que le dedica Roger Ayrault en su monumental trabajo en cuatro volúmenes sobre la génesis del romanticismo alemán (1970), al que debemos sumar el clásico y pionero trabajo de Walter Benjamin sobre el concepto de crítica de arte en el romanticismo alemán (2017) y el de los filósofos franceses Lacou-Labarthe y Jean Luc Nancy sobre la teoría literaria de este círculo intelectual (2012). En español, contamos con el trabajo de Pere Ballart sobre la ironía literaria, que incluye un completo recorrido por el desarrollo histórico del concepto (1994). Como decimos, la importancia de la ironía en la práctica y la teoría literarias del siglo XX es enorme, por lo que su bibliografía es inabarcable, aunque en el capítulo siguiente trataremos algunas obras fundamentales como la de Wayne Booth o Paul de Man.

${ }^{10}$ No hay, realmente, una definición exacta de la ironía ni de su mecanismo retórico en los escritos de Friedrich Schlegel, ni en los de su hermano August Wilhelm ni cualquier otro romántico y ni siquiera de su gran crítico, Hegel, como lamenta Kierkegaard. Baste señalar que la ironía implica un cierto distanciamiento por parte del autor respecto de su creación literaria, mediante cierta ridiculización de los personajes e ideas o bien mediante el contraste de registros altos y bajos, poéticos y prosaicos, como Schlegel mismo señala en su reseña al Wilhelm Meister de Goethe que comentamos más adelante (Schlegel, 2007: 23). En general, los procedimientos literarios de la ironía romántica se basan en la ruptura de la ilusión de realidad, el teatro dentro del teatro, la apelación directa al lector o espectador, la dilatación de la narración, etc. (Ballart, 1994); estrategias, en fin, que revelan lo que de artificioso tiene la obra literaria.
} 
vez ser expresión de lo Absoluto e indefinido, es necesaria una conciencia crítica de la insuficiencia de toda obra artística singular de expresar esta plena infinitud (Sánchez Meca, 2007: 11); la única respuesta al problema de cómo el lenguaje artístico, subjetivo y limitado, puede representar lo infinito, es tematizar irónicamente ese imposible (Ballart, 1994: 68).

Schlegel considera la novela de Goethe Wilhelm Meister como un ejemplo perfecto de esta ironía autoconsciente de la obra de arte, considerándolo incluso el análogo poético de la filosofía socrática (Ayrault, 1970: 163). Para el pensador romántico el Wilhelm Meister es un libro «que se juzga a sí mismo y que, por tanto, dispensa al crítico de este trabajo. Y no sólo se juzga a sí mismo, sino que también se pone a sí mismo en su sitio» (Schlegel, 2007: 20). Si Schlegel atribuye a Goethe la actitud irónica capaz de contemplar desde arriba su obra y distanciarse de ella, el lector también debe poder alejarse de la implicación emocional para ganar la perspectiva necesaria (Wheeler, 1984: 17):

Es bueno y necesario entregarse por completo a las impresiones de una narración, dejar que el artista haga con nosotros lo que quiera (...) Pero no es menos necesario ser capaz de abstraerse de todos los detalles para captar el concepto general que preside la obra, sobrevolarla en bloque y considerarla como un todo (...) Tenemos que elevarnos sobre nuestro propio amor y ser capaz de destruir en nuestro pensamiento lo que adoramos (Schlegel, 2007: 18)

Este distanciamiento sentimental tanto del autor como del lector de la obra de arte es también y sobre todo un acto de la libertad del sujeto y un primer paso para una elevación espiritual que debe dar lugar a un Yo trascendental; en este sentido, la obra de arte es concebida como una propedéutica, un ensayo o una educación del sujeto en su desarrollo espiritual (Wheeler, 1984: 17). Pues el romanticismo, como movimiento dentro del espíritu de la modernidad, también está definido por la búsqueda de la libertad, tanto en lo político como en otros ámbitos (Sánchez Meca, 1999: 86).

En el plano filosófico, esta búsqueda de la libertad tiene que ver con la filosofía kantiana y la radicalización que de esta realiza Fichte y su doctrina del sujeto como productor y autogenerador; en este sentido, la concepción irónica de Friedrich Schlegel es una re-interpretación muy libre del tema fichteano (Ayrault, 1970: 172-174): «esa negación o supresión de lo finito, que implica la ironía romántica, se clarifica al comprenderse el yo a partir de su autoposición y cuando todo lo que es no-yo es concebido 
como puesto por el yo»; si el yo se caracteriza por su capacidad de poiesis, «crear algo es el modo de crearse a sí mismo» (Sánchez Meca, 1999: 91): de ahí la importancia de la obra de arte como creación absoluta y no mimética del sujeto, y la necesidad de su autoconsciencia como expresión limitada e insuficiente de lo infinito. Es en este sentido en el que la ironía es el modo de ejercer la crítica para superar la escisión entre el yo y el mundo y es a la vez un ejercicio de la libertad absoluta de la conciencia, pues mediante ella el sujeto toma conciencia de sí mismo (Sánchez Meca: 1999: 89). Al presentarse a sí mismo a la conciencia como su objeto, el sujeto se muestra en su total aislamiento, pero a la vez se contempla contemplando el mundo, superando así «la escisión que la reflexión misma introduce»; pero al ser presentados tanto el mundo como el sujeto como reflejo, como apariencia, esta situación provisional solo puede ser superada mediante una nueva reflexión irónica del sujeto, en un juego de espejos que se prolonga ad infinitum (Sánchez Meca, 1999: 90).

La relativización irónica es, pues, el modo en el que yo, autocreado y creador, se distancia de su creación y de sí mismo para ser verdaderamente libre y superarse progresivamente (Sánchez Meca, 1999: 98-100). En el campo de la política, esta actitud implica abrir el orden burgués a la caótica productividad de la poesía, «apostando por una renovación incesante del mundo y una eterna juventud, frente a la fosilización y esclerotización de los valores y de las ideas propias de cualquier visión vulgar, mediocre y prosaica de la vida» (Sánchez Meca, 1999: 101) - en este sentido, la posición del ironista romántico resuena en la visión bajtiniana del carnaval como desacralizador y relativizador de todas las instituciones y verdades oficiales.

Esta vinculación de la ironía con las capacidades poiéticas del sujeto hay que ponerla en relación con otros dos conceptos fundamentales de la teoría schlegeliana, el del Witz y el de fragmento. En un fragmento de los publicados en el Lyceo, Schlegel asegura que la ironía «es la forma de la paradoja» $(\operatorname{Lyc}, 48)^{11}$ : el artista irónico debe captar lo contradictorio de la naturaleza de lo real, pero sin escamotear lo paradójico, no intentar explicarlo sino incidir en su inexplicabilidad (Ballart, 1994: 41). En este sentido, la ironía se acerca al Witz (que es el término equivalente alemán al «wit» inglés, el «esprit» francés y el «ingenio» o «agudeza» españoles), en tanto que esta es (en una definición análoga a la de Locke) la capacidad del poeta de unir dos realidades contradictorias, expresar

${ }^{11}$ Citamos los fragmentos de Schlegel por la edición de Sánchez Meca en Poesía y filosofía (1994). Señalaremos los fragmentos publicadas en la revista Lyceum por la abreviatura (Lyc.), y los del Athenaeum, por (Ath.) 
similitudes ocultas entre términos aparentemente alejados (Sánchez Meca, 1999: 112). En Sobre el estudio de la poesía griega, el Witz aparecía vinculado a la improvisación poética como fenómeno irracional (Ayrault, 1970: 141), en el sentido de inspiración que hemos comentado más arriba. En este sentido, Witz e ironía son dos caras de la misma moneda, los dos polos de la capacidad absolutamente libre y creativa del Yo trascendental: el Witz como capacidad de crear y expresar realidades nuevas u ocultas, y la ironía como el momento reflexivo de esta creación, que la mantiene como un proceso abierto e infinito:

«Witz », ironie : ces deux mots composent l'essentiel de la « terminologie mystique » de Friedrich Schlegel ; (...) ils désignent deux dispositions qui constituent pareillement l'essentiel de sa pensée par leur relation de complémentarité contradictoire. Comme l'ironie est « limitation » et comme le «Witz » est « épanchement » (...) Et l’idée se précise avec l'explication qui est donnée du premier mouvement de l'ironie : ce qui en lui est d'abord posé par l'esprit subjectivement comme « auto-création » se trouve aussitôt définie objectivement « invention et inspiration », et c'est là l'essence du « Witz » (...) Non seulement le «Witz » appelle l'ironie mais qu'il en contient la possibilité permanente (Ayrault, $1970: 178$ )

En su pura tendencia al infinito y al inacabamiento, la ironía también se acerca al fragmento, género privilegiado por el círculo de Jena como más adecuado a su filosofía ${ }^{12}$. Se puede decir que Witz, fragmento e ironía son los tres elementos que, interrelacionados, explican gran parte de la filosofía del primer romanticismo alemán. El fragmento como género de escritura, que Schlegel y sus compañeros habían heredado del moralista francés Chamfort y de la práctica de Lichtenberg (Lacou-Labarthe y Nancy, 2012: 81; Molpeceres Arnáiz, 2013), no solo desafiaba la unidad y completitud de la obra clasicista, sino que su naturaleza paradójica y autocontradictoria se planteaba como representación de la psique humana y de su proceso de conocimiento (Wheeler, 1984: 8):

The fragment by its very fragmentariness and simultaneous self-contained unity expressed the paradoxical identity of the preparative as also the goal, or the thinking itself as not only means but the end of thought. A thought posing as a solution and authorized end to thinking about something was seen as a delusory expectation and a false goal. (Wheeler, 1984: 9)

\footnotetext{
${ }^{12}$ Como señalan Jean Luc Nancy y Lacou Labarthe, en puridad solo se puede considerar fragmentos como tales, según los define la teoría romántica, a los publicados colectiva y anónimamente en el Athenaeum.
} 
El fragmento y la ironía, por tanto, se acercan mutuamente en tanto que ambos manifiestan la situación de eterna provisionalidad de todo conocimiento. Por otra parte, el Witz está relacionado con el fragmento en tanto que ambos están dados por la «ocurrencia» («Einfall», idea que invade a uno); en general, el Witz implica él mismo una estructura fragmentaria y dialógica como síntesis de pensamientos contrarios (LacouLabarthe y Nancy, 2012: 103).

Además, esta tríada idealista de nociones implica una concepción muy concreta del pensamiento y el conocimiento como diálogo, de la filosofía como proceso dialógico y comunicativo, opuesto a la tradición racionalista moderna; y esta concepción es el aspecto que, como veremos enseguida, quizá sea lo que más acerca al Romanticismo de Jena y a Friedrich Schlegel en particular al pensamiento retórico que mencionábamos al concluir el anterior apartado. Como expresa Schlegel en el fragmento 82 del Lyceum, lo único que vale en el proceso de conocimiento es «saber algo y decirlo»; es decir, Schlegel plantea el conocimiento como un acto de comunicación, cuestionando la capacidad del lenguaje para cerrar significados y proponiendo un lenguaje constructor de la realidad que solo adquiere su plenitud en la comunicación (Molpeceres Arnáiz, 2017). En este sentido, el fragmento como género de escritura filosófica apunta a la condición imperfecta, indirecta y dialéctica del lenguaje como comunicación, enfatizando el proceso de pregunta-respuesta como parte de un progreso fragmentario hacia el conocimiento (Wheeler, 1984: 8). Y en este proceso interviene tanto el autor como el lector: para el Romanticismo de Jena, ambos son poetas, protagonistas creativos de la lectura imaginativa; y por eso el texto debe dejar espacio que el lector pueda ocupar con su propia actividad (Wheeler, 1984: 11).

La fragmentación, la anonimia, la pluralidad autorial, el distanciamiento irónico, la necesidad de participación del lector, el carácter dialéctico del Witz, etc., todo está relacionado con la noción central de Symphilosophie, con la que los románticos querían indicar que el camino al conocimiento no es la demostración unilateral del discurso filosófico oficial, sino el intercambio dialógico y amistoso (Lacou-Labarthe y Nancy, 2012: 91). La symfilosofía quiere ser una filosofía unificada con la vida y el arte, una filosofía comunicable, comprensible, en el estilo del diálogo platónico: el diálogo es, en la concepción del Romanticismo alemán, una forma fragmentaria que responde a la concepción de la filosofía como arte de evocar el pensamiento y la respuesta activa del interlocutor más que un contenido dogmático aceptado acríticamente (Wheeler, 1984: 
13), de ahí que definan el diálogo como «corona de fragmentos» (Lacou-Labarthe y Nancy, 2012: 91):

La realización del fragmento se perfila así en el intercambio - o el cambio - absoluto, absolutamente natural, de los pensamientos-individuos entre los individuos que la producción de esa misma naturalidad verdadera como obra de arte también constituye en cada fragmento (...) Si, de este modo, el fragmento no es exactamente un diálogo, acaso se deba a que ya es algo más que eso y a que en él se franquea, de una manera específica al romanticismo, el paso de lo dialógico a lo dialéctico (Lacou-Labarthe y Nancy, 2012: 92)

Esta actitud filosófica es lo que más acerca a los románticos de Jena a sus predecesores en la práctica de las formas breves. Los géneros como la máxima o el aforismo habían servido a autores de diferentes épocas disconformes con los discursos de los grandes sistemas especulativos, excesivamente abstractos, y que buscan expresar una filosofía práctica (Molpeceres Arnáiz, 2013: 81). Chamfort, quien, como hemos dicho, tanto influyó a los románticos alemanes y sobre todo a Schlegel y su teoría del Witz (Ayrault, 1970: 112), fue el último de una tradición de moralistas franceses de los siglos XVII y XVIII (después de Pascal, La Rochefoucauld y La Bruyère), pensadores a caballo entre la filosofía y la literatura y que se interesaban por el ámbito concreto de lo social, de las relaciones del individuo con la sociedad (Molpeceres Arnáiz, 2013: 82).

En este sentido, las reflexiones de Schlegel sobre el Witz comparten con Chamfort este fondo social y se acercan a las reflexiones sobre la ocurrencia humorística en la conversación de los moralistas ingleses. De hecho, como señala Ayrault, la concepción schlegeliana del Witz, que, recordemos, apuntaba en principio a la inspiración poética irracional, dio un giro precisamente en 1797, cuando descubre los salones judíos de Berlín, donde abundaban las conversaciones ingeniosas y llenas de Witz:

Il y a effectivement découvert la disposition intérieure que les Fragments critiques nomment " sociabilité » avec un accent caractérisé de louange, et qui est tournée, non vers la société proprement dite, dont elle est même la négation, mais vers une communauté de choix, vers le petit nombre de ceux qu’elle a jugés «à la hauteur ». Toutes les définitions du « Witz » d'après sa forme élémentaire, le trait d'esprit, que va proposer Friedrich Schlegel, s’appuieront à la sociabilité ainsi comprise (Ayrault, 1970 : 143)

Así pues, el Witz está indisolublemente unido a la conversación, o, como el mismo Schlegel afirma, «el ingenio (Witz) es un espíritu incondicionalmente sociable» (Lyc., fr. 
9), No es que el Witz surja de esta sociabilidad, sino que es la misma estructura comunicativa del Witz, su «communicabilité initiale», la que posibilita la existencia misma de la sociabilidad (Ayrault, 1970: 144). Es en este contexto de sociabilidad y conversación en el que debemos situar también el desarrollo de la ironía. Es en este sentido como, en nuestra opinión, hay que interpretar el famoso fragmento 37 del Athenaeum, que constituye uno de los textos fundamentales desde donde entender el concepto romántico de ironía:

Para poder escribir bien sobre un asunto es necesario no interesarse más por él; el pensamiento que se ha de expresar con serenidad debe haber pasado ya del todo, no ocuparle ya más a uno realmente. En tanto que el artista crea y está entusiasmado se encuentra cuando menos una disposición iliberal para la comunicación. Querrá entonces decirlo todo, lo cual es una falsa tendencia de los genios jóvenes, o un prejuicio legítimo de viejos ignorantes. De este modo, no sabe apreciar el valor y la dignidad de la autolimitación, que es, sin embargo, para el artista como para el ser humano en general, lo primero y lo último, lo más necesario y lo más elevado. Lo más necesario, porque dondequiera que no se limita uno a sí mismo se ve uno limitado por el mundo, con lo que se convierte en un esclavo. Lo más elevado, porque uno sólo se puede limitar a sí mismo en los puntos y en los aspectos en los que posee fuerza infinita, creación y destrucción de sí mismo. Incluso una conversación amistosa que no se pueda interrumpir libremente en cualquier momento por un arbitrio incondicionado tiene algo de iliberal. Pero un escritor que puramente quiere y puede explicarse, que no se reserva nada para sí y gusta de decir todo lo que sabe, es muy de lamentar.

La ironía, como aquí leemos, es ante todo una «autolimitación», un no querer decirlo todo, es decir, un asumir que el proceso de conocimiento es un diálogo abierto, inacabado, y no se puede decir por entero. Por eso la expresión filosófica del romántico ha de ser irónica: es necesario distanciarse de su propio material, alejarse del «entusiasmo» inicial, ser consciente de la provisionalidad que le es propia. La ironía, por tanto, es ante todo una actitud comunicativa y epistemológica de honestidad y escepticismo. En otro de los fragmentos fundamentales respecto a la ironía, el 42 del Lyceum, la vincula a la filosofía en tanto que comunicación:

La filosofía es la auténtica patria de la ironía, la cual podríamos definir como belleza lógica: pues dondequiera que se filosofa en diálogos orales y escritos, y en general de manera no totalmente sistemática, se debe ofrecer y exigir ironía; e incluso los estoicos consideraron la urbanidad una virtud. Sin duda hay también una ironía retórica, que usada 
con moderación produce excelentes efectos, especialmente en la polémica; mas comparada con la sublime urbanidad de la musa socrática es como la pompa del discurso retórico más brillante comparada con una tragedia antigua de estilo elevado ${ }^{13}$. Únicamente la poesía puede alzarse también desde este aspecto hasta la altura de la filosofía, y no se apoya, como la retórica, en retazos irónicos. Hay poemas antiguos y modernos que, en su totalidad, exhalan por doquier universalmente el divino hálito de la ironía. Vive en ellos una verdadera bufonería transcendental. En su interior, la disposición de ánimo [Stimmung] que todo lo abarca y que se eleva infinitamente por encima de todo lo condicionado, incluso sobre el arte, la virtud o la genialidad propios; en el exterior, la manera mímica al actuar de un buen actor bufo italiano tradicional.

Como vemos, Schlegel habla de una filosofía dialógica ${ }^{14}$ (oral o escrita), es decir, no sistemática, aludiendo al ideal de la symfilosofía del que hablamos, que exige la ironía, es decir, una cierta actitud de reserva escéptica, y la relaciona con la urbanitas de la Antigüedad. La ironía es una disposición de ánimo, una Stimmung, una actitud «de elevarse por encima, de sobrevolar (Übersicht) todo lo condicionado» (Sánchez Meca, 1999: 97) ${ }^{15}$.

Si entendemos, por tanto, la ironía de Schlegel como un cierto ethos del pensador en el contexto de una filosofía que es ante todo conversación, son evidentes las similitudes de su pensamiento con el de Shaftesbury. Ambos, como vemos, promocionan una filosofía que no consista en las demostraciones unilaterales, los discursos abstractos y esotéricos de la filosofía oficial, sino una filosofía práctica y mundana, que se forje en la conversación y sirva a la realización personal de los individuos. Pero, ante todo, ambos insisten en la importancia del ingenio y del humor como la mejor garantía de la libertad de pensamiento. En este sentido, la petición de Shaftesbury de que se esté dispuesto en todo momento a que las propias opiniones puedan ser sometidas a la prueba de la burla, es análoga a la afirmación de Schlegel sobre la necesidad de la ironía en cualquier diálogo

\footnotetext{
${ }^{13}$ Con esta frase de Schlegel se inaugura, en la filosofía y la teoría literaria, la tradición de diferenciar entre una ironía "retórica", discursiva, limitada, y una "filosófica”, abstracta y elevada.

${ }^{14}$ Como decimos, esta oposición entre dialogismo y dialéctica como distintas concepciones del lenguaje y el conocimiento la encontraremos a lo largo del siglo XX [3.2.3; 4.2.1]

${ }^{15}$ Esto también tiene que ver con el papel cognoscitivo que el idealismo alemán otorga al sentimiento, revalorización que tiene sus inicios en Shaftesbury y se consolida en la filosofía kantiana: el objeto puede ofrecer un placer agradable, bello o bueno según la propia disposición del sujeto: «hay una correspondencia estricta entre la actitud del sujeto, su sentimiento y el objeto que se presenta a él a través de este sentimiento» (Sánchez Meca, 1999: 97). Por eso Schlegel entiende la ironía como una disposición de ánimo que conlleva una actitud epistémica.
} 
filosófico ${ }^{16}$. También Schlegel, igual que el conde, concibe la ironía como una cura contra el entusiasmo, en este caso creativo, contra la excesiva pasión que puede convertirse en fanatismo y ser un obstáculo para el conocimiento. Ambos pensadores, en suma, conciben la ironía y el humor, o el humor irónico, como una actitud social y epistemológica escéptica frente a la razón y al proceso de conocimiento, que plantean como provisional. La diferencia, y es una diferencia crucial que al fin y al cabo señala la distancia entre un pensador ilustrado y uno romántico, absolutamente moderno, es que mientras Shaftesbury no deja de creer en la capacidad humana de alcanzar verdades seguras, a salvo de la mirada burlona de la ironía, Schlegel ve como provisional todo conocimiento y prolonga ad infinitum la acción de la ironía.

Inextricablemente unido a las reflexiones de Schlegel sobre la ironía está, como ha señalado Paul de Man (1996: 4) el problema de la interpretación. La ironía como figura retórica, de hecho, se había relacionado con la interpretación desde muy pronto, en tanto que se definía como un tipo de alegoría, es decir, un tipo de discurso que, diciendo una cosa en la superficie, apunta en realidad otro significado distinto. Como vimos [1.1.4], Erasmo había recogido la comparación que en el Banquete de Platón Alcibíades establecía entre Sócrates y las figuras de Sileno (el filósofo, como estas estatuillas de figuras feas, escondían en su interior un tesoro) como metáfora del texto alegórico: el significado literal encierra un significado oculto y superior (Dane, 2011: 3) ${ }^{17}$.

Y si la ironía había estado mucho tiempo ligada a los problemas de interpretación alegórica, Schlegel llevará esta relación a un nuevo nivel al postular la imposibilidad de cualquier comunicación plenamente comprensible ${ }^{18}$. En realidad, ya el particular ethos del ironista, de distanciamiento escéptico y humorístico respecto de su propio lenguaje, hace que la interpretación de la ironía sea de por sí ambigua: es difícil saber cuándo un

\footnotetext{
${ }^{16}$ Quizá sea interesante resaltar en este punto que tanto Shaftesbury como Schlegel parecen estar hablando de una libertad de pensamiento no en el sentido de una libertad de expresión pública, sino como una libertad para consigo mismo, como una exigencia más bien ética de no dejarse atrapar por los propios prejuicios y por una soberbia seguridad en las propias creencias. En este sentido, esta libertad de pensamiento no tiene el mismo significado ni las mismas implicaciones que la libertad de expresión tal y como se debate en la actualidad, como veremos en el último capítulo.

${ }^{17}$ Y Rabelais adaptaba la imagen de Erasmo al problema de la frivolidad de su obra: «to Rabelais, the contrast between exterior and interior suggests less a difference between ugliness and beauty than one between frivolity and seriousness (...) it [the Silenus] bears on problems of interpretations of the superfically frivolous text» (Dane, 2011: 4). Como veremos más adelante [3.2.3.2.3], el problema de la frivolidad es un aspecto fundamental de la ironía.

${ }^{18}$ En general, los románticos alemanes habían utilizado la incomprensibilidad como recurso para incentivar la actividad creativa del lector, y, en general, la imposibilidad de agotar la interpretación era uno de los rasgos del lenguaje simbólico que los idealistas promocionaban (Wheeler, 1980: 8, 15).
} 
autor está siendo irónico, y, si lo está, cuánto hay de seriedad y cuánto de burla en su actitud. A este problema le dedica Schlegel un pequeño texto, «Sobre la incomprensibilidad» (2009), publicado en el último número de la revista Athenaeum, como defensa contra las críticas de hermetismo y frivolidad que había recibido. El tema del ensayo, anuncia Schlegel, va a ser el de la comunicación, de «la cuestión misma de si es posible alguna forma de comunicación» (Schlegel, 2009: 221).

El escritor decide afrontar «muy en serio y no sin un resquicio de mi antigua inclinación al misticismo (...) admitiendo con franqueza y sin reservas el frecuente fracaso» de sus fragmentos, para obligar al lector a que sea igual de honesto - y reconocer, por tanto, que la responsabilidad de la incomprensión no reside únicamente en el texto, sino también en el lector (Schlegel, 2009: 221). Es más, se propone ser realmente comprensible y alcanzar aquello que se ha pretendido durante toda la Historia: «la posibilidad de un lenguaje real que nos permitiera dejar de escarbar en las palabras y contemplar la fuerza y la semilla de toda actividad» (Schlegel, 2009: 222), un lenguaje que no se exponga a malentendidos - en directa y explícita relación, como vemos, con la utopía filosófica de la lengua perfecta. Schlegel relaciona estos problemas de comprensión con la ironía, y de hecho asegura que, de acuerdo con su intención de ser claro y honesto por una vez, ha escrito este texto «casi sin la menor sombra de ironía». El problema es, precisamente, que esta afirmación es irónica, y «Sobre la incomprensibilidad» es, de hecho, enteramente irónico, porque, en última instancia, Schlegel no cree en la posibilidad de una comunicación plena, y considera ingenuos a quienes sí lo hacen. Así lo había afirmado, de hecho, en el fragmento 108 del Lyceum, donde leemos que la ironía

para quien no la posee permanece como un enigma incluso tras la más abierta declaración. No ha de engañar a nadie, excepto a aquellos que la toman por un engaño (...) Los que son armoniosamente ramplones no saben en absoluto cómo tienen que tomarse esta continua autoparodia, creyendo y ahora desconfiando una y otra vez, hasta que la cabeza les da vueltas y toman la burla justamente por una cosa seria y lo serio por burla.

La víctima de la ironía, por tanto, es quien la toma como un enigma a resolver, por quien sospecha que el ironista, o bien está siendo frívolo y burlándose de él, o bien intenta transmitir un cierto significado oculto, y al buscar dicho significado, dicha seriedad dentro de la frivolidad, se ve inmerso en el torbellino interpretativo de la ironía. Pero en la ironía tal y como la entiende Schlegel, y tal y como cree que sus lectores la entienden, no hay 
ánimo de engaño, sino una disposición comunicativa de precaución respecto de la posibilidad de «decirlo todo», como hemos visto antes. Como afirma en la continuación del fragmento citado, la ironía «contiene y provoca un sentimiento del irresoluble conflicto entre lo incondicionado y lo condicionado, de la imposibilidad y la necesidad de una plena comunicación». En esta frase se reúnen, como vemos, la imposibilidad del conocimiento absoluto y la imposibilidad de una plena comunicación, pues ambos motivos están, como hemos argumentado, íntimamente relacionados.

En resumen, para Schlegel la ironía implica un absoluto escepticismo respecto de la razón y el lenguaje (en sus dos posibles usos, el de la comunicación y el de la producción de conocimiento; usos que, como decimos, están íntimamente vinculados en la idea de Symphilosophie), rechazando de pleno la posibilidad de una lengua perfecta que sea capaz de alcanzar y expresar sin equívocos un saber absoluto. Es por esta postura que Hegel arremetió con virulencia contra esta concepción de la ironía, acusándolo de subjetivista e irracional, de relativizar y renunciar al ideal de perfección al plantear toda experiencia de la realidad como una apariencia puesta por el yo (Sánchez Meca, 1999: 106). Para Hegel, la lógica de la ironía romántica es la de la disolución, la de una divergencia irresoluble entre subjetividad y exterioridad. La amenaza de este exceso de subjetividad es que nada es valioso en sí mismo sino solo como creación del yo, que puede abandonar su obra cuando guste: por tanto, nada puede ser tomado en serio,

pues la verdadera seriedad sólo se produce por un interés sustancial por una cosa, verdad, moralidad, etc., que tiene contenido en sí misma, por un contenido que como tal es esencial para mí, de modo que yo solo me hago esencial a mí mismo en tanto que me he sumergido en tal contenido y me he hecho adecuado a él en todo mi saber y hacer (Hegel, cit. en Sánchez Meca, 1999: 107)

Por tanto, Hegel acusa a la ironía de Schlegel de desustancializar todo lo sustancial, desacralizar y destruir todo lo que es bueno, noble, sagrado, etc.: «al querer disolverse y reivindicar su propia autodisolución, el arte romántico no accede, en definitiva, a la verdad (...) por lo que se queda en pura frivolidad, mera anécdota superficial e insignificante respecto a la verdad especulativa» (Sánchez Meca, 1999: 108). Esta concepción de la ironía, para Hegel, está muy lejos de la ironía socrática, que estaba al servicio de la verdad, puesto que destruye solo la pretensión de verdad, aquello que es erróneo, limitado e imperfecto, para poder alumbrar, mediante la mayéutica, la auténtica 
verdad (Sánchez Meca, 1999: 108). La ironía de Schlegel, en cambio, posterga la aparición de esta verdad hasta un final que no debe llegar (Ayrault, 1970: 167).

En todo caso, la ironía no está del todo ausente del sistema filosófico de Hegel. El mismo Kierkegaard, que asistió a sus lecciones, sugirió que parte de la animosidad contra la ironía schlegeliana se debía a su incómoda cercanía con la propia concepción hegeliana (Behler, 1990: 88). En su Historia de la filosofía, Hegel llega a establecer un paralelismo entre la ironía y la dialéctica, y concretamente habla de una «ironía universal del mundo» para designar el momento negativo y destructor de toda dialéctica (Behler, 1990: 89). Aunque, más precisamente, la ironía no es un rasgo del mundo o de la historia, sino de la consciencia que observa desde fuera este desarrollo histórico y conoce el carácter perecedero de toda forma histórica y su necesaria destrucción para que emerjan formas superiores (Behler, 1990: 90). La principal diferencia con el pensamiento de Schlegel sigue siendo, por supuesto, que para Hegel este proceso está gobernado por la Razón y tiene un significado y, ante todo, está orientado a un final, un conocimiento absoluto o un desarrollo absoluto de la razón. Como veremos, Hegel y Schlegel representan las dos posiciones filosóficas ante el problema de la ironía que se repetirán a lo largo del siglo XX.

Años más tarde, Kierkegaard que, como dijimos, asistió a las lecciones de Hegel y desarrolló sus esporádicas alusiones a la ironía, retomará esta problemática, reinterpretando de nuevo la figura de Sócrates y señalando lo que le distingue de la ironía romántica. Para Kierkegaard, la ironía consiste tomar conciencia de la separación que hay entre el pensamiento y su expresión, las palabras y la intención de quien las pronuncia, y en servirse de ello para jugar con el interlocutor, planteando un acertijo que dé acceso a un significado oculto (Kierkegaard, 2000: 276). También define al ironista como aquel que finge ignorancia o alabar a su interlocutor para mostrar su error. La ironía, por tanto, es una simulación que, más que ocultarse, busca desenmascarar la ignorancia del contrario (Kierkegaard, 2000: 278-279) ${ }^{19}$.

\footnotetext{
${ }^{19}$ En este punto, Kierkegaard introduce una reflexión muy interesante sobre la ironía como frivolidad o falta de seriedad, aspecto de lo cómico que, como trataremos más adelante, es uno de los puntos fundamentales alrededor de los que pivota la recepción de cualquier discurso humorístico. En opinión de Kierkegaard, Hegel ha errado en su descripción de Sócrates, pues confunde la ironía propiamente socrática con el uso que de la figura hace Platón en sus escritos: la dialéctica de Platón es especulativa y su fin último es dar un conocimiento positivo, mientras que la ironía de Sócrates es absolutamente negativa. La mayéutica de Platón se apoya en preguntas que buscan sinceramente el conocimiento, pero las preguntas de Sócrates únicamente quieren demostrar la vaciedad del saber de su interlocutor. De este modo, hay que entender de manera paradójica la afirmación de Sócrates de que su único saber es no saber nada: según
} 
El siguiente paso es el de distinguir entre este tipo de ironía oratoria, afín a la práctica socrática, y la ironía «sensu eminentiori», que «no se dirige a esta o aquella cosa existente en particular, sino que se dirige a toda la realidad dada», una visión de la existencia «sub specie ironiae» (Kierkegaard, 2000: 281). Este tipo de ironista se libera totalmente de la realidad y sus circunstancias:

Cuanto más vano se vuelve todo, tanto más leve, tanto más despojada, tanto más fugaz se vuelve la subjetividad (...) Para el sujeto irónico, la realidad ha perdido completamente su validez, ha llegado a ser para él una forma imperfecta que, sobre todo, estorba (...) Pero no tiene una alternativa válida que ofrecer. El entusiasmo del ironista no es aquel del profeta que espera la llegada de una nueva realidad, una nueva determinación histórica del espíritu absoluto, sino el entusiasmo de la aniquilación (Kierkegaard, 2000: 287-288)

Por tanto, según Kierkegaard la distancia entre Sócrates y Schlegel consiste en que, mientras la ironía de Sócrates estaba justificada en tanto que, siguiendo el esquema de Hegel, significa el advenimiento de la subjetividad y por tanto correspondía al desarrollo histórico del espíritu universal, la de Schlegel no está justificada. Para el pensador danés, el error de Schlegel y sus compañeros es que no negaban una realidad que pudiera ser desplazada por otra, sino que negaban «toda realidad histórica para dar lugar a una realidad autoengendrada» (Kierkegaard, 2000: 302).

Para Kierkegaard, la ironía es un instrumento útil de la subjetividad que sin embargo es necesario dominar, concebirla solo como un momento de la propia evolución del poema o de la vida misma: «La ironía limita, finitiza, restringe, y de esa manera proporciona verdad, realidad, contenido; la ironía disciplina y amonesta, y de esa manera proporciona solidez y consistencia» (Kierkegaard, 2000: 339; el destacado es del autor). La ironía es un momento saneador, pero no hay que confundirla con la única verdad: «es el camino; no la verdad, sino el camino» (Kierkegaard, 2000: 340). Es necesario, por tanto, dominar la ironía, no dejar que corra incontrolable:

\footnotetext{
Kierkegaard, Sócrates «da seriedad a su ignorancia, si bien a la vez no le da seriedad». Si Sócrates realmente supiera algo de manera positiva, estaría fingiendo su ignorancia, pero Sócrates se toma esta ignorancia muy en serio, de la misma manera que Schlegel afirma seriamente que la realidad es pura apariencia y por tanto no hay que tomársela en serio: «en última instancia, el ironista debe siempre afirmar algo si bien lo que afirma de este modo es nada (...) La ironía es el juego infinitamente fugaz con la nada, y esto no la asusta, sino que sigue asomando la cabeza. Cuando no se toma nada especulativa o personalmente en serio, es obvio que se toma algo a la ligera, y en este sentido no se lo toma en serio (...) Puede decirse, por tanto, que la ironía a nada le da seriedad en la medida en que no le da seriedad a algo»" (Kierkegaard, 2000: 293-294). Por tanto, la ironía es un juego con la frivolidad, una afirmación seria de no tomarse nada en serio, y en ese no tomarse nada en serio está toda la apuesta epistemológica del ironista. El peligro de esta actitud, para Kierkegaard, como veremos inmediatamente, es llevarla demasiado lejos.
} 
la ironía como momento dominado se muestra en su verdad precisamente cuando enseña a realizar la realidad, cuando coloca el debido acento sobre la realidad (...) debería haber en todo ser humano el anhelo de algo superior y más perfecto. Pero ese anhelo no debe socavar la realidad (...) La realidad no ha de ser descartada, y el anhelo debe ser un sano amor, y no un tibio y consentido huir del mundo a hurtadillas (Kierkegaard, 2000: 341)

Como dijimos, es difícil sobreestimar la importancia que la reflexión de Friedrich Schlegel sobre la ironía tiene para el pensamiento posterior sobre lo humorístico. A partir de ahora, la ironía se verá como un supremo valor de inteligencia y objetividad, un sano antídoto contra los absolutismos; o bien como un peligroso y corrosivo relativismo, incapaz de tomarse nada en serio ni de postular valores sólidos.

\subsubsection{La poesía humorística de Jean Paul}

Parecería que, con Schlegel, la ironía se ha distanciado del todo del ámbito de lo propiamente cómico ${ }^{20}$. Sin embargo, son varios los ejemplos y referencias del pensador alemán que lo desmienten. En la misma reseña del Wilhelm Meister de Goethe, Schlegel introduce ciertas descripciones de lo cómico al analizar el libro tercero de la obra:

Los ingredientes de esta comicidad no son, en modo alguno, finos, delicados o nobles. Muchos son, más bien, del estilo de lo que suele hacernos reír ordinariamente, como el contraste entre altas expectativas y un mal resultado. El contraste entre esperanza y éxito, y entre imaginación y realidad, juegan aquí un importante papel en general; los derechos de la realidad se dejan sentir con despiadado rigor, y hasta el pedante es golpeado porque también él es un idealista (Schlegel, 2007: 22)

Como vemos, la idea de lo cómico como contraste entre expectativa y realidad no se aleja de la descripción de los teóricos ingleses de la incongruencia cómica como una

\footnotetext{
${ }^{20} \mathrm{Y}$ así lo considerarán numerosos pensadores y críticos literarios en el siglo XX. Pere Ballart, por ejemplo, al hablar de las reflexiones de Baudelaire sobre lo cómico (de las que nos ocuparemos más adelante), se muestra sorprendido de que el poeta francés no hable directamente de la ironía cuando sus ideas se adecúan más a este fenómeno que al de lo cómico. Paul de Man, en su célebre trabajo «Retórica de la temporalidad», directamente trabaja el texto de Baudelaire como si tratara de la ironía, cuando este término no aparece ni una sola vez en él. Este es un caso más en el que se distinguen dos tipos de fenómenos humorísticos, uno "vulgar”, más limitado, y uno "superior", más abstracto y filosófico. En nuestro caso, en el capítulo correspondiente propondremos la ironía como punto de partida para el establecimiento de una hermenéutica de lo cómico, pero como ejemplo propedéutico, no porque consideremos que el tropo sea una clase superior de lo cómico.
} 
degradación de lo supuestamente superior ${ }^{21}$. También caracteriza a los personajes nobles que aparecen en este libro en contraste con los comediantes como torpes, vanos y estúpidos (Schlegel, 2007: 22-23), es decir, ridículos. Incluso entre este análisis de la comicidad de la novela incluye la ironía «que flota sobre toda la obra» pero que se muestra especialmente en esta parte, que define en términos asimilables a las descripciones retóricas clásicas como contrastes de estilos y el juego entre apariencia de seriedad e intención burlona:

Esta apariencia de dignidad y de importancia que se ríe de sí misma en estilo periodístico, esta aparente negligencia, estas tautologías que cumplen sus propias condiciones cuando llega la ocasión, parecen decirlo o quererlo decir todo o nada de ese alto prosaísmo en medio del talante poético del sujeto representado o hecho comedia, y ese sabor intencionado de poética pedantería en las idiosincrasias más prosaicas, dependiendo todo, a veces, de una única palabra o hasta de un simple acento (Schlegel, 2007: 23)

También describe el tono general de esta parte de la novela en unos términos que bien podríamos acercar al fantástico y encantador grotesco decorativo renacentista: «Esta frescura de colores, este infantil abigarramiento, este gusto por el adorno y el aderezo, esta chispeante frivolidad, esta fugaz vivacidad tienen algo de lo que podríamos llamar éter de jovialidad» (Schlegel, 2007: 23).

En otros escritos, Schlegel asocia estrechamente la ironía con la tradición cómica. En uno de sus fragmentos tardíos, definirá la ironía como «parábasis permanente» (cit. en De Man, 199: 232), haciendo referencia a la parte de la Comedia Antigua en la que los actores se quitan la máscara y se dirigen directamente a los espectadores. En otro, llega a comparar la literatura romántica moderna con la pantomima romana (Ath. 69). Sobre todo, no podemos dejar de notar que en el importantísimo fragmento 42 del Lyceum habla de la ironía como «bufonería trascendental» y comparándola con la gestualidad de un «actor bufo italiano». En el escrito «Sobre la incomprensibilidad» también pondrá como ejemplo de ironía una acción de Scaramouche, una de las máscaras de la commedia dell'arte.

\footnotetext{
${ }^{21}$ También en «Sobre la incomprensibilidad» se trasluce esta concepción de lo cómico/irónico como frustración de expectativas al ejemplificar los distintos tipos de ironía, como «la que emplea Scaramouche siempre que simula charlar en serio y amistosamente con alguien, cuando en realidad sólo está esperando la ocasión propicia para darle una buena patada en el trasero» o aquella «que, en su forma más pura y original, crece en aquellos jardines antiguos donde las maravillosas y amenas grutas atraen hacia sus entrañas al sensible amigo de la naturaleza para, una vez allí, salpicarlo de arriba abajo con un abundante chorro de agua y enjuagar de golpe cualquier rastro de candidez» (Schlegel, 2009: 231).
} 
Como vemos, Friedrich Schlegel no deja de asociar su concepción de la ironía con el ámbito más amplio de lo cómico. En realidad, los primeros románticos alemanes llevarán a cabo una sugestiva reflexión sobre el valor de lo cómico y lo humorístico desde el punto de vista de su propio pensamiento filosófico y estético. Entre ellos, el que realizará la aportación más relevante, llegando a hacer equivaler la literatura romántica con el humor, es Jean Paul Richter, escritor él mismo de varias novelas cómicas, que dedica varios capítulos de su Antesala de la estética a esta cuestión. En opinión de René Wellek, su concepción del humor lleva a un clímax la evolución del término iniciada en Inglaterra el siglo anterior (1981: 107), e influirá enormemente a críticos posteriores como Vischer, Coleridge o Meredith (Wellek, 1981: 105).

La poética de Jean Paul se basa en una confrontación crítica con el Romanticismo: aunque desprecie el solipsismo fichteano de los Schlegel, en general coincide con su teoría de lo poético (Wellek, 1981: 101). Ante todo, es consciente de que la estética romántica, encerrada en sí misma, no puede decir nada del mundo y solo da cuenta trágicamente de su incapacidad (Oliva Mendoza, 2011: 21). Dando por buena la definición aristotélica de la poesía como imitación de la naturaleza, denomina «nihilistas poéticos» a los ironistas románticos, a quienes censura su «capricho sin ley propio del espíritu de la época actual - que, enviciado por el Yo, prefiere anular el mundo y el universo todo para abrirse un espacio de juego libre en medio de la nada» (Richter, 2011: 46). Pero también desprecia a los «materialistas» que copian simplemente lo que ven en la naturaleza, sin ninguna conciencia artística, pues también sigue la poética de Aristóteles en cuanto al carácter ficticio o universalizante de la imitación: esta no ha de ser una mera copia, sino tener su propio aliento poético (Richter, 2011: 50-51): «crudas, ni la materia de la naturaleza, ni menos su forma, pueden servir al poeta» (Richter, 2011: 53). La poesía por tanto ha de ser una unión entre lo general y lo particular, lo que el poeta consigue mediante la imaginación y la fantasía (Wellek, 1981: 102; Oliva Mendoza, 2011: 22). Es en esta poética general en la que incluye su reflexión sobre lo cómico y la poesía humorística.

Richter considera las definiciones de lo cómico basadas en la incongruencia como insuficientes, puesto que fallan en explicar lo que es propiamente cómico de estos fenómenos - al fin y al cabo, hay incongruencias que no resultan cómicas (Richter, 2011: 125-127). Lo cómico no tiene que ver con el vicio, puesto que la moral o su falta lo que infunden son respeto o desprecio, «y lo cómico resulta demasiado insignificante para el 
desprecio y demasiado bueno para el odio» (Richter, 2011: 132). Tampoco el error es cómico por sí mismo, sino que debe manifestarse en una acción visible y esforzada: «un hombre sano que se cree enfermo sólo se vuelve cómico cuando lo vemos tomar medidas importantes contra su dolencia» (Richter, 2011: 133). Para explicar este último punto, Jean Paul pone un pasaje de Cervantes como ejemplo:

Cuando Sancho se sostiene una noche entera al borde de una zanja porque piensa que un abismo se abre bajo él, su esfuerzo es perfectamente comprensible; tendría que estar loco para intentar la caída. ¿Por qué reímos de todos modos? Aquí viene lo principal: porque a su esfuerzo le adjudicamos nuestro conocimiento y nuestra perspectiva y creamos así, mediante tal contradicción, la incongruencia infinita (Richter, 2011: 133)

Lo cómico, pues, surge de una contradicción, de una incongruencia, pero no de cualquier tipo: el observador debe suponer en la mente de la persona que percibe como cómica su propia percepción de la situación. Esta explicación es sin duda abstrusa y un tanto confusa, y Wellek la considera errada, puesto que es obvio que la comicidad viene precisamente de la ignorancia de Sancho Panza de la verdadera situación (1981: 106). Parece que para Jean Paul debemos ser capaces de adjudicarle al personaje cómico una intención y un conocimiento de la contradicción que está actuando, pero no se explica del todo por qué esta es una condición sine qua non de la comicidad. ¿Debe parecer que el personaje cómico actúa erradamente adrede? ¿Debe parecer el personaje cómico, en otras palabras, un humorista? En todo caso, este personaje abre con su acción incongruente un mundo absurdo, extravagante, en el que se superponen varios planos simultáneamente, como deja ver otro de los ejemplos que utiliza: una caricatura de Hogarth en la que una persona seca sus medias colocándolas sobre unas nubes de cartón que, en un primer vistazo, parecen de verdad (Richter, 2011: 134). También parece evidente que para Richter lo cómico es una percepción, una interpretación de la situación como cómica por parte del observador: «por esta razón nadie que esté en acción puede parecerse cómico a sí mismo; tendría que ser una hora más tarde, cuando se haya vuelto ya un segundo yo y pueda inventar que el primero sabe lo que él sabe» (Richter, 2011: 136).

Lo cómico provoca a este observador un placer, recibida como liberación. Para Richter, Hobbes se equivoca al derivar el placer de lo cómico del sentimiento de superioridad (2011: 144). Al contrario, es resultado de la conjunción simultánea de tres pensamientos: la percepción del espectador, la propia situación incongruente, y la percepción ilusoria que el espectador atribuye al personaje cómico: «lo cómico es 
entonces el goce o la fantasía y la poesía del entendimiento desatado en lo libre que se desarrolla jugando y danzando de aquí para allá» (Richter, 2011: 145). Al mismo tiempo, lo cómico es en parte incómodo, por lo desagradable que es esta falta de entendimiento momentánea (Richter, 2011: 146). Pero, ante todo, es inofensivo. Ahí es donde se distinguen la sátira y lo cómico: aquella tiene un fin de elevación moral mediante el castigo del vicio, mientras que lo cómico, ajeno a lo moral, juega con lo pequeño y con el entendimiento y lo libera (Richter, 2011: 138).

Además, Jean Paul apunta alguno de los rasgos de lo cómico muy sugerentes. Para empezar, es necesario que esta percepción de lo cómico sea súbita (Richter, 2011: 134). En general, lo cómico es absolutamente sensorial, no puede haber nada cómico sin lo sensible (Richter, 2011: 164), de ahí que sea colorido y lleno de contrastes. Lo cómico individualiza, es infinitamente concreto: «lo serio, como vemos arriba, coloca siempre primero lo general y de tal modo nos espiritualiza el corazón, que nos hace ver poesía en la anatomía más bien que anatomía en la poesía. Lo cómico, por el contrario, nos une estrechamente a lo que está determinado por los sentidos» (Richter, 2011: 165). Por eso, otro de los elementos que contribuyen a lo cómico es la profusión y la enumeración abigarrada de objetos o características $^{22}$, o las perífrasis que separan el sujeto y el predicado; también el movimiento o su contraste con el reposo (Richter, 2011: 167-169).

A partir de estas observaciones generales sobre lo cómico, Richter define lo que denomina «humor» o «poesía humorística». Para Jean Paul, el humor es el inverso de lo sublime: si este es lo infinitamente grande, aquel es lo infinitamente pequeño (Richter, 2011: 149). Como lo sublime, el humor juega con la idea de infinitud: no anula lo individual, sino lo finito; «para él no existen la tontería individual ni los tontos, sino solo la tontería y un mundo tonto» (Richter, 2011: 149). Por eso habla de la «totalidad» del humor, lo que, como decimos, le diferencia de la sátira: «Esta totalidad permite, además, explicar la suavidad y la tolerancia del humor con las tonterías singulares porque éstas, hallándose esparcidas entre la masa, tienen menos fuerza y hieren menos; además, el

\footnotetext{
${ }^{22}$ Valeriano Bozal, en su introducción al texto de Baudelaire que comentaremos más adelante, señala que el inventario abigarrado es un recurso habitual de los satiristas desde Esopo y Luciano, pasando por Rabelais, Swift, etc. (Bozal, 2015: 19): «El inventario es un recurso característico de la sátira, tiene la virtud de que siempre está abierto, siempre puede añadirse un aspecto más, un personaje más, un hecho o un lugar. El proceder del inventario es el de la acumulación, no se apoya con firmeza en necesidad alguna pues se atiene a la descripción de lo que hay y se interpreta. Agrupa a los motivos atendiendo a las diferencias existentes entre unos y otros, a los contrastes, y lo mismo que puede agrupar, puede deshacer el grupo. No hay esencia o fundamento que soporte el inventario salvo su propia condición de tal» (Bozal, 2015: 18-20).
} 
humorista no puede desconocer sus lazos de familia con el género humano» (Richter: 2011: 153).

Sobre todo, si el humor es la inversión de lo sublime, es porque también permite al ser humano alcanzar la Idea de lo infinito: «su descenso a los infiernos le abre las puertas del cielo» (Richter, 2011: 154). Mediante el humor el ser humano «contempla el mundo terrenal desde lo alto del mundo supraterrenal», dando lugar a esa risa «en la que vienen a mezclarse un dolor y una grandiosidad» (Richter, 2011: 154). De ahí que el humor sea, a pesar de las apariencias, absolutamente serio, como lo revela el hecho de que las farsas medievales tengan como protagonista al diablo caracterizado de tonto. De ahí que sean las naciones más serias y melancólicas, como Inglaterra o España, las que mejores ejemplos de humor han dado (Richter, 2011: 154). Por eso el humor está cerca de la tragedia, lo que explica que Platón, en el Banquete, admita una disposición a la comedia de los escritores de tragedias, o que los griegos ofrecieran el drama satírico tras la trilogía trágica: si el humor supone un descanso de la tensión patética, no es porque sea lo contrario, sino porque supone la misma emoción, pero en un grado más débil. También en los misterios medievales franceses la pasión de Cristo era acompañado por farsas (Richter, 2011: 155).

\subsubsection{Lo grotesco romántico: Victor Hugo. Lo cómico y lo siniestro}

En los últimos ejemplos citados de Jean Paul vemos aparecer la referencia a lo que los románticos alemanes consideran la tradición de lo «grotesco». Como vimos, durante los siglos XVII y XVIII este término se usaba como sinónimo de ridículo, cómico y burlesco, pero se problematizó como categoría estética con la aparición de las caricaturas de Callot o Hogarth; ya Diderot consideraba «grotescas» las figuras de la commedia dell'arte dibujadas por aquel (Kayser, 2010: 42-44, 48). De hecho, Richter cita las obras de Justus Möscher, Arlequín o la defensa de lo cómico-grotesco (1761) y de Flögel, Historia de lo cómico-grotesco (1784-1787), que incidían en esta asociación. El primero describía la commedia como un mundo grotesco, exagerado, quimérico, ajeno a las leyes del arte mimético (Kayser, 2010: 69-71). También hemos visto las referencias de Friedrich Schlegel a las máscaras de la commedia dell'arte, y en general la comedia del Sturm und Drang asimiló en gran medida la poética de esta práctica teatral (Kayser, 2010: 82). 
Hay, pues, a través de la commedia dell'arte, una fuerte presencia en la estética romántica germánica de lo que estos escritores consideran bajo la denominación de «grotesco», y que comprende también las manifestaciones populares medievales ${ }^{23}$. Pero sería Victor Hugo quien llevara el concepto de lo grotesco al centro de la estética moderna en el prefacio a su drama Cromwell (1827). En este texto programático divide la historia del arte en tres grandes épocas: la arcaica, la griega y la moderna o cristiana, asignándole a cada una el género lírico, el épico y el dramático, respectivamente ${ }^{24}$. Si la épica griega solo atendía a lo bello como perfección ideal y objetiva, el cristianismo, más espiritual, introduce lo feo, lo deforme y lo gracioso. El arte moderno, que combina en su seno la melancolía cristiana y la crítica filosófica, mezcla en sus obras lo sublime y su reverso, lo grotesco, lo bello y o feo, lo bueno y lo malo, frente a la uniformidad del arte antiguo. Claro que la poesía griega conoce lo deforme y lo cómico (ahí están las figuras de Tersites y Vulcano, los silenos, las harpías, las sirenas, etc.), pero no tienen la importancia ni el grado de deformidad de la literatura cristiana; la literatura medieval, en cambio, está poblada de monstruos y criaturas intermedias, o de personajes jocosos como las máscaras de la commedia dell'arte.

Estas figuras, que Hugo subsume en la noción de lo grotesco, suponen, como decimos, el contraste con lo sublime: la literatura moderna junta a Sganarelle con don Juan, a Mefistófeles con Fausto. Porque esta es, en fin, el reflejo de una realidad contradictoria: lo bello sublime alude a la perfección espiritual, mientras que lo grotesco revela la estupidez humana y su materialidad. En este sentido, la obra de Shakespeare representa el ideal del drama romántico, porque funde lo grotesco y lo sublime, la tragedia con la comedia: a Julieta, Desdémona y Ofelia con Yago o Falstaff. Lo feo es en sí mismo el principio del contraste y la variedad: a diferencia de lo bello, que es la armonía más simple, lo feo es múltiple, deforme y cambiante.

\footnotetext{
${ }^{23}$ Junto a lo «grotesco» encontramos el término muy cercano de «arabesco» (Connelly, 2005: 119), muy relacionado, además, con el Witz como facultad creativa. Esta vinculación se mantiene hasta bien entrado el siglo XIX y más allá de las fronteras de Alemania: Edgar Allan Poe llamará a sus narraciones fantásticas Cuentos de lo grotesco y arabesco.

${ }^{24}$ En general, subyace a toda la poética romántica una división histórica entre la poesía ingenua de los greigos y la sentimental moderna, por tomar los términos en que lo expresó Schiller. En este esquema, la autoconciencia irónica es una de las características fundamentales de la época moderna, como veremos, por ejemplo, al exponer las consideraciones de Baudelaire sobre lo cómico; de este modo, la ironía aparece asociada al progreso histórico, a la toma de conciencia, a la superioridad intelectual, pero también a la decadencia social, cultural y sobre todo espiritual de Europa.
} 
Víctor Hugo, en fin, está preconizando el principio de variedad del drama frente a las rígidas unidades clásicas. Pero lo que a nosotros nos interesa es que legitima lo feo o grotesco como categoría estética, y sobre todo que bajo esta categoría entiende dos manifestaciones distintas: lo grotesco cómico y lo grotesco terrorífico, las figuras de la commedia dell'arte y los monstruos y demonios medievales. Es en la época romántica, al fin y al cabo, cuando se desarrolla la acepción común contemporánea de lo grotesco como lo monstruoso y terrorífico (Connelly, 2015: 231). Ya en el siglo XVIII, como reacción al auge de la racionalidad ilustrada, había surgido una fascinación por lo irracional, y ya hemos mencionado cómo en los grabados de Goya se empezaba a vincular estrechamente la deformación satírica con la demoníaca (Connelly, 2015: 256257). Pero si en Goya todavía subsiste un cierto propósito de aviso moral, en el período romántico el terror y el horror se vuelven fines estéticos en sí mismos, como en la obra de E.T.A. Hoffmann o,

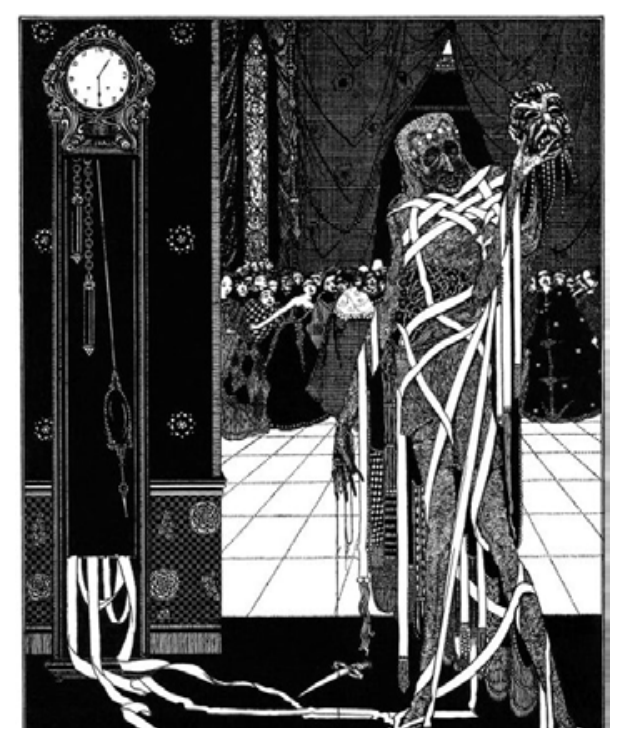

Fig. 11. Ilustración de Henry Clarke para el cuento de Edgar Allan Poe «La máscara de la muerte roja» (1919), en el que la muerte irrumpe en un baile de máscaras. más tardíamente, en la de Poe (Connelly, 2015: 257-258).

Frances Connelly señala de esta manera lo que distingue esta variante de lo grotesco del capriccio ornamental o lo carnavalesco:

Si lo grotesco improvisado y subversivo desafía las convenciones aceptadas, sociales y estéticas, esta línea hace visible lo que es más aterrador, lo que inspira miedo y repulsión, mientras se desgarra en el límite final entre el ser y el olvido. El significado de lo carnavalesco y el capriccio está deliberadamente al límite, pues utilizan la risa y el ingenio para abrir nuevas posibilidades; sin embargo, lo abyecto y monstruoso nos lleva a un mundo aterrador, liminal, que amenaza con craquelar el barniz cuidadosamente construido de nuestra identidad (Connelly, 2015: 231)

Lo grotesco terrorífico es por tanto una experiencia estética que amenaza los límites de la identidad y la otredad, que desafía los esfuerzos de presentar esta otredad como totalmente ajena al yo: en este sentido está relacionado con el concepto de lo siniestro de Freud (quien, precisamente, se servía de un cuento de Hoffmann para explicarlo). Lo 
grotesco terrorífico es, en suma, una manifestación de esta otredad oculta: de hecho, la etimología de «monstruos» es «monstrare», «revelar» (Connelly, 2015: 233).

De este modo se puede entender que lo grotesco se relacione inversamente con lo sublime, como hacen Richter o Hugo: John Ruskin habla del «grotesco noble» como medio para revelar y expresar las verdades más profundas (Connelly, 297). Esta vinculación, sin embargo, ha sido omitida por los filósofos y teóricos del arte a partir del siglo XVIII: se ha prestado más atención a los sublimes de David Friedrich o Mark Rothko que a las creaciones grotescas de William Blake o Rodin (Connelly, 2015: 302), quizá por el carácter más abstracto y por tanto supuestamente noble de lo sublime, mientras que lo grotesco «se hunde profundamente en la experiencia visceral» (Connelly, 2015: 305).

Como decimos, esta concepción de lo grotesco como lo terrorífico es la acepción común hoy en día. Wolfgang Kayser, autor del clásico estudio sobre lo grotesco en la literatura moderna, hace hincapié en esta visión tenebrosa y traumática de lo grotesco: este es lo abismal, lo que quita el suelo de la existencia (Kayser, 2010: 67). Por eso distingue la caricatura satírica de lo propiamente grotesco, aunque estén muy cerca y muchas veces se manifiesten simultáneamente: «lo grotesco difiere claramente del carácter lúdico de una caricatura o de la sátira tendenciosa, sin que tampoco deba preocuparnos cómo de amplias sean las transiciones entre lo uno y lo otro y la dificultad de llegar a una distinción entre los dos términos para cada caso concreto» (Kayser, 2010: $67)^{25}$. Sin embargo, hemos visto que tanto la época medieval como los románticos eran conscientes de la cercanía entre lo cómico y lo terrorífico. Recordemos, por ejemplo, la presencia de demonios y otras criaturas infernales en las fiestas carnavalescas, o que en la Edad Media la locura se relacionaba tanto con la risa como con la muerte. Y Friedrich Schlegel entiende en sus fragmentos lo grotesco como «el rotundo contraste entre forma y materia, la función centrífuga de lo heterogéneo, la fuerza explosiva de lo paradójico, lo ridículo y lo siniestro en combinación» (Kayser, 2010: 94; el destacado es nuestro), combinando la incongruencia cómica, la paradoja irónica y lo grotesco terrorífico. Lo grotesco a principios del siglo XIX estaba relacionado con la commedia dell'arte, pero no dejaba de expresar una sensación angustiosa y caótica, trágica y cómica al mismo

\footnotetext{
${ }^{25}$ Otra nueva distinción jerarquizadora entre un cómico simple y un cómico verdadero, esta vez apoyado en el carácter meramente lúdico de aquel.
} 
tiempo: la misma Revolución Francesa era descrita como "grotesca» en uno de los fragmentos del Athenaeum (Kayser, 2010: 94).

Jean Paul tampoco deja de mencionar esta asociación de lo cómico con lo inquietante. Recordemos que, para él, en la percepción de lo cómico aparecen unidos el placer y la inquietud. Pero, además, en cierto pasaje establece un paralelismo entre el uso del doble para fines cómicos y su posible efecto inquietante en otros contextos: «¿por qué un hombre que presenta una peculiaridad que no es cómica por sí misma se vuelve cómico con la imitación y adopción de la misma por parte de un rostro ajeno? ¿Y, por qué, en cambio, dos hermanos parecidos entre sí, mirados juntos de repente, más que risa producen un ligero susto?», a lo que añade en una nota al pie: «me extraña, por ello, que esta inquietante duplicación de la figura se emplee sólo en lo cómico y no en lo trágico también» (Richter, 2011: 135-136).

La duplicidad siniestra de lo cómico también se manifestaba en el propio drama del Sturm und Drang. Kayser se refiere a la caracterización grotesca de los personajes cómicos de Lenz como marionetas llevadas por un poder extraño (2010: 78) y establece una conexión entre la obra de este prerromántico y el teatro de marionetas a causa de la estilización rígida de la gestualidad (Kayser, 2010: 81). Y añade una sugestiva nota al pie en la que señala que el teatro de títeres no es grotesco en sí, sino solo cuando se confunden los límites entre marionetas y personas de carne y hueso: cuando los seres humanos se comportan como títeres, o al contrario los títeres parecen estar vivos (Kayser, 2010: 81$82)^{26}$.

\subsubsection{La esencia de la risa según Baudelaire}

Dos décadas después del prefacio de Hugo, Baudelaire retomaría la noción de lo grotesco en su relación con lo cómico y la caricatura en su relevante ensayo «De la esencia de la risa y en general de lo cómico en las artes plásticas» (1855), donde recuperará algunos de los temas y reflexiones de las que hemos hablado hasta ahora, empezando por la distinción entre un cómico local, limitado, satírico, que denominará «cómico significativo» y un cómico abstracto, revelador de verdades profundas, más cercano a la concepción de

\footnotetext{
${ }^{26}$ Como veremos [3.1.2], Bergson define lo cómico como la percepción de un comportamiento mecánico, antinatural, por parte de un ser humano.
} 
Kayser de lo grotesco, que llama «cómico absoluto». Esta distinción está presente desde el inicio del ensayo, donde distingue entre dos clases de caricatura: las que dependen demasiado del momento histórico y cuyo único valor es para el historiador, y las que «contienen un elemento misterioso, duradero, eterno» (Baudelaire, 2015: 33).

A continuación, pasa a definir el fenómeno de la risa, que vincula a la caída del ser humano (tanto literal como mítica), a la degradación física y espiritual: «en el paraíso terrenal (lo consideremos pasado o porvenir, recuerdo o profecía, como los teólogos o como los socialistas) no tiene cabida la risa» (Baudelaire, 2015: 36). El sentimiento de lo cómico, por tanto, está ligado a la imperfección, a la distancia entre lo ideal y lo real. Por otra parte, la risa es absolutamente dependiente de la cultura y la civilización: si una persona criada lejos de esta, como la Virginia de Chateaubriand, se encontrara con una caricatura, no sabría descifrarla e incluso la recibiría con temor: «mira lo desconocido. Por lo demás, no comprende ni lo que aquello quiere decir ni para qué sirve. Y, sin embargo, ¿ven ustedes ese repentino repliegue de alas, ese estremecimiento de un alma que se oculta y quiere retirarse? El ángel ha sentido que el escándalo se encontraba allí» (Baudelaire, 2015: 38-39) - más adelante señalará que la risa es un fenómeno exclusivamente humano (Baudelaire, 2015: 38) ${ }^{27}$. También describe la risa como un síntoma de inteligencia crítica, y que por tanto crece paralelamente al progreso de la civilización: «no encuentro sorprendente que nosotros, hijos de una ley mejor que las leyes religiosas antiguas, nosotros, discípulos de Jesús, poseamos más elementos cómicos que la pagana antigüedad. Eso mismo es una condición de nuestra fuerza intelectual general» (Baudelaire, 2015: 46-47). En este sentido, los elementos recibidos de la Antigüedad que hoy se consideran cómicos, como las máscaras, los silenos, los príapos, etc., estaban originalmente llenos de seriedad, y es nuestra civilización la que los percibe como cómicos (Baudelaire, 2015: 47).

Como vemos, Baudelaire asocia la risa con la inteligencia y la conciencia crítica distintiva de la época moderna - por eso asegura que la risa de los niños está más cerca de la de los animales que la de los adultos (2015: 48). De ahí su célebre caracterización de la risa como satánica: «lo cómico es uno de los más claros signos satánicos del hombre y una de las numerosas pepitas contenidas en la manzana simbólica» (Baudelaire, 2015:

\footnotetext{
${ }^{27}$ En este punto prefigura la afirmación de Henri Bergson de que lo cómico es exclusivamente humano y social. Como señala Bozal, el caricaturista sitúa al ser humano en su marco social: si el bufón sitúa al ser humano respecto al Ser absoluto, lo ideal, este está representado en el mundo de la caricatura por los jueces, los médicos, la sociedad (Bozal, 2015: 16).
} 
40). Baudelaire considera que la teoría hobbesiana de que la risa viene de la superioridad es acertada pero trivial. La risa es una expresión de superioridad, pero también un síntoma de debilidad: «¿hay síntoma más destacado de debilidad que una convulsión nerviosa, un espasmo involuntario comparable al estornudo, y causada por la visión de la desgracia de otro? Esa desgracia es casi siempre una debilidad de espíritu. ¿Existe un fenómeno más deplorable que la debilidad regocijándose de la debilidad?» (2015: 40). De ahí se deduce que la risa está en el que ríe y no en los objetos de los que se ríe: no hay nada de placentero en alguien que se tropieza y cae y que incluso podría haberse hecho daño, y sin embargo el que lo observa ríe: «encontraremos en el fondo del pensamiento del que ríe cierto orgullo inconsciente. Es el punto de partida: yo no me caigo; yo, camino derecho; yo, mi pie es firme y seguro. No sería yo quien cometería la teoría de mover una cerca cortada o un adoquín que cierra el paso» (Baudelaire, 2015: 41).

Este sentimiento de superioridad es ambiguo, como decimos: encubre una debilidad y, en cierto sentido, es absurdo. Baudelaire relaciona esta superioridad con la locura: «es notorio que todos los locos de los hospitales tienen desarrollada más allá de toda medida la idea de su propia superioridad (...) Observen que la risa es una de las expresiones más frecuentes y más numerosas de la locura» (Baudelaire, 2015: 40). Por eso la risa es un sentimiento contradictorio de placer y dolor: es el resultado de la superioridad del hombre pero también de su miseria, «miseria infinita respecto al Ser absoluto del que posee la concepción, grandeza absoluta respecto a los animales» (Baudelaire, 2015: 44).

Es en este contexto en el que hay situar la risa grotesca: «las creaciones fabulosas, los seres cuya razón, cuya legitimación no puede extraerse del código del sentido común, con frecuencia excitan en nosotros una hilaridad loca, excesiva, que se traduce en desgarramientos y desternillamientos interminables» (Baudelaire, 2015: 49). El poeta distingue entre lo cómico, que es una imitación, y lo grotesco, creación de un mundo aparte, aunque ambas se basan en la idea de superioridad: lo cómico, en la del hombre respecto de otros hombres; lo grotesco, la de la naturaleza sobre los hombres (Baudelaire, 2015: 49). Baudelaire distingue en esta última una percepción profunda de la realidad, a diferencia de la superficial risa de lo cómico: «la risa causada por lo grotesco tiene en sí algo de profundo, de axiomático y de primitivo que se aproxima mucho más a la vida inocente y a la alegría absolutas» (Baudelaire, 2015: 50). Por eso distingue entre lo cómico «significativo» y lo cómico «absoluto», diferencia que ejemplifica con las 
distintas tradiciones nacionales cómicas: en Francia, donde priman la razón y la utilidad, abunda lo cómico significativo, cuyo mayor representante es Molière; es en Inglaterra y España donde triunfa lo cómico absoluto (Baudelaire, 20515: 52-53).

El pasaje más sugestivo del ensayo es, sin duda, en el que, para ilustrar y profundizar en su concepción de lo cómico absoluto, describe una pantomima inglesa basada en la commedia dell'arte:

Pierrot no era ese personaje pálido como la luna, misterioso como el silencio, ligero y mudo como la serpiente, derecho y largo como una potencia, ese hombre artificial, movido por singulares resortes (...) El Pierrot inglés llegaba como la tempestad, caía como un fardo y, cuando reía, su risa hacía temblar la sala; esa risa se asemejaba a un alegre trueno. Era un hombre pequeño y grueso, que había aumentado su prestancia con un traje cargado de lazos que cumplían alrededor de su jubilosa persona la función de las plumas y del plumón alrededor de los pájaros o de la piel en torno a los angoras. Sobre la harina de su rostro, había pegado crudamente, sin gradación, dos enormes placas de rojo puro. La boca estaba agrandada por una prolongación simulada de los labios valiéndose de dos bandas de carmín, de forma que, cuando reía, la jeta parecía extenderse hasta las orejas (Baudelaire, 2015: 55)

El rasgo definitorio de lo cómico grotesco es, según Baudelaire, la violencia, lo que expresa como «el vértigo de la hipérbole» (2015: 55). Significativamente, la pieza termina con el espectáculo sanguinoliento de la decapitación de Pierrot: «pero he aquí que, súbitamente, el torso decapitado, movido por la monomanía irresistible del vuelo, se enderezaba, escamotaba victoriosamente su propia cabeza, como un jamón o una botella de vino, y, bastante más avisado que el gran Dionisio, ¡se la metía en el bolsillo!» (Baudelaire, 2015: 56). Como vemos, la descripción de Baudelaire hace hincapié en la violenta vitalidad del actor, en su corporalidad y la vistosidad de su atuendo, en los gruesos contrastes de su maquillaje; también en la violencia obscena pero también absurda de su decapitación. El poeta añade otra descripción que ayuda a comprender este «vértigo» con el que ha definido la pieza: esta comienza en calma; los personajes se comportan como personas normales y súbitamente surge el vértigo y se apodera de los actores, «que demuestran claramente que se sienten introducidos por la fuerza en una existencia» y realizan las acostumbradas cabriolas: «todos sus gestos, todos sus gritos, todas sus caras dicen: el hada lo ha querido, el destino nos precipita» (Baudelaire, 2015: 
57). En esta nueva descripción, como vemos, aparecen la enajenación del personaje cómico, así como la importancia de la gestualidad y el uso de su cuerpo.

En resumen, en cierto modo Baudelaire recoge algunos de los motivos que venimos tratando: la concepción de un cierto tipo de humor como capaz de transmitir una cierta visión profunda de la realidad, visión que es dependiente del espíritu crítico y escindido de la Modernidad; y, sobre todo, el imaginario de la commedia dell'arte con el que se ejemplifica este humor grotesco, primario, no exento de elementos terroríficos o cuanto menos siniestros - en este sentido, también usa como ejemplo algunos cuentos de Hoffmann (Baudelaire, 2015: 58-60), reforzando esta vinculación entre lo grotesco cómico y lo siniestro.

\subsubsection{Reflexión general sobre lo grotesco y lo cómico}

A lo largo de todas estas páginas nos hemos encontrado constantemente con esta cercanía entre lo cómico y lo inquietante, con la muerte, la locura, la violencia, y otras experiencias que dan a lo cómico un carácter profunda y perturbadoramente ambiguo. Hemos visto cómo, en el pensamiento griego, la risa era relacionada con la enajenación, con la pérdida de control del propio cuerpo, con la violencia y la muerte. También en la Edad Media las fiestas carnavalescas mezclaban la alegría de la risa con la violencia caótica, la locura santa con la muerte y el pecado. En esta cosmovisión que, como hemos apuntado, no ve contradicción en unir lo sagrado con lo bajo, no puede resultar extraña ni fuera de lugar esta mezcla. Sólo en una época, la nuestra, en la que en nombre de la razón se reprimen estos aspectos oscuros de la realidad y el ser humano, puede resultar inquietante su retorno en la forma de lo cómico o lo terrorífico - y no es extraño que sea el Romanticismo, como reacción contra la Ilustración, el que reivindique estos elementos.

En todo caso, creemos suficientemente fundada la profunda unión subyacente en las distintas manifestaciones artísticas y culturales que Connelly acoge como distintas especies de lo grotesco: el capriccio, lo cómico carnavalesco y lo terrorífico. Si lo grotesco se basa en la deformación, la exageración, la distorsión de lo real (Connelly, 2015: 305), es lógico que la estética de lo monstruoso se vincule con lo cómico a través de la categoría de lo feo (Connelly, 2015: 236), como vio Victor Hugo. El volumen coordinado por Umberto Eco acerca de la Historia de la fealdad (2007) así lo atestigua: en sus páginas encontramos juntos lo infernal, lo diabólico, lo cómico y burlesco, la 
brujería, etc. ${ }^{28}$ Además, en el siglo XVI lo monstruoso se asocia con la fantasía desatada del artista en las diableries, las grylles y las droleries (Connelly, 2015: 239-240) que inspiran al Bosco y a Brueghel. La cercanía de lo cómico con el capriccio o el grotesco ornamental también queda atestiguada en la estética romántica con la importancia del arabesco, o las referencias de Schlegel al «infantil abigarramiento», al «gusto por el adorno y el aderezo» y la «chispeante frivolidad» en el Wilhelm Meister, o las de Jean Paul a la profusión, al abigarramiento y los contrastes sensoriales necesarios para la percepción cómica ${ }^{29}$. En la sensorialidad propia de lo ornamental se manifiesta también la materialidad y la carnalidad propias tanto de lo cómico carnavalesco y de lo terrorífico que venimos destacando.

En resumen, estos estrechos vínculos entre las diferentes especies de lo grotesco ofrecen un sugestivo punto de partida para una reflexión general de lo cómico a la que deberemos volver en el capítulo quinto. Para Frances Connelly, lo grotesco es, ante todo, un Spielraum, un espacio lúdico, intersticial, liminal (2015: 42) [ver 5.2. para el aspecto lúdico de lo cómico]. Lo grotesco juega con la contradicción, con la combinación antinatural, con el límite: lo grotesco ingenioso cuestiona las formas y convenciones de la representación visual y literaria; lo grotesco subversivo cuestiona los roles, convenciones y jerarquías sociales; lo grotesco traumático amenaza directamente los límites de nuestra identidad, las fronteras entre lo humano y lo monstruoso ${ }^{30}$ (Connelly, 2015: 47).

Lo grotesco está por definición generado culturalmente, porque juega con los límites establecidos socialmente de lo que es conocido, propio o normal (Connelly: 2015: 25); pone de relieve estos límites, haciendo visibles los contornos de conocido y mezclándolo con lo extraño y lo inesperado (Connelly, 2015: 42). Lo grotesco (y lo cómico, por tanto) es una experiencia de la Otredad: lo feo, lo carnal, lo irracional, lo

\footnotetext{
${ }^{28}$ También lo camp, estética en la que nos centraremos en el capítulo dedicado a la narrativa de Eduardo Mendicutti.

${ }^{29}$ En este sentido, los artistas superrealistas como Magritte o Dalí, que Kayser señala como herederos del grotesco también muestran una preferencia notable con el juego onírico, el chiste visual, etc., al lado de la perversidad y lo provocador (Connelly, 2010: 284)

${ }^{30}$ Connelly relaciona lo grotesco terrorífico también con lo abyecto según lo define Julia Kristeva: si lo monstruoso es la combinación antinatural, lo abyecto es una relación de horror con el cuerpo en descomposición, con sus flujos y secreciones: «Cuando lo monstruoso amenaza con cazarnos y fagocitarnos, lo abyecto amenaza con salpicarnos, mezclarse con nosotros de cierta manera que no es deseable, que es repulsiva» (Connelly, 2015: 234-235). Lo abyecto es terrorífico porque nos recuerda nuestra materialidad: «Si lo carnavalesco produce risa ante las vulnerabilidades del cuerpo viviente y ostenta las convenciones sociales que intentaba ocultar, lo abyecto provoca un repentino horror, enfrentándonos a la mortalidad del cuerpo» (Connelly, 2015: 285)
} 
extranjero. Del mismo modo, lo grotesco está estrechamente unido a lo femenino en oposición a lo masculino: lo terrenal y lo carnal frente a lo cultural, lo abstracto, lo racional (Connelly, 2015: 25-26). Kayser menciona el origen de lo grotesco en el arte oriental, azteca, germánico y la Comedia Antigua (2010: 27); es decir, lo extranjero. Por tanto, lo grotesco y lo cómico se ubican también en los márgenes y límites del arte y la cultura oficiales: aparecen en las formas menores como la ornamentación, los grabados, la caricatura; la cultura popular y sus fiestas, los géneros literarios menores, etc. Esta posición de lo grotesco y lo cómico como lúdico, como juego frívolo, también supone una posición marginal respecto a la seriedad de la religión, la filosofía o las ciencias. Su representación de la otredad es, no obstante, ambigua: puede suponer una amenaza desde los márgenes de la cultura hacia la oficialidad, pero también puede ser excluyente, precisamente al expulsar los comportamientos desviados o marginales del seno de lo socialmente aceptado. Esto se relaciona con el interés de antropólogos como Mary Douglas o Victor Turner por lo liminar como modo de definir y reforzar las normas culturales: muchas culturas tradicionales incorporan períodos de desorden, inversión social, etc., análogos a los carnavales medievales, que sirven para reafirmar la norma (Connelly, 2015: 49) [ver 5.2, 5.4]. Reencontraremos todas estas características de lo cómico (su fundamental ambigüedad y su cercanía a lo inconsciente y lo oculto, su carácter marginal frente a la cultura oficial y la seriedad de la filosofía y la moral, su posible uso excluyente o subversivo, etc.) a lo largo de los capítulos siguientes.

\subsection{Conclusiones parciales al estudio histórico}

En resumen, podemos extraer de este extenso y aun así fragmentario recorrido por el pensamiento de lo humorístico varias lecciones con las que guiarnos en nuestras siguientes investigaciones. En un sentido, la época contemporánea ha heredado de los siglos XVIII y XIX la concepción del humor como un fenómeno discursivo, ligado al lenguaje y la razón. Sobre todo, la reflexión de los moralistas ingleses, principalmente el conde de Shaftesbury, que culmina en la de Friedrich Schlegel sobre la ironía, da lugar a una mitificación del humor como ethos escéptico, descreído, objetivo frente a las parcialidades del entusiasmo y el fanatismo [ver 3.4.1, 3.4.2]. Mitificación que tiene que ver con una cierta concepción progresiva de la historia y la sociedad, según la cual 
estadios de la cultura más evolucionados son más inteligentes y por tanto más dados a la risa cínica, en oposición a la risa vulgar de las culturas y grupos sociales menos sofisticados. Esta influencia se combina, por supuesto, con la tradición de la caricatura y la literatura y la prensa satíricas del humor como medio de oposición a las convenciones sociales hipócritas, al abuso de los poderosos, etc. - en general, el humor se extiende a partir del siglo XVIII como arma polémica, sea de signo progresista o conservador, en una época, claro, en que las democracias liberales dan un espacio cada vez más relevante a la pugna ideológica.

Esta concepción de lo humorístico difiere enormemente de la visión antigua, medieval y renacentista de la risa, anclada en lo festivo, lo sagrado o diabólico y lo corporal. Sus tradiciones, a través de lo grotesco, pervivirán, por supuesto, en el arte y la literatura vanguardistas, pero sobre todo en la nueva cultura popular de masas y sus formas particulares: en el cómic, en la comedia del cine mudo y el lenguaje de la animación, en los cabarés y music-halls, los programas televisivos y los clubes de comedia de stand-up, y reencontraremos el grotesco al hablar de la cultura camp en el capítulo correspondiente [6.1.2]. Sobre todo, aunque estas épocas están en este sentido tan lejos, nos recuerdan la ambigüedad fundamental de lo cómico, su lado oscuro y desestabilizador, y potencialmente agresivo, y que, como veremos, desafía la concepción eminentemente positiva y optimista del humor que impera en la época actual. No es que estos aspectos hayan sido desatendidos en el siglo XX: encontraremos en el tratado de Bergson una definición de la risa como herramienta de sanción social, y Koestler la ligará al impulso agresivo del ser humano - significativamente, este tipo de aproximaciones serán rechazadas por el grueso de investigadores. Y los rasgos inquietantes de la experiencia cómica, la emergencia a través de ella de lo Otro, de lo abyecto y de lo reprimido, será recuperado principalmente por la tradición psicoanalítica que, a partir del clásico libro de Freud sobre la relación del chiste con los procesos inconscientes, se interesará por lo cómico. 
II. MARCO RETÓRICO-HERMENÉUTICO PARA EL ANÁLISIS DE LOS DISCURSOS HUMORÍSTICOS 


\section{LAS CIENCIAS DEL HUMOR EN EL SIGLO XX Y EL XXI}

El pensamiento del siglo XX sobre el humor se caracteriza fundamentalmente por ser científico en un sentido más o menos contemporáneo. Deja de ser en su mayor parte reflexiones pasajeras sobre la risa y lo cómico en conexión con otros asuntos filosóficos, estéticos o morales, para conformar un corpus más o menos sistemático dentro del ámbito de disciplinas diversas: la teoría literaria, la lingüística (y posteriormente la pragmática), la psicología, la sociología... Es así como podemos hablar hoy en día de una disciplina académica multidisciplinar de estudios sobre el humor, que incluso cuenta con varias revistas internacionales surgidas a partir de los años ochenta y noventa, como HUMOR. International Journal of Humor research o Humoresques. Es por este carácter más sistemático y en cierto modo más teórico en un sentido actual que incluimos este capítulo como transición entre la parte histórica de nuestro trabajo y el marco teórico propiamente dicho: funciona al mismo tiempo como el capítulo final a dicho recorrido histórico y como un estado de la cuestión. Es por ello que también introduciremos en la exposición de las diversas teorías y puntos de vista anotaciones que preparen la discusión propiamente teórica que abordaremos en los dos capítulos siguientes.

\subsection{Humor y psicoanálisis}

El siglo se abre prácticamente con dos de los libros más importantes y sugerentes en la historia del pensamiento sobre el humor: el Ensayo sobre la significación de lo cómico del filósofo francés Henri Bergson, publicado en 1900, y El chiste y su relación con lo inconsciente, del padre del psicoanálisis, Sigmund Freud, aparecido apenas cinco años después. Prácticamente todo estudioso del humor posterior ha tenido que posicionarse a favor o en contra o al menos hacer alguna mención a estos dos libros, que paradójicamente son considerados menores en la producción total de sus autores respectivos. Aunque en realidad muchos de estos autores ofrecen una comprensión bastante limitada de la complejidad de estas obras, lo cierto es que ambas propusieron algunas de las ideas que más rendimiento tendrían en las décadas posteriores: Bergson se adelantó en cierto modo a las teorías sociológicas, al insistir en la función social correctiva que está en el origen de toda comicidad y Freud dio pie, con su análisis de las técnicas formales del chiste, al 
análisis lingüístico del humor. Sin embargo, como decimos, lo cierto es que los dos libros muchas veces son reducidos a afirmaciones bastante esquemáticas (lo cómico como algo mecánico incrustado en lo viviente, en el caso de Bergson, y la risa como una descarga de energía nerviosa, en el de Freud) que no hacen justicia a las valiosas y complejas aportaciones que realizan. Por ello merece la pena que hagamos una exposición más o menos detenida de cada uno de los libros, adelantando así algunas de las ideas que serán fundamentales para nuestra comprensión del fenómeno cómico.

\subsubsection{Antecedentes: la teoría del alivio}

Tanto Bergson como Freud responden o son continuación de las teorías decimonónicas de la risa que han terminado por ser conocidas como «teorías del alivio». Esta teoría, cuyos mayores exponentes son Alexander Bain y Herbert Spencer, se desarrolla en el contexto de la filosofía materialista y las ciencias positivistas de la fisiología y la psicología de finales del siglo XIX. Frente a la teoría de la superioridad y la de la incongruencia, este nuevo enfoque omite el contexto social de la risa y su proceso cognitivo para centrarse en la risa como un fenómeno emocional que tiene su raíz en la fisiología del sistema nervioso y se manifiesta corporalmente (Billig, 2005: 86). En los siglos XVIII y XIX se pensaba que lo que circulaba por los nervios eran fluidos líquidos o gaseosos: de ahí la metáfora tan utilizada de la risa como una “válvula de escape” similar a la de una olla a presión que evita que esta explote (Morreall, 2009: 15).

Para Alexander Bain, el origen de la risa está efectivamente en la incongruencia, aunque rechaza este término al no ser todas las incongruencias motivo de risa; según Bain, no hay una incongruencia sino una degradación del objeto cómico, sea una persona o una idea (Billig, 2005: 96). La risa supone un aumento de energía producido al ser liberado el sistema nervioso del individuo de ciertas restricciones: la degradación de los objetos cómicos permite una relajación moral o intelectual del que ríe: «if suddenly the dignified, solemn and stately are degraded, we delight in being momentarily released from our habitual constraint. A surge of freed energy passes through the body and we laugh like the schoolchildren rushing out of the school gates» (Billig, 2005: 97). La risa, por tanto, supone una momentánea rebelión contra la autoridad - claro que Bain no consideraba esto necesariamente positivo (Billig, 2005: 98). 
Más conocida es la teoría de Herbert Spencer, que escribió un artículo sobre la fisiología de la risa en respuesta a la propuesta por Bain. En primer lugar, Spencer rechaza la idea de este de la degradación de la risa y la sustituye por la noción de una «incongruencia descendente»: concretamente, la risa es provocada cuando algo que nos parece grande es en realidad pequeño (Billig, 2005: 99) - como es evidente, ambas presentan el mismo proceso, pero el concepto de «degradación» tiene un matiz moral que Spencer parece querer negar. Además, Spencer entiende el mecanismo fisiológico que da lugar a la risa al revés de como lo hace Bain: considera que las emociones implican algún tipo de acumulación de energía que ha de encontrar su salida en el movimiento corporal: así, el miedo provoca la huida, la ira deriva en actos violentos, etc. La risa constituye un caso especial, porque la activación de los músculos implicados no deriva en ningún movimiento efectivo, sino que su única función es la de la descarga de energía por sí misma (Morreall, 2009: 16-17).

La teoría del humor como “mero” alivio tendrá gran fortuna en las teorías posteriores, sobre todo en las psicológicas. Desde este enfoque, el humor se verá como algo intrínsecamente beneficioso para la salud física y mental, y, al centrarse solo en los procesos individuales, evita tener en cuenta las posibles consecuencias sociales. En todo caso, un aspecto sugestivo de esta explicación es que implica que, en el fenómeno cómico entero, en toda la construcción que prepara la descarga de la risa, se da una acumulación de energía nerviosa. Esta idea, como veremos, tendrá cierta relevancia en algunas explicaciones psicoanalíticas, que ven el humor como un mecanismo para manejar la angustia.

\subsubsection{Bergson: La risa. Ensayo sobre la significación de lo cómico}

\subsubsection{Consideraciones preliminares sobre la risa}

Si bien Bergson se sintió atraído de joven por la filosofía de Herbert Spencer, pronto se opuso a su excesivo positivismo (Billig, 2005: 112). El espiritualismo de Bergson no buscaba desdeñar los avances de la ciencia, pero sí defender la irreductibilidad de lo viviente, su espontaneidad, a la necesidad de la ciencia mecanicista (Graíño Ferrer, 2016: 18). Desde esta perspectiva, Bergson no se acercará a la risa como reacción fisiológica a un estado psicológico: su objeto de estudio será lo cómico, lo risible, su mecanismo y su 
significación social. A Bergson le interesa el fenómeno de lo cómico en lo que puede revelar acerca de la sociedad, el arte y la imaginación: «¿Cómo no habría de instruirnos la fantasía cómica acerca del modo en que trabaja la imaginación humana y, más concretamente, la imaginación social, colectiva, popular?» (Bergson, 2016: 36). Como veremos en estas páginas, el estudio de Bergson se mueve entre el enfoque sociológico, la crítica literaria, la teoría del arte, e incluso adelanta algunas ideas que podrían encajar sin dificultad en una teoría psicoanalítica - y, de hecho, Freud citará el libro de Bergson en su propio estudio.

Bergson comienza su ensayo haciendo tres observaciones preliminares muy sugestivas. En primer lugar, señala que la comicidad es siempre humana: siempre nos reímos de algo relacionado con lo humano; si nos reímos de un animal es porque proyectamos en él características propias de nuestra especie, y cuando lo hacemos de un objeto, es en tanto que creado por el ser humano (Bergson, 2016: 36). El segundo principio es aún más interesante: lo cómico necesita de la indiferencia hacia su objeto para surgir, por lo que su mayor enemigo es la emoción: en una sociedad puramente racional, ya no se lloraría, pero se seguiría riendo, y, al contrario, en una sociedad que fuera totalmente emocional no se conocería la risa (Bergson, 2016: 37). En este punto, como vemos, Bergson sigue la línea del conde de Shaftesbury y Friedrich Schlegel y todos aquellos para quienes lo cómico ofrece una distancia que hace que hechos dramáticos puedan ser percibidos como cómicos. Según Bergson, lo cómico es una ausencia total, no tanto de emociones, como de simpatía y piedad: «para producir todo su efecto, la comicidad exige algo así como una anestesia del corazón» (2016: 37).

Bergson, como decimos, no es especialmente original en este punto, pero sí lo es el énfasis que le da al hecho de que la ausencia de gravedad e implicación emocional necesaria para la risa es cuestión del punto de vista que se ofrece del hecho, y no tanto del hecho en sí: «Píntenme un defecto todo lo leve que ustedes quieran: si lo presentan de manera que despierte mi simpatía, mi temor o mi piedad, se acabó, no podré reírme de él. Elijan en cambio un vicio profundo e incluso generalmente odioso: podrán tornarlo cómico si consiguen, primero, mediante los artificios adecuados, hacer que me deje frío» (Bergson, 2016: 128). Al mismo tiempo, cuestiona hasta qué punto nos reímos solo de las cosas leves, o si no será precisamente el tratamiento trágico o cómico el que hace que percibamos algo como grave o divertido (Bergson, 2016: 125). En este sentido, señala algunas de las técnicas de las que un comediógrafo se puede servir para silenciar los 
afectos del espectador, que fundamentalmente consisten en evitar darle al personaje una profundidad psicológica con la que se pueda empatizar: por ejemplo, se puede aislar el sentimiento que se le atribuye a un personaje y que ha de ser visto como cómico, de modo que no entre en relación con el resto de su personalidad, o bien el autor se puede centrar en los aspectos más superficiales de la acción, sin entrar en las motivaciones o consecuencias psicológicas (Bergson, 129-130).

La tercera aclaración preliminar, y que fundamenta en gran parte la base de la explicación bergsoniana de lo cómico, es que la risa es un hecho social: nos reímos en grupo, «la risa esconde una segunda intención de avenencia, diría casi de complicidad, con otros que ríen, reales o imaginarios» (Bergson, 2016: 39). Por tanto, para comprender el fenómeno de la risa y lo cómico en su totalidad hay que situarla en su contexto, la sociedad, y sobre todo dilucidar su función en la misma (Bergson, 2016: 39).

\subsubsection{El mecanismo de lo cómico}

El mecanismo cómico básico que propone Bergson no deja de ser una versión muy concreta de las teorías de la incongruencia y la superioridad: nos reímos de las faltas en el comportamiento del otro; concretamente, de un defecto de flexibilidad, de capacidad de adaptación, «una rigidez de mecanismo ahí donde esperábamos encontrar la atenta agilidad y la viva flexibilidad de la persona» (Bergson, 2016: 41). Aquello que hace que aparezca esta rigidez puede ser un obstáculo externo (una cáscara de plátano que hace que un transeúnte se resbale y caiga) o, más comúnmente, un defecto interior de la persona: por eso la figura cómica más generalizada es el despistado o distraído, aquel que, como Don Quijote, se deja llevar por una sola idea fija sin atender a todo lo demás (Bergson, 2016: 42-43).

El esquema cómico de la rigidez mecánica obstaculizando lo viviente puede parecer, paradójicamente, excesivamente rígido y estrecho, como se le ha criticado muchas veces, pero lo cierto es que, además de estar en íntima conexión con la filosofía general de Bergson, permite explicar de una manera elegante muchos mecanismos generalizados de lo cómico. Por ejemplo, la relación entre la fealdad y lo cómico: la fealdad solo es cómica cuando no es "natural”, sino que está deformada, agrandada, cuando nos parece el resultado de una cierta rigidez de hábito: «un tic consolidado, una mueca congelada» (Bergson, 2016: 50). Por eso podemos decir que la exageración caricaturesca de gestos y defectos corporales funciona como reflejo del carácter moral de 
una persona: el caricaturista extrae y agranda estos rasgos y muecas para expresar los defectos del carácter (Bergson, 2016: 51).

¿Cuál es la razón por la que nos resultan cómicas estas caricaturas, o los movimientos mecánicos o exagerados de los payasos y actores cómicos? Porque nuestra imaginación percibe el cuerpo como guiada por el alma, la materia por el espíritu: este es «infinitamente flexible, eternamente móvil», mientras que la materia es obstinada, se mueve por inercia, de ahí que una persona nos pueda parecer cómica al presentar como arrastrada por la materia «en lugar de renovada constantemente con el contacto con un ideal vivo» (Bergson, 2016: 53). Los movimientos mecánicos de un títere o los tics repetitivos de un orador se nos vuelven cómicos cuando contradicen la perpetua movilidad del espíritu que supuestamente los anima. Este es el fundamento de la imitación: los gestos habituales de alguien se nos vuelven cómicos cuando una persona los imita, porque el ser imitables contradice nuestra presuposición de que el cuerpo y sus movimientos es la expresión de la individualidad de cada uno: «imitar a alguien es extraer la parte de automatismo que este ha dejado introducirse en su persona» (Bergson, 2016: 54-56).

Como vemos, el esquema bergsoniano es capaz de explicar muchos recursos típicamente cómicos, como el disfraz, que caracteriza la vestimenta como una rigidez impuesta al cuerpo, una imposición exterior al individuo (Bergson, 2016: 60) ${ }^{31}$. También el extendidísimo recurso de visibilizar y enfatizar la materialidad del cuerpo y cómo sus torpezas y debilidades se convierten en obstáculos para las intenciones del alma (Bergson, 2016: 67-68). También podemos aplicar esta materialidad a muchos otros ámbitos, como el de «la forma queriendo primar sobre el fondo, la letra contestando al espíritu» (Bergson, 2016: 69). Así se explica, por ejemplo, el mecanismo cómico por el que un juez o un médico le dan más importancia a su propia profesión, a la aplicación literal de la ley o el tratamiento sin más contemplaciones y actúan por tanto «como si la salud y la justicia fuesen poca cosa, siendo lo esencial que haya médicos, abogados y jueces, y que las formas exteriores de la profesión sean escrupulosamente respetadas» (Bergson, 2016: 70).

\footnotetext{
${ }^{31}$ Tanto en nuestro estudio de las novelas de Eduardo Mendicutti como en el análisis de la representación de la masculinidad en la comedia Friends tratremos, desde la perspectiva de Judith Butler o la sociología de la interacción de Erving Goffman, pero también desde un análisis de lo cómico desde la perspectiva metafórica de lo teatral [5.2, 5.3, 5.4] el género como una performance impuesta socialmente.
} 
Bergson desarrolla tres tipos de mecanismos cómicos: la repetición, la inversión y la interferencia de series (2016: 94):

i. La repetición puede ejemplificarse con el juego del diablo que sale de su caja mediante un resorte cada vez que se le intenta meter en ella, lo que equivale al «conflicto entre dos obstinaciones, en el que una de ellas, puramente mecánica, termina normalmente por ceder a la otra que se divierte» (Bergson, 2016: 81). En la comedia, este resorte es de tipo moral: una idea o una obsesión se expresa, se reprime, vuelve a expresarse, etc. Es el mecanismo básico de la comedia de caracteres, en que los protagonistas (el avaro, el misántropo, etc.) se ven llevados por una idea obsesiva (Bergson, 2016: 94-95).

ii. La inversión corresponde a la tradición del mundo al revés (Bergson, 2016: 97).

iii. Con la expresión «interferencia de series» Bergson se refiere a las situaciones ambiguas, de doble sentido: «una situación es siempre cómica cuando pertenece al mismo tiempo a dos series de acontecimientos absolutamente independientes, y puede interpretarse a la vez en dos sentidos del todo distintos (...) Es ese balanceo de nuestro espíritu entre dos interpretaciones opuestas lo que primero aparece en la diversión que nos produce» (Bergson, 2016: 99). El ejemplo más claro de este tipo de situaciones es el de la comedia de equívocos y enredos. La interferencia de series es el mecanismo que más claramente se asimila a lo que la teoría posterior llamará «bisociación» [ver 3.3.1.1 y 5.3].

Bergson también muestra cómo estos mecanismos también se pueden aplicar a la comicidad de las palabras: en este caso, el filósofo habla de la distracción del lenguaje mismo, la imposición de lo mecánico del instrumento que un espíritu vivo intenta usar como expresión de su flexibilidad (Bergson, 2016: 103-104). Es muy sugerente la caracterización que Bergson hace del dicho ingenioso como una forma «dramática» de pensar sobre el lenguaje: «en lugar de servirse de sus ideas como de símbolos indiferentes, el hombre ingenioso las ve, las oye y, sobre todo, las hace dialogar entre sí como personas. Las pone en escena, y también él mismo se pone un poco en escena» (Bergson, 2016: $105)^{32}$. Bergson explica de este modo recursos cómicos como aplicar una frase hecha o

\footnotetext{
${ }^{32}$ En su momento [5.3] exploraremos las implicaciones teóricas y hermenéuticas de esta dramatización del lenguaje.
} 
estereotipada a una idea absurda, o su transposición a un contexto totalmente distinto, o la aplicación de un vocabulario técnico de ciertos oficios como el derecho a asuntos mundanos, o ignorar el sentido figurado de una frase y tomarla literalmente (Bergson, 2016: 116-120).

\subsubsection{La función social de la risa}

Como vemos, el esquema de la mecanización tiene variadas aplicaciones a recursos cómicos muy frecuentes. Pero ¿cuál es la razón social de este mecanismo, si según Bergson lo cómico es siempre un hecho social? Para Bergson, la función básica de la risa es el de la corrección:

La comicidad es esa faceta de la persona que la hace parecer una cosa, ese aspecto de los acontecimientos humanos que imita, por una rigidez del todo particular, al mecanismo puro y simple, al automatismo, al movimiento sin vida finalmente. Es expresión, por tanto, de una imperfección individual o colectiva que requiere una corrección inmediata. La risa es esa misma corrección. La risa es un cierto gesto social que subraya y reprime una cierta distracción particular de los hombres y de los acontecimientos (Bergson, 2016: 93)

Bergson se adelanta, de este modo, a las investigaciones sociológicas que décadas más tarde estudiarán cómo la risa sirve para la cohesión de un grupo social mediante la censura de ciertos comportamientos [ver 3.3.2] - y recupera cierta tradición que defiende este uso de la risa y lo ridículo como correctivo, como vimos en el caso de Platón y la retórica antigua. Pero, además, la forma que toma la explicación de Bergson, que toma una descripción general de la función correctiva de la risa y la aplica a un esquema muy concreto, el de la denuncia de una cierta mecanización, inflexibilidad, falta de autonomía, etc., revela el contexto ideológico más amplio de lo que en su época se podía considerar como "bueno para la sociedad": «cada uno de sus [de la sociedad] miembros tiene que estar atento a lo que le rodea, amoldarse a su entorno, evitar, en suma, encerrarse en su carácter como en una torre de marfil» (Bergson, 2016: 125). Bergson deja traslucir aquí una cierta ideología burguesa de la necesidad del individuo no solo de tener cierta sociabilidad, sino de ser flexible, saber adaptarse, aplicarse con éxito a las circunstancias, etc. [ver 3.4; 7.1]

Bergson, como vemos, explica la risa en términos evolutivos, de “ecología social”, en unos términos que distan mucho de ser de índole estrictamente moral. De hecho, 
reconoce que lo que nos resulta cómico no tiene nada que ver con la moralidad, con la censura de los vicios, sino con esta sociabilidad: por ejemplo, la honestidad del Alcestes de Moliére es en sí una virtud, pero nos resulta cómica cuando se vuelve un hábito rígido que impide relacionarse con normalidad al personaje: lo que nos hace reír, entonces, no es la inmoralidad sino la insociabilidad ${ }^{33}$ (Bergson, 2016: 126-127). Bergson insiste en la amoralidad, cuando no la crueldad, de la risa: ya hemos comprobado cómo insiste en la necesidad de una falta de piedad para que una situación se perciba como cómica. Por eso, no se puede decir que esta función de la risa de mejorar el funcionamiento de una sociedad sea totalmente benévola: la risa no siempre acierta porque es un acto irreflexivo y mecánico que «castiga ciertos defectos más o menos como la enfermedad castiga ciertos excesos, golpeando inocentes, salvando culpables, buscando un resultado general y no pudiendo hacer a cada caso individual el honor de examinarlo separadamente» (Bergson, 2016: 166-167).

No debe sorprendernos, por tanto, que Bergson haya sido criticado posteriormente, al considerar que siempre existe un cierto aspecto negativo en lo cómico: «la risa (...) tampoco tiene que ser buena. Tiene por función intimidar humillando. Y no lo conseguiría si la naturaleza no hubiese dejado, a tal efecto, en los mejores hombres, un pequeño fondo de maldad o cuando menos de malicia» (Bergson, 2016: 167). La risa, por tanto, depende de cierta crueldad inherente al hombre, conectando de este modo con las teorías de la superioridad de Platón o Hobbes: «quien ríe entra inmediatamente dentro de sí, se afirma a sí mismo más o menos orgullosamente, y tendería a considerar a las otras personas como marionetas de la cuales él maneja los hilos» (Bergson, 2016: 167). Nótese que estas últimas consideraciones implican que la risa no conlleva simplemente una «anestesia del corazón», una ausencia de emoción, sino más bien un cierto placer que tiene que ver con la crueldad, un sentimiento de superioridad a partir de la humillación del otro. En la sección 5.5 exploraremos el carácter frívolo y cruel del pathos cómico y sus implicaciones ideológicas.

\subsubsection{La risa entre el arte y la vida}

Otro aspecto interesante del ensayo de Bergson es que plantea una cuestión que ocupará a muchos teóricos de la comedia y lo cómico: la distinción entre la risa como un fenómeno mundano, ordinario, y lo cómico como fenómeno estético y artístico. Para Bergson lo

\footnotetext{
${ }^{33}$ Ver las secciones 3.3.2; 8.3, donde se explora el sentido del humor como signo de cohesión de grupo.
} 
cómico se ubica en un nivel intermedio entre la función de perfeccionamiento social de la risa y el carácter desinteresado de la obra de arte, «pues lo cómico nace en el preciso instante en el que sociedad y persona (...) comienzan a tratarse a sí mismas como obras de arte (...) en una zona neutra en la que el hombre se ofrece simplemente como espectáculo al hombre» (Bergson, 2016: 48). Esta es una posición parecida a la que décadas después tomará el teórico literario Hans R. Jauss, quien se plantea no solo si el arte cómico presenta intereses mundanos, sino también hasta qué punto la risa supone una estetización de la vida cotidiana (Jauss, 1986: 205) [ver 5.3; 6.2; 6.3; 7.3]. Para Bergson toda comicidad está a caballo entre el arte y la vida real: si bien la risa tiene una significación social, no nos podemos reír de personas reales si antes no las contemplásemos como quien asiste a un espectáculo (para poder suspender nuestra simpatía por ellas); por otro lado, incluso en el teatro, donde se supone que la risa es totalmente desinteresada y alejada de la vida práctica, esta contiene siempre el placer de la humillación (Bergson, 2016: 125).

Por tanto, la discusión de lo cómico lleva a Bergson a exponer su propia teoría del arte en general y el arte dramático en particular. Para el filósofo francés, el arte, al ofrecernos la posibilidad de contemplar la naturaleza desinteresadamente, sin las urgencias de la vida cotidiana que nos hace relacionarnos con ella a través de un velo de necesidades y etiquetas generalizadoras, nos permite obtener una visión más profunda de la realidad natural y social (Bergson, 2016: 135-139). Y el arte dramático en concreto trae al primer plano el encuentro del hombre con el hombre y los conflictos y pasiones que surgen de este encuentro; conflictos que, prohibidos por las reglas que garantizan la existencia de la sociedad, normalmente permanecen ocultos:

Si la Tierra fuese un ser vivo, como pretendía la mitología, quizá le gustaría, mientras descansa, soñar con esas explosiones bruscas en las que, de golpe, vuelve en sí para recuperar lo que en ella hay de más profundo. Un placer de dicho tipo es el que nos proporciona el drama. Bajo la vida tranquila, burguesa, que la sociedad y la razón nos ha compuesto, acude a remover en nosotros algo que afortunadamente no estalla, pero de lo que nos hace sentir la dimensión interior. Ofrece a la naturaleza su venganza sobre la sociedad (Bergson, 2016: 141)

El arte dramático, y sobre todo la tragedia, a pesar de la opinión común de que aspira a lo universal, presenta siempre lo singular y lo individual: Hamlet es un individuo singular; lo universal es el juicio que establecemos sobre la existencia humana a partir de su 
tragedia (Bergson, 2016: 143). El poeta trágico es capaz de presentar personajes llenos de vida «porque son el poeta mismo, el poeta multiplicado, el poeta profundizando en sí mismo en un esfuerzo de observación interior tan potente que capta lo virtual en lo real y retoma, para hacer una obra completa, lo que la naturaleza dejó en él en estado de esbozo o de simple proyecto» (Bergson, 2016: 147). La comedia, por el contrario, aspira a la generalidad, es un arte de «superficies» que se basa en observaciones externas, puesto que si profundizara en sus asuntos y personajes sentiría una simpatía por ellos que es incompatible con la risa:

Por mucha curiosidad que el poeta cómico sienta por las ridiculeces de la naturaleza humana, no acudirá, creo yo, a buscar las suyas propias. Además, no las encontraría: no somos risibles más que por el lado de nuestra persona que se hurta a nuestra consciencia. (...) Por el mismo motivo, la observación adquirirá un carácter de generalidad que no puede tener cuando se la dirige hacia uno. Pues, al instalarse en la superficie, solo alcanzará la apariencia de las personas, que es por donde muchas de ellas se tocan y son capaces de parecerse (Bergson, 2016: 147-148)

\subsubsection{Lo cómico y la lógica del sueño y el juego}

A lo largo de todo su ensayo, Bergson señala un aspecto característico de lo cómico frente a otros fenómenos estéticos que, como veremos, tendrá cierta resonancia en el enfoque psicoanalítico de lo cómico: el de la cercanía de lo cómico con el juego y el sueño. La lógica de lo cómico es una lógica diferente que no depende de desvaríos individuales sino de una cierta característica general de la sociedad:

Existe, pues, una lógica de la imaginación que no es la lógica de la razón, que a veces incluso se le opone, y con la que la filosofía, por tanto, tendrá que contar, no solo para el estudio de la comicidad, sino también para otras investigaciones el mismo género. Es algo así como la lógica del sueño, pero de un sueño que no quedaría abandonado al capricho de la fantasía individual, pues es el sueño soñado por la sociedad entera (Bergson, 2016: 62)

El comportamiento de los personajes cómicos y de las mismas situaciones cómicas se acercan a la locura, pero más aún al sueño. Los juegos de ideas y palabras nos divierten porque nos recuerdan a los juegos infantiles y los oníricos (Bergson, 2016: 160). Esta lógica del sueño supone un relajamiento del razonamiento lógico, una mayor atención a lo material del lenguaje, al significante por encima del significado, y una fijación por unas ideas concretas (Bergson, 2016: 160-162) - estos rasgos son los mismos que Freud 
adjudica también al sueño en La interpretación de los sueños, publicado el mismo año que el ensayo de Bergson. El francés menciona incluso el mecanismo de condensación onírica: «la extraña fusión que a menudo opera el sueño entre dos personas que ya son solo una y que, sin embargo, siguen siendo distintas» (2016: 162).

Este carácter lúdico de lo cómico implica que, a pesar de la función correctiva de la risa, haya una cierta jovialidad en el que ríe y una paradójica simpatía por el personaje cómico: «hay sobre todo en la risa un movimiento de distensión que a menudo hemos observado» (Bergson, 2016: 164). Tanto en lo cómico como en el sueño y el juego hay un relajamiento de la tensión que nos impone el esfuerzo intelectual del razonamiento lógico y las obligaciones de la sociedad:

En el fondo de la comicidad siempre está la tendencia, decíamos, de dejarse deslizar por una pendiente fácil, que las más de las veces es la pendiente de la costumbre. Ya no se busca adaptarse y readaptarse sin cesar a la sociedad de la que se es miembro. Se relaja uno de la atención debida a la vida. Se asemeja, más o menos, a un distraído (...) En suma, se adopta la apariencia de alguien que está jugando (...) Al menos por un instante nos metemos en el juego (Bergson, 2016: 165)

Bergson, a pesar de todo, hace un énfasis importante en que el carácter correctivo y cruel de la risa nunca llega a desaparecer (Bergson, 2016: 166). Hay, por tanto, una ambigüedad constitutiva e indiscernible de lo cómico entre la diversión y la crueldad, entre la simpatía y la humillación.

\subsubsection{El personaje cómico. Preludio al inconsciente}

Como podemos comprobar, el ensayo de Bergson abarca los proteicos aspectos del fenómeno cómico, vinculando su mecanismo básico, su función social, su carácter estético, etc. A lo largo de todo el libro, y particularmente en la tercera parte, hace continuas referencias a la constitución del personaje cómico como figura fundamental de este arte, recurriendo sobre todo a las obras de Molière como ejemplos clásicos de la comedia de caracteres. No es de extrañar esta atención prestada por Bergson al estudio del carácter cómico, teniendo en cuenta que al inicio de su discusión había establecido que la risa tiene que ver directamente con lo humano, y sobre todo con el funcionamiento del individuo en sociedad.

Como dijimos, la figura cómica más general es la del despistado o distraído por una idea fija (Bergson, 2016: 42-43). Este personaje se mueve según una lógica absurda 
guiada por su obsesión: en lugar de dejar que la realidad amolde sus ideas, obliga a la realidad a amoldarse a estas ideas obsesivas, lo que le hace «ver ante sí lo que se piensa, en lugar de pensar lo que se ve» (Bergson, 2016: 158). El personaje cómico, por tanto, es fundamentalmente un inadaptado, incapaz de integrarse correctamente en la vida en sociedad - lo que deriva, claro está, de la función correctiva de la risa. El vicio cómico, por tanto, es de una naturaleza distinta del trágico: este vivifica el alma desde dentro, es lo que hace al personaje trágico funcionar y actuar en contra de la sociedad, es consecuencia de su irreductible individualidad vital; sin embargo, el vicio cómico aparece como algo que se escapa del control del personaje, como si fuera «un marco preestablecido en el que nos insertamos», que «nos impone su rigidez, en lugar de adquirir en él nuestra flexibilidad» (Bergson, 2016: 44) [ver 5.4; 7.3.4].

En este punto es evidente una cierta contradicción en la teoría de Bergson contradicción que, como veremos, será explotada por Alenka Zupančič. Bergson parte del principio de que la sociedad necesita que sus miembros se comporten de una manera flexible, adaptativa, no mecánica, y, sin embargo, en la descripción del vicio cómico que acabamos de exponer parece referirse a este como un marco traído desde fuera que podríamos interpretar como ciertos hábitos que la sociedad nos quiere imponer. Podría decirse que Bergson se refiere a hábitos y obsesiones que precisamente complican la vida en sociedad, pero a lo largo de todo su ensayo hace referencia a hábitos sociales como la ropa o las profesiones y sus lenguajes como fuente de comicidad. Llegará a decir incluso que los vodeviles son una exageración artística de la mecanicidad que es propia de la vida (Bergson, 102-103) y que si el lenguaje puede ser risible es porque «se trata de una obra humana, modelada con toda la exactitud posible según las formas del espíritu humano» (Bergson, 2016: 121). La misma risa, cuando se aplica injustamente tanto a los vicios como a las virtudes, a los justos y los viles, es descrita por Bergson como una fuerza mecánica e irreflexiva, como hemos visto. Por tanto, Bergson contradice aquí su principio según el cual la vida, la sociedad y el espíritu humano se caracterizan por su flexibilidad y su perpetuo cambio y movilidad. Como dice Zupančič, lo que revela el análisis de Bergson no es, como él se proponía, la irreductibilidad de lo viviente a lo mecánico, sino precisamente lo que de mecánico e irreflexivo hay en todo lo viviente (Zupančič, 2008: 114-115). Por ejemplo, en el caso de la imitación cómica, aunque Bergson argumente que se imita lo mecánico y por tanto supuestamente ajeno al individuo, precisamente estos gestos y rasgos que se repiten son lo más propio e individual de uno mismo: «a good 
imitator always imitates precisely our singularity, the uniqueness of our tics and gestures, and of their combination. He imitates our very difference, specificity, individuality; he imitates our inimitability, and makes it a matter of repetition» (Zupančič, 2008: 117).

En todo caso, la caracterización bergsoniana del personaje cómico apunta a una descripción psicoanalítica avant la lettre del funcionamiento del inconsciente. Para Bergson, el vicio cómico es algo ajeno a los personajes, un personaje en sí mismo, invisible pero central, que se mantiene independiente de los demás personajes y sin embargo les hace moverse como a marionetas (Bergson, 2016: 45). Un vicio es cómico cuando actúa por voluntad propia, cuando el personaje no lo controla, sino que es el vicio el que le controla a él. La distracción del personaje cómico es fundamentalmente una distracción de sí mismo: «un personaje cómico es cómico en la exacta medida en que se ignora a sí mismo. Lo cómico es inconsciente» (Bergson, 2016: 45; el destacado es nuestro). Esta observación es muy sugerente: el personaje es cómico cuando ignora su propia comicidad, su propio comportamiento obsesivo, cuando «se entra sin darse cuenta, en el gesto involuntario, en la palabra inconsciente (...) Las frases profundamente cómicas son las frases ingenuas en las que un vicio se muestra al desnudo» (Bergson, 2016: 132). En el arte cómico se saca a la luz aquel aspecto de su persona que ignora, «un flanco por el que se escapa a sí mismo» (Bergson, 2016: 132).

Bergson vuelve a entrar en una cierta contradicción cuando dice que un «carácter» es siempre cómico cuando entendemos este carácter como «lo que hay de preestablecido en nuestra persona, lo que en nosotros se encuentra en estado de mecanismo ya montado capaz de funcionar automáticamente» (Bergson, 2016: 133). En este sentido, el carácter sería lo más propio de cada uno: «carácter» es sinónimo de «personalidad», y decimos de alguien que "tiene mucho carácter" cuando tiene una personalidad fuerte, asertiva e individualizada. Bergson dice que el carácter es «si ustedes quieren, aquello por lo que nos repetimos a nosotros mismos» (2016: 134), es decir, lo que nos individualiza. Y sin embargo, paradójicamente, Bergson asegura que el personaje es, por consiguiente, un tipo y que la comedia es el arte de la generalidad (2016: 134).

Nos encontramos en este punto con esa paradoja que hace que las obras cómicas lleven nombres genéricos (El misántropo, El avaro, etc., frente a Hamlet o Edipo Rey), pero reconozcamos a los personajes trágicos como mitos universales y los personajes cómicos sean precisamente los más singulares, extravagantes e irrepetibles. Es sin duda una paradoja que se puede explicar desde la definición aristotélica del ethos como hábito 
y, sobre todo, el habitus de Pierre Bourdieu [ver 4.2.3]. Como veremos, este análisis bergsoniano del vicio cómico como lo más propio de un personaje y a la vez como algo ajeno a él será muy productivo desde la perspectiva psicoanalítica de Alenka Zupančič, expuesta al final de este capítulo, y también encontraremos el mismo esquema en nuestro análisis de los personajes masculinos de la telecomedia Friends.

\subsubsection{Freud: El chiste y su relación con lo inconsciente}

El otro libro que inaugura el estudio del humor en el siglo XX es, como hemos dicho, el estudio de Freud sobre los chistes. Como señalamos, su importancia reside en que, en cierto modo, es el primer estudio sistemático de las técnicas lingüísticas del chiste. Aunque Freud aparezca en todas las recensiones de la bibliografía sobre el humor, o bien se desdeña su explicación fisiológica de la risa como una extravagancia (Morreall, 2009: 19) o se reduce su alcance a su análisis de las técnicas del chiste, obviando las connotaciones hostiles y sexuales que Freud encontraba en el fenómeno cómico. Dentro del propio psicoanálisis, el libro sobre el chiste se ha considerado una pieza menor, al igual que la Psicopatología de la vida cotidiana, aunque bien es cierto que Jacques Lacan parte de la explicación freudiana del chiste para introducir su teoría de la estructuración lingüística del inconsciente, haciendo explícita la analogía que los mecanismos de condensación y desplazamiento presentan con la metáfora y la metonimia. En El chiste... Freud también introduce por primera vez la noción de «placer preliminar» que pocos años más tarde aplicará al arte en el trabajo «El poeta y la fantasía», estableciendo así ciertas conexiones con su propia teoría psicoanalítica del arte. Este legado será recogido por Ernst Kriss, un estudioso de las relaciones entre psicoanálisis y la creatividad artística, y Charles Mauron, el fundador de la psicocrítica. Más adelante recurriremos a algunos escritos freudianos relacionados con el arte y sobre todo la fantasía para explorar algunas de las ideas que el psicoanálisis plantea al tema de lo cómico.

El chiste y su relación con lo inconsciente es una de las pruebas más elocuentes de que se puede escribir un libro que analice el chiste hasta sus últimos detalles, sin que ese análisis obstaculice el disfrute del autor: ello se deduce de la cantidad de ejemplos que Freud incluye para apoyar sus análisis - le gustan, particularmente, los chistes de judíos. Hay que partir de la aclaración que el tema del libro es, efectivamente, el chiste: el término alemán Witz, en la época de Freud, ocupa un espacio intermedio a lo que en 
inglés correspondería al wit o ingenio verbal, respuesta espontánea e ingeniosa en una conversación, y el joke o chiste, la micronarración cómica "prefabricada” que se difunde anónimamente. Freud distingue aquí entre el chiste, lo cómico y el humor, si bien admite en varias ocasiones dificultades conceptuales y metodológicas para establecer diferencias claras. Al tipo de comicidad que llama humor dedicará, como veremos, un artículo muchos años después; y aunque lo cómico no sea el objeto central del libro, le dedicará el suficiente espacio al final del mismo como para ofrecer, como veremos, algunas observaciones interesantes.

\subsubsection{La técnica (verbal) del chiste: condensación y desplazamiento}

Como decimos, Freud prefigura el análisis lingüístico del humor al señalar el carácter básciamente verbal de la técnica del chiste (Freud, 2012: 21). Su estudio se abre con el ya famoso chiste de Heinrich Heine acerca del barón que trata a uno de sus personajes «muy “familionarmente” (familionär)» (Freud, 2012: 19): la agudeza consiste en la condensación de dos formas verbales, «familiar» y «millonario» (Freud, 2012: 21-24). Nótese, sin embargo, que la explicación del chiste no se reduce a la formación de la palabra: en esta formulación chistosa se combinan dos afirmaciones, «R. me trató como un igual, muy familiarmente» $\mathrm{y}$ «hasta el punto en que ello es posible a un millonario» (Freud, 2012: 22). La formulación chistosa es por tanto un vehículo para hacer un comentario irónico acerca de la simpatía de los millonarios, su manera de tratar a quienes consideran inferiores, etc.

En la extensa primera parte de la obra, Freud describe numerosas técnicas, verbales y no verbales, utilizadas en los chistes, reuniéndolas todas en dos grandes categorías: la condensación (que incluye condensaciones evidentes como su primer ejemplo, pero también el doble sentido, por ejemplo) (Freud, 2012: 47) y el desplazamiento, que consiste en el transporte de un proceso mental de su camino esperado a otro lugar (Freud, 2012: 59). Con este término Freud describe lo que Bergson llamaba «interferencia entre series» y que es la técnica más usual en los chistes (décadas más tarde, el lingüista Greimas la usará para explicar el concepto de isotopía, y muchos teóricos posteriores hablarán de «bisociación» y términos familiares, como veremos [3.3.1]). Las técnicas de desplazamiento ofrecen una apariencia de absurdo, o más bien de «sentido dentro del contrasentido», es decir, que guardan apariencia de lógica pero 
encubren un error intelectual (Freud, 2012: 65), o, mejor dicho, presentan una lógica alternativa a la del sentido común.

\subsubsection{Las dos tendencias del chiste y sus mecanismos de placer}

Posteriormente, Freud distingue entre dos grandes tipos de chistes, según sean inocentes, es decir, cuyo único fin sea la construcción cómica, o sirvan a alguna intención ulterior, lo que Freud denomina chistes tendenciosos (2012: 105). Los chistes inocentes están más cerca de los fenómenos estéticos en el sentido de que en ambos casos su único fin es el placer por sí mismo, sin estar ligados a ningún otro interés (Freud, 2012: 112) y, sin embargo, y muy significativamente, reconoce que es evidente que los chistes tendenciosos procuran un placer mucho mayor al obtenerlo de fuentes distintas a lo puramente intelectual (Freud, 2012: 113) - de hecho, es significativo que realmente Freud no llegue a ofrecer ningún ejemplo de chiste inocente: todos conllevan algún tipo de burla.

Freud, de este modo, igual que hizo Bergson, arroja una cierta sombra de duda acerca de los verdaderos sentimientos involucrados en la risa. Afirma que el chiste tendencioso puede ser hostil u obsceno, esto es, encubrir una agresión o una alusión sexual (o escatológica, dada la asociación infantil entre lo sexual y lo excrementicio) (Freud, 2012: 114-115). De hecho, considera que el chiste obsceno es un tipo de agresión sexual, ya que obtiene su placer de imaginar el cuerpo desnudo de una mujer. El chiste obsceno, afirma Freud, es una versión refinada, propia de la clase alta, de los piropos abiertamente sexuales de la clase obrera (Freud, 2012: 118-119). El chiste tendencioso, por tanto, es más placentero que el inocente porque permite la satisfacción de instintos hostiles o libidinosos reprimidos por la sociedad, hasta el punto que es imposible distinguir «qué parte de placer es producida por la técnica y cuál otra por la tendencia» (Freud, 2012: 120-121). El chiste, de esta manera, es el estado final de una sublimación progresiva de los instintos: la pulsión sexual o agresiva se sublima en el dicho procaz o el insulto, que queda disfrazada bajo la forma del chiste (Freud, 2012: 122-123).

El chiste hostil, por su parte, puede tener diferentes grados de concreción en su objetivo: puede ser un insulto contra una persona concreta, pero también contra grupos sociales o algunas instituciones, costumbres morales o dogmas filosóficos o religiosos (Freud, 2012: 126-132). El mayor grado de abstracción hostil corresponde a los chistes escépticos, que atacan «la seguridad de nuestro conocimiento mismo» (Freud, 2012: 135). Freud concede, por tanto, que el chiste puede encerrar alguna verdad que no se podría 
decir de otro modo; pero lo interesante es que asocia estos chistes, que podríamos llamar críticos o satíricos, no con una supuesta inteligencia objetiva o superior, sino con sentimientos hostiles y agresivos.

La tendencia del chiste, en resumen, explica el placer obtenido: este proviene de el ahorro del gasto psíquico empleado en la represión de dicha tendencia (Freud, 2012: 143), como la energía liberada al abrir un dique de contención. Este ahorro energético se puede comprobar también en los chistes inocentes: en ellos el ahorro producido es el del esfuerzo mental, pues es más fácil dejarse llevar por el absurdo, el sinsentido, los juegos de palabras, etc., que seguir el arduo proceso de la lógica (Freud, 2012: 144). En este sentido, el chiste inocente se asemeja al juego del niño, y de hecho se podría decir que parte del placer del chiste se debe a esta restauración de los placeres infantiles (Freud, 2012: 151, 154). Por tanto, se puede decir que también los chistes inocentes tienen una tendencia, puesto que liberan un instinto de “disparatar” (Freud, 2012: 161).

El placer del chiste, en definitiva, no se puede reducir a una única fuente de placer, sino que suele ser un complejo de fuerzas combinadas (Freud, 2012: 164). En el caso del chiste tendencioso, la tendencia reprimida se alía con el placer obtenido por la forma del chiste, venciendo así a la represión. En este sentido, Freud dice que la técnica del chiste actúa como «prima de atracción» o «placer preliminar» («Vorlust»): «[el mecanismo del chiste] se pone al servicio de determinadas tendencias con el fin de engendrar nuevo placer, suprimiendo retenciones y represiones por medio del placer del chiste, que actúa en calidad de placer preliminar» (Freud, 2012: 167).

A pesar de los mecanismos psíquicos que involucra, Freud insiste en la dimensión plenamente social del chiste: no se concibe un chiste que no se haya creado para ser contado (Freud, 2012: 173). Este esquema comunicativo, que consta del productor del chiste, el objeto o víctima del mismo y un tercero al que se le comunica, es lo que distingue el chiste de lo cómico y el humor: en lo cómico solo hace falta la persona que resulta cómica y el que la percibe como tal, y en el caso del humor basta una sola persona (Freud, 2012: 174). El chiste, por tanto, no se entiende del todo si no es teniendo en cuenta esta tercera persona a la que está dirigido. Es necesario que esta tercera persona esté en las condiciones anímicas para recibirlo positivamente, y también «cierto grado de complicidad o de indiferencia y la falta de todos aquellos factores que pudieran hacer surgir poderosos sentimientos contrarios a la tendencia» (Freud, 2012: 175). La técnica del chiste tiene que crear tres condiciones para provocar placer en el oyente: que exista 
una «carga de revestimiento» (es decir, que el oyente esté afectado de algún modo por el objeto del chiste); que la descarga de esta energía no se produzca por otros medios que la risa (el llanto o la violencia física, por ejemplo); y que el revestimiento sea intensificado previamente para que la descarga sea aún mayor (Freud, 2012: 182). Estas condiciones tienen algunas implicaciones interesantes, pues aseguran que el oyente del chiste, lejos de carecer de emociones, está afectado de alguna manera por el objeto cómico; emociones que han de ser intensificadas artificialmente para que el chiste sea más efectivo aún: así se podría explicar el típico mecanismo de la comedia de generar cierta ansiedad para luego liberarla, pero de modo más general implica que para que algo resulte cómico tiene que causar cierta angustia en primer lugar. Freud también señala que la resistencia a estos afectos es necesaria para que un chiste funcione: igual que no reirá aquel cuyas resistencias sean demasiado intensas, tampoco lo hará aquel que no tenga resistencia alguna o esté reprimiendo los afectos involucrados (Freud, 2012: 183).

\subsubsection{El chiste, el sueño y el juego}

En la última parte del libro, Freud relaciona las técnicas y mecanismos psíquicos del chiste que ha ido describiendo con la lógica del sueño que había descrito en $L a$ interpretación de los sueños - de hecho, ya anteriormente había relacionado estos procesos con el comportamiento de los psicóticos y los niños (Freud, 2012: 144, 151).

Si durante la elaboración del sueño se produce una regresión desde el pensamiento ideológico, el del razonamiento, al icónico, en que las ideas se transforman en imágenes sensoriales con el fin de vencer la censura y hacer emerger deseos inconscientes (Freud, 2012: 197-201), es evidente que podemos encontrar una coincidencia esencial entre los procesos de elaboración onírica y las técnicas del chiste: no solo los chistes juegan muchas veces con el aspecto material de las palabras, el icónico de las ideas, etc., sino que, sobre todo, ambos procesos se basan en mecanismos de condensación y desplazamiento (Freud, 2012: 201).

Ahora bien, Freud no está afirmando que el contenido del chiste sea un deseo reprimido, sino que utiliza los mismos procesos inconscientes que el sueño: en el chiste, «un pensamiento preconsciente es abandonado por un momento a la elaboración inconsciente, siendo luego acogido en el acto y rescatado por la percepción consciente» (Freud, 2012: 202). Esta observación es muy importante: no es que en el chiste emerjan deseos inconscientes; los materiales de los chistes (los deseos sexuales o de agresión o la 
hostilidad hacia determinadas personas o costumbres) son perfectamente conocidos por el productor y los oyentes. De hecho, en La interpretación de los sueños se puede comprobar que en la mayoría de los ejemplos de sueños analizados por Freud el contenido latente no son deseos reprimidos sino pensamientos preconscientes que incluso corresponden a eventos del mismo día. Lo inconsciente en ambos casos no es el material, sino el proceso de elaboración. Lo que Freud afirma en este pasaje es, ni más ni menos, que el chiste y el dicho ingenioso no son producto de la lógica racional sino de la intuición inconsciente (Freud, 2012: 204).

Además de con el sueño, Freud también hace explícita la relación del chiste con el juego infantil, algo lógico dado que el inconsciente es fundamentalmente infantil (2012: 207). Por otra parte, las semejanzas entre el chiste y el sueño no son absolutas. Principalmente, el sueño es un fenómeno no social, ocurre en una psique individual, mientras que el chiste es, como hemos visto, intrínsecamente social (Freud, 2012: 219) esta observación tiene cierto interés, puesto que apunta a la recepción colectiva de lo cómico: si el chiste alude a ciertos afectos del oyente, estos afectos y sus represiones son fenómenos sociales, determinados culturalmente. Charles Mauron, como veremos, basará su explicación del éxito de la comedia en que apela, de alguna manera, a deseos y ansiedades compartidos por toda la sociedad.

\subsubsection{El chiste y lo cómico}

Como hemos dicho, Freud también dedica algunas páginas a lo que él entiende como las diferencias entre el chiste y lo cómico y algunas particularidades de este último - si bien reconoce que la línea entre ambas especies es en ocasiones demasiado sutil. Como hemos visto, si el chiste consiste en la creación de una forma ingeniosa que sirve de agresión a una segunda persona en presencia de una tercera, en lo cómico, alguien observa algo risible en una segunda persona; en resumen, el chiste es algo que "se hace” mientras que la comicidad es “descubierta” en el otro (Freud, 2012: 221).

¿Cuál es el mecanismo psíquico de lo cómico? Para Freud uno de los ejemplos básicos de lo cómico es aquel en que nos reímos de alguien por su ingenuidad: aquí, observamos en este personaje ingenuo una falta de coerción. Por eso, dice Freud, nos divierten tanto los niños, los tontos, los borrachos y los locos: porque nos los imaginamos superando una coerción que en realidad no existe en ellos sino en nosotros (Freud, 2012: 227). La comicidad de lo ingenuo, por tanto, surge de una identificación o trasposición 
de nuestro yo al de la situación del ingenuo, y de la comparación entre ambos, de la que resulta un diferencial psíquico entre ambas representaciones, un ahorro de gasto (Freud, 2012: 227-229). Por tanto, más que de un contraste entre las representaciones, como afirma la teoría de la incongruencia, lo cómico surge de un contraste psicológico entre mi propio yo y el sujeto cómico. La comicidad de situación como la provocada en la parodia, la imitación, el disfraz o la caricatura, deriva de esta fabricación de las condiciones para que la representación nos parezca cómica (Freud, 2012: 231-232). Por ejemplo, la comicidad de la pantomima y los movimientos exagerados de los payasos reside en que percibimos en ellos un gasto desproporcionado comparado con nuestros movimientos normales (Freud, 2012: 233). Todas las especies de la comicidad se basan en general en esta comparación con nuestro propio yo. En ocasiones, esta comparación puede resultar inversa: el ahorro de gasto no lo observamos en nosotros sino en el otro, que realiza ciertas acciones con un esfuerzo menor del que debería emplear: por eso nos resultan cómicos las simplezas y los errores intelectuales, porque consideramos como inferiores la falta de trabajo intelectual además del exceso de movimiento de los payasos (Freud, 2012: 240).

Aunque de esta explicación se deduce una renovación de la noción de superioridad, Freud enseguida rechaza que este sentimiento sea esencial al placer cómico. En la comicidad de situación, por ejemplo, lo que es cómico son las características de la situación y no necesariamente la persona, a la que por tanto no nos sentimos superiores, puesto que «extraemos aquí la comicidad de la relación del hombre con el mundo exterior, que tan tiránicamente actúa con gran frecuencia sobre sus procesos psíquicos» (Freud, 241) - claro que en este punto podríamos argumentar que lo que se produce es una identificación con la persona que sufre la situación, lo que abre interesantes perspectivas respecto a la cuestión de en qué consiste exactamente el placer cómico, como veremos más adelante. Tampoco hay sentimiento de superioridad, asegura Freud, en la simplicidad fingida, puesto que el espectador sabe que el sujeto no es en realidad tonto, e incluso admira el buen hacer del fingidor (2012: 245); claro que en este caso estaríamos hablando de una representación «ficticia» respecto de la cual sí nos sentimos superiores. Como dice Bergson, ni siquiera en el teatro desaparece el sentimiento de humillación implicado en la risa.

Otra explicación posible para el placer cómico resulta de su comparación con el psiquismo infantil: según Freud, hay en la risa del niño un sentimiento de superioridad respecto a aquellos que no son capaces de dominar habilidades que él ya domina (Freud, 
2012: 279). En la vida adulta, por tanto, nos reímos de aquel en quien percibimos rasgos o comportamientos infantiles: así lo hace ese, yo lo hago de otra manera, ese lo hace como yo he hecho de niño. «La risa surgirá por tanto de la comparación entre el yo del adulto y el otro yo considerado como niño» (Freud, 2012: 279-280). De este modo, en todas las fuentes de comicidad podemos encontrar caracteres infantiles: bien sea por la comparación con el comportamiento propiamente infantil (la tendencia al exceso de movimiento, los errores intelectuales, la falta de control sobre el propio cuerpo o los instintos) o bien por la identificación con placeres infantiles, como la repetición, la exageración, la imitación, la ausencia de represiones, etc. (Freud, 2012: 283).

\subsubsection{El humor}

La tercera especie de la comicidad que Freud propone es lo que él llama «humor» para referirse a cierta actitud de distancia y ausencia de afectos por una situación que debería ser dolorosa. A diferencia del chiste y lo cómico, que necesitan, respectivamente, de tres y dos personas para realizarse, basta que exista una persona con dicha actitud humorística (Freud, 2012: 286). El primer ejemplo que pone Freud de esta actitud es la historieta cómica de un condenado a muerte que, camino de la horca, al enterarse de que es lunes, exclama «iVaya; buen principio de semana!» (2012: 286). Lo humorístico de esta escena es que, frente a la desgracia hacia el que se dirige el personaje, hay sin embargo una relativización e incluso desprecio por la situación, actitud que Freud considera como una «grandeza de ánimos (...) con la que el sujeto se aferra a su ser habitual, volviendo la espalda a todo aquello que le conduce a la muerte y puede antes provocar su desesperación» (Freud, 2012: 287). Lo que en el reo es actitud humorística, el espectador la recibe con placer cómico, pues ante una situación que esperaba recibir con compasión, ve que esta no es necesaria, y la energía preparada para dicha piedad es descargada mediante la risa (Freud, 2012: 288).

En suma, en ambos casos «el placer del humor surge a costa del desarrollo del afecto cohibido, esto es, del ahorro de un gasto de afecto» (Freud, 2012: 286). Claro que es muy cuestionable, y el mismo Freud lo da a entender, la distinción entre las tres especies de la comicidad. Si el dolor impide la aparición del sentimiento de la risa, la actitud humorística es uno de los medios por los que desaparece esta posibilidad (Freud, 2012: 291); de hecho, Freud describe la historia del reo, en efecto, como una historieta cómica (y así la recibe el espectador) que contiene un chiste (Freud, 2012: 285). De hecho, 
podemos explicar el bloqueo de afectividad que se produce en la actitud humorística como una especie particular de desplazamiento por el que una carga efectiva se ve desviada repentinamente hacia algo secundario (Freud, 2012: 291). Otra manera de entender el proceso es recurrir a la comparación entre actitudes adultas e infantiles que aparece en lo cómico: en el humor, el yo adulto se ríe de la importancia que el yo infantil da a ciertos eventos, como diciendo «soy ya demasiado grande para que esto pueda causarme disgusto» (Freud, 2012: 292-293). En este sentido, el humor es un mecanismo de defensa parecido a los que se hallan en la génesis de algunas neurosis (Freud, 2012: 292).

A pesar de todo, Freud decide mantener la distinción entre el humor, lo cómico y el chiste, al considerar que aquel carece la simultánea comparación de dos representaciones que es fundamental para la elaboración de estos - a pesar de que, como vemos, el humor surge del contraste entre la respuesta que sería esperable en cierta situación dolorosa y la actitud de indiferencia que presenta el sujeto humorístico. Podemos considerar, en todo caso, que Freud analiza bajo la categoría de humor lo que nosotros consideraríamos «humor negro», en tanto que es una subclase o más bien tradición cómica que juega con situaciones dolorosas o trágicas. La explicación ofrecida aquí por Freud ofrece interesantes consideraciones acerca de su mecanismo psicológico que pueden ser completadas con otras consideraciones dentro del mismo pensamiento freudiano, como veremos.

Freud volvería a tratar el humor en un brevísimo artículo homónimo publicado en 1927, cuando veintidós años de investigaciones psicoanalíticas le han llevado, entre otras cosas, a redescribir la tópica psíquica en la tríada ello-yo-superyó; conceptos que aquí utiliza para volver a analizar la actitud humorística, recuperando incluso el mismo chiste del reo que había usado en 1905. En este trabajo, centra su atención no en el proceso psíquico del espectador que disfruta de un ahorro de gasto al no necesitar sentir cierta compasión, sino en el propio sujeto humorístico que tiene esa actitud “estoica”. El humor, además de liberador, supone una cierta grandiosidad patética, según el Freud de 1927:

Lo grandioso reside en el triunfo del narcisismo, en la inatacabilidad del yo triunfalmente aseverada. El yo rehúsa sentir las afrentas que le ocasiona la realidad; rehúsa dejarse constreñir al sufrimiento, se empecina en que los traumas del mundo exterior no pueden tocarlo, y aun muestra que sólo son para él ocasiones de ganancia de placer (...) No solo significa el triunfo del yo, sino también el del principio de placer (Freud, 1992: 158) 
La actitud humorística, por tanto, consiste en una exaltación del narcisismo y el triunfo del principio de placer, lo que la acerca a los procesos regresivos que están en el origen de muchas psicopatologías como la neurosis o el delirio (Freud, 1992: 159). La cuestión es cómo consigue el sujeto humorístico no caer en estos estados patológicos. Según Freud, el humorista traslada el acento psíquico del yo al superyó: «a éste superyó, así hinchado, el yo puede parecerle diminuto, todos sus intereses desdeñables» (Freud, 1992: 160). Aunque Freud no llegue a elaborarlo, esta explicación encaja en su propia caracterización de lo cómico de años atrás, según la cual este fenómeno resultaba de la comparación entre el adulto y el niño; más exactamente, si según la misma tópica freudiana el «yo» representa el principio adulto de realidad, en el humor el superyó, instancia paterna pero de origen infantil, se alía con el ello, el yo propiamente infantil, para negar esta realidad y permitir así el triunfo del narcisismo y del principio de placer.

El mismo Freud reconoce que esta explicación de un superyó que colabora en la ganancia de placer a costa del principio de realidad resulta paradójica respecto a la caracterización usual de esta instancia como un amo severo y cruel para con el yo. De hecho, a pesar de reconocer que la actitud humorística presenta paralelismos con patologías neuróticas y otros estados como la manía persecutoria o la melancolía (Freud, 1992: 161), admite conceder «sin saber muy por qué» (Freud, 1992: 161) un gran valor espiritual a esta actitud. En efecto, la explicación dada en este trabajo resulta cuanto menos insatisfactoria, y da la impresión de que Freud se deja llevar por la alta estima en que cierta tradición filosófica y cultural tiene a esta actitud y no aplica las mismas sugerencias que él mismo había hecho en su libro sobre el chiste.

El hecho fundamental, a nuestro parecer, es que Freud parece olvidar que el chiste del reo es, precisamente, una historieta cómica ficcional, y que su actitud humorística está desde el principio ofrecida como espectáculo al oyente. El mismo Freud explica, tanto aquí como en El chiste... que el placer humorístico parece derivar de la comparación entre dos yoes dentro del sujeto, un yo adulto despreocupado y uno infantil, cuando el análisis de 1927 señala que en realidad la actitud despreocupada es debida a una creencia narcisista infantil a expensas del principio de realidad adulto. Solo podemos decir, con Baudelaire, que el sujeto que se ríe de sí mismo se desdobla y se ofrece a sí mismo como espectáculo.

No parece razonable, en suma, asumir que la actitud humorística denota una posición razonable y adulta frente a la realidad. Creemos más interesante plantear que, 
efectivamente, en el chiste del reo, se da un relato ficcional de cara a un espectador que observa una incongruencia entre la cercanía de la muerte del protagonista y su comentario a todas luces absurdo y fuera de lugar. ¿Cuál es el placer obtenido de esta historieta? ¿De verdad esta yuxtaposición lo que consigue es “relativizar” la muerte, aliviando de algún modo la sensación de desgracia? ¿No la hace, al contrario, más patética? Según la economía psíquica de lo cómico planteada por Freud en 1905, la comicidad surge entre la comparación entre un yo adulto, que respeta las normas que la realidad, la lógica y la sociedad imponen, y un sujeto infantil que, por incapacidad o desconocimiento de estas normas, las viola. También existe la posibilidad de que el yo adulto del espectador, en lugar de sentirse superior a este “él” infantil del reo, se identifique con él y represente una regresión a dichos placeres infantiles. Y, sin embargo, el espectardor es perfectamente consciente de que estas restricciones existen, más aún si se trata de una posibilidad tan cierta y terrible como la muerte. También hemos visto que Freud sugiere que para que se produzca el placer cómico debe existir una carga afectiva, una cierta angustia o displacer relacionado con el objeto cómico y que ha de ser acrecentado en el chiste o la historieta cómica - sugerencia que como veremos recogerán algunos psicoanalistas y críticos literarios posteriores. En conclusión, encontramos que, en lo cómico, o al menos en la subespecie humorística, el placer que se produce no deja de estar paradójicamente mezclado con una cierta cantidad de displacer, que no podemos explicar simplemente como una victoria del narcisismo. A continuación, exploraremos algunas ideas freudianas que nos permitan delimitar mejor este extraño placer humorístico, sobre todo las relacionadas con la fantasía y el arte, y que nos llevarán a explorar la postura psicoanalítica respecto a la catarsis estética para postular cómo podría aplicarse a la catarsis propiamente cómica.

3.1.3.6. Posibles aplicaciones de la explicación freudiana de la fantasía y el arte al fenómeno cómico

En un epígrafe anterior veíamos cómo Freud asociaba el fenómeno de lo cómico con otros procesos psicológicos como el sueño, el juego infantil o ciertas psicopatologías. También introducía en El chiste... el concepto de prima de atracción o placer preliminar, Vorlust, términos que retomaría unos pocos años después en «El poeta y la fantasía» (1908), donde se pregunta de dónde obtiene el poeta el material para sus obras y cómo consigue conmover al lector y hacerle sentir «emociones de las que ni siquiera nos juzgábamos 
capaces acaso» (Freud, 2019: 11); podemos decir, en suma, que se plantea la cuestión de la creación artística y su proceso comunicativo.

Para ello, Freud relaciona la creación artística con otras actividades de la fantasía como el juego infantil: «todo niño que juega se conduce como un poeta, creándose un mundo propio o, más exactamente, situando las cosas de su mundo en un orden nuevo, grato para él» (Freud, 2019: 12) [ver 5.2]. Del mismo modo, el poeta crea un mundo ficticio con el que se siente íntimamente ligado psíquicamente; en la obra de arte «mucho de lo que, siendo real, no podría procurar placer ninguno puede procurarlo como juego de la fantasía» (Freud, 2019: 12). Una vez dejada atrás la infancia, el adulto también deja atrás estos juegos, pero no abandona la actividad fantasiosa, que toma la forma de los «ensueños diurnos» (Freud, 2019: 13). Como el niño, el adulto proyecta en estos ensueños la satisfacción de sus deseos, normalmente relacionados con el poder narcisista o el sexo; la diferencia es que el adulto, al contrario que el niño, se avergüenza de sus fantasías por considerarlas pueriles u obscenas (Freud, 2019: 14-15). En este sentido, estos ensueños son la versión diurna de los sueños, y constituyen estados preliminares de las neurosis y las psicosis (Freud, 2019: 17-18). Otro tipo de fantasías que menciona Freud, y estas son muy interesantes porque apuntan a una suerte de deseos colectivos, son las que encontramos en las novelas populares, donde encontramos casi siempre un protagonista carismático e invencible, lo que nos revela un deseo narcisista de invulnerabilidad del yo (Freud, 2019: 19) - como veremos, Charles Mauron afirma que la comedia clásica presenta una «fantasía de triunfo» que satisface la sensación de impotencia del espectador.

En esta línea, Freud considera las obras artísticas, y sobre todo las literarias, como proyecciones de deseos del mismo tipo que los ensueños diurnos. Pero si el adulto oculta sus fantasías porque se avergüenza de ellas, ¿cómo consigue el poeta no solo comunicarlas sin pudor sino incluso conseguir que nos identifiquemos con ellas y obtengamos placer? Aquí es donde Freud introduce de nuevo el concepto de «prima de atracción»: «el poeta mitiga el carácter egoísta del sueño diurno por medio de modificaciones y ocultaciones y nos soborna con el placer puramente formal, o sea estético, que nos ofrece la exposición de sus fantasías» (Freud, 2019: 23). El verdadero ars poetica, dice Freud, consiste en deformar la fantasía personal de modo que sea aceptable para nosotros; pero la obra de arte no solo nos procura placer formal, sino que actúa como un «placer preliminar» que permite la descarga de emociones más profundas: «todo el placer estético que el poeta nos procura entraña este carácter de placer preliminar, 
y el verdadero goce de la obra poética procede de la descarga de tensiones dadas en nuestra alma» (Freud, 2019: 23).

Por tanto, teniendo en cuenta la mutua relación del chiste y la obra de arte con el sueño y el juego infantil, así como el hecho de que ambos comparten la técnica de la «prima de atracción» mediante la cual tanto el chiste como la obra de arte disfrazan la satisfacción de un deseo no expresable directamente, podríamos considerar lo cómico y el chiste, si no como un tipo de creación estética, al menos como un fenómeno análogo. Sobre todo nos interesa la relación que establece Freud entre el arte y el ámbito de lo fantástico: como dice en «El interés del psicoanálisis para la Estética», el arte forma «un dominio intermedio entre la realidad, que nos niega el cumplimiento de la fantasía, que nos procura su satisfacción, un dominio el que conservan toda su energía las aspiraciones a la omnipotencia de la Humanidad primitiva» (Freud, 2016a: 246).

Una dificultad que sin embargo ofrece el acercamiento de Freud al fenómeno artístico es que se centra en la creación artística, en cómo la obra de arte, como el sueño o la neurosis, está encaminada a la mitigación de deseos insatisfechos. Así, Freud parece reducir el interés del psicoanálisis para el arte como herramienta para relacionar las «impresiones infantiles» del artista con su obra (Freud, 2016a: 246). Pero, teniendo en cuenta el carácter anónimo y popular de los chistes e historietas cómicas, no se puede aplicar este tipo de análisis a lo cómico: es necesario atender al polo de la recepción, el por qué diferentes individuos se pueden sentir atraídos y obtener placer de este tipo de discursos (esta será, como veremos, la razón que guiará el estudio a Mauron en su Psicocrítica del género cómico).

Uno de los textos freudianos en los que podemos encontrar una teoría de la recepción estética es «Personajes psicopáticos en el teatro», de 1904, donde Freud se remite a la función catártica del teatro para elaborarla en términos psicoanalíticos: «se trata de procurarnos acceso a fuentes de placer y goce yacentes en nuestra vida afectiva, tal y como el chiste y lo cómico hacen en la esfera del intelecto ${ }^{34}{ }$ consistentes en la descarga de energías psíquicas y la estimulación sexual (Freud, 2016b: 427-428). Freud vuelve a relacionar la representación artística, en este caso teatral, con el juego infantil; concretamente al modo en que este supone la satisfacción del niño de poder comportarse

\footnotetext{
${ }^{34}$ Como vemos, aquí Freud asocia lo cómico con lo intelectual y no con los afectos, pero podemos ignorar esta afirmación teniendo en cuenta que este texto es anterior al de El chiste..., donde hemos visto que sí asocia el chiste y lo cómico a la satisfacción y representación de ciertos impulsos y deseos.
} 
como los adultos: el espectador, al identificarse con el héroe, tiene experiencias que no podría tener en la vida real (Freud, 2016b: 429). Al mismo tiempo, la distancia lúdica le evita la intensidad de esta experiencia, pues no tiene que padecer los mismos sufrimientos que el protagonista: «de ahí que su goce dependa de una ilusión, pues presupone la atenuación de su sufrimiento merced a la certeza de que, en primer término, es otro, y no él, quien actúa y sufre en la escena, y en segundo lugar trátase sólo de una ficción que nunca podría llegar a amenazar su seguridad personal» (Freud, 2016b: 429) ${ }^{35}$.

El arte dramático, por tanto, procura una experiencia de identificación y distanciamiento, de vivencia ilusoria que produce una cierta descarga catártica de los propios afectos del sujeto. Por tanto, el drama ha de relacionarse con el sufrimiento, como la tragedia, y también la comedia despierta una ansiedad para luego aplacarla (Freud, 2016b: 432). La acción dramática se basa para ello en la lucha entre una voluntad y una fuerza que se le opone, una lucha que muchas veces esconde un conflicto entre una motivación consciente y otra reprimida. Según Freud, es necesario, por tanto, que el espectador también sea hasta cierto punto un neurótico para poder sentirse identificado con el conflicto del drama y que se produzca el placer estético (Freud, 2016b: 432). Además, esta identificación "neurótica” ha de ser siempre inconsciente y producirse mientras el espectador está “distraído” por otros aspectos del drama (idea que, como vemos, luego tomará la forma del concepto de prima de atracción): en Hamlet, por ejemplo, nos distrae la acción vengativa, las dudas del protagonista, etc., pero el verdadero conflicto con el que nos identificamos inconscientemente es el deseo edípico por la madre (Freud, 2016b: 435). La recepción estética, en resumen, es también un fenómeno cercano a la neurosis en el que interviene una fantasía, solo que el placer obtenido no se da en la creación de dicha fantasía sino en la identificación con ella.

En este sentido es interesante la elaboración que hace el teórico Peter Brooks de la noción de transferencia con miras a la crítica literaria. La «transferencia» que se produce durante la terapia psicoanalítica se puede interpretar como la comunicación de una fantasía: los afectos del pasado que dieron origen a la neurosis tratada se ven proyectados en el presente de la relación entre el analista y el paciente, por lo que se puede considerar la neurosis de transferencia como una re-presentación de la neurosis

\footnotetext{
${ }^{35}$ Jauss incidirá en esta dualidad entre identificación y distanciamiento inherente al placer estético: «El placer estético, que se desarrolla en el movimiento pendular existente entre contemplación no interesada y participación experimentadora, es una forma de experimentarse uno mismo en esa capacidad de ser otro, que el comportamiento estético nos ofrece» (Jauss, 1986: 73)
} 
primigenia: la transferencia es «a semiotic and fictional medium where the compulsions and the unconscious desires and its scenarios of infantile fulfillment become symbolically present in the communicative situation of analysis» (Brooks, 1987: 342). La neurosis de transferencia toma la forma de una repetición inconsciente, de un «acting out», una representación («play») (Brooks, 1987: 342). La transferencia es descrita por Freud en los mismos términos que la fantasía artística como una región intermedia entre la neurosis y la realidad, una fantasía a la vez real y artificial (Brooks, 1987: 343). El texto literario, por tanto, se puede describir mediante la analogía de la transferencia, en el que el crítico hace de analista del síntoma que es el texto respecto de su autor. Pero, dado que el lector también construye el texto, se produce otra transferencia por su parte, y la interpretación se constituye de nuevo como un síntoma, esta vez del lector (Brooks, 1987: 346). Claro que en este artículo Peter Brooks restringe su propuesta a la actividad específica de la crítica literaria, y no a la comunicación artística en general, y el proceso que está describiendo no es sino el del círculo hermenéutico. Pero no deja de ser sugerente la equiparación de este proceso de recepción con el de la transferencia, y la conversión del texto literario como síntoma del autor en síntoma del lector. De este modo, y teniendo en cuenta, como decimos, el anonimato o al menos la popularidad de ciertos géneros cómicos, es más productivo estudiar estos como reflejo de ciertos deseos o "neurosis colectivas” [ver el epígrafe dedicado a Charles Mauron más adelante, y la sección 7.1, donde elaboramos esta hipótesis con respecto a la comedia televisiva contemporánea].

En este punto también consideramos ciertamente estrecha la noción de Freud del sueño y la fantasía como mera satisfacción de deseos. No solo porque la catarsis trágica suscite sentimientos de piedad y horror y no de satisfacción, sino, sobre todo, porque la comedia, aunque Freud considera que se limita a aplacar la ansiedad refiriéndose, seguramente, al final feliz por el que se suele definir al género, contiene muchos elementos y situaciones cómicas que distan mucho de suponer una mera satisfacción de deseos $^{36}$. Es cierto que algunas de estas escenas se pueden explicar, de acuerdo con el mismo esquema propuesto por Freud en El chiste..., según el placer obtenido por cierto sentimiento de superioridad respecto a los personajes de la comedia, pero también

\footnotetext{
${ }^{36}$ Ciertamente, como veremos, la mayoría de las definiciones de la comedia se centran en el final, más o menos feliz y esperanzador, que presenta el género en su forma clásica y clasicista. Pero si podemos decir que la acción trágica está encaminada en todos sus pasos hacia su resolución, la estructura de la comedia suele ser más compleja, presentándose en su mayor parte como una acumulación y articulación de diversas situaciones cómicas relativamente independientes, como el examen de algunas comedias de Shakespeare o Molière demostraría fácilmente.
} 
encontramos situaciones en las que el conflicto presentado cómicamente provocaría un seguro malestar si se produjera en la vida real. El mismo Freud asegura, como hemos visto, que, al trabajar el chiste y lo cómico con resistencias y obstáculos que suelen provocar ansiedad, es posible que el sentimiento cómico no sea aceptado por el oyente o espectador. En la comedia, por tanto, existe un riesgo de que el dolor o el miedo se impongan al placer, cosa que no sucede en la tragedia, donde cuanto más dolor y compasión se provoque, mayor será, en teoría, el efecto catártico; el dolor trágico no es evidentemente una emoción del mismo que el malestar producido por un chiste fallido, y en este sentido parece ser que la frivolización cómica puede ser más peligrosa que la propia seriedad [ver 5.5, 8.1, 8.3].

Por tanto, volvemos a encontrar con la paradoja del chiste del condenado a muerte: ¿cuál es el tipo de placer obtenido de esta situación? ¿la identificación que se pueda producir con el protagonista de la historieta es placentera en su sentido más simple e ingenuo? ¿qué tipos de deseos o impulsos son satisfechos en historias como esta? La posible explicación de que encontramos realizado un deseo de invencibilidad del yo concedida por el superyó parece poco satisfactoria. Sí que encontramos interesantes los paralelismos que podemos establecer entre esta clase de humor negro y otras especies cómicas y los distintos fenómenos que Freud presenta en su célebre trabajo «Más allá del principio del placer» y que reúne bajo la idea de «obsesión de repetición». Sin ser necesario llegar a relacionar el placer cómico con el instinto de muerte que es el destino último de la especulación freudiana en este texto (aunque no negaremos que resulta una tentación muy sugerente), nos contentaremos en señalar cómo podrían encajar los problemas planteados en la descripción de esta obsesión de repetición.

El objetivo de Freud en «Más allá del principio del placer» es cuestionar la hipótesis básica que la teoría psicoanalítica planteaba en sus primeras formulaciones de que toda vida anímica inconsciente está regida por el principio del placer. Así, Freud observa, por ejemplo, que los soldados con estrés postraumático («neurosis de guerra» lo denomina Freud) reviven en el sueño nocturno su vivencia traumática, lo que contraviene su intuición primera de que el sueño supone una satisfacción de deseos (Freud, 2018: 102). Pero el ejemplo más conocido de todos los propuestos por Freud es el del niño que juega a lanzar objetos, entre ellos un carrete con hilo que luego recupera tirando de él (Freud, 2018: 103-106). La explicación que Freud le da a este juego es que el niño representa de este modo la desaparición de la madre, lo que plantea de qué manera «está 
de acuerdo con el principio del placer el hecho de que el niño repita como un juego el suceso penoso para él» (Freud, 2018: 105). Se podría decir que la desaparición del objeto/madre es el paso previo para el retorno del mismo, que supondría la fuente de placer, pero Freud señala que la mayoría de las veces el niño solo cumple la primera parte del juego. Otra posible explicación es que el niño intenta disminuir su angustia al crear una ilusión de control sobre la situación al ser el que hace desaparecer el objeto, o bien satisface con este acto un impulso vengativo hacia la madre que le abandona. En esta línea Freud observa que en el juego infantil en general hay un aspecto de lograr un dominio sobre la situación representada que puede derivar en cierto placer sádico, al infligir a otros el daño que le han hecho al niño (Freud, 2018: 106-107).

Pero a Freud no le llega a satisfacer del todo su propio análisis, y plantea como otro ejemplo clarísimo de repetición la situación de transferencia, en la que el enfermo, a pesar de no recordar el suceso traumático que originó la neurosis, lo vuelve a provocar en la situación analítica (Freud, 2018: 108). Los síntomas neuróticos son otro ejemplo de «obsesión de repetición» que provoca una sensación de displacer en el yo, pero se podría decir que estas repeticiones constituyen la satisfacción de deseos reprimidos que causan displacer al yo consciente, pero satisfacen al inconsciente. Sin embargo, en otras ocasiones «la obsesión de repetición reproduce también sucesos del pasado que no traen consigo posibilidad ninguna de placer y que cuando tuvieron lugar no constituyeron una satisfacción» (Freud, 2018: 112): en la transferencia, de hecho, se reproducen escenas del desarrollo psicosexual del adulto cuando era bebé que tuvieron que ser dolorosas, como el sentimiento de abandono de la madre o la ansiedad de castración por parte del padre.

Freud concluye que la obsesión de repetición puede colaborar con el principio del placer, como en los juegos infantiles, pero que en todo caso son dos principios independientes, y la repetición parece ser «más primitiva, elemental e instintiva que el principio del placer al que se sustituye» (2018: 114). Desde esta perspectiva, podríamos considerar un análisis parecido del chiste del reo o del fenómeno cómico en general y cómo la angustia y otros afectos negativos juegan una parte importante en él: el placer cómico puede obtenerse a partir de un sentimiento de superioridad surgida de la comparación con un otro infantil, o bien de una ilusión de dominio o de una liberación de instintos reprimidos, pero en todos esos casos es necesario previamente repetir, representar, en la fantasía de la historia cómica, obstáculos y sensaciones que son fuente de ansiedad en la vida real del oyente u espectador [ver 3.2.1.3]. 
En resumen, vemos que la teoría freudiana de lo cómico va mucho más allá de las técnicas verbales del chiste o de su función de alivio. En lo cómico se dan complejas y variables dinámicas afectivas psicosociales que hace necesario que se analicen los casos concretos.

\subsubsection{Ernst Kris: Psicoanálisis de lo cómico}

Como hemos dicho, el libro de Freud sobre el chiste es generalmente considerado como menor dentro de su teoría psicoanalítica, pero ha tenido mejor fortuna en el ámbito de la teoría y la crítica de arte y literaria - dentro de la poca atención que han tenido los géneros cómicos en estas disciplinas. Uno de los primeros autores en tratar lo cómico desde una perspectiva freudiana fue el psicoanalista e historiador del arte Ernst Kris en una serie de trabajos sobre la caricatura y la relación de lo cómico con el desarrollo del yo. En estos trabajos, Kris retoma e insiste en los paralelismos señalados por Freud entre lo cómico, el sueño y el juego infantil. Los parecidos entre el sueño y el chiste tienen un límite: en el sueño, el yo baja sus defensas y el inconsciente toma el control, pero en el chiste el proceso de elaboración inconsciente está al servicio del yo. En este sentido, lo cómico presenta una analogía con el arte y sobre todo con el ritual y el culto (Kris, 1964: 15).

En cuanto a la relación de lo cómico y el juego infantil, Kris insiste en el carácter regresivo de lo cómico (Kris, 1964: 49) y ahonda en algunas características del juego descritas por la investigación psicoanalítica. El juego infantil tiene dos misiones: adquirir una habilidad o un dominio sobre el ambiente y eludir o dominar una experiencia desagradable (Kris, 1964: 20). En general, el niño empieza a encontrar cómica o graciosa una situación una vez que la ha dominado por completo, o cuando están aprendiendo a hacerlo: se puede comprobar cómo los niños dibujan objetos que están aprendiendo a dominar o situaciones que les producen ansiedad (Kris, 1964: 69). Por tanto, si Freud había señalado que en lo cómico se produce una comparación entre un yo adulto y otro infantil, es más preciso decir que en lo cómico hay una percepción, no tanto de superioridad, como de superación de una dificultad. Pero eso significa que un recuerdo o resto de esta dificultad o la ansiedad que provocaba sigue latente en lo cómico (Kris, 1964: 65); lo cómico, afirma Kris, se origina «más allá del principio del placer», ya que, 
como en el juego infantil, consiste en el intento de superar el mundo exterior y la angustia que produce (Kris, 1964: 66) ${ }^{37}$.

En el juego cómico del adulto, por su parte, este intento de dominio se traduce en el dominio de las tendencias libidinales y agresivas rechazadas por el superyó (Kris, 1964: 24), pero también podemos encontrar reminiscencias de conflictos pasados. En todo caso, la particular combinación entre placer y angustia de la experiencia cómica explica «su carácter de doble filo, la facilidad con que pasa del éxito agradable al fracaso desagradable» (Kris, 1964: 74). Al fin y al cabo, lo cómico combina el displacer de las barreras impuestas por el superyó y el placer de superarlas (Kris, 1964: 22). Por ello, las técnicas del chiste están dirigidas a evitar el fracaso de lo cómico:

Si el proceso cómico ha de tener éxito, tal éxito debemos concebirlo como dependiente de dos factores. Las exigencias de la vida instintiva son satisfechas por su contenido, las objeciones del superyó por la forma de su disfraz. Cuando el yo es capaz de dominar la tensión existente entre esos factores, el placer puede surgir del displace. Pero el carácter de doble filo de los fenómenos cómicos se ve como una cualidad condicionada por el conflicto en que éstos se originan; en ocasiones consigue oponerse a la labor que recae sobre el yo, de modo que nos impresiona como un fracaso (Kris, 1964: 27)

Por otra parte, esta dualidad de lo cómico explica su aspecto “subjetivo”, el hecho de que cada comunidad local y cada momento histórico conozca sus formas particulares de comicidad: no puede ser cómico lo que provoque indiferencia, lo que no se tenga en alta estima o esté relacionado con una fuente de displacer, y estos afectos suelen estar relacionados con aspectos sociales y culturales (Kris, 1964: 28).

En todo caso, el hecho de que lo cómico, como el juego, permita dominar la angustia y las situaciones difíciles a partir de su especial tratamiento, permite que se use frecuentemente como un mecanismo de defensa. En este sentido, hay que entender el humorismo, tal y como lo describió Freud, como el triunfo solipsista del individuo, y por ello es la última especie de lo cómico en desarrollarse en la psique individual (Kris, 1964: 31). Esto vuelve a poner de relieve la relación ya señalada por Freud entre lo cómico y algunas neurosis. Así, lo cómico, en tanto que triunfo del yo sobre el superyó y el

\footnotetext{
${ }^{37}$ Esto explica, según Kris, algunas de las asociaciones entre lo cómico y lo inquietante que estudiamos en la parte histórica de este trabajo. Explica, por ejemplo, el que muchas figuras cómicas tengan su origen en criaturas demoníacas o ctónicas como los sátiros, o los personajes de tradiciones como las diableries o la commedia dell'arte. Las gárgolas, por ejemplo, son figuras apotropaicas que evolucionaron hacia máscaras cómicas. Incluso en la etimología de los términos relacionados con lo cómico (drôle, komisch o funny) encontramos asociaciones con lo misterioso, lo extraño o inquietante (Kris, 1964: 71-72).
} 
principio de realidad, encuentra su paralelo patológico en la manía - del mismo modo que lo sublime, que es la contrapartida de lo cómico en el ámbito artístico, se corresponde con el éxtasis, la anulación del yo a favor del superyó (Kris, 1964: 30).

Ernst Kris, en suma, insiste en ciertos aspectos de lo cómico y sus paralelismos con el juego infantil que en Freud eran apenas sugerencias: principalmente, su carácter ambiguo, entre lo agradable y lo desagradable, y su relación con ansiedades y angustias infantiles que muchas veces permanecen en la vida adulta.

\subsubsection{Charles Mauron: Psicocrítica del género cómico}

Si Freud y Kris apenas fueron más allá de los chistes y pequeñas historietas o caricaturas, Charles Mauron, creador del método psicocrítico de crítica literaria, partirá de ambos autores para realizar un estudio de toda la tradición clásica de la comedia, desde Aristófanes hasta Molière, en su Psicocrítica del género cómico. Si la psicocrítica consiste en la lectura de la obra de un autor como expresión de su psicología profunda, Mauron, como él mismo explica, al intentar aplicar el mismo tipo de análisis que realizó con Racine a la obra de Molière, se topa con que, dada la fuerte tipicidad de sus personajes, imágenes y situaciones, es difícil analizar estos como una expresión personal de Molière y no como un repertorio de materiales propios del género. Dicho de otro modo, el análisis de estas imágenes, personajes y materiales no dibujaría el mito personal de Molière o Plauto sino toda una colectiva «mitología de la risa» (Mauron, 1998: 10).

Ahora bien, el hecho de que estas figuras y situaciones hayan pervivido durante siglos quizá no explique la personalidad de estos autores, pero sí implica que su éxito bien pueda deberse a que apela a los espectadores de las diferentes épocas en un nivel profundo: «la imitación o el préstamo voluntario no explica ni los tipos tradicionales, ni su poder mantenido de siglo en siglo, ni el compromiso que con ellos muestran los creadores. Los autores se copian, pero los públicos no. Es preciso, pues, invocar constantes psicológicas» (Mauron, 1998: 18). Una psicocrítica del género cómico, por tanto, se propone explicar cómo sus obras consiguen atraer a los espectadores, analizar sus figuras recurrentes en relación con constantes psicológicas inconscientes, no del autor individual sino del espectador como colectivo - una dimensión que ya se encontraba, como vimos tanto en Bergson como en Freud. 


\subsubsection{Risa y juego infantil}

Para ello Mauron se apoya, como hemos dicho, en la teoría de Freud de lo cómico y los apuntes de Ernst Kris acerca de su relación con la risa infantil. Para Mauron, como para Kris, lo esencial de la risa no es la sensación de superioridad sino la de dominio, la de triunfo sobre una dificultad o una angustia; por eso la risa se sitúa en los límites de esta angustia (Mauron, 1998: 21). La risa supone, primero, el triunfo sobre el miedo a ser devorado, y después, al castigo: «los bebés intentan muy pronto cometer actos prohibidos, seduciendo al adulto para ganarse un tierno cómplice: al delito sigue una expectación inmóvil, que explota en risa cuando la impunidad queda comprobada» (Mauron, 1998: 21). En este sentido, también Kris había destacado el carácter comunicativo del juego y social del chiste en el que, como vimos, tanto insistía Freud: el niño que juega siempre busca una segunda persona a la que se dirige una atención agresiva o libidinal y del que se espera su aprobación (Kris, 1964: 67). En todo caso, si el niño ahorra en la risa la angustia del castigo, el adulto hace lo propio con la energía psíquica movilizada por las exigencias del comportamiento socialmente sancionado como normal (Mauron, 1998: 22). Solo en un momento posterior la risa infantil se convierte en burlona: en este caso el niño no se compara con un estado de angustia anterior, sino con la inferioridad del prójimo. De la misma manera, en la risa del adulto encontramos la comparación entre la experiencia adulta normal y la de un comportamiento considerado infantil; el adulto incluso puede dejarse llevar por el infantilismo de la risa, abandonándose a la regresión que supone esta (Mauron, 1998: 23-24).

En resumen, lo cómico aparece «en el plano verbal y adulto, como un derivado del juego infantil y no cesa de mezclarse, como toda actividad lúdica, con la repetición de situaciones angustiosas todavía mal controladas, el placer de dominios adquiridos y, en fin, el aprendizaje de una libertad mayor» (Mauron, 1998: 24). El teatro cómico, además, añade a este placer del juego verbal el lujo de la regresión a las formas cómicas más primitivas e infantiles: la bufonada, la burla carnavalesca de las normas sociales, etc. (Mauron, 1998: 24).

\subsubsection{El arte cómico como juego}

El arte dramático de la comedia, por tanto, se puede entender como una elaboración artística de la risa infantil y la adulta. De hecho, nacida de «las manifestaciones populares y orgiásticas del sentimiento religioso», se ubica, como el juego, en un espacio liminar 
que determina sus dos aspectos característicos: «de una parte, el arte cómico, en el borde del sueño, sustituye sus obsesiones por la realidad concreta y cotidiana; por otra parte, exige una gran seguridad y, además, una protección contra los peligros, tanto externos como internos» (Mauron, 1998: 25).

El comportamiento psíquico del espectador teatral se asemeja al del soñador: al público se le presenta una fantasía ajena al mundo real y en la que no pueden participar a no ser que se proyectando sus propias experiencias afectivas. Pero donde en la tragedia la fantasía lleva a la angustia, aceptada por el espectador por estar diluida en la distancia artística, en la comedia la fantasía se aleja del mundo onírico para acercarse al mundo cotidiano; paradójicamente, a pesar de este mayor “realismo”, el espectador no anula la distancia estética y rechaza toda identificación afectiva (Mauron, 1998: 26-27). Este rechazo se consigue, en parte, por la inverosimilitud propia de la comedia, que la acerca más al juego que al sueño (Mauron, 1998: 28). En el mundo de la comedia, los actos no tienen consecuencias, ni los sentimientos se corresponden con la acción; la comedia «mantiene celosamente su derecho al absurdo: el no-sentido juega un papel demasiado destacado en el humor para que renuncie a él (...) Paradójicamente, la más mítica de las tragedias tiene menos derecho a la irrealidad que la comedia más cotidiana» (Mauron, 1998: 29).

\subsubsection{La fantasía cómica de triunfo}

Esta cercanía de la comedia con el juego permite la creación de un mundo al revés que afecta a la inversión de situaciones angustiosas: «el débil se imagina fuerte, el pobre rico, el culpable justiciero, etc.» (Mauron, 1998: 30). Estas inversiones cómicas se corresponden con mecanismos básicos de defensa contra la depresión - ya hemos visto, de hecho, que Kris relacionaba lo cómico con la manía. En este sentido, la comedia refleja esas inversiones infantiles de situaciones angustiosas, pero lo hace en el nivel inconsciente: el espectador que ve un personaje cómico en escena, lo percibe como infantil y se siente superior, pero inconscientemente se identifica con él (Mauron, 1998: 31). Mauron insiste en que las tendencias que se liberan gracias a la técnica del chiste no pertenecen al inconsciente, sino al preconsciente, según la distinción ya señalada por Freud: los espectadores de la comedia son conscientes de las limitaciones que se están burlando y que son fuentes de su placer consciente; de hecho, estas limitaciones son las de carácter más social, y por tanto sujetas a variación histórica (Mauron, 1998: 48). Sin 
embargo, la mitología de la risa, la arquitectura subyacente a toda comedia, se funda en esta inversión de una angustia:

Esta fantasía, esencialmente infantil, se proyecta sobre la pantalla de la vida cotidiana, admitiendo por convención los pequeños desajustes y las inverosimilitudes que puede haber (...) Este desajuste de causas y efectos (...) aseguran al espectador contra la ansiedad, el patetismo y la reflexión (...) La imagen final que resulta de esta compleja elaboración es presentada al espectador, que la compara en cada instante con su representación de adulto normal; la diferencia entre las dos representaciones suscita la risa (Mauron, 1998: 32)

\subsubsection{Figuras grotescas y fantasías edípicas}

Las figuras cómicas, por tanto, son materializaciones de fantasías infantiles, y también están relacionadas con una regresión a la mentalidad religiosa primitiva:

Esta infancia, este juego, esta desnudez, este triunfo del que hoy hacemos uno de los polos humanos de la risa, fueron antiguamente las danzas del drama satírico (...) La aparente regresión de lo cómico podría no ser más que un retiro más acá de lo social, que permite, después de recuperarse y romper las barreras, un avance más allá (Mauron, 1998: 51)

En este sentido, Mauron desdeña las distinciones entre un cómico alto y un cómico bajo, vulgar y grotesco, que derivan de criterios más morales que estéticos. El arte de lo cómico bajo «comprende además de una liberación (controlada) de las potencias instintivas, el sentimiento de su carácter sagrado ligado al misterio de la vida cósmica»: de ahí que en la Comedia Antigua los rasgos más obscenos fueran los más vinculados a su origen religioso (Mauron, 1998: 52-53). Las figuras cómicas grotescas como los parásitos, los cocineros, los soldados fanfarrones o los criados son las más ligadas a estos orígenes cultuales de la comedia (Mauron, 1998: 73). Esta muchedumbre grotesca representa algo más que las regresiones a una libertad sin límites: también son inversiones de miedos infantiles. El cocinero, por ejemplo, apunta a la agresividad angustiosa descrita por Melanie Klein, el miedo a devorar o ser devorado, mientras que el soldado fanfarrón representa una obvia defensa maníaca contra una herida narcisista (Mauron, 1998: 78).

Pero la forma clásica que toma la fantasía de triunfo cómica es la fantasía edípica en la que el joven burla al viejo (Mauron, 1998: 54). Como dice Jekels, la comedia deriva de un desplazamiento de la culpa trágica del hijo al padre; en el conflicto cómico entre padre e hijo, aquel «debe estar siempre por debajo», fruto de una defensa maníaca (Mauron, 1998: 55). Claro que el conflicto edípico del incesto y el parricidio debe 
aparecer de forma atenuada: así, el incesto se transforma en una competición por la misma mujer o en los impedimentos que el padre pone a que los jóvenes se casen, y el parricidio se limita a una victoria más o menos humillante del joven, pero nunca realmente dañina para el viejo (Mauron, 1998: 57). Muchas comedias, incluso, representan en las figuras de las alcahuetas, las esposas lujuriosas y las suegras controladoras, una regresión a un régimen matriarcal que favorece la victoria del hijo, "pues las fuerzas profundas de la vida están a su favor» (Mauron, 1998: 59-63).

El padre, por el contrario, siempre aparece como débil o indigno de respeto. Paradójicamente, es él quien presenta más rasgos infantiles: es narcisista, incapaz de controlar sus apetitos, etc. (Mauron, 1998: 59). No siempre el conflicto edípico se materializa en el padre como tal, sino que se proyecta en otras figuras de autoridad de la vida social, como soldados, médicos, jueces, policías, etc. (Mauron, 1998: 59). Por otra parte, la liberación de los instintos es proyectada desde los jóvenes a sus criados, que son los que bromean y abusan de las figuras de autoridad con total infantilismo (Mauron, 1998: 60).

\subsubsection{La fantasía de triunfo como proyección histórica}

Como vemos, la propuesta de Mauron presenta de manera aún más clara que lo cómico reproduce, aun inconscientemente, angustias colectivas. Además, y este es un punto muy importante, reconoce el carácter histórico de la fantasía de triunfo que analiza, historicidad que depende de la estructura de la sociedad que la comedia refleja. Concretamente, la arquitectura del triunfo edípico aparece como tal en la Comedia Nueva:

Para Aristófanes, y para toda la Comedia Antigua, la realidad agobiante tiene aspectos políticos: guerras, denuncias, procesos, etc. Es exterior al hogar, mientras que los placeres son domésticos (...) Después de que, en una Atenas vencida, la clase media se retira de la política en provecho de los intereses económicos individuales, los polos se invierten. El principio de realidad reina en el hogar. El mercado está fuera. La comedia hace del mundo exterior un lugar de aventuras, de cambios a menudo deshonestos, de encuentros amorosos (Mauron, 1998: 72-73)

Por tanto, el conflicto entre padre e hijo que domina la comedia desde Plauto hasta Molière depende de un contexto histórico y sobre todo social que determina su arquitectura. En el capítulo correspondiente [7.1] aplicaremos este esquema histórico a la 
sitcom, intentando dilucidar la fantasía subyacente de la serie Friends y el momento histórico que hipotéticamente proyecta.

\subsubsection{La escuela hegeliano-lacaniana: The odd one in, de Alenka} Zupancic

Tanto Kris como Mauron, como vemos, no se alejan apenas de las observaciones freudianas acerca de lo cómico. La última autora que trataremos en este apartado se sitúa en una perspectiva considerablemente diferente, la del psicoanálisis lacaniano. Alenka Zupančič pertenece a lo que podríamos llamar escuela eslovena, cuyo autor más conocido es, sin lugar a dudas, Slajov Žižek; tanto él y Zupančič como Madlen Dollar combinan en su filosofía el psicoanálisis lacaniano con nociones hegelianas.

Aunque, como hemos visto, las incursiones de Lacan en lo cómico se limitan a una lectura sobre El chiste... orientada a formular el funcionamiento del inconsciente en términos lingüísticos, lo cierto es que su pensamiento, sobre todo en lo referente a su definición paradójica tanto del sujeto como de la realidad simbólica, supone un terreno fértil para una especulación sobre lo cómico. No es de extrañar, por tanto, la conocida costumbre de Žižek de usar chistes, junto a películas de terror y ciencia ficción, para explicar algunos conceptos lacanianos como el del Otro. En este sentido, es necesario señalar que el libro de Zupančič sobre la comedia no se interesa por lo cómico como fenómeno comunicativo ni estético; no se plantea, como Freud, Kris o Mauron, los procesos de creación o recepción de lo cómico ni su relación con otros fenómenos y mecanismos psíquicos. El interés de Zupančič se centra en analizar la estructura y algunas comedias concretas en términos de su propia filosofía hegeliano-lacaniana, incidiendo en la estructura de la realidad simbólica, el funcionamiento del Otro o la constitución del sujeto. Aun así, como veremos, su descripción de lo cómico y algunos de sus análisis resultarán muy útiles para nuestro propio acercamiento al fenómeno.

\subsubsection{La incongruencia como cortocircuito y el materialismo cómico}

El estudio de Zupančič de la comedia está en parte guiado por oposición a algunas concepciones tradicionales de la misma que ella considera equivocadas. Por ejemplo, desdeña el lugar común de que la comedia consiste en devolver al ser humano a la naturaleza, humillándolo junto con sus aspiraciones idealistas y soberbias: para Zupančič 
el objeto de la comedia no es criticar cómo lo humano se aleja irresponsablemente de lo natural, sino mostrar cómo precisamente la misma naturaleza es poco "natural” en un sentido bergsoniano y está llena de contradicciones y discrepancias consigo misma (Zupančič, 2008: 7).

Para describir el mecanismo de la comedia, Zupančič se sirve de una noción sui generis de la teoría de la incongruencia: la comedia, según ella, funciona mediante un sinfín de cortocircuitos que ponen en relación órdenes heterogéneos entre sí; pero no presenta esta conexión como una suave yuxtaposición, sino como un corte material que los mantiene, paradójicamente, unidos. Por ejemplo, en un juego de palabras entre las palabras homófonas «break» $\mathrm{y}$ «brake», lo que conecta ambos términos es precisamente su diferencia irreductible: «the only genuine inmediate link between those things is the very cut between them» (Zupančič, 2008: 8). Otro ejemplo más claro es una escena protagonizada por Charles Chaplin: en ella, el compañero hambriento del actor se lo imagina como una gallina, pero en lugar de construir la escena mediante un montaje en el que Chaplin es sustituido por una gallina real, este se disfraza de gallina y es perseguido por su compañero. De este modo, lo cómico de la escena es la materialización de la incongruencia entre Chaplin y la gallina, basada, paradójicamente, en su superposición: «the scene is no longer constructed simply upon the discrepancy between what Charlie really is and how the other sees him (as a chicken), but adds something else: it brings to light the chicken-ish properties of the man-Charlie himself» (Zupančič, 2008: 19).

Zupančič parte de esta formulación para proponer su propia concepción materialista de la comedia, en un sentido diferente al tradicional. La filósofa parte de la concepción que tanto Hegel como Lacan comparten del Otro, del sistema simbólico que constituye nuestra realidad, o al menos su entendimiento. El Otro como orden simbólico, para Hegel, no es algo que se evite solo por reconocerlo como ilusorio, sino que, a pesar de ser efectivamente ilusorio, tiene «considerable material effects in which it does exist» (Zupančič: 2008: 17). La comedia, para Zupančič, sirve para mostrar este funcionamiento material del orden simbólico, además de para señalar sus incongruencias constitutivas: lo cómico, si es verdaderamente subversivo, no reside en la actitud ridícula de los personajes, sino en la misma estructura de la realidad (Zupančič: 2008: 19).

Es en este sentido que Zupančič, siguiendo a Hegel, define la comedia como materialista. Aunque muchos ven en la comedia un énfasis en la dimensión humana y por tanto imperfecta de nuestras representaciones, es decir, en el fracaso de los individuos de 
representar y actuar según conceptos ideales y universales, como una especie de llamada a la humildad, de recordatorio de nuestra propia finitud e imperfección, Hegel considera que lo cómico, más allá de toda representación individual, presenta estos universales en su esencia más material (Zupančič: 2008: 26). Así, en la escena cómica prototípica del aristócrata que se resbala con una cáscara de plátano, cae al suelo e inmediatamente se levanta, no estamos observando cómo la vida material interrumpe la aristocracia y lo revela como humano, sino la Aristocracia, en tanto que concepto ideal, en toda su concreción; no asistimos a la revelación de cómo un aristócrata, a pesar de serlo, también es humano y por tanto se cae, o del hombre que no está a la altura de la aristocracia, sino al espectáculo de un aristócrata que, a pesar de ser solo un hombre, persiste en ser aristócrata: «is precisely the baron’s unshakable belief in himself and his own importance what is really funny and make us laugh» (Zupančič: 2008: 19).

Si tuviéramos que redescribir la teoría de Zupančič en términos de "crítica ideológica”, diríamos que, en el chiste anterior, no se critica al hombre que fracasa en su intento de ser aristócrata porque es demasiado humano, sino que se critica el hecho mismo de tomarse en serio una noción como la de aristocracia. Es en este sentido en que Zupančič introduce una distinción entre lo verdaderamente cómico y la comedia solo aparentemente subversiva. Esta distinción no depende del contenido de la comedia, sino de su técnica. Una comedia conservadora nos presentaría un aristócrata que además es humano (y que se cae, emite flatulencias, etc.); esta comedia sería moralizante en el sentido de que nos alecciona acerca de la necesidad de recordar nuestras limitaciones, etc. Pero una comedia verdaderamente subversiva ridiculizaría el hecho mismo de que el aristócrata se crea aristócrata: lo que se presenta como algo material, concreto y contingente no es el individuo humano sino la misma idea de aristocracia (Zupančič, 2008: 30-32). Se trata del mismo razonamiento del apunte de Lacan de que el verdadero lunático no es el plebeyo que se cree rey, sino el rey que cree realmente es un rey gracias a unas cualidades intrínsecas a su persona y no a su posición fortuita en un orden sociosimbólico.

Para Hegel, en la lectura de Zupančič, la diferencia entre el personaje trágico y el cómico es que mientras aquel representa cierta idea, pero salvaguarda su individualidad (aunque Hamlet represente la duda, no deja de ser Hamlet), el cómico incluye la distancia misma entre la idea representada y su representación en su propio ser: hay una especie de escisión en la misma psique del personaje. El razonamiento de Zupančič en este punto es 
análogo al de Bergson cuando afirma que es necesario que el personaje, para resultar cómico, se ignore a sí mismo, y que los vicios cómicos constituyen un personaje independiente de los demás: hay una escisión entre Harpagón y su miseria, y esta escisión es el modo en que la Miseria se concretiza, se hace material y actúa como una entidad independiente (Zupančič, 2008: 37). En este sentido, la comedia no presenta las limitaciones de un individuo, sino hasta qué punto este es algo más que sí mismo: «one could say that the flaws, extravagances, excesses, and so-called human weaknesses of comic characters are precisely what account for their not being “only human” (...) What is “human” exists in this kind of excess over itself» (Zupančič, 2008: 49). Por esta razón precisamente los personajes que reusltan más cómicos son los más extravagantes.

En conclusión, el materialismo de la comedia no se refiere a la finitud del ser humano, sino de la realidad misma ${ }^{38}$; al presentar el orden simbólico en su realidad material, en sus efectos, se ponen al desnudo sus propias contradicciones (Zupančič, 2008: 38, 47). Por eso la comedia resulta adecuada para ejemplificar las tesis lacanianas: para Lacan, lo Real, ese exceso no simbolizado (y que tiene que ver con el síntoma y el retorno de lo reprimido), y el objeto $a$, que es el objeto de deseo, es este "algo en el ser humano que es más que humano”, lo que hay en la vida “más que la vida”.

Esta Otra escena es descrita por Lacan como la banda de Moebius en la cual, aunque solo haya una sola superficie, en cualquier punto siempre hay otro lado que en realidad no existe. Es en este sentido que la yuxtaposición cómica se puede entender como un cortocircuito, como una «inherent contradiction (of the finite) as the generating point of something that is not reducible to simple finitude» (Zupančič, 2008: 53-54). Para Zupančič, la comedia es la manifestación material de esta contradicción. La ténicca fundamental de lo cómico es el encuentro de dos realidades contradictorias entre sí que, sin embargo, existen al mismo tiempo sin que una llegue a excluir a la otra: lo cómico

\footnotetext{
${ }^{38}$ Este carácter "materialista” de lo cómico, por supuesto, está presente en toda su historia. Como vimos, el ámbito de la risa en el pensamiento antiguo y medieval es el de lo corporal, el de lo carnal. Así, no debemos entender la escatología propia de lo grotesco y el carnaval como una "crítica" a la abstracción de la seriedad oficial, sino en este sentido en que lo cómico es el arte que explora la materia y su funcionamiento. Tengamos en cuenta, por ejemplo, las referencias de Jean Paul a lo cómico como el arte de lo pequeño y lo sensible, o la relación que establece Hugo entre lo cómico y lo feo porque ambos apuntan a lo múltiple, lo deforme, lo cambiante, etc. También Baudelaire, en su descripción de una escena de la commedia dell'arte, hace un especial hincapié en la plasticidad y la corporalidad de sus actores. Como vimos, el automatismo propuesto por Bergson como fundamento de lo cómico es el rasgo principal de la materia opuesta al espíritu. También algunas técnicas verbales señaladas por Bergson o Freud son materialistas en este sentido: por ejemplo, la de tomar por literal lo figurado, o cualquier juego de palabras que explote los fenómenos de homofonía y doble sentido.
} 
reside en esta misma articulación imposible y que sin embargo da sentido a ambas realidades (Zupančič, 2008: 57) - recordemos lo que dice Freud acerca del «sentido dentro del sinsentido», y las «interferencias entre series» descritas por Bergson [ver 3.3.1, 5.3].

\subsubsection{Psicoanálisis de algunas figuras cómicas}

La metáfora usada por Zupančič para explicar lo cómico como un cortocircuito irreductible entre dos representaciones supone un sugerente refinamiento de la teoría de la incongruencia, y en epígrafes siguientes [3.3.1; 5.3] encontraremos formulaciones análogas que apuntan no solo a la diferencia entre las representaciones incongruentes sino a cierta ambigüedad constitutiva de la significación en el discurso cómico. Además, el libro de Zupančič presenta algunas consideraciones muy interesantes acerca de la naturaleza del personaje cómico y de la estructura de las situaciones cómicas en general.

Muchas de estas situaciones, por ejemplo, presentan la relación de discordancia entre el yo y el ello en la que el ello quiere algo distinto del yo: es decir, su efecto cómico se apoya en esta incongruencia y concretamente en la cuestión del goce (jouissance) como algo ajeno al yo: «there is something about satisfaction and enjoyment that has its own logic and a relatively independent autonomous life, which can land the subject in rather awkward situations» (Zupančič, 2008: 64). El sujeto, por su parte, «may feel rather frustrated: there is something there that does not concern him, something that is annoyingly indifferent and "unrelated” to his feelings» (Zupančič, 2008: 64). Como vemos, Zupančič describe el comportamiento del personaje cómico en los mismos términos que Freud describe el síntoma: el ello inconsciente encuentra una satisfacción que el yo, dominado por el superyó y el principio de realidad, vive como un malestar. El personaje cómico, por tanto, se encuentra en «the type of comic situation where a more or less agreeable image of the ego is challenged by the intrusion of some fundamental need that demands its satisfaction» (Zupančič, 2008: 65).

De este modo, podemos describir la estructura básica del carácter y la comedia de caracteres típica de Moliére entendiendo por «carácter» el personaje que, lejos de presentar una individualidad y una profundidad psicológica, está caracterizado por un único rasgo que, según esta perspectiva, representa su ello como una entidad ajena (Zupančič, 2008: 66). Estas comedias presentan una relación obsesiva del personaje con este rasgo característico, o bien con un cierto objeto o persona (por ejemplo, Orgón con 
Tartufo o Harpagón con su cofrecillo), siendo esta relación una materialización del vínculo entre el yo y el ello a través del goce: «we are delaing not so much with the protagonist's "inner struggle” as with the fact that the Id - incarnated in an external object or ritual - literally swings the character around, as if they were tied together by an invisible elastic band» (Zupančič, 2008: 68). Por eso estos personajes son a menudo “monológicos” en el sentido de que no establecen relaciones realmente intersubjetivas con los demás personajes, e incluso desatienden sus obligaciones familiares o sociales (Zupančič, 2008: 68-69). La situación paradójica de estos personajes es que parecen infelices en tanto que son presentados como paranoicos, obsesivos, preocupados en exceso por el objeto de su pasión, y sin embargo son felices: «they might constantly complain, yet this does not indicate that they are not satisfied with things as they are (...) They are quite content insofar as their Id is content» (Zupančič, 2008: 71).

Otro tema muy presente en la comedia es el del doble, mediante el cual se muestra, ya no la relación del yo con su inconsciente, sino que se enfrenta al yo con el yo, objetificando el ego y convirtiéndolo en una entidad independiente. El ejemplo paradigmático de esta técnica es, por supuesto, el Sosias del Anfitrión de Plauto y el versionado por Molipere (Zupančič, 2008: 73). De hecho, Lacan se sirve de un diálogo de dicha obra para deifnir el ego como construcción imaginaria de acuerdo a su teoría del estadio del espejo (Zupančič, 2008: 75). La lección de Sosias, dice Zupančič, es la siguiente: «identity is always a construction, if not pure fantasy; the subject does not exist, but is only a name for an assemblage of heterogeneous symbolic and imaginary procedures and determinations» (Zupančič, 2008: 77). Claro que lo fundamentalmente cómico del tema del doble es el momento en que la comedia, una vez que ha mostrado este carácter especular del ego, mantiene a ambos reflejos unidos por un vínculo imposible e inevitable (Zupančič, 2008: 78).

Una variación de este tema es la comedia de enredo en la que el personaje no se encuentra con su otro yo sino que simplemente se va encontrando con los efectos que su otro yo causa - un ejemplo es el final de Noche de reyes, de Shakespeare, en que Viola es confundida con su hermano gemelo. La comicidad en estos casos consiste en la inherente incapacidad del Otro, del sistema simbólico, para funcionar sin fisuras y evitar estos equívocos, mostrando los efectos de esta inconsistencia: «the comic suspension coincides with the surprising appearance of a (small) other: in the form of a double or in the form of a surplus comic object» (Zupančič, 2008: 92). Esta inconsistencia temporal 
del Otro, esta lógica equívoca es, por supuesto, lo que acerca la comedia a la lógica del sueño o la del juego, y tiene que ver con la inversión carnavalesca y otros fenómenos cómicos análogos. Aunque el orden se acabe por restaurar al final de la comedia, no es exactamente el mismo de la situación inicial: «comedy is thus also a practice demonstrating that the Other (as the symbolic presupposition of sense) is no ideal or eternal and unchangeable in its form; via the surplus-object, it is always irreducibly attached to and involved in concrete reality» (Zupančič, 2008: 93). En otras palabras, la comedia de enredos revela que esta incongruencia, esta lógica irracional momentánea es en realidad propia del Otro, del orden simbólico, del ordenamiento lingüístico-social de la realidad - lo que podemos relacionar con la afirmación de Bergson de la comedia popular como reflejo del automatismo de la vida.

\subsubsection{Estructuras temporales de lo cómico}

Esta suspension temporal del orden simbólico que encontramos en la comedia de enredo plantea a su vez la cuestión de la estructura de la comedia. Normalmente los téoricos de la comedia se centran en el final feliz, donde cada personaje obtiene todo lo que desea, sin contar con todos los infortunios caóticos y desplazamientos sucedidos a lo largo de la obra; más bien, el final de la comedia es el evento menos "feliz" en tanto que pone punto y final al ambiente onírico y festivo de la obra (Zupančič, 2008: 130), la Victoria de doña Cuaresma sobre Carnaval. El placer cómico, en tanto que se sitúa en la jouissance, es un placer que nunca puede ser enteramente satisfecho (Zupančič, 2008: 131-132).

Este mantenimiento del placer explica la diferencia estructural entre un chiste y una escena cómica. En el chiste, la incongruencia se sitúa al final y resignifica retroactivamente todo el relato desde una perspectiva sorprendente. En este sentido, en el chiste no solo nos reímos de una persona o una situación, sino del mismo funcionamiento del lenguaje como estructurador de nuestra realidad (Zupančič, 2008: 142). La escena, por el contrario, sitúa la incongruencia al inicio, y el resto de la escena consiste en desarrollar la incongruencia, explorando sus consecuencias (Zupančič, 2008: 133-137). Del mismo modo, la comedia presenta una estructura repetitiva y está comprometida con el presente: «comedy practically never tries to explain why something happens, but it is extremely adept at showing how something functions (...) The structure of comedy (...) replaces the cause-effect relationship and its temporal logic (before-after) with a juxtaposition of different elements, and their (active or not) connections (...) Comic 
repetition - which is always a repetition in the present - reactivates the very ground or presupposition of a given structure, and makes it appear as an object» (Zupančič, 2008: 178).

\subsection{La comedia, la parodia y la ironía en la teoría literaria}

\subsubsection{Visiones contemporáneas de la comedia}

\subsubsection{Comedia y vitalismo}

El impulso “antropológico” romántico que quiso buscar en las formas artísticas antiguas y las populares las raíces de lo profundamente humano, dio lugar en el siglo XX a un renovado interés por la comedia como género literario y un intento de dignificar lo cómico como categoría estético-filosófica equiparable incluso a la de lo trágico. Entre los primeros intentos significativos debemos contar con el estudio de Cornford sobre los orígenes rituales de la Comedia Antigua que mencionábamos en el primer capítulo [1.1.2.1], o la particular atención que Bergson, como pudimos comprobar, ofrece a las comedias de Molière en su estudio sobre la risa. El vínculo establecido entre la comedia y los rituales de fertilidad por Cornford y la oposición entre vitalidad y mecanismo que fundamentaba la teoría de la risa de Bergson ofreció para el siglo XX una visión de la comedia como el género del vitalismo, de la alegría de vivir, de la celebración de la comunidad, de la renovación de la naturaleza y la sociedad, de la victoria sobre la muerte, etc. Para Susanne Langer, por ejemplo, la comedia es «an art form that arises naturally wherever people are gathered to celebrate life (...) it is an image of human vitality holding its own in the world amid the surprises of unplanned coincidence» (Langer, cit. en Stott, 2005: 27). Los estudios de Bajtín sobre el carnaval y la literatura carnavalesca, que trataremos un poco más adelante, también revirtió en esta valoración de la Comedia como liberación festiva.

Durante buena parte del siglo XX, por tanto, el mundo académico ha tomado la comedia (al menos la que pudiéramos llamar clásica, la de Aristófanes, Plauto, Shakespeare y Molière) como el género por antonomasia de la festividad (con todo lo que conlleva de liberación de las presiones sociales y retorno a lo "natural” y la renovación del orden social). Cesar L. Barber, por ejemplo, en su libro de 1963 Shakespeare’s Festive 
Comedy, realizaba en su estudio un ejercicio paralelo al de Cornford relacionando las comedias del Bardo con las fiestas populares de la Inglaterra de su época (Stott, 2005: 30). La comedia “saturnaliana”, como él la denomina, llevaría a cabo un proceso social de «release and clarification», de liberación de las constricciones sociales y de reafirmación de la comunidad: «comedy thereby has the dual function of celebrating human relationships and merrymaking, while mocking what it considers 'unnatural', baiting killjoys and misery characters who fail to observe the feast or show some perverse aversion to happiness» (Stott, 2005: 30-31).

Otra de las obras de referencia en esta visión de la comedia es, por supuesto, la Anatomía de la Crítica de Northrop Frye, y concretamente su teoría de los mythos, la hipótesis de que toda la literatura se puede analizar partiendo de ciertas estructuras narrativas (puestas en relación con los ritmos cósmicos, que Frye vincula concretamente a las estaciones del año). Así, distingue cuatro tramas fundamentales y anteriores a los géneros literarios históricos: la romántica, la trágica, la cómica y la irónica o satírica (sobre la que volveremos más adelante al tratar del desarrollo de la ironía en la teoría literaria) (Frye, 1991: 215). Estas cuatro categorías se combinan en oposiciones binarias: trágico-cómico y romántico-satírico, dando lugar a categorías mixtas como el romance trágico o cómico o la tragedia satírica, etc. (Frye, 1991: 215).

La comedia, como decimos, equivale en el sistema de Frye al mythos primaveral. Aunque podamos identificar este mythos cómico en la narrativa, por ejemplo, de Dickens, su origen es la Comedia Nueva de Plauto y Terencio y su argumento básico, el de la pareja de enamorados que han de superar unos obstáculos para estar juntos:

En este sencillo patrón hay varios elementos complejos. En primer lugar, el movimiento de la comedia es, por lo común, el movimiento que va de una clase de sociedad a otra. Al comienzo de la obra, los personajes obstructores tienen a su cargo a la sociedad en escena y el público reconoce en ellos a los usurpadores. Al final de la obra, el recurso de la trama hace que una nueva sociedad se cristalice en torno al héroe (...) La aparición de esta nueva sociedad se señala, a menudo, por algún género de fiesta o rito festivo que, o bien se presenta al final de la obra o se supone que tiene lugar inmediatamente después (Frye, 1991: 216-217)

El hecho de que este obstáculo esté representado en la comedia por el padre o por una figura de autoridad paterna similar [ver 3.1.5.3 y 3.1.5.4] explica el que históricamente se haya percibido como un género supuestamente subversivo (Frye, 1991: 218). Aun así, 
para Frye la nueva sociedad es una sociedad lo más inclusiva posible, aceptando incluso a las figuras que en un principio se oponen a los jóvenes héroes - en este sentido, Falstaff o el Shylock de El mercader de Venecia representarían casos límite (Frye, 1991: 219).

Como decimos, la comedia puede combinarse con la sátira o el romance, según haga más hincapié en la descripción crítica de los antagonistas o en las aventuras que conllevan los procesos de reconocimiento y reconciliación, respectivamente: «La primera es la tendencia general de la ironía cómica, de la sátira, del realismo y de los estudios de costumbres; la segunda es la tendencia de la comedia de Shakespeare y de otros tipos de comedia dramática» (Frye, 1991: 221); esta tendencia a un mayor "realismo" por parte de la comedia satírica explica la mayor variedad de los personajes antagonistas, por ejemplo en las obras de Molière, frente al desarrollo casi nulo de los héroes cómicos (Frye, 1991: 221). En todo caso, este rasgo también da cuenta del carácter social y de crítica moral y de costumbres que se encuentra en muchas comedias: lo que se castiga en los personajes antagonistas son ciertos vicios y manías que obstaculizan el correcto funcionamiento de la sociedad y «la respuesta normal del público a tal desenlace es un “así es como debe ser”» (Frye, 1991: 222); «la sociedad que emerge al concluir la comedia representa, por contraste, una especie de norma moral, o una sociedad pragmática libre. Sus ideales rara vez se definen o formulan (...) Sencillamente, se nos da a entender que la pareja recién casada vivirá siempre feliz» (Frye, 1991: 224).

Este enfrentamiento entre la vieja y la nueva sociedad presenta, según Frye, una cierta analogía con la estructura retórica de un litigio judicial; de ahí que en el Tractatus Coislinianus se recurra a términos pertenecientes a la Retórica como la pistis (opinión) y la gnosis (conocimiento) para analizar la dianoia cómica como el paso de una opinión falsa a un conocimiento (por ejemplo, la anagnórisis cómica por la que se descubren los orígenes nobles de uno de los amantes, posibilitando el matrimonio). El paso de la sociedad vieja a la nueva se presenta, de este modo, como el paso de una ley absurda, obsoleta, representada por la autoridad paterna, a una mayor libertad y cercanía a la ley “natural” (Frye, 1991: 220):

Así pues, el movimiento que va de la pistis a la gnosis, de una sociedad controlada por la costumbre, la servidumbre ritual, la ley arbitraria y los personajes de más edad, a una sociedad controlada por la juventud y la libertad pragmática es, fundamentalmente, tal como lo sugieren las mismas palabras griegas, un movimiento que va de la ilusión a la realidad. Ilusión es todo aquello que es fijo o definible y la realidad mejor se entiende 
como todo lo contrario: sea lo que fuere, la realidad no es eso. De ahí la importancia del tema de crear y disipar la ilusión en la comedia: ilusiones causadas por el disfraz, la obsesión, la hipocresía o la ascendencia desconocida (Frye, 1991: 225)

En resumen, esta tradición crítica concibe la comedia, como decimos, como un género marcado por la festividad, la celebración y la renovación natural y social; un modelo que podríamos considerar común a las obras de Aristófanes, Menandro, Plauto, Shakespeare y Molière, por mencionar solo a los comediógrafos más importantes. Por ejemplo, David Grote, autor al que volveremos en nuestro estudio sobre la comedia televisiva o sitcom, la comedia es fundamentalmente anárquica, un escape de la ley representada por la figura autoritaria del Padre de familia. Esta figura paterna de autoridad representa un obstáculo social a la felicidad de los jóvenes amantes, y el triunfo de estos sobre aquel representa la renovación de una sociedad autorreguladora que elimina los elementos sociales que se han vuelto demasiado rígidos y obstaculizan la armonía de la comunidad que le es natural: «ultimately, the basic plot is a promise of the future, symbolized by the union of a couple leading to the birth of a child» (Grote, 1983: 36)

\subsubsection{Comedia: ¿control o subversión?}

Las imágenes de crítica de costumbres, renovación social, paso de una sociedad injusta a una sociedad justa, de festividad y liberación de las constricciones sociales, lleva implícita la cuestión de la subversión cómica. La idea de festividad conlleva la de la anarquía y transgresión de las normas sociales, y la de renovación social, la de un comentario de carácter supuestamente progresista que sería inherente al género cómico. Esta asociación entre comedia y subversión se hizo más estrecha con la obra de Bajtín y su idea del carnaval como oposición radical a la cultura y las instituciones oficiales [ver epígrafe siguiente, 3.2.2]. Sin embargo, como vimos en el capítulo correspondiente, antropólogos, historiadores y críticos literarios han puesto en duda la exactitud de las tesis bajtinianas acerca del carácter subversivo y “progresista” de las fiestas carnavalescas, y esta duda se puede aplicar también a la comedia: ¿hasta qué punto las transgresiones y críticas morales de la comedia son subversivas o por el contrario sirven para mantener el status quo? El mismo David Grote reconoce que los cambios que se producen en la Comedia son circunstanciales e individuales y dejan el sistema social intacto (Grote, 1983: 50-51). También se podría cuestionar el sentido de la celebración de la comunidad que la Comedia se supone que lleva a cabo: no hay más que pensar en cómo en El mercader de 
Venecia la reconciliación final se hace a expensas de la humillación y expulsión del judío Shylock.

En este sentido, el crítico neohistoricista Stephen Greenblatt plantea en sus estudios sobre Shakespeare cómo el teatro isabelino y concretamente la comedia se configura como el espacio en que se plantean las luchas ideológicas entre el poder estatal y sus oponentes, pero que en última instancia es controlado por dicho poder. En Enrique $I V$, por ejemplo, se deja cuestionar abiertamente el poder monárquico solo para desactivar estas probables oposiciones: «Power absorbs the potential for change, permitting itself to be questioned for the tactical and pragmatic purposes of seeming to appear open, before finally reasserting itself once more (...) Inversion and misrule, then, exist within a matrix of 'licensed transgression', and are expedient outlets for reckless behaviour that enable the continuance of the social order» (Stott, 2005: 33-34). En una línea similar, Stallybrass y White plantean en The Politics and Poetics of Transgression una revisión de la teoría bajtiniana del carnaval, donde efectivamente las distintas culturas y clases sociales se oponen al poder dominante en un agon permanente y dinámico: «This is not to say that carnival is suddenly a politically progressive force (...) inversion of the terms of normal social operation is not the same as redefining them (...). The carnivalesque is not then equipped to topple the dominant order, but neither is the dominant order able to silence the carnivalesque» (Stott, 2005: 35). En resumen,

Comic inversion not only makes visible those excluded from the hierarchy, therefore, but also symbolically foregrounds the tensions and desires that are elided parts of the identity of power itself, revealing power not to be the coherent and all-pervasive monolith (...) but constituted of contradictions and unacknowledged dependencies (Stott, 2005: 35)

En todo caso, es obvio que el carácter (o mejor sería decir “efecto”) subversivo o conservador de la comedia dependerá, en última instancia, de su recepción concreta por parte del público. Y a la hora de tener en cuenta de qué manera se desenvuelven los diferentes procesos de recepción posibles es necesario analizar las teorías contemporáneas acerca de lo que podemos englobar, grosso modo, bajo el problema de la catarsis en la comedia.

\subsubsection{La identificación cómica y el problema de la catarsis}

En el apartado anterior comprobamos cómo uno de los intereses de la teoría psicoanalítica por el fenómeno de lo cómico era el de la cuestión del placer derivado del chiste en el 
espectador; lo que podemos entender, mutatis mutandis, como la cuestión de la catarsis cómica. Ahora nos disponemos a comprobar cómo ha se ha afrontado este problema desde la teoría literaria del siglo XX, sobre todo de base aristotélica - aunque, como veremos, se tiene en cuenta las aportaciones de Freud, si bien reduciendo, como advertimos, su teoría a la fórmula del ahorro de energía psíquica.

Para empezar, de la teoría de Frye de la comedia como mythos primaveral se puede destacar el carácter eminentemente social al que el proceso de la catarsis está orientado, teniendo en cuenta que, según el esquema de Frye, el argumento cómico tiene como objetivo la "depuración” de la sociedad, la sustitución de una sociedad vieja por una nueva. Por tanto, el particular proceso catártico que ofrezca la comedia tiene que estar encaminado a la aceptación de esta "purga” de los elementos que obstruyen el correcto funcionamiento de la sociedad. Si en el final feliz de la comedia el estado de cosas que se ofrece se presenta como conveniente y deseable, lo que se impone es la confirmación por parte del público de la idoneidad de dicho estado de cosas (Frye, 1991: 217): el final feliz de la comedia pide al público un juicio moral y social, un "así es como debe ser” (Frye, 1991: 221). En resumen, podríamos aventurar que un rasgo de la catarsis buscada en la comedia es su carácter más explícitamente social que su contraparte trágica (Frye, 1991: 234): en la comedia, la purgación emocional catártica es a la vez individual y social.

¿En qué consiste, pues, este proceso catártico particularmente cómico? Como decimos, el problema de la catarsis en la comedia se suele abordar partiendo de la base aristotélica y por analogía con la definición de la catarsis trágica como la purga de la piedad y el temor, acudiendo en ocasiones a la definición del Tractatus Coislinianus, como vimos en el primer capítulo. Así, Northrop Frye afirma que «del mismo modo que hay una catarsis de la piedad y el temor en la tragedia, hay una catarsis de las correspondientes emociones cómicas, que son la simpatía y el ridículo» (1991: 67). Por lo que volvemos a encontrarnos con el problema de qué pueda significar «expulsar la simpatía y el ridículo», empezando por el sentido en que el ridículo puede ser entendido como una emoción del mismo modo que lo es la simpatía. Podríamos entender que tanto la piedad como la simpatía se refieren a la identificación con el héroe, y el temor y el ridículo, los sentimientos negativos que es necesario purgar - en este sentido, el "ridículo" se refiere a la burla hacia el personaje cómico. El problema de esta estrechamente literal analogía con la catarsis trágica es que en esta tanto la piedad como el temor del espectador se orientan al mismo personaje, el héroe de la tragedia, mientras que el espectador de la 
comedia siente simpatía hacia los héroes, los jóvenes enamorados, y se burla del antagonista, la figura de autoridad paterna que ha de ser superada para alcanzar el final feliz. Se podría argumentar que lo que se purga mediante la catarsis cómica es precisamente la agresividad orientada a la figura de autoridad - lo que impediría que esa agresividad actuara en el plano real y amenazara el orden social, según las teorías que niegan el carácter subversivo de la comedia. Pero cabría preguntarse qué sentido tiene eliminar la emoción (el ridículo o la burla) de la que precisamente se sirve la comedia para “destruir” la sociedad vieja y dar paso a la nueva.

Un planteamiento alternativo a esta lectura tan literal de la definición pseudoaristotélica que da el Tractatus Coislinianus es la que ofrece la prestigiosa helenista Dana Sutton en The Catharsis of Comedy. En este libro, Sutton rechaza la definición de la catarsis cómica según una analogía literal con el de la trágica, y plantea que los sentimientos que se purgan en la comedia no son «merriment» and «laughter» ${ }^{39}$, sino los mismos sentimientos que purga la tragedia, esto es, la piedad y el temor (Sutton, 1993: 14). Además, propone traducir el término utilizado por Aristóteles, «eleos», no por piedad, sino por «ansiedad», entendiendo por esta el estado de tensión producido en el espectador por su implicación emocional en las vicisitudes del héroe (1993: 15). Por último, duda de que la ansiedad y el temor sean las únicas emociones que, según Aristóteles, se purgarían en la tragedia, y, asimilando parte de la teoría freudiana del chiste, añade a estas la hostilidad y la agresividad sexual (Sutton, 1993: 30).

Además de esta reinterpretación de la doctrina aristotélica, Sutton tiene en cuenta la comedia como un género humorístico, por lo que considera el ridículo como el elemento fundamental de la catarsis cómica (Sutton, 1993: 41), en tanto que define la comedia como un género humorístico y representacional que se caracteriza por representar «people, things and situations in a characteristically distortive way whereby an element of the ridiculous is present» (1993: 37). El proceso catártico de la comedia, según Sutton, funciona como sigue: la comedia establece un "trasunto" dramático («comic surrogate») de un personaje o situación de la vida real que despierta en el espectador todos aquellos sentimientos que la catarsis busca purgar (ansiedad, miedo, etc.); pero dado el carácter caricaturesco y deformado de este «comic surrogate» y, en general, el ambiente distendido, festivo, “esterilizado”, de la representación cómica, estas

\footnotetext{
${ }^{39}$ Sutton sigue la traducción de Richard Janko a la que recurrimos en el capítulo correspondiente.
} 
emociones negativas que el personaje cómico despierta en el espectador son purgadas (Sutton, 1993: 40-42). Pero, además, Sutton añade un segundo proceso, por el que el espectador transfiere los rasgos ridículos y caricaturescos del personaje cómico a su referente real, de modo que este no pueda seguir despertando la ansiedad del espectador (Sutton, 1993: 44). Por tanto, el efecto de la catarsis cómica no es solo emocional sino también cognitivo: «comic catharsis is not only purgative but also educational (...) it has the ability to modify or, if you will, clarify the spectator's perceptions of - or feelings towards - comedy’s targets» (Sutton, 1993: 44)

La teoría de Sutton ofrece aspectos interesantes, sobre todo al introducir la posibilidad de que la comedia, frente a la visión que muchas veces se tiene de ella como un género ligero que trata temas sin importancia, ponga en escena situaciones que en la vida "real" son fuente de emociones negativas para el individuo y la sociedad. No obstante, también plantea algunas dificultades, sobre todo a la hora de abordar la dimensión social de la comedia y del proceso catártico. Por un lado, Sutton se posiciona en la tradición teórica que considera que la comedia es subversiva por ridiculizar figuras de autoridad (Sutton, 1993: 90-91). Pero, por otro, sigue la hipótesis psicoanalítica del “malestar en la cultura” producida por la represión de los instintos a la que el proceso de civilización somete a los individuos, según la cual la comedia (y sobre teniendo en cuenta su origen festivo) actuaría de "válvula de escape” de todos esos sentimientos de hostilidad, agresividad sexual, etc. (Sutton, 1993: 112) - de ahí que la mayoría de los personajes cómicos ridiculizados sean las figuras de autoridad a las que se culpa de esta pérdida de libertad individual (Sutton, 1993: 101).

Por tanto, desde un punto de vista individual, la catarsis cómica ofrece una fantasía de liberación análoga a la fantasía de triunfo que propone Charles Mauron, mientras que, desde el punto de vista social, la purga de esas emociones de inferioridad, hostilidad, etc., garantiza que estos no deriven en la contestación social, de lo que se podría deducir una concepción conservadora de la comedia. Y, sin embargo, al abordar explícitamente estas interpretaciones que ven la comedia como un género que garantiza el orden social, las rechaza, recurriendo a la obra de Aristófanes como ejemplo:

When comedy subjects its surrounding society to criticism, and when it seems to support hedonism and individualism, are we to supposed to imagine that it has the hidden purpose of strengthening society's hold over the individual? When comedy acquires a more pointedly satiric nature, are we to think that its real goal is to reinforce the prestige and 
power of its targets? (...) In noting that comic catharsis is beneficial for society we must exercise extreme caution not to manufacture a theory that thoroughly defies comedy's manifest spirit and intent, or that very unfairly accuses it of performing some shabby swindle on the spectator (Sutton, 1993: 115; el destacado es nuestro)

La teoría de Sutton, por tanto, resulta contradictoria respecto a la dimensión social de la comedia y los efectos de la catarsis propiamente cómica. Creemos que esto es consecuencia, principalmente, del carácter ahistórico y esencialista que presenta la teoría, en el sentido de que pretende ofrecer una definición de la catarsis cómica y una descripción del proceso catártico sin tener en cuenta la amplia gama de variaciones del género cómico y sobre todo su desarrollo en el tiempo. En este sentido, el modelo que propone Sutton es válido para la Comedia Nueva (ya que el personaje ridiculizado es la figura de autoridad paterna), pero difícilmente aplicable a la comedia aristofánica o, mucho menos, a la comedia contemporánea ${ }^{40}$ - como trataremos de demostrar en el capítulo dedicado al análisis de la serie televisiva Friends.

Otra de las objeciones que podemos presentar a la teoría de Sutton es que no termina de desarrollar las implicaciones que tiene su definición de la figura del «comic surrogate» y su relación con su referente real y el proceso de ridiculización. En primer lugar, en el modelo de Sutton, para que se produzca la purgación catártica de la ansiedad y el miedo, el referente real del personaje cómico debe producir estos sentimientos en el espectador: de este modo, las figuras paternas y de autoridad son personajes cómicos frecuentes porque en la vida real despiertan temor y ansiedad; mediante la catarsis cómica, el espectador “aprende” a “perderle el respeto” a la autoridad - de ahí el carácter supuestamente subversivo de la comedia. Pero ¿qué ocurre cuando el personaje cómico ridiculizado no es una figura de autoridad sino un individuo marcado por la otredad (un extranjero, el judío Shylock, por ejemplo)? En realidad, se podría aplicar la hipótesis de Sutton de que estos personajes causan "miedo" y "ansiedad” social en tanto que la sociedad los percibe como lo Otro o lo abyecto, por acudir a la noción de Julia Kristeva (2015) [ver 2.5]. La comedia, en este sentido, cumpliría la función de un ritual de expulsión de lo ajeno, esto es: podemos aceptar como válida la propuesta de Sutton de

\footnotetext{
${ }^{40}$ Por una parte, es explicable que la teoría de Sutton, en tanto que helenista, sea casi exclusivamente aplicable al modelo de la Comedia Nueva; pero por otro, el alcance universal que pretende su modelo es evidente cuando recurre a ejemplos de comedia contemporánea como los filmes de Chaplin, Keaton o Harold Lloyd, sin tener en cuenta las diferencias que puedan existir entre la comedia menandrea y las comedias cinematográficas de principios del siglo XX.
} 
que el personaje cómico representa una fuente de ansiedad, pero la consideramos insuficiente en tanto que solo admite las funciones supuestamente subversivas de la comedia e ignora cómo también puede contribuir a la estigmatización. Un ejemplo de esta argumentación la encontramos en el pasaje en el que Sutton analiza un popular chiste sobre polacos:

On one level, they work so well because there is something magnificently illogical about four men rotating a ladder while a fifth perches on top holding a light bulb. Or about four men shaking a stove while a fifth holds an unmoving pan full of popcorn kernels. For whatever reason - perhaps because human beings think perverted logic (a form of perceived incongruity is funny - such humour would hold its own, without any reference the ethnicity of the participants in these dubious proceedings (Sutton, 1993: 51)

Según Sutton, la comicidad del chiste reside principalmente en la falta de lógica demostrada por los personajes, sin importar el hecho de que estos sean polacos. ¿Por qué, entonces, el chiste necesita que estos personajes sean polacos para ser gracioso? «The first answer that springs to mind is that such jokes are a means of venting hostility against Poles» (Sutton, 1993: 52), cosa que Sutton niega con el argumento de que mucha gente en Estados Unidos no tiene nada en contra de los polacos y, sin embargo, disfruta esos chistes. Más bien, según Sutton, se elige a los polacos porque este grupo social no es controvertido (esto es, haciendo alusión, por elipsis, a que los protagonistas no sean de raza negra): «Since in contemporary society the open expression of fear or hostility against the ethnic groups in question has replaced the open discussion of sexual or scatological matters as our primary conversational taboo, the expression of ethnic bad feelings becomes shifted onto neutral and therefore "safe” ethnic groups» (Sutton, 1993: $51)$.

La lógica de la argumentación de Sutton es, por tanto, que el chiste elige a los polacos como personaje ridículo porque no son controvertidos, lo que permite «the expression of ethnic bad feelings», burlando así cierta censura social que consideraría que si se hablara de un grupo étnico más “controvertido” el chiste no sería gracioso, sino ofensivo. Sutton relaciona este movimiento con el trabajo de desplazamiento que según Freud opera tanto en el chiste como en el sueño, y parece celebrarlo como un modo de burlar la censura: la sustitución es un medio eficaz de «indirect representation adopted in social or political contexts where the surrogate's direct representation of its target would not be posible (Ethnic jokes fit in this category, and think of the kind of humor that occurs 
in puritanical societies or politically repressive)»(Sutton, 1993: 53). Sutton, de este modo, equipara la censura que pueda ejercer una sociedad autoritaria y represiva con el tipo de sensibilidad que consideraría racista un chiste (y nótese el eufemismo de «ethnic bad feelings» para referirse a creencias racistas).

Otro problema con esta argumentación es que no reconoce las consecuencias que su propio modelo de catarsis cómica tiene en el caso de concreto de un chiste "étnico". En primer lugar, el que los protagonistas del chiste sean polacos probablemente tenga más que ver con los sentimientos racistas que en el pasado se tuvo hacia los inmigrantes polacos en Estados Unidos; pero, sobre todo, más allá de la etnia concreta a la que se refiera, lo que hace el chiste es reproducir la lógica racista que presenta a un cierto grupo étnico como otredad (en este caso, irracional). Y si, según el modelo de Sutton, el personaje cómico es ridiculizado para proteger al espectador de la ansiedad y el miedo que el referente real le causa, significa que el polaco (en representación de cualquier otro grupo percibido por el espectador como "étnico”) causa miedo por el mecanismo de la abyección descrito por Kristeva [ver 5.4 para un desarrollo de esta cuestión]. Es decir, puede que no se ejerza una hostilidad directa y concreta contra los polacos, pero sí se reproduce una lógica racista.

Una última cuestión que no alcanza a explicar el esquema de Sutton es el del carácter ridículo del personaje cómico: ¿este es ridículo solo en la representación cómica, o es susceptible de ser representado cómicamente porque ya reconocemos rasgos ridículos en el referente real? Es decir, ¿podrían los polacos (o cualquier otro grupo que fuera considerado “étnico”) ser protagonistas del chiste si no fueran ya considerados ridículos? Según Sutton, es el subrogado cómico el que es presentado como ridículo y solo a posteriori estos rasgos caricaturescos son transferidos al referente real, pero parece cuestionable que los polacos (o, si queremos, el tipo del soldado fanfarrón o del senex en la Comedia Nueva) pudieran ser protagonistas de una representación cómica si previamente no fueran ya considerados ridículos de antemano.

En resumen, la propuesta de Sutton, y sobre todo su concepción de la catarsis cómica como purgación de sentimientos de miedo y ansiedad, contiene elementos provechosos para una explicación del funcionamiento de la comedia y en general de los discursos humorísticos, aunque pueda ser matizable. En este sentido, los trabajos de Hans Robert Jauss recogidos en su libro Experiencia estética y hermenéutica literaria (Jauss, 
1986) ofrecen, desde los presupuestos teóricos de la Estética de la Recepción, una perspectiva histórico-hermenéutica muy necesaria.

Las ideas de Jauss acerca de la experiencia estética y el lugar que el placer tiene en esta son lo suficientemente sugerentes como para que las tratemos por extenso en el capítulo siguiente, por lo que aquí nos limitaremos a apuntar las ideas que propone respecto al tipo de relación que el lector/espectador establece con el género cómico. De momento, será suficiente señalar que Jauss distingue en la experiencia estética tres momentos, la poiesis o el placer de la creación estética, la aisthesis o el placer puramente formal (relacionado con la mimesis aristotélica) y la katharsis, que se refiere a la capacidad del receptor de verse afectado por lo representado, de identificarse emocionalmente con los personajes e incluso de cambiar sus hábitos cognitivos o éticos al adoptar estas identificaciones como modelos de conducta (Jauss, 1986: 61, 75-76). Lo interesante de la propuesta de Jauss es que recupera la dimensión comunicativa e intersubjetiva de la experiencia estética y la vincula a la catarsis: no solo en el sentido de la doctrina retórica y horaciana de que mediante el arte y el placer que procura este se pueden ofrecer modelos de conducta, sino también por el papel activo que el receptor tiene en esta comunicación, que puede optar por ignorar esta propuesta ética, recibirla irónicamente, etc. (Jauss, 1986: 159-160). En resumen, el papel de la catarsis según Jauss es el de ofrecer

propuestas de identidad, porque hay una correspondencia objetiva entre la estructura de percepción de la postura estética y la idea de ejemplos y modelo de la conducta vital humana (...) Cuando el sujeto disfruta estéticamente, adopta toda una escala de posturas (tales como asombro, admiración, emoción, compasión, enternecimiento, llanto, risa, distanciamiento, reflexión) e introduce, en su mundo personal, la propuesta de un modelo, aunque también puede dejarse llevar por la fascinación del simple placer de mirar, o caer en una imitación involuntaria (1986: 160-161)

Lo importante de la propuesta de Jauss es que este comportamiento no es ni mucho menos único: los modelos estéticos de identificación son diferentes según horizontes de expectativas que dependen de géneros que varían históricamente y, sobre todo, en última instancia dependen de la actitud del receptor en el momento de la experiencia estética (Jauss, 1986: 277-278).

Además, la experiencia estética tiene siempre cierto contacto con otras áreas de la praxis social: «la actividad estética no se desarrolla De Manera orgánica en un campo 
autóctono, sino que parece ampliar y afirmar su esfera de significación, trasgrediendo límites, utilizando soluciones de otras competencias y usurpando o compensando experiencias de la realidad colindante» (Jauss, 1986: 185). Esto es cierto especialmente en el caso de la difícil delimitación de lo cómico como experiencia estética respecto a la práctica social de lo ridículo (Jauss, 1986: 201). Souriau, por ejemplo, propone que lo ridículo es aquello que ya está en el entorno y solo ha de ser señalado, mientras que lo cómico es una creación artística intencional: «lo hecho allí [lo ridículo] como espontaneidad contingente y que - sobrepasando los límites de la educación de la moral o del buen gusto - nos hace reír, se explica aquí como comicidad artificialmente producida y representada, éticamente justificada y elevada a función comunicativa» (Jauss, 1986: 202) - nótese como Souriau califica inequívocamente lo cómico, en tanto que artístico, como intelectual y moralmente superior a la risa cotidiana surgida de lo ridículo: la catarsis, según la propuesta de Souriau, no sería sino una «depuración», una «sublimación» de la agresividad y la vulgaridad de la risa del ridículo (Jauss, 1986: 202).

Jauss no niega esta “superioridad moral” de lo cómico respecto a lo ridículo, pero localiza la distancia entre ambos fenómenos en el contexto "festivo" de la comedia, que permite reír sin temor a consecuencias ni responsabilidades éticas:

Lo que garantiza el placer estético de la comedia es la seguridad de que el responder riéndose sólo necesita confirmar esa «positivización de la negatividad» que se está representando, ya que - a diferencia de lo ridículo del entorno - lo cómico representado en la obra le ahorra al espectador que se ríe el riesgo y el esfuerzo de una reacción límite o catastrófica: porque la obra que se representa en el escenario ha producido ya la positivación cómica de lo fútil, reprimida por la seriedad normativa, y ha asegurado así aquella básica y «festiva disposición del ánimo», que todo espectador, que toma parte en la obra de una «comunidad de personas que ríen», puede esperar (Jauss, 1986: 204-205)

Aunque, como argumentaremos más adelante, creamos cuestionable esta distinción entre lo ridículo y lo cómico (y de hecho, Jauss plantea explícitamente la cuestión de hasta qué punto lo cómico no revierte en lo cotidiano como una “estetización” de la experiencia), la definición de Jauss de lo cómico vuelve a remitir a la creación de una «comunidad de personas que ríen», es decir, el carácter social y colectivo de la catarsis cómica (si bien de nuevo sin tener en cuenta mediante qué exclusiones se produce esta comunidad): «ese responder riéndose ante lo cómico del mundo de la comedia es (...) un acuerdo-risa con un compañero y, por tanto, algo esencialmente comunicativo» (Jauss, 1986: 205). 
En todo caso, Jauss incluye lo cómico dentro de las posibilidades de la «identificación catártica» entendida como «la actitud estética, descrita ya por Aristóteles, que traslada al espectador, desde los intereses reales y los vínculos emotivos de su entorno, a la situación del héroe sufriente u oprimido, para provocar por la conmoción trágica o el alivio cómico - una liberación de su ánimo» (Jauss, 1986: 277). Si, como hemos dicho, la catarsis puede afectar al comportamiento del espectador ofreciéndole modelos de identificación, lo cómico, por tanto, puede tener una función comunicativa: Molière, por ejemplo, defiende que «los más estrictos métodos de la enseñanza moral para la mejora de las costumbres resultan menos adecuados que el ridiculum de su comedia» (Jauss, 1986: 281). Si, según Freud, en la recepción estética el espectador se identifica con el héroe pero desde una distancia de seguridad que a la vez le permite una regresión a placeres inconscientes (a lo que Jauss añade la función educativa de asunción de modelos morales), este esquema se puede aplicar también al héroe cómico (Jauss, 1986: 296).

Así, dentro de la identificación con el personaje cómico, Jauss distingue varias posibilidades. En primer lugar, el paso del héroe serio al cómico se puede obtener mediante el contraste con ciertos ideales y expectativas, como ocurre en la sátira, la parodia, la comedia francesa de caracteres, etc.: el héroe cómico es aquel que no cumple con ciertas expectativas, bien por ser incapaz por su inferioridad física, intelectual o moral, bien por sentirse ajeno o superior a ellas. Por lo tanto, el héroe cómico puede contraste puede servir a diferentes fines:

Sobre el héroe cómico se puede tematizar toda una serie de normas estéticas y morales, que pueden hacerse visibles desde su aparente evidencia o su validez silenciada, pudiendo - con intención lúdica - convertirse en objeto de burla y - con seriedad crítica - ser problematizadas. Entre la tendencia afirmativa y la destructiva hay, en este ámbito de la experiencia estética, otra posibilidad intermedia: la de que, con respecto al héroe cómico, no es preciso confirmar o combatir normas, sino que se puede abrir una vía para la autorización o justificación de aquello que, bajo el dominio de normas idealizadas, quedaba reprimido fuera del límite de la representación literaria (...) Estas tres funciones pueden resumirse de la siguiente manera: lo que el héroe da a conocer mediante la comicidad por contraste puede ser interpretado: o como un desahogo divertido (y, por tanto, afirmativo) de una autoridad sancionada por la tradición, o bien como una protesta seria contra ella, protegido por el ropaje de lo cómico; e, incluso, como el inicio de un proceso de solidaridad, en la medida en que no sólo se combaten las normas dominantes 
en el héroe cómico, sino que se pueden formar nuevas normas, al introducir lo marginado y reprimido (Jauss, 1986: 298)

Por tanto, la actitud respecto al personaje cómico puede ser de burla (confirmando las normas respecto a las que el personaje no es capaz de estar a la altura) o de simpatía (compartiendo la crítica y el desprecio a las normas transgredidas) o, incluso de conmiseración o identificación con el héroe fracasado - como podría ocurrir con Don Quijote.

Otro modelo de héroe cómico recogida por Jauss es la del grotesco rabelaisiano como «liberación y afirmación de los instintos reprimidos» (Jauss, 1986: 300). En suma, Jauss asimila las teorías de Freud acerca de la comicidad por contraste y superioridad con las concepciones bajtinianas de lo carnavalesco para presentar una gama de posibilidades de identificación cómica:

La comicidad por contraste nace de la degradación de lo ideal a un nivel que permite al lector o al espectador identificarse con el héroe, y que aquel experimenta como desahogo, protesta o proceso de solidaridad, frente a la opresión de la autenticidad. La comicidad grotesca nace de la elevación de las propiedades típicas de las criaturas y de lo materialcorporal a un nivel en el que la distancia entre lector o espectador y héroe se diluye en una convención de risas, que la «comunidad de risas» experimenta como liberación de lo sensual, triunfo sobre el miedo y sobre todas las fuerzas del mundo normativo y, por consiguiente, como implantación del principio del placer. La catársis cómica se explica, en el primer caso, como una ostentación ahorrativa de sentimientos, y en el segundo, como una intensificación surgida de la liberación de la naturaleza oprimida; en el primer caso se comunica a través de una imaginación distanciadora, y en el segundo, fomenta una convención supresora de la distancia. El placer provocado por el héroe cómico presupone la no-alienación del espectador y, con ello, la capacidad de reconocer y disfrutar la disolución cómica de las expectativas heroicas (...) Bajo el signo negativo del contraste, el héroe no heroico de la parodia o del poema heroico-burlesco, o un anti-héroe o un pícaro (...) pueden convertirse en una figura cómica, que, en el espacio vacío entre la broma y la seriedad, es capaz de rozar la validez de las normas ideales, sean éstas sociales o literarias. Bajo el principio del contraste, habría que incluir, también, al héroe cómico de la tradición inglesa del humours o de la francesa de los caractères, en la medida en que, aun cuando todos ellos representan la variedad de la naturaleza humana, contradicen, sin embargo, con su parcialidad interesada o extravagante, la idealidad de la misma. Bajo el signo positivo de afirmación del principio de placer, el héroe grotesco que triunfa sobre un miedo, puede contribuir a la ruptura de la verdad no oficial de la risa, 
produciendo así - en lo que se refiere a ésta - una convención con su público. Por último, el héroe humorístico, que es capaz de reírse de sí mismo, puede provocar en el espectador o en el lector, mediante el triunfo de la consciencia sobre las exigencias y circunstancias adversas de la realidad, una actitud humorística, restableciendo así, en el nivel del buen humor, la identificación admirativa que había roto la risa producida por el héroe ideal degradado (Jauss, 1986: 300)

Aunque la propuesta de Jauss sea matizable (por ejemplo, no hay nada que impida considerar que la comicidad del héroe grotesco no surge precisamente por un contraste respecto a las normas cotidianas de civilidad), no deja de sentar unas bases prometedoras desde las que analizar los procesos emocionales y de identificación puestos en juego en el género cómico e incluso en los discursos humorísticos en general; sobre todo al insistir en la variedad y variabilidad de estos modelos de identificación y catarsis. Porque si hay algo que debería ser evidente es la imposibilidad de dar una única respuesta a la problemática de los diferentes procesos de recepción e identificación que se dan en los géneros cómicos sin caer en la equivocación de ignorar la amplísima variedad de modelos literarios y de variables históricas, sociales e individuales de estos procesos, que al fin y al cabo son las que determinan la interpretación de estos discursos.

\subsubsection{Bajtín y la literatura carnavalesca}

Como hemos mencionado, uno de los referentes respecto del lugar común del carácter “progresista” de la literatura cómica es Mijaíl Bajtín, no solo por su estudio del carnaval medieval, sino por lo que en Problemas de la poética de Dovstoievsky llamó la «literatura carnavalesca». Si, como vimos [1.2.2.2], en su libro sobre la cultura popular en la Edad Media y el Renacimiento, el teórico ruso analizaba la presencia de esta cultura en la literatura de Rabelais; en su estudio de Dovstoievsky recurría a la más amplia tradición de lo «cómico-serio», caracterizada por tener una «percepción carnavalesca del mundo» (Bajtín, 2012: 218) para explicar el origen de la novela polifónica, como denomina al género del que el autor ruso es representante (Bajtín, 2012: 217).

Esta tradición, que recorre toda la literatura europea, se centra en la vida cotidiana, y no se apoya tanto en el canon literario sino que, conscientemente, se fundamenta en la experiencia del día a día, así como en la imaginación más fantástica (Bajtín, 2012: 219). Bajtín habla de una tradición de literatura carnavalizada más que de un género por la gran 
variedad de géneros, estilos y voces que encunetra en ella, que incluso juega con dialectos y jergas y otros tipos de discurso no literarios, como los tratados filosóficos (Bajtín, 2012: 220).

No obstante, sí que señala dos géneros concretos como fuente de esta literatura: el diálogo socrático, tal y como lo practican Platón o Jenofonte, y la sátira menipea. El primero comparte con la cosmovisión carnavalesca, más que sus temas o tonos cómicos, su concepción dialógica de la verdad: en estas obras «la verdad no nace ni se encuentra en la cabeza de un solo hombre, sino que se origina entre los hombres que la buscan conjuntamente» (Batjín, 2012: 222) [ver 4.2.1 para una exposición más detallada de esta concepción]. El método socrático de pregunta y respuesta (al menos el representado por Platón en sus primeros diálogos y no tanto en los más tardíos) consigue dialogizar el pensamiento, exponerlo a la interacción social, carnavalizándolo (Bajtín, 2012: 224).

Aunque el diálogo socrático comparta algunos rasgos con la sátira menipea, como la localización en cronotopos particulares y transicionales, esta es más visiblemente cómica y directamente relacionada con el folklore carnavalesco (Bajtín, 2012: 226-228). La sátira menipea se desliga de las exigencias memorísticas del diálogo socrático, ganando una gran libertad de invención formal, temática y filosófica: crea aventuras fantásticos que sirven de marco excepcioinal para poner a pruebas las ideas con las que trabaja: «lo fantástico sirve no para encarnar positivamente la verdad, sino para buscarla y provocarla y, sobe todo, para ponerla a prueba» (Bajtín, 2012: 229). Simultáneamente, este vuelo imaginativo y filosófico se combina con una exploración crítica descarnada y grotesca de los bajos fondos de la vida cotidiana (Bajtín, 2012: 232). También acostumbra a plantear los casos psicológicos y morales más extremos, presentando personajes dementes, atravesados por pasiones irrefrenables que «destruyen la integridad épica y tráfica del hombre y de su destino», manifestando «las posibilidades de otro hombre y de otro destino» (Bajtín, 2012: 233): los perosnajes de la sátira manipea dejan de tener una concepción integral y acabada de sí mismos y el mundo que les rodea.

De este modo, en la sátira menipea se unen lo escandaloso y excéntrico con los altos vuelos de la fantasía y el pensamiento utópico, ofreciendo perspectivas inéditas que suponen la «desvalorización de todas las situacoines externas de la vida del hombre, su conversión en papeles representados en el escenario del teatro universal según la voluntad de un destino ciego» (Bajtín, 2012: 237). Esto es, según Bajtín, lo que esta literatura le debe a la cosmovisión del folklore carnavalesco (Bajtín, 2012: 241): de las fiestas 
carnavalescas, antiguas y medievales, la literatura cómico-seria hereda el «mundo al revés» donde se suprimen las jerarquías, normas y etiquetas y se establece un nuevo modo de relaciones humanas; donde, mediante la práctica de la excentricidad y la profanación se liberan los acentos subliminales y profundos de la naturaleza humana (Bajtín, 2012: 242-243). Tanto el diálogo socrático como la sátira menipea heredan del carnaval la dialogización de la verdad y la materialización del pensamiento:

El pensamiento carnavalesco también existe en la esfera de las últimas cuestiones, pero no les da una solución abstracta filosófica o dogmáticamente religiosa, sino que las representa en la forma sensorial concreta de las acciones e imágenes carnavalesas. Por eso la carnavalización permitía trasladar las últimas cuestiones de la esfera filosófica abstracta, mediante la percepción carnavalesca del mundo, al plano sensorialmente concreto de varias y brillantes imágenes y acontecimientos» (Bajtín, 2012: 260) [ver 5.3, donde se retoma la cuestión de la materialización cómica]

La sátira menipea, además, absorbe y permea géneros menores como el simposio, la diatriba, el soliloquio... (Bajtín, 2012: 237). Sobre todo, la menipea y la literatura carnavalesca en general va a influir en toda la tradición europea posterior, determinando la producción de autores tan importantes como Rabelais, Cervantes, Erasmo, Hoffmann, Voltaire, Swift... (Bajtín, 2012: 246-265): «en el desarrollo posterior de la literatura europea la carnavalización ayudó constantemente a eliminar toda clase de barreras entre los géneros, entre los sistemas cerrados de pensamiento, entre diversos estilos, etc.; eliminó toda cerrazón y toda subestimación mutua, acercó lo lejano, unió lo desunido» (Bajtín, 2012: 261)

\subsubsection{Tropología: la visión irónica}

\subsubsection{La tradición norteamericana}

\subsection{A. Richards y el New Criticism}

Mucho más decisiva que la reflexión sobre la comedia es, sin que haya lugar a ninguna duda, la atención que se le ha dado a la ironía, tanto dentro de la teoría literaria como de la filosofía. A lo largo de todo el siglo XX la ironía ha sido un término comodín con el que se ha intentado explicar la literatura del modernismo, la novela, la poesía, el espíritu de la época moderna o posmoderna... Lo que hace que intentar abarcar aquí aunque solo 
sean los más trabajos relevantes sobre la ironía ${ }^{41}$ sea sencillamente imposible cuando no contraproducente. Por ello, nos limitaremos en las páginas que siguen a ofrecer esquemáticamente un recorrido de las conceptualizaciones de la ironía a través de los autores que se relacionen más directamente con la argumentación de este trabajo. Como veremos, en el ámbito de lo que denominamos «tropología» o teoría de los tropos, la reflexión sobre la ironía se moverá sin solución de continuidad apenas entre la teoría y la crítica literarias y el pensamiento filosófico y la epistemología, pues, como argumentaremos, la ironía lleva a primer plano la problemática común a ambos campos de conocimiento: la cuestión del lenguaje y su interpretación.

En realidad, como veremos, la teoría continental y, más concretamente, los autores más comúnmente asociados a cierto tipo de escritura irónica en un sentido más cercano al de la ironía schlegeliana como Jacques Derrida o Roland Barthes, apenas mencionan la ironía en sus escritos, y cuando lo hacen es en un acepción más tradicional, que rechazan, que el que se atribuye a su misma escritura. Más bien son sus intérpretes angloamericanos los que hablan de su obra o su estilo filosófico como irónico porque es en este ámbito donde el término «ironía» ha tenido mayor fortuna crítica desde la primera mitad del siglo XX, concretamente a partir de la influencia de los New Critics y la obra de Northrop Frye y Kenneth Burke (Ballart, 1994: 144).

Estos autores están, a su vez, muy influidos por la teoría romántica inglesa de Coleridge a través de la mediación de Eliot y, más concretamente, I. A. Richards (Ballart, 1994: 146-148), quien, en su Principles of Literary Criticism, recogía la doctrina sobre la poesía de Coleridge y particularmente su noción de la imaginación poética como aquel poder de síntesis que reúne y equilibra cualidades opuestas o discordantes, reduce lo múltiple en lo general... En la teoría romántica de Coleridge, nos dice Richards, el poeta es aquel capaz de recibir y manejar todos aquellos estímulos que, por múltiples y contradictorios, el hombre mundano no es capaz de percibir. Pero lo esencial de la imaginación poética no es tanto la capacidad de percepción multiplicada, sino la de reunir todas estas percepciones contradictorias en una sola imagen (Richards, 2001: 228). Las obras de arte más valiosas, según Richards, son aquellas que, como la tragedia, reúnen, ideas, sensaciones, emociones, etc., contrapuestas y contradictorias, en equilibrio, sin que

\footnotetext{
${ }^{41}$ Además del ya citado libro de Pere Ballart (1994), otra razonable introducción a la diversidad de usos del término ironía es el libro de Schoentjes (Schoentjes, 2003) y, por supuesto, el ya clásico de Muecke (1982)
} 
una se sobreponga a la otra. Por eso la prueba para distinguir un poema mediocre de un texto verdaderamente poético es la de la ironía: si esta se burla mediante la parodia la unilateralidad de una opinión ${ }^{42}$, la verdadera obra de arte la resiste porque es, en sí misma, multilateral; de hecho, la literatura de mejor calidad suele ser característicamente irónica (Richards, 2001: 234). La actitud imaginativa y/o irónica del poeta es la de una contemplación desinteresada que le permite ver el objeto de su reflexión desde distintos y hasta opuestos puntos de vista:

We cease to be orientated into one definite direction; more facets of the mind are exposed and, what is the same thing, more aspects of the thing are able to affect us. To respond, not through one narrow channel of interest, but simultaneously and coherently through many, is to be disinterested in the only sense of the word which concerns us here. A state of mind which is not disinterested is one which sees things only from one standpoint or under one aspect. At the same time since more of our personality is engaged the independence and individuality of other things becomes greater. We seem the 'all round' them, to see them as they really are (Richards, 2001: 235)

En resumen, Richards concibe la ironía como una «resolución de tensiones, característica de la poesía que es capaz de sintetizar impulsos heterogéneos», por lo que viene a «designar esta suerte de unidad estructural que ambicionaban Coleridge y Eliot» y que tan determinante es en la teoría literaria de los new critics (Ballart, 1994: 147). Cleanth Brooks fue quien llevó más lejos este razonamiento del lenguaje poético a partir de nociones como ambigüedad, ambivalencia, paradoja, tensión... (Ballart, 1994: 149-150), hasta el punto de extender el uso del término «ironía» a «todos aquellos juegos de connotaciones que pueden concitarse en el seno de un poema» (Ballart, 1994: 151). Brooks considera irónico cualquier oposición de elementos que aparezca en el poema, extendiendo el significado de la categoría hasta un punto en el que, según algunos críticos como Robert Crane, deviene inoperable en la práctica (Ballart, 1994: 152-155).

\subsection{Kenneth Burke}

En todo caso, vemos en las teorías de Richards y Brooks una concepción de la ironía asociada a un cierto «desinterés», una toma de distancia respecto del objeto y, sobre todo,

\footnotetext{
${ }^{42}$ Podemos oír en esta idea el eco de la opinión de Shaftesbury de que toda opinión debe ser sometida a la ironía para poder ser considerada verdadera. La noción de imaginación como aquel poder de la creatividad de unir ideas aparentemente alejadas e incluso opuestas, por supuesto, también nos remite a la teoría del ingenio o wit.
} 
como un modo de considerar los objetos y la realidad a partir de sus tensiones, ambigüedades, contradicciones, paradojas... La concepción de la ironía como toma de distancia y pensamiento de la contradicción es una constante del «pensamiento tropológico» angloamericano, como podemos comprobar, por ejemplo, en las breves reflexiones que Kenneth Burke le dedica en su influyente obra A Grammar of Motives.

El caso de Burke es especialmente interesante, puesto que es considerado por teóricos posteriores tan relevantes y dispares como Stanley Fish, Fredric Jameson, Edward Said o Wayne Booth como uno de los precursores más importantes en la renovación del interés de la teoría literaria angloamericana por la Retórica (Wess, 1996: 1). Burke, quien escribe durante el auge del New Criticsm, se ocupa en su obra de la centralidad del lenguaje en la construcción de la realidad: precursor también de la extensión de la noción de ideología más allá del ámbito económico, Burke entiende que lo que consideramos real no es sino un producto de actos de habla que, siendo actos de lenguaje insertos en un contexto social y con un propósito persuasivo concreto, son retóricos. Burke explora cómo las «reglas de juego» que validan los actos lingüísticos son constituidas y transformadas a través de los mismos actos de habla; «reglas» que nacen de un conflicto, un agon entre los diferentes actores sociales y que se representa lingüísticamente (Wells, 1996: 137-140). En los actos «constitucionales», uno de los «argumentos» agonísticos se instituye como principio necesario que jerarquiza el resto de argumentos; jerarquización que, al estar situada en un contexto social y material, es por supuesto provisional (Wells, 1996: 144).

Esta «constitución» de «lo real», de los sujetos y las sustancias es, ante todo, un hecho retórico en tanto que es resuelto «through the rhetorical struggle of the cultural conversation, not through an epistemological judgment of truth and falsity» (Wess, 1996: 150). Burke denomina esta lucha retórico-agonística «dramatismo» pero también «dialéctica»

in the most general sense as "the employment of the possibilities of linguistic transformation” (...) Dialectic is not a master historical narrative in the manner of Hegel and some versions of Marx (...) Burke's dialectic in general examines the operations involved in dialectical construction, opposition, and transformation in the agon of the conversation (...) The horizon of Burke's dialectic, in other words, is the horizon of the conversation. There is no origin or telos, only a middle. In hierarchizing, the act requires a totalizing substance, but there is no totalization of totalizations (Wess, 1996: 154) 
Es en este contexto teórico en el que debemos entender la reflexión sobre los tropos que Burke incluye como apéndice en A Grammar Motives. Este libro es, ante todo, una exploración del modo de interpretar los actos simbólicos y la manera en que los seres humanos explicamos nuestras propias acciones (Biesecker, 1997: 24) mediante la metodología del mencionado «dramatismo». Burke se preocupa, como decimos, del modo en que los seres humanos construimos socialmente la realidad mediante actos lingüísticos, y en este sentido entiende los «four master tropes» (la metáfora, la metonimia, la sinécdoque y la ironía) como modos de conocimiento y de representación de la realidad: «my primary concern with them here will be not with their purely figurative usage, but with their role in the discovery and description of "the truth”» (Burke, 1969: 503).

En la introducción al apéndice que nos ocupa, Burke advierte de lo complejo de la tarea: no es solo que la delimitación entre los cuatro tropos sea difícil, pues unos se deslizan sobre otros y los solapan; sobre todo hay que atender a la engañosa distinción entre lo literal y lo figurado, lo que Burke llama «realismo científico» y el lenguaje retórico: en realidad los modos del lenguaje supuestamente literal se corresponden con cada uno de los tropos: la metáfora con la perspectiva, la metonimia con la reducción, la sinécdoque con la representación y la ironía con la dialéctica (Burke, 1969: 503). La metáfora es perspectivística porque implica ver A bajo la perspectiva de B; la metonimia es una reducción de lo intangible a sus manifestaciones tangibles (un estado de ánimo por sus signos corporales, como la vergüenza por el enrojecimiento del rostro); y la sinécdoque incluye las relaciones entre microcosmos y macrocosmos, en las que una parte representa al todo porque es su imagen en miniatura (Burke, 1996: 505-510).

La ironía como trasunto tropológico de la dialéctica ocupa un lugar especial en la reflexión de Burke si tenemos en cuenta el papel que esta tiene a su vez en el plan general de A Grammar of Motives como un equivalente al «dramatismo»: en la teoría burkiana de la acción humana, «where the ideas are in action, we have drama; where the agents are in ideation, we have dialectic» (Burke, 1969: 511). La ironía, por tanto, establece una asociación entre el «rol» del drama como poseedor de «ideas» (que son producto de la interacción de los agentes con su situación) y de estas «ideas» como abstracción de los factores que determinan las acciones; hay, en resumen, una estrecha relación entre el lenguaje como dialéctica de las ideas y la interacción social como conflicto dramático [recordemos la imagen de Bergson de que el humorista es capaz de dramatizar el lenguaje 
3.1.2.2]: «one might speak of "socratic irony” as “dramatic” and of "dramatic irony” as “socratic”» (Burke, 1996: 512).

La ironía en tanto que dialéctica, por tanto, está relacionada con la diversidad de «ideas» o «argumentos» en liza en una situación dramática. La ironía hace interactuar dos o más términos para producir un desarrollo («development») dialéctico: «none of the participating "sub-perspectives" can be treated as either precisely right or precisely wrong. They are all voices, or personalities, or positions, integrally affecting one another» (Burke, 1969: 512). La dialéctica, entendida como ironía, avanza mediante la paradoja: la enfermedad sirve para encontrar la cura, una manera de perfeccionar el conocimiento racional es explorar la locura, etc. (Burke, 1969: 512).

Pero la ironía, advierte Burke, no equivale a aceptar el relativismo, que es el aislamiento de uno solo de los agentes o ideas en la situación dramática/dialéctica: «it is the very absence of irony in relativism that makes it so susceptible to irony. For relativism sees everything in but one set of term (...) The greater the absolutism of the statements, the greater the subjectivity and relativity in the position of the agent making the statements» (Burke, 1996: 512). La ironía, sin embargo, no es relativista porque no se limita a decir: este asunto puede ser visto desde otra perspectiva, sino que contribuye a profundizar en el desarrollo dialéctico de las diferentes oposiciones hasta que una de ellas sintetiza y “domina” a las demás (Burke, 1969: 513).

En este tratamiento de la ironía podríamos ver, sin duda, un ideal democrático, y de hecho Burke habla explícitamente de una «dialéctica parlamentaria»; un ánimo que podríamos relacionar de nuevo con las propias posiciones de Shafestbury. Sobre todo, vemos en su descripción de la ironía como lo contrario de la subjetividad relativista y la toma en consideración de los diferentes puntos de vista una concepción análoga a la de I. A. Richards, trasladando la ironía de la teoría literaria a un ámbito mayor de actuación del lenguaje. En todo caso, hay un componente particularmente moral en su discusión de la ironía: Burke dice, por ejemplo, que el relativismo «is the constant temptation of either dialectic or drama» (Burke, 1969: 512), o que la ironía «is never Pharisaic, but there is a Pharisaic temptation in irony» (1969: 513). La dialéctica irónica exige un compromiso moral democrático, y por eso distingue la ironía romántica, en la que el poeta se muestra superior a aquello o aquellos sobre los que ironiza, de la «true irony» que se muestra, por el contrario, humilde: «irony, however, irony that really does justify the attribute of humble irony, is based upon a sense of fundamental kinship with the enemy, as one needs 
him, is indebted to him, is not merely outside him as an observer but contains him within, being consustantial with him» (Burke, 1969: 514).

La ironía, en resumen, exige un cierre dialéctico, ha de ser detenida en el momento en el que se alcance una verdad, como en la concepción kierkegaardiana - y el uso de términos de ascendencia cristiana como «temptation» o "pharisaic» hace más estrecha esta asociación ${ }^{43}$. O, para ser más exactos, habría que decir que existe un posible "mal uso” de la ironía que lleva al relativismo y la ruptura de la deliberación democrática. No hay, en esencia, dos tipos de ironía, relativista y dialéctica o romántica y humilde, pues la «tentación del relativismo» es inherente a la ironía, pero sí una exigencia moral al tratar con ella. Nos encontramos de nuevo, por tanto, con las mismas connotaciones que la ironía tiene para Hegel y Kierkegaard y que volveremos a encontrar en la obra de Wayne Booth.

\subsection{El «modo irónico» de Northrop Frye}

Otra de las influencias más notables en el pensamiento tropológico vuelve a ser la de Northrop Frye y, en concreto, la teoría de los modos con la que abre su Anatomía de la Crítica. Según Frye, partiendo de la distinción aristotélica de los diferentes modos de imitación según se imite a personas mejores o peores, se pueden categorizar las ficciones según las capacidades del héroe y sus acciones en relación con el lector/espectador, de lo que resultan cinco modos diferentes (Frye, 1991: 53-55):

i. $\quad$ El modo mítico es aquel en el que el héroe es superior en clase tanto a los hombres como a la naturaleza

ii. Si el héroe es superior en grado a la naturaleza y los hombres corrientes, pero sigue siendo un hombre, hablamos de una leyenda o un romance.

iii. El modo mimético elevado, el correspondiente a la épica y la tragedia, es aquel en que el héroe es superior al hombre corriente pero no a la naturaleza: el héroe en este caso actúa como líder de un colectivo pues «tiene autoridad, pasiones y poderes de expresión mucho mayores que los nuestros, pero lo que hace está

\footnotetext{
${ }^{43}$ Para hacer verdadera justicia al pensamiento de Kenneth Burke, no obstante, es necesario señalar que este "cierre" dialéctico, este acto de jerarquización en el que uno de los argumentos en liza impone a los demás como síntesis del proceso dialéctico, es, como hemos apuntado, siempre provisional, y nada impide que los acuerdos alcanzados o constituidos en cierto momento no sean nuevamente disputados en un futuro. En este sentido, Burke se sitúa en una posición retórica en el que, si bien no niega que existan "verdades", es consciente del carácter convencional, acordado, provisional de las mismas. En el capítulo correspondiente nos extenderemos en esta concepción retórica de la verdad.
} 
sujeto tanto a la crítica social como al orden de la naturaleza» (Frye, 1991: $54)$.

iv. En el modo mimético bajo, el de la comedia y la novela realista, el héroe se sitúa al mismo nivel que el resto.

v. Por el último, el modo irónico o satírico es aquel en el que el héroe es inferior al hombre corriente ${ }^{44}$

A partir de esta clasificación, Frye distingue entre los «modos trágicos» y los «modos cómicos». Es a lo largo de la discusión de las diferentes gradaciones de ambos modos en la que Frye concreta sus ideas acerca de los modos cómicos e irónicos y de la ironía en general. Así, por ejemplo, se sirve de la distinción clásica entre el alazon y el eiron [ver 1.1.4] para analizar las ficciones del mimético bajo: la novela realista se puede centrar en individuos aislados y en pugna con la sociedad, cuya ignorancia o soberbia les caracteriza como alazon: Frye se refiere a Madame Bovary, por ejemplo, pero también a Hamlet o Fausto. La diferencia de estos personajes con los alazon de la Comedia Nueva es que estos son máscaras o tipos, mientras que los personajes de la novela realista están más individualizados (Frye, 1991: 61-62). Y en oposicíión al personaje del alazon encontramos al eiron, el personaje o el autor que se menoscaba a sí mismo, haciendo parecer menos de lo que en realidad es; para Frye, esta actitud le permite una objetividad de la que carecen el resto de modos ficcionales: «La total objetividad y la supresión de cualesquiera juicios morales explícitos son elementos esenciales de su método (...) Cuando tratamos de aislar lo irónico en cuanto tal, descubrimos que parece consistir simplemente en la actitud del poeta en cuanto tal: la construcción desapasionada de una forma literaria cuyos elementos aseverativos, implícitos o expresos, han sido todos eliminados» (Frye, 1991: 62-63) ${ }^{45}$. El ironista, así, «toma la vida exactamente como la encuentra», pero, a diferencia del escritor realista, «fabula sin sacar moralejas y no tiene más objetivo que su tópico» (Frye, 1991: 63).

En realidad, Frye entiende la ironía y el modo irónico de dos formas distintas. En un sentido, como vemos, es una cierta actitud de objetividad y distanciamiento del escritor respecto de su obra. Pero en otro también es, según la misma definición de Frye, la

\footnotetext{
${ }^{44}$ Frye especifica que «esto sigue siendo verdad cuando el lector siente que está o podría estar en la misma situación» (1991: 55); es decir, que la teoría de los modos no tiene una correspondencia exacta con la identificación del espectador con el héroe.

${ }^{45}$ Concretamente, Frye entiende la ironía como «decir lo menos y de significar lo más posible o, de modo más general, en un patrón de palabras que se aparta de la afirmación directa o de su propio significado evidente», lo que se manifiesta en un distanciamiento del autor (1991: 62).
} 
descripción de un héroe que es inferior al hombre y a la naturaleza, lo que en su versión trágica se manifiesta mediante la focalización del castigo absurdo del individuo: en el modo irónico trágico, el héroe no es castigado por un rasgo excepcional de su carácter, o al menos el castigo que recibe es desproporcionado respecto de su falta: «la ironía aísla de la situación trágica el sentido de arbitrariedad, el hecho de haber sido la víctima desafortunada, elegida al azar, o por suerte y sin merecer, más que cualquier otro, lo que le acontece» (Frye, 1994: 63-64). El típico héroe trágico irónico es el personaje kafkiano, cuya falta es únicamente ser humano, pero también lo es Cristo, que actúa de chivo expiatorio siendo absolutamente inocente. De este modo, aunque lo irónico en su evolución lógica e histórica surja como degradación del mimético bajo, en la obra de Kafka y James Joyce anuncia una re-mitificación (Frye, 1991: 65).

En los modos cómicos, como vimos, el tema central es la renovación de la sociedad mediante la reintegración de un personaje: así, son cómicos los mitos de Hércules o las leyendas cristianas de santos. Como en la tragedia, aparece en los modos cómicos el rito de la expulsión del chivo expiatorio. Lo característico de la comedia irónica y la sátira es el despliegue de violencia contra el pharmakos que vemos en obras como las aristofánicas: de este modo, en la comedia irónica el arte linda con el salvajismo, con lo más bajo de los instintos humanos, «mundo en el cual la comedia consiste en infligir dolor a una víctima indefensa» (Frye, 1991: 69). Es interesante que Frye reconozca aquí la violencia presente en muchas comedias, si bien establece una clara distinción entre el fenómeno artístico y los actos de salvajismo reales mediante el elemento de juego (play) y representación (play) que define los primeros (1991: 69).

En todo caso, encontramos en las formas populares del melodrama y las historias de detectives una recreación de esta expulsión del chivo expiatorio. Es en la discusión de estas ficciones populares donde volvemos a encontrar el modo irónico:

Si fuera posible tomarlas en serio, [estas ficciones populares] constituyen la propaganda de vanguardia del estado policial, en la medida que éste representa la regularización de la violencia de la turba. Pero esto no parece ser posible. La muralla protectora del juego sigue presente allí. El melodrama serio se enreda muy pronto con sus propios piedad y temor: mientras más serio sea, más probabilidades hay de que el lector lo considere irónicamente, siendo su piedad y temor tomados por ñoñez sentimental o solemne beatería, respectivamente (Frye, 1991: 71) 
Apreciamos fácilmente en la concepción de la ironía de Frye una actitud un tanto elitista: es irónico el modo de recepción que no se toma en serio estas ficciones populares, ingenuas:

La gente culta asiste a un melodrama para silbar al villano con aires de condescendencia: convierten así en principio el hecho de que no pueden tomar en serio su villanía. Tenemos aquí un tipo de ironía que corresponde exactamente a la de las dos otras grandes artes de la época irónica [la del siglo XX]: la publicidad y la propaganda. Estas artes pretenden dirigirse seriamente a un público subliminal de cretinos, un público que acaso ni siquiera existe, pero del que se supone que es lo suficientemente estúpido como para aceptar literalmente las afirmaciones que se hacen sobre la pureza de un jabón o las intenciones de un gobierno. El resto de nosotros, al darse cuenta de que la ironía nunca dice precisamente lo que quiere decir, toma estar artes irónicamente o, al menos, las considera como una especie de juego irónico. De modo semejante, elevamos historias de asesinatos con un fuerte sentido de la irrealidad de la villanía que entrar en juego (Frye, 1991: 72; el destacado es nuestro) [en 6.1 exploramos cómo la estética camp consiste en una apreciación irónica de los productos de la cultura de masas]

El modo irónico de la comedia comienza, por tanto, con la parodia de estas formas populares del melodrama y la historia de detectives, que pronto evoluciona a una «auténtica ironía cómica o sátira» que, en lugar de representar la expulsión de un chivo expiatorio, «define al enemigo de la sociedad como un espíritu que está dentro de ella» (Frye, 1991: 71). En estas formas más evolucionadas del melodrama, el autor «se dirige a personas que pueden darse cuenta [reencontramos el componente elitista] de que el villano no es alguien totalmente exterior a la sociedad, sino producto de los vicios que afectan a esta» (Frye, 1991: 73). Esta comedia satírica, en fin, es una comedia de costumbres, que retrata una sociedad en sí misma corrupta. Frente a esta situación, y en una nueva versión de la vuelta al modo mítico, el héroe puede aislarse voluntariamente de la sociedad, o aparecer como un tonto para la sociedad de la obra, pero como virtuoso para el lector (Frye, 1991: 73).

En el esquema evolutivo que Frye le da a su teoría de los modos, según el cual los diferentes modos se suceden según la sociedad progresa en racionalidad y se hace consciente de sí misma, el modo irónico aparece como el último paso y por tanto el estado más desarrollado de una cultura. En la teoría de Frye, el escritor irónico es el que ha logrado “ver la verdad” de la sociedad y la naturaleza humanas - su absurdez. La actitud irónica, como en las concepciones de Burke o Richards, es aquella que permite al autor 
una mayor objetividad y amplitud de miras, si bien la obra de Frye permite ver explícitamente el componente elitista que tiene esta posición. Por último, encontramos en ella de nuevo una distinción entre una actitud irónica parcial y una visión irónica “auténtica”. Al hablar del uso de un tono irónico por parte de algunos narradores del mimético bajo como Dickens afirma que «no es difícil percibir en la práctica la diferencia que existe entre el tono irónico que podemos descubrir en los modos miméticos bajos o primitivos y la estructura irónica del modo irónico mismo» (Frye, 1991: 74): en el primer caso, narradores como Dickens emplean un tono irónico porque cuentan con unos lectores con los que comparten ciertas convicciones y creencias que consideran fundamentales, mientras que, en el segundo, en el "verdadero" sentido del modo irónico, lo que encontramos es una concepción escéptica generalizada de la moral, el conocimiento, la sociedad...

\subsection{La tropología de Hayden White}

Como venimos comprobando, en las consideraciones sobre la ironía de estos autores está en juego mucho más que la definición de un mecanismo retórico o una técnica literaria, sino que se habla de la actitud irónica como una visión del mundo, como un modo de conocimiento. Sería un error, sin embargo, considerar este hecho como un "ir más allá" de la "mera" definición retórica de la ironía, de la actitud o el conocimiento irónicos como algo netamente diferente de un estudio de la ironía "restringido" a la retórica o la forma literarias. Esta distinción se muestra como errónea en el momento en que tenemos en cuenta la progresiva asunción, a lo largo del pensamiento del siglo XX, y sobre todo a partir de su segunda mitad, del papel que el lenguaje tiene en la construcción del conocimiento y de la realidad, y más aún de la naturaleza retórica de todo lenguaje. Es una premisa fundamental de este pensamiento retórico (sobre el que volveremos con más detalle en el siguiente capítulo) que las figuras del discurso retórico y especialmente los tropos no son meros añadidos ornamentales a un lenguaje fundamentalmente denotativo, sino que estructuran, en un nivel incluso pre-reflexivo, nuestro conocimiento. Como dice Stephano Arduini, «el mundo referencial sólo nos es dado a través de lentes retóricas, como estrellas que sólo se pueden contemplar por medio de los anteojos» (Arduini, 2000: 100), siendo la ironía, por supuesto, una de estas «lentes retóricas» ${ }^{46}$.

\footnotetext{
${ }^{46}$ Concretamente, siguiendo a Paolo Valesio, Arduini habla de la ironía dentro de la figura abarcadora de la antítesis, en la que incluye figuras como la negación, la inversión, el oxímoron o la paradoja. Para estos autores, la figura de la antítesis es la figura por antonomasia de la Retórica como dialéctica, como
} 
Dentro de la tradición angloamericana que venimos esbozando muy esquemáticamente, quizá sea Hayden White quien mejor represente esta postura, sobre todo en su influyente obra Metahistoria, donde analiza los textos de cuatro historiadores y cuatro filósofos de la historia del siglo XIX para mostrar de qué manera el pensamiento histórico está lingüísticamente construido. Para ello, considera la obra histórica como lo que literalmente es: «una estructura verbal en forma de discurso de prosa narrativa que dice ser un modelo, o imagen, de estructuras y procesos pasados con el fin de explicar lo que fueron representándolos» (White, 1992: 14); la calidad de estos modelos de historiografía no depende del manejo de mayor cantidad de datos de una manera más objetiva y racional, sino en la capacidad persuasiva de sus relatos. Estas obras y el pensamiento histórico de sus autores dependen en última instancia «de la naturaleza preconceptual y específicamente poética de sus puntos de vista sobre la historia y sus procesos» (White, 1992: 15). Concepción retórico-discursiva que White fundamenta explícitamente en el pensamiento de Kenneth Burke y Northrop Frye, además de autores postestructuralistas franceses como Derrida, Barthes, Foucault, etc.

En su modelo de análisis, White distingue cinco niveles de conceptualización del discurso histórico: la crónica, el relato, el modo de tramar, la argumentación y la implicación ideológica. El relato es la narración que ordena los hechos recogidos en la crónica, no solo para hacerlo inteligibles, sino para dar un sentido, un significado a estos hechos; sentido de los procesos históricos que se pueden explicar por la trama, la argumentación o la implicación ideológica (White, 1992: 16-18).

De estos tres modos de explicación, nos interesa especialmente el modo de explicación por la trama, pues White toma la taxonomía de Northrop Frye de los cuatro mythos: el romance, la tragedia, la comedia y la sátira (White: 1992: 18-21). White, además, distingue la trama irónica o satírica de los tres primeros, puesto que estos relatos irónicos «consiguen sus efectos precisamente frustrando las expectativas normales acerca del tipo de resoluciones que ofrecen las historias organizadas en los otros modos» (White, 1992: 19). Si el romance, la tragedia, o la comedia, resultan al fin en una resolución, de manera más o menos afortunada, de los conflictos que protagonizan los relatos

enfrentamiento de posturas irreconciliables; también como un modo de representarnos el mundo como interacción de opuestos. La antítesis «pone a prueba la compresión, crea una tensión creativa que rompe certezas definidas e ilumina las cosas con un sentido no reconocible inmediatamente (...) es uno de los procedimientos fundamentales de la expresividad porque se fundamenta en las contradicciones que nos rodean y que la opinión general trata de esconder» (Arduini, 2000: 120-121). 
historiográficos, la sátira ofrece una visión muy diferente del proceso histórico y sobre todo de nuestra capacidad de aprehensión de este:

Comedia y tragedia representan calificaciones de la aprehensión romántica del mundo, considerado como un proceso, con el objeto de tomar en serio las fuerzas que se oponen a la redención humana ingenuamente sostenida como posibilidad para la humanidad en el romance. La comedia y la tragedia toman el conflicto seriamente, aun cuando la primera desemboca en una visión de la reconciliación final de fuerzas opuestas y la segunda en una revelación de la naturaleza de las fuerzas que se oponen al hombre. Y para el escritor romántico es posible asimilar las verdades de la existencia humanas reveladas respectivamente en la tragedia y la comedia dentro de la estructura del drama de la redención (...) Pero la sátira representa un tipo distinto de calificación de las esperanzas, las posibilidades y las verdades de la existencia humana (...) En forma irónica, en la atmósfera generada por la aprehensión de la inadecuación última de la conciencia para vivir feliz en el mundo o comprenderlos plenamente. La sátira presupone por igual la inadecuación última de las visiones del mundo representadas dramáticamente en los géneros del romance, la comedia y la tragedia (...) El advenimiento del modo de representación satírico señala la convicción de que el mundo ha envejecido. Como la filosofía misma, la sátira “pinta de gris lo gris” en la conciencia de su propia inadecuación como imagen de la realidad (White, 1992: 20-21)

En este sentido, la trama satírica se asocia, por «afinidad electiva», con la argumentación contextualista (que parte de la provisionalidad de la explicación histórica) y la ideología liberal (que contempla el cambio social como una serie intermitente de reajustes locales del sistema, frente a la impugnación total de este por parte del radicalismo o el anarquismo) (White, 1992: 39) ${ }^{47}$. Pero, a pesar de estas afinidades “naturales”, los

\footnotetext{
${ }^{47}$ En la teoría de White, los modos de argumentación se refieren a las leyes de explicación histórica, el modo en que el historiador combina unos hechos con otros mediante relaciones de causalidad; White contempla cuatro posibles modos de argumentación: formista (el historiador identifica y reivindica lo exclusivo, individual y particular de cada objeto del campo histórico que investiga), organicista (el historiador incluye estos objetos particulares en un proceso de síntesis de mayor envergadura orientado a un fin o telos metahistórico), mecanicista (los elementos individuales son integrados en procesos históricos mayores, pero en lugar de remitirse a un proceso teleológico, se explica mediante leyes deterministas y mecánicas de causa-efecto) y contextualista (que representa un punto medio entre el excesivo individualismo del formismo y la abstracción de las teorías organicistas o mecanicistas: los acontecimientos individuales se explican según el contexto en el que aparecen, se entienden en relación a procesos superiores o de causa-efecto, pero la explicación se centra en relaciones específicas, no en leyes abstractas; la argumentación contextualista busca dar una explicación coherente y racional de los acontecimientos pero sin sacrificar su particularidad) (White, 1992: 22-30). Con las diferentes alternativas de implicación ideológica, White intenta dar cuenta de las diferentes actitudes que el historiador puede tomar frente al cambio social: conservador (que percibe el cambio como degradación y decadencia); liberal (que ve en él los necesarios reajustes del sistema, pero sin que este se vea afectado en su totalidad); radical (que impugna
} 
grandes historiadores se destacan por intentar resolver las tensiones que surgen de combinar en su relato tramas, argumentaciones y actitudes ideológicas que son en principio incompatibles. Porque, ante todo, estas obras históricas guardan una unicidad y una coherencia en su concepción de la historia; y, para White, esta unidad es garantizada por una pre-figuración del campo histórico que es de naturaleza lingüístico-poética. En el punto culminante de su teoría de la obra histórica, White considera, siguiendo las intuiciones de Giambattista Vico, que la visión histórica viene determinada prerreflexivamente por un acto que es fundamentalmente de índole poética, y concretamente tropológica:

El historiador tiene que prefigurar como posible objeto de conocimiento todo el conjunto de sucesos registrado en los documentos. Este acto prefigurativo es poético en la medida en que es precognoscitivo y precrítico en la economía de la propia conciencia del historiador. También es poético en la medida en que es constitutivo de la estructura que posteriormente será imaginado en el modelo verbal ofrecido por el historiador como representación y explicación de "lo que ocurrió realmente" (...) Pero es constitutivo no sólo de un dominio que el historiador puede tratar como posible objeto de percepción (mental); también es constitutivo de los conceptos que utilizará para identificar los objetos que habitan y para caracterizar los tipos de relaciones que pueden tener entre ellos. En el acto poético que precede al análisis formal del campo, el historiador a la vez crea el objeto de su análisis y predetermina la modalidad de las estrategias conceptuales que usará para explicarlo (White, 1992: 40)

Estas diferentes preconfiguraciones del pensamiento histórico se pueden explicar mediante los cuatro tropos considerados principales por la tradición: la metáfora, la metonimia, la sinécdoque y la ironía (White, 1992: 40). Los tres primeros son paradigmáticos de las operaciones fundamentalmente poéticas mediante las cuales prefiguramos y aprehendemos los campos de experiencia y ordenamos la realidad, son «ingenuos» «porque sólo pueden desplegarse en la creencia en la capacidad del lenguaje para captar la naturaleza de las cosas en términos figurativos» (White, 1992: 45). La ironía, por el contrario, es autoconsciente, es «esencialmente dialéctica, en cuanto representa un uso deliberado de la metáfora en interés de la autonegación verbal» (White, 1992: 45):

el sistema social in toto y busca sustituirlo por uno enteramente nuevo, más justo) y anarquista (que rechaza cualquier tipo de sociedad) (White, 1992: 30-34). 
El objeto de la afirmación irónica es afirmar en forma tácita la negativa de lo afirmado positivamente en el nivel literal, o lo contrario (...) La ironía es en cierto sentido metatropológica, porque se despliega en la conciencia autoconsciente del posible mal uso del lenguaje figurativo. La ironía presupone la ocupación de un punto de vista "realista" sobre la realidad, desde el cual es posible ofrecer una representación no figurativa del mundo de la experiencia (...) representa un estado de conciencia en que se ha llegado a reconocer la naturaleza problemática del lenguaje mismo. Señala la potencial futilidad de toda caracterización lingüística de la realidad tanto como el absurdo de las creencias que parodia (...) Por eso las caracterizaciones del mundo expresadas en el modo irónico a menudo son vistas como intrínsecamente refinadas y realistas. Parecen señalar el ascenso del pensamiento en determinada área de indagación en un nivel de autoconciencia que hace posible una conceptualización del mundo genuinamente "ilustrada", es decir, autocrítica (White, 1992: 46)

Volvemos a encontrarnos, en la definición de White, con la ironía como modo de autoconsciencia reflexiva, de actitud escéptica respecto a la posibilidad de un conocimiento definitivo. También vemos apuntada la concepción ventajosa de la ironía como modo de la objetividad realista, concepción que en realidad rechaza - por eso escribe que las caracterizaciones irónicas «a menudo son vistas como...»; «parecen señalar...», etc. La ironía, según White, es solo aparentemente transideológica, puesto que puede ser usada tácticamente desde posiciones conservadoras, liberales o progresistas para atacar la posición contraria, cuando en realidad la ironía «tiende a disolver toda creencia en la posibilidad de acciones políticas positivas. En su aprehensión de la locura o el absurdo esencial de la condición humana, tiende a generar creencia en la "demencia” de la civilización misma y a inspirar un desdén de mandarín por quienes tratan de captar la naturaleza de la realidad social en la ciencia o en el arte» (White, 1992: 47).

White, en resumen, repite el gesto de distinguir un uso retórico de la ironía que sirve «tácticamente» para defender una creencia propia atacando a la contraria, y una verdadera naturaleza de la ironía, la de negar cualquier posibilidad de conocimiento. Podríamos decir, por tanto, que la concepción de White del pensamiento histórico es, ella misma, irónica: la tesis que defiende a lo largo de su obra es, precisamente, la de asumir que toda posición y todo relato histórico es relativo, provisional, que no hay una verdad histórica fuera de la implicación ideológica, la elección de la trama o la teoría de la argumentación histórica y en última instancia, sobre todo, de la visión tropológica de la que se parta. Este entendimiento de la actitud irónica como escepticismo puede abocar, 
como señala el mismo White, a un «desdén de mandarín», un inmovilismo derivado de la imposibilidad de conocer y actuar en la realidad histórica. Esta es una postura que, como veremos, será criticada por algunos teóricos, especialmente marxistas, y de hecho también es, como vimos, la actitud que Hegel y Kierkegaard censuran a Friedrich Schlegel.

\subsubsection{La disputa por el sentido. Ironía e interpretación.}

En la ironía, como vemos, parece haber mucho en juego. A continuación presentaremos los trabajos de los críticos literarios Wayne Booth y Paul De Man como epítome de dos posturas opuestas acerca del "problema” de la ironía y, de paso, analizaremos las cuestiones epistemológicas, éticas e incluso ideológicas que lo atraviesan. De este modo no solo queremos mostrar la importancia que el debate acerca de la ironía ha tenido para la filosofía y la teoría literaria del siglo XX, especialmente alrededor del "postestructuralismo”, sino también presentar las problemáticas que, en nuestra opinión, plantea el humor en general en el discurso contemporáneo.

\subsection{La Retórica de la ironía de Wayne Booth}

Grosso modo, podemos decir que, en el debate que se plantea entre las posiciones (solo aparentemente irreconciliables, como intentaremos demostrar al final de este epígrafe) de Booth y De Man, se reedita el que se dio entre los ironistas románticos y sus enemigos, entre Schlegel y Hegel. En este caso, el principio de este debate dentro de la teoría literaria se da en el problema de la interpretación de las obras literarias irónicas. Esto es, de entrada, lo que plantea el crítico neoaristotélico Wayne Booth desde el comienzo de su conocida Retórica de la ironía (1974): frente a la conceptualización filosófica, abstracta, excesivamente amplia, que ha recibido el fenómeno de la ironía a partir del Romanticismo, Booth propone un enfoque exclusivamente retórico, esto es, que se centre en dilucidar qué quiere decir una ironía y cómo sabemos lo que quiere decir. Es decir, propone un modelo interpretativo formal (Booth, 1989: 13-15). Booth se posiciona explícitamente frente a autores quienes, como Northrop Frye o Cleanth Brooks, han extendido de manera desmesurada la definición de la ironía; contra aquellos críticos nuevos que niegan la posibilidad de una interpretación "normativa” y contra aquella literatura moderna como la de James Joyce o Samuel Beckett que promueve la imposibilidad de todo significado seguro. El crítico norteamericano defiende la capacidad 
de distinguir lecturas mejores y peores y de tener una certidumbre al identificar ironías y reconstruir su significado.

La operación teórica principal del libro de Booth es el de distinguir entre ironías «estables», aquellas de las que estamos seguros de la intención irónica de su autor y cuyo significado figurado es recuperable, y las ironías «inestables», de estirpe romántica, que niegan cualquier posibilidad de significación (1989: 298-305). Las ironías estables, a las que va a dedicar la mayor parte del libro, son definidas como intencionadas (el autor quiso que se interpretaran de manera irónica); encubiertas (la cualidad irónica, figurativa del pasaje en cuestión no es evidente, como puede serlo una metáfora); fijas (el significado figurado puede ser recuperado definitivamente) y finitas (el significado figurado es local, limitado a un determinado enunciado, sin llevar a reflexiones generales sobre el conocimiento o el lenguaje) (Booth, 1989: 25-32). Booth, como vemos, quiere limitar el sentido de la ironía a su sentido retórico clásico de antífrasis, de decir algo opuesto a lo que aparentemente se dice (1989: 33).

Después de definir lo que entiende por «ironía estable», Booth expone los cuatro pasos en los que se produce la interpretación o lo que él denomina como «reconstrucción» del significado irónico:

i. Al lector se le exige que rechace el significado literal al encontrar cierta incongruencia entre lo que lee y lo que él sabe.

ii. El lector lleva a cabo un «socavamiento», una retracción del sentido literal, destruyéndolo y buscando interpretaciones alternativas e incongruentes con la interpretación literal del texto.

iii. El lector toma una decisión sobre los conocimientos y creencias del autor que justifiquen la intención irónica del pasaje sospechoso - es decir, el lector decide que el autor no puede ser así de estúpido y solo puede decir cosas equivocadas de manera irónica.

iv. El lector elige una de las interpretaciones posibles de acuerdo con las creencias atribuidas al autor (Booth, 1989: 36-38).

En la exposición de este proceso interpretativo, Booth deja muy claro que su interés va mucho más allá de establecer didácticamente una guía de lectura de ciertas obras literarias: en juego están las bases epistemológicas de la crítica literaria y la naturaleza del conocimiento literario. La interpretación irónica demuestra la existencia de una comunicación entre autor y lector basada en los conocimientos compartidos (Booth, 1989: 
41) y, más importante aún, la posibilidad de que este conocimiento sea absolutamente riguroso: Booth, cuando decide leer irónicamente un pasaje, sabe y puede argumentar por qué motivos toma esa decisión (1989: 43).

En este sentido, polemiza con el tipo de lectura irónica que es fruto de una decisión arbitraria del lector, que achaca al afán de notoriedad de algunos críticos que buscan lecturas inesperadas: «una vez captado el truco, uno puede improvisar indefinidamente inversiones que podrán parecer ingeniosas a unos pocos pero que no significan nada para la inmensa mayoría» (Booth, 1989: 46). Como vemos en esta cita, Booth critica el individualismo de ciertos críticos frente al «sentido común» de «la mayoría»: según Booth, este tipo de críticos no “aportan” nada al interés común: «algunos debates sobre las lecturas irónicas podrían llegar a un término más provechoso si los críticos dejaran en claro qué tipo de aportación intentan lograr» (Both, 1989: 49).

Booth se opone, por tanto, a que la lectura irónica sea una decisión individual, sujeta a la arbitraria subjetividad de cada uno. Booth rechaza este tipo de postura al comentar una cita del crítico Lindenberger que niega que exista el «conocimiento objetivo» respecto de las obras literarias y que afirma que el papel del crítico es el de convencer a los lectores de la validez de su lectura: «Aunque la búsqueda del conocimiento siguiendo el modelo de la ciencia ha sido ciertamente motivo de opresión, la actitud opuesta, el pirronismo, que se deleita en un ilusorio sentimiento de libertad al mismo tiempo que nos hace seguir al que nos diga las palabras más atractivas, es mucho más destructiva» (Booth, 1989: 250). Es paradójico que Booth reclame estar haciendo un estudio retórico y sin embargo reniegue de lo que realmente implica una actitud retórica, que busca convencer y no demostrar. Booth, al contrario, recurre a criterios "científicos" e incluso llega a invocar el criterio de falsabilidad de Popper para defender el carácter racional de la crítica literaria (1989: 43). Esto implica, por tanto (y aunque a la vez reproche a los críticos irónicos que sus lecturas no sigan el sentido común de la mayoría) un conocimiento experto (Booth: 1989: 43) ${ }^{48}$.

\footnotetext{
${ }^{48}$ Joseph A. Dane relaciona la descripción de Booth de la interpretación irónica y el establecimiento de una jerarquía entre el significado literal y el irónico con el establecimiento de una autoridad profesoral: al describir cómo las ironías han de ser leídas, Booth establece un sistema en el que es el profesor el que enseña a los alumnos-lectores cómo leer obras literarias y discrimina entre las lecturas que considera válidas y las arbitrarias: «The meanings Booth claims to find are intended and thus authoritative; alternate readings are the products of a reader's bias and self-interest (...) Booth's literary universe (...) is one in which what is true is what can be taught; that is, it is one where the hierarchy of professors and students is unchallenged» (Dane, 2011: 62-63).
} 
En opinión de Booth, el que solo se pueda tener opiniones sobre las obras literarias, y no un conocimiento genuino, pone en riesgo la propia institución literaria y su valor para la sociedad. El carácter “edificativo” que Booth le concede al acto de lectura, y concretamente a la lectura irónica, es evidente en la propia metáfora de la «reconstrucción» que Booth usa para describir la interpretación de una ironía: esta alude al proceso de derribar el sentido literal, socavarlo en busca de significados más profundos para finalmente reconstruir un significado más alto (Booth, 1989: 65-70). El lector derriba toda una construcción de creencias que encuentra inadmisibles para levantar el edificio irónico: «el movimiento se dirige siempre hacia un punto (...) que se considera más sabio, más delicado, más sutil, más verdadero, más moral» (Booth, 1989: 69). El juicio de la reconstrucción irónica, por tanto, no es solo un juicio literario sino también, sobre todo, un juicio moral y que, como hemos visto en otros autores, permite un punto de vista más elevado $^{49}$.

Sin embargo, la ironía romántica y la propia de la literatura moderna reciente lleva a muchos críticos a considerar la ironía como corrosión del sentido, sin más: para estos críticos, el ironista no pretende dar una visión del mundo o criticar otra que consideren reprensible, sino dar cuenta de un universo permanentemente dislocado; no ataca la vanidad de tal o cual persona, hecho o idea, sino más bien el vanitas vanitatum general del mundo. En este tipo de ironía todo se disuelve para dar cuenta del significado supremo: no hay significado (Booth, 1989: 135). Para Booth, la creencia que normalmente acompaña a las ironías que él denomina «inestables» es la del caos ininteligible del cosmos y la imposibilidad de afirmar o conocer cualquier cosa aparte de la imposibilidad de tener y afirmar certezas. Para Booth esta postura nos lleva al fin de la interpretación, de la crítica literaria y de la literatura misma (1989: 308-309). En los capítulos últimos que Booth dedica al tipo de literatura irónica moderna representada por Samuel Beckett, el crítico norteamericano aprovecha para ajustar cuentas y criticar el tipo de visión del mundo que en su opinión representa este tipo de literatura. Como señala Susan Suleiman en su reseña del libro de Booth, «at this point, the reader of Booth's text becomes convinced of something that previously was only an intuition; namely, that for

\footnotetext{
${ }^{49}$ Esta superioridad "moral” de la lectura irónica tiene, por supuesto, como en otros autores, un rasgo de superioridad intelectual. En cierto pasaje, distingue ciertas ironías presentes en novelas de género detectivesco, adecuadas para un lector «torpe» que «no puede ser muy rápido ni exigente» mientras que «cualquier lector despierto, deseoso de invitaciones inteligentes a la reconstrucción, se habría cansado en la primera página» de este tipo de ironías (Booth, 1989: 257)
} 
Booth the problems of interpretation, like the classifications of irony, are formulable less in literary or epistemological terms than in metaphysicial or moral ones» (Suleiman, 1976: 20 ${ }^{50}$. En resumen, como anunciábamos más arriba, Booth reedita, en el siglo XX, la opinión de Hegel de que la ironía de Friedrich Schlegel de acabar con todo lo que es bueno y valioso en el mundo: el conocimiento, la moralidad, el arte...

\subsection{La ironía postestructuralista de Paul De Man}

Cuando Booth habla de los críticos contemporáneos que leen irónicamente cualquier texto de manera arbitraria, solo para epatar con su charlatanería a unos pocos, sin duda se refiere (recordemos que la Retórica de la ironía data de 1974) al tipo de críticos deconstructivistas o post-estructuralistas surgidos al calor de la llamada Escuela de Yale, y particularmente de la obra de Paul De Man. Al crítico de origen belga le debemos, sin duda, una de las lecturas modernas más interesantes de la concepción schlegeliana de la ironía en clave deconstructivista.

Paul De Man escribió sobre la ironía principalmente en dos ocasiones: en el conocidísimo trabajo acerca de la «Retórica de la temporalidad», incluido en su libro Visión y ceguera (1983), y el texto posterior, menos conocido pero más interesante, de una conferencia titulada «El concepto de ironía», incluida posteriormente en La ideología estética (1996). En el primero, Paul De Man analiza la presencia, tanto en la teoría como en la práctica poética alrededor del período romántica, de las figuras de la alegoría y la ironía frente a la supuesta supremacía del símbolo. Llevado por una de las ideas matrices del libro, a saber, la de que el lenguaje literario se deconstruye a sí mismo, es decir, que es el único lenguaje autoconsciente y que escapa a la ilusión del conocimiento no mediado, se interesa por el modo en el que la alegoría, a diferencia del símbolo, señala la distancia temporal que se da entre la figura y su sentido ${ }^{51}$. En este sentido, la definición

\footnotetext{
50 Suleiman, además, hace una anotación muy relevante a la afirmación de Booth de que, para que un lector interprete correctamente un enunciado irónico, ha de compartir los mismos valores que el autor: como señala Suleiman, el lector puede perfectamente identificar un enunciado irónico sin necesariamente estar conforme con el pensamiento o los valores que el significado figurado ofrece (1976: 20)

${ }^{51}$ Cuesta Abad critica que De Man, no obstante, mantenga la distinción entre símbolo y alegoría. Si bien el análisis del belga es brillante, es en realidad innecesario, pues «no hay modo de definir retóricamente la diferencia formal entre la alegoría y lo que el pensamiento romántico denomina símbolo» (Cuesta Abad, 1997: 34). Sean cuales sean las diferencias que la teoría romántica le atribuya a la relación entre estas dos categorías, dichas diferencias no se pueden plasmar en el discurso más que temáticamente, es decir, en el plano de contenido, pero en el plano formal no hay manera de distinguir una de otra, puesto que su funcionamiento semiótico-retórico es el mismo. En nuestra opinión, y como defenderemos más adelante, este análisis se puede aplicar también a la diferencia entre lo que Booth denomina ironías «estables» e «inestables», diferencia que los opositores a la postura de Booth comparten, como veremos: la estructura
} 
de la ironía como decir algo diferente a lo que se pretende decir es análoga a la de la alegoría: «en ambos casos, el signo indica algo que difiere de su sentido literal y cuya función es tematizar esa diferencia»; pero esta es una definición que, en realidad, se puede aplicar al lenguaje figurado en general (De Man, 1991: 232).

El interés que la lectura romántica y posromántica hace de la ironía reside para De Man en que hace hincapié no en la relación entre el lenguaje y su significado, como la alegoría, sino en la propia relación del sujeto consigo mismo y su conocimiento: hablar de la ironía supone «plantear un problema que existe en el propio sujeto» (De Man, 1991: 234). En su análisis del trabajo de Baudelaire sobre lo cómico que comentamos en el capítulo anterior, el crítico señala cómo este hace hincapié en el desdoblamiento reflexivo frente al yo ingenuo, atrapado en la cotidianeidad (1991: 235) ${ }^{52}$. La diferencia entre lo cómico significativo y lo cómico absoluto es que en el primero se establece una relación de superioridad de un sujeto respecto al otro, mientras que el segundo, al establecer una relación respecto al no-sujeto, a la naturaleza, desvela la distancia que se produce en todo acto de reflexión, «una discontinuidad y una pluralidad de niveles en un sujeto que llega a conocerse a través de una diferenciación progresiva respecto de lo que no es» (De Man, 1991: 236).

Lo interesante es que Baudelaire habla de este acto de reflexión como propio de artistas y filósofos, es decir, de personas que trabajan con el lenguaje como material y no simplemente como herramienta: por tanto, son conscientes que este acto de reflexión, desdoblamiento y auto-conocimiento no se da sino en el lenguaje: «la disyunción reflexiva (...) sustrae al yo del mundo empírico para trasladarlo a un mundo constituido de lenguaje y dentro del lenguaje (...) El lenguaje divide al sujeto en dos: en el yo empírico, inmerso en el mundo, y en otro yo que, en su intento por diferenciarse y autodefinirse, llega a ser como un signo» (De Man, 1991: 236). Este desdoblamiento desmitifica al sujeto ingenuo, quien tras la caída ha obtenido un conocimiento de su incapacidad. El yo irónico (que solo existe en el lenguaje) es, por tanto, aquel que es consciente de la inautenticidad ingenua del yo empírico (De Man, 1991: 237). Pero la clave del texto de Baudelaire es, según De Man, que el proceso irónico, una vez puesto en marcha, no es inocuo, puesto que es un proceso difícilmente refrenable: de ahí que

figurativa de la ironía es, en ambos casos, la misma, y lo único que cambia es su tematización, el “contenido" del enunciado irónico o el alcance que se le dé en la interpretación.

${ }^{52}$ En este punto, De Man se centra en el pasaje del texto de Baudelaire acerca del filósofo que se ríe de sí mismo por haberse caído. 
Baudelaire hable de lo cómico absoluto como el «vértigo de la hipérbole» y lo relacione con la locura. Porque la ironía tal y como la concibe Baudelaire, no se plantea como una posible "cura” de la ingenuidad, de una solución del error en el que se encuentra el yo empírico: si el yo irónico se propone a “ayudar” al yo empírico, vuelve a caer en la intersubjetividad de lo cómico significativo y por tanto en la falsa creencia de que se puede obtener algún progreso en el conocimiento; para evitar esto

el sujeto irónico (...) tiene que ironizar de inmediato su propia disyuntiva y observar, a su vez, con la distancia y el desinterés que exige Baudelaire a este tipo de espectador, la tentación en la que está a punto de caer (...) reafirmando la naturaleza puramente ficticia de su propio universo, y sosteniendo cuidadosamente la diferencia radical que separa la ficción del mundo de la realidad empírica (De Man, 1991: 240)

La ironía, por tanto, no permite, como defienden autores como Burke o Booth, un retorno a la realidad desde una distancia objetiva, sino que se limita a revelar lo ficticio de nuestro conocimiento de esta realidad: «Lejos de ser un retorno al mundo, la ironía a la segunda potencia (...) afirma y sostiene su carácter ficticio, declarando la imposibilidad de una reconciliación entre el mundo real y la ficción» (De Man, 1991: 241). En este punto, De Man vuelve a Friedrich Schlegel y su definición de la ironía como «parábasis permanente», como una insistencia al lector para que no caiga en la trampa de creer que la ironía le concede algo más que una ficción (De Man, 1991: 242). De Man critica a aquellos pensadores que conciben la ironía «como el movimiento preliminar hacia una unidad recuperable, o como la reconciliación del yo con el mundo mediante el arte» (1991: 242). Al contrario, la ironía es, como apunta Schlegel, un proceso infinito de autocreación y autodestrucción; «engendra una secuencia temporal interminable de actos de conciencia (...) La ironía no es provisional sino repetitiva, la recurrencia de un acto de conciencia que va escalonando y se autointensifica»(De Man, 1991: 244).

En resumen, como vemos, De Man se sitúa entre aquellos que siguen a Schlegel en su negación de la posibilidad de un cierre del proceso dialéctico iniciado por la ironía, frente a Hegel, Kenneth Burke, o Wayne Booth. Pero en la «Retórica de la temporalidad» su interés es el del fenomenólogo: le interesa la ironía en cuanto que expresión de la experiencia temporal del sujeto. Cuando vuelva a esta figura en «El concepto de ironía» sí se centrará en la naturaleza lingüística, tropológica, de esta experiencia. En este trabajo se centra en el problema de la interpretación de la ironía, y se sitúa explícitamente frente a Wayne Booth y su intento de establecer cómo reconocemos e interpretamos las ironías. 
Para De Man, el intento de Booth «supone, por supuesto, que tal cosa puede ser decidida, que la decisión que tomamos diciendo que un texto es irónico puede realidad, y que hay elementos que permiten tomar tal decisión, independientemente de los problemas de intención que pueden estar escondidos o pueden no ser manifiestos» (De Man, 1996: 3). El problema de la propuesta de Booth es, para De Man, que la distinción entre ironías estables e inestables es insostenible, puesto que en el mismo momento en que aparece una ironía «no hay ninguna razón intrínseca para interrumpir el proceso de duda en ningún punto anterior a lo infinito» (1996: 3). La cuestión que ocupa a Booth, esto es, la de cómo saber dónde detenerse en la lectura de la ironía, es por tanto una cuestión interpretativa. Pero, «¿qué sucedería si la ironía fuera siempre la ironía de la comprensión, si lo que estuviera en juego en cuanto a la ironía fuera siempre la cuestión de si es posible comprender o no comprender?» (De Man, 1996: 4). Como vimos al comentar el libro de Booth, «lo que está en juego tocante a la ironía es la posibilidad de la comprensión, la posibilidad de decidir sobre un significado, sobre un conjunto múltiple de significados, o sobre una polisemia controlada de significados» (De Man: 1996: 4).

Para De Man, y como vimos en nuestra lectura del texto de Schlegel «Sobre la incomprensibilidad», la posición del romántico alemán es la de la imposibilidad de una interpretación fija, definida y definitiva. En opinión del crítico belga, incluso los apologistas de la ironía romántica han neutralizado el pensamiento de Schlegel negando esta «negatividad absoluta» limitando el campo de acción de la ironía a una práctica artística, a una dialéctica reflexiva del yo (como, apunta De Man, él mismo hizo en la «Retórica de la temporalidad») o a una dialéctica de la historia (como hacen Kierkegaard o Walter Benjamin) (De Man, 1991: 7-8). El error consiste, en opinión de De Man, en haber reconocido la deuda del pensamiento de Schlegel con la filosofía de Fichte, pero haber entendido esta como una filosofía del Yo Transcendental, cuando Fichte en realidad habla del yo como una posición del lenguaje: «el yo es para Fichte el comienzo de un desarrollo lógico, el desarrollo de una lógica, y como tal no tiene nada que ver con el yo experimentable o fenomenológico bajo ninguna forma» (De Man, 1991: 9). Según De Man, a lo que nos enfrentamos en la filosofía de Fichte es «a la habilidad del lenguaje para postular (...) para nombrar catacréticamente cualquier cosa». De Man, por tanto, lee a Fichte en términos tropológicos: la posición del yo es una catacresis, los juicios sintéticos y analíticos son, en tanto que intercambio de propiedades, metáforas, etc., para 
concluir que el sistema fichteano del conocimiento es tropológico, constituye una «epistemología de los tropos» (1991: 11-13).

La filosofía de Fichte, de este modo, no es sino una narrativa alegórica acerca la catacresis, la negación, la circulación de propiedades, etc. (De Man, 1991: 14-15). Es a esta narrativa de posición y reflexión del yo a la que Schlegel se refiere en el famoso fragmento 42 del Lyceum. Pero lo fundamental de este fragmento es la descripción de la ironía en comparación al estilo bufo, es decir, la definición de la ironía como parábasis, como la ruptura de la ilusión narrativa, o como anacoluto «donde la sintaxis de una frase que crea ciertas expectativas es súbitamente interrumpida y, en vez de encontrar lo que se espera según la sintaxis establecida, se encuentra algo completamente diferente, una ruptura en las expectativas sintácticas del modelo» (De Man, 1991: 16-17). Por tanto, la ironía de Schlegel consiste en una interrupción, una parábasis o anacoluto de la alegoría de Fichte: la ironía es «la permanente parábasis de la alegoría de los tropos» (1991: 18).

En resumen, la ironía, en el sentido schlegeliano, desvela todo conocimiento como una construcción tropológica, ficticia. Más aún, el pensador alemán relaciona la ironía con el lenguaje de la mitología y del Witz como «la pura circulación del juego del significante, y que como saben es la fuente del error, la locura, la estupidez, y de todos los otros demonios» (De Man, 1996: 20). De ahí que los escritos de Schlegel estén llenos de juegos de palabras, de juegos con el significante: pretende apuntar de este modo la manera cómo el lenguaje tiene una forma de decir algo distinto a lo que queremos decir:

Las palabras tienen una forma de decir cosas que no coincide en absoluto con lo que queremos que digan (...) Hay aquí una máquina, una máquina textual, una determinación implacable y una total arbitrariedad (...) que habita las palabras en el nivel del juego del significante, que echa a perder cualquier consistencia narrativa, y que arruina los modelos reflexivo y dialéctico, que forman, como se sabe, la base de cualquier narración (De Man, 1996: 20)

3.2.3.2.3. Ironía y postestructuralismo: la frivolidad como categoría del pensamiento

Como vemos, por tanto, De Man recupera en «El concepto de ironía» la idea de la imposibilidad de un conocimiento claro, fijo y definitivo, trasladándolo de la «dialéctica de la reflexión del yo» a una reflexión sobre el carácter retórico del lenguaje. En este texto es más que evidente la filiación de la concepción demaniana de la ironía con el 
pensamiento postestructuralista de corte deconstructivista, sobre todo en lo que se refiere al «juego del significante», la imposibilidad de detener la interpretación, etc. Candace D. Lang señala que detrás de estas dos maneras enfrentadas de tratar la ironía que venimos mostrando subyacen dos visiones opuestas de concebir el lenguaje y el sentido de la interpretación. En la corriente de crítica literaria representada por Wayne Booth, el lenguaje se concibe verticalmente o según un modelo de profundidad, como un significante detrás o debajo del cual reside un significado que detiene la interpretación una vez hallado; y en la corriente postestructuralista el lenguaje se piensa como horizontal o superficial, como una relación interpretativa infinita de unos significantes con otros (Lang, 1988: 2-3). En estas dos visiones opuestas, la ironía juega un papel diferencial: o bien el discurso irónico es “expresivo” en el sentido de que, detrás del significado literal, pretende transmitir un mensaje, o bien, como se puede apreciar en los textos inspirados por el postestructuralismo francés, es un juego con el lenguaje que trae a primer plano su dimensión significante, productiva. Lang denomina como «ironía» al primer tipo de concepción, y «humor» al segundo:

If the fundamental problem raised (...) by the ironic work is the expression of meaning, it is for the humorous text the production of meaning. The humorous text, then, does not express meaning in the traditional, etymological sense of exteriorizing what was interior to the authorial psyche (...) It organizes a number of linguistic elements into systems offering a variety of potential meanings to be actualized by the reader. The humorist critic focuses on the functioning of the text (...) at the level of the signifier, rather than seeking to somehow "see through" the language to its referent or authorial source (Lang, 1988: $5)^{53}$

Efectivamente, en algunos textos de Roland Barthes como $S / Z$ o «De la obra al texto» podemos encontrar oposiciones análogas a las que propone Lang entre la concepción vertical u horizontal del lenguaje, entre la ironía y el humor: entre el texto legible y el texto escribible, el texto clásico y el texto moderno o la obra y el texto. Ya en el célebre artículo sobre «La muerte del autor», Barthes, haciéndose eco de la muerte del sujeto decretada por el estructuralismo (no solo por Foucault en Las palabras y las cosas o Maurice Blanchot en sus diversas obras, sino también por Benveniste en sus

\footnotetext{
${ }^{53}$ La puesta en primer plano del significante debería recordarnos a los juegos del grotesco con la forma y todo lo que, como vimos a lo largo de los dos capítulos anteriores, tiene que ver con la "corporeidad" de las formas cómicas. En general, la «materialidad» del lenguaje literario, y concretamente el poético es un rasgo puesto de relieve por la teoría literaria desde, al menos, el Formalismo Ruso y las diferentes poéticas lingüísticas a través de Roman Jakobson.
} 
investigaciones lingüísticas), rechazaba la crítica literaria consistente en relacionar la obra con su autor, como expresión suya o representación de sus ideas (Barthes, 1987: 66). Si «la escritura es la destrucción de toda voz, de todo origen», si es «ese lugar (...) donde acaba por perderse toda identidad, comenzando por la propia identidad del cuerpo que escribe» (Barthes, 1987: 65), no se puede seguir considerando el lenguaje como «una operación de registro, de constatación, de representación» (Barthes, 1987: 68), es decir, de expresión de una idea o estado de ánimo previo a la escritura. Y si el texto ya no es expresión del autor, no se puede concebir más la crítica literaria como un descifrar un texto, «imponerle un seguro, proveerlo de un significado último» (Barthes, 1987: 68); la muerte del autor supone la muerte también de la crítica así entendida (Barthes, 1987: 70). Pensar la escritura de este modo conlleva, en efecto, una concepción horizontal y no profunda del lenguaje: «el espacio de la escritura ha de recorrerse, no puede atravesarse» (Barthes, 1987: 70).

Posteriormente, en $S / Z$, Barthes hacía una distinción entre los textos «escribibles», los «modernos», y los textos «clásicos», «legibles». Mientras que el primer tipo corresponde a la concepción horizontal del lenguaje, de juego con el lenguaje, el segundo limita el papel del lector a un desciframiento del mensaje del autor; el lector del texto clásico «está sumergido en una especie de ocio, de intransitividad, y, ¿por qué no decirlo?, de seriedad: en lugar de jugar él mismo, de acceder plenamente al encantamiento del significante, a la voluptuosidad de la escritura, no le queda más que la pobre libertad de recibir o rechazar el texto: la lectura no es más que un referéndum» (Barthes, 2006: 2). El texto clásico, legible, se rige por la ley de la connotación, de los significados segundos que han de ser reconocidos por el lector: «al inducir sentidos aparentemente detectables (aunque no sean léxicos), la connotación funda una Literatura (fechada) del Significado» (Barthes, 2006: 6). Y aunque la oposición denotación/connotación sea, en último término, falsa, permite a esta Literatura del Significado una cierta inocencia, una creencia en la «naturalidad» del lenguaje:

por muchos sentidos que libere una frase posteriormente a su enunciado, ¿no parece decirnos algo sencillo, literal, primitivo: algo verdadero en relación a lo cual todo lo demás (lo que viene después, encima) es literatura? ${ }^{54}$ Por esto, si queremos ajustarnos al

\footnotetext{
${ }^{54}$ Esta es de hecho la premisa de la distinción de Hirsch entre significado y significación en la que se apoya Booth.
} 
texto clásico, hemos de conservar la denotación, vieja deidad vigilante, astuta, teatral, encargada de representar la inocencia colectiva del lenguaje (Barthes, 2006: 6)

De ahí que no nos pueda extrañar que, más adelante en el mismo texto, Barthes adscriba la ironía, entendida en el sentido expresivo, al texto clásico, legible:

Declarado por el propio discurso, el código irónico es en principio la cita explícita de otro, pero la ironía desempeña el papel de un anuncio y en consecuencia destruye la multivalencia que podría esperarse de un discurso citacional. Un texto multivalente sólo cumple hasta el final su duplicidad constitutiva si subvierte la oposición de lo verdadero y lo falso, si no atribuye sus enunciados (aun con la intención de desacreditarlos) a autoridades explícitamente, si le falta al respeto al origen, a la paternidad, a la propiedad, si destruye la voz que podría darle al texto su unidad (...) La multivalencia (desmentida por la ironía) es una transgresión a la propiedad. Se trata de atravesar el muro de la voz para llegar a la escritura: ésta rechaza toda designación de propiedad y, en consecuencia, no puede ser nunca irónica; o al menos su ironía no es nunca segura (...) Manejada en nombre de un sujeto que sitúa su imaginario en la distancia que simula tomar frente al lenguaje de los otros y se constituye así con tanta mayor seguridad en sujeto del discurso; la parodia, que en cierto modo es la ironía en acción, es siempre una palabra clásica. ¿Qué sería de una parodia que no se anunciase como tal? Este es el problema que se le plantea a la escritura moderna: ¿cómo forzar el muro de la enunciación, el muro del origen, el muro de la propiedad? (Barthes, 2006: 36)

El problema por tanto de la ironía moderna, romántica, "humorística”, por usar la nomenclatura de Lang, es el de una escritura que se escape a los mitos clásicos de la expresividad del lenguaje, del lenguaje como un medio, «a supplement whose sole function is to represent a preexistent idea or concept» (Lang, 1988: 5), del enunciado como propiedad del enunciador. La escritura, el «texto» que promueve Barthes, es aquel que, como dice De Man, demuestre su condición de «máquina textual», su capacidad de «decir cosas que no coinciden en absoluto con lo que queremos que digan» (De Man, 1996: 20).

Esta concepción de «la infinitud del significante no remite a ninguna idea de lo inefable (de significado innombrable), sino a la idea de juego» (Barthes, 1987: 77), y la práctica interpretativa que conlleva (puesto que Barthes no deja de hablar de interpretación, del acto de lectura) es concebida no como una actividad hermenéutica de desciframiento sino de juego: «el texto en sí mismo «juega» (como una puerta, como cualquier aparato en el que haya un «juego»); y el lector juega, por su parte, dos veces: 
«juega» al Texto (sentido lúdico), busca una práctica que le re-produzca; pero para que esta práctica no se reduzca a una mimesis pasiva, interior, ejecuta [joue] el Texto» (Barthes, 1987: 80).

En este sentido, creemos que sería más productivo la oposición entre estas dos concepciones de la interpretación y del lenguaje no en términos de finitud e infinitud o de expresividad o no decidibilidad del significado, sino en términos de actitud epistemológica (y tengamos en cuenta que el mismo Schlegel ya habla de la ironía como Stimmung, como estado de ánimo), y en concreto de una oposición entre seriedad y frivolidad, de una actitud científica y una actitud lúdica del lenguaje y la interpretación ${ }^{55}$. Hemos podido comprobar cómo Barthes define la actividad del lector del texto clásico como «seria», y la del lector escribible como «lúdica». También el discurso de Jacques Derrida se puede describir en los mismos términos:

What Derrida has sought to do is to critique the traditional discourses of philosophy and criticism (...) without resorting to irony, without futilely rejection the sole conceptual language at his disposal in the name of some imaginary new form of serious discourse whose claim to difference would only constitute a new stereotype or discourse of mastery (...)Derrida's jeu is not "merely" a game (gratuitous irony) as opposed to serious, productive work. Nor is it a revalorized, productive play (mastered irony) that ultimately "turns out" to be serious because it is dialectically incorporated as a negative moment in the progress of reason (as when critics redeem the comic by solemnly affirming that it is “really serious” i.e. profoundly meaningful). It is un autre jeu: the inter"play”, complicity, or symbiosis of le sérieux and le jeu that undercuts their opposition (Lang, 1988: 57)

Tal y como lo entiende el filósofo estadounidense Richard Rorty, Derrida pretende contrarrestar el intento de la filosofía analítica, de raigambre kantiana, de purificar el

\footnotetext{
${ }^{55}$ Esta noción del lenguaje ya la podemos encontrar en el pensamiento de Nietzsche, concretamente en su opúsculo Sobre verdad y mentira en sentido extramoral. Según el filósofo, lo verdadero no es la designación verídica de una realidad, sino una convención acordada por una sociedad que permite a los seres humanos convivir y cuyo carácter convencional ha sido olvidado (Nietzsche, 2007: 20-21). El lenguaje no designa, no puede designar, la verdad esencial de una realidad: las palabras son arbitrarias y parciales, producto de «las metáforas más audaces» (2007: 22), «creemos saber algo de las cosas mismas cuando hablamos de árboles, colores, nieve y flores y no poseemos, sin embargo, más que metáforas de las cosas que no corresponden en absoluto a las esencias primitivas» (2007: 22). Al lenguaje realista-científico, que se ha olvidado de su origen metafórico, Nietzsche le opone el lenguaje del arte, que «confunde sin cesar las rúbricas y las celdas de los conceptos introduciendo de esta manera nuevas extrapolaciones, metáforas y metonimias; continuamente muestra el afán de configurar el mundo existente del hombre despierto, haciéndolo tan abigarradamente irregular, tan inconsecuente, tan inconexo, tan encantador y eternamente nuevo, como lo es el mundo de los sueños» (2007: 34); el lenguaje del arte es aquel que juega con la retoricidad del lenguaje, creando constantemente metáforas, pero sin olvidar que no es más que un juego, sin confundir esas metáforas con una "verdad esencial" de las cosas.
} 
lenguaje «haciendo de la filosofía algo todavía más impuro: algo menos profesional, más divertido, más lleno de alusiones, más provocativo y, sobre todo, más «escrito»» (Rorty, 1996: 163; el destacado es nuestro). Si el objetivo de la filosofía logocéntrica es «regularizar la relación entre el hombre y el objeto de su búsqueda exponiendo su «estructura», congelando la sucesión histórica de reinterpretaciones, sonsacando la estructura de toda interpretación posible», «Derrida desea conservar el carácter horizontal de la noción hegeliana de filosofía dejando a un lado su teleología, su orientación a una meta, su seriedad» (Rorty, 1996: 163-164; el destacado es nuestro). Por esa razón Derrida toma como referente de la escritura el texto, no la realidad que se supone que el lenguaje representa, sino los textos: el conocimiento o la filosofía no son sino textos comentando otros textos (Rorty, 1996: 165), y esta perspectiva

justifica su empleo de cualquier texto en la interpretación de otro. Lo más escandaloso de su obra - incluso más escandaloso, aunque no más cómico, que su interpretación sexual de la historia de la filosofía - es su uso de juegos multilingüísticos de palabras, etimologías chistosas, referencias desde dondequiera hasta dondequiera y triquiñuelas fónicas y tipográficas (Rorty, 1996: 167; el destacado es nuestro)

Por ello no podemos tomarnos “en serio”, por ejemplo, la lectura que Derrida hace de Hegel a partir del parecido fónico de su nombre con el francés «aigle»: Derrida no quiere “comprender” a Hegel, sino jugar con sus textos: «La poca seriedad en el sentido en que se le atribuía a Derrida, es sencillamente su negativa a tomarse en serio las reglas al uso, sumada a su negativa a dar clara respuesta a la pregunta: «¿Se trata de otra manera de jugar el antiguo juego o de un nuevo juego?»» (Rorty, 1996: 168; el destacado es nuestro).

El mismo Derrida encuentra esta oposición entre lo serio y lo lúdico precisamente en el rechazo platónico de la escritura que analiza en el Fedro, concretamente en la distinción entre una escritura “buena”, en servicio de la Verdad, y la escritura “mala”, relacionada con la pura apariencia:

La relación de la escritura-simulacro con lo que representa — la escritura verdadera (la verdadera escritura porque es verdadera, auténtica, responde a su valor, conforme a su esencia, escritura de la verdad en el alma de quien tiene la episteme)—, esa relación es análoga a la relación de las simientes fuertes, fértiles, que engendran productos necesarios, duraderos y nutritivos (simientes frugíferas) con las simientes débiles, pronto agotadas, superfluas, que dan nacimiento a productos efímeros (simientes floríferas). Por un lado, el agricultor paciente y sensato (O nun ekón gueorgos); por el otro, el jardinero 
de lujo con prisas y jugador. Por un lado, lo serio (spude); por otro, el juego (paidia) y la fiesta (eorte). Por un lado, el cultivo, la cultura, el saber, la economía; por el otro, el placer y el gasto sin reservas (Derrida, 1997: 228) ${ }^{56}$

En general, como hemos podido comprobar, los defensores de la concepción tradicional de la interpretación y de una visión limitada de la ironía han rechazado su versión romántica por frívola e irresponsable:

In the mouths of the signified-oriented critics, it has a variety of negative connotations (frivolity, bad faith, onanism, etc., i.e., deviation or perversity), while on the tongues of those with poststructuralist sympathies it often takes on the positive overtones of liberation (with play, self-referentiality, etc., considered as healthy manifestations of naïve good faith) (Lang, 1988: 4)

Ya pudimos observar, en efecto, cómo Booth acusaba a los críticos postestructuralistas de irresponsables, de ser unos charlatanes que solo buscan impresionar a unos pocos despistados, poniendo en riesgo la verdadera comunicación literaria. También vimos cómo Kenneth Burke hablaba de la «tentación» relativista de la ironía, es decir, del peligro moral de caer en una ironía irresponsable para con el conocimiento y la sociedad, frente a una ironía sana y «humilde». Tenemos, por tanto, de un lado, la seriedad, la responsabilidad, el compromiso moral con la comunidad y con el conocimiento; de otro, la frivolidad, el juego, la irresponsabilidad individualista... Para los ironistas de raíz schlegeliana, no "tomarse en serio" algo es no creer en la verdad inamovible y universal de sus proposiciones; para sus opositores, implica una inmoral falta de compromiso con el conocimiento y la comunicación. La disputa con las filosofías “irónicas” de Derrida, De Man, o Barthes, no es, por tanto, un problema metodológico, de cuál sea el mejor modo de alcanzar conocimiento, o de describir la sociedad o las obras literarias, sino una falta moral, de no comprometerse con el diálogo acerca de los asuntos “serios”, de una insinceridad en la comunicación - tengamos en cuenta, en este sentido, que en «Sobre la incomprensibilidad» Schlegel se defendía, ante todo, de las acusaciones de «falta de sinceridad» en sus escritos del Athenaeum: no es una cuestión de proponer ideas inadecuadas, sino de no querer participar en una conversación verdadera ${ }^{57}$.

\footnotetext{
${ }^{56}$ Precisamente, como vemos, esta escritura falsa, perjudicial, se relaciona en el texto platónico con lo lúdico y lo festivo, con el despilfarro y el derroche sexual.

${ }^{57}$ Muy significativamente, cuando Derrida se defiende en Limited Inc de las críticas que John Searle había vertido sobre su trabajo acerca de la obra John Austin (un trabajo al que recurriremos en el quinto capítulo), afirma muy irónicamente, como hizo Schlegel al defenderse de las críticas al Athenaeum, que va a ser
} 


\subsection{Una propuesta pragmatista: los usos de la ironía}

Precisamente, las acusaciones vertidas sobre esta filosofía son equivalentes a las acusaciones seculares hacia la Retórica: la negatividad de lo retórico viene dada por su caracterización como lo afectado, los disfrazado, lo falso, lo vacuo (Fish, 1992: 258) ${ }^{58}$. La oposición a la Retórica siempre se realiza a partir de tres distinciones paradigmáticas:

La primera, entre una verdad que existe independientemente de todas las perspectivas y puntos de vista y las muchas verdades que surgen y parecen claras cuando se ha establecido y está en vigor una perspectiva o punto de vista particular; segunda, una oposición entre el conocimiento verdadero, que es el que existe aparte de uno y de todos los sistemas de creencias, y el conocimiento que, porque se origina en uno u otro sistema de creencias, es incompleto y parcial (...) y tercera, una oposición entre un yo o una conciencia que se vuelve hacia fuera en un esfuerzo para aprehender y unirse a la verdad y al conocimiento verdadero, y un yo o una conciencia que se repliega en sí mismo en la dirección de sus propios prejuicios que, lejos de ser trascendidos, continúan informando su palabra y su acción (Fish, 1992: 262)

Según Stanley Fish, subyace a esta oposición dos visiones acerca del lenguaje: «por un lado, el lenguaje que refleja o informa fielmente sobre cuestiones de hecho, no coloreadas por ningún programa o deseo personal o partidista y, por otro lado, el lenguaje que está afectado por programas y deseos personales y que, por tanto, colorea y distorsiona los hechos que se propone reflejar» (Fish, 1992: 262) ${ }^{59}$. Esta diferencia secular entre retóricos y antirretóricos, entre pragmatistas y esencialistas, es una oposición radical acerca de la naturaleza de la realidad y las actividades humanas, oposición que Richard Lahman explica como la oposición entre el homo seriosus y el homo rhetoricus. El primero

posee un yo central, una identidad irreductible. Estos yos se combinan homogéneamente en una única sociedad real que constituye una realidad referente para los hombres que

totalmente serio: «Pero seamos serios. ¿Por qué tengo tanta dificultad para ser serio en este debate, al que me han invitado, a su vez, a participar?» (Derrida, 2018: 78).

${ }^{58}$ La Retórica, además, es acusada de atraer al vulgo apelando a sus instintos más bajos: «bajo la postura antirretórica se esconde siempre un poderoso y corrosivo elitismo» (Fish, 1992: 259-260). De ahí que no deje de ser paradójico que la ironía sea, como hemos visto, muchas veces entronizada como garante de la objetividad frente a las posiciones partidistas, y que de hecho siempre connotaciones elitistas -en nuestra opinión la propia estructura figurativa de la ironía siempre conlleva una posición de "superioridad".

${ }^{59}$ Incluso la defensa aristotélica de la Retórica es igualmente elitista (hay personas a las que no le valen los argumentos científicos y hay que "persuadirles” con un lenguaje adornado) y basada en la epistemología "realista": el ejercicio retórico sirve para mirar las cosas desde distintos puntos de vista, lo que nos sirve para discriminar los argumentos que más se acercan a la verdad (Fish, 1992: 268-269) - esta es, recordemos, la posición de Shaftesbury o Kenneth Burke respecto a la ironía. 
viven en ella. Esta sociedad referente está a su vez contenida en una naturaleza física, ella misma referencial, que está «ahí afuera», independiente del hombre. El hombre ha inventado el lenguaje para comunicarse con sus semejantes. Comunica hechos y conceptos acerca de la naturaleza y de la sociedad. También puede comunicar una tercera categoría de respuesta, las emociones. Cuando comunica hechos o conceptos, su acierto se mide por algo que llamamos claridad. Cuando comunica sentimientos, el acierto se mide por algo que llamamos sinceridad, fidelidad al yo que experimenta el sentimiento (Lahman, cit. en Fish, 1992: 274)

\section{Mientras, el homo rhetoricus}

es un acto, su realidad es pública, dramática. Su sentido de identidad depende de la confirmación de una repetida y diaria actuación histriónica ${ }^{60}$. Su atención, pues, se concentra en un tiempo y en un lugar concretos. El mínimo común denominador de su vida es una situación social (...) Asume una agilidad natural para cambiar de orientaciones (...) Casi desde su nacimiento, no ha morado en una sino en varias estructuras de valores. Así, no se entrega a ninguna construcción única del mundo, sino que su compromiso es prevalecer en el juego que tiene a su alcance (...) Acepta el paradigma presenta y explora sus recursos. El hombre retórico no está educado para descubrir la verdad, sino para manipularla. la realidad es lo que se acepta como realidad, lo que es útil (Lahman, cit. en Fish, 1992: 274)

En este sentido, el pensamiento postestructuralista y concretamente el deconstructivista es fundamentalmente retórico al afirmar que cualquier realidad es leída, interpretada, construida discursivamente: «la deconstrucción derrideana no descubre las operaciones de la retórica con el fin de alcanzar la Verdad; por el contrario, descubre continuamente la verdad de las operaciones retóricas, la verdad de que todas las operaciones, incluso las de la misma deconstrucción, son retóricas» (Fish, 1992: 289).

Sin embargo, como apunta Rorty, lo cierto es que existe en la obra de Derrida y de sus seguidores el riesgo de volver a caer en la trampa esencialista si tomamos "en serio” términos como «escritura», «huella», «gramatología», «différance» (Rorty, 1996: 171), es decir, si los tomamos como conceptos explicativos pertenecientes a una metodología de análisis en su sentido tradicional. La obsesión derridiana de escapar del lenguaje de la metafísica, del logocentrismo, le lleva a caer en una terminología pseudomística que pretende describir trascendentalmente el lenguaje como las «palabras

\footnotetext{
${ }^{60}$ En el capítulo 5 insistiremos en la relación de lo cómico con un sentido teatral, y la metáfora dramática recorrerá los análisis de los capítulos 6 y 7
} 
elementales» de Heidegger (Rorty, 2015: 136). Este peligro existe también sin duda en la obra de De Man o Barthes, al reificar y remitificar la ironía, el lenguaje retórico o la escritura. Lo podemos observar, por ejemplo, en la personificación que en «El concepto de ironía» De Man hace de dicha figura, donde el tropo o el lenguaje actúan como por cuenta propia, De Manera independiente a quienes lo utilizan: así, habla de «la habilidad del lenguaje para nombrar» o «postular cualquier cosa que el lenguaje está deseando postular» (De Man, 1996: 8); las palabras «tienen una forma de decir cosas que no coincide en absoluto con lo que queremos que digan», existe una «máquina textual (...) que habita las palabras en el nivel del juego del significante» (1996: 20). También veíamos cómo la propuesta de Roland Barthes es la de una escritura sin propiedad, sin origen, sin intención.

En la obra de Derrida, De Man y Barthes, en suma, el lenguaje sustituye al yo como sujeto trascendental, como una sustancia independiente de toda conciencia, de todo origen, de toda meta. Pero, como advierte Rorty, «la literatura que no conecta con nada, que carece de objeto y de tema, que carece de una moraleja y de un contexto dialéctico, no es más que bla bla bla» (2015: 137). En nuestra opinión, la concepción retórica del lenguaje de De Man, por ejemplo, no deja de reducir el ámbito de la retórica (y del lenguaje) a su dimensión semántica, tropológica: aunque rechace la falacia representacional del lenguaje como medio, más o menos transparente, para designar la realidad, al hablar del «juego del significante» o del carácter autorreflexivo del lenguaje, no deja de permanecer en el ámbito de la semántica, del carácter significativo del lenguaje, pero obvia su carácter comunicativo, intersubjetivo, que es el ámbito original de la Retórica (como expondremos en el siguiente capítulo [ver 4.1, 4.2.1, 4.3]). El lenguaje, entendido retóricamente, no es simplemente una «máquina textual» tropológica que funcione de manera independiente, sino algo que se usa entre interlocutores con una historia, en cierto contexto y con una determinada actitud e intención. En este sentido, coincidimos con Terry Eagleton en su propuesta de entender la retórica no como un «mero tanteo de metáforas» sino en su dimensión isocrática-ciceroniana «donde las artes retóricas son inseparables de la práctica de una política» (Eagleton, cit. en Fish, 1992: 292).

Esta posición también se puede aplicar al entendimiento de la ironía. Como hemos ido apuntando, en las sucesivas teorizaciones de la misma se repite el gesto de distinguir entre una ironía "falsa”, limitada, “retórica”, y una ironía "verdadera”, “filosófica”. En 
este sentido, tanto De Man como Barthes repiten esta clasificación entre una ironía limitada y una ironía verdadera, limitando la ironía a una cuestión semántica, interpretativa - una cuestión acerca de la posibilidad o no de alcanzar un significado o una interpretación fija. Sin embargo, creemos que es más útil entender la ironía o la escritura irónica como un ethos, como una actitud comunicativa: ya observamos como Schlegel, al igual que Shaftesbury, hablaban de la ironía como una actitud “liberal”, en la comunicación, como una cautela hacia la posibilidad de comunicarlo todo o de decir la última palabra en una discusión filosófica o literaria, pero sin perder de vista el carácter de interacción entre un autor y un lector, de diálogo entre dos sujetos.

Por tanto, no parece adecuado sostener una distinción entre ironías falsas y verdaderas, o ironías mejores o peores, sino simplemente señalar diferentes usos de la ironía en la conversación cotidiana, artistíca o filosófica diferentes actitudes comunicativas e interpretativas que dependen no tanto de la esencia del lenguaje sino de diferentes tradiciones filosófico-literarias y de diferentes «comunidades interpretativas», en el sentido en que Stanley Fish usa este término (Fish, 1980). Existen, como establece Barthes, textos clásicos, legibles, y textos modernos, escribibles - aunque la “escribibilidad” no deje de ser un ideal inalcanzable ya que, como decimos, por mucho que un autor pretenda que su texto no tiene origen, ni tema, ni fin, no deja de estar situado en una interacción comunicativa entre autor y lector. Es cierto también que el carácter retórico del lenguaje conlleva que no podamos alcanzar significados fijos, no interpretables, pero el hecho es que hay interpretaciones y hay comunicación, establecidos según unas convenciones interpretativas determinadas, sean estas “tradicionales” o “postestructuralistas”.

En este sentido es en el que Stanley Fish critica el libro de Wayne Booth sobre la interpretación de la ironía: el proceso interpretativo se da exactamente como establece el crítico norteamericano, pero cada una de las “marcas” irónicas y “pasos” en la reconstrucción del significado son productos de una interpretación: la detección de incongruencias («el quid de la cuestión está en que las incongruencias no se anuncian por sí mismas (...) surgen en el contexto de los supuestos interpretativos»); la decisión sobre los conocimientos o creencias del autor («una decisión que no se basa en una inspección directa, sino en una reconstrucción conjetural de lo que el autor puede haber conocido o creído»); la elección segura del significado figurado (Fish, 1992: 139-140). Es decir, la interpretación de la ironía de hecho ocurre, pero no con la certeza que a Booth le gustaría: 
La certeza que Booth desea (...) tendría que fundarse en que no fuera materia opinable y, por tanto, susceptible de discusión; pero (...) cualquier fundamento que se emplee en el proceso de identificación de una ironía tendrá exactamente el mismo rango de la lectura que (con certeza) se siga de él; dicho de otra manera, será el producto de una interpretación (Fish, 1992: 138) ${ }^{61}$

El mismo Booth reconoce, aunque no quiera llevar sus afirmaciones a sus últimas consecuencias, que la interpretación de la ironía es, en última instancia, una decisión del lector basada en convenciones de lectura, y en general que la interpretación de una obra literaria es el producto de una discusión entre diferentes puntos de vista argumentables. Así, es el lector quien detecta una incongruencia entre el texto literal y lo que él supone que son las creencias del autor y elige una interpretación que sea acorde con lo que ha conjeturado como la intención del autor (Booth, 1989: 36-38). Pero todo este proceso es circular, basado en la suposición de una «comunidad de ideas» entre autor y lector (Booth, 1989: 42). En un momento determinado de su libro, Booth reconoce (en una nota al pie) que «la ironía misma plantea dudas en el mismo momento en que se nos ocurre su posibilidad, y no hay ninguna razón intrínseca para interrumpir el proceso de duda hasta en ningún punto anterior al infinito» (Booth, 1989: 96; el destacado es nuestro): es decir, reconoce que la interpretación irónica es potencialmente infinita, y que depende de una decisión del lector detener el proceso. Él mismo confiesa, ante una lectura de un texto de Huxley, la posibilidad de que se haya dejado llevar al creer que un pasaje era irónico y que, a partir de ahí, haya leído irónicamente todo el texto más allá de la intención de su autor (Booth, 1989: 127). También indica que existen lecturas alternativas a las que él ofrece, aunque tengan que demostrar su validez: «Si alguien desea mantener alguna objeción (...) deberá presentar sus razones para detenerse en un punto anterior del recorrido. Y creo que siempre se encontrará que su punto de parada es convencional» (Booth, 1989: 98; el destacado es nuestro).

\footnotetext{
${ }^{61}$ Fish apoya su posición mostrando cómo un texto de Swift no se había leído nunca como irónico hasta la publicación de un artículo en 1963. En su explicación del artículo, Fish muestra cómo la interpretación que da el crítico del texto se apoya en convenciones interpretativas aceptadas por la comunidad literaria: «Slepian tiene éxito no porque haya sido el único en trabar contacto con la obra misma ni porque haya creado la obra de una sola pieza, sino porque, de acuerdo con los procedimiento autorizados por la institución, ha alterado las condiciones de una determinada perspectiva (...) de tal manera que el resultado es que muchos vean una obra distinta a la que veían antes de que escribiera su artículo» (Fish, 1992: 151). De este modo, Fish demuestra no solo cómo la percepción de la ironía en un texto es de hecho producto de una interpretación, sino cómo cualquier interpretación no deja de ser un discurso retórico que tiene que recurrir a argumentos convencionales.
} 
Asimismo, también asume que estas decisiones interpretativas dependen de un conocimiento convencional compartido por autor y lector: «los hechos indiscutibles solo son indiscutibles, en el caso de la ironía, en la medida que lo consideran las suposiciones de autores y lectores sobre lo que es y no es innegable» (Booth, 1989: 98), por lo que reconoce también la posibilidad de que una ironía no sea leída como tal (cabe la posibilidad de que el autor ironice sobre las propias creencias del lector, y por tanto este no "perciba” la incongruencia que iniciaría el proceso interpretativo), o que un texto se lea como irónico aunque no fuera la intención original del autor («hay muchos autores que llegan a producir obras que tienen mucha más profundidad y alcance de lo que habían previsto»; la aceptación de esta posibilidad lleva a Booth a introducir el concepto de ironías «intencionadas desde el punto de vista de la obra») (1989: 305). También apunta a cómo, finalmente, las obras irónicas no son sino un género en sí mismo, una tradición que nos ha acostumbrado a leer ciertos textos de esta manera determinada (Booth, 1989: 144-145).

En resumen, el propio Booth reconoce que la lectura de la ironía, incluso la que él denomina estable, está lejos de ser un proceso seguro e independiente de convenciones de lectura, pero se niega, como decimos, a llevar este hecho a sus últimas consecuencias, porque, como opina Fish, «lo que Booth ve (...) es que la consolidación de la ironía estable es la consolidación del propio significado» (1992: 140). Fish reconoce que, en efecto, existen certezas comunicativas y acuerdos relativos sobre la interpretación de ciertas obras literarias, pero eso no impide que estas certezas y acuerdos no sean producto de convenciones interpretativas que pueden cambiar en algún momento (Fish, 1989: 141). Y sin embargo, aunque se confirmen los peores temores de Booth, esto es, la contingencia de toda interpretación, esto no tiene las consecuencias apocalípticas que el crítico norteamericano temía: esta contingencia no implica un todo vale de la interpretación porque aunque la lectura dependa de una decisión del lector esta «sólo será posible en relación con procedimientos de decisión autorizados por la institución» (Fish, 1992: 155).

En resumen, podemos decidir de hecho si una obra es irónica o no, pero este conocimiento no se basa en una realidad textual observable "científicamente", independiente del intérprete, sino que es producto de convenciones de lectura aceptadas por la comunidad: «la ironía no es una propiedad de la obra ni la creación de una imaginación desbordada, sino una manera de leer, una estrategia interpretativa que produce el objeto de su atención (...) si la ironía es una manera de leer, también lo es la 
literalidad» (Fish, 1992: 157; destacado del autor). Y lo importante es que esto también es aplicable a la distinción entre las ironías estables e inestables, como Fish apunta en una nota al texto:

Tanto la decidibilidad como la indecidibilidad, al igual que la ironía y la literalidad, son modos de leer. Esto es, no existe una forma pura (una interpretación delimitada, otra libre y a rienda suelta) que justifique la aparente urgencia del argumento de Booth. La distinción entre ironías estables e inestables es real, pero su realidad está en función de la disponibilidad de ciertos modos de lectura en un momento histórico particular: es por tanto una distinción convencional que corresponde a entes producidos convencionalmente. Sin embargo, no puede mantenerse como distinción entre esencias, porque las condiciones de pura racionalidad y total libertad interpretativa en que se asienta no pueden darse. Digámoslo de una forma que sólo en la apariencia es paradójica: todas las ironías son estables, incluso aquellas que apuntan en múltiples direcciones, por cuanto la forma que tienen (o no tienen) tendrá su origen en supuestos interpretativos presentes; y todas las ironías son inestables, incluso aquellas que están vigorosamente señaladas, en cuanto que son producto de supuestos interpretativos, de modos de lectura, y no propiedad de los textos (Fish, 1992: 356; el destacado es nuestro)

Por tanto, la distinción entre la ironía estable y la inestable, entre la ironía clásica o romántica, retórica o filosófica, no es una distinción que afecte a la “esencia” de la ironía, la retórica o el lenguaje, sino que depende de modos de leer que dependen de tradiciones literarias. En este mismo sentido se pueden entender las falsas jerarquías análogas a las de Baudelaire entre un «cómico significativo» y un «cómico absoluto» según la sátira afecte a una persona o vicio concreto o exprese un escepticismo generalizado respecto a la fútil naturaleza humana: al igual que ocurre con la distinción entre la alegoría y el símbolo, la estructura figurativa es la misma, lo que cambia es la tematización, el contenido objeto de la crítica cómica/irónica (la crítica de un vicio concreto o la crítica de la creencia en un conocimiento seguro de la realidad, por ejemplo).

\subsubsection{Linda Hutcheon: ironía, parodia y posmodernidad}

Un acercamiento distinto, también desde una perspectiva teórica posmoderna, pero más orientada directamente a la crítica y al funcionamiento "real” de las obras concretas, es la que ha ofrecido la crítica canadiense Linda Hutcheon a lo largo de una obra dedicada especialmente al estudio de la parodia y la ironía como formas privilegiadas del arte, la música, la literatura y demás formas artísticas consideradas posmodernas. 
Ya con A theory of parody, de 1985, Hutcheon intervenía en el debate acerca de la validez del arte posmoderno, defendiéndolo de las críticas de quienes, como Fredric Jameson, las consideraban obras nostálgicas, simulacros vacíos de contenido e incapaces de producir ninguna innovación artística ni comentario social ${ }^{62}$. Para ello, la decisión teórica fundamental de Hutcheon es el de ampliar la definición tradicional de la parodia como imitación burlesca o satírica de una obra o un género a la de paroida como eco de un texto anterior, que marca una distancia no necesariamente crítico, «a form of imitation, but imitation characterized by ironic inversion, not always at the expense of the parodied text (...) [It] is, in another formulation, repetition with critical distance, which marks difference rather than similarity» (Hutcheon, 2000: 6). La teórica señala el hecho de que en el étimo griego parodia, el prefjo para- puede significar tanto «contra» como «al lado de», por lo que encontramos «a suggestion of an accord or intimacy instead of a contrast» (2000: 32).

Hutcheon relaciona esta parodia (pos)moderna con la doctrina renacentista de la imitatio en el sentido de que ambas ofrecen «a workable and effective stance toward the past in its paradoxical strategy of repetition as a source of freedom» (2000: 10). Porque la parodia es una de las formas privilegiadas por el interés creciente del siglo XX por la autorreflexividad del arte y el lenguaje en general y su sentido histórico: «modern artists seem to have recognized that change entails continuity, and have offered us a model for the process of transfer and reorganization of that past» (Hutcheon, 2000: 4). La parodia, por tanto, es una manera de lidiar con el pasado artístico mediante esta "repetición con diferencia", es un proceso «of revising, replaying, inverting and "trans-contextualizing" previous works of art» (Hutcheon, 2000: 11).

Mediante la imitación paródica de textos del pasado, el artista ofrece un comentario, bien acerca de ese pasado o del presente, gracias a esa operación de “transcontextualización” «by which art reveals its awareness of the context-dependent nature of meaning, of the importance to signification of the circumstances surrounding any utterance» (Hutcheon, 2000: 85). En un libro posterior dedicado al arte posmoderno en general, Hutcheon defenderá la parodia, frente a quienes denuncian su vacuidad fetichista, como un trabajo crítico que problematiza la ideología burguesa y el utopismo del arte modernista (Hutcheon, 1988: 6). El arte posmoderno, mediante la parodia,

\footnotetext{
${ }^{62}$ Expondremos estas críticas en 3.4.3
} 
problematiza la historicidad de la obra de arte y sus conexiones con los contextos sociales en las que se producen tanto las obras del pasado como las actuales:

It is precisely parody - that seemingly introverted formalism - that paradoxically brings about a direct confrontation with the problem of the relation of the aesthetic to a world of significance external to itself, to a discursive world of socially defined meaning systems (past and present) - in other words, to the political and the historical (...) Postmodernist art offer a new model for mapping the borderland between art and the world, a model that works from a position within both and yet not totally within either, a model that is profoundly implicated in, yet still capable of critizicing, that which is set to describe (Hutcheon, 1988: 22-23)

Precisamente es esta capacidad de criticar un discurso desde dentro lo que ha atraído, según Hutcheon, el interés de las comunidades “excéntricas” (mujeres, homosexuales, personas racializadas, etc.) por la parodia, que les permite «to come to terms with and to respond, critically and creatively, to the still predominantly white, heterosexual, male culture in which they find themselves» (Hutcheon 1988: 35) - como podremos comprobar [6.1], la estética camp encajaría, con matices, en esta descripción de la parodia posmoderna.

Sin duda, el mayor interés de la propuesta de Hutcheon es que arroja luz sobre las características formales del arte posmoderno y sus implicaciones ideológicas y sociales al remitirlo a los problemas de las relaciones entre arte, historia y sociedad y el carácter fundamentalmente textual de ambos fenómenos; interés común a las teorías postestructuralistas a través sobre todo de la noción de intertextualidad (Hutcheon, 2000: 37) que, como veremos, ocupa un lugar fundamental en nuestra propio entendimiento del discurso humorístico [5.3]. Otro elemento fundamental de su definición de la parodia, y que la distingue de otros modos de intertextualidad como el pastiche, es el uso de la ironía o la distancia irónica (Hutcheon, 2000: 40).

Sin embargo, el mayor problema que presenta es el de descartar el carácter cómico de la parodia y la ironía como rasgo necesario para su definición. Esta ausencia deriva de su propuesta básica de ampliar el rango de actitudes que la parodia puede presentar hacia el texto parodiado: Hutcheon rechaza la inclusión del ridículo en la definición de la parodia porque, bajo su punto de vista, limita el potencial del género a una operación conservadora de denigración, mientras que lo que ella propone es entender la parodia como una forma seria de crítica de arte infundida en la propia creación artística: «this 
more serious function of parody has the potential to allow for a wider pragmatic range besides ridicule» (Hutcheon, 2000: 51; el destacado es nuestro), de ahí que prefiera hablar del carácter irónico más que cómico de la parodia (Hutcheon, 2000: 52).

Esta distinción proviene sin duda de una concepción excesivamente restringida de lo cómico como equivalente al ridículo denigrante cuando, como venimos defendiendo, el carácter cómico tiene que ver fundamentalmente con el campo de lo lúdico. El problema es que, al eliminar este rasgo cómico de la definición de la parodia, Hutcheon no puede dar cuenta satisfactoriamente de la diferencia de la parodia con la intertextualidad en general. En su razonamiento, esta diferencia reside en la diferencia que el proceso de “transcontextualización” le otorga a la imitación paródica; sin embargo, como ella misma reconoce, la "transcontextualización”, o dicho más sencillamente, el cambio de contexto que modifica irremediablemente el sentido de un texto es, por definición, común a toda forma de intertextualidad (Hutcheon, 2000: 41).

Resulta adecuado, por tanto, considerar la parodia como una forma de intertextualidad, pero sin admitir el carácter cómico o lúdico de esta imitación es muy difícil definir su particularidad. Hutcheon insiste en señalar la distancia irónica como rasgo particular, pero esta es una descripción circular: lo que hace irónica a la parodia es la distancia irónica. Retener el elemento crítico de la parodia y la ironía sin recurrir a su carácter cómico, lúdico y ridículo impide explicar de qué modo y respecto a qué puede ser crítica una parodia. ¿Qué diferencia hay entre una parodia que "respeta” el texto parodiado y un mero homenaje? ¿Podríamos considerar una parodia el filme Lejos del cielo de Todd Haynes, evidente homenaje de las películas de Douglas Sirk? Hutcheon menciona como ejemplo el cuadro de Picasso Masacres en Corea [Fig. 12], cuyo propósito al hacer referencia al cuadro De Manet La ejecución de Maximiliano y Los fusilamientos del 3 de mayo de Goya parece ser «to increase the horror and the drama through ironic contrast of plural nameless massacres with individual romantic execution» (Hutcheon, 2000: 65) 


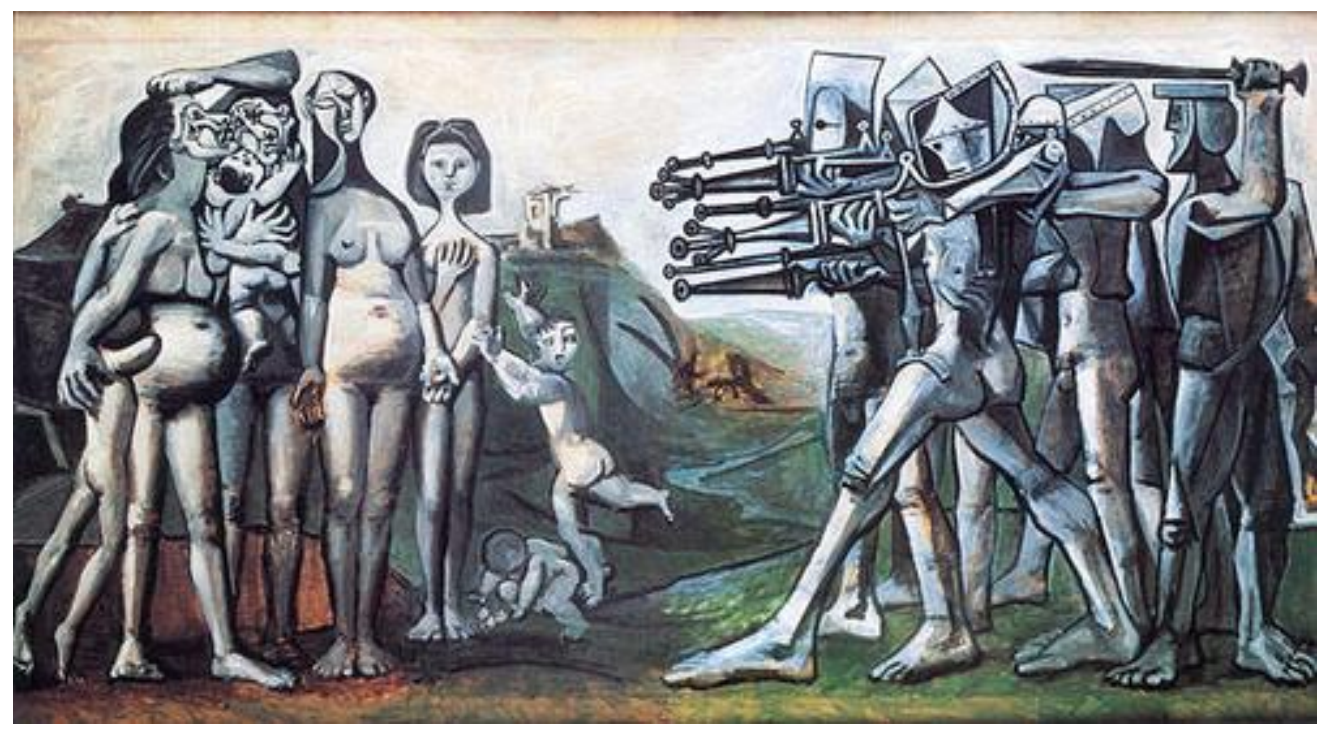

Fig 12. Pablo Picasso, Masacre en Corea (1951)

Sin embargo, encontramos problemático definir tanto el cuadro de Picasso como paródico e irónico. De hecho, este es el único ejemplo que Hutcheon da de "parodia trágica”, y en otras descripciones de obras irónicas reconoce que la actitud irónica es esencialmente burlona (Hutcheon, 2000: 61).

Otro momento problemático en la teorización de Hutcheon es su distinción de la sátira y la parodia. La crítica propone que la parodia es «intramural», trabaja únicamente con textos artísticos, mientras que la sátira tiene un objetivo social moralizante (Hutcheon, 2000: 43). La razón por la que tan frecuentemente se confunden ambos géneros es, según Hutcheon, que muchas veces la sátira utiliza la parodia como vehículo formal y, sobre todo, que ambos utilizan la ironía como estrategia discursiva (2000: 43). Hutcheon parte aquí de la doble dimensión de la ironía, semántica y pragmática, establecida por Kerbrat-Orecchioni (1980) (aunque no está del todo claro que estas dos dimensiones se puedan dar por separado, como pretende Hutcheon): la dimensión semántica corresponde al campo tradicional de la antífrasis, el contraste entre lo dicho y lo implicado irónicamente, mientras que el nivel pragmático hace alusión al carácter evaluativo de la ironía (Hutcheon, 2000: 53). En este sentido, mientras que la sátira se centra en este carácter evaluativo, la parodia moderna «rarely has such an evaluative or intentional limitation» y se centrar en el contraste semántico, antifrástico, entre los dos textos evocados (Hutcheon, 2002: 54-55).

Es en este punto debería ser evidente la preferencia de Hutcheon de la parodia frente a la sátira, “limitada” al comentario moral, y, sobre todo, a lo “meramente” cómico: 
en su intento de legitimar la parodia (pos)moderna de las acusaciones de frivolidad, parasitismo, falta de originalidad, etc., necesita enfatizar el elemento diferencial de la imitación paródica como factor creativo, y, ante todo, reclamar el carácter serio de la parodia frente a lo cómico y lo ridículo. La parodia, en la teoría de Hutcheon, es, frente al mero divertimento o el mero reproche “moralizante” de la sátira, un ejercicio de autorreflexividad, un comentario sobre la historicidad de las formas artísticas, etc. Esto es más evidente aun cuando describe el componente afectivo de la parodia - sobre todo desde el que momento en que prefiere hablar de este como ethos, aunque sea consciente de que, teniendo en cuenta la definición aristotélica, debería hablar de pathos (Hutcheon, 2000: 55). Mientras que el ethos de la sátira es peyorativo, idealista y moralizante, «the ethos postulated for parody probably should be labelled as unmarked, with a number of possibilities for marking» (Hutcheon, 2000: 60). La parodia, ante todo, «is never a mode of parasitic symbiosis. On the formal level, it is always a paradoxical structure of contrasting synthesis, a kind of differential dependence of one text upon another» (Hutcheon, 2000: 61).

Subyace a toda esta teoría, en suma, una preferencia por la parodia así entendida en la que encontramos ideas que ya nos son familiares: frente a los afectos peyorativos de la sátira, excesivamente limitados y locales, el carácter más formal, semántico, artístico, sofisticado, de la parodia le permite una mayor flexibilidad, una mayor libertad, al fin y al cabo, por ser más intelectual. De hecho, esta limitación de la parodia al ámbito textual del diálogo entre textos artísticos da lugar a otra dificultad teórica: la cuestión del aspecto ideológico, transgresor o conservador de la parodia (Hutcheon, 2000: 69). En este punto, Hutcheon recurre a la obra de Bajtín y su caracterización de la parodia carnavalesca como texto polifónico y dialógico (Hutcheon, 2000: 69) para explicar el carácter aparentemente paradójico de la parodia como transgresora y conservadora a un tiempo. Por un lado, el dialogismo carnavalesco es un modo de relativizar la cultura oficial, y en este sentido el arte posmoderno sería un momento más de la lidia histórica con los lenguajes oficiales y del pasado (Hutcheon, 2000: 72), pero por otro, «the recognition of the inverted world still requires a knowledge of the order of the world which it inverts and, in a sense, incorporates» (Hutcheon, 2000: 74): la parodia, de alguna manera, legitima el texto parodiado al actualizarlo en el presente: «in formal terms, it inscribes the mocked conventions onto itself, thereby guaranteeing their continued existence (...) It is in this 
sense that parody is the custodian of the artistic legacy, defining not only where art is, but where it has come from» (Hutcheon, 2000: 75).

El problema, sin embargo, es que la paradójica posición ideológica de la parodia o el carnaval no reside en la interacción con textos del pasado, tal y como defiende Hutcheon. En primer lugar, las nociones de polifonía y dialogismo de Bajtín, como veremos [4.2] son mucho más amplias de como lo trata Hutcheon, y abarca no solo textos artísticos y literarios, sino todos los lenguajes sociales. Y, sobre todo, la gran diferencia entre la parodia posmoderna y el carnaval medieval que describe Bakthin es que este es ante todo un fenómeno social: la ambigüedad de la transgresión llevada a cabo por el carnaval es debida a que este está literalmente autorizado por los poderes oficiales de la Iglesia y el Estado. En este sentido, como veremos, la crítica de Jameson a la cultura posmoderna no es (solo) una crítica formal, sino al contexto de producción y distribución en el que se produce - concretamente, la inclusión del arte en la lógica del mercado.

En todo caso, posteriormente, en el libro ya mencionado dedicado al arte posmoderno, Linda Hutcheon renuncia a diferenciar la sátira y la parodia y explica de un modo más satisfactorio las relaciones que a través de la parodia el arte posmoderno establece entre el texto, el contexto social y político y el proceso histórico. En cuanto al vago tratamiento de un elemento tan central en su teorización como es la ironía, lo remediará cuando dedique un libro entero al estudio de la figura, Irony’s edge (Hutcheon, 1994).

La propuesta de Hutcheon en este libro presenta, como ella misma afirma, la ventaja frente a otras de renunciar a las teorizaciones abstractas sobre el papel trascendental de la ironía en la naturaleza del lenguaje y permanecer en el funcionamiento de la ironía como estrategia discursiva usada por los artistas conflictivos (1994: 3). Al enfocar de este modo el problema, recupera la figura del ironista y su intención comunicativa, en equilibrio con el papel del lector, así como la dimensión afectiva que conlleva la ironía, mediante la que explica, como veremos, los conflictos a los que puede dar lugar; así mismo, advierte de la naturaleza transideológica de la figura, es decir, el hecho de que no hay nada intrínsecamente subversivo en la ironía ni en el escepticismo irónico, sino que tratamos con una figura que, como toda herramienta retórica, puede ser usada para fines ideológicos muy diversos (Hutcheon, 1994: 10). La ironía, en fin, es ante todo un fenómeno comunicativo que implica no solo una determinada forma retórica, sino todo un contexto cultural y social determinado por los interlocutores, el contenido 
temático del enunciado irónico, las relaciones de poder implicadas en la situación comunicativa... (Hutcheon, 1994: 17).

Hutcheon ofrece en este libro una estimulante descripción del significado análoga a la explicación de Zupancic del funcionamiento de lo cómico en general. Para Hutcheon, el significado irónico no es el que sustituye al significado literal, sino que interactúa con él: propone entender

ironic meaning as relational, as the result of the bringing - even the rubbing - together of the said and the unsaid, each of which takes on meaning only in relation to the other (...) In interpreting irony, we can and do oscillate very rapidly between the said and the unsaid (...) It is not the two "poles" themselves that are important; it is the idea of a kind of rapid perceptual or hermeneutic movement between them that makes this image a possible suggestive and productive one for thinking about irony (Hutcheon, 1994: 59-60; destacado de la autora)

Aunque más adelante matizaremos el que la yuxtaposición se produzca entre «lo dicho» y «lo no dicho», nos interesa la idea de una interacción entre varios significados y no de sustitución de uno por otro. Pero este significado no es relacional en el mismo sentido que la metáfora, puesto que más que la semejanza la ironía enfatiza ante todo la diferencia misma entre los varios significados que se ponen en juego (Hutcheon, 1994: 64). Es en este punto donde Hutcheon localiza el «filo evaluativo» («evaluative edge») que para ella caracteriza la ironía (Hutcheon, 1994: 58).

En este sentido, para captar correctamente el sentido irónico de un texto es imprescindible tener en cuenta la supuesta intención del autor: «in setting up a differential relation between the said and the unsaid, irony seems to invite inference, not only of meaning but of attitude and judgment» (1994: 39). Hutcheon argumenta muy razonablemente y de manera parecida a Stanley Fish, que aunque, como en todo proceso comunicativo, corresponda al receptor identificar una ironía, siempre lo hará según unas “marcas” textuales o convenciones de lectura: identificar una ironía es, al fin y al cabo, atribuir una intención irónica (Hutcheon, 1994: 120-121). Hutcheon amplía el concepto de acto intencional no solo al "codificador" del texto, sino también a su receptor (Hutcheon, 1994: 119):

Interpretation is, in a sense, an intentional act on the part of the interpreter. The recourse to the "invisible anonymity" of Foucaultian discursive power does not always answer the issues raised by irony, where human agency reasserts itself in complex ways and at many 
stages: in the intention, execution, interpretation, affective response, and consequences of irony (Hutcheon, 1994: 118) ${ }^{63}$

Que la ironía “ocurra”, por tanto, depende tanto de la intención del autor como del “ánimo” del receptor (Hutcheon, 1994: 45). En este sentido, Hutcheon insiste en la absoluta dependencia de la ironía respecto a las comunidades discursivas y, frente a las frecuentes propuestas de que la ironía sirve para crear una comunión entre los interlocutores, señala que, más bien, la ironía depende de que dicha comunión ya exista previamente (Hutcheon, 1994: 89-92). Esta postura invalida la hipótesis presente en muchas de las discusiones sobre la ironía acerca de la existencia de dos “audiencias” de la ironía, una que entiende la ironía, y otra que no la identifica y que, supuestamente, son las víctimas de la misma. Sin embargo, como señala Hutcheon, aquellos que no entienden una ironía «may not care at all; they may simply “misuderstand” (i.e. interpret differently) because they are operating within a different discursive context» (1994: 95). Y también cabe la posibilidad de que los receptores identifiquen la intención irónica y la rechacen por encontrarla problemática u ofensiva.

Es en este punto donde encontramos ciertas limitaciones en la descripción de Hutcheon, concretamente en dos aspectos: en primer lugar, vuelve a negar la vinculación necesaria de la ironía con el humor porque considera que la ironía puede ser seria:

This is not intended to take away from either the power or the presence of humorous irony but is the result of my conscious desire to short-circuit that knee-jerk rejection of irony (and irony theory) - as trivial and trivializing - that characterizes so many critiques of contemporary culture (Hutcheon, 1994: 26)

En segundo lugar, Hutcheon sigue sosteniendo un modelo interpretativo en el que la ironía es un modo más o menos particular de transmisión de información, y que

\footnotetext{
${ }^{63}$ En nuestra opinión, la distinción entre ironías intencionales y no intencionales, es decir, entre ironías buscadas por el autor y enunciados que el lector encuentra irónicos aunque no fuera intención del autor, es falsamente problemática: se trata, simplemente de dos modos de lectura bien distintos. En uno, el receptor del texto intenta inferir la posible intención que tuviera el emisor; en otro, el lector simplemente "usa" el texto sin "respetar" la intención del autor (en este sentido celebra Barthes la lectura como una violación de la propiedad burguesa) y puede encontrar cómico su texto, aunque el autor fuera absolutamente serio (y precisamente por su seriedad): en este caso, el lector se "apropia” del texto, lo hace suyo, "crea” un nuevo texto, y lo irónico es este texto-interpretación, no el texto original. Como veremos, la estética camp funciona de este modo. También Hutcheon destaca esta cuestión de la apropiación por parte de las comunidades excéntricas: «It is precisely this reassertion of human agency that has attracted oppositional politics to the power of irony» (Hutcheon, 1994: 118). Para una discusión sobre la lectura entendida como interpretación o como uso se puede consultar la intervención de Richard Rorty en el volumen colectivo Interpretación y sobreinterpretación (Eco, 2013).
} 
“entender” una ironía consiste en identificar no la intención irónica sino un determinado significado irónico. Así, en uno de sus primeros ejemplos, Hutcheon habla de la obra irónica de un artista alemán que juega con imaginería nazi y neofascista y confiesa que no sabe «how to go about interpreting the specific meaning of these ironies» (1994: 13). Esto es, reconoce que la obra es irónica pero no es capaz de “descifrar” su significado específico - suponemos, el significado “intencional” del autor. Esta afirmación contrasta con su teorización explícita acerca de la fluidez del significado irónico y el papel activo del lector. ¿ No sería más acertado considerar que la intención del autor era, simplemente, ser irónico, y que corresponde a cada espectador “sacar sus propias conclusiones” acerca de las consecuencias de la yuxtaposición de elementos provenientes de contextos heterogéneos? Tampoco podemos explicar, si eliminamos el carácter cómico, irreverente, qué hay de específicamente irónico en esta yuxtaposición, ni mucho menos las diferentes reacciones, algunas de ellas condenatorias, mencionadas por Hutcheon (1994: 13).

Estas limitaciones se hacen evidentes en el extenso análisis que la teórica dedica en el último capítulo del libro a una exposición celebrada en 1989 en el Royal Ontario Museum titulada Into the heart of Africa. Esta polémica exposición consistió en la exhibición del fondo colonial del museo con la intención de denunciar, irónicamente, tanto el pasado colonial de Canadá como el sesgo ideológico del discurso museístico tradicional, pero que recibió intensas críticas de varios grupos, sobre todo por parte de la comunidad negra de Ontario (Hutcheon, 1994: 176). Prácticamente todo el análisis de Hutcheon se centra en la cuestión de si la intención irónica del museo estaba suficiente y correctamente marcada, es decir, si las diferentes señales (carteles, espacios, etc.) que podían inducir a una lectura irónica de una exhibición que, por otra parte, ofrecía un formato más bien tradicional, eran suficientemente evidentes como para no llevar a error (Hutcheon, 1994: 179). Destaca así lo problemático del hecho de que la audiencia de un museo sea muy heterogénea y muy probablemente no esté familiarizada con el contexto teórico de los debates académicos acerca del papel de los museos en la ideología imperialista (Hutcheon, 1994: 180-184). Por tanto, intenta explicar la controversia creada como un error de comunicación, como un caso de que una falta de información llevara a no identificar correctamente la intención del autor, y solo pasa de puntillas por otro aspecto que en nuestra opinión explica mejor la controversia: a saber, la pregunta acerca de si la ironía era la mejor estrategia para tratar un tema tan delicado, teniendo en cuenta que los “emisores”, los directores del museo, eran personas blancas y no los propios 
afectados por el pasado colonial. Hutcheon cita en cierto momento, sin detenerse demasiado, varias personas que plantean este tema: «It is also a pretty limp way to examine a subject as grave as racially motivated genocide» 0 «In dealing with issuer as sensitive as cultural imperialism and racismo, the use of irony is highly inappropriate luxury» (Hutcheon, 1994: 192).

En suma, concebir el acto de recepción de una manera tan limitada como simple “desciframiento” de una intención, de un enigma previsto por el emisor que el receptor ha de identificar parece ser contraproducente a la hora de dilucidar los motivos por los que el discurso irónico puede dar lugar a tal controversia. El libro de Hutcheon tiene en cuenta los afectos involucrados en la ironía, pero en última instancia los plantea como un efecto perlocutivo del discurso irónico, como una reacción emocional individual del receptor que depende de su correcta identificación irónica, pero no tiene en cuenta que el propio discurso tiene su propia carga afectiva - en este caso, lo que muchos percibieron como una frivolización del colonialismo y el racismo que solo se pueden permitir las comunicades no afectadas por él. Como veremos en el siguiente apartado, esta limitación, que deriva de una concepción de la comunicación como transmisión de información y de lo cómico como una operación intelectual, vacía de afectos, es un problema común a la gran mayoría de investigaciones sobre el humor dentro del campo de las ciencias sociales.

\subsection{Humor y ciencias sociales: lingüística, psicología, sociología}

Cuando hablamos de la investigación sobre el humor en el campo de las ciencias sociales nos referimos, principalmente, a la lingüística, la psicología y la sociología. Realmente, es difícil deslindar las aportaciones de cada rama, puesto que todas comparten unos temas de investigación comunes y por consiguiente necesitan del apoyo de las demás: así, y dejando aparte las descripciones lingüísticas de orientación más netamente formalista, que trataremos en primer lugar, en el momento en el que el humor se concibe fundamentalmente como una interacción comunicativa, necesariamente se han de combinar los esfuerzos de la pragmática, el análisis de la conversación, la psicología cognitiva, la psicología social, la microsociología... Por esta razón hemos decidido dividir este apartado en dos epígrafes principales, el primero dedicado a las aportaciones desde la lingüística y el segundo, a las de la sociología, pero teniendo siempre presente la 
fundamental interdisciplinariedad del campo; así mismo, aunque no dediquemos un espacio exclusivo a la psicología, habremos de tener en cuenta que nociones y marcos teóricos tan importantes para la discusión que nos ocupa como los de frame o schema o las relaciones entre identidad individual e identidad social provienen de la psicología cognitiva (ver, por ejemplo Dynel, 2011) y de la psicología social (ver Holmes \& Marra, 2002).

En la gran mayoría de los casos, los corpora con los que trabajan estas investigaciones consisten en chistes o breves intercambios humorísticos, en conversaciones informales en situaciones cotidianas como el lugar de trabajo, reuniones familiares o de amigos, etc. En este sentido, se trata de discursos humorísticos muy distintos de los tipos de discurso que analizaremos más adelante (novelas, series de televisión, monólogos difundidos en internet, etc.). Sin embargo, algunas de las hipótesis y conclusiones de las investigaciones en ciencias sociales se mostrarán muy útiles para comprender el funcionamiento social del humor, sobre todo porque hemos de partir de la premisa de que los discursos literarios, audiovisuales, etc., no dejan de ser discursos sociales o interacciones comunicativas que no difieren en esencia del resto.

\subsubsection{Lingüística}

\subsubsection{Los modelos formales: de las isotopías a la script theory}

Como acabamos de adelantar, algunos enfoques lingüísticos de orientación más formalista presentan una cierta independencia del aspecto sociológico del fenómeno humorístico. Estas teorías lingüísticas son esencialistas en el sentido en que buscan describir las características necesarias para que el fenómeno humorístico sea considerado como tal (Attardo, 1994: 1). Dentro de este marco, y especialmente en el paradigma generativista en el que trabajan Attardo y Raskin, los principales proponentes de este tipo de teorías, «a formal theory is an abstract device which manipulates abstract objects on the basis of explicit rules and, given a set of primitives and a set of rules, will generate a set of objects distinct from the set of primitives» (Attardo, 1994: 197). En palabras de Victor Raskin,

a linguistic theory of humor is supposed to account for the fact that some texts are funny while some others are not and to do it in terms of certain linguistic properties of the text. 
Ideally, a linguistic theory of humor should determine and formulate the necessary and sufficiente linguistic conditions for the text to be funny (Raskin, 1985: 47; destacado en el original).

El interés por el humor como fenómeno lingüístico lo encontramos ya en la lingüística estructural, y particularmente en las propuestas derivadas de la semántica estructural establecida por Greimas - y, en última instancia, de las investigaciones freudianas sobre la técnica del chiste, en las que Greimas de hecho se inspira (Attardo, 1994: 64). El lingüista francés nunca estableció explícitamente una teoría del humor, sino que la que de su obra se deriva proviene de un ejemplo usado por él para explicar su concepto de isotopía (Attardo, 1994: 62). Con «isotopía» quería designar el conjunto de semas, sememas y clasemas que apuntan a la totalidad del significado de un texto y garantizan su coherencia semántica (Attardo, 1994: 70). En su presentación recurre al siguiente chiste:

C'est une brillante soirée mondaine, très chic, avec des invités triés sur le volet. A un moment, deux convives vont prendre un peu d'air sur la terrasse :

- Ah! fait l'un d'un ton satisfait, belle soirée, hein ? Repas magnifique... et puis jolies toilettes, hein?

- Ça, dit l'autre, je n'en sais rien

- Comment ça ?

- $\quad$ Non, je n’y suis pas allé ! (Greimas, cit. en Attardo, 1994: 63)

Según el análisis de Greimas, este chiste contiene dos partes: una narración en la que se establece la primera isotopía referida a la fiesta, y el diálogo en el que se introduce una segunda isotopía y que rompe con la coherencia del texto. El texto está apoyado en la ambigüedad del término «toilettes», que puede significar tanto «vestidos» como «aseos», pudiendo referirse al mismo tiempo a las dos isotopías en liza (Attardo, 1994: 63). La comicidad reside, por tanto, en la colusión de dos isotopías antitéticas (sofisticación/escatología, público/privado, etc.) (Attardo, 1994: 70). Las teorías basadas en este conflicto de isotopías hacen hincapié en la linealidad de la estructura narrativa del chiste y su explotación del proceso de desambiguación inherente a la interpretación de cualquier enunciado. El chiste se divide en dos partes, y contiene dos elementos: un conector o término que garantiza la ambigüedad entre las dos isotopías («toilettes» en este ejemplo) y un disyuntor (comúnmente llamado punch line en inglés) que provoca la irrupción de la segunda isotopía («je n’y suis pas allé») (Attardo, 1994: 95).

Es obvio que este tratamiento del chiste se puede enmarcar dentro de las teorías de la incongruencia, y que la definición de isotopía ha ido perdiendo su especificidad 
lingüístico-semántica hasta simplemente hacerse equivalente a otros términos, como el principio de bisociación propuesto por Koestler, que explica el texto humorístico como el choque entre dos ideas contrapuestas ${ }^{64}$ (Attardo, 1994: 85; ver también Forabosco, 1992 y Norrick, 1986 para la relación de este concepto con la psicología cognitiva).

La versión más formalizada de la descripción por incongruencia es la que ofrece Raskin (1985) ${ }^{65}$ en su Semantic Script Theory of Humor (SSTH). La noción de script deriva de la psicología de Bartlett y Bateson y más concretamente de la formulación en términos de lingüística computacional de Schank y Abelson, y se refiere a «an organized chunk of information about something (...) A cognitive structure internalized by the speaker which provides the speaker with information on how things are done, organized, etc.» (Attardo, 1994: 199). Partiendo de este concepto, la SSTH establece que para que un texto sea considerado humorístico debe cumplir las siguientes condiciones:

i. «the text is compatible, fully or in part, with two different scripts

ii. the two scripts which the text is compatible are apposite in a special sense (...) [and] are said to overlap fully or in part on this text» (Raskin, 1985: 99)

Raskin incluye además la idea de que el chiste supone un modo de comunicación non bona fide porque no respeta el principio de cooperación establecido por Grice. Este modo de comunicación consistiría en las siguientes máximas:

i. Máxima de cantidad: da exactamente tanta información como sea necesaria

ii. Máxima de cualidad: di solo lo que sea compatible con el mundo del chiste

iii. Máxima de relación: di solo lo que sea relevante para el chiste

iv. Máxima de manera: di el chiste de manera eficiente (Raskin, 1985: 103)

Los límites de una teoría lingüística formal así concebida parecen evidentes. En primer lugar, la propia descripción de Raskin de las condiciones para considerar un texto como humorísticas son insuficientes en tanto que describen cómo es un enunciado humorístico, pero no explica por qué la incongruencia entre los dos scripts resulta cómica y no, por

\footnotetext{
64 «The perceiving of a situation or idea ... in two self-consistent but habitually incompatible frames of reference (...) The event (...) in which the two intersect, is made to vibrate simultaneously on two different wavelengths, as it were. While this unusual situation lasts, [the event] is not merely linked to one associative context, but bisociated with two» (Koestler cit. en Attardo, 1994: 175). Como se puede apreciar, la metáfora de la vibración entre los dos marcos de referencias remite de nuevo a la noción del significado humorístico similar a la de Zupancic o Hutcheon.

${ }^{65}$ Posteriormente, Attardo y Raskin (Attardo, 2001; Attardo y Raskin, 1991) han propuesto una ampliación, la «General Theory of Verbal Humor», que no aporta ningún contenido teórico fundamentalmente relevante para el propósito de este trabajo.
} 
ejemplo, trágica o terrorífica. En segundo lugar, metodológicamente, las teorías desarrolladas por Attardo, Raskin y otros están centrados en la construcción de chistes y son difícilmente aplicables al discurso humorístico en general, sobre todo porque conciben el chiste como una estructura lingüística sujeta a ciertas leyes de transformación gramatical y no como un género narrativo, literario, y sujeto a una cierta tradición y unas ciertas convenciones “artísticas”. Así, por ejemplo, las cuatro máximas de la comunicación non bona fide que presenta Raskin pueden ser reducidas a la última, «cuenta el chiste de manera eficiente»; y la eficiencia del chiste no se regiría por criterios gramaticales o pragmalingüísticos, sino por unas ciertas convenciones genéricas: si alguien “violara” estas máximas, su interlocutor no le acusaría de mentir, o de no ser cooperativo en la comunicación, sino que simplemente le reprocharía contar "un chiste malo”, o de contarlo mal, desde criterios más estéticos que lingüísticos.

En general, las descripciones formales del funcionamiento de los chistes y otros textos humorísticos parecen poco adecuados para reflejar el proceso real, como se puede comprobar atendiendo al análisis de un chiste realizado por Raskin (1985: 117-127). El chiste es el siguiente: "Is the doctor at home?" the patient asked in his bronchial whisper. "No," the doctor's young and pretty wife whispered in reply. "Come right in"” (Raskin, 1985: 100). Raskin describe el proceso de interpretación del chiste en términos de lingüística computacional como un cálculo inferencial: primero, el receptor "procesa” el chiste según el script «doctor»y, al llegar al final, al percibir que el punch line no es coherente con dicho script, re-inicia el proceso inferencial desde el inicio del texto según un segundo script, de «amante». Es difícil imaginar que el receptor de un chiste realice un proceso cognitivo parecido al análisis de diez páginas que ofrece Raskin, en primer lugar porque, realmente, al receptor no le resultaría necesario realizar el proceso inferencial dos veces en el momento en el que, sabiendo que está frente a un chiste, activaría desde el principio unas ciertas convenciones de interpretación que dependen, como decimos, más de una tradición genérica que de una competencia más o menos gramatical. De hecho, que el receptor encuentre divertida la narración probablemente dependa enteramente de que, efectivamente, lo reconozca como chiste: la misma narración podría considerarse, en otros contextos, como un melodrama consistente en un triángulo amoroso, por ejemplo.

Ante todo, este tipo de descripciones, muy extendidas en las teorías humorísticas de base cognitiva, tratan el texto humorístico como un enigma, como un puzle a resolver, 
y centran su carácter divertido en el modo en el que dos scripts se combinan, cuando una parte importante es obviamente el carácter inmoral o al menos amoral (y ridículo en el caso del doctor cuya mujer le es infiel) de los personajes implicados en la narración. Hay detalles del texto que quedan sin explicar en la descripción de Raskin: ¿por qué la mujer ha de ser joven y guapa? (y además: ¿podemos imaginar que el doctor es de mayor edad? ¿Qué tipo de scripts concretos entran en juego aquí?). Existen detalles que no intervienen directamente en la "incongruencia" del chiste pero que son fundamentales para su comicidad y que dependen no de operaciones puramente cognitivas sino de marcados estereotipos sociales. Otro ejemplo es otro chiste citado por Raskin: «An English bishop received the following note from the vicar of a village in his diocese: "Milord, I regret to inform you of my wife's death. Can you possibly send me a substitute for the weekend?"» (Raskin 1985: 105). En este caso, la comicidad no depende solo de la "sorpresa” del final del texto, sino de un estereotipo (ya incluido en el script del chiste, y no producido por él) del clérigo lascivo e hipócrita que no respeta el celibato.

La teoría de Raskin (aunque divide los chistes analizados en tres categorías: sexuales, étnicos y políticos) explícitamente obvia de su explicación estos aspectos sociales del chiste:

The SSTH models the humorous competence of an idealized speaker/hearer who is unaffected by racial or gender biases, undisturbed by scatological, obscene or disgusting materials, not subject to boredom, and, most importantly, who has never "heard it before" when presented with a joke (...) This idealization is similar to the one adopted by most of generative linguistics, which assumes and idealized homogeneous speaker-hearer community (Attardo, 1994: 197)

A esta decisión metodológica subyace una concepción del humor muy concreta: supone que un texto es humorístico en sí según ciertas condiciones formales y que su correcta apreciación depende de que el oyente no caiga en ciertos “sesgos” (de raza, de género, etc.). Aunque los propios autores expliciten no interesarse por factores considerados extralingüísticos, la dificultad derivada de esta decisión metodológica es que se concibe el carácter cómico de un discurso como una cuestión formal en la que posteriormente pueden influir factores extraformales (sociales, psicológicos) cuando probablemente sea más adecuado enfocar el problema considerando que son estos aspectos, y sobre todo la función social y la intención comunicativa que el discurso humorístico cumple, los que determinan desde el principio estos aspectos formales. Este problema de no atender 
adecuadamente las relaciones entre la estructura y la función es también común a muchas de las explicaciones más explícitamente contextualistas.

\subsubsection{Teoría de la relevancia}

Como hemos podido ver, las teorías de Attardo y Raskin son pragmáticas en el sentido de que tienen en cuenta el contexto (entendido de una manera muy limitada) y recurriendo al principio de cooperación de Grice para definir un modo de comunicación especial. También se han desarrollado explicaciones de los textos humorísticos desde otro paradigma pragmalingüístico, el de la teoría de la relevancia de Sperber y Wilson. Esta teoría se articula a partir de la hipótesis de un principio de relevancia que guía a los oyentes en la identificación de la intención comunicativa de sus interlocutores, sustituyendo así el principio de cooperación de Grice y sus máximas conversacionales (Yus, 2003: 1296).

En este marco teórico, el receptor de un enunciado que identifica como humorístico asume que su interlocutor respeta el principio de relevancia y que las aparentes violaciones de este sirven a su intención de resultar cómico (Yus, 2003: 1298). Los enunciados humorísticos explotan los diversos procesos inferenciales que el receptor suele llevar a cabo para la interpretación del enunciado (resolución de ambigüedades léxicas, asignación de referentes, etc.) para su propio beneficio (Yus, 2003: 1304): «the humorist has a very fine-grained ability to predict which mental procedures the addressee is likely to go through in the relevance-seeking extraction of the information that utterances convey» (Yus, 2003: 1308). Para que el receptor realice las inferencias pertinentes, por supuesto, debe reconocer de algún modo que está entrando en un modo de comunicación humorística (Yus, 2003: 1310). La explicación del proceso de comunicación humorístico, en todo caso, se reduce de nuevo a la resolución de un cierto “enigma” o puzle propuesto por el interlocutor, consistente en la creación de unas expectativas desmentidas por la resolución del chiste (Yus, 2003: 1311).

\subsubsection{Pragmática y análisis de la conversación}

Otro tipo de acercamiento al problema desde la Pragmática, más orientada hacia el análisis de la conversación, estudia la relación de las “unidades humorísticas” con el resto de la conversación, su posición en ella y sus funciones (Dynel, 2011: 217), en un tipo de análisis inaugurado precisamente por el pionero de la disciplina del análisis 
conversacional, Harvey Sacks, en su famoso análisis de un chiste verde (Sacks, 1974).

Este tipo de análisis, pues, se basan, en primer lugar, en que los enunciados humorísticos son un tipo de enunciados “especiales”, no serios, y marcados como tales mediante varios recursos verbales, paraverbales, o extraverbales (avisos explícitos, gestos, entonación especial, etc.) (Dynel, 2014: 224); pero además, en segundo lugar, reconoce que estos enunciados no son totalmente independientes del resto de la conversación. Los fenómenos humorísticos son, esencialmente, un tipo de interacción en el que el receptor participa activamente: puede responder positivamente riendo, continuar la broma, expresar su disconformidad con lo expresado humorísticamente, etc. (Dynel, 2014: 225). En resumen, aunque el enunciado humorístico se conceptualice como un modo de comunicación no serio, inevitablemente forma parte de la comunicación "seria”:

Frequently an utterance suffused with humour cannot be unequivocally subsumed under the humorous frame, lying on the border between humorous and serious modes of communication, which holds true especially for categories of conversational humour (...) The distinction between humour and non-humour may transcend linearity, for an entire utterance may be double-framed, being serious in its content and yet suffused with humour in its form (Dynel, 2014: 227)

Esta combinación de lo serio y lo no serio puede cumplir varios propósitos en la conversación, como suavizar temas delicados o el mandato de órdenes, por ejemplo, sirviendo al principio pragmático de cortesía (Dynel, 2014: 230). El fenómeno humorístico es, en resumen, un fenómeno fundamentalmente social, y como tal es estudiado por la sociología.

\subsubsection{Sociología}

\subsubsection{Humor e interacción social}

Una idea clave, como venimos señalando, para el entendimiento del humor es que supone un tipo de comunicación y/o interacción social especial, no seria, regido por reglas particulares. Para describir este tipo de interacción está ampliamente extendido el uso de la noción de play frame o humorous frame. El concepto de marco o frame, paralelo al de script o schema, como hemos mencionado, proviene de la psicología de Bartlett y Bateson (quien fue el primero en proponer la distinción entre marcos serios y lúdicos) y puede 
tener una doble orientación: en un sentido cognitivo, los frames son esquemas incorporados social y experiencialmente mediante los que organizamos el conocimiento; en un sentido interaccional, tal y como lo entiende Erving Goffman, los marcos son guiones o scripts por los que los participantes son capaces de identificar la situación social en la que se hayan y los pasos a seguir: «the frame can be viewed as interactive event orientated towards a particular goal and centred on rules and expectations but negotiated and co-constructed by interacting parties» (Dynel, 2014: 220). Otra noción cercana es la de keying, acuñada también por Goffman, para designar «a systematic process of frame alteration, bracketed and restricted within time, which participants openly acknowledge» (Dynel, 2014: 221). El marco humorístico, por tanto, sería una forma de keying: es decir, no solo una clase particular de frame, sino una transformación de marcos preexistentes, ya que, como veremos en el capítulo correspondiente [5.3], el discurso humorístico se basa en gran parte en el juego con marcos, scripts y schemas estereotipados de la vida social.

No obstante, como hemos señalado ya, el carácter lúdico de la interacción humorística no excluye que tenga implicaciones "serias". Desde muy pronto, los sociólogos han reconocido la importancia que el humor y la risa tiene en las relaciones sociales inter e intragrupales:

Laughter can reveal group allegiances, communicate attitudes, and help in establishing and reaffirming dominance in a status hierarchy (...) Its effects must inevitably be mediated by the perceived values, motives, and intentions of the initiator, and in turn the effects on the initiator must depend to some extent on the perceived reactions of the recipients (Chapman, 1983: 135)

Por supuesto, como también han señalado los lingüistas y los teóricos literarios, para que la interacción humorística pueda producirse de manera exitosa es necesario que los participantes compartan ciertos conocimientos, creencias, valores, etc. En este sentido es un lugar común muy extendido el que el humor sirve para fomentar la cohesión grupal, o al menos es uno de sus síntomas. Ahora bien, las investigaciones sociológicas también han comprobado que, teniendo en cuenta que las interacciones sociales están determinadas por las identidades sociales y los roles de cada situación, y que estas identidades, roles e interacciones están atravesadas por relaciones de poder (Palmer, 1994: 165), la posibilidad de realizar acciones humorísticas depende no solo de la 
situación social, sino también de la posición que se ocupe en la jerarquía de dicha situación, por ejemplo en el lugar de trabajo (Holmes, 2000).

También son numerosas las investigaciones sobre la función de la comunicación humorística en la construcción social de la identidad de género (Hay, 2000; Crawford, 2003; Holmes, 2006; Kotthoff, 2006; Micke et al., 2011). Giselinde Kuipers, por ejemplo, encuentra una clara diferenciación por género en la población holandesa en cuanto a la costumbre de contar chistes: los hombres suelen contar más chistes, sobre todo en presencia de otros hombres; y si hay mujeres presentes, rebajan el tono obsceno (Kuipers, 2006: 44). Las distintas preferencias humorísticas también dan cuenta de los diferentes estilos comunicativos de hombres y mujeres: las mujeres interactúan más y de un modo más afectivo con sus interlocutores, por lo que prefieren el humor espontáneo, conversacional y personal, mientras que los hombres son más agresivos a la hora de monopolizar la conversación, por lo que prefieren los chistes al ser estos «relatively impersonal, uncooperative, disruptive and competitive» (Kuipers, 2006: 60).

Lo que se hace evidente es que el humor funciona como herramienta social comunicativa y, como tal, puede servir a muy distintos fines (Fine, 1983: 160). Los sociólogos han delineado tres categorías generales para las funciones sociales del humor: promover o señalar la cohesión grupal (el que un grupo pueda realizar intercambios humorísticos sin miedo de fracasar es prueba de sintonía social); provocar conflictos intergrupales («[humor] serves to separate a group from an undesirable, deviant out-group and maybe even provoke hostiliy by that group») y como control intragrupal (obligando a aceptar las normas del grupo y castigando mediante la burla las desviaciones de dichas normas) (Fine, 1983: 174).

\subsubsection{El sentido del humor y las jerarquías sociales del gusto}

Al decir que una de las funciones principalmente reconocidas del humor es la de la cohesión grupal, hablar de afinidades ideológicas, morales, de costumbres, etc., es solo una parte de la historia. La apreciación de un chiste es, fundamentalmente, una cuestión de gusto, y este, entendido desde la teoría de Pierre Bourdieu, es una herramienta muy importante en la delimitación de fronteras sociales de clase, raza, género, nivel educativo, etc. (Kuipers, 2006: 6-13). A lo largo de nuestra resención histórica, hemos podido comprobar cómo las definiciones, clasificaciones y delimitaciones de la risa y los fenómenos humorísticos se basaban en apreciaciones morales que eran, en última 
instancia, apreciaciones sociales (los que se ríen desmedidamente siempre han sido los otros: los extranjeros, los no cristianos, los herejes, los locos, los esclavos, los campesinos, etc.). En nuestra sociedad actual está aún más presente la idea de un «sentido del humor» que es parte fundamental de quienes somos:

The definitions of good and bad humor are connected with more general ideas about creativity and sociability. And these themselves are again connected with (...) an important theme: authenticity (...) "Being yourself" has become a central theme and mission for everyone. You have to "express yourself", through style, taste, as well as everyday behaviour (...) Humor had to do with "being yourself” and "revealing yourself" (...) Humor is always a presentation of the self. People use humor to create, save or maintain an image of themselves (Kuipers, 2006: 116)

Por supuesto, quiénes somos viene dado en gran parte por nuestra identidad social. Giselinde Kuipers estudia en su libro ${ }^{66}$, mediante encuestas y entrevistas, las diferencias sociales según divisiones fundamentalmente de nivel educativo respecto a la concepción del humor, sus características, sus funciones sociales, etc. Kuipers encuentra dos visiones casi contrapuestas entre la población de bajo nivel educativo y la de un nivel educativo mayor al universitario. Las pprimeras ven el humor, fundamentalmente, como un evento social (Kuipers, 2006: 40), y su concepción del fenómeno está guiado por criterios de sociabilidad: el humor es, ante todo, una herramienta para crear un ambiente agradable en las reuniones sociales y estrechar lazos afectivos, etc. (Kuipers, 2006: 81-82). Así, por ejemplo, evalúan a los humoristas televisivos en términos personales, les valoran según la proyección de simpatía o antipatía que les atribuyan y aprecian sobre todo que sean espontáneos y “auténticos”; también tienen una percepción más “realista” del humor, es decir, creen que el humor, al ser algo cercano y sociable, refleja o debería reflejar la realidad cotidiana (Kuipers, 2006: 89). Por otra parte, rechazan el humor que consideran ofensivo o hiriente (Kuipers, 2006: 81); la vulgaridad en el humor significa, para ellos, indecencia o falta de educación (Kuipers, 2006: 105).

Mientras que las personas de poca educación prefieren el humor de los chistes, las personas con educación superior, por lo general ${ }^{67}$, los consideran vulgares, simples,

\footnotetext{
66 Para otras investigaciones que amplían el marco teórico y el ámbito de aplicación, ver Friedman \& Kuipers, 2013; Kuipers, 2006b

${ }^{67}$ Incluso entre las consideradas clases altas se puede observar ciertas distinciones: en algunas profesiones fuertemente masculinizadas, como el mundo de los negocios, también se valoran positivamente los chistes como herramienta de interacción social: «jokes seem to be esteemed in the culture of the fraternities and in their extensions into, for instance, the financial and medical worlds (...) In sectors in which economic
} 
predecibles, etc. (Kuipers, 2006: 48). La población con cierto nivel cultural concibe el humor en términos artísticos y lo evalúa desde lo que Bourdieu llama una «disposición estética», «characterized by a distant way of viewing beauty and pleasure: not the directly accessible pleasure of something that is at the first glance attractive, beautiful or pleasant, but a pleasure at a greater remove, derived from things you "acquire a taste for" " (Kuipers, 2006: 79). Tienen un sentido del humor más “elaborado”, reflexivo y consciente que describen en términos artísticos y literarios (Kuipers, 2006: 84-85); prefieren un humor incluso complicado, que les sorprenda, y buscan en él algo más que el simple entretenimiento: un reto intelectual, una cierta reflexión... (Kuipers, 2006: 86). Por tanto, no conciben el humor como un evento social, sino como un estímulo intelectual individualizado, cercano a la experiencia estética de la obra de arte: «something that to be sure is shared with others, but in the first instance originates from the most highly individual creativity of the joke maker» (Kuipers, 2006: 113). Por ejemplo, no rechazan el humor porque sea ofensivo, sino porque lo sea de manera demasiado obvia: «coarseness has to do with lack of intellect and refinement» (Kuipers, 2006: 101).

De las investigaciones de Kuipers se pueden extraer varias conclusiones. En primer lugar, el humor depende del gusto, que es un fenómeno en el que se explicita los vínculos esenciales entre lo estético y lo social - nos permite pensar en el humor a la vez en términos estéticos, artísticos, y sociales o culturales. Y, sobre todo, y esta es una de las premisas básicas de este trabajo, no se puede hablar de lo que el humor, en singular, es en esencia, y la función que cumple, sino que la apreciación del humor y, de hecho, también su misma constitución, está determinado por las concepciones que los diferentes individuos y grupos sociales tienen de él, concepciones que en última instancia dependen de criterios ideológicos, sociales y morales.

\subsubsection{Humor y conflicto}

Si el humor tiene una presencia tan importante en las relaciones sociales interpersonales e intergrupales, y es un fenómeno que afecta y es afectado por aspectos tan importantes como la identidad social o las jerarquías del gusto, es obvio que un campo de estudio principal debería ser el del humor conflictivo. Pero lo cierto es que es en este aspecto en

capital has prominence, jokes are more popular than in sector where cultural capital is of prime importance» (Kuipers, 2006: 53) 
el que encontramos el mayor punto ciego de la mayoría de las investigaciones sociológicas.

En términos generales, las investigaciones en pragmática, análisis de la conversación y sociología se centran en una conceptualización del humor fallido («failed humor») como un error interpretativo: el humor fracasa porque el receptor del enunciado humorístico no es capaz de reconocer el modo humorístico, o no es capaz de "pillar el chiste” por falta de información (ver, por ejemplo, Bell, 2015). Por otro lado, hemos visto que se concibe la posibilidad de que el humor se use de manera agresiva contra otro grupo social mediante el sarcasmo, la sátira, la burla, etc., pero de esta manera se reducen los casos en los que el humor resulta conflictivo a aquellos en que es intencionada $y$ explícitamente ofensivo.

Estos enfoques presentan varios problemas conceptuales. En primer lugar, se concibe el humor y la comunicación en general según el modelo de transmitir información, por lo que el humor "fallido" se explica según errores de codificación o descodificación (recordemos el análisis de Hutcheon de la polémica exposición canadiense en términos de una ironía insuficientemente marcada). En segundo lugar, y en relación con lo anterior, se reduce lo potencialmente ofensivo del humor a un problema de intencionalidad. De este modo, por ejemplo, a la hora de abordar los chistes sexistas o racistas (llamados, eufemísticamente, «étnicos»), se reduce la conflictividad de estos a que, probablemente, las personas que los cuenten se fijen simplemente en la ingeniosa técnica del chiste y no busquen intencionadamente ofender a las mujeres o personas racializadas.

El problema común a estos enfoques es que, en la mayoría de los casos, las investigaciones de este tipo acerca de las funciones y consecuencias del humor en las relaciones sociales no llegan a relacionar forma y función, es decir, no se plantean qué hay en la técnica del chiste que le permite llevar a cabo funciones tan diversas (¿qué hay en un chiste que pueda a la vez servir para estrechar lazos y agredir?) (excepciones importantes son, por ejemplo, Mulkay 1988 y Palmer 1993). Y, cuando lo hacen, se limitan a una concepción muy pobre de la noción de incongruencia. Como argumentaremos más adelante [5.5], la frivolización juega un papel muy importante en la recepción del humor. 
Lo cierto es que en las interacciones reales las negociaciones acerca del humor conflictivo son más complejas de lo que estos modelos proponen, como lo prueba Elise Kramer respecto a los debates en internet acerca de los chistes sobre violaciones (Kramer, 2011) o la polémica ocasionada por Berlusconi que comenta Michael Billig (2005: 177178): en el año de 2003, en una alocución del por entonces jefe de gobierno italiano en el Parlamento Europeo, hizo un comentario jocoso relacionando a Martin Schultz con los nazis («Mr. Schultz, I know there is a producer in Italy who is making a film on Nazi concentration camps. I will suggest you for the role of commandant. You'd be perfect»). Ante la indignación del resto de parlamentarios, Berlusconi se defendió diciendo que solo estaba bromeando siendo irónico, lo que causó mayor indignación. Como vemos, en este caso el problema no fue no identificar el tono humorístico de Berlusconi, como prueba el hecho de que, aunque el político italiano recurriera a la común estrategia de desligarse de lo dicho aduciendo que estaba siendo irónico. Desde el primer momento, los parlamentarios sabían que Berlusconi está bromeando, y de alguna manera, el hecho de que el insulto estuviera formulado como una broma provocó que lo percibieran como más ofensivo que si hubiera sido un insulto explícito. Como en el caso de la exposición comentada por Hutcheon, lo problemático no es solo el contenido del enunciado, sino también el propio uso de la ironía para tratar un contenido como el racismo colonial o el nazismo. Intentar establecer un modelo de análisis que pueda dar cuenta de todos estos aspectos será nuestro objetivo en el capítulo correspondiente.

\subsection{Apocalípticos e integrados frente a la sociedad humorística}

\subsubsection{Los mitos humorísticos en el pensamiento actual}

¿A qué se debe esta aparente ausencia en las investigaciones sociológicas, su incapacidad para explicar los conflictos derivados de las interacciones humorísticas? Como señala Michael Billig en su libro Laughter and Ridicule, en el que critica las corrientes mayoritarias en la investigación sobre el humor, el problema de parte de la psicología y la sociología que se encarga del fenómeno es que han incorporado de manera acrítica en sus premisas, hipótesis, y diseño de experimentos las asunciones del "sentido común” acerca del humor (Billig, 2005: 10): si la psicología se centra en los supuestos efectos beneficiosos del humor para la salud física y mental, obviando o negando los casos 
conflictivos o perniciosos, es porque ha asumido una creencia profundamente ideológica en el humor como algo intrínsecamente positivo.

Como hemos afirmado a lo largo de este trabajo, no es adecuado hablar de una naturaleza intrínseca y esencial del humor, su estructura, sus funciones y efectos, y menos aún de su bondad o maldad generalizadas. Como señala Billig, el humor es ante todo un fenómeno retórico, una herramienta comunicativa que como tal no es intrínsecamente positiva o negativa, subversiva o reaccionaria, sino que estos aspectos dependen del uso que se le dé, así como de la recepción y su contexto. Podemos ir más allá y afirmar que no solo la recepción de los discursos humorísticos, sino que la producción misma y su estructura están determinadas por lo que los individuos piensan que es el humor y para qué sirve.

La posición que mantenemos en este trabajo es que el humor no es un fenómeno unitario, sino que está conformado por muy distintas tradiciones humorísticas (la comedia, lo carnavalesco, la sátira, el chiste, etc.) que implican unas ciertas convenciones formales y también unas ciertas convenciones de lectura que determinan y son determinadas por una serie de efectos ideológicos. Así, podemos encontrar una tradición humorística determinada por la creencia en el humor como liberación momentánea de los aspectos terribles y angustiosos de la vida cotidiana, que comparten tanto los productores que elaborarán su discurso humorístico según las convenciones genéricas de esa tradición como los receptores que interpretarán dicho discurso pensando en los efectos liberadores que el humor produce. No se trata de negar que existan discursos humorísticos que estén orientados a la liberación de las angustias cotidianas o existenciales, a la suspensión temporal de las preocupaciones al poner estas en perspectiva, etc., y que puedan tener dichos efectos; simplemente queremos señalar que esto no se debe a lo que el humor es intrínsecamente y en toda circunstancia, sino a la pertenencia de dicho discurso a dicha tradición (o comunidad interpretativa, u horizonte de expectativas o cualquier otra noción lingüística o hermenéutica similar).

El esquemático repaso a las reflexiones teóricas sobre el humor, la comedia, la ironía, etc., en los campos de la teoría literaria, la filosofía y las ciencias sociales nos permite vislumbrar dos importantes posiciones que, por su relevancia y omnipresencia en el discurso contemporáneo sobre el humor, nos inclinamos a llamar mitos humorísticos. De nuevo, al usar el término «mito» no queremos desechar estas posiciones como simplemente falsas, sino indicar su funcionamiento como axiomas que determinan gran 
parte de los discursos humorísticos y su interpretación - y ciertamente, de paso, dejan en la sombra algunos aspectos que quedan sin explicar. Ambos comparten una valoración fundamentalmente positiva del humor y explican la importante posición que este ocupa en la cultura contemporánea, tanto en el ámbito cotidiano y el cultural como el académico o político.

El primero de estos mitos, que podríamos llamar, muy provisionalmente, popular, se basa en una supuesta inocuidad del humor: el discurso humorístico es un modo noserio, lúdico, de comunicación y actividad, sin mayor intención que la de promover ambientes agradables, el entretenimiento de los interlocutores, estrechar lazos afectivos, etc. (en suma, “pasar un buen rato”), y que por tanto solo puede tener efectos beneficiosos y, sobre todo, no es capaz de hacer daño. Como veremos, la mayor parte de las ciencias sociales comparten este paradigma, así como las clases “populares”, si bien, como demuestran las investigaciones de Giselinde Kuipers [3.3.2.2] y veremos en el capítulo correspondiente [8.1], la concepción popular del humor tiene casi siempre presente que el humor puede ser ofensivo (el qué se considere ofensivo en estos casos es otra cuestión, no exenta de interés, como veremos [8.1, 8.2.1, 8.3]).

El segundo mito, que queremos llamar equivocadamente intelectual, confía en el discurso humorístico, del que la ironía es la forma más acabada, como el perfecto instrumento de la crítica ideológica y la vía más adecuada para alcanzar verdades objetivas. La autoconciencia y autorreflexividad del discurso irónico (aspecto que, como hemos visto [3.2.3], comparten las teorizaciones Kenneth Burke, Wayne Booth, Paul De Man, etc.; y que en última instancia remite al conde de Shaftesbury y Friedrich Schlegel [2.3.3, 2.4.1]) garantiza, al establecer una distancia respecto a las distintas posiciones ideológicas, una objetividad que permite desembarazarse de los distintos prejuicios, disfraces ideológicos e implicaciones emocionales (puesto que, en este paradigma, el discurso humorístico es epítome de discurso racional ${ }^{68}$ ) y por tanto alcanzar una verdad aparentemente segura. Dentro de este paradigma encontramos también un ethos particular del humorista como sabio que en última instancia tiene su origen en las figuras casi legendarias del bufón de la corte o el loco que es capaz de ver la verdad porque no está sometido a los engaños de la gente supuestamente cuerda. Por otro lado, otra vertiente de

\footnotetext{
${ }^{68}$ Es sin duda significativo que, si en la época medieval la risa se condenaba por ser un fenómeno puramente carnal y pasional, la revalorización moderna del humor sea invirtiendo esta definición y concibiendo el humor como algo puramente racional y espiritual. En ambas posturas lo que se desprecia es el cuerpo y las emociones a favor de una pretendida objetividad racional.
} 
este mito es la de lo cómico-carnavalesco como crítica y liberación de un orden social anquilosado, del triunfo de la vida y de lo nuevo frente a la sociedad vieja o muerta. En ambos casos, predomina una visión del humor como potente instrumento de crítica ideológica y política y vehículo de cambio social.

En ambos axiomas, en resumen, encontramos la idea básica del discurso humorístico como algo que está por debajo o por encima del discurso serio, y que por tanto no puede tener consecuencias negativas: o bien el humor no es serio, y por tanto no puede ser ofensivo o conflictivo; o bien el humor está por encima de los prejuicios emocionales del ámbito de lo serio, que está ideológicamente distorsionado. Es esta distancia respecto de lo serio, aclamada por los «integrados» (en los términos de Umberto Eco (2013)) de uno u otro signo frente a la omnipresencia ya señalada del humor en todos los ámbitos de la sociedad actual, la que precisamente condenan los «apocalípticos», que denuncian este impulso humorístico como frivolidad, alienación, falta de compromiso, etc. Esta posición apocalíptica, que es al final una posición respecto de la sociedad actual (concebida, como veremos a continuación [3.4.3], como sociedad de masas, o sociedad postmoderna, o sociedad del espectáculo, o cultura del simulacro), también determinará, como tendremos ocasión de comprobar [6.1], muchas interpretaciones en contra de los discursos humorísticos.

\subsubsection{La «ideología positiva» en las ciencias del humor}

Como adelántabamos, Michael Billig critica la asunción por parte de las ciencias sociales y de la psicología en particular de una visión intrínsecamente positiva del humor: en el paradigma que denomina «psicología positiva», el humor es un fenómeno que es natural $e$ intrínsecamente beneficioso para la salud física y mental. Según Billig, el lenguaje conceptual de esta psicología está construido en torno a lo positivo y lo negativo, sin que estos calificativos estén realmente definidos: se asume que lo positivo son las emociones que nos hacen sentir bien, mientras que lo negativo es aquello que nos hace sentir mal; al mismo tiempo, la utilización de estos términos evita la dimensión moral de lo «bueno» y lo «malo»: «a 'negative emotion' seems to denote something more objective tan a 'bad' or 'evil' emotion. Its negativity doesn't depend on the moral preferences of the observer (...) The positivity and negativity of emotions are just as objectivively founded as the positivity and negativity of electrical currents» (Billig, 2005: 20). 
De este modo, el humor se presenta como algo "naturalmente" positivo tras una comprobación supuestamente científica, sin ningún tipo de valoración moral que enturbie los resultados. Pero, para Billig, que esta postura es ideológica se comprueba en el momento en que son muchos más abundantes los estudios que confirman los beneficios del humor que los que se centran en sus aspectos negativos ${ }^{69}$ (Billig, 2005: 23). El argumento de Billig es que este énfasis en los beneficios del humor oculta lo que este tiene de control social y agresión. Para ello, los investigadores distinguen entre un «buen» humor y un humor «malo», el ofensivo (Billig, 2005: 22). Para estos psicológicos, el humor "pesimista", expresado en el sarcasmo o la ironía, no es verdaderamente "humorístico" porque los sentimientos que provoca y/o expresa no son los considerados positivos por ellos: «the dark cloud is dispelled by asserting that positive and negative humour are totally different phenomena and that they produce very different effects. Ridicule cannot bring positive benefits because it is not proper humour, however much enjoyment ridicule brings to those who practise it» (Billig, 2005: 23) ${ }^{70}$.

Es decir, estos investigadores distinguen entre dos clases de humor como si fueran fenómenos esencialmente distintos, en lugar de investigar qué hay en el humor en general que pueda servir a dos fines aparentemente opuestos. Ciertamente, el que las investigaciones, sobre todo en lingüística y psicología cognitiva, se hayan apoyado casi exclusivamente en la noción de incongruencia señala una propensión a eliminar los aspectos del humor que parecen ser más afectivos que cognitivos - $\mathrm{y}$, cuando reconocen alguna dimensión afectiva en la recepción del humor, explican el placer humorístico como un placer "intelectual” ante el ingenio sorprendente de la técnica del chiste. En este sentido también es significativo que estas investigaciones se centren en el análisis del chiste $^{71}$, que toman como forma prototípica del discurso humorístico, cuando probablemente sea actualmente la más minoritaria.

\footnotetext{
${ }^{69}$ Lo cierto es que sí existen, y cada vez más, estudios psicológicos sobre los efectos negativos de cierto tipo de humor. Por ejemplo, existen estudios que muestran una correlación entre la "exposición” a chistes sexistas y étnicos y la falta de sensibilidad hacia problemas derivados del machismo y el racismo, como la violencia sexual (Ferguson y Ford, 2008; Ford, 2000, 2015; Sriwattanakomen, 2017; Thomae y Tendayi Viki, 2013; Woodzicka y Ford, 2010).

${ }^{70}$ La propuesta de Billig es recuperar el ridículo como un elemento fundamental de la risa y el humor, asociado a la vergüenza como herramiento de control social (de manera parecida a como Bergson lo trata). Aunque estemos de acuerdo con esta hipótesis en lo básico, su limitación es que no es capaz de dar cuenta del ridículo como un elemento no intencional, es decir, cuando en el discurso humorístico no hay una intención explícita de humillar a alguien en concreto.

${ }^{71}$ Que no solo tiene una estructura discursiva regular, sino que conlleva una serie de asunciones que ayudan a disimular sus implicaciones ideológicas: es popular, anónimo, descontextualizado, sin ningún propósito más allá de hacer reír...
} 
Para Billig, esta psicología positiva del humor tiene que ver con un paradigma ideológico más amplio, el neoliberal, «in which the 'positives' of life ar to be stressed» (Billig, 2005: 10). En el paradigma neoliberal la sociedad se concibe como un lugar en el que el individuo puede desarrollarse social, económica y espiritualmente, por lo que le es dado vivir experiencias positivas: «it is as if the positive outer world has been successfully established, and now all that is required is for the inner world to be aligned with the positive conditions of social reality» (Billig, 2005: 30) ${ }^{72}$. En este contexto, se responsabiliza al individuo de su propio malestar (Billig, 2005: 30), por lo que un "buen humor” es un síntoma, además de de pujanza económica, de bienestar psicológico; hoy en día es un imperativo casi moral tener "sentido del humor”: «if a person is said not to possess a sense of humour, this means more than thaty they might be boring company: it suggests that they lack a vitual human quality» ${ }^{73}$ (Billig, 2005: 11). También Zupančič señala cierto clima ideológico en el que una falta de sentido del humor es visto como un error moral o incluso biológico (Zupančič, 2008: 4-6). Como veremos [8.2.1, 8.3], la acusación de no tener sentido del humor es una estrategia común en ciertos discursos ideológicos para caracterizar al «ellos» como adversario frente al «nosotros».

Un ejemplo muy significativo de esta tendencia ideológica es el célebre libro, muy citado, de John Morreall, Taking humor seriously (1983), y su continuación Comic Relief (2009). El principio común de ambos es que el humor es algo beneficioso y casi imprescindible, tanto a nivel individual como social; el humor según Morreal es un fenómeno cognitivo que nos permite distanciarnos de las preocupaciones de la vida cotidiana, lo que nos hace sentirnos bien y también nos otorga una cierta perspectiva sobre las cosas.

Según su teoría, la risa es un proceso psico-fisiológico que conlleva un cambio psicológico «from a serious state of perceiving and thinking (...) to a nonserious state of being amused by some incongruity»; este cambio cognitivo debe pillarnos por sorpresa y ha de ser agradable (Morreall, 1983: 40). En principio, la descripción de Morreall parece acertada, puesto que resultaría obvio que la risa o el discurso humorístico son placenteros, y son provocados por una ruptura de las expectativas. Pero, aunque la descripción nada

\footnotetext{
${ }^{72}$ En este sentido, en el capítulo 7.1 expondremos cómo la comedia de situación, y Friends en particular, se ha descrito como un puntal de esta ideología del «feel good».

${ }^{73}$ De ahí que cualquier académico que quiera escribir sobre humor tenga que justificarse por hablar "seriamente" sobre un tema así y demostrar que está legitimado porque también tiene "sentido del humor" (Billig, 2005: )
} 
dice de que este placer pueda ser obtenido mediante el ridículo o la agresión que Billig u otros como Konrad Lorenz (Morreall, 1983: 4) encuentran en lo cómico, Morreall rechaza explícitamente que este elemento afectivo sea consustancial al humor: el placer cómico es ante todo intelectual, de ahí que lo considere como una experiencia estética:

Our amusement at humor is a kind of aesthetic experience, I suggest, when it is the enjoyment of incongruity for its own sake, the enjoyment of a conceptual shift by itself (...) The enjoyment of an emotional shift is neither necessary nor sufficient for humor (...) Much humor occurs without it, and where an emotional shift is enjoyed by itself, we have not humorous laughter ${ }^{74}$, but the laugh of derision, perhaps, or the laugh of selfglory (...) Where the conceptual shif in humor is accompanied by an emotional shift, then we are not enjoying the incongruous object of our amusement in an aesthetic way, because we are not enjoying it for its own sake alone (Morreall, 1983: 93)

Como vemos, Morreall repite el consabido gesto de distinguir entre una forma genuina de humor y una forma "corrompida”, y de hecho asigna esta risa de la burla ofensiva como algo propio de niños y pueblos "primitivos"75: «our objections to cruel laughter are not, even today, part of all cultures» (1983: 9); y también de las clases populares que disfrutan del humor "de masas":

The worst manifestation of our taste for this kind of laughter is probably the pitifully childish "situation comedies" that have glutted our television schedules for the past decade or so, many of which have almost no plot but consist simply of a group of family members or friends trading obvious and stupid insults (Morreall, 1983: 10; el destacado es nuestro)

El sentido del humor, por tanto, es una característica deseable en cualquier persona: «studies with both children and adults have shown the connection of laughter with the person’s sense of security and control» (Morreall, 1983: 54). Así, quien ríe es una persona flexible en su pensamiento, optimista a la hora de enfrentarse a los problemas de la vida, ciertamente más exitosa que el hombre serio: «while the serious person tends to be solemn and anxious about how things are going to turn out, the person with a rich sense of humor tends to be more relaxed, less disappointed by failure, and in general more cheerful»

\footnotetext{
${ }^{74}$ Nótese como Morreall distingue el humor como proceso intelectual de la risa como reacción emocional.

${ }^{75}$ Morreall presenta cierta tendencia a equiparar a los pueblos "primitivos" con la mente infantil. Así, cuando comenta que muchas veces la risa de los niños está motivada por el placer del descubrimiento de algo extraño, menciona también el encuentro de estos pueblos con la tecnología occidental: «here adults are in a position similar to that of our own children in facing new kinds of things» (Morreall, 1983: 44).
} 
(Morreall, 1983: 121). Por contra, el que no disfruta del humor es incluso sospechoso de padecer una enfermedad mental: «people with severe mental problems usually lack a sense of humor, and, we should note, a capacity for aesthetic experience generally» (Morreall, 1983: 106) ${ }^{76}$.

Morreall llega a equiparar la «actitud humorística» con el pensamiento filosófico y de este modo se desliza hacia lo que hemos llamado el mito intelectual del humor ${ }^{77}$ : «The person who looks at his life philosophically does not let his emotions color his view: he is distanced, as we have been saying, from the practical aspects of his situation. And this calmness makes his assessment of his situation more objective, more like that of an unbiased observer» (Morreall, 1983: 105). Esto hace que, en Comic relief, llegue a valorar la comedia por encima de la tragedia a partir del argumento de que, al estar exenta de emociones, nos distancia del aquí y el ahora: «since tragedy fosters an attitud toward life based on negative emotions, and comedy fosters a non-emotional, playful attitude» (Morreall, 2009: 76). Contradiciendo su propio postulado de que la experiencia estética es la que está desprovista de cualquier juicio moral y afectivo, considera que una manera de evaluar la tragedia y la comedia es comparar los valores y emociones que la actitud trágica y la cómica promueven respectivamente (Morreall, 2009: 76):

Tragic heroes are role models for the mental rigidity of emotions. They often face problems with simplistic, standard conceptual schems that divide the world into good and bad, honorable and dishonourable, etc. (...) The world of tragedy is full of problems that would be quickly solved in comedy, with a little imagination. Like tragic heroes, comic protagonists face big problems, but they think rather than feel their way through them. Instead of chaining themselves to a principle or a tradition and dying in the process, they find a new way to look at things, wriggle out of the difficulty, and live to tell the tale (...) However valuable the attitudes fostered by tragedy were in past centuries, they are now largely obsolete, and some of them dangerous to the survival of the species. Comedy fosters a more rational, critical, creative attitude that is more adaptive. It grew out of

\footnotetext{
${ }^{76}$ Como vemos, Morreall aplica una clásica retórica del ellos y nosotros, siendo ellos, los que no saben reír o ríen De Manera inadecuada, los niños, los primitivos, las clases populares y los enfermos mentales, y «nosotros» las personas seguras de sí mismas, equilibradas mentalmente, intelectualmente flexibles, etc. Esto es explícito cuando, al comparar al hombre serio como al hombre que ríe, habla de aquel en tercera persona, y describe al segundo en primera persona del singular (1893: 121-122).

${ }^{77}$ Morreall compara la censura soviética de la literatura humorística con la sana democracia estadounidense, que garantiza la total libertad de expresión y permite la sátira política (Morreall, 1983: 101-102). Parece olvidar la existencia del macartismo, el código Hays y el comics code, que regulaban la producción cinematográfica y las de las historietas, respectivamente, y las leyes contra la obscenidad que llevaron a Lenny Bruce a la cárcel. Realizamos esta mención para mostrar cómo la falta de sentido del humor es una estrategia discursiva muy común para atacar a los rivales ideológicos.
} 
fertility rites and ever since has emphasized the basics in human life - food, sex, and getting along with family, friends and even enemies. Treating life as a series of battles is now a source of harmful stress. The playful, imaginative attitude fostered by comedy not only feels better, but makes us healthier psychologically and physically (Morreall, 79-81; el destacado es nuestro)

Unas páginas antes, Morreall ha criticado las snuff movies (películas caseras distribuidas clandestinamente que muestran escenas reales de asesinatos, torturas, violaciones, etc.) por promover el sadismo y la violencia, y sin embargo utiliza el ejemplo siguiente para demostrar la superioridad moral e intelectual de la comedia:

In the 1998 Irish comedy Waking Ned Devine, an older man dies of a heart attack on learning that he has won the national lottery. Such an event could easily fit into a tragedy, but here the rest of the village comes up with a scheme to keep Ned's death secret and have another villager impersonate him to claim the huge jackpot. If the ruse works, everyone will split the winnings. As the government agent comes to the village to arrange payment of the prize, Lizzie Quinn, an irritable, unsociable woman, threatens to reveal the plan unless she gets half the money. The other villagers refuse to give her more than anyone else will get. On her way to make the phone call that will put the whole village in prison, Lizzie's wheelchair accidentally rolls over a cliff into the ocean. Despite her disability and awful death, theatre audiences cheer, because she was thinking only of herself (Morreall, 2009: 82)

Es significativo que Morreall critique el sadismo de las snuff movies, o adjudique a niños y pueblos primitivos una risa cruel y violenta que no ha de confundirse con el humor "verdadero", y sin embargo no vea nada problemático en una comedia que celebra la muerte de una anciana con discapacidad. Es evidente que, más allá de celebraciones o condenas morales absolutas, un modelo de análisis de los discursos humorísticos tiene que hacerse cargo del componente cruel o, cuanto menos, insensible, que existe en el humor si quiere explicar la conflictividad a que puede dar lugar, como trataremos de argumentar en el siguiente capítulo [4.3.3; 5.4].

\subsubsection{La sociedad humorística}

A lo largo de nuestro recorrido histórico hemos podido comprobar cómo la risa y lo cómico han estado íntimamente ligados a las formas culturales populares o las artes consideradas menores: la comedia, el mimo, la farsa, los carnavales, las caricaturas, las 
artes ornamentales, las tiras de prensa y, en la cultura del siglo XX, el cine, la animación, las comedias televisivas... Las transformaciones de lo cómico, en suma, han estado determinadas por las transformaciones de la cultura popular en general: así, como vimos [2.1], el nacimiento de la caricatura y la sátira modernas tiene que ver con las transformaciones sociales y culturales ligadas a la desaparición de la fiesta popular por la pérdida de autonomía de las ciudades y la aparición de la prensa y otros medios de difusión. En este sentido, es obvio que para analizar el lugar de lo humorístico en la cultura contemporánea es necesario situarlo en el contexto de lo que se ha dado en llamar la sociedad postindustrial, del capitalismo tardío o simplemente postmoderna (Jameson, 2016), o sociedad del espectáculo (Debord, 2015), sociedad de consumo (Baudrillard, 2009), o cultura del simulacro (Baudrillard, 1978) o de masas (Eco, 2013) - en última instancia, estas descripciones apocalípticas de la sociedad y la cultura contemporáneas derivan de las críticas de la Escuela de Frankfurt (Benjamin, 2020; Horkheimer y Adorno, 2016; Marcuse, 2016).

Más allá de las estructuras socioeconómicas que condicionen estas transformaciones, el rasgo característico de la cultura contemporánea es la aparición o crecimiento de la industria cultural y los medios de difusión de masas, así como la transformación de una cultura genuinamente popular, creada y difundida por sus propias clases populares, en una cultura heterodirigida en la que estas clases (y toda la sociedad en general, pues los productos de la mal llamada «alta cultura» también se producen y difunden por los mismos medios) ocupan el papel de meros consumidores (Eco, 2013: 47); algo que los críticos marxistas consideran como una nueva forma de alienación de las clases populares, no mediante el trabajo, sino el ocio ${ }^{78}$.

Estas descripciones de la cultura contemporánea coinciden en señalar la omnipresencia del humor, lo cómico y lo lúdico, vaciados, como veremos, de sus sentidos carnavalescos o satíricos; vaciados, en general, de todo sentido. Baudrillard, por ejemplo, considera la proliferación de aparatos («gadgets») como una conversión del instrumento, provisto de funcionalidad real o simbólica, en una mera práctica lúdica: «Lo lúdico (...) consiste en un juego con las combinaciones, en una modulación combinatoria, en un juego sobre las variantes o las posibilidades técnicas del objeto, juego con las reglas del juego en la innovación»; lo lúdico, según Baudrillard, es una curiosidad sin fundamento ni fin

\footnotetext{
${ }^{78}$ En el apartado 7.1 analizaremos las consecuencias de estos hechos para la producción y significados sociales d ela comedia televisiva como discurso humorístico de masas.
} 
que es lo contrario de la pasión: «es el alma misma del juego/pasión pero generalizada y difusa y, por eso mismo, menos conmovedora, vaciada de lo patético y devuelta a la curiosidad - algo intermedio entre la indiferencia y la fascinación y que se definiría por oposición a la pasión» (Baudrillard, 2009: 133; destacado del autor). Y, en relación con lo dicho anteriormente acerca de la psicología positiva y el mandato biológico-moral del buen humor, Baudrillard también habla de un «mandato de goce»:

El hombre consumidor se considera obligado a gozar, como una empresa de goce y satisfacción (...) que es el equivalente, en la nueva ética, de la obligación tradicional de trabajar y producir. El hombre moderno pasa cada vez menos parte de su vida en la producción del trabajo y cada vez más en la producción e innovación continua de sus propias necesidades y de su bienestar (1978: 83; destacado del autor)

La crítica más explícita a la omnipresencia de lo humorístico en la cultura contemporánea es la que realiza Gilles Lipovetsky a lo que él llama, precisamente, «sociedad humorística». Según el sociólogo y filósofo francés, tras la risa carnavalesca medieval y el humor satírico del siglo XIX, el humor pop no es revitalizador ni sarcástico sino lúdico, «no se burla, no critica, afanándose únicamente en prodigar una atmósfera eufórica de buen humor y de felicidad sin más» (Lipovetsky, 2006: 140). El humor contemporáneo «de masas» se muestra insustancial, carente de sentido, y Lipovestky lo describe en términos de «banalización», «desubstancialización», «exceso lúdico de los signos», y como colaborador en la atmósfera general del imperativo del goce: «el humorista de masas es excitante, tonificante y psicodélico, reclama un registro expresivo, cálido y cordial» (2006: 140). Tras la intención satírica que mueve al humor de los siglos XVIII y XIX, asistimos, por tanto, a un «saneamiento» y «pacificación» de lo cómico (Lipovestky, 2006: 142) que, lejos del sentido cósmico y comunitario que suponía el carnaval, es «un efecto típicamente narcisista, hiper-individualizado, espectacular, que da lugar a una sobrepuja de máscaras, de oropeles, de disfraces, de atavíos heteróclitos» (2006: 143). La pujanza del humorismo, pues, tiene que ver con la extrema individualización de la sociedad de consumo, con un «nuevo tipo de individualidad que aspira al placer y a la expansión, alérgica a la solemnidad del sentido» (Lipovestky, 2006: 157). La supuesta desaparición de las divisiones jerárquicas del gusto cultural según la clase social es un espejismo que «se debe menos a la obra de la ideología igualitaria que al auge de la 
sociedad de consumo, que extiende las pasiones individualistas, induce un deseo de masa de ser libre» (Lipovetsky, 2006: 157) ${ }^{79}$ :

El humor desempeña esa doble función democrática: permite al individuo liberarse, aunque sólo sea puntualmente, de la fuerza del destino, de las evidencias, de las convenciones, afirmar con ligereza su libertad de espíritu; simultáneamente impide al ego tomarse en serio, forjarse una imagen «superior» o altiva, manifestarse sin dominio de sí, impulsiva o brutalmente (...) Por el humor el individuo disciplinario presenta una liberación, una desenvoltura, al menos aparente, inaugurando a ese nivel una emancipación de la esfera subjetiva que no cesa de aumentar (Lipovetsky, 2006: 159)

Pero, como decimos, la crítica a la cultura contemporánea no se limita a la cultura popular. Como señalamos en su momento, la obra de Linda Hutcheon es una defensa de la parodia contemporánea de las críticas vertidas, entre otros, por Fredric Jameson en su artículo de 1984 «Postmodernism, or the cultural logic of late capitalism». En él, Jameson habla de la cultura postmoderna en términos análogos a los de Lipovetsky y en general todos los autores de citados, es decir, como banalización, espectacularización, consumismo pasivo, vaciamiento del significado... De hecho, señala el vínculo del arte y la «alta cultura» con la «baja» cultura en dos sentidos: por un lado, en el interés del arte postmoderno por las formas de la cultura de masas, el kitsch, las series televisivas, el cine de serie B, la «paraliteratura» (la ciencia ficción, el terror gótico, la novela negra, etc.): los autores postmodernos «ya no se limitan a «citar» estos materiales, como hubieran hecho un Joyce o un Mahler, sino que los incorporan a su propia sustancia» (Jameson, 2016: 25); por otro, la cultura en su totalidad se ha integrado en la lógica del mercado y la innovación vanguardista en la de la producción de mercancías, perdiendo así su filo crítico, provocador, escandaloso, etc. (Jameson, 2016: 27).

Jameson centra su crítica en el hecho de que la cultura contemporánea, con su poética del reciclaje nostálgico de formas artísticas del pasado y de la cultura popular, expulsa el sentido histórico, y por tanto político, del arte y la sociedad, convirtiendo todo lenguaje cultural en imagen, superficie, simulacro (2016: 28). Si la cultura moderna se puede entender bajo el modelo hermenéutico, en tanto que la obra es la clave o el síntoma de una verdad interior y profunda, el arte pop de Warhol, por ejemplo, es fetichista y descontextualizador, representa «la aparición de un nuevo tipo de ausencia de

\footnotetext{
${ }^{79}$ Respecto al cambio de la estructura social del gusto en la cultura contemporánea, se puede consultar Friedman y Kuipers, 2013 y Kuipers, 2006.
} 
profundidad, un nuevo tipo de superficialidad en el sentido más literal, quizás el supremo rasgo formal de todas las postmodernidades» (Jameson, 2016: 28-31).

Jameson relaciona el arte postmoderno con la crítica postestructuralista al modelo hermenéutico y su preferencia por el juego (inter)textual (Jameson, 2016: 34). En este sentido, la práctica más representativa de la cultura postmoderna es el pastiche, la repetición impersonal de formas y estilos desprovistos de la intención crítica de la parodia (y es a esta noción a la que Hutcheon opone su propia teoría) (Jameson, 2016: 36):

El pastiche es, como la parodia, la imitación de un estilo peculiar o único, idiosincrásico; es una manera lingüística, hablar un lenguaje muerto; pero es una práctica neutral de esta mímica, no posee las segundas intenciones de la parodia; amputado su impulso satírico, carece de risa y de la convicción de que, junto a la lengua anormal que hemos tomado prestada por el momento, todavía existe una sana normalidad lingüística. El pastiche es, entonces, una parodia vacía, una estatua ciega: es a la parodia lo mismo que esa práctica moderna (tan interesante e históricamente original) de la ironía vacía es respecto a lo que Wayne Booth llama las «ironías estables» del siglo XVIII (Jameson, 2016: 38)

Esta práctica tiene que ver con lo que Jameson llama «ocaso de los afectos»: en el arte postmoderno encontramos un placer «compensatorio, decorativo», una «frivolidad gratuita» (2016: 32): «esta omnipresencia del pastiche no es incompatible con un cierto humor, ni está exenta de pasión: es, como poco, compatible con la adicción, con ese aptetito, único en la historia, que tienen los consumidores de un mundo transformado en meras imágenes de sí mismo» (Jameson, 2016: 39). En este sentido, el crítico norteamericano habla de una cierta «euforia de las superficies»: lo que debería ser terrorífico (y de hecho lo fue en las grandes obras de la modernidad artística) como la desaparición del sujeto y la figura humana, el vaciamiento de todo significado, etc., se vive en realidad como algo jubiloso compatible con la cultura camp (que será objeto de análisis en el sexto capítulo [6.1], lo que lleva a Jameson a hablar de una «sublimidad camp o histérica» (2016: 52-53).

En la obra de Jameson y la mayor parte de estos autores, por lo tanto, no solo se critica la cultura de consumo como una nueva forma de alienación, sino que también se cuestiona el supuesto potencial subversivo de formas cómicas como el carnaval o la parodia. Ya hemos mencionado en varias ocasiones cómo, a partir sobre todo de la obra de Bajtín, se han valorado estas formas populares o que imitan las fórmulas carnavalescas como expresión de transgresión y subversión de las clases dominadas frente a la cultura 
y jerarquía dominantes, y cómo también se ha cuestionado este potencial subversivo, tanto en las fiestas carnavalescas históricas como sus herederos literarios y artísticos (Stallybrass y White, 1986: 12-14).

Del mismo modo, a lo largo del siglo XX se ha producido una revalorización (hasta el punto, como defendemos aquí, de su mitificación) del humor satírico y político como garante de libertad frente a la tiranía, particularmente fascista y estalinista. Ya hemos mencionado cómo Morreall adjudicaba estos beneficios al humor frente a la represión soviética; también es un tema muy tratado la relación del humor con el nazismo y particularmente el horror del Holocausto. Así, Morreall afirma que el humor durante la persecución de los judíos cumplió tres papeles:

First was its critical function humor focused attention on what was wrong and sparked resistance to it. Second was its cohesive function: it created solidarity in those laughtin together at the oprressors. And third was its coping function: it helped the oppressed get through their suffering without going insane (Morreall, 1983: 119)

Los poderes que Morreall le atribuye al humor en este pasaje parecen ciertamente hiperbólicos, y resulta difícil pensar que sin los chistes contra el nazismo los judíos no se habrían unido frente a los nazis, y si llegaron a ser un consuelo real frente a los campos de concentración. En cualquier caso, Morreall también entiende el humor como defensa frente a los intentos del gobierno nazi de control ideológico (1984: 120). Esto también se ha afirmado respecto a la dictadura soviética y en general cualquier dictadura que haya pretendido el adoctrinamiento ideológico: «Political jokes are the citizens’ response to the state's efforts to standardise their thinking and to frighten them into withholding criticism and dissent (...) The politically powerless use it as a tribunal through which to pass judgements on society where other ways of doing so are closed to them» (Benton, 1988: 33).

Sin embargo, y aunque están bien documentados los chistes que corrían en Alemania durante el gobierno de Hitler, cabe dudar de si estos eran la causa o más bien el síntoma de la resistencia ideológica al nazismo, es decir, si los chistes “convencían” a los ciudadanos de las maldades del gobierno o, más bien, solo se contaban entre aquellos a los que no afectaba la propaganda. Parece más razonable aceptar lo segundo; de hecho, estos chistes se han llamado en muchas ocasiones «chistes susurrados» porque solo se contaban en pequeños círculos de confianza donde era seguro que el interlocutor 
compartía las ideas del chiste (Benton, 1988: 36) (algo que, obviamente, y como la mayoría de investigadores afirman, es común a toda forma de intercambio humorístico). En todo caso, muchos pensadores coinciden en evaluar el chiste político como un mero sustituto de la lucha política real, incluso condenándolos por considerer que “desvían” el descontento social de un compromiso serio:

Political jokes are revolutions only metaphorically. They are moral victories, not material ones (...) The more cynical and far-sighted [bosses] know that political jokes and the other small freedoms that irritate some zealots are a useful means of dissipating tensions and of keeping people happy (...) The political joke is not a form of resistance. Revolutionaries and freedom-fighters are engaged in a serious and even deadly business, and are reluctant to make light of the enemy or to fritter away hatred through laughter (Benton, 1988: 41)

Contrary to a widely held view, whispered jokes are not necessarily an indication of resistance (...) In real mutinies, ridicule and laughter stop. Instead, laughter about whispered jokes eases the adaptation to the discipline and regimen of a strict regime (...) Throughout history, whispered jokes have been safety valves, enabling men to reduce the frustrations inflicted through taboos, laws, and conventions (Speier, 1998: 1395)

Como vemos, en esta discusión se reedita la oposición entre el compromiso serio de los revolucionarios y el juego frívolo e improductivo de aquellos que se limitan a hacer bromas:

The revolutionary and the scientists are humourless (...) Humor does not change the circumstances that it illuminates, although it is able to lessen the discontent and even the despair that these circumstances produce. It does not alter the life meanings of people or the forces that control them. It helps one only to bear somewhat better the unalterable; sometimes it reminds both the mighty and the weak that they are not to be taken seriously (Speier, 1998: 1358)

En general, muchos críticos, sobre todo marxistas como Jameson o Eagleton, desconfían del potencial subversivo de las formas humorísticas como la parodia o la ironía, sobre todo por la defendida por los autores postestructuralistas como Barthes o De Man. Así, tanto Slajov Žižek como Zupančič critican la idea, popularizada por Eco en El nombre de la rosa, de la comedia y la risa como antídoto infalible contra el "serio" dogmatismo: la distancia irónica es precisamente una condición de la ideología, que impide que esta sea sentida como explícitamente represora: es este margen de libertad para distanciarse el que 
permite a la ideología capturarnos al darnos una ilusión de autonomía (Zupančič, 2008: 4; Žižek, 2018:55).

En general, para muchos críticos de la ideología, la problemática fundamental es cómo seguir realizando esta en una época en la que la ideología parece permear todos los aspectos de la vida social e incluso de la conciencia, colonizando incluso las prácticas subversivas y transgresoras como parte del sistema que critican [ver 4.2.3]. Así, por ejemplo, el filósofo alemán Peter Sloterdijk (2014) habla de una razón cínica, de una «falsa conciencia ilustrada» en la que la población es consciente de la existencia de una ideología que "falsea” la realidad social y, sin embargo, siguen actuando cínica e irónicamente (Sloterdijk, 2014, ver también Žižek, 2018). Por otra parte, Foucault, en su definición de un poder que no es algo que se tenga, sino una relación que se ejerce en red a lo largo de todo el tejido social, afirma la posibilidad de resistencia en cada una de esas relaciones, y que, a pesar de que sean los discursos del poder los que configuren las identidades, estas mismas subjetividades pueden volverse lugares de resistencia y subversión. En esta línea, Judith Butler entre otros, como veremos [6.1.5], ha defendido la posibilidad de ejercer esta resistencia mediante desplazamientos paródicos e irónicos de estas formas discursivas de poder.

En todo caso, más allá de lo acertado o no de estas descripciones, lo que nos interesa en este punto es cómo sus discursos, entre muchos otros, son síntomas de un clima discursivo respecto al fenómeno humorístico que a la vez permean los contextos y las herramientas interpretativas que se aplican a los discursos humorísticos. En los capítulos siguientes tendremos ocasión de comprobar cómo la estética camp y las comedias televisivas como Friends, en primer lugar, están atravesadas de lleno por el contexto de la cultura de masas (no solo porque Friends sea efectivamente uno de estos productos, sino también porque la estética camp, como veremos, es una manera de lidiar con la cultura de masas), y, en segundo lugar, en las diferentes interpretaciones a favor o en contra de estos fenómenos reaparecerán las nociones de alineación, superficialidad, frivolidad, etc.: el potencial político subversivo o conservador del camp se discutirá en los mismos términos de la frivolidad como desactivador de compromisos reales o de la ineficacia de una "subversión autorizada”; por otro, como intentaremos plantear, quizá la mejor manera de enfrentarse a los productos culturales como Friends sea adoptando una perspectiva irónica. 


\section{LA RetóRICA CONSTRUCTIVISTA COMO MARCO EPISTEMOLÓGICO Y TEÓRICO}

\section{1. ¿Qué Retórica?}

\subsubsection{Los orígenes de la Retórica en la antigua sofística}

No se debería confundir el campo teórico y práctico de la Retórica con las nociones con las que el lenguaje cotidiano ha aprendido a asociarlo como lenguaje, en el mejor de los casos, hortera o engolado, cuando no discurso falso, engañoso, propagandístico, manipulador, etc., aunque sí sea necesario tener en cuenta el camino por el que se ha llegado a concebir de este modo la Retórica, ya que, como veremos, y sobre todo por su estrecha relación con el punto en que se entrecruzan lenguaje e ideología, tenga una relevancia notable en la recepción del discurso humorístico. Ciertamente, que la definición más común de la Retórica sea la de «arte de la persuasión» (López Eire, 2000: 14; Pujante Sánchez, 2003a: 71-72) contribuye a una visión peyorativa en un contexto en el que aún se mantiene en pie la oposición entre persuadir (mediante la manipulación emocional) y convencer (mediante argumentos racionales). Pero para entender cabalmente esta definición es necesario atender a la circunstancia sociopolítica en el que nace la Retórica, esto es, la del nacimiento de la democracia en las polis griegas (Pujante Sánchez, 2003a: 19), un contexto en el que los ciudadanos libres se ven en la necesidad de defender sus intereses en los tribunales de justicia así como sus opiniones respecto a las mejores soluciones para los problemas políticos de la ciudad (Pujante Sánchez, 2017: 43).

En su origen, por tanto, el arte retórico abarca mucho más que una serie de figuras y tropos con los que embellecer el lenguaje poético: en realidad constituye un complejo aparato teórico encaminado a la producción de discursos, articulado en cinco «operaciones retóricas»: la inventio (el hallazgo de ideas y argumentos que sustenten nuestra propuesta), la dispositio (la organización de dichas ideas y argumentos en el modo que resulte más convincente y efectivo), la elocutio (la puesta en palabras de las ideas), la memoria (el acto de memorización del discurso ya compuesto) y la actio (la realización efectiva del discurso ante un auditorio) (Albaladejo, 1993: 45-46). Además, en tanto que 
el discurso retórico es un discurso persuasivo, es decir, su objeto es el de convencer a los oyentes de la posición defendida, la Retórica toma también en cuenta la situación en la que el discurso ha de pronunciarse (lo que la moderna pragmática llamaría la situación comunicativa o contexto) y las características de los posibles oyentes del oyente incluyendo consideraciones que hoy consideraríamos psicológicas, sobre todo referentes a los afectos que tener en cuenta para una realización exitosa del discurso. La Retórica es, en definitiva, una completa teoría del discurso en cuanto texto y en cuanto acto comunicativo (ver Albaladejo, 1993).

Pero, sobre todo, a esta comprensión total del texto como acontecimiento comunicativo subyace una posición epistemológica muy concreta que tiene que ver con la filosofía del movimiento sofista que fundaron la disciplina retórica. No solo los sofistas tenían «un nuevo ideal de cultura fundamentado en la formación de ciudadanos conscientes, juiciosos y elocuentes» (Pujante Sánchez, 2003a: 19), sino que, al moverse en el ámbito de la polis y orientar todas sus habilidades a la vida política, promocionan el saber práctico sobre el especulativo de los filosófos como Parménides - siglos más tardes, Ciceron seguiría defendiendo la indisoluble relación entre el saber político y la filosofía especulativa (Pujante Sánchez, 2017: 43): «the so-called Sophists (the rhetoricians) remained in the sphere of doxa, of opinion, because they did not seek access to transcendent truths, but instead social ones» para lo que el lenguaje se convirtió en la herramienta fundamental (Pujante Sánchez, 2017: 44).

El papel del lenguaje era central no solo como medio de comunicación, sino porque los sofistas consideraban que la verdad no podía ser sino producto del consenso social, lo que en un momento dado fuera bueno para la sociedad en su conjunto; consenso establecido por la mediación del lenguaje, «que permite mostrar a cada ciudadano ante los otros su sentido de las cosas» (Pujante Sánchez, 2003a: 20). La epistemología subyacente a la Retórica sofista, en resumen, consistía en un «constructivismo radical», que queda plasmada en la famosas sentencias de Protágoras («El hombre es la medida de todas las cosas») (Pujante Sánchez, 2003a: 20) y la demostración de Gorgias de la imposibilidad de conocer el Ser y comunicar eficazmente este conocimiento: «existe un desajuste, un desfase, un desacuerdo, entre el mundo real (si es que existe) y el «mundo» (entre comillas) tal como nosotros lo aprehendemos, lo pensamos, lo estructuramos, lo expresamos y se lo comunicamos a los demás con palabras» (López Eire, 2000: 16). 


\subsubsection{Decadencia y reconsideración de la Retórica}

Por supuesto, es este relativismo el que Platón atacó en su polémica con los sofistas, plasmada en los diálogos de Fedro, los dos Hipias y Gorgias; polémica en la cual, como sabemos, triunfaron los filósofos (Pujante Sánchez, 2003: 21). A partir de entonces solo se consideraron dos vías filosóficas de acceder al conocimiento: mediante el racionalismo idealista de Platón o el cientificismo empirista de Aristóteles; pero ambas tradiciones coincidían en concebir la Verdad, en mayúscula, como algo absoluto y universal, confinando el conocimiento de los sofistas al terreno de la doxa, de la mera opinión, de la mera apariencia de conocimiento (Pujante Sánchez, 2003: 50; 2017: 42) Incluso en el tratado que Aristóteles dedicó a la Retórica y que sigue siendo una de las fuentes clásicas fundamentales de esta disciplina, el filósofo trató la retórica no como un camino epistemológico, sino como una herramienta de comunicar argumentos en el ámbito de las opiniones y creencias, y por tanto ajena al verdadero conocimiento racional (Pujante, 2017: 44).

Paralelamente a su desprestigio filosófico, la Retórica terminó de perder su razón de ser con la caída de la República romana: al no existir la democracia, y por tanto la necesidad de debatir colectivamente el futuro de la sociedad, la Retórica dejó de ser un instrumento esencial en la vida política y pasó a ser un elemento más, sin bien muy importante, de la educación erudita de las clases cultas. El único contexto en que el discurso retórico pudo subsistir fue el de la conferencia epidíctica, en la que no importaba tanto el tema y la eficacia persuasiva como demostrar el propio virtuosismo al elaborar el lenguaje, lo que llevó a que las cinco operaciones retóricas fueran reducidas a la de la elocutio (Pujante Sánchez, 2003a: 55), y esta como «traslado lingüístico de lo previamente concebido por la mente», es decir, como añadido ornamental que en nada contribuía al contenido cognoscitivo del discurso (Pujante Sánchez, 2012: 176). De este modo, en resumen, la Retórica sufrió una decadencia de siglos, convertida en un débil reflejo de lo que fue; su desprestigio aumentó con el nacimiento de la filosofía racionalista moderna, que tomó el lenguaje retórico como lo opuesto a su ideal de lenguaje científico universal (tal y como reseñamos en el capítulo correspondiente [2.3.1]), y, en el plano estético, con el Romanticismo y su doctrina del genio creador, ajeno a toda norma (Pujante Sánchez, 2003a: 67). 
Aun así, lo que podemos denominar «pensamiento retórico» (en concordancia con lo que, como vimos [3.2.3.2.4], Fish llama homo rhetoricus), es decir, la creencia en el carácter construido y social de la verdad, y del papel central del lenguaje en la constitución del conocimiento, pervivió como corriente subterránea de todo el pensamiento occidental que resurge en algunos pensadores marginales, algunos de los cuales ya hemos tratado en nuestra reseña histórica: los humanistas italianos (ver Grassi, 1993, 2015); Giambattista Vico, Baltasar Gracián, el conde de Shaftesbury (Pujante Sánchez, 2017: 42), los autores del idealismo alemán con Friedrich Schlegel a la cabeza (Molpeceres Arnáiz, 2017)... Ya en el siglo XX, y sobre todo a partir de su segunda mitad, la Retórica vive una nueva época de esplendor y ocupa un lugar central en varios campos de conocimiento relacionados con el lenguaje y la comunicación, no solo porque la expansión de las democracias capitalistas junto con la aparición de los nuevos medios de comunicación han vuelto a poner en el centro discursos prototípicamente persuasivos como el político o el publicitario. Pensadores como Wittgenstein y Heidegger, o ya en la vena posmoderna, el postestructuralismo francés, con Derrida, Lacan y Foucault a la cabeza, lo que Vattimo llama el pensiero debole, la hermenéutica filosófica de Gadamer y Paul Ricoeur, el pragmatismo norteamericano de Richard Rorty y Stanley Fish, han vuelto a poner el lenguaje en el centro de la discusión filosófica, y sobre todo su papel ineludible en la construcción del conocimiento y en nuestra relación con la realidad social (Pujante Sánchez, 2017: 42). También la sociología del conocimiento, de Durkheim a Berger y Luckmann, han hecho hincapié en el carácter de constructo social e histórico de todo conocimiento.

\section{2. ¿Qué constructivismo?}

\subsubsection{Una aproximación retórico-pragmatista al lenguaje: como uso, como acción, como diálogo}

Como venimos diciendo, a lo largo de la historia del pensamiento occidental se enfrentan dos posiciones acerca de la naturaleza y posibilidades de nuestro conocimiento de la realidad y del papel del lenguaje en ello. Cuando tratamos la disputa en el campo de la filosofía y la teoría literaria acerca del problema de la interpretación del discurso irónico [3.2.3.2], expusimos dos concepciones enfrentadas del lenguaje y de la interpretación: el 
lenguaje y el significado como representación de la realidad exterior a la palabra, o como juego de la interpretación de un significante por otro. Hablamos, por tanto, de una tradición científica, platónica, metafísica, logocéntrica, que concibe el lenguaje como instrumento de representación y análisis de la realidad (cuya búsqueda de un lenguaje perfecto, como vimos [2.3.1], es un síntoma muy significativo que se repite en la filosofía analítica de Frege, Russell o el primer Wittgenstein), y de una tradición retóricohermenéutica, deconstructivista, pragmatista, que considera el papel que el lenguaje tiene en la construcción de conocimiento.

En esta tradición, como decimos, se considera que la realidad no es algo independiente al lenguaje y al sujeto que se pueda conocer de manera exhaustiva y de manera que el conocimiento sea uno y universal para todos los seres humanos, sino que solo conocemos la realidad a través de interpretaciones lingüísticas. Esta es la posición, como vimos, de Kenneth Burke y sobre todo de Hayden White, según quien solo podemos construir relatos a partir de operaciones metafóricas, metonímicas, etc., mediante las que ordenamos la realidad, o la de Derrida cuando afirma que no hay un afuera del texto, es decir, una posición exterior al lenguaje desde la que podamos juzgar objetivamente la adecuación de nuestras formas discursivas a una realidad independiente. Es una posición que deriva en última instancia de Friedrich Nietzsche, que señaló la importancia de la retórica y del lenguaje artístico como modos de conocimiento en sus cursos sobre retórica en la universidad de Basilea y en obras como El nacimiento de la tragedia o Sobre verdad y mentira en sentido extramoral (Nietzsche, 2007, 2012; ver Pujante Sánchez, 1997 y Santiago Guervós, 2012).

También encontramos esta posición en la línea de la hermenéutica filosófica que va desde Heidegger a Gadamer y Ricoeur y que eleva la noción de círculo hermenéutico de herramienta metodológica a principio ontológico de la comunicación como comprensión del otro: según Gadamer, no podemos comprender los textos sino es a partir de la apertura de un horizonte de sentido que nos proporciona nuestra propia tradición (Gadamer, 2012: 363), comprensión que siempre se da en el lenguaje (Gadamer, 2000: 475). La noción de tradición guarda mucha relación con lo que Stanley Fish (1980) denomina «comunidades interpretativas», esto es, el grupo de personas que comparten ciertas prácticas interpretativas. Según Fish, solo podemos comprender el sentido de un texto o enunciado si compartimos con el productor de los mismos los mismos presupuestos de sentido; por tanto, diferentes comunidades interpretativas darán 
diferentes sentidos a un mismo texto. Para Stanley Fish, cuya teoría podemos relacionar con el pragmatismo de Richard Rorty (1996, 2001), no existe significado literal «si por significado literal uno entiende un significado claro, transparente», sino que el significado de un enunciado siempre depende del contexto de recepción del mismo (Fish, 1992: 13). Con el concepto de «comunidad interpretativa», Fish viene a señalar que todo significado es producto de un acto de interpretación individual que sin embargo viene delimitado y posibilitado por las tradiciones y las comunidades a las que el intérprete pertenece.

Como señala Fish, en este debate se enfrentan dos nociones de verdad: «una noción de la verdad como algo independiente de los puntos de vista particulares o parciales, y una noción de la verdad como algo que, en cualquier caso, aparece clara y obvia a quienes se colocan en cierta perspectiva particular o parcial (...) Una verdad que juzga los actos humanos y otra verdad que es un acto humano» (Fish, 1992: 15); es decir, las posiciones que como vimos él denomina como las propias del homo seriosus y el homo rhetoricus. Porque, al fin y al cabo, la alternativa al paradigma que él llama formalista es un paradigma retórico (Fish, 1992 46-47).

Sin embargo, y como ya advertimos [3.2.3.2.4], se corre el riesgo de reducir la concepción retórica del lenguaje a su dimensión puramente semántica, de descripción de la realidad: si seguimos hablando del lenguaje en términos de una representación más o menos ajustada, más o menos objetiva, más o menos universal o histórica, de la realidad, estamos extendiendo nuestra concepción del lenguaje y la verdad a su dimensión intersubjetiva y por tanto comunicativa, pero seguimos concibiendo la comunicación como una mera transmisión de información sobre el mundo. Por ello es necesario acudir a autores como Wittgenstein o Austin, para quienes el lenguaje es ante todo algo que hace cosas, algo que se usa para diferentes funciones, entre las cuales están, en efecto, la descripción de la realidad.

En las Investigaciones filosóficas, Wittgenstein desafía la tendencia de la filosofía analítica a estudiar el lenguaje según su capacidad representativa del mundo, y defiende que la explicación ostensiva de una palabra («esta palabra se refiere a este objeto, está en lugar de él») es solo uno de sus posibles usos; en otros usos del lenguaje, en otros juegos ${ }^{1}$,

\footnotetext{
${ }^{1}$ «El lenguaje se parece a un juego en tanto que es una actividad con palabras dirigida por relgas... en el lenguaje hay innumerables juegos, es decir, procedimientos para el uso de signos. Los juegos de lenguaje son contextos reales de acción y constituyen la forma de vida de una cultura en la cual, a su vez, están inscritos» (Reguera, 2017: CXVII)
} 
el significado de una palabra podrá ser una orden (Wittgenstein, 2017: 100). El sentido de una oración, por tanto, no es el estado del mundo al que supuestamente se refiere, sino su empleo (Wittgenstein, 2017: 105), de ahí que Wittgenstein describa el lenguaje como una caja de herramientas (2017: 102). En ese sentido, si el lenguaje se adapta al uso que se le dé en cada situación, cada juego del lenguaje representa una forma de vida (Wittgenstein, 2017: 104, 107), y el significado del lenguaje dependerá de los intereses de la práctica en que se dé.

Cabe señalar también la recuperación que realiza Gadamer de la aplicación del texto interpretado como momento fundamental del proceso interpretativo, no externo o posterior a la comprensión sino inherente a ella (Gadamer, 2012: 379). En este sentido, ya Heidegger en Ser y Tiempo afirmaba que los objetos del mundo no son simples presencias, sino instrumentos, es decir, que conocemos los objetos según su "utilizabilidad”, y su significación consiste en cómo nos afectan: el ser humano «encuentra las cosas, en primer lugar, incluyéndolas en un proyecto, es decir, asumiéndolas, en un sentido amplio, como instrumentos» (Vattimo, 1998: 28). Esta afirmación le sirve al filósofo alemán para cuestionar la tradición filosófica y científica de la presencia, de pensar la realidad como algo «objetivo» aprehendido por una mirada des-interesada: la objetividad, en este marco, no es sino un modo de percibir la realidad que no deja de estar orientada a ciertos fines precisos, los de la ciencia, entre otros posibles (Vattimo, 1998: 29). Una posición análoga muestra Wittgenstein cuando afirma que los significados de las palabras, como los de los colores, cambian según el contexto de uso en el que aparezca (2017: 112).

Otra filosofía del lenguaje en esta misma línea de enorme importancia es, por supuesto, la de los actos de habla propuesta por John L. Austin en Cómo hacer cosas con palabras. Como se sabe, en este libro, que recoge una serie de conferencias, Austin partía de la distinción entre enunciados constativos, que se limitan a afirmar un estado del mundo, y los enunciados realizativos o performativos (performativos), que más que describir un estado de cosas realizan una acción como prometer, jurar, etc. (Austin, 2018: 47-48). Esta distinción se diluye conforme avanza en su investigación: en realidad, arguye Austin, las condiciones de veracidad de un enunciado constativo equivalen a las condiciones de felicidad de uno realizativo, es decir, que no se puede decir simplemente que un enunciado sea verdadero y falso, sino que lo es según ciertas condiciones concretas y convencionales de verdad y falsedad (Austin, 2018: 102-103). 
Este “descubrimiento" le lleva a reconducir su investigación hacia la definición de todo enunciado como acto, es decir, «los sentidos en que decir algo puede ser hacer algo, o en que al decir algo hacemos algo (y también, quizá, considerar el caso diferente en el que por decir algo hacemos algo)» (Austin, 2018: 139). De este modo, Austin distingue en el acto de habla tres niveles diferentes: el acto locucionario («decir algo» en el sentido de emitir una oración según unas ciertas reglas gramaticales), el ilocucionario (aquell o que se hace al decir algo: afirmar, preguntar, prometer, insultar) y el perlocucionario (los efectos a los que damos lugar por decir algo) (Austin, 2018: 145$147)^{2}$.

La distinción entre el acto ilocucionario y el perlocucionario podría presentarse como problemática si entendemos de manera confusa la distinción entre uno y otro como lo que un enunciado hace y lo que provoca, como la intención de un hablante al decir algo y los efectos reales que tiene lo que dice. Según Austin, la diferencia reside en realidad en que la fuerza ilocucionaria de un enunciado es convencional, es decir, codificada y reconocible por el oyente (Austin, 2018: 148-150) - es decir, un enunciado puede ser convencionalmente una promesa y ser usado para producir un cierto efecto en el oyente, como hacer que se enamore o manipularle emocionalmente. En este sentido no hay que confundir la fuerza ilocucionaria de un enunciado con lo que un enunciado hace:

The only thing that performative or illocutionary ${ }^{3}$ acts produce is recognition on the part of a hearer that the procedures constitutive of a particular act have been invoked: illocutionary force is not something an illocutionary act exerts but something it has (...) It is simply wrong to think of an illocuitonary act as producin meaning in the sense of creating it (...) The meaning the act produces (a better word would be presents) necessarily preexistis it; or, to put it in another way, in speech-act theory, meaning is prior to utterance (Fish, 1980: 221-222)

En todo caso, la teoría de Austin nos permite adoptar una concepción del lenguaje como acción, en la que hablar es fundamentalmente hacer, y que el análisis del discurso no

\footnotetext{
${ }^{2}$ Tengamos en cuenta que esta definición del lenguaje como acción es, a fin de cuentas, análoga al de la retórica, como defiende el profesor López Eire: la retórica tiene en cuenta la dimensión del lenguaje en que este se construye como discurso pronunciado en un cierto contexto y encaminado a persuadir al otro a realizar una acción - es decir, un discurso que pretende cambiar el estado de cosas.

${ }^{3}$ Una de las dificultades de la teoría de los actos de habla es la confusión terminológica posterior entre actos performativos y actos ilocucionarios, cuando Austin propone este último cuando ya ha negado la distinción entre actos constativos y performativos.
} 
puede sino tener en cuenta su función según una intención concreta y en un contexto determinado.

En general, la teoría de Austin ha tenido un gran impacto, no solo en los estudios de lingüística y filosofía del lenguaje, sino también en ámbitos tan aparentemente alejados como el psicoanálisis o la teoría feminista (ver Parker y Sedgwick, 1995; Pratt, 1986; Weber, 1978). En el siguiente capítulo nos ocuparemos de algunas de estas ramificaciones y su interés para nuestro análisis del discurso humorístico; principalmente, de la lectura que de Austin realiza Derrida. De momento nos interesa resaltar algunos olvidos significativos del libro de Austin, y que tienen que ver sobre todo con una de las condiciones que establece para que un enunciado realizativo sea "feliz": a saber, el requisito de que los pensamientos y sentimientos de los participantes en un acto de habla correspondan con los requisitos de dicho acto (por ejemplo, si alguien pide disculpas, debe sentirse realmente arrepentido para que el enunciado sea válido). Esta condición presenta una concepción de un sujeto presente a sí mismo y plenamente consciente y responsable de sus sentimientos, sus ideas, su intención, etc., que precisamente vendrían a problematizar autores como Freud, Lacan, Derrida, Foucault, y otros pensadores postestructuralistas.

Por ejemplo, Mary Louise Pratt (1986) señala varios problemas en la teoría de los actos de habla tal y como está desarrollada por Searle y Grice: esta considera como situación de habla prototípica la interacción oral entre dos personas, no mediada por escrito o medios audiovisuales, ni difundida de un solo productor a muchos receptores; tampoco tiene en cuenta la identidad social de los interlocutores; sobre todo, al entender Grice la interacción según un principio de cooperación racional obvia las posibles relaciones afectivas y/o de poder entre los participantes y los intereses compartidos o divergentes de cada uno de ellos. En general, la teoría de Austin, al señalar los aspectos convencionales de los actos lingüísticos que llevamos a cabo continuamente, da pie a estudiar los aspectos institucionales que rodean los acontecimientos discursivos (por ejemplo, las normas que designan a un interlocutor como adecuado para realizar actos determinados como prometer o bautizar), lo que Norman Fairclough, siguiendo a Foucault, analiza como orden del discurso (Fairclough, 2001: 24-25).

La última propuesta que reseñaremos, que se encuentra también en el fundamento epistemológico de la Retórica Constructivista y sobre la que nos apoyaremos en gran 
medida en nuestro modelo de análisis del humor, es la del dialogismo desarrollado por Bajtín y su círculo, concretamente por Voloshinov en El marxismo y la filosofía del lenguaje $^{4}$. En esta obra de 1929, Voloshinov acuña el concepto de «signo ideológico» para referirse al hecho de que el lenguaje y la ideología (entendida esta en un sentido mucho más amplio que en el marxismo ortodoxo) están inevitablemente vinculados: «donde no hay signo no hay ideología» (Voloshinov, 2009: 27).

Voloshinov debate con algunas corrientes científicas de su tiempo, sobre todo con el psicologismo empirista, el idealismo de la estilística de Spitzer o el objetivismo abstracto representado por las ideas de Saussure, contra quienes sostiene la omnipresencia del lenguaje en todo proceso psicológico, comunicativo e ideológico. Aunque tanto el idealismo como la psicología consideren el conocimiento como un fenómeno de la conciencia como un objeto aparte, exclusivamente interno, no hay idea posible sin la mediación del lenguaje, puesto que «la comprensión del signo es el proceso de relacionar un signo dado que tiene que ser comprendido con otros signos ya conocidos» (Voloshinov, 2009: 30). Pero, además, el lenguaje es ante todo un producto ideológico, es decir, fruto de la interacción social; ni siquiera se puede decir que el lenguaje sea un instrumento que se usa entre dos individuos aislados, sino que tanto estos como el lenguaje ya están sumergidos en una organización social mayor (2009: 31-32). De este modo, como decimos, Voloshinov se enfrenta a las dos corrientes lingüísticas imperantes de aquel momento: la lingüística protoestructural, formalista, de Saussure y la estilística idealista-subjetivista de Leo Spitzer: «la realidad concreta del lenguaje en cuanto discurso no es el sistema abstracto de forma lingüísticas, ni tampoco una enunciación monológica y aislada, ni el acto psicofísico de su realización, sino el acontecimiento social e interacción discursiva» (Voloshinov, 2009: 161).

Respecto a la corriente del «objetivismo abstracto» representado por las teorías de Saussure, Voloshinov critica la idea de un sistema de normas homogéneo para toda la lengua, puesto que estas normas (de uso) del lenguaje se están generando y transformando continuamente en cada interacción (2009: 112). Si pensamos en la naturaleza comunicativa del lenguaje como su rasgo esencial, tampoco se puede decir que el hablante perciba el lenguaje como un sistema abstracto de normas, sino que está orientado por la

\footnotetext{
${ }^{4}$ No intentaremos entrar en el debate acerca de la autoría de algunos de los textos firmados por los colegas de Bajtín. Consideraremos El marxismo y la filosofía del lenguaje escrito por Voloshinov, teniendo en cuenta sus evidentes cercanías con los escritos de Bajtín.
} 
obtención de un enunciado adecuado a cierto contexto: «no ubica el centro de gravedad en la adecuación de la forma, sino en aquella nueva significación concreta que la forma adquiere en el contexto dado (...) No le importa la forma lingüística como una señal estable y siempre igual a sí misma, sino como un signo siempre mutante y elástico» (Voloshinov, 2009: 116). Del mismo modo, la comprensión de un enunciado no consiste en el reconocimiento de una forma correspondiente a un sistema, sino la comprensión de un objetivo de significación en un contexto dado (Voloshinov, 2009: 116). El oyente, según Bajtín, no es simplemente un receptor pasivo del enunciado, sino que está llamado a interactuar con él de manera activa: está de acuerdo con él o no, lo completa, lo aplica, lo matiza... Toda comprensión constituye un nuevo acto de habla: «Toda comprensión está cargada de respuesta y en una u otra forma la genera obligatoriamente: el oyente se convierte en hablante (...) Tarde o temprano lo escuchado y activamente comprendido se manifestará en los discursos posteriores o en el comportamiento del oyente» (Bajtín, 2011: 23-24).

En resumen, y dada la naturaleza dialógica del lenguaje, no percibimos este como un sistema abstracto sino como un medio de relacionarnos con los demás y con la realidad: «nosotros jamás pronunciamos ni oímos palabras, sino que oímos la verdad o la mentira, lo bueno o lo malo, lo importante o lo nimio, lo agradable o lo desagradable. La palabra siempre aparece llena de un contenido y de una significación ideológica» (Voloshinov, 209: 120). Afirmar la naturaleza ideológica de la palabra también supone comprender su historicidad: ningún enunciado es un enunciado aislado, sino que está siempre respondiendo a los enunciados anteriores y esperando la respuesta de enunciados por venir; inserto en la vida social, artística, política, espera una comprensión activa, polemiza con sus antepasados y sus contemporáneos... (Voloshinov, 2009: 124). Como dice Bajtín, no existe un enunciado aislado, sino una «corriente discursiva» en la que todos los enunciados de una sociedad se responden entre sí (Bajtín, 2011: 26).

Hasta este punto, la descripción del lenguaje como inter-acción acerca la obra de Voloshinov y Bajtín a la de Gadamer o Austin. Pero, además, el dialogismo bajtiniano contempla, bajo los términos de polifonía y plurilingüismo con los que trabajaremos más adelante [5.3], la dimensión social del lenguaje y la interacción. Si para la estilística idealista de Spitzer, el enunciado es expresión de la interioridad única del individuo, y lo expresado se concibe como algo anterior e independiente a la misma expresión, para Voloshinov no hay diferencia alguna entre el interior y el exterior, entre la conciencia y 
el entorno social, pues ambos están hechos del mismo material sígnico labrado en la interacción social: «el centro organizativo y formativo no se encuentra en el interior (...) sino afuera. No es la vivencia la que organiza la expresión, sino por el contrario, es la expresión la que organiza la vivencia, le da por primera vez una forma y una determinación de sentido» (Voloshinov, 2009: 145).

La lengua no es un sistema abstracto ni un instrumento neutro, sino que, al estar presente en toda interacción social, en ella se acumulan lentamente los distintos usos y transformaciones de la palabras, dando forma a su contenido ideológico, que de este modo no es un producto espontáneo de la conciencia ni de su relación individual con el mundo, sino que se manifiesta siempre en la acción social de la palabra (Voloshinov, 2009: 43). Y dado que estas interacciones sociales están determinadas por las condiciones concretas en las que se dan, condiciones que son particulares a cada actividad y cada grupo social, estas acaban reflejándose en el lenguaje de los distintos grupos sociales. Cada palabra acaba recibiendo ciertos «acentos axiológicos» que son reflejo de las condiciones, intereses y vivencias colectivas de los grupos en los que se usa (Voloshinov, 2009: 47), y cada relación de dicho grupo con el mundo está mediado también por esos signos ideológicos: «las mismas condiciones económicas unen un elemento nuevo de la realidad con el horizonte social y le adjudican una significación social, lo hacen “interesante”, así como las mismas fuerzas crean las formas de la comunicación ideológica (...), las cuales a su vez determinan las formas de la expresión sígnica» (Voloshinov, 2009: 49).

En suma, el lenguaje determina de antemano la manera en la que nos relacionamos con los objetos y otros enunciados. Toda palabra encuentra, cuando se orienta a un objeto, que este está ya condicionado, evaluado por palabras ajenas pertenecientes a enunciados posteriores,

envuelto en una bruma que lo enmascara; o, por el contrario, inmerso en la luz de las palabras ajenas que se han dicho acerca de él. El objeto está rodeado e impregnado de ideas generales, de puntos de vista, de valoraciones y acentos ajenos (...) Un enunciado vivo, aparecido conscientemente en un momento histórico determinado, en un medio social determinado, no puede dejar de tocar miles de hilos dialógicos vivos, tejidos alrededor del objeto de ese enunciado por la conciencia ideológico-social; no puede dejar de participar activamente en el diálogo social (Bajtín, 1989: 94). 
Ningún enunciado es mera expresión de una interioridad, sino que está desde el principio orientado a su interlocutor y hacia la situación social inmediata en la que aparece; además, este individuo que habla nunca es un individuo abstracto, por encima de sus condicionantes sociales (Voloshinov, 2009: 146). El hablante se apropia de una palabra que es colectiva y le da un acento individual en su uso concreto, pero un acento que siempre está determinado por las relaciones sociales que con ella establece: «aquella individuación estilística del enunciado de la que hablan los vosslerianos representa un reflejo de las interrelaciones sociales en cuya atmósfera se construye el enunciado dado» (Voloshinov, 2009: 147). La propia conciencia del individuo hablante (y también del oyente), la propia vivencia que se intenta expresar (o comprender), al estar mediada por el lenguaje, es también un producto ideológico, un reflejo del diálogo social que encontramos en la palabra: «El proceso de la formación ideológica del hombre es (...) un proceso de asimilación selectiva de las palabras ajenas (...) La palabra ajena ya no aparece aquí en calidad de información, de indicación, de regla, de modelo, etc.; tiende a definir las bases mismas de nuestra actitud ideológica ante el mundo» (Bajtín, 1989: 152).

\subsubsection{Constructivismo en las ciencias biológicas y cognitivas}

Este cambio de perspectiva no se ha producido solo en el ámbito de la filosofía del lenguaje: también en la ciencia, a partir del impacto de la mecánica cuántica y los descubrimientos y teorías como las de Einstein, Schrödinger o Heisenberg, se ha desafiado al centenario paradigma de Newton y Descartes. El cambio de paradigma en la física cuántica es parte de un cambio de paradigma mucho más amplio, desde una visión del mundo mecanicista y racionalista (en la que se concibe «el universo como un sistema mecánico compuesto de piezas, la del cuerpo humano como una máquina, la de la vida en sociedad como una lucha competitiva por la existencia, la creencia en el progreso material ilimitado a través del crecimiento económico y tecnológico») hacia una perspectiva holística y ecológica que «reconoce la interdependencia fundamental entre todos los fenómenos y el hecho de que, como individuos y sociedades, estamos todos inmersos (y finalmente dependientes de) los procesos cíclicos de la naturaleza» (Capra, 2015: 27-28).

Este cambio de paradigma es, en primer lugar, un cambio en la manera de entender la ciencia y el conocimiento general que Capra identifica como la emergencia de un 
«pensamiento sistémico» consistente en entender la realidad «en términos de conectividad, relaciones y contexto» (Capra, 2015: 48). Si el paradigma cartesiano operaba mediante el análisis aislado de las partes constituyentes de un mecanismo, el pensamiento sistémico entiende que las propiedades de un organismo o sistema son características emergentes que no se encuentran en ninguna de sus partes, y que por tanto dichos sistemas y sus partes constituyentes solo pueden ser comprendidas en su contexto mayor (Capra, 2015: 48-49); las partes de un sistema no son objetos aislados, sino que solo se comprenden en su relación con las demás partes (Capra, 2015: 57): «aislar un patrón dentro de esta compleja red dibujando una frontera aleatoria a su alrededor y denominarlo un “objeto” resulta un tanto arbitrario» (Capra, 2015: 60).

El paradigma sistémico proviene de diferentes disciplinas como la física cuántica, la psicología Gestalt o la ecología, y afecta a muchas otras ciencias, no necesariamente naturales, como la lingüística, la economía o la psicología (ver Morales López, 2013; Morin, 1995), entre las cuales nos interesa especialmente la ciencia cognitiva. Si esta ha estado dominada durante décadas por el paradigma cibernético o computacional, que define la inteligencia como procesado de información, como la manipulación racionalizada de símbolos o representaciones mentales según un conjunto de reglas (Capra, 2015: 275), los avances científicos han demostrado la inadecuación de este modelo. «el sistema nervioso humano no procesa información alguna - en el sentido de elementos prefabricados existentes en el mundo exterior (...) - sino que interactúa con el entorno por medio de una constante modulación de su estructura» (Capra, 2015: 86). Además, esta interacción no es exclusivamente racional en un sentido cartesiano, sino que está mediatizada por el cuerpo, tanto por los sistemas sensoriales y motrices, como por las emociones (Varela, Thompson and Rosch, 2011; Damasio, 2018a, 2018b).

Uno de las teorías que han desafiado este paradigma computacional es la conocida como «teoría de Santiago» propuesta por los biólogos Maturana y Varela (Maturana y Varela, 2003, 2004). Estos científicos chilenos toman la postura radical de hacer equivaler la cognición con la vida al definir la cognición como la interacción de un organismo con su entorno (Capra, 2015: 276), desechando de este modo el concepto de representación mental, es decir, la idea de que el conocimiento está validado por su fidelidad a la realidad y no por su eficacia operacional (Maturana y Varela, 2003: 161); algo que Maturana y Varela resumen con el adagio «todo hacer es conocer y todo conocer es hacer» (2003: 13). Esta concepción implica que el conocimiento de cada individuo depende de esta 
interacción con el medio, y esta interacción y las estructuras y necesidades del organismo son las que determinan la forma de este conocimiento:

La cognición no es una representación de un mundo independiente y predeterminado, sino más bien el alumbramiento de un mundo. Lo que un organismo particular da a luz en el proceso de vida no es el mundo sino un mundo determinado y siempre dependiente de la estructura del organismo (...) No hay estructuras objetivamente existentes, no existe un territorio predeterminado del que podamos levantar un mapa: es el propio acto de cartografiar el mundo quien lo crea (Capra, 2015: 280)

Aunque este proceso cognitivo sea individual, cuando dos seres vivos interactúan uno con otro se dan fenómenos sociales, y si estas interacciones son recurrentes y garantizan la supervivencia de los individuos, constituyen sociedades, y los conocimientos y conductas transmitidos generacionalmente, cultura (Maturana y Varela, 2003: 129). Estas conductas se conciben entonces como comunicación, que para Maturana no consiste en transmitir información sino en una «coordinación de comportamientos» (Capra, 2015: 296). Maturana y Varela describen un tipo particular de conductas sociales como lingüísticas cuando se pueden describir como intercambio de significados, entendiendo «significados»; y cuando estas conductas lingüísitcas son a su vez objeto de descripciones lingüísticas es cuando podemos hablar de lenguaje (Maturana y Varela, 2003: 138-139). El tipo particular de organismo que es el ser humano se caracteriza porque para esta especie la conducta lingüística pasa de ser una interacción con el medio a ser el medio: «existimos en nuestro operar en el lenguaje y conservamos nuestra adaptación en el dominio de significados que este crea: hacemos descripciones de las descripciones que hacemos (...) y somos observadores y existimos en el dominio semántico que nuestro operar lingüístico crea» (Maturana y Varela, 2003: 139).

En la teoría de Maturana y Varela, en resumen, el conocimiento no es una representación más o menos fidedigna del mundo exterior ni una pura invención ideal, sino una serie de procesos y conductas que resultan efectivos para la autoconservación. Por tanto, el mundo no existe externamente, sino que aparece en nuestro interactuar con el medio: al actuar «traemos el mundo a la mano»; y como en el ser humano este hacerconocer se da en el dominio del lenguaje, que es una conducta heredada culturalmente, el mundo que el lenguaje trae a la mano de cada individuo depende de su historia particular pero es compartido con los demás en el lenguaje (Maturana y Varela, 2003: 161). 
Los paralelismos con la perspectiva pragmatista del lenguaje expuesta en el apartado anterior son obvios: en primer lugar, el conocer es un hacer, y por tanto el conocimiento no se valida según su fidelidad representacional a la realidad exterior, sino por su efectividad y utilidad; en segundo, este conocer se da única y exclusivamente en el lenguaje, que no es representación sino interacción con los demás; por último, el individuo no puede conocer objetivamente sino solo a través de su lenguaje y su experiencia, pero al ser el lenguaje una conducta social, los conocimientos, conductas y objetivos son guiados y compartidos por la colectividad.

El enfoque constructivista de Maturana y Varela y el pensamiento sistémico expuesto por Capra no solo apuntala la perspectiva teórica de la Retórica Constructivista que aquí tomamos como marco, sino que guía algunos aspectos concretos de nuestro trabajo. Así, por ejemplo, en el capítulo anterior [3.3] cuestionamos lo limitado de ciertos enfoques lingüísticos, psicológicos y sociológicos respecto al humor: estos conceptualizaban el chiste como un puzle o enigma, por lo que la recepción se limitaba a una serie de procesos computacionales para resolver dicho enigma y el placer cómico se explicaba como el placer de la resolución puramente intelectual del chiste. Sin embargo, este enfoque, como argumentamos, no es capaz de explicar muchos casos de "humor fallido”, ni muchos de los componentes formales de los enunciados o discursos cómicos. Es necesario explicar estos rasgos según los variados usos que dichos discursos pueden tener, así como atender, de manera sistémica, al contexto más o menos amplio en el que aparecen y se reciben.

\subsubsection{El Análisis Crítico del Discurso y el concepto de ideología}

Otras de las ramas de investigación contemporáneas que trata las relaciones entre el lenguaje, los conocimientos y las prácticas de una sociedad es el Análisis Crítico del Discurso (ACD), aunque más que de un cuerpo teórico unificado y homogéneo estemos hablando de una cierta perspectiva en el análisis del funcionamiento del lenguaje, esto es, crítica respecto a los modos en que el lenguaje y su realización en el discurso, reproduce y legitima relaciones de dominación, discriminación, y control (Wodak, 2003: 19). Por tanto, el ACD se ocupa de ciertos problemas centrales a la tradición de la teoría crítica tal y como la concibieron los pensadores de la Escuela de Frankfurt, de Horkheimer a Habermas: qué es el conocimiento, cómo se construye el discurso en las instituciones 
sociales y cómo este es a su vez constructor de ellas, de qué modo opera la ideología en dichas instituciones, cómo conserva el poder la clase dominante, etc. (Wodak, 2003: 32).

Por tanto, las metodologías, enfoques, conceptos teóricos e intereses difieren de una tradición de ACD a otra. Así, por ejemplo, el profesor Van Dijk se basa en un enfoque sociocognitivo (Van Dijk, 2003: 145), por lo que se interesa por los modelos, representaciones, ideas, tanto personales como sociales, mediante los cuales los individuos se representan a sí mismos la situación comunicativa y el universo del discurso, y cómo estas representaciones mentales, que, como decimos, dependen a su vez de representaciones sociales, se reflejan en el discurso y lo determinan. En este sentido, una aportación fundamental de Van Dijk a la comprensión del acontecimiento discursivo es que el contexto no es algo estable y objetivo que se impone a los hablantes desde fuera, sino que también es una construcción interpretativa de los hablantes mediante la que se guían en la conversación (Van Dijk, 2008, 2009) - de este modo, la producción y recepción del discurso humorístico no dependerá de unas condiciones objetivas del discurso ni del contexto en el que se produce, sino de cómo los actores implicados “interpreten” la situación. Como hemos dicho, una de las hipótesis básicas de este trabajo es que tanto la producción como la recepción del discurso humorístico depende fundamentalmente de la concepción del humor que tengan los interlocutores.

Si el modelo sociocognitivo de Van Dijk parece interesarse por las representaciones que los hablantes nos hacemos y cómo estas aparecen en el discurso, la propuesta de Norman Fairclough (1995, 2001, 2003) concibe el discurso como práctica social, y engloba no solo el discurso en cuanto texto sino todo el proceso de su producción, difusión y recepción (Fairclough, 1995: 71), lo que le lleva a interesarse por las condiciones de estos procesos, lo que llama, siguiendo a Michel Foucault, orden del discurso (Fairclough, 1995: 23-26).

Una tradición sensiblemente diferente de análisis del discurso es la francesa, que se desarrolla en los años ochenta bajo la influencia de la obra de Foucault, con autores como Michel Pêcheux, Patrick Chareaudeau, Dominique Maingueneau o Marc Angenot. A lo largo de toda su obra, desde la Historia de la locura hasta el primer volumen de la Historia de la sexualidad, Foucault se dedicó a estudiar las relaciones entre saber y poder, es decir, cómo ciertas verdades científicas y las disciplinas que las fundamentan, como la medicina o la psicología, no hacen sino servir a determinadas formas de control y 
normalización. Los analistas del discurso de esta tradición se sirven sobre todo de términos clave de la primera época del filósofo francés, como los de episteme o, sobre todo, el de «formación discursiva» y otros relacionados expuestos en La arqueología del saber (Foucault, 2015b). Marc Angenot, por ejemplo, habla de un discurso social, no como la suma de todos los discursos efectivos de una sociedad, sino más bien de las condiciones de posibilidad epistemológicas, institucionales, etc., que los regulan, «los sistemas géneros, los repertorios tópicos, las reglas de encadenamiento de enunciados que, en una sociedad dada, organizan lo decible - lo narrable y opinable -» (Angenot, 2010: 21$)^{5}$.

Una de las diferencias más importantes entre estas dos tradiciones es, en fin, la diferente noción de cómo se relacionan conocimiento (aun en tanto que construido socialmente) y lenguaje. Las líneas de Van Dijk, Fairclough o Wodak, a pesar de las diferencias de énfasis y enfoques, se mantienen, como dijimos, en la tradición de la teoría crítica que viene de la Escuela de Frankfurt, y utilizan de modos diferentes la noción de ideología. Van Dijk, por ejemplo, entiende la ideología desde su perspectiva sociocognitiva como «las creencias fundamentales de un grupo y de sus miembros» que fundamentan su identidad y sus prácticas (Van Dijk, 2005: 15-16): por tanto, Van Dijk parte de una definición neutra de ideología en tanto que todo grupo social tiene una ideología, aunque esto no implique renunciar a la crítica de ideologías "negativas” que justifican la desigualdad y la dominación (Van Dijk, 2005: 16) ${ }^{6}$, mientras que Fairclough, más cerca de la tradición marxista, habla directamente de la ideología como «assumptions which directly or indirectly legitimize existing power relations» (Fairclough, 2001: 27).

La noción de ideología es, de hecho, uno de los conceptos más discutidos en la teoría social de orientación crítica de las últimas décadas, hasta el punto de que muchos autores directamente abogan por desecharla como herramienta analítica. Las diferentes definiciones de ideología que podemos encontrar son muchas veces contradictorias entre sí o su campo de aplicación es divergente (Eagleton, 1997: 20-21). A grandes rasgos,

\footnotetext{
${ }^{5}$ En este punto cabe hacer una aclaración terminológica: efectivamente, el término «discurso» puede referirse tanto a la noción extendida de discurso como acto de habla, sea oral u escrito, abarcando desde discursos más o menos preparados y oficiales hasta la conversación cotidiana; pero puede referirse, en un sentido mucho más amplio, a las «formaciones discursivas» de las que habla Foucault. En este trabajo usaremos el término en el primer sentido.

${ }^{6}$ Si bien los ejemplos que da Van Dijk de ideologías, como el feminismo y el racismo son problemáticos en tanto que un sistema de pensamiento es hasta cierto punto reflexivo y el otro no: una persona normalmente se dirá feminista y adoptará voluntariamente esta ideología como un sistema de creencias bien definido, mientras difícilmente alguien se declarará racista en el mismo sentido.
} 
podemos esbozar dos modos mayoritarios de concebir este fenómeno. El primero viene a coincidir más o menos con el sentido original que le dieron los pensadores ilustrados, que definían de manera literal «ideología» como «ciencia de las ideas»: en esta tradición, la ideología no es más que el proceso por el que una sociedad o grupo social se representa a sí misma y sus prácticas mediante formas simbólicas que reproducen, legitiman y perpetúan dichas prácticas y organizaciones. Dicha concepción de la ideología es neutra en cuanto a su valoración y se limita a explicar cómo una comunidad dada produce conocimiento y se relaciona con la realidad social. Es la que corresponde a términos parecidos de la sociología del conocimiento y la psicología social como «imaginario», «representaciones sociales» o «marcos cognitivos» (Pujante Sánchez y Morales López, 2013: 34).

La segunda tradición se atiene al sentido marxiano de ideología como el modo en que las clases dominantes imponen las ideas que legitiman sus intereses y posición de poder al resto de la sociedad (Stoddart, 2007: 195). Esta línea de análisis se centra en explicar por qué aquellos individuos que carecen den poder aceptan estas jerarquías y desigualdades (Stoddart, 2007: 192), y si los autores que la siguen coinciden más o menos en entender la ideología como aquel proceso epistemológico o discursivo por el cual se legitiman las estructuras de dominación y desigualdad, difieren enormemente en cómo esto se produce. La teoría original de Marx, sobre todo a través de la interpretación de Friedrich Engels, hace hincapié en la ideología como una mistificación, una «falsa conciencia» que impide ver a la clase obrera la realidad social “tal cual es”, esto es, les impide ser conscientes de su explotación o de que este orden social podría ser de otro modo (Stoddart, 2007: 196). Pero muchos teóricos de la ideología difieren en cómo entender la noción de una «falsa conciencia»; concretamente, cuestionan que el criterio para definir un enunciado como ideológico sea el de la veracidad o falsedad de sus proposiciones, su adecuación a la realidad: un enunciado puede ser "objetivamente" verdadero, pero funcionar ideológicamente en tanto que se usa para legitimar una relación de poder (Eagleton, 1997: 30-39; Žižek, 2003: 15).

En general, el mayor problema epistemológico que plantea una teoría crítica de la ideología es que explícita o implícitamente postula un lugar no-ideológico desde el que juzgar si un enunciado o una práctica concreta es ideológica o no, si mistifica o no la realidad (Žižek, 2003: 9; ver Ricoeur, 2001) - esta cuestión es muy relevante para nuestro trabajo, puesto que, como hemos visto, muchas veces se plantea el discurso humorístico 
como ese modo privilegiado de conocimiento absolutamente objetivo, y, como defendemos, esta posición es absolutamente ideológica. Como vimos en el capítulo anterior, existe en la cultura contemporánea un cierto clima anti-ideológico y cínico, en el que como todo es ideológico y es imposible escapar de la ideología, toda ideología es válida, y al mismo tiempo es imperioso (y un rasgo de superioridad intelectual) ver la realidad “tal cual es” sin ninguna distorsión:

La forma de conciencia que se adecúa a la sociedad "postideológica” capitalista tardía la actitud “sobria”, cínica, que aboga por la “apertura” liberal en cuestión de “opiniones” (todos somos libres de creer lo que queramos; esto únicamente incumbe a nuestra privacidad) - pasa por alto las frases ideológicas emocionantes y sólo sigue motivaciones utilitarias y/o hedonísticas. En sentido estricto, sigue siendo una actitud ideológica: implica una serie de presupuestos ideológicos (sobre la relación entre los “valores” y la “vida real”, sobre la libertad personal, etc.) que son necesarios para la reproducción de las relaciones sociales existentes (Žižek, 2003: 24)

Para Žižek y otros teóricos, aunque sea correcto afirmar que cualquier posición es ideológica, que no hay un punto de vista extra-ideológico, extra-social o extra-lingüístico en el que juzgar el resto de posiciones como ideológicas, es necesario mantener la tensión inherente a la crítica ideológica: la ideología, según Žižek, no reside en una ilusión mistificadora ni en la idea igualmente ilusoria de una realidad no-ideológica, sino precisamente en la tensión entre ambas posiciones (2003: 28-29) ${ }^{7}$.

Realmente, esta postura no difiere de la asumida por la Retórica en su sentido originario, en cuanto arte de la persuasión y la polémica. Si la Retórica se presenta como herramienta de producción de discursos capaces de persuadir y convencer a los conciudadanos de una determinada posición es porque se presupone que existen al menos dos perspectivas o puntos de vista respecto al asunto del que se trata el discurso, y, lejos de dar ambos por válidos, se trata de elegir uno de ellos como preferible (Pujante Sánchez, 2003a: 80). La verdad retórica, como defiende Burke, surge de esta polémica; el pensamiento retórico presupone esta tensión entre diferentes puntos de vista. Que el sentido de un discurso es siempre polémico es algo que también asegura Michael Billig cuando afirma que pensar es discutir, aunque sea imaginariamente, con otros puntos de

\footnotetext{
${ }^{7}$ La teoría lacaniana de Žižek del fantasma ideológico como "resto" de lo Real, como retorno de lo reprimido ideológicamente (Žižek, 2011, 2018), será de mucha utilidad para nuestro análisis del tratamiento de la masculinidad en la comedia televisiva Friends.
} 
vista (Billig, 1996). También es la postura que defiende Bajtín cuando define el lenguaje en términos de diálogo social, o Voloshinov al hablar del signo ideológico como multiacentuado: como cada signo es común a varios grupos sociales con intereses distintos y estos intereses se sedimentan en la palabra, «en cada signo ideológico se cruzan los acentos de orientaciones diversas. El signo llega a ser la arena de la lucha de clases» (Voloshinov, 2009: 50) $)^{8}$.

En esta línea, nos interesa la noción de «hegemonía» acuñada por el teórico italiano Antonio Gramsci, como el modo en que las clases dominantes llegan a persuadir a las subalternas de adoptar los modos de vida que benefician a aquellos. Más que un corpus coherente y explícito de ideas, la hegemonía está más relacionada con el sentido común como conjunto difuso de ideas y prácticas que guían inadvertidamente nuestra vida cotidiana (Stoddart, 2007: 202). Sobre todo, para Gramsci la hegemonía es el resultado de luchas de poder entre las élites y las clases subalternas, por lo que nunca llega a ser un sistema cerrado y totalizador: «whereas ideology connotes closure and a unidirectonal flow of power, hegemony emphasizes the inherent conflict involved in constructing getworks of power through knowledge» (Stoddart, 2007: 193). Del mismo modo, en la concepción de Foucault del poder no como algo que una superestructura como el Estado ejerce de arriba abajo, sino como una red microscópica de relaciones que recorren toda la sociedad, esto permite aparecer oposiciones y resistencias a lo largo de toda esta red: por tanto, el establecimiento del poder no es algo homogéneo y estable sino que encuentra resistencias e inversiones a lo largo de todo el cuerpo social (Stoddart, 2007: 205), por lo que toda relación de dominación posibilita su subversión.

Una cuestión particularmente interesante para este trabajo es el de la relación de la ideologíca con la subjetividad y la identidad, es decir, el papel que la ideología tiene en la constitución de los individuos. Uno de los primeros teóricos en plantear esta relación fue Louis Althusser con su noción de «interpelación» expuesta en su famoso trabajo «Ideología y Aparatos Ideológicas del Estado». Allí, sustituye la definición clásica de ideología como falsa representación por la de «relación imaginaria de los individuos con sus condiciones reales de existencia» (Althusser, 2003: 139) - entendiendo el adjetivo

\footnotetext{
${ }^{8}$ La idea del sentido como conflicto también la encontramos, en última instancia, en el principio analítico de la deconstrucción, del psicoanálisis como desvelamiento de lo reprimido del texto del inconsciente, o de la hermenéutica en tanto que el arte de la interpretación nace precisamente del encuentro con lo incomprensible del sentido (ver Cuesta Abad, 1997)
} 
«imaginaria» no en el sentido de ilusorio sino en el lacaniano de méconnaissance o falso reconocimiento (Žižek, 2018: 25). La ideología, por tanto, no consiste tanto en un cierto contenido cognitivo, sino en la manera que tienen los individuos de vivir su relación con la sociedad. En este sentido, su función principal es la constitución de sujetos como tales sujetos ideológicos mediante lo que Althusser llama «interpelación» (Althusser, 2003: 145-147): los individuos solo son capaces de considerarse como tales al reconocerse en la posición que el sistema ideológico les asigna previamente: la ideología interpela, "llama" al individuo, que solo responde a esta llamada porque ya se reconoce en la posición a la que la ideología le interpela (Althusser, 2003: 147): «ya antes de nacer el niño es por lo tanto siempre-ya sujeto, está destinado a serlo en y por la configuración ideológica familiar específica en la cual es “esperado” después de haber sido concebido (...) El antiguo futuro-sujeto debe “encontrar” "su” lugar, es decir “devenir” el sujeto sexual (varón o niña) que ya es por anticipado» (Athusser, 2003: 148-149).

Otra de las teorizaciones más relevantes acerca de la constitución social de los sujetos es, por supuesto, la que ofrece Michel Foucault a partir de su noción de «sociedad disciplinaria»:

En nuestra sociedad existe algo que podríamos llamar poder disciplinario (...) cierta forma terminal, capilar del poder, un último relevo, una modalidad mediante la cual el poder político y los poderes en general logran (...) tocar los cuerpos, aferrarse a ellos, tomar en cuenta los gestos, los comportamientos, los hábitos, las palabras; la manera, en síntesis, como todos esos poderes, al concentrarse en el descenso hacia los propios cuerpos y tocarlos, trabajan, modifican, y dirigen lo que Servan llamaba "las fibras blandas del cerebro" (Foucault, 2005: 51)

Según el filósofo francés, en la sociedad moderna y contemporánea se habría producido una sustitución de un poder de soberanía, propio de las monarquías feudales, por un poder disciplinario. Si el poder de soberanía funcionaba por sustracción (de productos, cosechas, objetos, armas, fuerza de trabajo), se legitimaba por referencia a una “anterioridad fundadora” (una conquista, una rendición, una promesa de fidelidad, un nacimiento o un derecho de sangre) mantenida con la amenaza de violencia bruta (Foucault, 2005: 53-54), el poder disciplinario no se encarga solo de sustraer ciertos productos o unidades de tiempo, sino que consiste en una captura total y exhaustiva del cuerpo, los gestos, el uso del tiempo, el comportamiento: «El poder disciplinario no es discontinuo; implica, al contrario, un procedimiento de control constante (...) se refiere a 
un estado terminal u óptimo. Mira hacia el porvenir, hacia el momento en que todo funcione por sí solo (...) cuando la disciplina se haya convertido en un hábito» (Foucault, 2005: 58). Los mecanismos y procedimientos que caracterizan a este poder fueron analizados y descritos por Foucault en su Vigilar y Castigar (Foucault, 2009c). Lo que a nosotros nos interesa especialmente de su reflexión en este momento es que el poder disciplinario constituye un poder de normalización, que opera produciendo y clasificando subjetividades y sujetos dóciles que faciliten la gobernanza y la producción económica.

En el esquema de Foucault, el poder de soberanía no se aplicaba a los cuerpos individuales (2005: 55); el nacimiento del sujeto individual como hoy lo entendemos se debe a la emergencia de este poder disciplinario: por un lado, inventando un "alma”, origen no de los actos punibles y de los comportamientos, sino de la voluntad, de la actitud, de la disposición (Foucault, 2005: 63); por otra parte, el sistema de clasificación y distribución de individuos que lleva a cabo el sistema disciplinario para optimizar su funcionamiento «implica necesariamente un residuo: siempre hay, entonces, algo «inclasificable»” (Foucault, 2005: 64) que hay que recuperar: «El poder disciplinario tiene la doble propiedad de ser anomizante, es decir, de poner siempre a distancia a una serie de individuos, exponer la anomia, lo irreductible, y de ser siempre normalizador, inventar siempre nuevos sistemas de recuperación, restablecer siempre la regla» (Foucault, 2005: 66; Foucault, 2001).

El poder disciplinario, por tanto, es un poder normalizador porque opera estableciendo series de normalidades o sujetos normales y corrigiendo a los sujetos que se escapaban de esa norma (delincuentes, homosexuales, enfermos mentales, etc.). Es así como es posible la emergencia del individuo, un individuo cuya normalidad siempre se establece, en realidad, sobre el fondo de la anormalidad:

No se puede decir que el individuo preexiste a la función sujeto, a la proyección de una psique, a la instancia normalizadora. Al contrario, el individuo apareció dentro de un sistema político porque la singularidad somática, en virtud de los mecanismos disciplinarios, se convirtió en portadora de la función sujeto (...) Debido a que el cuerpo fue «subjetivizado» - esto es, la función sujeto se fijó en él-, a que fue psicologizado, a que fue normalizado, resultó posible la aparición del individuo (...) el individuo es, desde el comienzo y por obra de esos mecanismos, sujeto normal, sujeto psicológicamente normal (Foucault, 2005: 67-68) 
Althusser, además, considera que la ideología tiene una existencia material en el sentido de que un sujeto ideológico tiene ciertos comportamientos y realiza ciertas prácticas reguladas por los Aparatos Ideológicos del Estado (es decir, las instituciones) que reproducen dicha ideología (Althusser, 2003: 141-142). Es decir, que un cristiano, por ejemplo, materializa su ideología en las prácticas asociadas al cristianismo, como ir a misa, dar limosna, sostener una cierta moral... El teórico francés toma esta idea crucial de Pascal, según el cual alguien que quiera creer en Dios puede empezar a actuar como si creyera hasta que haya interiorizado la creencia (Althusser, 2003: 143). La materialidad y la exterioridad de la creencia ideológica es también un rasgo fundamental de la caracterización de Žižek de la ideología: «la creencia, lejos de ser un estado “íntimo”, puramente mental, se materializa siempre en nuestra actividad social efectiva: la creencia sostiene la fantasía que regula la realidad social» (Žižek, 2018: 64); la ideología, así, no es un conjunto subjetivo de creencias sino una «máquina», que funciona según el «automatismo del significante», la «red simbólica en la que están atrapados los sujetos» (Žižek, 2018: 65) - en este sentido podemos entender la teorización que Zupancic hace de la materialidad de lo cómico [3.1.6].

Esta materialización de la sujeción ideológica en sus prácticas nos remite a la noción de la subjetividad como actuación, en el sentido de que un individuo se identifica con una cierta posición de sujeto mediante ciertos comportamientos, actitudes, etc. - lo que, como veremos [5.3, 6.1.5, 7.2, 7.3.4], se relaciona con la idea de la identidad como performance. Esta noción, teorizada por sociólogos como Goffman (Goffman, 2009), la encontramos en el concepto de habitus de Pierre Bourdieu, que lo define como «sistema de disposiciones», es decir, como actitudes, comportamientos y elecciones aprendidas y automatizadas por los individuos por medio de su socialización (Bourdieu, 2007: 86). La noción de habitus, según su creador, permite un acercamiento a las prácticas sociales que escapa tanto del objetivimos radical de la estructura, que deterimna por entero y desde fuera las acciones de los individuos, y el subjetivismo espontaneísta, que explica las acciones de los sujetos como planes racionales motivados espontáneamente:

El habitus es una capacidad infinita de engendrar, con total libertad (controlada), unos productos - pensamientos, percepciones, expresiones, acciones - que siempre tienen como límite las condiciones histórica y socialmente situadas de su producción, la libertad condicionada y condicional que él asegura está tan alejada de una creación de novedad 
imprevisible como de una simple reproducción mecánica de los condicionamientos iniciales (Bourdieu, 2007: 90)

De este modo, el habitus es una manera de incorporación de las instituciones en los individuos: «la virtud de la incorporación, que explota la capacidad del cuerpo para tomarse en serio la magia performativa de lo social, es lo que hace que el rey, el banquero, el sacerdote sean la monarquía hereditaria, el capitalismo financiero o la Iglesia hechos hombre» (Bourdieu, 2007: 93). El habitus, por tanto, de una manera parecida a la interpelación ideológica, constituye a los individuos según ciertas posiciones sociales preestablecidas:

El proceso puramente social y cuasi mágico de socialización, inaugurado por el acto de marcación que instituye a un individuo como el primogénito, heredero, sucesor, cristiano, o simplemente como hombre (por oposición a la mujer), con todos los privilegio sy todas las obligaciones correlativas, y prolongado, reforzado, confirmado por los tratamiento sociales apropiados para transformar la diferencia de institución en distinción naturales, produce efectos muy reales, puesto que se encuentran perdurablemente inscritos en el cuerpo y en la creencia (Bourdieu, 2007: 93)

El habitus, como decimos, supone una in-corporación en un sentido literal, como algo que afecta principalmente al cuerpo del individuo. En este sentido, también la disciplina foucaultiana funciona inculcando en el cuerpo del sujeto una serie de gestos, comportamientos, habilidades, etc. Este enfoque, en suma, señala la materialidad de la ideología, así como sus efectos reales sobre los cuerpos. La ideología es, así, una interiorización de la exterioridad, lo que explica, por un lado, que los sujetos no puedan ser fuera de la ideología, y, por otro, que al mismo tiempo los individuos perciban los mandatos ideológicos como algo ajeno a ellos. Como veremos [6.1.5], en este enfoque se apoyará Judith Butler para formular su teoría de la sujeción a la identidad de género y, en general, nos servirá para entender tanto el género como la identidad como productos ideológicos, siendo el centro de nuestros análisis tanto de las novelas de Eduardo Mendicutti como en la comedia televisiva Friends. En el caso concreto de Friends, veremos cómo sus protagonistas perciben la masculinidad como algo ajeno a lo que aspirar, fantasías ideológicas que llegan incluso a materializarse amenazadoramente [6.1.5]. En este sentido, más que apoyarse en las teorías de Althusser o Žižek, los análisis del tratamiento cómico de ciertos fenómenos ideológicos como la masculinidad nos permitirán profundizar en las relaciones entre ideología y subjetividad. 


\subsection{La Retórica Constructivista}

Todas estas tendencias que consideran el carácter de constructo social del conocimiento y hacen hincapié en el papel inevitable del lenguaje en la regulación de la sociedad y las prácticas que la definen vienen a confluir en la propuesta teórica que tomamos como marco en nuestro trabajo, la Retórica Constructivista (Pujante Sánchez y Morales-López, 2013; Pujante Sánchez, 2016, 2018), que es también el marco en el que se ha desarrollado la actividad de los investigadores involucrados en los proyectos «RECDID (Retórica Constructivista y Discursos de la identidad)» y «La construcción discursiva del conflicto: territorialidad, imagen de la enfermedad e identidades de género en la literatura y en la comunicación social». Desde esta perspectiva, los discursos son considerados como «propuestas discursivas ideológicas con las que los actores pretenden construir una determinada visión del mundo, conseguir así la adhesión del ciudadano al proyecto político propio y provocar cambios reales en las instituciones» (Pujante Sánchez y Morales-López, 2013: 33-34). Es decir, no solo se entiende, desde una perspectiva constructivista, que el significado «emerge en las prácticas comunicativas como una construcción negociada» (Morales López, 2013) y que por tanto «es inseparable de la selección intencionada que realiza el agente de las prácticas comunicativas; inseparable de la acción humana y del contexto en el que se insertan tales prácticas; así como de las construcciones cognitivas de los actores sociales» (Pujante Sánchez y Morales-López, 2013: 34); la Retórica Constructivista también propone, desde una perspectiva retórica, que los discursos en los que estos significados aparecen se construyen «con la finalidad de llevar persuasivamente a la sociedad hacia acuerdos eficaces para los problemas con que se encuentra en cada momento de su historia» (Pujante Sánchez y Morales-López, 2013: 37).

\subsubsection{Retórica y construcción de significado. La recuperación de la elocutio como operación fundamental del discurso.}

Además del interés ya reseñado que ciertos filósofos mostraron por la Retórica a lo largo del siglo XX, podemos hablar de tres fases en la progresiva recuperación de la disciplina en este siglo (Pujante Sánchez, 2017: 49). En una primera fase podemos contar con la magna recopilación de Heinrich Lausberg del reservorio retórico clásico, si bien hay que 
tener en cuenta que llevó a cabo esta tarea desde una perspectiva puramente arqueológica y sin ánimo de adaptar todo ese saber a la situación contemporánea (Pujante Sánchez, 2003a: 326-327). Asimismo cabe dar cuenta del proyecto de una Retórica General elaborado por el Grupo $\mu$ y que constituye el resultado lógico del interés que la teoría literaria de orientación formalista mostró por los mecanismos del lenguaje literario; aunque dicho proyecto se centró exclusivamente en la doctrina de los tropos y lo figuras, desatendiendo por completo el resto de operaciones que hacían de la Retórica una teoría textual completa (Pujante Sánchez, 2016: 32).

Una segunda fase de los estudios retóricos permitió recuperar el aparato teórico completo de la Retórica, recuperando las operaciones de la inventio y la dispositio. En este sentido, un gigantesco aporte fue el de Perelman y su teoría de la argumentación (Perelman y Tytteca, 2006), mediante la cual buscaba recuperar el sentido de la Retórica aristotélica y sistematizar los diversos modos de argumentar y convencer mediante razones basadas en conocimientos y opiniones compartidas - lo que denominó lugares de argumentación. De este modo, recuperaba la dimensión de la Retórica que iba más allá del mero repertorio de tropos y figuras con los que embellecer el lenguaje. En esta línea, y en el ámbito académico español, es imprescindible tener en cuenta el proyecto de García Berrio (1984) y su discípulo Tomás Albaladejo (1989) de construir, en alianza con la por entonces pujante lingüística del texto, una Retórica genuinamente General como «ciencia de la expresividad del lenguaje», es decir, como marco teórico que abarcara todos los procedimientos mediante los que el lenguaje podía cumplir sus fines estéticos o persuasivos (Pujante Sánchez, 2016: 32-33). El profesor Albaladejo ha desarrollado en los últimos años el proyecto de una Retórica Cultural (Albaladejo, 2013, 2016), marbete bajo el cual se pretende analizar las mutuas interrelaciones entre estos dos términos, considerando el papel que los discursos retóricos (y los literarios y artísticos) tienen en la cultura y cómo esta influye a su vez en la retórica, tanto en el nivel de contenido, como el de su producción y recepción. En esta dirección, el profesor Albaladejo ha acuñado herramientas teóricas muy eficientes, como el análisis interdiscursivo (Albaladejo, 2005, 2011b, 2011a) o la poliacroasis, término con el que se refiere a la multiplicidad de receptores diferentes que puede tener un mismo discurso (Albaladejo, 2012), algo especialmente relevante en el contexto de los actuales medios de comunicación digitales y redes sociales. 
Es la tercera fase de esta recuperación de la Retórica la que protagoniza la Retórica Constructivista al recuperar los fundamentos epistemológicos y ontológicos originales de esta, esto es, no solo como herramienta más o menos eficaz de producción y análisis de discursos públicos, sino como constructora de conocimiento:

Rhetorical-discursive construction is not a pure technique for making speeches of social persuasion (if this technique is considered to be something alien to the construction of meaning), instead, and on the contrary, the key to interpreting the world and our relationship with the world in which we live lies in discursive construction (Pujante, 2017: 50)

Para ello, es necesario que la Retórica Constructivista restituya el papel esencial de la elocutio, del nivel formal y más propiamente lingüístico del discurso, no como añadido ornamental sino como mecanismo interpretativo presente en todo el proceso de conocimiento (Pujante Sánchez, 2017: 51). En este sentido, David Pujante ha insistido en que los tratadistas clásicos, con Quintiliano a la cabeza, consideraban indisoluble la relación entre la elocutio y las otras dos operaciones constructoras del discurso, la inventio y la dispositio, entre res y verba, fondo y forma. La producción efectiva del discurso, su puesta en palabras, no puede ser considerada como un paso posterior al diseño temático y argumentativo del mismo; estos tres procesos no se dan en sucesión lineal sino simultánea, porque, si solo podemos pensar y conocer mediante el lenguaje, ya la inventio y la dispositio se dan lingüísticamente:

Constructivist rhetoric requires that the third rhetorical operation be the basis for the construction of discourse, and that tropological and figurative mechanics be considered as the interpreters for relationships between the elements of the world referred to in the discourse, in asmuch as the subject producing the discourse is able to find and establish these relationships (Pujante Sánchez, 2017: 51)

David Pujante se apoya, entre otros pensadores, en la teoría de Hayden White que, como vimos, considera que solo podemos pensar tropológicamente, es decir, que nuestra ordenación del mundo previa a todo conocimiento consciente se da en forma de metáforas, metonimias, antítesis, etc. (Pujante Sánchez, 2018). Idea que también podemos encontrar, por ejemplo, en la noción de metáfora conceptual de Lakoff y Johnson (1986) y en general en la obra de los filósofos como Paul Ricoeur (1980) y lingüistas, psicólogos, etc., que consideran que la metáfora y la analogía son los mecanismos básicos de producción de conocimiento. 
Sara Molpeceres, por ejemplo, ha mostrado que el discurso mítico, lejos de ser un pensamiento pre-filosófico y pre-científico de los pueblos primitivos, opera en nuestras sociedades discursivas como potente vehículo de conocimiento e ideologías (Molpeceres Arnáiz, 2013a, 2014). Y Víctor Gutiérrez, en su tesis doctoral, ha aplicado la teoría tropológica de Hayden White y la teoría de la argumentación de Perelman al análisis de la construcción de personajes malvados en la prensa y la literatura actuales (GutiérrezSanz, 2019). En el capítulo dedicado al análisis de la recepción académica de la novela de Eduardo Mendicutti Una mala noche la tiene cualquiera, podremos comprobar cómo las metáforas asociadas al discurso humorístico en términos de superficie, espectáculo, simulacro, etc. (que, como vimos, provienen de las obras de Debord, Jameson y Baudrillard entre otros), afectan al modo en que se interpreta la novela y conceptualiza la identidad trans del personaje [6.2.5]. Y, por supuesto, en el capítulo siguiente propondremos un acercamiento a la estructura tropológica de la ironía y sus posibles consecuencias retóricas y hermenéuticas [5.1].

La Retórica Constructivista, en resumen, considera la dimensión elocutiva, formal, figurativa y tropológica del discurso como elemento fundamental de construcción del significado. Pero, y en este sentido no nos alejamos de la concepción expuesta anteriormente del lenguaje como acción social dialógica, al situar el discurso en un contexto de construcción intersubjetiva y orientada a fines sociales del significado, esta construcción tropológica está siempre determinada por la situación e intereses que mueven a los diferentes actores discursivos. Como remarca David Pujante en la cita anterior, no hay ninguna razón para distinguir la construcción del significado de los objetivos persuasivos de la palabra.

\subsubsection{Retórica y Hermenéutica. La dispositio como operación interpretativa.}

La Retórica Constructivista, en estos términos, guarda estrechas relaciones, en niveles metodológicos, epistémicos y ontológicos, con la Hermenéutica. También, por supuesto, en un sentido histórico, ambas disciplinas han estado siempre estrechamente ligadas (ver Gadamer, 1998: 267-282). La Hermenéutica, como arte de la interpretación de textos, depende en gran medida de otras ciencias del lenguaje como la gramática, la poética y la retórica (Cuesta Abad, 1997: 9) y de sus instrumentos formales; teniendo en cuenta que 
la Retórica se concibe tanto como la técnica de producción de discursos como la ciencia de su análisis (Albaladejo, 1989), es claro que puede servir de base formal para la interpretación de dichos textos, por lo que podemos hablar de la Hermenéutica como una «Retórica de la Interpretación» (Cuesta Abad, 1997: 20). En tanto que ciencias del discurso, la Retórica y la Hermenéutica son las dos caras de la misma moneda. Es en este sentido que decimos que en este trabajo adoptamos una perspectiva retóricohermenéutica.

Pero, además, ambas disciplinas aparecen vinculadas en un nivel epistemológico y ontológico en cuanto que la Retórica Constructivista entiende, como hemos visto, que interpretamos discursivamente la realidad social, que solo conocemos la realidad lingüística, tropológicamente. En este sentido, nociones básicas de la Hermenéutica, en especial en su versión gadameriana, como «círculo hermenéutico», «precomprensión», «horizonte de sentido», etc., son fundamentales para nuestra perspectiva: si interpretamos nuestra realidad discursivamente, lo hacemos siempre desde nuestro propio horizonte de expectativas (o, en términos sociocognitivos, desde nuestros marcos cognitivos, nuestra ideología, o nuestra comunidad interpretativa). Como hemos dicho anteriormente, la Retórica parte de la presuposición de que no hay conocimientos claros y objetivos, que todo asunto se puede pensar desde varios puntos de vista, es decir, que se pueden hacer varias interpretaciones de él. Como insiste David Pujante, el discurso retórico no es una mera técnica de poner en discurso una perspectiva para convencer a los demás, sino que el primero que tiene “convencerse” a sí mismo es el orador, que en primer lugar interpreta la realidad desde su posición discursiva:

La construcción retórico-discursiva no es una pura técnica de hacer discursos de persuasión social (entendida dicha técnica como algo ajeno a la construcción del significado); sino que, muy por el contrario, en la construcción discursiva está la clave de interpretación del mundo y de nuestra relación con ese mundo. El proceso de construcción discursivo-retórica y su culminación, por tanto, nos permite tomar conciencia de nuestras vivencias, personales y sociales. Y esa toma de conciencia es la visión de la realidad del sujeto, realidad que se construye en el discurso (Pujante Sánchez, 2018: 13)

A este respecto, es útil tener en cuenta la compleja posición de la segunda de las operaciones retóricas, la dispositio, en el conjunto del proceso de construcción discursiva. Si la inventio es la operación que “descubre” los materiales del discurso, las ideas y argumentos que tenemos a nuestra disposición, la dispositio es la operación que ordena 
dichos materiales de manera coherente y convincente; lo relevante es que la misma necesidad de ordenar implica que dichas ideas y materiales no se presentan de una manera clara y evidente en la realidad externa al discurso y necesita una operación interpretativa: «If the referential world offered us a clear design o reality, there would be no need for rhetorical discourse (...) The order of the world is not given; it is determined by us. Interpretation requires a specific design, order and arrangement of ideas, creating an indisoluble link between inventio and dispositio» (Pujante Sánchez, 2003b: 170). La misma operación de inventio presupone un «orden intuitivo» nacido del sentido de común (Pujante Sánchez, 2003a: 331) (que, como hemos visto, está lejos de ser “objetivo”). Si tenemos en cuenta que en la teoría retórica se contemplan dos aspectos de este ordenamiento, el orden natural y el orden retórico orientado a la persuasión, podemos decir que toda interpretación está desde el principio orientada al objetivo de la persuasión, toda interpretación está orientada siempre al diálogo, como afirma Bajtín. Además, la dispositio también interviene en la ordenación de la verba, del material lingüístico (Pujante Sánchez, 2003a: 338), lo que reafirma el presupuesto de la Retórica Constructivista de la indisoluble vinculación entre fondo y forma, entre conocimiento y lenguaje. En resumen, para la Retórica Constructivista, todo discurso es interpretativo, y solo podemos conocer la realidad y relacionarnos con ella de manera discursiva y mediante la interpretación:

Creamos discursos (...) para aclarar un lugar de la realidad (...) para engarzar en un hilo significativo un conjunto de hechos que en su referente aparecen confusos para nosotros. Nada entendemos del mundo los humanos sin discursos. $\mathrm{Y}$ nuestras personales construcciones discursivas (interpretación de los diferentes lugares del mundo que observamos o transitamos), cuando las dirigimos a los demás, con el ánimo de participarles y a la vez persuadirlos de nuestras conclusiones interpretativas, se convierten en discursos retóricos. El discurso retórico (...) es el traslado a terceros de un discurso de interpretación personal sobre alguna faceta de la realidad con la finalidad de persuadirlos de su inmejorabilidad interpretativa (Pujante Sánchez, 2003a: 333)

Esta íntima vinculación entre Retórica y Hermenéutica, entre discurso e interpretación, implica, además, no solo que toda retórica es hermenéutica, sino que toda hermenéutica es retórica, que toda interpretación es un discurso retórico, por tanto mediado lingüísticamente y dirigido a un tercero al que se intenta persuadir. En este sentido, Stanley Fish defiende que las diferentes interpretaciones no se valoran según criterios de 
veracidad y objetividad, sino de mayor o menor fuerza retórica, mayor o menor capacidad de convencer a una cierta comunidad interpretativa de la idoneidad de una interpretación concreta (Fish, 1992). Esto implica, también, que no existen interpretaciones como meras “lecturas desinteresadas” de textos, que solo buscan descifrar "la verdad del texto” o la “intención del autor”, sino que toda interpretación está orientada y determinada por ciertos fines e intereses que son, en última instancia, ideológicos. Como afirma Richard Rorty, no existe la diferencia entre interpretar un texto y usarlo: todo uso depende de una cierta interpretación, y toda interpretación sirve a un cierto uso de un texto (Rorty, 2013).

Para nuestro trabajo, esta discusión significa entender que el discurso humorístico, como todo discurso, es un discurso interpretativo, y que por tanto depende de los marcos cognitivos, imaginarios, representaciones sociales, ideologías, etc., del productor de dicho discurso. Pero, a su vez, la recepción de un discurso humorístico depende también de una interpretación, y por tanto dependerá de las expectativas del receptor, pero también de sus intereses - del uso que le quiera dar. En nuestro análisis de las novelas de Eduardo Mendicutti comprobaremos cómo las diferencias entre las interpretaciones que se les han dado dependen de los distintos presupuestos e intereses ideológicos con los que los críticos se han acercado a ellas. Además, partimos de la idea de que el discurso humorístico es, como todo discurso, ideológico, pero de una manera especial, cercana al discurso artístico, lo que muchas veces se presta a una mayor ambigüedad interpretativa, como defenderemos en nuestro análisis de la comedia Friends. Por último, la manera en que la producción e interpretación de discursos humorísticos son procesos ideológicos y, concretamente el hecho de que existen diferentes maneras de concebir esta relación entre el humor y la ideología y por tanto diferentes maneras de producir y recibir discursos humorísticos, tiene consecuencias sociales y en última instancia políticas que determinan un cierto orden del discurso humorístico, la manera en que estos discursos circulan y se reciben mediáticamente y se convierten en centros de discusiones políticas e ideológicas, como estudiaremos en el último capítulo de este trabajo.

\subsubsection{Retórica y emociones. Persuadir para convencer.}

Otro de los puntos en que la Retórica Constructivista y la tradición en la que se inserta rompe con la tradición racionalista y logocéntrica occidental es en el papel que las emociones tienen en el conocimiento. Como hemos visto, el rechazo filosófico a lo 
retórico ha tenido que ver con el uso de las emociones para manipular a las masas por parte de esta; un rechazo que tiene como base la oposición entre convencer mediante argumentos racionales y persuadir mediante artimañas emocionales. Como hemos visto también, Aristóteles mantuvo una distinción entre la lógica racional y el ámbito de la Retórica, que era el de la doxa, la verosimilitud y la emotividad.

La tradición retórica, por el contrario, ha contemplado desde sus inicios el papel de las emociones, distinguiendo las funciones argumentativas y emocionales («psicagógicas», «conductora de almas») del discurso (Pujante Sánchez, 2003a: 37; Martín Jiménez, 2014: 57). De este modo, la tradición retórica presenta un completo y minucioso estudio de las emociones y su papel en el discurso persuasivo. Aristóteles, por ejemplo, analizó la amplia variedad de emociones que podía suscitar el orador en su auditorio; distinguió tres aspectos del discurso, el ethos, el pathos, y el logos; además del importante papel que le otorgaba a la catarsis en la Poética (Martín Jiménez, 2014: 59). Tanto Cicerón como Quintiliano insistieron en la gran importancia que tenía que el orador fuera capaz de identificarse emocionalmente con el oyente, y enumeraron los tres fines que tenía el discurso: docere (enseñar), movere (conmover) y delectare (deleitar) (Martín Jiménez, 2014: 59). Los tratados también contemplaban la función emocional que podían tener las distintas figuras y tropos (Martín Jiménez, 2014: 64). La distinción entre las funciones racionales y emotivas del discurso podría llevarnos a considerar que efectivamente son dos aspectos nítidamente diferenciables y que en todo caso las emociones son una herramienta auxiliar a la argumentación racional, cuando no una artimaña moralmente reprobable. Sin embargo, como vimos, la biología y la neurociencia actuales han insistido en el papel cognitivo que tienen las emociones, defendiendo la concepción de una cognición corporeizada. La obra del neurocientífico Antonio Damasio ha explicado cómo la razón y la emoción van indisolublemente unidas, hasta el punto de que no puede existir razón sin emoción (Damasio, 2018a, 2018b).

En esta misma línea, resulta muy interesante la recuperación que hace Hans R. Jauss del placer como categoría estética y hermenéutica. Por ejemplo, rechaza la distinción que realiza la teoría marxista que sigue a la Escuela de Frankfurt entre un arte “verdadero” solo válido para la reflexión racional, y la producción de los mass media y la industria cultural que aliena a los individuos mediante el consumo por el mero placer (Jauss, 1986: 25), y continúa la interpretación freudiana del arte como un modo de identificación catártica (Jauss, 1986: 74-75), Según Jauss, la distinción entre el placer y 
el juicio estético viene en última instancia del Clasicismo y sobre todo de la filosofía kantiana, y supone una ruptura con toda la tradición antigua y medieval que conciben la unión entre placer y utilidad, tanto en la doctrina poética como la retórica (Jauss, 1986: 60):

Si, en otro tiempo, el verbo «disfrutar» justificaba la relación con el arte, primero como forma de apropiación del mundo y de autorratificación, y, más tarde, como concepto histórico-filosófico y psicoanalítico, hoy se considera genuina sólo aquella experiencia estética que ha dejado tras de sí todo el placer y se ha elevado al grado de reflexión estética (...) [Para Adorno y sus seguidores,] quien no es capaz de desprenderse del gusto placentero del arte, lo equipara al placer gastronómico o al pornográfico (...) El placer en el arte no es sino una reacción burguesa a la espiritualización del arte y, con ello, el presupuesto para la industria cultural del presente, que, en el círculo más cerrado de necesidades dirigidas y de sucedáneos de la satisfacción estética, está al servicio de ocultos intereses de poder (Jauss, 1986: 66-67)

Jauss, por el contrario, defiende la capacidad comunicativa del placer estético, basado en propuestas de imitación, reconocimiento e identificación (1986: 70) tal y como se recoge en el concepto aristotélico de mimesis. El teórico alemán distingue tres lugares de placer estético: la poiesis o el placer de la misma creación estética, que corresponde a la noción hegeliana de la creación como un situarse en el mundo y apropiarse de él; la aisthesis, que señala la idea aristotélica del placer de la imitación y también se puede relacionar con la contemplación desinteresada de Kant o los procedimientos de desautomatización de los formalistas rusos; y la catarsis, las emociones provocadas por el discurso poético o el retórico, que llevan a una liberación del ánimo pero también a un cambio de convicciones (Jauss, 1986: 75). La catarsis, por tanto, es el aspecto del arte que cumple su función comunicativa y social (Jauss, 1986: 76, 159). En el siguiente capítulo exploraremos las ideas de Jauss en torno al tipo de conocimiento y emociones que involucra la experiencia estética y su posible relevancia para el análisis de los discursos humorísticos.

Otras ramas de investigación han señalado el papel comunicativo de las emociones, y sobre todo cómo pueden servir a los procesos de formación ideológica. Althusser, por ejemplo, entiende la ideología no como un sistema de creencias cognitivas, sino más bien como las relaciones afectivas inconscientes del individuo con las posiciones de sujeto que les ofrece el entramado simbólico, en sentido lacaniano, de una sociedad (Eagleton, 1997: 40). En esta línea, las propuestas más interesantes son las que pertenecen 
al llamado giro afectivo, cuyas autoras más representativas son Laurent Berlant, Ann Cvetkovich, Eve K. Sedgwick o Sara Ahmed - autoras y tendencias que provienen, en gran medida, de los ámbitos del feminismo y la teoría queer. Ahmed, por ejemplo, en la Política cultural de las emociones, defiende que las emociones no son algo que los individuos poseen en su interioridad privada, sino que recorren el espacio social, estableciendo relaciones entre los cuerpos y fundando relaciones de identificación y oposición, de “nosotros” y “ellos” (Ahmed, 2017: 34). Las emociones, según Ahmed, son prácticas socioculturales (2017: 32) con un papel político e ideológico fundamental: «las emociones están entreveradas con el afianzamiento de la jerarquía social: se convierten en atributos de los cuerpos en tanto transforman lo que es "más bajo" o lo "más elevado" en aspectos corporales» (Ahmed, 207: 23). La misma distinción jerárquica entre razón y sentimiento, tan presente en la cultura occidental, según la cual lo sentimental está asociado a lo blando, lo pasivo, lo corporal, lo perverso, es una construcción ideológica muy potente (Ahmed, 2017: 22-23). Incluso la supuesta ausencia de sentimientos y emociones no es solo una posición ideológica, sino una emoción de por sí: «la dureza no es la ausencia de emoción, sino una orientación emocional diferente hacia los otros» (Ahmed, 2017: 24).

Desde esta perspectiva, se puede analizar el uso político de las emociones, cómo legitiman posiciones ideológicas e identitarias: cómo, por ejemplo, el miedo puede servir de sustento al racismo. Ahmed, de hecho, propone una metodología de investigación que permite analizar cómo dichas emociones y su circulación política se inscriben en los textos culturales, y especialmente en sus figuras retóricas (2017: 39). En nuestro trabajo, mostrará un rendimiento importante el análisis de las emociones involucradas en el discurso humorístico, no solo respecto a las emociones que estos discursos provocan en su recepción, sino el mismo estado emocional que constituye al propio discurso. Este aspecto es particularmente importante, sobre todo si tenemos en cuenta que, como hemos visto, un aspecto fundamental de parte del discurso contemporáneo sobre el humor es el que atañe a su distanciamiento emocional, a su supuesta objetividad gracias a la ausencia de emociones. 


\section{UNA PROPUESTA DE ANÁLISIS DE LOS DISCURSOS HUMORÍSTICOS}

\subsection{Propedéutica: la estructura de la ironía}

Como vimos en el capítulo correspondiente [1.1.4], la descripción de la ironía en los tratados clásicos de retórica es sensiblemente más compleja que su posterior reducción a la antífrasis: tratadistas como Quintiliano consideraban el fenómeno de la ironía a caballo entre el tropo y la figura, por lo que su ámbito de actuación superaba el de la palabra; además de contemplar su uso polémico para atacar al adversario, se relacionaba con otros recursos oratorios como la parodia (al imitar jocosamente las palabras del contrincante) o la simulación (el ironista no solo imita las palabras, sino que “actúa como” su adversario u otro personaje real o inventando, al imitar su tono de voz, su gestualidad, etc.).

La lingüística del siglo XX heredará, sin embargo, una definición de la ironía reducida a la antífrasis, a decir lo contrario de lo que se dice ${ }^{1}$. Grice, por ejemplo, explica la ironía como una ostensible violación de la máxima de cualidad: el hablante dice algo que obviamente es falso para que su oyente infiera justamente lo contrario (Reyes, 2002: 94-96). Los lingüistas y pragmatistas posteriores, como Kerbrat-Orecchioni (1980), rechazarían esta explicación por ser demasiado estrecha (no siempre el significado de una ironía es justamente lo contrario de su significado literal) y poco explicativa (¿por qué un hablante recurre a un modo de comunicación tan enrevesado?) (Reyes, 2002: 92).

Una de las primeras definiciones alternativas, y la de mayor fortuna, es la que propondrán Sperber y Wilson, los creadores de la teoría de la relevancia, basándose en la distinción entre uso y mención. Sperber y Wilson rechazan la concepción “clásica” de la ironía: el ironista no quiere decir otra cosa, lo contrario del enunciado literal, sino que expresa una actitud (negativa) del hablante hacia lo enunciado; el ironista, por tanto, no usa un enunciado para emitir una proposición, sino que lo menciona para opinar algo sobre el mismo (Sperber y Wilson, 1978: 403-404). Esta propuesta pasaría a ser conocida como la «teoría del eco», o de la «mención ecoica», porque según sus autores el hablante irónico se "hace eco" de un pensamiento anterior para manifestar su actitud crítica: mediante la ironía el hablante se burla de lo que alguien concreto ha dicho, o de una

\footnotetext{
${ }^{1}$ En otro lugar (Romero Velasco, 2018) nos hemos ocupado de los paralelismos de la definición de la ironía en la Retórica clásica y las modernas teorías lingüísticas, trabajo en el que basamos las páginas siguientes.
} 
opinión general o un lugar común, etc. Comprender un enunciado irónico, por tanto, es reconocer su carácter de eco, el origen de la mención y la actitud crítica que el hablante introduce sirviéndose del contexto, el tono de voz u otras señas para o extraverbales (Sperber y Wilson, 1978: 407-409).

Según sus autores, esta descripción de la ironía da cuenta de muchas sus características que eran dejadas de lado por la concepción antifrástica: el uso de un "tono irónico” o de cualquier otro tipo de señales, más o menos codificadas, que señalan la modalidad especial del enunciado, y el carácter burlón y más o menos crítico que está siempre presente en la ironía, así como la existencia de una víctima, más o menos concreta, que es aquella enunciadora de la idea de la que el ironista se hace eco (Sperber y Wilson, 1978: 409-412). Sin embargo, la teoría del eco ha recibido varias críticas, por ejemplo por parte de quienes entienden la noción de «mención ecoica» como una mención literal de en un enunciado efectivamente dicho, a pesar de que Sperber y Wilson lo entienden como el eco no de una expresión, sino de una proposición o pensamiento que puede haber sido dicho o no, y que por tanto puede pertenecer a una persona concreta o bien a un colectivo, un lugar común, una frase hecha, etc. (Reyes, 2002: 105).

Una de las pocas teorías que se han ofrecido como alternativa solvente a la de Sperber y Wilson es la conocida como «teoría del fingimiento» de Clark y Gerrig. Estos autores se basan en la crítica a la noción de eco mencionada y proponen que el ironista no "se hace eco" de lo dicho por otra persona, sino que "finge" ser otra persona capaz de decir las cosas absurdas que expresa un enunciado irónico y por tanto ridiculizando al tipo de persona que las diría (Clark y Gerrig, 1984: 121). Por ejemplo, la ironía no consiste en que alguien se haga eco de un presentador del tiempo diciendo que hace buen tiempo en un día lluvioso, sino que finge ser dicha persona que es tan estúpida como para decir que un día lluvioso es un buen día (Clark y Gerrig, 1984: 122). En todo caso, es bastante evidente que la diferencia entre eco y fingimiento es mínima: al fin y al cabo, al hacerte eco de alguien, finges ser esa persona, y viceversa.

La tercera alternativa que presentamos armoniza, de algún modo, estas dos proposiciones. Oswald Ducrot parte de la teoría de Sperber y Wilson para matizarla, al tiempo que, si bien no de manera explícita, utiliza el mismo ámbito conceptual de fingimiento para explicar la figura irónica. Ducrot recurre en su explicación al concepto de «enunciado polifónico», basado en la teoría bajtiniana del lenguaje como depositaria 
de las variadas voces y puntos de vista de la sociedad. Así, la idea de mención ecoica es sustituida por la de polifonía: el hablante irónico, más que transmitir el discurso de otro, "hace oír una voz”, “pone en escena” un interlocutor más o menos ficticio que dice cosas consideradas ridículas, incongruentes o absurdas. El hablante hace como si dijera algo al tiempo que marca claramente la distancia respecto de lo dicho (Ducrot, 1986: 215).

Como vemos, las expresiones usadas por Ducrot como "hacer como si se dice algo” o "poner en escena una voz” acercan su explicación a la teoría del fingimiento de Clark y Gerrig, y su uso de la noción de polifonía lo vincula con la teoría del eco de Sperber y Wilson. Por otra parte, las tres explicaciones presentan unas claras analogías con la descripción retórica clásica de la ironía: su uso crítico y polémico basado en la burla, la imitación de un punto de vista ajeno, la definición del ironista como “fingidor”... En conjunto, se nos ofrece un esquema lo suficientemente articulado de la ironía del que extraer ciertas implicaciones e intuiciones de cara a nuestra propuesta de análisis del discurso humorístico:

i. El enunciado irónico es un tipo especial de comunicación (como violación de las máximas conversacionales, como una comunicación no seria, como una mención y no como un uso, etc.). Concretamente, implica un cierto fingimiento del hablante, que actúa como si dijera algo, pero no lo hace en serio - o, mejor dicho, no del todo en serio, puesto que el ironista siempre quiere comunicar algo. Este carácter “fingido” del enunciado irónico implica que entraña algún tipo de ficción que ha de ser señalada como tal mediante el gesto, el tono, el contexto, u otros recursos más o menos fijados convencionalmente.

ii. El enunciado irónico es un enunciado ecoico o polifónico: juega con voces, opiniones o perspectivas ajenas. Esto implica, además, rechazar la diferenciación entre el sentido literal y el irónico, según una explicación que simplemente desecha el sentido literal una vez que el enunciado se reconoce como irónico. Más bien, el significado irónico consiste en la relación de vaivén entre el significado literal, la proposición de la que el hablante se hace eco, y la actitud implícita. Implica también que este significado irónico no se puede reducir a “lo opuesto al significado literal”; más aún, no se puede hablar de un significado irónico: el hablante se limita a dar a entender una cierta distancia respecto a lo dicho, y corresponde al oyente interpretar el grado y la 
dirección de este distanciamiento. Por tanto, la ironía no depende solo de ser reconocida como irónica, sino que presenta siempre un cierto grado de ambigüedad.

iii. La ironía presenta siempre, merced a este distanciamiento del significado literal, algún grado de ridiculización o degradación. La actitud irónica no tiene por qué ser siempre una crítica hacia lo enunciado, pero presenta un rango afectivo, desde la crítica más ácida hasta el mero juego, que implica una actitud que podría calificarse como frívola, de "no tomarse en serio" lo dicho en el enunciado irónico (que supone una víctima de la ironía, sea esta víctima reconocida como una persona real o no). El alcance de esta frivolización, y su función crítica, depende también exclusivamente de la interpretación por parte del oyente, que se basa en el contexto, el conocimiento de la mentalidad del hablante, y su propia actitud respecto al hablante y el contenido de la ironía, entre otros factores. Esta actitud y esta labor de interpretación dan lugar a una respuesta por parte del oyente, que no es simplemente la del reconocimiento de la intención irónica del interlocutor: el oyente puede mostrarse de acuerdo con la ironía, o rechazarla, o sentirse molesto o incómodo por la actitud del hablante, etc.

Parecería arriesgado tomar la ironía como punto de partida para una descripción de lo cómico en general. No obstante, no pretendemos aquí afirmar que todo discurso cómico es irónico, ni dilucidar si la ironía es una especie de lo cómico o no ni qué relación existe exactamente entre el discurso irónico y el cómico. De hecho, no consideramos útil una clasificación ni delimitación teórica de las diferentes especies de lo cómico como la sátira, lo burlesco, la parodia, el chiste, etc., o un inventario de sus técnicas. Simplemente, teniendo en cuenta que la ironía es el fenómeno que más atención ha recibido desde la lingüística, la teoría y la crítica literarias, la filosofía, etc., es el punto de acceso más fácil a una visión general (que, insistimos, no quiere ser ni sistemática ni exhaustiva) de lo humorístico. Estas implicaciones extraídas de las descripciones retóricas y pragmáticas de la ironía serán exploradas y ampliadas en las siguientes páginas. 


\subsection{Lo cómico como fiesta, como juego, como ficción}

Como hemos comprobado a lo largo de todos los capítulos anteriores, lo cómico siempre se ha asociado a áreas de la cultura y el comportamiento humanos como la fiesta y lo lúdico, con toda la importancia y las implicaciones que la antropología le ha dado a este fenómeno desde la publicación de Homo ludens de Huizinga. En la antigua Grecia, la risa estaba vinculada a los ritos religiosos, y también la comedia nace en el seno de las festividades dionisíacas [1.1.1.2, 1.1.2.1]; la risa y lo cómico se denominaba con los términos paizein y paidia, relacionado con lo infantil, que implicaba una fuga de la normatividad cotidiana (Halliwell, 2008: 21). En la Edad Media, la risa nacía en los carnavales y otras festividades análogas [1.2.2], y los fenómenos cómicos y carnavalescos estaban relacionados, como vimos [1.2.3], con la tradición cultural y artística de lo grotesco como Spielraum, como lugar de juegos o «espacio lúdico», espacio de fantasía y libertad creativa (Connelly, 2015: 42). También vimos [3.1.2, 3.1.3] cómo Bergson y sobre todo Freud relacionaban lo cómico con el sueño y el juego, y psicoanalistas posteriores como Mélanie Klein o Winnicott han insistido en la importancia del juego y la fantasía para la vida psíquica.

Como pudimos comprobar [3.3], esta asociación no solo se da en el ámbito cultual o psicológico: tanto lingüistas como sociólogos comprenden el fenómeno humorístico como un modo de comunicación especial, no-seria, con una serie de reglas interpretativas y comunicativas particulares. En este sentido, también es obvia la analogía que las técnicas de lo cómico, especialmente en su manifestación verbal, presentan con las características que las teorías formalistas han establecido para el lenguaje literario como una forma, por ejemplo, de desautomatización (y no es extraño que los formalistas rusos tuvieran especial interés en obras y géneros literarios humorísticos, como el Quijote o Tristram Shandy): en todo caso, como un uso del lenguaje no comunicativo ni referencial, sino que, de algún modo, juega con la propia forma del lenguaje, así como los chistes explotan las homofonías, los dobles sentidos, las ambigüedades, etc.

Por tanto, es útil un acercamiento al fenómeno de lo cómico considerándolo como un fenómeno estético o quasi-estético, no solo refiriéndonos a las propias formas artísticas cómicas como la caricatura o la novela humorística, sino cualquier tipo de enunciado de carácter cómico, aunque se dé en una conversación cotidiana. El humor es 
un tipo de comunicación estética a la que podemos aplicar la distinción entre comunicación transparente u opaca según la usual concepción del lenguaje literario, en tanto que suspende momentáneamente las normas comunicativas usuales, por las que la comunicación se concibe como un mero transporte de información referencial, y las sustituye por otros protocolos interpretativos que obligan en cierto modo a centrarse en estos mismos procesos - que obliga, por ejemplo, a centrarse en los dobles sentidos, o las mismas expectativas de comunicación e interpretación. Graciela Reyes, por ejemplo, concibe la ironía como una figura «meta-pragmática», es decir, como un enunciado que implícitamente conlleva un comentario reflexivo sobre el propio proceso de comunicación, los usos del lenguaje, sus expectativas no cuestionadas, sus lugares comunes, etc. (Reyes, 2002: 106-109). La ironía y lo cómico como un comentario autorreflexivo sobre el carácter retórico y en última instancia ilusorio del lenguaje, por supuesto, es una caracterización común entre muchos filósofos y teóricos de la literatura, desde Kenneth Burke y Hayden White hasta Paul De Man.

Una de las características más notorias del juego es su cercanía con la actuación y la representación, algo evidente en la misma terminología, tanto en el inglés (donde «(to) play» significa tanto «juego» o «jugar» como «actuar» $\mathrm{y}$ «obra de teatro») como en alemán (das Spiel presenta la misma dualidad entre juego y representación dramática) e incluso en griego antiguo donde paizein significa también «fingir que se es niño» (Halliwell, 2008: 21). También Bajtín, en su caracterización del carnaval, alude a su cercanía con el teatro (1998: 12).

Gadamer no encuentra la esencia del juego en la actitud subjetiva del que juega, sino en el juego mismo que «accede a su manifestación» a través de los jugadores (Gadamer, 2012: 145): «el juego no tiene su ser en la conciencia o en la conducta del que juega, sino que por el contrario atrae a éste a su círculo y lo llena de su espíritu» (Gadamer, 2012: 153). La supuesta libertad del que juega, por tanto, no es exactamente tal, sino que se rige por las reglas del juego que lo constituyen como tal. Y como jugar es siempre “jugar a algo”, la consecución de estas reglas constituye una (auto)representación de aquello a lo que se juega: el juego, en fin, es siempre una representación y el jugador se representa en él como jugando/representando (Gadamer, 2012: 151). El juego en tanto que representación alcanza su máxima expresión precisamente en la representación teatral, que supone representar para alguien: «el jugador experimenta el juego como una realidad que le supera; y esto es tanto más cierto cuando que realmente hay «referencia» 
a una realidad de este género, como ocurre cuando el juego parece como representación para un espectador» (Gadamer, 2012: 152-153). En resumen, hay una extraña relación e incluso una equivalencia indisoluble entre el juego y la representación de tipo teatral, y esto se puede extender, como desarrollaremos más adelante, al fenómeno de lo cómico al fin y al cabo, como hemos visto, el ironista "finge" decir algo "como en broma", y se puede decir que todo humorista o cualquier hablante que en un momento dado pretende ser cómico, introduce una distancia de tipo dramático entre él y su enunciado cómico. Como veremos, la metáfora dramática tendrá una importancia fundamental en nuestro estudio de la estética camp y de las identidades de género tanto en la obra de Mendicutti como en la serie Friends.

El juego en tanto que representación, por tanto, implica necesariamente un componente de ficcionalización y distanciamiento: el juego crea un mundo con sus propias reglas, y aunque el jugador «juega seriamente», su seriedad implica al mismo tiempo una conciencia de que su actividad es mero juego, sin referencia ni objetivo "real” (Gadamer, 2012: 144). Por ello los fenómenos cómicos, lúdicos y festivos están siempre claramente delimitados respecto al mundo “ordinario”: desde los enunciados cómicos que han de estar señalados por marcas verbales, paraverbales o extraverbales, hasta las fiestas carnavalescas, celebradas en unos días del año marcados previamente (y sancionadas por las autoridades competentes). Esta separación entre el mundo lúdico y el serio no es, sin embargo, una total independencia; más aún, lo lúdico o lo festivo siempre se constituye en referencia a lo serio. En el «mundo al revés» de las fiestas carnavalescas siempre hay, aun por inversión, una referencia al mundo oficial, en forma de autoridades festivas o parodias de textos y ritos litúrgicos. La tradición de lo grotesco es, por definición, algo generado culturalmente, porque juega con los límites culturales de lo que es conocido, propio o normal (Connelly, 2015: 25); lo grotesco no elimina un límite existente, sino que lo pone de relieve, haciendo visibles los contornos de lo conocido y lo normal, mezclándolo con lo extraño y lo inesperado (Connelly, 2015: 40). Y, como señala Freud, para que un chiste sea efectivo, siempre debe haber una referencia a un límite o un obstáculo que se supera [3.1.3.2].

En lo lúdico (y por extensión en lo cómico) siempre hay, en suma, una referencia a la "realidad oficial”, “normal”, o "seria”, y el que juega lo hace siempre desde su conocimiento previo de ella: «el que imita algo, hace que aparezca lo que él conoce y tal como lo conoce» (Gadamer, 2012: 158). En este sentido, hay que entender la mimesis 
aristotélica como un reconocimiento: «lo que realmente se experimenta en una obra de arte, aquello hacia lo que uno se polariza en ella, es más bien en qué medida es verdadera, esto es, hasta qué punto uno conoce y reconoce en ella algo, y en este algo a sí mismo» (Gadamer, 2012: 158). Esto no significa que la realidad y su conocimiento aparezca tal cual en el contexto del juego, sino que lo hace a la luz de una perspectiva especial que puede mostrar aspectos inéditos de aquello a lo que se juega - o, más bien, sacar a la luz aspectos ya conocidos pero no tenidos en cuenta; como dice Paul Ricoeur de la metáfora: lo que descubre, lo inventa, y lo que parece inventar es en realidad descubierto (1980: 315).

Es de hecho Ricoeur en La metáfora viva quien propone que es incorrecto pensar en el lenguaje literario como simplemente carente de significado y referencia, sino como un lenguaje que suspende la referencialidad “estándar” como prerrequisito para desplegar una nueva referencialidad hipotética y heurística que permite redescribir lo real (Ricoeur, 1980: 308-309). La metáfora, al establecer unas nuevas relaciones semánticas basadas en la semejanza, no solo juega con esta proximidad en el sistema lingüístico, sino que lo hace en el propio mundo referencial, ofreciendo así un nuevo modo de relacionar y percibir los objetos del mundo (Ricoeur, 1980: 310). No basta, pues, con afirmar la naturaleza lúdica de lo cómico: también hay que indagar en su estructura particular, las “reglas” que le son propias, y su relación con el mundo “ordinario”, su modo de jugar con este y hasta qué punto presenta una nueva perspectiva de la realidad.

A este respecto, podemos traer a colación las teorías del antropólogo Victor Turner acerca de los fenómenos liminales y liminoides y el papel de lo lúdico en el desarrollo y mantenimiento de las culturas. Turner parte de la descripción de Van Gennep de los ritos de pasaje, en los que distingue tres fases: separación, transición e incorporación. El interés del antropológo inglés se centra en la segunda fase, la transicional, que se sitúa en un espacio, físico o simbólico, marginal o «liminal» donde «the ritual subjects pass through a period and area of ambiguity» (Turner, 1982: 24). El período de transición suele incluir algún elemento lúdico y “subversivo” en que tanto los iniciados y los símbolos rituales son indefinidos, ambiguos: «in liminality people "play” with the elements of the familiar and defamiliarize them» (Turner, 1982: 27) - más adelante mencionaremos la importancia que Mary Douglas da al desorden como ambigüedad. Es evidente, claro está, que podemos identificar los ritos dionisíacos griegos y las fiestas carnavalescas medievales con estos períodos transicionales, donde las 
jerarquías y significados se invierten, inaugurando un «mundo al revés». Turner cita al antropólogo Sutton-Smith, quien habla de anti-estructuras o proto-estructuras, cronotopos particulares en los que la estructura social se subvierte de manera lúdica: «we may be disorderly in games (...) either because we have an overdose of order, and want to let off steam (...) or because we have sometihng to learn through being disorderly» (Turner, 1982: 28).

Como vemos en la última cita, Turner especifica los dos posibles efectos que estos momentos transicionales pueden tener sobre una sociedad, y que coinciden con las ambivalencias que hemos atribuido a lo cómico: o bien contribuyen a su mantenimiento, aliviando las tensiones, o bien estimulan el cambio. En este sentido, Turner afirma que los fenómenos que denomina «liminales» no son realmente subversivos, sino que, al jugar con los significados culturales y sus límites, los refuerzan:

A mirror inverts but also reflects an object. It does not break it down into constituents in order to remold it, far less does it annihilate and replace that object (...) The liminal phases of tribal society invert but do not usually subvert the status quo, the structural form, of society; reversal underlines to the members of a community that chaos is the alternative to cosmos, so they'd better stick to cosmos, i.e., the traditional order of culture, though they can for a brief while have a whale of a good time being chaotic (Turner, 1982: 41)

En el capítulo segundo [2.1; 2.2] describimos la transformación que para el entendimiento de lo cómico implica en la Edad Moderna la desaparición de las fiestas carnavalescas y la emergencia de formas como la caricatura o la literatura burlesca o irónica. En este sentido, Turner insiste en que es necesario distinguir entre las sociedad preindustriales e industriales (y aún más las posindustriales [3.4]), y sobre todo respecto de fenómenos y nociones como trabajo, ocio («leisure») y juego, que parecerían similares pero que en realidad pueden significar cosas bien distintas en cada tipo de sociedad. En las preindustriales, el «trabajo» tiene que ver con lo divino, y los individuos que participan en los rituales lúdicos consideran que están llevando a cabo un «trabajo», una «tarea» seria: "what we are seeing here is a universe of work, an ergon- or organic- universe, in which the main distintction is between sacred and profane work, not between work and leisure» (Turner, 1982: 30-31). En su momento [1.1.1, 1.2.1], de hecho, mencionamos las funciones apotropaicas o mágicas de la risa ritual y el carácter obligatorio de las fiestas carnavalescas, antiguas o medievales: 
It is, furthermore, a universe of work in which whole communities participate, as obligation, not optation. The whole community goes through the entire ritual (...) The passage of the whole society through crises, collective and individual, directly or proxy, are the hallmarks of the "work of gods" and sacred human work - without which profane human work would be, for the community, impossible to conceive (Turner, 1982: 31)

El elemento lúdico de estos rituales, por tanto, tiene unas implicaciones serias que no tienen los momentos de ocio propios de una sociedad industrial (Turner, 1982: 32). Por ello, Turner distingue lo liminal, propio de las sociedades agrarias y preindustriales, de lo liminoide, que es el juego con las ideas propia de una división social industrial y postindustrial, asimilable a lo que Marx llamaría la superestructura - pero con una mayor autonomía respecto de la base económica, capaz incluso de generar nuevas ideas y modelos de sociedad:

"Liminoid" actions of industrial leisure genres can repossess the carachter of "work" though originating in a "free time" arbitrarily separated by managerial fiat from the time of "labor" (...) The liminoid can be an independent domain of creative activity, not simply a distorted mirror-image, mask or cloak for structural activity (...) "Antistructure”, in fact, can generate and sort a plurality of alternative models for living, from utopias to programs, which are capable of influencing the behavior of those in mainstream social and political roles (Turner, 1982: 33)

Los géneros y fenómenos cómicos de la sociedad moderna, por tanto, como fenómenos de ocio, no pueden ser iguales que las fiestas religiosas de las sociedades preindustriales: como vimos, las manifestaciones artísticas inspiradas en la tradición carnavalesca son algo muy distinto de las fiestas medievales propiamente vividas y no contempladas estéticamente; y la comedia televisiva [7.1] no puede tener el mismo significado social que la Comedia Antigua [1.1.2.2]. En nuestra sociedad, incluso, existen individuos especializados profesionalmente en la producción de ocio - en un sentido muy distinto del que en las sociedades agrarias existen chamanes o sacerdotes encargados de los rituales (Turner, 1982: 37-39); lo liminoide, a diferencia de lo liminal, llega a ser incluso una mercancía que se consume, dado que hay que pagar por un libro, un concierto, un partido de fútbol... (Turner, 1982: 55). Lo que sí tienen en común lo liminal y lo liminoide es el elemento lúdico:

Leisure is etimologically derived from the Old French leisir, which itself derives from the Latin licere, "to be permitted", an which, interestingly enough, comes from the Indo- 
European base *leik - "to offer for sale, bargain", referring to the "liminal” sphere of the market, with its implications of choice, variation, contract - a sphere that has connections, in archaic and tribal religions, with Trickster deities such Eshu-Elegba and Hermes. Exchange is more "liminal" than production. Just as when tribesmen make masks, disguise themselves as monsters, heap up disparate ritual symbols, invert or parody profane reality in myths and folk-tales, so do the genres of industrial leisure, the theatre, poetry, novel, ballet, film, sport, rock music, classical music, art, pop art, etc. play with the factors of culture (Turner, 1982: 40)

Ambos comparten, por tanto, el carácter ambiguo que permite jugar con los límites sociales y culturales y explorar nuevos significados. Turner considera que los fenómenos liminoides sí que pueden cumplir una función subversiva, de desafío a los significados establecidos y cambio social, que en los rituales solo encontramos en potencia recordemos que, de hecho, la ofensiva contra los carnavales se intensificó cuando estos empezaron a ser vehículos de protestas sociales reales [2.1]:

Such relatively "late" social processes, historically speaking, as "revolution", "insurrection", and even "romanticism" in art, characterized by freedom in form and spirit, emphasis on feeling and originality, represent an inversion of the relation between the normative and the liminal in "tribal" and other essentially conservative societis. For in these modern processes and movements, the seed of cultural transformation, discontent with the way things are culturally, and social criticism, always implicit in the preindustrially liminal, have become situationally central, no longer a matter of the interface between "fixed structures" but a matter of the holistically developmental (Turner, 1982: 45)

Ahora bien, Turner reconoce que no todos los fenómenos liminoides son siempre y necesariamente subversivos: la mayoría de ellos, muy al contrario, funcionan en la práctica como fenómenos liminales en el sentido de que contribuyen a reforzar el status quo (Turner, 1982: 40). En este sentido, se ha de insistir en el carácter fundamentalmente ambivalente de lo cómico, que puede ser subversivo o conservador. La sátira, por ejemplo, en opinión de Turner, es esencialmente conservadora: «Satire exposes, attacks, or derides what it considers to be vices, follies, stupidities, or abuses, but its criterion of judgment is usually the normative structural frame of officially promulgated values» (Turner, 1982: 40) 
Por supuesto, también las escuelas críticas como el marxismo, el feminismo, los estudios coloniales, etc., nos han enseñado cómo las obras literarias no son ajenas al contexto histórico y sociopolítico en el que se producen o reciben, y cómo reflejan y contribuyen a reproducir discursos ideológicos de dominación o subversión. Es por esto que el carácter ficcional del discurso humorístico, por muy sofisticado que sea, no nos puede llevar a concluir que no tiene lazos con presupuestos ideológicos; es más: es un argumento básico de este trabajo que el discurso humorístico trabaja conscientemente a partir de estereotipos y prejuicios ideológicos, y es necesario analizar el modo especial en que lo hace.

\subsection{Lo cómico como incongruencia, como ruptura de expectativas, como polifonía}

Lo cómico, como coinciden casi todos los especialistas, consiste en la ruptura de una expectativa: allí donde nuestra experiencia o nuestro sentido común esperaba un cierto desenlace, irrumpe otro. También podemos hablar de una dislocación o, siguiendo a Hutcheon [3.2.3.3], «transcontextualización»: una frase, objeto o persona aparece en un contexto inesperado o que no le corresponde. Esa es la técnica del chiste que Freud llama «desplazamiento» y Koestler «bisociación», consistente en construir una cierta historia para luego introducir un elemento que obliga a reinterpretar la historia entera. También podemos decir de una situación o, sobre todo, de un personaje, que es cómicamente ridículo al fracasar en alcanzar un cierto estándar de comportamiento (por no ser lo suficientemente ágil, o lo suficientemente inteligente); también es cómico el niño, el loco o el borracho, que se muestran desinhibidos frente a las normas sociales, o el pícaro héroe cómico que se sale con la suya burlando las prohibiciones y limitaciones que le impone la sociedad o las hace jugar a su favor. Incluso podemos decir que la forma más aparentemente inocua de comicidad, el juego de palabras, rompe nuestras expectativas respecto al uso del lenguaje.

Lo cómico necesita, como decimos, de un límite, puesto que siempre se produce en relación a ese límite. Esto permite, incluso, la existencia de especies cómicas que juegan precisamente con los propios límites socialmente aceptados del humor: gran parte 
del atractivo del humor negro, por ejemplo, resulta de jugar con tabúes como la enfermedad o la muerte que supuestamente no pueden ser objeto de comicidad.

Podemos decir por tanto que la caracterización de lo cómico que ofrece la conocida como «teoría de la incongruencia» es, a grandes rasgos, adecuada, si definimos esta incongruencia como la relación entre una expectativa y su negación. Pero es necesario matizar aún más esta definición básica: la negación de una expectativa siempre tiene, como han destacado muchos autores, un carácter de degradación: lo esperado resulta, en un sentido amplio, “menor”. Tampoco es del todo preciso decir que la negación sustituye la expectativa, que la segunda interpretación de un chiste ocupa el lugar de la primera, que desaparece, sino más bien que ambas permanecen yuxtapuestas y entran en mutua relación. Hemos encontrado diversas metáforas y descripciones que apuntan a este rasgo de lo cómico: Zupančič, por ejemplo, habla de un cortocircuito que mantiene unidos dos órdenes heterogéneos (Zupančič, 2008: 8); también Linda Hutcheon habla del significado irónico como «relacional», como resultado del «frotamiento» («rubbing») entre lo dicho y lo no dicho (Hutcheon, 1994: 59), y Koestler explica la bisociación cómica como una vibración en dos longitudes de onda diferentes pero simultáneas (Attardo, 1994: 175). También Gadamer habla del «movimiento de vaivén» que caracteriza el juego (2012: 146).

De hecho, Paul Ricoeur basa su teoría de la metáfora en la crítica al entendimiento de esta como sustitución de un término por otro: prefiere, por el contrario, entender el significado metafórico en términos de tensión entre el término sustituido y el que lo sustituye, entre la interpretación literal y la metafórica, entre la identidad y la diferencia que se da en el juego de la semejanza (Ricoeur, 1980: 332-333). En este sentido, podemos entender la ironía y lo cómico en general como un mecanismo análogo de yuxtaposición y tensión entre dos términos, interpretaciones, enunciados, contextos, situaciones, etc. Pero mientras la metáfora se centra en las semejanzas entre ambos objetos por encima de sus diferencias, lo cómico se centra en las desemejanzas, o, más bien, puesto que la desemejanza se podría aplicar a casi cualquier par de objetos, a la indisoluble vinculación entre la identidad y la diferencia, a cómo la semejanza depende siempre de una desemejanza y cómo toda repetición conlleva una diferencia. Si retomamos el ejemplo presentado por Zupančič de la escena en que Charles Chaplin se disfraza de gallina, diremos que la comicidad no consiste en la simple diferencia o el simple parecido de Chaplin y dicho animal, sino en cómo ambos se asemejan y se distancian al mismo 
tiempo: «the only genuine inmediate link between those things is the very cut between them» (Zupančič, 2008: 8).

Tomemos como segundo ejemplo uno de los chistes más conocidos de la bibliografía sobre el humor en el ámbito de la lingüística: el que Harvey Sacks utiliza en una serie de artículos que, como dijimos, inauguran el análisis conversacional:

Three sisters get married to three brothers and they spend the night at their mother's home. That night, the mother walks up to the first door and she hears «uuooo», at the second door the sound is «HHHHOOOHhhh», and then at the third door she hears nothing. She stands there for twenty-five minutes waiting for something to happen, but she hears nothing. The next morning she asks the first daughter «how come you went 'uuuoooo' last night?», and the daughter says «Well, it tickled, mommy». Then she asks the same to the second daughter and she answers «Oh, mommy, it hurt». And then she asks the third daughter «Why didn’t you say anything last night?» «Well you told me it was impolite to talk with my mouth full» (adaptado de Sacks, 1974)

Cuando, en otro trabajo (Sacks, 1978), Sacks analiza la estructura y la técnica de este chiste, se centra en el modo en el que la narración está construida en un modo en el que los oyentes obvian todas las inconsistencias e inverosimilitudes del chiste y son guiados hacia la interpretación final del chiste, a la vez que son sorprendidos por ella. Posteriormente, Mulkay propondría una explicación alternativa, enfatizando cómo el chiste establece un modo comunicativo particular que exige una serie de reglas interpretativas especiales que realzan las ambigüedades, las contradicciones, los dobles sentidos, etc., recursos que pueden ser englobados bajo el término de incongruencia o bisociación, como vimos [3.3.1]. Ambos análisis son, en lo básico, correctos, pero no llegan a explicar lo que es propiamente cómico del chiste. Como dijimos [3.3.1], este tipo de explicaciones son excesivamente racionales, y reducen la comicidad a una serie de cálculos computacionales que tratan el chiste como un enigma a resolver.

Quizás sea más productivo acercarse a este chiste no como a un puzle sino como a lo que es, esto es, una narración cómica o, mejor aún, una comedia en miniatura, en la que lo importante no es tanto la línea final o punch-line sino la caracterización de los personajes como comportándose de una manera cómica. La madre, por ejemplo, actúa de una manera extravagante al inmiscuirse en la vida sexual de sus hijas. Ciertamente, la punch-line basa su sorpresa en la ambigüedad de la expresión «tener la boca llena» que 
utiliza la tercera hija, al hacer referencia a una felación en lugar de a la comida. Pero esta ambigüedad es cómica no tanto por ella misma sino por el "choque” entre el significado sexual de la escena y el contexto con el que la frase se asocia, esto es, como el de una madre enseñando a su hija pequeña las normas de comportamiento durante una comida y también podríamos mencionar la asociación carnavalesca entre el sexo y la alimentación. No es que el sentido sexual sustituya este contexto, sino que se produce una interacción entre ambas interpretaciones y sus contextos respectivos que precisamente ayuda a caracterizar al personaje de la hija: la incongruencia cómica reside en el choque entre su caracterización infantil e ingenua y su comportamiento sexual - recordemos, también la importancia para la comicidad que Freud le da a lo infantil. De hecho, las tres hijas son retratadas a lo largo de la narración como niñas pequeñas: la falta de experiencia sexual y su ingenuidad respecto a ella, la dependencia de su madre, e incluso el uso de términos infantiles como «mommy». Podríamos añadir, además, que la incongruencia entre este infantilismo y la experiencia sexual se ve realzada por que la felación se pueda ver en este contexto como una práctica particularmente "atrevida” y activa. En todo caso, la narración no ofrece solamente un ingenioso juego de palabras, sino una representación muy particular de las mujeres y su sexualidad, incluso con ciertas connotaciones eróticas ${ }^{2}$.

Como vemos, la comicidad de la anterior historia depende por entero de ciertas expectativas, contextos y estereotipos: a cada una de las interpretaciones yuxtapuestas les acompaña una serie de representaciones y esquemas que son traídas a primer plano en el chiste - en este sentido, no es del todo preciso decir que la ruptura de una expectativa se da por algún tipo de "choque con la realidad”, o de un "idealismo” preconcebido que se enfrenta a "la vida real": ambas interpretaciones dependen en igual medida de estereotipos y prejuicios. En todo caso, lo que nos interesa por el momento es el hecho de que lo que atrae a la interpretación el contexto de la situación «madre enseñando a su hija los modales en la mesa» no es tanto el significado ambiguo de la expresión «tener la boca cerrada» como la misma forma estereotipada de la expresión.

A este respecto nos parece útil el recurso, ya sugerido por Oswald Ducrot para su explicación de la ironía, a la teoría de la polifonía de Bajtín, y, más concretamente, su

\footnotetext{
${ }^{2}$ De hecho, podemos tener en cuenta el contexto de la conversación recogida por Sacks en la que se cuenta este chiste: este es relatado a dos amigos por un adolescente, que a su vez lo ha oído de su hermana pequeña. La particular tensión que analiza Sacks es la que hay entre el conocimiento de la niña acerca de temas sexuales, y la supuesta falta de este por parte de los adolescentes.
} 
concepto de «género discursivo» según el cual las actividades humanas y los usos del lenguaje que se les asocian se depositan en la forma de los enunciados como «tipos relativamente estables de tales expresiones» (Bajtín, 2011: 11). Es decir, que cada contexto de uso del lenguaje, relacionado con la actividad que se lleve a cabo en dicho contexto, conlleva una cierta forma estereotipada del enunciado; y, por tanto, dichas formas estereotipadas o "géneros discursivos» reflejan el contexto habitual de uso, así como la posición de los interlocutores, las ideas y puntos de vista recibidos a cuenta del tema del enunciado, etc. No podemos no expresarnos según determinados géneros discursivos y sus formas típicas y relativamente estables, y dado que no aprendemos la lengua materna en su plasmación lingüística abstracta, sino en estos géneros discursivos, nuestra experiencia de la lengua y de la realidad está prefigurada por ellos (Bajtín, 2011: 37-38). Al hablar, por tanto, no utilizamos un sistema neutro y objetivo, sino que nos lo apropiamos y respondemos a enunciados anteriores que han sido ya acentuados afectiva y axiológicamente: «elegimos palabras según su especificación genérica», y esta especificación tiene una expresividad y una afectividad relativamente típica, pues los géneros «corresponden a las situaciones típicas de la comunicación discursiva, a los temas típicos y, por lo tanto, a algunos contactos típicos de los significados de las palabras con la realidad concreta en sus circunstancias típicas» (Bajtín, 2011: 49). Hablamos, en resumen, de una «aureola estilística» de la palabra, que no consiste en un significado léxico como tal sino una «suerte de eco de una totalidad del género que resuena en la palabra» (Bajtín, 2011: 50). Es en este sentido que decimos que la expresión «me dijiste que no hablara con la boca llena» conlleva, como expresión genérica, un cierto contexto de uso con una serie de estereotipos e implicaciones ideológicas; y la comicidad del chiste no proviene de la incongruencia entre una interpretación esperada y un sentido imprevisto, sino del choque entre dos situaciones o contextos que son igualmente estereotipados.

Los conceptos bajtinianos de polifonía, estratificación lingüística o plurilingüismo, según la cual las situaciones de uso se sedimentan en las formas del lenguaje (Bajtín, 1989: 106), son extraordinariamente útiles para aventurar una descripción de todo discurso humorístico como intertextual, por utilizar el término popularizado por Julia Kristeva (2001). Nos referimos al hecho de que, si lo cómico se basa en la frustración de una expectativa o la transgresión de una norma, estas normas y expectativas están siempre formalizadas lingüísticamente, y se frustran o transgreden al 
desplazarlas paródicamente y yuxtaponerlas a otros contextos en los que resultan incongruentes. El mismo Bajtín afirma que la manera más directa de re-acentuar los enunciados genéricos es utilizarlos de manera irónica o paródica (Bajtín, 2011: 39); y recordemos que la definición de Lausberg de la ironía incluye la imitación de las ideas del adversario según su «escala léxica», es decir, según la forma de su expresión - en este sentido, podemos decir que toda ironía es en cierto modo paródica.

Para ilustrar de una manera más clara nuestra propuesta de que todo discurso humorístico es paródico (en el sentido intertextual en que Hutcheon define la parodia), podemos recurrir a un artículo de la web de periodismo satírico El Mundo Today, titulado «Rubalcaba deja la política y ficha como asesor en Pollerías Loreto». Toda la comicidad de la falsa noticia reside, como es evidente, en el contraste degradante en el lugar común de las «puertas giratorias» por las que todos los políticos acaban fichando por una gran empresa, y que esa "gran” empresa sea «una pequeña pollería del mercado municipal de Santa Coloma de Gramenet, en Barcelona». Pero lo que nos interesa es que la comicidad se produce mediante el contraste entre diferentes lenguajes igualmente formalizados. Así, por ejemplo, se refieren irónicamente las declaraciones de Rubalcaba de que rechazó otras grandes empresas «porque no quiero renunciar al contacto con la realidad de la calle»; y también se parodia el discurso empresarial aplicándolo a situaciones impropias del mismo y combinándolo con el lenguaje cotidiano: ««Resulta que le conocimos un día que vino a hacer campaña a Santa Coloma y allí establecimos los primeros contactos y le hablamos de nuestra 'Business Strategy', que es básicamente vender pollo y huevos, y pareció interesado y nosotras también porque somos todas mujeres menos el Paco, que está el pobre muchacho harto ya de aguantarnos y le irá bien un compañero», explica la Loreto, CEO, propietaria y «Head of Sales» del establecimiento.» De este modo, al parodiar los distintos lenguajes, se satirizan tanto la hipocresía política como los artificiales lenguajes empresariales.

No en vano, Bajtín le concede una gran atención en su teorización del plurilingüismo, no solo a la literatura carnavalesca, sino a las novelas humorísticas de Fielding, Sterne o Dickens como ejemplos de plurilingüismo al parodiar las formas del lenguaje parlamentario, jurídico, periodístico, las jergas de los bajos fondos, etc., para mostrar, irónicamente, sus puntos de vista, opiniones, modos de conocimiento, etc., respectivos (Bajtín, 1989: 118-119). En esta línea, uno de los elementos fundamentales en su caracterización de la obra de Dovstoievsky como polifónica es su consideración de 
la «palabra bivocal» como estilización paródica (Bajtín, 2012: 342). Según la definición de Bajtín, la palabra bivocal es dialógica porque ofrece no solo un punto de vista sobre el tema del enunciado, sino también sobre su forma en cuanto polifónica, en cuanto ya usada y acentuada previamente: «la estilización presupone la existencia de un estilo, es decir, reconoce que el conjunto de procedimientos estilísticos que ella reproduce en algún momento tuvo un significado directo e inmediato (...) Lo que al estilizador le importa es el conjunto de procedimientos del discurso ajeno, precisamente en cuanto expresión de un peculiar punto de vista» (Bajtín, 2012: 348). Es decir, que el estilizador solo toma la forma de la expresión en cuanto expresión de un sentido ajeno sobre el que hace un comentario, creando una distancia entre el imitador y lo imitado (Bajtín, 2012: 349). Existen, incluso, casos de estilizaciones en los que la palabra imitada ofrece una resistencia tal que su orientación se muestra «turbulenta, irresoluble internamente y ambivalente» (Bajtín, 2012: 362), es decir, que se da una auténtica dialogización de la palabra en tanto que los dos enunciados y sus dos respectivos contextos se entrecruzan, se iluminan el uno al otro, se confirman o se refutan, se reorientan mutuamente (Bajtín, 2012: 347).

La cuestión de la estilización como imitación y apropiación irónica puede ser iluminada y profundizada recurriendo a las nociones de iterabilidad y citabilidad que Derrida emplea en su crítica a la teoría de John Austin en «Firma, acontecimiento, contexto», sobre todo en su relación con la ficcionalización y representación de los actos de habla. Derrida afirma que lo que caracteriza a todo signo, escrito o no, es su iterabilidad esencial, el hecho de que, para garantizar su legibilidad, su capacidad de ser reconocido, debe ser repetible e imitable (Derrida, 2019: 359). La posibilidad de repetición implica, además, la posibilidad de inscribir todo signo o cadena de signos en un contexto totalmente diferente, cambiando por tanto su sentido: «todo signo (...) puede ser citado, puesto entre comillas; por ello puede romper con todo contexto dado, engendrar al infinito nuevos contextos (...). Esto no supone que la marca valga fuera de contexto, sino al contrario, que no hay más que contextos sin ningún centro de anclaje absoluto» (Derrida, 2019: 362) ${ }^{3}$.

\footnotetext{
${ }^{3}$ Derrida no está afirmando, en ningún caso, que cualquier marca pueda significar cualquier cosa según el capricho del hablante individual, sino, simplemente, de una forma con la que estarían de acuerdo Bajtín o Voloshinov, que el sentido total de una palabra depende de la interacción entre su significado "usual” (es decir, según sus usos típicos en ciertos contextos) y el contexto actual. Podemos decir, por tanto, que el
} 
La crítica que Derrida hace de Austin parte del hecho de que el filósofo inglés ignore la citabilidad de todo signo, incluido el acto locucionario y su «estructura grafemática» (Derrida, 2019: 363). Los análisis de Austin, según Derrida, presuponen un contexto total y exhaustivamente determinable, así como un sujeto totalmente presente y responsable de su enunciado, pero estas condiciones son las que pone en duda la esencial iterabilidad del acto de habla. Así, cuando Austin afirma que la posibilidad de fracaso de un acto de habla es un rasgo inherente a «todos los actos convencionales» como las ceremonias (Austin, 2018: 64), olvida que cualquier enunciado o acto de habla es ritual en tanto que es iterable (Derrida, 2019: 365) - aunque lo cierto es que de hecho Austin sí afirma que un acto ilocucionario lo es según ciertas convenciones que dictan que un enunciado que cumpla ciertos rasgos sea reconocido, por ejemplo, como una promesa (Austin, 2018: 148). En todo caso, Derrida rechaza la decisión de Austin de considerar los casos de enunciados emitidas por un actor en escena o que encontramos en un poema como peculiares, no serios, vacíos o parasitarios (Austin, 2018: 67, 151). Es decir, para Derrida estos casos de cita de un enunciado no son anomalías, sino modificaciones concretas de una «citacionalidad general» que garantiza el funcionamiento de cualquier acto de habla (Derrida, 2019: 367): «un enunciado performativo ¿podría ser un éxito si su formulación no repitiera un enunciado codificado o iterable, en otras palabras, si la fórmula que pronuncia (...) no fuera identificable como conforme a un modelo iterable, si por tanto no fuera identificable de alguna manera como «cita»?» (Derrida, 2019: 368).

El análisis derridiano de la teoría de los actos de habla nos interesa porque nos permite ampliar la teoría bajtiniana de la polifonía, el plurilingüismo y sobre todo de los géneros discursivos y la palabra bivocal a dicha teoría a partir de la idea de imitación y citabilidad, de un modo aplicable a un análisis intertextual de los discursos humorísticos. Sin embargo, la asimilación entre estas concepciones lingüísticas y el carácter teatral que hemos aceptado como rasgo fundamental de lo cómico en tanto que juego aún ofrece ciertas dificultades. Como veremos en el capítulo siguiente, algunas lecturas de la crítica de Derrida, por ejemplo por parte de Butler y su teoría de la «performatividad de género», dieron lugar a ciertas confusiones entre una interpretación “teatral” y una eminentemente discursiva de la performatividad. Pero es una dificultad que se podría resolver, creemos, acortando la distancia entre ambos planos, es decir, entendiendo el lenguaje como una

sentido de lo cómico (igual que el de la metáfora) surge de la aparición de un enunciado en un contexto, más que inesperado, inapropiado. 
forma de acción y, sobre todo, la acción desde una perspectiva discursiva, intertextual y teatral

Al fin y al cabo, la aparente distinción hecha por Austin entre los ritos convencionales, así como las palabras de los actores, y el resto de actos de habla parece provenir de una concepción de la acción como acontecimiento irrepetible y pleno de significado - algo que el mismo Austin refuta al describir los procedimientos que constituyen un acto de habla realizativo como convencionales (2018: 59). Encontramos un razonamiento análogo cuando Bergson opone la flexibilidad y la irreductible individualidad de lo viviente al automatismo de lo mecánico como fundamento de lo cómico, lo que refuerza nuestro intento de relacionar lo humorístico con la imitación y la repetición. Y encontramos que Paul Ricoeur introduce esta misma «iterabilidad» en la definición misma de acción al equiparar esta a un texto (Ricoeur, 2001: 162). La acción es significativa en tanto que se puede fijar, objetivar de la misma manera que un texto porque la acción presenta una estructura similar a la de un acto de habla (Ricoeur, 2001: 176). Del mismo modo que cada acto de habla tiene una serie de rasgos locucionarios e ilocucionarios que son convencionales y que lo constituyen como tal, una acción tiene una estructura noemática, un núcleo que debe poder ser fijado e imitado para ser reconocido, así como una serie de reglas constitutivas como las de un juego, una serie de guías y procedimientos que de hecho constituyen la acción como tal (Ricoeur, 2001: 177178). En este sentido, se puede decir que, igual que todo signo y todo enunciado está constituido por una citabilidad generalizada, también cada acción puede ser considerado como un «juego de lenguaje» y, por tanto, como una imitación o una representación de una acción igualmente codificada. En nuestro análisis de la estética camp propia de las novelas de Eduardo Mendicutti, veremos que los personajes actúan imitando ciertos códigos, cinematográficos, literarios, artísticos, etc., borrando la distinción entre imitación y autenticidad, en una concepción de la identidad como construida en gestos y actitudes que son citaciones de otros referentes. También, en nuestros análisis de la representación de la masculinidad en Friends, veremos cómo esta se presenta como ciertos estereotipos que los protagonistas se ven obligados a cumplir como siguiendo un guion.

La filosofía del lenguaje no es la única, por supuesto, que ha recurrido a la metáfora teatral para explicar el fundamento de los actos de habla y de la acción en general; también es un elemento central, por ejemplo, en la sociología de Erving 
Goffmann (2009) o el habitus de Bourdieu. En este sentido, por supuesto, y como hemos señalado ya, los contextos o expectativas que entran en juego en lo cómico pueden ser explicados desde términos tales como representaciones sociales, marcos cognitivos y, sobre todo, scripts o frames - como han hecho lingüistas como Victor Rashkin. Es significativo, de hecho, que tanto Schank y Abelson como Goffmann utilicen chistes e historietas cómicas para explicar sus conceptos de script y de frame, respectivamente. Schank y Abelson utilizan el siguiente chiste para ilustrar lo que llaman «scriptal ambiguity»:

A traveling salesman found himself spending the night at home with his wife when one of his trips was unexpectedly canceled. The two of them were sound asleep, when in the middle of the night there was a loud knock at the front door. The wife woke up with a start and cried out, 'Oh, my God! It's my husband!' Whereupon the husband leapt from the bed, ran across the room, and jumped out the window (Schank y Abelson, 1977: 59)

La estructura de este chiste es bastante peculiar, pues encontramos, por así decir, un solo script o situación estereotipada, pero que se desarrolla de manera sorprendente: así, al script de la mujer infiel descubierta por su marido con su amante, se le superpone el hecho de que el marido también es, a su vez, el amante de alguna mujer casada. La superposición, por tanto, se da en el mismo personaje entre su rol de marido cornudo y amante pícaro. Esta cómica superposición se da, por así decirlo, en la cabeza del oyente del chiste, pero el análisis puede ir más allá: como explican Schank y Abelson, se cruzan dos lecturas distintas de la situación, la de la mujer que piensa que su marido es su amante, y la del marido que piensa que él mismo es el amante y que su mujer es su querida. Es más, no solo es cómica esta mala interpretación, sobre todo del marido, que es quien se lanza por la ventana, sino que la comicidad se ve enfatizada por el automatismo de su respuesta, que da a entender que ambos están más que acostumbrados a este tipo de situaciones.

En todo caso, la anécdota ilustra a la perfección la definición de script que manejan Schank y Abelson como una manera de "leer” una situación dada y actuar, en su doble sentido de acción y representación, de manera acorde a esta lectura: «A script is a predetermined, stereotyped sequence of actions that defines a well-known situation» (Schank y Abelson, 1977: 41). Del mismo modo, para Goffman «los actos de la vida cotidiana son comprensibles sobre la base de algún marco (o marcos) de referencia primarios que los informan» (Goffman, 2006: 28). También Goffman asocia «las 
bromas» como una tensa ambivalencia de una situación que puede ser leída desde dos marcos distintos (Goffman, 2006: 37), pero lo más importante es la dualidad presente en el concepto tanto de marco como de script como un esquema interpretativo o como una guía de acción. Así, Goffman afirma que los marcos «someten a quienes los realizan a «criterios», a la valoración social de la acción (...)» (2006: 24) y un fracaso a la hora de ejecutar esta acción conlleva una censura a menudo ejercida mediante la risa, como vio Bergson (Goffman, 2006: 41). De este modo, lo cómico como ruptura de una expectativa se puede describir como un script que no se lleva a cabo de la manera predeterminada, o que se lleva a cabo en un contexto inusual, o que se superpone a otro; en todo caso, nos reímos de alguien que no cumple con el script correspondiente.

En suma, podemos entender de una manera literal el concepto de scripts como guiones, de tipo dramático, que guían nuestras acciones cotidianas, para dar cuenta de cómo al actuar estamos “citando" una acción anterior del mismo modo que “representamos un papel”, y esta acción tiene una forma lingüística o la aprehendemos lingüísticamente. Es en este sentido en el que proponemos un análisis intertextual del discurso humorístico, como parodia de uno o más scripts [en 7.3.4 analizaremos una escena de Friends que sirve de ejemplo perfecto].

Otro aspecto del particular funcionamiento de lo cómico es el de su materialidad, mencionada a lo largo de este trabajo. Si lo cómico consiste en una imitación paródica de un script, podemos decir también que hace visible este script o marco, lo opaca o desautomatiza como hace el lenguaje literario. Tanto Derrida como Ricoeur hacen referencia a esta materialidad de la escritura en relación con la iterabilidad y la permanencia del lenguaje: así, Ricoeur afirma que la «autonomía semántica del discurso» depende de su objetivación, de su «fijación exterior» (Ricoeur, 2001: 153): «la inscripción en signos exteriores, que al principio parecía enajenar el discurso, señala también su espiritualidad real» (Ricoeur, 2001: 173). En este sentido, lo cómico depende, como lo poético, de un juego con la forma significante, con la materialidad del lenguaje, así como lo grotesco en el arte es ante todo un juego con la forma. También Bergson señaló la relevancia del cuerpo y la materia como un obstáculo para el espíritu en el mecanismo de lo cómico y lo relacionó con fenómenos parecidos de la comicidad verbal como la interpretación literal de una frase hecha. El cuerpo, sin duda, tiene una importancia central en la historia de lo cómico, no solo por la asociación antigua entre la risa y lo carnal, sino por la misma presencia del cuerpo en tradiciones como la commedia dell'arte o, en el 
siglo XX, la comedia muda de Buster Keaton, por ejemplo. Quizá el caso más ejemplar de esta materialidad de lo cómico sea el lenguaje de animación. Es necesario, pues, concebir lo cómico como un fenómeno plenamente material en el sentido de atención a lo formal, a lo objetual en un sentido muy literal, pero no según el lugar común de la escatología como remedio al idealismo u obstáculo temporal a la grandeza humana, sino en la línea que propone Alenka Zupančič [3.1.6.1]: la materia no como algo inerte, sino precisamente como algo vivo y con un funcionamiento independiente y ajeno a la voluntad humana. En el análisis de la representación de la masculinidad en la comedia Friends [7.3.4], pondremos en relación esta materialidad de lo cómico con la materialidad y exterioridad propia de la ideología que teorizan autores marxistas como Althusser [4.2.3].

\subsection{Caracterización del personaje cómico}

Por supuesto, si consideramos lo cómico según la perspectiva metafórica de lo teatral, es evidente que el centro del análisis ha de ser el personaje cómico. En este sentido, seguimos la sugerencia de Bergson de que la risa tiene que ver siempre con lo humano [3.1.2]. A grandes rasgos, podemos decir que el personaje cómico es un personaje extravagante, que se sale, para bien o para mal, de una norma. La mayoría de las veces este personaje es, simplemente, ridículo: la norma es transgredida por un defecto, por incapacidad de alcanzar un estándar de desempeño intelectual o físico, de ejercer un control sobre el propio cuerpo o de seguir exitosamente sus intereses. Esta transgresión, en todo caso, como advierten todos los tratados clásicos y renacentistas, no debe ser considerada realmente peligrosa o dañina para la sociedad - ha de consistir más en un error que en una transgresión intencional y malévola.

Muchas veces, la extravagancia del personaje tiene que ver con su caracterización neurótica. Como hemos visto [1.1.1, 1.1.5, 1.2.2.3], la risa estuvo ligada en la Antigüedad y la Edad Media a la locura, contemplada esta como castigo o privilegio sagrado, pero en todo caso como algo extrahumano. También los caracteres de la comedia estaban asociados a cierto tipo de patología espiritual, como sugería la adaptación de Ben Jonson de la teoría medieval de los humores a su concepción de la comedia [1.2.4.4]. La vinculación de lo cómico y la neurosis es explícita en el psicoanálisis: Freud no solo 
equiparó las técnicas del chiste al proceso de elaboración onírica, sino que comparó la economía psíquica del chiste con algunos procedimientos de defensa de los neuróticos [3.1.3]. Pero quien más ha atendido, en esta línea, a la caracterización del personaje cómico es Henri Bergson, al afirmar que el personaje cómico por excelencia es el distraído u obsesionado por una idea fija (Bergson, 2016: 158). Tanto Bergson como Alenka Zupančič, como vimos [3.1.2.6, 3.1.6.2], coinciden en hablar del vicio cómico como algo externo al personaje, lo que concuerda con nuestra consideración de la materialidad y la objetualidad de lo cómico: estos vicios aparecen como objetos exteriores y con voluntad propia que amenazan al personaje cómico como algo ajeno a él - así, mostraremos en nuestro análisis de Friends cómo la masculinidad aparece como algo externo y amenazador para los protagonistas [7.3.5].

La perspectiva psicoanalítica ve este objeto cómico como una materialización del inconsciente o del ello, y en general esta alienación del personaje respecto a su misma comicidad, como algo que se escapa fuera de su control, y que es precisamente el fundamento de la misma, da cuenta de la ambigüedad afectiva de lo cómico que también ha sido destacada a lo largo de toda su historia, de su cercanía a otros fenómenos como lo terrorífico, lo demoníaco, lo monstruoso o lo siniestro [2.5]. Este carácter liminar es lo que explica la ambivalencia del sentimiento de lo cómico, como un fenómeno en el que se obtiene placer de la misma fuente que nos produce ansiedad. Como vimos [3.2.1.3], Dana Sutton proponía entender la catarsis cómica como una domesticación de lo que en la vida real provoca miedo y ansiedad, y Connelly asocia lo grotesco terrorífico con lo abyecto según la caracterización realizada por Julia Kristeva.

Los fenómenos de abyección se suelen relacionar con los estudios de la antropóloga Mary Douglas de los conceptos de suciedad e impureza y los rituales de purificación asociados. Para Douglas, la noción de suciedad remite a la idea de orden: lo sucio no es un objeto predeterminado sino algo culturalmente construido, en relación a un orden concreto (Douglas, 2007: 20).

Si pudiéramos abstraer lo patógeno y la higiene de nuestra noción de suciedad, nos quedaríamos con la vieja definición de ésta como materia fuera de lugar (...) Supone dos condiciones: un juego de relaciones ordenadas y una contravención de dicho orden. La suciedad no es entonces nunca un acontecimiento único o aislado. Allí donde hay suciedad hay sistema (...) en la medida en que el orden implica el rechazo de elementos inapropiados (Douglas, 2007: 53) 
Lo sucio, por tanto, sirve para marcar a algo o alguien como ajeno al orden, peligroso para la sociedad: «el orden ideal de la sociedad es custodiado por peligros que amenazan a los transgresores (...) Las leyes de la naturaleza son aludidas para sancionar el código moral» (Douglas, 2007: 21). Pero, ante todo, lo sucio y su limpieza es expresivo de un intento individual y colectivo de ordenar la experiencia de la realidad para poder manejarse en ella: «las ideas acerca de la separación, la purificación, la demarcación y el castigo de las transgresiones tienen por principal función la de imponer un sistema a la experiencia, desordenada por naturaleza. Sólo exagerando la diferencia entre adentro y afuera, encima y debajo, macho y hembra, a favor y en contra se crea la apariencia de orden» (Douglas, 2007: 22). De ahí que la suciedad y el desorden se reciban con una sensación de angustia ante la ambigüedad que suponen (Douglas, 2007: 23). En este sentido, lo cómico cumple una doble función: por un lado, sanciona a los transgresores, conminándoles a no desviarse de los comportamientos estipulados socialmente; por otro, alivia la sensación de angustia al ridiculizar al transgresor, negando su potencial peligrosidad.

No obstante, la experiencia de la ambigüedad no tiene por qué ser del todo desagradable; puede servir para fundamentar mejor los límites existentes o modificarlos (Douglas, 2007: 56). En general, toda cultura tiene ciertos procedimientos para lidiar con la ambigüedad, a los que puede dar diferentes usos: o bien reducen la ambigüedad de modo que quede anulada al asignarse a alguno de sus sentidos posibles; o bien la suprimen, física y simbólicamente; o bien la prohíben y reprimen, estableciéndola como tabú, reforzando los límites establecidos; o incluso se puede utilizar para aprender de ella, «para enriquecer el significado o llamar la atención sobre otros niveles de existencia» (Douglas, 2007: 57-58).

Para Kristeva, la abyección consiste en un gesto violento de rechazo de aquello que, como lo excrementicio, nos pertenece pero no es considerado como propio y amenaza nuestra identidad. Sin embargo, lo así rechazado no desaparece del todo, sino que permanece en los límites de uno mismo o de la cultura, como amenaza permanente para esos mismos límites (Kristeva, 2015: 8). La abyección, por tanto, es aquello que amenaza los límites de una identidad, individual o social, y que despierta sentimientos ambiguos de fascinación y rechazo (Kristeva, 2015: 11) 
De acuerdo con Kristeva, «reír es una forma de rechazar la abyección» (2015: 16). De este modo se explica, en efecto, que las máscaras cómicas tengan su origen en figuras demoníacas o que el mismo diablo sea el protagonista de algunas farsas medievales, o, en el sentido contrario, que el payaso sea en muchas ficciones una figura terrorífica. Incluso en la actualidad podemos ver esta misma dualidad, por ejemplo, en la persona racializada que es objeto de chistes pero también protagonista de narraciones violentas. También la homosexualidad ha sido asociada en el cine de Hollywood a la criminalidad durante décadas, al tiempo que el «mariquita» era un personaje cómico recurrente.

Kristeva también analiza la catarsis, tal y como la concibe Aristóteles, como una forma de purificación de lo abyecto «a fuerza de sumergirse en él»: «lo abyecto, imitado con el sonido y el sentido, es repetido. No se trata de liquidarlo (...) Se trata más bien de hacerlo existir por segunda vez, y no como la impureza original» (Kristeva, 2015: 42). En este sentido, quizá, se pueda explicar la ambigüedad entre placer y displacer que encontramos en algunos casos de recepción de lo cómica, y de algunos juegos y fantasías expuestos por Freud [3.1.3.6].

Lo sucio y lo abyecto, por tanto, suponen formas marginales, limítrofes de una construcción cultural, cuyos efectos pueden ser ambiguos: o bien pueden reforzar los límites establecidos, o bien los pueden desafiar. Lo mismo sucede con lo cómico, y se puede decir que algunos personajes cómicos llevan la marca de la abyección. En el capítulo dedicado al análisis de la serie televisiva Friends [7.3.3] veremos cómo una broma recurrente es la "amenaza de la homosexualidad" como algo que pone en entredicho la masculinidad de los personajes ${ }^{4}$. Al mismo tiempo, la marginalidad también puede ser un elemento sobre el que se apoye una mirada crítica y satírica a la sociedad, como veremos en el caso de la novela Una mala noche la tiene cualquiera, donde la sociedad española de la dictadura y la transición es vista desde la excentricidad de un personaje transgénero [6.2.3].

\footnotetext{
${ }^{4}$ Judith Butler (2007), de hecho, apoya su análisis de la represión de la homosexualidad como garante de la heterosexualidad en la idea de la abyección
} 


\subsection{La recepción y el pathos de lo cómico: identificación, distanciamiento, frivolización}

Por supuesto, no todos los personajes cómicos son ridículos. En este sentido nos podemos remitir a la clasificación de Northrop Frye entre los eiron y los alazon (Frye, 1991: 61): los héroes aristofánicos, o los criados y otros personajes que ayudan a los jóvenes enamorados en la Comedia Nueva, o incluso personajes contemporáneos como el personaje de animación Bugs Bunny, no son personajes ridículos, sino que son admirados porque mediante su particular inteligencia se burlan de las constricciones sociales para su propio beneficio o, de manera incidental, el de la comunidad. En general, la caracterización de los personajes como ridículos no implica necesariamente que el espectador se sienta superior a ellos. Como señala Jauss [3.2.1.3], existen muy diversos modelos de identificación estética que dependen de horizontes de expectativas y tradiciones diferentes. Así, los personajes grotescos, los locos, los niños, los borrachos son personajes ridículos, pero el placer que obtenemos de ellos consiste en que subliminalmente nos identificamos con su falta de límites y su predominio del principio del placer sobre el de la realidad [3.1.5.3]. También podemos sentir conmiseración de un personaje ridículo, como Don Quijote, o incluso sentirnos identificados con sus problemáticas, lo que da lugar a una paradoja entre el placer y displacer en el seno de lo cómico, como parece ocurrir en la mayor parte de la comedia contemporánea, tanto televisiva como cinematográfica, y trataremos de mostrar en nuestro análisis de Friends [7.1].

No obstante, los eiron, los héroes cómicos, siempre realizan sus acciones a costa de un alazon, un personaje que sí aparece caracterizado como inferior, sea intelectual, física o moralmente [3.2.3.1.3]. Parece, por lo tanto, que es inherente a la comedia un elemento de humillación y superioridad, aunque nos identifiquemos con el personaje ridículo. Esto nos lleva a la consideración general de que la ridiculización, o, más exactamente, la frivolización, es un rasgo inherente al modo de ser del discurso cómico. Como hemos visto a lo largo de los capítulos anteriores, sobre todo a partir del siglo XX se ha rechazado de manera casi unánime la teoría de la superioridad, la hipótesis de que toda risa conlleva un sentimiento de superioridad respecto del otro, alegando que en la mayoría de los chistes no existe un sentimiento de superioridad consciente, o cuando hay un cierto grado de ridiculización, se aduce que no se hace en serio. Como vimos [3.4.1, 
3.4.2], el postulado de la inocuidad del humor es la base de algunas de las posiciones que consideran el humor como algo inherentemente benéfico e inofensivo. Y, sin embargo, también hemos visto que, incluso en el ámbito de las teorías de la incongruencia, se reconoce que esta incongruencia tiene que consistir una "degradación” o una “incongruencia descendente” para que resulte cómica, y no trágica. Otros muchos autores, como Bergson [3.1.2], afirman que lo fundamental es que no haya ninguna implicación emocional en lo cómico, puesto que si la hubiera la risa sería sustituida por el malestar o por una piedad por el protagonista de lo cómico. Claro que esto implica que lo que ocurre en la comedia es algo violento, que hace daño y que, en condiciones normales, nos afectaría de manera negativa.

La recepción de lo cómico, la manera en que los espectadores perciben y se relacionan con lo cómico, tiene mucho que ver, por tanto, con la cuestión de la distancia estética, que, como decimos, es un rasgo fundamental de lo cómico en cuanto fenómeno lúdico. Como hemos visto, uno de las características básicas de lo lúdico es que "abre un mundo” aparte del mundo serio, ajeno a la cotidianeidad, que garantiza, por ejemplo, que podamos obtener placer de un espectáculo trágico. Como afirma Jauss, solo se puede disfrutar de lo cotidiano en la medida en que se contempla reflexiva y estéticamente: la experiencia estética consiste en contemplar como desde fuera nuestro propio rol cotidiano (Jauss, 1986: 34) - supone, en otras palabras, contemplar nuestra propia experiencia como la ejecución de un papel dramático.

La experiencia estética, por tanto, supone un distanciamiento y la suspensión de una implicación afectiva seria, pero esto no significa que no tenga consecuencias en la esfera de lo serio: Jauss, como Ricoeur, propone que mediante la experiencia estética aprendemos a experimentar la vida cotidiana - y pone como ejemplo extremo la figura cómica de Don Quijote (Jauss, 1986: 36). Por tanto, lo estético, mediante el distanciamiento, abre la posibilidad de identificaciones alternativas que son a su vez modelos de conducta moral, ofrece «un marco ejemplar de relaciones para situaciones y funciones que pueden adoptarse mediante una mímesis espontánea o una imitación libre $\mathrm{y}$, por último, ofrece la posibilidad - frente a todas las funciones y situaciones - de comprender la realización en sí misma como un proceso de formación estética» (Jauss, 1986: 40). En suma, la distancia estética no solo no implica una ausencia total de emociones, sino que, al contrario, muchas veces la experiencia estética "nos enseña cómo sentirnos” frente a determinadas situaciones. Además, hay que tener en cuenta que la 
experiencia estética siempre tiene cierto contacto con el resto de ámbitos de praxis social, y que en ocasiones, como vimos, es difícil delimitar los límites entre la experiencia cotidiana y la estética, sobre todo en el caso de la distinción entre lo ridículo y lo cómico.

Por tanto, la noción de superioridad no parece ser particularmente precisa ni apropiada para describir el pathos de lo cómico, sobre todo si la entendemos en un sentido intersubjetivo como "alguien que se siente superior a alguien”. Pero es evidente que lo cómico, por su naturaleza lúdica, necesita un distanciamiento, que no es ausencia de emociones, ni tampoco una superioridad en aquel sentido intersubjetivo, pero sí un cierto sentimiento de estar "por encima” de las circunstancias, de modo que lo que ocurre en el mundo ficticio de la comedia no nos afecta porque no es realmente importante. Por esta razón, parece más precisa la idea de frivolización, que no afecta únicamente a la "víctima” de la burla, sino que es una condición de todo el discurso cómico.

Consideremos el siguiente ejemplo, tomado de Billig (2005: 121): «A blind man enters a department store, picks up his dog by the tail and begins to swing it over his head. A clerk hurries over and says, 'Can I help you, sir?' 'No, thanks' the man replies. 'I’m just looking around.'». La comicidad del chiste reside, es evidente, en la literalización (materialización) de la frase hecha «looking around» superpuesta a la idea, también tomada en sentido literal (material), de que el perro guía son los ojos de una persona ciega. Casi nadie diría, en todo caso, que el chiste se burla de las personas ciegas, y que no hay ninguna ridiculización ni humillación: el chiste no consiste en nada más que el ingenioso absurdo de la situación. Pero tampoco es imposible imaginar a una persona, preocupada por el bienestar animal, que señalara el maltrato al que es sometido al perro. El hecho es que, efectivamente, el chiste está construido de tal manera que el animal aparece como un objeto, casi de atrezzo, de modo que no nos parece escandaloso el comportamiento de su dueño.

¿Sería legítima o razonable esta objeción? ¿Estamos hablando de una mala interpretación del chiste, o como poco exagerada? Este tipo de preguntas son las que trataremos en el último capítulo, al analizar el debate público sobre los límites del humor. Como veremos, las posibles respuestas ofrecerían argumentos correspondientes a distintos ámbitos, desde algunos más aparentemente “formales” (del tipo: «la persona que protesta no ha entendido cómo funciona el chiste» o «evidentemente la intención del chiste no es humillar al perro») hasta psicológicos («la persona no sabe disfrutar del 
humor», «se lo toma todo en serio», etc.). En todo caso, la interpretación es plausible, y su aceptación o no depende de razones ideológicas en un sentido amplio, incluso las que se centran en los rasgos supuestamente objetivos y estables del discurso humorístico: como venimos defendiendo, no solo la interpretación de un chiste concreto puede variar, sino el propio funcionamiento del discurso humorístico en general y su uso están determinados por preconcepciones que son ideológicas en un sentido amplio.

Podemos poner otro ejemplo en el que sí se produjo una controversia real. En el año 2002, Ann Winterton tuvo que renunciar a su puesto en el Parlamento británico por contar el siguiente chiste durante una cena oficial:

There were an Englishman, a Cuban, a Japanese man, and a Pakistani on a train. The Cuban throws a cigar out the window, saying they are ten-a-penny in his country. The Japanese man throws a Nikon camera out, saying they are ten-a-penny in his country. Then the Englishman throws the Pakistani out the window (Morreall, 2009: 99)

Según una de las posibles interpretaciones del chiste dadas para defender a Winterton, el verdadero objetivo del chiste es la actitud racista del personaje inglés, y es él quien aparece como humillado: «The Pakistani in this joke doesn't do anything, and isn't even described. It is the Englishman who acts, by murdering him. If the target of the joke is English racism, of course, the joke isn't and expression of prejudice and hostility toward Pakistanis» (Morreall, 2009: 99). Pero, aun cuando se pueda hacer del inglés el verdadero objeto de la crítica del chiste (aunque también exista la posibilidad de que una persona racista no vea nada malo en su actitud, y de hecho sienta admiración por él al haberse librado de las convenciones sociales hipócritas que impiden dar rienda suelta a sus sentimientos contra otras razas), el problema es precisamente que el paquistaní cumple aquí el mismo papel que el perro del chiste anterior: es una simple pieza de atrezzo; efectivamente, no tiene ninguna agencia y ni siquiera aparece descrito, está totalmente deshumanizado. En este sentido, puede que el chiste no exprese una hostilidad directa hacia los pakistaníes, pero sí es comprensible que se señale la frivolización de la violencia racista. También vimos [3.3.2.3] un caso parecido cuando analizamos la descripción de Linda Hutcheon de la polémica en torno a la exposición de un museo canadiense contra el colonialismo, que levantó controversia al decidir aproximarse a un tema tan espinoso desde la ironía. 
En resumen, es necesario insistir en que la distancia estética inherente a lo cómico no supone, en ningún caso, una ausencia de emociones. La falta de compasión o piedad necesita, simultáneamente o no, de un sentimiento de superioridad respecto de los personajes cómicos o bien una frivolización de los asuntos que aparecen en la comedia. La distancia proporcionada por lo cómico no deriva de una absoluta objetividad racional, sino más bien de una actitud de minusvaloración, desprecio o, incluso, crueldad, puesto que podemos decir que el placer cómico se obtiene del sufrimiento de los personajes que viven una situación angustiosa. Como hemos visto, son muchos los autores que suponen en la risa una descarga de agresividad. Observemos, asimismo, que la frivolización parece suponer un malestar especialmente doloroso, puesto que un drama o una tragedia mal ejecutada no suele causar tanta indignación como una broma de mal gusto. Un caso límite que se nos plantea en muchas ocasiones es el que el espectador se sienta identificado con el dolor del personaje cómico.

Esta afirmación no tiene por qué suponer una condena moral totalizante de lo cómico, pero sí un reconocimiento de los afectos implicados en lo cómico, no solo en su recepción sino en la misma constitución de su discurso, que ha de rebajar, por así decirlo, la dignidad de sus personajes para que los espectadores puedan disfrutar de la risa. Ciertamente, no se puede olvidar tampoco que se trata de un entorno de ficción que cuanto menos problematiza una simple lectura ética. Pero es un hecho también que existe en todo individuo y en toda sociedad un umbral de tolerancia a la frivolidad cómica, como ya expresaba perfectamente Aristóteles en su definición: «lo risible es un defecto y una fealdad que no causa dolor ni ruina» (Aristóteles, 2018: 1449a31-35). Por supuesto, como decimos, estos límites de lo que causa dolor son variables a nivel individual y colectivo y sobre todo son, en última instancia, ideológicos.

\subsection{Conclusiones: usos de lo cómico}

Esta descripción, ciertamente esquemática, de los rasgos del fenómeno cómico, más que aclarar sus funciones y repercusiones sociales, debería haber puesto de relieve la enorme variabilidad y complejidad de estas. Los mecanismos cómicos pueden servir a muy diversos propósitos. La implicación más evidente de nuestra definición de lo ridículo es el uso de la risa como sanción social: la risa y el humor sirven para castigar las 
desviaciones de las normas sociales - se usa, por ejemplo, para burlarse de los homosexuales, las mujeres, las personas racializadas, los débiles, los inferiores intelectualmente... y/o perpetuar estereotipos negativos sobre estos grupos. En este sentido, la risa tiene una función de conservación del grupo y de las estructuras sociales que lo definen. Un uso más reconocido y prestigioso, que parece contradecir esta visión, es el de la sátira como crítica social: el humor, por una parte, permite distanciarse de las creencias dogmáticas y criticar en lo que estas puedan tener de erróneo o ridículo; o puede usarse, por ejemplo, contra un político para señalar que no está a la altura de su cargo por incompetente o inmoral. Pero es necesario señalar que, en realidad, en ambos casos funciona el mismo mecanismo del ridículo: en el caso de la sátira política, es cierto que el ridículo se dirige contra una figura con autoridad y poder, o un colectivo o una cierta idea o convención más o menos aceptada, pero se les sigue caracterizando como incumpliendo un “estándar” moral que se considera superior (el político es insincero, incompetente, etc.): se sigue aplicando la sanción social mediante la risa de aquel que incumple ciertas normas. En última instancia, el cómico satírico es siempre un moralista: Lenny Bruce, quizá uno de los cómicos más legendarios de la cultura occidental contemporánea, se definía a sí mismo de este modo: «El mundo está enfermo y yo soy el médico. Soy un cirujano con bisturí para los falsos valores» (ver Bruce, 1989; Paton, 1988).

Por tanto, parece poco adecuado decir que lo cómico supone una perspectiva totalmente objetiva y que, consecuentemente, es el modo discursivo más adecuado para la crítica política, moral o filosófica: esta postura es, de por sí, altamente ideológica [4.2.3]. Si todo discurso, como dijimos en el capítulo anterior, es ideológico, depende de una serie de presuposiciones y marcos cognitivos, el discurso humorístico no es una excepción. El discurso humorístico, como dijimos, depende de estereotipos y lugares comunes, y para que sea efectivo, como remarcan casi todos los estudiosos de este tipo de comunicación, es necesario que los interlocutores compartan una serie de valores. Si alguien se ríe con una caricatura que caracteriza a cierto político como incompetente, será porque previamente considera que, efectivamente, dicho político es un incompetente. Le parecerá que la caricatura ofrece un ajustado reflejo de la realidad (tal y como esa persona la percibe). Si, por el contrario, le parece un buen político, encontrará la caricatura como ofensiva, o al menos equivocada. Pero será difícil que la caricatura le persuada de ver al político de otra manera. 
Del mismo modo, hemos argumentado que los propios mecanismos de lo cómico ponen de relieve las expectativas, prejuicios y estereotipos de la vida cotidiana. Al parodiar estos estereotipos y creencias, o los diferentes lenguajes sociales, al mostrar, en fin, cómo toda la vida social está previamente codificada, parecería que el humor es intrínsecamente crítico y subversivo, pero esta afirmación sería apresurada: revelar una creencia como estereotípica no significa desautorizarlo. Por ejemplo, una de las situaciones cómicas más típicas, la de un hombre vestido de mujer y comportándose como tal, puede dar lugar a muchas interpretaciones no necesariamente críticas: la actuación del hombre puede estar basada en estereotipos misóginos, por ejemplo, y si bien alguien podría interpretar que de este modo se está criticando el estereotipo, también se podría decir que se está reforzando al caricaturizar cómo las mujeres son “de verdad”; la actuación también puede ser una ridiculización del hombre que incumple los estándares de masculinidad: de nuevo, se podría estar criticando estos estándares como ideales falsos e inalcanzables, pero también sancionando al hombre por no ser lo suficientemente masculino. Finalmente, más que burlarse de los estereotipos de género como tales estereotipos, se puede estar reforzando la naturalidad de los mismos al mostrar como evidente la imposibilidad de que un hombre sea una mujer. En suma, es apresurado declarar la subversión como un rasgo inherente al discurso paródico: este siempre dependerá de cada interpretación particular y, por tanto, de nuestras opiniones previas, en este caso acerca de la naturaleza de la identidad de género.

¿Significa eso que el discurso humorístico no puede cumplir el mismo papel cognitivo y heurístico que se le reconoce a la metáfora? Por supuesto que no. Lo cómico, como una dislocación, una recontextualización o una yuxtaposición incongruente de elementos, puede llevarnos, como el enunciado metafórico, a contemplar estos elementos desde una perspectiva novedosa. El discurso irónico supone una recontextualización que nos permite apropiarnos de un sentido y modificarlo. Como veremos en el capítulo siguiente, la estética camp supone una reapropiación cómica de los estereotipos de género, y en el dedicado al análisis de Friends propondremos cómo es posible realizar lecturas alternativas de la serie que problematizan los aspectos considerados más retrógrados. El juego camp con lo material y lo imaginario nos permitirá, por ejemplo, reelaborar una concepción de la identidad trans. Pero también hay que tener en cuenta, como decimos, que esta repetición irónica es fundamentalmente ambigua y exige un proceso de interpretación que depende, en última instancia, de nuestros propios 
presupuestos ideológicos e interpretativos. En ese sentido, veremos cómo para algunos la estética camp más que una subversión de dichos estereotipos de género supone una confirmación de su misoginia y su homofobia.

Es más, como hemos defendido en muchas ocasiones a lo largo de este trabajo, estas variables dependen enteramente de las concepciones previas que tanto el productor como el receptor del discurso cómico tengan de la naturaleza del humor y sus significados. Así, quien asuma como esencial la inocuidad de la risa rechazará las asociaciones de esta con los sentimientos de superioridad y agresividad, y usará el humor como señal de integración interpersonal, como herramienta de relajación, de relativización de los problemas, etc. Otra persona que crea en el potencial humorístico del humor defenderá su fundamental objetividad, mientras que otra considerará que el discurso humorístico, crítico o no, no tiene ninguna eficacia política real y crea una falsa sensación de implicación, cuando no frivoliza las problemáticas sociales y desactiva la lucha de la ciudadanía. Cuando estas diversas perspectivas se encuentran dan lugar a polémicas, controversias y conflictos interpretativos acerca de lo que podemos llamar un orden del discurso humorístico; es decir, plantean conflictos acerca de lo que es susceptible de ser tratado cómicamente o no, de los efectos sociales del humor, de hasta qué punto el humor es tolerable o deseable en los distintos ámbitos de la vida pública y privada, etc. Estas cuestiones están relacionadas con otras, como la libertad de expresión, los equilibrios de poder en una sociedad o cuáles son las formas más adecuadas de crítica ideológica o conversación social y política. Este será el tema de nuestro último capítulo, dedicado a la controversia actual en la sociedad española respecto a los límites del humor. 
III. EL ORDEN HUMORÍSTICO DEL DISCURSO 


\section{LA ESPECTACULAR VERDAD DEL CUERPO: CAMP, PARODIA E IDENTIDAD TRANSEXUAL EN DOS NOVELAS DE EDUARDO MENDICUTTI}

En la madrugada del 8 de junio de 1969, los clientes del bar Stonewall Inn, en el Greenwich Village de Nueva York, iniciaron las revueltas contra las redadas y los acosos de la policía alentados por un sistema que perseguía a los homosexuales. Ese lugar y esa fecha se consideran el origen de los movimientos implicados en la lucha por los derechos del colectivo LGTBI. Pero, con el tiempo, el colectivo, demasiado preocupado a veces por su respetabilidad, tiende a olvidar o a deformar el hecho de que los protagonistas de aquel levantamiento de Stonewall fueron, sobre todo, travestis, transexuales y drag queens. También ahora, en estos tiempos en los que se suceden violentos actos de homofobia, quienes siguen siendo los más marginados del colectivo dan con frecuencia ejemplo de dignidad y coraje en defensa de los gays, lesbianas, transexuales, bisexuales e intergénero que padecen agresiones, desprecio, marginación y odio por ser lo que son. Este libro quiere ser, también, un homenaje y una expresión de gratitud a todos ellos y todas ellas, y a su dignidad, su lucha, su furia justa y su lenguaje.

Eduardo Mendicutti, nota a Furias divinas (2015)

En este capítulo analizaremos dos novelas del popular escritor español de literatura LGTB, Eduardo Mendicutti. Principalmente, queremos estudiar cómo las interpretaciones que se le han dado a estas novelas, sobre todo a Una mala noche la tiene cualquiera, dependen, por un lado, de la ideología política de los críticos, y, por otro, especialmente por sus concepciones sobre el humor - muy influidas, como veremos, por el discurso de los críticos marxistas de la sociedad actual que estudiamos en la sección 3.4.3. El capítulo, además, nos permitirá adentrarnos en uno de los fenómenos más polifacéticos y omnipresentes en la cultura contemporánea: la estética camp. Esta estética está relacionada con muchos de los aspectos de lo cómico que hemos estudiado en los 
capítulos precedentes: por un lado, está íntimamente relacionado con la cultura de masas: consiste, en esencia, en una mirada irónica hacia ella. Por otro, es una estética muy vinculada a la historia de la comunidad gay estadounidense de los siglos XX y XXI: forma parte, como veremos, de manera controvertida, de la identidad social de este colectivo. En este sentido, lo camp nos permite estudiar los aspectos más explícitamente políticos de lo cómico: ¿cómo se puede entender este carácter humorístico de la cultura gay? ¿cuál es su función? ¿es efectivo o más bien contraproducente utilizar un discurso humorístico como estrategia política? Por otro lado, en la última sección del capítulo exploraremos las posibilidades hermenéuticas de la estética camp más allá de sus implicaciones más directamente ideológicas y políticas.

¿De qué hablamos cuando hablamos de lo camp? En la película de 2005 Los Productores (adaptación del musical de Broadway homónimo de 2001, que a su vez estaba basado en la película de Mel Brooks de 1967), el contable Leo Bloom y el productor de Broadway en horas bajas Max Bialystock descubren que el fracaso en taquilla de una obra daría más dinero que un modesto éxito, así que deciden montar una estafa produciendo el peor musical posible. Para ello, utilizan el guion escrito por un nazi lunático, titulado Springtime for Hitler. Llegado el estreno, todo parece ir sobre ruedas: el primer número musical (cuya letra dice: «Springtime for Hitler and Germany,/ Deutschland is happy and gay./ We're marching to a faster pace. / Look out: Here comes the master race») indigna a los burgueses espectadores, que se levantan airados de sus butacas y comienzan a abandonar la sala. Pero todo se tuerce cuando aparece Hitler en escena. El actor que iba a encarnar al dictador iba a ser el propio guionista neonazi, pero por culpa de un accidente de última hora, tiene que sustituirle el director artístico, Roger De Bris. Este, homosexual afeminado, traslada su amaneramiento al personaje, por lo que los espectadores ven es a un Hitler "con pluma” que gesticula de manera exagerada y “ridículamente” afeminada y no dejar de mirar obscenamente a los soldados nazis del cuerpo de baile (Fig. 13). La interpretación provoca la risa del público, que decide quedarse hasta el final de la obra, y esta acaba siendo un éxito rotundo.

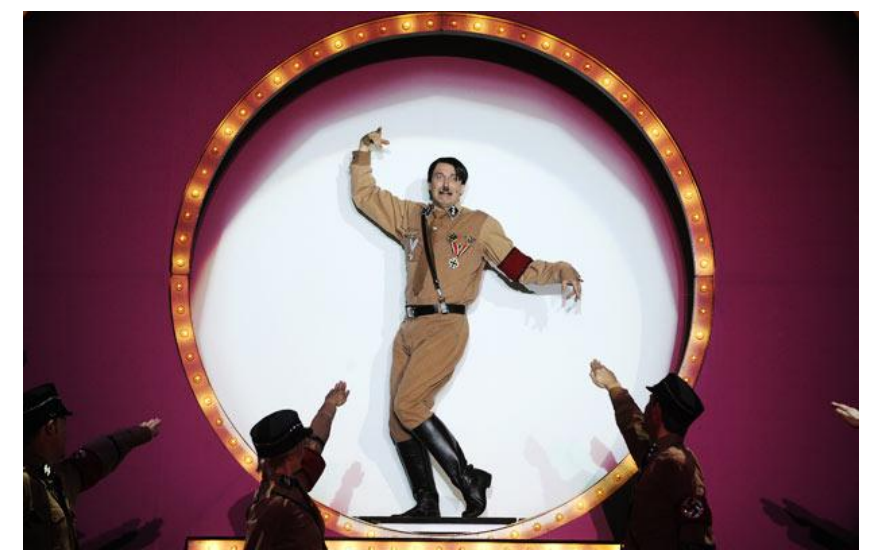

Ilustración 1Fig. 13. Fotograma de Los productores (2005) 
El número en cuestión es una muestra perfecta del estilo camp, una estética propia de la cultura de masas emparentada con el kitsch (como se denomina a los productos de la cultura de masas de ínfima calidad, horteras, pretenciosos, etc.) y el pop, que nace en Estados Unidos hacia mediados del siglo XX, muy vinculada con la comunidad homosexual. La cualidad camp está presente, en primer lugar, por la decisión de hacer un número de burlesque de uno de los eventos históricos más graves de la Historia, con la absoluta frivolización del Tercer Reich y la Segunda Guerra Mundial que supone - habría que tener en cuenta, sobre todo, la siniestra pero frecuente atracción que la sensibilidad camp parece sentir por las manifestaciones del fascismo y que también encontraremos en Una mala noche la tiene cualquiera ${ }^{5}$. En el plano estético, encontramos el exceso, lo hortera y la aparatosidad de la puesta en escena, amén de lo ridículo, no solo en la actuación del Hitler afeminado: tengamos en cuenta, por ejemplo, el efecto tan kitsch de unas mujeres semidesnudas con figuras de pretzels y salchichas alemanas en la cabeza, o unos soldados con uniforme nazi bailando claqué (Fig. 14) (el uniforme, sobre todo militar, como metonimia de hipermasculinidad y, en cierto sentido, expresión drag, también tiene un sitio privilegiado en el repertorio del estilo camp). También, y sobre todo, la teatralidad intrínseca de todo el número: no solo, por supuesto, porque se trate de un musical, sino en la propia gestualidad exagerada de Hitler, quien en un momento llega a cantar «everything is showbiz».

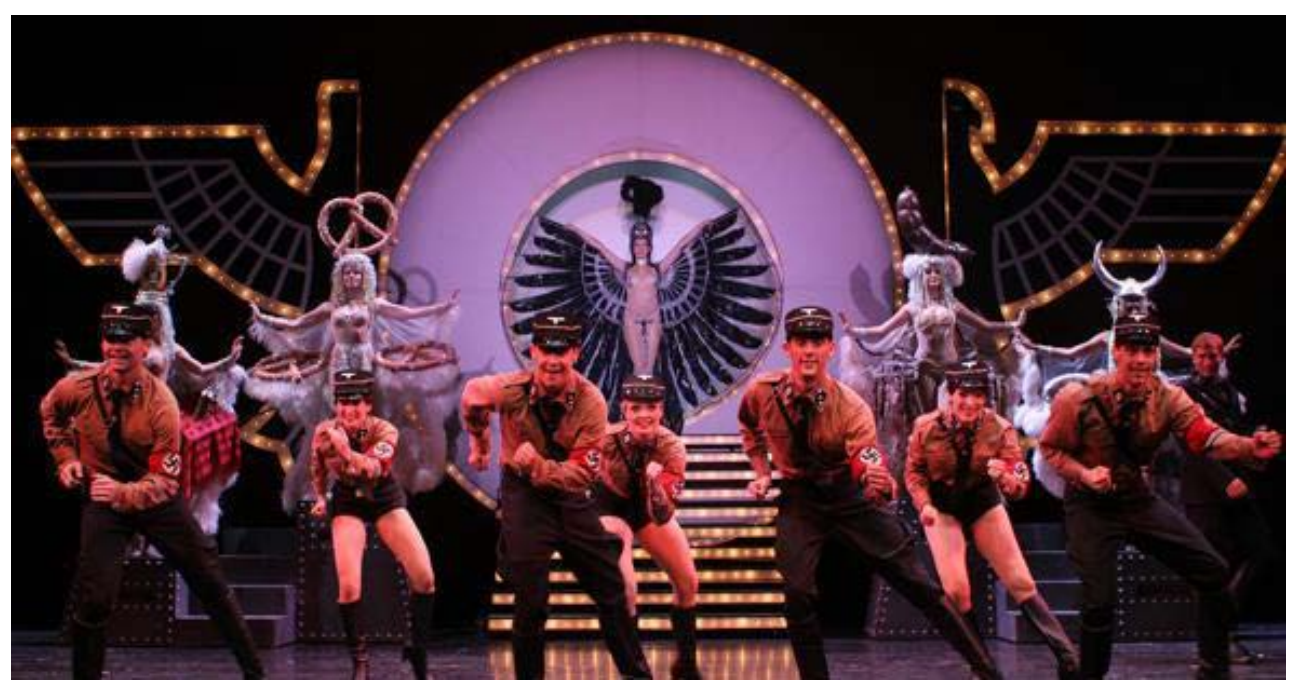

Fig 14. Fotograma de Los productores (2005)

\footnotetext{
${ }^{5}$ Claro que hay características evidentemente camp en las manifestaciones artísticas y militantes del fascismo: su aparatosa teatralidad, su hiperbólica pretenciosidad, su exacerbada promoción de la masculinidad...
} 
Pero, ante todo, debemos atender a la cualidad homosexual (más exactamente: marica ${ }^{6}$ ) de todo el espectáculo. Tengamos en cuenta que lo que hace al público reír y decidir quedarse es la actuación amanerada de Hitler, con la que el musical pasa de ser una indignante apología del nazismo una hilarante ridiculización de uno de los dictadores más sangrientos de la Historia. Es el personaje homosexual, no solo como actor, sino como director artístico, el que impregna de "mariconerío" todo el musical y transforma una producción simplemente kitsch en un fantasioso espectáculo camp.

Ya el número en que se presenta al director Roger De Bris, cuando los productores protagonistas intentan convencerle de que dirija el guion de Springtime for Hitler, se titula «Keep it gay» (jugando con el doble sentido, como «alegre» $\mathrm{y}$ «homosexual», que tiene el término inglés) y representa una auténtica declaración de intenciones. Les recibe en su casa su ayudante personal, un homosexual también visiblemente afeminado, y el mismo director con un vestido de lentejuelas (se supone que va a acudir a una fiesta de disfraces travestido de la duquesa Anastasia). En un principio, este se niega a ocuparse de la obra porque la Segunda Guerra Mundial le parece un tema demasiado deprimente: «Shows should be more pretty / Shows should be more witty / Shows should be more... What's the word?... Gay! / No matter what you do on the stage/ Keep it light, keep it bright, keep it gay!». Ante la insistencia de Bialystock, Roger decide consultar a su equipo de producción: el asistente de vestuario, un aficionado al leather, con bigote y ataviado con cadenas y gorra de policía, al estilo de una figura de Tom de Finlandia, el coreógrafo y el director de peluquería (otros dos hombres con pluma) y, por último, la asistenta, una mujer de aspecto masculino (es fea, viste pantalones y camisa de cuadros y canta con voz exageradamente grave) - el número terminará con un desfile literal estereotipos homosexuales acorde con el imaginario de Tom de Finlandia y los Village People: un nativo americano, un hindú, un marinero... (Fig. 15)

\footnotetext{
${ }^{6}$ A lo largo de este capítulo no tendremos reparo en usar palabras que en otros contextos son despectivas, como «marica», «maricón», «loca» o «pluma», como equivalentes en la cultura española a lo que representa, en Estados Unidos, la reapropiación del insulto «queer», que equivale a «maricón» [ver más adelante, 6.1.4].
} 


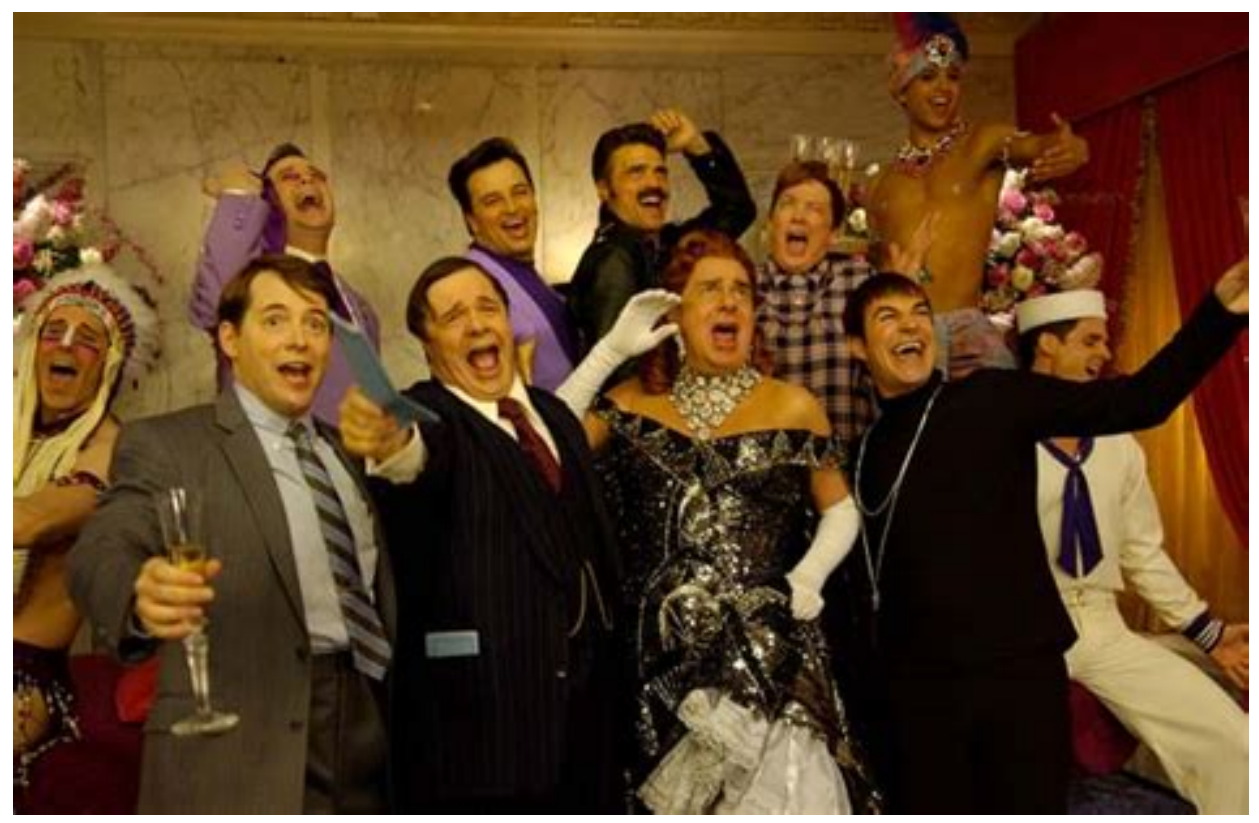

Fig. 15. Fotograma de Los productores (2005)

En resumen, estos dos números musicales nos hablan de una cierta mirada gay, que identificamos inequívocamente como camp, basada en la espectacularidad y la frivolización, que proyecta una luz satírica que ridiculiza a un personaje como Hitler y todo lo referente al nazismo. Ahora bien, y aun teniendo en cuenta que tanto la película original de Mel Brooks y la versión musical son obras tremendamente irreverentes y, de hecho, muy disfrutables, cabría preguntarse, primero, por la efectividad o necesidad de una sátira del nazismo hecha en Estados Unidos, el vencedor de la Guerra Mundial, a la prudente distancia de 1959 (año en el que está localizada la película, y aún podríamos destacar que la cinta original es de 1964, y su versión musical, de 2005); y, segundo, por las implicaciones ideológicas que tiene que esa ridiculización del personaje de Hitler se realice, precisamente, a través del afeminamiento o, dicho más claramente, su mariconización.

En el primer caso, podríamos argumentar que es “fácil” reírse de Hitler y el nazismo desde la sociedad que, realmente, no llegó a sufrir de primera mano el horror de sus crímenes - cabría preguntarse, por ejemplo, la reacción de un judío superviviente al holocausto: al fin y al cabo, se está ridiculizando a Hitler, pero a costa de frivolizar el nazismo y la Segunda Guerra Mundial. En segundo lugar, esta satirización, efectivamente, se hace a través de la trans-formación de Hitler en un estereotipo negativo del homosexual como afeminado y, por tanto, risible. Esta estereotipación está ya, como hemos visto, en la caracterización del director y su equipo de producción. 
Todas estas ambivalencias interpretativas y sus consecuencias idoelógicas (por un lado, la ironía camp como frivolización de lo serio; por otro, la perpetuación del estereotipo del afeminamiento del homosexual) son precisamente las que atraviesan todos los temas que trataremos en las páginas siguientes. Como veremos, tanto la estética camp como la figura del $d r a g /$ transgénero $^{7}$ serán interpretados por las teorías feminista y queer, los Estudios Culturales, etc., entre dos polos opuestos: por un lado, el camp y el drag como subversión de la cultura heterosexista y sus símbolos, el sistema sexo/género y sus distinciones naturalizadas, etc.; por otro, la absoluta dependencia y, por tanto, legitimación, de la parodia camp y las actuaciones (performances) del drag/transgénero de ese mismo sistema sexo/género normativo.

Por un lado, como veremos, el camp funcionó durante la primera mitad del siglo XX como un código identitario de la comunidad homosexual en la sociedad angloamericana - y también en la española, como defiende Mira (2007: 146). Pero su asociación con el estereotipo del homosexual invertido o afeminado dio lugar a que, a partir de los años setenta, con la intensificación de los movimientos por los derechos civiles de las comunidades homosexuales, se rechazara esta cultura por considerarla perpetuadora de un estigma; al mismo tiempo, y sobre todo a partir de los años noventa, muchos activistas y teóricos gays y queer reivindicarían precisamente el potencial subversivo que tienen tanto la homosexualidad "marica” contra la naturalización del género como la estética camp contra los presupuestos culturales heterosexistas.

Por otro, y como apunta Prosser (1998: 6), la teoría queer ha tomado precisamente al sujeto transgénero o transexual ${ }^{8}$ como epítome de la subversión de la naturalización del sexo y el género a través, precisamente, de una determinada interpretación del camp como estética queer. Como veremos, la asociación que realizó la antropóloga Esther Newton entre el camp y la cultura drag en su libro de 1972 Mother Camp: female impersonation in America servirá de inspiración a Judith Butler para su teoría del género como performatividad, poniendo como ejemplo la actuación drag en su libro El género

\footnotetext{
${ }^{7}$ Como veremos más adelante, unos de los mayores problemas a la hora de teorizar la identidad transexual desde la teoría feminista y queer es la confusión entre dos fenómenos bien distintos, el del espectáculo drag y los cuerpos transgénero o transexuales.

${ }^{8}$ La terminología respecto a este tema es variada y muy cambiante. Tradicionalmente se ha distinguido «transexual» de «transgénero», según la persona quiera o se haya sometido a la operación de reasignación de sexo. En los últimos tiempos, tanto en la teoría como el activismo trans se han cuestionado los presupuestos ideológicos que subyacen a esta distinción, y se prefiere el adjetivo «trans» o, incluso, «trans*», donde el asterisco quiere señalar las muy variadas maneras en que cada persona vive su experiencia (ver Halberstam, 2018; Stryker, 2017).
} 
en disputa. Cuando en su siguiente obra, Cuerpos que importan, vuelva sobre sus pasos para cuestionar el potencial subversivo del drag e insista en la ambigüedad intrínseca de sus actos performativos, se servirá del documental Paris is Burning de 1989, que muestra los usos y costumbres de la cultura del ball neoyorquino de aquellos años, retratado recientemente por Ryan Murphy en la serie Pose. Precisamente su directora, Jenni Livingstone, llegó a decir haberse inspirado para la realización de su película en las películas de Pedro Almodóvar de los ochenta y su representación de identidades trans (Vilarós, 2018: 163). Por tanto, vemos que existe una importante conexión, no solo en el plano teórico sino también en el histórico, entre la estética camp (como estética cómica), la identidad trans y la cultura española de la Transición

En efecto, en los años ochenta España contemplará una explosión de libertades individuales entre las que destacan, por su importancia simbólica respecto a la moralidad franquista y su visibilidad inusitada, las libertades sexuales, concretamente la libertad homosexual y transgénero. Es la época, por ejemplo, de los cómics de Nazario o los actos callejeros de Ocaña. Precisamente, la figura del travesti o "travestí" se convertirá en metáfora y símbolo privilegiado de esa trans-ición española de la dictadura a la democracia, con todos sus éxitos pero también sus ambigüedades y vestigios del pasado. Esta metáfora toma cuerpo, literalmente, en la celebrada novela de Eduardo Mendicutti Una mala noche la tiene cualquiera, que es el objeto principal de estudio en este capítulo; una muestra exquisita de estética camp en que asistimos al monólogo histérico de un travestí ${ }^{10}$ conocido como La Madelón la noche del golpe de Estado del 23 de febrero de 1982. La novela, publicada apenas un año después del golpe, ha atraído la atención de numerosos críticos literarios y culturales que han tomado a La Madelón, como decimos, como la metáfora perfecta de la España del momento: como un símbolo de la libertad obtenida con la llegada de la democracia, pero también como un cuerpo en transformación, que celebra la diversidad pero que mantiene intacto, aun oculto, el fantasma de su pasado. Lo interesante de esta recepción es que, y en consonancia con la

\footnotetext{
${ }^{9}$ Esta anécdota no es la única que une la teoría queer internacional con la escena contracultural y de la movida española. El importante teórico Guy Hocquenguem, por ejemplo, vivió en Barcelona y escribiría un artículo sobre Barcelona 'la loca' (El viejo topo, 8, 1977). De este modo, podríamos decir que la escena contracultural y específicamente los espectáculos de travestis o los personajes transgénero de Almodóvar, O y Nazario son tan importantes para el nacimiento de la teoría queer como los ball neoyorquinos o los espectáculos drag que estudiaron Butler y Newton.

${ }^{10}$ Utilizamos aquí la expresión extendida en la época, que confundía transformismo, homosexualidad y transexualidad, aun cuando la protagonista es una mujer transexual, porque precisamente la confusión de los términos, como veremos, dará lugar a la variedad de interpretaciones contradictorias a la que da lugar la novela.
} 
ambigüedad interpretativa desde la teoría tanto del camp como de la figura del sujeto trans, la visión y valoración del fenómeno histórico de la Transición que supuestamente ofrece la novela variará enormemente, desde la celebración del proceso democratizador hasta la absoluta condena por tratarse de la continuidad solapada del franquismo.

Es por eso por lo que, partiendo del camp como discurso humorístico, estamos ante un campo privilegiado para el estudio de las diferentes implicaciones ideológicas de fenómenos como la parodia, la ironía, la carnavalización, etc., y su papel en la formación de identidades sociales y, sobre todo, su importancia política. Los análisis que siguen quieren mostrar esta ambigüedad interpretativa inherente al discurso humorístico; porque, como intentaremos demostrar, gran parte de las ambivalencias y conflictos en torno a la estética camp o las figuras del homosexual afeminado, de las personas transgénero, etc., se debe al valor y consideración que se tenga del humor y, en última instancia, a la propia naturaleza del fenómeno cómico.

En el primer apartado de este capítulo, pues, llevaremos a cabo una revisión histórico-teórica de la estética camp, partiendo de las fundacionales «Notas sobre lo camp» de Susan Sontag, desde su configuración como «sensibilidad gay», como rasgo identitario de la comunidad gay pre-Stonewall, hasta los recelos de los movimientos sociales de derechos homosexuales y feministas y su reapropiación por parte de la teoría y el activismo queer en los años noventa. Atenderemos también a la ambivalencia política del drag y el sujeto transexual en las teorías y las políticas feministas y gays, y su relación con la estética camp. A continuación, analizaremos Una mala noche la tiene cualquiera: los rasgos que hacen de ella una novela camp, la consideración por parte de la crítica del personaje de La Madelón como metáfora de la España transicional y las interpretaciones divergentes respecto a la imagen de la Transición que ofrece la novela.

En el curso de estos análisis, argumentaremos que la fijación de la crítica de la protagonista como metáfora de la Transición lleva a pasar por alto la atención al propio personaje como delicado retrato de la identidad trans y sus circunstancias sociales. Esta atención a la construcción de la identidad trans se verá completada en el apartado siguiente, en el que llevaremos a cabo un análisis de otra novela del autor, Yo no tengo la culpa de haber nacido tan sexy, cuya protagonista, Rebeca Soler, es una mujer transexual que decide imitar a Santa Teresa y otros místicos para poder llegar a ser santa. En esta novela, la mirada paródica camp proyectada sobre los textos fundamentales de la mística española sirve al autor para profundizar en este retrato. En todos estos análisis, por 
supuesto, atenderemos al papel de la estética camp en tanto que estética cómica en el conflicto de interpretaciones que nos encontraremos irremediablemente a cada paso.

\subsection{Camp: de una sensibilidad "gay" a la teoría queer. Conflictos de interpretación en torno a la identidad transexual}

La risa frente a las categorías serias es indispensable

- Judith Butler, El género en disputa

\subsubsection{Notas sobre lo camp}

Lo camp, bien sea entendido como un estilo estético o una manera de comportarse, como una cierta mirada o modo de interpretación o una serie discreta de objetos culturales con unas características bien definidas, es uno de los conceptos críticos más cotizados (aunque no demasiado conocido en el ámbito español) en una amplísima gama de disciplinas que podríamos englobar dentro de los Estudios Culturales (feminismo, teoría queer, estudios gays y lésbicos, sociología, materialismo cultural...) y a la vez, y tal vez precisamente por eso, una noción cuya definición, características, especies, repertorio y significación estética y/o política son debatidas intensamente hasta nuestros días. El mismo exceso, gratuidad efímera y aparente frivolidad que parece determinar la naturaleza del fenómeno lleva continuamente al fracaso de cualquier intento de estabilizar su significado (Cleto, 2008: 2-3). De orígenes y etimología incierta, lo que empezó siendo un término det argot norteamericano a principios del siglo XX, y hasta los años setenta solo era objeto de estudio de la sociología como un producto residual de la subcultura urbana, se abrió paso hacia la relevancia académica en una época, como señala Bergman, en la que la crisis del sida, por un lado, y el auge del postestructuralismo, por otro, definían «an age (...) in which sexual and epistemological borders, cultural hierarchies and the very idea of ‘respectability’ were under siege» (Bergman, cit. en Cleto, 2008: 4).

En este mismo texto, introducción a la primera colección de estudios sobre lo camp, Bergman delineaba los pocos puntos en común a los que había llegado la crítica (y estos mismos puntos, más que un consenso describen los lugares del debate): 
First, everyone agrees that camp is a style (whether of objects or of the way objects are perceived is debated) that favors 'exaggeration', 'artifice', and 'extremity'. Second, camp exists in tension with popular culture, commercial culture, or consumerist culture. Third, the person who can recognize camp, who sees things as campy, or who can camp is a person outside the cultural mainstream. Fourth, camp is affiliated with homosexual culture, or at least with a self-conscious eroticism that throws into question the naturalization of desire (Bergman, cit. en Cleto, 2008: 4)

Como vemos, son varios los aspectos implicados en la cuestión del camp: una estética neo-barroca de la exageración y el artificio; su relación con la cultura de masas contemporánea; su vinculación, necesaria o no, quizás estereotipada, con la comunidad homosexual. En todo caso, la dificultad teórica específica del camp en tanto que modo de expresión privilegiado de la epistemología postmoderna reside precisamente en que, al ser una sensibilidad derivativa, fundada en la imitación y el artificio, depende completamente de la cultura en que se desarrolla y que lo interpreta. Por otra parte, en tanto que gusto 'elitista', refinado, requiere de un cierto capital cultural, un cierto conocimiento, para saber localizarlo y apreciarlo: «Just like a diamond, camp (...) is inscribed within the signifying system of preciousness and luxury, and draws its significance when, and as, culturally constructed» (Cleto, 2008: 1). Por lo tanto, al abordar el camp, en lugar de intentar elaborar una definición esencialista y estable, la mejor estrategia es rastrear su práctica material, sus usos y circulación a lo largo del tiempo y las culturas, esto es, atender a las prácticas camp concretas, contextualizadas: en qué momento histórico se dan, en qué lugar social, mediante qué agentes, con qué propósitos, provocando qué reacciones, etc. (Cleto, 2008: 6-7, 35).

Los orígenes y etimología de la palabra «camp», como hemos apuntado, no están nada claros. Encuentra su primer registro en un diccionario de argot de 1909 bajo la definición «actions and gestures of exaggerated emphasis (...) used chiefly by persons of exceptional want of character», siendo de uso corriente en la jerga de la vida suburbana del mundo del espectáculo y la moda, y de manera relevante en la escena drag, tal y como años después la estudiaría Esther Newton (Cleto, 2008: 9, 44); así mismo, «camp» era también un código semiclandestino de comunicación entre homosexuales, una manera de reconocer y ser reconocidos por sus pares, y a partir de los años veinte se usaría para describir el estilo literario de autores como Oscar Wilde, refiriéndose particularmente a 
las estrategias de esteticismo, distanciamiento aristocrático o dandy, ironía, frivolidad, teatralidad, afeminamiento y transgresión sexual (Cleto, 2008: 9).

Siendo un término de argot, por tanto, solo podía aparecer en medios escritos marginales, como diccionarios de jerga suburbana, como hemos visto, u obras de creación que reflejaran ese mundo. De hecho, la primera discusión más o menos extendida sobre el camp como fenómeno estético la encontraremos en la novela de Christopher Iserwood de 1954 The Word in the Evening (Cleto, 2008: 44). Al llegar a los años sesenta, la palabra ya aparecía de manera relativamente más frecuente y de manera más articulada en revistas más populares como Life o The Spectator, refiriéndose por ejemplo al gusto popular por viejas formas culturales representado en los mercados callejeros de antigüedades («fleamarkets»), la androginia de estrellas de la música como David Bowie, el Pop Art de Andy Warhol y la apreciación irónica de productos de masas como la televisión o el cine kitsch (Cleto, 2008: 10); pero, a pesar de todo, seguía siendo un término hasta cierto punto esotérico, solo identificable por un grupo reducido de connaiseurs.

Es en este contexto cuando en 1964 aparece el fundacional ensayo de Susan Sontag «Notas sobre lo camp»; fundacional porque era la primera vez que se consideraba el fenómeno como objeto digno de estudio y atención crítica “seria” (Cleto, 2008: 45) en un momento en que la revolución sexual y los movimientos por los derechos civiles encontraban su reflejo en el mundo académico con el asalto de lo pop. En este sentido, el objetivo del ensayo de Sontag era capturar el Zeitgeist cultural del momento presentando el camp como el gusto por antonomasia de la (post)modernidad en su paradójica combinación de un gusto a la vez elitista y democrático, un gusto snob por los productos de la cultura de masas (Cleto, 2008: 46): para Sontag, lo camp era la respuesta a la cuestión de cómo ser dandy en la cultura de masas, cómo disfrutar de los productos de dicha cultura al tiempo que uno se seguía distinguiendo del gusto vulgar (Sontag, 1967: 317-318).

Por la enorme importancia que tiene este texto para entender tanto el camp como fenómeno como las discusiones teóricas y críticas alrededor de él, es preciso detenerse en la caracterización que ofrece Susan Sontag. Para empezar, la intelectual estadounidense entiende el camp no como una serie de objetos o personas concretas, sino como una «sensibilidad», es decir, un tipo concreto de mirada que percibe (interpreta) lo camp en ciertas manifestaciones culturales (1967: 305). La mirada camp no es, sin embargo, una mirada natural en el sentido de un gusto “espontáneo”, sino, como todo gusto, algo 
aprendido, como una suerte incluso de iniciación en el selecto grupo de los apreciadores; de hecho «la esencia de lo camp es el amor a lo no natural: al artificio y la exageración» (1967: 304).

En efecto, si bien es la mirada camp la que transforma ciertos objetos y personas (personas que, de hecho, esta mirada convierte en objetos), no todos los objetos son susceptibles de ser percibidos como tal. El gusto camp tiene preferencia por las artes ornamentales: el vestuario, el mobiliario, la decoración, etc., artes que subrayan lo superficial, la textura, el estilo sin profundidad (Sontag, 1967: 306). Porque lo camp «es una cierta manera de esteticismo. Es una manera de mirar al mundo como fenómeno estético» (1967: 305), no en términos de belleza “natural”, sino como exageración: «todos los objetos, y las personas, camp contienen una parte considerable de artificio (...) Lo camp es una concepción del mundo en términos de estilo; pero de un tipo particular de estilo. Es el amor a lo exagerado (...) el ser impropio de las cosas» (1967: 307). Es por ello por lo que muchos objetos camp serían considerados como kitsch desde un punto de vista del arte serio (1967: 306): lo camp aprecia la seriedad fracasada, «aquella que contiene la mezcla adecuada de lo exagerado, lo fantástico, lo apasionado y lo ingenuo» (Sontag, 1967: 311). Según la autora, la obra camp no es simplemente una obra de arte fracasada, sino un fracaso debido concretamente a una desmesura en la ambición: «es el intento de hacer algo extraordinario. Pero extraordinario en el sentido, muchas veces, de especial, de seductor» (Sontag, 1967: 312).

Esta atención a la seriedad fracasada, a las obras de estilo exagerado que en su desmesura revelan su artificiosidad implica una visión del mundo muy concreta que es, precisamente, lo que despierta el interés de la teoría postestructuralista, en su afán de deconstruir los binarismos natural/construido, pues es este rasgo en el que los teóricos ven el potencial subversivo de lo camp:

La sensibilidad camp es aquella que está abierta a un doble sentido en que las cosas pueden ser tomadas. Pero no es ésta la construcción familiar dicotómica de un significado literal, por una parte, y un significado simbólico, por otra. Es, más bien, la diferencia entre la cosa en cuanto significa algo, cualquier cosa, y la cosa en cuanto puro artificio (Sontag, 1967: 305)

El camp lo ve todo entre comillas. No será una lámpara, sino una «lámpara»; no una mujer, sino una «mujer». Percibir lo camp en los objetos y las personas es comprender el 
Ser-como-Representación-de-un-Papel. Es la más alta expresión, en la sensibilidad, de la metáfora de la vida como teatro (Sontag, 1967: 308)

Es en este sentido que el camp tiene que ver (de manera frecuente, pero, insiste Sontag, no necesariamente) con el travestismo, la imitación («impersonation»), la teatralidad (Sontag, 1967: 308). Por ejemplo, la admiración camp por las estrellas de Hollywood se basa en la atención a lo exagerado o lo exageradamente atenuado: la figura del andrógino por una parte, pero también la hipermasculinidad y la hiperfeminidad, representada por algunas estrellas de cine (Sontag, 1967: 305) - de ahí que sean vistos como iconos camp actrices como Mae West, Marlene Dietrich, etc.

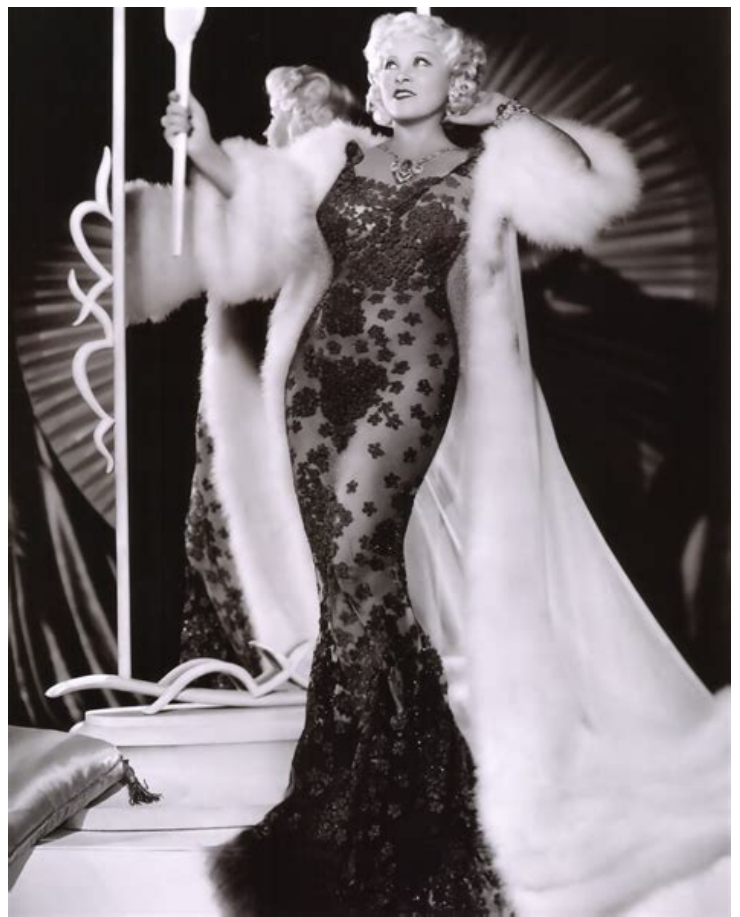

Fig. 16. Mae West

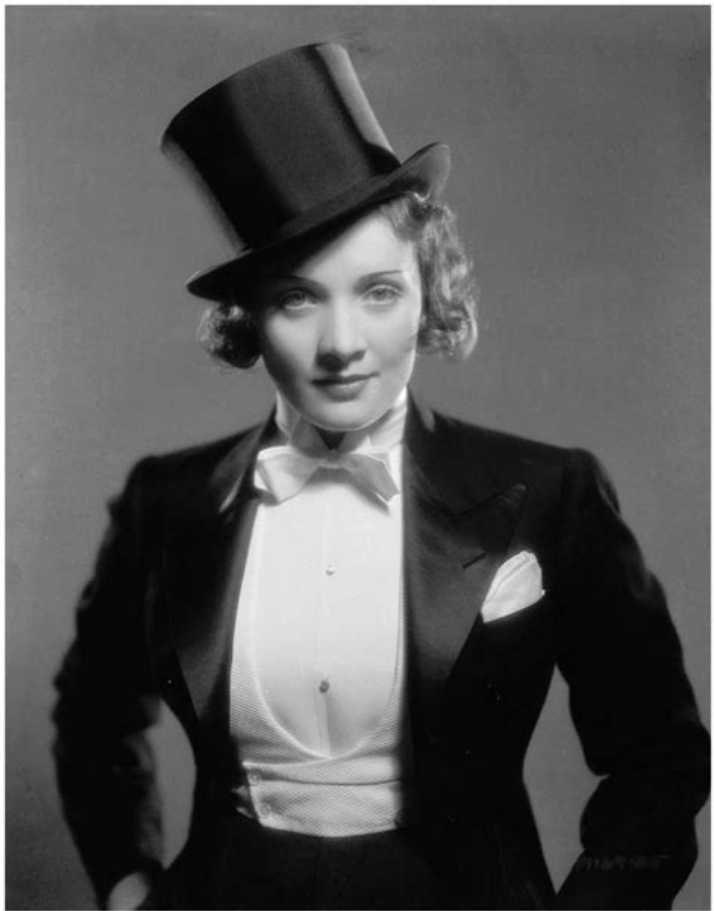

Fig. 17. Marlene Dietrich

Estas características defendidas por Sontag son las que, a grandes rasgos, con más o menos matices y énfasis, atribuyen al camp la mayoría de los críticos posteriores - aunque sea, al menos, porque todos ellos toman como punto de partida el propio artículo de Sontag. Como ya hemos citado, Bergman consideraba como consenso el definir el camp como un estilo que favorece la exageración y el artificio, y que existe en una relación tensa e irónica con la cultura de masas. Esther Newton también describe el camp, más que como una propiedad intrínseca de las cosas, como una relación entre las cosas y la mirada (como veremos, homosexual) que las percibe; una mirada que, aunque variable, se guía generalmente por tres rasgos: la incongruencia, la teatralidad y el humor (Newton, 
1972: 105-106). También Babuscio describe características parecidas: la ironía, en tanto que incongruencia, el esteticismo, la teatralidad y el humor (Babuscio, 2008: 119.)

El camp, según estos dos autores, se produce por una yuxtaposición incongruente, que normalmente implica la oposición masculino/femenino pero que puede referirse a cualquier otra oposición (joven/viejo, antiguo/moderno, sagrado/profano) (Newton, 1972: 107; Babuscio, 2008: 119): en todo caso, existe una tensión entre el objeto o persona camp y el contexto en el que actúa (Newton, 1972: 107), y es esta incongruencia la que revela el carácter actuado del camp. Este es teatral en tres sentidos. Por un lado, por su predilección por el estilo y la superficie: centra su atención no en lo que algo es sino cómo es («how it looks») (Newton, 1972: 107); Babuscio apunta a la estetización de la vida en un sentido wildeano como núcleo de la práctica camp (2008: 120). Por otro, también implica teatralidad en tanto que este estilo, como ya apunta Sontag, es un estilo exagerado, como «consciously staged $(. .$.$) - this is especially true for the camp [la$ persona que actúa de manera camp conscientemente], who is definitely a performer». Por tanto, el camp implica una forma dramática, un actuar (perform) frente a una audiencia (Newton, 1972: 107). La teatralidad del camp se refiere en última instancia, y aquí Newton cita textualmente el ensayo de Sontag, a la metáfora de la vida como teatro (1972: 107; Babuscio, 2008: 123).

Otro aspecto importante del camp es el que atañe no a las obras artísticas sino a las personas. Particularmente, el gusto camp ha sentido predilección por el cine (en parte por su modernidad como forma de arte; también podríamos traer a colación su omnipresencia en la cultura de masas) y, sobre todo, sus estrellas: como hemos dicho, son iconos camp actrices como Marlene Dietrich, Mae West, Judy Garland, y actores como Victor Mature y hasta John Wayne en tanto que icono de una masculinidad exacerbada. Como ocurre con el camp dirigido a los objetos, llaman la atención los personajes o intérpretes que conlleven cierta exageración, artificiosidad, espectacularidad: el camp es la glorificación de la persona en cuanto personaje, de su fuerza espectacular pero no su desarrollo o su pluridimensionalidad: «el personaje es comprendido como un estado de continua incandescencia: una persona que es una, intensísima, cosa» (Sontag, 1967: 314). De ahí la preferencia del gusto camp por actores y actrices cuyo estilo interpretativo resulte exagerado, o, en otro sentido, las divas, las actrices de carácter muy fuerte cuyos papeles precisamente son vehículos para mostrar su exuberante personalidad (Babuscio, 2008: 124-125). En general, la visión estética del camp, aplicado a la máxima wildeana 
de la vida como obra de arte, implica considerar la persona en el sentido de máscara, como la proyección de uno mismo, como la construcción artificial de la imagen espectacular de uno - de ahí, por tanto, la importancia dada a elementos como el vestuario o la decoración, tanto en el cine como en la vida personal (Babuscio, 2008: 122).

\subsubsection{El camp como discurso humorístico}

Un aspecto que nos interesa especialmente, claro, es la del camp como «sistema de humor» (Newton, 1972: 109). Es evidente que todos los teóricos y críticos del camp coinciden en que es una mirada cómica, irónica, del arte y el mundo. Para el camp en tanto que estética contemporánea, las formas cómicas tradicionales como la ironía y la sátira son insuficientes, lo específico de lo camp es la teatralidad y el artificio como ideal (Sontag, 1967: 317). Como hemos visto, la visión irónica es fundamental para la mirada camp: al fin y al cabo, no es sino un gusto irónico por las formas kitsch, por el arte fracasado, por los personajes patéticos y desmesurados, etc. Es decir, que los mecanismos que producen el "efecto camp" tienen que ver directamente con los que hemos visto a lo largo de este trabajo: la incongruencia, la descontextualización, la exageración, la inadecuación, etc. Particularmente, es interesante destacar que la concepción de la vida como teatro, la naturaleza como artificio, el juego con las convenciones, etc. están claramente relacionados con el carácter polifónico y teatral del discurso humorístico que detallamos en su momento.

Más reveladora aún es la evidente vinculación de lo camp con la tradición de lo grotesco que estudiamos en el primer capítulo de este trabajo [1.2.3]: lo grotesco entendido como juego con las formas, con el exceso, con lo artificial, que precisamente se manifiesta especialmente en las artes decorativas, menores y/o populares - en este sentido, tanto lo camp como lo grotesco son formas estéticas que se posicionan en los márgenes del arte y la cultura oficiales. Efectivamente, si Connelly describe lo grotesco como una estética que fusiona «humor y horror, ingenio y transgresión» y, sobre todo, como algo definido culturalmente (Connelly, 2015: 23-25), entender el camp a la luz de las características que esta historiadora del arte ofrece de lo grotesco se muestra especialmente provechoso. Connelly afirma, por ejemplo, que lo grotesco desafía las fronteras de lo natural y lo convencional, lo familiar y lo extraño (Connelly, 2015: 23); lo grotesco tiene que ver con lo fluido: lo aberrante, lo metamórfico, lo que está en 
transición o a medias: «la respuesta a lo grotesco se desencadena la fusión de realidades irreconciliables (...) lo grotesco plantea respuestas contradictorias y conflictivas, al tiempo que une lo inesperado y disparatado» (Connelly, 2015: 35). En este sentido, en el siguiente apartado también definiremos a La Madelón, la protagonista de Una mala noche la tiene cualquiera, como cuerpo grotesco o carnavalesco en tanto que cuerpo abierto, en transición. En todo caso, en general el camp se acerca a lo grotesco en su gusto por el juego con el exceso (Connelly, 205: 38) y en que su objetivo no es romper ni superar nada, sino poner de relieve un límite cultural existente, haciendo visibles los contornos de lo conocido como normal (Connelly, 2015: 40), cuestionando las formas y convenciones de la representación, tanto visual como literaria, poniendo el énfasis en lo artificioso de estas (Connelly, 2015: 47).

Por otro lado, como señala Fabio Cleto, existe una constante en todas las discusiones teóricos acerca de la naturaleza de lo camp, lo que podríamos llamar el problema de su 'intencionalidad', relacionado directamente con la cuestión de si lo camp es una propiedad particular de los objetos o, más bien, depende de la sensibilidad específica del observador - ya hemos visto que tanto Sontag como Newton o Babuscio definen lo camp como una sensibilidad, si bien reconocen que no todos los objetos son susceptibles de ser considerados así. Esto lleva a Sontag a establecer una distinción entre el camp «ingenuo», el que no sabe que lo es, y el deliberado, refiriéndose a la persona u obra de arte que intencionalmente busca ser camp (1967: 310) ${ }^{11}$. En términos humorísticos, esto correspondería a la distinción entre aquello no intencionalmente cómico que es visto como tal debido a la interpretación del observador, y lo humorístico producido intencionalmente. En ambos casos se trata de producir lo cómico a partir de la incongruencia, bien sea esta "hallada” o “fabricada”. Cleto argumenta, de manera análoga, que la distinción entre camp ingenuo o deliberado es inestable, puesto que al fin y al cabo en ambos casos el camp remite a la noción de performance y de artificio:

Both camp object and subject are made into a situation, a theatrical setting and scene, by taking part in the same role play in which the actors constantly refer to an extemporised 'script', and to an audience (...) in front of which both camp object and subject perform (...) Camp is a mode of perception, in other words, that cannot in its enactment leave out an element of performance on the part of the (naïvely camped up) object, the decoding of

\footnotetext{
${ }^{11}$ En este sentido, recordemos que lo grotesco no es necesariamente el producto de la imaginación del artista, sino que también podía ser hallado en la naturaleza: en las formas caprichosas de algunos vegetales o conchas, o en las formas monstruosas o deformes de algunos animales o personas.
} 
which emphasise its failure in performance, nor on the part of the subject, whose perception is in itself an act of performance, with its necessary audience and its allusive, winking narcissism. Vice versa, camp as a ‘style’ of performance doesn’t exclude - quite the reverse: it presupposes - an element of perception, an encoding and decoding of the self and the world as stage, and of failure of intentions (Cleto, 2008: 25-26)

Esta situación problematiza la pregunta por la intencionalidad: la cualidad camp de iconos como Mae West, Greta Garbo, Marlene Dietrich, Marilyn Monroe, depende en gran parte de su ambigüedad en la intención: no podemos saber si estas desplegaban su performance camp consciente o inconscientemente (Cleto, 2008:27) - al fin y al cabo, en parte, la mirada camp depende de que actúen en serio, pero también esta performance tiene que mostrarse como fallida, como no natural, esto es, tiene que haber en cierto nivel una especie de consciencia de estar representado un guion - y esto está relacionado directamente con la noción propuesta en este trabajo del discurso humorístico como fundamentalmente teatral en este sentido.

Esto último está relacionado con otro rasgo de la actitud camp determinada por su naturaleza humorística e irónica: su pathos frívolo y la relación que establece con "lo serio”. Para Newton, por ejemplo, el camp es pura diversión: su objetivo es únicamente hacer reír (1972: 109); y Sontag asegura que «lo único importante en lo camp es destronar lo serio. Lo camp es lúdico, antiserio» (1967: 317). La experiencia camp como cómica es, ciertamente, compleja, puesto que por un lado implica un distanciamiento, «una experiencia de la infraimplicación» (Sontag, 1967: 317): de ahí, precisamente, junto a la tendencia estetizante de ver las cosas en términos exclusivamente de estilo, las acusaciones al camp y sus practicantes de frivolizar en exceso - como hemos mencionado, por ejemplo, respecto al caso del fascismo. Pero, por otra parte, esta relación con lo serio es bastante más ambigua: «lo camp implica una nueva, más compleja, relación para con lo serio. Es posible ser serio respecto de lo frívolo y frívolo respecto de lo serio» (Sontag, 1967: 317). Sontag defiende que, a pesar de la apariencia de frivolidad e incluso distanciamiento cruel de la mirada camp,

el gusto camp es, sobre todo, un modo de deleitarse, de apreciar; no de enjuiciar. Lo camp es generoso. Quiere deleitar. Sólo aparentemente es malicioso, cínico (...) El gusto camp es una especie de amor, amor a la naturaleza humana. Más que juzgar saborea los pequeños triunfos y las horribles intensidades del personaje (...) Lo camp es un sentimiento tierno (Sontag, 1967: 320-321) 
También Isherwood aseguraba que solo se podía tratar de manera camp aquello por lo que se tuviera una auténtica pasión, en el sentido de identificación (Cleto, 2008: 28). Es decir, que en cierto modo la mirada camp es una mirada de comprensión e incluso de identificación con los objetos y personas de los que aparentemente se burla; que el aparente distanciamiento no es tal. Para otros críticos, como Babuscio, es precisamente este distanciamiento, visto por muchos como frivolidad irresponsable, lo que le da a la mirada camp su potencial subversivo, al señalar, mediante esa distancia, las incongruencias de la cultura y la sociedad (Babuscio, 2008: 127-128). Este debate en torno al potencial frívolo y subversivo de lo camp es, de hecho, lo que está en el centro de la discusión acerca de su vínculo con la comunidad homosexual.

\subsubsection{El camp como sensibilidad gay}

Como hemos visto hasta ahora, la sensibilidad o la estética camp se basa en la atención a la apariencia, a lo ornamental; evalúa cualquier fenómeno en términos estéticos, incluso los hechos y temas "graves"; y se basa en una concepción de la personalidad como personaje, en la teatralización de la experiencia y en la estilización desmesurada. Debemos atender ahora el rasgo que determina todo lo anterior: el camp como sensibilidad gay, o, al menos, su relación con la homosexualidad masculina ${ }^{12}$; su condición de expresión o gusto particularmente homosexual.

Como hemos visto, en su origen la palabra camp se refería a una especie de código de reconocimiento entre homosexuales a principios del siglo XX. Otros autores, como Richard Dryer, denominan "to camp” a la gestualidad “amanerada” y modo afeminado de expresarse, específica de algunos homosexuales (Dryer, 2002: 49); lo que Alberto Mira, para el contexto español, hace equivaler a "tener pluma” (Mira, 2007: 146). Susan Sontag apuntaba al estrecho vínculo del camp con el gusto homosexual, si bien señalaba explícitamente que esta relación no era necesaria (Sontag, 1967: 319) - lo que, como veremos, llevó a muchos autores homosexuales a criticar el artículo por haber permitido una posterior apropiación del camp por el sistema. En todo caso, necesaria o no, existe una vinculación histórica innegable entre el camp y la cultura homosexual pre-Stonewall

\footnotetext{
12 Aunque puedan encontrarse algunos ejemplos de un camp lésbico (véase por ejemplo Case, 1988), lo cierto es que este ha sido un rasgo distintivo casi exclusivamente de la comunidad homosexual masculina y la comunidad drag, al menos hasta los años ochenta; de ahí que en estas páginas hablemos casi exclusivamente de una sensibilidad "gay", homosexualidad masculina, etc.
} 
(Cleto, 2008: 91), esto es, la época en que la homosexualidad era no solo mal vista sino perseguida y los homosexuales tenían que vivir en la “clandestinidad”.

En efecto, muchos autores explican el fenómeno camp y sus características como determinadas por la situación de opresión social del colectivo homosexual en la época, en cierta manera equivalente a lo que el soul significó para la población afroamericana (Newton, 1972: 105). Para Newton, lo camp es una «estrategia situacional», un modo de intentar lidiar con la situación social de los homosexuales a mediados del siglo XX, a través, en este caso, del alivio cómico (1972: 109) ${ }^{13}$ - en este aspecto, la concepción del camp entronca con la tradición de entender el humor como alivio. Para Jack Babuscio, los rasgos del camp derivaban directamente de la especificidad de la experiencia homosexual; así, la incongruencia irónica sería un trasunto de la incongruencia que representa en sí misma la persona que, siendo de sexo masculino, desea a otros hombres; la teatralidad sería la consecuencia de la propia experiencia del hombre homosexual que debía aparentar no serlo («passing for straight») de estar actuando, de representar el papel de heterosexual (Babuscio, 2008: 119, 123-124). Andrew Ross interpreta el camp como a survivalist culture that found, in certain fantasmatic elements of film culture, a way of imaginatively expressing its common conquest of everyday oppression (...) Denied the conventional 'masculine' and 'feminine' positions of spectatorship, and excluded by conventional representations of male-cis-hetero narrative agent, and female-as-image or object of spectacle, the gay and lesbian subcultures express their lived experiences largely through imaginary or displaced relations to the images and discourses of a straight, 'parent' culture (Ross, 2008: 323)

En concreto, se identificaban con la posición de la subjetividad femenina en la cultura sexista de Hollywood, vinculada a la emocionalidad (Ross, 2008: 323) ${ }^{14}$. Es decir, la apropiación camp del cine y el fenómeno en general servía no solo para “aliviar” mediante

\footnotetext{
${ }^{13}$ De hecho, en una nota al pie propone como un estudio de interés un análisis comparativo del humor camp con otras estrategias humorísticas de grupos oprimidos, como el humor judío o afroamericano (1972: 109)

${ }^{14}$ En este sentido, lo camp se puede relacionar con los estudios de cine feministas llevados a cabo por Laura Mulvey y Mary Ann Doanne acerca de la posición sexual de la mirada del espectador (Doanne, 1982; Mulvey, 1989). Concretamente, si la mirada masculina se codifica como activa y heterosexual, como un deseo sexual de apropiación, mientras que la mirada femenina se concibe como una identificación emocional y narcisista, encarnada en el melodrama como género cinematográfico "para mujeres" por excelencia, el hombre homosexual invierte estas posiciones, identificándose con el deseo de la mujer. Por otra parte, Doanne recurre al concepto de «mascarada» de la psicoanalista Joan Rivière para explicar la interpretación del personaje de la femme fatale por actrices como Marlene Dietrich como una sobreactuación de la feminidad; en este sentido, la mirada camp se centra, como hemos dicho, en la identidad como actuación teatral. Judith Butler también recurre al concepto de mascarada para apoya su teoría performativa de género [ver más adelante 6.1.5]
} 
el humor las dificultades de pertenecer a un colectivo oprimido, sino también para la construcción de una identidad positiva más allá de la estigmatización a la que les condenaba la sociedad heterosexista (Newton, 1972: 110-111).

Ahora bien, esta identificación del camp con la comunidad homosexual nunca ha estado exenta de polémica. En primer lugar, hablar del camp como la sensibilidad gay supone una esencialización de la identidad homosexual que es en sí misma problemática. Ya Newton y Dryer señalaban que no todos los homosexuales se sentían atraídos, e incluso cómodos, con estas prácticas (Dryer, 2002: 51; Newton, 1972: 110). Hay que tener en cuenta que el momento en que los críticos explicitan esta asociación del camp y la homosexualidad, a principios de los años setenta, es un momento de urgencia política, en el que los emergentes movimientos por los derechos de los homosexuales necesitaban la definición de una identidad colectiva positiva, con su historia y cultura propias (frente a la aseveración de Sontag de que se trataba de un vínculo no necesario, y en general, como veremos, frente al fenómeno de popularización del camp en el mundo normativo, "heterosexual”); de hecho, piezas tan importantes como los propios ensayos de Babuscio o Dryer no eran publicaciones académicas, sino que aparecieron en revistas culturales y/o activistas como Gay News, Playguy o Gay Left (Cleto, 2008: 89-90).

Pero estos mismos movimientos miraban con recelo el camp. Por un lado, dudaban de la eficacia política de una práctica basada en el humor y la frivolidad. La misma Sontag calificaba el camp de «apolítico» (1967: 305), y Newton, en una nota al pie, señalaba cómo el humor del camp como válvula de escape apartaba el sentimiento de opresión de una posible respuesta política: «it is clear to me now how camp undercuts rage and therefore rebellion by ridiculing serious and concentrated bitterness« (1972: 109); en todo caso, para ella el camp era un «pre- or protopolitical phenomenon» (1972: 111). Para Dryer, el riesgo de la frivolidad de los practicantes del camp era no ser capaces de tomarse nada en serio, incluso el propio activismo de organizaciones como el GLF (Gay Liberation Front) (2002: 51).

Pero, sobre todo, lo que llevaba a muchos a cuestionar el camp era su dependencia del estigma. Al fin y al cabo, el camp se apoya en el estereotipo del hombre homosexual como afeminado, y su práctica venía a confirmar, de algún modo, ese descalificativo homófobo y misógino. Dryer, por ejemplo, señalaba que la asociación de los gays con las profesiones de lo decorativo refuerza su consideración de marginales, inútiles, parásitos de la sociedad, frívolos, improductivos (2002: 52); y su visión de la mujer, basada en los 
estereotipos de Hollywood, contribuía de algún modo a la objetificación de esta (2002: 59). Sontag, al comentar la relación del camp con la comunidad homosexual, describía aquel como una estrategia «propagandística» de los homosexuales para ser integrados en la sociedad por su aportación estética, pero muchos activistas se negaban a ser aceptados por el precio de convertirse en los «bufones de la corte» o decoradores de interiores:

That acceptance as the court jester (or fashion designer, if you prefer), much in contradiction with the radicality of camp, is precisely what movements like GLF and CHE invited gay people to abandon in favour of an integration as equal subjects within the social contract (Cleto, 2008: 91)

A partir de los años setenta, los movimientos pro-gay se podían dividir, a grandes rasgos, en dos facciones: la de los «asimilacionistas», que buscaban negar el estigma de los homosexuales como desviados y ser integrados en la sociedad, y los activistas radicales que preferían cuestionar la propia sociedad y su normatividad desde su posición marginal (Spargo, 2004: 42-43). Para los primeros, el camp representaba todo aquello de lo que pretendían diferenciarse por ser la definición homófoba que les había asignado la cultura heterosexista, mientras que para los segundos era el arma política perfecta de cuestionamiento radical de esa misma cultura. La mirada camp a la cultura hegemónica implicaba, por tanto, una estrategia característicamente queer de reapropiación del estigma para convertirlo en una identidad positiva vuelta en contra de la sociedad que la había creado (Cleto, 2008: 90). Pero, al actuar así, el camp renunciaba en cierto sentido a crear una identidad diferente a la definida por el sistema que oprimía a los homosexuales:

The politics of camp assumes there is no easy escape from these definitions, and in this respect, it is opposed to the search of an alternative, utopian, or essentialist identities that ley behind many of the countercultural and sexual liberation movements. Because of its zeal for artifice, theatricality, spectacle, and parody, camp has often been seen as prepolitical, even reactionary (Ross, 2008: 325)

La práctica totalidad de los teóricos señalan esta ambivalencia política del camp como estrategia identitaria:

The camps says, "I'm not like the oppressors", but in so doing he agrees with the oppressors' definition of who he is. The new radicals [los activistas asimilacionistas] deny the stigma in a different way, saying that the oppressors are illegitimate. This step is only foreshadowed in camp (Newton, 1972: 111) 
And yet, the extraordinary significance of camp within the 1960s scene is inexorably linked not only to its oppositional value, but also its availability as a weapon of containment - to its counter-value as an oppositional strategy inherently haunted by its otherness, the spectre of complicity (Cleto, 2008: 304)

Es evidente, por supuesto, que esta ambigüedad intrínseca del camp depende directamente de su naturaleza de discurso paródico, humorístico. De hecho, Fabio Cleto establece explícitamente una analogía con el carnaval bajtiniano, pues ambos trabajan con la inversión jerárquica, la burla para-dóxica, e incluso el tono sexual; y, sobre todo, suponen una compleja relación de poder entre los subordinados y los dominantes, lo que da lugar al problema de hasta qué punto una subversión “permitida” es subversiva: si el camp, como el carnaval, al romper la norma, no la legitima al invocarla como tal; al fin y al cabo, el camp como discurso derivativo, paródico, solo puede existir allá donde haya una norma, una doxa que se pueda teatralizar, travestir (Cleto, 2008: 32-33). De nuevo, antes de definir el camp como intrínsecamente subversivo o reaccionario, se impone la necesidad de estudiar cada práctica camp en su contexto concreto (Cleto, 2008: 35).

\subsubsection{La reapropiación queer del camp}

Como hemos apuntado, Sontag negaba la necesidad de la relación de la homosexualidad con el camp, lo que dio lugar a las críticas de muchos teóricos y activistas por, según ellos, permitir la apropiación de la cultura gay por parte del sistema. Sin duda, el ensayo de Sontag puso en circulación mayoritaria el término «camp», que en pocas semanas se había convertido en moneda de uso corriente en las publicaciones culturales (Cleto, 2008: 46). Es innegable la existencia de un straight («hetero») camp o camp pop, una reapropiación burguesa del camp pero, según Fabio Cleto, no por culpa del artículo de Sontag sino, más bien, por la propia popularización y mercantilización en masa del fenómeno que ya se estaba produciendo en los años sesenta con las figuras, por ejemplo, de Andy Warhol o David Bowie y productos cinematográficos que conscientemente explotaban la estética camp como The Rocky Horror Picture Show (Cleto, 2008: 33). Pocos años más tarde, Andrew Ross hablaba explícitamente en su artículo «Uses of Camp» del «pop camp» como una estrategia cultural en términos de la relación entre high brow y cultura de masas, sin relación con la homosexualidad (Ross, 2008) y Mark Booth afirmaba, de manera un tanto abrupta, «Troglodytes sometimes confuse camp with 
homosexual» (Booth, 2008: 70). Richard Dryer y Jack Babuscio se lamentaban, en los años setenta, de esta apropiación burguesa de la cultura gay: el primero aseguraba que el camp practicado por personas heterosexuales perdía todo su potencial crítico (Dryer, 2002: 60) y Babuscio denunciaba a los críticos que se ocupan del camp sin atender a su origen en la opresión de los homosexuales (Babuscio, 2008: 117).

Este fenómeno de “pop-ularización” del camp, unido al rechazo que producía en los movimientos activistas asimilacionistas dio lugar a un claro declive de esta estética en los años ochenta y noventa, y era percibido, efectivamente, como expresión evidente de lo que Fredric Jameson denunciaba como el vaciamiento de la cultura en el capitalismo tardío (Cleto, 2008: 90). Sin embargo, a principios de los años noventa, la labor teórica de Judith Butler y otros dio una nueva dignidad al camp y permitió el tratamiento del fenómeno desde la perspectiva de la teoría queer (Cleto, 2008: 356). En este contexto, el crítico cultural Moe Meyer editó The poetics and politics of camp, cuya introducción se titulaba de manera elocuente «Reclaiming the discourse of camp». En este ensayo, Meyer criticaba la apropiación por parte del sistema al que el artículo de Sontag había dado lugar (Meyer, 2010: 35) ${ }^{15}$ y proponía una definición del camp que explícitamente consideraba como tal toda expresión de una identidad gay (Meyer, 2010: 36). El crítico aseguraba el potencial político subversivo del camp, frente a la visión pre-Stonewall del camp como una estrategia de supervivencia clandestina, gracias a la teoría feminista y la praxis política de grupos como ACT UP o Queer Nation ${ }^{16}$ (2010: 35).

Fabio Cleto señala las muchas analogías que de hecho la palabra “camp” guarda con el término «queer». «Queer» proviene del indoeuropeo -twerkw, que significa torcido, atravesado, etc. (dando la palabra latina «torquere», por ejemplo) y entró en el inglés isabelino como «oblicuo, doblado, retorcido» (en este sentido se opone al término «straight», «recto», con el que se denomina coloquialmente en inglés a las personas

\footnotetext{
${ }^{15}$ En cualquier caso, la vigencia actual de la sensibilidad camp en su relación con la homosexualidad es clara si pensamos en iconos de la cultura gay contemporáneos tan fácilmente identificables como camp como Madonna, Britney Spears o, en una línea más queer, Lady Gaga. A pesar de que críticos como Meyer denuncian la "heterosexualización" del fenómeno, más bien deberíamos hablar de una apropiación por parte del sistema de la propia sensibilidad gay y drag, como se puede ver en el caso de programas televisivos tan populares como Rupaul Drag's Race o Queer eye, cuyas políticas homo-neoliberales de la identidad serían dignas de un análisis crítico.

${ }^{16}$ Precisamente fueron grupos como estos los que, en los años ochenta y noventa, habían reclamado el insulto queer (aproximadamente, "maricón”) como la denominación de una identidad positiva y contestaria, tal y como Butler estudió (1993): el término queer se reivindica en los años noventa, como decimos, en el contexto del activismo "post-gay", en el que sirve de herramienta a una política agresiva, confrontacionista, desviante, reorientando el estigma heteronormativo y oponiéndose con el activismo gay y lesbiano de los años setenta por “asimicionalista” (Cleto, 2008: 14)
} 
heterosexuales); por tanto, ya en su origen el término tenía que ver con la excentricidad, la perversión y lo inauténtico, con el sujeto inestable, falsario, que amenaza la rectitud ortodoxa de la sociedad y el lenguaje: la palabra señalaba, por tanto, su propia indecidibilidad, su ambigüedad semántica (Cleto, 2008: 12-13) - en un sentido muy cercano, por cierto, al que también en el siglo XIX acabaría teniendo la noción de ironía, como vimos en su momento. Solo a partir del cambio de siglo se aplicó restringidamente a la abyección concreta que es la homosexualidad, teniendo como primer referente a Oscar Wilde como símbolo del hombre afeminado de clase media. Por tanto, la estabilización del término «queer» coincidió con la “normalización” en sentido foucaultiano del homosexual como tipo definido (Cleto, 2008: 13-14) y también con la aparición del término «camp».

Es en este sentido en el que ambos términos presentan cierta afinidad: ambos implican, en su definición y su práctica, una cierta desestabilización de la ortodoxia cultural epistemológica, de clase, etc. (Cleto, 2008: 16):

the transgressiveness of camp relies in its privilege of the secondary and derivative (...), of serial reproduction over the original, showing that the secondary is always already copy of a copy. An investment in seriality undermines in fact the original/secondary binarism that bourgeois epistemology posits within sexuality, and that camp, at least potentially, queers and crosses (Cleto, 2008: 20)

Camp and queer are cognate terms: camp is queer as a mode of being, as posturing a body, as a modality of distribution within social spaces and within the economy of the social contract, and as a mode of communication - indirect, oblique and secondary, unstable and improvised according to its specific, hic et nunc, relation to the other (Cleto, 2008: 30)

La particularidad del camp como práctica queer, frente a la de los años anteriores a Stonewall, es que estos movimientos conciben la identidad (tanto la orientación sexual como la identidad de género) como una construcción normalizada en el sentido foucaultiano y no como la expresión de una verdad biológica interior, rechazando por tanto los binarismos hombre-mujer, hetero-homo: lo que interesa en este contexto del camp es su manera de desestabilizar las oposiciones masculino-femenino y la naturalidad de las identidades de género. De ahí la importancia de la figura de los sujetos trans- y, particularmente, del fenómeno drag. 


\subsubsection{Camp y drag. La teoría de la identidad performativa de Judith $\underline{\text { Butler }}$}

Es por tanto natural que lo camp, con su atención al artificio y la teatralidad y su cuestionamiento de la categoría de lo "natural” y de las jerarquías culturales y sociales, atrajera a una comunidad marcada precisamente por el estigma de lo desviado, lo abyecto, lo no natural. Concretamente, la exageración paródica de los caracteres masculinos y femeninos o su estudiada ambigüedad por parte de las estrellas camp hollywoodienses ponían en un brete la supuesta naturalidad del deseo heterosexual y las identidades de género que constituía la base del rechazo a los homosexuales. Ya Sontag hablaba en sus notas del triunfo del «estilo epiceno», «la convertibilidad de «hombre» y «mujer», «persona» $\mathrm{y}$ «cosa» (1967: 308).

Pero más allá de las divas cinematográficas, si había un lugar donde esas categorías se ponían espectacularmente en entredicho era sin duda el de la subcultura drag, vinculada desde sus orígenes a la homosexualidad y la estética $\operatorname{camp}^{17}$. Ya Isherwood en su novela The world in the evening apuntaba a la existencia de un «High Camp», más vinculado al mundo del arte y la literatura, y un denigrado «Low Camp», el ejemplificado por «a swishy little boy with peroxided hair, dressed in a picture hat and a feather boa, pretending to be Marlene Dietrich» (cit. en Cleto, 2008: 12). Y, por supuesto, el fundamental estudio de Esther Newton que venimos citando era una descripción etnográfica de los ambientes del drag en los años sesenta, subcultura que la antropóloga veía estrechamente vinculada a la estética y práctica camp, si bien los consideraba fenómenos diferenciados: el drag, una subcultura dentro de la subcultura gay, supondría uno de los ejemplos de prácticas camp características del mundo homosexual (Newton, 1972: 99-100).

Los motivos de la importancia de la práctica drag para la mirada camp gay ya han sido mencionados en parte. Si la cultura gay está estructurada principalmente por la oposición masculino/femenino, análoga a la oposición dentro/fuera, según las cuales el yo social del hombre homosexual es una calculada proyección de respetabilidad en el mundo heterosexual "oficial”, una «fachada» («cover») que oculta el verdadero yo, la actuación del drag refleja esta oposición entre el yo verdadero y el yo social, el interior y

\footnotetext{
${ }^{17}$ De hecho, y como apunta Cleto, parece ser que uno de los primeros usos de la palabra «camp», todavía en el siglo XIX, se encuentra en el epistolario entre dos conocidas personas transgénero (Cleto, 2008: 21)
} 
el aparente, y su teatralidad paródica de las expresiones de género recrea la experiencia del homosexual de tener que actuar para «pasar por hetero» (Newton, 1972: 100-102). En este sentido, se podría decir que toda experiencia homosexual es drag y juega, en diferentes escalas e intensidades, con esta oposición entre masculino/femenino y la teatralidad del género ${ }^{18}$, como bien muestran las referencias a lo largo de todo el libro de Newton a los diferentes “tipos” y “personajes” de la cultura gay: las queens, las lesbianas butch, las street fairies, los pretty boys ...

Es por eso por lo que la drag queen cumple una función tan importante en la comunidad gay, pero, al igual que ocurre con el camp, es una figura polémica no aceptada por todos, ya que simboliza el estigma de inversión de género al que los homosexuales están condenados (Newton, 1972: 103-104). En todo caso, el espectáculo drag/camp, en la interpretación de Newton, implica una desnaturalización del género y los roles sexuales y un juego con los binarismos masculino/femenino, interior/exterior, verdad/apariencia:

At the simplest level, drag signifies that the person wearing it is a homosexual, that he is a male who is behaving in a specifically inappropriate way, that he is a male who places himself as a woman in relation to other woman. At the most complex, it is a double inversion that says 'appearance is an illusion'. Drag says, “my 'outside' appearance is feminine, but my essence 'inside' [the body] is masculine”. At the same time, it symbolizes the opposite inversion: "my appearance outside [my body, my gender] is masculine but my essence ‘inside’ [myself] is feminine” (Newton, 1972: 103)

El estudio de Newton (y este párrafo en concreto) llevaría a la teórica feminista/queer Judith Butler a utilizar el espectáculo drag como ejemplo de su teoría de la identidad como performatividad. Como es bien conocido, Butler exponía en su libro de 1990 El género en disputa una crítica a la idea humanista y de ciertas corrientes del feminismo de una identidad de género esencialista y previa a la socialización, llevando un paso más allá el famoso epigrama de Simone de Beauvoir según el cual «la mujer no nace, se hace».

Ubicándose explícitamente en una línea foucaultiana de pensamiento, si una premisa de la filosofía humanista de la identidad es la pregunta acerca de qué aspecto interno de la persona garantiza su continuidad en el tiempo, Butler propone preguntarse qué prácticas reguladoras producen y mantienen el sujeto y en qué medida la identidad es un ideal normativo y no un aspecto descriptivo de la persona (Butler, 2007: 71). En este

${ }^{18}$ Claro que la cultura drag es mucho más que simple travestismo, y contiene un importante elemento de fantasía grotesca. 
sentido, son las prácticas y normas de género las que hacen a un individuo socialmente inteligible, reconocible por los demás como hombre o mujer - y, por lo tanto, habría individuos que, al no adecuarse a esas normas, no serían «reconocidos» como sujetos (Butler, 2007: 72). Según la concepción popular la identidad de género, una afirmación del tipo «Soy hombre [heterosexual]» o «Soy mujer [y heterosexual]» implica supeditar la identidad al género y concluir que una persona es de un género, y lo es en virtud de su sexo anatómico, su sentido psíquico del yo y diferentes expresiones de esa psique, entre las cuales ubicaríamos el deseo sexual (Butler, 2007: 79).

El género en esta concepción, por tanto, se concibe como una coherencia de ciertos atributos que son causados por un cierto sexo biológico. A ello Butler le opone una concepción performativa de la identidad del género según la cual la frase «Es una niña» no es la descripción de una identidad producto de una determinada formación anatómica, sino que nombra al sujeto como femenino y le impone una serie de prácticas reguladoras de dicho género (Butler, 2007: 84). A partir de entonces, el sujeto se ve impelido a identificarse como hombre o mujer, esto es, a reconocerse o asumir como propios una serie de significados que son culturales y sociales ${ }^{19}$ :

En este sentido, el género no es un sustantivo, ni tampoco un conjunto de atributos vagos, porque hemos visto que el efecto sustantivo del género se produce performativamente y es impuesto por las prácticas reguladoras de la coherencia de género (...) El género resultar ser performativo, es decir, que conforma la identidad que se supone que es (...) No existe una identidad de género detrás de las expresiones de género; esa identidad se construye performativamente por las mismas “expresiones” que, al parecer, son resultado de esta (Butler, 2007: 85)

Al hablar de «performatividad», Butler se refiere a la lectura derridiana de la teoría de Austin de los actos de habla constatativos y performativos, según la cual el poder “necesario” para que estos actos performativos tengan efectos no proviene de la autoridad de quien los ejecuta, sino de su carácter de cita y repetición de una Ley que es tal solo en la medida en la que precisamente es citada como Ley. Es en este sentido en que Butler ve la posibilidad de la subversión de dicha ley: en el contexto de una concepción foucaultiana del poder según la cual las propias relaciones que crean sujetos producen al mismo tiempo la posibilidad de resistencia, es viable una repetición paródica de la ley que suponga el

\footnotetext{
${ }^{19}$ Recordemos nuestra exposición [4.2.3] acerca de los conceptos de interpelación y habitus, de Althusser y Bourdieu, respectivamente.
} 
desplazamiento de la misma y una ampliación de las posibilidades de aplicación: de ahí que prácticas de la sexualidad lesbiana, como el juego de roles butch/femme o el uso en las relaciones sexuales de dildos con formas fálicas, durante mucho tiempo criticados por considerarse la reiteración de la heterosexualidad en un contexto lésbico, puedan por el contrario suponer una repetición irónica que desvele la propia estructura heterosexual como construida, artificial, y no natural: «así pues, gay no es a hetero lo que copia a original sino, más bien, lo que copia es a copia» (Butler, 2007: 94-95).

Es en este contexto teórico en el que Butler cita a Newton y a la figura de la drag queen como ejemplo de este tipo de repeticiones paródicas. Según Butler el género no es la expresión de una interioridad sino un conjunto más o menos coherente de enunciados performativos inscritos en la superficie corporal (gestos, actos, signos): si la identificación con un género es fantasmática, «actos, gestos y deseo crean el efecto de un núcleo interno o sustancia, pero lo hacen en la superficie del cuerpo»; son estos gestos y signos los que suponen identidad interior de la que serían expresión pero, bien al contrario, son la causa de esta supuesta coherencia (Butler, 2007: 266). De ahí que la contradicción interior/exterior que personifica la drag queen, tal y como lo expresa Newton en el fragmento citado anteriormente, desplaza la estructura de significación de género y desmorona la oposición misma (Butler, 2007: 267-268). Es la noción de una identidad de género original e interior de la que la actuación es expresión lo que se parodia en los espectáculos drag: a pesar de que en la teoría feminista estas prácticas hayan sido criticadas por representar estereotipos misóginos, el travestismo desnaturaliza el sexo y manifiesta el carácter imitativo, citacional, del género (Butler, 2007: 268-269). La parodia drag del género, el motivo de la risa que provoca, es la revelación de que lo considerado como original (la identidad de género) no es sino una copia de un ideal inalcanzable (Butler, 2007: 270).

En el mismo pasaje del libro Butler reconoce que no todo acto paródico es subversivo, y que es necesario atender al contexto de cada uno (2007: 270-271). Aun así, pocos años más tarde se vio obligada a matizar su lectura del drag a raíz de lo que consideraba eran malas interpretaciones de su obra, primero en el artículo «Critically queer» y posteriormente en el libro Cuerpos que importan. En estos textos, Butler salía al paso de las lecturas que colegían de su estudio del drag que el género era algo accesorio y opcional: 
The misapprehension about gender performativity is this: that gender is a choice, or that gender is a role, or that gender is a construction that one puts on, as one puts on clothes in the morning, that there is a "one" who is prior to this gender, a one who goes to wardrobe of gender and decides with deliberation which gender it will be today (Butler, 1993: 21)

Este malentendido se debe, principalmente, a la confusión en torno al término «performatividad» [performativity], que puede ser entendido como derivado de performance, «actuación», o de performative en la concepción austiniana de los actos de habla performativos (Prosser, 1998: 28), siendo la primera acepción la que supuestamente permite la interpretación “voluntarista” del género. De ahí que Butler insistiera posteriormente en que sí, la identidad de género podía ser una construcción cultural y una imposición performativa, pero eso no la hacía menos obligatoria (1999: 21-22; 2008: 145).

En «Critically queer» y la introducción a Cuerpos que importan, la teórica se detendría en detallar su interpretación de la performatividad como acto de habla, distinguiéndolo de la “actuación” de roles y normas género («performing of gender norms») (1993: 22). La identidad de género es performativa para Butler en el sentido de que es instituida mediante el acto de habla que dice «Es una niña» («It’s a girl») - y que, en la lectura derridiana, obtiene su "poder” no del sujeto que lo pronuncia, sino de la invocación de una norma que solo es tal en virtud de su repetición (Butler, 2008: 28). Esta noción de performatividad es muy cercana a la de interpelación empleada por Althusser, según la cual el sujeto no obtiene existencia y visibilidad social hasta que no es interpelado por la ley (Butler, 2008: 179-180). Es a partir de ese momento cuando el sujeto que es interpelado como niña se ve obligado a "citar” la norma del género que le ha sido impuesta, en el sentido de afirmar «Soy una mujer/ Me identifico como mujer»: «Feminity is thus not the product of a choice, but the forcible citation of a norm, one whose complex historicity is indissociable from relations of discipline, regulation, punishment» (Butler, 1993: 23) ${ }^{20}$.

A lo largo del artículo, Butler distingue esta definición de performatividad de la teatralidad, y parece que únicamente entiende por tal las actuaciones hiperbólicas,

\footnotetext{
${ }^{20}$ En todo caso, la dificultad teórica de aclarar la relación entre el acto de habla performativo y el carácter teatral no sería tal si nos remitiéramos, como hemos hecho en la discusión teórica de este trabajo, al funcionamiento de la ironía como fundamentalmente teatral.
} 
conscientemente teatrales y explícitamente paródicas, características de las intervenciones políticas de organizaciones como ACT UP o Queer Nation (Butler, 1993: 23), mientras que la identidad en cuanto performática lo sería de manera inconsciente. Sin embargo, a pesar de los intentos de la teórica feminista por distinguir ambos sentidos del término «performativity», lo cierto es que en ningún momento llega a quedar clara la diferencia, ni siquiera en los mismos escritos de Butler. Así, por ejemplo, la filósofa habla de la mujer que cita la norma de género como una «corporeally enacted feminity», o, en El género en disputa, habla del género como un estilo corporal, una reiteración estilizada de actos, gestos, etc. (Butler, 2007: 273). Por otra parte, es evidente la cercanía que esta discusión tiene con la propuesta del sociólogo Goffmann en La presentación de la persona cotidiana y su metáfora de la persona como actuada frente a los demás (Guasch, 2006: 33, 133). Y a pesar de que Butler insista en utilizar la noción de performatividad en un sentido derridiano y no goffmanesco (Prosser, 1998: 28), lo cierto es que Esther Newton sí utiliza explícitamente el modelo sociológico de Goffmann para sus investigaciones. Por tanto, el uso del espectáculo drag como ejemplo por parte de Butler no puede hacer sino promover la confusión

Esta interpretación supuestamente errónea no termina de ser solucionada con la lectura del documental Paris is burning que Butler realiza en Cuerpos que importan, centrándose en la mujer transexual Venus Xtravaganza, pues en este caso, al analizar los espectáculos de la cultura neoyorquina del ball ${ }^{21}$, se centra en prácticas que son explícitamente teatrales. En todo caso, en dicho capítulo, Butler cuestiona sus propias afirmaciones acerca de la capacidad subversiva de la parodia de las normas de género de las prácticas drag, asegurando que «no hay una relación necesaria entre el travesti ${ }^{22}$ y la subversión, y que el travestismo bien puede utilizarse tanto al servicio de la desnaturalización como de la reidealización de las normas heterosexuales hiperbólicas de género» (Butler, 20008: 184). Insiste en que el drag muestra el carácter imitativo de la propia heterosexualidad (Butler, 2008: 184), cuyos binarismos de género quedan como consecuencia desnaturalizados y desestabilizados, pero que efectivamente cabe la

\footnotetext{
${ }^{21}$ Esta cultura, que ha sido retratada recientemente en la serie Pose, de Ryan Murphy, surgió en el Nueva York de los años ochenta de los círculos afroamericanos y latinos queer como conformación de un espacio seguro en respuesta a la exclusión, y consistía en espectáculos, “balls” entre el desfile y el baile, en el que los participantes compiten en distintas categorías de "tipos” de la alta sociedad (mujeres ricas, hombres de negocios, hombres masculinos, etc.), a los que tienen que imitar tanto en el vestuario como en la gestualidad, ganando aquel que mejor pase por "real” (ver Elidrissi, 2018)

${ }^{22}$ En la traducción española se traduce «drag» como «travesti», obviándose en ambos casos que Venus Xtravaganza, como la mayoría de las que aparecen en el documental, es una mujer trans.
} 
posibilidad de que las normas heterosexuales del género, al ser imitadas como ideales de autenticidad, sean por el contrario legitimadas y reidealizadas - concretamente, Butler se referirá a los deseos de Venus Xtravaganza de ser una mujer «completa» (operada) para poder encontrar un hombre que la saque de la pobreza (Butler, 2008 188-190). En los ball en que participan las protagonistas del documental, se incluye

el intento fantasmático de aproximarse a la autenticidad, pero también [se] pone en evidencia que las normas que regulan la autenticidad también se instituyen y sostienen fantasmáticamente (...) En las producciones de autenticidad del baile travesti, vemos y producimos la constitución fantasmática de un sujeto, un sujeto que repite y parodia las normas de legitimidad mediante las cuales se lo ha degradado (...) Este no es un sujeto que se aparta de sus identificaciones y decide instrumentalmente cómo elaborar cada una de las que elige en cada ocasión; por el contrario, el sujeto es la imbricación incoherente y movilizada de varias identificaciones (...); una repetición que le sirve a la vez para legitimar e ilegitimar las normas de autenticidad que lo producen a él (...) El hecho de citar la norma dominante, en este caso, no desplaza dicha norma; antes bien, llega a ser el medio a través del cual se reitera de manera más dolorosa esa norma dominante, como el deseo mismo y las acciones de aquellos sujetos (Butler, 2008: 191-194).

Por tanto, en la lectura del filme vuelve a ser central el carácter teatral de los ball. En la interpretación del drag, esta ambivalencia de sus efectos políticos es análoga a la propia ambivalencia del camp, ya que ambos fenómenos plantean hasta qué punto la parodia de las normas sociales no las legitima como tales - y esto se debe, en última instancia, a la propia ambigüedad interpretativa que es característica del discurso humorístico. En todo caso, la ambivalencia que Butler señala en este capítulo se debe más bien a una omisión fundamental: confundir el carácter espectacular del ball con la propia subjetividad de Venus Xtravaganza, es decir, confundir el espectáculo drag con la identidad trans ${ }^{23}$.

\subsubsection{Crítica de Jay Prosser a la lectura butleriana de la transexualidad}

El uso del drag en la teoría de Judith Butler fue pronto criticado en las comunidades transgénero y transexuales de Estados Unidos (Preciado, 2018: 80). Como asegura Jay

\footnotetext{
${ }^{23}$ Ver (Meyer, 2010b) para una lectura alternativa del documental Paris is burning. Meyer también criticará la abstracción teórica del Travesti al que los críticos someten a las participantes del documental, abstracción que da lugar al olvido de sus condiciones materiales.
} 
Prosser, en general el sujeto transexual ha recibido mucha menos atención en la teoría queer que el travestido o el drag, y si la recibe es para señalar lo no subversivo y hasta reaccionario de su identidad (Prosser, 1998: 57-58). Pero esto no se debe, en opinión de Prosser, a la propia identidad transexual sino a la insuficiencia de las lecturas derivadas de Butler para asimilarla, originada principalmente por los problemas de materialidad, literalidad y referencialidad del cuerpo sexuado que el sujeto transexual pone de manifiesto (Prosser, 1998: 58).

En efecto, si el afán postestructuralista de la teoría queer ${ }^{24}$ es la deconstrucción de las categorías de sexo y género, señalando como esencialmente negativo lo construido (Prosser, 1998: 8), el deseo del sujeto transexual de construir literalmente un sexo que se ajuste a su identidad de género es criticado como una re-naturalización del sistema heterosexual. Así, por ejemplo, los historiadores gays y lesbianas que critican la transexualidad como una construcción del discurso médico, resultado de la medicalización de la homosexualidad como inversión de género, tratan a las personas transexuales como objetos pasivos e incluso víctimas de la tecnología médico-quirúrgica del sexo, ignorando la propia agencia de estas personas que precisamente empujaron el avance de las tecnologías quirúrgicas de reasignación de sexo (Prosser, 1998: 7-10)².

De este modo, en la teoría queer la transexualidad se ve contenida en la dicotomía de literalización o desliteralización del género; oposición que supone un nuevo binarismo que descarta la concreción y multiplicidad de los sujetos, narrativas y cuerpos transexuales - «the binary of textual effect (subversive/ hegemonic) is calcified onto the binary of the subject's relations to referentiality (literalizing/ deliteralizing)» (Prosser, 1998: 15). Sin embargo, si para la teoría queer la identidad en su relación con el género solo puede ser subversiva o hegemónica, se ignora la compleja experiencia que el sujeto transexual tiene del cuerpo sexuado. Frente a las afirmaciones de la teoría queer del sexo

\footnotetext{
${ }^{24}$ Cuando en este apartado hablemos de «teoría queer» lo haremos en singular porque así es como lo denomina Jay Prosser, escribiendo en 1998, en los primeros años de estos estos estudios - de hecho, la crítica de Prosser se centra casi exclusivamente en los textos de Butler. No podemos pasar por alto que es más adecuado hablar de teorías queer, en plural, como hace Lorenzo Bernini (2018), teniendo en cuenta que estas no son una doctrina definida sino un conjunto de estudios desde muy diversas orientaciones y en ocasiones incluso contradictorias.

${ }^{25}$ Algo similar ocurre, de hecho, en la misma teoría de Butler, en la que los sujetos se ven forzados a incorporar las normas de género, una identidad fantasmática, una subjetividad ficticia, etc., pero no tiene en cuenta la propia experiencia real y efectiva del sujeto. De manera parecida, Raewyn Connell, sociólogo del género y la masculinidad, a quien acudiremos en detalle en el próximo capítulo, critica el exceso discursivo de la teoría postestructuralista, que acaba ignorando la propia experiencia subjetiva de los individuos reales.
} 
y el género como construcciones ficticias y su celebración de los casos en que, como ocurre con el espectáculo drag, se muestra esta misma ficcionalidad, el sujeto transexual manifiesta la importancia tanto de la identidad sentida como de la realidad material y literal del sexo:

Transsexual and transgendered narratives alike produce not the revelation of the fictionality of gender categories but the sobering realization of their ongoing foundational power (...). These narratives return us to the complexities and difficulties that inevitably accompany real-life experiences of gender crossing and to the personal costs of not simply being a man or a woman (Prosser, 1998: 11-12)

La importancia de este binarismo desliteralizante/literalizante, subversivo o no subversivo, que al fin y al cabo se enmarca en un planteamiento discursivo del cuerpo y el género, está directamente relacionada, según Prosser, con la propia centralidad de la estrategia camp en la obra de las autoras pioneras de la teoría queer, Eve Sedgwick y la propia Butler. Este hecho fue posible, como hemos comentado, gracias a la reapropiación queer de lo camp a finales de los ochenta y principios de los noventa; en la teoría gay y lesbiana este llega a ser no solo un objeto de estudio, sino una metodología interpretativa, como lo ejemplifica Sedgwick en Between men con su lectura de clásicos decimonónicos desde una perspectiva queer (Prosser, 1998: 25).

Es esta perspectiva camp (por, como venimos destacando, su atención a lo artificial, a lo no natural, su visión del mundo como representación y de la vida como teatro), espoleada por la dimensión exclusivamente discursiva de la teoría postestructuralista, lo que da lugar a que el sujeto transgénero funcione como ejemplo idóneo de la ficcionalidad del género, pero a costa del olvido del cuerpo. De este modo, en la lectura que realiza Butler en El género en disputa, que destaca la parodia de género como rasgo definitorio de las culturas gay y lesbiana, se hace equivaler la heterosexualidad con la literalidad y la naturalización del género y el transgénero con su desliteralización (Prosser, 1998: 26, 30). Sin embargo, esta operación teórica supone ignorar la corporalidad en favor de la dimensión puramente discursivo-performativa del sujeto. A pesar de las afirmaciones de la teoría post-estructuralista acerca de la importancia del cuerpo, en las teorías de Foucault y Lacan esta materialidad depende siempre del discurso y la simbolización, pero no refieren a la carne; el cuerpo se toma como punto de partida para analizar las instituciones, las tecnologías del poder, del 
discurso, pero no se analiza el cuerpo mismo ni la experiencia de este que es central para la identidad transexual (Prosser, 1998: 12-13):

Since the body is conceived as a discursive effect in terms of signification, the transsexual is read as either a literalization of discourse - in particular the discourse of gender and sexuality - or its deliteralization (...) When figured as literalizing gender and sexuality, the transsexual is condemned for reinscribing as referential the primary categories of ontology and the natural that poststructuralism seeks to deconstruct (...) in the second mode the transsexual is celebrated for pushing sex as a linguistic signifier beyond the body. (...) In [these] readings, the referential transsexual subject can frighteningly disappear in his/her very invocation. Like the materiality of the body, the transsexual is the very blind spot of these writings on transsexuality (Prosser, 1998: 13-14)

¿Cómo se da en la teoría de Butler concretamente, según Prosser, este olvido del cuerpo transexual? En El género en disputa, el espectáculo drag era presentado como la ejemplificación más evidente del carácter performativo del sexo y el género, lo que, como ya hemos comentado, abría la posibilidad de dos interpretaciones que Butler rechazaría posteriormente: la equivalencia de la performatividad de género y la teatralización y el carácter intrínsecamente subversivo del sujeto trans. De este modo, a la oposición literalización/desliteralización le correspondería la oposición heterosexual/transgénero o queer:

Heterosexuality and queer are represented as, respectively, restrictive interiority and playful surface. If gay and lesbian cultures are said to be characterized by camp, parodic subversive - that is, transgendered - performances that deliteralize the apparently real of sex, heterosexuality is said to be characterized by a literalizing of the apparently real (Prosser, 1998: 44)

Para solucionar estos malentendidos, Butler afirmaba que en su discusión del drag pretendía presentarlo como una metáfora o alegoría de la construcción heterosexual del género, relacionándola explícitamente con su discusión sobre la teoría psicoanalítica de la incorporación fantasmática del sexo. Para Prosser esta discusión tiene dos consecuencias para la cuestión transexual: por un lado, postula el sexo no como materialidad corpórea sino como una superficie fantaseada (en el texto de Butler hay, de hecho, una intercambiabilidad entre superficie e interioridad), y, por otro, a partir de ello se reinscribe la oposición entre heterosexual y queer como literalizante/desliteralizante ya que lo queer, en la lectura de Butler, supone señalar lo fantasmático de esta 
construcción (Prosser, 1998: 40). Esta consideración del sexo como fantasmático depende, principalmente, de la concepción de Butler del cuerpo como una superficie psíquica, en una lectura particular de la definición freudiana del ego. De hecho, si Freud intentaba demostrar en El yo y el Ello el origen del yo en las sensaciones corporales, Butler entiende inversamente el cuerpo como una proyección psíquica, según la teoría lacaniana del estadio del espejo como proceso formación del yo, y por tanto del cuerpo como proyección imaginaria (Prosser, 1998: 40-42).

De hecho, es frecuente en la teoría de Butler este énfasis en la superficie y su prioridad frente a lo profundo o lo interior, nociones rechazadas por su dependencia de la epistemología moderna (Prosser, 1998: 42):

Gender Trouble's theoretical economy of gender relies heavily on a notion of the body as that which can be seen, the body as visual surface. This is possibly most marked in its deployment of the transgendered subject to illustrate gender performativity: girls who look like boys and boys who looks like girls. In this sense, then, in its dependence on the visible, on body-as-surface, the theory of gender performativity does in fact work out of a definitively theatrical arena. Any claim to a sense of sexed interiority, any feeling of being sexed or gendered (...), along with other ontological claims, is designated phantasmatic (Prosser, 1998: 43)

Al fin y al cabo, lo que Butler hace en El género en disputa y posteriormente en su discusión sobre Venus Xtravaganza en Cuerpos que importan es leer, e incluso podríamos decir, con Prosser, desde una mirada camp, la superficie del cuerpo del sujeto trans, sus gestos, actos, etc. como subversivos o no, pero sin atender a su interior, a su condición transexual en tanto que el individuo se identifique con un género determinado, porque este interior, esta identificación de género, se considera falsa.

En la problematización del potencial subversivo de la parodia drag que Butler realiza en su ensayo sobre Venus Xtravaganza, esta se hace a expensas de considerar la transexualidad como una metáfora, dejando a un lado la materialidad del cuerpo de Venus (Prosser, 1998: 46). Parece ser que en Cuerpos que importan sigue en pie el binarismo heterosexual $=$ literalizante/ queer $=$ desliteralizante $=$ subversivo, solo que esta vez el sujeto transexual está más cerca del primer término que del segundo (Prosser, 1998: 48). El propio ensayo está estructurado sobre una ambivalencia en la interpretación de la transexualidad y su relación con la literalidad que reside en la noción de 
transubstanciación de género: en este esquema el deseo de Venus es al mismo tiempo una literalización y una desliteralización, performativo y constatativo:

Venus's desire is here said to represent a transubstantiation of gender in that her transsexuality is an attempt to depart from the literal materiality of her sexed and raced body (and as her class intricated with these corporeal materialities, thus also a move away from her social materiality) precisely according to a strategy that reliteralizes sex: the acquisition of a vagina to make her a "complete woman”. If Venus's transsexuality transubstantiates in Butler's account (...) it is because transsexuality is perceived (ambivalently) as seeking out a heterosexual melancholic literalization of sex (the vagina) precisely through a queer resignification (the quest for the vagina is the penis's deliteralization) (Prosser, 1998: 49-50)

Butler no niega la capacidad subversiva del sujeto trans, sino que subraya su ambigüedad inherente a partir de la ambivalencia literal del cuerpo de Venus, que sigue teniendo genitales masculinos: para Butler, si su asesinato representa el triunfo de la hegemonía heterosexual es porque el cuerpo de Venus, a la vez masculino y femenino, de hecho desnaturaliza esta hegemonía. En su argumentación, es esta ambivalencia entre los genitales de Venus y los signos de su género (el resto de caracteres sexuales secundarios, su vestuario y su actuación de género) lo que es propiamente subversivo en el sentido de desnaturalizador de Venus, pero al mismo tiempo es lo que causa su muerte. A pesar de que Butler describa el asesinato como homófobo, el hecho es que Venus no es un hombre homosexual ni travesti, sino una mujer transexual latina de piel clara, y por tanto la violencia que la mata no es homófoba ni racista, sino violencia hacia el individuo que cae en el espacio entre todas las divisiones blanco - negro; heterosexual - homosexual, hombre - mujer (Prosser, 1998: 46-47):

Her death is indexical of an order that cannot contain crossings, a body in transition off the map of three binary axes (...): a light-skinned Latina transsexual body under construction as heterosexual and female. At work in Venus's murder is not fear of the same or the other but fear of bodily crossing, of the movement in between sameness and difference: not homo- but transphobia, where "trans" here signifies the multileveled status of her crossing (Prosser, 1998: 47)

El hecho de que Butler señale como no subversivo los deseos de Venus de someterse a la reasignación de sexo para poder encontrar un hombre, es decir, aquello de que hecho la hubiera salvado del asesinato, «is not only strikingly ironic, it verges on critical 
perversity» y en opinión de Prosser constituye uno de los momentos más incómodos de la obra de la teórica (1998: 49). Otro hecho relacionado con que Butler entienda la transexualidad como algo que no tiene que ver con la materialidad del cuerpo de Venus es su equiparación de su transexualidad con la “transexualidad” metafórica de la mirada de Jenni Livingstone (Prosser, 1998: 54-55):

The critic's metaphorization of the transsexual body transcends the literality of transsexuality in precisely a way in which Venus cannot - Venus who is killed for her literal embodiment of sexual difference (...) In metaphorizing transsexuality, Butler inadvertently repeats something of this deliteralization of the subject, her body, and her death. The substance of the transsexual body is sublimated in the move from the literal to the figurative (Prosser, 1998: 55).

Del mismo modo, en «Critically queer», el drag es una alegoría de la melancolía heterosexual, es decir, funciona como metáfora para el espectador heterosexual u homosexual, pero sin atender la propia subjetividad de quien hace drag. También Paul B. Preciado critica esta excesiva discursividad y el olvido del cuerpo de la teoría de Judith Butler. Según Preciado, Butler se esfuerza por vincular la performance en términos de performatividad, completando el proceso

de reducción de la identidad a un efecto del discurso, ignorando las formas de incorporación específica que caracterizan distintas inscripciones performativas de la identidad (...) Durante todo este proceso argumentativo, Butler parece haber puesto entre paréntesis tanto la materialidad de las prácticas de imitación como los efectos de inscripción sobre el cuerpo que acompañan a toda performance (...) Lo que las comunidades transexuales y transgénero han puesto sobre la mesa no son tanto performances teatrales o de escenario a través de los géneros (cross-gender), sino transformaciones físicas, sexuales, sociales y políticas de los cuerpos fuera de la escena, dicho de otro modo, tecnologías precisas de transincorporación (Preciado, 2018: 80-81)

En oposición a esta postura, Preciado destaca la literalidad material de la construcción que significan el género y el sexo:

El género no es simplemente performativo (es decir, un efecto de las prácticas culturales lingüístico-discursivas) como habría querido Judith Butler. El género es ante todo prostético, es decir, no se da sino en la materialidad de los cuerpos. Es puramente construido y al mismo tiempo enteramente orgánico. Escapa a las falsas dicotomías metafísicas entre el cuerpo y el alma, la forma y la materia (...) Su plasticidad carnal 
desestabiliza la distinción entre lo imitado y la imitación, entre la verdad y la representación de la verdad, entre la referencia y el referente, entre la naturaleza y el artificio, entre los órganos sexuales y las prácticas del sexo. El género podría resultar una tecnología sofisticada que fabrica cuerpos sexuales (Preciado, 2018: 21)

\subsubsection{Conclusiones parciales: el camp como discurso cómico y como problema hermenéutico}

Fundamental para nuestro trabajo es destacar cómo este proceso de desliteralización y discursivización del género y de la identidad transexual es consecuencia en parte de la mirada camp que está en el origen de la teoría de la performatividad de Butler y su lectura del drag, y sobre todo el carácter cómico de esta mirada. A lo largo de esta discusión hemos señalado cómo muchas de las características y ambivalencias que se le atribuían tanto a la estética camp y a la práctica del drag dependían de su naturaleza humorística: su carácter irónico, la frivolización frente a la seriedad, la atención a lo artificioso y convencional, lo hiperbólico, la ambigüedad entre subversión y legitimación, etc. Prosser destaca cómo, en la teoría de Butler,

Heterosexuality and queer are represented as, respectively, restrictive interiority and playful surface. If gay and lesbian cultures are said to be characterized by camp, parodic subversive - that is, transgendered - performances that deliteralize the apparently real of sex, heterosexuality is said to be characterized by a literalizing of the apparently real (Prosser, 1998: 44; el destacado es nuestro)

Y críticos como Biddy Martin critican las teorías de Butler y Sedgwick por presentar lo queer, la identidad transgénero, como figurativa, performativa, lúdica, divertida, frente a los géneros heterosexuales como fijados, constreñidos, etc. (Prosser, 1998: 31), lo que, efectivamente, da una idea del sujeto transexual como una identidad voluntarista, frívolamente celebratoria y, sobre todo, ajena a los peligros reales que sufren las personas trans.

En todo caso, es evidente que el propio efecto de discursivización al que Butler somete la identidad transexual está determinado por la estrategia camp que guía su lectura: si uno de los fundamentos del mecanismo irónico, como hemos visto, es destacar el carácter discursivo, polifónico, estereotipado, de las situaciones sociales, la mirada camp en cuanto irónica produce este efecto sobre el género; asimismo, su atención 
(irónica) a la superficie, a lo decorativo (y por tanto la superficie misma como artificial) promueve efectivamente este olvido de la materialidad corporal; la misma esencia de lo camp como una mirada, como un modo de interpretación, se plasma en la estrategia de Butler de lectura del cuerpo trans- sin atender a su subjetividad.

Podemos señalar un proceso análogo en cuanto a la cuestión del potencial subversivo del drag y del cuerpo transexual. Al fin y al cabo, el considerar que la parodia drag, al señalar la condición imitativa del género heterosexual, su no naturalidad, es subversiva, está directamente relacionado con la consideración del discurso paródico, humorístico, como discurso intrínsecamente subversivo - y la creencia de que precisamente esta subversión se da gracias a este señalar lo falso, lo artificial.

Esta condición está vinculada también con la oposición seriedad/frivolidad que supuestamente el camp pone en juego: la parodia camp sería crítica en tanto que supuestamente frivoliza con las normas y estereotipos con los que juega; pero, como ya hemos comentado, cabe la posibilidad de que estas normas y estereotipos queden legitimadas por su misma invocación. En última instancia, también adujimos cómo los propios teóricos del camp como Sontag o Ross negaban que el camp fuera enteramente frívolo, sino que, como aseguraba Isherwood, solo se podía establecer una relación camp con aquello que era realmente importante para el sujeto.

Todas estas cuestiones y ambivalencias podrían ser entendidas según la noción de la materialidad de lo cómico de Zupancic que expusimos en su momento. Según esta noción, efectivamente, el drag y el camp en general no estaría rechazando como falso las normas y estereotipos que señala, sino que los muestra en su especificidad y funcionamiento material, como construcciones ideológicas reales: de ahí, por ejemplo, que como dice Preciado en la cita anterior, desestabilice «la distinción entre lo imitado y la imitación, entre la verdad y la representación de la verdad, entre la referencia y el referente, entre la naturaleza y el artificio» (el destacado es nuestro) - en [7.3.4] realizaremos un análisis similar respecto a la masculinidad

En todo caso, en el siguiente apartado comprobaremos cómo los mismos problemas hermenéuticos respecto al camp, el drag y el sujeto transexual se repetirán en las interpretaciones de Una mala noche la tiene cualquiera: en virtud de la estética camp de la novela, el personaje de La Madelón se leerá como una metáfora de la España transicional y se discutirá su carácter crítico o acrítico respecto a este proceso histórico y 
político, pero a costa de no atender a lo que La Madelón literalmente es, una mujer transexual española en la noche del Golpe de Estado de 1981, y cómo se plantea, sí, mediante la mirada camp, la problematización de su identidad que esta circunstancia supone.

\subsection{Metáforas travestis y cuerpos transexuales: análisis de Una mala noche la tiene cualquiera}

«La gente que escribe tiende mucho a teorizar sobre mí, a considerarme un fenómeno que hay que explicar, sobre el cual elucubrar y trasladar sus propias obsesiones»

Bibi Andersen, entrevista con Jorge Berlanga (cit. en Garlinger, 2010: 4)

\subsubsection{La cultura camp en España}

A pesar de que la cultura camp sea a primera vista un fenómeno exclusivamente anglosajón, como parece indicar el hecho de que el término no tenga una traducción exacta en otros idiomas, Alberto Mira, en su historia de la homosexualidad en el siglo XX español (Mira, 2007) defiende que la cultura ibérica de la pluma, tanto en el sentido de “afeminamiento" en el gesto y la palabra como de una cierta sensibilidad moral y cultural, es perfectamente interpretable en los mismos términos que el camp angloamericano (Mira, 2007: 146): Jaime Gil de Biedma, sin ir más lejos, cita el artículo de Susan Sontag y lo relaciona con la tradición gay hispánica (Mira, 2007: 149).

La versión ibérica del camp presenta incluso las mismas tensiones ideológicas que su homólogo estadounidense: la pluma como expresión de la concepción del homosexual como invertido es uno de los puntales del discurso homófobo hispánico (Mira, 2007: 143), como se puede comprobar, por ejemplo, en la representación cinematográfica del “mariquita”, de la cual el papel de Alfredo Landa en No desearás al vecino del quinto es un ejemplo perfecto:

Aquí, las formas exageradas producían una carcajada que desviaba la atención de la homosexualidad como problema y, especialmente, lo situaba más allá de la experiencia cotidiana que pudiera afectar al ciudadano normal. La representación popular del mariquita hace al homosexual perfectamente reconocible y uno puede erigir contra su presencia la barrera de la risa. Uno no tenía que pensar en sexo cuando veía al mariquita 
de revista: el afeminamiento y la imagen de debilidad era tal que el peligro quedaba difuminado (Mira, 2007: 367) 26

Esto llevará a muchos homosexuales y activistas de los años setenta y ochenta a mirar con recelo y rechazo la pluma camp, tanto por su relación con el estereotipo homófobo como por cómo su aparente frivolidad lleva a cuestionarse su potencial político (Mira, 2007: 150-152). Pero Mira defiende que la mirada camp puede ser también una herramienta de subversión cultural y expresión de la identidad homosexual en España: así será entendido, como veremos, por algunas manifestaciones literarias, artísticas y contraculturales (Terenci Moix, Nazario, Ocaña, el primer Almodóvar...). Los espectáculos de transformistas de los años ochenta, por ejemplo, se apropiarán de la tradición del “chiste de mariquitas” para invertir el estigma y usarlo contra los poderes hegemónicos que primero lo enunciaron (Mira, 2007: 152):

La mirada camp siempre ha encontrado difícil acomodo en el discurso homófilo y en la crítica gay contemporánea asociada a esta. La acusación principal es la de frivolidad y escapismo. Se trata de una actitud que se manifestaría en los primeros años de la transición y que (...) llevaría a un cisma en el frente homosexual de finales de los años setenta. En estas reservas frente a la frivolidad y la pluma se excluye del ámbito de la homosexualidad a la loca y al travesti, ya que utilizan discursos que simplemente confirman el estereotipo y se alejan de la lucha política (...) Pero, como acabamos de ver, ambos discursos [el de la apropiación camp de Hollywood y de la copla] se activan para dar respuesta a una situación de marginalidad asumida frente al mundo. En otras palabras, la mirada camp está procesando mitos culturales heterocentristas, potencialmente opresivos, para convertirlos en un discurso de placer y de afirmación de la marginalidad (Mira, 2007: 349)

En cualquier caso, lo que durante el franquismo es una corriente hasta cierto punto subterránea y dependiente del estereotipo del afeminado, con el final de la dictadura la

\footnotetext{
${ }^{26}$ Por tanto, en la representación del "mariquita”, el humor tiene la sencilla función de estigmatización, de ridiculización del personaje homosexual por diferente, abyecto, no adaptado a las normas sociales y por tanto objeto susceptible de escarnio, que, además, "desactiva” su potencial desestabilizador. Como reflexiona Martínez-Expósito: «El chiste ofrece un marco discursivo sobre la homosexualidad muy estrecho y sin gran margen de maniobra intelectual, pero enormemente seguro y eficaz para transmitir un haz de valores culturales, generalmente basados en la noción del homosexual como ser inferior. Los chistes de maricas han servido a generaciones de varones españoles para conjurar miedos, transmitir valores culturales, afianzar el mito de la masculinidad heterosexual, afianzar también el mito del amaneramiento del homosexual, condenar al homosexual a una otredad radical y exterior a la comunidad, educar a los miembros del grupo en las respuestas o reacciones ante la homosexualidad (la risa despectiva, la mofa burlesca y la agresión física), y evitar toda elaboración intelectual al respecto» (Martínez-Expósito, 2012: 172)
} 
pluma camp se convertirá en una corriente perfectamente identificable como gay y utilizada de manera consciente como estilo por autores de diversas disciplinas (Mira, 2007: 150), como Pedro Almodóvar en sus primeras películas (Entre tinieblas, Laberinto de pasiones, La ley del deseo...), Nazario y su Anarcoma, Costus (por ejemplo, con la impresionante serie del Valle de los Caídos [Fig. 17], pinturas en que la pareja de artistas travisten las estatuas del monumento franquista con personalidades de la contracultura de la época), Terenci Moix (Garras de astracán) o Eduardo Mendicutti.

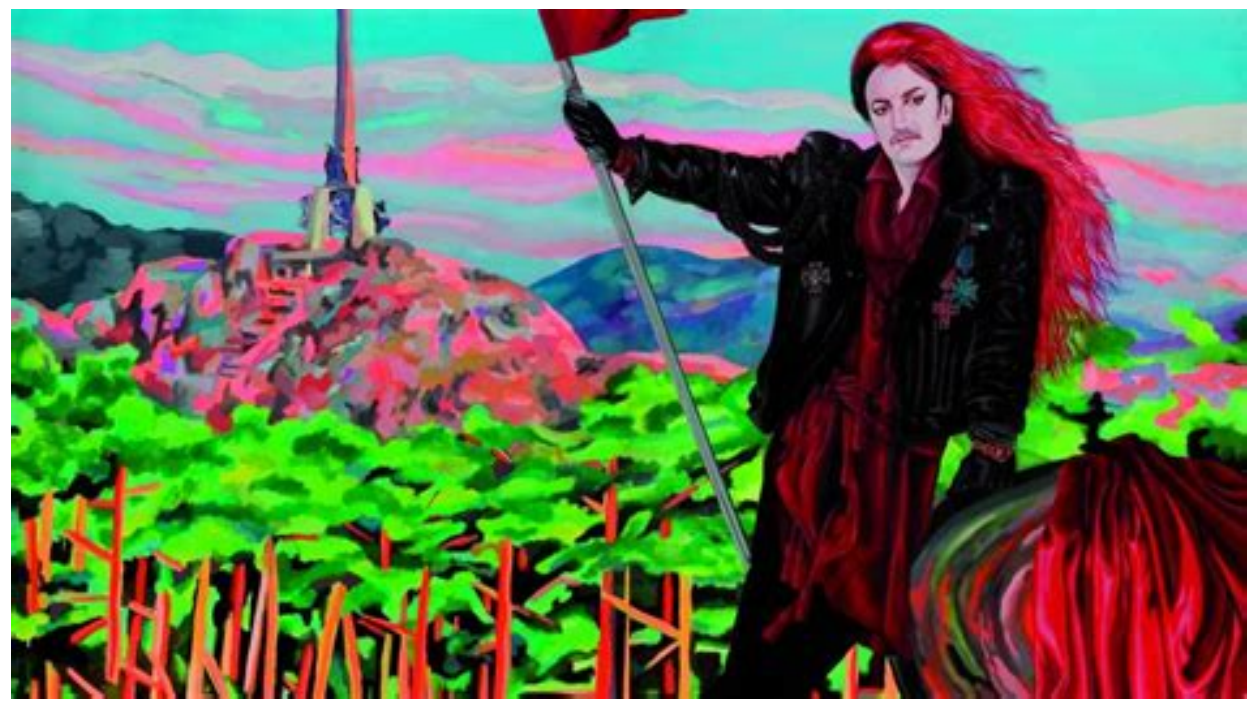

Fig. 17. Una de las reinterpretaciones de Costus en El Valle de los Caídos (1989)

La cultura española de la pluma incluiría, como su versión anglosajona, el cine "de mujeres” sentimental, el Hollywood clásico y sus divas y los musicales, a los que añadiría "productos autóctonos" como los shows de transformistas y el mundo folclórico de la copla y sus artistas (Mira, 2007: 143). Este es el ejemplo más claro de la ambigüedad ideológica de la mirada camp, pues, por una parte, la copla pertenecía supuestamente a la cultura franquista más oficial ${ }^{27}$ : Lola Flores, Juanita Reina o Concha Piquer eran símbolos de la feminidad católica que el franquismo quería promover. Pero al mismo tiempo, representaban una teatralización de la sexualidad y el género espoleada por las letras de Rafael de León, que ponían en escena sentimientos y deseos prohibidos con los que muchos homosexuales del periodo dictatorial podían identificarse. Las letras de Rafael de León pervivirían en la cultura gay durante décadas, incluso en autores tan contraculturales como Nazario, y también estaban muy presentes en los shows de

\footnotetext{
${ }^{27}$ Supuestamente, ya que en realidad la apropiación franquista de la copla, rebautizada como "canción española”, fue una herramienta propagandística de reconstrucción de una identidad nacional maniquea en que las mujeres "malvadas" eran castigadas ejemplarmente, sirviendo de contramodelo de la mujer católica que el régimen pretendía impulsar (ver García García, 2019)
} 
transformistas y travestis (como comprobamos en Una mala noche la tiene cualquiera) (Mira, 2007: 344, 348).

También la religión católica será un rasgo particular y ambiguo del camp hispánico. La cultura homosexual, a pesar de reconocer los aspectos represivos de su dogma, no prescindirá de la belleza extrema y barroca de las manifestaciones católicas y tendrá un papel importantísimo, por ejemplo, en las actuaciones de Ocaña (Mira, 2007: 457) o en los filmes de Almodóvar como Entre tinieblas y La ley del deseo, y, por supuesto, la imaginería híperteatralizante de vírgenes y santas tendrá una papel importantísimo en la lectura camp del discurso místico de Yo no tengo la culpa de haber nacido tan sexy, como veremos.

El transformista y los espectáculos en los que participa también tendrán un lugar central en la cultura gay española desde principios de siglo (tal y como se refleja en Un hombre llamado flor de otoño, estrenada en 1978) y, de hecho, forma parte de la cultura del cuplé desde el inicio de la centuria (Mira, 2007: 152). El travestí28, por una parte, es, por supuesto, un estereotipo homófobo del homosexual como invertido, pero a partir de la muerte de Franco se convertirá en el símbolo de las nuevas libertades obtenidas (Mira, 2007: 416-417), como ocurre en Una mala noche la tiene cualquiera.

El travestí es una figura ubicua en la cultura de los años de la transición con lecturas totalmente opuestas y contradictorias. La cultura oficial le recibirá con los brazos abiertos como símbolo de las nuevas libertades que es «en su exceso, tan asimilable como espectacular» (Mira, 2007: 435): es decir, el travestí, al tiempo que escenifica la libertad democrática al aparecer en el espacio público que antes le estaba vedado, en su extravagancia no cuestiona los binarismos de género ni plantea un cambio radical en la sociedad. Pero, paralelamente, y como veremos en detalle más adelante, la figura del travesti será utilizado por artistas contraculturales como Nazario o revistas como

\footnotetext{
${ }^{28}$ Recordemos que, a lo largo del siglo XX hasta aproximadamente los años noventa, la palabra travesti o travestí se usa indistintamente para el transformista (el hombre, homosexual o no, que se viste de mujer durante el espectáculo, pero en su vida cotidiana lleva ropa de hombre), el cross-dresser y la mujer transexual, siendo todos, al final, expresión máxima del homosexual como invertido. De momento utilizaremos la palabra "travesti" a sabiendas de las confusiones que implica, aunque posteriormente haremos hincapié el hecho de que La Madelón, la protagonista de Una mala noche... es claramente una mujer transexual y no un transformista.
} 


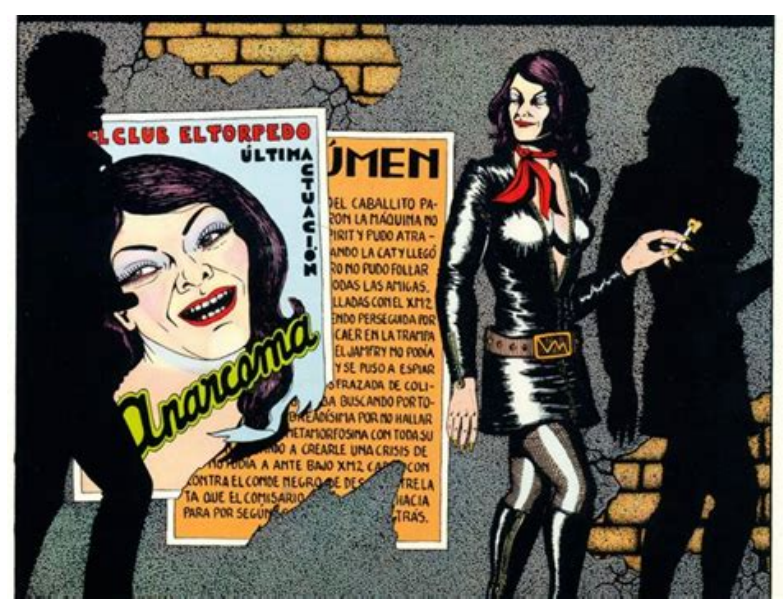

Fig. 18. Anarcoma de Nazario

Ajoblanco o El viejo Topo como signo libertario y desestabilizador de la sociedad solo aparentemente moderna de la Transición (Picornell, 2010).

Paralelamente, el travesti pertenece al mundo del espectáculo y el entretenimiento masivo. Es utilizado en el cine español del tardofranquismo y los primeros años de la democracia como un recurso cómico en que los hombres se travisten para conseguir ciertos objetivos laborales, amorosos, sexuales, etc., y en general los transexuales, como los homosexuales, son objeto de burla (Vegas, 2019: 57-58); al mismo tiempo es un tema predilecto en el docudrama por su excepcionalidad a los ojos de la época, como en el caso de Vestidas de azul, de Antonio Giménez-Rico, filme conocido por ser el primer retrato con intención objetiva y respetuosa de las vidas de seis mujeres transexuales ${ }^{29}$. El travestí es también, como se refleja tanto en Una mala noche la tiene cualquiera como en Yo no tengo la culpa de haber nacido tan sexy, el centro de los shows de revistas y cabarets. La falta de oportunidades laborales aboca a las mujeres transexuales a estas salas de espectáculos, donde sirven como objeto de consumo visual, utilizadas por los empresarios como reclamo publicitario y morboso por la expectación que suscitaban en plena época del destape (Vegas, 2019: 138, 159).

El mundo del cabaré y la revista de los años ochenta era plenamente camp y, como hemos mencionado, estaba especialmente vinculado con el mundo de la copla. La sala Centauros, por ejemplo, era en un local de referencia al que acudían periodistas, políticos, cineastas, artistas e incluso las cantantes que eran imitadas en sus espectáculos como Lola Flores, Sara Montiel o Marisol (Vegas, 2019: 155). Si la copla, el bolero, el cine de Hollywood o las manifestaciones religiosas eran parte del repertorio básico de estos espectáculos en la voz de estos artistas del transformismo no estaban exentos de ironía

\footnotetext{
${ }^{29}$ Aunque no todos compartan esta valoración. Mientras que Valeria Vegas loa la objetividad y la ternura de la mirada de Giménez Rico, reflejando las duras condiciones de la vida de las mujeres transexuales en la época, Alberto Mira, por ejemplo, critica la retórica heterosexista del director, que se centra en los aspectos más negativos de la vida de las protagonistas, presentando la transexualidad como abocada inevitablemente a la marginalidad y la tragedia (Mira, 2007: 443). Postura análoga, por ejemplo, a la que toma Prosser respecto a la película de Livingston, de quien critica que presente al transexual como una “falta”, retratando sus personajes exclusivamente según lo que desean y a lo que aspiran (1998: )
} 
camp. A pesar de todo, el elemento central de estos números y el reclamo principal era, como no podía ser de otra manera, el desnudo integral del travesti, el momento en que enseñaba sus genitales masculinos (Mira, 2007: 440).

En resumen, la posición del travesti en la cultura camp hispánica es altamente compleja: como confirmación del estereotipo heterosexista, como símbolo de tolerancia (que no integración) democrática, como arma contracultural de subversión, como objeto de consumo morboso, tanto en el docudrama como en el show arrevistado... En todo caso, las personas trans se verán, como veremos, reducidas en todos estos casos a meras representaciones que no tienen en cuenta las condiciones materiales y dificultades a las que se enfrentaba este colectivo: criminalización, marginalidad, prostitución, pobreza, enfermedad...

\subsubsection{Una mala noche la tiene cualquiera como novela camp}

En los años setenta y ochenta, por tanto, la estética camp empieza a ser reivindicaba abiertamente como discurso identitario gay en las obras de Terenci Moix o Pedro Almodóvar. En este contexto, Eduardo Mendicutti es el ejemplo más descollante de esta literatura camp, rasgo al que hay que añadir una popularidad no muy común entre los autores de la considerada como subgénero literatura de temática gay; popularidad sintomática de los cambios de la sociedad española hacia la homosexualidad (PérezSánchez, 2007: 92-93); de hecho, y dado el apego a la actualidad de las sucesivas novelas de Mendicutti, su obra sirve como reflejo cronológico de este cambio de la situación de la homosexualidad en España (Jurado Morales, 2012: 42). Como dice Alberto Mira:

\footnotetext{
Mendicutti introduce un elemento que «cierra» el periodo [de la Transición]: su expresión camp se identifica de manera contundente con la experiencia homosexual (...). Frente a la experimentación solipsista de los autores más radicales de los setenta, la voz que surge en las novelas desaforadas de Mendicutti es ya parte de una comunidad que, si bien no se reivindica en el sentido activista, se admite como una cuestión de hecho y se hace plenamente visible (Mira, 2007: 527)
}

Una mala noche la tiene cualquiera es una de las novelas más conocidas de su autor. En ella, asistimos al atropellado monólogo de La Madelón, mujer transexual, durante la noche del intento de golpe de Estado del 23 de febrero de 1981. Durante este, la narradora y protagonista revivirá los momentos más significativos, en su vida y la del país, durante 
los años de la transción, desde la muerte de Franco y la coronación de Juan Carlos I hasta la manifestación a favor de la democracia realizada unos días después del golpe del coronel de Tejero. La crítica reconoce unánimemente el valor de la novela como fiel reflejo de aquel período, distorsionado a través de la estética camp que impregna a la narración. ¿En qué sentido concreto es la escritura de Eduardo Mendicutti en esta breve novela descriptible como camp? Atendamos al inicio de la misma:

Qué sobresalto, por Dios. El Paco se fue a su casa, en taxi, que cuesta un dineral hasta el pueblo de Vallecas, y yo me vine a la mía, a encerrarme con siete llaves, nerviosísima, que hacía siglos que no me sentía tan descontrolada, ni siquiera por un hombre. En seguida puse el loro, o sea Radio Nacional, pero allí sólo daban música de zarzuela; bueno, para mí que era zarzuela. Me quedé quieta, en cuclillas, pegadita al transistor, a ver si decían algo, si daban el parte. Claro que cuando yo llegué a casa y puse el transistor eran sólo menos diez - las ocho menos diez -, me acuerdo divinamente, y hay que ver cómo son siempre de puntuales esas mujeres de Radio Nacional; una cosa mala, puntuales hasta morir. Qué coraje. Allí estaba yo, con el corazón en un puño, arrugadita como un perrillo enfermo lo mismo que la Bautista en Locura de amor junto al ataúd de su hombre - que menudo pendón tenía que ser el gachó, todo hay que decirlo - y las de Radio Nacional impertérritas, oye, hay que ser sangregordas. Y a mí es que iba a darme algo: un ataque, un soponcio, una alferecía. Malísima me estaba poniendo. Una descomposición de cuerpo estaba entrándome que no la puedo ni explicar. En cinco minutos que faltaban para los ocho a lo mejor me daba tiempo a prepararme algo. No quería perderme del parte ni media palabra. Claro que yo necesitaba algo urgentemente: una tila, un Valium, lo que fuera. Un tío. La verdad es que a mí lo que me arregla el cuerpo es un tío, y hasta creo que lo dije en voz alta. Qué espanto. Menos mal que no me escuchaba nadie. (Mendicutti, 2008: 9-10; el destacado es nuestro)

Lo que primeramente llama la atención es la oralidad coloquial de la protagonista, La Madelón: uno de los rasgos más característicos de la escritura de Mendicutti es su habilidad para utilizar el lenguaje oral meridional como vehículo de una gran expresividad (y, como veremos, como reivindicación de lo “andaluz”). Este monólogo, además, con su atropellamiento, sus idas y venidas, sus imprevistos cambios de tema, etc., tiene una cualidad histérica (melodramática) que refleja el momento de tensión vivido la noche del intento de golpe de estado (Colmeiro, 2010: 592-593) ${ }^{30}$. Y como

\footnotetext{
${ }^{30}$ Como Colmeiro señala y vemos en este pasaje, son abundantes las referencias de la narradora a un desorden nervioso del cuerpo. En nuestra opinión y como tendremos ocasión de defender, esta primacía de
} 
rasgos específicamente camp del discurso de la protagonista encontramos la feminización de los periodistas de Radio Nacional (feminización recurrente a lo largo de toda la novela y con prácticamente toda clase de personas en cualquier contexto), la yuxtaposición de comentarios de índole sexual y, sobre todo, las referencias al cine con las que evalúa su experiencia. Un poco más adelante, La Madelón expresará su preocupación por su compañera de piso, La Begum, cuyo paradero desconoce en esos momentos, en estos términos:

(...) y me dio por pensar que La Begum estaba ya camino de un campo de concentración. Una es así de novelera. Enseguida pienso en cosas horribles. Tampoco es que una sea de mucho pensar, las cosas como son, pero de vez en cuando sí que me gusta, me encuentro yo de lo más intelectual y de lo más etérea, sobre todo porque casi siempre pienso en cosas de mucho sufrir y me encanta. De modo que ya veía yo a mi Begum hecha unos zorros, sin pintar y sin nada, rodeadita de porquería y de unos soldados alemanes maravillosos de guapos, y ella en los huesos, demacrada, zarrapastrosa, pero divina a pesar de todo, lo mismo que Vanessa Redgrave en Julia, qué mujer tan ideal. (Mendicutti, 2008: 13; el destacado es nuestro)

Podemos observar perfectamente los rasgos de estilo camp en este fragmento: empezando por la referencia fílmica, no solo en la alusión a Julia y concretamente a su actriz principal, sino en el modo en que su imaginación recrea el destino de su compañero según los clichés de un cierto cine de Hollywood; imaginación que, a pesar de la gravedad de su contenido, evalúa la escena en términos estéticos: los soldados alemanes son «maravillosos de guapos» y La Begum, «divina a pesar de todo». Lo camp no solo se materializa en las fantasías de la protagonista, sino en su misma manera de actuar:

Pensaba yo en todo eso, con aquel porvenir que se nos venía encima, con la visión de todas nosotras en el desolladero -que por lo visto también hacían eso los nazis, cuando se ponían en plan Empresa Nacional de Artesanía - y (...) me fui poniendo sentimental: empecé a mirarlo todo muy dramática, muy despacito, como en el cine, y se me saltaban las lágrimas sólo de pensar que a lo mejor ya, a esas horas, aquello era lo único que me quedaba (Mendicutti, 2008: 35-36)

Como vemos, La Madelón describe su angustia en términos (melo)dramáticos a través de su gestualidad, explícitamente relacionada con el cine - nótese también la cómica yuxtaposición, por escandalosa y absurda, del riesgo real que corre la protagonista con el

las sensaciones corporales, e incluso las alusiones sexuales, son un puntal fundamental del discurso de la identidad de La Madelón como identidad corporal. 
golpe de Estado y la comparación de los nazis con la «Empresa Nacional de Artesanía». Frank Links ha estudiado las diferentes referencias fílmicas de la novela, tanto al cine clásico de Hollywood como al español del período franquista, y analiza cómo «los gestos que hacen los personajes se convierten en unas performances inspiradas en largometrajes en los que actúan sus grandes ídolos del cine hollywoodiense. La autenticidad consiste en una sobre-actuación exagerada y artificial» (Links, 2012: 125-126).

La Madelón lo evalúa todo en términos estéticos, incluso la actuación del teniente coronel Tejero: «Qué número, por Dios, como en Sudamérica: hala, a tiro limpio, todas al suelo, se acabó lo que se daba, guapos. Qué cosa más ordinaria» (Mendicutti, 2008: 10). La propia democracia es vista desde un punto de vista camp: «(...) me vine a mi casa a soñar con la libertad. Huy, sí, qué cosa más bonita. Me la imaginaba divina, todo la mar de bien, para todo el mundo lo mejor de lo mejor. La gloria» (Mendicutti, 2008: 19). Esta estetización alcanza, en el recorrido del monólogo interior de La Madelón, todo el período de la Transición desde la muerte de Franco hasta la noche del 23 de febrero. Podemos tomar como muestra varias escenas, como la primera votación democrática o la manifestación regionalista por Andalucía. En el primer caso:

Cuando las últimas elecciones, con todo aquel mogollón del censo y la madre que los parió, servidora movió cielo y tierra para poder votar en Madrid, que aquello de hacerlo por correo no me merecía confianza ninguna, y me presenté en mi mesa electoral, la que me correspondía, a media mañana, cuando había más barullo, hecha un brazo de mar, que fue una sensación, y eché la papeleta del Partido Comunista y lo dije en voz alta: "Yo voto Comunista”. Fue divino (...) Aquel día, después de soltar la papeleta y armar el taco - que el deber no tiene por qué estar reñido con esas ganas que a una le vienen cada dos por tres de dar el golpe (ay, Jesús, el golpe no; quiero decir llamar un poquito la atención, hacer algo vistoso, pero sin maldad ninguna, ya se entiende) (Mendicutti, 2008: 18-19)

Y en cuanto a la manifestación andalucista:

Una siempre ha sido medio levantisca y, para colmo, me encanta todo este zascandileo que hay ahora con las autonomías y las banderas de cada uno y elecciones cada dos por tres, y un referéndum de esos todos los fines de semana, y unas manifestaciones preciosas que se montan corriendo, a cuenta de lo que sea, y a poca alegría que le eches te lo pasas de cine. A mí toda esta bulla es que me encanta. (Mendicutti, 2008: 47)

Pero en aquel domingo, 4 de diciembre, Día de Andalucía, nada de eso tenía la menos importancia. Nos pusimos guapísimas porque queríamos causar sensación, que eso es 
algo que siempre gusta, pero servidora al menos lo único que quería de verdad era arrimarse a lo que es tu gente (Mendicutti, 2008: 56-57)

Como vemos, estos eventos no se evalúan (solo) por su trascendencia histórica, su significación democrática, sino por su carácter estético. La Madelón concibe el acto de votar como una auténtica performance «que fue una sensación», y asiste a manifestaciones «preciosas» porque le apasiona «toda esta bulla» - aunque, insistimos, también vemos cómo explícitamente le da más valor a la manifestación de su comunidad de origen. La campificación también afecta a las personalidades de la época:

A mí el presidente del Congreso es que me encantaba, con una facha estupenda y aquellos ojos de dulce; para el catre, la verdad, no era mi tipo, pero para ponerlo así, tan planchadito él, en el recibidor y que te contase el último cotilleo de los políticos, me habría chiflado (Mendicutti, 2008: 36)

El propio personaje de La Madelón es típicamente camp en cuanto está, usando las palabras de Susan Sontag, en «continua incandescencia» (1967: 314), por su intensísima y espectacular personalidad, inspirada por las divas del cine y de la copla a las que refiere continuamente:

Una siempre ha tenido a gala ser una profesional fetén y siempre he pensado que, si alguna vez me pasara un drama espantoso, un drama de ésos que te dejan hecha mixto y como sonámbula durante meses - como a la Conchita Bautista, cuando se le murió su única hija de doce años, que era lo único que tenía; algo así -, servidora saldría a escena como todas las noches y el público, que es maravilloso, no se daría cuenta de nada, porque el dolor verdadero de una artista es sólo cosa suya y tiene que ir por dentro. Y si aquella noche, con la zapatiesta tan gordísima que se había armado, con lo peligroso que tenía que ser todo, Federico me llamaba en cualquier momento y me decía: «Madelón, aquí hay público que ha pagado su entrada y hace falta que vengas», pues servidora iría como si tal cosa, maravillosa, deslumbrante, con mi número hecho como siempre, sin una prisa de más, mi número de Marlene Dietrich, que es una sensación, una cosa medio morbosa, muy sexual, pero con mucho gusto, y de aparecer los civiles tendrían que echarme de la pista a empujones o esperar como lobas a que terminara el número. Mi arte para mí es una cosa sagrada (Mendicutti, 2008: 63)

Y es que una es así, una le echa mucho brío y mucho corazón a todas sus cosas, mucha sensibilidad, y luego me gustan los trapos y los potingues y un buen maromo como a la que más, pero con eso nunca se me olvida que, antes que nada, una es persona. Una es así (Mendicutti, 2008: 42) 


\subsubsection{Lecturas maricas e histéricas de la Transición}

Tanto la mirada camp de novela como la ambigüedad material del género de su protagonista da lugar a que toda la crítica académica ${ }^{31}$ coincida en interpretar la figura de La Madelón como una metáfora de la España de la época, ya desde su mismo título: una mala noche la tiene cualquiera, apuntando a la experiencia de La Madelón como metonímica del sentir colectivo de toda la ciudadanía, como de hecho se explicita en la novela:

a mí, oyendo aquello, me entró de pronto una especie de alucine, como un éxtasis mayormente, que no sé si sabré explicarlo: me veía yo escuchando aquello con una angustia de lo más excitante (...) y dejé la vista muy fija y muy fuerte en el transistor, como si fuera capaz de ver lo que pasaba por lo que me estaban contando, y es que era el único modo, y además yo sentí que no estaba sola, que en todo Madrid - que en toda España - había miles de personas como yo, o sea que éramos multitud, un gentío que daba gloria vernos, todos en el tormento de no saber, todos con el corazón en un puño (...), solo con unas ganas de que aquello terminara bien, con una necesidad loca de escuchar hasta por el ombligo, por mentar un sitio raro, pero decente, y con el pecho lleno de ansia de libertad. Me sentía yo hermana de todos, una cosa preciosa que nunca me había pasado antes. (Mendicutti, 2008: 41)

En un sentido histórico y social, la elección de un travestí como representante de la España de los primeros años de la democracia parece paradójica por su posición marginal pero particularmente adecuada, dado que en efecto la muerte de Franco se vio acompañada por las primeras apariciones públicas de personas transexuales, tanto en la proliferación de cabarés de transformistas, como en las primeras manifestaciones LGTB, con personas trans a la cabeza. Así pues, el travesti es el símbolo más visible de las nuevas libertades que llegan con la democracia (Garlinger, 2000: 366, ver también Platero, 2011). En este sentido, la biografía de La Madelón es paralela a la historia de España: vive en la

\footnotetext{
${ }^{31}$ La novela, de hecho, ha tenido que superar el "escollo" de tener un tono humorístico para poder ser interpretada "seriamente", como si a pesar de lo alocado del discurso de La Madelón hubiera, debajo de él, un significado "serio”. Así, por ejemplo, leemos: «Underneath the histerically ludic surface of a monologue directed explicitly at the reader, La Madelón engages in a critical analysis of sexual and national identities as she recounts her experiences of the night of Tejero's aborted coup» (Garlinger, 2000 :368); o Gema Pérez Sánchez cita como ejemplo al crítico Leopoldo Azconat, para quien la frivolidad del discurso de La Madelón la deslegitima como portavoz de la ciudadanía española (Pérez-Sánchez, : 109)
} 
clandestinidad en los últimos años de la dictadura ${ }^{32}$, nace oficialmente con la muerte del dictador $^{33}$ y vive su mayor crisis con el golpe de Estado ${ }^{34}$ (Paredes, 2007: 58).

Pero el travesti también funciona simbólicamente como metáfora de la España de la transición precisamente por ser un cuerpo en transición. Para Teresa Vilarós la Transición es un ejemplo de lo que llama Homi Bhabha llama «hybrid betweenness», el momento histórico en el que una nación se debate entre el pasado y el futuro y se abre a la posibilidad de transformación, «un espacio de crisis entre lo conocido y lo nuevo» (Paredes, 2007: 57). De ahí que la naturaleza «híbrida e imprecisa» de La Madelón sea la figura perfecta para significar esta «betweenness» entre el oscuro pasado franquista y la promesa de la libertad democrática ${ }^{35}$. Si, como apunta Vilarós, la identidad de la España democrática se basa en un "pacto del olvido" de la dictadura ${ }^{36}$, el intento del golpe de Estado del teniente coronel Tejero se presenta como la irrupción de un pasado no eliminado del todo y que amenaza con una involución de las libertades. Esto se simboliza en la novela de dos maneras: primero, por la presencia en el cuerpo de La Madelón de los genitales masculinos, que le recuerdan su pasado de hombre (Paredes, 2007: 61); y segundo, la maleta en la que ella y La Begum han guardado los trajes que se pusieron la última vez que vistieron como hombres y que la protagonista se plantea si tendrá que volver a utilizar.

La hibridez del cuerpo de La Madelón lo es, en primer lugar, precisamente de lo masculino y lo femenino, con toda la importancia que la construcción de la diferencia de género tenía para el edificio ideológico del franquismo: la oposición hombre/mujer era un espacio simbólico básico en la moral del régimen; en contra de la perniciosa influencia del feminismo de los años veinte y treinta, la dictadura encumbraba a la mujer dócil, sumisa, etc., al tiempo que le oponía el destino viril del franquismo, del que el

\footnotetext{
32 «La Madelón no tuvo juventud, nació con la verde (...) Así que nada más terminar la «mili» me viene a Madrid, que allí en mi pueblo uno no podía realizarse ni nada (...) y como a los cinco meses, aquí en Madrid, nació La Madelón. Al comienzo de tapadillo» (Mendicutti, 2008: 11)

${ }^{33}$ Muy simbólicamente, como tendremos ocasión de analizar, La Madelón y La Begum ofician la ceremonia de su "bautismo" como mujeres la misma noche en que el rey Juan Carlos I es coronado. (Mendicutti, 2008: 127)

34 «¿Qué sería de nosotras? Lo mismo les daba por volver a lo de antes (...) Pues seguro que había que resucitarlo - a Manolito [García Rebollo, su nombre masculino], quiero decir -, qué horror, con lo mal que o pasaba el pobre» (Mendicutti, 2008: 17)

35 «El destino de una que es ser mitad y mitad; pero no en orden - como las sirenas, como los centauros -, qué va qué más quisiera yo. Lo nuestro es ser mitad y mitad, pero a la rebujina, para qué engañarse» (Mendicutti, 2008: 25)

${ }^{36}$ «La Madelón, como cualquier mujer que se precie, no tiene pasado»
} 
Generalísimo era el máximo símbolo (Picornell, 2010: 286). Según Labany, la mitología franquista simbolizaba España como la madre patria salvada mediante el sometimiento del Padre/Caudillo (Pérez-Sánchez, 2007: 64). En esta vigilancia del orden de género y sobre todo del cuerpo masculino, exaltado y vigilado a partes iguales, se entiende la especial preocupación del régimen por la homosexualidad y la promulgación de la serie de leyes que buscaban perseguirla y denunciarla (Picornell, 2010: 286-287) ${ }^{37}$.

Así mismo, el transexual no solo supone una transgresión de la virilidad franquista, sino que además es una subversión del orden público - de ahí que a los travestis y transexuales también se les aplicara el delito de escándalo público, incluso bien entrada la democracia (Picornell, 2010: 287; Vegas, 2019: 23, 143). Por tanto, la figura del travestí es símbolo del fin de la dictadura en cuanto aparece en el espacio público, significando las libertades recién adquiridas, y en cuanto feminiza el cuerpo viril del franquismo, en una metaforización en que lo masculino es asignado al pasado, y la feminidad, o más exactamente la virilidad travestida o el cuerpo híbrido, al presente y al futuro utópico y libre.

Pero esta feminización no es exclusiva de la protagonista, sino que como hemos podido comprobar, La Madelón insiste en usar el pronombre femenino para nombrar a cualquier persona sea cual sea su sexo u orientación sexual ${ }^{38}$. Garlinger señala cómo en ciertos momentos significativos la narradora vacila en el uso del pronombre (por ejemplo, cuando llama a La Begum por su nombre de varón: su pasado (franquista, añadimos) de hombre desestabiliza su identidad femenina (democrática) del presente (Garlinger, 2000: 369). Lo mismo ocurre con su nombre de nacimiento, Manuel García Rebollo, que es a la vez visto como más “auténtico” (es el nombre que aparece en su DNI, el que le da el estatuto de ciudadano) y como resto desechable: la elección de su nombre de mujer, La Madelón o La Begum, se ve ambiguamente como «a playful masquerade» (Garlinger, 2000: 369) pero a la vez como un acto deliberado de auto-nominación independiente de la «interpelación» ideológica del Estado.

\footnotetext{
${ }^{37}$ La Ley de Peligrosidad Social da lugar a la categoría de «peligrosos sociales» que será reapropiada por los medios contraculturales y libertarios como sujeto de lucha desde la marginalidad, representada precisamente en muchas ocasiones por el travesti, por ejemplo en el dibujo de Nazario de «Miss Peligrosidad Social» (Picornell, 2010: 287)

38 «Al segundo salieron charlando como cotorras medio histéricas, pero divinas, todas esas mujeres tan maravillosas de Radio Intercontinental» (Mendicutti, 2008: 26)
} 
Esta ambigüedad genérica también afecta a los roles sexuales, sobre todo en la relación entre La Madelón y su compañera de piso, La Begum. En ocasiones, la protagonista se siente como la madre de su compañera (Mendicutti, 2008: 13), pero en cierto momento dice también ocupar el rol masculino: «Hasta en una pareja rarísima como la que nosotras hacemos, una de las dos tiene que hacer de macha» (Mendicutti, 2008: 108). En cierto sentido, parece que La Madelón naturaliza los roles de padre y de madre, de hombre y mujer, como inevitables: «Conozco yo a dos, La Crafor y La Coquina, que se alternan - según las circunstancias, la hombra es una o la otra, que se tienen sus temperamentos enseñados divinamente -, pero eso es un caso raro. Lo normal es que siempre le toque apechugar a la misma con la voz cantante.» (Mendicutti, 2008: 108). Sin embargo, nótese que al travestir también los nombres de “macho” (“macha”) y "hombre” (“hombra”) también está desnaturalizando estos papeles, desvinculándolos de cualquier supuesta base biológica, en una clara “teatralización” travesti del género: «drag uncouples social roles from their sexual difference specificity» (Garlinger, 2000: 372); «Mendicutti brilliantly establishes a complex play of gender switching: la hombra is a neologism that insists on using hombre as a signifier for an active sexual role in a same-sex relationship, but denies and subverts its heterosexist mark by creating a female version of the Word» (Pérez-Sánchez, 2007: 102). Hombre y mujer son solo significantes, papeles sociales, que pueden asignarse a cualquier cuerpo independientemente de su anatomía - porque, de hecho, La Madelón y La Begum son mujeres con genitales masculinos.

Una parecida desnaturalización opera ambiguamente en la declarada pasión de la protagonista por los uniformes ${ }^{39}$. Ambigua porque, siendo los hombres uniformados (militares, guardias civiles, legionarios, etc.) no solo epítomes de virilidad sino representantes de aquellos poderes reaccionarios que han irrumpido en el Congreso y que amenazan su misma existencia, La Madelón se siente atraídos por ellos, en una especie de fantasía sadomasoquista, como comprobamos en sus propias imaginaciones. Ya es sintomático de por sí el hecho de que La Madelón elija su nombre del personaje de una canción militar cantada por Marlene Dietrich y Sara Montiel ${ }^{40}$. En cierto sentido, el

\footnotetext{
39 «Ay, los uniformes... A mí es que me privan los uniformes. Desde siempre. De toda la vida. Desde que era un renacuajo y se me iban los ojos detrás del municipal que dirigía el tráfico en la calle Ancha, frente a la plaza Cabildo. ¡Todo por un uniforme! Mi reino de plumas y ligueros, de cremas carísimas, de perfumes de importación, por un uniforme» (Mendicutti, 2008: 58)

${ }^{40}$ «De alguna parte tenía que salir mi nombre de guerra: La Madelón (...) La Madelón es dulce y complaciente, La Madelón a todos quiere igual; da su amor a todo el frente, del soldado al general. Ay, La Madelón: muerta en la bañera por un paracaidista» (Mendicutti, 2008: 58)
} 
hombre uniformado, viril, vinculado al poder, es la contraparte necesaria en la fantasía de la identidad imaginaria (en sentido lacaniano) de La Madelón. Precisamente, algunos estudiosos critican o leen irónicamente la imagen de feminidad que la protagonista de la novela proyecta para sí misma; a este respecto cabría señalar cómo la protagonista se imagina a sí misma, con todas sus contradicciones, pero rechazando cualquier imagen de mujer sumisa:

(...) de vez en cuando me pongo a cavilar en estas cosas y a mí me parece que me haría ilusión encontrarme a alguien que me viera como una mujer de las formales de toda la vida, no una pazguata que no se enteran de la misa la media, sino sencillamente una tía con personalidad, que sabe decir que no cuando hay que decirlo, que sabe elegir por su cuenta y además ser exigente, y si no encuentra nada que le convenza del todo pues pasa, sin ninguna clase de complejo, se lo monta por su cuenta o con otra gachí, si eso le convence más, y no se deja avasallar por nadie. No es que yo diga que me gustara del todo ser así - que una es polvorilla de nacimiento y eso no hay manera de quitárselo de encima ni a la hora de fantasear -, sino que me gustaría encontrar a alguien que me tomara desde el primer momento por una de ésas, que no me tomara desde el primer momento por una cosa sencillita, que fuera calculando por su cuenta la forma de camelarme, que sufriera muchísimo por mí, y que al final me pidiera que lo dejara todo y me dedicara solamente a cuidarle. Yo seguro que le diría que no, pero la ilusión y el orgullo no me los iba a quitar nadie (Mendicutti, 2008: 78)

En todo caso, el carácter fetichista de esta afición de La Madelón por los uniformes funciona también como una denuncia del uniforme como drag, como “disfraz” que busca compensar una falta de masculinidad (Colmeiro, 2010: 601). La novela parece ridiculizar esta construcción fantástica de la hombría en varios momentos: en la yuxtaposición del uniforme militar con el uniforme, mucho menos "glamuroso", del uniforme de conductor de autobús del novio de la protagonista (Colmeiro, 2010: 601), o en el pasaje en que La Madelón comenta que, en muchas ocasiones, al ir a la cama con algún soldado o guardia civil ha descubierto que debajo del uniforme no hay nada ${ }^{41}$. En estos pasajes se ve cómo la fantasía fetichista del uniforme no proviene de La Madelón, sino del mismo régimen militar, y por extensión franquista, que busca sin resultado ocultar la falta de virilidad de sus sujetos (Garlinger, 2000: 376) - virilidad cuya supuesta heterosexualidad también se

\footnotetext{
${ }^{41}$ «Eso es lo que le pasa a los soldaditos en general, ya los paracas en particular: les quitas el uniforme, los lavas un poco, pones en la alcoba una luz indirecta, y cuando te metes a la labor lo que te encuentras es una criatura más sosa que un muergo hervido con Lanjarón» (Mendicutti, 2008: 137)
} 
ve puesta en duda en las relaciones sexuales que los soldados establecen con La Madelón ${ }^{42}$. La misma supuesta hombría de Tejero queda cuestionada por la narradora: «Y el Tejero, mientras, dándose el pisto de machirulo. Como si hubiera que tener muchas agallas para hacerles frente, con sus buenos pistoleros, a unos señores tan cultos, tan finos y desarmados completamente» (Mendicutti, 2008: 35).

Bajo nuestro punto de vista, tanto el uniforme como la vestimenta masculina en general, están significadas en la novela como “disfraces” impuestos a los individuos, símbolos de la opresión de género por parte del régimen ${ }^{43}$. Esto es evidente en la aversión que La Madelón manifiesta ante la posibilidad de tener que desenterrar los trajes de la maleta y vestirlos, ocultando así su verdadera identidad; en muchas ocasiones la protagonista habla de su actuación como hombre como efectivamente una actuación que disfraza su identidad femenina ${ }^{44}$. Lo mismo ocurre cuando trata de los soldados y policías: hay una clara separación entre el uniforme y su subjetividad individual, «una resignación vestida de uniforme», como dice la misma protagonista (Mendicutti, 20008: 58). Así, en la manifestación regionalista, La Madelón se encuentra con que uno de los policías que vienen a desalojarlos es de Granada:

Y a mí con aquello me entró una emoción que no lo pude evitar, me planté en jarras delante del muchacho, yo la mar de jacarandosa, y se lo eché en cara: «Hijo de mi alma, si tú lo que tienes que hacer es echarte una bulería, que tú también eres de por allí...». Y a la criatura media sonrisa se le puso dichosa y la otra media se le puso triste, y tuvo que darse media vuelta. A mí me dio mucha lástima. (Mendicutti, 2008: 59)

Otro signo de masculinidad tratado ambiguamente en la novela es, por supuesto, el propio pene. Son varias las referencias de La Madelón a la atracción que tanto ella como La

\footnotetext{
${ }^{42}$ Garlinger califica estas relaciones y el propio deseo de la protagonista como homosexuales; también Colmeiro dice que esta «se construye a sí misma como objeto de deseo homosexual» (2010: 301). Sin embargo, el deseo de La Madelón y las relaciones que establece con los hombres solo puede ser entendida como homosexual desde una perspectiva, ciertamente anticuada, del transgenerismo como inversión homosexual, es decir, considerando que La Madelón en realidad es un hombre porque tiene pene, y por tanto su deseo por los hombres es homosexual. Desde el otro polo de la relación, la transexualidad del objeto de deseo de los hombres no puede ser calificada de una manera simple de homosexual.

${ }^{43}$ En general, y como comprobaremos también en el análisis de Yo no tengo la culpa de haber nacido tan sexy [6.3.3], toda la obra de Mendicutti retrata la masculinidad como una imposición opresora.

${ }^{44}$ Lo que explícitamente contradice a aquellos críticos que conceptualizan el ropaje, el maquillaje y la gestualización femeninas como mascarada, como disfraz: es claro que para La Madelón el verdadero disfraz es su ropa de hombre.
} 
Begum tienen por hombres con un miembro grande ${ }^{45}$. Irónicamente, en uno de los pasajes más divertidos de la novela la protagonista relatará sus dificultades para ocultar adecuadamente sus genitales dado su gran tamaño:

Lo mío, en cambio, es una verdadera ordinariez, más de una y de dos me lo envidiarían: ancho, macizo y graciosamente arqueado, como a mí gusta decir, porque a todo hay que ponerle un poquitín de delicadeza. Qué sufrimiento. Qué desperdicio (...) Servidora no conseguía disimular toda aquella cesta de la merienda que la Naturaleza - madrastra, braguetadicta, putón de feria - me había regalado, con tan poquísimo sentido de la oportunidad (Mendicutti, 2008: 55; el destacado es nuestro)

Como hemos dicho, el pene es interpretado por la crítica como el recordatorio de su pasado como hombre que metafóricamente remite al pasado franquista del país. En este sentido, el pene cobra una importancia central como el significante primario de la masculinidad: como ya hemos mencionado, la atracción principal de los espectáculos de transformistas era el descubrimiento del pene, y en los contextos de las prácticas contraculturales de un Ocaña, por ejemplo, la presencia de los genitales masculinos era condición sine qua non de su potencial subversivo (Piconnel, 2010: 293). La misma Madelón reconoce el potencial revolucionario de su miembro:

Eso sí, de lo que no me preocupé mucho fue de que las bragas me quedasen perfectamente lisas. Al principio, qué mal lo pasé por culpa de eso. Pero aquel domingo, en la Gloria de un día tan nuestro, qué más me daba. Hasta se me ocurrió que, si alguien me obligaba a enseñar mis bajos - que una nunca sabe por dónde va a salirle la degeneración a las ministras del Interior -, mejor era que se me notasen los tolondrones; me parecía a mí más revolucionario. (Mendicutti, 2008: 54)

Esta centralidad del pene como significante masculino de los sujetos transformistas y transexuales ha sido ampliamente criticado por la naturalización de esa relación entre genitales, sexo y género (Prosser, 1998: 64, 90). Para Garlinger, muy al contrario, el drag «uncouples the necessary relationship between the phallus and the penis, thereby putting into question the penis as a bodily marker of sexual difference» (2000: 371). En este sentido, tanto el "destape" del transformista, la mostración performativa del travesti contracultural o la consideración desmitificadora de La Madelón de sus propios genitales

\footnotetext{
45 «Porque mi Paco, la verdad sea dicha, es un poquito cuajón y bastante pejiguera, pero de carrocería está un rato bien, y la maneja con muchísimo entusiasmo y sin ningún remilgo, que a todo le saca él un disfrute» (Mendicutti, 2008: 77)
} 
actúan ambiguamente concentrando la masculinidad en el pene, al tiempo que lo descentran como significante de género ${ }^{46}$.

Pero no solo es el género lo que desestabiliza el cuerpo, el gesto y la palabra de nuestra protagonista: su condición de metáfora camp de la nación española abarca también otros aspectos ideológicos, a primera vista de manera ambigua: La Madelón es a la vez femenina y masculina, andaluza y española, comunista y monárquica, reflejo del crisol ideológico que hallamos en el período de la Transición:

El travesti incorpora lo aparentemente irreconciliable. Madelón es hombre/mujer, es macho/hembra, es andaluza/española, es monárquica/comunista, e incluso, como veremos, exhibe ocasionales coqueteos con la extrema derecha. En conjunto, aparece como un ser de naturaleza improbable cuya identidad integra las diversas facetas del nuevo mapa ideológico de la nación española en proceso de transformación (Paredes, 2007: 61)

La Madelón ocupa el lugar intermedio entre lo masculino y lo femenino, el norte y el sur, la metrópoli y el pueblo, ese "tercer espacio", “ni aquí ni allá” que Bhabha atribuye al sujeto nomádico poscolonial, en perpetuo estado de dislocación, y que por su posicionamiento dentro y fuera a la vez, tiene la capacidad de dislocar el sistema (Colmeiro, 2010: 603) ${ }^{47}$

Respecto al andalucismo de La Madelón, ya hemos anotado su entusiasta implicación en la manifestación y su estilo coloquial lleno de regionalismos. Es en este punto en que cobra sentido este recurso del autor al lenguaje oral y coloquial de su tierra natal: no como un mecanismo humorístico más de frivolización camp, como deslegitimación irónica de la voz de la narradora como portavoz del sentir colectivo, sino bien al contrario como reivindicación de la validez y expresividad del lenguaje meridional y la autenticidad de la identidad andaluza. Así es como opina explícitamente La Madelón, que se lamenta de que tras pasar tanto tiempo en Madrid haya perdido parte de la espontaneidad que caracterizaba su lenguaje.

\footnotetext{
${ }^{46}$ En todo caso, en el caso concreto de La Madelón, que rechaza su pene pero lo busca en sus parejas sexuales, se trata simplemente de la diferencia entre la identidad de género y la orientación sexual: rechaza sus propios genitales porque no se ajustan a su imagen corporal, y busca el pene en sus parejas porque le gustan los penes.

${ }^{47}$ En este sentido, el cuerpo de La Madelón se puede conceptualizar como un cuerpo carnavalesco en el sentido bajtiniano [ver 1.2.3.2], en tanto que cuerpo abierto, híbrido, ambiguo, festivo, representante de la colectividad, promesa de futuro...
} 
Esta reivindicación del lenguaje andaluz forma parte de una reivindicación en general de la identidad andaluza, que no entra en contradicción con su sentir español, como vemos en uno de los pasajes más emotivos de la novela ${ }^{48}$. Retrata, sobre todo, el drama de la emigración del sur al centro del país y del pueblo a la gran urbe, fenómeno social que afectaba especialmente a la población LGTB (Mira, 2007:456):

Yo antes en esas cosas me fijaba menos, pero ahora me entra un orgullo grandísimo a cuenta de mi manera de ser y de cómo es mi gente, y me llevo unos sofocones de espanto cundo pienso en lo fatal que está todo por allí, la cosa del trabajo sobre todo, y es esta desgracia tan enorme de tener que emigrar, que yo creo que es como si te arrancaran el pellejo, que es verdad que te sale otro y es por el estilo, porque no te va a salir torcido como el de un japonés, pongo por caso, pero ya nunca será la misma cosa (Mendicutti, 2008: 46)

En todo caso, vemos cómo esta ambivalencia Andalucía/Madrid, pueblo/metrópoli, periferia/centro, sur/norte, etc., es un rasgo más de la hibridez en la identidad de La Madelón. Otro es su ambigüedad ideológica en la medida en que vota al Partido Comunista pero se declara monárquica y fiel a la figura de Juan Carlos I, amén de la ya comentada pasión fetichista y sadomasoquista por lo militar. Como dice Francisca Paredes: «El cuerpo de Madelón, (...) es también locus perfecto para la combinación esquizofrénica de movimientos ideológicos de la España en frenético proceso de cambio de los valores que durante la dictadura la habían gobernado a los que la democracia ofrece como alternativa» (2007: 62).

\footnotetext{
48 «Ay, los trenes del Sur... También a mí a veces me da por irme con La Begum a la estación de Atocha, a pasarme la tarde entre el bullerío de los viajeros, los soldados que vienen con la resaca del permiso - esos ojitos brillantes y la boca guasona, como un rescoldo que se traen pegado a las carnes y al mismo aire con que caminan, miran y se menan -, los soldados que se van con las ganitas saliéndoles por el cogote afeitado, a veces familias enteras que vienen de Alemania o de cualquier otra parte de por ahí, y seguro que a todos les va cambiando la voz, el habla, el color y el gesto conforme se acercan a Despeñaperros, que es una cosa que no se puede evitar ni disimular, porque a mí me pasa y sé bien lo que eso. Es que yo me monto en el tren para ir a mi tierra, a ver a mi gente, y es que soy otra, una mujer distinta, como si con sólo pensarlo me entrara de pronto una especie de tranquilidad que en Madrid no tengo nunca, porque no es cosa de nervios, yo creo que es sólo una cosa de comodidad, de sentirse a gusto de la cabeza a los pies, por dentro y por fuera, y para mí que más que nada es una cosa de los huesos, el esqueleto de una se relaja, se pone confortable de verdad, se deja ganar poco a poco por esa galvana tan rica que no es pereza ni holgazanería ni desidia, es como una parsimonia sabrosa y divinamente aliñada, no esa patarra insípida de la gente patosa y lacia, o sea que no es despego sino una dedicación a tope pero sin ninguna prisa, sin agobio ninguna, para que nada se desperdicie. Esto es una cosa que en Madrid se pierde mucho, por tantísima bulla como aquí tenemos, pero que a mí se me resucita en cuanto me pongo en camino, y que yo creo que se le nota a cualquiera que sea de allí, siempre se acaba notando, más temprano o más tarde, esté uno donde esté y por el tiempo que lleve fuera y por mojarrilla que sea» (Mendicutti, 2008: 45-46)
} 
Esta ambigüedad también se da entre la declarada afición de La Madelón por el partido comunista y el coqueteo con el fascismo. En uno de los pasajes más comentados de la novela, nuestra protagonista acude con La Begum y la Soraya a una manifestación de falangistas en la Plaza de Oriente. Aunque este pasaje haya llevado a algunos críticos a cuestionar la ideología política de La Madelón, lo cierto es que ella asiste a regañadientes, y en la novela se contrasta explícitamente el sentimiento de integración que vive, por ejemplo, durante la manifestación regionalista, o en la manifestación a favor la democracia narrada al final de la obra, con el rechazo que siente en la manifestación falangista $^{49}$. En todo caso, la presencia de las tres transexuales en dicho evento tiene un efecto más bien provocativo: «íbamos armando el taco, porque había gente, sobre todo mayor, que al vernos arremangaba el hocico y rajaba horrores, «qué barbaridad, qué mamarrachada, esto no debería consentirse» y cosas así» (Mendicutti, 2008: 96). Como dice José Colmeiro: «el inoportuno travestismo de La Madelón representa un acto de subversión maricona que contagia el acto político de una nota de lo grotesco por medio de la parodia» (2010: 599). Sobre todo, la mirada camp vuelve a evaluar el evento en términos estéticos, no solo su presencia sino la propia manifestación:

Nos vestimos las tres de falangistas, la mar de monas, con las gorritas ladeadas, una faldita azul marino, un correaje - a la cintura y cruzando el pecho - finito pero de calidad, botas altas, guantes de cuero, y las mangas arremangadas hasta los codos. La pura verdad es que parecíamos sacadas una fotografía de época, que hasta nos maquillamos a juego y La Soraya era clavadita a la Pilar Primo de Rivera cincuentona (Mendicutti, 2008: 95; el destacado es nuestro)

si supieran comportarse, el cisco tan vicioso que arman quedaría hasta simpático y con gancho a su manera, y es que fotogénicas por lo menos sí que son (Mendicutti, 2008: 97; el destacado es nuestro) $)^{50}$

\footnotetext{
49 «Algunos se desinhibieron que daba gloria, aunque, eso sí, todo la mar de patriótico, huy, muchísimo, y con un esportón de vivas a todo lo de antes - que empachera -, y después un diluvio de ordinarieces contra todo lo de ahora - qué jartura, por Dios -, yo con eso me ponía mala» (Mendicutti, 2008: 96)

${ }^{50}$ Cabe insistir en que, a pesar de estas valoraciones estéticas, La Madelón no llega a sacrificar su "ética”, y no dejara de explicitar los remordimientos que siente por haber acudido a la manifestación.
} 
Esta estetización es general: afecta tanto a las verbenas del Partido Comunista ${ }^{51}$ como al mismo intento de golpe de Estado ${ }^{52}$. En cierto modo, la mirada camp de La Madelón da pie a una visión en parte teatral de la Transición y supone un comentario acerca de la construcción mediática del período, incluyendo la intentona golpista. Al menos así lo han visto críticos como José Colmeiro o Alberto Medina, quienes coinciden en hacer equivaler la espectacularidad del travesti con la propia del período, centrándose sobre todo en el carácter televisado del mismo. Así, para Medina, el hemiciclo del Congreso de los Diputados es la representación mediatizada por la televisión de la democracia para los ciudadanos, «cuya condición de tales resultaba inseparable de la de televidentes» (Medina, 2009: 76). En este contexto, el golpe militar también es entendido como un fenómeno televisivo (Colmeiro, 2010: 604), tal y como también lo describe Teresa Vilarós:

Aquel 23-F, tan inadecuado y fuera de lugar, espectáculo performativo de un posmoderno teatro de corral. O mejor, de teatrito de guiñol español con su personaje malo, muy malo, de tricornio acharolado. Sainete de guión truncado, haciéndose realidad ante el atónico público en uno de los momentos televisivos de mayor audiencia de la historia. El 23-F como un reality show de televisión concebido antes de que existieran los reality shows, vivido con el miedo en el alma por todos menos por unos pocos (Vilarós, 2005: 37)

Alberto Medina interpreta el relato de la noche del 23-F de La Madelón como una escenificación de la economía libidinal de la monarquía: según él, el golpe de Estado es una fantasmática puesta en escena sadomasoquista del pasado franquista. De manera análoga a la fetichización del uniforme y la identificación imaginaria de La Madelón con las heroínas humilladas del cine (Medina, 2009: 79), la imagen civilizada del hemiciclo como representación de la democracia es «violada» por la masculinidad agresiva y «espectacularmente anacrónica» de Tejero, imitando un teatro masoquista, un juego erótico de sometimiento de un cuerpo político feminizado por una hipermasculinidad agresiva (Medina, 2009: 76-77). De este modo, en un contexto de inestabilidad y fluidez

\footnotetext{
51 «A mí las verbenas que orgniza el Partido en la Casa de Campo me enloquecen, una comprende que aquello no es Jaidpar o como se diga, pero siempre me lo paso de buten, siempre acabo bailando con unos tíos buenísimos y echándole mano a Lenin en el aglomeramiento que siempre se forma» (Mendicutti, 2008: 120)

52 «Y me dije, tratando de convencerme, aquí por lo menos estás segura, no van a ir casa por casa sacando a todo el loquerío, hala, a trabajos forzados, a hacer una copia al natural del Valle de los Caídos, Eso no lo iban a hacer; al menos aquella misma noche, que igual estaban todos ocupadísimos en hacerse fotos monas para la posteridad, que eso sí, a fotogénicos no hay quien les gane a los guardias civiles, yo sé que a los extranjeros les encanta» (Mendicutti, 2008: 28)
} 
simbólica en la que la maniquea claridad del discurso franquista y anti-franquista es sustituido por un clima de máscaras, indefiniciones y ambigüedades» (Medina, 2009: 75), la sombra del pasado dictatorial se ve reducido tanto en las fantasías de la protagonista como en el espectáculo del golpe militar a un «jugueteo erótico de carnaval, (...) inofensivo vicio colectivo que reduce pasados traumas a pura puesta en escena del placer» (Medina, 2009: 76).

La clave en la lectura de Medina es que esta puesta en escena de la amenaza hipermasculina y uniformada del pasado franquista da paso a su sustitución por otro uniforme militar, el del rey Juan Carlos, más benévolo, que toma el papel de salvador de la democracia, que necesita esta puesta en escena de la humillación, el sometimiento y la amenaza de involución para su propia consolidación (Medina, 2009: 82). Así, en la emisión televisada del intento de golpe militar y posteriormente la salvación por parte del rey «la estructura de la monarquía y de la sociedad del espectáculo confluyen en meticulosa complicidad» (Medina, 2009: 79); el rey aparece como un mito creado por los medios de comunicación (Colmeiro, 2010: 604). Para Medina, el fetichismo por el uniforme de La Madelón no se ve disuelto por la intervención del rey, sino solo sustituido en sus figuras: «Un uniformado arbitrario y cruel no será sustituido por el cuestionamiento de la autoridad, sino por otro uniformado, eso sí, ahora de mirada benévola y rasgos juveniles» (Medina, 2009: 79) ${ }^{53}$.

El golpe de Tejero, de este modo, no sería sino el síntoma que revela que, en realidad, la monarquía parlamentaria representa la misma sumisión, la misma obediencia, pero bajo la máscara benévola de la democracia. En esta línea, tanto para Medina como para Brice Chamouleau, La Madelón puede ser integrada en la sociedad democrática de La Transición, pero al precio de la «decencia», de renunciar a su extravagancia (Medina, 2009: 78; Chamouleau, 2017:125-126): «un gentío que daba gloria vernos, todos en el tormento de no saber, todos con el corazón en un puño, todos apretujados, sin tiempo ni ocasión para remilgos, sin ganas de posturitas» (Mendicutti, 2008: 41; el destacado es nuestro); «y digo yo que la libertad pide un control y un comportamiento, que de lo

\footnotetext{
53 «Yo estoy convencida - convencidísima - de que cuando promete ser rey de todos los españoles está pensando también en nosotras. Por mi parte, puede contar conmigo para lo que quiera. Él no lo sabe, claro, pero lo sé yo, y cuando yo me juro a mí misma una cosa, eso ya es lo más sagrado. Conmigo no lo tiene ni que dudar, y eso que cuando me entra la picá me pongo de un marxista y de un revolucionario que rompe con todo. Ahora bien, saber que el rey está ahí, nada más que eso, me da una confianza horrorosa. Me la dio desde el primer momento. Desde que hizo aquel juramento en las Cortes, después de morirse Franco. Fue una corazonada. Así, por las buenas, supe que me podía fiar» (Mendicutti, 2008: 126)
} 
contrario se vuelve libertinaje. Una es muy clásica para esas cosas» (Mendicutti, 2008: 155). Sin embargo, cabe destacar que esta última afirmación viene desmentida a continuación en una clara defensa de La Madelón del derecho a la diferencia:

Claro que tampoco se trataba de ir totalmente de incógnito. Yo creo que eso hubiera sido una cobardía. La gente se tiene que dar cuenta de cómo es una y de que no muerde. La gente tiene que acostumbrarse. Que una puede llevar una vida tan decente como la que más. O tan indecente. Que nosotras no somos ni peor ni mejor. Todas igual. Todas por el mismo rasero (Mendicutti, 2008: 155; el destacado es nuestro)

\subsubsection{El conflicto de interpretaciones}

En todo caso, vemos cómo en los últimos comentarios citados se adivina una visión más bien crítica del período transicional. La noción de la Transición como espectáculo para Colmeiro, Medina o Chamouleau tiene el sentido de falsedad, de simulacro, de disimulo. Por ejemplo, para Colmeiro la negación de la masculinidad por parte de La Madelón es paralela a la negación del pasado dictatorial del país: «como espectacular sujeto democrático de la transición, el cuerpo del travestí, en su doblez identitaria y biográfica, performa o escenifica el pacto con el olvido» (Colmeiro, 2010: 596); y para Rosa Tapia, la protagonista de Mendicutti, en analogía con el cuerpo franquista, «transforma su cuerpo, su apariencia y su historia personal en concordancia con las exigencias de su nueva identidad, lo cual conlleva una dosis significativa de ambigüedad y capitulación ideológica» (Tapia, 2012: 85). La propia escenificación televisada del juramento del rey, yuxtapuesto al bautismo de La Madelón y La Begum como mujeres que renuncian a su pasado masculino, es interpretada por Colmeiro como un acto de travestismo de franquista a demócrata: al establecer dicho paralelismo entre ambos juramentos y el discurso del rey la noche del 23 de febrero, «se contamina igualmente el discurso [dado por el rey la noche] del 23-F con la sospecha de falsedad» (Colmeiro, 2010: 594-595).

Como señala Garlinger, la figura del travesti ha sido utilizada generalmente para simbolizar la España transicional ${ }^{54}$ (2000: 364), y ha sido conceptualizada en términos binarios: antes/después de Franco, viejo/nuevo, moderno/posmoderno,

\footnotetext{
${ }^{54} \mathrm{Y}$, en general, el gesto retórico de simbolizar la nación mediante metáforas corporales tiene una larga tradición; por ejemplo, desde la imagen de Joaquín Costa de la nación como cuerpo enfermo que necesita la intervención de un cirujano de hierro (Garlinger, 2003: 16)
} 
auténtico/artificial, etc. (Garlinger, 2000: 364). Así mismo, la metáfora tiene que ver con las nociones de desmemoria y desencanto como descriptores privilegiados de la cultura y la política españolas (Vilarós, 2018): el intento de borrar el pasado franquista, por un lado, y la sensación de que esta borradura, este cambio, es insuficiente o inocua y que las bases del franquismo, sobre todo las económicas, han permanecido intactas (Garlinger, 2000: 365). En este sentido, la interpretación que se le da a esta figura es diametralmente opuesta según el crítico: o bien el travesti significa la libre construcción y proliferación de identidades, o bien es conceptualizado como una mera fachada («masquerade») que oculta que debajo de ese nuevo y espectacular ropaje todo sigue igual. Por tanto, el travesti como metáfora de la Transición es utilizado bien en un sentido celebratorio, como emblema de las nuevas libertades conseguidas, o bien en el de una ilusión de cambio que oculta la nula evolución del país en que las viejas estructuras económicas, militares, políticas, jurídicas, etc. siguen activas pero con otra apariencia (Garlinger, 2000: 365).

Podemos tomar como ejemplo de cada una de estas posiciones los artículos de Francisca Paredes y José Colmeiro, “celebratorio” y “crítico” respectivamente. En el ensayo de Paredes, la ambigüedad e hibridez de las que dan testimonio el cuerpo y el discurso de La Madelón no suponen ningún conflicto hermenéutico ni ideológico, sino que muy al contrario representan a la perfección el carácter democrático del país:

Los españoles, hombres y mujeres, se incorporan al vagón de la libertad, olvidan viejas imposiciones y acogen este nuevo estado de esquizofrenia cultural. La España de la transición abraza la ausencia de limitaciones, de identidad predestinada (...) Como ser ambiguo que fusiona opuestos (...) [el cuerpo de La Madelón] se convierte en un espacio de diálogo en el que comulgan todas las entidades que en sus relaciones dan vigencia al nuevo sistema democrático (Paredes, 2007: 56-58)

A lo largo de todo el artículo, Paredes utiliza la estructura argumentativa «La Madelón, como todos los españoles...», a la vez símil alegórico y signo de inclusión: «Su integración corre paralela a la de las voces acalladas por el régimen, que por fin sienten tener permiso para hacerse oír» (2007: 59); «como la España que estaba deseosa de libertad y que se volcó en la marea de las reformas democráticas (...)» (2007: 59). En suma, «la puesta en escena de La Madelón se hace eco del espíritu de una nueva nación que es, por fin, fruto de la comunión entre sus miembros» (Paredes, 2007: 64). De manera parecida, para Pérez-Sánchez Mendicutti no denuncia la democracia como un franquismo travestido sino que, al contrario, define la democracia como ambigua, contradictoria, pero 
respetuosa con las libertades: «Mendicutti's use of the transvestite functions as an allegorical representation of the incipient democracy of the late 1970s, a regime that had to negotiate the opposing forces of the old, conservative Spain (...) and the new, progressive Spain» (Pérez-Sánchez, 2007: 110).

En el polo opuesto, Colmeiro cuestiona la supuesta lectura celebratoria de la novela, que según él más bien plantea preguntas sobre la Transición y la construcción oficial de la Historia a través del ambiguo discurso del travestí:

La Madelón aporta una mirada maricona, irreverente, paródica, histérica, excesiva y de total irrisión, que campifica la nación y trastoca la historia de la Transición (...) Pone en crisis todo el entramado ideológico y cultural de la transición por medio de la pluma (...) Si bien la resolución narrativa celebra explícitamente la restauración final del orden con la libertad y la democracia, la novela tiene un efecto desestabilizador a nivel más profundo, revelando otras ansiedades culturales, cuestionando valores inamovibles, y desvelando en el proceso la construcción maleable de la historia y de la identidad sexual (Colmeiro, 2010: 591-592)

Para Colmeiro, el travestí y su máscara representan «la operación de maquillaje del antiguo régimen, su aparente desaparición, pero también su continuidad real en los poderes fácticos y las instituciones del Estado» (2010: 595-596). El exagerado, histriónico y frívolo discurso de La Madelón obliga a no tomarnos en serio sus comentarios, como por ejemplo su confesa admiración por la figura del rey (Colmeiro, 2010: 593): «Detrás de las exageradas palabras de encomio, se puede escuchar la sombra de una duda ciudadana (...) Como sugieren las ambiguas palabras de La Madelón, el desenlace con final feliz se revela como una construcción discursiva, una realidad embellecida por el lenguaje, en donde quedan todavía muchas cosas por aclarar» (Colmeiro, 2010: 606).

Ahora bien, ¿cómo se explican estas lecturas tan diametralmente opuestas de la misma novela, e incluso de los mismos pasajes? La respuesta está, por supuesto, en el carácter cómico y camp de la obra. El mismo Colmeiro explicita su estrategia de interpretación basada en una lectura irónica de la novela, que se caracteriza «por el uso de un doble discurso disonante en la voz narrativa de La Madelón, quien vocaliza un comentario exagerado, trivial o superficial, típicamente camp, a través del cual se puede oír el comentario transversal del autor, lo que produce un efecto de distanciamiento irónico» (Colmeiro, 2010: 599). Este procedimiento corresponde sin duda a la descripción 
de Wayne Booth del proceso de lectura de la ironía: el lector percibe una incongruencia en el texto, postula que el autor tiene en realidad una intención irónica, y busca un nuevo significado que sustituya y resuelva la incongruencia.

Pero, como demuestra Stanley Fish [3.2.3.2.4], este proceso interpretativo está muy lejos de ser unívoco y estable y depende enteramente de las decisiones del lector. En este caso, la percepción o no de una incongruencia entre las palabras de La Madelón y el comentario irónico del autor está determinado por la ideología del crítico y su propia valoración previa del período transicional: Francisca Paredes, al considerar que la Transición fue efectivamente un estallido de libertades y una aceptación democrática de todas las ideologías, no ve incongruencia ninguna en el discurso novelístico; Colmeiro, al contrario, al considerar la Transición como una mera operación de disimulo de las estructuras del régimen, encuentra una incoherencia entre lo que dice la narradora y los hechos y por tanto decide tomar las palabras de La Madelón como irónicas. Así, por ejemplo, respecto del encomio del rey por parte de la protagonista, Colmeiro opina que «solo se pueden entender de manera paródica e invertida, obligando al lector a aceptar una lógica maricona» (2010: 593; el destacado es nuestro): el crítico decide obviar la literalidad de sus palabras en beneficio de una lectura irónica - según una concepción, por otra parte, donde la ironía implica necesariamente una visión crítica.

Existen otras decisiones interpretativas que dependen del carácter camp de la novela, por ejemplo, en el uso de La Madelón de las referencias al cine tanto patrio como de Hollywood. Para Colmeiro, esto «pone de relieve la falsificación ideológica de la realidad, el carácter de construcción de la representación de la historia a través de los clichés de Hollywood, y en última instancia pone en tela de juicio la fiabilidad en la construcción de la historia misma» (2010: 600). Para Frank Links, en cambio, son referencias que tienen «el fin de manejar la situación crítica de la noche del 23-F y tomar una cierta distancia al respecto (...) convierte entonces la realidad en ficción al comparar el golpe de Estado con una película. De este modo, el personaje principal encuentra explicaciones familiares a una situación desconocida y por ende lograr manejar la realidad» (Links, 2012: 120).

En este sentido, para Links el humor camp de La Madelón parece servir como alivio cómico de la dramática situación que está viviendo; de manera parecida, Colmeiro entiende que la histeria del personaje «solo tiene salida a través del absurdo y del 
humor» ${ }^{55}$ (2010:592). Sin embargo, al mismo tiempo ambos autores afirman que la comicidad surge de una percepción de incongruencia por parte del lector entre la gravedad del momento histórico y el alocado discurso de la protagonista; incongruencia supuestamente provocada de manera intencional por el propio autor (Colmeiro, 2010: 599; Links, 2012: 121). Esta contradicción puede explicarse por la compleja relación entre el autor y su personaje, y al mismo tiempo con la ambigüedad crítica de entender el camp o bien como sensibilidad, como manera de entender las cosas cómicamente, o bien como una manera intencionada de actuar.

La cuestión es, por lo tanto, si la actuación camp, alocada, histérica, histriónica, descontrolada, etc., de La Madelón es intención del propio personaje o más bien un mecanismo usado por el autor para la construcción del mismo. Nosotros nos inclinamos por la segunda opción, y ello tiene que ver también con la cuestión de la supuesta frivolidad del discurso de La Madelón y las implicaciones que tiene que Mendicutti elija a este personaje como voz narrativa y representante de una situación emocional colectiva. Para algunos críticos como Colmeiro o Leopoldo Azconat, como hemos visto, esta misma frivolidad es la fuente de la incongruencia irónica del discurso de la novela, y lo que deslegitima a La Madelón como tal portavoz. Nosotros creemos que es obvia la incongruencia entre la (solo en ocasiones) frívola voz de La Madelón y la gravedad del momento histórico, y sobre todo en el hecho de escoger un sujeto tan marginal como una mujer transexual como portavoz de la ciudadanía. Este es sin duda el juego de la novela. El lector, al enfrentarse al discurso de La Madelón, efectivamente ve contradichas sus expectativas, puesto que el sujeto narrador no es la esperada voz supuestamente objetiva de la historiografía oficial, sino el emocional y fuertemente subjetivo discurso de un individuo proveniente de la periferia social. Pero no creemos que este hecho deslegitime la voz de La Madelón, sino que más bien obliga, a través del discurso humorístico pero comprometido ${ }^{56}$ de la protagonista, a aceptar su voz y su relato como legítimo. Como dice Martínez-Expósito, «la propuesta de Eduardo Mendicutti» es la de «recurrir a un tono

\footnotetext{
${ }^{55}$ Cabe destacar que tanto Links como Colmeiro citan explícitamente a Freud y su teoría del humor como descarga nerviosa.

${ }^{56}$ Creemos totalmente inconsecuente con el retrato que la novela hace de La Madelón considerarla como una persona ideológicamente ambigua o directamente apolítica. A lo largo de la novela se deja clara su implicación en la democracia sobre todo en contraste con La Begum, a la que de hecho obliga a participar en las elecciones y las diferentes manifestaciones del período.
} 
desenfadado y alegre con el objetivo abiertamente pedagógico de reeducar la sensibilidad moral del lector» (2012: 174).

El humor es aquí entendido, por tanto, como herramienta de normalización de las diferencias de género y sexuales: Mendicutti obliga por así decirlo al lector a ir en contra de sus propias expectativas y reconocer la legitimidad de individuos como La Madelón. Sin embargo, no podemos negar tampoco que se trata de un gesto potencialmente ambiguo: más que que La Madelón, como opinan Medina o Chamouleau, deba perder su extravagancia para acceder al discurso público, el resultado puede ser que su voz quede legitimada pero precisamente en su extravagancia, su frivolidad, y sea escuchada pero al precio de ser considerada como bufón de la corte. Esta es, en efecto, la consideración que encontramos en alguno de los artículos que venimos tratando hasta ahora, y sin duda el uso del humorismo por parte de Mendicutti le ha pasado factura en su recepción crítica, que a menudo ha calificado su obra como ligera o intrascendente. En todo caso, es algo que depende, efectivamente, de la concepción que se tenga del humor y sus implicaciones como discurso frívolo, crítico, superficial, etc., en una situación análoga al propio estatuto político del camp y del travestismo en los activismos LGTB, como hemos visto en el apartado anterior.

En su artículo del año 2000, Patrick Garlinger advertía de los riesgos de entender la metáfora del travestí en términos binarios tal y como los hemos expuesto. Por un lado, por el peligro de generalización: «the reduction of an entire country to a single body is a rhetorical move to provide a coherent identity to a social collective that cannot ever possess one» (Garlinger, 2000: 367). Pero, sobre todo, interpretar este símbolo en términos binarios supone olvidar la ambigüedad y fluidez propias del significado camp del travestí, como la propia Madelón ejemplifica:

Through the metaphorical projection of her identity [la de La Madelón] as a drag queen onto the national plane, she begins to rearticulate that identity, breaking down the facile dichotomies of "before" and "after" and "inner" and "outer" that have conventionally served as a means of reading both the transvestite body and national identity (Garlinger, 2000: 368)

Sin embargo, y a pesar del valor que tiene la intervención de Garlinger con este artículo, a nuestro juicio comete dos errores: primero, al traducir el término «travesti» como drag queen omite todos los posibles referentes que este tenía en la época, refiriéndose a la protagonista como transformista y no como mujer trans; y segundo, derivado de esto, 
actúa como los demás críticos que se han ocupado de la novela e interpreta exclusivamente como una metáfora del país, como una alegoría que puede ser leída y no como ejemplo de un referente histórico y real.

Según Mercè Picornell, estas lecturas de la figura del travesti, no solo en la novela que nos ocupa sino en otras manifestaciones culturales de la época como las primeras películas de Almodóvar o un docudrama como Vestidas de azul suelen estar descontextualizadas respecto del marco contracultural donde se origina (Picornell, 2010: 285). En medios de comunicación alternativos como Ajoblanco o El Viejo Topo, la figura del travesti se forjó «como portavoz de una oposición al poder cuya práctica se va cargando de diferentes sentidos no necesariamente relacionados con las políticas de género, sino también con la disolución de la estructura simbólica del poder franquista» (Picornell, 2010: 287-288); la figura del travesti por tanto asimila no solo la transgresión del sistema de género sino las distintas variantes de oposición al poder hegemónico (Picornell, 2010: 288).

Esta apropiación, sin embargo, es «algo perversa en tanto que no define la transgresión transgénero como una opción o como una práctica que tenga sentido en ella misma, sino como un emblema vacío del contrapoder que es posible llenar de distintos significados» (Picornell, 2010: 288). En un gesto análogo al de la teoría butleriana criticada por Prosser por el cual el sujeto transgénero queda reducido a una alegoría, subversiva o no, del sistema heterosexual, el travesti en la contracultura española queda reducido a una metáfora del momento político y social. Por ejemplo, en un artículo de Ajoblanco, Toni Puig llega a afirmar «yo también soy travesti», donde el término «travesti» ya no tiene un referente real sino que deviene plenamente una figura del discurso (Picornell, 2010: 289). Podemos comparar esta afirmación con la de Colmeiro, quien en su artículo sobre Una mala noche la tiene cualquiera niega cualquier condición de individualidad psicológica a La Madelón: «Su cuerpo adquiere un protagonismo icónico. Importa más su mirada transversal, el simbolismo de su cuerpo frente al entorno social que su misma verosimilitud sicológica [sic]» (Colmeiro, 2010: 598)

Por tanto, el travesti, «como emblema apropiado, no dará cuenta de la experiencia «real» de las opciones transgénero, de su propia posición en el espacio público o de su marginación en la legislación que se inaugurará con la democracia» (Picornell, 2010: 301). En otro artículo de 2003, el mismo Garlinger asumirá también esta opinión: 
The use of transgenderism as a trope to characterize political transformations at the national level tens to reiterate a discourse of masquerade and inauthenticity that perceives transgendered people as artificial or, conversely, portrays a celebratory mode of transsexualism as the epitome of postmodern ambiguity, failing at the same time to attend to the real-life legal and economic difficulties that afflict many transsexuals (2003: 6)

Garlinger advierte que este uso retórico y hermenéutico omite las dificultades sociales, políticas y jurídicas con que las personas transexuales se encuentran en su vida real, empezando porque no es hasta 1983 cuando se descriminaliza la transexualidad (Garlinger, 2003: 6), y hasta 2007 no se promulga la primera ley sobre la transexualidad (Platero, 2011: 601). Como señala Garlinger en un artículo de 2003 (matizando, por tanto, su postura anterior), la situación legal de la transexualidad en España es, en todo caso, lo contrario de la fluidez que el sujeto transgénero se supone que representa:

Such legal limitations are a stark reminder of the pitfalls of using a transsexual discourse to describe cultural change in a nation that continues to oppress transsexuals and to ignore their material concerns (...) the danger of advocating "sex change” as a symbol of cultural transformation is that it runs the risk of erasing the referent: in the end the material, live transsexual is all too absent in these formulations (Garlinger, 2003: 11)

En esta misma línea, Chamouleau critica la apropiación por parte de la cultura y la historiografía oficiales de la Transición de la pluma y el transgenerismo como «estética de consumo democrático» capitalizada por la cultura posfranquista para paralelamente borrar las subjetividades «queer» realmente vividas y la marginación social a la que se enfrentaron: «en cierto modo, más que una negación del referente, de lo que se trata es de su inserción obligada dentro de un relato que ha estabilizado el lugar simbólico de las subjetividades queer de la Transición» (Chamouleau, 2017: 115-117): en la memoria oficial de la Transición, el sujeto transgénero es incorporado como símbolo a cambio de no tener en cuenta las condiciones de existencia de las personas trans reales (Chamouleau, 2017: 134).

En cierto modo, efectivamente, en la imaginación cultural se confunde a las mujeres transexuales con las performances contraculturales basadas en el travestismo: La Madelón se interpreta desde una posición más cercana a Ocaña que a las protagonistas de Vestidas de azul. Ocaña fue y es celebrado por la contracultura como lo que debía ser o debería haber sido el símbolo de la Transición en cuanto que desafío festivo a la hegemonía cultural (Picornell, 2010: 301), y particularmente, en el contexto de los 
movimientos LGTB, como desafío a los movimientos asimilacionistas por su desnaturalización del binomio heterosexual (Chamouleau, 2017: 135). Pero Ocaña no fue una persona transexual, sino un performer homosexual; como dice Paul B. Preciado, no se entiende a sí mismo como travesti sino como pos-travesti, un artista que teatraliza lo travesti (Preciado, cit. en Chamouleau, 27: 135) ${ }^{57}$. Y, sobre todo, en esta celebración de Ocaña «no se recalca que lo que media entre él y sus coetánexs travestis es una cuestión de clase»: al tiempo que Ocaña se declara artista, las personas trans y homosexuales no normativos sufren desclasamiento y marginación, sin la posibilidad de recibir el reconocimiento que sí recibe Ocaña (Chamouleau, 2010: 135-136). Mientras que las actuaciones en el espacio público de Ocaña eran permitidas, las mujeres transexuales obligadas a prostituirse eran detenidas por escándalo público ${ }^{58}$.

Parte de estas problemáticas sociales aparecen de hecho reflejadas en Una mala noche la tiene cualquiera, algo que ha sido desatendido por la crítica. Dejando aparte el riesgo que La Madelón y sus compañeras hubieran corrido si el Golpe de Estado llega a triunfar, en la novela se narran episodios que reflejan las dificultades a las que se enfrentaban las personas transexuales en aquella época, incluso ya en período democrático. Por ejemplo, el hecho de que en el documento nacional de identidad La Madelón siga figurando con su identidad masculina, problema frecuente a la hora de efectuar trámites burocráticos (Vegas, 2019: 113). Durante el período de la Transición era obligatorio someterse a la cirugía de reasignación sexual para poder cambiar el género en el DNI, y hasta la promulgación en 2007 de la ley para la transexualidad, este fundamental trámite se situaba en un vacío jurídico-legal (Vegas, 2019: 113; Platero, 2011: 600-601) $)^{59}$.

En la novela también se narran los encontronazos de la población transexual con la policía, cuando La Madelón teme que La Begum aparezca en alguna ficha policial por haber sido detenida por un policía de paisano (Mendicutti, 2008: 28). Las personas

\footnotetext{
57 De hecho, en los círculos contraculturales el travestismo se celebra solo como impostura, abiertamente paródica y con intención política, no como expresión de un sentimiento de transexualidad. Así, por ejemplo, Toni Puig afirma que "pasa” de los travestis que se consideran auténticas mujeres (Picornell, 2010: 293)

58 Obviamente, no negamos ni dejamos de valorar la gran aportación de Ocaña a la contracultura y a la cultura LGTB. Simplemente, queremos insistir en la necesidad de distinguir fenómenos distintos: el de un cierto tipo de activismo y "postura artística” y el de la vida real de las personas transgénero.

59 De hecho, incluso en la Ley de 2007 son necesarios una serie de requisitos, si no arbitrarios, cuanto menos elocuentes: la persona que quiera cambiar el sexo en el DNI deberá ser diagnosticada con disforia de género por un psiquiatra, deberá haber estado al menos dos años en tratamiento hormonal, y deberá elegir un nombre que sea claramente masculino o femenino (Platero, 2010)
} 
transexuales eran criminalizadas en virtud de varias leyes: la de Vagos y Maleantes de 1954, en la que la transexualidad se incluye como un caso de homosexualidad; la de Peligrosidad Social de 1970 y también la de Escándalo Público, que no fue modificada hasta 1988 y derogada en 1995 (Vegas, 2019: 21-23, 135). Como dice Valeria Vegas, aún en la democracia, bajo el marbete de «escándalo público» se seguía deteniendo a personas «que se saliesen de lo normativo, las que tuvieran una apariencia que no resultaba invisible o que dejaba adivinar una masculinidad que se podía catalogar como desorden público» (2019: 143).

Mendicutti tampoco deja de mencionar la relación entre la transexualidad y la prostitución. Expulsadas del mercado laboral, la prostitución era uno de los pocos modos de supervivencia de las mujeres transexuales (Vegas, 2019: 192); con los shows de transformistas como única alternativa, donde eran exhibidos «como animales de zoológico» (Vegas, 2019: 220). En Una mala noche la tiene cualquiera, La Madelón menciona que su compañera se prostituía en la calle - si bien, como para quitarle dramatismo, explica que La Begum incluso disfrutaba con ello.

En general, y a pesar de la operación de legitimación de la voz transexual que opera el autor, la protagonista no deja de ser consciente en ningún momento de su posición marginal en la sociedad, e, incluso, la novela llega a ironizar en dos momentos sobre la mirada científica y la "intelectual” sobre el sujeto transgénero. En el primero de ellos, La Madelón narra la ocasión en la que ella y La Begum son captadas en la calle para hacerse un test de personalidad. Cuando el joven que sirve de gancho las lleva al piso donde esperan para hacerles la prueba «una docena de abortitos llenos de gafas», el muchacho “con muy poca consideración” les pregunta a los científicos: «¿Os sirve esto?» (Mendicutti, 2008: 142-143; el destacado es nuestro), lo que indigna a la protagonista («Leñe, ni que fuéramos bichos raros»). De este modo, el autor señala la mirada médica y científica que estudia a las personas trans como "bichos raros". El segundo momento es el reportaje que el escritor Estanislao Villán («la Plumona») dedica a las dos protagonistas en un pasaje que parece parodiar la visión que los intelectuales ofrecen de las personas transgénero como espectáculo poético:

«Ellas encarnan, como nadie, la tragedia y la gloria de la imprecisión, del tránsito, el drama del trasvase de una tierra a otra, el dudoso y pícaro vodevil del balanceo entre un sexo y otro. Ellas son puro trasvase, puro balance, la quintaesencia de la emigración, 
desterradas españolitas de a pie, criaturas movedizas y errantes, exaltados nenúfares que flotan en las aguas más turbias del día y de la noche» (Mendicutti, 2008: 81)

Aunque La Madelón confiese sentirse identificada con las palabras de La Plumona, no deja de mostrar recelos por lo que le parece una cierta condescendencia en la mirada del escritor: «un reportaje maravilloso y para mí que un poquito trapero, quiero decir que en el fondo a mí me dio que se cachondeaba de ella [La Begum]» (Mendicutti, 2008: 65). Aquí, Mendicutti parodia una cierta clase de discurso ${ }^{60}$ que, como vemos, entiende al sujeto transgénero alegóricamente en el sentido de que el travesti significa otra cosa y no a sí mismo, en una postura interpretativa que no se adecúa a la realidad social y material de su referente.

Hacia el final de la novela, nuestra protagonista incluso parece hacerse eco de la acusación de frivolidad espectacular hacia los travestis. Tras el discurso del rey, La Begum propone La Madelón llevar comida a los diputados secuestrados en el Congreso, en otra nueva muestra de campificación de procesos políticos y las manifestaciones del período $^{61}$. Aunque a La Madelón no le parezca mala idea, no deja de tener sus reservas acerca de la recepción que podría tener en la prensa:

Pero lo que me hacía contenerme y me sabía mal - porque la idea no era desaboría del todo, para qué voy a decir lo contrario - era el quedar demasiado folclórica, que lo mismo La Begum tenía razón y salíamos en los periódicos, incluso en los periódicos de por ahí, en los de Jolibú - la ilusión de su vida - e igual se pensaban todas ahí fuera que sólo había una chirigota, que para mí que la mayoría de las extranjeras se piensan que aquí y en Italia estamos todo el tiempo de farra, y tampoco es eso (Mendicutti, 2008: 144)

Como vemos, la narradora hace un comentario acerca del riesgo que puede tener un exceso de frivolización camp de un hecho histórico tan serio. Por otra parte, como hemos dejado dicho anteriormente, esta aparente contención por parte de La Madelón no es,

\footnotetext{
${ }^{60}$ Puede compararse este fragmento con un pasaje del artículo de Toni Puig citado por Picornell: «Adorables e ignotos travestis. Caballos galopantes en el universo de lo prohibido y codiciado. Perversos destructores de toda norma y seguridad. Sorprendentes en el amor. Fantásticos en el maridaje de los sexos. En vosotros se aúna el placer, la pasión, la anormalidad, la imaginación, el desconcierto, la frivolidad y la subversión corporal. Estáis más alejados que cualquier otro - en lo real y simbólico- de ese afán por clasificarlo y dilucidarlo todo. Vivís del placer. Estáis más allá del sexo y de toda cultura. En subversión continua» (Puig, cit. en Picornell, 2010: 289)

61 «Podíamos llamar a todas las amigas, inventarnos alguna consigna mona - «Desayuno para los cautivos», por ejemplo; o «Cada mariquita, un diputado, por lo menos», o «Campaña pro alimentación de los golpeados», que esta última me parecía a mí que resultaba como más responsable -, y que cada una eligiera su diputado preferido, que ya puestas a hacer una obra patriótica, que por lo menos hubiera una compensación» (Mendicutti, 2008: 136)
} 
como algunos críticos interpretan, una claudicación al discurso mesocrático oficial de la Transición, de integración al precio de la invisibilidad, pues al final de la novela, como hemos visto, la protagonista reivindica su derecho a ser tenida en cuenta.

\subsubsection{La retórica de la lectura y sus metáforas}

Ya hemos visto cómo en general la crítica de la novela insiste en leer la figura de La Madelón como una alegoría de la España transicional en perjuicio de lo que el personaje pueda tener de reflejo sociológico de un referente real. Ahora bien, estas lecturas tienen su propia retórica, y concretamente unas metáforas muy particulares que determinan el sentido que los críticos dan al sujeto transexual. En los trabajos aquí tratados se puede observar la recurrencia de una serie de metáforas acerca del travesti como figura de la Transición. Ya hemos visto cómo para Colmeiro la esencia del travestismo es su ropa y su maquillaje en el sentido de disfraz, de disimulo. Para Colmeiro el travesti y su discurso son ante todo unas superficies bajo las que se oculta lo verdadero: el pasado franquista o el "comentario transversal” e irónico del autor. En el ensayo de Francisca Paredes, el cuerpo del travesti que se supone “encarna” la identidad nacional es nombrado en repetidas ocasiones como espacio. Y para Galinger, el travesti es significado sobre todo como flujo, pero, aunque esta metáfora parezca un tanto más dinámica y por tanto más adecuada que las anteriores, como hemos visto, sigue hablando de una manera adecuada de interpretar la metáfora del travesti, encerrado en el marco conceptual del espectáculo de las drag queens.

Como hemos visto, la estrategia hermenéutica del ensayo de Colmeiro es el del doble discurso narrativo: bajo la aparente frivolidad de la narración de la protagonista, yace el comentario crítico del autor:

Si bien la resolución narrativa celebra explícitamente la restauración final del orden con la libertad y la democracia, la novela tiene un efecto desestabilizador a nivel más profundo, revelando otras ansiedades culturales, cuestionando valores inamovibles, y desvelando en el proceso la construcción maleable de la historia y de la identidad sexual (Colmeiro, 2010: 591-592; el destacado es nuestro)

El doble discurso camp de la novela deconstruye el golpe de estado, entre la aparente inocencia naif de la protagonista y la intencional ironía profunda del autor (Colmeiro, 2010: 593; el destacado es nuestro) 
La operación fundamental en la retórica de Colmeiro es, pues, la de desvelar, la de revelar lo verdadero debajo de las apariencias explícitas. Esa es la clave del cuerpo del travesti como metáfora de la Transición: sugiere la «superficialidad del cambio político» como una «operación de maquillaje del antiguo régimen (...) y su aparente desaparición fantasmagórica» (Colmeiro, 2010: 595; el destacado es nuestro). Evidentemente, esta interpretación implica la concepción de la identidad de La Madelón como superficial, como una «máscara» construida a través del maquillaje, la ropa, la actuación bajo la que encontramos los restos de la identidad masculina, que se postulan como la verdad oculta del travesti - aunque, como hemos visto, la protagonista se refiera en reiteradas ocasiones a su actuación masculina como el verdadero disfraz que oculta su identificación femenina. Para Colmeiro, en definitiva, la pluma y el cuerpo de La Madelón revelan el carácter de fachada de la construcción social, política e historiográfica de la Transición.

En el caso de Francisca Paredes, son abundantísimos los casos en los que en su ensayo el cuerpo travesti aparece nombrado como «espacio»: «la naturaleza "híbrida e imprecisa» de La Madelón la convierte en el vehículo perfecto para dar voz y cuerpo al sentir de la nación, como «espacio simbólico de la España de la transición» (Paredes, 2007: 56); «Como ser ambiguo que fusiona opuestos (...) se convierte en un espacio de diálogo» (2007: 58); «La hibridez del travesti lo convierte en un espacio abierto y flexible» (2007: 60; los destacados son nuestros), etc. A pesar de que Paredes insista, ya desde el título de su artículo, en la importancia del cuerpo del travesti como encarnación de la nación, al cuerpo de La Madelón le ocurre algo análogo a lo que, como señala Prosser, sucede en general en la teoría postestructuralista: este se toma como punto de partida donde se inscriben distintos signos ideológicos, pero no se toma en consideración la propia experiencia de la carne. Aunque no exista la misma dialéctica entre apariencia y profundidad que encontramos en el discurso crítico de Colmeiro, al conceptualizar el cuerpo de la protagonista de la novela como espacio, se destaca su condición de superficie donde aparecen y se leen los distintos signos identitarios e ideológicos.

Aparentemente, el rechazo de Garlinger de entender la figura del travesti en términos binarios para entenderlo como flujo o fluido supone un acercamiento más adecuado a la identidad transgénero, pero encontramos, como hemos dicho, que la retórica de Garlinger sigue siendo la de la interpretación alegórica. Concretamente, el crítico se centra en las actuaciones de las drag queens, en su cuerpo como performance: 
Instead, drag often describes two contradictory but inseparable performances: the first calls attention to itself as performance while the second attempts to eliminate any trace of performance and pass unnoticed as the opposite gender (2000: 366)

This dialectical play of gender is at the core of the transvestite performance. The drag queen questions the epistemological capacity of language, clothing, and other gendered signifiers to reveal adequately the "true" sex of the individual (2000: 369)

Como vemos, sobre todo en la segunda cita, la performance del travesti sigue planteando la cuestión de la posibilidad de leer adecuadamente los signos (lenguaje, ropa, y otros “significantes”) de la identidad sexual. También en el artículo de Colmeiro tiene cierta importancia la performatividad del travesti y la condición de puesta en escena de su identidad: "como espectacular sujeto democrático de la transición, el cuerpo del travestí, en su doblez identitaria y biográfica, performa o escenifica el pacto con el olvido” (2010: 597; el destacado es nuestro), hasta el punto de que la "artificiosa fachada” del travestí funciona como denuncia de la "cultura espectacular del simulacro" en su totalidad (Colmeiro, 2010: 597). También podríamos entender de manera análoga la metáfora espacial usada por Paredes como espacio de representación, de puesta en escena.

Es evidente que esta serie de metaforizaciones (superficie, espacio, puesta en escena...) están estrechamente vinculadas a las características del discurso camp de artificiosidad y teatralización, asociadas en general al mundo del travestismo y en particular a través de la teoría queer, como explicamos en el apartado anterior. También la tendencia a leer el cuerpo del travesti alegóricamente viene determinada por la visión textual que la teoría queer, a través del camp como mirada y estrategia de lectura, impone al sexo y al género, y que, como expone Prosser, lleva a teóricas como Butler a conceptualizar el cuerpo, particularmente el transgénero, en términos de literalización, delisteralización, parodia, etc.

En nuestra opinión, la centralidad de la metáfora teatral para la concepción de la identidad transexual es insuficiente, no solo en los casos en los que esta metáfora implica superficialidad y apariencia en términos de falsedad, sino porque implica una temporalidad inexistente: al hablar de la identidad como una serie de actos performativos puntuales se impide el entendimiento de la identidad transexual como tránsito de una identidad a otra, de un cuerpo a otro, de un cuerpo (percibido como equivocado) a otro (sentido como el correcto), de reencuentro con la identidad sentida desde la infancia. Es por eso por lo que Prosser propondrá en su estudio la narrativa autobiográfica como la 
manera más adecuada de comprender el camino a la integridad de la identidad corporal, como veremos en el epígrafe siguiente.

¿Significa eso que debemos desechar la estética camp como vehículo de expresión adecuado? ¿El humor no cumple entonces ningún papel en la formación de una identidad para La Madelón en una novela como Una mala noche la tiene cualquiera? Esto constituye un problema solo si entendemos la artificiosidad y la teatralidad camp como frivolidad inocua o arma crítica y olvidamos la "seriedad” que, como hemos visto, late en el centro de la sensibilidad camp, y sobre todo su papel en la formación de una identidad gay o queer positiva. Fijémonos, por ejemplo, en la función de las referencias cinematográficas tanto en la cultura camp norteamericana como en la novela de Mendicutti. En ambos casos no son sino modelos de conducta, de identificación en la construcción de una subjetividad propia. Alberto Mira destaca el papel que tanto el cine de Hollywood como los personajes del mundo de la copla tuvo en la construcción de la personalidad de personas como Vicente Molina Foix (Mira, 2007: 339), y debemos asumir que cumple el mismo propósito en la construcción de la subjetividad de La Madelón: con más importancia, si cabe, en tanto que La Madelón tiene que construirse a sí misma como mujer, literalmente. En el siguiente apartado veremos de qué otras maneras la estética camp como discurso humorístico puede servir de vehículo a la construcción de la identidad, especialmente a partir de la literalidad del cuerpo de Rebeca Soler, la protagonista de Yo no tengo la culpa de haber nacido tan sexy. 


\subsection{La mística del cuerpo en Yo no tengo la culpa de haber nacido tan sexy}

En una noche oscura, con ansia, y en ardores inflamada,

en busca de aventura

salí, toda alocada, dejando atrás mi celda sosegada.

Jaime Gil de Biedma

\subsubsection{Santa Rebecca de Windsor, o un Quijote transexual a lo divino}

Yo no tengo la culpa de haber nacido tan sexy narra las peripecias de Rebecca de Windsor (nombre artístico de Rebeca de Jesús López Soler) en su aventura espiritual que la llevará de monasterio en monasterio buscando la santidad y la unión mística con el Amado, a imagen y semejanza de Santa Teresa y San Juan de la Cruz. Pero dejemos que lo explique ella misma:

A lo mejor cuesta trabajo entender que una mujer tan sexy como yo se entregue a la santidad, pero esa decisión no la tomé porque me diese el siroco, sino porque, en una noche oscura, y hallándome enfrascada en labores de mantenimiento con productos de doña Margaret Astor, tuve una iluminación. A San Pablo, como era machito, la iluminación le llegó mientras galopaba camino de Damasco; yo la tuve mientras me desmaquillaba (...) cuando vislumbré de repente en el espejo mi carne mortal, toda mi verdad facial sin el engaño de la cosmética, y de pronto me encontré mirándome con mis ojos venideros y supe que mi cutis no podría aguantar con entereza el paso de los años, y tuve tanta lástima de mí que, la verdad creí que me moría por no morirme (...) Menos mal que pude oír que una voz misteriosa me llamaba a cuidar en prados deliciosos la belleza de mi alma, y me sentí arrobada, arrebatada, ajenada, arrancada de mí, y volé tan alto, tan alto, que, ya digo, no me lo pensé dos veces y decidí que sería santa. Porque ésa es otra: yo no iba a ser una santa corriente, yo iba a ser una santa de lujo. Una de esas santas que tienen deliquios, éxtasis, heridas en las manos como las llagas de Cristo, y que viven sin vivir en sí. (Mendicutti, 2003: 11-12; el destacado es nuestro)

Lo que en un primer momento destaca de la narración de la protagonista es el remedo, deliciosamente camp, del lenguaje de la mística española renacentista. Esto, como la 
misma Rebecca explica, se debe a sus lecturas de la obra de los grandes místicos ${ }^{62}$, que han trastornado su lenguaje - y, como veremos, también su visión de la realidad. Y es que, efectivamente, además de estos textos de la mística española, el otro gran intertexto de la novela de Mendicutti es El ingenioso hidalgo Don Quijote de La Mancha, de cuyo primer capítulo son parodia directa las primeras páginas. Luego de enumerar las lecturas que, como los libros caballerías en el caso de Don Quijote, trastornan la mente de la protagonista, Rebecca, como Alonso Quijano, se plantea cambiarse de nombre por uno más adecuado a sus aventuras. De hecho, como ella misma dice, no es la primera vez que lo hace, puesto que mantuvo su nombre de bautismo, Jesús López Soler, hasta los quince años, cuando a hurtadillas se hacía llamar Sandra, y doce años más tarde cambió su nombre en el Registro Civil por el de Rebeca Soler, antes de someterse a una cirugía de reasignación de sexo. Sin embargo, decide no elegir un nombre nuevo porque, de hecho, Rebecca de Windsor ya tiene suficiente gancho: «¿Qué otro nombre podía yo adoptar que fuese digno de toda la categoría espiritual que iba a poseerme en cuanto holgase, cual doncella por su gozo desmayada, en el conocimiento del Altísimo? (...) Y, después de todo, también es hora de que el santoral se actualice un poco e incluya nombres modernos y con gancho» (Mendicutti, 2003: 15-16). Y a continuación, igual que Don Quijote desempolva su armadura, Rebecca elige su nuevo atuendo:

Rebecca, olvídate de lo que has sido - una mujer de bandera, por cierto -, olvídate de lo que eres, concéntrate en lo que vas a ser, la más mística de todas. Olvida los potingues, los modelazos, el tacón alto, la melena ahuecada, las candilejas, el alterne y la nueva cocina. A partir de ahora llevarás la cara lavada, falditas y rebecas catequistas, calzado plano, cola de caballo o moño bajo y sencillo, y te comprarás la lencería en la ciudad del Vaticano (Mendicutti, 2003: 16)

Por último, al final del primer capítulo, Rebecca encontrará a su particular Sancho Panza: Dany, un exculturista al que descubre levitando en una iglesia y al que pide que le deje acompañarle para aprender de él los caminos de la elevación espiritual ${ }^{63}$.

\footnotetext{
${ }^{62}$ Concretamente, Las moradas, El castillo interior y Camino de perfección, de Santa Teresa de Jesús; la obra poética de San Juan de la Cruz; De los nombres de cristo y La perfecta casada de Fray Luis de León; El libro de la contemplación de Ramón Llull y «una biblia que debía de ser protestante, porque no tenía notas a pie de página y tuve que leer el cantar de los cantares guiada sólo por mi devoto recogimiento en el retrete de mi corazón» (Mendicutti, 2003: 14)

${ }^{63}$ Las referencias a la inmortal obra de Cervantes no acaban aquí. Más adelante, por ejemplo, se recreará la escena de los molinos de viento cuando Dany confunda a unos jugadores de fútbol con ángeles. Incluso la estructura narrativa se asemeja al Quijote, al intercalar en la aventura principal diversas historias narradas
} 
Por supuesto, la referencia a Don Quijote no es anecdótica. Si uno de los temas de la novela de Cervantes es la identidad como voluntad de ser («Yo sé quién soy y si quiero puedo ser más grandes que los Siete Infantes de Lara», proclama el gran hidalgo), también lo es de esta novela sobre su trasunto posmoderno y transexual. Rebecca ha forjado su identidad, al fin y al cabo, a fuerza de voluntad, y su decisión de cambiar «el chochito de Grace Kelly» por la jacarandosa Santa Teresa como modelo vital es solo la última de una larga serie de transformaciones:

Y es que mi vida ha sido eso, un rosario de determinaciones tajantes que sólo tenían la finalidad de ponerme cada vez más a mi gusto, cada vez mejor, más divina, que siempre me lo ha dicho todo el mundo, hija, Rebecca, tú siempre con tus manías de perfección. Eso sin contar con que, en cuanto tuve la iluminación, supe que lo mío era ser amada en el Amado transformada. Qué bonito. Lo de la iluminación fue precioso. (Mendicutti, 2003: 12)

Es este aspecto quijotesco por el que Rebecca se ha hecho a sí misma, muy literalmente, el que lleva a Francisca Paredes a analizar el personaje como «la identidad posmoderna por excelencia», ya que esta «se presenta abiertamente como una construcción de género, un proyecto personal actualizado en actos específicos que le dan vida» (Paredes, 2012: 205-206). Como decimos, la decisión de Rebecca de hacerse santa emula, o más bien es un paso más de un proceso, el periplo de convertirse en mujer, de cuyas distintas fases (su juventud, el proceso de hormonación, su operación, la confesión a su madre, su primera relación sexual tras la cirugía, etc.) da cuenta a lo largo de la novela.

Paredes parte de la noción de performatividad de Judith Butler para explicar la construcción de la identidad femenina de Rebecca, basada en la «apropiación» de signos culturales sobre su cuerpo:

Su única opción a la hora de crear la identidad propia es acudir, de forma consciente, a una serie de signos que, superpuestos a su realidad biológica, le permiten crear la identidad de género con la que de hecho se identifica. Al desvelar el proceso por el cual construye Rebecca su identidad, al enfocarse en los signos dramáticos que adopta la transexual - la ropa, el peinado, los giros lingüísticos, y los signos anatómicos - y exagerarlos a través de la lupa camp, Mendicutti no sólo reconoce el proceso de creación

por sus propios protagonistas, a los que Rebecca va encontrando en su peregrinaje - aunque la estructura externa remita a Las moradas de Santa Teresa, al dividirse la novela en siete moradas y una conclusión. 
de la identidad queer sino que revela también el proceso que todos usamos a la hora de definir y pulir nuestra persona (Paredes, 2012: 212; el destacado es nuestro)

Sin embargo, y aunque, en efecto, Rebecca presenta su proceso de cambio de sexo como un perfeccionamiento continuo, como una construcción bastante literal de su cuerpo, el análisis de Paredes no deja de ser incompleto, al volver a tomar la noción butleriana de performatividad y estilo corporal en su sentido más superficial, igualándolo incluso al concepto de «simulacro» de Baudrillard [ver 3.4.3]. Para Paredes, Rebeca Soler es un ejemplo de la noción de identidad de las teorías de la posmodernidad que la definen como una serie de signos, en términos de apariencia, estilo, imagen (2012: 210), y, de nuevo, el camp resulta ser el vehículo de expresión perfecto para esta identidad posmoderna por su énfasis en la teatralización y la imitación (Paredes, 2012: 211). En este sentido, la mirada camp aplicada a su decisión de hacerse santa lleva a Rebecca a centrarse de nuevo en el estilo, el vestuario, el lenguaje, etc. de los místicos con un resultado cómico y paródico: «en su imaginación, su existencia como mística no puede separarse de la articulación visual de su identidad que ha marcado su vida hasta el momento» (Paredes, 2012: 217) ${ }^{64}$.

En efecto, las referencias de Rebecca a los éxtasis místicos y de la santidad en general son camp en el sentido de centrarse en la "puesta en escena” de los mismos, como vemos en los siguientes ejemplos:

Corría el riesgo de entrar en el santoral hecha un fantoche, pero todo podría arreglarse después mediante un par de apariciones a alguna pastorcita, con un vestuario ideal. (Mendicutti, 2003: 22)

Yo me imaginaba la santidad, especialmente la santidad mística, de una forma mucho más poética, (...), con mucha luz y un aire muy limpio, con una piel muy tersa, con unas posturas sencillas pero elegantes, con una música suave y con suspiros producto del embeleso (Mendicutti, 2003: 92)

En virtud de esta campificación del discurso místico, la unión espiritual del alma y el Amado son presentados como encuentros sexuales, retomando el carácter erótico de los propios textos místicos. De este modo, todos los supuestos éxtasis de Rebecca acaban

\footnotetext{
${ }^{64}$ Es muy larga la tradición en la literatura y el arte "homosexuales" el recurso a la imaginería cristiana, desde Wilde y Genet a Ana Rosetti (Ingenschay, 2011: 70); de hecho, la portada de la edición original de Tusquets de la novela es una fotografía de los franceses "Pierre et Gilles" que representa a una María Magdalena en postura de diva, provocadoramente semidesnuda (Ingenschay, 2011: 71). Y ya hablamos en el apartado anterior de la importancia de la barroca imaginería de las manifestaciones católicas en la tradición del camp hispánico.
} 
convirtiéndose en fantasías eróticas - e incluso encuentros sexuales reales, como el que mantiene con una monja. El primero de ellos, sin ir más lejos, acaba convirtiéndose en un sueño erótico con el Che Guevara como co-protagonista:

Me vi en la puerta de un pajar, monísima, muy fresca, recién bañada en una cascada de agua pura de montaña, perfumada con lavanda simplemente, vestida con un modelito adlib que me había comprado en Ibiza hacía siglos y que ya no usaba para no ser llamada antigua, aunque seguía favoreciéndome una barbaridad, apoyada en el tronco de un magnolio. Respiraba yo de manera muy sensual cuando, de pronto, como un fulgor, moreno, sonriente, apareció él (...) Una vaca soñadora le salió al encuentro y él la saludó como si la conociera de toda la vida. Qué porte, me dije. Qué aura desprende. Cómo me mira. Cómo le ríen los ojos y cómo sabe que yo lo noto desde la distancia. Qué magnetismo derrama. Y cómo me desea. Porque yo me sentía muy deseada (...). Cada paso que daba hacia mí era como si me desabrochara un corchete del vestido. Yo no quería moverme: sabía que aquella postura, apoyada en el magnolio, me favorecía. Tampoco quería desmayarme. Me llegaba, como un tigre de Bengala, el olor que desprendía (Mendicutti, 2003: 38)

Todo esto es cierto, y sin embargo, como decimos, no del todo exacto, al centrarse Francisca Paredes en una retórica del signo, el gesto, la actuación, la superficie, etc., que le lleva a decir, por ejemplo, que «Rebecca se enfoca, sobre todo, en el aspecto dramático y visual de la santidad, más que en el aspecto de perfección interior», y que los sueños de unión con la divinidad tienen una carga sexual tan fuerte porque se fija «no en la purificación del espíritu y en la lucha por abandonar las distracciones mundanas, sino en los fuegos artificiales» (Mendicutti, 2012: 217). La cuestión, no obstante, es mucho más compleja: como veremos, no es que Rebecca no se fije en los aspectos doctrinales y de perfección espiritual, que sí lo hace, sino que concibe ambos aspectos a la vez y de manera inseparable.

En todo caso, Paredes tiene razón al decir que la identidad de Rebecca está insoslayablemente unida a su cuerpo, que se convierte en el eje temático de la narración (2012: 208). Rebecca apuesta toda su identidad en estar en armonía con su cuerpo, y precisamente lo que le lleva a tomar la decisión de hacerse santa es, como hemos leído, el percatarse de que los años no están pasando en balde y su cuerpo está envejeciendo. Lo que da inicio al conflicto de la novela y se desarrollará a lo largo de la narración es, por tanto, una crisis de identidad respecto al propio cuerpo: la mayor dificultad que encontrará la protagonista es, precisamente, el tener que menospreciar el cuerpo que tantos años y 
sacrificios le ha costado conseguir para que estuviera en acuerdo con sus sentimientos. De hecho, en cierto momento mantendrá una discusión con Dany cuando este le recomiende recurrir a la vía punitiva de refinamiento espiritual, es decir, castigar la carne mortal con un cilicio, a lo que Rebecca se negará rotundamente: el desacuerdo consiste en que, si Dany entiende que su cuerpo, construido en el gimnasio, es un obstáculo para su elevación espiritual por ser producto de la vanidad y el apego a lo terrenal, a Rebecca precisamente la ha costado mucho sufrimiento llegar a estar a gusto con el suyo, y no piensa renunciar a él:

Yo estaba contentísima del fachón que había conseguido, que también a mí me había costado mucha fatiga y mucho ánimo y un dineral (...) Al principio mi cuerpo sólo cambió de una manera psicológica, quiero decir que bastaba con que me pusiera una blusita mona y una falda que me marcase bien la cintura y zapaos de tacón y un maquillaje juvenil y artístico al mismo tiempo y un peinado gracioso para que yo me sintiese dueña de un busto de anuncio de sostenes, de unas caderas de bailarina hawaiana, de una melena como la de la Rita Hayworth y hasta de un chochito como el de Grace Kelly, que me imaginaba yo que era lo más fino que podía haber en chochitos (...) Eso sólo ayuda un poco al principio, pero después tú misma te pides más, y empiezas con las pastillitas, y con los apliques y la silicona, y empiezas a darle vueltas a la idea de la operación, y comprendes que es el único camino, y mientras tanto te esmeras en estar vistosa, así que yo también he hecho por mí misma muchos sacrificios, porque mi cuerpo era lo único que me podía salvar, y todo lo que puse y todo lo que me gasté lo doy por bien empleada (...), que yo no me arrepiento, que si yo no hubiera hecho todo lo que hice, ahora estaría asfixiada (...) Mi cuerpo ha sido siempre mi mejor amigo, gracias a lo que ha ido cambiando y mejorando mi cuerpo yo me he sentido cada vez mejor, y sería un contradiós echarle ahora la culpa de no ser lo suficientemente espiritual (...), sería un contradiós (...) avergonzarme ahora del cuerpo que tengo (Mendicutti, 2003: 73-75)

Rebecca, como mujer transexual, ha construido su cuerpo con el objetivo de que estuviera en sintonía con su identidad ${ }^{65}$. Sin embargo la cuestión es mucho más compleja de como lo plantea Francisca Paredes al concebir, siguiendo a Butler, no ya el cuerpo sexuado,

\footnotetext{
${ }^{65}$ La narrativa de la transexualidad reflejada por el autor en esta novela (y, de hecho, también la de Jay Prosser) sigue la metáfora del «cuerpo equivocado». Esta narrativa metafórica, según la cual la persona transexual nace en un cuerpo que rechaza y que le lleva a modificarlo hormonal y quirúrgicamente hasta alcanzar el que supuestamente corresponde a su identidad de género, ha dominado durante décadas el discurso de la transexualidad, incluido el de sus protagonistas, pero en los últimos años está siendo puesto en duda por los activistas trans (ver Missé, 2018). En nuestro análisis, sin embargo, mantendremos la metáfora, al ser el fundamento tanto de la novela de Mendicutti como de la teoría de Prosser.
} 
sino el género como un conjunto de signos: «si el sexo biológico nos viene dado de forma natural - uno es hembra o macho en función de sus órganos reproductivos -, el género es una construcción que se basa en la adopción de ciertos actos que culturalmente se entienden como apropiados o naturales para un hombre o una mujer» (Paredes, 2012: 211). Aquí vemos cómo Paredes habla del carácter «hembra o macho» del cuerpo, pero, como la misma Butler argumenta, también el sexo es construido - tanto cultural como literalmente, como matiza Preciado. Así mismo, Paredes comete el error que señala Butler de entender el género no como algo obligatorio e impuesto, sino como algo que Rebecca elige - cuando, insistimos, todos los cambios que realiza son para acercar su cuerpo al sexo que ella ya es. Por otra parte, al insistir en el carácter de signo de la vagina, por ejemplo, apropiado por Rebecca en la realización de su identidad, no deja de presentar estos cambios como construidos frente a un sexo biológico “natural”.

\subsubsection{La narrativa autobiográfica del cuerpo transexual según Jay Prosser}

De este modo, como vemos, Paredes repite un esquema epistemológico que, no siendo del todo inexacto, es insuficiente para explicar la complejidad de la identidad transexual tal y como se presenta en la novela de Mendicutti. Esquema basado, como argumenta Prosser, en una concepción del cuerpo como superficie y, por tanto, menos verdadero. Según este teórico, en la imaginación popular el cuerpo es visto como una superficie, como un disfraz, y esto es más evidente en el caso del cuerpo transexual, cuyo cambio de sexo es entendido como un cambio de ropa y por tanto como algo provisional, inmaterial en el sentido de inocuo (Prosser, 1998: 62). Esta concepción es apoyada por la concepción médica del sexo como un complejo de signos que van mucho más allá de la superficie corporal y lo que en ella se puede ver, los genitales, y que abarca las gónadas, las hormonas, los cromosomas, etc., y por tanto, se entiende que el sujeto transexual «can alter sex only partially and superficially» (Prosser, 1998: 63).

La propia Rebecca habla en estos términos, rechazando en cierto sentido la supuesta artificialidad de su cuerpo sexuado:

Era como si, después de haber llevado durante años la chaqueta heredada de un hermano que murió en la mili, le dieses la vuelta y te encontraras con la sorpresa maravillosa de que, por la cara escondida, no solo era mejor sino más tuya, más dibujada a tus hechuras, 
sin ninguna querencia del cuerpo del otro. También esto es una manera de hablar, claro, porque lo que yo sentía era mucho más profundo, se trataba de mis costuras de adentro, de algo que ya no sería jamás de quita y pon, algo mío para siempre, porque mi físico estaba ya a la vera de mis sentimientos, y mis sentimientos eran de verdad (Mendicutti, 2003: 117)

La paradójica centralidad del cuerpo en la identidad transexual da lugar a una complicación en el diálogo entre lo superficial y lo interior, entre el cuerpo que se ve y el que se siente:

The transsexual doesn't necessarily look differently gendered but by definition feels differently gendered from her or his birth-assigned sex. (...) It demands some recognition of the category of corporeal interiority (internal bodily sensations) and of its distinctiveness from that which can be seen (external surface) (Prosser, 1998: 43)

Decimos que esta centralidad del cuerpo es paradójica porque, por un lado, el cuerpo de una persona transexual antes de ser operado es percibido como equivocado (ver nota 61) respecto a lo que esa persona siente en su interior, pero al mismo tiempo el cuerpo “imaginado" es demasiado real, hasta el punto de que la persona transexual está dispuesta a pasar por un complicado proceso fisiológico, psicológico y quirúrgico para obtener un cuerpo que se vea como esta persona se siente.

Por tanto, en la identidad transexual es fundamental la imagen corporal (body image); en concreto, según la teoría de Prosser, la de una persona transexual es la de estar en el cuerpo equivocado (Prosser, 1998: 69), como Rebecca afirmará en numerosas ocasiones a lo largo de la novela. En este sentido, Prosser critica la concepción de la operación de cambio de sexo en términos de cirugía estética, entendida como cambios superficiales y “caprichosos” y defiende, en cambio, que esta operación se debería entender como una cirugía plástica reconstructiva, puesto que, al igual que las mujeres que reconstruyen su pecho tras una mastectomía, la persona transexual se opera para recuperar un cuerpo que siempre ha sentido como suyo (Prosser, 1998: 83).

En todo caso, como decimos, la identidad transexual cuestiona la relación entre superficie e interioridad: la importancia de la imagen corporal no implica, como querría cierta teoría postestructuralista, el carácter fantasmático (falso) del sexo, sino el papel fundamental que el cuerpo, la imagen y lo imaginario tiene en la identidad: 
If the goal of transsexual transition is to align the feeling of the gendered embodiment with the material body, body image - which we might be tempted to align with the imaginary - clearly already has a material force for transsexuals. The image of being trapped in the wrong body conveys this force. It suggests (...) how body image can feel sufficiently substantial as to persuade the transsexual to alter her or his body to conform to it (Prosser, 1998: 69)

Por lo tanto, la identidad transexual implica desechar la distinción entre lo superficial y la interioridad: «not being able to tell the difference on the surface bestows the security of a profound identity sameness; the fantasy of sex reassignment surgery is that it erases the difference of transsexuality, covers its traces with a seamlessly sexed body» (Prosser, 1998: 89).

Prosser recurre al concepto del psicoanalista freudiano Didier Anzieu del yo-piel, que recupera la definición de Freud en el Yo y el Ello del ego como surgido de las percepciones sensoriales: en contra de la lectura lacaniana y su teoría del estadio del espejo, Anzieu interpreta literalmente la descripción freudiana del ego como la proyección de la superficie corporal y sus sensaciones (Prosser, 1998: 65) ${ }^{66}$. Anzieu retoma e insiste en la premisa fundamental del padre del psicoanálisis de que todas las actividades psíquicas derivan de funciones biológicas, frente a la centralidad que Lacan le otorga al lenguaje (Prosser, 1998: 66).

La teoría psicoanalítica de Anzieu, por tanto, le otorga a la piel el papel más importante en la delimitación y definición del ego, como lo que se ve pero también, y sobre todo, como el órgano que permite las percepciones del yo y sus relaciones con el mundo exterior. En la teoría de Anzieu el yo no es más que superficie, y en este sentido la narrativa transexual sirve de ejemplo perfecto, ya que tanto la terapia hormonal como las operaciones de reasignación de sexo lo que hacen es transformar la "superficie" corporal en consonancia con la identidad sentida, en un sentido muy literal (Prosser, 1998: 66): «apprehending the figure of the wrong body as part of a transsexual unconscious according to Anzieu's concept of the skin ego emphasizes not the imaginariness of the figure (rhetorical image) but its sensibility (embodied image)» (Prosser, 1998: 72). Para

\footnotetext{
${ }^{66}$ Judith Butler, señala Prosser, interpreta esta descripción a la inversa: para la teórica feminista es el cuerpo el que constituye una proyección psíquica, imaginaria, del ego.
} 
Prosser, esta importancia de la superficie corporal como imagen del ego demuestra la literalidad de esta imagen más que el carácter fantasmático del sexo, como Butler querría:

The transsexual's often declared capacity to experience his or her body as differently sexed from its materiality certainly supports Freud's notion of a bodily ego. But, because the subject often speaks of the imaginary body as more real or more sensible, I argue that this phenomenon illustrates the materiality of the bodily ego rather than the phantasmatic status of the sexed body: the material reality of the imaginary and not, as Butler would have it, the imaginariness of material reality (Prosser, 1998: 43-44; el destacado es nuestro)

En este sentido, tanto Anzieu como Prosser insisten en la predominancia del tacto frente a la vista en la configuración de la imagen corporal: es el tacto el que produce la identidad como un yo-piel: «in thinking body image, we seem to have emphasized "image" at the expense of the body, the body as it is (or is not) felt» (Prosser, 1998: 77). En Yo no tengo la culpa de haber nacido tan sexy encontramos un muy emotivo pasaje que precisamente enfatiza esta importancia del tacto - y, de paso, de la imagen corporal. Nos referimos al momento en que Rebeca se tiene que disfrazar de hombre para poder acceder al monasterio de San Juan de Lara y, la noche anterior, se detiene frente al espejo y acaricia su cuerpo:

Hacía mucho que no me acariciaba como estuve acariciándome aquella noche, mirándome en el espejo de aquel ropero en el que había colgado la ropa de hombre que me iba a poner al día siguiente. Me acaricié con mucho cariño la garganta, que es una parte del cuerpo que me exigió muchísimo trabajo y atención para no encontrarme, el día menos pensado, con una papada de arzobispo. Me acaricié, como si estuviera despidiéndome de ellos y los consolara diciéndoles que iba a ser un viaje corto y sin fatigas, aquellos pechos que seguían siendo espectaculares. Me acaricié el estómago con un sentimiento tan grande que a punto estuvieron de saltárseme las lágrimas, porque el estómago es como un hijo rebelde que, en cuanto te descuidas, te da un disgusto y te hace barrigona, pero al que se quiere como solo una madre puede querer a un hijo difícil. Me acaricié, con un nudo en la garganta, el montecito al que por fin pude subirme para ser una mujer de cuerpo entero, y le pedí perdón porque a él también iba a tenerlo que disfrazar (...) Me acaricié como si acariciase la grupa de un caballo que ya no podía llevarme tan lejos como yo quería llegar, como si acariciase a un campeón que acababa 
de perder su primera carrera, aquel cuerpo que me había ganado a pulso y que en cualquier momento empezaría a tiritar (Mendicutti, 2003: 108) ${ }^{67}$

Como apuntábamos, en este pasaje encontramos también el motivo del espejo, que de hecho servirá de pretexto a la protagonista para recordar el espejo que la acompañó en su juventud en los comienzos de su proceso de transición:

Había un espejo encima de la consola del recibidor en el que yo me miraba un montón de veces al día, y siempre antes de salir de casa y cada vez que volvía, a la hora que fuere, que mirarme en aquel espejo me vi yo crecer, cambiar, encogerme de pena o estirarme de coraje, en aquel espejo me gustaba a veces y me aborrecía otras, hasta que un día el espejo se rompió, o mi madre lo quitó porque se cansó de él, y fue como si en aquella pared se hubiera hecho un agujero muy hondo, que quería yo mirarme un montón de veces al día y siempre que entraba o salía de casa y ya no podía verme, por unos segundos pensaba que me había vuelto invisible para mí mismo ${ }^{68}$, o que nunca más iba a reconocerme, y me daba vértigo (Mendicutti, 2003: 113)

Como podemos observar, el espejo se convierte aquí en una metáfora perfecta para la importancia de la imagen corporal en la identidad transexual: sin la imagen que le devuelve el espejo, Rebeca se siente perdida. Para Prosser, el espejo es además una imagen recurrente en la narrativa autobiográfica escrita por personas transexuales como metáfora del mismo acto autobiográfico: «autobiography is ostensibly anyway the literary act of self-reflection, the textual product of the "I" reflecting on itself» (Prosser, 1998: 100).

Para Prosser la forma autobiográfica es idónea para dar cuenta de la problemática identidad transexual por varios motivos. El más inmediato, en un plano anecdótico, es el hecho de que la persona transexual, para poder acceder al tratamiento hormonal y quirúrgico, debe ofrecer al psiquiatra y al médico un relato de su vida que justifique su identidad transexual y su voluntad de pasar el proceso de tránsito (Prosser, 1998: 101). Por otro, la narrativa, en tanto que diacrónica, es más adecuada que la puntualidad de los actos performativos para expresar la experiencia transexual, sobre todo en el sentido en que la autobiografía transexual, al tener su telos en la compleción del cambio de sexo, no

\footnotetext{
${ }^{67}$ Cuando esté, vestida de hombre, en el monasterio, Rebecca comenzará a sufrir un picor insoportable en el cutis y en las ingles. La teoría de Anzieu del yo-piel también da cuenta de estas reacciones psicosomáticas en la piel (Prosser, 1998: 71)

${ }^{68}$ Muy significativamente, la narradora utiliza el género masculino para referirse a sí misma en el pasado, antes de estar en un estado avanzado de su transición, y lo usará también cuando se disfrace de hombre en San Juan de Lara.
} 
implica una falta o una fantasía, sino que expresa una "realización”, la consecución del cuerpo sentido (Prosser, 1998: 118). Además, la dialéctica del dispositivo narrativo autobiográfico entre el yo presente que narra la vida de un yo pasado refleja la misma experiencia del tránsito de un sexo a otro: «autobiography, like the transsexual’s first look in the mirror, breaks apart the subject into the self reflected upon and the self that reflects; autobiography, like transsexuality, instantiates (or reveals) a difference in the subject» (Prosser, 1998: 102). En este sentido el género autobiográfico también permite salvar la aparente contradicción de someterse al proceso de cambio de sexo y, a la misma vez, declarar que uno siempre ha sido de ese sexo:

Within the genre of autobiography this play between transformation and the continuity of the self, between conversion and identity, is not a disruptive paradox but a founding dynamic: a dynamic that in turn, as transsexuality is reliant on the autobiographical form, founds transsexuality. (...) For if the narrative of autobiography documents change (why deploy a form, after all, whose very purpose as diegesis is to trace the passage of time, if the subject does not change?), the autos of autobiography presumes identity, the continuity of the self (Prosser, 1998: 119)

En esta línea, se puede leer perfectamente Yo no tengo la culpa de haber nacido tan sexy como una autobiografía: a lo largo de la novela, Rebeca irá recordando y relatando las diferentes fases de su proceso de conversión, desde la primera vez que su padre le descubra vestido de mujer con cuatro años, hasta su primera relación sexual después de la operación, pasando por su adolescencia, el comienzo de su terapia hormonal, el reencuentro con su madre, la decisión de someterse a cirugía y los preparativos para la misma.

En todo este relato autobiográfico, el cuerpo de la narradora es el motor de la narración, no solo como eje temático sino como pretexto que da lugar a los diferentes recuerdos de la protagonista, empezando por que, como hemos señalado, es el descubrimiento de los primeros signos de vejez lo que lleva a la protagonista a comenzar su periplo espiritual. Como hemos dicho, es esta crisis de identidad relacionada con el cuerpo lo que da inicio a la narración, y, en cierto sentido, la solución de esa crisis será obtenida a través de la memoria de su cuerpo.

El conflicto entre cuerpo y memoria es explicitado por la misma Rebeca cuando confiesa sus dudas antes de someterse a la cirugía de reasignación de sexo acerca de qué sucederá con los recuerdos de lo que ha vivido en su cuerpo de hombre: «Después de la 
operación, ¿cómo iba a ser mi memoria? ¿Cómo, de quién iban a ser los recuerdos, todos aquellos recuerdos que había ido guardando hasta entonces? ¿Iban a desaparecer, seguirían ahí, pegados en mi cerebro durante el resto de mi vida, como recuerdos de otro?» (Mendicutti, 2003: 255) ${ }^{69}$. Incluso el propio tránsito de un sexo a otro, que culmina con la cirugía de reasignación, entendida, como apuntábamos, como una cirugía reconstructiva, implica una memoria paradójica, en tanto que supone recuperar un cuerpo que siempre había estado allí pero se había perdido:

What makes possible the psychic translation of the surgical incursions into the body into a poetics of healing is a kind of transsexual somatic memory (...) In the case of the transsexual the body constructed through sex reassignment surgery is not one that actually existed in the past, one that is literally re-membered, but one that should have existed; sex reassignment is a recovery of what was not (Prosser, 1998: 83)

En la novela de Mendicutti, de hecho, la memoria de Rebecca aparecerá al final de la obra personificada como una niña vestida de comunión: esta niña representa a la propia Rebeca, de niño, como a ella le hubiera gustado vivir su comunión, vestida de niña, y no de marinero, como efectivamente sucedió, encarnando así esta concepción paradójica de la memoria transexual como recuerdo de algo que no fue.

En todo caso, como vemos, la identidad, la memoria y el cuerpo están indisolublemente unidos: la identidad de Rebeca son sus recuerdos y su cuerpo, porque es su cuerpo el depositario de su memoria. De hecho, es fácil observar cómo, como una suerte de magdalena proustiana, son los diferentes éxtasis sexuales que Rebecca experimenta a lo largo de su periplo los que desencadenan sus recuerdos. En este sentido, es la lectura camp de la mística, que sexualiza los encuentros místicos con el Amado, lo que permite esta recuperación de la memoria de Rebeca y, por lo tanto, su reconciliación con su cuerpo. Por ejemplo, en el último éxtasis vivido por la protagonista, esta recuerda los amantes más significativos que ha tenido a lo largo de su vida, aquellos que la han hecho sentirse bien con su propio cuerpo, y es la sexualización de esta experiencia espiritual la que permite la equiparación del “alma” con el cuerpo, solucionando la disyuntiva a la que se ha enfrentado la protagonista a lo largo de la novela:

El Amado (...) hizo caso omiso de mi insistencia en que se fijara un poco más en mi emoción y un poco menos en mi constitución, y me susurró al oído que no me preocupase,

${ }^{69}$ En este sentido, Prosser cita las experiencias del neurobiólogo Oliver Sacks para dar cuenta de la importancia de la memoria en la manera en que experimentamos nuestros cuerpos (Prosser, 1998: 84-86) 
que todo formaba parte de mi alma (...) Y entonces me percaté de que si aquello era un éxtasis yo los había tenido antes a montones (Mendicutti, 2003: 265)

Puesto que, en efecto, la estética camp es el mecanismo textual que vehicula y permite esta dialéctica entre el cuerpo y la identidad.

\subsubsection{El camp como mística del cuerpo}

Como vemos, si en la identidad transexual se da una compleja relación entre la identidad, el cuerpo y la imagen corporal que queda reflejada a la perfección en la historia de Rebecca de Windsor, nuestra hipótesis es que es la estética camp aplicada a la lectura del discurso místico lo que permite esta interpretación. Pero, ¿cómo trabaja concretamente el camp sobre los textos místicos?

Consideremos este sencillo ejemplo: al comienzo de la novela, Rebecca sigue a Dany hasta el interior de una iglesia poco iluminada: «hasta el punto de que me entró como un aturdimiento, yo creo que de debilidad, y apenas distinguí el lugar donde por fin se entraba, que entréme yo donde no supe y quedéme un buen rato no sabiendo, entre otras razones porque aquello estaba oscurísimo» (Mendicutti, 2003: 13; el destacado es nuestro). El remedo del lenguaje renacentista es más que evidente por ejemplo en la colocación del pronombre personales detrás de los verbos («entréme», «quedéme») dentro de una cita directa de San Juan de la Cruz; y el carácter paródico de este pastiche está garantizado, en primer lugar, por la inadecuación del uso de este estilo en un contexto tan cotidiano y, sobre todo, por la incoherencia que supone yuxtaponer la cita de San Juan a la segunda parte de la frase, «entre otras razones porque aquello estaba oscurísimo». Esta yuxtaposición es cómica no solo por su incongruencia, sino porque obliga a leer la cita del poeta místico de manera literal, abandonando la significación que la paradójica expresión tiene en su contexto original: Rebecca no se queda «no sabiendo» porque esté «trascendiendo toda ciencia», sino simplemente porque la iglesia donde entra está demasiado oscura.

Este procedimiento tan típicamente cómico de tomar literalmente las expresiones figuradas se aplicará al resto de la novela, dando lugar, efectivamente, a la sexualización de las experiencias místicas de la protagonista. Como ya mencionábamos, para Francisca Paredes la mirada camp hace que Rebecca se fije en los aspectos más "superficiales” y teatrales de la experiencia mística y desatienda los “contenidos" espirituales, 
manteniendo así una oposición entre lo superficial y lo interior, lo literal y lo figurado; y los éxtasis de unión con el Amado tienen una gran carga sexual porque la protagonista se centra «no en la purificación del espíritu y en la lucha por abandonar las distracciones mundanas, sino en los fuegos artificiales del estado final» (Paredes, 2012: 217). Sin embargo, como decimos, en nuestra opinión es erróneo mantener esta separación tajante entre lo "superficial” y lo "espiritual” de la experiencia mística. Bien es cierto que el conflicto de la novela se basa precisamente en esta oposición entre lo mundano y lo divino, y Rebecca se esfuerza en reducir los cuidados cosméticos y los alardes de vestuario al mínimo para poder enfocarse en su enriquecimiento espiritual, pero, como hemos visto es la sexualización de los éxtasis lo que le permite reconocer que, en realidad, cuerpo y alma van de la mano.

En este sentido, creemos equivocado considerar que, en la lectura camp de la metáfora erótica de la mística, por la cual Rebeca “ignora” el sentido espiritual alegórico para "conformarse" con el sentido literal profano, sino que más bien el procedimiento literalizante evidencia lo apto de la metáfora erótica para hablar de la experiencia mística: más que separar los dos sentidos, espiritual y profano, muestra cómo estos están indisolublemente unidos ${ }^{70}$.

En todo caso, esta lectura sexualizada no solo se aplica a los propios éxtasis de la protagonista. En el tercer capítulo o morada, Dany y Rebeca llegan a un monasterio “especializado” en la vía punitiva de purificación espiritual, esto es, el recurso al castigo corporal mediante cilicios, al que Dany es aficionado. En la imaginación camp de Rebeca, a la que le horroriza la idea de castigar el cuerpo que tanto tiempo le ha costado conseguir, las noches en el monasterio en que puede oír los latigazos a los que se someten el resto de los huéspedes se convierten en espectaculares escenas de sadomasoquismo:

Qué angustia. Me imaginaba yo los cuerpos retorciéndose, pero sin parar de castigarse, porque tenían que purgar sus culpas. Me imaginaba a aquella pareja que tenía una pinta tan fenomenal - el cincuentón canoso y la cuarentona bajita, pero bien formada turnándose con el látigo, y la veía a ella desnuda y amarrada al sobrio cabecero de madera de la cama, con su media melena pringosa como una aljofifa después de fregar un quirófano, con todo el cuerpo en carne viva, con la voz ronca por el sufrimiento, pero sin

\footnotetext{
${ }^{70}$ En su estudio, Georges Bataille rechaza tanto la postura de evitar toda referencia al erotismo evidente de los textos místicos, como de reducir toda la experiencia mística a experiencias meramente sexuales, como hacen psicoanalistas como Marie Bonapate, y pide analizar las analogías que efectivamente existen entre la experiencia de la sensualidad y de la mística (Bataille, 2002)
} 
dejar de pedir más latigazos porque estaba a punto, lo que se dice a punto de levitar, y lo veía a él, al principio él no iba completamente desnudo, llevaba un taparrabos de cuero que le sentaba como un guante, y desde luego se conservaba divinamente para la edad que tenía, se le marcaban bastante los músculos cada vez que pegaba el latigazo, y estaba empapado en sudor (...) La verdad es que él no perdía el estilo en ningún momento, ni siquiera cuando perdía la cabeza y se ponía a chillar y a decirle a ella que ya estaba bien, que también él quería purgar sus culpas, que también quería estar completamente desnudo, amarrado a la cama, cosido a latigazos (Mendicutti, 2003: 89-91)

Esta vinculación tan queer entre la espiritualidad punitiva y el sadomasoquismo se repite hacia el final de la novela, cuando la pareja se encuentre en la carretera con un grupo de homosexuales aficionados al leather, que, de camino a un encuentro de este fetichismo, se dirigen a un monasterio especializado en la manufactura y comercialización de productos de cuero. Rebecca, en una nueva muestra de delirio quijotesco, confundirá a estos representantes de una de las subculturas gay más marcadas por la hipermasculinidad (hay incluso una referencia a los dibujos de Tom de Finlandia), con ángeles:

De hecho, por las pintas, parecían más bien centuriones selectos del ejército celestial. Fornidos, vestidos de la cabeza a los pies con prendas de cuero - aunque algunos lucían sólo un chaleco que les dejaba los musculosos brazos al aire - y con el pelo muy corto, lograron maravillarme cuando comprendí que en la milicia seráfica también había un cuerpo de élite (Mendicutti, 2013: 208)

Dany (que al final del capítulo acabará por renunciar a su viaje espiritual y se unirá a la comitiva leather) intenta sacarla de su error, haciéndole notar que cada uno lleva varios pañuelos de colores y en lugares (bolsillos del pantalón, muñecas, etc.) según la semiótica propia de las prácticas culturales de este grupo, pero sin éxito:

-Hay que reconocer - le dije a Dany - que no les falta un detalle.

-Son fanáticos del cuero y de zurrarse - dijo él.

-Son ángeles con sentido del adorno y del color, sencillamente (Mendicutti, 2013: 215)

Y esta no es la única conexión que Mendicutti hace entre los conventos religiosos y la comunidad gay. En el folleto del monasterio de San Juan de Lara, el autor introduce una cierta nota irónica respecto a las connotaciones homoeróticas que un lugar reservado solo para hombres y dedicado al ejercicio físico y el cultivo del cuerpo tiene:

El folleto, profusamente ilustrado con fotografías muy artísticas y sugestivas de las instalaciones que el santuario ponía a disposición de los huéspedes - piscina, frontón, 
pista de tenis, gimnasio completísimo y sauna, además de salas de lectura y de un salón social destinado «a disfrutar de la mutua compañía sin menosprecio alguno de la virilidad» - hablaba de los gozos de la divina camaradería, del delirio exclusivo que está reservado en el verde embeleso de la vida celestial al amor de los amigos, de los sublimes espasmos que proporciona la fraternidad bien entendida y mejor elevadas hasta las cumbres del espíritu, y de los manjares que celosamente se guardan par el amigo en la alacena cuya llave sólo tiene el Amado (Mendicutti, 2013: 96; el destacado es nuestro)

Estas tres referencias (planteadas, recordemos, desde la perspectiva camp que vinculan la espiritualidad religiosa con una sexualidad queer) ofrecen varias líneas de interpretación que insisten en la relación entre el cuerpo y la identidad, específicamente la identidad de género.

El sadomasoquismo o S/M, en primer lugar, que se extendió como práctica en los años sesenta y setenta en algunas comunidades homosexuales estadounidenses, generalmente en comunidades leather, suscitó el interés de pensadores relacionados posteriormente con la teoría queer como Michel Foucault o Gayle Rubin. Para Foucault, el S/M ejemplificaba a la perfección un uso estratégico de las estructuras sociales de poder para producir placeres que modificaban la relación del sujeto con su propio cuerpo y la sexualidad como se había instaurado en la época moderna ${ }^{71}$ : la puesta en escena erótica de formas de dominación no reproducen, en el análisis del filósofo francés, las estructuras de poder, sino más bien las subvierten al usarlas estratégicamente como "juego" mutuamente consensuado que es fuente de placer (Halperin, 2007: 108). Además, representa una invención respecto de la sexualidad burguesa: en la escena S/M no importa el género ni la orientación sexual de los participantes, solo los roles que ocupan; y el placer físico se desvincula de los genitales, resignificando el cuerpo entero en su relación con el placer (Halperin, 2007: 109). EL S/M, así como otras prácticas relacionadas como el bondage, la flagelación, el fist-fucking, etc., no solo destronan los genitales y en

\footnotetext{
${ }^{71}$ Como se sabe, Foucault había lanzado en el primer volumen de su Historia de la sexualidad, La voluntad de saber (2009), la provocadora afirmación de que la sexualidad no consistía, como se argumentaba en los movimientos freudomarxistas y de liberación sexual de la década de los sesenta, en una constante biológica que habría sido reprimida por la sociedad victoriana burguesa, sino en una compleja tecnología de poder y saber que servía a la normalización de los cuerpos y el control biopolítico de la sociedad. En este sentido, las prácticas de las comunidades gays y lesbianas le inspiraban la posibilidad de unas prácticas sexuales y formas de vida que se escaparan a este control de la sexualidad y una manera más libre de relacionarse el sujeto consigo mismo y los demás. A partir del segundo volumen, El uso de los placeres (Foucault, 2009b), Foucault daba un giro a su investigación y volvía su atención a los textos grecolatinos que trataban el sexo, proponiendo que suponían una forma diferente de concebirlo, no como objeto de una scientia sexualis sino como parte de una serie de prácticas "ascéticas" de dominio de sí y de perfeccionamiento de uno mismo.
} 
concreto el pene, su erección y su eyaculación, como centro de las relaciones sexuales, sino que este órgano se reintroduce incluso como zona de vulnerabilidad (Halperin, 2007: 110).

Hay, en la campificación del ritual religioso de la punición como práctica sadomasoquista realizada por Rebeca, un elemento central para dicho juego, el del látigo, que nos permite relacionarlo con la lectura que Paul B. Preciado hace del dildo. En la novela de Mendicutti, el producto estrella de la tienda del Monasterio de San Esteban de los Patios son unos cilicios incrustados con piedrecitas extraídas de las piedras con que se lapidó al mártir San Esteban, reliquia que se conserva en el mismo monasterio; el objeto es presentado con una clara fascinación fetichista por parte de Dany: «A mí me parecía estremecedor, pero a Dany se le puso de repente cara de coleccionista vicioso ante una pieza única. No pudo evitar que se le fueran las manos impacientes hacia aquella atrocidad» (Mendicutti, 2003: 68).

Respecto a las consideraciones del fetichismo del cuero, los látigos y de los diversos instrumentos de las prácticas sadomasoquistas, la pensadora feminista Gayle Rubin desecha las interpretaciones psicoanalíticas y las críticas feministas para vincular estas prácticas a una historia material de la producción y el consumo, el urbanismo, etc., y cómo estos nuevos objetos y prácticas se deben entender, no como perversiones concretas apartadas de una sexualidad normativa, sino en relación con la moderna construcción tecnológica del cuerpo (Preciado, 2018: 86):

No veo cómo se puede hablar de fetichismo y de sadomasoquismo sin pensar en la producción del caucho, en las técnicas usadas para guiar y montar a caballo, en el betún brillante de las botas militares, sin reflexionar sobre la historia de las medias de seda, sobre el carácter frío y autoritario de los vestidos medievales, sobre el atractivo de las motos y la libertad fugaz de abandonar la ciudad por carreteras enormes. Cómo pensar sobre el fetichismo sin pensar en el impacto de la ciudad, en la creación de ciertos parques y calles, en los "barrios chinos” y sus entretenimientos "baratos”, o la seducción de las vitrinas de los grandes almacenes que apilan bienes deseables y llenos de glamour. Para mí, el fetichismo suscita toda una serie de cuestiones relacionadas con cambios en los modos de producción de objetos, con la historia y la especificidad social del control, de la destreza y de las "buenas maneras”, o con la experiencia ambigua de las invasiones del cuerpo y de la graduación minuciosa de la jerarquía” (Rubin, cit. en Preciado, 2018: 8586) 
Como apunta Preciado, todos los aparatos destinados al control de la masturbación, al tratamiento de la histeria femenina y en general a la producción de la sexualidad (guantes, cinturones de castidad, vibradores, etc.) son reapropiados paródicamente por las prácticas sadomasoquistas y lésbicas, entre otras comunidades (Preciado, 2018: 97), revelando el importante papel de la tecnología en la construcción, literal, del cuerpo humano y la sexualidad. En este sentido, el dildo, que surge del entrecruzamiento de tres tecnologías distintas (la represión de la masturbación infantil, el tratamiento de la histeria femenina y las prótesis para soldados mutilados durante la Primera Guerra Mundial) (Preciado, 2018: 107) es el objeto que muestra la concepción tecnológica y prostética del cuerpo sexuado.

El dildo, que Preciado relaciona explícitamente con el látigo, no debe ser criticado como una imitación falocéntrica, sino analizado, insertado en una historia tecnológica y biopolítica del sexo, y en una lectura cercana al concepto derridiano de suplemento, como un objeto que desplaza la naturalidad del cuerpo y cuestiona la centralidad del pene - se supone que el dildo es una imitación del pene, pero más bien es su superación, hasta el punto de ser más real que el propio órgano:

Como copia, mímesis parásita del pene, siempre está camino de aproximarse, cada vez más, al ideal de la imitación. Nunca es suficiente. Nunca está bastante cerca del órgano. En realidad, no se basta en sí mismo como imitación del órgano. No se contenta con imitar. Por eso debe transformarse constantemente, autoexcederse de tal manera que va literalmente más allá de la forma, de la talla y de la excelencia de aquello que supuestamente imita. El dildo dirige el pene contra sí mismo (Preciado, 2018: 71)

El dildo, por tanto, que supuestamente sirve para cubrir una falta del pene, constituye su superación hasta el punto de que es el dildo el que sirve como ideal al que el pene "real" aspira y revela cómo el cuerpo, concretamente el masculino, es concebido plásticamente:

Muestra que la masculinidad está, tanto como la feminidad, sujeta a las tecnologías sociales y políticas de construcción y de control. El dildo es el primer indicador de la plasticidad sexual del cuerpo y de la posible modificación prostética de su contorno (...) El dildo se revela entonces como un instrumento entre otras máquinas orgánicas e inorgánicas (las manos, los látigos, los penes, los cinturones de castidad, los condones, las lenguas, etc.) y no simplemente como la réplica de un miembro único (Preciado: 2018: 68; el destacado es nuestro)

En este sentido, el látigo como dildo y fetiche sadomasoquista, no solo implica una resignificación desgenitalizadora del cuerpo; tiene que ver también con el cuerpo de 
Rebeca en cuanto que cuerpo prostético. Como mencionábamos en el primer epígrafe de este capítulo, Preciado usa la expresión de «prostético» para apuntar, frente a la primacía de lo discursivo en el concepto de performatividad de Butler, que el sexo también es literalmente construido por medio de prótesis, abstractas o concretas: «la tecnología sexual es una especie de «mesa de operaciones» abstracta donde se lleva a cabo el recorte de ciertas zonas corporales como «órganos»» (Preciado, 2018: 116). A la mesa de operaciones abstracta de la interpelación butleriana (“es niño” o “es niña”) le sigue, en el caso de los bebés intersexuales y las personas transexuales, una mesa de operaciones literal que, al construir un sexo mediante prótesis e injertos, revela un trabajo de la tecnología sexual que afecta a todos los cuerpos (Preciado, 2018: 118-119). La prótesis desestabiliza la concepción natural del cuerpo, al estar a medio camino entre lo orgánico y lo inorgánico, lo corporal y lo in-corporado ${ }^{72}$ :

Resulta imposible estabilizar la prótesis, definirla como mecánica u orgánica, como cuerpo o máquina. La prótesis pertenece por un tiempo al cuerpo vivo pero se resiste a una incorporación definitiva. Es separable, desenganchable, desechable, reemplazable (...) El sexo y el género deberían considerarse formas de incorporación prostética que se hacen pasar por naturales, pero que, pesa a su resistencia anatómico-política, están sujetos a procesos constantes de transformación y de cambio (Preciado, 2018: 152,155)

En este sentido, Rebeca no ha producido su identidad, como afirma Francisca Paredes, por medio de una serie de actos performáticos y de incorporación de signos sobre su cuerpo, sino que literalmente ha construido su cuerpo sexuado como femenino mediante el vestuario, las hormonas, implantes de pechos, vaginoplastia, etc.

El cuerpo de Rebeca representa esta condición de prostético de manera más evidente, pero no debemos pasar por alto que también el cuerpo de su compañero Dany ha sido construido tecnológicamente. Cuando ambos discuten acerca de la idoneidad de la vía punitiva como modo de purificación espiritual, Dany le explica a Rebeca cómo su obsesión por su cuerpo, esculpido en un gimnasio, era resultado del complejo que de niño tenía por ser un enclenque objeto de burlas (Mendicutti, 2018: 72). Existe, por tanto, un paralelo en la trayectoria vital de Rebeca y Dany, pues ambos han tenido que construir su cuerpo para alcanzar sus identidades soñadas. La diferencia, y es lo que desembocará en

\footnotetext{
${ }^{72}$ En general, Preciado se propone en su Manifiesto Contrasexual la polémica de las teorías feministas y sociológicas entre el esencialismo y el constructivismo, entre lo natural y lo social o tecnológicamente construido (2018:83), cuestión que atraviesa sin duda todas las discusiones de este capítulo.
} 
que Dany acabe por renunciar a la vía mística, es que mientras que Rebeca se siente orgullosa del cuerpo que ha conseguido, y alcanza una reconciliación entre su espíritu y su carne, Dany no dejará de estar arrepentido de lo que considera un excesivo culto al físico, habiendo dejado de lado alimentar su alma (Mendicutti, 2008: 71).

En todo caso, esta cuestión de la construcción de la identidad propia mediante el trabajo del cuerpo también tiene que ver con las comunidades leather y las identidades hipermasculinas y, en general, el culto al cuerpo propio de la cultura gay. Las prácticas S/M que Foucault analiza son las que conoce de las comunidades homosexuales de San Francisco, vinculadas a la cultura leather. Esta subcultura había surgido en los cincuenta, en grupos de hombres que se identificaban con las formas y códigos tradicionales de masculinidad, en oposición al estereotipo imperante del homosexual afeminado por invertido, imitando signos hipermasculinos: relaciones de dominación y sumisión, el cuero como signo de dureza, signos corporales de virilidad como bigotes, vello corporal, músculos, etc. (Sáez, n.d.). Foucault distingue cuidadosamente estas identidades, que más bien son construcciones simbólicas, performativas, de los ideales masculinos machistas heterosexuales, respecto de los cuales estas prácticas representan más bien su desmitificación:

Lo que me sorprende es que esos perifollos, todo ese blasonamiento de la masculinidad no coincide en nada con una revalorización del macho en tanto que macho. Ya que, por el contrario, al abrigo de las miradas y bajo el signo de esos blasones tan masculinos, lo que se desarrolla son formas de relaciones sexuales masoquistas o de afirmación masoquista, donde no hay ninguna valorización del macho en tanto que macho. Para nada. Por el contrario, va a haber usos del cuerpo que se pueden definir como desexualizados, como desvirilizados (...) En resumen, se utilizan los signos de la masculinidad pero en absoluto para volver a algo que sería del orden falocéntrico o machista, sino más bien para inventarse, para permitirse hacer con su cuerpo masculino un lugar de producción de placeres extraordinariamente polimorfos y apartados de las valorizaciónes del sexo y particularmente del sexo macho (Foucault cit. en Halperin, 2007: 111-112)

Por tanto, esta clonación de la hipermasculinidad en las comunidades gays son más bien una vía de deslegitimar las masculinidades heterosexuales, ya que el cuerpo hipermasculino, en el contexto de estas prácticas sadomasoquistas, se resignifican como receptivo, penetrable, vulnerable (Halperin, 2007: 112). 
Las prácticas como el S/M, el fetichismo, el fist-fucking, etc., en suma, no solo eran prácticas sexuales alternativas, sino que estaban directamente relacionadas con unas formas de vida, unos códigos de vestimenta: unas identidades propias, al fin y al cabo. Foucault va a entender estas estilizaciones propias de las comunidades gays y lesbianas como ejemplos modernos de la askesis antigua, ese riguroso trabajo ético que los individuos practicaban en Grecia y Roma sobre sí mismos como formas de sujeción distintas de la disciplina moderna (Halperin, 2007: 98-99). Halperin pone como ejemplo el body-building de las comunidades gays, de estas prácticas que suponen, mediante un trabajo del cuerpo, un trabajo sobre sí mismo de subjetivación que se aparta de los modos de subjetivación burgueses. Los músculos queer no son lo mismo que los músculos straight porque si estos están enmarcados en una ideología de la naturalidad, de la funcionalidad, de la acción, etc., el cuerpo musculado queer no significa poder sino que está dedicado a ser mirado, a la atracción erótica (Halperin, 2007: 138):

Lo que distingue a los cuerpos gays trabajados en el gimnasio, aparte de su belleza espectacular, es la manera en que se anuncian como un objeto de deseo. Los músculos gays no significan poder. No se parecen a los músculos producidos por una ardua labor física. Por el contrario, los músculos exagerados, misteriosos, bien esculpidos de los cuerpos gays no provienen de una actividad útil y no tienen una función práctica: son el tipo de músculos que sólo se puede desarrollar en un gimnasio. Están diseñados específicamente para la atracción erótica. Y en su misma solicitación del deseo, se burlan de las normas visuales de la masculinidad straight que imponen una cierta discreción y exigen que la belleza masculina se exhiba sólo de un modo casual, que no reconozca sus estrategias (...) el objetivo de esta ascesis física no es parecer normal sino bizarros, hipertrofiados, incluso grotescos - es decir, queer - y, no obstante, intensamente deseables (Halperin, 2007: 138-139) ${ }^{73}$

\footnotetext{
${ }^{73}$ Por supuesto, esta celebración de la masculinidad por parte de las comunidades gays, supuestamente subversivas, no deja de estar exenta de polémica y lecturas contradictorias. En primer lugar, muchos homosexuales, no solo miembros de subculturas como el leather, practican desde este concepto de masculinidad una plumofobia activa (y la misoginia que esta implica). Por otra parte, no hay que olvidar cómo estas prácticas y comunidades, que en su origen pudieron ser subversivas, al final se han normativizado a través de su comercialización - en general, y como se ha criticado en varias ocasiones, Foucault no quiso, no pudo o no supo ver cómo el neoliberalismo se apropiaría de estas prácticas antidisciplinarias de construcción de sí.

Sin duda, en la novela de Mendicutti también encontramos, como apuntan tanto Paredes como Ingenschay (2011) una crítica a estos procesos de comercialización y globalización de las formas de vida tanto religiosas como homosexuales. Por una parte, es evidentemente irónico el retrato que el autor hace de los monasterios, reconvertidos en hoteles casi de lujo y tiendas de regalos (los productos de cuero del monasterio de blablá se distribuyen en diversas tiendas especializadas de capitales del mundo gay: Madrid, Londres, Ámsterdam, Nueva York, San Francisco...). Por otro, Mendicutti menciona la normalización de
} 
¿No podemos ver en esta descripción de Halperin, con su insistencia en la artificiosidad, la no naturalidad, el esteticismo, la erotización del cuerpo, etc., un perfecto ejemplo de una práctica camp? Al fin y al cabo, como hemos dicho, tanto en el caso de Rebeca como de Dany se establece una vinculación entre identidad, cuerpo e imagen corporal que las hace, al final indistinguibles. Esta es una relación que es camp en su origen y en su desarrollo textual: como hemos insistido, es la mirada camp literalizante de Rebeca sobre los textos místicos que permite insistir en la dimensión visual y corporal de dicho discurso, no rechazando o burlándose, como se suele argumentar, de la dimensión alegórica y espiritual de la mística, sino equiparando esta dimensión espiritual con la de la experiencia del propio cuerpo y la identidad, poniendo en el mismo nivel el cuerpo y el alma. Al mismo tiempo, mediante su equiparación entre los rituales de purificación punitiva y las prácticas S/M, y la cultura leather y su culto al cuerpo hipermasculino, el discurso camp de la novela extiende esta concepción del cuerpo transexual como prostético, como construido, a los cuerpos masculinos y, por ende, a cualquier tipo de identidad en tanto que anclada al cuerpo.

Lo mismo puede decirse del sentido de cómo Rebeca “construye” su identidad, bien sea su decisión de ser santa emulando a Santa Teresa de Jesús o su necesidad de parecerse a Rita Hayworth o Grace Kelly: este carácter imitativo, imaginario, de una identidad camp no puede entenderse como "fantasmático" en el sentido de falso, sino como algo lo suficientemente real como para que Rebecca está dispuesta a sacrificar su vida por ella. Tomando las palabras de Prosser, estas identificaciones camp demuestran «the material reality of the imaginary and not, as Butler would have it, the imaginariness of material reality». Esta es, en nuestra opinión, la "seriedad" de lo camp de la que hablaba Isherwood: una identificación literal que borra las diferencias entre superficie y profundidad, entre construcción y naturalidad, entre teatralización y verdad interior.

\footnotetext{
los aficionados al leather: «quitando a algunos negros muy aparatosos y un par de japoneses (...) el resto de los ángeles - rubios, castaños o morenos - estaban cortados por el mismo patrón, todos parecían haber puesto en manos del mismo cirujano plástico para tener idéntico corte de cara, todos se movían de la misma manera, todos iban vestidos con prendas de cuero y bastante chatarrería, y todos llevaban en las muñecas o en los bolsillos traseros del pantalón, a la derecha o a la izquierda, pañuelos de distintos colores» (Mendicutti, 2003: 220)
} 


\section{ANÁLISIS IDEOLÓGICO DE UN DISCURSO HUMORÍSTICO DE MASAS. LA MASCULINIDAD EN FRIENDS}

Si en el capítulo anterior estudiábamos dos obras de un novelista y, en general, una estética que, si bien vinculada a la cultura de masas, se puede considerar "culta" o especializada, así como los discursos teóricos y académicos relacionados, en este analizaremos uno de estos productos de masas: Friends, una de las comedias de situación o sitcom más popular de la historia, sino la que más. El análisis de esta serie se propone por varias razones: en primer lugar, al ser, como decimos, un producto típico de la cultura de masas, permite estudiar el discurso cómico en el contexto de la cultura de masas actual: la concepción del humor que ofrece, su función social, cómo determina su recepción... En segundo lugar, aunque se trate de una comedia televisiva, intentaremos mostrar cómo se puede analizar en los términos de una comedia en su sentido más genérico o teatral. Al elegir la representación de la masculinidad como hilo temático conductor del análisis, podremos estudiar cómo la ideología aparece, más o menos transformada, en una creación como esta, poniendo a prueba algunas de las nociones e ideas que hemos visto aparecer en los capítulos anteriores, como la perspectiva psicoanalítica del personaje cómico, los procesos de identificación, la relación de lo cómico con lo abyecto, la materialidad de lo cómico y sus analogías con la materialidad de la ideología propuesta por Althusser...

Si bien podríamos haber elegido cualquier producto de masas más actual para un análisis así planteado, ¿por qué elegir Friends, concretamente? En agosto de 2019, la marca de juguetes de construcción Lego anunciaba la salida al mercado de un set especial dedicado a la comedia de situación Friends por su veinticinco aniversario (Arcones, 2019b), apenas tres meses después de que Amazon anunciara la comercialización de una edición especial del clásico juego de mesa Trivial Pursuit dedicado a la serie (Arcones, 2019a). En mayo de 2019 se volvió a celebrar el Friends Fest en Madrid y Barcelona, una exhibición que reproducía escenarios míticos de la telecomedia y que ya se había realizado en 2018 (20 Minutos, 2019). Aunque estos hechos se enmarquen en la celebración del cuarto de siglo de la serie, otra muestra de su omnipresencia en la actualidad es que en junio de 2019 se convirtiera en noticia de prácticamente todas las ediciones digitales de la prensa española de que el servicio de streaming HBO fuera a adquirir los derechos de emisión de Friends, lo que dejaba en el aire la pregunta, recibida 
con temor, de que fuera a desaparecer del catálogo de Netflix, donde se podía ver desde el año 2015, y que en 2018 había pagado la friolera de 100 millones de dólares por mantenerla en su catálogo al año siguiente (González, 2018; La Vanguardia, 2019; Zamora, 2019). Que Netflix pague una cantidad superior a lo que costó producir la última temporada de Juego de Tronos (González, 2018) por una serie que finalizó hace quince años es indicativo del peso que aún tiene en la audiencia. En 2017 se calculaba que la serie tenía 16 millones de espectadores en la plataforma de streaming, y que en 2018 había supuesto un 4,13\% del consumo total (Lorente, 2019).

Se podría pensar que esta importante presencia de la serie tanto en los servicios de streaming como en las conversaciones de internet ${ }^{1}$ es parte de la ola de nostalgia que nos invade desde hace algunos años, pero lo cierto es que la fiebre de Friends nunca desapareció tras su final. Se pueden encontrar, incluso en medios españoles, artículos y columnas de opinión comentando la permanencia de la comedia, de al menos cada año.

Si bien es irrefutable que Friends, la que fue una de las comedias de mayor audiencia de la historia de la televisión (la emisión de su último capítulo congregó a 54 millones de espectadores solo en Estados Unidos), es un clásico moderno de la televisión que triunfa incluso entres quienes ni siquiera habían nacido cuando finalizó, también es cierto que no está exenta de polémicas. En 2018, después de la llegada de la serie al catálogo de Netflix, aparecieron varios titulares que informaban de que los jóvenes que veían la serie por primera vez estaban expresando en redes sociales su sorpresa e indignación por lo que consideraban que era una comedia homófoba, machista, racista y retrógrada en general (Kaplan, 2018b). A estas noticias le sucedieron un incontable número de artículos a favor y en defensa de la serie, recopilatorios de momentos efectivamente incómodos desde el punto de vista de la sensibilidad actual y otros que la mostraban como una serie adelantada a su tiempo (C., 2018; Horrillo, 2018; Kaplan, 2018a; Riedel, 2018).

Todo esto hace de Friends un ejemplo palmario de cómo la recepción de una comedia y del discurso humorístico en general nunca es unívoca. No solo porque las sensibilidades sociales cambien y en un momento dado se pueda encontrar ofensivo el contenido de bromas que pasaban desapercibidas hace apenas veinte años, ya que en la

\footnotetext{
${ }^{1}$ Como hemos argumentado [3.4.3] y veremos con más detalle en el próximo capítulo [8.2], a la hora de analizar la producción y difusión de los discursos humorísticos y su recepción es necesario tener en cuenta su contexto material: en nuestra época, este es el de la sociedad digital.
} 
misma época de su emisión la serie era alabada y denostada a un tiempo en Estados Unidos. Algunos denunciaban la falta de diversidad racial de la serie mientras que otros celebraban la presencia normalizada de una pareja de lesbianas - no sin cierta controversia, como veremos. Un buen ejemplo de ello es el caso de «la Monica gorda». Una de las bromas recurrentes en la serie es que Monica, una de las protagonistas, encarnada por la actriz Courteney Cox, había tenido en su adolescencia una exagerada obesidad y obsesión por la comida. Como escribe Kelsey Miller en su libro dedicado a la serie, en parte del cual comenta los pasajes más polémicos y que peor han envejecido:

No es Monica solo que más gorda. Se trata de un personaje completamente distinto (...) Es una caricatura que no guarda ningún parecido con la Monica polifacética, madura y segura de sí misma a la que estamos habituados. Monica la Gorda solo tiene una dimensión: su gordura. Habla con voz nasal y bobalicona y da un brinco cada vez que oye hablar de dulces. Nunca ha tenido una relación sexual o amorosa, y su vida gira por completo en torno a la comida (Miller, 2018, pos. 2522)

Sin embargo, mientras que para muchos era y es un grotesco estereotipo, para otros era un símbolo de liberación y aceptación de los cuerpos diversos. En 2015, la periodista Mathilda Gregory escribía un artículo titulado «Fat Monica was the TV role model I never expected» (Gregory, 2015), donde defendía que, más allá ser un objeto de mofa, Monica la Gorda era un personaje orgulloso de su cuerpo y que daba rienda suelta a sus deseos sin importarle la opinión de las personas de su alrededor. Citaremos por extenso el artículo por sus interesantes implicaciones:

I loved Fat Monica. OK, I was also terribly conflicted about Fat Monica. I didn’t want to like her. Not at all. I knew Fat Monica was a joke at my expense. I knew Fat Monica existed to mock me and bodies like mine. A joke fatty to laugh at, played by a thin actor in a fatsuit. Not a real fat person, but a gross mockery of one whose only purpose on the show was cheap laughs and to humiliate uptight present-day Thin Monica.

When fatsuited Courtney Cox danced as Fat Monica, her enthusiastic padded body gyrating prompted gales of laughter from the audience. The joke was that Fat Monica should know she shouldn't dance this way. She was fat. Had no one told her she had no business moving her body around and drawing attention to it in public?

I complained: No fat person would dance like that, with such a lack of self-consciousness, I said. You could tell Fat Monica was really a thin person covered in foam and latex, and 
not a real fat person. But then I realised that part of the brilliance of Fat Monica was that she was precisely that. She was not that fat person who has a thin person inside, she was simply a person whose body happened to be a different shape.

Fat Monica laughed, and Fat Monica desired. Oh, the lust of Fat Monica! Yes, she ate all the time, but on the other hand, SHE ATE ALL THE TIME. Her opinions on low-fat mayonnaise were well known: “It’s not mayonnaise!". Fat Monica ate publicly and unashamedly because she wanted to, and food is delicious. Having fun at a college party, she ordered herself a pizza and yelled out excitedly to claim it when it was delivered. I was amazed. Seeing a fat person order some food she wanted and claim it unabashed in a room full of people! Were we allowed to do that? Didn't we have to keep still and quiet, and certainly not be seen eating anything, ever - all in the vain hope that maybe, if we tried really hard, people around us might somehow not notice that we're fat?

But Fat Monica didn’t care. Fat Monica kept on dancing with a slice of pizza in her hand.

The joke of Fat Monica was that she didn't even seem to realise how "grotesque" she was (most of the time). We weren't just supposed to be laughing at her fatness, we were laughing at how clueless she was about it. But then I spotted a loophole this "cluelessness" offered up: an interpretation in which Monica was fine with her fatness (Gregory, 2015; el destacado es nuestro)

Lo interesante de esta opinión es que, aunque la autora es consciente de lo problemático de Monica la Gorda y de que el personaje era un gag andante y bailante cuya única razón cómica era, simplemente, ser gorda, decide darle otra interpretación en que lo cómico no es que un personaje gordo no sea consciente de su gordura y se comporte de manera despreocupada sin seguir las normas sociales, sino precisamente que se comporte de esa manera a pesar de esas expectativas sociales. En la perspectiva de Gregory, no es la sociedad quien se ríe de Monica la Gorda, sino ella la que se ríe de la sociedad, convirtiéndose así en un símbolo de liberación y aceptación de los cuerpos diversos.

Es en esta dirección en la que nos gustaría guiar nuestros análisis, centrándonos en la masculinidad como tema de estudio. Por una parte, es clara la pertinencia de un análisis ideológico de un producto cultural tan presente en la sociedad de su tiempo y en la actual, precisamente como reflejo de las preocupaciones, estereotipos y prejuicios de dicha sociedad. La premisa subyacente es que los contenidos de la comedia, los objetos de los que se ríe una sociedad y cómo se ríe de ellos y por qué, es un reflejo de cómo 
piensa esa sociedad, y que el tratamiento cómico de ciertos temas es una manera de legitimar ciertos contenidos ideológicos, al tiempo que exorciza otras angustias sociales. Pero, al mismo tiempo, en un nivel hermenéutico, sostendremos que este reflejo no es una imagen cristalina, y que el tratamiento humorístico al que la comedia somete sus temas problematiza esta misma legitimidad y la vigencia y naturaleza de estos contenidos ideológicos, permitiendo una lectura crítica o subversiva, como vemos.

En primer lugar, deberemos analizar las condiciones de recepción de la serie. Para ello, necesitamos determinar la posición social de la comedia en la época en que se emitió originalmente y la actual, con lo que deberemos estudiar las condiciones de producción de la industria televisiva y la historia del desarrollo del género de la comedia de situación, así como situar nuestro objeto de estudio en ese esquema histórico. En segundo lugar, necesitaremos establecer un marco conceptual desde el que poder estudiar la representación de la masculinidad en la serie. Finalmente, podremos dedicar el resto del capítulo al análisis temático y sus consecuencias ideológicas y hermenéuticas de nuestro objeto de estudio.

\subsection{Psicopolítica del género cómico. El significado social de la comedia de situación}

Como hemos visto a lo largo de este trabajo, lo cómico siempre ha estado ligado a manifestaciones artísticas menores y populares como el mimo, la sátira y la parodia, el grabado, etc. Entre estos géneros, no obstante, siempre ha tenido un prestigio relativamente mayor la comedia, a la que se le ha adjudicado importantes funciones psicológicas y sociales. Entre las formas cómicas populares del siglo XX, y a pesar de la comedia cinematográfica, no encontramos demasiado arriesgado considerar la comedia televisiva, y concretamente el subgénero de la comedia de situación o sitcom, dada su inmensa popularidad, como heredero directo de la comedia teatral en lo que a su significación social se refiere: ello implica, sin duda, entender la sitcom, dejando atrás su aparente inocuidad o frivolidad y su consideración de mero entretenimiento, o precisamente por ello, como receptora y vehículo de las ideologías y preocupaciones cotidianas de una sociedad dada en un momento concreto. 
En efecto, y como hemos visto en la primera parte de este trabajo, son muchos los estudiosos que, desde distintas disciplinas, coinciden en considerar el género de la comedia, dada su predisposición a tratar temas y personajes cotidianos, como especialmente permeable a las angustias y tensiones específicas de una sociedad, frente a la tendencia a la universalización y abstracción de la tragedia [ver 3.1.2.4]. Como apunta David Grote, «socially, comedy is very serious business and always has been (...) comedy has been our way of dealing with life as it happens. The kinds of comedy that we choose and enjoy tells us a great deal about the kind of people we are» (1983: 13).

En este sentido partimos de una hipótesis similar a la que expone el Nuevo Historicismo, según la cual las obras literarias, y particularmente las teatrales, son un reflejan, de manera más o menos indirecta, los significados sociales de una cultura y las tensiones de su época. Stephen Greenblatt, en su influyente trabajo «The circulation of social energy», proponía una nueva manera de leer el texto del teatro isabelino, (concretamente la obra de Shakespeare), no buscando un valor artístico supuestamente intrínseco sino las huellas de la sociedad isabelina que podía contener; o, mejor dicho, defendía que el poder de un objeto artístico no se debía, o no solo, a sus valores estéticos autónomos y universales o atemporales, sino por su capacidad de convocar y manipular energías y tensiones sociales dadas en el contexto social mediante la apropiación y transformación de entidades e instituciones, metáforas, ceremonias, etc.: «el placer y el interés literarios», dice Greenblatt, «son creaciones colectivas. Y ello es así dado que el mismo lenguaje, situado en el centro del poder literario, es el ejemplo supremo de creación colectiva» (1998: 37).

La Poética Cultural, como denomina Greenblatt a su método de análisis, busca investigar los modos en que el lenguaje literario, en tanto que práctica sociocultural, adquiere su autoridad estética y su fuerza «conmovedora»: lo que los teóricos renacentistas llamaron, siguiendo la tradición retórica griega, «energeia» (Greenblatt, 1998: 39). Esto es, la capacidad de ciertas «huellas textuales» de suscitar inquietud, placer, emociones, risa... mediante «la configuración de las creencias y experiencias colectivas, su desplazamiento de un medio a otro, su concentración en un modo estético manejable» (Greenblatt, 1998: 38-39). Estas huellas textuales «se construyeron mediante la traslación de ciertas entidades - sobre todo lenguaje corriente, pero también metáforas, 
ceremonias, danzas, emblemas, prendas de vestir, historias trilladas y otras cosas por el estilo - de una zona culturalmente delimitada a otra» (Greenblatt, 1998: 41)².

Es en esta dirección en la que querríamos estudiar Friends: nuestra hipótesis de partida es que el éxito duradero de la serie se debe a haber logrado capturar ciertas “energías sociales”, inquietudes y ansiedades, y reflejarlas de una manera que ha logrado atraer, no sólo a los espectadores contemporáneos a la época de emisión de la serie, sino a las generaciones actuales. Y el análisis debe tener en cuenta cómo Friends, en el contexto del género de la sitcom, trabaja con dichas energías sociales y, sobre todo, cómo se las ofrece al espectador, qué promesa de placer efectúa para atraerlos.

\subsubsection{Estructura y función de la comedia de situación en su contexto $\underline{\text { socio-cultural }}$}

Para ello, es necesario examinar la visión ideológica y la función que cumple la sitcom como producto de entretenimiento televisivo, es decir, cómo se justifica a sí misma; cuál es, según su propia auto-definición, el papel que la industria televisiva, y la cultural en general, asigna al entretenimiento, a la sitcom y a la comedia y el humor en general. Porque su principal función declarada es entretener, en efecto, pero hay que analizar en qué consiste dicho entretenimiento, qué es lo que atrae a la audiencia a esos productos, de qué se ríen, qué placer concreto encuentran en ella, qué es lo que les hace volver a una sitcom. Ello pasa, en primer lugar, por entender el lugar de la comedia de situación en el proceso productivo de la televisión:

Important to the analysis of broadcast sitcom is that it is made for, and distributed on, television. This may seem like a truism, but the television-ness of sitcom is something which has an impact on all aspects of it (...) Television is, whether due to technological factors or historical and cultural ones, a form of communication that has its own particular conventions, expectations, production practices and modes of reception (Mills, 2009:13)

En efecto, Greenblatt (y, en el contexto concreto de la comunicación de masas, otros autores como Umberto Eco, Raymond Williams o Stuart Hall) plantea como algo fundamental analizar el sistema de producción del objeto artístico; en su caso, los

\footnotetext{
2 Es evidente la cercanía de esta noción de «huella textual», vinculado al de «energía social», con el concepto bajtiniano de «polifonía» que en el capítulo correspondiente [5.1.3] establecimos como clave del proceso humorístico.
} 
circuitos del teatro isabelino: Shakespeare no escribía sus obras aisladamente, sino dentro de una dinámica práctica comercial que implicaba a una colectividad tanto en el proceso de creación (la compañía teatral) como el de recepción (el público). En el caso del sistema televisivo, es obvio que tanto la producción como la recepción también son colectivos, pero existen también diferencias esenciales.

En el polo de la producción, encontramos un tejido industrial e institucional altamente complejo, tal y como lo analizó Raymond Williams en su clásico estudio sobre la televisión. En la historia de los medios de comunicación modernos, Williams encuentra una diferencia notable entre el desarrollo de los primeros medios (el telégrafo y la telefonía) y las tecnologías denominadas de difusión o broadcasting: si aquellos fueron creados por necesidades de las crecientes y cada vez más complejas industrias y jerarquías militares, con las consecuentes demandas de transporte y control, y eran comunicaciones orientadas de persona a persona, en el caso del broadcasting la comunicación consistía en la difusión de mensajes variados a un público general (2003: 13).

No obstante, Williams critica el uso del término «masa» en la expresión «comunicación de masas» por inexacta: la radio y la televisión fueron desarrolladas para hogares individuales; de hecho, el único uso «masivo» y genuinamente público de la radio fue el de Goebbels en la Alemania nazi (Williams, 2003: 17). En efecto, la industria de la radio y posteriormente la televisión era un sector particular dentro la creciente industria de bienes de consumo privado, como la cámara portátil, los electrodomésticos, los automóviles... La relativa mejora en las condiciones de vida, sobre todo en el salario y el aumento de horas libres a lo largo de la semana, conllevó una mejora de la vida familiar dentro del hogar que, sin embargo, conllevaba una necesidad de nuevas formas de comunicación con el "exterior”: tanto el coche privado como la radio vinieron a cubrir esta nueva necesidad social (Williams, 2003: 20-21); la televisión tuvo un desarrollo similar, si no más acentuado, puesto que estas condiciones eran tanto más intensas en la época en que esta se popularizó (Williams, 2003: 23). Por consiguiente, tanto la radio como sobre todo la televisión estuvieron, desde su origen, particularmente ligados al ámbito de lo doméstico: «television played an important role in the ways in which domesticity was transformed in the twentieth century, as the house became a site of leisure and there was a gradual movement away from community activities in public spaces» (Mills, 2009: 19); lo que, como veremos enseguida, tuvo una importante repercusión en 
los contenidos y la estructura narrativa y argumentativa de las primeras décadas de la historia de la sitcom.

En cuanto al proceso de creación de las instituciones, públicas y privadas, de televisión (canales, productoras, emisoras, etc.), Williams destaca el hecho de que en Estados Unidos la televisión fue desde el principio una institución comercial, ya que las primeras redes de radiodifusión eran propiedad de las federaciones de productores de aparatos de televisión que, como operación secundaria, se encargaban de producción de contenido como medio de vender los aparatos que construían; la financiación, en este ambiente competitivo, se obtenía mediante la publicidad (Williams, 2003: 29). A partir de los años cincuenta, el desarrollo de la industria de broadcasting a escala global estuvo determinada por su desarrollo en este país, donde se creó una estrecha relación entre esta industria y la investigación en comunicaciones por parte del ejército y el Estado (Williams, 2003: 34): «[this] led to a situation in which it was not posible to separate, into distinct categories, military electronics, government agencies concerned with information and propaganda, and the most visible institutions of general 'commercial' broadcasting» (Williams, 2003: 35). De nuevo, esta estrecha colaboración será determinante para el desarrollo de la sitcom, pero más aún su estatus público eminentemente comercial, que, como apunta Williams, «has then to be seen at several levels: as the making of programmes for profit in a known market, as a channel for advertising; and as a cultural and political form directly shaped by and dependent on the norms of a capitalist society, selling both consumer goods and a 'way of life' based on them» (2003: 36; el destacado es nuestro).

¿Qué implicaciones tiene este contexto general de la institución televisiva en la gestación y desarrollo de la comedia de situación, que David Marc define como «the technology of the assembly line brought to art» (1997: 10)? Ante todo, hay que tener presente, como venimos insistiendo, en que la comedia de situación no es sino la traslación de la tradición cómica popular al entorno de los medios de difusión: «Sitcom can therefore be seen as the answer to the question: how can comedy be made effectively for broadcasting?» (Mills, 2009: 14). De hecho, como veremos más adelante, el estilo de grabación de la sitcom tradicional, que se ha mantenido vigente hasta hace muy pocos años, fue el resultado del intento de capturar la experiencia teatral en vivo de la representación cómica (Mill, 2009: 14). 
La principal dificultad es, por supuesto, el hecho de que la comedia tradicional sea un fenómeno fundamentalmente presencial. Si los diferentes géneros cómicos populares (no solo la comedia teatral, también el vodevil, los espectáculos de variedades, el naciente stand-up...) tenían la ventaja (y los riesgos) de mantener un contacto directo con el público, lo que facilitaba crear la relación de complicidad necesaria al tiempo que permitía modificar el número según la respuesta del público, esta posibilidad no existía para la comedia televisiva, que no solo era grabada en estudio, sino que además tenía como público potencial, casi literalmente, a todo un país, por lo que tenía que adaptar su producto a estas circunstancias (Mills, 2009: 15).

Los estudios concibieron dos soluciones a este problema: la grabación delante de una audiencia, cuyas reacciones se grababan y luego se incluían en el montaje final de la comedia (las laugh tracks o canned laughter; «risas enlatadas», como se conoce popularmente en España) y las muestras de audiencia ${ }^{3}$. Para David Marc, es esto último lo que determinaba realmente el contenido del programa y lo que caracteriza a la sitcom definitivamente como epítome de producto industrial de masas (1997: 27). La sitcom es un producto que requiere unas grandes cantidades de inversión de capital, destinado a un mercado nacional: es necesario un sistema de producción que supervise todos los factores posibles y que nada quede al azar para satisfacer a un complejo entramado de equilibrios entre creadores, productores, canales de televisión, anunciantes... (Marc, 1997: 27)4.

Las audiencias de muestra, y posteriormente el rating o cuota de audiencia como confirmación de los pronósticos que las encuestas realizaban, sirven a los creadores como único contacto con su posible público para confeccionar un producto diseñado al mínimo detalle para alcanzar el mayor número posible de espectadores. Este hecho, hasta la llegada de la televisión por cable, que llevó a una fragmentación de la audiencia y permitió crear una programación más ajustada y, en algunos casos, sofisticada (Marc, 1997: 136), conllevaba que las comedias de situación fueran lo más amables posibles y apelaran las sensibilidades mayoritarias(Marc, 1997: 20-23): «sitcoms depend on

\footnotetext{
${ }^{3}$ Por «muestra de audiencia» nos referimos al sistema por el que una cadena testeaba previamente sus productos con una pequeña muestra de espectadores de cierto nicho social, a los que posteriormente preguntaba sus opiniones.

${ }^{4}$ En el libro de Kelsey Miller sobre Friends (Miller, 2018) podemos encontrar jugosas anécdotas sobre el nacimiento de la serie, las negociaciones que los creadores tuvieron que mantener con los ejecutivos de la cadena (NBC) y la productora (Warner Brothers) y los continuos «consejos» y «peticiones» creativos por parte de estos que tuvieron que sortear, además de con las agencias de publicidad, y la manera en que todas estas relaciones influían en la creación final de la comedia y determinaban en muchas ocasiones los argumentos.
} 
familiarity, identification and redemption of popular beliefs (...) Despite several attempts to push it in deviant directions, insists on a portrayal of reality that can best be defended with statistics», lo que daba lugar al «genre’s unflappably centrist political psychology» (Marc, 1997: 20).

En lo que atañe al laugh track, si bien es un recurso que ha sido habitualmente denostado por artificial y “manipulador”, también podría leerse como la mayor seña de autenticidad y sinceridad por parte de la comedia de situación. Como ya hemos mencionado, el laugh track surgió como intento de retener parte de la naturaleza colectiva de la experiencia de la comedia tradicional en su emisión televisiva. Pero la inclusión de una audiencia en la grabación del programa (lo que todavía se practicaba en el caso de Friends) también determinaba otros aspectos estéticos de la sitcom. En primer lugar, implicaba que las cámaras estaban localizadas solo a un lado de la escena, recordando, de alguna manera, la disposición en caja de una representación teatral burguesa tradicional. En segundo lugar, los actores debían realizar una interpretación más “exagerada” (más propiamente teatral), de modo que sus gestos pudieran ser percibidos por el público presente. Esto, que da pie a que muchos críticos de la sitcom le reprochen su artificiosidad y poca verosimilitud, hace de la comedia de situación un género peculiar dentro de los géneros de ficción televisivos por su carácter declaradamente teatral, artificioso (Mills, 2009: 14). En efecto, aunque todo producto de un medio de difusión, incluyendo los dramas o los noticiarios, al tener que apelar a grupos diversos de audiencia tienden a ofrecer representaciones normalizadas con los que la audiencia debe coincidir/admitir para obtener placer, la sitcom es el único género que, al incorporar las respuestas de una audiencia “real”, reconoce ofrecer unas posiciones concretas desde las que leer sus productos (Mills, 2009: 16).

Pues la función principal del laugh track, en efecto, es guiar la interpretación del espectador, al señalarle qué momentos son cómicos (o cuáles son enternecedores, sorprendentes, etc.). Otros recursos tradicionales sirven a este papel. Por un lado, el estilo de grabación conocido como «monstruo de tres cabezas», que consistía en una cámara que grababa un plano general y otras dos que enfocaban a dos actores dialogando en plano/contraplano, otorgaba a la reacción gestual del actor tanta o más importancia que al propio texto del diálogo: la reacción sorprendida o burlona de un personaje ante la acción de otro indica a la audiencia que se trata de un comportamiento anormal, y por tanto cómico (Mills, 2009: 39). Por otro lado, esto concuerda con el peso de la 
interpretación gestual del actor cómico, que para Wes D. Gehring define la comedia como un género clown (Gehring, 1997: 1, cit. en Mills, 2009: 37).

Es difícil subrayar lo suficiente la importancia que tiene esta función de guía del laugh track por sus implicaciones ideológicas ${ }^{5}$ (implicaciones que tendremos oportunidad de comprobar más adelante en el análisis). De momento, y aun a riesgo de ser redundante el principal y más relevante es que explicita el carácter cómico de la comedia de situación. Esta boutade deja de serlo si pensamos en las consecuencias que tiene el pathos cómico en el contenido y tratamiento del género. Como dice Chesebro, «these series are designed to entertain, but they are often constructed to convey “messages" to their viewers», mensajes que son más fácilmente “digeridos” (y disimulados) bajo la apariencia del entretenimiento inocuo (Chesebro, 2005: 368).

\subsubsection{Breve historia de la comedia de situación}

En efecto, desde sus orígenes, la sitcom se plantea como un género de entretenimiento distinto, por tanto, también en la valoración de su calidad ética y estética, de los programas informativos como los documentales o, dentro de los géneros de ficción, los dramas. Como anota Mills, la caracterización más habitual de la comedia de situación es su simpleza:

The sitcom is a genre which is highly complex but which must pretend it is not. In itself this says something highly significant about the social role entertainment culture is often required to play (...) The sitcom's primary aim is to be funny; it is defined by its humorous content and audiences come to it with the expectation of laughter (2009: 5)

Buena muestra de ello es el que el laugh track sea, precisamente, únicamente grabación de las reacciones positivas del público, y que la sitcom nunca deje de la posibilidad de mostrar su desacuerdo con ella (Mills, 2009: 17).

\footnotetext{
${ }^{5}$ Una propuesta es la de Žižek: «Después de algún comentario supuestamente ingenioso o divertido, se escucha la risa y el aplauso incluido en la banda de sonido del espectáculo - ésta es la contrapartida exacta del coro en la tragedia clásica y es en ella donde hemos de buscar la "Antigüedad viva”. Es decir, ¿por qué esta risa? La primera respuesta posible - que sirve para recordarnos cuándo hemos de reír - es bastante interesante porque implica la paradoja de que la risa es una cuestión de obligación y no un sentimiento espontáneo; pero esta respuesta no basta porque en general no nos reímos. La única respuesta correcta sería que el Otro - encarnado en el aparato de televisión - nos está descargando de la obligación de reír, ríe en vez de nosotros. Así que, aun si cansados de un fatigoso día de trabajo estúpido, nos pasamos la tarde mirando amodorrados la pantalla de televisión, después podemos decir que, objetivamente, por medio de otro, nos la pasamos realmente bien» (Žižek, 2018: 64)
} 
El pathos de la comedia de situación, por tanto, es el de lo entretenido, lo simple, lo amable ${ }^{6}$, en consonancia con la «ideología de la positividad» [ver 3.4] que permea todo el siglo XX, sobre todo en Estados Unidos: de todos los rangos de emociones que puede suscitar lo humorístico, excluye los más incómodos u ofensivos. Para David Marc, la sitcom ofrece, para los Estados Unidos de la posguerra y la Guerra Fría, de la sombra amenazante de la bomba nuclear y el posible Fin del Mundo, una optimista promesa de paz social, felicidad individual y crecimiento económico y ascenso de las clases medias (1997: 9; 22-23), frente al cinismo propio de la filosofía y la «Alta Cultura» de posguerra:

The agnostic cosmic Weltschmerz that pervaded "high culture" post-war philosophy and literature stood at the margin of terminally happy popular culture, insisting upon a subjective counterpoint to the well-promoted images of upwardly-mobile mortgagees happily abandoning the complexities of urban life in station wagons (...) Meanwhile, the television played on. A message so old (i.e. Good is rewarded; evil is punished) from an Oracle so new implied an historical continuity that flew in the face of the bombed-out world of the dying inner-city streets and the pockmarked suburban landscape. TV was a medium committed to happiness and it had little use for comedians or anyone else who refused to share in the joys of material consumption (Marc, 1997: 37)

Por tanto, podemos decir que la sitcom estadounidense vende, casi literalmente, una imagen idílica del país y acorde con una ideología capitalista y de la sociedad de consumo, como advertía Williams en el párrafo citado más arriba («[television] as a cultural and political form directly shaped by and dependent on the norms of a capitalist society, selling both consumer goods and a 'way of life' based on them»). Y, si algunos «integrados», rescatando la clasificación de Eco, como Brett Mills mantienen una visión positiva del papel de la televisión y la comedia de situación en particular («television’s domesticity is a powerful tool for engaging all citizens in democracy and social activities both within and outside of the home» (2009: 19)), probablemente sea más acertado caracterizar el género, generalmente, «as a (...) powerful form of social integration and control», ya que «many of its main uses can be seen as socially, commercially and at

\footnotetext{
${ }^{6}$ Cuenta Kelsey Miller en su libro que cuando preguntaba a conocidos suyos por qué les seguía gustando Friends, estos les respondían que acudían a la serie cuando necesitaban evasión: «Ponían Friends cuando las noticias de los informativos se les hacían insoportables. Para quienes crecieron viendo la serie, era una forma de recordar una época más sencilla, menos conflictiva, no del mundo en general, sino de sus propias vidas. Muchos veían la serie durante épocas de intensa depresión o de estrés: rupturas de pareja, desempleo, los primeros meses de insomnio después de tener un bebé... «Pero ¿por qué Friends?», me preguntaba yo. ¿Porque la serie tocaba todos esos temas con un punto de optimismo? ¿Era ese eco emocional lo que buscaban al verla? «No, qué va» me decían. «Es que es divertida, nada más».” (Miller, 2018: pos. 102).
} 
times politically manipulative» (Williams, 2003:16). Ya Hans Magnus Enzensberger, al caracterizar lo que él llama «la industria de la conciencia», advertía de que «the mind industry's main business is not to sell its product; it is to "sell" the existing order, to perpetuate the prevailing pattern of man's domination by man, no matter who runs the society and no matter by what means» (Enzensberger, 1982: 10) - una definición que compartiría casi cualquier miembro de la Escuela de Frankfurt (Horkheimer y Adorno, 2016; Marcuse, 2016).

Esta función que podemos llamar ideológica de la sitcom es sin duda facilitada precisamente por esta imagen de sencillez y de entretenimiento inocuo que mencionábamos más arriba, que ayuda a fomentar una visión “naturalista”, auténtica y sincera de lo que representa, esto es, la familia americana. Ya hemos hecho alusión varias veces a la domesticidad propia de la televisión y particularmente del género de la sitcom. La necesidad de los productores de contenido de apelar a una audiencia muy amplia les lleva a hablar del hogar para reflejar y encajar en el contexto doméstico en que los programas de televisión son mayoritariamente consumidos (Mills, 2009: 19), y especialmente los programas cómicos se centraron desde muy pronto en el hogar y la familia como temas predilectos (Mills, 2009: 20).

La comedia de situación, por tanto, se presenta como un duplicado del espacio doméstico americano, si bien uno visiblemente idealizado y alejado de la realidad. Además, desde los orígenes televisivos del género hasta aproximadamente los años ochenta, el espacio doméstico representado es concretamente el de los hogares suburbanos que se empezaron a desarrollar a mediados del siglo XX (Marc, 1997: 42) y que se han convertido en el estereotipo principal de la clase media blanca estadounidense; unos suburbios que servían de espacio simbólico para esta imagen de optimismo pacífico de posguerra:

Television - especially the sitcom - valorized suburbia as democracy's utopia realized, a place where the white middling classes could live in racial serenity, raising children in an engineered environment that contained and regulated the twin dangers of culture and nature (...) [Representa el retorno a un] stable, divorce-free, two-parent household in which father ventures out into the wild to hunt for a paycheck while mother stays at home enforcing physical and spiritual cleanliness. Drugless and anti-erotic, this suburb of dreams is devoid of dangerous strangers, public transportation, economic fluctuation and other anxiety-producing phenomena associated with the urban world (Marc, 1997: 42-43) 
Como venimos diciendo, esta representación de la vida suburbana estaba altamente idealizada, y hasta Brett Mills reconoce que una representación así de lo doméstico tiene unas fuertes implicaciones ideológicas que hacen de la mayoría de las sitcoms productos terriblemente conservadores (2009: 21). Ya hemos podido leer en la anterior cita de Marc que el modelo familiar que se representa en la sitcom tradicional es el del matrimonio heterosexual en los que el padre constituye la figura de autoridad moral y económica, la madre ejerce las funciones de ama de casa y madre ideal y los hijos, aunque rebeldes en ocasiones, son esencialmente bienintencionados y respetuosos con sus mayores.

$\mathrm{Y}$ es que, como venimos apuntando, la otra cara del entretenimiento prometido por la sitcom es su fundamental didacticismo: sería difícil dilucidar si este carácter pedagógico es la manera del género para justificar su valor social, o por el contrario el entretenimiento sirve para hacer llegar más fácilmente una función esencialmente ideológica. En cualquier caso, es imposible obviar el hecho de que «producers working in the genre have taken careful pains to respect the age-old tradition of grafting humour to moral suasion» (Marc, 1997: 20).

Esta tarea didáctica tiene como vehículo la estructura narrativa típica de la sitcom tradicional: el episodio se inicia con un status quo familiar; un error (cometido, normalmente, por los hijos o la esposa) provoca un desequilibrio de este estatus que ha de ser corregido; tras la intervención de la figura de autoridad (el padre), la armonía familiar es restaurada y, de paso, una lección es aprendida tanto por la familia como por los espectadores (Marc, 1997: 191; Kutulas, 2018: 1173) ${ }^{7}$.

\footnotetext{
${ }^{7}$ Chesebro, en su estudio de los valores transmitidos por las series de televisión "deduce” este esquema al adaptar el sistema dramático de Kenneth Burke, que divide las etapas de una acción de la siguiente manera (Chesebro, 2003: 372):

i. $\quad$ polución, a la que corresponde la pregunta ¿qué normas sociales se han roto?

ii. culpa; ¿de quién es la responsabilidad?

iii. purificación: ¿de qué manera se restaura la polución?

iv. redención: ¿qué orden social emerge de este proceso?

Chesebro también toma prestado la clasificación de Northrop Frye en cinco modos de representación (2003: 370-371):

a) el modo irónico, en el que el protagonista es menos inteligente y capaz que el espectador, y normalmente es el causante de la polución;

b) el modo mimético, en el que el personaje es tan inteligente como el espectador;

c) el centrado en el liderazgo, en el que un personaje es superior a los demás, pero como consecuencia de un entrenamiento especial y al enfrentarse a las mismas circunstancias que la gente "corriente" les ofrece un modelo de virtud a seguir;

d) el modo romántico el personaje es superior en inteligencia y en control sobre el medio;

e) y el modo mítico, el personaje es superior a los demás en virtud de una naturaleza especial y sobrehumana
} 
Podemos tomar como ejemplo evidente dos de las primeras sitcom de éxito de la historia, ambas emitidas en los años cincuenta: Father Knows Best y I love Lucy. La primera representa prototípicamente el modelo de familia blanca heterosexual en que el padre ocupa la posición de autoridad moral, representando lo que algunos historiadores denominan «The American Celebration» (Marc, 1997: 46). La particularidad de I love Lucy es que el personaje protagonista que da nombre a la serie, la esposa, representa lo que se ha dado en llamar «rowdy wife» («esposa alborotadora»), puesto que el argumento de la mayoría de episodios consiste en sus intentos por menoscabar la superioridad intelectual, moral y económica del marido realizando planes absurdos por participar en el mundo del espectáculo al que pertenece su marido, para al final fracasar y aprender la lección de no cuestionar la estructura patriarcal (Marc, 1997: 46).

Para David Marc Father Knows Best ejemplifica perfectamente la estructura pedagógica de la sitcom tradicional, ocultando su función pedagógica hasta tal punto de que «the lessons of Father Knows Best are never dramatized as revelations. They are more in the spirit of smiling reminders, aimed at well-fed, rational, civilized citizens, of the universal and eternal truths that already dwell in a Christian soul tempered by American egalitarianism» (1997: 53).

Este modelo para la comedia de situación permaneció prácticamente inalterado hasta los años noventa, con algunas excepciones. Incluso en los años sesenta, la época en que la guerra de Vietnam, los movimientos por los derechos civiles y el desarrollo de la contracultura hacían tambalear los cimientos ideológicos de la sociedad estadounidense, la sitcom continuó en una huida hacia delante de despolitización escapista con series con elementos fantásticos o de ciencia ficción como Bewitched (en el que un marido "normal” o normativo tiene prohibido a su mujer bruja usar sus poderes) o My Favorite Martian (en el que un alienígena empieza a convivir con otro hombre blanco heterosexual de clase media) (Marc, 1997: 106 y ss.). Y, a pesar de estos elementos fantásticos, la enseñanza normalizadora del género seguía intacta: si en estas comedias se introduce Otro mágico (una bruja, un alien) en la vida de un hombre blanco heterosexual de mediana edad, es para que este le enseñe las ventajas de una vida “como dios manda”:

Según este esquema, es evidente que una serie como I Love Lucy se clasificaría como de modo irónico, mientras que Father Knows Best entraría en la categoría del modo de liderazgo; ambos casos servirían a la perfección al propósito didáctico de la sitcom. 
The discipline and respectability of a nine-to-five, Thank-God-Its-Friday existence are valorized as far more satisfying than the freedom to gratuitously manipulate the world to one's individual pleasure (...) Though on the Surface the Other seems capable of simplifying life with its magical Powers, the heroic "normal" persona knows that achievement is only truly worthwhile if it comes as the result of self-repression; he prefers to do it the hard way (Marc, 1997: 109)

Este aspecto es lo que llevará a muchos críticos a denostar la sitcom. David Grote, en su libro de elocuente y apocalíptico título, The End of Comedy (1983), lamenta que la sitcom haya eliminado el carácter subversivo que ha caracterizado al género cómico a lo largo de los siglos, desde Menandro hasta Molière. Grote, apoyándose en Northrop Frye, describe el Argumento (Plot) esencial que vertebra toda la Comedia desde Menandro hasta Moliére, como vimos en los capítulos correspondientes [1.1.2.3; 3.2.1.1]: un joven pretende a una joven, se le opone una cierta autoridad paternal, algún giro de guion acaba con esa resistencia y acaba en final feliz con la unión de los jóvenes amantes (Grote, 1983: 18). Como vemos, el argumento cómico es una rebelión contra la figura del Padre o cualquier figura de autoridad de carácter paternalista (viejos, jueces, médicos, etc.) y la comedia representa un escapismo de la ley y la norma social:

The comedy plot is a threat to all of his power and authority because in the comedy, Father knows best. Pop is never right, and Junior not only rises in result but always wins. By implication, every social code, every piece of social authority, can fall for the young lover. Comedy ultimately, is anarchy, even if only a most temporarily form of anarchy. When Father can safely be challenged, temporarily anything goes (Grote, 1983:27)

Por tanto, la comedia tradicional es fundamentalmente social en el sentido de que analiza y critica mediante la risa los obstáculos que encuentran los amantes como elementos que interrumpen con sus vicios (la avaricia, la misantropía, la lascivia, como vemos en la obra de Molière) la salud de la sociedad (Grote, 1983: 19).

Si bien estos obstáculos, como decimos, siempre se materializan en una figura de autoridad paternal, este argumento es, en definitiva, una promesa de un futuro mejor, simbolizada por la unión de los jóvenes amantes (Grote, 1983: 36). Esta sería la principal diferencia de la comedia de situación estadounidense con respecto a esta tradición milenaria: que obvia el cambio (Grote, 1983: 59) ${ }^{8}$. Normalmente, la premisa de la serie

\footnotetext{
${ }^{8}$ Claro que, como el mismo Grote reconoce, el cambio que promete la comedia tradicional es más bien de pequeño calado, ya que los vicios atacados son siempre individuales, mientras que el sistema social sigue
} 
empieza con una familia ya establecida, y sus personajes no evolucionan, no aprenden, siempre se vuelve al status quo: por tanto, no podemos hablar de héroes cómicos, pues los protagonistas de la sitcom no son agentes activos que buscan el cambio (Grote, 1983: 71).

Si bien The Dick Van Dyke Show (1961-1966), de Carl Reiner, había introducido un tímido intento de mayor realismo social en la estructura de la sitcom doméstica, su legado no germinaría hasta los años setenta con All in The Family (1971-1979), M.A.S.H. (1972-1983) y, sobre todo, The Mary Tyler Moore Show (1970-1977) (Marc, 1997: 98). Esta tres series significarían la madurez del género en cuanto a realismo, ideología tímidamente progresista, riqueza en la caracterización de personajes, sofisticación del humor, etc., y sin embargo, en los años ochenta se volvió a la sitcom familiar más conservadora (Chesebro, 2003: 368) al tiempo que series como Cheers (1982-1993) continuarían el legado de esta litcom como subgénero prestigioso pero limitado en audiencia (Marc, 1997: 164-166; Kutulas, 2018: 1173).

La gran innovación de series como The Mary Tyler Moore Show fue trasladar el modelo familiar al lugar de trabajo e introducir como elemento narrativo la evolución psicológica del personaje, lo que requería una caracterización más rica y "realista" (Kutulas, 2018: 1173). Por lo tanto, si volvemos a tener en cuenta el modelo de análisis de Chesebro, en un programa como este primaría el modo mimético. El propio Chesebro usa The Mary Tyler Show para ejemplificar el modo mimético, y recuerda que este es el más persuasivo de todos, pues nos invita a mirar la rutina cotidiana como divertida o significante, al tiempo que ofrece fácilmente modelos y valores que deberían ser adoptados; la adopción de estos valores y virtudes son fácilmente asimilables precisamente porque no se proponen como extraordinarios, sino entrelazados y compatibles con la vida cotidiana (Chesebro, 2003: 376-378).

intacto. En este sentido, las dos tradiciones cómicas no difieren tanto, salvo en el hecho de que, efectivamente, en la sitcom clásica estadounidense la familia es respetada. 


\subsubsection{La revolución televisiva de Friends: su significado psico- $\underline{\text { social }}$}

A pesar de todo, en estas series de los ochenta la estructura familiar del dramatis personae sigue vigente, así como la fórmula argumental de ruptura del orden-restauración y moraleja (Kutulas, 2018: 1174). Esto es lo que, ya en los años noventa, vendría a romper la muy innovadora (y mucho más valorada y atendida por la crítica especializada que Friends) Seinfield (1989-1998), que empezó a emitirse dos años antes que nuestro objeto de estudio. Sus personajes, profundamente llenos de errores y deficiencias morales, no mostraban ni siquiera intención de mejorar como personas (Kutulas, 2018:1174); en ella los personajes principales nunca llegaron a formar una familia. También la revolucionaria serie de animación The Simpsons (1989) se significó como una sátira de la familia tradicional estadounidense y del género que la idealizó.

En este sentido, parecería que Friends imitaba la misma premisa que Seinfield al tratar la vida cotidiana de un grupo de amigos en una gran ciudad como Nueva York, pero las diferencias también eran notables. En primer lugar, el hecho de que Friends, como el título de la serie y el estribillo del tema de apertura («I’ll be there for you») apuntan, sí que proponía la formación de una familia sui generis compuesta por los seis personajes principales que se apoyaban unos a otros (Kutulas, 2018: 1176; Miller, 2018: pos. 1372). Por otra parte, es cierto que, como hemos visto, el concepto de una serie sobre adultos solteros no era nuevo, pero sí lo era el hecho de que no fueran compañeros de trabajo ${ }^{9}$ así como la juventud de los personajes, que empezaron la serie en la veintena (Kutulas, 2018: 1175).

Es decir, era la primera vez que se representaba en una serie popular la Generación $\mathrm{X}$ y, sobre todo, con un "realismo" 10 inusitado: como los propios creadores declaraban, no querían hacer «a typical 'family in the living room' sitcom» sino algo basado en su propia experiencia vital (Marc, 1997: 77). Por tanto, había una intención de sinceridad autobiográfica por parte de los creadores que se complementaba con la búsqueda de una

\footnotetext{
${ }^{9}$ El elenco protagonista de Friends está formado por seis personajes: Monica es la hermana pequeña de Ross, amiga del instituto de Rachel y antigua compañera de piso de Phoebe; Chandler y Joey viven en el apartamento de enfrente del de Monica.

${ }^{10}$ Por supuesto, la serie tuvo desde el principio críticas y burlas por su inverosimilitud en algunos aspectos, como que Monica se pudiera permitir pagar un apartamento como el suyo o que pasaran la mayor parte del tiempo y en cualquier horario en la cafetería. Friends reflejaba la vida real «solo que un poquitín mejorada» (Miller, 2018: 1799), lo que Lauren Zalaznick denominaba «la normalidad deseable» que presentaba la televisión de la época (Miller, 2018: 1799). Este idealismo ingenuo es la principal razón de las críticas que suele recibir la serie, aun en la actualidad.
} 
intensa relación con los espectadores: la sensación de que el espectador se sintiera parte de esa familia de amigos (Todd, 2011: 856), «facilitating the interactions between audience and characters with the expectation that viewers would not just watch the show passively or while channel-surfing but care enough about the characters to pay attention and interact with the show» (Kutulas, 2018: 1177).

Es cierto que la identificación con los personajes televisivos es un fenómeno típico del medio e incluso de la cultura popular debido en parte a la percepción de la televisión como objeto cotidiano y doméstico, que lleva a ver a los protagonistas de sus contenidos como gente corriente (Mills, 2009: 20), y las sitcoms hacía mucho que eran centro de conversaciones cotidianas, pero es innegable que la influencia de Friends fue y sigue siendo mucho más intensa que la mayoría de producciones televisivas de su época, solo a la altura de series como Los Simpsons. Además de haber sido durante su emisión una de las series más vistas en Estados Unidos, y aumentar esas cifras de audiencia en las reposiciones actuales; o su presencia continuada en internet, con artículos con anécdotas del rodaje, recopilatorios de mejores momentos o rumores de un posible regreso de la serie, el mundo de Friends pasó a la vida real. Muchas mujeres imitaban el peinado de Rachel; las cafeterías como Central Perk, si bien ya existían, no eran conocidas fuera de Nueva York y su popularidad se debe en gran parte al éxito de la serie; incluso, como estudió Paolo Quaglio, la manera de hablar de los personajes ha influido en los jóvenes de los noventa y el nuevo milenio (Kutulas, 2018: 1181)

Ahora bien, el objetivo de este análisis es precisamente intentar dilucidar cuál es la causa de esta identificación tan intensa y duradera, una vigencia inusitada en el panorama de la comedia de situación (Seinfield es ahora una serie mucho menos conocida) que convierte a Friends en un clásico en toda regla ${ }^{11}$. Para muchos autores como Kutulas o Kelsey Miller, la razón del éxito transcultural y prolongado a lo largo de generaciones es que, más allá de su apego superficial por el contexto de los años noventa, «es una serie acerca de algo universal: la amistad; una serie que trata del periodo de transición de la primera madurez, cuando tus coetáneos y tú carecéis de ataduras familiares y de pareja, y os sentís al mismo tiempo ilusionados con el futuro y

\footnotetext{
${ }^{11}$ Otro ejemplo de la pervivencia en el imaginario popular de la serie: en julio de 2019, la revista satírica El Mundo Today publicaba el artículo "El tribunal de Estrasburgo ratifica que Ross y Rachel no estaban juntos cuando él se acostó con la chica de la fotocopiadora” (https://www.elmundotoday.com/2019/06/eltribunal-de-estrasburgo-ratifica-que-ross-y-rachel-no-estaban-juntos-cuando-el-se-acosto-con-la-chica-dela-fotocopiadora/), haciendo referencia a uno de los debates más socorridos y acalorados entre los aficionados a la serie y del que tendremos ocasión de ocuparnos en su debido momento.
} 
desorientados. Lo único seguro que tenéis es vuestra pandilla de amigos» (Miller, 2018: 136). Como decimos, Friends era la primera telecomedia que tenía como protagonista a la Generación X, la cual presentaba un cambio profundo respecto a las anteriores: los jóvenes que a principios de los años noventa estaban en la veintena se casaban cada vez más tarde y no elegían su carrera profesional estable hasta pasados los treinta, prolongando de esta manera esa etapa vital en la que su entorno social y de apoyo inmediato eran sus amigos (Miller, 2018: 1834). Sin embargo, no creemos que esto sea enteramente la razón de su éxito, o, mejor dicho, probablemente esta "exaltación de la amistad” sea más bien el síntoma superficial de unas transformaciones sociales y en el inconsciente colectivo más profundo.

En el capítulo correspondiente [3.1.5] expusimos cómo Charles Mauron, en su Psicocrítica del género cómico, planteaba que la comedia clásica debía su vigencia secular a que apelaba al inconsciente profundo del espectador, presentando una fantasía de triunfo que compensaba su sometimiento a la figura paterna en la realidad cotidiana, y, sobre todo, que esta fantasía de triunfo era una proyección histórica que respondía a un cierto tipo de sociedad, pero que no se ajustaba, por ejemplo, a la comedia aristofánica.

La pregunta que debemos formularnos ahora es, por tanto: ¿̇a qué mutaciones en la sociedad se deben las transformaciones que operó Friends en la tradición de la comedia de situación? ¿Cómo afecta a la estructura de la comedia y los procesos de identificación y catarsis correspondientes? ${ }^{12}$ En el cuarto capítulo expusimos [4.2.3] la teoría foucaultiana de la sociedad disciplinaria, un poder de normalización que producía sujetos dóciles según las necesidades económicas y de gobernanza. ¿Cómo podría reflejarse este poder normalizador en la comedia de situación? En el caso de la sitcom familiar tradicional nos parece evidente, y ya lo hemos venido esbozando a lo largo de este epígrafe al hablar de la estructura didáctica de estos programas, alrededor de la figura del padre como autoridad. En estos casos, la risa de la comedia serviría como una sanción normalizadora tal y como hemos visto que la plantea Bergson y según el esquema que presentan Freud y Mauron: los espectadores se reirían del infantilismo propio de los personajes adolescentes o de las esposas díscolas, quienes serían, mediante el ridículo, devueltos al redil de la autoridad patriarcal.

\footnotetext{
12 Ver 3.2.1.3 para la discusión teórica de Jauss acerca de los procesos de identificación y catarsis involucrados en lo cómico.
} 
Este esquema, sin embargo, no funciona al intentar aplicarlo a una serie como Friends. No sólo por la sustitución de la familia como protagonista ${ }^{13}$ (cuyas consecuencias más profundas analizaremos enseguida), sino que la misma estructura coral del protagonismo facilitaba a los creadores y guionistas liberarse del esquema narrativo pedagógico ruptura de la armonía - reconstrucción - moraleja (Kutulas, 2018: $1181)^{14}$. El propio mecanismo de la risa cambiaría, dado el especial hincapié que los creadores hacían sobre la identificación mimética del espectador con los personajes: estos no eran simplemente unos caracteres infantiles de quienes reírse desde la superioridad y utilizando la risa burlona como sanción social, sino alguien con los que identificarse - lo que, sin duda, complica nuestra percepción del mecanismo catártico de la risa, al buscar la identificación y no la superioridad respecto a unos personajes ridiculizados.

¿Qué cambios en los procesos de subjetivación han ocurrido? Ya el propio Foucault llegó a darse cuenta de que su concepto de sociedad disciplinaria no era del todo adecuado para describir la sociedad contemporánea (Foucault, 2016; Han, 2014: 39), fruto de las transformaciones operadas por el neoliberalismo (Santamaría, 2018) y que el filósofo francés no llegó a ver en toda su evolución. Entre todas las propuestas para llenar esta laguna, una de las más conocidas y valoradas es la expuesta por Byung-Chul Han en trabajos como La sociedad del cansancio (2017) o Psicopolítica (2014).

Según el filósofo de origen coreano, en la actualidad se ha sustituido el poder disciplinario por un sistema aparentemente más libre, en el que los individuos ya no sufren las coacciones propias de estructuras disciplinarias como las escuelas, las fábricas, etc., y tienen la libertad de "hacerse a sí mismos”. Pero esta libertad es una trampa, puesto que esta libertad de auto-creación, de una «permanente optimización propia», el imperativo del «poder hacer» que sustituye al «deber» de la sociedad disciplinaria se convierte en una coacción aún más intensa por voluntaria (Han, 2014: 12; 45-46). El poder neoliberal, según Han, encuentra más eficiente que la explotación mediante coacciones externas el conseguir que el sujeto se explote a sí mismo mediante ese mandato inconsciente del

\footnotetext{
${ }^{13}$ Para entender la vigencia del esquema familiar-moralizante en los años noventa, cabe mencionar la anécdota de que uno de los productores de la cadena donde se iba a emitir la serie propuso la creación de un personaje de mayor edad que, de vez en cuando, apareciera en escena para aconsejar a los jóvenes protagonistas (Miller, 2018: 429)

${ }^{14}$ Ahora, en cambio, la estructura típica del episodio sería la siguiente: dos de los amigos del grupo iniciarían alguna actividad juntos, uno heriría los sentimientos del otro y, al final del episodio, pediría disculpas y se reconciliarían.
} 
«hacerse a uno mismo», «ser la mejor versión de sí mismo» (2014: 28-29; 2017: 27) ${ }^{15}$. El sujeto en la época contemporánea, por tanto, ha pasado de ser un «cuerpo dócil» a ser un «sujeto de rendimiento» ${ }^{16}$. Es importante recalcar que, en este paso de la sociedad disciplinaria a la sociedad del rendimiento, sigue vigente la función de normalización del poder: aunque hayan cambiado las técnicas de subjetivación y las características del sujeto, el objetivo y el resultado sigue siendo la constitución de un sujeto «normal» que sea productivo para el poder.

Nuestra hipótesis es que, precisamente, una serie como Friends refleja, en sus innovaciones respecto a la tradición de la comedia anterior este cambio de paradigma hacia una sociedad del rendimiento. Sin ir más lejos, y como venimos diciendo, el principal cambio que opera la serie es la desaparición de la familia como núcleo de la serie. Para Foucault, la familia, que era en sí misma una isla de poder de soberanía en la sociedad disciplinaria, constituía «precisamente la bisagra, el punto de engarce absolutamente indispensable para el funcionamiento mismo de todos los sistemas disciplinarios» (2005: 91). Según el estudioso francés, la institución familiar era la pieza esencial sobre la que se sostenían el resto de instituciones disciplinarias.

Pues bien, en Friends no sólo desaparecía la familia como centro de la comedia, sino que era representada como el foco problemático desde el que se originaban todas las inseguridades y faltas de los protagonistas. En el proceso de crear unos personajes con los que el público se pudiera sentir identificados, era necesario dar a conocer un pasado que explicara su personalidad, y uno de los elementos cruciales de estas historias era la

\footnotetext{
${ }^{15}$ Cada vez es mayor la bibliografía que critica el imperativo de felicidad contemporáneo, la obligación de ser feliz, como una estrategia del poder neoliberal para mantener a la población en permanente estado de insatisfacción y promover el consumo (ver Ahmed, 2019; Berlant, 2020; Santamaría, 2018, entre otros). También hemos mencionado este fenómeno al hablar en el capítulo anterior de la normalización de las identidades homosexuales. Sin duda, y como hemos tenido ocasión de discutir [3.4], el lugar del humor en la sociedad actual tiene que ver con esta atmósfera ideológica.

${ }^{16}$ Foucault, en su Curso del Collège de France dedicado al Nacimiento de la biopolítica, analizaba cómo la teoría neoliberal del trabajo entiende que el trabajador es un capital de sí mismo, que sus aptitudes para el trabajo son el capital necesario para percibir ingresos, y por tanto es un «empresario de sí mismo» (Foucault, 2009: 226-228). En consecuencia, en la actualidad el trabajador tiene que embarcarse en un proyecto («emprender», según la jerga) de mejora de sí mismo, no solo en sus conocimientos habilidades propiamente técnicas, sino también en su actitud, personalidad, capacidades sociales, etc., de modo que ese "capital humano" sea más valorable en el mercado de trabajo. A esto nos referiremos cuando hablemos de éxito respecto a las trayectorias de nuestros personajes: éxito en la vida laboral, pero también en la vida amorosa, familiar, social, etc. Miller describe como sigue la Generación X: «La Decimotercera Generación estaba marcada por un sentimiento de desorientación, quizá porque se les había dirigido muy poco de pequeños. Además, cada vez era más difícil acceder al mercado laboral, dado que la mayoría de las profesiones seguían copadas por la gigantesca generación del baby boom. No eran vagos, sino independientes y emprendedores a los que les interesaba menos trepar en la jerarquía empresarial que labrarse un nuevo camino» (Miller, 2018: 1834; el destacado es nuestro).
} 
complicada relación de cada uno de ellos con sus padres (Kutulas, 2018: 1177). Al acabar la primera temporada, ya conocemos a los progenitores de todos los protagonistas. La madre de Monica la censura constantemente y no tiene reparos en criticar cualquier aspecto de su vida amorosa o profesional ni en mostrar su preferencia por su hermano Ross, provocándole un cúmulo de inseguridades. Los padres de Chandler se divorciaron cuando él era pequeño, siendo este hecho señalado en muchas ocasiones como el origen de sus varias neurosis; su madre era una escritora de novelas eróticas que hablaba sin tapujos de su sexualidad y se besaba con uno de sus mejores amigos, y más tarde se descubriría que su padre era ahora una mujer transexual que trabajaba en Las Vegas como cabaretera. Joey descubría que su padre tenía una amante, lo que le llevaba a plantearse si su incapacidad de tratar a las mujeres como algo más que objetos sexuales era, de algún modo, herencia familiar. Los padres de Rachel la habían convertido en una niña malcriada incapaz de desenvolverse en la vida real. Y, por último, a Phoebe su padre la había abandonado y su madre se había suicidado cuando ella tenía dieciocho años ${ }^{17}$.

En principio, este era un requisito argumental para justificar la creación del grupo de amigos como familia sustituta: «the series needed to demonstrate that the characters' nuclear families would not or could not adequately prepare their offspring for the modern world, followed by its ongoing celebration of the Friends' superior ability to perform those same tasks» (Kutulas, 2018: 1176). No solo los padres de nuestros protagonistas no se comportaban como los progenitores modélicos de series como Father Knows Best, sino que, muy al contrario, con su comportamiento visiblemente egoísta e incapaz habían hecho de sus vástagos unos adultos disfuncionales y neuróticos, incapaces de desenvolverse adecuadamente en el mundo.

La serie, así recogía la enseñanza freudiana ${ }^{18}$ de que la familia es el origen de todos los problemas psicológicos de los adultos y a la vez, quizá sin querer, reflejaban

\footnotetext{
${ }^{17}$ El tratamiento de la historia de Phoebe es, sin duda, digno de mención. La suya es innegablemente la vida más trágica de los seis protagonistas: su padre la había abandonado, su madre se había suicidado, había vivido durante un tiempo en la calle, en la tercera temporada descubriría que tenía una madre biológica que la había abandonado de pequeña, tenía una hermana gemela con la que apenas hablaba... Lo curioso es que en los momentos en los que se van desvelando estas informaciones son siempre momentos cómicos, favorecidos sin duda por el carácter excéntrico del personaje interpretado por Lisa Kudrow. Pero el hacer de todos estos momentos algo cómico evita apuntar realmente a la gravedad de todos ellos, quizá por el miedo de los creadores a realizar un tratamiento "serio" de una historia tan potencialmente trágica. En todo caso, habla muy bien de los ambiguos efectos de la frivolización efectuada por la comedia.

${ }^{18}$ Es interesante también destacar la presencia constante de un subtexto “freudiano” en la forma, claro está, de una popularización vulgarizante de la doctrina psicoanalítica. Sin ir más lejos, el primer capítulo de la serie se abre con el relato por parte de Chandler de un sueño con claros tintes freudianos: "miré abajo y vi que tenía un teléfono en lugar de ... eso. Y el teléfono empezaba a sonar y la que llamaba era mi madre”.
} 
una característica de la sociedad coetánea ${ }^{19}$. Si la familia, como unidad de soberanía, servía para garantizar la eficacia de un poder disciplinario externo a ella, su descomposición permitiría sin duda la autonomización del individuo, la "liberación” de esta coacción externa, lo que a su vez, como argumenta Han, promueve la auto-disciplina y la auto-exigencia: la creación del sujeto de rendimiento. La premisa de Friends era seguir la vida de unos personajes en la veintena, faltos de toda autoridad paternal que les sirva de guía mientras que intentan abrirse paso en la vida social, amorosa y laboral: «the tensions, pain, commitments, responsibilities, and pleasures of becoming fully functioning adults were at the center of Friends' narrative» (Kutulas, 2018: 1175; el destacado es nuestro $)^{20}$.

Los personajes de Friends no solo se nos presentan bajo la presión de hacerse a sí mismos, sino característicamente psicopatologizados ${ }^{21}$. Las carencias de sus padres son el origen de las neurosis de los seis protagonistas según un rudimentario esquema freudiano, pero es necesario advertir que la psique del sujeto contemporáneo tal y como lo describe Han es bien distinta de la descrita Freud. El aparato psíquico de Freud, constituido por imperativos y represiones, tiene su lugar histórico en una sociedad represiva como la del pensador austriaco, pero «el sujeto de la modernidad tardía que está obligado a aportar rendimientos tiene una psicología totalmente distinta» (Han, 2014: 7778). De esta manera, es importante tener presente que los padres de Friends no crían hijos reprimidos, sino adultos incapaces.

\footnotetext{
Más tarde, el mismo personaje describiría a su madre como "pesadilla freudiana". Esto no son solo anécdotas, sino que apuntan a una especie de psicología popular latente que, sin duda, influye en la caracterización de los personajes y su psique, una creencia popular acerca de los mecanismos de construcción de la personalidad que se reflejan en estas "historias de origen" (principalmente, como venimos diciendo, en atribuir un origen familiar a sus neurosis).

${ }^{19}$ Miller, en su descripción de la Generación X representada en Friends, escribe: «Casi la mitad de sus integrantes se habían criado con padres divorciados, un número mayor que cualquier generación anterior o posterior (...) Habían aprendido desde muy pequeños a valerse por sí solos y a apoyarse en los chicos y chicas de su edad, no en su familia, ni en ninguna otra institución tradicional» (2018: 1834)

${ }^{20}$ A este respecto, la canción de apertura de la serie no solo destaca la importancia de la amistad como premisa de la serie, sino también las dificultades de desenvolverse en la vida adulta: "So no one told you life was gonna be this way / Your job's a joke, you're broke / Your love life's D.O.A / It's like you're always stuck in second gear / When it hasn't been your day, your week, your month / Or even your year”. Por otra parte, el motivo de "becoming functioning adults" que hemos destacado concuerda con la idea de que la sociedad de rendimiento sigue siendo una sociedad normalizadora, y, como veremos en el análisis, esta "normalización" será fundamental en la segunda mitad de la serie, sobre todo para el personaje de Chandler.

${ }^{21}$ Otro importante momento en la caracterización de los personajes como neuróticos es en el episodio X de la primera temporada, en el que un novio temporal de Phoebe, psiquiatra de profesión, "psicoanaliza" a los seis protagonistas sacando a relucir sus problemas de conducta.
} 
Han sitúa los trastornos neuróticos como la ansiedad, la depresión o el síndrome del burn out como las enfermedades características de la sociedad del rendimiento (2017: 13), en las que el sujeto cae agotado por esa continua exigencia de autoproducción: «lo que enferma no es el exceso de responsabilidad e iniciativa, sino el imperativo del rendimiento, como nuevo mandato de la sociedad del trabajo tardo-moderna» (2017: 29). Para Han, lo que causa la depresión no es, como opina Alan Ehrenberg, el imperativo de ser soberano de sí, sino la presión por el rendimiento: no solo ser dueño de sí mismo, sino de ser la mejor versión posible de sí mismo (Han, 2017: 28).

Para Han, la consecuencia de esta constitución del individuo como sujeto del rendimiento, que se cree libre, que es esclavo absoluto porque se explota a sí mismo, es que no entra en conflicto con el sistema de poder que le somete, sino consigo mismo: «Quien fracasa en la sociedad neoliberal del rendimiento se hace a sí mismo responsable y se avergüenza, en lugar de poner en duda a la sociedad del sistema» (2014: 18). El individuo actual no es capaz de llegar nunca a su “mejor versión de sí mismo” porque el mandato del «poder hacer» es, virtualmente, infinito, y se castiga con la exigencia de una optimización permanente:

Lo que causa la depresión (...) es más bien una relación excesivamente tensa, sobreexcitada y narcisista consigo mismo que acaba asumiendo rasgos destructivos. El sujeto que se ve forzado a aportar rendimiento y que termina quedando extenuado y siendo depresivo, por así decirlo, acaba desazonado de sí mismo. Se siente cansado, hastiado de sí y harto de pelear contra sí mismo (Han, 2014: 87)

En el tránsito de la sociedad disciplinaria a la sociedad del rendimiento el yo superpuesto [el superego freudiano] se positiviza convirtiéndose en yo ideal (...) A diferencia del represivo yo superpuesto, el yo ideal resulta seductor. El sujeto obligado a rendir se proyecta hacia el yo ideal, mientras que el sujeto obediente se somete al yo superpuesto (...) El proyectarse al yo ideal, por el contrario, se interpreta como un acto de libertad. Pero si el yo se queda atrapado en un yo ideal inalcanzable, entonces se siente desazonado en toda regla por su causa. Del abismo que se abre entre el yo real y el yo ideal surge entonces una autoagresividad (Han, 2014: 95)

Como vemos, para el filósofo coreano los trastornos neuróticos ${ }^{22}$ son la enfermedad característica de la sociedad del rendimiento, que produce sujetos agotados,

\footnotetext{
${ }^{22}$ En general, Han habla de "psicopolítica” (en contraste con la "biopolítica” de Foucault) porque para él el gran descubrimiento de la sociedad neoliberal es haber tomado no el cuerpo sino la "psique" como objeto
} 
permanentemente insatisfechos ante las exigencias de auto-creación. Ahora bien, Han habla únicamente de la depresión como característica del sujeto de rendimiento, cuando nosotros en nuestros análisis de la masculinidad hablaremos más de ansiedad, ya que como veremos en el siguiente epígrafe ambas, masculinidad y ansiedad, están estrechamente vinculadas ${ }^{23}$.

En efecto, esta va a ser nuestra hipótesis de trabajo, la arquitectura subyacente que presenta Friends a partir de la cual centraremos nuestros análisis sobre la masculinidad: el personaje cómico ya no es el fantoche que rompe las normas sociales e interrumpe el correcto funcionamiento dentro de una sociedad, y que para Mauron representa una regresión a un estado infantil del inconsciente, sino un neurótico que fracasa continuamente en la tarea de medrar en el mundo social, de convertirse en un adulto funcional. Como planteamos en su momento, toda comicidad parece basarse en el fracaso del carácter cómico respecto de unas expectativas sociales. El fracaso de los personajes de Friends es el de no alcanzar el éxito que se les supone a los miembros de su generación; no de no adaptarse a las normas sociales, sino no conseguir tener éxito (en el trabajo, con las mujeres, etc.). Lo que constituye el núcleo de la comedia de Friends es la identificación del espectador con este fracaso del personaje. Es lo que tenemos que deducir de la intención declarada de los creadores, y de cuyo éxito habla permanencia de la serie en el imaginario popular: su vigencia actual se basa sin duda no en el atractivo de la fantasía de la familia sustituta del grupo de amigos, sino en algo más profundo: en representar la problemática del sujeto de rendimiento contemporáneo.

\subsection{El concepto de masculinidad. Parámetros del análisis.}

Al hablar, en el capítulo anterior, de la identidad transexual, analizábamos, en cierto sentido, un caso límite donde la identidad de género aparecía muy literalmente construida;

idóneo del poder (Han, 2014: 37-38; 42). Santamaría detalla en su libro cómo el trabajo con las emociones y la psicología del trabajador empezó a formar parte esencial de los programas neoliberales (2018)

${ }^{23}$ En los análisis siguientes nos centraremos exclusivamente, en efecto, en la ansiedad reflejada por los personajes masculinos, pero nos atrevemos a decir, a mero modo de apunte, que quizá podría hacerse un análisis similar de los personajes femeninos relacionados con la depresión, sobre todo en el caso de Monica. Tendremos ocasión de ver cómo la guerra de sexos y la gradual conciencia popular acerca de la igualdad de la mujer, y sobre todo su inclusión en el mundo laboral, ocupan una parte no pequeña de las situaciones cómicas pero también dramáticas. 
hacíamos mención, asimismo, al hablar de los uniformados de Una mala noche la tiene cualquiera o el esculpido cuerpo de Dany en Yo no tengo la culpa de haber nacido tan sexy, de la identidad masculina, pero en tanto que esta también se mostraba como construida y realizada en sus actos corporales. En cambio, al hablar de la masculinidad y la identidad de género en un producto popular como Friends, nos enfrentaremos a una concepción del género y especialmente de la masculinidad como natural. El estudio de la identidad masculina ofrece ciertas dificultades precisamente porque se tiende a concebir como algo dado naturalmente al varón merced a ciertos determinantes biológicos (genes, hormonas, etc.) ${ }^{24}$. Es decir, se entiende que (todos) los hombres lo son simplemente por tener una biología determinada, y los que no se comportan como tales no lo son, al igual que las mujeres con comportamientos masculinos no son mujeres. La masculinidad se ve como algo obvio, dado por hecho, natural; solo nos damos cuenta de que existe cuando no funciona bien, cuando está fuera de sitio (Reeser, 2010: 1), y es en este sentido en el que analizarla en el contexto de una comedia, donde la comicidad de los personajes se encuentra por definición en su disfuncionalidad, ofrece unos interesantes resultados.

En efecto, si bien podemos encontrar conocimientos rivales acerca de qué es la masculinidad (el sentido “común”, la religión, las distintas ciencias naturales y sociales, etc.), (Connell, 2018: 3) la concepción popular asume generalmente que hay una masculinidad natural, fija e inevitable, ligada al cuerpo del hombre, sea por causa de la testosterona, la genética o cualquier causa biológica ${ }^{25}$; asociación típica del pensamiento moderno sobre el género (Connell, 2018: 45). Existe por tanto una ideología popular acerca de la naturalidad del género, según la cual cada sexo, hombres y mujeres, tiene unos rasgos psicológicos particulares que dependen de las diferencias biológicas y que definen lo que se entiende por masculinidad y feminidad (Connell, 1991: 167), concepción que también está presente en la ciencia e incluso en ciertas ramas del feminismo (Connell, 1991: 167). Y, dentro de este binarismo, la masculinidad tiende a funcionar como el género no marcado, al igual que la heterosexualidad respecto a la

\footnotetext{
${ }^{24}$ En este sentido, en la actualidad, si la feminidad permite mostrar, a través de todos los rituales de expresión de su género como el maquillaje, el vestuario, etc., todo lo que tiene de construcción artificial, la masculinidad se conceptualiza como totalmente natural, en relación directa con su cuerpo - en los análisis siguientes veremos cómo los personajes masculinos son presentados como simples, movidos por sus apetitos sexuales, etc. En el capítulo anterior [6.3.3] ya vimos, sin embargo, cómo el cuerpo masculino está igualmente construido.

${ }^{25}$ Anthony Clare discute y desmiente en su libro la extendida creencia de la influencia de las hormonas en el comportamiento del hombre, o las diferencias estructurales entre cerebros de hombres y mujeres (Clare, 2002)
} 
homosexualidad. En Occidente, las mujeres tienen género, pero los hombres no (Reeser, 2010: 9).

\subsubsection{El estudio de la masculinidad}

Esta naturalidad o invisibilidad de la masculinidad da lugar a que los estudios sobre ella sean relativamente recientes. Los men's studies se consolidan como disciplina académica a finales del siglo XX, a partir de la irrupción en la academia del feminismo y los movimientos LGTBI (Reeser, 2010: 9): la reivindicación y legitimación de las mujeres y de los hombres homosexuales, hasta entonces identidades subalternas respecto del varón hegemónico, descentra y vacía de significado el rol masculino. El problema de la masculinidad, como algo distinto al machismo, solo puede surgir, hacerse visible, como consecuencia de un feminismo que denuncia el patriarcado como estructura de poder y opresión pero no logra acabar con el sistema de género y el sometimiento a la que somete también a los hombres (Guasch, 2006: 26) ${ }^{26}$. De hecho, los primeros intentos de crear una ciencia social de la masculinidad nacen a finales del siglo XIX como respuesta a los primeros movimientos feministas: se comienza a investigar las supuestas diferencias sexuales innatas que justifiquen la superioridad de los hombres sobre las mujeres (Connell, 2018: 21) - irónicamente, los resultados de esta línea de investigación, que se sigue dando hoy día, no dejan de desmentir la teoría de la diferencia sexual, aunque siga siendo un lugar común en la comunidad científica (Connell, 2018: 21-22)27.

\footnotetext{
${ }^{26}$ Es abundantísima la literatura en lo que llevamos de siglo que trata el "problema del hombre", que constata, efectivamente, que existe una crisis de la masculinidad por la aparición y consolidación definitiva de los derechos de las mujeres, y que proponen nuevas vías e identidades para que los varones puedan adaptarse a la nueva sociedad - lo que se ha dado en llamar "nuevas masculinidades. Sin embargo, por muy bienintencionada que sea esta literatura, tienden a seguir concibiendo el género como algo natural, consecuencia directa de la diferencia biológica de sexo; es decir, aunque admitan que el papel del hombre ha cambiado, mantienen la oposición de roles hombre-mujer, en la que el hombre es heterosexual y por tanto su mayor preocupación es su posición en la relación con su pareja mujer, con sus hijos, etc (ver Azpiazu Carballo, 2013). La obra básica del estudio de la masculinidad sigue siendo el libro de Connell (2018), ya citado, sobre todo por su concepto de “masculinidad hegemónica” que explicaremos más adelante. Connell aúna en su proyecto de sociología las enseñanzas del feminismo, el psicoanálisis en su vertiente más crítica y los movimientos políticos como la lucha LGTB. En España también son varios los autores que tratan el problema de las masculinidades y las nuevas masculinidades, desde una perspectiva estrechamente asociada al pensamiento feminista. Véase, por ejemplo, Azpiazu Carballo, 2017; Carabí \& Armengol, 2015; Bacete, 2017; Salazar, 2017; Salazar, 2018.

27 «Sex differences, on almost every psychological trait measured, are either non-existent or fairly small. Certainly they are much smaller than the differences in social situations that are commonly justified by the belief in psychological difference - such as unequal incomes, unequal responsibilities in child care and drastic differences in access to social power. When groups of studies are aggregated by the statistical technique of meta-analysis, it is more likely to be concluded that some sex differences in psychological
} 
Los movimientos feministas a favor de los derechos civiles de la mujer, como el sufragismo o los socialismos que reivindicaban a la mujer obrera, desembocaron a principios del siglo XX en una ciencia social del género, que entendía la diferente posición de hombres y mujeres como producto de la sociedad - aunque la idea de que el carácter de las mujeres estaba determinado por su educación y socialización ya estaba latente en la obra de Mary Wollstonecraft, así como la idea de que la estructura social del género, sobre todo la familia, es un producto histórico está presente en el socialismo utópico (Connell, 1991: 25-26). Aun así, estas corrientes reivindicaban la igualdad de derechos de hombres y mujeres, pero sin negar la premisa de la existencia de una feminidad y una masculinidad intrínsecas a cada sexo (Connell, 1991: 26).

A partir de los años treinta, la investigación sobre el género y la diferencia sexual se encontraría con la teoría del rol social, dando lugar al concepto de «rol sexual», según el cual «being a man or a woman means enacting a general set of expectations which are attached to one's sex (...) Masculinity and feminity are quite easily interpreted as internalized sex roles, the products of social learning or 'socialization'» (Connell, 2018: 22) - una noción muy cercana, pues, dadas las connotaciones dramáticas del término «rol», a la de Goffmann, y que, como vimos en el capítulo anterior, daba lugar a la confusión al interpretar el concepto de performatividad de Butler. La teoría del rol sexual aunaba la idea de lugar en la estructura social con la de una norma cultural aprendida.

Ahora bien, si la idea de masculinidad o feminidad como un rol social interiorizado permitía, en teoría, un cambio mediante la reforma de las normas culturales en los procesos de socialización, en general se asumía que los roles sociales estaban bien definidos y eran plenamente funcionales, así como en sintonía con las supuestas diferencias sexuales biológicas (Connell, 2018: 23). La teoría del rol sexual que se mantiene hasta los años setenta es una teoría conformista y normalizadora, que no contempla la posibilidad de una discordancia entre rol social y personalidad, y si lo hace es para achacar al individuo una "mala adaptación” al rol que le es propio que debe ser corregida (Connell, 2018: 23; 1991: 32-33). Es a partir de los años setenta, con la llegada de la segunda ola del feminismo y los movimientos de derechos LGTB, cuando la academia se vuelve a encontrar con la lucha activista y convierte la teoría de género en una estrategia política (Connell, 1991: 33). Las preguntas acerca la naturaleza de la

characteristics do exist. But their modest size would hardly register them as important phenomena if we were not already culturally cued to exaggerate them» (Connell, 2018: 21) 
feminidad, las relaciones de poder entre sexos, la división del trabajo, etc., que ya estaban presentes en la literatura académica, recibieron un nuevo enfoque más crítico y centrado en las cuestiones de poder y desigualdad.

Una de las consecuencias más tempranas fue la multiplicación de la investigación sobre roles sexuales, sobre todo por parte del feminismo liberal, con un reforzado interés en el proyecto político de reformar los roles sociales asignados a las mujeres (Connell, 2018: 33-34), mientras que los feminismos radical y socialista se centraron en las estructuras de dominación de las mujeres por parte de los hombres, bien de forma directa o bien como consecuencia de relaciones económicas y de poder más amplias (Connell, 1991: 35). Paralelamente, el movimiento de liberación gay y LGTB centraba su crítica en la familia como institución de producción heterosexual y la represión del deseo homosexual, cuya consecuencia era la violencia contra los homosexuales (Connell, 1991: 36-37; 2018: 39-40), uniéndose al feminismo en su denuncia contra el patriarcado como forma de dominación masculina - al fin y al cabo, el hombre gay es oprimido por ver en él rasgos de feminidad.

A mediados de la década de los setenta surgió en Estados Unidos el Men’s liberation movement y otras asociaciones que señalaban el rol masculino como opresor y también oprimido y en necesidad de reforma, iniciando una especie de alianza entre feminismo y men's studies (Connell, 2018: 23-24). Pero también surgía una contracorriente reaccionaria, no en todos los casos de carácter religioso, que intentaba justificar la necesidad de la estructura social de género basándose en la evolución de la especie o de determinaciones biológicas, cuya corriente más popular, aún hoy día, es la sociobiología (la explicación de formaciones sociales por supuestas causas biológicas) (Connell, 1991: 37-38). Esta doctrina vino a ocupar el papel de la religión como justificación de la ideología del género. Según su planteamiento, heredamos los caracteres entendidos como masculinos (agresividad, competitividad, promiscuidad, etc.) como resultado de un proceso evolutivo reflejado en las hormonas, las estructuras cerebrales, etc.; determinaciones que la cultura y la sociedad no ha hecho más que elaborar (Connell, 2018: 47).

Por otra parte, al impulso de las "historias de mujeres" surgidas al calor del feminismo, le siguió la aparición de una historia de los hombres; no de los Grandes Hombres, pues esta ya estaba escrita por la historiografía de siempre, sino de la idea de masculinidad (Connell, 2018: 28) y de cómo esta se había transformado a lo largo del 
tiempo y también del espacio. Estas nuevas investigaciones historiográficas, junto a un también creciente volumen de etnografías y enfoques sociológicos sobre la masculinidad, venían a dar al traste con la idea de una masculinidad natural e inevitable, anterior a la sociedad y en su base: muy al contrario, eran las sociedades y sus diferentes intereses políticos y económicos las que promocionaban determinadas ideas de lo que la masculinidad debía ser (Connell, 2018: 28-39).

\subsubsection{La masculinidad como ideología}

En resumen, todas estas rupturas epistemológicas propiciadas por el feminismo y los movimientos LGTB obligan a repensar el concepto de masculinidad como producto de la determinación biológica del cuerpo del varón, que da lugar a una serie de características psicológicas concretas para todos los hombres, para atender al carácter construido sociohistóricamente de la idea de masculinidad. La masculinidad no es un objeto coherente y aislado sino que hay que estudiarlo en relación con la estructura social (el género) en que aparece (Connell, 2018: 71): en relación por tanto respecto a la feminidad pero también la relación de la masculinidad denominada «hegemónica» por Connell con las masculinidades subalternas (los hombres homosexuales, los hombres racializados y de clases bajas...). Como dice Guasch:

Ningún lugar hay en la naturaleza humana, ni en el cuerpo de los varones, donde habite la masculinidad. La masculinidad es una idea, un producto histórico, una invención en que las hormonas y la fisiología sexual juegan un papel secundario (por no decir nulo) (...) Afirmar que una conducta humana es natural (además de ser falso, ya que los humanos somos seres sociales) implica una opción política porque lo natural se piensa como permanente y, en consecuencia, de difícil transformación (Guasch, 2006: 23)

La historia de las ideas de masculinidad y las denuncias feministas y LGTB del patriarcado demuestran también que esta construcción de la masculinidad está siempre ligada a ciertas instituciones sociales y sirven a ciertos intereses políticos y económicos. De este modo, podemos definir la masculinidad como una ideología, no solo en el sentido de visión de mundo, como vimos que entiende la Retórica Constructivista el término, sino en su sentido más tradicional y de raigambre marxista de justificación del orden social de dominación (Reeser, 2010: 20), así como de producción de subjetividades [ver 4.2.3]. 
Existe una masculinidad hegemónica que se puede definir «as the configuration of gender practice which embodies the currently accepted answer to the problem of legitimacy of patriarchy, which guarantees (or is taken to guarantee) the dominant position of men and the subordination of women» (Connell, 2018: 77). Claro que hablamos de una hegemonía cultural, simbólica, que ayuda a legitimar la clase dominante sin que los miembros de esta representen necesariamente dicha masculinidad hegemónica: un representante de aquella puede ser un actor o un futbolista, o un personaje de ficción, mientras que un hombre efectivamente en el poder (político, empresario) no tiene por qué cumplirla: simplemente, los valores que la masculinidad hegemónica promociona (autoridad, agresividad, competitividad, por ejemplo) sirven a sus intereses (Connell, 1991: 185).

En todo caso, la masculinidad no es una, sino que existen otras masculinidades subordinadas a la hegemónica, como los hombres homosexuales o, más en general los "afeminados” o cualquier hombre que se salga de la norma: «We must also recognise the relations between the different kinds of masculinity: relations of alliance, dominance and subordination. These relationships are constructed through practices that excludes and include, that intimidate, exploit and so on. There is a gender politics within masculinity» (Connell, 2018: 37).

Los discursos ideológicos de la masculinidad funcionan, por tanto, como discursos normalizadores:

One of the purposes of discourse is to normalize human beings and to make them conform to the power that institutions want to exert over people. Masculinity plays an important role in this exertion of power: because there are certain advantages and privileges accorded to it, masculinity functions as an effective carrot to normalize those within discourse (Reeser, 2010: 31)

No podemos decir, claro está, que la masculinidad como ideología sea propagada por un grupo particular y concreto (Reeser, 2010: 17). La masculinidad está ligada de manera diferente y a veces contradictoria a distintas instituciones (el ejército, el mundo empresarial, la escuela, la Iglesia...) y se difunde de muy diversos modos interrelacionados: mediante imágenes a través de la televisión, el cine, la publicidad, etc.; mitos (tanto clásicos, como Ulises; como modernos, como el cowboy); discursos de distinta índole (médicos, legales, políticos, filosóficos, pedagógicos...). La ideología de la masculinidad también aparece en prácticas ligadas a situaciones concretas (ciertos 
deportes, profesiones y hobbies; formas de vestir, gustos musicales...) que, por supuesto, están inextricablemente vinculadas a ciertos discursos, imágenes y mitos (Reeser, 210: 21-24).

Lo importante es que la mayoría de estas representaciones e imágenes no lo son de hombres frecuentes o ni siquiera reales, sino imágenes cargadas simbólicamente que sirven de ideales de masculinidad (Reeser, 2010: 21). Un ideal masculino funciona como hegemónico precisamente en su encarnación en figuras pseudomíticas como personajes de ficción, estrellas de cine o del deporte, etc. (Connell, 1991: 184). De este modo, la idea de masculinidad revela su carácter ideológico en el hecho de que no es una representación de los hombres reales, sino una representación ideal a la que los hombres deben aspirar:

Los procesos de socialización siempre son imperfectos, porque los humanos no son máquinas que reproducen sin más los programas. De ahí deriva la necesidad de mitos (y la masculinidad lo es) que actúen como referentes y guías de la acción social cotidiana (...) existe una meta ideal, un diseño normativo que sirve de referente para los varones reales. Se supone que los hombres, cuanto más se acerquen al modelo normativo, mejores varones serán (Guasch, 2006: 31)

Así, a pesar de la extendida creencia en que la masculinidad es algo natural, dado y espontáneo en el hombre, en realidad es más bien una norma de comportamiento ${ }^{28}$ y un estándar que los varones deben alcanzar. El hombre, más incluso que la mujer, se hace; debe demostrar continuamente, frente a otros hombres, su masculinidad (Badinter, 1993: 30). Este hecho demuestra que la masculinidad, lejos de ser algo estable, está continuamente en entredicho y debe ser alcanzada y aprobada continuamente, lo que desmiente su supuesta naturalidad.

Una de las ventajas de la teoría del rol sexual es la distinción analítica entre rol y personalidad, es decir, entre la psique de un individuo y su posición en la estructura social y en las distintas situaciones e interacciones (Connell, 1991: 47). Para Connell, es

\footnotetext{
${ }^{28}$ Aunque una mayor libertad y autonomía es uno de los elementos fundamentales de la moderna ideología de la masculinidad, en realidad el hombre está muy limitado en sus acciones y actitudes por esta ideología: «Practices of masculinity (...) leave the boy with little choice of how to act. But oddly, masculinity is often perceived to be free, unlike feminity and its imagined constraints. One paradox of masculinity as ideological is that it often gives the illusion of freedom (...), whereas in fact it is this very illusion of freedom that ¿insures? subjugation and hides its own arbitrary functioning» (Reeser, 2010: 25). De manera general, Connell destaca el carácter "represor" de la estructura social en tanto que limita las posibilidades de práctica: «The concept of 'structure' is more than another term for 'pattern' and refers to the interactability of the social world. It reflects the experience of being up against something, of limits of freedom (...). The concept of social structure expresses the constraints that lie in a given form of social organization» (Connell, 1991: 92)
} 
necesario un acercamiento al estudio del género que no atienda exclusivamente a las imágenes y representaciones mediáticas de la masculinidad, sino a la relación entre la práctica individual y la estructura social, entendiendo los roles, categorías y sistemas sociales de género como experiencias vividas por individuos reales (Connell, 1991: 91): «rather than attempting to define masculinity as an object (a natural character type, a behavioural average, a norm), we need to focus on the processes and relationships through which men and women conduct gendered lives» (Connell, 2018: 71) ${ }^{29}$. Análogamente, Guasch destaca el carácter de la masculinidad no solo como una ideología, sino también como una identidad:

Más allá de los estereotipos la masculinidad también puede definirse como un proceso identitario que ayuda a los varones a pensarse a sí mismos y a ubicarse respecto a su entorno social. La masculinidad es una forma de identidad social y personal que regula las relaciones con los demás y que se aprende en los procesos de socialización. La masculinidad es un proceso social, emocional y subjetivo. Es social porque tiene que ver con algo que se adquiere (...) (Guasch, 2006: 29)

Si la masculinidad no es naturalmente intrínseca al varón sino que esta es un rol que debe ocupar, una norma a la que adecuarse o un estándar que alcanzar, el varón vive la masculinidad como algo hasta cierto punto ajeno a él: «masculinity functions as an other to the male body» (Reeser, 2010: 103). Esta relación del hombre con su masculinidad puede ser conflictiva, por ejemplo, al intentar aplicar alguno de los principios de la masculinidad hegemónica a la vida cotidiana: «I might experience masculinity as a tension between this image of masculinity and my actual life in which I cannot quite reproduce the image or in which I can only recreate it in minor ways» (Reeser, 2010: 27). La masculinidad en estos casos se vive como una opresión, y se produce una sensación de ansiedad de no poder alcanzar los estándares o estar obligados a demostrarlos continuamente, como apunta Guasch:

Adecuarse a los roles de género (...) genera en los varones estrés, tensión y ansiedad, porque incumplirlos conlleva la pérdida de estatus social. Los varones buscan entre sus pares la aprobación y el reconocimiento social derivado del cumplimiento de las normas de género. Estas limitan el desarrollo social y emocional de los varones. Las normas sociales que regulan el género prescrito a los varones originan la discriminación que padecen (Guasch, 2006: 104)

\footnotetext{
${ }^{29}$ Ver, a este respecto, la definición de habitus de Bourdieu [4.2.3]
} 
También Judith Butler en El género en disputa hace una lectura de la obra de Lacan en la que destaca el carácter del género, y en particular de la masculinidad, como una mascarada en la que la imposibilidad de alcanzar la posición simbólica del Falo o el Padre genera ansiedad en el varón: «retorciéndole el cuello a la “envidia de pene” defendida por Freud, Butler señala que los hombres deben medirse sin cesar con el ideal del falo precisamente porque están dotados de pene y no de falo, estando pues obligados a demostrar su virilidad de forma compulsiva» (Preciado, 2018: 65).

Recordemos que la teoría lacaniana se centra en los procesos simbólicos de la psique más que en hechos empíricos reales o imaginados, por ejemplo, al hablar de lo Simbólico o la Ley del Padre, que constituye la cultura y la comunicación. Para Lacan, la masculinidad no es ni un hecho empírico, como en Freud, ni un arquetipo jungiano, sino un lugar en las relaciones sociales y simbólicas (Connell, 2018: 19-20) ${ }^{30}$. Según la lectura butleriana de Lacan, las identificaciones de género, que constituyen posiciones en el campo de lo simbólico, no son espontáneas y automáticas, sino que requieren de un rechazo del sexo contrario; de este modo, la masculinidad se presenta como una identidad autónoma que sin embargo está levantado sobre el «espectro amenazador» del sexo rechazado: la identidad de género también es para Lacan y Butler una ilusión precaria ${ }^{31}$ (Butler, 2007: 20).

El sujeto masculino, por tanto, es un sujeto que ha tenido que renunciar a sus deseos e impulsos de identificación con lo femenino (Butler, 2007: 117), pero siempre

\footnotetext{
${ }^{30}$ Para Connell, ya la teoría freudiana abre múltiples y revolucionarios caminos en la comprensión de la masculinidad. En primer lugar, «Freud understood that adult sexuality and gender were not fixed by nature but were constructed through a long and conflict-ridden process» (Connell, 2018: 9). En segundo lugar, su idea de que la psique de tanto hombres como mujeres es originariamente bisexual, en el sentido de tener a la vez rasgos masculinos y femeninos (de hecho, en una nota al pie al Malestar en la cultura, Freud señala lo poco acertado que le parece el atribuir lo masculino y lo femenino a lo activo y lo pasivo respectivamente; (Freud, 2017: 328)). Por tanto, la masculinidad y la identidad de género en general son construcciones complejas, precarias, variables a lo largo de todo el proyecto vital, y muy influidas por las relaciones sociales (Connell, 2018: 10). Algunos continuadores de Freud, como Karen Horney o Albert Adler introdujeron otras valiosas aportaciones, como la idea de una identificación pre-edípica con la madre o la noción de protesta masculina (Connell, 2018: 12-18). En general, para Connell una de las mayores aportaciones del psicoanálisis es la de ofrecer un modelo de análisis que consiste en que «understanding masculinity will depend on our ability to grasp the structuring of personality and the complexities of desire at the same time as the structuring of social relations» (2018: 20).

31 «La formación de un sujeto exige una identificación con el fantasma normativo del "sexo" y esta identificación se da a través de un repudio que produce un campo de abyección, un repudio sin el cual el sujeto no puede emerger. Este es un repudio que crea la valencia de "abyección” y su condición de espectro amenazador para el sujeto. Por otra parte, la materialización de un sexo dado es esencial para la regulación de las prácticas identificatorias que procurarán persistentemente que el sujeto rechace la identificación con la abyección del sexo. Y sin embargo, esa abyección rechazada amenaza con exponer las presunciones propias del sujeto sexuado, basadas como el sujeto mismo en un repudio cuyas consecuencias él no puede controlar plenamente» (Butler, 2007:20)
} 
tiene presente lo que Freud denominó la «ansiedad de castración», el temor a la pérdida del pene, de la masculinidad:

Llegar a ser como ella [la mujer castrada], devenir esa figura, ese es el temor de la castración (...) La posición simbólica que marca un sexo como masculino es una posición a través de la cual se dice que lo masculino "tiene” el falo 32 ; es una posición que obliga mediante la amenaza del castigo, es decir, la amenaza de feminización (...). De modo que el esfuerzo imaginario masculino de identificarse con esta posición de tener el falo supone ya cierto fracaso inevitable, una imposibilidad de tener y un anhelo de tener una envidia del pene que no es lo opuesto del temor a la castración, sino que es su suposición misma (Butler, 2007: 154)

Para Butler, esta angustia no existiría si el falo no se considerara como algo separable, inalcanzable, ya perdido de antemano. La angustia de castración «es en realidad angustia de que se reconozca que el falo ya está perdido, de que es imposible identificarse con él» (Butler, 2007: 155). Esta ansiedad típicamente masculina y heterosexual, el temor a la castración, es sobre todo un temor a perder una posición de poder, los privilegios que vienen con el ser hombre (y actuar como tal). Puesto que las posiciones masculina y femenina son lugares de lo Simbólico (podríamos decir: lugares en la estructura social, roles), la plena identificación del individuo empírico es imposible y genera ansiedad, sobre todo en los hombres:

En este sentido, la heterosexualidad proporciona posiciones sexuales normativas que son intrínsecamente imposibles de encarnar, y la incapacidad permanente de equipararse plenamente y sin incoherencias con estas posiciones demuestra que la heterosexualidad misma no sólo es una ley obligatoria, sino una comedia inevitable (...) una parodia permanente de sí misma (Butler, 2007: 242)

Se afirma que los hombres “tienen” el falo, pero nunca que lo "son”, en el sentido de que el pene no es equivalente a esa Ley y nunca puede representarla completamente. Por tanto, hay una imposibilidad indispensable o presupuesta de cualquier intento por apropiarse de la posición de “tener” el Falo, con el resultado de que ambas posiciones de "ser” y “tener” deben considerarse, según Lacan, fracasos de una comedia; con todo, esas posiciones deben estructurar y representar estas imposibilidades repetidas (Butler, 2007: 119) ${ }^{33}$

\footnotetext{
${ }^{32}$ Recordemos que para Lacan el Falo representa la Ley Simbólica del Padre; es, ante todo, un símbolo y no debe confundirse con el pene empírico. En la teoría lacaniana de la diferencia sexual, la mujer "es” el Falo mientras que el hombre lo "tiene".

${ }^{33}$ Fijémonos cómo, muy significativamente, en esta cita y la anterior Butler utiliza la metáfora de la comedia para hablar de esta ansiedad masculina.
} 
Acatar la ley, acceder a lo que prescribe la ley es producir un alineamiento con la posición sexual señalada por lo simbólico, pero también es fracasar siempre en el intento de aproximarse a esa posición y sentir la distancia entre esa identificación imaginaria y lo simbólico como amenaza de castigo, la incapacidad de ajustarse al modelo, el espectro de la abyección (Butler, 2007: 154)

\subsubsection{Parámetros del análisis}

Vemos, en resumen, que muchos de los estudiosos de la masculinidad coinciden en el diagnóstico de que la masculinidad se vive como una presión social interiorizada individualmente que les causa, entre otros problemas, ansiedad. Esta relación de la masculinidad con la ansiedad nos permite vincular el estudio de la masculinidad en Friends con lo expuesto en el epígrafe anterior acerca de las condiciones vitales en la sociedad del rendimiento. Si nuestra hipótesis era que en Friends se reflejan las angustias de este sujeto contemporáneo por el rendimiento, la auto-superación, el éxito, etc., en el caso de los personajes masculinos podríamos argumentar que, respecto a su género, la problemática se formula de la siguiente manera: el fracaso del personaje masculino, que es lo que provoca la comicidad, es el de no alcanzar los estándares de éxito de masculinidad (por ejemplo, no tener éxito con las mujeres, no alcanzar un número razonable de conquistas sexuales). Un personaje masculino será cómico en el momento en que fracase en alcanzar unos estándares de masculinidad demasiado altos para él. Este fracaso no consiste, o no sólo, simplemente en no cumplir unas normas sociales, en no comportarse como un hombre, sino en no rendir como tal. Así pues, por la noción de la identidad género como performativo, como performance, no solo habría que entender actuación, sino también rendimiento.

Entender la masculinidad como una construcción ideológica que se transmite en discursos e imágenes culturales nos permite justificar plenamente su estudio en una serie como Friends: nuestro objetivo es analizar cómo este discurso, de una gran influencia en la sociedad por las razones ya presentadas, presenta la masculinidad. Pero queremos estudiar no solo qué idea de masculinidad se presenta en la serie, sino cómo se presenta, y qué consecuencias tiene que se presente en un discurso cómico. ¿Facilita la naturaleza cómica de Friends la normalización de esta ideología de la masculinidad o por el contrario la descalifica, burlándose de ella? Como veremos, la respuesta es: ambas. 
El concepto de rol sexual también es de mucha utilidad para enfocar nuestros análisis. Este paradigma presenta una serie de postulados generales: i) una distinción analítica entre la persona y la posición social que ocupa, ii) definida según una serie de acciones y comportamientos asignados a dicha posición, iii) dadas según unas expectativas sociales y normas culturales respecto a qué acciones o actitudes son apropiadas para este rol iv) establecidas por una serie de contraste entre dichos roles y v) reforzadas por una serie de recompensas y sanciones sociales (Connell, 1991: 47). Entender la masculinidad como un rol que una persona lleva a cabo permite relacionarlo, por supuesto, con la idea del género como performatividad en el sentido de actuación. Pero, por otro, también permite una reflexión del papel de la ideología en una teoría de la comedia basada, como expusimos en el capítulo correspondiente, precisamente en el personaje cómico y la polifonía inherente a la estructura del discurso humorístico, así como en la materialidad de lo cómico como reflejo de la materialidad de la ideología $[4.2 .3,5.3,5.4]$

Connell define tres estructuras o campos en los que es necesario estudiar la definición de los géneros y su interacción: la división sexual del trabajo, el ejercicio del poder de un género sobre otro, que eran los temas clásicos en los estudios de género, a los que él añade la catexis o la cuestión del deseo sexual (Connell, 1991: 97). Sin embargo, como veremos, en la época en que se desarrolla Friends, el avance del feminismo y la inclusión de la mujer en el mundo laboral hace que el eje del trabajo pierda su especificidad masculina y por tanto su importancia en la caracterización de la masculinidad de nuestros personajes, salvo algunos casos en que, por ejemplo, se bromee sobre profesiones supuestamente femeninas (enfermería, cuidado de niños) ocupadas por un hombre. Del mismo modo, la dimensión del poder no está tan presente de manera explícita en la serie, sino íntimamente vinculada, si bien de un modo sutil, en las relaciones amorosas. Por tanto, el eje principal en el que nos moveremos será el de la catexis, analizando cuestiones como la sexualidad de los hombres en oposición a la de las mujeres o la ansiedad homosexual.

Por otro lado, es necesario atender a los estereotipos y características que supuestamente definen la masculinidad. Según Kiesling, los estudiosos han identificado cuatro premisas claves en la construcción de la masculinidad hegemónica: la diferencia sexual, la dominación, la solidaridad entre hombres y la presunción de heterosexualidad (Becker, 2014: 235). Guasch establece la homofobia y la misoginia como pilares 
fundamentales de la masculinidad hegemónica (2006: 20). El título de su libro, Héroes, científicos, heterosexuales y gays, resume de manera óptima estos rasgos asociados tradicionalmente al hombre. Por un lado, el héroe apunta a los aspectos de fuerza, valentía, aventura, protección, etc., supuestamente característicos del hombre, así como el carácter mítico y, por tanto, inalcanzable, de estos estereotipos, y cómo afectan a la constitución psíquica de los varones. La figura del científico está relacionada con la racionalidad asociada tradicionalmente al hombre, en oposición a las mujeres, a las que se les vincula con el mundo de los cuidados, emociones y afectos. Finalmente, Guasch señala la heterosexualidad del varón y sus relaciones con la mujer, en oposición al hombre gay. También nos será de gran ayuda las diversas consideraciones del libro de Todd Reeser y su lectura postestructuralista de la masculinidad, que plantea cuestiones como la dimensión discursiva e ideológica de la misma, y otros temas como la relación entre hombres, la dimensión corporal de la identidad masculina, las interferencias entre raza, clase y género, etc.

Cierto es que uno de los puntos que critica Connell del paradigma del rol sexual es que se centra demasiado en las representaciones de lo que supuestamente caracteriza dicho rol y olvida las prácticas que los individuos reales realizan. El análisis de la masculinidad, en efecto, obliga a enfrentarse al problema recurrente en las ciencias sociales de la dialéctica individuo-estructura, personalidad-rol social, de la agencia del sujeto. Pero, en nuestro análisis de una comedia, operaremos en varios niveles. Por un lado, al analizar una ficción popular, y no individuos reales, lo que estamos realizando efectivamente es un análisis de las representaciones, de los estereotipos de la masculinidad - como hemos dicho, realizamos un análisis ideológico del discurso. Por otro, dado que el género de la comedia precisamente enfatiza las relaciones entre el individuo y el medio social, y sobre todo teniendo en cuenta que la intención de los creadores de Friends era una representación más o menos realista de la juventud de su tiempo, también estamos analizando cómo los personajes, dentro de la ficción, se relacionan con su masculinidad, cómo la sufren y cómo esta determina su personalidad y sus acciones.

Y, sobre todo, al tratarse de una comedia, esta representación de la masculinidad tiene, inevitablemente, un carácter paródico que, en un nivel hermenéutico, problematiza la masculinidad precisamente al convertirla en un estereotipo. Un personaje masculino actúa: la comicidad de su acción reside en que rompe unas expectativas, en que fracasa 
en cumplir con su masculinidad, lo que provoca la risa del espectador: nos reímos, por tanto, del fracaso del personaje masculino; pero ¿no se está parodiando también esta expectativa de masculinidad, que se presenta como falsa por irrealizable? ¿No nos sentimos identificados con el personaje al enfrentarse a un ideal inalcanzable?

Unas pocas notas metodológicas adicionales. La recopilación del “corpus” de lo que denominaremos indistintamente gags, bromas, momentos cómicos, etc. (una clasificación sutil ayudaría poco al análisis) ha abarcado la serie entera, que consta de diez temporadas. Evidentemente, no consignaremos todas y cada una de las bromas que puedan tener algo que ver con la masculinidad, sino las que consideremos suficientes para apoyar la argumentación; estos ejemplos pertenecerán sobre todo, a las primeras temporadas, principalmente por dos razones: primero, muchas de estas bromas son repetitivas, y los momentos recogidos de estas temporadas son más que suficientes para el objetivo que nos proponemos; segundo, los primeros episodios son más ricos en material y ofrecen para un análisis de la masculinidad, a lo que hay que sumar el hecho de que la serie sufrirá un pronunciado declive de calidad a partir, aproximadamente, de las tres últimas temporadas.

A la hora de identificar los momentos cómicos, ha servido simplemente con atender a las risas grabadas de la audiencia presentes durante el rodaje de la serie, si bien es útil distinguir entre los momentos en que los personajes se burlan unos de otros, y aquellos en los que el público ríe “espontáneamente”. Como hemos dicho, la laugh track tiene una importante función tanto estructural como ideológica al señalar al espectador qué momentos tiene que considerar cómicos. Por otro lado, es un inconveniente el analizar por escrito un material audiovisual sin que el lector tenga presente dicho material, ya que el análisis pierde mucha información relevante al dejar desatendida la actuación de unos actores francamente dotados para la comedia gestual. En muchas ocasiones, la interpretación de los actores, su gestualidad, será determinante para la identificación del carácter cómico de un gag, y añadirá interesantes matices al diálogo. En dichos casos, intentaremos anotarlo en la medida de lo posible. 


\subsection{Análisis de la masculinidad en Friends}

El vigésimo episodio de la quinta temporada, «El de la ronda policial», reúne casi todos los elementos que vamos a encontrar en las siguientes páginas. En él, Gary, el novio en ese momento de Phoebe, detective, invita a los chicos a hacer una ronda policial nocturna. Como veremos, las parejas de los personajes femeninos tienden a representar modelos ideales de masculinidad, modelos de “deseabilidad”; estos hombres, sobre todo en el caso de los compañeros sentimentales de Phoebe, vienen de la esfera de ocupaciones asociadas a una masculinidad heroica: bomberos, activistas, $\mathrm{y}$, como en este caso, policías. También veremos que, si bien en la mayoría de las veces los protagonistas se sentirán amenazados por este tipo de personajes de masculinidad superior, otras los tomarán como modelos a imitar. En este caso, el interés que muestran por participar en una ronda policial constituye una fantasía infantil de participar en esta esfera de masculinidad legendaria (con todos los elementos heroicos que la constituyen: peligrosidad, aventura, lucha contra el mal, etc.) 34 . De hecho, Gary se sorprende de que Chandler quiera ir con ellos a la ronda: «It’s kind of dangerous»; «Well, I like danger», le responde Chandler, en una sobreactuación de virilidad, para luego añadir con cierto temor: «You didn’t say it was going to be at nighttime», provocando las risas del público por esa muestra de cobardía que no se le supone a un hombre. Como veremos, la feminidad de Chandler será un gag recurrente a lo largo de la serie, hasta que comience su relación con Monica.

Más tarde, durante la ronda, Joey compra un bocadillo que en su opinión es de los mejores de la ciudad, pero no permite que Chandler, que va a en el asiento de al lado, lo huela: «Half the taste is in the smell. You're sucking up all the taste units». Cuando Chandler le pregunta qué es lo que tiene ese bocadillo, Joey le responde: «Okay, imagine the best sex you've ever had... Are you thinking about Monica [a estas alturas de la serie los dos amigos ya están juntos]?»; «Yeah»; «Yeah, what is it like?», le dice Joey, con expresión lasciva. En este breve diálogo vemos los tres rasgos principales de la caracterización cómica de Joey: estúpido y obsesionado con la comida y con el sexo - en una asociación de clara raigambre carnavalesca.

\footnotetext{
${ }^{34}$ Por supuesto, todas las referencias a la práctica policial de los protagonistas están sacadas de películas y series policiales, destacando el origen de dicha fantasía masculina.
} 
Más tarde, Ross alardeará de ser «más poli» que sus dos amigos por ir en el asiento del copiloto, en otra sobreactuación de masculinidad típica del personaje. «I’m in the front seat. I’m Gary’s partner»; «You know, when you say “partner” it doesn’t sound cop, it sounds gay» le responde Chandler. Momentos después, Ross enciende sin querer la sirena de policía, y en castigo Gary le hace sentarse en los asientos traseros, para mofa de sus amigos.

En la siguiente escena, encontramos al grupo vigilando a un sospechoso. En un momento de tensión, se oye el sonido de un disparo, y (a cámara lenta, parodiando los estilemas del cine policiaco), Joey cubre a Ross con su cuerpo. Inmediatamente sabemos que fue el ruido de un coche, pero este comportamiento da lugar a que Ross y Gary alaben la valentía de Joey, mientras que Chandler está visiblemente molesto. Al final de la escena, cuando Joey y Ross se quedan solos en la cafetería, este le mira con agradecimiento, pero de una manera que podría ser confundida cómicamente con enamoramiento, lo que molesta a Joey: «Cut it out, Ross, I'd hate to have to save your life and kick your ass in the same day». En la escena siguiente nos enteramos (después de un gag en el que Joey hace una interpretación estúpidamente errónea de su comportamiento) de que Chandler está celoso porque intentó salvar la vida de Ross antes que la suya, su mejor amigo. Esta escena es un recuerdo de la relación entre ambos compañeros de piso, cuya amistad es a lo largo de las primeras temporadas confundida con una relación amorosa por motivos cómicos. También el comportamiento de Ross con Joey juega a teñir de homoerotismo la relación entre los tres personajes. Ahora bien, en esta misma escena Joey confiesa que no quiso salvar a Ross, sino a su bocadillo, exagerando a la vez su estupidez y su obsesión con la comida.

En la escena final del episodio, los seis amigos fantasean con participación en una guerra (pasando de la fantasía del policía a la del soldado). Monica se apresura a asegurar que ella sería una excelente líder militar. La masculinidad de Monica es algo que veremos en repetidas ocasiones en nuestros análisis.

En resumen, vemos aparecer en un solo capítulo muchos elementos de cómo se muestra la relación con la masculinidad en la serie. Encontramos dos chistes sobre homosexualidad, además de la acusación de feminidad a Chandler al principio del capítulo, y otras dos bromas sobre la relación homoerótica subyacente a la relación de camaradería de los tres amigos. Vemos la sobre-actuación de Ross respecto a su masculinidad seguida inmediatamente de su humillación, y también la caracterización de 
Joey como un hombre básico, que se mueve exclusivamente por sus apetitos. Así mismo, debemos tener en cuenta la presencia de la masculinidad como fantasía en el sentido en que, como hemos dicho, participar en una ronda policial significa participar en una fantasía asociada a dicha idea de masculinidad. De esta manera, los personajes, al jugar, de una manera marcadamente infantil, a ser policías, se acercan imaginariamente a ese estándar de masculinidad heroica.

Sin duda estos juegos fantasiosos son lo más cerca que van a estar de alcanzarlo. Como ya hemos comentado, por una parte la comicidad de los tres protagonistas se basa principalmente en su imperfección y su imposibilidad de comportarse adecuadamente como hombres. Por otra, la época de Friends es también la de la popularización del feminismo ${ }^{35}$. Ello da lugar a ciertas transformaciones en el entendimiento de la masculinidad: la inclusión de la mujer en el entorno laboral, como ya hemos dicho, hace que este aspecto pierda importancia en la constitución de la masculinidad ${ }^{36}$; también, y quizás relacionado con este aspecto, podemos decir que uno de los aspectos más estrechamente vinculados con la ideología moderna de la masculinidad, la racionalidad (ver Guasch, 2006), también está prácticamente ausente en nuestra serie; de hecho, como

\footnotetext{
${ }^{35}$ De hecho, este tema será objeto de parodia en el decimonoveno episodio de la segunda temporada, en el que las chicas leen un libro que denuncia la opresión de su espíritu por parte de los hombres. Es paródico porque, cómo no, es un libro de autoayuda con un lenguaje místico. El empoderamiento y la sororidad propiciados por este libro se termina cuando, hacia el final del episodio, las tres amigas se pelean por un hombre.

${ }^{36}$ Mientras que la carrera de Monica y sobre todo Rachel tiene bastante importancia en el desarrollo de sus personajes a lo largo de la serie, no es así en el caso de Ross y Chandler. La única excepción sería Joey, actor fracasado, cuyas estrategias y trampas para conseguir un trabajo son el motor de muchos argumentos cómicos, pero, creemos, sin que estas dificultades laborales afecten a su identidad de género. En ningún momento Joey se siente menos hombre por no tener trabajo. De hecho, a veces significativamente ocurre lo contrario. En un episodio, a Joey se le plantea el dilema de acostarse con una directora de casting para conseguir un papel, y acaba accediendo. Es significativo porque, de haber sido una mujer a la que se le planteara el dilema, la percepción habría sido bien diferente. En otro episodio, debido a un malentendido, Rachel cree que el hombre que le entrevista para un puesto de trabajo quiere sexo a cambio de conseguirlo, a lo que ella se niega rotundamente.

Megan Garber dedica un sugestivo artículo en The Atlantic a analizar la cultura del trabajo en la serie a partir de la ocupación de Chandler, ya que, de hecho, será una broma recurrente que sus propios amigos no conozcan exactamente a qué se dedica su amigo. Garber señala cómo las profesiones del resto del grupo, conectadas de alguna manera con la creatividad (Monica es cocinera, Joey actor, Rachel conseguirá trabajar en el mundo de la moda, Ross trabaja en un museo y más tarde de profesor de paleontología, su pasión) vinculan el trabajo con la posibilidad de autorrealización de uno mismo, la creencia de que «work is not only necessary to economic production, but also the centerpiece of one's identity and life's purpose», mientras que la relación de Chandler con su trabajo de contable, que le es indiferente cuando no lo detesta profundamente, dinamita esta relación. La argumentación de Garber, como vemos, es muy cercana a la expuesta por nosotros en el primer epígrafe.
} 
corresponde a una comedia, los comportamientos de los personajes se caracterizan por su irracionalidad ${ }^{37}$.

La relativa aceptación de las ideas feministas, por supuesto, no significa que la serie esté libre de estereotipos de lo que son los hombres y las mujeres. La tradición cómica de la «guerra de sexos» y el contraste entre las formas de ser supuestamente propias de cada género son el motor de muchas bromas a lo largo de la serie, sobre todo en sus primeras temporadas. Por tanto, y teniendo en cuenta que, como dejamos dicho, la masculinidad es un concepto relacional, a lo largo de los siguientes análisis nos tendremos que remitir en muchas ocasiones a la contrapartida femenina de los casos que tratemos, por ejemplo, al hablar de la sexualidad de los hombres y cómo ven las relaciones románticas ambos géneros.

Sin ir más lejos, el segundo episodio de la serie se abre con una conversación entre los seis protagonistas acerca de la importancia que les dan a los besos en la relación sexual. Para ellas es muy importante, mientras que para ellos, como dice Chander, «kissing is pretty much like an opening act, you know? It's like the stand-up comedian you have to sit through before Pink Floyd comes in». "Yeah, and it’s not that we don't like the comedian», le apoya Ross, «It's just that that's not why we bought the ticket». «The problem is, though», prosigue Chandler, «after the concert's over, no matter how great the show was you girls are always looking for the comedian again. I mean, we're in the car, fighting traffic. Basically, just trying to stay awake.» La oposición es evidente: las mujeres buscan en la relación sexual cariño y sentimientos, mientras que los hombres se centran en la penetración, el mero placer físico y genital ${ }^{38}$.

En general, la serie presenta como dado por hecho, sin mayor reflexión acerca de las posibles razones, que los hombres y las mujeres son, simplemente, diferentes, tienen aficiones e intereses diferentes y se comportan de manera diferente. Por eso, como se ve

\footnotetext{
${ }^{37}$ Si bien no del todo. En unas pocas ocasiones, será Ross, como científico (paleontólogo) de profesión, el que represente esa racionalidad científica propia de la masculinidad, sobre todo en sus enfrentamientos con la mística y supersticiosa Phoebe. En un episodio, Ross se muestra incrédulo e incluso ofendido con que Phoebe no crea en la teoría de la evolución. En un caso mucho más significativo, en un capítulo el que Phoebe cree que un gato que ha encontrado en la calle es la reencarnación de su madre fallecida, es Ross el único que actúa de manera tajante y le dice que en realidad es el gato perdida de una niña pequeña.

${ }^{38}$ Los hombres en general no prestan mucha atención a los detalles. Después del primer beso entre Ross y Rachel en la segunda temporada, se comparan en dos escenas paralelas cómo ambos lo cuentan a sus amigos. Monica y Phoebe enseguida se interesan por todos los detalles: cuánto duró, qué hacía con sus manos, si la abrazó, etc. Ross se limita a decirles a Joey y Chandler: «So we kissed»; «Tongue?» preguntan ellos. «Yeah»; «Cool». Y eso es todo.
} 
en el episodio decimonoveno de la primera temporada, hay «chick flicks», películas para chicas protagonizadas por Hugh Grant, mientras que las «pelis para tíos» consisten, según las caracteriza Phoebe, en «guns, and bombs, and buses going really fast» - «Hey», responde Joey, «I don't need violence to enjoy a movie, just so long as there's a little nudity».

Existen, por tanto, unas actividades específicamente masculinas, unas prácticas de masculinidad que caracterizan a los hombres, como ir a clubes de striptease o jugar al póker. Esta es, de hecho, la premisa del capítulo decimonoveno de la primera temporada, sobre el que tendremos ocasión de volver, en que las chicas se quejan de que los chicos nunca les inviten a jugar al póker con ellos («What is that? Some kind of guy thing, like some kind of sexist guy thing? Like, it’s poker, so only guys can play?», dice Phoebe). Como es de esperar, cuando ellas empiezan a jugar, no siguen las reglas, como niños pequeños, para exasperación de los hombres. La partida de póker, como espacio de homosocialización, tiene hasta sus rituales: Monica sirve unos aperitivos sofisticados y Joey se queja porque «you can’t serve food with more than one syllable» en una partida de cartas.

También existen lugares masculinos, como el apartamento de Joey y Chandler, marcado en varias ocasiones como tal en oposición al de Monica, más claramente femenino. En un episodio en que, a causa de un incendio, Rachel y Phoebe pierden su piso y tienen que ir a vivir a estos dos apartamentos, estos espacios quedan claramente contrapuestos: por un lado, el piso de Monica es más ordenado, acogedor, pero lleno de normas y exigencias, mientras que el piso de Joey está sucio y huele mal, pero es un espacio de libertad y diversión.

Como contrapartida, también existen unas prácticas específicamente femeninas, cuya realización por parte de un varón provoca dudas acerca de su masculinidad, lo que también será un motivo cómico en repetidas ocasiones. Por ejemplo, y volviendo al motivo del espacio masculino, cuando Joey acepta como compañera de piso a una chica, Janine, esta empieza a llenar el apartamento de objetos “típicamente femeninos” (cuadros de bebés, cojines de color púrpura, flores, cuencos de popurrí, etc.) y persuade a Joey de participar de esta decoración e incluso aprender cómo hacer arreglos florales. Chandler 
se indigna ante este comportamiento: «This is a guy’s place! Talk to her [para decirle que guarde toda esa decoración], you're a man!», le espeta. ${ }^{39}$

También puede ocurrir a la inversa, y que las mujeres ocupen espacios y prácticas masculinas con resultado cómico, como en la partida de póker mencionada. En otro gag, Phoebe decide comportarse como un «tío» para comunicarle a Chandler que una chica le está mirando, así que le dice con voz exageradamente grave: «Dude, eleven o’clock, totally hot babe checking you out». Phoebe se muestra satisfecha con su actuación: «That was really good! Think I'm ready for my penis now». La práctica de la masculinidad por parte de mujeres es, como argumenta Reeser (2010: 131-142), un buen modo de entender la masculinidad como una ideología y algo no anclado naturalmente en el cuerpo del varón. El mejor ejemplo de esto es, sin duda, el personaje de Monica, cuyas muestras de masculinidad (competitividad, agresividad, fuerza física, etc.; lo que da lugar a una “atípica” pasión por los deportes) suponen en muchas ocasiones, además de un motivo cómico, una amenaza para los personajes masculinos (como en el episodio en que Joey y Chandler compran un futbolín y se cansan de que Monica les gane continuamente): «Part of the anxiety created stems from the fact that, like effeminacy, female masculinity destabilizes imagined binary oppositions between male masculinity and female feminity» (Reeser, 2010: 133). En todo caso, estos motivos, hasta cierto punto independientes (pues los efectos cómicos no son los mismos ni tienen la misma estructura) de mujeres comportándose como hombres y hombres realizando prácticas femeninas, más allá de la burla por afeminamiento que implica lo segundo, muestra una ambigua permeabilidad en las prácticas de ambos géneros que desmiente, en cierto nivel, la idea también declarada por la serie de que, simplemente, hombres y mujeres son diferentes por naturaleza.

Estos son algunos de los ejes sobre los que tratarán los análisis siguientes. Si la premisa de la serie respecto al género es que existen identidades masculinas y femeninas, con rasgos psicológicos específicos y prácticas particulares, lo primero que habrá que atender es las características de la masculinidad, cómo son los hombres. Pero también habrá que prestar atención a cómo se relacionan los hombres con las mujeres y con otros hombres. Como veremos, el ámbito principal de estos análisis será la sexualidad: por un lado, los hombres están estereotípicamente centrados en el sexo, obsesionados con él y

\footnotetext{
${ }^{39}$ Esto es interesante: no provoca dudas acerca de la sexualidad de los varones (como veremos, también acerca de esto hay muchas bromas) sino de su identidad de género: en estos gags es típico que uno de los personajes llame al varón que está realizando prácticas femeninas por un nombre de chica.
} 
movidos por sus apetitos sexuales; por otro, las relaciones entre hombres y mujeres que se tratan en la serie son específicamente las relaciones sentimentales. Así mismo, las relaciones entre hombres darán lugar en muchas ocasiones a momentos de confusión teñidos de homoerotismo y amenazas de homosexualidad. Esto está relacionado, por supuesto, por la confusión de la identidad de género, y la amenaza de afeminamiento de los personajes masculinos será una constante cómica. Por último, discutiremos cómo, en cierto nivel, y debido a las características propias del discurso y el género cómicos, se cuestionan estas representaciones supuestamente naturales de la masculinidad precisamente como representaciones, imágenes estereotipadas que conforman la masculinidad más como una idea que como una realidad.

\subsubsection{Joey o el latin lover. Hombres, apetitos y sexualidad.}

«If I wanted to start a conversation with Joey I would talk about sandwiches and my underwear» - Rachel Green

Matt Le Blanc, el actor que encarna a Joey Tribbiani, tuvo claro desde el principio de la serie que su personaje era bastante prescindible. Desde el guion original de la serie, Joey quedaba caracterizado como el salido del grupo, «un tío de veintitantos años, guapo, engreído y muy macho» (Miller, 2018: pos. 941). De hecho, el «macho italoamericano» era un estereotipo bastante difundido en la televisión de la época «teñido además de esos matices de criminalidad y misoginia que se asociaban con la comunidad italoamericana desde tiempos de El padrino» (Miller, 2018: pos. 974), y el propio actor ya había realizado en otras ocasiones ese papel. Joey es, literalmente, un «latin lover». Por eso, Le Blanc tuvo dudas desde el principio acerca de la continuidad de su personaje, dada la unidimensionalidad de su caracterización (Miller, 2018: 1285). Esta anécdota es ya de por sí interesante, dado que muestra cómo ya en los años noventa se tenía una visión de esa clase de masculinidad como vacía, prescindible.

La solución del actor fue, ya desde la prueba para el papel, hacer el personaje un poco más tonto de como estaba escrito en el guion, lo que le daba al personaje una pátina de inocencia y ternura que moderara su machismo (Miller, 2018: 941). Al final, estos son los dos rasgos que definen la masculinidad representada por Joey: su sexualidad y su estupidez. Ya en el primer episodio Joey intentaba ligar con Rachel el día en que esta se había fugado de su propia boda. En el segundo encontramos un gag en el que Joey se 
come una lasaña, a pesar de que su amigo Ross esté pasando por un mal momento debido a su divorcio, provocando la mirada de reproche de sus amigos. Como hemos dicho, en Joey se dan conjuntamente el apetito por la comida y el sexual, en una vinculación claramente carnavalesca. Esto, unido a su estupidez, hace de su personaje el de más clara ascendencia en la tradición cómica: representa, por un lado, el personaje carnavalesco movido por sus instintos, que resulta gracioso por mostrar sus apetitos a pesar de las normas sociales, y el del bobo ${ }^{40}$. También lo convierte en la encarnación de uno de los estereotipos masculinos más negativos: el del «hombre básico», que solo piensa en el sexo y que es incapaz intelectual y emocionalmente.

En una primera etapa de la serie, ciertamente, el rasgo definitorio de Joey es su libido. En el cuarto episodio de la primera temporada, cuando entiende por error que Monica le pregunta qué haría si fuera impotente, responde: «Probably kill myself (...) If little Joey didn’t work, I’ll have no reason to live» ${ }^{41}$. La mayoría de los comentarios cómicos de Joey, o bien muestran su estupidez, o son de índole sexual, o se dan ambos rasgos a la vez. Cuando Ross tiene que elegir entre Rachel y su actual pareja, Julie, Joey le aconseja: «Two words: threesome». O, cuando Monica tiene que llevar unos pechos postizos exageradamente grandes en su trabajo de camarera, Joey no puede dejar de mirarlos. Otro motivo recurrente es su obsesión por la fantasía masculina del sexo entre mujeres. En un capítulo de la tercera temporada, Monica y Rachel se caen una encima de la otra justo cuando Joey entra al apartamento, y este gestualiza su excitación cómicamente. En la cuarta temporada, cuando están en el hospital durante el parto de Phoebe, Rachel le dice a Monica que ha conseguido una cita con unos enfermeros («nurses), y Joey las mira lascivamente; «male nurses» (en inglés no se distingue el género) especifica Rachel; «not in my head» insiste él, lascivamente.

La obsesión por el sexo y el cuerpo de la mujer no es solo cosa de Joey. La sexualidad de los hombres en general está representada de esta manera; mediatizada, en general, por la pornografía y la televisión. Una de las actividades comunes de Joey y

\footnotetext{
${ }^{40}$ Es necesario destacar el hecho de que, efectivamente, la estructura de la comicidad de los gags que tienen que ver con la sexualidad no implican en general el fracaso del personaje en los términos antes establecidos, sino en la liberación carnavalesca de los tabúes relativos a los instintos.

${ }^{41}$ Las referencias jocosas a la impotencia también son relativamente frecuentes. Cuando Rachel presenta una demanda para anular su matrimonio con Ross, una de las razones que da, además de ser heroinómano y homosexual, es su incapacidad para consumar el matrimonio, a lo que Ross se defiende gritando «I can consumate right here, right now!». En el primer episodio de la séptima temporada, Chandler sufre un gatillazo la noche en la que pide matrimonio a Monica, con las consiguientes bromas a lo largo de todo el episodio.
} 
Chandler es ver Los vigilantes de la playa solo por las actrices en bañador. En otro episodio, por un error de la compañía de televisión Joey y Chandler sintonizan gratuitamente el canal de pornografía, y se pasan días enteros viendo la tele. Son abundantes las referencias cómicas a la lectura de revistas como Playboy o las visitas a la sección erótica del videoclub. En algunas ocasiones se señala lo ridículo de las fantasías que proyectan esta. Por ejemplo, al final del mencionado episodio en que Joey y Chandler ven pornografía en la televisión, se sorprenden de que las fantasías de las películas no se produzcan en la vida real. De manera más sutil, en un capítulo de la primera temporada en que están buscando a la mascota de Ross por todo el edificio, ambos llaman a un apartamento en que dos atractivas jóvenes les preguntan si saben arreglar la calefacción, porque está rota y, debido al calor que hace en el apartamento, tienen que ir desnudas, en una clara parodia de un argumento de película pornográfica. Ahora bien, es difícil decidir si este gag se limita a señalar lo absurdo de esta fantasía, pero sigue dando por hecho la atracción natural de los personajes masculinos por este tipo de fantasías - es decir, si los hombres tienen esta concepción de la sexualidad por culpa de la pornografía, o si la pornografía tiene tanto éxito porque proyecta el tipo de sexualidad que naturalmente es propia de los hombres.

En todo caso, esta sexualidad está caracterizada por su objetificación del cuerpo de la mujer. En el primer episodio, Joey le recomienda a Ross, recién divorciado, que para superarlo vaya a un club de estriptis y «libere sus hormonas», remitiéndose a un cierto motivo popular del hombre como un cazador sexual natural, libre por fin de la monogamia conyugal - además de equiparar «ligar» con un ir a un club de estriptis. En otra ocasión, cuando es Chandler quien ha roto con su pareja, las chicas le proponen ir a uno de estos clubs para animarle. Sin embargo, esto no funciona, y Chandler solo se anima cuando las chicas comentan delante de él con cuál de las bailarinas tendrían relaciones sexuales - de nuevo, el motivo de la mirada masculina fetichizadora del sexo lésbico.

Esta obsesión por el cuerpo femenino erotizado provoca que en muchas ocasiones los personajes masculinos se comporten de manera irracional y se dejen llevar por sus impulsos - uniendo de alguna manera, como venimos diciendo, la sexualidad desenfrenada y la estupidez como rasgos del estereotipo del hombre básico. Por ejemplo, en la primera temporada, Chandler tiene que despedir a una empleada, pero no es capaz de hacerlo porque le parece atractiva, lo que da lugar a una serie de enredos y malentendidos a lo largo del episodio. En la segunda temporada, Joey sale con una 
acosadora mentalmente desequilibrada que cree que su personaje en una telenovela es una persona real, solo porque le resulta atractiva físicamente. Y en otra ocasión, Ross y Chandler son incapaces de cancelar su inscripción a un gimnasio porque, cuando intentan hacerlo, el encargado llama a una mujer atractiva para que les atienda y se sienten incapaces de llevarle la contraria. Este comportamiento toma, como vemos, rasgos exageradamente ridículos. Cuando en una ocasión los protagonistas están jugando un partido de fútbol americano, una de las estrategias de las chicas para distraerles es enseñarle los pechos. Cuando Rachel y Monica pierden el apartamento en una apuesta y tienen que intercambiarlo con Joey y Chandler, lo recuperan solo con besarse entre ellas durante un minuto.

Otro motivo asociado a la sexualidad de los hombres, y que tiene que ver directamente con la idea de la masculinidad como éxito, es la capacidad de los personajes para ligar con mujeres. Mientras que Joey es un ligón nato, Ross y Chandler son protagonistas de muchos momentos cómicos al comportarse de manera ridícula delante de las mujeres cuando intentan ligar con ellas. Relacionado con esto, encontramos repetidamente el motivo de las estratagemas usadas por los chicos para conquistar mujeres que, como veremos enseguida, implica normalmente el engaño y la manipulación. En un episodio de la segunda temporada, por ejemplo, Chandler y Joey se ofrecen a cuidar del hijo de Ross para poder aprovecharse del supuesto instinto maternal de las mujeres para mostrarse como deseables - el desarrollo del argumento es bastante elocuente: por un lado, algunas mujeres les confunden, para frustración de ambos, con una pareja gay; por otro, en un momento dado olvidan al bebé en el autobús porque estaban distraídos hablando con dos mujeres.

En su relación con las mujeres, por supuesto, a Joey solo le interesa el componente sexual. Por ejemplo, en el quinto episodio, se reencuentra con una antigua amante («We were great together», recuerda Joey, «not just the fun part - all the talking too») que es más atractiva de lo que recordaba y decide que tiene que volver con ella, aunque para ello tenga que hacer que ella corte con su actual pareja (como veremos enseguida, las estratagemas para ligar de los hombres también son un motivo recurrente): todo ello por su aspecto físico, más allá de cualquier sentimiento profundo. A la altura de la sexta temporada, cuando tiene que buscar un nuevo compañero de piso, acepta a Janine, una atractiva australiana, sin saber nada de ella: ni su apellido, ni su origen, ni su profesión. 
Como contrapartida, la sexualidad de las mujeres está caracterizada por su interés y casi obsesión por los sentimientos y el compromiso, como hemos señalado al comentar la conversación acerca de la importancia de los besos para unos y otras. Incluso cuando las mujeres muestran deseo sexual, este es motivado no por el atractivo físico de los hombres, sino por aspectos sentimentales. Es lo que podemos comprobar en la estrategia de Joey y Chandler de aludir a los instintos maternales de las mujeres al pasear al bebé de su amigo. En un capítulo de la primera temporada, Phoebe y Monica muestran una sexualidad activa al proyectar sus fantasías sobre un hombre que ha entrado en coma en un atropello. Y, sin embargo, las fantasías que proyectan sobre él, lejos de ser sexuales, son acerca de su carácter y moralidad y la relación sentimental que podrían mantener. En otra ocasión, Joey dice estar cansado de relaciones únicamente sexuales, sin ninguna intimidad como la que tienen Monica y Chandler y decide empezar una relación con una mujer, pero sin tener sexo, solo estableciendo una base de confianza. Sin embargo, al final del episodio relata cómo se ha acostado con ella porque cuando le contó cómo estaba buscando una relación de confianza más allá del sexo, la mujer en cuestión se sintió irremediablemente atraído sexualmente por él.

De las tres mujeres protagonistas, solo Phoebe muestra ocasionalmente una sexualidad abierta, activa y desprejuiciada, y está dispuesta a mantener relaciones sexuales ocasionales. Y, aunque estas muestras de sexualidad activa por parte de las mujeres que hemos mencionado antes sean más bien escasas, representan una amenaza para los hombres. La madre de Chandler, por ejemplo, es una famosa autora de novelas eróticas, lo que incomoda de manera exagerada a su hijo. En el episodio sexto de la primera temporada, el mismo personaje conoce a una chica poliamorosa que solo busca una relación sexual y no sentimental con él, ya que tiene pareja, y si bien el sexo sin compromiso representa «a guy fantasy», él se muestra cómicamente incómodo por la sexualidad fuerte de su pareja. Cuando se lo comenta a sus amigos, a ellas les parece algo inconcebible, mientras que Joey asegura que él lo que necesita saber es que sale con más personas que ella. En la cuarta temporada, cuando Rachel acaba de salir de una relación estable, le dice a Chandler que quiere tener una aventura ocasional («fling») sin las inconveniencias de las relaciones serias, a lo que Chandler se muestra sorprendido («I didn't know that women also wanted flings»). Cuando este le busca una cita a su amiga 
entre sus compañeros de trabajo y les cuenta que ella solo está buscando algo ocasional, estos se muestran más que deseosos de ser el elegido ${ }^{42}$.

Este tópico acerca de una sexualidad femenina centrada en lo sentimental alcanza su máxima expresión en los momentos en que se da a entender que la mayor aspiración de las mujeres es casarse. En el vigésimo capítulo de la cuarta temporada, Monica tiene que recoger el vestido de novia de la prometida de su hermano, Emily. Monica se prueba el vestido y comienza a fantasear con el día de su boda, llegando a llevarlo puesto mientras friega los platos. Más tarde, Phoebe también alquila un vestido de novia y ambas juegan a tirarse el ramo. El clímax de este gag sostenido a lo largo del capítulo llega al final, cuando Rachel también se pone un vestido: anteriormente, esta le había pedido matrimonio a su novio de cuatro semanas, Joshua; cuando este va a su apartamento para arreglar la relación con ella, la encuentra vestida de novia y huye despavorido. La importancia no solo del matrimonio sino del día de la boda es un motivo frecuente en la serie. Cuando llega la boda entre Emily y Ross (en el vigésimo tercer episodio de la cuarta temporada), Monica asegura a su hermano que cualquier chica ha planeado el día de su boda desde los cinco años, enfrentándolo al pragmatismo (racionalista) con la que los hombres encaran este día. Esto vuelve a ocurrir en la séptima temporada cuando Monica descubre que sus padres han gastado el dinero que tenían para su boda, y le pide a Chandler que gasten todos sus ahorros en la ceremonia; al principio a él le parece una locura, pero acaba cediendo dada la importancia que tiene para su prometida.

Otro tópico en la relación entre ambos géneros es el de la inmoralidad y falta de empatía de los hombres hacia las mujeres. En el primer episodio de la serie, Monica tiene una cita con un compañero de trabajo que le miente afirmando que no ha sido capaz de tener erecciones satisfactorias desde que se divorció para poder acostarse con ella ${ }^{43}$, representando el tópico de la mujer crédula que busca sentimientos en sus relaciones, y el hombre que solo busca sexo y recurre a artimañas y engaños para conseguirlo. En el capítulo catorce de la primera temporada, las chicas deciden hacer por San Valentín una

\footnotetext{
${ }^{42}$ En este episodio, Chandler trafica casi literalmente con Rachel, ya que recibe un montón de regalos por parte de sus compañeros a cambio de que les consiga una cita con ella, en una suerte de intercambio ritual sui generis de mujeres como los descritos por Levi-Strauss o Gayle Rubin. Por supuesto, los regalos que recibe son típicamente masculinos: whiskey, puros, etc.

${ }^{43}$ Una anécdota significativa: uno de los ejecutivos de la cadena, al leer el guion de este episodio piloto, mostró su indignación porque una mujer tuviera sexo con un hombre en la primera cita. Los creadores, para solucionarlo, decidieron hacer una encuesta a una audiencia de muestra acerca de qué les parecía este comportamiento (encuesta que más tarde se recordaría como "encuesta de la zorra"). Los encuestados aseguraron no tener ningún inconveniente. (Miller, 2018: ref)
} 
especie de ritual para vengarse de los hombres y conjurar su mala suerte con ellos. Como el ritual implica fuego, hay un pequeño accidente que requiere el auxilio de unos bomberos, que les cuentan a las chicas que ese ritual anti-hombres es algo que hacen muchas chicas por San Valentín, dando a entender, por tanto, que es general que las mujeres sufran por el mal comportamiento de los hombres. Al final del episodio, los bomberos les dan su número de teléfono a nuestras protagonistas, pero cuando salen del apartamento mencionan entre ellos que ya están casados. Moraleja: todos los hombres son unos cerdos, pero las mujeres, irremediablemente ingenuas, siguen cayendo en sus trampas.

Parece haber un cierto consenso acerca de que lo único que los hombres buscan en su relación con las mujeres es sexo. Cuando Rachel recibe una oferta de trabajo gracias al favor de un hombre que ha conocido en un restaurante, Mark, Ross, que en esa época es su novio, se pone celoso porque sospecha de las intenciones de Mark. «Joey», le pregunta a su amigo para apoyar su argumento, «have you ever been nice to a woman just for nothing?»;««No, just for sex» le responde él.

Chandler y sobre todo Joey tampoco tienen ningún problema en manipular a las mujeres para conseguir sexo. En cierta ocasión, Joey revela una de las claves de su éxito con las mujeres: «I can sense when woman are depressed and vulnerable, that's one of my gifts». En otro gag, Joey confiesa en dos ocasiones, pero de manera traviesa, que se acostó con una mujer y no la llamó aunque le dijo que no lo hizo. En el quinto capítulo de la primera temporada, Chandler no se atreve a cortar la relación con quien será un personaje secundario recurrente a lo largo de la serie, Janice, y Joey le dice: «Why do you have to break up with her? Be a man, just stop calling her» ${ }^{44}$.

Esta manera de tratar a las mujeres tiene que ver, sobre todo, con la incapacidad emocional que en la serie caracteriza a los personajes masculinos, sobre todo a Chandler, como tendremos ocasión de ver. En general, otro rasgo relacionado con la masculinidad es el infantilismo y la inmadurez. Como hemos apuntado, la otra característica dominante de Joey es su estupidez que, si bien es simplemente ingenuidad o distracción en las primeras temporadas, se exagera conforme avanza la serie hasta llegar a extremos inverosímiles que, sin duda, arruinaron al personaje al hacerlo excesivamente infantil. A

\footnotetext{
${ }^{44}$ Ya avanzada la serie, después de un breve reencuentro, Chandler llegará a decirle que se muda a Yemen para no tener que cortar con ella.
} 
lo largo de la serie cada vez son más frecuentes las intervenciones de Joey, o tramas enteras dedicadas a mostrar su escasa inteligencia. Esta infantilización, como veremos, tiene que ver con el cambio en la dinámica de su relación con Chandler.

De nuevo, aunque sea un rasgo predominante de Joey, no es el único personaje caracterizado por el infantilismo. En el segundo episodio de la segunda temporada, Chandler y Joey se pelean por quién se sienta en el sofá, dando lugar a una serie de gags en los que cada cual se muestra más infantil. En el siguiente capítulo, Joey se hace un esguince saltando en la cama; en otro, Monica recibe por error una cama con forma de coche de carreras, diseñada para los niños, y en un gag vemos a Chandler jugando con ella. En el episodio duodécimo de la tercera temporada, Chandler se entretiene jugando con un bolígrafo con una mujer desnuda que ha conseguido en una despedida de soltero, conjugando la sexualidad y la cosificación de la mujer con el infantilismo.

En resumen, los protagonistas masculinos, sobre todo Chandler y más aún Joey, están caracterizados según un estereotipo negativo de la masculinidad, que representa a los hombres como seres básicos movidos por sus instintos sexuales, y también como niños grandes, inmaduros emocionalmente. Esta imagen, tan aparentemente alejada de lo que una ideología de la masculinidad ideal promocionaría ${ }^{45}$, es fácilmente justificable si tenemos en cuenta que estamos analizando una comedia, y por tanto, los personajes tienen que ser inferiores de alguna manera para ser cómicos - además de presentar una cierta liberación de los instintos con los que el espectador también se puede sentir identificado. Además, más adelante veremos cómo esta caracterización de los protagonistas masculinos como hombres imperfectos (recordemos, por ejemplo, que uno de los motivos cómicos recurrentes es el de la incapacidad de Chandler y Ross para ligar) queda contrastada con personajes masculinos secundarios que aparecen como modelos ideales de varones, lo que es fuente de ansiedad para nuestros protagonistas.

\footnotetext{
${ }^{45}$ Solo aparentemente. Por un lado, el supuesto desinterés de los hombres por cuestiones como los sentimientos y el compromiso emocional, que tanto obsesiona a las mujeres, tiene que ver con una división tradicional según la cual a la mujer le corresponde el ámbito de los afectos, las relaciones amorosas y, en fin, el ámbito de lo matrimonial, y lo privado. Por otro, esta supuesta sexualidad mucho más activa e irrefrenable y cosificadora del cuerpo de la mujer en los hombres que en las mujeres, es un típico argumento que justifica cuestiones como la promiscuidad, la violación o la necesidad "natural” de la prostitución.
} 


\subsubsection{Ross 0 el perdedor romántico. Sobre-actuaciones de} masculinidad. Hombres, mujeres y relaciones de poder.

«It’s so typical. Oh, I am a man, I have a penis, I have to win money to exert power over women» - Rachel Green

Durante la partida de póker que mencionábamos antes, Ross advierte: «Look, this is poker, I play to win, ok? And for me to win other people have to lose. So if you play poker with me, don't expect me to be a nice guy. Cause once the cards are dealt... I'm not a nice guy». Esta exagerada muestra de masculinidad, con la que Ross espera resultar atractivo a Rachel, es recibida por sus amigos entre la risa y la mera indiferencia. Como habíamos adelantado, las sobreactuaciones de masculinidad de Ross siempre son recibidas con alguna cómica humillación para dejar claro que, por mucho que lo intente, Ross “no da el pego” como hombre “de verdad”. Esta performatividad hiperbólica del personaje es un motivo bastante frecuente. Unos capítulos antes, también con el objetivo de seducir a Rachel cuando la ayuda a hacer la colada, decide cambiar su suavizante, que es demasiado femenino («It says I'm a sensitive, warm kind of guy, like a little fuzzy bear», se defiende, frente a la mirada de reprobación de Chandler) por el detergente de la marca alemana Überweiss («It’s extra tough»).

No todas estas muestras de masculinidad tienen el objetivo de resultar atractivo. Cuando en la quinta temporada descubre la relación entre Chandler y Monica, con su reacción airada busca mostrarse como el protector de su hermana pequeña, lo que llega a un punto culminante cuando, días antes de su boda, amenaza a Chandler con darle una paliza si alguna vez le hace daño a Monica - lo que le provoca al prometido un ataque de risa. En general, como vemos, estas sobre actuaciones de masculinidad tienen que ver con el estereotipo de la violencia, la agresividad y la protección ${ }^{46}$ - que, como veremos, tiene mucho que ver con la dominación.

Esto tiene que ver con ciertas prácticas de masculinidad, como la fantasía policíaca que reseñábamos al comienzo del epígrafe, o algunos deportes especialmente físicos. En el episodio número quince de la cuarta temporada, Ross y su pareja de entonces, Emily, se encuentran con unos amigos de ella, que representan el tipo de hombres grandes y fuertes que juegan al rugby, deporte, por su agresividad y violencia,

\footnotetext{
${ }^{46}$ En el mismo episodio en que Rachel y Ross hacen la colada juntos, este increpa a una mujer (de caracteres muy masculinos, por cierto) que ha quitado la lavadora a Rachel.
} 
masculino por antonomasia - al terminar la escena, uno de ellos bebe una cerveza de un trago y aplasta la lata con una mano. Ross, al sentirse amenazado por ellos, se apunta al partido para demostrar su virilidad, con resultados cómicos.

El deporte, de hecho, está marcado en muchas ocasiones como una práctica masculina típica. En un capítulo, Chandler está jugando a encestar una bola de ping pong en un cuenco con una cuchara, y cuando llega Joey, coloca a una mayor distancia el bol, diciéndole «at least you suck at a men’s game now». Durante una cena de Acción de Gracias, Monica le dice a Chandler que puede ver el desfile en lugar del partido de la Superbowl porque los chicos no están presentes, para la alegría de aquel. Y, como hemos dicho, uno de los signos cómicos de la masculinidad de Monica es su competitividad y su afición por los deportes.

En cierto sentido, el deporte aparece como la institucionalización de la violencia como práctica de asociación masculina (Guasch, 2006: 21, 32). En el vigésimo primer episodio de la segunda temporada, Ross y Chandler son acosados por unos matones (bien vestidos, hombres de negocios de éxito: otro modelo de masculinidad triunfante) que les echan de su sitio habitual en la cafetería. En un determinado momento, al encararse con ellos, los matones les retan a una pelea callejera, que, en tanto que ritual de masculinidad $^{47}$, tiene sus reglas y directrices. Pero antes de llegar a pelearse, los protagonistas y sus rivales se tienen que enfrentar a unos ladrones y, en la escena siguiente vemos cómo todos se sientan en el café como buenos amigos: al haber participado en ese despliegue de fuerza, los matones les respetan - menos a Chandler, que no ha participado en la pelea porque se tropezó con la cuerda de la comba de una niña.

Teniendo en mente esta idea del deporte como práctica de masculinidad que ritualiza la competitividad y la violencia, y por tanto el poder ${ }^{48}$, y también que la protección de la mujer es un elemento fundamental de esta masculinidad agresiva, volver a la partida de póker de la primera temporada ofrece matices muy interesantes. Como hemos comentado, la intrusión de las mujeres en ese espacio de socialización masculina, y su comportamiento infantil en el juego, supone una frustración para los hombres, que

\footnotetext{
47 «La masculinidad se logra merced al reconocimiento del grupo de pares, y, para mantenerlo, es preciso probar que se es merecedor del mismo compitiendo con otros varones por idéntico galardón»: se compite por las mujeres, por un puesto de trabajo, exhibiendo la riqueza, en los eventos deportivos o en las muestras más crudas de violencia (Guasch, 2006: 32)

48 Al principio del episodio, Joey es humillado por sus compañeros por haber llorado tras perder en la anterior partida. Como vemos, el póker es una práctica mediante la que se demuestra la hombría.
} 
enseguida da paso a la condescendencia cuando, terminada la partida, Joey propone que las chicas no tengan que pagar el dinero que deben por haber perdido. Monica, la competitiva, protesta ante lo que considera una ofensa por dar a entender que son débiles y necesitan ser protegidas, y pide una revancha. Las chicas piden ayuda a una familiar de Monica experta en póker (que muestra ademanes masculinos, claro) para que les enseñe, pero aun así vuelven a perder y Monica pide una tercera partida. En esta ocasión, Rachel se enfrenta especialmente a Ross por su agresividad y prepotencia, para frustración de este cuando empieza a perder ante una mujer. Todo cambia cuando Rachel recibe una llamada en la que le comunican que no ha conseguido un trabajo que deseaba con fervor. Sus amigos le ofrecen dejar de jugar, a lo que esta se niega, y empieza a apostar cada vez más dinero contra Ross. En una escalada de tensión, se forman dos bandos, el de las chicas y el de los chicos, hasta que, en el último momento, Ross renuncia a ganar la partida no revelando que sus cartas son mejores que las de Rachel.

En esta escena se muestra claramente las tensiones de atracción y poder que van a subyacer a la relación entre Ross y Rachel, y en general todas las relaciones de él, a lo largo de la serie. La justa de poder entre hombres y mujeres acaba con la victoria de estos, y si durante el episodio se ha señalado la condescendencia de los chicos con las chicas como un desequilibrio de poder, el gesto final de Ross es un ejemplo aún más evidente. Además, es un gesto de romanticismo, en el que Ross decide perder para poder hacer feliz a la chica por la que se siente atraído. Este del sacrificio por amor será un motivo recurrente en la relación con Rachel. Por ejemplo, en la tercera temporada, cuando ya han roto el noviazgo, renunciará a acudir a una entrevista en televisión por ayudarla a ir al hospital. De hecho, el comienzo de su relación se da finalmente cuando ven un vídeo del baile de graduación de Rachel y Monica en que se conoce cómo Ross estaba dispuesto a ser el acompañante de Rachel cuando creen que la han dejado plantada.

Estos gestos están pensados para mostrar el profundo amor que Ross siente por Rachel, pero la romantización de la relación de ambos esconde lo tóxico de algunas actitudes de Ross, uno de los aspectos más discutidos de la serie conforme ha pasado el tiempo: su aparente romanticismo esconde unas maneras posesivas y controladoras de desempeñarse en las relaciones amorosas. Esto se hace más evidente cuando Rachel consigue cambiar su trabajo de camarera por uno en una marca de moda y empieza a pasar menos tiempo con Ross; además, la presencia de Mark, su compañero de trabajo, provocará unos celos descontrolados (fomentados por los “expertos” consejos de sus 
amigos Chandler y Joey) que hará que actúe de manera ridícula, enviando montones de flores y regalos a Rachel en su oficina o presentándose él mismo en el momento más inoportuno. Este comportamiento paranoico será finalmente la causa de la ruptura de la pareja.

Aunque el comportamiento de Ross no sea tolerado por Rachel, reconociendo y explicitando su toxicidad, y el proceso de deterioro y ruptura de la relación contenga algunas de las escenas más dramáticas y mejor escritas de la serie, los celos de Ross son, la mayoría de las veces, motivo de comicidad. Cada muestra de nerviosismo por la presencia de Mark en la vida de Rachel, o cada gesto grandilocuente para "marcar su territorio”, como el envío de regalos a su oficina, está acompañado de la risa del público. Ahora bien, cabe preguntarse cuál es el objeto de la risa en estos casos, lo considerado ridículo del comportamiento de Ross: ¿lo exagerado del mismo? ¿el hecho mismo de que Ross esté celoso sin motivo? De cómo se reciban estos momentos humorísticos depende de que se considere que legitima o deslegitima el comportamiento del personaje: se podría plantear que los momentos son cómicos porque efectivamente se consideran ridículos los celos de Ross; pero, al mismo tiempo, este comportamiento que hoy en día es visto como tóxico y misógino, se ve frivolizado y considerado de menor importancia, precisamente por ser tratado cómicamente.

Lo cierto es que Rachel no es la única pareja con la que Ross se muestra celoso y posesivo. Ya hemos mencionado la ocasión en la que decide jugar al rugby porque se siente amenazado por los amigos de Emily, que considera más masculinos que él. En la sexta temporada, convertido en profesor universitario, empieza a salir con una de sus alumnas, Elizabeth. En un episodio se mostrará preocupado porque ella vaya de vacaciones a Florida con sus amigos (de nuevo por culpa de la influencia de Joey y Chandler, que les advierte que esos viajes universitarios suelen estar llenos de alcohol y sexo). A pesar de que Elizabeth le asegure una y otra vez que solo va a pasar unos días con sus amigos y no piensa acostarse con nadie, porque quiere que su relación funcione, en el último gag del capítulo los protagonistas verán en la televisión una transmisión en directo de una fiesta de Florida por la que descubrirán que Ross ha decidido acompañar a su novia para evitar que se acueste con nadie (en el gag vemos cómo aparta a un chico que se ha puesto a bailar con ella).

Este continuado tratamiento cómico de los celos de Ross como un chiste recurrente termina por frivolizar y restarle importancia a una actitud que, de nuevo, es 
producto de una masculinidad en la que las relaciones amorosas con las mujeres se conciben como una ambigua mezcla de protección, posesión y control. Al fin, lo que subyace a estas relaciones es una relación de poder del hombre sobre la mujer. De nuevo, cabe preguntarse sobre la comicidad de los celos que siente Ross porque Elizabeth se vaya de vacaciones es una censura de esos mismos celos o, más bien, es una burla a su masculinidad porque no es capaz de mantener a su pareja bajo control. Esto nos parece más evidente en la relación de Ross con Carol, su exmujer lesbiana, y su pareja actual, Susan.

Ya en la presentación del personaje en el episodio piloto se nos informa de que Ross acababa de divorciarse de su mujer porque esta ha descubierto que es homosexual. El primer gag cómico es la incredulidad de Joey de que no se hubiera dado cuenta antes. A partir de entonces, y durante toda la serie (mucho después incluso de que Susan y Carol hayan dejado de ser personajes secundarios recurrentes) bastará con que se haga referencia a la sexualidad de su exmujer para que se oigan las risas del público. De alguna manera, es ridículo y por lo tanto gracioso que Ross tuviera una pareja lesbiana. ¿Sería, tal vez, por no ser capaz de controlar la sexualidad de su mujer?

Según apunta Kelsey Miller, para muchos espectadores de la época, la caracterización pareja formada por Susan y Carol eran la prueba más evidente de la homofobia de la serie (2018: 1521). En nuestra opinión, y como tendremos ocasión de argumentar, resulta más problemático el tratamiento de la homosexualidad masculina, pero ciertamente hay una serie de chistes (además de las fantasías sexuales de rigor protagonizadas por Joey y Chandler) a costa del lesbianismo y sus estereotipos, como la masculinidad de la lesbiana. En el mismo episodio piloto, Ross comenta que debería haber averiguado que era lesbiana porque le gustaba beber la cerveza directamente de la lata. En una ocasión, Ross saluda a Susan con un puñetazo en el hombro, es decir, como saludaría a un hombre; en otra, confunde a una amiga de la pareja con un actor de la época.

En cualquier caso, también la serie, como veremos, contribuyó enormemente a la normalización de que una pareja de mujeres aparezca en una serie popular. Sin embargo, quizá lo más problemático fuera la propia actitud de Ross respecto a la sexualidad de su exmujer. En el segundo episodio de la serie, Carol le comunica que está embarazada de él y que ella y Susan quieren que participe en la vida de su hijo, con lo que las acompaña a la primera visita al ginecólogo. Desde que coincide con Susan en la consulta («Good 
shake, Good shake» dice a modo de saludo, ya que por lo visto Susan ha apretado su mano demasiado fuerte, “masculinamente”) se muestra incómodo por la situación, lo que se agrava cuando se entera de que la ginecóloga que va a atender a Carol es una mujer. De alguna manera, se siente amenazado por Susan, que le ha "robado” a su mujer, y por esa alianza de mujeres que se escapan a su control. Para Ross, el mundo lésbico es algo desconocido y hasta exótico. Cuando en un episodio posterior les visita en su apartamento, se sorprende por el contenido de la biblioteca: «you guys sure have a lot of books on how to be a lesbian»; «yes, you have to take a course, otherwise the don't let you» le responde Susan, sarcásticamente. O, en otra visita, Carol le pregunta: «Do you want to know about the sex?», refiriéndose al sexo del bebé, pero él, entendiendo que habla del sexo entre la pareja de mujeres, contesta: «The sex? I'm having enough trouble with the image of you and Susan together».

En general, y sobre todo al principio de la serie, Ross niega incluso que Carol y Susan tengan una relación sentimental. Cuando Ross, durante una cita, coincide con ellas en un restaurante, le dice a su acompañante: «the blonde one is my exwife, and the woman touching her is her close, personal friend». En otra ocasión, en las presentaciones de las clases de preparación al parto, a las que acuden los tres, Ross se niega a decir que Susan es la pareja sentimental de la madre de su hijo «Susan’s Carol’s friend. Like buddies»; «life partner. Like lovers», le corrige Susan.

De nuevo, la comicidad de todos estos momentos podría interpretarse como una censura del comportamiento de Ross por disparatado. Pero insistimos en que basta que se mencione que Carol es lesbiana para que se oigan risas, es decir, que la sexualidad de la exmujer de Ross es cómica en sí, sin que tenga nada que ver el comportamiento de este. Es cómico porque, de alguna manera, Ross es menos hombre por no haber sabido controlar la sexualidad de su pareja. Esto se ve de manera más clara si atendemos a la tensa relación que mantiene con Susan, que representa el papel de algo así como una "lesbiana fálica”. Su aversión contra ella va más allá de la comprensible inquina por la persona por la que su esposa le ha dejado, y llega a tomar la forma de una rivalidad: es una cuestión de poder. Desde el principio, Susan y él compiten por ver quién atiende más a Carol durante su embarazo y más tarde al bebé (por ejemplo, aunque al principio muestra su asco por probar la leche materna de Carol, lo hace en cuanto Susan le dice que ella sí la ha probado). En una ocasión en que tienen que ir a las clases de preparación al parto sin Carol, discuten sobre quién tiene que hacer el papel de embarazada y, tras lanzar 
una moneda al aire, Ross pierde y tiene que hacerlo él, para su humillación. El ejemplo más evidente es cuando al principio de la serie, Ross se siente frustrado porque el bebé vaya a llevar los apellidos de Susan y no los suyos. En cierto modo, el problema es que Susan, al ser la nueva pareja de Carol, ocupa la posición que, para Ross, corresponde al hombre, por lo que siente su masculinidad amenazada solo por su mera existencia. El “trauma” de la separación de Carol será la justificación a lo largo de la serie para el comportamiento celoso y posesivo de Ross. Así se lo reprochará Monica cuando Ross sienta celos de que Emily y Susan empiecen a pasar tiempo juntas en Londres y crea que Emily también se va a volver lesbiana.

Kelsey Miller cita una entrevista a la crítica cultural Sarah Beauchamp, quien asegura que el comportamiento de Ross y sus dificultades para aceptar la sexualidad de Carol era algo frecuente en la época, y que el proceso que tuvo que pasar el personaje era algo normal y comprensible (2018: 1688). Este proceso de aceptación llegaría a su fin en el undécimo episodio de la segunda temporada, en que asistíamos a la boda de Carol y Susan, y Ross, ante la negativa de los padres de su exmujer de asistir a la boda, se ofrecía a llevarla al altar. Miller registra la opinión de varios periodistas y críticos culturales, según los cuales Carol y Susan era, por su mera presencia, un gran avance en la televisión por la mera presencia normalizada de dos lesbianas en una serie de éxito, visibilidad que llegaría a su máximo exponente con la boda (siendo la tercera boda homosexual que aparecía en televisión en horario de máxima audiencia, la primera entre dos mujeres) (Miller, 2018: 1536).

Según admitieron los creadores de la serie, no intentaban hacer un episodio político, ni provocador, aunque hubo varios guiños al movimiento LGTB, como la presencia de la conocida activista de la época Candace Gringrich como oficiante de la ceremonia (Miller, 2018: 1570). La boda fue pensada para que fuera lo menos polémica posible, renunciando por ejemplo a que la pareja se diera un beso delante de las cámaras, a pesar de lo cual el episodio estuvo a punto de no emitirse en algunas ciudades de Ohio y Texas (Miller, 2018: 1604; 1672). El visible intento de normalizar al máximo la boda era comentado sarcásticamente por algunas mujeres lesbianas como Lea DeLaria, quien ironizaba con que para que fuera una boda lesbiana realista, «habrían hecho falta por lo menos treinta o cuarenta camioneras más, vestidas con esmoquin» (cit. en Miller,2018: 1637). Todas las asistentes a la boda, en efecto, eran muy femeninas, e incluso Jessica Hecht, la actriz que encarnaba a Susan, contó que cuando la convocaron para el casting 
le dijeron que buscaban a una mujer «que pudiera hacer de lesbiana pero que no pareciera lesbiana, alguien a quien pudiera quedarle bien, por ejemplo, un vestido de corte antiguo y que no tuviera un aspecto muy agresivo» (cit. en Miller, 2018: 1637). La “heterosexualización” de los personajes homosexuales en Friends, como en todas las series de su época, era una práctica generalizada, una suerte de invisibilización que para el guionista Ryan O’Connell era «casi un acto de homofobia» (Miller, 2018: 1655).

En todo caso, esta anécdota nos habla del afán de normalización y del objetivo de ser "para todos los públicos" y no herir sensibilidades (las sensibilidades de la mayoría de la población y no sus minorías, en todo caso) de una de las series más populares de la época, una tendencia común a cualquier producto de la cultura popular, y más en el caso de una comedia. También nos habla de las contradicciones de una época y una serie que podía, al mismo tiempo, reírse del personaje de Ross por tener una esposa lesbiana y mostrar la primera boda entre mujeres de la televisión de máxima audiencia; o hacer continuamente bromas sobre la aparente homosexualidad de Chandler y, al mismo tiempo, parodiar de manera crítica muchos tópicos sobre la homosexualidad masculina en el episodio en que conocemos al marido gay de Phoebe ${ }^{49}$. Porque, como ya hemos adelantado, nos parece mucho más problemática la representación de la homosexualidad masculina, como veremos en el siguiente epígrafe.

\subsubsection{Chandler o el sujeto neurótico. Afeminamiento, ansiedad} homosexual y homosocialidad.

«Get ready to get out of the non-gay closet!» - Joey Tribbiani

Cuando, en el episodio, ya comentado, en que Janine, la compañera de piso de Joey, redecora de manera “femenina” el apartamento, este le pide que quite sus cosas del salón («The living room has to remain a guy place, ok?»), le dice, de manera fingidamente despreocupada: «Well, but you could the picture of the baby in my room. I mean, if you want to. And, uh, maybe the watering can, and a couple of these little boxes too», a lo que su compañera responde: «Joey, do you want me to put it all in your room?». La comicidad

\footnotetext{
${ }^{49}$ En este episodio, conocemos que Phoebe se casó con su mejor amigo gay, del que estaba enamorada, para que pudiera conseguir el permiso de residencia en los Estados Unidos. Cuando este, que es patinador artístico, vuelve a la ciudad, le confiesa a Phoebe que necesita el divorcio para poder casarse con una mujer, porque ha descubierto que en realidad es heterosexual. En una divertida escena que analizaremos más adelante se parodian todos los tópicos acerca de la salida del armario.
} 
de esta escena reside, como en tantos otros gags, en el comportamiento femenino de un hombre. Pero desde una perspectiva psicoanalítica podríamos entender el dormitorio de Joey como el espacio de su subconsciente en que quedan recluidos esos aspectos femeninos que no pueden ser mostrado en público, el cuarto de estar, porque el Yo (público) de Joey no puede reconocer. Las tendencias femeninas son reprimidas por las constricciones sociales en un espacio que, de hecho, casi nunca se muestra en la serie.

Muchas de las bromas acerca de los comportamientos femeninos de los protagonistas son ofrecidas o bien como tímidas confesiones o, cómo no, en forma de lapsus freudianos («Sometimes, I wish I was a lesbian. Did I say that out loud?», dice Chandler en el primer episodio). Son muchísimos los momentos cómicos en los que descubrimos, casi por accidente, a los personajes masculinos comportándose como mujeres: en un episodio, Chandler se avergüenza de que sus amigos descubran que usa crema hidratante; en otro, Joey lee, por consejo de Rachel, Mujercitas, a raíz de lo que vemos momentos de sensibilidad - que son graciosos porque no son esperables en un hombre.

En primera instancia, el ridículo cómico reside en que un hombre no debería comportarse como una mujer y, de alguna manera, es inferior y por tanto risible por ello, haciendo evidente la misoginia que está en la base de las concepciones tradicionales de la masculinidad. También se podría interpretar que el objeto del ridículo es precisamente ese intento de los hombres de ocultar los aspectos "sensibles" de su personalidad, su feminidad, por ser síntoma de una idea estúpida y restrictiva de lo que significa ser un hombre. Porque, en cierto sentido, esta feminidad se muestra como inevitable, como si los protagonistas tuvieran de hecho rasgos femeninos que han de ser ocultados; la comicidad surge cuando los mecanismos de represión fallan y atisbamos, como en una grieta, la feminidad de nuestros personajes. Como dice Butler en su lectura de Lacan,

Lacan (...) establece el vínculo entre los sexos en términos que muestran al “yo” hablante como un efecto de represión masculinizado, el cual se revela como un sujeto autónomo y basado en sí mismo, pero cuya coherencia en sí es discutida por las posiciones sexuales que descarta en el proceso de formación de la identidad (...) Así pues, el problema de la masculinidad parece ser justamente la reivindicación de un reconocimiento total de autonomía que además, y no obstante, promete un retorno a esos placeres totales previos a la represión y la individuación (Butler, 2007: 117) 
De manera similar, Todd Reeser señala que, a pesar de todos los intentos de definir la masculinidad como una identidad estable, fija y autónoma, está siempre amenazada por la cercanía de las identidades contra las que se define, lo que constituye la fuente de la «ansiedad masculina»:

Masculinity is not the actual difference between heterosexuality and homosexuality [o entre masculinidad y feminidad], but the linguistic act of attempting to separate them. I might try to construct masculinity in pure opposition to other signs, to carve out a discrete meaning for masculinity, to imagine clear-cut categories of gender, but those attempts are doomed to failure. In any binary opposition, the separation is not an impervious dividing line, but a permeable or porous membrane through which elements inevitably pass (Reeser, 2010: 38)

This kind of approach (...) means that all masculinity is always fluid, or unstable, that masculinity always bleeds or risks bleeding over its definitional other, despite efforts to the contrary (...) Consequently, attempts to define masculinity in a stable way can be interpreted as responses to unstability, as a kind of anxiety about undefined masculinity, and the articulation of stability might be indirectly proportional to cultural anxieties about instability (Reeser, 2010: 40)

Los comportamientos femeninos, sin duda, responden a este esquema de represión de lo que amenaza la estabilidad de la masculinidad, representando su abyección [ver 5.4]. En el cuarto capítulo de la tercera temporada, Ross recibe con terror el que a su hijo le guste jugar con muñecas, e intenta convencerle de que juegue con camiones, soldados, dinosaurios... Al final del episodio, Monica revela que cuando era pequeño a Ross le gustaba disfrazarse de chica, para mofa de sus amigos. En la quinta temporada, Joey se tiene que enfrentar a las humillaciones y burlas del resto del grupo por llevar un bolso, y al final del episodio, Rachel le convence de que lo devuelva: «I don't know if the world's ready for you and your bag». En otro episodio de la misma temporada, Phoebe le cuenta a Joey que al chico con el que está saliendo le gusta llevar ropa interior femenina, y le reta a probarlo: su argumento, precisamente, es que solo un hombre seguro de su masculinidad puede atreverse a llevarla («I'm a man. Haven’t you seen my stack of porn?», le responde, indignado, Joey). Y, en otro episodio, Ross le dice a Phoebe: «That's how she [su abuela] payed for my dance... karate lessons. Yes, it's a mortal but beautiful sport». 
Lo interesante de todos estos ejemplos es que estos comportamientos son practicados con placer por los personajes masculinos: el hijo de Ross disfruta jugando con muñecas, a Joey le gusta llevar bolso y la ropa interior femenina le parece más cómoda que la masculina, etc., y, sin embargo, tienen que renunciar a ello por la humillación, por medio de la risa y la burla, de sus amigos. Es el ejemplo más evidente de la masculinidad entendida como represora de las tendencias de los varones - y del ridículo como herramienta normalizadora.

Todo este tipo de bromas se suelen centrar en Chandler. Su personaje es el más claramente diseñado, como apuntamos en el primer epígrafe, según un rudimentario esquema psicológico según el cual sus muchos traumas y neurosis son producto de una infancia problemática. Sus padres se divorciaron cuando él era pequeño, y el que el motivo de la separación fuera la homosexualidad de su padre y su ambigua identidad de género es lo que más afecta al adulto. La sexualidad de su padre será uno de los tics más homófobos de toda la serie ${ }^{50}$ : al igual que ocurre con la mujer lesbiana de Ross, cada vez que Chandler mencione a su padre, su afición por vestirse de mujer o sus relaciones con otros hombres, será motivo de risa. En la relación con su padre apreciamos, sin duda, una homofobia hondamente arraigada en el personaje ${ }^{51}$, que se podría explicar en cierto modo por las dudas acerca de su propia sexualidad.

En todo caso, el Chandler adulto es un hombre lleno de traumas, manías, inseguridades y problemas con el compromiso emocional. Es también el personaje cuya expresión de género es más ambigua de los tres protagonistas, siendo el objeto de la mayoría de las bromas sobre comportamientos femeninos. En la tercera temporada Rachel le presta una cinta de hipnosis durante el sueño para que le ayude a dejar de fumar ${ }^{52}$. Los gags cómicos comienzan cuando descubrimos que la cinta está dirigida específicamente a mujeres («You’re a strong confident woman», le recita la cinta mientras duerme). A

\footnotetext{
${ }^{50}$ La condición del padre de Chandler como hombre gay, drag queen, o mujer transgénero no queda nunca clara a lo largo de la serie: sabemos que en Las Vegas, donde trabaja como artista transformista, es Helena Handbasket, pero tanto su hijo como su exmujer se dirigen a él en masculino y con su nombre de hombre, por lo que no sabemos si Helena es solo su nombre artístico o es una falta de respeto por parte de sus familiares. Estas confusiones son, hasta cierto punto, explicables, dada la falta de concienciación respecto a la transexualidad en la mentalidad popular de la época.

${ }^{51}$ Cuando se aproxima la boda entre Monica y Chandler, esta le convence para ir a Las Vegas a invitarle a la celebración, y Chandler confiesa que llevan años sin hablarse con su progenitor, a pesar de que este le haya llamado muchas veces e incluso haya visitado Nueva York para encontrarse con su hijo. En los dos episodios en que el personaje aparece en la serie (interpretado, por cierto, por una actriz cis-género, Kathleen Turner), Chandler está claramente avergonzado de la identidad no normativa de su padre.

${ }^{52}$ Hábito al que había vuelto a raíz de la ruptura de Ross y Rachel, que le recuerda al divorcio de sus padres.
} 
partir de entonces, Chandler se empieza a comportar como una mujer: alaba la ropa de sus amigos, se aplica bálsamo labial de la misma manera que una mujer se pinta los labios, sale de la ducha con una toalla cubriéndole el torso y otra la cabeza, como hace una mujer... En otro episodio, acompaña a Rachel a hacerse la manicura. «Don’t worry», le asegura su amiga, «this doesn’t make you less than a guy»; pero, al ver cómo Chandler se mira las uñas con ademán codificado como femenino, le dice: «That does» ${ }^{53}$.

Lo interesante de estas muestras de feminidad de Chandler es que en ocasiones le concede ciertas ventajas al permitirle participar en prácticas sociales supuestamente vetadas a los hombres. Cuando en la tercera temporada pasa por una crisis en su relación con Janice, recibe los consejos y el apoyo emocional de las chicas. El problema es que a Chandler le entra el pánico cuando empieza a notar que la relación está convirtiéndose en algo serio, así que para superar su miedo al compromiso decide ofrecer a Janice vivir con él. En ese momento, los papeles se invierten, y es el hombre el rechazado por la mujer, que huye de él por tener miedo al compromiso. Por tanto, Chandler experimenta en sus propias carnes cómo es ocupar el papel de la mujer en la relación. Eso le permite, como decimos, participar en las prácticas femeninas de cuidados y afectos, tanto emocionales como físicos, como comer helado en compañía de sus amigas. El comportarse como una mujer y tener sus experiencias le concede unas ventajas que, siendo hombre, no hubiera podido tener.

Junto a las bromas acerca del afeminamiento de los hombres, son mucho más abundantes los chistes sobre su supuesta homosexualidad, que afectan sobre todo a Chandler. En el octavo episodio de la primera temporada, una compañera de trabajo le ofrece concertarle una cita con otro hombre, para trastorno de Chandler, que pregunta a sus amigos por qué habría creído que era gay, a lo que ellos contestan que no les parece extraño para nada, ya que ellos mismos lo habían pensado cuando le conocieron. «You have a quality», le dicen. En otra escena, la compañera de trabajo le pide disculpas por el malentendido, y cuando le dice con quién pensaba concertar la cita, Chandler protesta porque la hubiera preferido con otro compañero más atractivo - lo que le hace parecer definitivamente homosexual, para gozo del público. Las bromas de este tipo se repiten en todas las temporadas. En 2011, la artista Tijana Mamula publicó un vídeo en que

\footnotetext{
${ }^{53}$ No deja de ser interesante que este "ser mujer" se exprese por la ejecución de un cierto habitus de gestos y comportamientos, evidenciando el carácter teatral de la expresión de la identidad de género.
} 
recopilaba todos los chistes sobre homosexualidad de la serie, titulado «Homophobic Friends»; la duración total alcanza los cincuenta minutos.

Estos gags no tienen por lo general una estructura muy trabajada. Alguien da a entender que un hombre, normalmente Chandler, es homosexual, y hay risas. Eso es todo: la única comicidad reside supuestamente en que un hombre pueda ser gay. La cuestión es que estas bromas no son directamente homófobas en el sentido de que no humillan a personajes homosexuales, casi nunca tratan de una manera explícitamente irrespetuosa a los escasos personajes homosexuales que aparecen en la serie, solo a los hombres heterosexuales que lo parecen. Como dice Becker,

many of the straight men in such narratives found themselves in what could be called a gay-friendly straight man's double bind. On the one hand, faced with the dynamics of a new gay-inclusive world ${ }^{54}$, these straight characters were forced to establish their heterosexuality and were usually very anxious to do so (...) At the same time, however, most of the straight men were equally anxious to make clear that they didn't have a problem with gay people (Becker, 2014: 239)

Becker cita como ejemplo el episodio de Friends en que Joey y Chandler cuidan del hijo de Ross y son confundidos por una pareja de padres homosexuales. Según el crítico, la frecuencia en las sitcoms de los noventa como Friends, Seinfield o Fraisier de argumentos en que hombres heterosexuales eran confundidos por gays «relied on (and reinforced) the perceived illegibility of sexual identity and focused on the anxieties it produced for straight male characters» (Becker, 2014: 240).

Por eso, los hombres rehúyen cualquier tipo de contacto que pueda ser confundido con un acercamiento de carácter homoerótico. En la segunda temporada, Joey tiene que besar a un hombre para conseguir un papel, pero el director opina que no besa bien. Joey pide a sus amigos practicar con ellos, a lo que se niegan rotundamente. El gag se prolongará cuando Joey intente seducirles como seduce a las mujeres. En otra ocasión, Ross pregunta al grupo su opinión sobre el traje que lleva puesto, y Joey dice que va muy bien con sus ojos y marca bien su trasero, para incomodidad de Ross y gozo del público. Durante una fiesta de la segunda temporada, Chandler se emborracha y besa a todos sus

\footnotetext{
${ }^{54}$ Kelsey Miller ofrece en su libro una visión mucho menos positiva de la situación de la población LGTB en la sociedad norteamericana de la época, que define como "una época homofóbica en el sentido más literal del término” (2018: 161). Menciona la política don't ask, don’t tell, que condenaba el acoso a miembros homosexuales del ejército, pero al mismo prohibía a estos hacer pública su identidad sexual (Miller, 2018: 1632).
} 
amigos, incluido Ross, lo que también le resulta incómodo. En la tercera temporada, una chica insinúa la posibilidad de un trío con Joey y Chandler. Aunque al principio rechazan la posibilidad, un poco después se abren a ella pero deciden poner ciertas reglas para impedir cualquier contacto sexual entre ambos: «The first one would be: never open your eyes. Because you know, you don't want to be doing something and then look up and see something you don’t wanna be seeing», propone Joey, pero Chandler le corrige: «Hold it! What if my eyes are closed and my hand is out there...». En general, el contacto con el cuerpo de otro hombre o incluso la visión de un cuerpo masculino desnudo están prohibidos: por ejemplo, Chandler reacciona horrorizado cuando descubre que Joey duerme desnudo y ve sus genitales; en otra ocasión, tiene que ayudar a su amigo a ducharse cuando este sufre de una hernia, y le pide que nunca hablen de ello ${ }^{55}$.

En este grupo de gags sobre contactos homosexuales no deseados podríamos incluir las bromas sobre agresiones sexuales. Por ejemplo, uno de los argumentos de un episodio de la tercera temporada consiste en que el jefe de Chandler le toca el trasero sin su consentimiento, lo que le hace sentir incómodo. En otro ejemplo, más grave, Chandler descubre que el sastre de Joey abusa sexualmente de sus clientes al tocar sus genitales. La denuncia de Chandler («He took advantage of me!») es recibida con risas por el público por mostrar vulnerabilidad. En general, la comicidad de este argumento reside en que Joey permita contactos homosexuales ${ }^{56}$. De manera parecido, otro gag consistirá en el relato de Joey de cómo mantuvo relaciones con una mujer con una nuez enorme, es decir, una persona transgénero.

Muchas de las bromas homófobas de Friends funcionan a partir de la premisa tradicional que relaciona la homosexualidad masculina con el afeminamiento. Al final del mencionado episodio en que todos sospechan de la homosexualidad de Chandler, cuando el grupo se dirige a una cena de gala y por lo tanto vestidos para la ocasión, este dice:

\footnotetext{
${ }^{55}$ Miller también menciona la gay panic defense, una alegación jurídica que «justificaba un comportamiento criminal escudándose en el miedo a un acercamiento de índole homosexual por parte de la víctima de una agresión o un homicidio» (Miller, 2018: 1616). Sin duda, esto último se puede relacionar con las bromas de Friends en las que los hombres se sienten amenazados por el contacto físico o emocional íntimo con otros hombres.

${ }^{56}$ Este argumento está incluido como ejemplo en el vídeo-ensayo «Sexual assault on men for the laughs», del canal de Youtube Pop culture detective. El ensayo analiza de manera brillante la enorme frecuencia de bromas en series y películas de gran éxito sobre violaciones y agresiones sexuales a hombres, y las consecuencias que estas bromas tiene, como la legitimación de la masculinidad tóxica, la humillación de la víctima, la perpetuación de estereotipos negativos de hombres homosexuales y hombres racializados, y la frivolización de temas de gravedad como la violencia sexual, las violaciones en prisiones o la brutalidad policial.
} 
«Don’t we look nice all dressed up?»; «It's stuff like that, right?», continúa, al darse cuenta de lo femenino de su comentario. En el personaje de Chandler la duda respecto a su sexualidad suele ir unida con la confusión respecto a su género. En la quinta temporada, Phoebe, que está embarazada de los hijos de su hermano por gestación subrogada, le promete a Chandler que uno de los tres bebés que va a tener se llamará con él. Pero, cuando da a luz, el bebé que se supone que iba a recibir ese nombre es una niña, pero el hermano de Phoebe lo llama Chandler igual. «It’s a girl! Chandler is a girl!» exclama; «Kindergarten flashback», responde Chandler. Cuando, al final del episodio, este le pregunta a Phoebe si no le parece que Chandler es un nombre demasiado masculino para una niña, esta le responde, «Well, it works on you».

En otro capítulo, Joey se ve obligado a practicar bailes de salón con el portero del edificio, haciendo, por supuesto, el papel de mujer. El subtexto homoerótico del argumento es declarado explícitamente («Shouldn’t we get drunk first?»). En una escena, Monica se ríe de Joey y le pregunta si se ha vuelto gay ya, a lo que Joey le responde que en realidad bailar es como un deporte, esto es, una práctica masculina y no femenina. Sin embargo, cuando se ofrece bailar con Monica, no sabe bailar en el papel masculino. La confusión entre la homosexualidad y ocupar el papel femenino en una relación continúa conforme se desarrolla el arco argumental. Cuando el portero va a ir al baile para el que se ha estado preparando para conquistar a una mujer, Joey se pone celoso al sentir que le abandonan por otra. Sin embargo, como para ahuyentar el fantasma de la homosexualidad, el portero le ofrece acompañarle y presentarle a otra mujer.

El motivo del temor al afeminamiento y la amenaza del contacto entre hombres se unen en el de la ambigüedad inherente a las muestras de intimidad en las amistades masculinas. El inicio del vídeo de Mamula citado consiste en una recopilación de gags en los que los protagonistas masculinos, o bien evitan abrazarse, o bien se sienten incómodos cuando los abrazos se prolongan más de lo necesario. A pesar de que en la serie se muestre continuadamente a los tres protagonistas masculinos saliendo juntos y hablando de sus problemas, encontramos también muchas bromas a costa de esta misma intimidad o de la falta de ella. En un momento muy emotivo en que Ross le pide a Chandler y Joey que sean sus padrinos en la boda con Emily, ninguno de los tres es capaz de expresar sus emociones, hasta que Joey se aparta para llorar y sus dos amigos se unen a él, provocando las risas del público. Cuando Chandler va a ir a vivir con Monica y se despide de Joey, este se lamenta de que no podrán hacer cosas juntos como «meet in the middle of night 
and have a long talk about our feelings and the future», a lo que Chandler le responde: «Not once did we do that».

Como dice Reeser, «men's fear of avoidance of physical and emotional closeness with other men (e.g., shaking hands and not hugging, not talking about how they feel) could be taken as indicative of this homoerotic threat» (Reeser, 2010: 58). Sin embargo, uno de los argumentos más interesantes y con más potencial cómico tendrán en las primeras temporadas será la ambigüedad de la relación de amistad entre Joey y Chandler. En el duodécimo episodio de la primera temporada, los dos compañeros de piso discuten sobre quién debe pagar por una nueva mesa de comedor, y asistimos a la conversación siguiente:

JOEY- How about we split it together?

CHANDLER- What do you mean, like, buy it together?

JOEY- Yeah.

CHANDLER- You think we're ready for something like that?

JOEY- Why not?

CHANDLER- It's just - It's a pretty big commitment. What if one of us moves out?

JOEY- Why? Are you moving out?

CHANDLER- I'm not moving out.

JOEY- You would tell me if you were moving out, right?

CHANDLER- Yes, yes. It's just my last roommate, Kip...

JOEY (visiblemente incómodo por la mención) - I know all about Kip.

CHANDLER- ... We bought a hibachi together and then he ran off and got married and things got pretty ugly.

JOEY- Let me ask you something. Was Kip a better roommate than me?

CHANDLER- Oh, don't do that.

Como vemos, es bastante evidente la parodia del script de la conversación que mantendría una pareja acerca de su relación, incluyendo los celos de la anterior pareja de uno de ellos. Como decimos, los creadores explotarán de manera muy inteligente el subtexto homoerótico de la estrecha relación entre los dos compañeros de piso. Este gag continuado alcanzará su cénit en el arco argumental que ocupa cinco episodios en la segunda temporada, en que Joey decide mudarse de casa; historia que los guionistas decidirán escribir como una ruptura y posterior reconciliación de los amigos como si fueran una pareja. Por ejemplo, en el capítulo diecisiete, los dos mantienen una conversación telefónica mientras comentan Los vigilantes de la playa, que cada uno está 
viendo en su apartamento. Al día siguiente, Joey habla con Monica y Phoebe de lo que echa de menos vivir con Chandler, y Phoebe le sugiere que intente volver con él, a lo que él responde lo que sigue: «You really think he’d take me? I mean, we had a pretty good talk last night but when I moved out I hurt him back»; «I promise you», le asegura Monica, «he would definitely take you back». Paralelamente, Chandler está teniendo esta conversación con Ross y Rachel:

Ross- I'm telling you there's no way he's moving back.

CHANDLER- But we had one of the greatest talks we ever had last night. I mean, it was like when we first started living together.

Ross- Look, I know you don’t want to hear this right now, but... We've seen him in his new place, all right? and he’s happy. He’s... he’s decorated.

RACHEL- Look, Chandler, he has moved on, okay? You have to too.

CHANDLER- But...

Ross- No. You're just going to have to accept the fact that you're friends now, okay? You're not... roommates anymore.

La parodia del script de la ruptura de una pareja heterosexual es también evidente en este ejemplo. Esta conversación es un excelente ejemplo de cómo la estructura de un discurso humorístico consiste en la unión indecidible entre dos scripts estereotipados: en cada línea se esconde un doble sentido. Más tarde en el mismo episodio, Joey se pondrá celoso del nuevo compañero de piso de Chandler, Eddie, y le molesta que a Chandler le guste cómo prepara los huevos Eddie («Tell me, whose eggs you like better, his or mine?»; «What’s the differece?», le reprocha Chandler, «your eggs are not here anymore. You took your eggs and you left! Did you really expect me to never find new eggs?»). Felizmente, ambos descubrirán que se necesitan y volverán a mudarse juntos.

Este dispositivo cómico es, de nuevo, ambiguo respecto a sus posibles interpretaciones. En un nivel superficial, podría argüirse que, como el resto de las bromas que hemos analizado hasta ahora, la comicidad consiste en la amenaza de homosexualidad masculina. Pero, en otro nivel, podría constituir el rechazo mismo de esta supuesta amenaza y una celebración de la amistad masculina ${ }^{57}$. La relación entre Joey y Chandler

\footnotetext{
57 «Men's jokes about male homosexuality with other men might be an expression of homophobia and a way to dispel the threat by making a joke, or they might be a way to mock the very idea of homoerotic anxiety in the first place (...) In the latter case, two men might be subverting or resisting the homophobic injuction by playing with it and making it seem ridiculous, or they may be expressing their implicit agreement with the idea that there is a homosocial continuum and that they do have some kind of ambiguous attraction to other men» (Reeser, 2010: 59-60)
} 
es claramente un ejemplo de la ambigüedad del deseo en las relaciones entre hombres, que oscilan entre la «homosocialidad», tal y como la describió Sedgwick (1985) y la abierta homosexualidad. Como explica Reeser:

In addition to the constant homophobic threat, another result of the fluidity between identification and desire is that masculinity is always located in some ultimately indefinable place on a continuum of desire for other men. Such a continuum of desire might be considered to have on one end what Sedgwick calls "homosocial" desire (...) and on the other end "homosexual" desire (...) Homosociality constitutes a fuller spectrum of male-male desire. The fluidity of male-male desire between the heterosexual and the homosexual are what define their desire, not their precise location on a continuum (Reeser, 2010: 59)

El esquema homosocial de Sedgwick coincide hasta tal punto con la relación entre Joey y Chandler, que incluso en cierto momento se forma un triángulo amoroso entre ambos y la novia de Joey, Kathy, de la que Chandler se enamora. A medida que avanza el argumento, Chandler se siente cada vez más culpable de sus sentimientos hacia Kathy, que empiezan a ser correspondidos por ella, a pesar de que Joey demuestre no merecer estar con ella (llega a salir con dos mujeres a la vez aparte de Kathy), hasta tal punto que, después de besar a la novia de su amigo, renueva todo el mobiliario de la casa (parodiando el script según el cual el infiel hace regalos a su pareja para lidiar con la culpa). Este arco argumental es uno de los más tensos y dramáticos en la relación de ambos, y sobre todo sirve para desactivar el subtexto homoerótico que le había subyacido hasta ese momento:

The birth of this kind of desire means that the love triangle is not a preexisting condition (...) but is in fact created out of the relation between two men. By loving a woman, men defuses the threat of homoerotic desire onto his and his rival's relationship with a woman (...) [el triángulo amoroso] comes to being because of an anxiety about the unstable relationship between the men (Reeser, 2010: 61)

Con el paso del tiempo, este subtexto homoerótico mutará a una relación paterno-filial cuando Chandler comience su noviazgo con Monica, hasta el punto de que Joey pasará de ser la pareja de Chandler a ser el hijo de ambos.

En general, a pesar de todas las bromas, el personaje de Chandler pasará por un proceso de "heterosexualización”, esto es, de “normalización”. Si uno de los rasgos cómicos de Chandler era su miedo al compromiso y su incapacidad de lidiar con las relaciones sentimentales entre adultos, podríamos decir que a partir de su unión con 
Monica se inicia un proceso de “enseñanza” sentimental. Los primeros episodios de su relación consistirán, a grandes rasgos, en el siguiente esquema: ambos tendrán alguna discusión, normalmente por culpa de Chandler; este creerá que la relación ha terminado, pero se dará cuenta de que quiere continuar con Monica y le pedirá disculpas. De ser el “compañero de aventuras” de Joey, siendo incluso tan infantil u obseso sexualmente como él, Chandler comenzará a vestir trajes de chaqueta, tendrá un comportamiento más serio y asumirá una actitud protectora y paternalista con su antiguo compañero de piso por ejemplo, cuando se mude con Monica, insistirá en ofrecerle dinero para ayudarle a pagar las facturas y el alquiler.

Después de explotar todas las ambigüedades respecto al género y la sexualidad del personaje, Chandler y Monica serán los personajes que tengan una trayectoria vital más normativa: de la maduración del noviazgo a la convivencia, de ahí al matrimonio, la decisión de tener hijos y, al final de la serie, la mudanza a un barrio de los suburbios para formar una familia típica de una sitcom de los años cincuenta. También Phoebe, el personaje más radicalmente diferente de los seis protagonistas, tanto por su pasado, su personalidad y su sexualidad, acabará casándose y Rachel renunciará al trabajo de sus sueños en París por estar con Ross. Joey será el único que no madure, dado que ya se había decidido que protagonizaría su propio spin-off. Como escribe Judy Kutulas:

The series' end (...) evolved the characters in more predictable-and conservativedirections, culminating in a widely watched series finale that lived up to the Friends' comfort food stereotype. (...) its conclusion subverted the series' central premise. Despite its many explorations of unconventional situations and oddball characters, the series defined being a grown-up very traditionally. (...) Thus, the series counterbalanced its innovations with an essentially conservative message. Although it showed "how the species adapts to propagate itself when the old nuclear-family methods do not work" (Poniewozik), it nevertheless held out hope for those old nuclear families. (Kutulas, 2018: 1183-1184; el destacado es nuestro)

Así pues, a pesar de todas las innovaciones llevadas a cabo en Friends respecto a sus predecesoras, sobre todo respecto al protagonismo de la familia nuclear y su no tan escondido didacticismo autoritario, la serie resultaba cumplir la misma función normalizadora que la sitcom llevaba cumpliendo toda su historia, solo que con muchos más desvíos. Si bien expresaba las dificultades de llegar a ser lo que se consideraba un adulto funcional en una sociedad cada vez más exigente con uno mismo, al final seguía 
manteniendo como objetivo ideal esa imagen del adulto de éxito, y como modelo de vida deseable el de la familia nuclear estable, con hijos y viviendo en las afueras ${ }^{58}$.

\subsubsection{La masculinidad son los otros. La masculinidad como performance. Fantasmas y fantasías de la masculinidad.}

En el episodio veintiuno de la tercera temporada, Joey compra un pollito que ha visto anunciar por televisión (después Chandler adoptará un pato, dando inicio a uno de los argumentos más famosos y divertidos de la serie, por lo absurdo). En una escena del mismo episodio, vemos cómo Chandler está al pollito cuando Joey llega de trabajar, y asistimos a la siguiente conversación:

JOEY- I'm going to get changed, I'm meeting some of the cast for drinks.

CHANDLER- Excuse me? (...) I stayed home from work today while you were at rehearsal so somebody could be here with our chick.

JOEY- Hey, who was up from 2 o'clock this morning until five o'clock this morning trying to get her back to sleep?

CHANDLER- You don't think I get up when you get up?

JOEY- Oh, here it comes.

CHANDLER- Yes, here it comes! I'm stuck here all day and then you come in and spend two seconds with us and then expect to go off gallivanting with your friends? Well, I don't think so, mister!

JOEY- I need to relax, okay? I was working all day.

CHANDLER- And you don't think taking care of our chick is work?

JOEY- That's not what I said. I just meant...

CHANDLER- I know what you meant!... Have you noticed that ever since we got this chick we've been fighting a lot more than we used to?

JOEY- I don’t know - Maybe we weren’t ready to have a chick.

\footnotetext{
${ }^{58}$ En este sentido, y en relación con el paradigma neoliberal que exponíamos en el primer epígrafe como contexto de la serie, también el trabajo de Chandler representa una sintomática anomalía. Como expone Megan Garber en un artículo para la revista The Atlantic (Garber, 2019), mientras que el trabajo de los protagonistas se ajustan a la fantasía neoliberal en la que el oficio ha de convertirse en un aspecto esencial de la personalidad y la mejor posibilidad de autorrealización (casi todos tienen trabajos creativos o relacionados con sus pasiones: Joey es actor; Monica, cocinera; Ross, paleontólogo, primero trabaja en un museo y luego como profesor de universidad; Rachel trabaja en el mundo de la moda), Chandler es la excepción: ninguno de sus amigos sabe exactamente qué hacer, él protesta continuamente de lo embrutecedor de su rutina laboral, etc. Como dice Garber, frente al idealismo optimista generalizado de la ficción, esta «sacrificed Chandler to the demands of reality». Sin embargo, hacia el final de la serie, hasta Chandler sucumbe a la fantasía: se despide de su trabajo y, al poco tiempo, descubre que su pasión es la publicidad y entra a formar parte de una agencia.
} 
Este gag es un ejemplo más en que se explota el subtexto homoerótico de la relación entre los dos amigos, apoyándose en la parodia de una escena fuertemente estereotipada: la de una discusión entre un matrimonio heterosexual con hijos. Siguiendo con la discusión anterior, esta escena, ¿ridiculiza a los personajes masculinos heterosexuales al hacerlos pasar por pareja, sobre todo en el caso de Chandler, a quien le toca ocupar el papel de mujer? ¿O, más bien, podríamos decir que lo que se está parodiando es precisamente la fuerte estereotipación de una escena así? Tal vez, lo que realice esta escena sea expulsar la posibilidad de homosexualidad precisamente al hacerla efectiva: al ver comportarse a la pareja de compañeros de piso como una pareja heterosexual se comprueba lo absurdo de esta situación y la imposibilidad de hecho de que los dos hombres sean pareja, exorcizándose así la amenaza homosexual. Probablemente todas las hipótesis sean correctas, o ninguna lo sea, y el objetivo de los guionistas sea simplemente realizar un ingenioso juego de palabras. Sin embargo, las palabras con las que se juega no dejan de tener una importante carga ideológica que merece la pena explorar. La posible labor de interpretación podría prolongarse ad infinitum, al plantear las implicaciones de asimilar la relación homosocial/homoerótica de dos compañeros de piso a la de una pareja heterosexual: ¿quizás que esta es el modelo “natural” al que incluso las parejas homosexuales se acercan? ¿o precisamente la incapacidad de los guionistas de imaginar una relación de pareja que no sea heterosexual y en que los papeles de género no están ya previamente asignados según una división binaria del género? ¿O una crítica de todas estas asunciones? Este es un ejemplo claro de lo que Zupančič entiende por materialidad de lo cómico y objetificación de lo abstracto: en el juego de esta escena, Joey y Chandler son, al mismo tiempo, compañeros de piso y un matrimonio heterosexual, sin que ninguna de las posibilidades interpretativas llegue a imponerse a la otra.

El uso de la noción del cognitivismo social script, cuya pertinencia ya exploramos en el capítulo correspondiente [5.3], es aquí más adecuado que nunca, porque la escena está literalmente guionizada: los personajes hablan como si, efectivamente, estuvieran recitando unas líneas de diálogo escritas por otro. Este posible carácter meta-referencial de la escena es apoyado sobre todo por la actuación de Matthew Perry, tan manierista, exagerada y anti-natural, en contraposición a la de Matt LeBlanc, hasta el punto de que, incluso, durante unos segundos, se muestra dubitativo, como si el actor (o el personaje) no se creyera lo que está diciendo. Se produce un extraño efecto de ventriloquía por el que los personajes parecen obligados a decir cosas que por un lado hacen emerger lo 
reprimido (la tensión homoerótica subyacente) pero por otro no correspondieran y lo sintieran como algo ajeno a ellos (el script del matrimonio heterosexual). Este carácter ajeno del script, su efecto de ventriloquía, se puede relacionar además con la «interiorización de la exterioridad» de la que habla Bourdieu para definir el habitus [ver 4.2.3]

Esta estructura cómica de la parodia del script es un recurso utilizado por los guionistas de manera relativamente frecuente. Muchas veces, se plantean escenas que remiten a otras fuertemente estereotipadas y ponen en bocas de los personajes los guiones que supuestamente encajan con esas escenas. En uno de los primeros episodios, Monica sale con un hombre del que sus amigos se quedan prendados, incluso más que la propia Monica: a lo largo del capítulo, será el grupo de amigos, y no ella, quienes digan frases típicas de un enamorado. Ya hemos analizado el uso de esta técnica en la relación entre Joey y Chandler, y también hicimos alusión a la escena en que el marido de Phoebe le confiesa su heterosexualidad, recurriendo a todos los tópicos sobre la salida del armario, o los tópicos alrededor de los hombres gays:

DUNCAN- I don't know how to tell you this... I'm straight

Phoebe (hace un gesto de sorpresa) - I don't understand... How can you be straight? I mean, you're so smart, and funny, and you throw such great academy award parties.

DUNCAN- I know, that's what I kept telling myself, but you just reach a point where you can’t live a lie anymore.

PHOEBE - How long have you known?

DunCAN- Well, I guess on some level I always knew I was straight. I thought I was supposed to be something else: I'm an ice skater, all my friends are gay. I was just trying to fit in.

$(\ldots)$

PHOEBE - Is she [la mujer con la que Duncan va a casarse] the first woman you've been with?

DUNCAN- Well, I never told you this, but there were one of two times, back in college, when I'd get really drunk, go to a straight bar and wake up with a woman next to me. But I told myself it was the liquor, and everyone experiments in college... But now I know I don't have a choice, I was born this way.

PHOEBE - I don't know what to say... I mean, you know, you're married to someone for six years and you think you know him and then one day he says, “Oh, I'm not gay”.

DUNCAN- I'm... I'm still me. 
Estos ejemplos vienen a coincidir con nuestro entendimiento general de la comedia como fundamentalmente paródica [5.3], en el sentido de que, al trabajar con las asunciones y expectativas previas de los receptores, lo que se hace es poner en primer plano la intertextualidad o polifonía características del discurso social, tal y como la plantean Bajtín, Derrida o Kristeva - además, en estos casos se trata de una intertextualidad casi literal, al plantear estas parodias de los scripts como citas textuales de las escenas que se plantean como referencia.

Por tanto, al parodiar estas situaciones, lo que hace Friends es precisamente mostrar su carácter estereotípico, de lugar común, y quizá señalar el origen de estos estereotipos en los discursos de las ficciones populares, televisivas, cinematográficas o literarias. Ciertamente, se puede localizar un sutil discurso auto-consciente en la serie. Continuamente hay referencias paródicas a la televisión y la omnipresencia de sus ficciones en las vidas de nuestros protagonistas, bien con escenas que nos muestran al grupo de amigos en el salón de Monica viendo sus series favoritas, o bien mediante los diferentes papeles que Joey tiene que interpretar. En todas estas referencias, las series de televisión (docudramas, telenovelas, series policíacas o de médicos...) aparecen como ficciones inverosímiles, exageradas, llenas de tópicos, etc. Pero, además, en ciertos momentos la propia serie alude a su naturaleza de ficción. Por ejemplo, al comienzo de un capítulo, los protagonistas llegan al café para encontrar a otros clientes sentados en el sofá que suelen ocupar. Tras intercambiar varias miradas de incredulidad, se encogen de hombres y deciden salir del café. Son varias las bromas que hacen alusión al hecho de que siempre estén sentados en el mismo sofá, confirmando la propia inverosimilitud de muchos tics de la serie. Otras bromas recurrentes, como la alusión a los tres divorcios de Ross, inciden en la representación de la historia como una narrativa serializada y a la propia elaboración de un "grandes momentos de Friends" dentro del mismo universo ficticio - cosa que se hace explícito en los varios episodios recopilatorios de flashbacks.

Desde esta perspectiva, podríamos aventurar la hipótesis de que también los estereotipos de género son presentados como eso, guiones estereotipados. Esto es algo que veíamos al analizar los casos en que se intercambiaban las prácticas femeninas y masculinas. En el episodio octavo de la sexta temporada, Chandler, que ha estado realizando labores domésticas con Monica, le dice que va a ir al piso de Joey ya que ha estado «in touch with my feminine side enough today. I think we're two sauchets away from becoming a lesbian couple», lo que Monica apoya: 
MONICA- You're right, it's been kind of a girly day, I'm sorry

CHANDLER- I feel like I need to be in a guy place, you know, do kind of, like a man thing. MoNICA- Yeah, go over to Joey's and drink some beer and hammer up some drywall.

CHANDLER- You know guys they don’t just drink beer and hammer up drywall.

MONICA- Yeah, when girls hang out, we don't have pillow fights in our underwear. (Al ver el gesto de espanto de Chandler) I'm sorry, we do, we do, I don't know why I said that (y le abraza para tranquilizarle)

Aunque en escenas como la que hemos comentado al inicio de este epígrafe sea más evidente, tal vez podríamos extrapolar el análisis al resto de situaciones cómicas más aparentemente cotidianas en que los personajes masculinos fracasan en su intento de mantener su masculinidad. Por ejemplo, en las sobre actuaciones de hipermasculinidad por parte de Ross, o cuando, en la escena mencionada al principio del análisis, Chandler asegura «I like danger», para poder dar la imagen de hombre viril y valiente. En estos casos, el efecto de ventriloquía que se produce revela la ansiedad de unos personajes por alcanzar una idea de masculinidad que les ha sido impuesta: la masculinidad se vive como algo ajeno y amenazante para nuestros protagonistas.

Hay muchos casos en los que podríamos identificar la presencia de la masculinidad como un Otro o como una idea estereotipada. Algunos de los más evidentes son los que conciernen a las parejas de las protagonistas o los hombres deseados por ellas, que constituyen modelos de deseabilidad, de hombres ideales a los que temer o a los que parecerse. El undécimo episodio de la primera temporada, Phoebe y Monica se muestran atraídos por un hombre en la calle, y al silbarle provocan que le atropelle una ambulancia, dejándolo en coma. A esta primera muestra de una sexualidad activa por parte de la mujer basada solo en el sexo, le sucede la proyección de las fantasías de las dos protagonistas sobre la identidad del hombre.

MoNICA- Even asleep, he looks smart. I bet he's a lawyer

PHOEBE- You see the dents in his knuckles? That means he’s artistic

MONICA- Okay, he's a lawyer who teaches sculpting on the side. And he can dance.

PHOEBE- Yeah, he’s the kind of guy who, when you're talking, he's actually listening, and not saying “yeah, I understand” but really wondering what you look like naked.

MONICA - I wish all guys could be like him.

Como ya hemos mencionado, las parejas de Phoebe son particularmente reveladoras de este ideal de hombre: son muy atractivos físicamente, atléticos, y ocupan profesiones típicamente masculinas como policías, bomberos, científicos... En un capítulo de la 
cuarta temporada, Phoebe tiene un problema cuando se siente atraída por uno de sus clientes de masaje, atracción al principio totalmente física que se acentúa cuando descubre que es activista de Greenpeace. Curiosamente, muchos de los hombres resultan más atractivos si participan en algún tipo de activismo u ONG. Justo antes de que Chandler pida matrimonio a Monica, esta recibe la visita de su antiguo amor, Richard, quien le confiesa que aún tiene sentimientos por ella. Cuando le dice que después de su ruptura estuvo en África ayudando a niños ciegos, ella le suplica: «Please, don’t this to me!». Los hombres ideales de nuestras tres protagonistas, por tanto, suelen tener oficios codificados como de éxito o con alto salario, o representantes de cierta masculinidad heroica, y combinan el atractivo físico con la sensibilidad emocional. En otro episodio, Phoebe no sabe decidirse entre un bombero, quien es realmente atractivo pero no parece tener mucha profundidad psicológica, y un maestro de primaria que no es tan atractivo. Aunque al principio se decida por el profesor, la cosa se complica cuando, al cortar con el bombero, descubre que tiene una gran sensibilidad (hasta tiene un diario en el que escribe sobre sus emociones); para terminar, cuando decide romper con el profesor, al acudir a su apartamento lo ve sin camiseta para descubrir que tiene un cuerpo muy musculado.

Por supuesto, estos modelos de masculinidad deseable suponen una amenaza para nuestros protagonistas, quienes se sienten inferiores ante ellos en la “competición” por “conseguir” mujeres. El primer ejemplo es Paolo, el personaje italiano que aparece en la primera temporada para seducir a Rachel, provocando los celos de Ross. Paolo es un ejemplo aún más exagerado del estereotipo de italiano hipersexual, lo que intimida a los demás personajes. En la segunda temporada, Ross, quien ya mantiene una relación estable con Rachel, se sentirá celoso y amenazado por la sombra de su antiguo amante, al sospechar su mayor pericia a la hora de mantener relaciones sexuales con Rachel. Cuando Mark aparece en la serie, el compañero de trabajo de Rachel que provoca los celos de Ross que darán lugar a su ruptura, representará otro prototipo de hombre deseable: atractivo, blanco, con poder adquisitivo, sensible, con instinto paternal (uno de los gags en los que Ross muestra sus celos se debe a que Mark ha estado ayudando a su sobrina a hacer los deberes)... Como ya hemos visto anteriormente, Ross también se sentía amenazado por la masculinidad de los amigos jugadores de Rugby de Emily.

En otras ocasiones, será Chandler el que se sentirá amenazado por otros hombres más típicamente masculinos. En la cuarta temporada, se pone celoso de un compañero de reparto de su novia Cathy, que es actriz, con el que representa una escena de sexo en una 
obra de teatro. Al ver esta escena, se pone nervioso y fantasea con la posibilidad de que el actor, al que considera más atractivo que él, le ningunee y convenza a Cathy de dejarle. En la quinta temporada, Monica y él acaban de empezar su relación y, cuando le dice que solo están tonteando y pueden salir con otras personas, Monica, ofendida, decide salir con un enfermero. Al encontrarse con él, intenta despreciarlo haciendo alusión a su profesión: «Not a doctor, huh, kind of girlie, isn’t it?»; a lo que el enfermero le responde: «I’m doing this top ut myself through the medical school. And it didn't feel so girlie during the Gulf War» ${ }^{59}$.

Pero aparte de sentirse amenazados por ellos, en ocasiones los protagonistas masculinos los tomarán como modelos a los que admirar y de los que aprender ${ }^{60}$. Por ejemplo, en el capítulo veinte de la segunda temporada, Joey y Chandler empiezan a salir con el novio de Monica, Richard ${ }^{61}$, quien representa para ellos un modelo de masculinidad y empiezan a imitarlo, por ejemplo, dejándose un bigote como el que lleva Richard - con efectos cómicos porque, obviamente, nuestros protagonistas no son capaces de alcanzar estos ideales, en este caso literalmente: los dos protagonistas apenas consiguen hacer crecer una leve sombra.

En todos estos ejemplos, la masculinidad, para nuestros protagonistas, son los otros. Tanto en los casos de los rivales, como aquellos que les sirve de modelo (Richard, el novio policía de Phoebe), la masculinidad es algo externo y ajeno a ellos que toma la forma de una amenaza o una fantasía en la que participar. Lo cómicamente exagerado de estos estereotipos nos lleva a pensar que los creadores de la serie los presentan, efectiva y conscientemente, como tales.

\footnotetext{
${ }^{59}$ En esta escena se podría considerar que se censura a Chandler por su comentario sexista al considerar que es negativo que un hombre ocupe una profesión supuestamente femenina. Sin embargo, la solución cómica no es negar que ser enfermero sea afeminado, sino que el hombre realmente no es enfermero sino estudiante de medicina, que sí es una profesión masculina. Y, además, veterano de guerra. Lo que humilla a Chandler no es, pues, su manifiesto sexismo, sino la mayor masculinidad de su rival.

${ }^{60}$ En cierto modo, también admiran a los hombres rivales que consideran amenazantes, teniendo en cuenta hasta qué punto es ambigua la distinción entre rivalidad y deseo de identificación en las relaciones entre hombres (Reeser, 2010: 59)

${ }^{61}$ El personaje de Richard, además, era interpretado por Tom Selleck, el legendario actor de la serie policiaca de acción de los ochenta Magnum P.I. e icono sexual masculino de la época, recordado sobre todo por su característico y viril bigote. En la sexta temporada haría de actor invitado otra estrella del cine de acción, Bruce Willis, como el padre de Elizabeth, la novia universitaria de Ross. Su personaje era caracterizado como el epítome de masculinidad dura, amenazante y sobreprotectora, con la que seducía a Rachel; pero esta caracterización era cómicamente contrastada cuando, en el episodio en que esta intentaba que se abriera un poco y le hablara de su infancia, Bruce Willis no podía contener sus emociones traumáticas y lloraba durante el resto del capítulo.
} 
Esto es evidente en el segundo episodio de la segunda temporada, en que Joey empieza a trabajar en los grandes almacenes ofreciendo muestras de colonia. En este capítulo, aparece un compañero de trabajo al que las trabajadoras del centro llaman «The hombre man». Obviamente, enseguida Joey lo ve como un rival. Lo sugestivo es que este argumento se desarrolla como una parodia de los códigos del western, género masculino por excelencia. Este hombre aparece como un trasunto de Clint Eastwood, vestido de negro y como un cowboy, incluso con las espuelas haciendo eco de sus pasos y desenfundando el bote de colonia como si fuera un revólver. La rivalidad entre Joey y «Hombre Man» es en términos de poder (el vaquero “invade” el territorio de Joey), labor (desempeña mejor su trabajo al dar más muestras de colonia) y catexis (le "roba” la chica con la que Joey quería salir). El argumento llega a su clímax, cómo no, con un duelo entre ambos por ver quién ofrece más colonia. Sin querer, “Hombre Man” echa colonia en los ojos de un cliente, con lo que es despedido, y el episodio termina con Joey dirigiéndose con su compañera de trabajo del brazo hacia el fondo del pasillo, decorado con el póster de un sol poniente.

Lo interesante, como decimos, de este episodio no es solo cómo representa en casi todos sus matices la masculinidad hegemónica: fuerza, rivalidad por el poder sobre las mujeres y sobre el territorio con otros hombres... sino que lo hace parodiando el que quizá sea uno de los mayores mitos masculinos del imaginario occidental moderno y particularmente el estadounidense, el del cowboy. Al parodiar el mito, el episodio muestra el origen legendario de la masculinidad que representa. A pesar de todo, esto no implica que dicha idea de masculinidad quede deslegitimada por el mero hecho de ser presentada, literalmente, como una fantasía. Lo interesante, precisamente, es que Joey no deja de sentirse amenazado por esa fantasía y se siente impelido a participar en ella al competir con el cowboy, transformándose él mismo en uno.

Encontramos otro ejemplo de materialización de una fantasía en uno de los gags que ya hemos citado, aquel de la primera temporada en que Joey y Chandler llaman a una puerta de su edificio y les abren dos atractivas chicas que les piden que les ayuden a arreglar la calefacción, porque tienen calor y están muy sudadas, lo que distrae totalmente a ambos personajes. Es evidente, por lo exagerado y absurdo de la situación, que esta escena es una referencia paródica a las fantasías pornográficas, y, a pesar de ello, los personajes no pueden dejar de sentirse atraídos por esa fantasía literalmente encarnada. 
Todos estos casos permiten una lectura que van más allá de la cuestión del entendimiento del género como estereotipo social o naturaleza inmutable. Más bien nos permiten observar el funcionamiento general de la comedia: lo cómico, como quiere Zupancik, al trabajar con estereotipos, los materializa; los estereotipos, lejos de ser descartados como mera ilusión son materializados en el universo ficticio de la comedia. La materialización externa del carácter fantasmático de la ideología es, de hecho, una de las características fundamentales que Žižek le atribuye al fenómeno ideológico (Žižek, 2011: 8). Por tanto, podemos decir que, tanto en estos ejemplos tan evidentes, como en los que los ideales de masculinidad se encarnan en personajes rivales o deseables, a lo que asistimos es a la materialización cómica de esta masculinidad como efectivamente fantástica, sin que eso implique necesariamente su inautenticidad. Precisamente, la paradoja es que estas fantasías son demasiado reales, y de ahí que se vivan como amenazas $^{62}$.

Sobre todo, este análisis se puede extender a todas las situaciones que hemos venido analizando, en que los hombres se comportan, adecuada o inadecuadamente, siguiendo el script de la masculinidad, sin que el reconocimiento implícito de este script de género como tal impida que los hombres se sientan obligados a intentar seguirlo. Se produce lo que hemos denominado un efecto de ventriloquía por el que los protagonistas masculinos se ven llevados a cumplir con un guion escrito anteriormente; por mucho que la masculinidad se perciba como un estándar impuesto, los personajes masculinos se sienten obligados a intentar imitarlo (y experimentan ansiedad al fracasar), se sienten obligados a comportarse como hombres por el preciso hecho de ser hombres: la masculinidad se presenta en este sentido como una exterioridad interiorizada. Como asegura Butler, la imposibilidad de ocupar la posición simbólica de la matriz imaginaria heterosexual no significa que el sujeto no se sienta compelido a hacerlo: «Insofar as heterosexual gender norms produce inapproximable ideals, heterosexuality can be said to operate through the regulated production of hyperbolic versions of "man" and "woman". These are for the most part compulsory performances, ones which none of us choose, but which each of us is forced to negotiate» (Butler, 1993: 26). Recordemos el pasaje del

\footnotetext{
${ }^{62}$ Podríamos traer a colación otro chiste utilizado tanto por Žižek como por Zupančič: el de un hombre que es ingresado en un psiquiátrico por creerse un grano de maíz. Meses después, se cura y aprende que es un hombre, sale del psiquiátrico, pero vuelve casi inmediatamente. Cuando el médico le pregunta por qué ha vuelto, el enfermo le dice que había una gallina en la puerta y temía que le comiera, a lo que el médico le dice: «Pero usted ya sabe que es un hombre, y no un grano de maíz», a lo que le responde el enfermo: «Sí ¿pero lo sabe la gallina?» (Žižek, 2018: 64; Zupančič, 2008: 15)
} 
libro de Henri Bergson en que asegura que la comicidad del personaje de Tartufo reside no en su hipocresía, sino en el hecho de que, a fuerza de repetir el papel de hipócrita, acaba por volverse un hipócrita (Bergson, 2016: 131). Este mismo pasaje sirve a Žižek para apoyar su tesis de la materialización externa de la ideología (Žižek, 2011: 10) y a Zupancic su concepción de lo cómico como materialización concreta de lo abstracto universal (2008: 82), y es lo que nos permite entender el funcionamiento del script de género en la comedia de Friends.

En todo caso, debemos recordar la ambigüedad propia del travesti de la que hablábamos al analizar el potencial crítico de la figura de La Madelón respecto a la Transición, y del drag en sí respecto a las normas de género: el reconocer el género como un performativo y una performance no conlleva necesariamente un descarte de dichas normas de géneros implicadas, e incluso puede servir para su reforzamiento como normas ideales. Respecto a la masculinidad, como dice Reeser, "masculinity itself could be viewed as always moving between parody and performance” (2010: 90). Lo mismo ocurre con Friends: el juicio que el espectador realice sobre el hecho de que la comicidad se base en estereotipos de cómo los hombres son o se comportan dependerá del concepto de identidad de género que el espectador tenga: podrá considerar en que es gracioso porque los hombres se comportan efectivamente así; o, por el contrario, si cree que los estereotipos respecto del comportamiento de los hombres son eso, estereotipos sin ninguna base real, considerará que la comicidad reside en la parodia de dichos estereotipos.

\subsection{Conclusiones hermenéuticas: lecturas ideológicas de la Comedia}

Como hemos visto, Friends es percibida como la joya de la corona nostálgica de una época en la que las comedias tenían el único y honesto objetivo de entretener. Sin embargo, su estatuto de clásico moderno, testimonio del fin de una era y el comienzo de otra, es paradójico. Por un lado, se asegura que su éxito se debe precisamente a su inocuidad e irrealismo, a que da una visión altamente idealizada de la vida la juventud, que su éxito se debe a su constitución como fantasía a la que escapar de los pesares de la vida cotidiana. Pero, por otro, como hemos visto, son innumerables y recurrentes los artículos, de mayor o menor rigor, seriedad y profundidad, que desgranan los aspectos 
supuestamente serios de la serie y le buscan un significado más allá del mero entretenimiento, ensayos sobre la significación del trabajo de Chandler, la filosofía de vida de Phoebe, la relación entre Ross y Rachel, etc. Es decir, Friends es vista como un mero producto de entretenimiento para pasar el rato y a la vez como preñada de significaciones y sentidos sobre la vida contemporánea.

¿Cómo se explica esta ambivalencia por la que la sitcom es a la vez una nadería y el espejo donde mirarnos? En la manera en la que hemos conducido este estudio se pueden aducir dos razones. Una, la más evidente, es que el análisis ideológico es aplicable a todo tipo de discurso, y aún más pertinente si es un discurso tan popular extendido y que se presenta precisamente como no ideológico - y, de hecho, hemos comprobado cómo se puede llevar a cabo un exhaustivo análisis de la masculinidad. Además, es esta apariencia de inocuidad, ese objetivo de simplemente hacer reír hace que Friends sea una pura comedia, una obra cuya única razón de ser es ser comedia. Por tanto, sirve para analizar de forma transparente los mecanismos de la comedia, o más bien los de una especie concreta, la sitcom estadounidense, en relación con su significación social y sus funciones - de normalización o no.

Este carácter cómico, entre inocuo y demasiado serio, afecta directamente a la percepción de sus contenidos ideológicos, concretamente a la masculinidad tal y como la hemos analizado en estas páginas, sobre todo en la tensión que se da entre la supuesta intención de realismo declarada por sus creadores en la construcción de los personajes (y su contrapartida en la identificación o por lo menos implicación por parte de los espectadores) y el carácter deformado y/o estereotipado al que obliga el carácter cómico de la obra. La cuestión de la presentación de las identidades de género, la ideología del carácter masculino o femenino en la serie es, como hemos visto, ambigua. Si en ciertos casos la parodia crítica de ciertos aspectos de la masculinidad es evidente, en su mayor parte la serie presenta los estereotipos de género sin problematizarlos, como algo dado por hecho. Deberíamos aducir, por supuesto, que no podemos esperar de una serie popular de los años noventa que consta de diez temporadas una fuerte intención programática al respecto.

Pero, por otro lado, a lo largo de este trabajo hemos defendido que es propio de la comedia funcionar mediante el recurso a estereotipos e ideas comunes, lo que afecta a la construcción del personaje cómico, y, al mismo tiempo, su carácter autoconsciente implica que estos estereotipos se presenten como tales. Por último, el carácter 
intrínsecamente ambiguo del discurso humorístico da lugar a que la interpretación, crítica o no, dependa casi por entero de su recepción. En este sentido, el análisis de un fenómeno ideológico como la masculinidad desde un discurso cómico ha permitido enriquecer nuestra comprensión tanto de este discurso de la comedia como de la ideología. Igual que el carácter imaginario y construido de la identidad, y concretamente la de género, se ha visto clarificado mediante el análisis del discurso camp de las obras de Mendicutti, conceptos teóricos como habitus, normalización, o la materialidad de las prácticas ideológicas, han iluminado y se han visto iluminadas a su vez por elementos de la comedia como la caracterización del personaje cómico o el carácter material de lo cómico.

La masculinidad, como toda construcción ideológica discursiva, es susceptible de ser parodiada, resignificada (Reeser, 2011: 35). Pero, como avisan teóricas como Judith Butler o Linda Hutcheon, presentar algo como un estereotipo no significa automáticamente su deslegitimación. Como venimos diciendo, la percepción de la masculinidad como paródica o ridícula depende de la relación de la representación con quien la emite y quien la recibe: «masculinity can be called a parody only by someone, the relation between a performance and those who view it and between a performance and those who perform it determines whether it is coded as performance» (Reeser, 2011: 89). Como hemos visto a lo largo de nuestros análisis, la masculinidad se presenta en Friends como una otredad, como una exterioridad que hay que imitar: «masculinity itself could be viewed as always moving between parody and performance» (Reeser, 2011: 90). Pero, como hemos visto, por mucho que los protagonistas perciban la masculinidad como algo ajeno, no significa que no se sientan obligados a cumplirla. En resumen, para explicar la extraña relación que Friends establece con la masculinidad como ideología y como estereotipo, que presentan como tal y al mismo tiempo como natural, podríamos aducir la tesis de Žižek acerca del funcionamiento de la ideología en nuestro tiempo: «ellos saben lo que hacen, y aun así lo hacen» (Žižek, 2018: 61). 
IV. EL ORDEN DEL DISCURSO HUMORÍSTICO 


\section{EL DEBATE SOBRE LOS LÍMITES DEL HUMOR EN ESPAÑA}

En este trabajo hemos visto cómo el conflicto atravesaba, en diferentes formas e intensidades, las discusiones acerca de lo cómico, de sus significados y sus consecuencias. A lo largo de la historia, la risa ha sido algo peligroso que hay que acotar, limitar, controlar, someter. Prácticamente ningún autor que haya tratado el humor o la risa, ni siquiera los más favorables, ha dejado de establecer distinciones, de orden social, moral o intelectual, entre un humor bueno y otro malo, una risa beneficiosa o maligna. No obstante, no deberíamos limitarnos a enfocar las suspicacias levantadas contra el humor sin tener en cuenta cómo de hecho el humor muchas veces ha sido usado intencionadamente para provocar el conflicto, cómo ha sido usado como arma polémica en disputas teológicas, sociales, o políticas. Es más: el humor, en general, implica siempre un conflicto, un choque de representaciones, una incongruencia; necesita un límite con el que poder jugar, bien sea para reforzarlo o para denunciarlo: es transgresión, burla, frivolidad...

Los conflictos en torno al humor, como decimos, pueden tomar varias formas. En primer lugar, el discurso humorístico puede dar lugar a un conflicto de interpretaciones que es consecuencia directa de su ambigüedad semántica intrínseca: como vimos en nuestro análisis de Una mala noche la tiene cualquiera, la novela presentaba una valoración diferente del proceso histórico y político de la Transición según las convicciones previas del intérprete. En segundo, lugar, este conflicto de interpretaciones puede tomar una dimensión de debate social y cultural: también mencionamos la manera en que la percepción de la serie Friends había cambiado en los últimos veinticinco años, generando rechazo en las generaciones más jóvenes que la veían desde la sensibilidad social actual. Por último, y lamentablemente, el conflicto en torno a los discursos humorísticos puede tener consecuencias trágicamente violentas como la de la matanza perpetrada por la revista satírica francesa Charlie Hebdo en enero de 2015, que es un punto de referencia para cualquier discusión acerca de los límites del humor.

Este debate ha tenido una importante presencia en la opinión pública española de los últimos años. Actualmente no pasa mucho tiempo sin que los medios de comunicación no recojan alguna polémica acaecida en redes sociales a cuenta de algún humorista o pieza humorística; cada vez son más los casos judiciales contra cómicos, desde Cassandra 
Vera hasta Daniel Suárez; y no hay entrevista a algún humorista en que no se le pregunte por los límites del humor. En los muchísimos libros y artículos de opinión acerca del tema encontramos expresiones hasta hace poco desconocidas para el público español como «corrección política», «ofendiditos», «guerras culturales», porque el debate se enmarca en cuestiones culturales y sociales más amplias como la libertad de expresión, los cambios culturales y la polarización política, así como el papel de los medios de comunicación digitales y las redes sociales en todo ello.

Se trata, en fin, de un debate acerca del orden del discurso, particularmente humorístico: un cuestionamiento acerca de qué se puede decir y qué no, quién puede decirlo, de qué manera, cómo se ha de interpretar, etc.; y en estos términos trataremos los discursos acerca del humor que han aparecido en España en los últimos años. Nuestro objetivo es analizar, por una parte, cómo la disputa se enmarca en términos de «libertad de expresión» de un lado y «derecho a la protesta» de otro y cómo esto sirve como estrategia de discusión política; y por otro, qué rasgos concretos del discurso humorístico pueden contribuir al conflicto ideológico, especialmente en el contexto de la comunicación en redes sociales, y sobre todo qué concepciones del humor se proponen para criticarlo o defenderlo. En primer lugar, realizaremos una primera aproximación introductoria al estado actual del debate realizando dos estudios de caso: una extensa entrevista al cómico Jorge Cremades, en que expone de manera cristalina una concepción popular del humor y sus límites; y un polémico artículo del escritor Arturo Pérez Reverte que, como veremos, es una irónica provocación a una supuesta actitud censora por parte de colectivos activistas. Seguidamente, situaremos esta discusión sobre los límites del humor y la libertad de expresión en su contexto amplio, analizando el origen en las disputas ideológicas estadounidenses de términos como «corrección política», «guerra cultural» 0 «cultura de la cancelación», así como el contexto aún más amplio que las redes sociales y la adaptación de los medios de comunicación al ámbito digital parece haber tenido sobre la circulación contemporánea de los discursos. Finalmente, nos centraremos qué forma toma la discusión de la libertad de expresión en España y cómo se relaciona con su contexto político y cultural particular, y analizaremos algunas de las defensas por parte de humoristas ante polémicas recientes, explicándolas a la luz de las sugerencias teóricas de Michel Foucault acerca del «orden del discurso» y de Pierre Bourdieu acerca de lo que denomina «economía de los intercambios lingüísticos». 
En este punto, parecen necesarias algunas consideraciones acerca de la objetividad o su falta en los análisis que siguen. Tal objetividad, que se supone exigida en un trabajo académico como este, parece imposible cuando se tratan de asuntos tan actuales y marcadamente ideológicos, que toman una forma tan explícitamente polémica que hace que cualquier intervención implique inevitablemente “tomar partido”. Por una parte, para que sea mínimamente profundo y productivo, el análisis ha de ir más allá de una mera descripción superficial y supuestamente neutra de los acontecimientos y los discursos. Por otra, a lo largo de este trabajo se ha defendido, tanto en los análisis de los dos capítulos precedentes, como desde el punto de vista teórico, que todo discurso y toda interpretación es, inevitablemente, ideológico, y este trabajo, obviamente, no es una excepción. Por tanto, y aunque se haya intentado reducir la valoración particular en los análisis que siguen, es inevitable que esta toma de partido se transparente en mayor o menor medida, y parecerá que algunas de las afirmaciones que se hagan se saldrán del ámbito del análisis propiamente lingüístico o retórico para entrar en consideraciones ideológicas e incluso morales. Pero esa falta de objetividad (objetividad que, tal y como se defiende en nuestro marco teórico, no puede existir) no tiene por qué implicar una falta de rigor en el análisis. Es más, una de las conclusiones que se pretenden defender en este capítulo es que, desde el punto de vista metodológico, un análisis meramente descriptivo de su dimensión discursiva es, cuando no imposible, inútil a la hora de explicar por entero las dimensiones de polémicas como las que nos ocupan.

Otra de las conclusiones que este capítulo querría aportar es la ausencia de auténticos debates en temas tan fundamentales como los que aquí se van a tratar. Si bien es cierto que las ciencias sociales y las humanidades no pueden otorgar un punto de vista definitivo ni mucho menos objetivo, al menos pueden aportar una visión profunda e informada con la que mejorar el rigor de dichos debates. En este sentido, debemos recordar que ni el Análisis Crítico del Discurso ni mucho menos la Retórica Constructivista quieren rehuir de un posicionamiento ético en sus planteamientos ni sus investigaciones. 


\subsection{Dos estudios de caso acerca de la posición actual del humor}

\subsubsection{Una concepción popular del humor: entrevista a Jorge $\underline{\text { Cremades }}$}

Una de las hipótesis que venimos defendiendo en este trabajo es que no se puede hablar de lo que el discurso humorístico es, ni mucho menos de lo que necesariamente hace o los efectos que tiene. Las funciones y efectos que un discurso humorístico tenga dependerán tanto del contexto del productor como el del receptor, y una parte importante de estos contextos está determinada por la concepción del humor que ambos tengan, concepción desde la que interpretarán el discurso humorístico concreto. También vimos cómo estas concepciones del humor dependían de predisposiciones ideológicas y, quizá en mayor medida, de factores socioculturales. Así, el trabajo de Giselinde Kuipers [ver 3.3.2.2], partiendo del modelo del «gusto» como criterio de distinción social tal y como lo presenta el sociólogo Pierre Bourdieu, mostraba cómo la valoración de los chistes y las preferencias por ciertos tipos de humor variaban según variables de género y sobre todo de clase sociocultural, permitiendo esbozar dos concepciones diferentes del humor: una concepción popular, en la que el chiste constituye una práctica social encaminada al estrechamiento de lazos afectivos, la creación de ambientes amables y el entretenimiento; y una concepción "sofisticada” que evalúa el humor según criterios estéticos e intelectuales. En su momento [3.4.1.] relacionamos estas dos concepciones con dos «mitos humorísticos», el ingenuo y el intelectual, y en este capítulo nos encontraremos con ejemplos de ambos.

En esta línea, la entrevista que analizaremos a continuación ofrece la oportunidad de analizar un ejemplo de esta concepción "popular” del humor tal y como la comparte una amplia parte de la población. Tal y como se puede comprobar, la opinión de Jorge Cremades se presenta aquí de una manera, digamos "en bruto", sin la elaboración reflexiva que encontraremos en otras defensas del humor por parte de otros humoristas; es en este sentido que decimos que la entrevista presenta unas consideraciones que podrían ser compartidas de manera generalizada por personas que no se dedican ni profesional ni académicamente al humor. En general, el tipo de comedia representada por Jorge Cremades se presta a un análisis parecido al de un producto tan masivamente popular como es la serie Friends. Jorge Cremades (Alicante, 1988) es el ejemplo paradigmático de nuevo cómico producto de la nueva industria cultural digital, que se 
hizo inmensamente popular haciendo brevísimos vídeos caseros para la desaparecida plataforma de vídeos Vine antes de saltar a circuitos más convencionales como los monólogos en teatros. Actualmente acumula poco más de un millón de suscriptores en YouTube, casi tres millones de seguidores en Instagram, y casi siete en Facebook. La otra cara de esta popularidad es que Cremades ha llegado a ser una de las personas más polémicas en las redes sociales, donde se le ha acusado en muchas veces de machista y homófobo, llegando a boicotearse algunos de sus espectáculos (El Mundo, 2017), mientras que otros han sido directamente cancelados por autoridades municipales ( $\mathrm{La}$ Vanguardia, 2017).

¿En qué consiste el humor de Cremades para ser calificado como machista? La descripción que realiza la periodista Lorena G. Maldonado, la realizadora de la entrevista objeto de nuestro análisis, como introducción a la misma, es bastante reveladora:

Jorge Cremades (Alicante, 1988) es un niño grande -sin maldades, sin discurso políticoque construye fruslerías ágiles, cotidianas, humanas hasta el ridículo. Humor de consumo rápido, cuentos de 30 segundos, retratos costumbristas de una juventud de novias breves, botellones y leyes no escritas de un grupo de colegas. Es un animal cómico sin intenciones, quiere la coña por la coña, exenta de análisis, sólo cubierta de salsa, y le funciona (...).

Es el Ocho apellidos vascos de los vídeos cortos, un rosario de topicazos y de pequeñas reyertas sexistas, un tipo grandote y bonachón -de sonrisa cuadrada- que se hace el perdedor, el incorrecto, el temeroso, el egoísta o el crápula según se tercie. Engancha y genera rechazo a partes iguales: para muchos es como esas mágicas patatas de bolsa que devoras y nunca te sacian del todo, para otros es la grasa que se queda entre los dedos. Han dicho de él que es el Bertín Osborne púber, que algunos de sus vídeos rebosan contenido machista, que homogeneiza a las mujeres y las convierte en una sola que se mueve muy rápido y que peca de celosa, pesada, intensa y adicta a las compras y a los regalos de aniversario.

Otros lo ven como el indiscutible rey del humor, el profeta de las cosas pequeñas, el espejo portátil en forma de Iphone en el que verse reflejado a uno mismo. Con lo mejor y lo peor. Con lo vergonzoso, lo hilarante y lo mortal. A gusto o disgusto del consumidor que lo solicite (Maldonado, 2016; el destacado es nuestro)

Efectivamente, el humor de Cremades entronca con la tradición más literal de humor costumbrista, que podemos reducir fácilmente a la fórmula «es gracioso porque es cierto»: 
presenta escenas supuestamente cotidianas, con los problemas reales pero nimios de su generación. Es por esto que decimos que es un tipo de humor que se ofrece a un análisis similar al de una serie como Friends: no porque efectivamente represente fielmente una realidad cotidiana, sino porque más bien refleja los tópicos y los estereotipos con los que se lee dicha cotidianidad. Y la mayor parte de estos tópicos hacen referencia a una guerra de sexos establecida con base en estereotipos de género muy arraigados en el imaginario popular, imaginario que podríamos relacionar incluso con las comedias populares del tardofranquismo y la transición (ver Huerta Floriano y Pérez Morán, 2013, 2015; Pérez Morán, 2019; Pérez Morán y Huerta Floriano, 2018), pero también con la misma construcción de género que encontramos en Friends.

En los primeros vídeos de Jorge Cremades, se establece una distinción tópica entre las mujeres, atentas a los detalles, reflexivas hasta la complicación inútil, propensas a preocuparse en exceso o molestarse por nimiedades, poniendo siempre a prueba a sus parejas; y los hombres, más despreocupados y simples, directos, que viven su relación de pareja como una opresión de la que solo le pueden salvar sus amigos. Las chicas tardan más en hacer la maleta o en vestirse porque tienen que elegir cuidadosamente su apariencia, o tienen problemas en elegir un regalo mientras que los chicos simplemente compran lo más barato. Ellas comparten con sus amigas sus sentimientos y problemas con el sexo opuesto, mientras que los chicos solo piensan en divertirse, consumir alcohol o competir por ver con cuántas mujeres se acuestan. Esto afecta, claro, a sus relaciones románticas (siempre heterosexuales). Por ejemplo, en un vídeo vemos a una chica que cuenta a sus amigas que no va a hablar a su novio para hacerle ver que está enfadada con él, a lo que se contrapone la reacción de este, que celebra con sus amigos que su pareja «lleva tres horas sin dar por culo». Los hombres, en el universo cómico de Cremades, huyen del compromiso (en un vídeo, el protagonista huye a otro país cuando se entera de que su novia puede estar embarazada) y solo piensan en las mujeres como posibilidades de tener sexo (en otro vídeo, Cremades ayuda a una chica a sujetar unas maletas, pero la abandona cuando se entera de que tiene novio). Incluso encontramos el juego cómico con la amenaza de homosexualidad que, como vimos en el capítulo interior, es un elemento básico para la construcción de la masculinidad normativa: así, en muchos vídeos se bromea con que alguno de los integrantes del círculo de amigos sea secretamente homosexual e intente hacer aproximaciones de tipo sexual hacia el otro - que por supuesto, recibe el avance con una mezcla de extrañeza y miedo. 
Además de esta demostración de estereotipos de género más o menos pasados de moda, dos vídeos en especial atrajeron las críticas por bromear con la violencia sexual y la violación. En uno de ellos, que el autor llegó a eliminar de las redes, vemos a Cremades dirigirse a la cámara y diciendo que va a enseñar a ligar con mujeres, para a continuación usar un pañuelo con cloroformo para secuestrar a una mujer por la calle y meterla a un portal. En otro, cuando una chica ebria en una discoteca le dice al protagonista que ha perdido de vista a sus amigas, todos los hombres del local se abalanzan sobre ella entre gritos de «iMe la pido!». Una de las mayores polémicas, que de hecho fue el pretexto para la cancelación de su espectáculo en Vigo en enero de 2017, vino, sin embargo, por una de las declaraciones que hace en la entrevista objeto de nuestro estudio, hablando precisamente de este último vídeo, y que la periodista Lorena Maldonado eligió como titular de la pieza: «Hay más violaciones a hombres que mujeres» (Maldonado, 2016).

Algunos periodistas, como Soto Ivars, defendieron a Cremades alegando que la frase estaba sacada fuera de contexto (Soto Ivars, 2017: 226). En realidad, si tenemos en cuenta el párrafo donde aparece, la afirmación no cambia mucho su sentido ${ }^{1}$, pero sí es cierto que desentona con el resto de la entrevista, en la que los temas tratados se acercaban más a una discusión sobre las relaciones cotidianas entre hombres y mujeres y, lo que más nos interesa, el humor y sus límites. En todo caso, la elección de esa afirmación como titular más o menos descontextualizado de la entrevista, sin duda con el objetivo de llamar la mayor atención posible a costa de la polémica que se esperaba generar (es decir, la práctica de lo que se conoce como «clickbait» o «cibercebo», elegir los titulares más llamativos con el fin de obtener más visitas, en el contexto de una economía digital en que los medios cobran publicidad según el número de estas visitas) es un buen ejemplo de las prácticas que, como veremos, condicionan el orden actual de los discursos en el medio digital. Pero, de momento, analizaremos el discurso sobre el humor que Cremades despliega en la entrevista:

\footnotetext{
${ }^{1}$ En la entrevista, Maldonado, en respuesta a la afirmación de Cremades de que el vídeo sobre la chica ebria no representa necesariamente una agresión sexual porque si fuera un chico del que se aprovecharan unas mujeres simplemente sería divertido, dice que en realidad no hay violaciones de mujeres a hombres, a lo que Cremades contesta: «Ya... pero sí que hay violaciones en hombres, y ese tema no se trata. Hay estadísticas que dicen que realmente hay más violaciones a hombres que a mujeres, y de eso no se habla. En las cárceles hay muchísimas violaciones de hombre a hombre, y violaciones de mujer a hombre en otros temas, no físicas» (Maldonado, 2016). El humorista se disculpó posteriormente en Twitter afirmando que efectivamente la estadística mencionada por él se refería a violaciones ocurridas en cárceles, pero el sentido global se sigue pudiendo interpretar como un intento de atenuar la relevancia de la violencia sexual concreta hacia mujeres, que fue la causa de la indignación.
} 


\section{¿Tiene límites el humor o en esa esfera todo es posible porque pertenece a la ficción?}

No sé qué decirte. Yo pienso que el humor en sí no tiene límites, los límites están en la gente que los recibe. Hay situaciones o casos en los que no se puede tratar un tema en concreto, porque te afecta. Pero hay situaciones en las que esa persona, la que tiene el problema, lo lleva con humor.

\section{¿Por ejemplo?}

Por ejemplo, alguien con una enfermedad. Joder, tú que estás sano no puedes meterte con alguien que tenga cáncer, pero luego hay mucha gente que afronta el cáncer con mucho humor, lo cual es genial, ¿¿sabes? ¿Dónde está la línea? Ojalá no me pase nunca y no lo tenga que demostrar, pero si alguna vez me veo en esa situación, me lo tomaré con humor. Y gastaré chistes de eso, pero ahora no me atrevo. Entiendo que hay gente a la que no le haría ni puta gracia.

En ficción se puede hacer. Mira Intocable. Es una película que se ríe entre comillas de una enfermedad.

\section{Se ríe con ternura.}

Sí, no se ríe de, se ríe con, y todos flipamos. Esa esfera de ficción que crea esa película si te permite reírte. Pero que luego vayas por ahí y sueltes un chiste respecto a ese tema y a la gente no le haga gracia, lo entiendo. Entonces no sé dónde está el límite. El límite está en el cariño, en el amor. Si haces chistes de esos con amor, funciona.

\section{Tres temas que nunca te atreverías a tocar en tus vídeos.}

Pues mira, política no lo toco. Supongo que desgracias sociales o personales no me atrevería a tocar. Por ejemplo, nunca haría un chiste de las torres gemelas, ni del hambre en África. Bueno, igual digo ahora que no lo haría, pero un día encuentro un chiste guay para hacerlo. ¿Otro tema...? No tocaría el maltrato animal, ni el machismo, ni el bullying, ni de gente bulímica. Temas que no tocaría porque no me hacen gracia, directamente. No me esperaba preguntas tan serias (Maldonado, 2016; el destacado es nuestro)

En este fragmento, Cremades ofrece varias afirmaciones interesantes respecto a los límites del humor. En general, el límite parece estar en que el tema con el que se bromea afecte a la persona, y esos límites de tolerancia al humor parecen ser individuales. Como regla general, Cremades parece poner el límite en que una persona no puede hacer humor a costa de las desgracias de otras personas, pero menciona dos excepciones relacionadas: 
por un lado, si el humor aparece en una ficción más elaborada como una película como Intocable, la comedia francesa acerca de una persona tetrapléjica, o si la broma está lo suficientemente conseguida («pero un día encuentro un chiste guay para hacerlo...»). Asimismo, la intención es un factor importante: el límite del humor está en el cariño con el que se hace, es decir, en la falta de malicia o de ánimo de ofensa. En todo caso, parece haber una serie de temas acerca de los cuales parece haber un consenso colectivo: tragedias como el terrorismo o lacras sociales como el maltrato animal, el acoso escolar o el machismo ${ }^{2}$. Claro que estos consensos cambian conforme cambia la sociedad:

\begin{abstract}
¿España echa de menos los chistes "de mariquitas", como los de Arévalo?
No, yo creo que no (ríe). Ahora hay una línea en la que ya no es gracioso como tal porque lo vemos normal. Ser "mariquita", como dices, es lo más normal del mundo. Antes era gracioso porque se hablaba de algo, entre comillas, prohibido. (Maldonado, 2016; el destacado es nuestro)
\end{abstract}

En todo caso, parece que, si Cremades considera que no se debería hacer humor con temas especialmente graves, es porque hay un rasgo del humor que puede afectar a quien lo recibe, bien porque haya un componente de ridiculización o simplemente de frivolidad ${ }^{3}$. Por tanto, el humor es algo potencialmente dañino, lo que, como decimos, implica que si Cremades hace bromas sobre agresiones sexuales es porque realmente no es consciente de que lo está haciendo. Esta consideración nos lleva a replantearnos el papel de la intención en el discurso humorístico y su recepción: Cremades, efectivamente, no tiene intención de hacer apología de la violación o de humillar a las mujeres. De lo que se trata es de diferentes interpretaciones de sus vídeos, como él mismo dice:

Hubo un vídeo tuyo que me pareció especialmente grave. Sale una chica en un bar y dice "estoy to' ciega, me he perdido"... y salís tus amigos y tú en plan "¿borracha? ¡Me la pido!". Y claro, en España, según los últimos datos de Interior, hay una

\footnotetext{
${ }^{2}$ Lo curioso de esta afirmación es que Cremades el machismo no le parece un tema apto para el humor, lo que significa que no ve las actitudes que se pueden calificar de sexistas en sus vídeos como tales. Como veremos enseguida, más adelante en la entrevista se verá cómo efectivamente en la discusión sobre el humor también aparece el factor de las posibles interpretaciones de un chiste.

${ }^{3}$ Cremades parece conceptualizar el humor en general como una forma de agresión bienintencionada: «(...) nos gusta reírnos de nosotros, y eso es fundamental en la vida. Ser tan idiotas nos hace felices (ríe). Nos metemos muchísimo con el amigo que acaba de meter la pata, lo acribillamos y nos reímos. Toca reírse porque mañana se reirá de nosotros» (Maldonado, 2016). El límite de esta agresión está, de nuevo, en la gravedad: «hay dos tipos de caídas, las que haces buajaja y las que haces uh. Pero si después no pasa nada, te ríes» (Maldonado, 2016)
} 


\section{violación cada ocho horas. ¿Qué piensas de este vídeo? ¿El humor debe estar}

desvinculado de los problemas actuales?

Es que, ¿ves? Yo cuando hago ese vídeo, en ningún momento se me pasa por la cabeza una violación. Ni del palo.

\section{Ya, pero va por "está borracha y es más fácil tener sexo con ella".}

Yo lo miro así y pienso "tienes razón", pero... no sé, no sé. Entiendo que lo veas así y claro que diría "hay que separarlo", pero yo no me refería a violar a esta chica. Si hago un vídeo en el que salgo con un amigo y digo "vamos a emborracharla que me quiero liar con ella", ese vídeo hablaría de violación. Si una tía lo hace: "Chicas, vamos a emborracharle que me quiero liar con él", sería un vídeo divertido (Maldonado, 2016; el destacado es nuestro)

Por tanto, Cremades tiene presente que el humor no es inocuo, que puede herir y por tanto es necesario que tenga límites; pero esos límites dependen de la interpretación que el receptor haga del chiste, más allá de cualquier posible intención original del autor. En suma, los límites del humor no tienen tanto que ver con una cuestión de la intención de ofender sino de cómo se recibe: el conflicto que puede provocar un chiste es un conflicto de interpretaciones. Como veremos, la inocuidad del humor (su incapacidad de molestar o conllevar comportamientos nocivos) y la intencionalidad son elementos muy presentes en las discusiones sobre los límites del humor.

En todo caso, sobrevuela a la entrevista la cuestión, aparejada a la de los límites del humor, de la censura: ¿es necesario censurar los chistes que propasen estos límites, o más exactamente autocensurarse? Cremades reconoce que un artista público, como un humorista, ha de ser consciente de cómo su humor es recibido: «Yo tampoco voy a empeñarme en "voy a hacer vídeos machistas", ni "voy a hacer chistes de mariquitas", no, no. Me censuro porque no quiero herir» (Maldonado, 2016). 


\subsubsection{El humor como provocación: un artículo de Arturo Pérez Reverte}

La pregunta a Cremades acerca de los límites del humor y de la necesidad de autocensura aparece, como dijimos al principio, en un clima de opinión pública en el que ambas cuestiones se están debatiendo intensamente: ¿debe tener límites el humor? ¿se debe censurar? ¿es censuradora, y por tanto censurable, la pregunta misma acerca de los límites del humor? Estas preguntas, en fin, se producen en un clima en el que periódicamente aparecen polémicas acerca de algunos discursos humorísticos que "causan malestar" en parte de la población. Uno de estos polémicos discursos fue el artículo del escritor Arturo Pérez Reverte, «Christina Hendricks y nosotros» y publicado en el semanario XLSemanal en mayo de 2017:

No se atreven. Mucha chulería de boquilla, pero no se mojan. El plan era que cada cual contaría su versión de los hechos para luego compararlas entre sí. Será divertido, decíamos. Pero me han salido unos mantequitas blandas. Barruntan que los llamarán machistas, chulitos de barra o algo así. Son jóvenes, y aún están en esa edad en la que uno se cuida con las redes sociales. El caso es que no cumplen. Así que, tras esperar un tiempo dándoles la oportunidad de teclear lo ocurrido, me tiro al ruedo y lo cuento yo. Lo de aquella noche, en Casa Lucio, con Cristina Hendricks. La pelirroja de Mad Men, ya saben. La de las tetas grandes. Además de anatómica, ésta es una definición sexista, claro. Pero cuando uno escribe debe buscar, ante todo, la brevedad y la eficacia. Y reconozcan que la definición es breve y eficaz a tope: pelirroja de tetas grandes. Ahora todos -y todassaben a quién me refiero.

Estábamos cenando, los compadres habituales: Antonio Lucas, Manuel Jabois, Edu Galán y David Gistau. En realidad Gistau no estaba esa noche, pero da lo mismo. A efectos de la narración, estaba. Me lo invento y no pasa nada. También se sentaba a la mesa -esto no me lo invento- mi carnal el novelista mexicano Élmer Mendoza. Nos acompañaba su mujer, Leonor; pero como ella no me viene bien al relato, diré que esa noche no estaba. Éramos seis tíos, por tanto, cenando cocochas a la plancha y solomillos poco hechos, con tinto Luis Cañas reserva. Hablando de lo habitual: libros, periodismo, política, mujeres, el musical de Mongolia, el último poema de Luki, la potencia sexual de Jabo, los cuatro niños de Gistau -que no estaba-, que pasan todo el puto día, papi, papi, papi, pidiendo de comer. En fin. Cosas de ésas. Entonces suena mi teléfono y un amigo me dice. «Cristina

\footnotetext{
4 Más adelante discutiremos las consecuencias y los presupuestos ideológicos que subyacen a esta expresión.
} 
Hendricks va a cenar a Lucio». Se lo digo a la peña, y mientras lo hago, se acerca Teo, el maître. «Cristina Hendricks acaba de sentarse en la mesa de Severo Ochoa», susurra. Miramos todos, como un solo hombre y una sola mujer. Y la vemos.

En carne mortal pierde mucho. Suele ocurrir. Pero sigue siendo guapa y bien dotada. La acompaña un pavo enchaquetado que Teo define como el legítimo esposo. Estudiamos al pavo con ojo crítico. «No tiene ni media hostia», apunta Edu Galán, ecuánime. Todos nos mostramos de acuerdo. «Habría que decirle algo a ella», sugiere Gistau, que sigue sin estar allí. «Esa gringa no puede escaparse viva», opina Élmer. Todos se muestran de acuerdo y me miran, tanto porque soy el mayor -aún respetamos esas cosas entre nosotros- como porque esta noche me toca a mí pagar la cuenta. Así que, asumiendo mi responsabilidad, me vuelvo a Jabois. «Tú eres el guapo y el cachas de esta mesa», digo, autoritario. «Nuestro semental de concurso», puntualiza Edu, y acto seguido nos enfrascamos en un breve repaso biográfico-sexual de Jabo, políticas y periodistas incluidas, hasta que retomo el hilo. «Te toca hacerte una foto con ella, camarada. Ya estás tardando».

Nos mira Jabois, indeciso, y asentimos todos. «Vuelve con tu escudo o sobre él», sugiere Lucas, épico. Casi homérico. Con su bondad habitual, Jabo asiente, respira hondo, se pone en pie, va con su mejor sonrisa hasta la mesa de la Hendricks, le pide hacerse una foto, y ella pasa de él. Por su parte, el marido pone mala cara y dice que de fotos, nada. Regresa humillado Jabois. «Me han mandado a tomar por culo», dice con su tierno acento gallego. Y se sienta. Nos agitamos, indignados. «El marido no tiene media hostia», insiste Edu Galán. «Menudo gilipollas», dice Luki. «Deberíamos romperle el morro», digo yo. «En Sinaloa le daríamos plomo», remata Élmer. Pedimos las copas, y Edu encarga un Fra Angélico. «Bebida de puticlub», comento. Edu me llama clasista e hijoputa.

Salimos al rato. En la puerta, la Hendricks se hace fotos con los camareros, con el guardacoches, con el que vende lotería, con todos los que pasan por allí. Jabois se deprime un huevo. Nos agrupamos, consolándolo. «El marido no tiene media hostia», insiste Edu. Nos quedamos mirando a la pelirroja y al legítimo con ganas de darle a éste las del pulpo. Haciendo cálculos entre las ganas que le tenemos y los titulares de prensa del día siguiente: «Reverte y otros cinco desaprensivos inflan al marido de la Hendricks en Casa Lucio». O sea, que no. Al final decidimos irnos con las orejas gachas, mientras Edu, que va hasta las patas de Fra Angélico, insiste: «El marido no tenía media hostia». Asentimos todos, cabizbajos y resignados, mientras nos alejamos en la noche. Asiente incluso Gistau, que no estaba (Pérez Reverte, 2017) 
El artículo levantó una cierta polémica en redes sociales, y Pérez Reverte respondió a sus críticos llamándoles «imbéciles sin comprensión lectora» y alegando que se trataba de un relato inventado y paródico (El HuffPost, 2017). Como veremos, la condición de ficcionalidad suele servir como argumento para defender los discursos humorísticos controvertidos, así como la acusación de haber realizado una mala interpretación. En todo caso, la estructura retórica del relato es bastante interesante para el tema que nos ocupa.

En primer lugar, si tomamos las indicaciones que el mismo autor ofrece, habríamos de considerar en qué sentido el texto puede ser «paródico». Podemos suponer que, según Pérez Reverte, el carácter humorístico del relato lo hace inofensivo y que si en todo caso humilla a alguien es a los protagonistas, que parecen ser dejados en ridículo: en efecto, narra el fracaso de la supuesta hombría de Reverte y sus compañeros El relato, efectivamente, es una buena muestra del estereotipo cómico de masculinidad con el que nos hemos encontrado en muchas ocasiones a lo largo de los tres últimos capítulos de este trabajo: la hombría puesta en duda queda definida, en primer término, por la capacidad sexual del hombre, no como destreza sino como capacidad de conquista (el relato se centra en la potencia sexual de «el guapo y cachas del grupo», el «semental del grupo», que se mide en términos cuantitativos y no cualitativos); en segundo, por el poderío físico expresado como agresividad (el marido de la actriz «no tiene ni media hostia», se bromea con la posibilidad de agredirle...). La comicidad del relato, por tanto, reside en la caracterización ridícula, por inadecuada, de los protagonistas, que no son capaces de estar a la altura de los estándares de masculinidad socialmente sancionados. Pero, al mismo tiempo, el relato ofrece una representación sexista de la feminidad: la objetualización de la mujer no está solo en que se describa a Christina Hendricks como «la pelirroja de las tetas grandes» y que en general de ella solo se haga alusión a su belleza física, sino que se le niegue cualquier agencia en el relato. Toda responsabilidad del fracaso de los protagonistas se achaca al marido, que es al que deberían dar una paliza, dando a entender que la conquista de la mujer pasa por la superación del actual, como si el consentimiento debiera venir de él y no de la propia mujer ${ }^{5}$.

El relato, por tanto, no es una parodia sino más bien una comedia en su sentido más genérico, en tanto que es protagonizada por unos personajes que son puestos en

\footnotetext{
${ }^{5}$ En el capítulo teórico, aventuramos que es un rasgo general del discurso cómico la frivolización general de todo su universo ficcional, que afecta no solo a los protagonistas ridiculizados sino también a los personajes secundarios, que funcionan como de atrezzo. En este sentido, Christina Hendricks tiene aquí el mismo papel que el perro guía en el chiste del ciego comentado en dicho lugar.
} 
ridículo por no ser capaces de llegar a ciertos estándares. Los protagonistas obtienen incluso cierta aura de héroe fracasado, merecedores quizás de suscitar simpatía y piedad en su patetismo por parte de aquellos hombres que se hayan visto envueltos en situaciones parecidas. El objetivo polémico del artículo, al contrario, es la controversia que el autor sabe que va a levantar. Desde el comienzo del texto, Pérez Reverte acusa a sus compadres de «chulería de boquilla», de ser unos «mantequitas blandas» y unos cobardes (lo cual es otro elemento propio de la masculinidad representada en el relato) por no ser atreverse a contar la historia que se dispone a relatar. Reverte sabe que va a ser acusado de machista, y precisamente por eso escribe - para demostrar su hombría. Afirma que es consciente de que definir a la actriz como «la de las tetas grandes» es sexista, y más adelante dice «ahora todos - y todas - saben a qué me refiero», haciendo una alusión al lenguaje inclusivo promovido por instituciones comprometidas con el feminismo. La estructura de este párrafo es, por tanto, irónica: al parodiar su lenguaje, Reverte está criticando a los colectivos que puedan sentirse identificado con el mismo, que supone que serán los mismos que criticaran su artículo por machista. El significado del texto es performativo: no reside en el contenido mismo del relato, sino en el hecho de ser escrito.

El artículo, en resumen, es más una provocación que un mero discurso humorístico sin intención de resultar ofensivo, como ocurría en el caso de los vídeos de Cremades. De este modo, Pérez Reverte interviene en lo que parece considerar un clima de miedo y autocensura, en el que los autores no se atreven a publicar ciertos textos por temor a ser criticados, clima que el autor localiza en las redes sociales: «Son jóvenes, y aún están en esa edad en la que uno se cuida con las redes sociales». Con esta provocación, Pérez Reverte da a entender que se está produciendo un clima en el que la libertad de expresión se está viendo limitada por culpa de ciertos colectivos comprometidos (feministas, en este caso). Entre las muchas críticas que recibió, la periodista Isabel Calderón subió un vídeo en el canal del periódico La Vanguardia en que respondía a las insinuaciones del escritor (Calderón, 2017). Calderón cuestionaba hasta qué punto era legítimo que un escritor con el respaldo institucional y de lectores (siendo académico de la Real Academia Española de la lengua, y uno de los autores más vendidos) declare sentirse coartado en su libertad de expresión, mientras que personas, normalmente mujeres o pertenecientes a algunas minorías, sí que sufrían acoso cibernético real y eran despedidos por sus opiniones - la propia periodista había sido despedida del periódico El Español por una sátira sobre la Biblia. 
En todo caso, tanto en esta polémica como en la entrevista a Jorge Cremades vemos muchos de los elementos con los que nos encontraremos en las páginas que siguen: los cambios históricos en la aceptación de ciertos tipos de humor, la inocuidad o seriedad del humor, las diferentes interpretaciones a los que puede dar lugar un discurso humorístico como motivo de conflicto, el papel de las redes sociales, el lugar de la categoría de intencionalidad en dichas polémicas, su relación con el derecho a la libertad de expresión, la caracterización como valiente de quien se atreve a cuestionar los límites del humor, la dimensión del poder económico y social para el acceso a dicha libertad de expresión... Más adelante analizaremos cómo estos elementos aparecen en otros discursos de defensa y crítica de ciertos discursos humorísticos, y cómo se pueden explicar en los términos foucaultianos de orden del discurso. Antes de eso, en el epígrafe siguiente situaremos estas polémicas sobre los límites del humor en el contexto más amplio de los debates sociales y culturales acerca de la libertad de expresión, la corrección política, las guerras culturales, y la polarización identitaria.

\subsection{El orden del discurso en la aldea global}

\subsubsection{Las caricaturas danesas de Mahoma y la tragedia de Charlie $\underline{\text { Hebdo }}$}

Por supuesto, cualquier discusión sobre los límites del humor parece tener que partir por los trágicos sucesos de enero de 2015, cuando dos hombres entraron en las oficinas del semanario satírico francés Charlie Hebdo y mataron a doce personas e hirieron a otras cuatro. El ataque era el punto culminante de una serie de amenazas, denuncias y ataques cibernéticos que la revista llevaba recibiendo desde la publicación de una serie de viñetas y críticas al islamismo integrista (Pujante Sánchez, 2018: 10-11). El atentado provocó una ola de solidaridad en toda Europa y protestas por lo que se percibió como un ataque contra el derecho democrático fundamental a la libertad de expresión, pero también hubo voces que antes y después de los hechos habían cuestionado la legitimidad de la revista de atentar contra los sentimientos religiosos de la población musulmana y que alertaba 
contra una posible ola de islamofobia y racismo en Europa (Pujante Sánchez, 2018: 21$22)^{6}$.

Que el atentado de 2015 significó algo más que un nuevo episodio de violencia terrorista, y que continuó e intensificó un debate en torno a la libertad de expresión, se ha hecho evidente en el juicio contra los autores no materiales del mismo (los autores materiales murieron en la persecución policial subsiguiente), que comenzó en septiembre de 2020. Los abogados que representan a la revista han enmarcado este juicio como un proceso acerca de la libertad de expresión que involucra no solo a los radicales que urdieron la matanza, sino también a los que habían señalado con sus críticas al semanario (Ayuso, 2020): como afirmó la periodista Caroline Fourest «Es importante que nos interroguemos sobre la responsabilidad de los terceros cuchillos, los que señalaron a Charlie como un posible objetivo a fuerza de estigmatizarlo, de llamarlo racista, con una deshonestidad intelectual muy peligrosa e inflamable» (cit. en Ayuso, 2020). Otro periodista colaborador de la revista compartía la opinión de que las críticas a la revista por parte de parte de la izquierda habían servido de preparación psicológica y pretexto a los terroristas (Bassets, 2020).

En cierto modo, los atentados de Charlie Hebdo han eclipsado casi por entero la polémica original que había dado lugar al señalamiento de la revista francesa: la publicación en 2006 de unas caricaturas de Mahoma en un periódico danés, el JyllandsPosten. Aunque en un principio las caricaturas solo atrajeron la atención y dieron lugar a protestas y denuncias por parte de la población musulmana y no musulmana en Dinamarca, la difusión de los dibujos en países árabes y del sur de Asia provocó una ola de peticiones de boicot a productos daneses y europeos por parte de algunos países como Egipto y Pakistán, retiradas de embajadores en dichos países, y manifestaciones y protestas violentas que incluso produjo la muerte de alrededor de 200 personas (la mayoría de ellas responsabilidad de las fuerzas de seguridad que reprimían las protestas) (El Mundo, 2006). En respuesta a las críticas y las protestas, medios de comunicación de Europa publicaron las polémicas viñetas, Charlie Hebdo entre ellos.

Durante mucho tiempo, la controversia se convirtió en un problema político y diplomático global de primer orden. Muchos interpretaron el episodio como un signo más

\footnotetext{
${ }^{6}$ Desgraciadamente, el 16 de octubre de 2020, mientras se revisaba este texto, un profesor francés fue asesinado por haber mostrado las caricaturas de las que hablamos en este epígrafe en una clase en la que precisamente se debatía sobre la libertad de expresión (Ayuso, 2020a).
} 
del «choque de civilizaciones» entre Occidente y Oriente: como una agresión más por parte de los musulmanes a la defensa de la cultura occidental por el pensamiento crítico y la libertad de expresión, o bien como una muestra más de la impiedad y degradación moral de Occidente (Klausen, 2009: 10-11). En Europa y Estados Unidos, la gravedad de los hechos dio lugar a una polarización de la opinión pública y a una falsa homogeneidad entre los dos supuestos actores del conflicto, el Occidente laico y el Islam integrista, cuando, evidentemente, hablar de «occidentales» y «musulmanes» es un gesto muy reduccionista, empezando porque existen occidentales musulmanes: «in the heat of controversy it was forgotten that large majorities of Muslims are very supportive of European political institutions - elections, governments, and the police - and, according to some opinion surveys, more trusting of those institutions than is the general population» (Klausen, 2009: 3). Por otra parte, para la población musulmana y parte de la población no musulmana, el conflicto dejó al descubierto una islamofobia subyacente y no resuelta en Europa (Klausen, 2009: 5).

La controversia, de hecho, tomó diferentes sentidos según el contexto de cada país en que se dio: en Países Bajos, las caricaturas fueron defendidas por la derecha antiinmigración, mientras que en Francia la discusión se centró en el derecho a la libertad de prensa por parte de medios de izquierdas. Mientras, en Estados Unidos, donde el sentimiento religioso tiene una mayor presencia en la vida política y cotidiana, ni siquiera se llegaron a publicar en los medios principales (Kuipers, 2008: 9). Tampoco es cierto que el derecho a la blasfemia sea algo unánimemente reconocido en los países occidentales: un buen número de países europeos tienen leyes contra la blasfemia y que limitan la libertad de expresión (Klausen, 2009: 9); en España, como veremos, algunas de las polémicas en torno a los límites del humor incluyen la ofensa a los sentimientos religiosos, penada por la ley. De hecho, una de las respuestas a la acusación a la cultura musulmana de estar contra la libertad de expresión vino de parte de un periódico iraní, que organizó un concurso internacional para premiar al mejor dibujo sobre el Holocausto, argumentando así que también los países occidentales tienen temas tabú sobre los que no es legítimo hacer humor (Kuipers, 2011: 74).

En todo caso, la «crisis de las caricaturas» tuvo también su repercusión en el ámbito académico dedicado al estudio del humor. Por ejemplo, en la conferencia de 2006 de la International Society for Humor Studies tuvo lugar una mesa redonda en la que algunos de los más prestigiosos investigadores sobre el humor (como Christie Davies, 
Giselinde Kuipers o Victor Raskin) ofrecieron sus consideraciones sobre la controversia y su implicación en la manera en que se enfocaba la investigación sobre el humor. Para Davies, por ejemplo, «humor scholars must expand their range of study to include the social and cultural and indeed psychological qualities of the targets of humor as well as those who produce it» (Davies, 2008: 6). Para Paul Lewis, la polémica había sido la prueba definitiva contra la asunción general por parte de muchos investigadores del papel esencialmente beneficioso del humor, y era necesario comenzar a explorar de qué modo también podía servir como ariete polémico. Metodológicamente, además, la controversia cuestionaba hasta qué punto los estudios sociológicos y psicológicos individuales o de pequeños grupos eran extrapolables a casos de estas dimensiones (Lewis, 2008: 14-16). Elliot Oring llegaba hasta el extremo de afirmar que «humor theory illuminates nothing beyond what is provided by commonsense understanding» (Oring, 2008: 22), mientras que Victor Raskin negaba que el humor político tuviera ninguna repercusión social real: la crisis había sido más bien deliberadamente provocada por motivos políticos (Raskin, 2008: 27).

Sin embargo, en ningún caso los intentos de analizar la controversia desde un punto de vista académico están exentos de posiciones ideológicas. Por ejemplo, Christie Davies establecía lo ocurrido en los términos explícitos de un islam esencialmente fundamentalista que atentaba contra los principios democráticos básicos defendidos por el Occidente cristiano: «the Christians accept that in a free society cartoonists can do this [blasfemar] with impunity» (Davies, 2008: 5). Más aún, los países musulmanes habían utilizado las caricaturas como pretexto para intensificar el choque de civilizaciones que tanto buscan, revelando así a los daneses y a los europeos en general «the nature of many of the Muslims in their midst» (Davies, 2008: 6). Raskin afirma algo parecido cuando asegura que «the Muslim reaction to them [los dibujos] was deliberatly magnified by the enemies of the West suprised only those who do not know anything about Islam, the Arab world, and the history of the Arab-Western conflict» (Raskin, 2008: 28).

Raskin, como decimos, considera que el carácter humorístico de los dibujos no tuvo nada que ver con la crisis más allá de servir de excusa a los países musulmanes para protestar contra Occidente. De manera similar, Christie Davies afirma:

The moral of the story is not so much that humor can be conflictful and can offend but rather that a sense of offense at a humorous ítem can be amplified and used as a political asset and weapon (...) Humor does not give offense; its recipients take offense. The 
members of a group can choose to avoid humor that they know might offend them or they can seek it out and get angry (...) Taking offense at humor is not a simple individual response to be measured by psychologists but something socially constructed and used for a purpose (...) We must study not attacking humor but attacks on humor (Davies, 2008: 6)

Como vemos, ambos autores se acogen a una concepción del humor como inocuo e incapaz de ofender. Giselinde Kuipers, por el contrario, rompe una lanza a favor, evidentemente no de las protestas violentas, sino de aquellos que vieron la publicación de los dibujos como una agresión. De hecho, originalmente el periódico había hecho explícito su objetivo polémico: era la respuesta a la noticia de que un autor danés estaba teniendo problemas para encontrar alguien que ilustrara su libro infantil sobre Mahoma ${ }^{7}$. De este modo, la publicación de las viñetas era una abierta crítica a una supuesta posición antidemocrática de la población musulmana, como declaraba el texto que acompañaba a los dibujos: «The modern secultar society is rejected by some Muslisms. They demand a special position, insisting on special consideration of their own religious feelings. It is incompatible with contemporary democracy and freedom of speech, where you must be ready to put up with mockery, ridicule and derision» (cit. en Kuipers, 2011: 65).

Por otra parte, algunos de los dibujos no eran simplemente humorísticos en el sentido de meras frivolidades, sino que eran caricaturas con una evidente intención satírica. No todos los dibujos eran agresivos contra el islam (algunos de ellos incluso criticaban las opiniones del equipo editorial del periódico danés); pero, de los dos que atrajeron mayores críticas, uno hacía alusión a las vírgenes que se les promete a los terroristas suicidas cuando lleguen al paraíso, mientras que el otro retrataba a Mahoma con una bomba escondida en su turbante (Kuipers, 2011: 66). En todo caso, el texto antes citado encuadraba la intención satírica global de las viñetas, que situaba a la población musulmana aludida en una posición difícil: «any response to these cartoons - even the most acculturated one - was destined not only to set protesters (and their communities) apart from Danish society as "not having the same values", but also to open the way for the devastating reproach of "not being able to take a joke”, "not having a sense of humor", and "not being able to laugh at yourself"» (Kuipers, 2008: 9). En este sentido, la crisis

\footnotetext{
${ }^{7}$ Es un lugar común afirmar que el origen de este tipo de controversias tiene que ver con la prohibición en el Islam de representar gráficamente a Mahoma, algo que es erróneo (Klausen, 2009: 11).
} 
recordaba que «sometimes, a joke seems rather an invitation to a fight: a challenge» (Kuipers, 2008: 11).

Además del carácter provocativo o inocente o de las posibles connotaciones islamófobas y racistas de la publicación, esta controversia mostró las consecuencias de una comunicación globalizada, y sin duda, lo que diferenció esta crisis de otros incidentes anteriores fue el papel que internet tuvo en la difusión de las viñetas fuera del contexto original de Dinamarca. Para explicar cómo un discurso humorístico pudo ser usado con fines políticos al descontextualizarlo y difundirlo globalmente, Kuipers hace referencia al concepto de «comunidades normativas», el hecho de que cada grupo social tiene unas reglas, generalmente implícitas, acerca de lo que se puede bromear o no, y sobre todo unos procedimientos y canales para negociar estas normas en casos conflictivos, dado que estas comunidades normativas no se establecen por consenso ni son estables, sino que contienen ciertas tensiones: «groups may feel that they are unjustly barred from telling the jokes they would most like to tell; others that they are too often the butt of jokes» (Kuipers, 2008: 8). En este sentido, la polémica que los dibujos causaron en un primer momento dentro de Dinamarca no tuvo nada de especial: las personas concernidas sabían qué herramientas tenían a su disposición para negociar su descontento (manifestaciones, la prensa, instancia judicial, etc.); el problema fue cuando los chistes alcanzaron un ámbito global (Kuipers, 2008: 8-9).

Lucía Lijtmaer, en el ensayo sobre la criminalización de la protesta que comentaremos más adelante, opina que el incidente los juicios por brujería de Salem a principios del siglo XVII, se ha convertido en un mito que sirve como término de comparación a cualquier fenómeno que se quiera tachar de «caza de brujas» fundamentalista, de persecución política o ideológica; pero que, al destacar con tanta insistencia un hecho que no deja de ser excepcional, se desdibujan algunos abusos sistemáticos y se impide el análisis necesario de la situación, como sucede con las denuncias falsas por violencia de género para desdibujar la violencia social y real ejercida contra las mujeres (Lijtmaer, 2019: 39). En este sentido, se corre el riesgo de que, al situar el atentado contra Charlie Hebdo como el ejemplo prototípico de los problemas actuales de libertad de expresión, se impida, por un lado, analizar las causas políticas y sociales 
que realmente están detrás de una lacra como el terrorismo islamista ${ }^{8}$ y, por otro, paralizar el necesario debate sobre la libertad de expresión y los límites de la ofensa en torno a un caso tan obviamente excepcional y extremo como la tragedia del semanario ${ }^{9}$.

\subsubsection{Corrección política y guerras culturales}

Christie Davies, en su intervención en la mesa redonda que venimos tratando, menciona varias veces la «corrección política» como uno de los factores a tener en cuenta en la controversia por las caricaturas fomentada por la población musulmana. Señala, por ejemplo, que mientras que los sentimientos de los cristianos noruegos no son tenidos en cuenta por el gobierno, la «corrección política» había llevado al primer ministro de este país a “ceder” a las protestas de los habitantes de origen pakistaní (Davies, 2008: 5). La expresión «political correctness», derivados como «politically correct» o su calco en español «corrección política» son recurrentes en cualquier discusión acerca de los límites del humor y la libertad de expresión en general, más aún desde que Donald Trump la usara con cierto éxito en su campaña a la presidencia de Estados Unidos de 2016. Aunque no tiene una definición exacta, la «corrección política» parece referirse a un código más o menos implícito que regula el discurso público y prohíbe ciertas expresiones o ciertas afirmaciones respecto a temas sensibles como el sexismo, la raza, la sexualidad, etc. La corrección política actuaría en varios niveles, desde el plano discursivo (materializado, por ejemplo, en el lenguaje inclusivo o no sexista) hasta el ámbito de discusión y acción política (por ejemplo, el tabú de no mencionar las estadísticas de actos delictivos cometidos por inmigrantes). De este modo, la corrección política falsearía la realidad, bloquearía el debate, y, en última instancia, degradaría la democracia al recortar la libertad de expresión. Tampoco es claro si la corrección política actuaría a nivel legal e institucional, o simplemente sería una simple cuestión de etiqueta discursiva y política.

\footnotetext{
${ }^{8}$ Huelga decir, por supuesto, que no todos los actos terroristas son cometidos por islamistas: cada vez es mayor el número de atentados y actos violentos por parte de la extrema derecha, en algunos casos contra la propia población musulmana.

${ }^{9}$ Como afirma David pujante: «Parecía en principio que cualquier opinión disidente del general Je suis Charlie caía bajo la sospecha de la apología del terrorismo» (Pujante Sánchez, 2018: 22). Es decir, parece que cualquier crítica o apreciación sobre las posibles interpretaciones racistas e islamófobas de las caricaturas u otras publicaciones del semanario constituyera un ataque a la libertad de expresión y una justificación de la violencia.
} 
El problema con la noción de «corrección política», además de su indefinición, es que el discurso periodístico y el comentario político y cultural la ha adoptado de manera acrítica, sin tener en cuenta ni su existencia empírica ni su origen, ni los contextos sociales, políticos y culturales donde se ha intentado importar (siendo un término de origen estadounidense, es difícil, como intentaremos argumentar, trasladarlo sin más al contexto español actual). Como dice la periodista estadounidense Morgan Weigel, el término de «corrección política» se podría definir como un exónimo, un término utilizado por un colectivo para designar de manera peyorativa a su contrincante dialéctico (Weigel, 2016): fue apropiado por el conservadurismo estadounidense en los años ochenta para atacar a la izquierda; siendo usada exclusivamente de manera peyorativa, predetermina de manera polarizada la discusión acerca de algo que el discurso mismo inventa: «like the example sentence illustrating presupposition in the semantics textbook, 'The King of France is bald', the question 'are you politically corect?' depends on a false or contested proposition (that there is a King of France, or that 'political correctness' refers to a real entitiy with such-and-such characteristics)»(Cameron, 1995: 123). Es, pues, necesario realizar una genealogía del término y trazar su evolución para evitar malentendidos y falsas presuposiciones.

Aunque no se sabe a ciencia cierta si la expresión se empezó a usar en los años treinta o en los años cincuenta, parece indudable que en el contexto de los movimientos civiles izquierdistas de los años sesenta y setenta, sobre todo en los colectivos feministas y los de derechos raciales, la expresión era usada irónicamente para referirse críticamente a la propia ortodoxia de algunos de sus miembros (Wilson, 1995: 4). Así, por ejemplo, una activista feminista podía decir de forma autoirónica que estaba siendo «políticamente incorrecta» al disfrutar de películas románticas. En los años ochenta, una serie de grupos de intelectuales conservadores se apropiaron de la expresión, tomándola literalmente, para referirse a un supuesto control por parte de profesores izquierdistas que imponían en las universidades estadounidenses, y sobre todo en las facultades de humanidades, programas de estudios que buscaban deslegitimar y disolver la cultura occidental (con la creación, por ejemplo, de cánones de lectura alternativos que incluyeran a mujeres y miembros de minorías raciales): «the liberals' original "I'm not politically correct” was an ironic defense against those who took extermism to new extrems, who demanded absolute consistency to radical principles. The conservatives warped this meaning to 
convey the image of a vast conspiracy controlling American colleges and universities» (Wilson, 1995: 4).

Por tanto, durante los años ochenta la discusión se limitaba al ámbito universitario: los currículos de las asignaturas, las investigaciones, la libertad de cátedra, la discriminación positiva en los criterios de admisión y contratación de profesorado... (Cameron, 1995: 129). Fue a partir de los años noventa cuando la expresión saltó al ámbito público, sobre todo a partir de la publicación en 1990 de un artículo en el New York Times, «The rising Hegemony of the Politically Correct», donde Richard Bernstein alertaba a la población general «that the country’s universities were threatened by "a growing intolerance, a closing of debate, a pressure to conform”» (Weigel, 2016). A este artículo le siguieron muchos más publicados en importantes medios como el Times o The Wall Street Journal, así como la venta masiva de varios libros que criticaban la implantación de estudios sobre temas de género, raza, o sexualidad; la supuesta desaparición de obras clásicas de los currículos; cómo las cuotas raciales en la admisión a las universidades estaban afectando al nivel general de la educación, o supuestas persecuciones a profesores que no concordaban con las nuevas imposiciones ideológicas. En estos reportajes y muchos artículos de opinión se denunciaba la existencia de una «policía del pensamiento», de una nueva «caza de brujas» similar a la purga anticomunista de los años cincuenta, o incluso se comparaba con el estalinismo o el nazismo (Weigel, 2016). Muchos profesores e intelectuales criticaron estas acusaciones, desmintiendo la gran mayoría de los ejemplos que se presentaban como pruebas por descontextualizados (Wilson, 1995; Weigel, 2016). Paralelamente, en 1992 Miccael Miccino había publicado en la revista Fidelio el artículo «The New Dark Age: The Frankfurt School and Political Correctness», vinculando la corrección política con una supuesta infiltración en las universidades de agentes comunistas que difundían propaganda antiamericana y antioccidental, dando lugar a la noción de «marxismo cultural», una teoría de corte más conspirativo que ha alimentado desde entonces los movimientos de ultraderecha en Estados Unidos (Jamin, 2018). En este sentido, al hablar de «corrección política» hemos de distinguir dos posibles significados. En su versión moderada, adoptada por conservadores moderados y liberales, el término haría referencia a una hipocresía moral o un cierto puritanismo por parte de la élite cultural de izquierdas, que coartaría la libertad de expresión y que, aun bienintencionado, tendría repercusiones negativas en el debate político. En su versión fuerte, la corrección política sería el 
instrumento principal de una conspiración de las élites y los lobbies controlados por minorías para reprimir a la mayoría de la población ${ }^{10}$.

Para algunos analistas, el término y el supuesto fenómeno que designa ha cambiado su significado en los últimos años. Si en los ochenta y noventa los críticos con la «corrección política» denunciaban el asalto a una milenaria cultura occidental y sus valores, en la última década la corrección política se ha relacionado con otras nociones como la «cultura de la víctima» (Campbell y Manning, 2018) o «snowflakes» ${ }^{11}$ y fenómenos como la denuncia colectiva de abusos sexuales en la industria cultural bajo el lema \#MeToo o de la violencia racial del Black Lives Matter. Significativamente, uno de los primeros artículos que pusieron sobre la mesa esta nueva mutación, «Not a very P.C. thing to say», de Jonathan Chait, compara el incidente del que parte su reflexión (una protesta en un campus universitario contra un artículo satírico en la revista de la institución) con los atentados de Charlie Hebdo (Chait, 2015). Otro puntal de esta segunda ola de discursos contra la corrección política lo representa el artículo, luego ampliado a libro, «The Coddling of the American Mind» publicado por Jonathan Haidt y Greg Lukianoff (2015), en el que se argüía que la creciente tendencia de proteger a los alumnos de posibles daños morales y mentales evitando la mención a hechos violentos o lenguaje considerado sexista, racista, homófobo, etc., estaba empeorando la salud mental de las nuevas generaciones. Además, esta supuesta corrección política habría sobrepasado el ámbito académico e invadido la cultura en general, como demostraría la cantidad de superproducciones cinematográficas con un reparto inclusivo, llegando a cambiar de género o raza a personajes tradicionales.

Como hemos mencionado, la noción de «corrección política» tiene muchos detractores, que niegan, por un lado, que exista tal cosa como un establishment que imponga una etiqueta o una censura implícita de temas supuestamente sensibles, y, por otro, acusan a los opinadores que utilizan este término de deslegitimar las luchas sociales por la igualdad. Morgan Weigel, por ejemplo, afirma que, en realidad, son los críticos de

\footnotetext{
${ }^{10}$ Algunos analistas han analizado la victoria de Donald Trump en estos términos: el magnate, al declarar que estaba en contra de la corrección política, se presentaba como una persona ajena al establishment político y que por tanto podía enfocar y solucionar los verdaderos problemas del país, como la inmigración (Weigel, 2016)

11 «Copos de nieve», en referencia a la supuesta hipersensibilidad de las nuevas generaciones, que consideran casi cualquier cosa una agresión racista, machista, etc. «If the first round of anti-politicalcorrectness evoked the spectres of totalitarian regimes, the more recent revival has appealed to the commonplace that millennials are spoiled narcissists, who want to prevent anyone expressing opinions that they happen to find offensive» (Weigel, 2016)
} 
la corrección política los que pretenden imponer de qué se puede hablar y qué no y qué asuntos son dignos de ser discutidos:

They complained that other people were creating and enforcing speech codes, while at the same time attempting to enforce their own speech codes. Their writers designated themselves the arbiters of what conversations or political demands deserved to be taken seriously, and which did not. They contradicted themselves in the same way: their authors continually complained, in highly visible publications, that they were being silenced (Weigel, 2016)

Otro debate estrechamente relacionado es el de la «cultura de la cancelación», que ha cobrado especial relevancia pública en los últimos meses. La cultura de la cancelación o cancel culture se refiere a la práctica, promovida en redes sociales por individuos anónimos comprometidos con causas sociales, de «cancelar», es decir, retirar el apoyo y, sobre todo, dejar de consumir los productos, de creadores o intelectuales cuya conducta moral puede ser reprochable, lo que puede incluso llegar a que estas personas sean despedidas. Algunos ejemplos de estas prácticas serían los casos de Kevin Spacey o Woody Allen, acusados ambos de abuso de menores. En julio de 2020, la revista estadounidense Harper's publicó una carta firmada por reputados intelectuales y creadores norteamericanos, alertando de que esta práctica podía estar degradando la cultura del debate y el diálogo: el dogmatismo demagogo que parte de la derecha estadounidense ha demostrado históricamente parecería estar siendo adoptado por parte de la izquierda: «the free exchange of information and ideas, the lifeblood of a liberal society, is daily becoming more constricted (...) While we have come to expect this on the radical right, censoriousness is also spreading more widely in our culture» (Harper's Magazine, 2020). La cultura de la cancelación, según los firmantes, estaría creando un clima de censura y silenciamiento que, en última instancia, a pesar de lo encomiable del objetivo final, no es la estrategia más adecuada para combatir ideas nocivas que sería mejor rebatir mediante argumentos persuasivos. A los pocos días, la revista The Objective publicó una respuesta firmada por otros políticos, creadores e intelectuales, criticando algunas de las presuposiciones de la carta original (THe Objective, 2020). Los autores de esta segunda carta desmentían algunos de los casos que los primeros habían puesto como ejemplo del riesgo que algunos periodistas y trabajadores de la cultura corren por expresar sus opiniones, y sobre todo criticaban que no reconocieran el silenciamiento al que autores pertenecentes a colectivos discrimandos habían estado sometidos durante 
décadas. Señalaban también la ironía de que estuvieran denunciando ser víctimas de censura personas, en su mayoría varones blancos, que contaban con el apoyo de importantes plataformas mediáticas.

Lo cierto es que la primera carta estaba firmada por muchas mujeres como Margaret Atwood, personas de diferentes etnias e intelectuales poco sospechosos de reaccionarismo como Noam Chomsky, y que no expresaba ningún miedo a que fueran ellos los que perdieran su trabajo, sino trabajadores de algunos medios e industrias culturales. De nuevo, es necesario distinguir las opiniones que pudieran ser consideradas reaccionarias de aquellas que, con mayor o menor acierto, muestren una genuina preocupación por el estado del debate público o cuestionen, en un nivel estratégico, la utilidad de ciertas prácticas de protesta social. En todo caso, la respuesta señala algunas circunstancias, históricas y actuales, que se olvidan en estos debates, como las diferentes posibilidades de acceso al poder y a plataformas mediáticas, y advierte de cómo se demonizan ciertos modos de protesta, como el uso de las redes sociales, que son las únicas vías de denuncia con las que cuentan algunos sectores de la población ${ }^{12}$. Por otra parte, en la mayor parte de los casos no estamos ante situaciones de censura estatal o legal sino más bien de dinámicas del mercado cultural: no se trata de autoridades políticas o judiciales que prohíben mediante la ley ciertas expresiones, sino de consumidores que deciden dejar de consumir ciertos productos o apoyar económicamente a ciertas personas o instituciones (Hernández-Echevarría, 2020) ${ }^{13}$. En este sentido, se puede sospechar que las empresas culturales y mediáticas que despiden a trabajadores no lo hacen por reparos morales, sino por cálculos económicos.

En todo caso, esta polémica responde a cambios sociales, culturales y demográficos muy reales: la inclusión de mujeres y minorías raciales y sexuales en la universidad o en la industria cultural, o la influencia en la discusión académica del postestructuralismo francés y los propios movimientos de los derechos civiles, que llevaron a la creación de departamentos de estudios de la mujer, de las minorías raciales y sexuales, etc. (Weigel, 2016). En este sentido, la polémica sobre la corrección política se relaciona con la noción de «guerra cultural», expresión popularizada en los años

\footnotetext{
${ }^{12}$ En España se publicó una carta en apoyo de la carta original de Harper's firmado por escritores y periodistas (El Confidencial, 2020), que recibió las mismas críticas que la carta original (Piqueras, 2020). ${ }^{13}$ El escritor Bob Pop había expresado una opinión similar respecto al anuncio de Campofrío que comentaremos más adelante: ante las quejas de humoristas que protestaban por el supuesto estrechamiento de los límites del humor, comentaba estar «cansado de los cómicos lloricas» cuyo problema no es la censura sino que no tenían éxito con tipos de humor pasados de moda.
} 
noventa por el libro de James Davidson Hunter The Struggle to define America (Hunter, 1991; ver también Hartman, 2015). La expresión se referiría al intento de grupos políticos y colectivos sociales, progresistas o conservadores, de imponer sus valores propios a toda la sociedad a través de la definición de claves como familia, nación, cultura, la historia del país, etc. La idea, por supuesto, tiene sus raíces en la Escuela de Frankfurt y, sobre todo, en la teoría de la hegemonía de Gramsci, si bien es una expresión cada vez más usada por la derecha política y cultural tanto en Estados Unidos como en España, como veremos.

Lo realmente relevante de la omnipresencia de estas expresiones en el debate público, y que marca su diferencia frente a épocas anteriores, es que efectivamente se han popularizado ideas y teorías que habían sido exclusivas del especializado pensamiento marxistas o progresista en general, como «ideología», «hegemonía», «discurso», etc. Entender el debate público social, político y cultural en términos de «guerra» es, sin duda, desacertado, como argumentaremos más adelante, pero el adjetivo «cultural» refleja el hecho que no solo se trata de un debate de asuntos concretos como el machismo, el sexismo o la desigualdad social y económica, sino, en última instancia, acerca del papel fundamental que el lenguaje y la cultura, que hasta pocas décadas se consideraban neutrales, juegan en este debate (ver Fairclough, 2003). Como afirma Deborah Cameron, la resistencia que mucha gente ofrece a las propuestas del lenguaje inclusivo o a la crítica cultural no tiene tanto que ver con un auténtico sexismo o racismo interiorizado sino con que son propuestas que afectan a unas creencias muy arraigadas acerca del lenguaje y su funcionamiento:

What many people dislike, specifically, is the politicizing of their words against their will. By calling traditional usage into question, reformers have in effect forced everyone who uses English to declare a position in respect of gender, race or whatever (...) Choice has altered the value of the terms and removed th eoption of political neutrailty (Cameron, 2009: 120)

Las propuestas académicas progresistas de crítica del lenguaje, del discurso y de la cultura popular atacan creencias muy arraigadas acerca de la neutralidad del lenguaje y, sobre todo, de la autonomía del pensamiento individual y su control sobre sus intenciones significativas: esta neutralidad del lenguaje ayuda a sostener 
the even more fundamental illusion that speakers have total control over the meaning of their own discourse - that when we speak, we engage in individual acts of will whose outcome, ideally, is to communicate our own unique intentions (thus if I don't intend to convey a political attitude by my choice of words, anyone who discerns one is making an illegitimate inference (...) [El lenguaje inclusivo cuestiona que] althoug my utterances express my own unique intentions, the linguistic code through which those intentions were 'put into words' is unproblematically shared by other speakers of my language. Once again, this implies that someone who fails to recognize what I 'really mean', or who imputes to me intentions I do not in fact have, is not only in error but in breach of universally accepted rules (Cameron, 2009: 120)

\subsubsection{Identidad social, comunicación en internet y polarización política}

Una nota común que permea casi cualquier discurso acerca de la corrección política es la impresión de que se ha producido un deterioro en el debate público y una merma del pensamiento crítico colectivo a favor de ciertos dogmas morales e ideológicos identitarios o partidistas. Como hemos dicho, no queremos dar a entender que todo aquel que ponga en duda la eficacia de las mal llamadas políticas de identidad o esté en desacuerdo con ciertos tipos de análisis cultural como los feministas, poscoloniales, etc., sean reaccionarios que estén en contra de los avances en materia de igualdad social. Hay muchos periodistas y pensadores que expresan una genuina preocupación por el estado de la conversación pública; simplemente, parece inadecuado emplear como herramienta de análisis un término como «corrección política», tan alejado de la realidad y sobre todo tan cargado de connotaciones negativas que lo relacionan con censura, dogmatismo, etc. Obviamente no todos los movimientos aludidos por el término, como el feminismo, el antirracismo o los movimientos LGTB son uniformes y homogéneos en sus ideas, y están exentos de debates en su seno. Dentro del marxismo y la izquierda en general ha habido voces en contra de la excesiva atención a la dimensión cultural y lingüística de la desigualdad, que ha hecho olvidar la desigualdad económica (Hall, 1994; Rorty, 1999; Anderson, 2017); y pensadoras feministas han cuestionado la idoneidad de la retórica de la victimización y la herida como base de la identidad de colectivos oprimidos (Ahmed, 2017; Berlant, 2020). 
Asimismo, sería ingenuo negar que existe una cierta degradación del discurso público, una cierta agresividad proteccionista en la exposición de las ideas y en la crítica hacia los adversarios ideológicos. En este sentido, la expresión «guerra cultural» para designar los debates culturales y los discursos de cambio es desafortunada, pero sí que refleja ciertos rasgos de estos debates en tanto que «batalla» en las que se trata de vencer, pero no de convencer, y en el que la cultura "del otro" ha de ser eliminada. No cabe duda, tampoco, de que es una buena definición del estado del discurso político contemporáneo en algunos países como Estados Unidos o España. A este respecto, cada vez es más frecuente encontrar en noticias, reportajes y columnas de opinión la impresión de una creciente «polarización» política que hemos de poner en relación con la omnipresencia de la expresión «guerra cultural». Pero, de nuevo, sería desacertado limitar el análisis a una supuesta consecuencia de la insistencia de la izquierda cultural en la censura y el dogmatismo o un intento por su parte de imponer su modelo cultural, y no a factores sociales y culturales más globales ${ }^{14}$.

El «giro discursivo» de la izquierda académica, sobre todo la norteamericana influida por la teoría continental, tiene una importancia considerable, sí; pero quizá no tanta como el mismo, e inevitable, cambio social impulsado por los movimientos de derechos civiles de los años sesenta, tanto en Estados Unidos como en Europa; ni siquiera debería descartarse el impacto cultural de la Guerra Fría y el rechazo a todo lo que se asemejara mínimamente al comunismo (Saunders, 2013); o los mitos asociados a los regímenes totalitarios del siglo XX y su uso de la propaganda y la persecución política e ideológica a ellos asociada ${ }^{15}$.

Por encima de todo, hay que tener muy en cuenta el papel que los medios de comunicación de los siglos XX y XXI tienen en el discurso. No hay por qué asumir una posición apocalíptica que culpe de todos los males públicos y privados a la televisión e internet, pero es necesario reconocer la influencia que ha tenido, sobre todo, en relación a nuestro tema, en la forma de comunicarnos y las repercusiones que esto ha tenido en

\footnotetext{
${ }^{14}$ Norman Fairclough nos recuerda que, de hecho, la izquierda no ha sido la única fuerza política y cultural que ha hecho del lenguaje un campo de batalla: el proyecto neoliberal ha recurrido muchas veces a un cambio de lenguaje y de términos que disfrazaban la precariedad laboral y económica consecuencia de sus políticas (Fairclough, 2003: 20)

${ }^{15}$ Hemos mencionado ya la referencia continuada a Salem; imagen de la caza de brujas mediada por la obra de teatro de Arthur Miller, que convirtió el hecho histórico en una metáfora de la era del mccarthismo de los años cincuenta. En muchos de los discursos que analizamos en este capítulo nos encontramos, efectivamente, con referencias a la propaganda nazi o la quema de libros, a la novela de 1984 de George Orwell, al estalinismo cultural...
} 
nuestros discursos. Como hemos visto a lo largo de nuestro trabajo, los medios materiales de comunicación y sus condiciones de producción han sido determinantes en el desarrollo y la consideración de las tradiciones cómicas y humorísticas: vimos, por ejemplo, cómo la extinción de las fiestas populares y la aparición de los primeros periódicos dio lugar al nacimiento de la caricatura y la creciente importancia de su función satírica y de crítica ideológica; asimismo, las grandes industrias culturales del siglo $\mathrm{XX}$, el cine y la televisión, han tenido un interés especial en nuestra consideración de la estética camp y de la tradición de la sitcom en la que se encuentra Friends.

En este sentido, cualquier consideración de la situación del humor en el siglo XXI ha de tener en cuenta el papel fundamental que internet y las nuevas redes sociales tienen en ella. Ya hemos mencionado, por ejemplo, cómo la difusión en internet fue uno de los factores considerados determinantes y más novedosos de la crisis de las viñetas de Mahoma; y las polémicas protagonizadas por Jorge Cremades o Arturo Pérez Reverte se han dado, principalmente, en redes sociales como Twitter. Pero el nuevo medio digital no solo afecta a las condiciones de recepción de los discursos humorísticos, sino a su propio lenguaje: si la prensa dio lugar a la caricatura, el cine a los dibujos animados, y la televisión a la sitcom, la forma característica y absolutamente particular de internet es el meme.

Dada la complejidad de la investigación del impacto de las redes sociales en la comunicación y la sociedad en general, y sobre todo lo rápido que se dan las transformaciones en este ámbito, en este apartado nos limitaremos a ofrecer a algunas notas que quizás ayuden a contextualizar y explicar algunas de las características de la comunicación digital y en cómo afecta a la discusión sobre los límites del humor, aunque su desarrollo total necesitaría de un trabajo mucho más extenso. De un modo superficial, podríamos señalar, como ya se ha hecho, las repercusiones que la «descontextualización» puede tener en la interpretación de los mensajes en internet. Si es un lugar común decir que la comunicación escrita contiene menos marcas contextuales que ayudan a inferir la intención original de un mensaje, estas condiciones se agravarían en una red de microblogging como Twitter, donde a la limitación del espacio se le suma la posibilidad de «retwittear», compartir, y, por lo tanto, descontextualizar y recontextualizar, un mensaje. Además, hay que tener en cuenta la difusión masiva de mensajes que normalmente pertenecerían a una conversación cotidiana en un espacio público. En este sentido, un discurso tan ambiguo y necesitado del contexto como es el humorístico corre 
más riesgo de ser malinterpretado que cualquier otro. Muchas veces, se argumenta que la polémica levantada por un chiste en internet se ha debido a una descontextualización, a una deficiencia a la hora de interpretar el mensaje como humorístico. Sin embargo, y como hemos argumentado en varias ocasiones, muchas de estas polémicas no se deben a no identificar un mensaje como humorístico, sino por el propio mensaje, o, incluso, a la propia naturaleza humorística del mensaje, que en cierto modo agrava los efectos del mismo. Por ejemplo, en el caso de la crisis de las viñetas de Mahoma, la polémica no se originó en un primer momento por no haber captado su naturaleza humorística, sino precisamente por esta condición y la provocación que implicaba.

Por tanto, más allá de las dificultades en la interpretación a las que pueda dar lugar la comunicación en internet, es importante las consecuencias globales que la mediación digital tiene en la conversación pública. Fairclough afirma, de hecho, que la primacía del discurso en la vida política cotidiana se debe, en gran parte, a la propia acción de la industria cultural, cuyos medios de difusión han servido de mediación de todos los aspectos de la vida política y cotidiana, transformándolas, de este modo, en discurso (Fairclough, 2003: 19). También Kibédi Varga argumenta que la nueva relevancia de la Retórica se debe a que vivimos en lo que llama «sociedad mediática» (Kibédi Varga, 2000). Internet, sin embargo, no es un medio de difusión más como el periódico, la radio o la televisión. Si el medio televisivo, como afirmaban sus críticos, reducía al consumidor a una posición pasiva, que solo podía elegir recibir una oferta más o menos reducida, la característica más significativa de internet, más allá de la masiva proliferación de información o la inmediatez de su difusión, sería el papel cada vez más activo otorgado a los usuarios y consumidores (Jenkins, 2006) ${ }^{16}$. Los usuarios no solo podían interactuar de manera más directa con los productores de contenidos culturales, sino que ellos mismos podían ser productores y construir comunidades políticas alternativas (ver Jenkins, 2004). Internet, y más concretamente las redes sociales, han dado lugar a una relativa democratización de la cultura y la información, al facilitar su acceso, producción y difusión, y también a una democratización social y política, como lo atestiguan fenómenos tan relevantes como las primaveras árabes. Esta democratización, sumada a la progresiva popularización del feminismo y otros movimientos sociales, explica en parte

\footnotetext{
${ }^{16}$ El papel activo del consumidor en los medios de comunicación ha sido planteado en los media studies, al menos, desde los estudios de Stuart Hall de los años ochenta (Hay \& Couldry, 2011: 477). Ciertamente, los antiguos medios de difusión estaban provistos de canales a través de los cuales los consumidores podían expresarse, pero apenas tienen que ver con las posibilidades brindadas por internet.
} 
la cada vez mayor visibilidad de intervenciones, protestas, polémicas y críticas a los discursos políticos y culturales, los artísticos y humorísticos entre ellos.

Pero este no es el único factor a tener en cuenta. Muchas voces más o menos apocalípticas han alertado sobre las repercusiones negativas que las redes sociales tienen a nivel individual y colectivo (Jenkins, 2004: 33). Términos como «infoxicación» o fake news también son expresiones corrientes en el discurso público. Por un lado, ante la ilusión de que internet supondría total acceso al conocimiento, se ha cuestionado hasta qué punto los algoritmos con los que las redes sociales y los motores de búsqueda ofrecen información no hacen sino crear «burbujas cognitivas» que alimentan nuestros sesgos y gustos previos (Verdú, 2016; Finn, 2018; O’Neil, 2018); estas burbujas fomentarían la construcción de la identidad individual y social sobre criterios ideológicos, lo que sería uno de los factores implicados en las actuales polarización y radicalización políticas (Aparici y García-Marín, 2019) $^{17}$.

Sobre todo, es necesario tener en cuenta cómo los modelos de negocio implicados en las grandes plataformas de internet como Google o Facebook influyen en la manera en que nos comunicamos. Junto a «sociedad de la información» han venido apareciendo nociones como «economía de la atención» o «capitalismo de vigilancia» para dar cuenta de cómo estas empresas obtienen beneficios económicos de la venta de datos personales de sus usuarios referentes a sus gustos, costumbres, comportamientos, etc., a agencias de publicidad y a otras empresas. De este modo, estos negocios comercian con nuestra atención (Wu, 2020) y convierten literalmente el discurso en economía: en ello se basa, por ejemplo, la práctica del clickbait, en la que la prensa digital elige titulares impactantes para atraer a más lectores y aumentar los beneficios obtenidos por la publicidad - el titular de la entrevista a Cremades es un buen ejemplo de ello. Así, nos encontramos con que en la economía digital, literalmente, vende más el discurso polémico que el debate de ideas; se favorecen los discursos provocadores, que apelen a las identidades sociales, políticas o ideológicas de los usuarios de modo que una noticia, un vídeo o un artículo se difunda

\footnotetext{
${ }^{17}$ En este sentido, la relación de la ideología, en su acepción más cercana a la de conjunto de ideas, con la identidad tiene todo que ver con lo que Foucault, en su descripción del «orden del discurso», denomina como «doctrina»: «La doctrina vale siempre como el signo, la manifestación y el instrumento de una adhesión propia - pertenencia de clase, de estatuto social o de raza, de nacionalidad o de interés, de lucha, de revuelta, de resistencia o de aceptación. La doctrina vincula a los individuos a ciertos tipos de enunciación y como consecuencia les prohíbe cualquier otro; pero se sirve, en reciprocidad, de cierto tipos de enunciación para vincular a los individuos entre ellos, y diferenciarlos por ello mismo de los otros restantes» (Foucault, 2019: 43-44)
} 
masivamente (se "viralice") con mayor facilidad. De este modo opina, por ejemplo, Morgan Weigel:

The climate of digital journalism and social media sharing enabled the anti-politicalcorrectness (and anti-anti-political correctness) stories to spread even further and faster than they had in the 1990s. Anti-PC and anti-anti-PC stories come cheap: because they concern identity, they are something that any writer can have a take on, based on his or her experiences, whether or not he or she has the time or resources to report. They are also perfect clickbait. They inspire outrage, or outrage at the outrage of others (Weigel, 2016)

En resumen, hemos de tener en cuenta, además de las propias características de la comunicación digital, de qué manera esta es condicionada por su economía; cómo la «economía de la atención» fomenta (sin ser, por supuesto, la única causa) la polarización, la radicalización ideológica, el discurso polémico y, en suma, la degradación del debate de la que tanto se lamenta la opinión pública (Contreras y Baroja, 2020).

\subsection{El debate sobre los límites del humor en España en su contexto político}

\subsubsection{Ofendiditos y guerras culturales en el contexto español}

Parecería que ha tardado años, pero que ha llegado para quedarse durante un tiempo: cada vez son más frecuentes las menciones en artículos de opinión y declaraciones de políticos acerca de la «guerra cultural» o las «batallas de ideas» que se están librando en España en los últimos años, sobre todo por parte de políticos y expolíticos de la derecha como Cayetana Álvarez de Toledo, Juan Carlos Girauta o Rosa Díez (Caballero, 2020; Girauta, 2020; Madina, 2020; Ondarra, 2020; Raya Pons, 2020), si bien es cierto que la importancia de la disputa por la hegemonía cultural fue puesta en primer plano por los nuevos políticos de izquierdas de Podemos (Molpeceres Arnáiz, 2016; Montesano Montesori y Morales-López, 2019; Morales-López y Montesano Montesori, 2016), sobre todo por parte de Iñigo Errejón, seguidor confeso de las teorías posgramscianas de Laclau y Mouffe (Errejón y García Linera, 2020; Errejón y Mouffe, 2015). Claro que no deberíamos apresurarnos en establecer una equivalencia total del fenómeno tal y como se manifiesta en Estados Unidos: más allá de que el término en sí sea adecuado o no, o que 
las universidades españolas tengan bastante menos influencia en la vida cultural de la sociedad española que en el caso estadounidense, ciertamente la disputa por la hegemonía cultural no se da en los mismos ámbitos ni tiene el mismo desarrollo histórico en ambos países. Grosso modo, podríamos decir que los «puntos calientes» del debate cultural en España se reúnen en torno al feminismo, la memoria histórica, especialmente en lo referente al pasado franquista, algunas tradiciones como la tauromaquia, etc. La raza, por ejemplo, un tema clave de la cultura estadounidense, no tiene la misma presencia en el discurso español - no porque en España no existan problemas de desigualdad y estigmatización por razones de raza, ni mucho menos, sino porque no tiene la misma visibilidad pública. Podemos localizar, además, tres momentos en los que estos debates se dieron con especial intensidad en lo que llevamos de siglo, y que vendrían a romper lo que algunos estudiosos han llamado Cultura de la Transición o del consenso (Delgado, 2014): los primeros años del gobierno socialista de José Luis Rodríguez Zapatero, cuando se aprobaron el matrimonio igualitario, la Ley de Memoria Histórica, la Ley de Igualdad y la Ley de Violencia de Género entre otras medidas sociales, etc.; la aparición del movimiento 15-M y el partido Podemos; y el momento actual, señalado quizá por la influencia en los términos del debate cultural del partido Vox.

Más importante aún que el término «guerra cultural», es la presencia de la expresión «corrección política», que, como sabemos, lleva aparejada todo un discurso de censura, control dogmático, persecuciones ideológicas, etc. De un tiempo a esta parte, parecería, atendiendo a los artículos de opinión y las entrevistas a creadores culturales de todo tipo, que vivimos en un momento opresivo para la libertad de expresión, de pensamiento, y que la cultura está ahogada por el afán casi patológico de resultar «políticamente correctos» (Ventoso, 2020); por ejemplo, cuando la popular serie de animación para adultos Padre de familia anunció que dejaría de hacer chistes que se pudieran considerar homófobos, el titular del periódico La Razón anunciaba que había sido víctima de la corrección política (García, 2020). En una columna reciente, Pérez Reverte advertía contra la dictadura de los «ofendidos», que estaba afectando a la libertad de expresión por culpa de su dogmatismo:

A falta de argumentos intelectuales serios, echando las redes en los caladeros de lo elemental y fácil, toda la sociedad occidental se sume en una simpleza sin precedentes en sus treinta siglos de memoria. Por muy complejo que sea, nada escapa a la aplicación de ortodoxias de nuevo cuño, propagadas como pandemias a través de las redes sociales: 
vida cotidiana, historia, arte, cultura. Todo debe ser contemplado ahora con la nueva óptica, y cuando escapa a ella es atacado, exterminado. No se tolera la libertad de pensamiento ni la expresión pública de ésta, convertida en crimen social. Se exige sumisión a un nuevo canon moral de un infantilismo y simpleza aterradores. Se habla de cordones sanitarios, de espacios seguros. Las universidades, antaño motor del pensamiento, se han convertido en sanedrines de corrección política donde se reemplaza la razón por la emoción y el debate por la ignorancia, con alumnos felices de cantar a coro y profesores acojonados o cómplices.

De ese modo, la represión contra los espíritus libres es implacable. Nunca se masacró a la disidencia con tanta saña ni con tantos medios. Si el mundo fue primero de los brutos, luego de los ricos y después de los rencorosos inteligentes, hoy pertenece a los ofendidos y a los grupos de presión que los controlan. Mostrarse ofendido es garantía de integración social. ¿Quién va a resistirse, cuando hace tanto frío fuera? Todavía queda, naturalmente, quien se ofende y quien no; pero para eso están las líneas rojas y los que se atribuyen autoridad para establecerlas. En realidad siempre hubo dictadores -obispos, ayatolás, espadones-, pero antes lo eran tras imponerse con las armas, la religión o el dinero. Ahora lo hacen con los votos de una sociedad que los aplaude y apoya. Pobre de quien se atreva a contradecirlos; a no ofenderse como es la nueva obligación. Tenemos, $a$ fin de cuentas, los amos que deseamos tener: fanáticos y oportunistas respaldados por el pensamiento infantil de millones de imbéciles (Pérez Reverte, 2020; el destacado es nuestro)

También Javier Marías cargaba tintas «contra la susceptibilidad» de los nuevos consumidores culturales, que estaba acabando con la libertad creativa:

Llevamos años prestando atención y "obedeciendo" a cuantos aseguran "sentirse ofendidos" por algo, como esos alumnos por el sexo, hasta el punto de querer desterrarlo como asunto o descripción (ya hubo un pasado con gente que se ofendía por un tobillo femenino al descubierto). Es decir, llevamos años haciendo caso a la subjetividad de cada cual, algo que, a la larga, nos impediría hacer ni decir nada. El mundo está plagado de personas quisquillosas y tiquismiquis, de finísima piel (...) Cualquiera se puede sentir ofendido, herido o ultrajado por cualquiera y por cualquier cosa. Porque respiremos cerca, porque existamos, no digamos por una opinión contraria y por lo tanto "perturbadora". Si hacemos caso, si nos tomamos en serio la subjetividad de cada individuo ególatra, o mojigato, o hipersensible y frágil, o directamente demente, no sólo morirá la literatura (...) sino el cine y todas las artes, la filosofía y el pensamiento, la discrepancia y el contraste de pareceres, por supuesto la discusión y la argumentación. 
Hay políticos y una buena parte de la población que buscan eso, supongo que se han percatado, y no debemos dejarlos salirse con la suya si no queremos una vida uniforme y plana. Entre la ristra de “derechos” infundados y absurdos que muchos se están sacando de la manga, figura "el derecho a no sentirse ofendido", como si los sentimientos fueran objetivables. No lo son, y en el reino de la susceptibilidad nada es factible. Es hora de que ante tantos "vejámenes" y "heridas", dejemos de asustarnos y acobardarnos y contestemos alguna vez: "Por favor, absténganse de tonterías y ridiculeces. Así sólo vamos hacia atrás” (Marías, 2019; el destacado es nuestro)

Como vemos, estos dos fragmentos presentan ciertas semejanzas en la construcción del fenómeno: lo subjetivo y lo sentimental ha sustituido a lo intelectual y racional; al mismo tiempo, aunque se supone que la «corrección política» está producida por un narcisismo exacerbado, es un fenómeno de masas, que afecta a personas sin criterio que se dejan arrastrar por el pensamiento dogmático y fanático del grupo, ahogando el pensamiento libre y crítico. Los guardianes de la «corrección política» son sentimentales, hipersensibles, de piel fina, infantiloides, etc. Como vimos, la afectividad y la fragilidad sentimental también eran elementos de la crítica a la corrección política en su contexto original estadounidense. La afectividad concreta que se describe en estos discursos es el de la ofensa o, más concretamente, el de sentirse ofendido, lo que en España, como veremos con más detalle más adelante, ha dado lugar a la figura del ofendidito.

Uno de los escritores más representativos de este tipo de discurso es, sin duda, el periodista Juan Soto Ivars, quien suele dedicar sus columnas de opinión a la supuesta «censura» contemporánea, tema al que le ha dedicado un libro, Arden las redes. En este libro acuña el término de «poscensura», para distinguirlo de la censura tradicional, penal o administrativa. Según Soto Ivars, esta poscensura no es un mecanismo legal de un Estado autoritario, sino que viene de abajo, se produce por la presión de las redes sociales y no consiste tanto en prohibir la libre expresión como en crear un clima de miedo a enunciar en público ciertas ideas por el temor a ser señalado (Soto Ivars, 2017: 32). Para el periodista, el signo de los tiempos también consiste en la preferencia por el sentimiento antes que por el pensamiento racional (Soto Ivars, 2017: 124), y existe un clima censor y dogmático, promovido por jóvenes de izquierdas que «conectados a las redes sociales y reblandecidos por el sentimentalismo online, reaccionan de forma colectiva ante cualquier idea que violente su cosmovisión», lo que les lleva a ejercer «una vigilancia paranoica» (Soto Ivars, 2017: 126). En este contexto, «quien violenta ciertos dogmas, quien se atreve a ser escéptico o hasta provocador con ciertos temas, solo puede ser un 
tipejo despreciable» (Soto Ivars, 2017: 124). Y, por supuesto, el humor es uno de los discursos más afectados: «el sentido del humor siempre es una víctima propicia para los censores, que en general son personas incapaces de comprender la ironía, bien por la rigidez de su responsabilidad pública o bien por estrechez mental. (...) Los censores ven malas intenciones en la risa porque tienen pavor de que alguien se esté riendo de ellos» (Soto Ivars, 2017: 41); como vemos, los que desprecian el humor lo hacen porque no son capaces de «comprender» la ironía.

Este tipo de discursos ha recibido muchas críticas, en general por los mismos motivos que los discursos estadounidenses: los que critican la «corrección política» como forma de censura y la cultura de la victimización, suelen disfrutar de importantes plataformas mediáticas para expresarse e incurren en la estrategia discursiva de presentarse ellos mismos como víctimas de una supuesta caza de brujas; sobre todo, lo que hacen es deslegitimar protestas sociales contra el sexismo, el racismo, la homofobia, etc. La periodista Lucía Lijtmaer, por ejemplo, publicó en 2019 un breve ensayo titulado elocuentemente Ofendiditos: la criminalización de la protesta. En él, la escritora describe ciertas figuras que se han utilizado en este tipo de discursos, como el del nuevo puritanismo (Lijtmaer, 2019: 18-20); o el «ofendidito», «un tipo de sujeto demasiado preocupado y en muchas ocasiones profundamente escandalizado por algún suceso cultural, político o mediático de alto impacto» (Lijtmaer, 2019: 41). Este término es usado exclusivamente como mofa. El ofendidito es caracterizado por la hipersensibilidad y la ignorancia; es egocéntrico, histérico y llorón (Lijtmaer, 2019: 43). Frente al ofendidito, los críticos de la corrección política se presentan a sí misma como lo que Lijtmaer denomina caricaturescamente «Fiero Analista»: «políticamente incorrecto, que no respeta las normas y el statu quo, que dice lo que pienso y está dispuesto a llevarlo hasta las últimas consecuencias, aunque le linche la turba», es «valiente, arrojado aunque reflexivo, y está dispuesto a todo» (Lijtmaer, 2019: 43). Como vemos, para Lijtmaer la posición del Fiero Analista es la de quien se quiere situar como marginal, crítico con el pensamiento corriente, y, por ello, “especial”:

Reírse del ofendidito genera un placer parecido al de pertenecer a una subcultura: quien lo hace se distingue por sus gustos, ajenos al mainstream, y por ende se identifica y se siente especial en un grupo más reducido (...) El que se ríe demuestra así su superioridad, su conocimiento. El que se ríe automáticamente queda por encima del otro, porque le da 
una vuelta de tuerca a la broma, porque considera que está haciendo una crítica social y cultural descarnada (Lijtmaer, 2019: 450)

Lijtmaer considera que la burla del ofendidito como alguien «blando», «moralista» y falto de sentido del humor permite al que utiliza este término presentarse, no solo como intelectualmente superior, también por encima de la ideológica y el partidismo, pero deslegitima las luchas de quienes normalmente no tienen más plataformas para hacerse oír que las redes sociales (Lijtmaer, 2019: 48-51). Sobre todo, la burla del ofendidito contribuye a invisibilizar los verdaderos abusos de poder y la verdadera censura, la que viene del Estado y de grupos reaccionarios que se amparan en la llamada Ley Mordaza (Lijtmaer, 2019: 74-75).

Es necesario señalar en este punto que estos dos últimos libros expuestos no son ensayos académicos, sino textos polémicos, explícitamente posicionados, que tienden a homogeneizar a sus adversarios ideológicos, sean los «ofendiditos» o los «Fieros Analistas». Sin embargo, insistimos, sería ingenuo considerar que todos los críticos con la «corrección política» sean individuos reaccionarios (aunque el término nos parezca absolutamente inadecuado), así como negar que todas las polémicas y protestas que se dan en redes sociales contra ciertos discursos o creadores estén justificados. Aun así, por supuesto, también sería inadecuado achacar a la "izquierda cultural” (sea lo que sea eso) la entera responsabilidad de la crispación del debate público en redes sociales. En todo caso, lo relevante para este trabajo es que este debate no es, como venimos diciendo, sino una disputa por el orden del discurso. Los críticos con la «corrección política» denuncian que se está imponiendo normas y enunciados dogmáticos y estableciendo tabúes, mientras que para Lijtmaer, por ejemplo, lo que intentan es recuperar una hegemonía discursiva perdida: «la sorna del Fiero Analista ofendido contra el ofendidito no busca otra cosa que recuperar su centralidad perdida en el discurso dominante y reafirmar aquello que conforma el «buen gusto», determinar de qué se habla y de qué no y, sobre todo, cómo se habla de ello» (2019: 83).

\subsubsection{Algunos discursos de defensa de humoristas}

Uno de los campos de batalla de este debate es, por supuesto, el humor. En la Navidad de 2018 se difundieron dos vídeos humorísticos que reflejaban un supuesto sentir general de 
que ya no se podía bromear con la misma libertad de antes. Uno de ellos fue la campaña navideña de la marca Campofrío, que jugaba con la idea de que, como hacer chistes es algo que sale caro, se ha convertido en producto de lujo: en el vídeo se veía a varios actores y humoristas populares entrando en una especie de joyería preguntando por ciertos temas sobre los que, supuestamente, es difícil hacer bromas: funerales, la monarquía, el feminismo... También se hace referencia a algunos hechos recientes, como la polémica protagonizada por el cómico Rober Bodegas respecto a unos chistes sobre la etnia gitana que comentaremos más adelante; incluso a los «ofendiditos»: en cierto momento, se ve a unos pocos manifestantes con pancartas en los que se puede leer frases como «Lloro por no reír» o «Como lo siento así tengo razón». Para reforzar la idea de que esta situación es una cosa del presente, también se alude a cómicos como Eugenio, Martes y 13 y Chiquito de la Calzada ${ }^{18}$.

El otro vídeo es un sketch que formó parte del especial de Nochevieja preparado por José Mota para TVE, titulado «La milla del chiste verde», y que transcurre en una cárcel en la que se encarcela a las personas por hacer chistes - la escena también se abre con referencias a Chiquito de la Calzada, Alfredo Landa o Eugenio. El gag también responsabiliza la criminalización del humor con ciertos movimientos sociales (uno de los reos ha sido condenado por hacer un chiste verde, pero no ofendió a las feministas sino a los ecologistas). En este sentido, tanto esta pieza como el anuncio de Campofrío fueron criticados por señalar estos movimientos y no a otros colectivos como las asociaciones conservadoras que denunciaron a Dani Mateo por su broma con la bandera de España (Rubio Hancock, 2018; Tecé, 2018).

En todo caso, lo que sí es una verdad es que en los últimos años parece haber aumentado el número de polémicas y procesos judiciales contra humoristas y discursos cómicos, o al menos se les está dando más visibilidad. Enumeremos algunos de los más mediáticos: en 2014, la revista satírica El Jueves es obligada a retirar unas portadas sobre la abdicación del rey Juan Carlos I (Riveiro, 2014); en 2016, una desconocida Cassandra Vera es denunciada por publicar en Twitter unos chistes sobre el atentando contra Carrero Blanco y será absuelta dos años después (Pérez and Torrús, 2018); a principios de ese mismo año, unos titiriteros eran detenidos, acusados por enaltecimiento del terrorismo en

\footnotetext{
${ }^{18}$ Esta mención a una especie de pasado idílico, donde las cosas, en este caso el humor, era mucho mejor que el presente, es una estrategia común a muchos de estos discursos.
} 
uno de sus espectáculos para ser absueltos en los meses siguientes (Barroso, 2016; Pérez, 2016); aún en 2016, el concejal de cultura del ayuntamiento de Madrid Guillermo Zapata se ve obligado a dimitir por unos tuits en los que citaba chistes sobre Irene Villa (Bécares y Belver, 2015) y es denunciado y posteriormente absuelto (Recuerdo, 2016); en 2018, Rober Bodegas recibe denuncias y amenazas a causa de unos polémicos chistes contra la etnia gitana (Rodríguez Sojo, 2018); por la misma época, Dani Mateo era denunciado (y absuelto posteriormente) por sonarse los mocos con una bandera en el programa de televisión satírico El Intermedio ( Gálvez, 2018; “El Juez Archiva La Causa Contra Dani Mateo Por Sonarse Los Mocos Con La Bandera,” 2019); ese mismo año, Edu Galán y Darío Adanti, directores de la revista satírica Mongolia ven cancelado uno de sus espectáculos en Valencia por presiones de colectivos de ultraderecha (Público, 2018); el caso más reciente, aún activo, es el de David Suárez, un cómico denunciado por publicar en Twitter un chiste de índole sexual sobre una mujer con síndrome de Down como protagonista (S.F., 2020).

Cada uno de estos casos, por supuesto, necesitaría de un análisis contextualizado y pormenorizado. En este epígrafe, sin embargo, nos centraremos en los discursos de defensa que algunos de los afectados difundieron por redes sociales, así como artículos de opinión a favor o en contra, para analizar en qué términos se establecen en estos discursos, qué concepción del humor se ofrece, y cómo se enmarcan en contexto general de la discusión sobre los límites de la libertad de expresión de la que venimos hablando en las páginas anteriores.

La estrategia más común es el intento de neutralizar la protesta recurriendo al pretexto de que el discurso es “solo una broma”. En esta idea se basaban, por ejemplo, las disculpas que Dani Mateo ofreció a cuenta de la ya mencionada polémica por fingir sonarse los mocos con una bandera española ${ }^{19}$ :

Quiero aclarar que no había ninguna intencionalidad política ni ningún posicionamiento detrás. Era solo una broma (...) Si ha generado crispación y hay gente que se ha sentido ofendida, les pedimos perdón. A lo largo de nuestra historia hemos hecho chistes malos, mediocres, buenos y muy buenos, aunque de estos últimos no recuerdo ahora

\footnotetext{
${ }^{19}$ Además de la denuncia, el gag también provocó que algunas empresas retirasen su publicidad del programa.
} 
ninguno. Este 'sketch' era solo eso, humor. Si no ha hecho gracia, pedimos disculpas (cit. en Costas, 2018)

Como decimos, el carácter humorístico del discurso, que implica, por un lado, que las cosas "no se dicen en serio”, sin ánimo de ofender ni de realizar ninguna crítica real, y, por otro, que se trata de un discurso ficcional y, por tanto, sin "víctimas" reales, es utilizado a menudo por los humoristas que levantan polémica. Así, Rober Bodegas, después de las protestas por un controvertido monólogo sobre la población gitana en España ${ }^{20}$ difundió un comunicado en su cuenta de Twitter en que decía comprender que algunas personas se hubieran sentido ofendidas, pero que él no era capaz de ofenderse por un chiste porque no los tomaba en serio: «No hay que esperar pedagogía ni didáctica en la comedia cuando se dirige a personas adultas, pues confío en el criterio personal de cada persona para discernir entre un chiste y un discurso serio» (cit. en "Rober Bodegas Pide 'Disculpas’ Tras Sufrir ‘Amenazas’ Por Hacer Chistes Sobre Gitanos En Comedy Central,” 2018). También David Suárez, en otro comunicado publicado en Twitter respecto a su polémica por su chiste sexual relacionado con el Síndrome de Down, afirmaba: «Mi tuit no era más que un chiste, y como tal, forma parte única y exclusivamente del terreno de la ficción. No es una opinión ni, por supuesto, un hecho real». Juan Soto Ivars, en sendas defensas de ambos humoristas, esgrimía el argumento de la ficción para los dos casos (Soto Ivars, 2018, 2019). En uno de estos artículos, por ejemplo, decía:

Unos dijeron que estaba humillando a las mujeres, otros que estaba humillando más concretamente a las que tienen síndrome de Down, y nadie parecía darse cuenta de lo único evidente: la chica del chiste no existe. (...) Suárez creó de la nada una chica con dos frases y un montón de locos salieron a defender su honra al estilo don Quijote. Vi

\footnotetext{
${ }^{20}$ Este es un fragmento del monólogo: «Si una raza es más poderosa que otra [en España] son los gitanos. Pero ya no se pueden hacer chistes de gitanos. Desde hace unos años, cuando alguien hacía un chiste sobre gitanos llegaba una carta — sorprendentemente bien escrita — pidiendo que no se hiciesen más. Ya es difícil ver un chiste sobre gitanos en la tele, y me parece bien. Oye, ellos han pedido que no hagamos chistes y lo estamos cumpliendo; nosotros hemos pedido que vivan acorde a nuestras normas sociales y ellos supongo que necesitan tiempo. Pero tranquilos, que no voy a ser yo quien rompa esta tregua. Yo, como payo, voy a hacer chistes de payo. Puedo reírme sobre las cositas que tenemos los payos. Si me lo permitís, os voy a contar unos chistes de payos:

"Esto es un payo que va conduciendo, lo para la Guardia Civil y tiene la ITV en regla, el seguro... 'Continúe', le dice el agente."

"Esto es un payo que va por un polígono por la mañana y no vende droga. Entra a una empresa, está allí ocho o nueve horas, coge el metro y vuelve a casa."

"Esto es un payo que el día de su boda no le mete un pañuelo (...) a su mujer y de hecho espera a que tenga más de 13 años para casarse".” (cit. en Rodríguez Sojo, 2018)
} 
parrafadas sobre la dolorosa humillación de una chica que no existe, defensores a capa y espada de su dignidad inexistente, diagnósticos sobre la salud mental de un tipo que confiesa que ha hecho algo que no ha hecho, etc. (Soto Ivars, 2019)

Este argumento, que también se esgrimía, por ejemplo, en defensa de Jorge Cremades, se entronca, en última instancia, con lo que hemos venido llamando el "mito" de la inocuidad del humor: el hecho de que, por ser ficción y no ir "en serio”, el humor no puede ofender ni agredir, o, en todo caso, no era la intención del humorista (más adelante veremos de qué manera este argumento sirve para atacar a aquellos que critican este tipo de humor). También encontramos frecuentemente manifestaciones discursivas del otro axioma que consideramos central en la concepción actual del humor: su carácter crítico e intelectual y por tanto por encima de la moral. David Suárez continúa el mencionado comunicado de la siguiente manera:

Dicho esto, soy cómico. y mi género es el humor negro. El humor negro es un género pedregoso, que transita muchas veces carreteras complicadas, que trata temáticas sensibles y que juega a poner sobre la mesa todo aquello de lo que nadie quiere hablar. Y mi personaje sobre el escenario y en redes consiste muchas veces en plantear situaciones moralmente abyectas, para precisamente señalar lo abominable de las mismas.

Como vemos, Suárez argumenta que lo que pretendía su chiste no era humillar a las mujeres con síndrome de Down, sino criticar ciertos estereotipos y asunciones implícitas sobre lo que se puede decir o no. De este modo, el verdadero objetivo del chiste sería, supuestamente, criticar precisamente los límites del humor: «Mi objetivo ha sido siempre ir contra la gente que usa las minorías para justificar sus ganas de coartar la libertad de expresión. Y así seguirá siendo»

Como venimos observando, es un lugar común equiparar las polémicas provocadas por ciertos discursos humorísticos con un intento de limitar la libertad de expresión. En este sentido, el codirector de la revista Mongolia, Darío Adanti, era muy explícito al titular una columna de opinión publicada en eldiario.es «No es el humor, es la democracia» (Adanti, 2018). En este texto enunciaba la idea de que el humor era lo primero en ser atacado cuando se intentaba limitar la libertad de expresión; idea expresada originalmente en un artículo de 2014 que había recogido en Disparen el humorista, un ensayo en formato cómic sobre los límites del humor: «el humor es como el pajarito que los antiguos mineros llevaban consigo cada vez que tenían que bajar a la mina y que les servía como alarma; si el pajarito se moría, estaba claro que los niveles de oxígeno habían 
bajado y todo el mundo debía abandonar la mina para no morir intoxicado» (Adanti, 2017).

Este libro es un ejemplo muy interesante y completo de discurso autorreflexivo sobre el humor en la actualidad, y merece un análisis pormenorizado. En él, en general, vuelve a criticar la tendencia actual de parte de la izquierda cultural de sacrificar la creatividad y la libertad de expresión en defensa de la «corrección política»: «se mantiene latente bajo la superficie una férrea moral asociada a la culpa que entraña la dualidad religiosa de virtud o pecado y que nos aleja de lo democrático y coarta el derecho a la libertad de expresión y la creación artística» (Adanti, 2017). Por otra parte, defiende la amoralidad del humor por su carácter ficticio ${ }^{21}$ :

Tu chiste es una falta de respeto - ¿Cómo se aplica el respeto en una obra de ficción como es un chiste? (...) Tu chiste resulta dañino - ¿Cómo puede ser dañina una ficción que nadie te obliga a ver, oír o leer? (...) Tu chiste le hace el juego al poder - ¿Desde cuándo un chiste ha tenido tanto poder como para hacerle el juego al poder? (...) Tu chiste es ideológicamente peligroso - Vale, pero, como ficción, no hay que confundir la ideología representa en la obra o el chiste, con la ideología del autor o la ideología de quien la representa (...) Con este chiste te has pasado - Vale, pero ¿̇acaso no sirve para eso la ficción, para pasarse, para jugar a ser lo que no somos, para sacar a pasear nuestros demonios y que paseen en la ficción para que sigan contenidos y ocultos en los actos del día a día, terreno de la realidad? (...) Tu chiste puede causar dolor - ¿̇realmente crees que la palabra, en la ficción, tiene tanto poder como para doler más allá de una incomodidad momentánea que dura lo que dura tu lectura de mi chiste? (Adanti, 2017)

Adanti se basa principalmente en una concepción intelectual del humor: «todo humor es un proceso inteligente, por más básico que sea el chiste no deja de ser un juego de conceptos que sólo se perciben mediante la inteligencia»; «el humor es algo netamente mental». Otra de las ideas que recorren el libro es que si el universo, según la física cuántica, consiste en una existencia caótica, inverosímil, improbable, contradictoria, el humor, en tanto que funciona mediante paradojas, incongruencias, unión de contrarios, etc., es el mejor modo de comprender la naturaleza de la existencia: «la comicidad es

\footnotetext{
${ }^{21}$ En este sentido, Adanti denuncia que, aunque el humor es una ficción como el drama, hemos construido una escala de valores diferente para cada género, y mientras que el dolor y la angustia son permitidos y valorados positivamente en el drama, son criticados en el humor. Idea que hemos comentado en varias ocasiones en este trabajo y que hemos relacionado con el carácter inherentemente frívolo de lo cómico.
} 
intrínseca a la realidad y lo impregna todo. El humorista sólo se entrena para captarla y representarla» (Adanti, 2017).

En este sentido, como vemos, Adanti presenta el humor como un modo de conocimiento casi científico, puramente racional. A partir de esta idea, Adanti afirma que humor y activismo social son dos principios irreconciliables ${ }^{22}$, porque «el activismo requiere potenciar las emociones: necesita empatía para entender el dolor de los demás como si fuera el propio», mientras que el humorismo «requiere potenciar la inteligencia: necesita el desapego para relativizar el dolor y encontrar la comicidad». El activismo, por su parte, es anti-intelectual: «requiere el cese momentáneo de la inteligencia para enfrentarse a la dura realidad». Como vemos, Adanti recurre a la centenaria tradición trazada en este trabajo y que concibe el humor en términos puramente cognitivos, y en la tradición aún más amplia que concibe razón y sentimiento como principios incompatibles.

En esta misma línea, considera la limitación del humor, por un lado, como un nuevo puritanismo, pero, sobre todo, como un resto de cierta mentalidad primitiva:

En las culturas primitivas al mal no se lo nombra porque es tabú. En cambio, en una cultura más racional, al mal se lo representa para poder reconocerlo e identificarlo. Hemos llegado a un punto de represión en el lenguaje que nos ofenden más las palabras que los actos, como si el delito no fuera el hecho, sino su representación. ¡En el fondo seguimos viendo el humor como una ofensa y no como una metáfora! Porque seguimos siendo una cultura primitiva pero sofisticada y, dentro de esa sofisticación, el humor negro rompe con el tabú transformándose en el ritual que exorciza nuestros miedos (Adanti, 2017)

En este contexto, Darío Adanti enmarca el debate sobre los límites del humor y de la «corrección política» como la manifestación de miedos atávicos y pensamiento mágico, en un discurso que opone el siempre racional humor frente a la miopía puritana de la corrección política. Así, por ejemplo, dice: «el idealismo de la corrección política nos particulariza mediante el respeto por la diferencia del otro, mientras que el materialismo del humor debe aspirar a disolver esa frontera para hallar lo universal en el fracaso de todas las diferencias», o afirma que la corrección política triunfará como doctrina totalizadora porque su mecanismo es análogo al de la fe mientras que «el humor, como

\footnotetext{
${ }^{22}$ Hay un cierto cientificismo en el ensayo de Adanti: no solo por las referencias a la mecánica cuántica (utiliza frecuentemente metáforas como «la paradoja como el modelo de interacción total de los campos humorísticos» para dar a entender un isomorfismo esencial entre el humor y la estructura del universo), sino también a la teoría evolucionista de Darwin. Por ejemplo, basa su distinción entre la sentimentalidad del activista y la racionalidad del humorista en supuestos mecanismos biológicos de supervivencia.
} 
ficción, nos enfrenta a la complejidad donde lo cómico surge como superación de lo bueno y lo malo (...) La batalla por los límites del humor no es otra cosa que el intento de implantar la dualidad de la "o” donde el humor ve la complementariedad de la "y”" (Adanti, 2017).

\subsubsection{El conflicto del humor desde el punto de vista del orden del discurso}

Como vemos, el humor se ha convertido en los últimos años en uno de los puntos calientes de la mal llamada «guerra cultural», pero ¿a qué se debe? ¿Qué rasgos encontramos en el discurso humorístico que lo hacen tan propenso a crear conflictos? Sería erróneo conformarnos con el lugar común de que el humor equivale a la libertad del pensamiento crítico, y por eso los regímenes totalitarios suelen censurar el humor en primer lugar. Es cierto que hemos mencionado varios casos en los que humoristas se han visto implicados en procesos judiciales que podrían entenderse como intentos de censura, pero en la mayor parte de los casos han sido absueltos; por otra parte, resulta más verosímil considerar que la denuncia había sido provocada por la percepción de una burla denigratoria que concuerda con el carácter frivolizador del humor, y no con un supuesto poder crítico inherente a todo discurso humorístico. En cualquier caso, el debate acerca de la delimitación, en el plano jurídico, entre la libertad de expresión y los delitos de odio o injurias, sobrepasa con mucho el ámbito de este trabajo y la disciplina académica en la que se enmarca.

En un plano formal-estructural, la característica más obvia del humor que explica su propensión a la conflictividad es su dependencia de estereotipos y representaciones que pierden legitimidad conforme una sociedad cambia: chistes “de mariquitas” que hace unas décadas eran normales ahora son inadmisibles por el cambio de la sensibilidad social hacia la homosexualidad. Otra causa podría ser el de su ambigüedad interpretativa: la posibilidad de no identificar correctamente el modo humorístico de un discurso, sobre todo, pero también de la interpretación en sí del texto: ¿¿cuál es la víctima de la burla? ¿cuál era la intención del humorista? La probabilidad de malas interpretaciones se habría visto aumentada por la influencia de las redes sociales y la facilidad aparejada de descontextualizar estos discursos. Sin embargo, reducir los conflictos provocados por el humor a una "mala” interpretación es equívoco: según esta explicación, el conflicto se 
percibe como un accidente de la comunicación, pero ¿qué ocurre cuando el conflicto es buscado? ¿y si el conflicto, como hemos argumentado, es inherente al discurso humorístico? ¿y si precisamente el conflicto de interpretaciones es en realidad una disputa por imponer la interpretación que convenga a uno de los actores? (ver Molpeceres Arnáiz, 2018).

La mayoría de los discursos citados en este capítulo son, en este sentido, discursos intencionadamente polémicos que buscan la confrontación, porque, como hemos señalado, el debate en torno a la «corrección política» y los límites del humor y la libertad de expresión es un debate ideológico y político en el sentido amplio que tiene que ver ante todo con el orden del discurso, y de este modo lo queremos enfocar en las páginas que siguen, siguiendo las líneas generales expuestas por Michel Foucault y también algunas sugerencias de Pierre Bourdieu en torno a la «economía de los intercambios lingüísticos» (Bourdieu, 1985; Foucault, 2019). En este sentido, no estamos hablando simplemente de que ciertos estereotipos sean o no sean legítimos como objetos de discursos humorísticos como reflejo de un cambio social, sino que el control ideológico e institucional del discurso es un asunto político central: «el discurso no es simplemente aquello que traduce las luchas o los sistemas de dominación, sino aquello por lo que, y por medio de lo cual se lucha, aquel poder del que quiere uno adueñarse» (Foucault, 2019: 15).

Desde esta perspectiva teórica, es fácil comprender que los discursos acerca de los límites del humor, sobre todo los que lo equiparan a la censura y la limitación de la libertad de expresión, se sitúan en lo que Foucault llama «procedimientos de exclusión», sobre todo el de «lo prohibido»: «uno sabe que no tiene derecho a decirlo todo, que no se puede hablar de todo en cualquier circunstancia, que cualquiera, en fin, no puede hablar cualquier cosa. Tabú del objeto, ritual de la circunstancia, derecho exclusivo o privilegiado del sujeto que habla» (Foucault, 2019: 14). En este sentido, se trata de un debate acerca de "sobre lo que uno puede bromear o no": ¿ ¿se pueden hacer chistes sobre enfermedades, sobre situaciones de violencia, sobre “mariquitas”? Sin embargo, más que el contenido, parece que el debate se centra en la «circunstancia» especial que supone el discurso humorístico: así, se suele criticar que ciertos temas son demasiado serios para tomárselos “a broma”, mientras que sus defensores precisamente se apoyan en el modo humorístico del discurso como un espacio de especial libertad. 
Otro procedimiento de exclusión señalado por Foucault, el del rechazo del discurso de la locura (2019: 16-17) no tiene tanto que ver directamente con el humor, pero sí con el debate general acerca de la «corrección política» y los «ofendiditos»: como hemos visto, en muchos de estos discursos se dibuja a los supuestos instigadores de protestas contra el humor y la libertad de expresión como sujetos excesivamente emotivos, hipersensibles y por tanto irracionales. De este modo, como hemos señalado, se intenta deslegitimar los discursos críticos y de protesta por ser ajenos a la razón; también se suele atacar estas posiciones con acusaciones de ignorancia, de no ser capaces de interpretar correctamente los discursos humorísticos.

La misma elección de construir el discurso alrededor, ni siquiera de la ofensa sino del «ofendidito», apunta en esta dirección: no es el humor el que ofende o agrede, sino que es el crítico el que "se siente ofendido". Muchos de los discursos de defensa del humor cuentan con una afirmación del tipo «siento que alguien se pueda haber sentido ofendido», para normalmente cargar contra la misma persona ofendida: Rober Bodegas, como vimos, continuaba su comunicado asegurando que él no se sentía ofendido por chistes hacia él porque era capaz de distinguir el discurso serio del humorístico - haciendo una alusión al "infantilismo” de sus críticos. De este modo, se desliga la responsabilidad del humorista, no solo de su intención, sino de su propio discurso, y se construye al afectado como demasiado sensible cuando no incapaz de interpretar un discurso correctamente; es el “ofendidito” el que inicia la polémica al ofenderse, y no el humorista.

Por tanto, la disputa es también por el acceso al discurso, por quién está cualificado y legitimado para ser emisor de discursos (Foucault, 2019: 39) - es en esta línea en la que se puede entender la deslegitimación de los «ofendiditos» como ignorantes, sentimentales, etc., mientras que humoristas como Darío Adanti o David Suárez se presentan como legitimados porque su discurso es, al contrario, racional, objetivo, crítico, etc. Desde otro punto de vista, cuando un humorista o un escritor como Pérez Reverte es acusado de sexismo, racismo, homofobia, etc., traslada la discusión de estos campos discursivos al campo de la censura y la libertad de expresión, en una operación de lo que Lakoff llama «reenmarcado» entendido como «tomar un concepto que procede de un marco ajeno y redefinirlo desde el marco propio» (Molpeceres Arnáiz, 2018: 74).

En este sentido, también se puede entender estas polémicas desde lo que Bourdieu llama «mercado lingüístico» (o, en nuestro caso, discursivo) como «sistema de sanciones 
y censurar específicas» (Bourdieu, 1985: 12). Si los discursos circulan en un mercado en el que no solo han de ser «comprendidos», sino sobre todo «valorados» (Bourdieu, 1985: 66), podemos entender que estos humoristas, al establecer la creencia en un clima más o menos opresivo, puritano, dogmático, etc., obtienen ganancias simbólicas o económicas al presentarse como críticos, transgresores, valientes, independientes... Estos beneficios son muy reales en muchos casos: Cassandra Vera, quien era una estudiante desconocida cuando fue procesada por sus tuits, es ahora colaboradora de medios como eldiario.es gracias a una visibilidad que probablemente no hubiera obtenido de no haber sido por la polémica; Guillermo Zapata publicó un libro en el que reflexionaba desde un punto de vista por lo visto privilegiado por la controversia en la que se había visto envuelto; Dani Mateo y Rober Bodegas, en el V Congreso de Comedia celebrado en la Universidad Autónoma de Madrid celebrado en abril de 2019, al que asistió presencialmente quien esto escribe, fueron recibidos literalmente como héroes de la libertad de expresión.

En todo caso, considerar que lo controvertido de un chiste o discurso humorístico es su capacidad de ofender ofrece un análisis muy superficial, pues centra la discusión, por un lado, en la intencionalidad del emisor del chiste (que su intención sea ofender o no) o en la recepción (que el oyente sea más o menos tolerante al humor). Sin embargo, como hemos visto a lo largo de este trabajo, el humor puede ser visto perjudicial por otros motivos: principalmente, o bien por frivolizar con temas sociales considerados de gravedad (como una enfermedad, situaciones de violencia, etc.) o bien por perpetuar estereotipos negativos (sexistas, homófobos, racistas, etc.).

En este sentido, toda la disputa se podría reducir, como hemos apuntado, a una disputa por la interpretación los discursos de humorísticos, por las interpretaciones legítimas e ilegítimas de este tipo de discursos, lo que Foucault identifica con la figura del comentario como procedimiento interno de regulación discursiva (Foucault, 2019: 2829). Como dijimos, muchos de los discursos de defensa de ciertas polémicas giraban en torno a la correcta interpretación del discurso: o bien el discurso, al ser ficcional, no tiene repercusiones “serias”, o bien se propone como discurso crítico. Del otro lado, se ofrecen interpretaciones alternativas $\mathrm{y}$, sobre todo, nuevos modos de interpretación que, por ejemplo, desde una perspectiva feminista, antirracista, etc., señalan las implicaciones ideológicas de los discursos ficcionales. ¿Cómo ha de ser interpretado, por ejemplo, el artículo de Pérez Reverte citado en el primer epígrafe de este capítulo? ¿Como una historieta sexista, o como una burla del comportamiento masculino? 
La interpretación está relacionada con el problema de la intencionalidad. Como hemos visto, la mayoría de los humoristas se defienden asegurando que su intención no era ofender, o que la intención de sus chistes no es burlarse de cierto colectivo, etc. Las preguntas que se plantean en muchas de las controversias son del tipo: ¿es Rober Bodegas racista por hacer chistes de gitanos? ¿hace Cremades apología de la violación en sus vídeos? En este sentido, obviar la responsabilidad de un humorista afirmando que su intención era hacer reír y no ofender, es un pretexto erróneo; del otro lado, también lo es responsabilizar por entero y “culpabilizar” a aquel humorista que, inadvertidamente, pueda perpetuar estereotipos injustos o comportamientos perniciosos. Se puede discutir el contenido sexista del humor de Jorge Cremades, pero considerar que su intención explícita es perpetuar el sexismo en lugar de interpretarlo como un prejuicio implícito en la sociedad respecto al cual Cremadeses es responsable, en todo caso, de no revisarlo críticamente (y, como vimos, en la entrevista afirma haber asimilado el punto de vista de sus críticos) es un salto interpretativo arriesgado - por otra parte, sí que comprobábamos una intención explícitamente polémica en el artículo de Pérez Reverte.

Pero la cuestión es más profunda que simplemente preguntarse por la verdadera intención de un humorista: se trata de la relación entre la intención del humorista y las implicaciones ideológicas de su discurso, la cuestión de a quién pertenece el discurso. En este sentido, por ejemplo, como vimos, Cremades aseguraba que no era su intención hacer apología de la violación, pero que otras personas le habían hecho ver una posible interpretación alternativa de sus vídeos.

Como señalaba Deborah Cameron, la cuestión de la mal llamada «corrección política» es que cuestiona creencias muy arraigadas acerca de la neutralidad del lenguaje y de nuestro control sobre el propio discurso. En el caso del humor, además, se está cuestionando la misma naturaleza del humor, su supuesta inocuidad. Los que critican ciertos discursos están señalando que el humor puede, como venimos diciendo, perpetuar estereotipos negativos, aunque no sea intencionadamente. Esta crítica no solo se opone al positivismo en las ciencias del humor del que habla Michael Billig, del clima ideológico del optimismo y la obsesión por la felicidad que tantos críticos culturales han señalado [ver 3.4; 7.1], sino también a la función socializadora del humor. Como hemos visto, una de las funciones del discurso humorístico puede ser el estrechamiento de vínculos sociales afectivos y la creación de ambientes colectivos agradables, y así lo percibe la mayor parte de la población, por lo que una crítica a un chiste o a un monólogo es recibido como una 
interrupción de esta socialidad, como una agresión. No solo eso, sino que el que protesta corre el riesgo de identificarse como ajeno, de situarse fuera de la comunidad de la risa. Es por esto que el humor no solo es un indicador muy preciso de similitudes ideológicas sino también una potente arma de exclusión, que coloca al afectado por el humor en una posición cuanto menos incómoda:

Humor and laughter are directly connected with the drawing of social boundaries: laughing at someone is among the strongest markers of social exclusión in human communication. Moreover, ridicule leaves very few ways for the ridiculed to respond in a dignified manner: you can laugh along (and probably feel bad about it); try to ignore it; or protest and be accused of not having a sense of humor. Therefore, ridicule is often felt to be more humiliating than other forms of interaction, including phsysical or verbal violence (Kuipers, 2008: 10)

De este modo, no es de extrañar que el humor se encuentre en el centro de muchos debates sociales, culturales y políticos, sobre todo los que tienen que ver con identidades sociales, bien como objeto de disputa, bien como pretexto retórico para caracterizar polémicamente las posiciones respectivas, según una operación ideológica básica de construcción discursiva de un «ellos» y un «nosotros» (ver Van Dijk, 2003), donde «ellos» siempre son los que quieren acabar con nuestra cultura, los que quieren imponernos sus ideas, $\mathrm{y}$, lo que es peor, los que no tienen sentido del humor. Es así como estos discursos de defensa del humor, muchas veces, reflejan el clima ideológico en un sentido amplio, vinculando a los «ofendiditos» y los «políticamente correctos» a otros grupos sociales percibidos como "conflictivos".

El caso más evidente es el de la crítica a «las feministas». No solo el feminismo suele ser uno de los primeros movimientos que se citan como impositores de la corrección política, sino que, en general, los «ofendiditos» suelen ser caracterizados mediante rasgos peyorativos que tradicionalmente han sido asociados a la feminidad: la emocionalidad exagerada, la hipersensibilidad, la fragilidad, la irreflexividad, etc. Es muy común que se identifique las protestas colectivas en redes sociales como "masas histéricas" (ver, por ejemplo, Soto Ivars, 2017: 29, 110-112). Esta acusación generalizada contra el feminismo tiene que ver con lo que Sara Ahmed describe como la figura de «la feminista aguafiestas», la general asociación del feminismo con la infelicidad y la agresividad antisocial: 
La palabra feminismo está saturada de infelicidad (...) De las feministas se piensa que vienen a destruir algo que los demás consideran no solo bueno, sino la causa de la felicidad. La feminista aguafiestas le "arruina” la felicidad a los demás (...) Se atribuye a las feministas ser el origen de varios malos sentimientos, ser aquellas que arruinan la atmósfera, lo que a su vez permite imaginar (de manera retrospectiva) dicha atmósfera como algo común (Ahmed, 2019: 145)

Como vemos, la «feminista aguafiestas» es aquella que no solo viene a causar infelicidad, sino sobre todo a destruir la atmósfera de convivialidad de una comunidad imaginada. Del mismo modo, el «ofendidito» impide la felicidad de los demás y niega una comunidad de risa apoyada en una identidad histórica - recordemos las alusiones nostálgicas a Chiquito de la Calzada y Eugenio del skecth de José Mota y el anuncio de Campofrío. Como dijimos, la retórica del «sentirse ofendido» supone una trampa discursiva que atribuye la responsabilidad del malestar al que protesta y no al discurso que ha originado la protesta; pero, como dice Sara Ahmed:

¿Es verdad que la feminista viene a arruinarle la feliz fiesta a los demás al señalar situaciones de sexismo? ¿O acaso viene a exponer malos sentimientos que suelen estar ocultos, marginados o negados bajo los signos públicos de la felicidad? Los malos sentimientos, ¿aparecen cuando alguien expresa su enojo por ciertas cosas, o bien el enojo es aquello que permite traer a la superficie los malos sentimientos que circulan por debajo de los objetos? (Ahmed, 2019: 146)

La feminista aguafiestas se puede poner en relación con otras figuras que, en opinión de Luisa Elena Delgado, causan “malestar” en el clima político-afectivo español. Según Delgado, la llamada Cultura de la Transición es un claro ejemplo de lo que denomina «cultura de consenso», en la que «todo litigio político y social se entiende como problemático, puesto que atenta contra la normalidad de una comunidad definida en virtud de su cohesión y cuyos componentes se presumen bien integrados, y representados del todo» (Delgado, 2014: 18). Según esta idea, hasta hace bien poco (la crisis económica de 2008, concretamente) dominaba en España un «estado de consenso», que gozaba de la hegemonía del «sentido común» y que deslegitimaba cualquier idea o movimiento que cuestionara dicha hegemonía representativa (que “crispara” el debate político): «La articulación de la idea de la España democrática fue inseparable de los conceptos de “normalización” y “normalidad” (...) Cuando España iba bien, se entendía que los problemas existentes eran atribuibles a los otros, los aguafiestas que no se sentían felices de participar en el goce de una españolidad triunfante» (Delgado, 2014: 20). 
En este contexto, el feminismo y el populismo supuestamente traído por el 15-M y representado por Podemos han venido a romper con la cultura política de las últimas décadas (ver Montesano Montesori y Morales-López, 2015; Morales-López, 2016, 2020; Pujante Sánchez y Morales-López, 2013). Por ello, feminismo y populismo constituyen, junto con el nacionalismo,

lo que en el contexto español de la crisis se percibe como su exceso, que es a la vez su residuo: lo que queda de la repartición de lugares y funciones asignados por el consenso (...) En los debates políticos y mediáticos actuales, estos tres elementos a menudo ocupan un continuo discursivo, simbolizando abusos de la democracia que deben ser controlados (cuando no eliminados en beneficio de ésta) (Delgado, 2017: 266)

No es de extrañar, por tanto, que en muchos discursos acerca de la corrección política y en torno a los límites del humor encontremos una retórica similar a la usada para caracterizar negativamente al populismo. Como hemos visto, Pérez Reverte y Javier Marías caracterizaban al «ofendidito» como un individuo incapaz de pensar por sí mismo, que, en busca de integración social, se deja llevar por una masa acrítica e informe que protesta arbitrariamente. Las polémicas se suelen caracterizar en artículos de prensa y columna de opinión como persecuciones de masas ciegas e iracundas; se habla frecuentemente de «caza de brujas», «linchamientos» que suceden en ese lugar de paradójico anonimato que son las redes sociales. Juan Soto Ivars, por ejemplo, habla en su libro de «multitud sin cuerpo», «barullo enfurecido», «pueblerinos virtuales» ... (2017: 115, 127). La “masa”, por supuesto, suele estar caracterizada como irracional y temperamental; y recordemos cómo Adanti hacía referencia a una mentalidad “primitiva” para caracterizar la supuesta obsesión contemporánea por la corrección política. La «corrección política» parece actuar de la misma manera que la política populista, manipulando a la masa: «la corrección política de izquierdas pretende influir en la percepción social de las minorías de arriba abajo»; «quien ha elegido un bando en la guerra cultural suele erigirse en representación de una mayoría - el pueblo, las mujeres, la patria - y, con una trampa retórica, coloca al adversario en la posición marginal, para convertirlo en un elemento disolvente que actúa contra los intereses de la verdadera sociedad («nosotros»)» (Soto Ivars, 2017: 133; 157).

Claro que la retórica antipopulista permite a sus portavoces caracterizarse a sí mismos como racionales, críticos, libres, etc.: «la racionalidad performativa del legítimo discurso político se presenta como objeto perdido, inaccesible a unas masas ignorantes 
que están manipuladas por los medios de comunicación y por la tiranía de lo “políticamente correcto”»(Delgado, 2017: 266). En este sentido, es particularmente interesante la importancia que tiene la ironía en estos discursos: no solo se erige como paradigma del discurso humorístico como crítico, sino que se usa asiduamente como figura retórica - pensemos, por ejemplo, en la figuración irónica del artículo de Pérez Reverte analizado en el primer epígrafe de este capítulo. La ironía parece ser el tropo más adecuado a la posición anti-populista y anti-corrección política, por dos razones: por su especial conexión con el “mito” del humor "intelectual” tal y como lo describimos en el apartado 3.4.1., es decir, la mitificación de la ironía como posición epistemológica objetiva, distanciada, ajena a lo emocional, etc.; y, por tanto, por su carácter fundamentalmente elitista, ya prevista en su propia estructuración retórica, que opone el eiron al alazon.

\subsection{Conclusiones metodológicas}

La primera conclusión que podríamos extraer de las páginas anteriores es la imposibilidad de "solucionar" o siquiera analizar estos debates en torno a los límites del humor únicamente desde la perspectiva del ACD o cualquier disciplina similar. No solo porque estén en juego conflictos que van mucho más allá de la interpretación meramente “discursiva” del humor, y que sea necesario ampliar la concepción del contexto a factores sociales, culturales y políticos, sino porque, como hemos comprobado tanto en este capítulo como en todo este trabajo, no es posible analizar discursos humorísticos sin que intervengan preconcepciones ideológicas, ni siquiera en los enfoques más puramente descriptivos o formales. El análisis retórico-discursivo puede certificar la existencia de un conflicto, describirlo, pero el diagnóstico, si quiere ser profundo, será inevitablemente ideológico. El debate en torno a los límites del humor y de la libertad de expresión implica debates jurídicos (¿cuál es la frontera que separa la libertad de expresión del delito de odio?), políticos (¿se les debe dar espacio a discursos que presuntamente atentan contra la democracia o permitir que aparezcan en el debate público, aunque sea para rebatirlos, supone legitimarlos?) y de diversa índole ética, filosófica, etc.

La propia naturaleza del humor es, como hemos visto, ideológica, y sobre todo moral. El discurso humorístico juega con estereotipos y representaciones que tienen un 
origen ideológico, pero más allá de que estos estereotipos sean perpetuados o criticados, el juego humorístico, lejos de ser aséptico, implica una frivolización. Esta es la razón por la que, en toda la historia del pensamiento humorístico, incluso sus más acérrimos defensores han reconocido la necesidad de adoptar una ética que limite sus posibles efectos negativos: no se trata de negar el discurso humorístico, sino de ser responsable de él. En este sentido, es desacertada la posición de quienes niegan cualquier posible efecto negativo a los efectos humorísticos, bien porque lo consideren un discurso intrínsecamente inocuo, o bien porque lo consideren el máximo representante del pensamiento crítico e independiente. Como expusimos en el apartado correspondiente, frente a la libertad de expresión entendida como libertad para decir todo lo que se quiera decir, la libertad que el conde de Shaftesbury pedía para el humor y el ingenio no era sino libertad de ser criticado, de someter las ideas de uno a la prueba del ridículo. Del mismo modo, la ironía recomendada por Schlegel no implicaba ningún tipo de discurso de conocimiento privilegiado, sino, muy al contrario, una postura epistemológica de no dejarse atrapar por los propios prejuicios ni por la soberbia. En este sentido, si la judicialización de los discursos humorísticos potencialmente ofensivos parece ser equivocado por implicar una especie de imposición, la sacralización de la libertad de expresión muchas veces se utiliza, como en los discursos aquí analizados, como una estrategia para eludir las críticas mediante su deslegitimización. En ambos casos se impide el verdadero debate, y se produce la tan temida degradación del discurso público. Como propone Luisa Elena Delgado, siguiendo a Jacques Rancière, es necesario desechar la búsqueda de una cultura del consenso en favor de una democracia del disenso:

La lógica del consenso entiende la comunidad como el resultado natural de una forma común de ser, la suma de todas las partes de un todo. Bajo ese prisma, la identificación con el todo es la única forma de «ser en común», y esa forma a su vez está siempre mediada por el Estado. La lógica del disenso, por el contario, sostiene que la democracia implica un debate abierto sobre lo que constituye lo común y la división del todo. En efecto, la comunidad democrática no se puede dar nunca por cerrada, como constituida de forma permanente (...) tiene que existir la posibilidad de que en ella quepan formas singulares de pertenecer a ella. A la vez, la pertenencia a una comunidad no puede excluir la realidad del litigio político, ni de un antagonismo que tiene que ser reconocido y negociado. Esto implica una forma de entender la comunidad, que no se define en base a una delimitación constante de «lo nuestro», ni en la convergencia y la cohesión ni en la aspiración siempre frustrada a la plenitud del todo (Delgado, 2014: 26) 


\section{CONCLUSIONES}

El objetivo preliminar con el que, en su momento, se había iniciado esta investigación era el estudio las relaciones que el texto humorístico establecía directamente con su contenido ideológico, tomando como modelo privilegiado la ironía. Sin embargo, al poco de comenzar las indagaciones se comprobó que la tarea era más compleja de lo que podía parecer, y que el enfoque era del todo inadecuado. Cada vez parecía más evidente el peso que en las distintas opiniones, teorías, e interpretaciones del humor tenían las propias concepciones previas de los autores e investigadores, por lo que la investigación se reorientó al estudio, no tanto a la ideología de los discursos humorísticos, sino a la de sus intérpretes.

Ha sido necesario, por tanto, realizar un estudio histórico preliminar acerca de qué se había dicho acerca de la risa, lo cómico y el humor a lo largo de la historia y cómo este «pensamiento humorístico» se relacionaba con los cambiantes contextos sociales, culturales y filosóficos. Esta tarea ha ocupado los dos primeros capítulos de este trabajo. El tercero ha ofrecido asimismo un recorrido por algunos de los estudios sobre el humor más relevantes del siglo XX desde distintas disciplinas: el psicoanálisis, la teoría y la crítica literarias, la lingüística y la sociología y la crítica cultural. En el cuarto capítulo hemos establecido el marco teórico que ha orientado toda la investigación. La Retórica Constructivista no solo constituye una útil perspectiva metodológica; sobre todo ofrece una concepción del lenguaje y su relación con el conocimiento y la vida social perfectamente adecuada para nuestros fines. Así, hemos partido de una visión retóricopragmática del lenguaje y la comunicación, concebidos no solo como mero vehículo neutro de información o herramienta de representación de la realidad, sino como una forma de acción que, mediante la construcción colectiva del significado, pretende influir socialmente. De este modo, todo discurso es una construcción interpretativa influida tanto por el contexto inmediato como por el bagaje social e ideológico de los interlocutores y orientado a un fin determinado.

Es evidente que el discurso humorístico, como todo discurso, es ideológico. Desde la Retórica Constructivista, como decimos, se afirma que interpretamos la realidad discursivamente desde nuestras propias creencias, valores, afectos y vivencias particulares. Cada discurso humorístico, desde esta orientación, es el reflejo de la visión 
del mundo de su productor, tanto si es “conservador” (si perpetua sin cuestionarlo ciertos prejuicios o estereotipos) como “crítico" (no obstante, teniendo en cuenta que siempre se critica desde un punto de vista concreto, podriámos a decir que el humor siempre es conservador). Si hemos dicho que lo cómico se produce a partir de la ruptura de unas expectativas, estas expectativas dependen de creencias, valores, representaciones sociales, etc. que son ideológicas. Así es como funciona, por ejemplo, el mecanismo de lo ridículo, que ha tenido una gran importancia a lo largo de nuestro trabajo: hemos definido el personaje ridículo como aquel cuyo comportamiento es anómalo, aquella persona incapaz de alcanzar un estándar sancionado socialmente como normal (un estándar de inteligencia, de destreza física, de masculinidad, etc.). Del mismo modo, también se puede considerar que un discurso cómico es “crítico” si lo que queda ridiculizado no es tanto el personaje como el estándar o estereotipo en sí (no el personaje que no alcanza un cierto estándar de masculinidad, sino la idea misma de masculinidad como un estándar, por ejemplo); pero, en todo caso, el mecanismo es el mismo (hay una ridiculización) y, como decimos, este carácter “crítico” depende igualmente de una postura ideológica determinada (el productor o receptor considera previamente que la idea de masculinidad es ridícula, etc.). Como exponen los antropólogos Victor Turner y Mary Douglas al hablar de los fenómenos liminales o ambiguos, estos pueden dar lugar a un reforzamiento del orden previo, o a su modificación. En el caso de obras literarias o artísticas o productos culturales populares, el carácter “conservador” o “crítico” de un discurso humorístico depende, en gran medida, de la interpretación que le dé el receptor según sus propias ideas. Así, hemos visto que la novela de Eduardo Mendicutti Una mala noche la tiene cualquiera daba pie a dos interpretaciones opuestas: o bien la novela se veía como una celebración del proceso democrático de la Transición, o bien como una ácida crítica al mismo. En el mismo capítulo comprobamos que la cultura camp, asociada a la identidad homosexual, era vista o bien como una crítica a los estereotipos homófobos y sexistas tradicionales, o bien como su perpetuación.

Ello hace, en todo caso, que la apreciación del humor siempre esté ligada a la identidad social e ideológica del receptor y su conocimiento y sintonía con el emisor. Un receptor puede no identificar un enunciado como humorístico, o no localizar el elemento humorístico, si no reconoce que se está realizando una cierta ridiculización de una idea o personaje, por no estar familiarizado con dicha idea o no considerarla ridícula. También puede darse cuenta del carácter humorístico del enunciado, pero no compartirlo, o incluso 
encontrarlo ofensivo o pernicioso: es entonces cuando se produce el conflicto. En los últimos años, estos conflictos parecen ser cada vez más frecuentes, hasta el punto de que hay un debate abierto acerca de los límites del humor y su relación con la libertad de expresión.

En muchas ocasiones, estos conflictos se explican por un cambio de sensibilidad social: así, la percepción de una serie como Friends ha cambiado desde el momento de su emisión, y bromas y situaciones que en ese momento eran permitidas ahora son vistas por parte de la población más joven como sexistas, retrógradas, etc. Pero los factores ideológicos que determinan la interpretación del discurso humorístico no dependen únicamente del contenido del discurso humorístico: también influye, e incluso en mayor medida, la concepción que se tenga del humor en sí. Hemos comprobado cómo en la actualidad existen dos concepciones predominantes sobre el humor que, a pesar de las diferencias, coinciden en considerar el humor como un discurso a-ideológico o antiideológico, por encima o por debajo de lo ideológico. Una de estas dos posturas considera que el humor es un mero entretenimiento, sin ningún ánimo de resultar ofensivo o pernicioso; la otra idealiza el discurso humorístico, particularmente el irónico-satírico, como un tipo de discurso escéptico, racional, objetivo, superior, que permite alcanzar ciertas verdades universales (políticas, morales, vitales...).

El estudio histórico nos ha permitido vislumbrar esquemáticamente la genealogía de ambas posturas. La creencia en la inocuidad del humor parece ser relativamente contemporánea: según Billig (2005), es producto de un clima ideológico que favorece la positividad, en lo que coincide con críticos como Debord, Baudrillard, Jameson o Lipovetsky que desde diferentes puntos de vista, predominantemente marxistas, han criticado la sociedad actual por su frivolidad. En todo caso, encontramos antecedentes, principalmente, en las teorías del alivio elaboradas por Spencer y Bain a finales del siglo XIX, así como en la tradición que considera la comedia como una liberación momentánea de los pesares de la vida cotidiana. El mito del humor crítico tiene, por así decirlo, un mayor pedigrí filosófico, pues se le emparenta nada menos que con el nacimiento de la filosofía en la figura de Sócrates, el primer ironista, así como con el Demócrito que ríe ante las vanas locuras humanas. Pero su mayor fundamentación filosófica la encontramos en las diferentes teorías del ingenio que, desde el siglo XVIII en adelante, han definido lo cómico como un proceso puramente mental concerniente a la creación de ideas, así como en las distintas ramificaciones del pensamiento sobre la ironía que comienzan en 
las reflexiones de Friedrich Schlegel y que llegan al arte moderno y posmoderno, y a la teoría literaria de la mano, entre otros, de Kenneth Burke o Paul De Man.

Estas variadas concepciones del humor, como decimos, suelen determinar en buena medida los conflictos y polémicas provocadas por ciertos discursos humorísticos. Sin embargo, en el octavo capítulo hemos visto cómo a veces subyacen a estos debates otros conflictos de tipo social o político que poco tienen que ver con el humor en sí. Así, las diversas opiniones sobre el humor se utilizan como estrategias retóricas para caracterizar tanto el «Nosotros» como el «Ellos» que fundamenta todo conflicto ideológico: «Ellos» son siempre los que no tienen sentido del humor, los que no son lo suficientemente inteligentes para apreciarlo, o son demasiado dogmáticos, o demasiado susceptibles, etc. El carácter colectivo y de cohesión ideológica del que depende el sentido del humor compartido se utiliza, de este modo, como arma arrojadiza contra el otro, y a quien critica o cuestiona determinados discursos humorísticos (sean "las feministas”, o "los progres”, o "los puritanos") se le acusa de ser un elemento amenazante que viene a romper la armonía de la «comunidad humorística». En todo caso, hemos visto cómo el debate contemporáneo sobre la naturaleza del humor es un debate acerca del orden del discurso, sobre el acceso al derecho de expresión y de protesta, y, sobre todo, acerca de los modos legítimos de interpretación y de la concepción del humor, la cultura y el lenguaje y sus fundamentos y consecuencias ideológicos y sociales.

Estas dos posturas, popular e intelectual, idealizadoras del humor, que por su importancia en el pensamiento contemporáneo sobre el humor hemos llamado «mitos humorísticos», determinan, como decimos, gran parte de las interpretaciones de los distintos fenómenos humorísticos, e incluso las teorías lingüísticas y las investigaciones sociológicas. También dan lugar a puntos ciegos que en ocasiones impiden una correcta aprehensión de ciertos fenómenos, como son los conflictos derivados del humor. Como vimos, muchas veces se considera, tanto en el día a día como en la investigación académica, que los conflictos y polémicas provocadas por el humor se deben a un error en el reconocimiento de un cierto discurso como humorístico. Este planteamiento, basado en última instancia en un paradigma cognitivista que contempla el lenguaje y la comunicación como un proceso pseudocomputacional de transmisión y decodificación de información, pasa por alto el componente afectivo de todo discurso y especialmente el humorístico. En este sentido, hemos insistido a lo largo de todo este trabajo en el carácter frívolo que constituye a todo discurso humorístico y que afecta a todos sus elementos. 
Muchos son los autores que reconocen que lo cómico impone una distancia emocional respecto a su objeto - lo que garantiza a los dos mitos mencionados, bien su inocuidad, bien su carácter objetivo. Pero Bergson, entre otros, ha resaltado que esta distancia no es una simple ausencia de emociones, sino que implica un sentimiento de desatención, desprecio, superioridad, etc., e incluso una cierta malicia por parte de quien ríe.

No se trata de catalogar todo humor como violento o agresivo: en ese sentido, este trabajo ha contribuido a cuestionar la categoría de «intencionalidad» - y consideramos erróneas tanto la postura que exime al humorista de cualquier responsabilidad al afirmar que su intención era hacer reír y no ofender, como la que “culpabiliza” al humorista que, inadvertidamente, pueda estar perpetuando un prejuicio o un comportamiento pernicioso. Se trata de señalar que, aunque no sea la intención de quien produce o transmite un discurso humorístico, lo cómico impone un pathos frivolizador que lleva a "no tomarse en serio” los temas o personajes que en él aparecen.

En general, la revisión histórica llevada a cabo en la primera parte del trabajo ha demostrado que en todas las épocas se ha reconocido, en mayor o menor medida, un aspecto siniestro o peligroso de lo cómico que es necesario controlar. Esto se comprueba desde la misma definición de Aristóteles de lo risible como lo deforme que no causa daño; después de él, los teóricos clásicos y renacentistas de lo cómico y lo risible han advertido que no era permisible hacer bromas con ciertos personajes o asuntos elevados, y que, si lo risible bien podía servir como castigo de ciertos vicios, estos no debían ser especialmente dañinos. Ya en el inicio del siglo XX, Freud y sus seguidores señalaban que para que algo causase risa, el oyente o espectador no debía sentir demasiada angustia ante el objeto cómico, a riesgo de que se produjera malestar. En todas estas advertencias, por tanto, encontramos implícita la idea de que la frivolización que conllevan la risa y lo cómico entraña el riesgo de que sea recibido como una violencia - advertencia que no encontramos, por otra parte, en las reflexiones acerca de lo trágico, donde parecería que cuanto más doloroso resulte un hecho, mejor.

Casi todos los autores reseñados en el apartado histórico han establecido límites al humor y la risa, y han hecho distinciones entre una risa buena o mala, sofisticada o vulgar, alegre o violenta, cristiana o pagana, noble o campesina, etc. Incluso en la actualidad, a pesar de que, como hemos dicho, se valora enormemente el sentido del humor y se acusa de no tenerlo a los oponentes ideológicos, se hacen valoraciones de la risa en términos estéticos (la mayor o menor sofisticación formal de la pieza humorística) 
o éticos (condenando la burla más abiertamente agresiva) bajo las que existen distinciones de clase, género, identidad cultural o ideológica, etc. En todo caso, se ha comprobado que el humor generalmente implica un componente moral, al que subyacen factores ideológicos, que es necesario tener en cuenta a la hora de analizar y describir los conflictos provocados por él.

En nuestra resención histórica y bibliográfica, y en particular en nuestra lectura de la disputa entre Schlegel y Hegel y Kierkegaard en torno a la ironía y, ya en el siglo XX, de las críticas al ironismo filosófico de Derrida o De Man, hemos descrito este componente moral como una oposición entre seriedad y juego, a partir de la cual hemos descrito dos visiones y actitudes filosóficas contrapuestas que hemos puesto en relación con la distinción, expuesta por Fish, entre el homo seriosus, que cree en la posibilidad de un conocimiento racional, objetivo y definitivo de ciertas verdades absolutas e independientes del sujeto observador, y el homo rhetoricus, que considera el conocimiento como algo provisional, construido socialmente según su efectividad social y no tanto su adecuación a la realidad. En este sentido, la actitud irónica de Shafesbury o Friedrich Schlegel se puede poner en relación con la Retórica Constructivista, tal y como la hemos expuesto en el cuarto capítulo.

Lo que Hegel le reprocha a Schlegel, o Booth a los críticos ironistas de los años setenta y ochenta, es una «falta de compromiso» con la verdad. Teóricos como Schlegel, Derrida, Barthes o De Man son vistos como «irresponsables», al convertir la filosofía y el pensamiento en un juego frívolo, negar la posibilidad del conocimiento y, con ello, la idea de progreso histórico. Esta consideración de la actitud cómica o humorística como «frívola» lleva aparejadas una serie de metáforas acerca de lo «superficial», lo «artificial», lo «espectacular», que encontramos, en sentido sensiblemente diferente, en las críticas que autores como Debord, Baudrillard, Lipovetsky o Jameson han vertido contra la sociedad actual. Estos y otros autores consideran la cultura de la sociedad posindustrial decadente, consumista, preocupada solo por el placer frívolo y superficial, vacía de todo significado. Esta posición permea, por ejemplo, en la opinión de aquellos críticos de la cultura camp, que la consideran políticamente contraproducente por frivolizar con la situación de la comunidad LGTB. Además, el análisis de las novelas de Mendicutti ha revelado cómo estas metáforas de lo humorístico como superficial, frívolo, espectacular, vacío, etc., determinan una concepción del todo inadecuada de la identidad 
transexual y de las condiciones materiales de las personas trans, llegando, incluso, a cuestionar la validez de esta identidad como simulacro o disfraz.

En este sentido, creemos que este trabajo ha demostrado hasta qué punto las diferentes concepciones del humor pueden determinar las interpretaciones de los discursos humorísticos concretos. Hemos visto, por ejemplo, cómo gran parte de la investigación lingüística ha tomado la forma humorística del chiste como modelo prototípico del discurso humorístico. Esto deriva, como hemos dicho, del paradigma que desde el siglo XVIII concibe lo cómico como un proceso abstracto y cognitivo, y determina tanto los modos de describir formalmente e interpretar los discursos humorísticos en general, como su consideración ideológica del humor como algo racional, abstracto, inocuo, etc.

En este trabajo, al contrario, hemos optado por tomar la comedia como modelo hermenéutico de nuestro entendimiento de los discursos humorísticos. Creemos que este punto de vista ofrece algunas aportaciones originales al estudio del humor: nos ha permitido analizar aspectos como el carácter ficcional de todo discurso cómico, la centralidad del personaje y su caracterización, la importancia de los procesos afectivos de identificación y catarsis, etc. Además, la relación histórica y fenomenológica que lo cómico establece con los fenómenos de la fiesta y el juego o lo que Victor Turner llama «liminalidad» nos permite una comparación de lo cómico con lo estético y la asimilación de muchas de las características que se le reconocen al lenguaje poético o artístico: ficcionalidad, opacidad del lenguaje, autorreferencialidad, materialidad...

La cercanía de la ironía o lo cómico general con la metáfora nos ha llevado a redescribir la noción de incongruencia o bisociación como yuxtaposición de contextos o scripts, apoyándonos en la teoría bajtiniana del plurilingüismo y la palabra bivocal: en un enunciado cómico se produce la ruptura de una expectativa (semántica, narrativa, social, etc.), pero no se produce una sustitución de un sentido por otro, sino que se da una yuxtaposición irresoluble entre enunciados de distintos «géneros discursivos» que atraen sus contextos respectivos. La yuxtaposición cómica, en resumen, es una yuxtaposición de lenguajes, lo que nos ha llevado a un análisis intertextual del discurso humorístico. Asimismo, la consideración del carácter material de lo cómico tal y como lo plantea, entre otros, Alenka Zupančič, nos ha descubierto un enorme potencial hermenéutico. Así, el carácter material del discurso camp nos ha llevado en nuestro análisis de Yo no tengo la culpa de haber nacido tan sexy a redefinir las relaciones que se pueden establecer entre 
el cuerpo, la fantasía y la propia identidad. En el caso del análisis de la masculinidad en Friends, dicha materialidad de lo cómico nos ha permitido enriquecer tanto el análisis de los personajes y de la representación de la masculinidad como el entendimiento de las teorías de Althusser o Žižek respecto a la materialidad de la ideología.

La analogía más importante, sin embargo, es la que encontramos entre lo cómico y lo teatral o dramático en sentido amplio: el ironista o humorista finge, juega o representa un cierto papel, incluso dramatiza o pone en escena ideas y palabras. La metáfora dramática autoriza la elección de la comedia como modelo general de lo humorístico y la puesta en relación con la metáfora teatral de la interacción social de Erving Goffmann o la noción de habitus de Bourdieu. De este modo, la metáfora dramática nos ha servido en los análisis de la identidad de género en las novelas de Mendicutti y la serie Friends para describir esta como una actuación, paródica o no, de la identidad, precisando las ideas de autores como Judith Butler. Así, los personajes trans de Mendicutti construyen su identidad mediante la actuación e imitación de modelos camp, pero no de una manera que nos pueda llevar a considerar esta identidad como parodia, inautenticidad o impostura. De distinto modo, hemos definido las prácticas de masculinidad de los protagonistas de Friends como actuaciones fracasadas, e incluso como fantasías ideales a imitar o por las que se sentían amenazados. La masculinidad, en este contexto, se daba mediante un extraño efecto de ventriloquía que podemos relacionar con el concepto de «mascarada» de Joan Rivière, tan importante en las teorías feministas y queer.

Como vemos, la metáfora dramática y la importancia de la comedia nos ha llevado a centrar nuestra atención en la construcción del personaje cómico. A partir de las intuiciones que hemos encontrado en nuestra reseña histórica (la relación en la Antigüedad y la Edad Media de la risa y la comedia con la locura) y de las analogías psicoanalíticas entre lo cómico y algunos fenómenos y mecanismos neuróticos, hemos relacionado el carácter ridículo del personaje cómico con su calidad de neurótico. Así mismo, esta vinculación de lo cómico con la vida psíquica nos ha servido para relacionarlo con otros fenómenos psíquicos o antropológicos como el de la impureza, tal y como lo describe Mary Douglas en términos de desorden y ambigüedad, o el de abyección, estudiado por Julia Kristeva. Estas relaciones explican no solo algunas de las funciones sociales que puede tener el personaje cómico (el reforzamiento del orden social mediante la sanción ridiculizadora, y el alivio de la angustia despertada por la impureza 
o la abyección), sino también la ambivalencia afectiva que en ocasiones encontramos en lo cómico.

En todo caso, como afirma Hans R. Jauss, estas posibilidades de identificación con los personajes cómicos son muy numerosas y dependen tanto de la tradición y el horizonte de expectativas en que se inscriban tanto el discurso como sus receptores e intérpretes. Ello ha motivado nuestro interés, no por las clasificaciones y descripciones formalistas de los distintos tipos y mecanismos del humor, sino por las diferentes tradiciones y géneros cómicos. De acuerdo con la perspectiva hermenéutica que, como indicamos en la introducción, ha guiado nuestra investigación, hemos creído conveniente situar cada uno de los objetos de estudio de los tres capítulos analíticos en su contexto. Así, hemos descrito la historia de la cultura camp como expresión de la comunidad homosexual estadounidense durante todo el siglo XX y sus relaciones con los distintos activismos políticos LGTB y la teoría queer, así como la importancia de esta sensibilidad y de la figura del transexual en la cultura popular y la contracultura de la Transición española. En el caso de Friends, hemos estudiado la historia de la comedia de situación y su relación con la industria televisiva y la cultura estadounidense de posguerra. Partiendo de los modelos que tanto Charles Mauron como Stephen Greenblatt, entre otros, proponen para la comedia clásica y shakespeariana como receptáculo de fantasías, tensiones y energías sociales, hemos analizado la serie Friends como un reflejo de las ansiedades sociales que la sociedad contemporánea liberal provoca en los ciudadanos: así, hemos leído las innovaciones que Friends presenta respecto a las comedias de situación anteriores como un reflejo de los cambios sociales acaecidos en Occidente en los años ochenta y noventa. En este sentido, las teorías psicoanalíticas de Freud y las propuestas hermenéuticas de Hans R. Jauss nos han servido para tener en cuenta las complejas y cambiantes relaciones que los receptores establecen con la comedia en términos de identificación catártica, mecanismos de defensa, fantasías regresivas, etc. Por último, para situar el actual debate acerca de los límites del humor ha sido necesario rastrear la genealogía de algunas de las expresiones fetiche de este debate, como «corrección política» u «ofendiditos».

En todo caso, creemos haber mostrado la variedad de enfoques hermenéuticos que se pueden adoptar en el análisis de los discursos humorísticos. En este sentido, este trabajo abre varias líneas de investigación con enormes posibilidades. En el ámbito historiográfico, es necesario profundizar y matizar la transformación de la concepción de 
la risa en el período de los siglos XVII y XVIII descrita en el segundo capítulo. Ya en el siglo XX, sería interesante continuar la indagación en las diferentes concepciones del humor, tanto populares como artísticas o filosóficas, y sus implicaciones ideológicas. La relación, en la tradición grotesca descrita por Frances S. Connelly, de lo cómico con el manierismo y lo siniestro, abre un amplio campo de estudio, tanto desde el punto de vista histórico como teórico. En este sentido, las perspectivas ofrecidas en el quinto capítulo pueden ser continuadas en varias direcciones: en la relación del personaje cómico con la locura y la neurosis en su acepción psicoanalítica; en la dimensión polifónica de la estructura cómica; en el carácter material de lo cómico... Estas perspectivas, por supuesto, se pueden extender a otros géneros de los estudiados en este trabajo: a la poesía, al cine, al lenguaje de la animación, etc.

En un ámbito más general, creemos que este trabajo también ha demostrado el interés de adoptar una postura pragmatista y retórica en la crítica literaria, el análisis del discurso y otras disciplinas relacionadas como la lingüística. Sobre todo, es una apuesta por la transdisciplinariedad y el análisis holístico. 


\section{CONCLUSIONS}

The first approach of this investigation focused on the relationships that the humourous text directly established with its ideological content, taking irony as a privileged model for analysis. However, soon it became clear that the proposed task was notably more complex that it first appeared and that the point of view had to be modified. The importance that the unexamined preconceptions on humour had on the different opinions, theories and interpretations became more and more evident. Consequently, the focus was shifted from the ideology in humourous discourses towards the ideology of their interpreters.

Therefore, a historical review on what has been said about laughter, comedy and humour over the centuries and how this «humourous thought» has been linked with the changing social, cultural and philosophical contexts has been deemed mandatory. This task has taken up the first two chapters of this work. The third chapter offered an examination of some of the most relevant studies on humour from the 20th century from different fields: psychoanalysis, literary theory and criticism, linguistics and sociology and cultural studies. In the fourth chapter we have established the theoretical framework which has led the whole investigation. Constructivist Rhetorics not only makes a useful methodological tool, but it offers a conception of language and its relation with knowledge and social life perfectly apt for our purposes. Thus, we have relied on a rhetorical and pragmatic vision of language and communication, conceived not only as a blank vehicle for the transmission of information or a means for the representation of reality, but as a type of action which, through the collective construction of meaning, aims to influence society. Therefore, every discourse is an interpretative construction affected both by the immediate context and the social and ideological background of speakers, oriented towards a certain goal.

It is obvious that humourous discourse, as every other discourse, is ideological. Constructivist Rhetorics assert that we interpret reality discursively and from our own beliefs, values, affection and personal experiences. Therefore, any humourous discourse reflects the world view of its producer, whether it is conservative (i.e. it might unwittingly perpetuate certain prejudices, negative stereotypes) or "critical” (although one always

criticizes from a certain point of view: in this sense, we dare to affirm that humour is 
always conservative). Specifically, if humour is produced by the denial of some expectation, these expectations depend on beliefs, values and representations which are entirely ideological. That is the fundamental working of the ridicule, which has played an important role in our own work: we defined the ridicule character as that whose behaviour can be defined as anomalous, that character who is unable to reach some socially sanctioned standard of behaviour (a standard for intelligence, physical ability, masculinity, and so on). In addition, one can also consider certain humourous discourse as "critical" if it is that standard or stereotype and not so much the character which is being ridiculed. Nonetheless, it works the same way: there is ridiculisation and its conservative or critical nature depends on a previous ideological stance (the producer or receiver might consider a fixed idea for masculinity as ridicule prior to the joke). As anthropologists Victor Turner and Mary Douglas state in regard to ambiguous or liminal phenomenons, these can result in a reinforcement or a modification of the established order. In the case of literary or artistic works or popular cultural products, the critical or conservative nature of discourse depends mostly on the interpretation of the receiver on account on her own ideas. Thus, we have confirmed how Eduardo Mendicutti's Una mala noche la tiene cualquier gave way to two opposed readings: whether the novel was a celebration of the start of the democratic period known as the Transición, or whether it was read as a harsh critic of it. In the same chapter, we have seen how camp culture, linked to homosexual identity, was considered both an opposition to homophobic and sexist stereotypes and their perpetuation.

Appreciating humour, thus, is always linked to the social and ideological identity of the receiver and her attitude towards the producer. She may not acknowledge some utterance as humourous, or she may not be able to properly locate its humourous features if she does not notice the fact that some idea or character is being ridiculised because she does not consider that idea or character suitable for ridiculisation. She also might acknowledge the humourous nature of the utterance, but not share its assumption or even consider it offensive or negative: then, conflict erupts. In the last years these conflicts seem to be more and more frequent, to the point that there is an ongoing public discussion on the limits of humour in relation to freedom of speech.

Most of the time, these conflicts can be explained by a change in the social sensitivity toward certain subjects. Perception toward Friends has greatly changed since the time it was on TV, and jokes and situations that were then overlooked are nowadays 
considered sexist or reactionary by the younger population. Nevertheless, interpretations of humourous discourses do not only relyon the ideological content but also on the general conception of humour. This work has shown two current axioms for the understanding of humour which agree in considering it a non-ideological or even anti-ideological discourse. One of these axioms considers humour simply as entertainment, without any further goal than to be funny. The other one idealises humour, especially satirical humour, as a rational, objective, superior discourse that enables some universal political, moral or vital truths.

Historical research has roughly outlined the genealogy of both stances. Belief in the harmless nature of humour seems to be relatively recent: according to Michael Billig it is the result of a neoliberal ideological background which stresses positivity and happiness. We find corresponding views as those of marxist critics and sociologists as Debord, Baudrillard, Jameson or Lipovetsky, who have criticised the frivolity of the current consumerist mass culture. Additionally, earlier predecessors are found in Alexander Bain and Herbert Spencer and their «relief theories» and the tradition that views comedy as temporary liberation from everyday burdens. Critical humour myth has more renowned roots, for it is related with the birth of philosohy in the figure of Socrates, the first ironists, and the laughing Democritus before the follies of the human race. Its more recent and systematic foundation is to be found in the several theories on wit that since the $18^{\text {th }}$ century on have defined the comic as an entirely mental and cognitive process. Friedrich Schlegel's thougts on irony and his influence on modern and postmodern art and philosophy have also played a major role in this development.

These different views on humour partly determine conflicts and controversies triggered by certain humourous discourse. Nonetheless, the eighth chapter showed how sometimes other social or political conflicts and interests underlie these controversies. Different opinions on humour are weaponised as rhetorical and ideological strategies to characterise the «We» and «They» positions found in every ideological discourse: «They» do not possess a sense of humour, «they» are not clever enought to appreciate humour, or «they» are too dogmatic or too sensitive, and so on. Thus, the grupal and cohesive ideological nature of sense of humour is used a weapon against the ideological opponent, and those who criticize certain humourous discourse ("feminists" or "wokes" or "snowflakes”) are marked as a disrupting element dangerous to the survival of the «humour community». To sum up, this work has shown that the current debates over the 
nature and limits of humour, are fights over the order of discourse, access to media, freedom of speech and the right to protest, and specially to the legitimate modes of interpretation and the nature of humour, culture and language and their ideological and social effects.

Both "popular" and "intellectual " visions on humour that we have named humour myths due to their main role in contemporary thought determine a great part of the humourous discourses reception and even linguistic theories and sociological research, resulting in blindspots that can prevent from an adequate understanding of certain humour-related phenomenons such as the forementioned controversies. Both everyday thinking and scholar research often consider that conflicts and controversies related to humour are caused by a failure in acknowledging or correctly reading the humourous nature of an utterance. This approach, ultimately based on a cognitivist paradigm of language and communicaton as a computational encoding-decoding process, pass over the affective traits inherent to all discourse, specially humourous. In this sense, this work has stressed the frivolous nature of all humourous discourse which influences all its elements. Many authors acknowledge that comic discourse impose an emotional distancing from its subject, which guarantees both harmlessness or objectiveness for the forementioned humour myths. Among others Bergson highlights the fact that this distance a mere lack of emotion but implies some kind of disaffection, disdain, scorn, or even certain degree of cruelty.

These assertions are not meant to categorize all humour as violent or aggresive. This work has questioned the theoretical and analytical notion of intentionality, and considers as a mistake both the stand that absolve humorists from all responsability by asserting her intention is merely to have fun, and that which blames the humorist who unwittingly may be perpetuating a negative prejudice or attitude. Its aim is to highlight the fact that, whatever it be the humorist's intention, the comic discourse always implies a frivolising pathos which brings about not taking seriously the subjects or characters in it.

The historical review conducted in the first part of this work has proved how certain sinister or dangerous aspect have been recognised in laughter through all ages. Aristotle's own definition of the comic as something ugly which causes no harm. After him, Classic and Rennaissance theoriticians have warned against joking about certain characters or serious issues and that, if laughter can be used as social punishment of some 
vices, these should not be too harmful. In the beginning of the twentieth century, Freud and his followers pointed out how the receiver of a joke must not feel an excessive anguish to be able to laugh. Underlying all these warning we find the idea that frivolization inherent to laughter and humour carries the risk of being perceived as a form of violence - a warning not to be founded in reflections on tragedy, where the more pain the better.

Generally, nearly all the authors set some kind of limit to humour and laughter and distinguish between a good or bad laughter, vulgar or sophisticated, joyful or violent, pagan or Christian, etc. Even nowadays although, as mentioned, a sense of humour is highly valuable, laughter is evaluated in aesthetic or ethical terms under which we can find distinctions in terms of class, gender, social or cultural identity, etc. To sum up, it has been found that humour always implies a moral and ideological element which has to be acknowledged in order to properly describe and analyse conflicts triggered by it.

In our historical and bibliographical review, and particularly in our reading of the controversy about irony between Friedrich Schlegel and Hegel and Kierkegaard and, in the twentieth century, of the critiques of ironic philosophies posed by authors like Derrida or De Man, we have defined this moral aspect of humour as an opposition between seriousness and play. From this definition we have outlined two opposed philosophical attitudes which we have related to the distinction by Stanley Fish between the homo seriosus, who believes in the possibility of gaining a rational, definitive and absolute knowledge separated from the knowing subject, and the homo rhetoricus, who considers knowledge as something provisional, socially disputed according to its effectiveness and persuading power, more than his appropriateness to a somehow independent reality. In this sense, ironic attitude as expressed by Shaftesbury or Schlegel can be compared to Constructivist Rhetoric, as posed in the fourth chapter.

What Hegel condemns in Schlegel's attitude, or Booth complains about the ironist critics from the seventies and eighties, is a lack of compromise to Truth. Theoriticians like Derrida, Barthes or De Man are seen as irresponsible for transforming philosophy in a frivolous game, denying the possibility of knowledge and, with it, the idea of historical progress. This view of comic and humourous attitude as «frivolous» involves a series of metaphors about «superficiality», «artifice» or «spectacular» which are to be found, in a different sense, in the critiques that authors like Debord, Baudrillard, Lipovetsky or Jameson have made against contemporary culture and society. These and others authors 
describe postindustrial culture as decadent, consumerist, only worried about frivolous and superficial pleasures, empty of any meaningful thought. We can find this kind of thinking pervading opinions about camp culture, which is seen as politically improductive, for it frivolizes with the social conditions and representations of the LGTB community. Besides, the analysis of the novels by Eduardo Mendicutti has shown how these metaphors about superficiality, frivolity, spectacle, etc., determine a vision of trans identity and the social and material conditions of living of trans people far from adequate, even questioning the validity of their gender identity as simulation or disguise.

In this sense, we believe this work to have proven how different views on humour can determine interpretations of particular humourous discourse. We have seen, for instance, how a great deal of linguistic research has taken the verbal joke as the main model for the analysis for all kinds of comic discourses. As we have seen, this manner of thinking derives from the paradigm which from the XVIII ${ }^{\mathrm{e}}$ century conceives humour as an abstract and purely mental process, and determines the ways of formally describe general humourous discourses, as well as the ideological patterns of conceiving humour as rational, abstract, inocuous, and so on.

In this work, nevertheless, we have chosen to take comedy as our hermeneutical model for the understanding of humourous discourses. We think this point of view offers some original contributions to humour research: it has enabled us to analyse aspects like the fictional nature of the comic discourse, the relevance of the comic character, the prominence of the affective processes of identification and catharsis, etc. Besides, historical and fenomenological relationship that humour establishes with the phenomenons such as the festival, the play or what Victor Turner calls «liminality» allow us to compare humour with aesthetics and the assimilation of many characteristics recognised for literary or poetic language such as fictionality, opacity, autoreferenciality, etc.

The closeness between irony or comedy in general to metaphor has taken us to rewrite the concept of incongruency or bisocitation as juxtaposition of contexts or scripts, relying on Bakhtin's accounts of plurilinguism. In a comic utterance, a semantic, narrative or social expectation is frustrated, but this anticipated meaning is not simply replaced: there is a juxtaposition that cannot be resolved between utterances from different «discursive genres» which attract their respective contexts. Comic juxtaposition, thus, consists in a juxtaposition of language, which has led us to practice what we have called 
an intertextual analysis of humourous discourse. Likewise, consideration of comic materialistic nature as proposed by Alenka Zupančič has opened a great hermeneutical potential. For instance, in our analysis of the novel Yo no tengo la culpa de haber nacido tan sexy, the materialistic nature of camp discourse led us to redefine the relationships established between body, fantasy and (gender) identity. In our analysis of the representation of masculinity in the sitcom Friends, this same characteristic allowed us to enrich our understanding of the materialistic view of ideological phenomenons as theorised by Althusser or Slajov Žižek.

The most relevant analogy, however, is that which can be found between comedy and theatre or performance in a broad sense. The ironist or humourist pretends or plays some role, even stages ideas or words. The dramatic metaphor authorizes choosing comedy as a general prototype for humourous discourse and exploring its relationship with theatrical metaphor in the sociological theories of Erving Goffman or Bourdieu's notion of habitus. Thus, the dramatic metaphor served us through our analysis of gender identity in the novels by Eduardo Mendicutti or the sitcom Friends to describe identity as performance, whether parodic or not, relying and deepening the theoris of Judith Butler. Trans characters in Mendicutti's novels create their identity through performance and impersonation of camp stereotypes, but not in a way which could be considered as inauthenticity or imposture. Conversely, we have defined practices of masculinity by male characters in Friends as failed perfomances or even idealised fantasies which are often threatening. Masculinity in this context is given as a sort of ventriloquism which can be linked to the psychoanalytical concept of «masquerade» by Joan Rivière, so relevant in feminist and queer theories.

As we can see, the importance of comedy and theatrical metaphors have led us to focus on the construction of the comic character. Building on intuitions found in our historical review, like the link between laughter and madness established during Antiquity and the Middle Ages, and on the analogies made in psychoanalysis between comic phenomenons and neurotic mechanisms, we have related the ridiculousness of the comic character with neurosis. Furthermore, this link between humour and psychic life enabled us to relate it with other psychic and anthropological phenomenons as impurity as described by Mary Douglas in terms of disorder and ambiguity, and Kristeva's notion of abjection. This relationships not only explain some of the social functions that humourous discourse and the comic character can accomplish (like the reinforcement of the current 
social order through comic sanction, or the relief of the anxiety produced by impurity or abjection) but also the affective ambiguity between pleasure and pain we can sometimes encounter in humourous discourse.

Nevertheless, as Hans R. Jauss asserts, the possibilities of identification with humorous characters are numerous and depend ultimately on literary tradition and the hermeneutical horizon in which both discourse and reader are situated. This has motivated our focus not in abstract clasifications or formal descriptions of humourous mechanisms, but in the different traditions and humorous genres. According to the hermeneutical perspective undertaken in this work, we believed it necessary to locate every subject of analysis in its proper context. Thus, we have studied the history of camp culture as an expression of the LGTB community through the 20th century, as well as the impact of camp sensibility and drag culture in popular culture and counterculture in Spain during the Transición period. In the case of Friends, we have studied the history of the situational comedy and its relationship with the television industry and the post-war culture in the United States. Relying on the analytical models by Charles Mauron and Stephen Greenblat, who treat comedy as a reflection of social fantasies, tensions and energies, we have analysed Friends and its formal innovation with regard to previous sitcoms as an echo of the social changes from the eighties. In this respect, Freudian psychoanalytic theory and the hermeneutical proposals by Hans R. Jauss have helped us to consider the complex and changing relationships which the audience establishes with comedy in terms of cathartic identification, defense mechanisms, regressive fantasies, and so on. At last, in order to locate the current debate on the limits of humour it was necessary to trace the genealogy of some mainstream expressions suchs as «political correctness» or «snowflakes».

In general, we believe we have shown the great variety of hermeneutical approaches that can be adopted for the analysis of humourous discourses. In this sense, this work opens some interesting research lines. In the historiographic field, it is needed to look further into the transformation of the conception of laughter and humour in the time period between the 17th and 18th centuries. It would also be interesting to continue research in the different popular, artistic or philosophical conceptions of humour from the $20^{\text {th }}$ century and its ideological consequences. The relationship between comedy and humour and manierism and ideology we have found in the grotesque tradition as described by Frances S. Connelly is a fertile research field in both its historical and 
theoretical facets. In this sense, the views offered in the fifth chapter can be continued on different fronts: the relationship between the comic character and neurosis; the polifonic nature of comic discourse; materialistic aspect of humour... These perspectives can be extended to other genres than the analysed in this work, like poetry, film, and so on.

In conclusion, we believe this work has also proved the advantages of adopting a pragmatist and rhetorical perspective in literary criticism, discourse analysis and other related disciplines like linguistics. Furthermore, this work is a vindication of transdisciplinarity and holistic analysis. 


\section{BIBLIOGRAFÍA}

20 minutos (2017, 10 de junio) ‘Boicot y tensión en una función de Jorge Cremades en Barcelona'. Recuperado el 10 de octubre de 2020 de https://www.20minutos.es/noticia/3060948/0/boicot-y-tension-en-una-funcionjorge-cremades-barcelona/

20 Minutos (2019) 'El FriendsFest regresa a Madrid y Barcelona y celebra los 25 años de “Friends"”. Recuperado el 19 de agosto de 2019 de https://www.20minutos.es/noticia/3630365/0/friendsfest-regresa-madridbarcelona-celebra-25-anos-friends/

Adanti, D. (2017) Disparen al humorista. Un ensayo gráfico sobre los límites del humor. Madrid: Astiberri.

Adanti, D. (2018, 30 de noviembre) 'No es el humor, es la democracia', Eldiario.es. Recuperado el 10 de octubre de 2020 de: https://www.eldiario.es/opinion/zonacritica/humor-democracia_129_1810467.html

Addison, J. (1970) Critical Essays from The Spectator. With four Essays by Richard Steele. Edited by D. F. Bond. Oxford: Clarendon Press.

Ahmed, S. (2017) La política cultural de las emociones. Ciudad de México: Universidad Nacional Autónoma de México.

Ahmed, S. (2019) La promesa de la felicidad. Una crítica cultural al imperativo de la alegría. Buenos Aires: Caja Negra.

Albaladejo, T. (1993) Retórica. Madrid: Síntesis.

Albaladejo, T. (2005) 'Retórica, comunicación, interdiscursividad', Revista de Investigación Lingüística, VIII, pp. 7-33.

Albaladejo, T. (2011a) 'Accesibilidad y recepción en el discurso digital. La galaxia del discurso desde el análisis interdiscursivo’, en Vilches, F. (ed.) Un nuevo léxico en la red. Madrid: Dykinson, pp. 15-28. 
Albaladejo, T. (2011b) ‘Los discursos del conflicto y los conflictos del discurso. Análisis interdiscursivo y Retórica cultural', en Macedo, A. G., Mendes de Sousa, C., y Moura, V. (eds) Vozes, Discursos e Identidades em Conflito. Braga: Humús, pp. $41-60$.

Albaladejo, T. (2012) 'Retórica política y comunicación digital. La ampliación de la poliacroasis’, en del Río San, E., Ruiz de la Cierva, M. del C., y Albaladejo, Tomás (eds) Retórica y política. Los discursos de la construcción de la sociedad. Logroño: Instituto de Estudios Riojanos, pp. 49-66.

Albaladejo, T. (2013) ‘Retórica cultural, lenguaje retórico y lenguaje literario’, Tonos digital. Revista electrónica de estudios digitales, 25.

Albaladejo, T. (2016) 'Cultural Rhetoric. Foundations and perspectives’, Res Rhetorica. Polskie Towarzystwo Retoryczne., 1, pp. 17-29.

Althusser, L. (2003) 'Ideología y Aparatos Ideológicos del Estado’, en Žižek, S. (ed.) Ideología. Un mapa de la cuestión. México D. F.: Fondo de Cultura Económica, pp. 115-156.

Anderson, P. (2017) Consideraciones sobre el marxismo occidental. Madrid: Siglo XXI de España.

Andreu, A. (1995) 'Estudio introductorio: Liberación de la inteligencia y sensación estético-moral de los otros en tanto destinos en copresencia', en Shaftesbury, A. A. C. C., Sensus Communis. Ensayo sobre la libertad de ingenio y humor. Valencia: Pre-textos.

Angenot, M. (2010) El discurso social. Los límites históricos de lo pensable y lo decible. Buenos Aires: Siglo XXI.

Aparici, R. y García-Marín, D. (2019, 15 de junio) 'La posverdad de la burbuja informativa', HuffPost. Recuperado el 10 de octubre de 2020 de https://www.huffingtonpost.es/entry/la-posverdad-de-la-burbujainformativa_es_5d03dfade4b0dc17ef098912 
Arcones, J. (2019a) ““Friends”: demuestra todo lo que sabes haciéndote con este Trivial’, Fotogramas. Recuperado el día 19 de agosto de 2019 de https://www.fotogramas.es/series-tv-noticias/a27624666/friends-trivialcomprar- amazon/

Arcones, J. (2019b) ““Friends” tendrá su propio set de Lego’, Fotogramas. Recuperado el 19 de agosto de 2019 de https://www.fotogramas.es/series-tv-noticias/a28643936/friends-lego/

Arduini, S. (2000) Prolegómenos a una teoría general de las figuras. Murcia: Universidad de Murcia.

Aristóteles (2018) Poética. Edición y traducción de Valentín García Yebra. Madrid: Gredos.

Attardo, S. (1994) Linguistic theories of humor. Berlin; New York: Mouton de Gruyter.

Attardo, S. (2001) Humorous Texts: A semantic and pragmatic analysis. Berlin/ New York: Mouton de Gruyter.

Attardo, S. y Raskin, V. (1991) 'Script theory revis(it)ed: joke similarity and joke representation model', Humor, 4(3/4), pp. 293-347.

Austin, J. L. (2018) Cómo hacer cosas con palabras. Barcelona: Paidós.

Ayrault, R. (1970) La genèse du romantisme allemand. T. III: 1797-1804 (I). Paris: Aubier Montaigne.

Ayuso, S. (2020a, 16 de octubre) 'Decapitado un profesor francés en un presunto ataque terrorista cerca de París', El País. Recuperado el 6 de noviembre de 2020 de https://elpais.com/internacional/2020-10-16/la-policia-abate-a-un-hombre-trasun-ataque-con-cuchillo-cerca-de-paris.html

Ayuso, S. (2020b, 31 de agosto) 'El juicio de “Charlie Hebdo” pone a Francia ante sus fantasmas', El País. Recuperado el 10 de octubre de 2020 de https://elpais.com/internacional/2020-08-30/el-juicio-de-charlie-hebdo-ponea- francia-ante-sus-fantasmas.html 
Azpiazu Carballo, J. (2017) Masculinidades y feminismo. Barcelona: Virus.

Babuscio, J. (2008) 'The cinema of camp (aka the gay sensibility)', en Cleto, F. (ed.) Camp. Queer Aesthetics and the Performing Subject. Edinburgh: Edinburgh University Press.

Bacete, R. (2017) Nuevos hombres buenos: la masculinidad en la era del feminismo. Barcelona: Península.

Badinter, E. (1993) XY: la identidad masculina. Madrid: Alianza.

Bajtín, M. (1989) Teoría y estética de la novela. Madrid: Taurus.

Bajtín, M. (1998) La cultura popular en la Edad Media y el Renacimiento. El contexto de Rabelais. Madrid: Alianza.

Bajtín, M. (2011) Las fronteras del discurso. Buenos Aires: Las cuarenta.

Bajtín, M. (2012) Problemas de la poética de Dovstoievski. México: Fondo de Cultura Económica.

Ballart, P. (1994) Eironeia: la figuración irónica en el discurso literario moderno. Barcelona: Quaderns Crema.

Barroso, F. J. (2016, 7 de febrero) 'Dos titiriteros, detenidos por hacer apología del terrorismo', El País. Recuperado el 10 de octubre de https://elpais.com/ccaa/2016/02/05/madrid/1454695514_093587.html

Barthes, R. (1987) El susurro del lenguaje. Más allá de la palabra y la escritura. Barcelona: Paidós.

Barthes, R. (2006) S/Z. Madrid: Siglo XXI.

Bassets, M. (2020, 9 de septiembre) 'Los otros "acusados" en el juicio de "Charlie Hebdo”', El País. Recuperado el 10 de octubre de 2020 de https://elpais.com/internacional/2020-09-09/los-otros-acusados-en-el-juicio-decharlie-hebdo.html

Bataille, G. (2002) El erotismo. Barcelona: Tusquets. 
Baudelaire, C. (2015) Lo cómico y la caricatura; El pintor de la vida moderna. Madrid: Antonio Machado Libros.

Baudrillard, J. (1978) Cultura y simulacro. Barcelona: Kairós.

Baudrillard, J. (2009) La sociedad de consumo. Sus mitos, sus estructuras. Madrid: Siglo XXI.

Bécares, R. and Belver, M. (2015, 15 de junio) 'Guillermo Zapata dimite del cargo de responsable de Cultura, pero no renunciará al acta de concejal tras la polémica por sus “tuits”, El Mundo. Recuperado el 10 de octubre de 2020 de https://www.elmundo.es/madrid/2015/06/15/557ebf73e2704e782a8b4572.html

Becker, R. (2014) 'Becoming bromosexual. Straight men, gay men and male bonding on U.S. TV', en Michael (ed.) Reading the Bromance. Homosocial relationships in Film and Television, pp. 233-254.

Behler, E. (1990) Irony and the Discourse of Modernity. Washington: University of Washington Press.

Bell, N. (2015) We are not amused. Failed humor in interaction. Berlin/Boston/Munich: Mouton de Gruyter.

Benjamin, W. (2017) El concepto de crítica de arte en el Romanticismo alemán. Madrid: Abada Editores.

Benjamin, W. (2020) 'La obra de arte en la época de su reproductibilidad técnica', en Iluminaciones. Madrid: Taurus.

Benton, G. (1988) 'The Origins of the Political Joke', en Powell, C. y Paton, G. E. C. (eds) Humour in Society. Resistance and Control. London: Macmillan Press, pp. 33-55.

Bercé, Y.-M. (1976) Fête et révolte: des mentalistés populaires du XVIe au XVIIIe siècle. Paris: Hachette.

Bergson, H. (2016) La risa. Ensayo sobre la significación de lo cómico. Madrid: Alianza Editorial. 
Berlant, L. (2020) El optimismo cruel. Buenos Aires: Caja Negra.

Bernini, L. (2018) Las teorías queer. Una introducción. Barcelona: Egales.

Berthold, M. (1974) Historia social del teatro. 2. Madrid: Guadarrama.

Bertrand, D. (1995) Dire le rire à l'âge classique: représenter pour mieux controler. Aixen-Provence: Université de Provence.

Biesecker, B. A. (1997) Addressing Postmodernity. Kenneth Burke, Rhetoric, and a Theory of Social Change. Tuscaloosa: The University of Alabama Press.

Billig, M. (1996) Arguing and thinking: A rhetorical approach to social psychology. Cambridge: Cambridge University Press.

Billig, M. (2005) Laughter and ridicule: towards a social critique of laughter. London: Thousand Oaks Sage.

Blanco Valdés, C. F. (2003) 'El renacimiento de un nuevo género literario: la comedia italiana en el “Cinquecento”, en Alemany Bay, C. et al. (eds) Con Alonso Zamora Vicente: Actas del Congreso Internacional "La Lengua, la Academia, lo Popular, los Clásicos, los Contemporáneos. Alicante: Universidad de Alicante.

Booth, W. C. (1989) Retórica de la ironía. Madrid: Taurus.

Bourdieu, P. (1985) ¿Qué significa hablar? Economía de los intercambios lingüísticos. Madrid: Akal.

Bourdieu, P. (2007) El sentido práctico. Buenos Aires: Siglo XXI.

Bozal, V. (2015) ‘Introducción. El caricaturista y el pintor’, en Baudelaire, C. Locómico y la caricatura; El pintor de la vida moderna. Madrid: Antonio Machado Libros, pp. 11-24.

Brooks, P. (1987) 'The Idea of a Psychoanalytic Literary Criticism', Critical Inquiry, 13(2), pp. 334-348.

Bruce, L. (1989) El cómico del escándalo. Madrid: Fundamentos.

Burckhardt, J. (2004) La cultura del Renacimiento en Italia. Madrid: Akal. 
Burke, K. (1969) A Grammar of Motives. Los Angeles: University of California Press.

Burke, P. (1996) La cultura popular en la Edad Moderna. Madrid: Alianza.

Burke, P. (1999) 'Fronteras de lo cómico en Italia, 1350-1750', en Bremmer, J. y Roodenburg, H. (eds) Una historia cultural del humor. Desde la Antigüedad a nuestros días. Madrid: Sequitur, pp. 63-78.

Burucúa, J. E. (2001) Corderos y elefantes. La sacralidad y la risa en la modernidad clásica -siglos XV a XVII-. Buenos Aires: Universidad de Buenos Aires.

Burucúa, J. E. (2007) La imagen y la risa. Las pathosformeln de lo cómico en el grabado europeo de la modernidad temprana. Periférica.

Butler, J. (1993) 'Critically queer’, GLQ: a journal of lesbian \& gay studies, 1, pp. 1732.

Butler, J. (2007) El género en disputa. El feminismo y la subversión de la identidad. Barcelona: Paidós.

Butler, J. (2008) Cuerpos que importan: sobre los límites materiales y discursivos del cuerpo. Buenos Aires: Paidós.

C., M. (2018, 29 de enero) 'No millennials, Friends ni es machista ni es homófoba', El Español. Recuperado el 19 de agosto de 2019 de https://www.elespanol.com/social/20180129/no-milenials-friends-machistahomofoba/280972943_0.html

Caballero, F. (2020, 29 de enero) 'Ayuso llama al PP madrileño a expresarse "sin complejos” y a “librarse de los excesos progresistas”, Eldiario.es. Recuperado el 10 de octubre de 2020 de https://www.eldiario.es/madrid/ayuso-ppexpresarse- expresiones-progresistas_1_1051892.html

Calderón, I. (2017, 9 de mayo) ‘Isa Calderón tiene algo que decirle a Pérez-Reverte’, La Vanguardia. Recuperado el 10 de octubre de 2020 de https://www.lavanguardia.com/demoda/feminismo/20170509/422417199097/video-isa-calderon-respuesta-perezreverte.html 
Cameron, D. (1995) Verbal Hygiene. The politics of language. London: Routledge

Campbell, B. y Manning, J. (2018) The Rise of Victimhood Culture: Microaggressions, Safe Spaces, and the New Culture Wars. Palgrave Macmillan.

Capra, F. (2015) La trama de la vida. Una nueva perspectiva de los sistemas vivos. Barcelona: Anagrama.

Carabí, A. y Armengol, J. M. (eds) (2015) Masculinidades alternativas en el mundo de hoy. Barcelona: Icaria.

Caro Baroja, J. (1988) Historia de la fisiognómica: el rostro y el carácter. Madrid: Istmo.

Caro Baroja, J. (2006) El carnaval (análisis histórico-cultural). Madrid: Alianza Editorial.

Case, S.-E. (1988) ‘Towards a Butch-Femme Aesthetic’, Discourse, 11(1), pp. 55-73.

Chait, J. (2015, 27 de enero) 'Not a very P.C. thing to say', New York Magazine. Recuperado el 10 de octubre de 2020 de https://nymag.com/intelligencer/2015/01/not-a-very-pc-thing-to-say.html

Chamouleau, B. (2017) Tiran al maricón: los fantasmas queer de la democracia (19701988). Tres Cantos: Akal.

Chapman, A. J. (1983) 'Humor and laughter in social interaction and some implications for humor research', en Mcghee, P. E. y Goldstein, J. H. (eds) Handbook of humor research. New York: Springer-Verlag, pp. 135-157.

Chesebro, J. W. (2003) 'Communication, Values, and Popular Television Series - A Twenty-five Year Assessment and Final Conclusions', Communication Quaterly, 51(4), pp. 367-418.

Cicerón, M. T. (2002) Sobre el orador. Madrid: Gredos.

Clare, A. (2002) Hombres. La masculinidad en crisis. Madrid: Taurus.

Clark, H. H. y Gerrig, R. J. (1984) 'On the pretense theory of irony.', Journal of experimental psychology, 113(1), pp. 121-126. 
Cleto, F. (2008) 'Introduction: Queering the camp', en Cleto, F. (ed.) Camp: Queer Aesthetics and the Performing Subject. Edinburgh: Edinburgh University Press, pp. 2-42; 44-48; 88-95; 302-307; 356-360.

Coddon, K. S. (1993) “"Slander in an Allow’d Fool”: "Twelfth Night's” Crisis of the Aristocracy', Studies in English Literature, 33(2), pp. 309-325.

Colmeiro, J. F. (2010) 'Plumas ypistolas: la crisis constitucional del 23-F y la memoria histérica de Eduardo Mendicutti’, Revista de estudios hispánicos, 44(3), pp. 589609.

Connell, R. W. (1991) Gender and Power: society, the person and sexual politics. Cambridge: Cambridge Polity in association with Blackwell.

Connell, R. W. (2018) Masculinities. Cambridge: Polity.

Connelly, F. S. (2015) Lo grotesco en el arte y la cultura occidentales : la imagen en juego. Madrid: Antonio Machado Libros.

Contreras, J. M. y Baroja, E. (2020, 14 de septiembre) ‘Polarización: por qué no podemos ser amigos', Eldiario.es. Recuperado el 10 de octubre de 2020 de https://www.eldiario.es/opinion/zona-critica/polarizacion-noamigos_129_6221198.html

Costas, N. (2018, 5 de noviembre) ‘Dani Mateo y Gran Wyoming dan la cara: "No había intencionalidad política”', El Confidencial. Recuperado el 10 de octubre de 2020 de https://www.elconfidencial.com/television/programas-tv/2018-11-05/elintermedio-dani-mateo-bandera-espana-gran-wyoming-disculpas_1640703/

Crawford, M. (2003) 'Gender and humor in social context', Journal of Pragmatics, 35, pp. 1413-1430.

Cuesta Abad, J. M. (1997) Las formas del sentido. Estudios de Poética y Hermenéutica. Madrid: Servicio de Publicaciones de la Universidad Autónoma de Madrid.

Damasio, A. (2018a) El error de Descartes. La emoción, la razón y el cerebro humano. Madrid: Booket. 
Damasio, A. (2018b) En busca de Spinoza. Neurobiología de la emoción y los sentimientos. Madrid: Booket.

Dane, J. A. (2011) The critical mythology of irony. Georgia: University of Georgia Press.

Daraki, M. (2005) Dionisio y la diosa tierra. Madrid: Abada Editores.

Debord, G. (2015) La sociedad del espectáculo. Valencia: Pre-textos.

Delgado, L. E. (2014) La nación singular: fantasías de las normalidad democrática Española (1996-2011). Madrid: Siglo XXI de España.

Delgado, L. E. (2017) 'Nacionalistas, populistas, feministas y las paradojas de la democracia’, Arizona Journal of Hispanic Cultural Studies, 21(1), pp. 263-286.

Derrida, J. (1997) La diseminación. Madrid: Fundamentos.

Derrida, J. (2018) Limited Inc. Santiago: Pólvora.

Derrida, J. (2019) Márgenes de la filosofía. Madrid: Cátedra.

Van Dijk, T. A. (2003a) Ideología y discurso. Barcelona: Ariel.

Van Dijk, T. A. (2003b) 'La multidisciplinariedad del análisis crítico del discurso: un alegato en favor de la diversidad', en Wodak, R. y Meyer, M. (eds) Métodos de análisis crítico del discurso. Barcelona: Gedisa, pp. 143-178.

Van Dijk, T. A. (2005) 'Ideología y análisis del discurso', Utopía y Praxis Latinoamericana. Revista Internacional de Filosofía Iberoamericana y Teoría Social, 29, pp. 9-36.

Van Dijk, T. A. (2008) Discourse and Context. A Sociocognitive Approach. Cambridge: Cambridge University Press.

Van Dijk, T. A. (2009) Society and discourse: How social contexts influence text and talk. Cambridge: Cambridge University Press.

Doanne, M. A. (1982) 'Film and the masquerade: theorising the female spectator', Screen, 23(3-4), pp. 74-88. 
Douglas, M. (2007) Pureza y peligro. Un análisis de los conceptos de contaminación y tabú. Buenos Aires: Nueva Visión.

Dryer, R. (2002) 'It's being so camp as keeps us going', en The culture of queers. New York: Routledge.

Ducrot, O. (1986) El decir y lo dicho. Polifonía de la enunciación. Barcelona: Paidós.

Dynel, M. (2011) 'Joker in the pack. Towards determining the status of humorous framing in conversations', en Dynel, M. (ed.) The Pragmatics of Humour across Discourse Domains. Amsterdam/Philadelphia: John Benjamins, pp. 217-241.

Eagleton, T. (1997) Ideología: una introducción. Barcelona: Paidós.

Eco, U. (1994) La búsqueda de la lengua perfecta en la cultura europea. Barcelona: Crítica.

Eco, U. (ed.) (2007) Historia de la fealdad. Barcelona: Lumen.

Eco, U. (2013) Apocalípticos e integrados. Barcelona: Debolsillo.

Eco, U. et al. (2013) Interpretación y sobreinterpretación. Madrid: Akal.

El Confidencial (2020, 19 de julio) 'Vargas Llosa y otras 100 firmas apoyan el manifiesto Harper's por la democracia'. Recuperado el 10 de octubre de 2020 de https://www.elconfidencial.com/cultura/2020-07-19/manifiesto-harperslibertad- de-expresion_2688296/

El Español (2019, 16 de enero) 'El juez archiva la causa contra Dani Mateo por sonarse los mocos con la bandera'. Recuperado el 10 de octubre de 2020 de https://www.elespanol.com/espana/tribunales/20190116/archiva-causa-danimateo-sonarse-mocos-bandera/368964483_0.html

El HuffPost (2017, 9 de mayo) ‘Pérez-Reverte llama “imbéciles sin comprensión lectora” a quienes critican su columna sobre Christina Hendricks'. Recuperado el 10 de octubre de 2020 de https:/www.huffingtonpost.es/2017/05/09/perez-revertellama-imbeciles-sin-comprension-lectora-a-quiene_a_22077789/ 
El Mundo (2006, 6 de febrero) 'Las protestas contra las viñetas de Mahoma se recrudecen en los grandes países musulmanes'. Recuperado el 10 de octubre de 2020 de https://www.elmundo.es/elmundo/2006/02/06/internacional/1139214590.html

Eldiario.es (2018, 27 de agosto) 'Rober Bodegas pide “disculpas” tras sufrir “amenazas” por hacer chistes sobre gitanos en Comedy Central'. Recuperado el 10 deoctubre de 2020 de https://vertele.eldiario.es/noticias/Robert-Bodegas-disculpasComedy-Central_0_2043695615.html

Elias, N. (1988) El proceso de la civilización. Investigaciones sociogéneticas y psicogenéticas. México: Fondo de Cultura Económica.

Elidrissi, F. (2018, junio) ““Pose”: el voguing y el sueño americano’, Pikara Magazine. Disponible en https://www.pikaramagazine.com/2018/06/pose-voguing/

Enzensberger, H. M. (1982) 'The industrialization of mind', en Grimm, R. y Armstrong, B. (eds) Critical Essays. New York: Continuum, pp. 3-14.

Errejón, I. y García Linera, Á. (2020) Qué horizonte. Hegemonía, Estado y revolución democrática. Madrid: Lengua de Trapo.

Errejón, I. y Mouffe, C. (2015) Construir pueblo. Hegemonía y radicalización de la democracia. Madrid: Más Madera.

Escarpit, R. (1967) L’humour. Paris: Presses universitaires de France.

Fairclough, N. (1995) Critical discourse analysis: the critical study of language. London: Longman.

Fairclough, N. (2001) Language and Power. London: Longman.

Fairclough, N. (2003a) ‘El análisis crítico del discurso como método para la investigación en ciencias sociales’, en Wodak, R. y Meyer, M. (eds) Métodos de análisis crítico del discurso. Barcelona: Gedisa, pp. 179-204.

Fairclough, N. (2003b) “"Political correctness”: the politics of culture and language', Discourse \& Society, 14(1), pp. 17-28. 
Ferguson, M. A. y Ford, T. E. (2008) 'Disparagement humor: A theoretical and empirical review of psychoanalytic, superiority, and social identity theories', Humor, 21(3), pp. 283-312.

Findlen, P. (1990) 'Jokes of Nature and Jokes of Knowledge: The Playfulness of Scientific Discourse in Early Modern Europe’, Renaissance Quarterly, 43(2), pp. 292-331.

Fine, G. A. (1983) 'Sociological approaches to the study of humor', en McGhee, P. E. y Goldstein, J. H. (eds) Handbook of humor research. New York: SpringerVerlag, pp. 159-181.

Finn, E. (2018) La búsqueda del algoritmo. Imaginación en la era de la informática. Barcelona: Alpha Decay.

Fish, S. (1980) Is there a text in this class? The Authority of Interpretive Communities. Cambridge, Massachussets; London: Harvard University Press.

Fish, S. (1992) Práctica sin teoría: retórica y cambio en la vida institucional. Barcelona: Destino.

Forabosco, G. (1992) 'Cognitive aspects of the humor process: the concept of incongruity’, Humor, 5(1/2), pp. 45-68.

Ford, T. E. (2000) 'Effects of Sexist Humor on Tolerance of Sexist Events', Personality and Social Psychology Bulletin, 26(9), pp. 109-1107.

Ford, T. E. (2015) 'The social consequences of disparagement humor: Introduction and overview', Humor, 28(2), pp. 163-169.

Foucault, M. (2001) Los anormales. Curso del Collège de France (1974-1975). Madrid: Akal.

Foucault, M. (2005) El poder psiquiátrico. Curso del Collège de France (1973-1974). Madrid: Akal.

Foucault, M. (2007) El nacimiento de la clínica. Una arqueología de la mirada médica. Madrid: Siglo XXI. 
Foucault, M. (2009a) Historia de la sexualidad, I: La voluntad de saber. Tres Cantos: Siglo XXI España.

Foucault, M. (2009b) Historia de la sexualidad II. El uso de los placeres. Tres Cantos: Siglo XXI España.

Foucault, M. (2009c) Vigilar y castigar. Nacimiento de la prisión. México: Siglo XXI.

Foucault, M. (2015a) Historia de la locura en la época clásica. México: Fondo de Cultura Económica.

Foucault, M. (2015b) La arqueología del saber. Buenos Aires: Siglo XXI.

Foucault, M. (2016) Nacimiento de la biopolítica. Madrid: Akal.

Foucault, M. (2017) Las palabras y las cosas. Una arqueología de las ciencias humanas. Buenos Aires: Siglo XXI.

Foucault, M. (2019) El orden del discurso. Barcelona: Austral.

Freud, S. (1992) 'El humor', en Obras completas, XXI. Buenos Aires: Amorrortu Editores, pp. 157-162.

Freud, S. (2012) El chiste y su relación con lo inconsciente. Madrid: Alianza.

Freud, S. (2016a) 'Múltiple interés del psicoanálisis', en Esquema del psicoanálisis y otros estudios de doctrina psicoanalítica. Madrid: Alianza Editorial, pp. 216-250.

Freud, S. (2016b) 'Personajes psicopáticos en el teatro’, en Esquema del psicoanálisis y otros estudios de doctrina psicoanalítica. Madrid: Alianza Editorial, pp. 427-436.

Freud, S. (2017) El malestar en la cultura. Madrid: Alianza Editorial.

Freud, S. (2018) ‘Más allá del principio del placer’, en Psicología de las masas. Madrid: Alianza, pp. 95-160.

Freud, S. (2019) 'El poeta y la fantasía', en Psicoanálisis aplicado y técnica psicoanalítica. Madrid: Alianza Editorial, pp. 11-23. 
Freudenburg, K. (2005) 'Introduction: Roman Satire', en Freudenburg, K.(ed.) The Cambridge Companion to Roman Satire. Cambridge: Cambridge University Press, pp. 1-30.

Friedman, S. and Kuipers, G. (2013) 'The Divisive Power of Humour: Comedy, Taste and Symbolic Boundaries’, Cultural Sociology, 7(2), pp. 179-195.

Frye, N. (1991) Anatomía de la crítica. Caracas: Monte Avila.

Gadamer, H.-G. (1998) Verdad y método II. Salamanca: Sígueme.

Gadamer, H. G. (2012) Verdad y Método. Salamanca: Sígueme.

Gaignebet, C. (1972) 'Le combat de Carnaval et de Carême de P. Bruegel (1559)', Annales. Histoire, Sciences Sociales, 27(2), pp. 313-345.

Gálvez, J. J. (2018, 23 de noviembre) 'Dani Mateo, imputado por sonarse con una bandera de España', El País. Recuperado el 10 de octubre de 2020 de https://elpais.com/politica/2018/11/23/actualidad/1542980080_588311.html

Garber, M. (2019, 12 de septiembre) ‘On Chandler Bing’s Job’, The Atlantic. Disponible en https://www.theatlantic.com/entertainment/archive/2019/09/friends-25prescience-chandler-bing-job/597829/

García Berrio, A. (1984) 'Retórica como ciencia de la expresividad (Presupuestos para una Retórica General)’, Estudios de Lingüística, 2, pp. 7-59.

García, C. (2020, 20 de enero) 'La corrección mató a Peter Griffin’, La Razón. Recuperado el 10 de octubre de https://www.larazon.es/cultura/la-correccionmato-a-peter-griffin-he21528069/

García García, L. (2019) 'La copla cautiva', El salto diario. Disponible en https://www.elsaltodiario.com/musica/lidia-garcia-copla-cautiva

Garlinger, P. P. (2000) 'Dragging Spain into the 'Post-Franco' Era: Travestism and National Identity in Una mala noche la tiene cualquiera' Revista canadiense de Estudios Hispánicos, XXIV(2), pp. 363-382. 
Garlinger, P. P. (2003) 'Transgender Nation: Bibi Andersen, Postmodernity and the Spanish Transition to Democracy’, Revista de estudios hispánicos, 33, pp. 3-30.

Gil Fernández, L. (1996) Aristófanes. Madrid: Gredos

Gil Fernández, L. (2010) De Aristófanes a Menandro. Madrid: Fundación Pastor.

Girauta, J. C. (2020, 15 de septiembre) 'Guerra cultural', ABC. Recuperado el 10 de octubre de 2020 de https://www.abc.es/opinion/abci-juan-carlos-girauta-guerracultural-202009150054_noticia.html?ref=https:\%2F\%2Fduckduckgo.com\%2F

Le Goff, J. (1977), Pour un âutre Moyen Age: temps, travail et culture en Occident. Paris: Gallimard.

Le Goff, J. (1999) 'La risa en la Edad Media', en Bremmer, J. y Roodenburg, H. (eds) Una historia cultural del humor. Desde la Antigüedad a nuestros días. Madrid: Sequitur, pp. 41-54.

Goffman, E. (2006) Frame analysis: los marcos de la experiencia. Madrid: Centro de Investigaciones Sociológicas.

Goffman, E. (2009) La presentación de la persona en la vida cotidiana. Buenos Aires: Amorrortu.

González, M. (2018) Por qué Warner es capaz de sacarle 100 millones de dólares a Netflix por 'Friends' 15 años después, Xataka. Disponible en https://www.xataka.com/streaming/netflix-pagara-100-millones-dolaresmantener-friends-ano-bienvenidos-a-nueva-era-streaming

Graf, F. (1999) ‘Cicerón, Plauto y la risa romana’, en Bremmer, J. y Roodenburg, H. (eds) Una historia cultural del humor. Desde la Antigüedad a nuestros días. Madrid: Sequitur, pp. 29-40.

Graf, F. (2005) 'Satire in a ritual context', en Freudenburg, K. (ed) The Cambridge Companion to Roman Satire. Cambridge: Cambridge University Press, pp. 192202. 
Graíño Ferrer, G. (2016) 'Introducción', en Bergson, H. La risa. Ensayo sobre la significación de lo cómico. Madrid: Alianza, pp. 9-27.

Grassi, E. (1993) La filosofía del humanismo. Preeminencia de la palabra. Barcelona: Anthropos.

Grassi, E. (2015) Retórica como filosofía. La tradición humanista. Barcelona: Anthropos.

Greenblatt, S. (1998) 'La circulación de la energía social’, en Penedo, A. y Pontón, G. (eds) Nuevo Historicismo. Madrid: Arco/Libros.

Gregory, M. (2015) 'Fat Monica Was The TV Role Model I Never Expected', Buzzfeed. Disponible en: https://www.buzzfeed.com/mathildia/why-i-loved-fat-monica.

Grote, D. (1983) The End of Comedy. The Sit-Com and the Comedic Tradition. Handem: Archon Books.

Guasch, Ó. (2006) Héroes, científicos, heterosexuales y gays. Los varones en perspectiva de género. Barcelona: Bellaterra.

Gurevich, A. (1999) 'Bakhtin y el carnaval medieval', en Bremmer, J. y Roodenburg, H. (eds) Una historia cultural del humor. Desde la Antigüedad a nuestros días. Madrid: Sequitur, pp. 55-61.

Gutiérrez-Sanz, V. (2019) Sujetos malvados en el periodismo y la literatura española del siglo XXI. Un análisis retórico de su construcción discursiva. [tesis doctoral] Universidad de Valladolid.

Halberstam, J. (2018) Trans*. Una guía rápida y peculiar de la variabilidad de género. Madrid: Egales.

Hall, S. (1994) 'Some “Politically Incorrect” Pathways Through PC', en Dunant, S. (ed.) The War of the Words: The Political Correctness Debate. London: Virago Press, pp. 164-184.

Halliwell, S. (1987) The Poetics of Aristotle. Translation and commentary. The University of North Carolina Press. 
Halliwell, S. (2002) The aesthetics of mimesis: ancient texts and modern problems. Princeton, N.J.: Princeton University Press.

Halliwell, S. (2008) Greek Laughter: a study of cultural psychology. Cambridge: Cambridge University Press.

Halperin, D. (2007) San Foucault. Para una hagiografía gay. Buenos Aires: Cuenco de Plata.

Han, B.-C. (2014) Psicopolítica. Neoliberalismo y nuevas fuerzas de poder. Barcelona: Herder.

Han, B.-C. (2017) La sociedad del cansancio. Barcelona: Herder.

Harper's Magazine (2020, julio) ‘A Letter on Justice and Open Debate’. Disponible en https://harpers.org/a-letter-on-justice-and-open-debate/

Hartman, A. (2015) A War for the Soul of America. A History of the culture wars. Boston:The University of Chicago Press.

Hay, J. (2000) 'Functions of humor in the conversations of men and women' Journal of Pragmatics, 32(6), pp. 709-742

Hay, J. y Couldry N. (2011) 'Rethinking convergence/culture: an introduction’, Cultural Studies, 25(4-5), pp. 473-486.

Heers, J. (1983) Fêtes des fous et Carnavales. Paris: Fayard.

Henderson, J. (2004) ‘Attic Old Comedy, Frank Speech, and Democracy’, en Boedeker, D. y Raaflaub, K. A. (eds) Democracy, Empire, and the Arts in Fifth-Century Athens. London: Harvard University Press, pp. 255-273.

Hernández-Echevarría, C. (2020, 14 de julio) ‘Despedido por racista: verdades y mentiras de la “cultura de la cancelación”", Eldiario.es. Recuperado el 10 de octubre de 2020 de https://www.eldiario.es/internacional/despedido-racista-verdadesmentiras-cultura-cancelacion_129_6104594.html

Holmes, J. (2000) 'Politeness, Power and Provocation: How Humour Functions in the Workplace', Discourse Studies, 2(2), pp. 159-185. 
Holmes, J. (2006) 'Sharing a laugh: Pragmatic aspects of humor and gender in the workplace', Journal of Pragmatics, 38(1), pp. 26-50.

Holmes, J. y Marra, M. (2002) 'Humour as a discursive boundary marker in social interaction', en Duszak, A. (ed.) Us and Others. Social identities across languages, discourses and cultures. Amsterdam: John Benjamins, pp. 377-400.

Hooley, D. M. (2007) Roman Satire. Oxford: Blackwell.

Horkheimer, M. y Adorno, T. W. (2016) Dialéctica de la ilustración. Madrid: Trotta.

Horrillo, E. (2018) ‘Nueve momentos de “Friends” que en su día nos hicieron reír y hoy nos escandalizan', El País. Recuperado el 19 de agosto de 2019 de https://elpais.com/elpais/2017/10/09/fotorrelato/1507560594_704531.html

Huerta Floriano, M. Á. y Pérez Morán, E. (2013) ‘La imagen de la España tardofranquista en las películas de Manolo Escobar’, Revista Latina de Comunicación Social, 68(967-997), pp. 189-216.

Huerta Floriano, M. Á. y Pérez Morán, E. (2015) ‘De la comedia popular tardofranquista a la comedia urbana de la transición: tradición y modernidad’, Historia Actual Oline, 37(2), pp. 201-212.

Hunter, J. D. (1991) Culture Wars. The struggle to define America. Making sense of the battles over the family, art, education, law, and politics. New York: Basic Books.

Hunter, R. L. (1985) The new comedy of Greece and Rome. Edited by M. Revermann. Cambridge: Cambridge University Press.

Hutcheon, L. (1988) A Poetics of Postmodernism: History, Theory Fiction. New York: Routledge.

Hutcheon, L. (1994) Irony's edge. The theory and politics of irony. New York: Routledge.

Hutcheon, L. (2000) A theory of parody. The teachings of Twentieth-century art forms. Illinois: University of Illinois Press.

Ingenschay, D. (2011) 'Sobre machos reales y santos ficticios: Yo no tengo la culpa de haber nacido tan sexy, de entre lo global y lo local', Lectora. 17, pp. 67-78. 
Jameson, F. (2016) Teoría de la postmodernidad. Madrid: Trotta.

Jamin, J. (2018) ‘Cultural Marxism: A survey’, Religion Compass. 12(1-2), pp. 212-258.

Janko, R. (1984) Aristotle on comedy: towards a reconstruction of Poetics II. London: Duckworth.

Jauss, H. R. (1986) Experiencia estética y hermenéutica literaria. Ensayos en el campo de la experiencia estética. Barcelona: Taurus.

Jenkins, H. (2004) 'The Cultural Logic of Media Convergence', International Journal of Cultural Studies. 7(1), pp. 33-43.

Jenkins, H. (2006) Convergence culture. Where old and new media collide. New York: New York University Press.

Jenkins Logan, T. (1982) 'Twelfth night: the limits of festivity', Studies in English Literature, 22(2), pp. 223-238.

Jurado Morales, J. (2012) 'Eduardo Mendicutti o el discurso de una conciencia solidaria’, en Jurado Morales, J. (ed.) Una ética de la libertad. La narrativa de Eduardo Mendicutti. Madrid: Visor Libros, pp. 35-50.

Kaplan, I. (2018a) 'Friends: 10 times the classic sitcom was problematic', The independent. Recuperado el 19 de Agosto de 2019 de https://www.independent.co.uk/arts-entertainment/films/friends-netflix-sitcomproblem-sexism-men-joey-phoebe-chandler-ross-rachel-a8168976.html

Kaplan, I. (2018b) 'Millennials watching “Friends” on Netflix shocked by storylines', Independent. Recuperado el 19 de agosto de 2019 de https://www.independent.co.uk/arts-entertainment/tv/friends-netflix-sexistracist-transphobic-problematic-millenials-watch-a8154626.html?jwsource=cl

Kayser, W. (2010) Lo grotesco. Su realización en la literatura y el arte. Madrid: Antonio Machado Libros.

Kerbrat-Orecchioni, C. (1980) 'L’ironie comme trope’, Poétique, 41, pp. 108-127. 
Kibédi Varga, Á. (2000) 'Universalité et limites de la rhétorique’, Rhetorica, XVIII(1), pp. 1-28.

Kierkegaard, S. (2000) De los papeles de alguien que todavía vive. Sobre el concepto de ironía. Madrid: Trotta.

Klausen, J. (2009) The cartoons that shook the world. Pennsylvania: Yale University Press.

Klein, L. E. (2012) 'Introduction', en Shaftesbury, Lord Characteristics of Men, Manners, Opinions, Times. Cambridge University Press, pp. vii-xxxi.

Kotthoff, H. (2006) 'Gender and humor: The state of the art', Journal of Pragmatics, 38(1), pp. 4-25.

Kramer, E. (2011) 'The playful is political: The metapragmatics of internet rape-joke arguments', Language in Society, 40(2), pp. 137-168.

Kris, E. (1964) Psicoanálisis de lo cómico y psicología de los procesos creadores. Buenos Aires: Paidós.

Kristeva, J. (2001) 'La palabra, el diálogo y la novela', en Semiótica 1. Madrid: Fundamentos, pp. 187-226.

Kristeva, J. (2015) Poderes de la perversión. México: Siglo XXI.

Kuipers, G. (2006a) Good Humor, Bad Taste. A sociology of the Joke. Berlin: Mouton de Gruyter.

Kuipers, G. (2006b) 'Television and taste hierarchy: The case of Dutch television comedy', Media, Culture and Society, 28(3), pp. 359-378.

Kuipers, G. (2011) 'The politics of humour in the public sphere: Cartoons, power and modernity in the first transnational humour scandal', European Journal of Cultural Studies, 14(1), pp. 63-80.

Kutulas, J. (2018) 'Anatomy of a Hit: Friends and Its Sitcom Legacies', Journal of Popular Culture, 51(2), pp. 1172-1189 
La Vanguardia (2017. 7 de marzo) ‘Cancelado un espectáculo de Jorge Cremades por sus declaraciones sobre violencia machista'. Recuperado el 10 de octubre de 2020 de https://www.lavanguardia.com/cultura/20170307/42629749900/canceladojorge- cremades-violencia-machista.html

La Vanguardia (2019, 20 de enero) 'Netflix anuncia si "Friends” desaparecerá de la plataforma a partir de julio o no’. Recuperado el 19 de agosto de 2020 de https://www.lavanguardia.com/series/netflix/20190620/463007970060/netflixfriends-se-queda-plataforma.html

Lacou-Labarthe, P. y Nancy, J. L. (2012) El absoluto literario. Teoría de la literatura del romanticismo alemán. Buenos Aires: Eterna Cadencia.

Lakoff, G. y Johnson, M. (1986) Metáforas de la vida cotidiana. Madrid: Cátedra.

Lane, M. (2011) ‘Reconsidering Socratic Irony’, en Morrison, D. R. (ed.) The Cambridge Companion to Socrates. Cambridge: Cambridge University Press, pp. 258-280.

Lang, C. D. (1988) Irony/Humor. London: The John Hopkins University Press.

Lausberg, H. (1994) Manual de Retórica Literaria: fundamentos de una ciencia de la literatura. Madrid: Gredos.

Lavie, F. (2014) '«Humour» et «Wit»: Faire l’histoire de deux mots dans l’Angleterre moderne (XVIIe - XVIII e siècles)', Eighteenth-Century Fiction, 26(4), pp. 625649.

Lear, J. (1988) 'Katharsis’, Phronesis: A Journal for Ancient Philosophy1, 33, pp. 297326.

Lewis (ed.), P. (2008) 'The Muhammad cartoons and humor research: A collection of essays', Humor, 21(1), pp. 1-46.

Lijtmaer, L. (2019) Ofendiditos. Sobre la criminalización de la protesta. Barcelona: Anagrama. 
Links, F. R. (2012) ‘¿No es de cine? Miradas intermediales en Una mala noche la tiene cualquiera', en Morales, J. J. (ed.) Una ética de la libertad. La narrativa de Eduardo Mendicutti. Madrid: Visor, pp. 111-126.

Lipovetsky, G. (2006) La era del vacío. Barcelona: Anagrama.

Llanos López, R. (2007) Historia de la teoría de la comedia. Arco/Libros.

López, A. and Pociña, A. (2007) Comedia romana. Akal.

López Eire, A. (2000a) Esencia y objeto de la retórica. Salamanca: Ediciones Universidad de Salamanca.

López Eire, A. (2000b) ‘Reflexiones sobre la comedia aristofánica’, Myrtia, (15), pp. 69_ 101.

López Eire, A. (2004) ‘Risa, ritual y poesía’, Cuadernos del CEMyR, (12), pp. 155-209.

Lorente, N. (2019, 27 de enero) ““Friends” (Netflix): 16 millones de episodios se ven al día en todo el mundo', El Confidencial. Recuperado el 19 de agosto de https://www.elconfidencial.com/television/series-tv/2019-01-27/exito-friendsserie-netflix-aniversario_1782002/

Lukianoff, G. and Haidt, J. (2015) 'The Coddling of the American Mind', The Atlantic. Disponible en https://www.theatlantic.com/magazine/archive/2015/09/thecoddling-of-the-american-mind/399356/

Madina, E. (2020, 8 de febrero) ‘Guerra cultural’, El País. Recuperado el 10 de octubre de 2020 de https://elpais.com/elpais/2020/02/07/opinion/1581098996_408179.html

Maldonado, L. G. (2016, 13 de diciembre) 'Jorge Cremades: “Hay más violaciones a hombres que a mujeres”', El Español. Recuperado el 10 de octubre de 2020 de https://www.elespanol.com/cultura/20161212/177733142_0.html

De Man, P. (1991) Visión y ceguera: ensayos sobre la retórica de la crítica contemporánea. Puerto Rico: Universidad de Puerto Rico.

De Man, P. (1996) El concepto de ironía. Eutopías. Valencia: Episteme. 
Marc, D. (1997) Comic Visions. Television Comedy \& American Culture. Oxford: Blackwell Publishing.

Marcuse, H. (2016) El hombre unidimensional. Madrid: Austral.

Marías, J. (2019, 13 de octubre) ‘Contra la susceptibilidad’, El País Semanal. Recuperado el 10 de octubre de 2020 de https://elpais.com/elpais/2019/10/07/eps/1570465684_984883.html

Martín Jiménez, A. (2014) ‘La retórica clásica y la neurociencia actual: las emociones y la persuasión’, Rétor, 4(1), pp. 56-83.

Martin, R. P. (2007) 'Ancient theatre and performance culture', en McDonald, M. y Walton, J. M. (eds) The Cambridge Companion to Greek and Roman theatre. Cambridge: Cambridge University Press, pp. 36-54.

Martínez-Expósito, A. (2012) 'Humor y narración gay en Los novios búlgaros y Fuego de marzo, de Eduardo Mendicutti', en Jurado Morales, J. (ed.) Una ética de la libertad. La narrativa de Eduardo Mendicutti. Madrid: Visor Libros, pp. 171190.

Maturana, H. R. y Varela, F. J. (2003) El árbol del conocimiento: las bases biológicas del entendimiento humano. Barcelona: Lumen

Maturana, H. R. y Varela, F. J. (2004) De máquinas y seres vivos : autopoiesis : la organización de lo vivo. Santiago de Chile: Editorial Universitaria

Mauron, C. (1998) Psicocrítica del género cómico. Madrid: Arco/Libros.

Medina, A. (2009) 'Placeres de la auto-renuncia. 23-F, contrato libidinal de la monarquía', El Viejo Topo, 257, pp. 75-83.

Ménager, D. (1995) La Renaissance et le rire. Paris: Presses Universitaires de France.

Mendicutti, E. (2003) Yo no tengo la culpa de haber nacido tan sexy. Barcelona: Tusquets.

Mendicutti, E. (2008) Una mala noche la tiene cualquiera. Barcelona: Tusquets. 
Meyer, M. (2010a) 'Reclaiming the discourse of camp', en An archaelogy of posing. Essays on camp, drag and sexuality. Madison: Macater Press.

Meyer, M. (2010b) 'Rethinking Paris is burning: performing social geography in Harlem drag balls', en An archaelogy of posing. Essays on camp, drag and sexuality, pp. 105-139.

Miller, K. (2018) I'll be there for you. Friends, todo lo que quisiste saber de la serie y nunca te atrevista a preguntar [e-book]. Madrid: Harper Collins.

Mills, B. (2009) Sitcom. Edinburgh: Edinburgh University Press.

Minois, G. (2000) Histoire du rire et de la dérision. París: Fayard.

Mira Nouselles, A. (2007) De Sodoma a Chueca: una historia cultural de la homosexualidad en España en el siglo XX. Barcelona, Madrid: Egales.

Missé, M. (2018) A la conquista del cuerpo equivocado. Madrid: Egales.

Molpeceres Arnáiz, S. (2013a) Pensar en imágenes. Los conceptos de mito, razón y símbolo en la cultura occidental. Murcia: Editum. Ediciones de la Universidad de Murcia.

Molpeceres Arnáiz, S. (2013b) ‘Una Hermenéutica fragmentaria: formas breves, símbolo e ironía en el Romanticismo alemán’, Monteagudo, 18, pp. 79-93.

Molpeceres Arnáiz, S. (2014) Mito persuasivo y mito literario. Bases para un análiss retórico-mítico del discurso. Valladolid: Ediciones Universidad de Valladolid.

Molpeceres Arnáiz, S. (2016) 'Podemos: discurso retórico, Juego de Tronos, redes sociales’, Opción, 32(12), pp. 2019-2043.

Molpeceres Arnáiz, S. (2017) ‘Saber algo y decirlo: el Romanticismo alemán como fuente de la retórica constructivista', en La(s) literatura(s) en lengua alemana y su apertura internacional. Madrid: Dykinson, pp. 217-227.

Molpeceres Arnáiz, S. (2018) ‘Ideología hegemónica, conflicto discursivo y construcción de identidad en la cobertura mediática de la 'Nochevieja alemana de 2015', Pensamiento al margen, 9, pp. 68-110. 
Montesano Montesori, N. y Morales-López, E. (2015) 'Multimodal narrative as an instrument for social change: reinventing democracy in Spain -the case of 15M', Critical Approaches to Discourse Analysis Across Disciplines, 7(2), pp. 200-221.

Montesano Montesori, N. y Morales-López, E. (2019) 'The articulation of "the people” in the discourse of Podemos', en Zienkowski, J. y Breeze, R. (eds) Imagining the peoples of Europe. Amsterdam: John Benjamins, pp. 123-147.

Morales-López, E. (2016) 'Frame construction in post-15M speeches’, Res Rhetorica. Polskie Towarzystwo Retoryczne, 1, pp. 50-67

Morales-López, E. (2020) 'La creatividad en los discursos de cambio social: del 15M al post-15M en España’, en Oliveira de Aquino, Z. G., Gonçalves Segundo, P. R., y Guerdes Pinto, M. A. (eds) Argumentação e discurso: fronteiras e desafíos. Sao Paulo: FLCH-USP Universidade de São Paulo, pp. 76-99.

Morales-López, E. y Montesano Montesori, N. (2016) 'Podemos’ shift of the political landscape in Spain: the emancipation of the "demos"', KIB.

Morin, E. (1995) Introducción al pensamiento complejo. Barcelona: Gedisa.

Morreall, J. (1983) Taking Laughter Seriously. Albany: State University of New York Press.

Morreall, J. (1989) 'The rejection of humor in Western thought', Philosophy East and West, 39(3), pp. 243-265.

Morreall, J. (2009) Comic Relief. A Comprehensive Philosophy of Humor. Malden: Wiley-Blackwell.

Muecke, D. C. (1982) Irony and the ironic. Bristol: Methuen.

Muecke, F. (2005) 'Rome’s first “satirists”: themes and genre in Ennius and Lucilius', en Freudenburg, K. (ed) The Cambridge Companion to Roman Satire. Cambridge: Cambridge University Press, pp. 31-45.

Mulvey, L. (1989) 'Visual Pleasure and Narrative Cinema', en Visual and other pleasures. New York: Palgrave Macmillan, pp. 14-28. 
Newton, E. (1972) Mother Camp: Female impersonators in America. Chicago: The Univesity of Chicago Press.

Nietzsche, F. (2007) Sobre verdad y mentira en sentido extramoral. Madrid: Tecnos.

Nietzsche, F. (2012) El nacimiento de la tragedia. Madrid: Alianza.

Norrick, N. R. (1986) 'A frame-theoretical analysis of verbal humor: Bisociation as schema conflict', Semiotica, 60(3/4), pp. 225-245.

O’Neil, C. (2018) Armas de destrucción matemática. Cómo el big data aumenta la desigualdad y amenaza la democracia. Madrid: Capitán Swing.

Oliva Mendoza, C. (2011) ‘Introducción. La poética de Jean Paul Richter’, en Ricther, J. P. Antesala de la estética; Sobrea magia natural de la imaginación. México: Ítaca, pp. 13-23.

Ondarra, M. (2020, 4 de octubre) 'Así lucha la derecha contra el relato de la izquierda: la “guerra cultural” también se libra en España’, El Español. Recuperado el 10 de octubre de 2020 de https://www.elespanol.com/espana/politica/20201004/lucha- derecha-relatoizquierda-guerra-cultural-espana/525447853_0.html

Palmer, J. (1994) Taking Humour Seriously. New York: Routledge.

Paredes, F. (2007) 'La nación se hace carne: la construcción del travesti como metáfora de la transición en Una mala noche la tiene cualquiera, de Eduardo Mendicutti', Hispanófila. Literatura- Ensayos, 149, pp. 55-68.

Paredes, F. (2012) 'El trazo de la identidad posmoderna en Yo no tengo la culpa de haber nacido tan sexy, de Eduardo Mendicutti’, en Morales, J. J. (ed.) Una ética de la libertad. La narrativa de Eduardo Mendicutti. Madrid: Visor, pp. 205-224.

Parker, A. and Sedgwick, E. K. (eds) (1995) Performativity and performance. New York: Routledge. 
Paton, G. E. C. (1988) 'The Comedian as Portrayer of Social Morality’, en Powell, C. y Paton, G. E. C. (eds) Humour in Society. Resistance and Control. London: Macmillan Press, pp. 206-233.

Perelman, C. y Tyteca, L. O. (2006) Tratado de la argumentación: la nueva retórica. Madrid: Gredos.

Pérez-Sánchez, G. (2007) Queer Transitions in Contemporary Spanish Culture. From Franco to la Movida. New York: State University of New York Press.

Pérez, F. J. (2016, 29 de junio) 'Archivada la causa por enaltecimiento del terrorismo contra los titiriteros', El País. Recuperado el 10 de octubre de 2020 de https://elpais.com/politica/2016/06/28/actualidad/1467119956_320215.html

Pérez, J. and Torrús, A. (2018 1 de marzo) 'El Tribunal Supremo absuelve por unanimidad a Cassandra por los chistes de Carrero Blanco’, Público. Recuperado el 10 de octubre de 2020 de https:/www.publico.es/sociedad/cassandraabsuelta- supremo.html

Pérez Morán, E. (2019) 'De parientes, putas y pobres. Aproximación dialéctica a las comedias más exitosas del felipismo’, Área Abierta. Revista de comunicación audiovisual y publicitaria, 19(1), pp. 93-104.

Pérez Morán, E. y Huerta Floriano, M. Á. (2018) 'La comedia subgénerica de la Transición española: Paradojas en la tormenta’, Historia y Comunicación Social, 23(2), pp. 389-404.

Pérez Reverte, A. (2017, 7 de mayo) 'Christina Hendricks y nosotros’, XLSemanal. Disponible en https://www.xlsemanal.com/firmas/20170507/perez-revertecristina-hendricks-y-nosotros.html

Pérez Reverte, A. (2020, 26 de septiembre) 'Ofendidos del mundo, uníos’, XLSemanal. Disponible en https://www.xlsemanal.com/firmas/20200926/ofendidos-delmundo-unios-arturo-perez-reverte.html 
Picornell, M. (2010) ‘¿De una España viril a una España travesti? Transgresión transgénero y subversión del poder franquista en la transición española hacia la democracia’, Feminismo/s (16), pp. 281-304.

Piqueras, J. A. (2020, 26 de julio) ‘Libertad de debate y mimetismo asimétrico’, Ctxt

Platero, L. (2011) 'The narratives of transgender rights mobilization in Spain', Sexualities, 14(5), pp. 597-614.

Platón (1999) Diálogos, 9: Leyes (libros VII-XII). editado por F. Lisis. Madrid: Gredos.

Platter, C. (1993) 'The Uninvited Guest: Aristophanes in Bakhtin's “History of Laughter”, Arethusa, 26(2), pp. 201-216.

Pratt, M. L. (1986) ‘Ideology and Speech-Act Theory’, Poetics Today, 1, pp. 59-72.

Preciado, P. B. (2018) Manifiesto contrasexual. Madrid: Anagrama.

Prosser, J. (1998) Second Skins: the body narratives of transsexuality. New York: Columbia University Press.

Público (2018, 30 de noviembre) 'Cancelan la actuación de Mongolia en València tras las amenazas de ultraderecha'. Recuperado el 10 de octubre de 2020 de https://www.publico.es/politica/mongolia-hielo-rambleta-cancela-espectaculomongolia-hielo-amenazas-redes-directas-trabajadores.html

Pueo, J. C. (2001) Ridens et Ridiculus. Vincenzo Maggi y la teoría humanista de la risa. Zaragoza: Universidad de Zaragoza.

Pujante Sánchez, D. y Morales López, E. (2013) 'Discurso (discurso político), constructivismo y retórica: los eslóganes del 15-M’, Language, Discourse, \& Society, 2(2), pp. 32-59.

Pujante Sánchez, D. (1997) Un vino generoso (sobre el nacimiento de la estética nietzscheana: 1871-1873). Murcia: Universidad de Murcia.

Pujante Sánchez, D. (1999) El hijo de la persuasión: Quintiliano y el estatuto retórico. Logroño: Instituto de Estudios Riojanos. 
Pujante Sánchez, D. (2003a) Manual de Retórica. Madrid: Castalia.

Pujante Sánchez, D. (2003b) 'The role of dispositio in the construction of meaning: Quintilian’s perspective', en Tellegen-Copelius, O. (ed.) Quintilian and the law: the art of persuasion in law and political aspects. Leuven: Leuven University Press, pp. 169-178.

Pujante Sánchez, D. (2012) ‘La operación elocutio, ¿una reina destronable? Sucomplejo predominio en el discurso retórico’, en del Río Sanz, E., Ruiz de la Cierva, M. del C., y Albaladejo, T. (eds) Retórica y política. Los discursos de la construcción de la sociedad. Logroño: Instituto de Estudios Riojanos, pp. 175-188.

Pujante Sánchez, D. (2016) 'Constructivist rhetoric within the tradition of rhetorical studies in Spain’, Res Rhetorica. Polskie Towarzystwo Retoryczne., 1, pp. 30-49.

Pujante Sánchez, D. (2017) 'The discursive construction of reality in the context of rhetoric. Constructivist Rhetoric.', en Morales-López, E. y Floyd, A. (eds) Developing New Identities. Constructivist perspectives. Amsterdam/Philadelphia: John Benjamins Publishing Company, pp. 41-65. Versión en español: Pujante Sánchez, 2018b

Pujante Sánchez, D. (2018a) ‘El conflicto discursivo sobre el atentado a Charlie Hebdo’, Pensamiento al margen, 9, pp. 5-36.

Pujante Sánchez, D. (2018b) 'La construcción discursiva de la realidad en el marco de la retórica. La retórica constructivista.', Tonos digital: Revista electrónica de estudios filológicos, (34), pp. 1-24.

Pujante Sánchez, D. (2018c) Oráculo de tristezas: la melancolía en su historia cultural. Barcelona: Xoroi.

Raskin, V. (1985) Semantic Mechanisms of Humor. Dordrecht - Boston - Lancaster: D. Reidel Publishing Company.

Raya Pons, J. (2020, 22 de agosto) ‘¿De qué habla Cayetana Álvarez de Toledo cuando habla de guerra cultural?’, The Objective. Recuperado el 10 de octubre de 2020 de https://theobjective.com/further/cayetana-alvarez-toledo-guerra-cultural 
Recuerdo, M. (2016, 15 de noviembre) 'La Audiencia Nacional absuelve a Zapata por el “tuit” sobre Irene Villa', El Mundo. Recuperado el 10 de octubre de 2020 de https://www.elmundo.es/madrid/2016/11/15/582afd37468aeba3328b4579.html

Reeser, T. W. (2010) Masculinities in theory: an introduction. Chichister: WileyBlackwell.

Reguera, I. (2017) 'Introducción. Ludwig Wittgenstein, el último filósofo', en Wittgenstein, L. Tractatus logico-philosophicus. Investigaciones filosóficas. Madrid: Gredos, pp. I-CXXII.

Reyes, G. (2002) Metapragmática. Lenguaje sobre lenguaje, ficciones, figuras. Valladolid: Universidad de Valladolid.

Richards, I. A. (2001) Principles of Literary Criticism. London: Routledge.

Richter, J. P. (2011) Antesala de la estética; Sobre la magia natural de la imaginación. México: Itaca.

Ricoeur, P. (1980) La metáfora viva. Madrid: Cristiandad.

Ricoeur, P. (2001) Del texto a la acción. México D. F.: Fondo de Cultura Económica.

Riedel, S. (2018) 'Why Everyone’s Favorite 90’s Show Is Hugely Transphobic', Them. Disponible en : https://www.them.us/story/friends-is-transphobic.

Riu, X. (1999) Dionysism and comedy. Lanham: Rowman \& Littlefield.

Riveiro, A. (2014, 5 de junio) 'El Jueves retira 60.000 ejemplares con una portada sobre la abdicación del rey’, Eldiario.es. Recuperado el 10 de octubre de 2020 de https://www.eldiario.es/sociedad/jueves-retira-ejemplares-portadaabdicacion_1_4840738.html

Rodríguez Adrados, F. (1969) ‘El banquete platónico y la teoría del teatro’, Emerita, 37, pp. 1-28.

Rodríguez Adrados, F. (1972) Fiesta, comedia y tragedia: sobre los orígenes griegos del teatro. Barcelona: Planeta. 
Rodríguez Sojo, J. (2018, 1 de septiembre) 'Rober Bodegas (Pantomima Full), amenazado de muerte por un monólogo sobre gitanos’, El Confidencial. Recuperado el 10 de octubre de 2020 de https://www.elconfidencial.com/cultura/2018-08-27/rober-bodegas-pantomimafull-amenazado-muerte_1608277/

Romero Velasco, P. (2018) ‘La ironía en la Retórica Clásica y la pragmática. Un estudio comparativo’, en Díaz Ferro, M. et al. (eds) Novas perspectivas na Lingüística Aplicada. Lugo: Axac, pp. 163-182.

Rorty, R. (1996) Consecuencias del Pragmatismo. Madrid: Tecnos.

Rorty, R. (1999) Forjar nuestro país. El pensamiento de izquierdas en los Estados Unidos del siglo XX. Barcelona: Paidós.

Rorty, R. (2001) La filosofía y el espejo de la naturaleza. Madrid: Cátedra.

Rorty, R. (2013) 'El progreso del pragmatista', en Eco, U. (et al.) Interpretación y sobreinterpretación. Madrid: Akal, pp. 104-126.

Rosen, R. M. (2014) ‘The Greek Comic Hero’, en Revermann, M. (ed.) The Cambridge Companion to Greek Comedy. Cambridge: Cambridge University Press, pp. 222240.

Rubio Hancock, J. (2018, 19 de diciembre) 'Las críticas al anuncio de Campofrío: ¿¿salemás caro un chiste sobre feminismo que sobre monarquía?’, Verne. Recuperado el 10 de octubre de 2020 de https://verne.elpais.com/verne/2018/12/19/articulo/1545218581_913778.html

Ruffell, I. (2014) 'Utopianism', en Revermann, M. (ed.) The Cambridge Companion to Greek Comedy. Cambridge: Cambridge University Press, pp. 206-221.

S.F. (2020, 15 de julio) 'La Fiscalía pide prisión para el cómico David Suárez por su chiste sobre las mujeres con síndrome de Down', ABC. Recuperado el 10 de octubre de 2020 de https://www.abc.es/familia/padres-hijos/abci-fiscalia-pideprision-para-comico-david-suarez-chiste-sobre-mujeres-sindrome-down202007151838_noticia.html 
Sacks, H. (1974) 'Analysis of the course of a jokes telling in conversation', en Bauman, R. y Sherzer, J. (eds) Explorations in the Etnography of Speaking. Cambridge: Cambridge University Press, pp. 337-353.

Sacks, H. (1978) 'Some technical considerations of a dirty joke’, en Schenkein, J. (ed.) Studies in the Organization of Conversational Interaction. New York, San Francisco, London: Academic Press, pp. 249-269.

Sáez, J. (20005) 'Excesos de la masculinidad: la cultura leather y la cultura de los osos’, en Barragueiras Martínez, C., Romero Bachiller, C. y García Dauder D. (eds) El eje del mal es heterosexual: figuraciones, movimientos y prácticas feministas "queer". Madrid: Traficantes de Sueños

Salazar, O. (2017) Autorretrato de un macho disidente. Madrid: Ediciones Huso.

Salazar, O. (2018) El hombre que no deberíamos ser: la revolución masculina que tantas mujeres llevan siglos esperando. Barcelona: Planeta.

Salvat, R. (1996) El teatro: como texto, como espectáculo. Barcelona: Montesinos.

Sánchez Meca, D. (1999) 'Friedrich Schlegel y la ironía romántica’, Er. Revista de Filosofía, 26, pp. 85-115.

Sánchez Meca, D. (2007) 'Un texto de Friedrich Schlegel sobre el Wilhelm Meister de Goethe’, Volubilis, 14, pp. 10-30.

Sánchez Meca, D. (2013) Modernidad y Romanticismo. Para una genealogía de la actualidad. Madrid: Tecnos

Santamaría, A. (2018) En los límites de lo posible: política, cultura y capitalismo afectivo. Madrid: Akal.

Santiago Guervós, L. E. de (2012) El poder de la palabra. F. Nietzsche y la retórica.

Saunders, F. S. (2013) La CIA y la guerra fría cultural. Madrid: Debate.

Schank, R. C. and Abelson, R. P. (1977) Scripts, Plans, Goals and Understanding. An Inquiry into Human Knowledge Structures. New York, Toronto, London, Sidney: John Wiley \& Sons. 
Schlegel, F. (1994) Poesía y filosofía. Editado por D. Sánchez Meca. Madrid: Alianza Editorial.

Schlegel, F. (2007) ‘Sobre el Wilhelm Meister. Trad. de Diego Sánchez Meca’, Volubilis, 14, pp. 10-30.

Schlegel, F. (2009) Fragmentos. Seguido de Sobre la incomprensibilidad. Barcelona: Marbot Ediciones.

Schoentjes, P. (2003) Poética de la ironía. Madrid: Cátedra.

Sedwick, E. K. (1985) Between Men: English Literature and Male Homosocial Desire. New York: Columbia University Press.

Shaftesbury, A. A. C. C. de (1997) Carta sobre el entusiasmo. Madrid: Crítica

Shaftesbury, A. A. C. C. de (1995) Sensus Communis. Ensayo sobre la libertad de ingenio y humor. Valencia: Pre-textos.

Shakespeare, W. (2006) Twelfth Night / Noche de Reyes. Madrid: Cátedra.

Sloterdijk, P. (2014) Crítica de la razón cínica. Madrid: Siruela.

Sommerstein, A. (2014) 'The Politics of Greek Comedy', en Revermann, M. (ed) The Cambridge Companion to Greek Comedy. Cambridge: Cambridge University Press, pp. 291-305.

Sontag, S. (1967) 'Notas sobre lo camp’, en Contra la interpretación. Barcelona: Seix Barral, pp. 323-344.

Soto Ivars, J. (2017) Arden las redes. La poscensura y el nuevo mundo virtual. Madrid: Debate.

Soto Ivars, J. (2018, 27 de agosto) ‘No pidas perdón, Bodegas: solo quieren destrozarte’, El Confidencial. Recuperado el 10 de octubre de 2020 de https://blogs.elconfidencial.com/cultura/tribuna/2018-08-27/rober-bodegasgitanos-chistes-ni-caso_1608585/ 
Soto Ivars, J. (2019, 26 de abril) 'Dejadnos reír en paz: manifiesto en defensa del mal chiste', El Confidencial. Recuperado el 10 de octubre de 2020 de https://blogs.elconfidencial.com/cultura/tribuna/2019-04-26/davd-suarezdown- manifiesto-defensa-chiste_1965030/

Spargo, T. (2004) Foucault y la teoría queer. Barcelona: Gedisa.

Speier, H. (1998) 'Wit and Politics: An Essay on Laughter and Power', American Journal of Sociology. pp. 1352-1401.

Sperber, D. y Wilson, D. (1978) 'Les ironies comme mentions’, Poétique, 36, pp. 399412.

Sriwattanakomen, N. (2017) ‘Who’s Laughing Now? The Effects of Sexist and Rape Humor', Psi Chi Journal of Psychological Research. 22(2), pp. 85-97.

Stallybrass, P. y White, A. (1986) The Politics and Poetics of Transgression. New York: Cornell University Press.

Steen, G. Van (2007) 'Politics and Aristophanes: watchword “Caution!”', en McDonald, M. y Walton, J. M. (eds) The Cambridge Companion to Greek and Roman Theatre. Cambridge: Cambridge University Press, pp. 108-123.

Stoddart, M. C. J. (2007) 'Ideology, Hegemony, Discourse : A Critical Review of Theories of Knowledge and Power', Social Thought \& Research, 28, pp. 191225.

Storey, I. C. y Allan, A. (2014) A Guide to Ancient Greek Drama. Oxford: Wiley Blackwell.

Stott, A. (2005) Comedy. Nueva York: Routledge.

Stryker, S. (2017) Historia de lo trans. Las raíces de la revolución de hoy. Madrid: Continta Me Tienes.

Suleiman, S. (1976) ‘Interpreting ironies’, Diacritics, 6(2), pp. 15-21.

Sutton, D. F. (1993a) Ancient Comedy: the war of the Generations. Woodbrige: Twayne Publishers 
Sutton, D. F. (1993b) The Catharsis of Comedy. Woodbrige: Twayne Publishers.

Tapia, R. (2012) ‘Cuerpo, transición y nación en Una mala noche la tiene cualquiera’, en Morales, J. J. (ed.) Una ética de la libertad. La narrativa de Eduardo Mendicutti. Madrid: Visor, pp. 83-96.

Tecé, G. (2018, 19 de diciembre) ‘¿A cuánto salen los chistes con banderas?’, Ctxt. Recuperado el 10 de octubre de 202 de https://ctxt.es/es/20181219/Firmas/23561/limites-del-humorcampofr\%C3\%ADo-echenique-bandera-gerardo-tec\%C3\%A9.htm

The Objective (2020, 10 de julio) 'A more specific letter on justice and open debate'. Disponible en https://www.objectivejournalism.org/p/a-more-specific-letter-onjustice

Thomae, M. y Tendayi Viki, G. (2013) 'Why did the woman cross the road? The effect of sexist humor on men's rape proclivity', Journal of Social, Evolutionary, and Cultural Psychology, 7(3), pp. 250-269.

Todd, A. M. (2011) ‘Saying goodbye to Friends: Fan culture as lived experience’, Journal of Popular Culture, 44(4), pp. 854-871.

Turner, V. (1982) From ritual to theatre. The human seriousness of play. New York: PAJ publications.

Valverde, J. M. (2000) Historia de las mentalidades. Madrid: Trotta.

Varela, F. J., Thompson, E. y Rosch, E. (2011) De cuerpo presente. Las ciencias cognitivas y la experiencia humana. Barcelona: Gedisa.

Vattimo, G. (1998) Introducción a Heidegger. Barcelona: Gedisa.

Vegas, V. (2019) Vestidas de azul. Análisis social y cinematográfico de la mujer transexual en los años de la Transición española. Madrid: Dos Bigotes.

Ventoso, L. (2020, 11 de julio) 'El virus de la corrección política corroe la libertad de expresión', ABC. Recuperado el 10 de octubre de 2020 de https://www.abc.es/cultura/cultural/abci-virus-correccion-politica-corroe- 
libertad-expresion-201812020129_noticia.html

Verdú, D. (2016, 11 de julio) ‘El gusto en la era del algoritmo’, Babelia. Disponible en https://elpais.com/cultura/2016/07/07/babelia/1467898058_835206.html

Vilarós, T. M. (2005) 'Banalidad y biopolítica: la transición española y el nuevo orden del mundo', Desacuerdos. Sobre arte, políticas y esfera pública en el Estado español, 2, pp. 29-56.

Vilarós, T. M. (2018) El mono del desencanto. Una crítica cultural de la transición española (1973-1993). Madrid: Siglo XXI de España.

Vlastos, G. (1991) Socrates: ironist and moral philosopher. Cambridge: Cambridge University Press.

Voloshinov, V. N. (2009) El marxismo y la filosofía del lenguaje. Buenos Aires: Ediciones Godot.

Weber, S. (1978) 'It’, Glyph, 4, pp. 1-31.

Weigel, M. (2016, 30 de noviembre) 'Political correctness: how the right invented a phantom enemy', The Guardian. Disponible en https://www.theguardian.com/us- news/2016/nov/30/political-correctness-howthe-right-invented-phantom-enemy-donald-trump

Wellek, R. (1981) A History of Modern Criticism (1750-1950): The Romantic Age. Wess, R. (1996) Kenneth Burke: Rhetoric, Subjectivity, Postmodernism. Cambridge: Cambridge University Press.

Wheeler, K. M. (1984) 'Introduction’, en Wheeler, K. M. (ed.) German aesthetic and literary criticism: the Romantic ironists and Goethe. Cambridge: Cambridge University Press.

White, H. (1992) Metahistoria: la imaginación histórica en la Europa del siglo XIX. México: Fondo de Cultura Económica.

Williams, R. (1982) Cultura. Sociología de la comunicación y del arte. Barcelona: Paidós. 
Williams, R. (2003) Television: Technology and cultural form. New York: Routledge.

Wilson, J. K. (1995) The Myth of Political Correctness. The conservative attack on higher education. Durham, London: Duke University Press.

Wittgenstein, L. (2017) Tractatus logico-philosophicus. Investigaciones filosóficas. Madrid: Gredos.

Wodak, R. (2003) 'De qué trata el análisis crítico del discurso (ACD). Resumen de su historia, sus conceptos fundamentales y sus desarrollos', en Wodak, R. y Meyer, M. (eds) Métodos de análisis crítico del discurso. Barcelona: Gedisa, pp. 17-34.

Woodzicka, J. A. y Ford, T. E. (2010) 'A Framework for Thinking about the (not-sofunny) Effects of Sexist Humor', Europe’s Journal of Psychology, 6(3).

Wu, T. (2020) Comerciantes de la atención. La lucha épica por entrar en nuestra cabeza. Madrid: Capitán Swing.

Yus, F. (2003) 'Humor and the search for relevance', Journal of Pragmatics, 35(9), pp. 1295-1331.

Zamora, I. (2019, 30 de enero) 'El idilio millonario entre Netflix y «Friends»', $A B C$. Recuperado el 19 de agosto de 2019 de https://www.abc.es/play/series/noticias/abci-idilio-millonario-entre-netflix-yfriends-201901300119_noticia.html

Žižek, S. (2003) 'Introducción. El espectro de la ideología’, en Žižek, S. (ed.) Ideología. Un mapa de la cuestión. Buenos Aires: Fondo de Cultura Económica, pp. 7-42.

Žižek, S. (2011) El acoso de las fantasías. Madrid: Akal.

Žižek, S. (2018) El sublime objeto de la ideología. Ciudad de México: Siglo XXI.

Zupančič, A. (2008) The odd one in. On comedy. Massachussets: Massachussets Institute of Technology Press. 